\title{
جلة علمية
}

عحكمة نصف سنوية

كلية التربية للطفولة الهبكرة

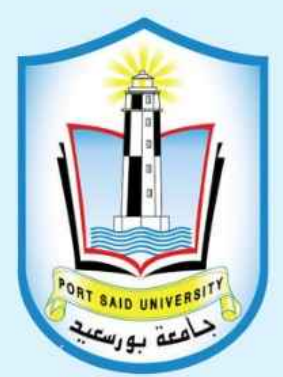

جامعة بورسعيد

\section{البجلة العلمية}

لكلية رياض الأطفال

ISSN.Print :2356 - 6485

ISSN.OnLine :2682-3276

العدد السابع عشر (أول يوليو - آخر ديسمبر)

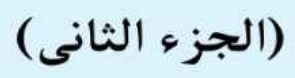



المجلة العلمية لكلية رياض الأطفال - جامعة بورسعيد

مجلة علمية محكمة ـ نصف سنوية

المجلة العلمية

لكلية رياض الأطفال

العدد السابع عشر

$$
\begin{gathered}
\text { ( أول يوليو - آخر ديسمبر ) } \\
\text { ( الجزء الثاني (. . . . . }
\end{gathered}
$$




\section{المجلة العلمية لكلية رياض الأطفال - جامعة بورسعيد}

\section{هيئة تحريز المبلة العمية لكلية رياض الأطفال بيوررسعيد}

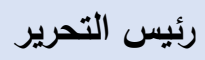

أستاذ علم نفس الطفل ( الصحة النفسية) -

عميد كلية التربية للطفولة المبكرة- جامعة

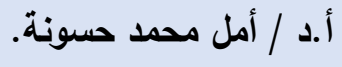

تصميم

$$
\text { بورسعيد. }
$$

\section{نائب رئيس التحرير}

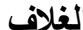

د/ داليا

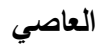

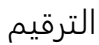

أستاذ أصول التربية المساعد-وكيل كلية

$$
\text { التزبية للطفولة المبكرة للدراسات العليا }
$$

أ.م.د/ زينب موسى السماحي.

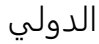

\section{ISSN2356}

6485

$$
\text { والبحوث- جامعة بورسعيد. }
$$

$$
\text { سكرتير تحرير المجلة }
$$

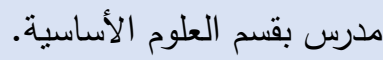

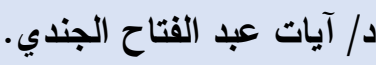

المراجع اللغوي

أستاذ اللغة العربية بكلية الآداب- جامعة

أ. أد / محمد سعد محمد العبد.

$$
\text { بورسعيد. }
$$

المراجع اللغوي

أستاذ مناهج وطرق تدريس اللغة الإنجليزية -

أ.د / جيهان محمود البسيوني.

كلية التربية- جامعة بورسعيد.

المشرف المالي والإداري للمجلة المبلة المبلة

المراجع المالي - المي

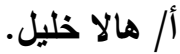

المسئول الإداري المي

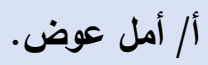

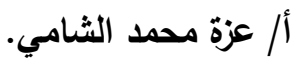




\section{المجلة العلمية لكلية رياض الأطفال - جامعة بورسعيد}

\section{الهيئة الاستشارية للمجلة العلمية لكلية رياض الأطفال - جامعة \\ بورسعيا}

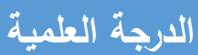

أ.د / ابتهاج محمود طلبة أستاذ مناهج وبرامج طفل ماقبل المدرسةكلبة التربية للطفولة المبكرة- جامعة القاهرة

أ.د/ أحمد حسين عبد أستاذ ورئيس قسم أصول التربية بكلبة تربية-

$$
\text { جامعة أسيوط. }
$$

\section{الاسمم}

أ.د/ أحمد سيد إبراهيم أستاذ المناهج وطرق تدريس اللغة العربية والدراسات الإسلامية بكلية التربية- جامعة

أسيوط وعميد كلية التربية بالوادي الجديد-

$$
\text { جامعة أسيوط. }
$$

أ.د/ إسماعيل محمد أستاذ تكنولوجيا التعليم - كلية التربية-

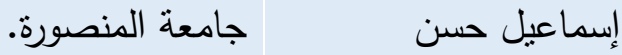

م أ.د/ أثنرف عبد الغني أستاذ الصحة النفسية ورئيس قسم العلوم

شريت النفسبة بكلية التربية للطفولة المبكرة- جامعة

$$
\text { الاسكندرية. }
$$

أ.د// اعتماد خلف معبدأستاذ الإعلام وثقافة الأطفال بكلية الدراسات العليا للطفولة -جامعة عين شمس. 


\section{المجلة العلمية لكلية رياض الأطفال - جامعة بورسعيد}

\section{الارجة العلمبة}

أ. دم/ أمل محمد أحمد أستاذ مناهج وتربية الطفل وعمبد كلية التربية

للطفولة المبكرة -جامعة المنصورة.

القداح

أ.د/ أمل محمد حسونة أستاذ الصحة النفسية وعميد كلية التربية

للطفولة المبكرة - جامعة بورسعيد.

أستاذ الصولفيج بكلية التربية الفنية -جامعة

أ.د/ أميرة سيد فرج

حلوان.

أ.د/بطرس حافظ بطرس أستاذ والعميد السابق لكلية التربية للطفولة المبكرة- - جامعة القاهرة.

أ.د/ جبريل بن حن أستاذ علم المعلومات وعضو مجلس الثورى سابقاً - جامعة الملك سعود بالمملكة العربية

العربشي.

$$
\text { السعودية. }
$$

أ.د/جمال شفيق أحمد أستاذ علم النفس الإكلينيكي - كلية الدراسات محمد عامر لعليا للطفولة- جامعة عين شمس. ب أ.د/ جمال عطية خليل أستاذ بقسم العلوم النفسية كلية التربية فايد لطفولة المبكرة-جامعة المنصورة. 


\section{المجلة العلمية لكلية رياض الأطفال - جامعة بورسعيا}

\section{الدرجة العلمبة}

أ.د/ جمال محمد فكري أستاذ المناهج وطرق التدربس المتفرغ بكلية التربية للطفولة المبكرة-جامعة أسيوط.

ه أ.د/ حازم أنور محمد أستاذ الإذاعة والتليفزيون - قسم الإعلام

$$
\text { التربوي - جامعة المنصورة }
$$

أستاذ علم النفس بكلية التربية النوعية-

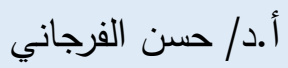
جامعة بنها.

أ.د//حسن عمران حسن أستاذ المناهج وطرق تدربس اللغة العربية

والدراسات الإسلامية المساعدة بكلية

$$
\text { التربية- جامعة أسيوط. }
$$

أ.د//حمدي محمد مرسي أستاذ المناهج وطرق تدريس الرياضيات المساعد بكلية التربية -جامعة أسيوط. 1 أ.د/ عنان إسماعيل أستاذ أصول التربية - كلية البنات -جامعة

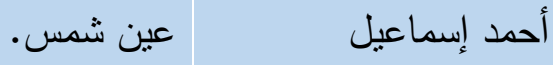




\section{المجلة العلمية لكلية رياض الأطفال - جامعة بورسعيد}

\section{الدرجة العلمبة}

\section{الاسم}

أ.د/ حنان محمد صفوت أستاذ تربية الطفل ( مناهج الطفل) ورئيس قسم العلوم التربوية- كلية التربية للطفولة

المبكرة- جامعة المنيا.

أ.د// خالد عبد الرازق أستاذ ورئيس قسم العلوم النفسية -كلية

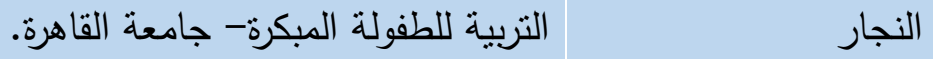

أ.د/ / رفعت محمد أستاذ المناهج وطرق تدربس الرياضيات

$$
\text { بكلية التزبية - جامعة أسيوط. }
$$

الملبجي

أستاذ وعمبد كلبة التربية للطفولة المبكرة -

$$
\text { أ.د/ زينب دردير }
$$

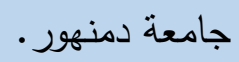

أ.د/ سحر توفيق نسيم أستاذ بقسم المناهج وطرق التدريس بكلية التربية للطفولة المبكرة -جامعة المنصورة.

ه P أ.د/ سعدية محمد علي أستاذ علم نفس النمو بكلية الدراسات العليا

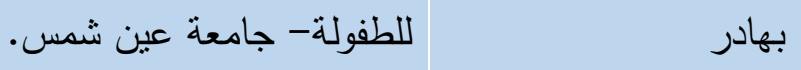

أ.د// سعدية ميوسف أستاذ أصول التربية كلية التربية للطفولة

$$
\text { المبكرة- جامعة بورسعيد. }
$$

$$
\begin{aligned}
& \text { أ.د/ سلوى عبد السلام أستاذ علم نفس الطفل - كلية التربية للطفولة }
\end{aligned}
$$

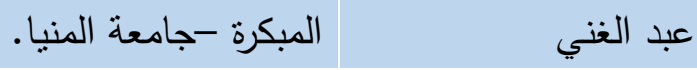




\section{المجلة العلمية لكلية رياض الأطفال - جامعة بورسعيد}

\section{الارجة العلمبة}

\section{الاسمب}

r^ أ.د/ مليمان محمد أستاذ علم النفس التربوي- كلية التربيةسليمان أباظة امعة بني سويف.

أ.د/ سهير كامل محمود أستاذ الصحة النفية المتفرغ بقسم العلوم النفية كلية التربية للطفولة المبكرة- جامعة القاهرة.

أ.د/ سهير عبد الحميد أستاذ متفرغ بقسم العلوم التربوية كلية التربية للطفولة المبكرة -جامعة المنيا. عثمان أ.د/ السيد عبد القادر أستاذ أصول تربية الطفل - كلية التربية

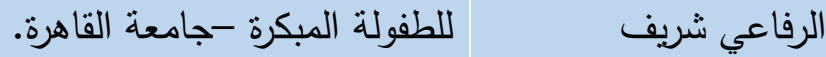
أ.د/ شحاتة سليمان أستاذ بقسم العلوم النفسية كلية التربية للطفولة المبكرة -جامعة القاهرة. محمد أ.د/ شهناز محمد عبد أستاذ الصحة النفسية المتفرغ -كلية التربية -جامعة أسيوط. الله ع r أ.د/ شيرين محمد أستاذ علم النفس ورئيس قسم علم النفس

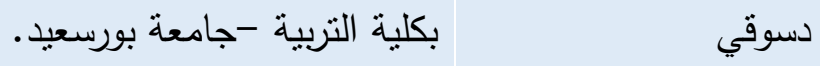

هץ أ.د/ عادل رسمي حماد أستاذ المناهج وطرق التدربس- كلية التربية -جامعة أسيوط. 


\section{المجلة العلمية لكلية رياض الأطفال - جامعة بورسعيد}

\section{الارجة العلمبة}

\section{الاسمب}

أ.د// عادل سعد خضر أستاذ علم النفس التربوي بكلبة التربيةجامعة الزقازيق.

أ.د/ عاطف عدلي فهمي أستاذ وعمبد كلية التربية للطفولة المبكرة جامعة القاهرة.

أ.د/عبدالرقيب أحمد أستاذ الصحة النفسية ورئيس قسم علم النفس $\ddot{r}$

$$
\text { بكلية التربية- جامعة اسيوط. }
$$

أ.د/عبد السلام مصطفى أستاذ المناهج وطرق التدربس كلية التربية -

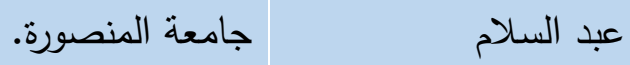

أ.د/عبد الصبور منصور أستاذ الصحة النفية ورئيس قسم بكلية

$$
\text { التربية- جامعة بورسعيد. }
$$

أ.د/ عبد الكريم الثاذلي أستاذ المناهج وطرق تدريس الرياضات كلية

$$
\text { التربية- جامعة أسيوط. }
$$

أ.د//عفاف محمد محمود أستاذ الصحة النفسية بقسم علم النفس كلية

$$
\text { التربية- جامعة أسيوط. }
$$

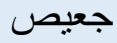

أستاذ المناهج وطرق التدريس ووكيل كلية أ.د/ عفت الطناوي التربية لشئون الطلاب- جامعة دمياط. 


\section{المجلة العلمية لكلية رياض الأطفال - جامعة بورسعيا}

\section{الارجة العلمبة}

\section{الاسم}

أ.د// عماد أحمد حسن أستاذ ورئيس قسم علم النفس- كلية التربيةجامعة أسيوط.

أ.د/ علاء الدين حامد أستاذ الجمباز بكلية التربية الرياضية-

\section{جامعة بورسعيد.}

أ.د/ علاء محمد حسونة أستاذ مناهج وطرق تدريس التربية الفنية بكلية التربية -جامعة حلوان.

أ.د// عيد عبد الواحد أستاذ مناهج وطرق تدريس اللغة الإنجليزية-

علي درويش. عمبد كلية التربية للطفولة المبكرة - جامعة المنيا.

أ.د// الغربب اهر أستاذ تكنولوجيا التعليم- كلية التربية-

أ.د/فاتن عبد الرحمن أستاذ الاعلام وتقافة الأطفال جامعة عين

شمس وعميد كلية الاعلام- جامعة 7

$$
\text { أكتوبر }
$$

• • أ.د/ فهر ماجد فهذ أستاذ بكلية التربية- جامعة أم القرى بالمملكة العربية السعودية. 


\section{المجلة العلمية لكلية رياض الأطفال - جامعة بورسعيا}

\section{الادجة العمبة:}

أ.د/ فيوليت فؤاد ابراهيم أستاذ الصحة النفسية بكلية التربية- جامعة عين شمس.

أ.د/ كاميليا جمال الدين أستاذ الصولفيج بكلية التربية الموسيقيةجامعة حلوان.

أ.د/ كمال الدين حسين أستاذ الأدب الثعبي المتفرغ بقسم العلوم

الأساسية- كلية التربية للطفولة المبكرة -

$$
\text { جامعة القاهرة. }
$$

أستاذ علم النفس بكلية دراسات الطفولة -

$$
\text { جامعة عين شمس. }
$$

أ.د/ ماجدة هاشم بخيت أستاذ الفئات الخاصة وعمبد كلية التربية للطفولة المبكرة - جامعة أسيوط.

أ.د/ محمد إبراهيم عبد أستاذ ورئيس قسم المناهج وطرق التدريس

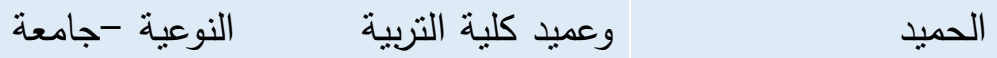

\section{بنها.}

أ.د/ محمد أحمد دسوفي أستاذ علم النفس التربوي المتفرغبكلية التربية -جامعة الزقازيق. 


\section{المجلة العلمية لكلية رياض الأطفال - جامعة بورسعيا}

\section{الارجة العلمبة}

أ.د//محمد السيد الزغبي أستاذ الاقتصاد المنزلي - بكلية السياحة

والفنادق -جامعة قناة السوبس.

أ.د// محمد معوض أستاذ الإعلام وثقافة الأطفال - بكلية شمس.

أ.د/ محمد حسين إبراهيم أستاذ التصميم الجرافيكي ورئيس قسم التربية الفنية- - كلية التربية النوعية- جامعة

وصنيف.

\section{بورسعيد.}

أستاذ الإعلام وثثافة الأطفال - بلية

أ.د/محمودحسن

الدراسات العليا للطفولة- جامعة عين

إسماعيل

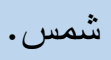

أ،د// محي / الدين أستاذ الحاسبات وتكنولوجيا المعلومات إسماعيل موسى العلامي بكلية التربية النوعية - جامعة المنصورة.

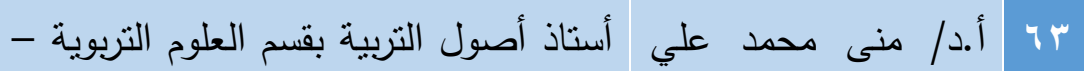

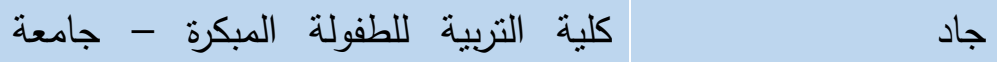

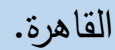




\section{المجلة العلمية لكلية رياض الأطفال - جامعة بورسعيد}

\section{الارجة العلمبة}

أ.د// مها زكريا عبد أستاذ التربية الفنية بكلية التربية النوعية -

ونائب رئيس الجامعة لخدمة المجتمع وتتمية

$$
\text { البيئة -جامعة بورسعيد. }
$$

أ.د/ ميادة محمد الباسل أستاذ أصول التربية وعمبد كلية التربية -

$$
\text { جامعة دمباط. }
$$

أ.د/ ناصر فؤاد علي أستاذ المناهج وطرق تدربس ووكيل الكلية للدراسات العليا -كلية التربية للطفولة المبكرة

أ.د/ نبيل السبد حسن أستاذ الصحة النفسية وعميد كلية التربية

$$
\text { للطفولة المبكرة - جامعة المنيا. }
$$

أستاذ العلوم الصحية بكلية التربية الرباضية

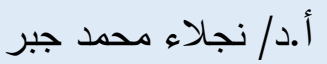

$$
\text { - جامعة بورسعيد. }
$$

أستاذ علم نفس الطفل - وكيل كلية التربية

للطفولة المبكرة لشئون خدمة المجتمع وتتمية

$$
\text { المجتمع - جامعة القاهرة. }
$$

أستاذ الصحة النفسية وعميد كلية التربية 


\section{المجلة العلمية لكلية رياض الأطفال - جامعة بورسعيد}

\section{الارجة العلمبة}

أ.د// هاشم أحمد محمد أستاذ مناهج وطرق تدريس اللغة الإنجليزية-

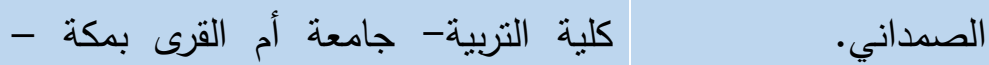
المملكة العربية السعودية.

أ.د// هدى محمد قناوي م أستاذ علم النفس المتفرغ - كلية التربية للطفولة المبكرة - جامعة بورسعيد.

أ.د/ هند إسماعيل أستاذ علم نفس الطفل -كلية التربية للطفولة المبكرة- جامعة القاهرة. امبابي أ.د/وديع مكسيموس أستاذ المناهج وطرق التدربس المتفرغ بكلية التربية -جامعة أسيوط. أ.د/ وفاء محمد كمال أستاذ علم نفس النمو المتفرغ بقسم العلوم

النفسية - كلية التربية للطفولة المبكرة جامعة القاهرة. أ.د/ يوسف سيد محمود أستاذ أصول التربية- كلية التربية -جامعة الفيوم . 


\section{كلمة رئيس التحرير}

تتشـرف أسـرة تحرير المجلة بإصــدار العدد الســابع عثـر الذي

يصـدر في جزئين، ومن دواعي الفخر ما نشــهده المجلة من إقبالٍ

كبيرٍٍ من الباحثين على النشـر في المجلة، مما يعد مؤثـراً على ما تتمتع به المجلة من ســمعةٍ طيبةٍ في المحافل الأكاديمية، حيث

حرصـت إدارة المجلة على انتقاء الأبحاث التي تهتم بمشكلاتٍ بحثيةٍ

هامةٍ في التخصسصات التثلاث لأقسـام كليات التربية للطفولة المبكرة

$$
\text { ( التربوبة والنفسية والأساسية ). }
$$

وتثقدم إدارة المجلة وأسـرة التحربر بجزيل الثـكر والامتتان للسـادة

الأفاضـل محكمي العدد السـابع عشـر بجزئيه ( الأول ،الثاني)؛ لأنهم

هم صــاع الجودة في البحث العلمي، ولتحكيمهم ولتعديلاتهم القيمة

يرجع الفضل في إخراج هذه الأبحاث في الصورة المرجوة .

ونتمنى لجميع الباحثين التوفيق والسداد في رسالتهم السـامية في إثراء

البحث العلمي.

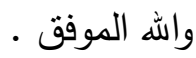

رئيس مجلس الإدارة ورئيس التحرير

عميا الكلية

أ.د/ أمل محمد حسونة. 


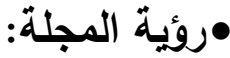

أن يكون للمجلة الريادة والتمبز في نشر البحوث التربوية والنفسية

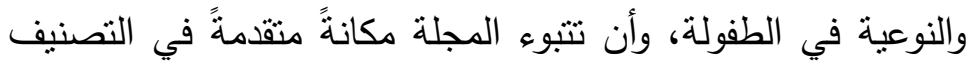

المحلي والإقليمي والعالمي.

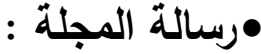

تسعى المجلة لنشر البحوث المحكمة علمياً المتخصصة في مجالات دراسات الطفولة وفق المعايير المهنية والأكاديمبة والعلمية

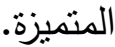

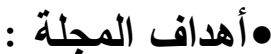

() مساعدة الباحثين المتخصصين في مجال الطفولة على الاطلاع على أبحاث في تخصصات الطفولة ( النربوية ، النفسية، النوعية). r) إتاحة الفرصة للباحثين لنشر أبحاثهم في مجلة متخصصة في مجال

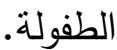




\section{شروط وقواعد النشر بالمجلة العلمية:}

تقبل المجلة العلمية للكلية الدراسات والبحوث المقدمة من الباحثين في مجالات الطفولة (النفسية- التربوبة- وجميع التخصصات النوعية للعلوم الأساسية ومنها موسيقى الأطفال - التربية الفنية للطفل - أدب

الأطفال- التكنولوجيا- التربية الرياضية للأطفال- تغذية الطفل مسرح الطفل - إعلام الطفل) وفق شروط وقواعد النشر العلمية التالية:

\section{أولاً: إجراعات التقدم بورقة بحثية :}

1- يتم سحب استمارة التقدم يدرج بها بيانات الورقة البحثية ،وكذلك بيانات المؤلفين والمؤلف المسؤول التواصل "Corresponding Author" وتاريخ استلام الورقة البحثية.

r- يتم استيفاء استمارة خاصة من خلال المؤلف المتقدم بمقترح للمحكمين الداخلبين والخارجيين.

r- يرفق مع استمارة التقدم للمجلة عدد(r) نسخ ورقية بالإضافة إلى

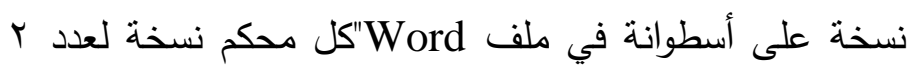
محكمين ونسخة تحفظ بإدارة المجلة. 


\section{المجلة العلمية لكلية رياض الأطفال - جامعة بورسعيد}

ع - يقوم المؤلف المسؤول بتقديم شهادة بنسبة التشابهة والنزاهة الأكاديمية معتمدة من الجامعة.

0- تقدر رسوم النشر طبقاً لعدد صفحات البحث وبسدد الباحث أولاً رسوم التحكيم فقط بخزبنة الكلية بناءً على أمر توربد صادر من مالي المجلة ،وعند قبول البحث للنشر من قبل المحكمين يستكمل رسوم النشر أيضاً بناءً على أمر توريد صادر من مالي المجلة.

7- الأبحاث العلمية المكتوبة باللغة العربية لابد من نوافر النقاط التالية $-:$

\section{- - العنوان مترجم باللغة الإنجليزية .}

- عمل ملخص باللغة العربية للبحث "Abstract" - ترجمة الكلمات المفتاحية للبحث "Key Words" باللغة الإنجليزية.

- قائمة بالمراجع مترجمة باللغة الإنجليزية "References" -

V- الأبحاث العلمية المكتوبة باللغة الإنجليزية لابد من توافر النقاط

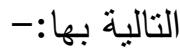

- العنوان مترجم باللغة العربية. - عمل ملخص باللغة العربية للبحث. 


\section{المجلة العلمية لكلية رياض الأطفال - جامعة بورسعيد}

^- يكون التواصل بين المؤلف المسؤول مع المجلة عن طريق سكرنير

المجلة ومن خلال البريد الاكتروني المسجل باستمارة التقدم.

ثانياً: إجراعات تحكيم الورقة البحثية :

1-بعد سداد الرسوم المقررة للتحكيم يعرض على مجلس الإدارة لتحديد

المحكمين مع الأخذ في الاعتبار مقترحات المؤلفين المسجلة في استمارة التقدم من خلال لجنة منبثقة من مجلس الإدارة من الأقسام

$$
\text { العلمية الرئيسية تسمى (لجنة توزيع الأبحاث). }
$$

r- تعرض ردود المحكمين الواردة على الأبحاث التي سبق أن حدد فيها المحكمين لاعتماد قرار النشر من عدمه وتحدد الحالات التالية:• في حالة موافقة المحكمين على البحث يتم الموافقة على نشر الورقة البحثية بالمجلة.

في حالة رفض أحد المحكمين للورقة البحثية ، تختار لجنة توزيع الأبحاث محكماً ثالثاً ،وفي حالة موافقته تتشر الورقة البحثية ،وإذا رفض يتم رفض النشر •

وفي حالة رفض المحكمين يتم رفض نشر الورقة البحثية بالمجلة.

ب- يتم إثبات تاريخ قبول البحث للنشر بتاريخ موافقة سكرتير المجلة بناء على رأي المحكمين ،ويمكن استخراج إفادة للمؤلفين بذلك. 
ع- يتم تحديد ميعاد النشر ورقم المجلد وسنة النشر حسب الدور بأولوبة تاريخ النشر وحسب حجم المجلد أو مايحدده من مجلس الإدارة من قواعد ويكون المسؤول عن تطبيقها سكرنير المجلة.

0- في حالة رفض البحث لعد استيفاء معايير التحكيم ،فان المجلة غير مسئولة عن إعادته للباحث مرة أخرى.

تكاليف نشر البحث بالمجلة:

أولاً: إجراعات رسوم التحكيم للورقة البحثية :-

ا - يحصل من الباحث مبلغ · . ج جنيهاً مصرياً رسوم تحكيم فقط ، وهي منفصلة عن رسوم النشر لعدد ب محكم فقط ،وفي حالة الحاجة لوجود محكم ثالث يجب أن يسدد الباحث مبلغ ، 10 جنيهاً إضافياً.

r- بالنسبة لرسوم التحكيم للأجانب والوافدين يحصل مبلغ بالجنيه المصري مايقابل • ه دولار بسعر البنك المركزي في يوم تسديد

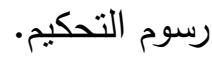


ثانياً: نشر ورقة بحثية لعضو هيئة تدريس أو هيئة معاونة من داخل

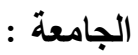

بعد قبول البحث للنشر يحصل مبلغ ، . 7 جنيهاً للبحث الواحد حتى عدد · r صفحة للبحث باللغة العربية و • 1 صفحات للبحث باللغة الإنجليزية ، ومايزيد عن ذلك يكون مقابل الصفحة الواحدة 10 جنيهاً. ثالثاً: نشر ورقة بحثية لعضو هيئة تدريس أو هيئة معاونة من خارج

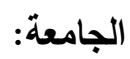

بعد قبول البحث للنشر يحصل مبلغ ، . 1 جنيهاً للبحث الواحد حتى عدد · r صفحة للبحث باللغة العربية و • 1 صفحات للبحث باللغة الإنجليزية ،ومايزيد عن ذلك يكون مقابل الصفحة الواحدة ، ب جنيهاً.

رابعاً: نشر ورقة بحثية لعضو هيئة تدريس أو هيئة معاونة من المعارين: بعد قبول البحث للنشر يحصل مبلغ . . r ا جنيهاً للبحث الواحد حتى عدد · r صفحة للبحث باللغة العربية و • 1 صفحات للبحث باللغة الإنجليزية ،ومايزيد عن ذلك يكون مقابل الصفحة الواحدة • ب جنيهاً. خامساً: نشر ورقة بحثية للأجانب والوافدين : ro. بعد قبول البحث للنشر يحصل مبلغ بالجنيه المصري مايقابل دولار بسعر البنك المركزي في يوم التسديد حتى عدد . r صفحة 


\section{المجلة العلمية لكلية رياض الأطفال - جامعة بورسعيد}

للبحث باللغة العربية و • 1 صفحات للبحث باللغة الإنجليزية ،ومايزيد عن ذلك يكون مقابل الصفحة الواحدة V دولار .

سادساً: نشر ورقة بحثية لمؤلفين مشاركين بين مصريين وغير المصريين:

أ- إذا كان البحث مشترك بين باحث مصري واحد ،باحث وافد واحد

يتقاسم الباحثان مناصفة رسوم النشر والتحكيم " الباحث المصري

بالعملة المصرية الأجنبية بماهو وارد باللائحة في هذا

الثأن،والباحث الوافد بمايقابل العملة الأجنبية بماهو وارد باللائحة

في هذا الثأن أيضاً.".

ب- إذا كان البحث مشترك بين ثناثة باحثين أو أربعة باحثين مختلفين تتطبق عليهم نفس الإجراءات السابق ذكرها كل منهم حسب نسبة

مشاركتهم في البحث. 
المجلة العلمية لكلية رياض الأطفال - جامعة بورسعيد

\section{ق ق ق ائمة الأبحاث}

الصفحة

\section{$q r \vee-\Lambda \vee q$}

$q \wedge r-q r \wedge$

\section{incie}

Brain Gym as a Strategy for Developing Some Psycho Linguistic Skills among Kindergarten Children Prone to Learning Difficulties in English Language.

Prof. Dr. Aml Mohamed Hassona. *

Prof.Dr/Jehan Mahmoud El-Bassuony.**

Rania Salem Salama Salem. ***

فعالية برنامج إرشادي لخفض بعض المخاوف المرضية المستحدثة لدى الأطفال من جائحة فيروس برس برس

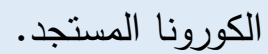
* د منى محمد إبراهيم هبد.

برنامج تدريبي لتتمية مهارة الاستماع لدى عينة من أطفال الروضة المنبئين بصعوبات تعلم قراءة اللغة $1 \cdot r \varepsilon-9 \wedge \varepsilon$

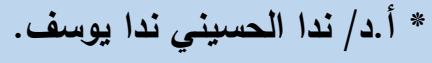

$$
\begin{aligned}
& \text { * * أ. أد/ أمل محمد حسونة. }
\end{aligned}
$$

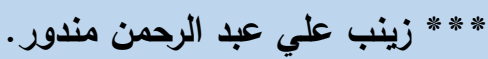


المجلة العلمية لكلية رياض الأطفال - جامعة بورسعيد

^ 1 فاعلية استخدام القصص الإككترونية في تتمية بعض

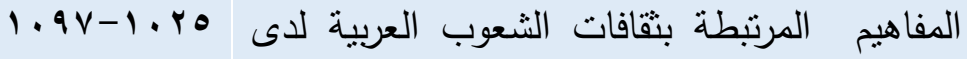

طفل الروضة.

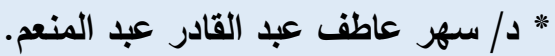

برنامج قائم على خرائط التفكير الإلكترونية في تتمية

مهارات التمبيز السمعي للغة الإنجليزية لدى طفل

$11 \leqslant 0-1 \cdot 91$

الروضة.

* أ.د/ جيهان محمود البسيوني.

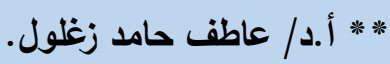

**** آية محمد عبد الباقي جودة.

فاعلية استخدام مسرح الدمى في تامية الوعي

$\mid 1 \wedge \leq-11 \leq 7$

الغذائي لأطفال الروضة.

* د / يوسف محمد كمال يوسف.

فاعلية استخدام إستراتيجية قائمة على نظرية التعلم المستندة إلى الدماغ على تتمية مهارات الحس

$\mid r \leqslant V-1110$ العددي والتفكير البصري لدى أطفال الروضة. * د إيمان لطفي عبد الحكيم خليفة. 
المجلة العلمية لكلية رياض الأطفال - جامعة بورسعيد

فاعلية برنامج قائم على مدخل ريجيو إميليا في تتمية Y Y

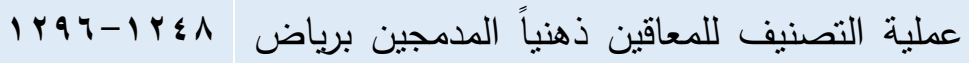
الأطفال.

* أ أ.د/ إبراهيم محمد شعير.

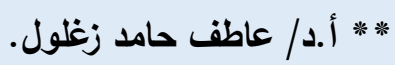

* * * * * * * سلامة عبد العزيز محمود.

فاعلية برنامج تدربي قائم على استخدام القصص في ت تمية مهارة الدافعية للإنجاز لدى أطفال

Irrs-1 IrqV الروضة.

* أ.د/ كمال الدين حسين محمد حسين.

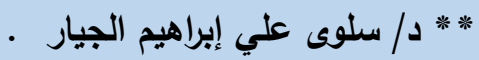

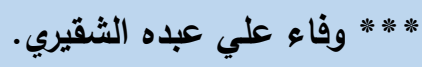

A Training Program Based on Brain Gym

to Develop Auditory and Visual Memory in English Language for Kindergarten

irqo-irro Children Predictive of Learning Difficulties.

Prof. Dr. Aml Mohamed Hassona. *

Prof.Dr/Jehan Mahmoud El-Bassuony. ** Rania Salem Salama Salem. *** 
المجلة العلمية لكلية رياض الأطفال - جامعة بورسعيد

فاعلية برنامج إثرائي متكامل لتتمية الإدراك الحسي

ومهارات التفاعل الاجتماعي لدى أطفال اضطراب

$1 \leqslant \vee \wedge-1+44$

$$
\text { التوحد (دراسة ميدانية). }
$$

* د/أندريا أنور أيوب البزنط.

دور تطبيقات الهاتف المحمول في تعزيز قيم المواطنة الرقمي لدى طلاب وطالبات بعض الجامعات المصرية "دراسة مبدانية".

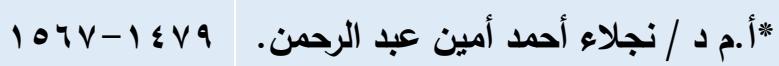
* أ. م. د /هيام عبد الرحيم أحمد علي.

$1741-1071$

فاعلية برنامج إرشادي قائم على الأنشطة الحسية في خفض بعض مظاهر الاضطرابات الحسية لدى YV الأطفال ذوي الإعاقة العقلية البسيطة. * أ.د/ أمل محمد حسونة. العبه.

* * نهى عبد الحميد رضوان.

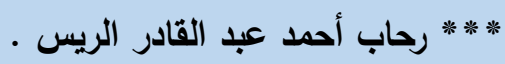




\section{المجلة العلمية لكلية رياض الأطفال - جامعة بورسعيد}

فاعلية برنامج قائم على طريقة المشروع في تتمية Y Y

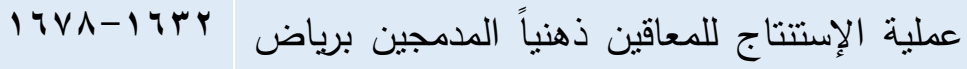

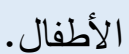

| (أ.د/ إبراهيم محمد شعير.

| * * أ.د/ عاطف حامد زغلول.

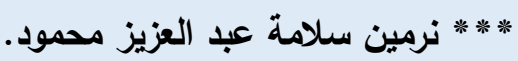

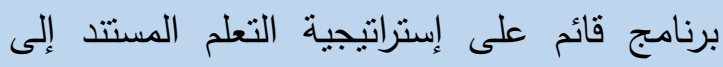

เทด^-1 เทด

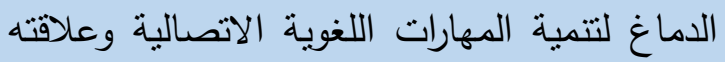
بتحسين مستوى الوعي المورفولوجي للغة لدى أطفال ما قبل المدرسة ذوبي صعوبات التعلم.

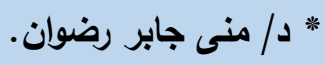

أنز برنامج في الرياضة الدماغية في تحسين كفاءة

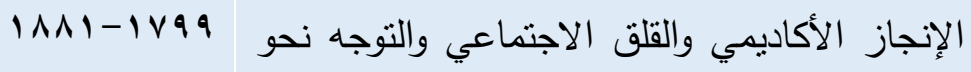

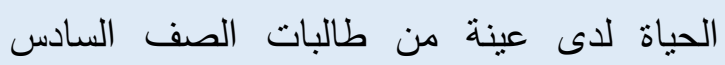
الابتدائي في دولة الكويت. " د / مصة دغيثم محمد الدغيشم. 


\section{Brain Gym as a Strategy for Developing Some} Psycho-Linguistic Skills among Kindergarten Children Prone to Learning Difficulties in English Language

\section{Prof. Dr/ Aml Mohamed Hassona. *}

Prof.Dr/Jehan Mahmoud El-Bassuony. **

Rania Salem Salama Salem. ***

\section{Abstract:}

The research aimed to measure the effectiveness of the brain gym strategy in developing some psycho-linguistic skills among gifted kindergarten children prone to difficulties in learning English language. The research followed the Quasi-Experimental Approach in the one-group method. The research tools were given in a pre-post gauge of psycholinguistic skills (prepared by the researcher), and a training program to develop some psycholinguistic skills among gifted kindergarten children prone to learning difficulties in English language (prepared by the researcher) on a sample of children (15 male and female children) at kindergarten, second level,

* Professor of Child Psychology (Ment: Head of the Psychological Science, Faculty of Early Childhood Education - Portsaid University.

** Professor of Curricula and Methods of Teaching English Language Faculty of Education - Port Said University.

*** Researcher, Department of Psychological Sciences - Faculty of Early Childhood Education - Portsaid University.

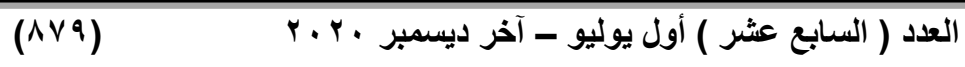


gifted children prone to learning difficulties in English language. Battery diagnostic measures for the difficulties of "social and emotional" behavior (Prepared by: Fathi El Zayat). The findings of the research reached the effectiveness of brain gym in developing some psycholinguistic skills (reception skills - correlation skills expression skills) among gifted kindergarten children prone to difficulties in Learning English.

\section{Research Terminology:}

- Brain Gym.

- Psycholinguistic Skills.

- Gifted children prone to learning difficulties in English Language.

\section{Introduction:}

The early childhood stage is one of the most important stages in which the human race goes through; therefore, preparing the child at this stage to face the future life has become an urgent requirement. Hence, such a stage is attracting care and attention of contemporary educational scholars and sociologists to form a healthy society that can face all problems. 
With the increasing number of the population, the number of groups with special needs who need special care and attention with their teaching-learning methods increased. Among these groups is the gifted group prone to learning difficulties.

Since the gifted group who are prone to learning difficulties is one of the most important groups with special needs, caring for them and their innovative capabilities and heading such capabilities to the right direction has become a necessity in developed countries, as these countries are interested in caring for their talented and gifted children, offering them various programs and modern techniques that help them to continue their superiority to optimally invest them, especially in the fields of science, arts and language. Developed countries also provides them with tangible and intangible incentives to push them to continue their perseverance and achieve more advancement and progress for their societies.

In this regard, developed countries have paid attention to studying and developing psycho-linguistic skills as significant skills for gifted children prone to learning difficulties. There is no doubt that developing or

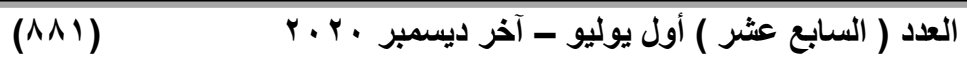


amending these skills is a vital factor for gifted children prone to learning difficulties, especially in early childhood (Saqr, 2008, 11).

One of the most important aspects of interest in these skills is to shed light on the mental and cognitive processes that take place at that stage and the mechanisms of the child's use of these modern processes and programs and various techniques, and their development, and to study the relationship between those processes and their functions in the brain. This is to improve those mental processes and effective functions that are the main driver of all activities existing in the work of the brain, as psycho-linguistic skills are one of the cognitive mental processes responsible for the issuance of language in the gifted child prone to learning difficulties (Abdel Ghaffar, Al-Sayed, Ghoneim, 2017, 353) .

Therefore, in the recent period, the field of the gifted who are prone to learning difficulties at the global and Arab level has witnessed a tremendous development in the use of different instructional and educational applications, strategies and methods so as to teach this group and train them on various skills and abilities to advance them and ensure their progress in their lives, and

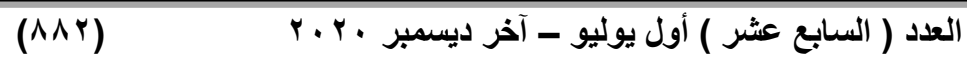


achieve the desired instructional and educational goals (Al Hateila, 2020, 79).

In this regard, the strategy of brain sport appeared, including various movements that activate the brain, which enhances the formation of a group of neurotic patterns that, in turn, positively affect the learning process. It is a therapeutic strategy that seeks to improve or restore the child's skills in the areas of attention, remembering, organizing, reasoning and understanding, problem-solving, decision-making, and high-level cognitive abilities. Such skills are all interrelated with each other.

Brain Gym is a fast and enjoyable series of effective activities that help gifted children prone to learning difficulties to gain proficiency and mastery of psycholinguistic skills, as these skills are taught within the context of balanced work to achieve the desired goals to make them easier and more coordinated. Psycholinguistic skills promoted by brain sport are seen as an integral part of a comprehensive program of selfdevelopment that works to harmoniously balance movement and learning and helps to challenge and overcome any difficulty in learning, better reflected

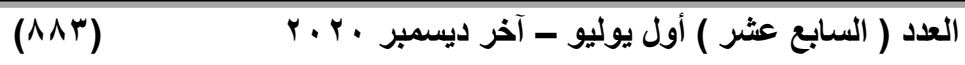


towards the desired goal, i.e. the development of some psycho-linguistic skills (Al-Sharifain \& Farah, 2011).

In the context of the current research and discussion about brain gym as a strategy that has great importance in the field of education for gifted children prone to learning difficulties, the findings of the Baqbas' study (2017) indicated the effectiveness of the brain gym strategy in improving some academic and social skills of kindergarten children with Attention Deficit and Hyperactivity Disorder (ADHD). Its findings recommended that teachers of kindergarten children with ADHD should focus on using the brain gym strategy when preparing and implementing lessons and in teaching such children different behaviors.

The findings of Abd Al-Rahman's study (2020) showed the effectiveness of brain gym activities in reducing the manifestations of Attention Deficit of pre-school children with developmental learning difficulties.

Al Hateila (2020) demonstrated the effect of brain gym strategy in improving mathematics skills among students with learning difficulties. 
Based on the importance of psycho-linguistic skills, many studies have dealt with them according to multiple topics and recommended to pay attention and employ them, e.g. Saqr's study (2017) that sought to improve psycholinguistic abilities using the multi-sensory strategy, El-Sayed's study (2018) that used a therapeutic program based on play in developing psycholinguistic skills, and the study of Abu Rayyah, Hegazy and Abdel Rahman (2011), which aimed to develop some psycholinguistic skills.

As far as the researcher knows, there is a dearth of studies that have dealt with the effect of using brain gym strategy on developing psycho-linguistic skills. Due to the importance of brain gym, the current research seeks to use it to find out its impact on the development of psycholinguistic skills among gifted kindergarten children prone to difficulties in learning English.

\section{The Research Problem:}

The development of psycho-linguistic skills is an integral part of the cognitive revolution that emerged in the beginning of the 1950's against the behavioral school. The pioneers of cognitive theories believe that the

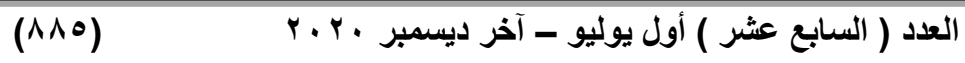


behavioral approach cannot be used in explaining some complex phenomena, including linguistic activities (Moore, 2015).

Based on this trend, and from the researcher's experience with the reality of kindergarten during her work as a kindergarten instructor and direct contact with children, and also on the basis of the importance of psycholinguistic skills and abilities in English language as one of the necessary requirements for children's adaptation to modern progress in education, and in light of some previous Arabic literature that emphasized the effectiveness of the early intervention in the development of the child's psycho-linguistic skills, and the effectiveness of the programs provided to improve these skills, the importance of psycholinguistic skills for kindergarten children in general and those who are prone to learning difficulties in particular has been evident.

Therefore, the researcher sought to study the strengths and weaknesses of the cognitive channels of gifted kindergarten children who predicted difficulties in learning the English language, with the aim of diagnosing those points and seeking to improve and develop weaknesses by setting up and designing a program to

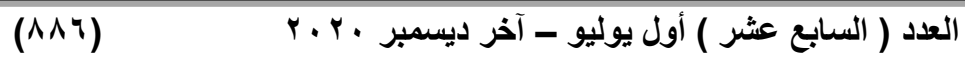


treat deficiencies in psycholinguistic skills in the research sample.

The researcher conducted open interviews with some kindergarten teachers and mothers of children. The interviews were conducted with the aim of getting acquainted with the views of both the teacher and the mother towards the skills that the child is missing and that limit creativity among the children who are prone to learning difficulties with the teacher and peers. Through these interviews, it was revealed that the child's ability and level of psycho-linguistic skills in English language is low.

The researcher also conducted open interviews with some children who are prone to of learning difficulties to determine the skills that they miss and that affect their psycho-linguistic skills in English language.

On the grounds of the foregoing, and with the researcher's observation that there are no local studies that have dealt with this topic, as this field lacked previous studies and research, and based on the importance of developing treatment strategies that help reduce the difficulties of psycho-linguistic skills in English language 
among kindergarten children who are prone to learning difficulties and improve their academic performance in English, it has been proven that the strategy of brain gym may be effective in developing the psycholinguistic skills of gifted kindergarten children prone to learning difficulties in English language.

Therefore, the current research tries to answer the following main question:

What is the effectiveness of the brain gym strategy in developing some psycho-linguistic skills among gifted kindergarten children prone to learning difficulties in English language?

This main question is divided into the following subquestions:

1. What are the psycho-linguistic skills that need to be developed among gifted kindergarten children prone to difficulties in learning English language?

2. What training activities can develop psycholinguistic skills for kindergarten children prone to English language learning difficulties? 
3. What are the differences between the mean scores of the gifted kindergarten children prone to difficulties in learning English language in the pre-post measurement of the Psycholinguistic Skills Scale?

4. What are the differences between the mean scores of the gifted kindergarten children prone to difficulties in learning English language in the post and follow-up measurement of the Psycholinguistic Skills Scale?

\section{The Research Objective:}

In general, the research aimed to measure the effectiveness of the brain gym strategy in developing the psycholinguistic skills of gifted kindergarten children to reduce learning difficulties in English language, in addition to knowing the extent to which the psycholinguistic skills of children have improved after applying the program later.

\section{Importance of the Research:}

- The research gains its importance from the scarcity of Arabic studies, which dealt with the psycholinguistic skills of gifted children prone to learning difficulties, to the best of the researcher's knowledge. 
- The importance of the current research also comes through dealing with an important aspect of the educational process, which is to reveal the effect of the brain gym strategy on developing some psycho-linguistic skills among gifted kindergarten children prone to learning difficulties in English language.

- The results of this research and the knowledge contained in it may contribute to raising the level of cognitive awareness of kindergarten teachers and mentors about taking advantage of the measures of brain gym strategy in their interaction with gifted children who are prone to difficulties learning English language and improving the level of psycho-linguistic skills in English language.

\section{Methodological Procedures of the Research:}

\section{First: The Research Sample:}

The current research sample consisted of (15) gifted kindergarten children who are prone to difficulties in learning English language at the age of (5-6) years. It is a systematic sample selected from Port-Said Language School Kindergarten in Port Said Governorate. The form of "Indicators of The Gifted Prone to Learning Difficulties" was distributed on female teachers to assess

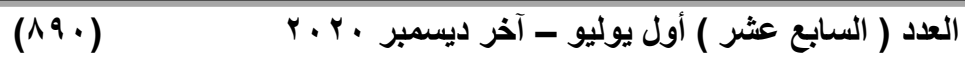


the children in the four halls, including (15) children (boys and girls) at the second level. The (15) children and (boys and girls) who are agreed upon as gifted children prone to learning difficulties have been identified according to the indicators of learning difficulties and through the opinions of the teachers. The homogeneity of the children of the study sample was taken into account by observing the following:

1. The chronological age of all the children of the sample ranges between (5-6) years.

2. IQ scores should not be less than (90-110) on the Stanford-Binet scale, Fifth Edition.

3. Children got the highest marks in the difficulty scale, prepared by (Fathi Mustafa Al-Zayat)

4. Children of the sample who are obligated to attend kindergarten, which facilitates their commitment to attend and then undergo the current study program.

5. Those with obvious health problems or disabilities were excluded from the research sample so as not to affect the sample's performance in the program.

Based on the previous conditions, the study sample was identified (15) boys and girls (9) males, and (6) females. Data were collected on the chronological age of the

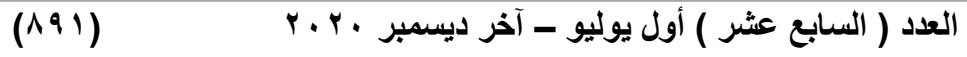


sample members from the lists of the school administration.

\section{Second: Research Methodology:}

The quasi-experimental approach, one-group design, was used to investigate the effectiveness of the brain gym strategy in developing psycho-linguistic skills among gifted kindergarten children prone to learning difficulties.

\section{Third: Research Instruments:}

The researcher prepared the following instruments:

1. A scale of psycho-linguistic skills among gifted kindergarten children prone to learning difficulties (prepared by the researcher)

2. A program based on brain gym to develop the psycholinguistic skills of gifted kindergarten children prone to learning difficulties (prepared by the researcher)

3. A scale of psycho-linguistic skills among gifted kindergarten children prone to learning difficulties: The scale consists of six sub-tests divided into three main areas that cover linguistic communication methods and their levels, and the psychological and mental processes involved in those methods. These areas and their sub-tests

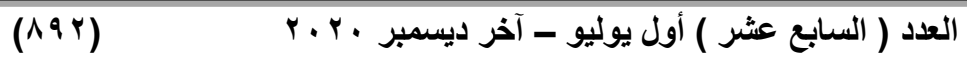


are as follows:

\section{The first area: (reception skills):}

It means the ability of a kindergarten child to comprehend spoken or written English words, and it includes:

1) Auditory reception: It refers to the kindergarten child's ability to understand spoken English words, meaning (extracting the meaning from the material presented to him/her verbally). The response to the test here does not require the child's ability to express, but the answer is Yes or No.

2) Optical reception: It means the ability of the kindergarten child to understand pictures and words written in the English language by matching a picture with another related image, meaning (gaining meaning from visual symbols).

\section{The second area: (correlation skills):}

It means the ability of a kindergarten child to perceive the relationships between visual or auditory symbols, and it includes: 
1) Auditory correlation: It means the ability of the kindergarten child to relate concepts and ideas presented to him/her in a verbal way, meaning (linking words spoken in a meaningful way).

2) Visual correlation: It means the ability of the kindergarten child to connect concepts and ideas presented to him/her in a visual way, meaning (linking between homogeneous or related visual stimuli).

\section{The third area: (expression skills):}

It refers to the ability of the kindergarten child to put ideas into words and express them with a gesture or sign, and it includes:

1) Verbal expression: It means the ability of the kindergarten child to express things phonetically in the form of spoken English words.

2) Manual expression: It means the ability of the kindergarten child to express things in a manual or kinesthetic manner.

The scale was rationed in terms of reliability validity as follows: 


\section{Reliability of the Scale:}

The researcher used (Cronbach's Alpha Coefficient) to measure the reliability of the scale on a pilot sample consisting of (30), and it was excluded from the main sample of the study. The following table illustrates the statistical procedure:

Table (1)

Demonstrates reliability coefficients for the Psycholinguistic Skills Scale using Cronbach's Alpha

\begin{tabular}{|l|l|}
\hline $\begin{array}{l}\text { Dimensions of the } \\
\text { Psycholinguistic Skills } \\
\text { Scale }\end{array}$ & $\begin{array}{l}\text { Cronbach's Alpha } \\
\text { Coefficient }\end{array}$ \\
\hline Reception Skills & 0.820 \\
\hline Correlation Skills & 0.895 \\
\hline Expression Skills & 0.902 \\
\hline Total Score & 0.886 \\
\hline
\end{tabular}

Table No. (1) Shows that the general reliability coefficient for the scale dimensions is high as it reaches $0,886 *$ for the total items of the scale. This indicates that the scale has a high degree of reliability to be relied upon in the area of application of the search according to the 
Nunnalle Scale, which adopts 0,70 as a minimum limit for reliability.

\section{Validity of the Scale:}

Validity of Terminal Comparisons:

The scale was applied to the standardization sample $(n=30)$ of gifted kindergarten children who were not included in the final application of the scale, with the aim of calculating the differences between the highest and lowest quartiles $(27 \%)$ of the children's scores, by using the $(\mathrm{T})$ test shown in the following table:

\section{Table (2)}

Results of the "T" test to study the differences between the averages of the peripheral groups of the Psyco-Linguistic Skills Scale for the pilot sample

\begin{tabular}{|c|c|c|c|c|c|c|c|c|}
\hline \multirow{2}{*}{ Variable } & \multicolumn{3}{|c|}{ Higher Quadrant } & \multicolumn{3}{|c|}{ Lower Quadrant } & \multirow[b]{2}{*}{$\begin{array}{c}\mathrm{T} \\
\text { Value }\end{array}$} & \multirow{2}{*}{$\begin{array}{l}\text { Significance } \\
\text { Level }\end{array}$} \\
\hline & $\mathrm{N}$ & Mean & $\begin{array}{c}\text { Standard } \\
\text { Deviation }\end{array}$ & $\mathrm{N}$ & Mean & $\begin{array}{c}\text { Standard } \\
\text { Deviation }\end{array}$ & & \\
\hline $\begin{array}{l}\text { Psycho- } \\
\text { Linguistic } \\
\text { Skills as a } \\
\text { Whole }\end{array}$ & 8 & 8.750 & 0.462 & 8 & 5000 & 0.000 & 22.913 & 0000 \\
\hline
\end{tabular}


According to the above-mentioned table, It is evident that there is a statistically significant difference at the level (0.001) between the upper and lower quadrants on the psycho-linguistic skills scale in favor of the average of the higher quadrant in the total sample. This indicates that the Psycho-linguistic Skills Scale has a high ability to distinguish between children with high psycho-linguistic skills and those with low psycho-linguistic skills.

Thus, the researcher has made sure that the Psycholinguistic Skills Scale has a high degree of reliability on the pilot sample of the current research.

\section{A program based on the brain gym strategy to} develop the psycho-linguistic skills of gifted kindergarten children prone to English language learning difficulties:

The researcher has designed and implemented a set of (32) training sessions based on a brain gym strategy. She has also prepared activities to cover all dimensions of psycho-linguistic skills, the subject of the study (i.e. reception skills, correlation skills, and expression skills). The activities have been designed to develop such skills while being used correctly for gifted kindergarten

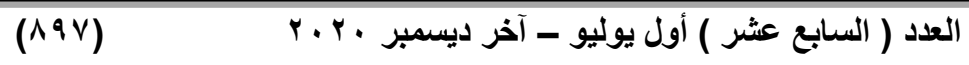


children who are prone to learning difficulties.

\section{Program Building Steps:}

The program was built with the following steps:

First: the main objective:

Developing some psycho-linguistic skills in English language among gifted kindergarten children prone to difficulties in learning English language

\section{Second: The sub-objectives:}

- Developing the child's ability of auditory reception,

- Developing the child's ability of visual reception,

- Developing the child's ability of auditory interconnection,

- Developing the child's ability of visual interconnection,

- Developing the child's ability of verbal expression, and

- Developing the child's ability of manual expression.

\section{- Cognitive objectives:}

- After completing the program, the child should be able to:

- Learn common concepts and terms used in activities,

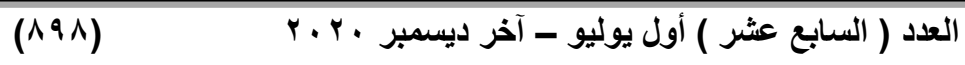


- Ask about new things,

- Simulate simple letters and words in creative ways,

- Identify creative methods for implementing the activity.

- Mention the steps of the game.

- Repeat the correct sounds of letters and words s/he heard.

- Respond to the teacher's questions.

- Take the initiative to speak English.

- Connect kinesthetic performance with implementing language skills.

- Answer the questions asked in English.

- Understand the rules of exercises during the activity.

- Understand creative methods before carrying out the activity.

- Mention the letters of his/her name in English, and pay attention to brain gym exercises.

\section{- Skill objectives:}

After completing the program, the child should be able to:

- Perform the required movements.

- Follow a planned path to draw a picture, letter and word.

$$
\text { r.r. العدد ( السابع عثر ) أول يوليو - آخر ديسمبر }
$$


- Imitate the teacher's correct ways of exercises and activities.

- Do some brain gym exercises.

- Recognize converging sounds in pronunciation.

- Practice some brain gym exercises.

- Move his/her hands and feet correctly during an activity.

- Use new methods of language development.

- Use new words, grammar, and structures in speech.

\section{- Affective goals:}

After completing the program, the child should be able to:

- Respect his/her colleagues and appreciate belonging to the group.

- Feel his/her talent during the activity.

- Collaborate with the teacher in a variety of creative ways during the implementation of the activity.

- Respect the rules of carrying out exercises.

- Feel satisfied and happy through the activities.

- Participate in activities.

- Find creative ways to implement exercises and activities of brain gym.

- Show a response that denotes joy. 
- Collaborate with teammates to help the group win.

- Appreciate the importance of activities.

- Respect the opinions of colleagues.

- Feel happy through the activities.

- Participate in activities.

- Respect the rules of the instructional game.

- Find it easy to play with other children.

- Collaborate with the teacher while performing exercises.

- Want to do things over and over in creative ways.

- Take initiative to speak with the teacher.

Second: Designing sessions and activities of the program based on the strategy of brain gym:

In light of the objectives that the program seeks to achieve, (23) training sessions have been determined aimed at developing psycho-linguistic skills to reduce learning difficulties in the English language.

\section{Third: Preparing the evaluation instruments:}

The purposes of evaluating the brain gym program appear as follows:

1) Ensure the effectiveness of the brain gym strategy in

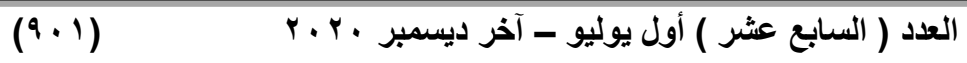


developing psycho-linguistic skills among gifted kindergarten children prone to learning difficulties in English language.

2) Identify the difficulties that children face during the implementation of the brain gym program.

Three methods of assessment are used in the program:

1) Pre-assessment: This is done before implementing the program by applying the Psycho-linguistic Skills Scale to the children of the experimental group, and recording the children's grades on the scale in order to determine the psycho-linguistic difficulties while learning English language.

2) Formative assessment: The child is evaluated continuously from the beginning of the program until its end. This is done on a daily basis during or after the presentation of the activity through cards presented to children daily as an application of the activity, and can be called (individual assessment) to know the progress made by children after they have undergone the Brain Gym Program, then compare this to their scores before exposure to the program.

3) Post-assessment: It is used after the completion of the application of the Brain Gym Program to find out the

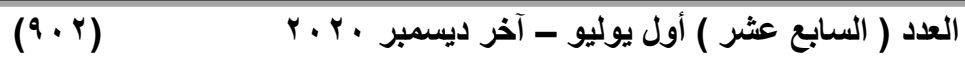


progress achieved by the program and compare that with the children's scores before exposure to the program. This is done by re-applying the Psycho-Linguistic Skills Scale on the children.

\section{Research Hypotheses:}

Based on the research problem and objectives, the researcher puts the following hypotheses for the research:

1) There are statistically significant differences between the mean scores rank of the experimental group children (the experimental study sample) on the Psycho-Linguistic Skills Scale of gifted kindergarten children prone to learning difficulties in English language before/after the application of the Brain Gym Program in favor of the post-measurement.

2) There are no statistically significant differences between the mean scores rank of the experimental group children (the experimental study sample) on the PsychoLinguistic Skills Scale of gifted kindergarten children prone to learning difficulties in English language, in the post and follow-up measurements. 


\section{Research Findings:}

The hypotheses formulated were tested with the aim of ensuring the effectiveness of the brain gym strategy in developing psych-linguistics skills among gifted kindergarten children prone to learning difficulties in English language.

\section{Findings of the First Hypothesis: Discussion and Interpretation:}

The first hypothesis of the research states that:

"There are statistically significant differences between the mean scores rank of the experimental group children (the experimental study sample) on the Psycho-Linguistic Skills Scale for gifted kindergarten children prone to learning difficulties in English language before/after the application of the Brain Gym Program in favor of the post-measurement."

To verify the validity of this hypothesis, the researcher used the Wilcoxon Test for Related Groups, to find the significance of the differences between the mean scores rank of gifted kindergarten children before applying the program, and the mean scores of the same group after 
applying the program, as shown in the following table:

Table (3)

The mean and sum of the negative and positive ranks and the $Z$ value between the pre and post measures on the Psycho-Linguistic Skills Scale as a whole by Wilcoxon Method

\begin{tabular}{|c|c|c|c|c|c|c|}
\hline \multirow[t]{2}{*}{ Skills } & \multirow{2}{*}{$\begin{array}{l}\text { Rank of } \\
\text { the } \\
\text { Psycho- } \\
\text { Linguistic } \\
\text { Skills } \\
\text { Variable }\end{array}$} & Number & \multicolumn{2}{|c|}{$\begin{array}{c}\text { Pre/post } \\
\text { Measurement }\end{array}$} & \multirow[b]{2}{*}{ Z Value } & \multirow[b]{2}{*}{$\begin{array}{l}\text { Statistical } \\
\text { Significance }\end{array}$} \\
\hline & & $(\mathrm{N})$ & $\begin{array}{l}\text { Ranks } \\
\text { Mean }\end{array}$ & $\begin{array}{l}\text { Ranks } \\
\text { Total }\end{array}$ & & \\
\hline \multirow{4}{*}{$\begin{array}{l}\text { Psycho-- } \\
\text { Linguistic } \\
\text { Skills as } \\
\text { a Whole }\end{array}$} & $\begin{array}{c}\text { Negative } \\
\text { Ranks }\end{array}$ & 0.0 & 0.00 & 0.00 & \multirow[t]{4}{*}{-3.424} & \multirow[t]{4}{*}{0.001} \\
\hline & $\begin{array}{l}\text { Positive } \\
\text { Ranks }\end{array}$ & 15 & 8 & 120 & & \\
\hline & $\begin{array}{l}\text { Neutral } \\
\text { Ranks }\end{array}$ & 8 & & & & \\
\hline & $\begin{array}{c}\text { Total } \\
\text { pummation }\end{array}$ & 15 & & & & \\
\hline
\end{tabular}


From the above table, it is evident that there are statistically significant differences at the level of significance (0.001) between the score ranks mean of gifted children who are prone to learning difficulties who are members of the study sample before and after the application of the program on the dimension of PsychoLinguistic Skills Scale as a whole used in the current study in favor of the post application. The $\mathrm{Z}$ values between the pre and post applications of the current study sample have gone to (-3.424).

\section{Interpretation and Discussion of the First Hypothesis Findings:}

It is evident, from the previous table, that there are statistically significant differences between the score ranks of the experimental group before and after applying the program on the Scale of Psycho-Linguistic Skills as a whole. The researcher attributes these differences to the brain gym strategy used in this research, where the lack of psycholinguistic abilities experienced by gifted kindergarten children who are prone to learning difficulties (the research sample) is an important factor influencing the deficiency of language skills in English language. The lack of psycho-linguistic skills is reflected

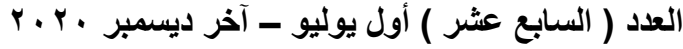


in the child's deficiency in both reception and audiovisual interconnection, which affects the ability of these children to satisfy their needs and desires to learn English language, as well as the ability to recall and remember audio and visual information, which in turn, affects their ability to follow instructions and recall information related to the language. This of course required the preparation of the current program, including many objectives and activities based on brain gym that the researcher sought to prepare in a way that suits the capabilities of gifted children who are prone to learning difficulties to achieve the aims of the current study. The objectives of the program were applied to the members of the experimental group, which contributed to finding statistically significant differences between the mean scores of the experimental group's children's score ranks before and after the implementation of the program on psycho-linguistic skills in favor of the post application.

The researcher's brain gym exercises helped gifted kindergarten children who are prone to learning difficulties, as brain sport activities played a large role in helping children understand and absorb the new language and develop it in innovative and new ways. Since the

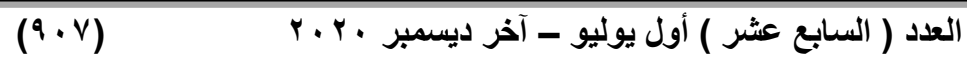


English language and its establishment for children should be given all the care and attention, it is no secret to any of us that the learners suffer from linguistic weakness in the different stages of education, whether in their speech, writing, or reading, which is caused by various factors, including the lack of developing the methods used in teaching English language, the lack of interest of the child's family members in the language, the negative use of pressures, and the resort, in most cases, to punishment during teaching the language, without taking into account the innate preparations and natural growth and not using modern and innovative means to develop gifted children who are prone to learning difficulties.

For children, the new language needs stimulation and creativity in order for the child to master it without boredom or fear. Many English language teachers in different instructional stages still adopt sterile methods of teaching that do not attract children and do not work to develop their linguistic vocabulary and develop their language skills as required. In fact, some of these methods diminish the enthusiasm for learning English language, weaken the ability to acquire its correct vocabulary and formulas, and lead to aversion to its

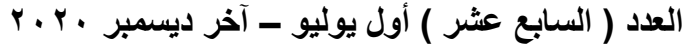


lessons.

Despite the current linguistic situation and the general weakness of children in English language, we see the lack of academic studies that look into the real causes of such weakness and the its consequences. Therefore, the researcher was interested in developing psycho-linguistic skills in English from the beginning of the educational stage with the aim of empowering the child with language skills, by providing them with basic skills, such as listening, speaking, reading, and writing, in addition to helping them acquire its correct practices and sound directions. This also gradually develop such skills at all instructional stages so that, at the end of this stage, the child reaches a language level that enables him/her use the language in a way that aids them to continue studying at the following educational stages. One of the most essential factors in the communication process is reception.

Therefore, the researcher was interested in developing reception skills to learn English correctly in terms of speaking and pronunciation.

Since the second language plays an important and 
tangible role in human life as it is the main means of acquaintance and interaction between all people, seeking to enhance and develop it according to the characteristics, readiness and ability of man begins from the first stages of instruction.

The researcher saw weak reception, interconnection, and expression skills in English language among gifted children who are prone to learning difficulties; therefore, the researcher used modern methods of innovative programs, as well as various and innovative activities to develop the psycho-linguistic skills in English language among gifted children who are prone to learning difficulties.

The researcher has used brain gym exercises and activities that resemble a field which most countries of the world seek to rely on for instruction and training in early childhood, especially gifted children who are prone to learning difficulties. That is because experts in the field of special education realize the importance of brain gym activities and exercises because they lead to the prevention of many problems, and stimulate such children to learn innovatively. 
The stage of childhood occurs in what is known as "critical periods of development, where the child is at the height of his/her preparations and ability to grow and change. Therefore, the use of speaking and listening skills through brain gym activities helps to invest those periods to develop the child's mental, linguistic and social abilities.

Educators and psychologists have unanimously agreed that kindergarten is the most important period in a child's life. Hence, the urge to engage in physical and mental activity "brain gym" at this stage is considered a matter of great importance. If the child is not able to treat the problems that arise during that period, s/he is able to alleviate them, or at least be able to prevent their exacerbation in the future.

Numerous studies and researches concerned with early detection of gifted people who are prone to learning difficulties indicate that the ability of this group to make any progress or educational effectiveness is steadily diminishing with delayed detection and treatment of them via physical activity. These studies also confirm that early detection of them has a positive effect on the effectiveness of programs and activities prepared for their 
treatment.

Therefore, the need for early identification, diagnosis and treatment of this group is a basic and important prerequisite for dealing with its members.

Results of the second hypothesis: discussion and interpretation:

The second hypothesis of the research states, "There are no statistically significant differences between the mean score ranks of the experimental group children (the experimental study sample) on the Psycho-Linguistic Skills Scale of gifted kindergarten children prone to learning difficulties in English language in the post and follow-up measurements."

To verify the validity of this hypothesis, the researcher used the Wilcoxon Non-Parametric Test to reveal the significance of the differences between the post and follow-up measurements of the research sample. Table (4) illustrates what the findings have revealed: 


\section{Table (4)}

The mean and sum of negative and positive ranks and the $Z$-value between the post and follow-up measures of the Wilcoxon

Psycholinguistic Skills Scale

Scale

Psycho-

Linguistic

Skills as

Whole

\begin{tabular}{|c|c|c|c|c|c|}
\hline \multirow{2}{*}{$\begin{array}{l}\text { Ranks of the } \\
\text { variable in the } \\
\text { Psycholinguistic } \\
\text { Skills Scale }\end{array}$} & Number & \multicolumn{2}{|c|}{$\begin{array}{l}\text { Follow-up \& } \\
\text { post } \\
\text { measurement }\end{array}$} & \multirow[t]{2}{*}{ Z-value } & \multirow[t]{2}{*}{$\begin{array}{l}\text { Its } \\
\text { Significance }\end{array}$} \\
\hline & $\mathrm{N}$ & $\begin{array}{l}\text { Ranks } \\
\text { Mean }\end{array}$ & $\begin{array}{l}\text { Ranks } \\
\text { Total }\end{array}$ & & \\
\hline Negative Ranks & 0.0 & 0.00 & 0.00 & 0.000 & 1.000 \\
\hline Positive Ranks & 15 & 8 & 120 & & \\
\hline Neutral Ranks & 0 & & & & \\
\hline $\begin{array}{l}\text { Total } \\
\text { Summation }\end{array}$ & 15 & & & & \\
\hline
\end{tabular}

The above table shows that there are no statistically significant differences between the mean score ranks of gifted children who are prone to learning difficulties (individuals of the study sample) after implementing the program and after a month of post application of the 
Scale of Psycho-Linguistic Skills as a whole, used in the current research, and the Z-values reached between the post and follow-up measurements of the study sample on the scale as a whole (0.000).

\section{Interpretation of the second hypothesis findings:}

It is evident, from the previous table, that there are statistically significant differences between the score ranks of the experimental group in the post and follow-up application on the Scale of Psycho-Linguistic Skills as a whole. The researcher attributes these differences to the brain gym strategy used in the current research, as this is due to the continuing effect of brain gym on the research sample in the total score of the Psycho-Linguistic Skills Scale used in the post and follow-up-measurement.

This may be due to the mental age convergence of the children, which led to the convergence of their responses despite the repetition of the follow-up application after a month of the post application, which, in turn, indicates the stability of effect of the program.

The researcher believes that the use of brain gym contributed to improving the child's motivation to accomplish the activities required of them. The diversity

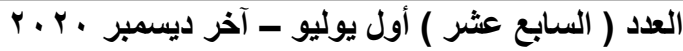


in the use of audio-visual stimuli included in the training program led to the motivation of the child to pay attention to those stimuli more positively, and improved the child's performance in terms of receptivity. During the implementation of the training program, the researcher noticed the transfer of the impact of improving receptive skills from the child's reception of audio-visual stimuli to an improvement in the reception and understanding of verbal instructions addressed to them. The child's ability to receive the researcher's verbal vocabulary during the performance of the training program activities increased.

The current research findings showed the effectiveness of using brain gym activities in developing psycholinguistic skills (reception, interconnection, and expression) among gifted kindergarten children with learning difficulties, as was evident from the results of the research hypotheses. This reflects the tangible improvement in psycho-linguistic skills that are measured by the Psycho-Linguistic Skills Scale after implementing the program, which indicates the feasibility of the program in developing psycho-linguistic skills.

Perhaps the program's dependence on the brain gym activities has increased the effectiveness of the program 
used. In addition, taking into account the characteristics of gifted children with learning difficulties in preparing the program has increased its effectiveness, in addition to the fact that the children of the experimental sample have an intelligence level located in the medium term. Consequently, when a suitable learning environment was created for them, which would enable them to benefit from their abilities, it resulted in their learning as it appeared in the improvement of the level of their psycholinguistic skills after applying the proposed training program.

This result is consistent with what was presented by the theoretical heritage and previous studies on programs that work to develop skills and psycho-linguistic abilities, with the need to emphasize enriching the environment surrounding a gifted kindergarten child prone to learning difficulties with resources and capabilities that help them develop their audio and visual independence skills, optical and audio interconnection, and the skills of verbal and manual expression..

The effectiveness of the use of brain gym and the spirit of fun that dominated it can be attributed to utilizing it in the context of competitive games among children, which 
increased their attention and awareness.

Previous studies and theoretical frameworks have confirmed that gifted kindergarten children prone to learning difficulties in English language benefit from the programs offered to them, especially in the field of psycho-linguistic skills, such as Saqr study (2008) that aimed to reveal the differences between individuals with learning difficulties in the academic fields (reading and writing) and normal ones in performance on the Illinois Battery's sub-tests of psycho-linguistic abilities.

The researcher attributes the effectiveness of the current research program to the inclusion of brain sport, which stimulates and activates the manifestations of reception, visual and auditory interconnectedness of the gifted child with learning difficulties and activates his role. This results in increasing the child's motivation to learn actively and efficiently.

The effectiveness of the program based on brain gym on developing psycho-linguistic skills (auditory reception, visual reception, optical interconnection, auditory interconnection, linguistic expression, and manual expression) is also evident in this research 
through the improvement in the aspects of reception, correlation and expression among the members of the experimental group. This was done through the PsychoLinguistic Skills Scale, whose results indicated an improvement in the reception, correlation and expression skills of children through the post-measurement. This improvement of gifted kindergarten children prone to learning difficulties (children of the experimental group) is due to the fact that they have been affected by the program based on brain gym, which aims to develop psycho-linguistic skills (auditory reception, visual reception, optical interconnection, auditory interconnection, linguistic expression, and manual expression).

Due to the increased motivation provided by the program for gifted kindergarten children with learning difficulties, and their desire to learn brain gym activities that led to an improvement in the manifestations of psycho-linguistic skills (auditory reception, visual reception, optical interconnection, auditory interconnection, linguistic expression, and manual expression), the study program could develop the psycholinguistic skills of gifted kindergarten children who are 
prone to learning difficulties in English language, depending on the activities of brain gym, which confirms the effectiveness of the current research program.

The researcher attributes the improvement of children's performance on the Psycho-Linguistic Skills Scale to the use of brain gym, which is an important method on which the current study program relied for developing psycholinguistic skills (auditory reception, visual reception, optical interconnection, auditory interconnection, linguistic expression, and manual expression).

The sessions also included musical, story and kinesthetic activities related to brain gym activities that help to increase the concentration of the reception time for children and focus on performing the required tasks, which leads to the development of reception skills.

The researcher explains the improvement in children's performance after the program due to taking into account the mental characteristics of gifted kindergarten children with learning difficulties. In addition, the study program relied on group sessions containing small groups to train the child in psycho-linguistic skills. Thus, the reliance of the program sessions on group activities is one of the 
factors that helped the effectiveness of the current program and the improvement of children's performance in doing brain gym activities and thus the development of psycho-linguistic skills.

The results of the hypotheses indicated the effectiveness of the program used in the research in the development of psycho-linguistic skills (auditory reception, visual reception, optical interconnection, auditory interconnection, linguistic expression, and manual expression) among gifted kindergarten children who are prone to learning difficulties in English language (members of the experimental group). It indicates the presence of positive effects of the program in providing experiences and brain-motor practices that led to improvement of psycho-linguistic skills (auditory reception, visual reception, optical interconnection, auditory interconnection, linguistic expression, and manual expression). This, in turn, can lead to many positive effects on gifted kindergarten children who are prone to learning difficulties. Therefore, it was rational that the children of the experimental group showed significant improvement after undergoing the study program based on brain gym. 
Thus, the hypotheses of the current study on the effectiveness of the current program in developing psycho-linguistic skills (auditory reception, visual reception, optical interconnection, auditory interconnection, linguistic expression, and manual expression) were realized in accordance with the previous interpretation of the results and depending on the theoretical heritage and various theories of learning.

Thus, all the results of the current research indicate that all the hypotheses that the researcher tried to answer in the current research have been fulfilled, and they all aim to verify the effect of using the kinesthetic brain gym on developing psycho-linguistic skills (auditory reception, visual reception, optical interconnection, auditory interconnection, linguistic expression, and manual expression) for gifted kindergarten children with learning difficulties. The results are evident through a comparison between the responses of the children of the experimental group in the pre- post- and follow-up measurements.

These findings confirm the effectiveness of using the brain gym strategy in developing psycho-linguistic skills (auditory reception, visual reception, optical interconnection, auditory interconnection, linguistic 
expression, and manual expression) in gifted kindergarten children prone to learning difficulties in English language.

Based on the above, and by accepting the two hypotheses of the research, the strategy of brain gym has done well in developing psycho-linguistic skills (auditory reception, visual reception, optical interconnection, auditory interconnection, linguistic expression, and manual expression) among gifted kindergarten children who are prone to learning difficulties in English language.

Hence, the effectiveness of brain gym in developing psycho-linguistic skills (auditory reception, visual reception, optical interconnection, auditory interconnection, linguistic expression, and manual expression) in gifted children prone to learning difficulties in English language is confirmed.

\section{Recommendations and Proposals:}

Based on the foregoing, the researcher can mention the following recommendations and suggestions:

1. Holding lectures and awareness seminars for parents 
who have gifted children who are prone to learning difficulties in English language to familiarize them with their children's learning difficulties, characteristics, needs, and appropriate programs.

2. Trying to inform parents about the conditions of gifted children prone to learning difficulties in English language, encourage them to accept their capabilities and convincing them of the possibility of using these capabilities to produce a child with learning difficulties who is effective and compatible with themselves.

3. Holding special courses for ordinary teachers who teach gifted children prone to learning difficulties in English language on a regular basis to familiarize them with children with learning difficulties and how to deal with them.

4. Conducting special programs for gifted children prone to learning difficulties in English language to equip them with social communication skills and raise their selfconcept.

5. Conducting more research on psycho-linguistic skills in English language for gifted children who are prone to 
learning difficulties, this measures the extent to which parents know the characteristics of their children who suffer from learning difficulties.

6. Conducting further research and studies dealing with linguistic skills in English language for gifted children who are prone to learning difficulties in environments other than those in which this study was conducted in order to generalize the findings to a larger possible sample.

\section{Suggested Research:}

1. Conducting a study on the effectiveness of a training program to develop reception skills for gifted children prone to learning difficulties.

2. Conducting a study on the importance of brain gym to help teach English language to gifted children prone to learning difficulties and dealing with the surrounding community.

3. Doing a study dealing with training kindergarten teachers to develop the psycho-linguistic skills of kindergarten children. 
4. Conducting a study on the effectiveness of a counseling program to learn the basics of brain gym for successful communication with gifted kindergarten children who are prone to learning difficulties.

5. Conducting a study that deals with the effectiveness of training mothers on how to teach languages to gifted children who are prone to learning difficulties.

6. Conducting a study that deals with a training program using brain gym to modify some wrong behaviors for kindergarten children.

\section{Bibliography}

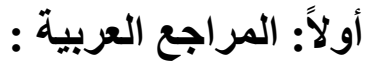

- أبو ريـة، سـارة فتحي أحمد؛ حجـازي، سناء محمد نصر ؛ وعبد الرحمن،

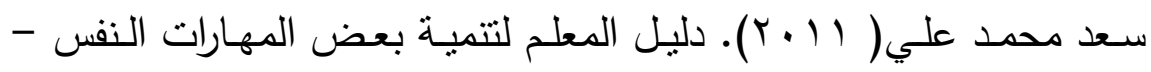
لغوية لأطفال ضعاف السمع مجلة البحث العلمي في التربية: جامعة عبن

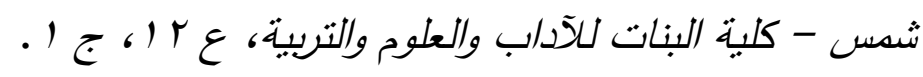

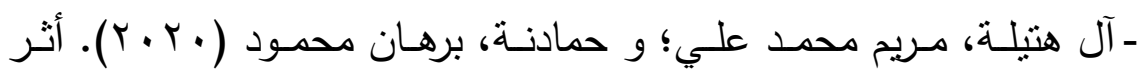
إسـتراتيجية رياضـة الـماغ في تحسـين الرياضـيات لـدى التلميذات ذوات 
صعوبات التعلم .المجلة السعودية للتربية الخاصسة: جامعة الملك سعود، $.1 \mathrm{re}$ - باقبص، حنان علي (Y V • r). أثر إستراتيجية رياضـة الدماغ في تحسين بعض المهارات الأكاديمية والاجتماعية لدى أطفال الروضـة ذوي اضطراب تشتت الانتباه والنشاط الزائد .مجلة كلبة رباض الأطفال: جامعة بورسعبي كلية رباض الأطفال، ع. ـ السبد، زبنب ماضسي محمود (1 ( • r).فعالية برنامج علاجي باللعب في تنعبة القدرات النفس لغوبة لدى الأطفال ذوي الإعاقة الذهنبة القابلين للتعلم • رسالة دكتوراه غير منشورة. كلية التربية . جامعة حلوان. ـ الثريفين، أحمد عبد الله محمد؛ والفرح، عدنان (Y ( ( ). فاعلية برنامج إرشـادي مسـتـد إلىى رياضـة الـدماغ في خفض اضـطراب نقص الانتبـاه المصحوب بالنشاط الزائد .دجلة العلوم الإنسانية والاجتماعية: جامعة الإمام محمد بن سعود الإسالاية - عمادة البحث العلدي، عrr. - صقر ، السيد أحمد محمود (ی . . r). القدرات النفس لغوية لدى التلاميذ ذوي صعوبات التعلم بالحلقة الأولى من التعليم الأساسي، التربية المعاصرة:

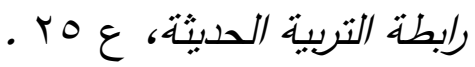

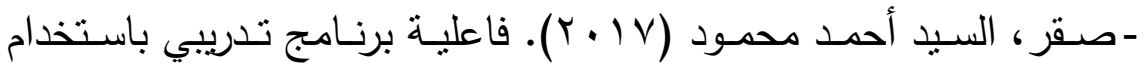
إستراتيجية الحواس المتعددة في تحسبن القدرات النفس لغوبـة لدى التلاميذ 
ذوي صـوبات تعلم القراءة بالصف الثالث الابتدائي .المجلـة المصسية

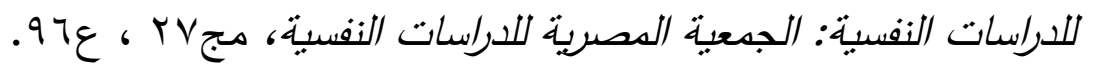

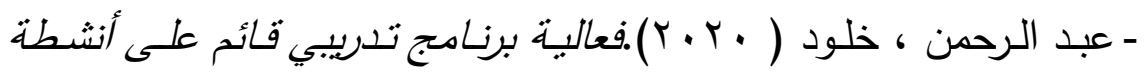

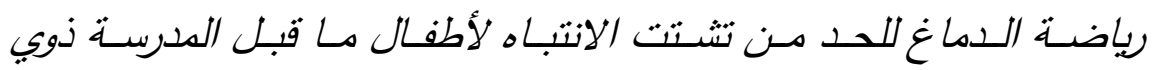
صعوبات التعلم النمائية . رسالة دكتوراه غير منشورة. كلية التربية للطفولة المبكرة. جامعة بورسعيد.

- عبد الغفار ، محمد عبد القادر ؛ السيد، زينب ماضي محمود؛ وغنيم، محمد

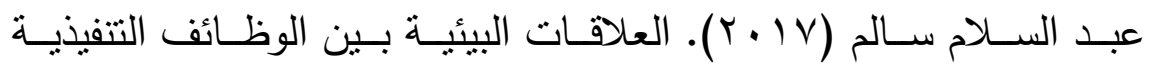
والعمليات المعرفية والقدرات النفس لغوية لدى أطفال المرحلة الابتدائية . مجلة الإششاد النفسي: جامعة عين شمس - مركز الإششاد النفسي، عroه .

\section{Second: Foreign Resources:}

-Moore, J. (2015). Behavior analysis and psycholinguistics. European Journal of Behavior Analysis, 1,5-22. 



\section{فعالية برنامج إرشادي لخفض بعض المخاوف المرضية} المستحدثة لدى الأطفال من جائحة فيروس الكورونا المستجد بردي لئد

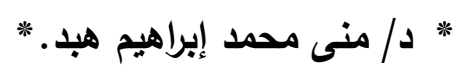

\section{ملخص البحث :}

هدف البحث الحسالي إلى الكثـف عن فعاليـة برنـامج إرشـادي لخفض

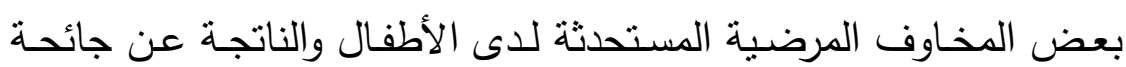
فيروس كورونـا المستجد، وذللك عن طريـ تصميم برنـامج إرشـادي قائم على فنيات الإرشاد النفسي ، وتتمثل الفنيات المستخدمة في البرنامج في لهي

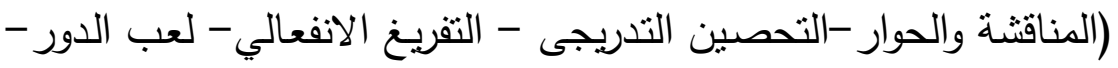
التعزيز)، ولتحقيق هدف البحث قامت الباحثة بإختيار عينة تجريبية واحدة التئية

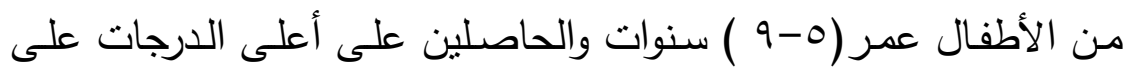

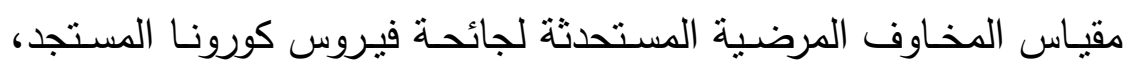

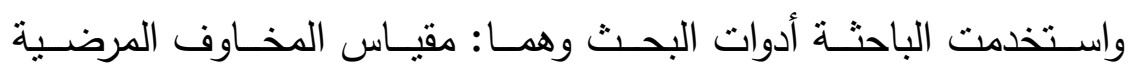

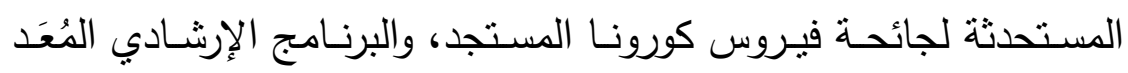
لخفض بعض المخاوف المرضية المستحدثة (إعداد الباحثنة) ، وتم تطبيق الإنيق

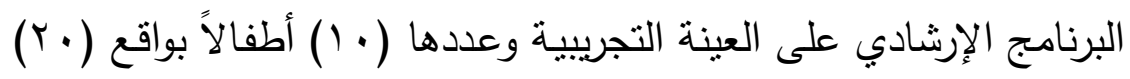

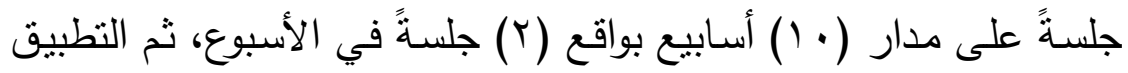
* مدرس علم نفس الطفل بقسم العلوم النفسية- كلية التربية للطفولة المبكرة - جامعة بورسعيد. 
البعدي لأدوات البحث وتحليل النتائج ومعالجتها بأساليب إحصائية علمية تتمثل في (المتوسط الحسابي - الانحراف المعياري -اختبار وليكوكسن) .

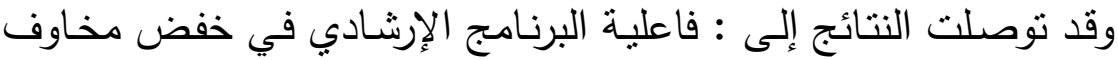

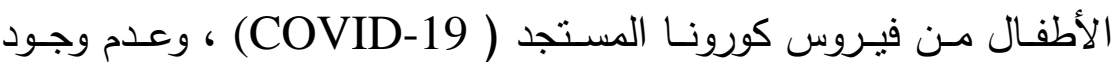

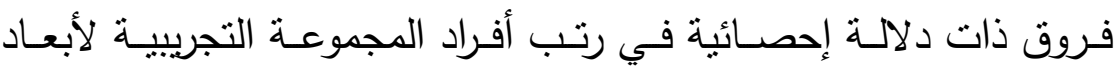

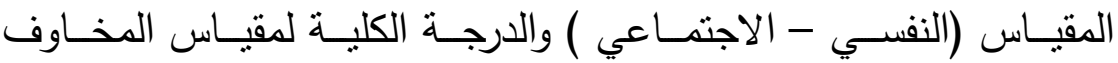

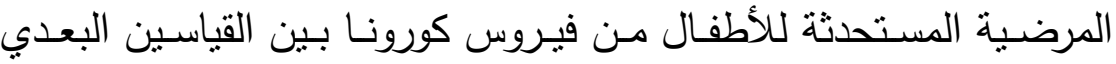

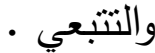

The Effectiveness of a Counseling Program to Reduce Some New Phobia of Disease from COVID-19

Pandemic among Children

Prepare: Dr. / Mona Mohammad Ibrahim Hbad. *

\section{Abstract:}

The Present research aims at investigating the Effectiveness of a Counseling Program to Reduce Some New Phobia of Disease from COVID-19 Pandemic among Children. The Counseling program based on the techniques of psychological counselling presented in the program (e.g. the discussion and dialogue, emotional discharge, imagination). In order to achieve the goal of

*Lecturer, Department of Psychological Sciences- Faculty of Education Early Childhood - Damanhour University. 
the research, the researcher choose one experimental sample of children Nile Egyptian School NES Port Said branch with the highest scores on the scale of newly emerging COVID-19-related Phobias. The researcher used the following instruments: the scale of newly emerging COVID-19-related Phobias and the counselling program designed for reducing these phobias (prepared by the researcher). The Counseling program was applied on the experimental group (10 children); 20 sessions during 10 weeks-2 sessions per week. A post administration of the COVID-19-related Phobias scale was conducted followed by the results analysis and processing methods of scientific statistical represented in the (arithmetic mean - standard deviation - wilcocxon test). The results indicated the Effectiveness of an Counseling Program to Reduce Some New Phobia of Disease from COVID-19 Pandemic among Children. Also results revealed that there is no a statistically significant difference at the level $(\mathrm{s} \leq 0,05)$ ranks in the mean scores of the experimental group participants after receiving the Counseling program and the mean scores in the follow-up administration on the scale of newly emerging COVID-19-related Phobias (as a whole).

\section{الكلمات المفتاحية Keywords:}

A Counseling program

Newly Phobia of Disease

COVID-19 Pandemic

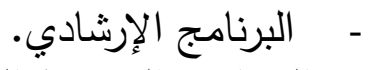
- - - المخاوف المرضية المستحدئة.

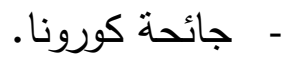




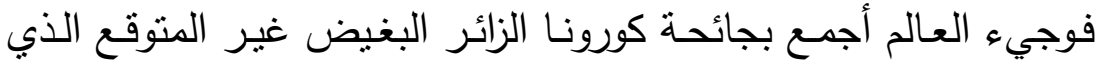

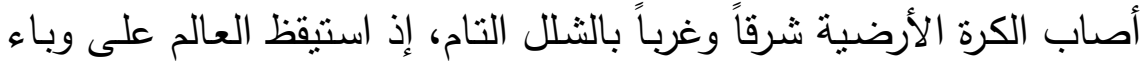

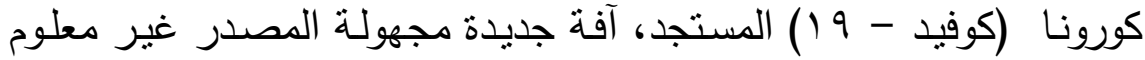

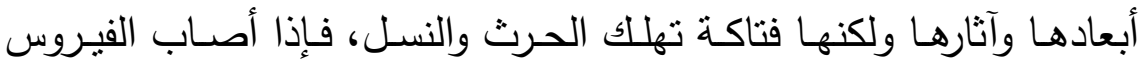
الإنسان وتمكن منه قضى عليه؛ لعدم معرفة طبيعته وأسبابه. وقد أدى انتشار الفيروس إلى تغيرات ملحوظة في عالمنا الاجتماعي في غضون فترة زمنية قصيرة جدًا. فهناك قلق وخوف وضيق على نطاق واسع

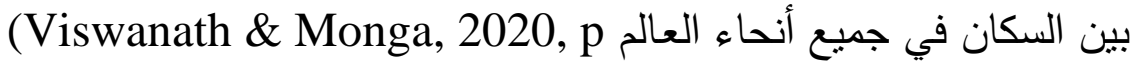
120).

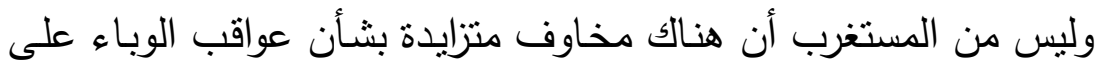
الصحة النفسية للإنسان، وما سببه من قيود اجتماعية جديدة، فظهوره تسبب إنباء

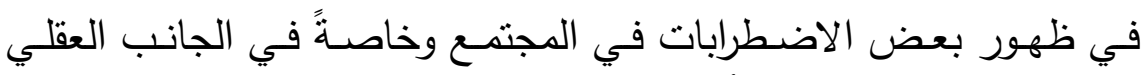

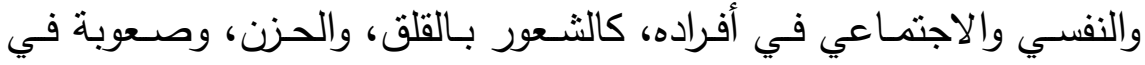
النوم، وكذللك العزلــة والخـوف مـن الاختـاط بـالآخرين، وكلهـا اسـتجابات

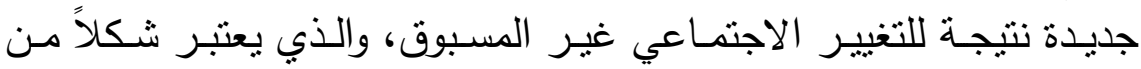

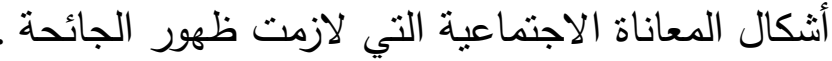

ومما لاثكلك فيه أن فئة الأطفال هم الفئة الأكثر تأثراً بهذه الجائحسة ؛

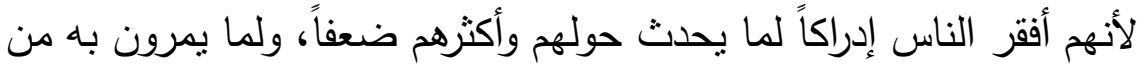

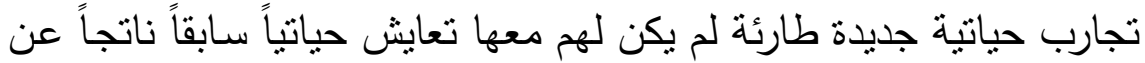

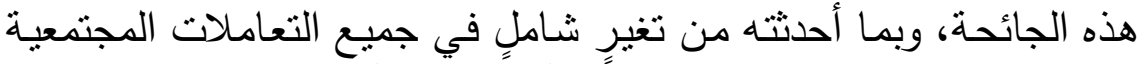

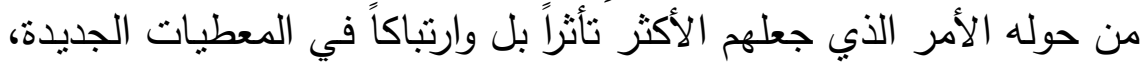


و الذي ظهر من خلال ظهور أعراض لمخاوفٍ مرضيةٍ لم تكون موجودةً

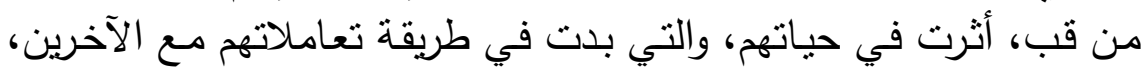
وأثثاء ممارستهم لأنشطتهم المختلفة.

فقي الجوائح البالغـة الخطورة كجائحسة كورونـا المستجد، فإن الإجراءات الاحترازية والتي تتضمن إغلاق المدارس، المتتزهات والمالاعب من شـأنها الإخـلال بـمط حيـاة الأطفال المعتاد والذي بـدوره يزيد مسن فرصـة ظهور أعراض الضـط و الارتبالك. وجراء التغيرات في الروتين اليومي والالتزام

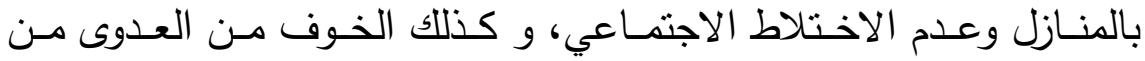
مخالطـة الآخـرين الذي ضـاعف مـن تلك الآثار النفسية والعقليـة، و مدـا

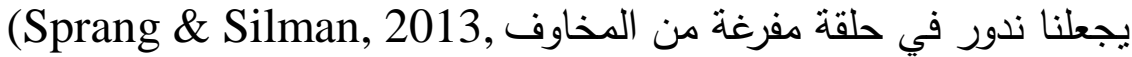
p. 106; Prete, et al, 2020, p, 3027).

وقد أكدت العديد من الدراسات إلى أن تعرض الأفراد داخل مجتمعاتهم لمثل هذه الجوائح بؤدي إلى تأثز الصحة النفسية والعقلية سلباً بشكلٍ كبيرٍ

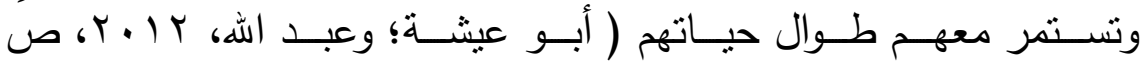
.(Wu at al., 2009,p 307; Sim \& Chua, 2004, p: 811; ) r

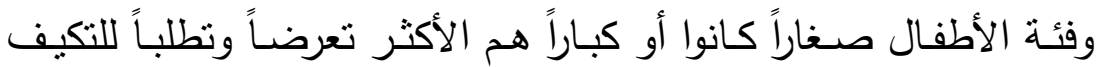
للتوافق مع هذه التغيرات الطارئة مما يجعلهم أقل صبراً وأكثر عدائبة، مما

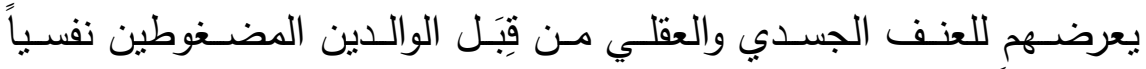
واقتصادياً من نلإ الأحداث الخطيرة التي قد تسببها العوامل الضاغطة منت : الثعور بالرتابة، الإحباط، افتقاد التواصل وجهاً لوجهٍ مع الأقران، الأصدقاء

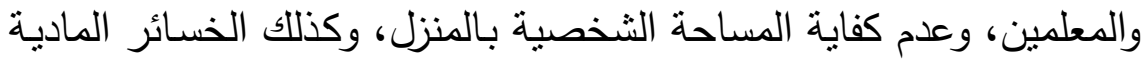
(Kayyalha et al., 2020, p. 65; Prete, et المترتبة على الإغلاق وعنه al,. 2020, p. 3033). 
فالدعم النفسي الاجتماعي هو المصدر الرئيسي الفعال الذي يؤثز على الذي

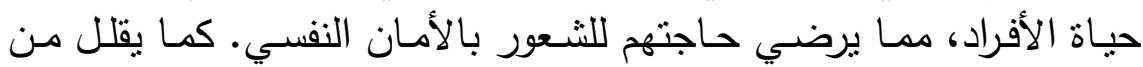
مستوى معاناتهم من الأحداث و المواقف الصسبة التي تواجههم، و بالتالي

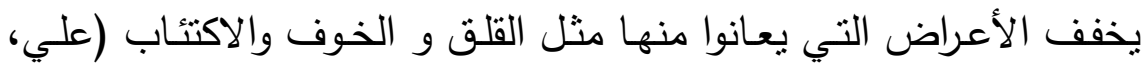

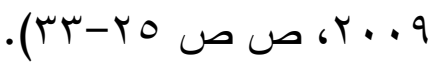

$$
\begin{aligned}
& \text { مشكلة البحث: }
\end{aligned}
$$

يعتبر الخوف من العوامل شديدة التأثير في الكائن الحي، وهو من أهم المحركات التي تذفعـه إلى القيام بسلوكٍ معينٍ كرد فعل لدفع الاضطراب الناشـيء منـه والوصـول إلى مرحلـة الاسـتقرار ، ويختلف سـولك الفرد تجـاه المؤثر المسبب، وبحاول إختبار أفضل الطرق المتاحة بالنسبة إلبه للتغلب

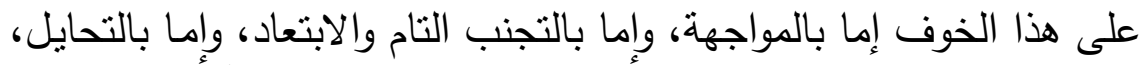
غير أن المشكلة تكمن في مدى كون مسبب الخوف قائمساً و لا بسـتطيع

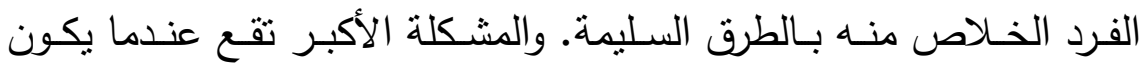
ضحية هذا الخوف هو الطفل الذي قد يكتسب سلوكيات سيئة في محاولته

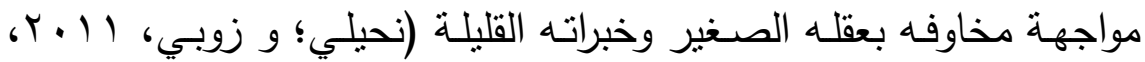
ص (r)

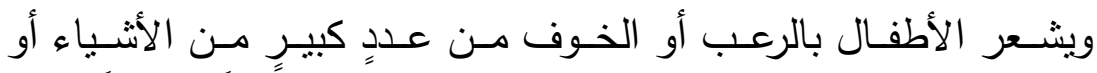
المواقف، وعندما يستمر الخوف غير المنطقي يصبح خوفاً مرضياً. لقد لقد أثنار ظهور فيـروس كورونـا المستجد (كوفيد -9 1) خـلال الثـهور القليلـة

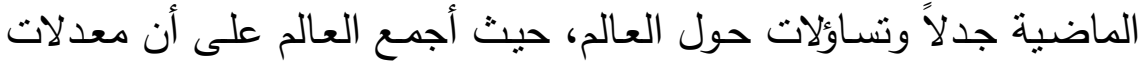

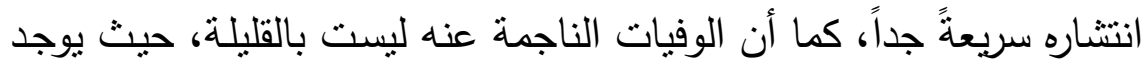
عدداً كبيراً من الأشخاص المصابين بعدوى فيروس كورونا المستجد (كوفيد -9 ( ) ماتزال مجهولة الهوية، فهذا الفيروس القاتل انتشر بصورة كبيرة دولياً 
وبوسع من نطاقه الجغرافي، خاصـةً في ظل السفر وحركة الانتقال والتجارة بين الدول، ولم يدع هذا الفيروس أحداً من أي فئة إلا وكان لـه أثراً مدمراً

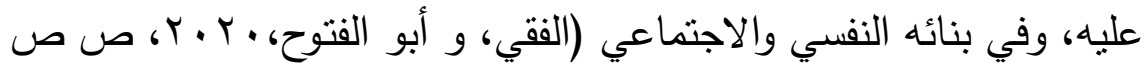
. (1.Vr-) . 71

والأساس في تلك المشكلات التي ترتبط بالجائحة لا تكمن في الاصسابة في حد ذاتها، بل في الإطار الاجتماعي واتجاهات المجتمع نحوها، وكذللك

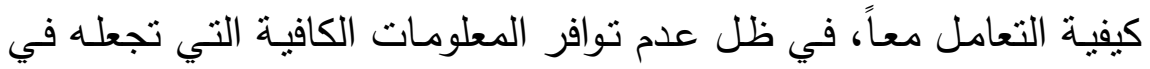

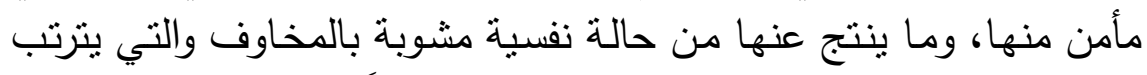

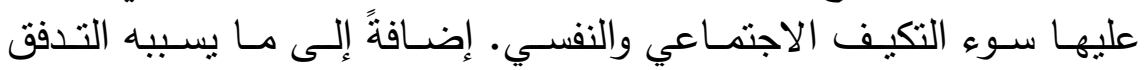

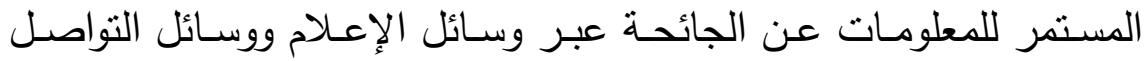
الاجتمـاعي والتي سـاعدت في ظهـور أعـراض نفسجسمية لـدى الأفـراد الطبيعيين و ظهور مخاوف هيستيرية متعلقة بفيروس كورونا المستجد لدى الاعي مختلف القطاعات الإقتصـادية والاجتماعيـة والتي قد يكون لهـا أثراً سـلبياً (Depoux et al., 2020, pp. 22-28; يتخطى تأثير الفيروس نفسه Prete, et al,. 2020, pp. 3035-3036)

وهنـا يمكـن الإشـارة إلـى أن الأطفـال وهـم أكثر الفُـات تـأثراً عنـدما

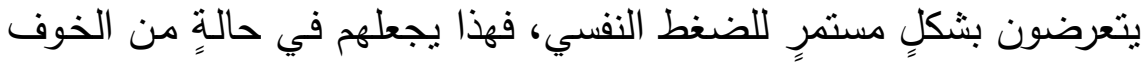
والإجهاد (Dong \& Bouey, 2020, p. 127). وهي حالة تعد أسوأ حالة من حالات الاستجابة للضغط النفسي ولها آثار كبيرة وفوربة وضـارة، ولو تركت هذه الحالة دون إرشـاد وعـلاج نفسي، فإن العواقب المحتملة طويلـة

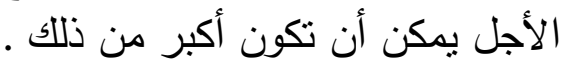

ولا شك أن ما يتعرض إليه الطفل من مخاوف توهن من قدرته، وتجعله في أمس الحاجة إلى عونٍ خارجي واعٍ مرتكزاً على أسس علمية تعيده إلى 


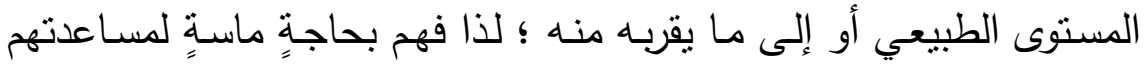

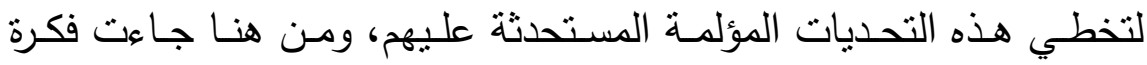

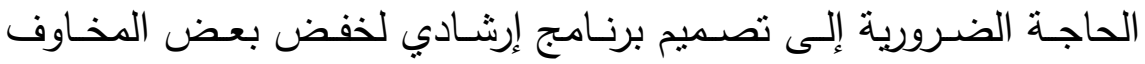

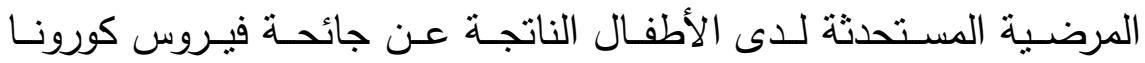

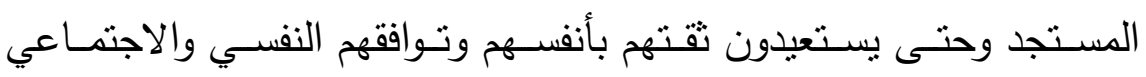
والمعايشة مع معطيات الحياة الجديدة في ظل تواجد هذئن هذا الفيروس. و يحاول البحث الحالي الإجابة على السؤال الآتي:

ما فاعلية برنامج إرشادي في خفض بعض المخاوف المرضية المستحدثة

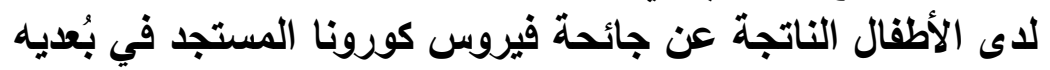
( النفسي - الاجتماعي ) و مدى استمراريته بعد مرور شهر من الأنه التطبيق؟

\section{أهداف البحث:}

يتمثنل الهدف العـام مـن البحث في خفض بعض المخـاوف المرضية

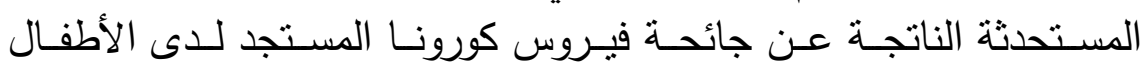

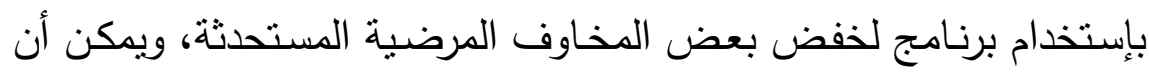

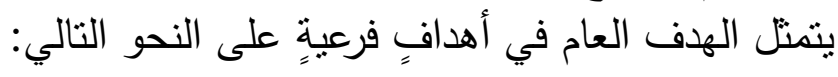

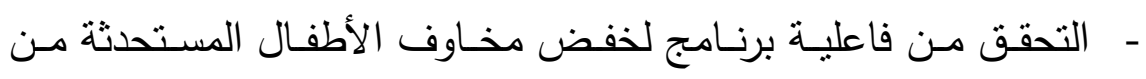

$$
\text { فيروس كورونا في بُعديه ( النفسي - الاجتماعي ). }
$$

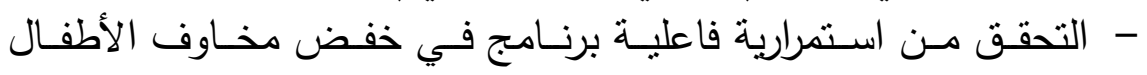

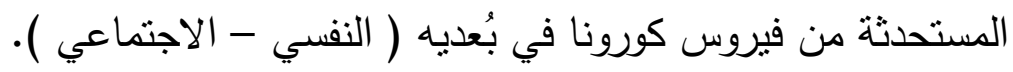


تكمن أهمية البحث الحالي في الموضوع الذي يدرسه حيث أنه ييحث

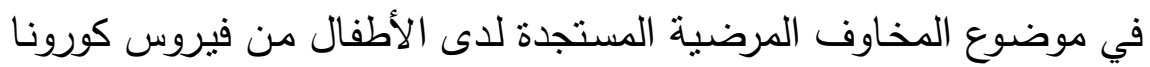
المستجد (كوفيد - 19 Covid-19 ) ، كون هذا البحث يهتم بشريحة هامة المية

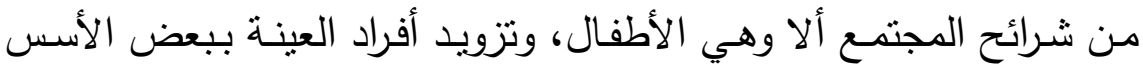

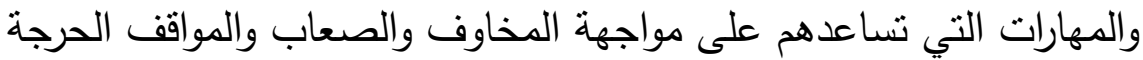

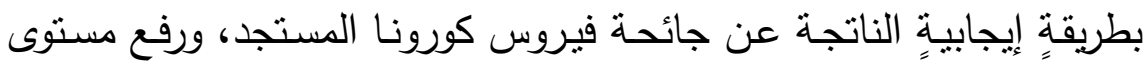

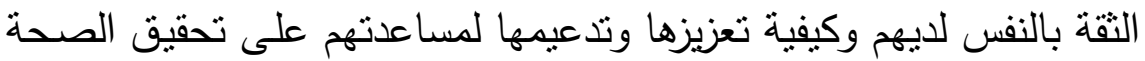

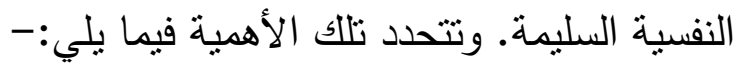
وترجع أهمية البحث إلى : الأهمية النظرية: - ماك

- قد تشهم نتائج هذا البحث في إثراء المكتبة النفسية بموضوع يتسم بالندرة في الوقت الحالي وذللك لإستحداث المشكلة. - مساعدة أفراد العينة على تخطي مخاوفهم ومساعدتهم على تلى تحقيق قدرٍ عالٍ من النقة بالنفس في مواجهة مخاوفهم المستحدثة . لإنة

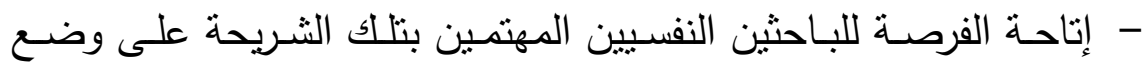

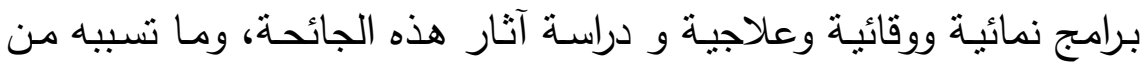

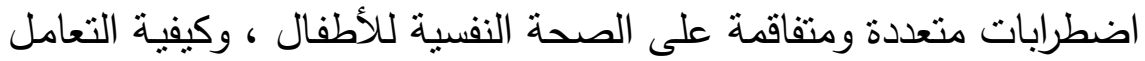
معها للتخفيف من هذه الآثار . مناب 


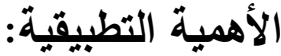

تتمثل الأهمية التطبيقية للبحث فيما يلي:

1-تـدريب الأطفـال على مجموعـة مـن المهارات الانفعاليـة والاجتماعيـة

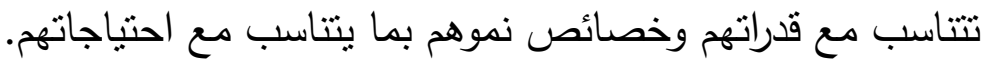

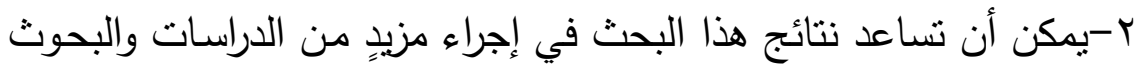

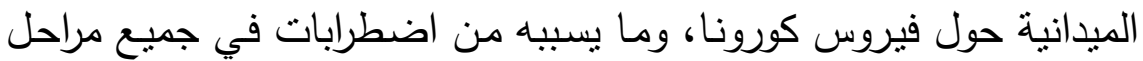
النمو وكذللك في فئاتٍ مختلفةٍ .

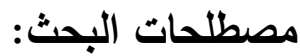

\section{1-البرنامج الإرشادي Counseling Program}

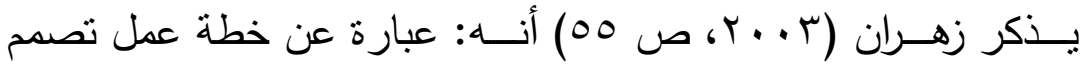

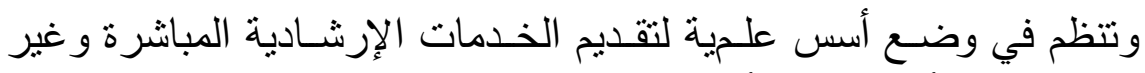
المباشرة من أجل تحقيق أهداف الإرشاد النفسي النمائية والوقائية.

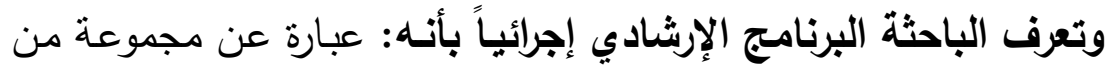

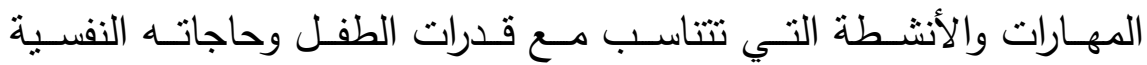

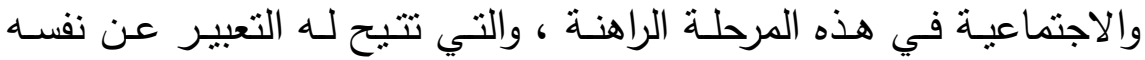
ومكنوناته وكذلك تتمية ثقته بذاته ، وتقدم في صورة مشوقة وجذابة تبعث الطفل على الطمأنينة في نفسه وفي من حوله ، وتقديم الحوافز والمعززات التي تأكد على تقته بنفسه وعلى خفض فلف مخاوفه من فيروس كورونا.

r : Newly Phobia of Disease المخاوف المرضية المستحثثة

بعد الإطـلاع على الدراسـات التي اهتمـ بدراسـة فيروس كورونـا مثل

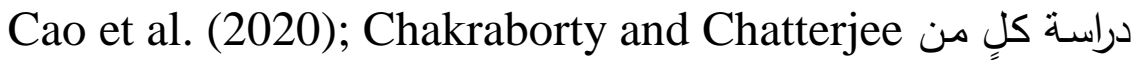


(2020); Haleem et al. (2020), Huang and Zhao (2020); عرفت المخاوف المرضية من فيروس كورونا Wang et al., (2020)

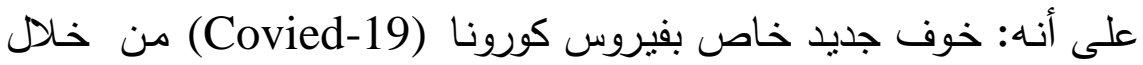

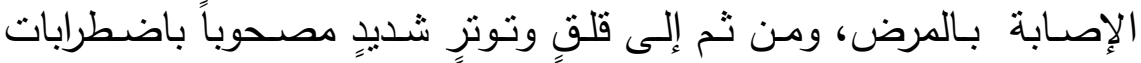

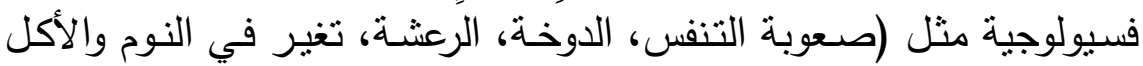

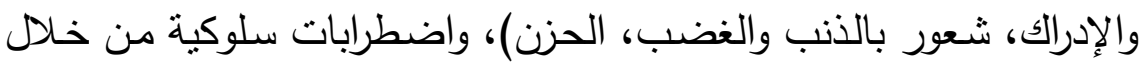
تجنب الأماكن والمواقف العامة مثل (مقابلة أثخاص، ولاص، عدم مغادرة المنزل

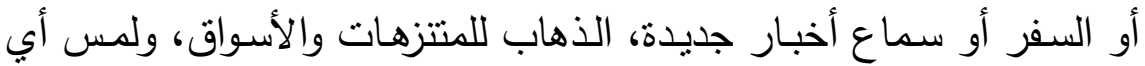

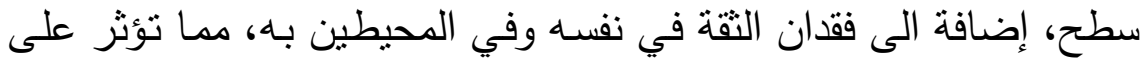

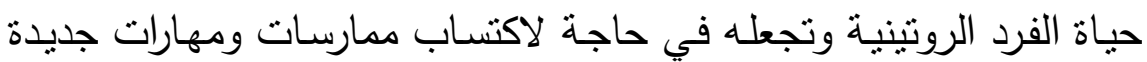
تساعده على التكيف.

وتعرف الباحثة المخاوف المرضية المستحدثة إجرائياً بأذها: الدرجة

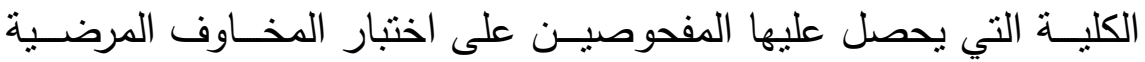

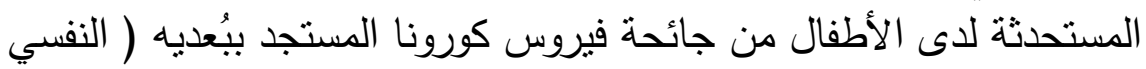

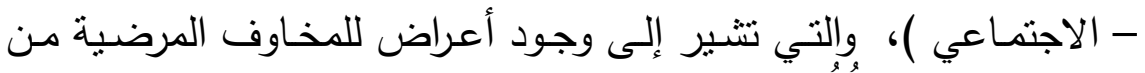
فيروس كورونا والمعد لأغر اض البحث الحاعير الحالي.

\section{- Covied-19 فيروس كورونا المستجد}

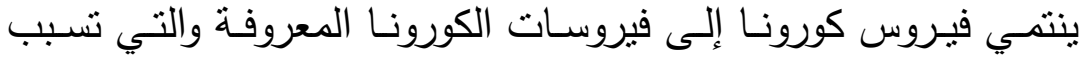

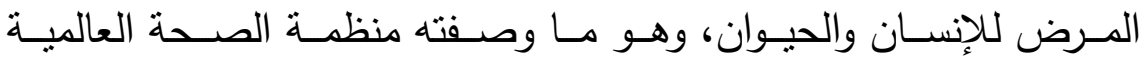

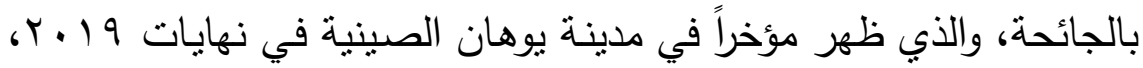

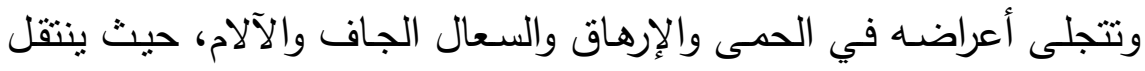

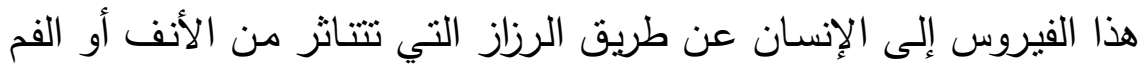

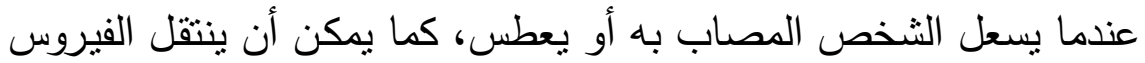


للإنسـان من خـلال ملامسـة الأسطح المحيطة بـه أو لمخالطته لشخصٍ مصاب بهٍ (WHO, 2020; Wang et al., 2020, p. 1729)

\section{الإطار النظري والدراسات السابقة:}

تمر الحضارة الإنسانية في الوقت الحالي بواحدة من أصسعب المنعطفات

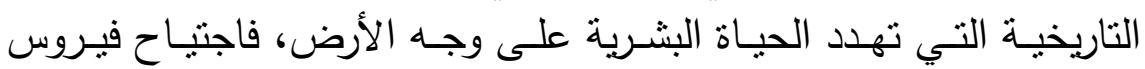

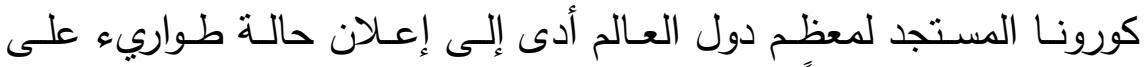

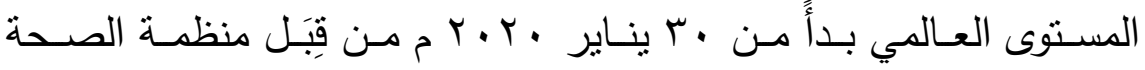

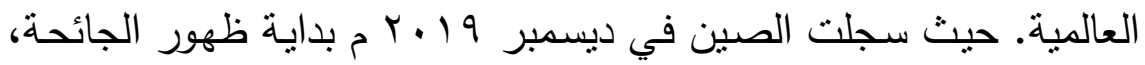

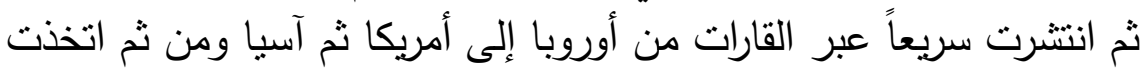
الحكومات إجراءات إحترازية كفرض الإغـلاق الكلي والجزئي بمناطق كثيرة

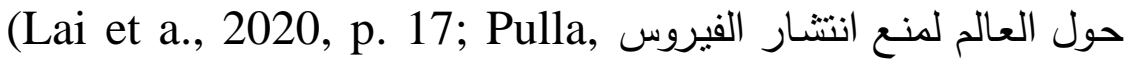
2020, p. 5).

هذا الوبـاء غيـر المعهود أدى إلىى زيـادة في الإرتبـاك العـالمي والقلق، الضـغط النفسي والتي تعتبرهم منظمـة الصـحة العالميـة جميعـاً ردود فعـل (Kluge at al, فسية طبيعيـة للتغيرات الاجتماعيـة غير المتوقعـة. 2020,p . 1233 وقد امتدت تداعيات فيروس كورونا بعدد من المراحل،

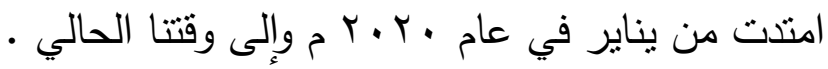

المحور الأول: المخاوف المرضية:

American Psychiatric ) تعرف المنظمة الامريكية للطب النفسي (Association, 2013 المخـاوف المرضية بأنها: "اضطراب يتميز بأنسه خوف دائم مفرط من موضـع أو موضـوع (شخص أو شيء أو موقف أو فعل أو مكان أو حيوان ) غير مخيف بطبيعته، ولا يستند على أساس واقعي 
ولا يمكن ضبطه أو التخلص منـه أو السبطرة عليه، ويعرف المريض أنـهـ

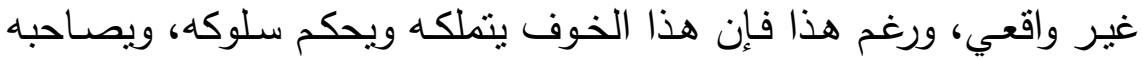
القلق والعصابية والسلوك القهري" .

وتنقسم المخاوف المرضية إلى ثلاثة أقسام:

1 -الرهـاب البسـيط: إنـه رهـاب شـديد، مثنابرة وغير عقلانيـة وهو الخوف

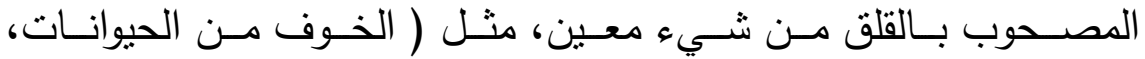

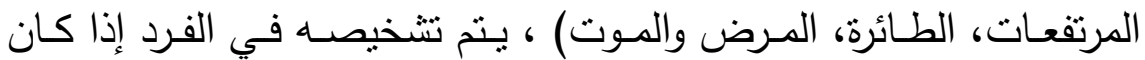

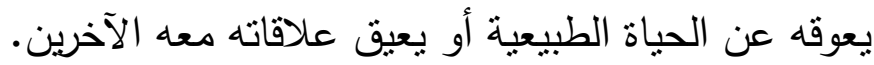

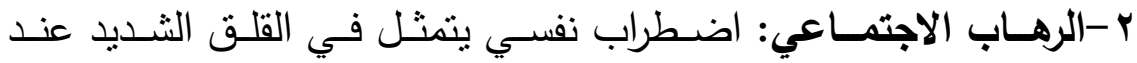

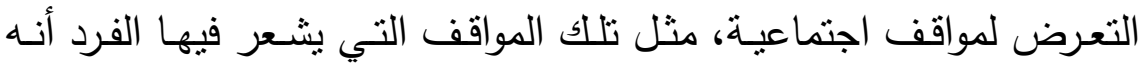
مُراقَب خاصة عند دخول الأماكن العامة على سبيل المثال المطاعم.

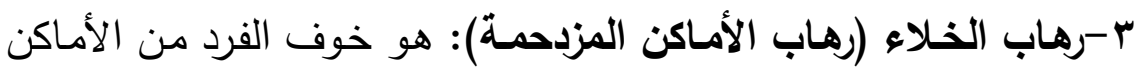

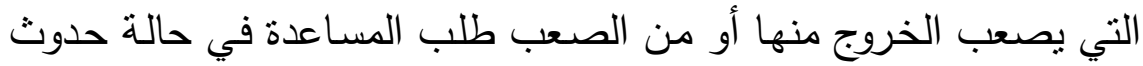

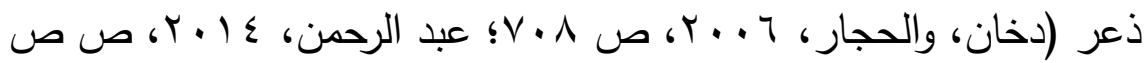
$\cdot(r+r-r$.

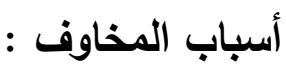

يرى كثير من العلماء أن الإنسـان يولد مزوداً ببعض المخـاوف القليلة

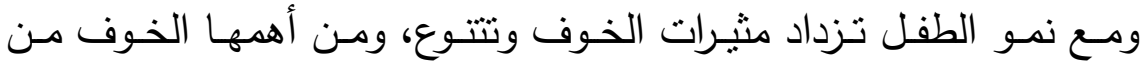

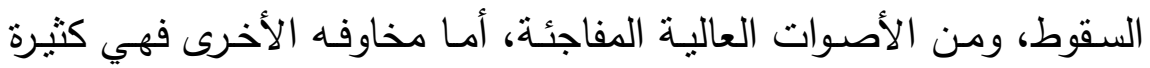

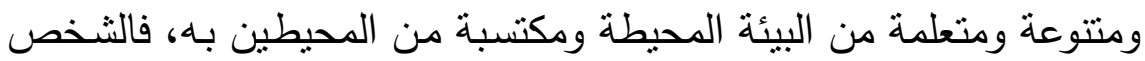
الذي تربى في بيئة تعرضه لمثثيرات الخوف من أثنياء كثيرة بنشأ جباناً، أمسا

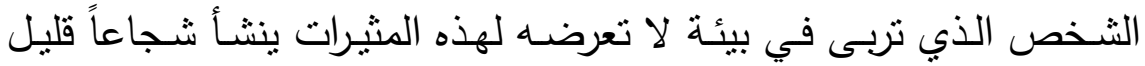


المخاوف. و المخاوف مكتسبة، على اعتبار أن الخوف استجابة مشتقة من

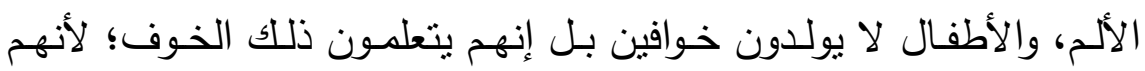

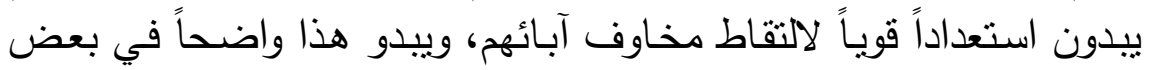

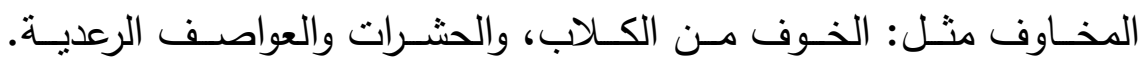
ويصعب على الآباء أو غيرهم التتبؤ بمخاوف أطفالهم. ففي جميع الأعمار

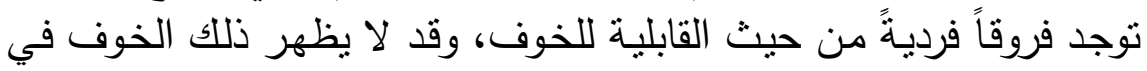
جميع المواقف، وتتوقف على عردئ موامل متعددة.

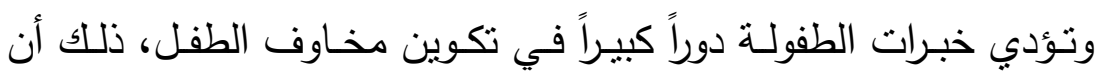

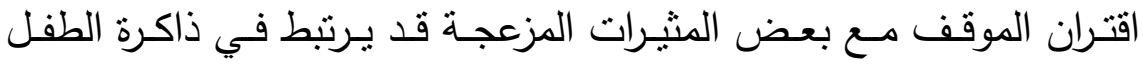
الثعورية و اللاشعورية فتكتسب تلك المواقف نفس قيمة المثيرات المزعجة. (Epkins, 1996, p. 90)

وق تمثلت استجابات الأطفال التي ظهرت في فترة كورونا في :-

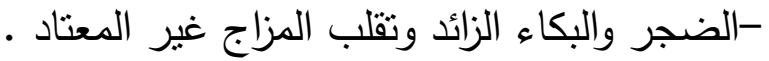
- الخوف من الجلوس بمفرده أو لا يجلس إلا بوائ وبل الطود الآخرين .

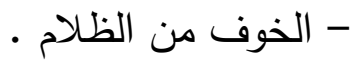

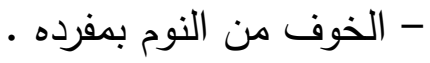
- الخوف من الأبواب المغلقة. -مشكلات في النوم والأحلام المزعجة. -تخيل المخاوف.

(Huang and Zhao, 2020; Wang et عدم التركيز والثرود الذهني al., 2020). 


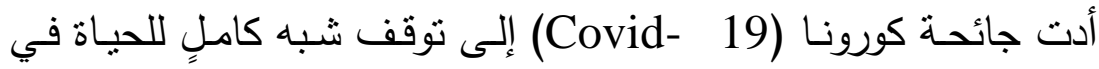
بعض البلدان، حيث تضمنت إغلاق معظم المؤسسات والمراكز التجارية،

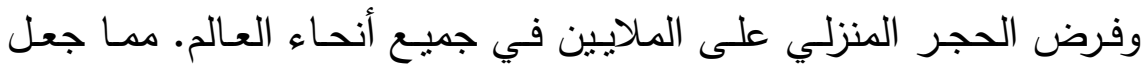

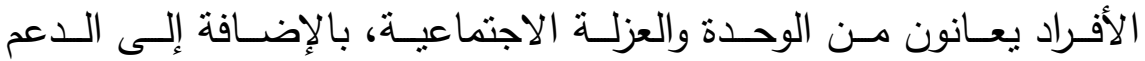

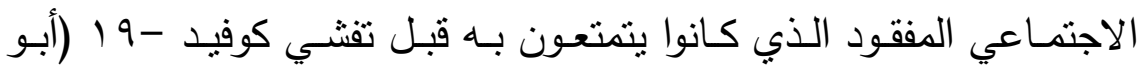

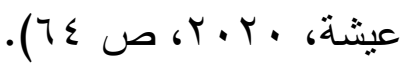

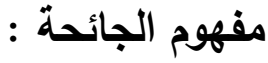

هي مصطلح يستخدم عادةً على نطاقٍ واسِِ لوصف أب أي مشكلة خرجت

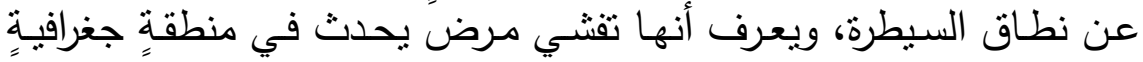

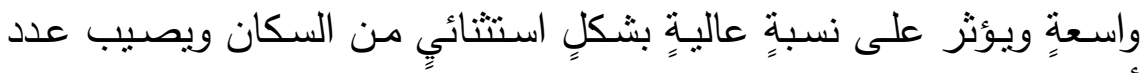
أكبر من الناس من الوباء.

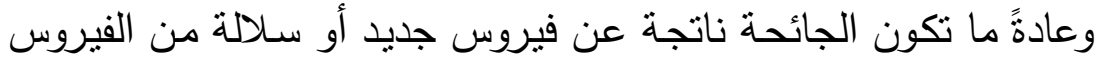

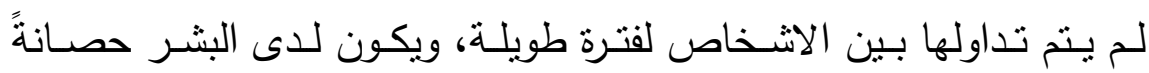

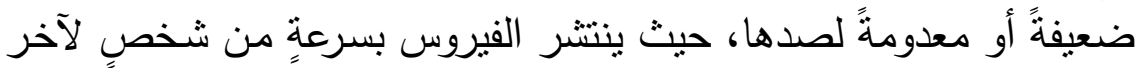
في جميع أنحاء العالم (Pulla, 2020, p 25) نشأة الجائحة :

في نهايات 9 1 ب r م ظهر في مدينة يوهان Wuhan عاصمة مقاطعة هوبي Hubei الصينية ما يُعرف بفيروس كورونا المستجد

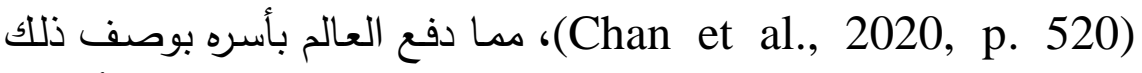

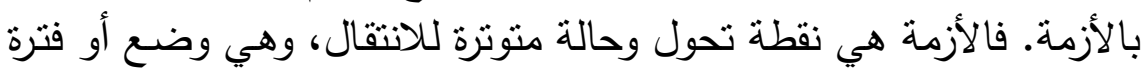




\section{المجلة العلمية لكلية رياض الأطفال - جامعة بورسعيد}

حرجة وخطرة وحالة تطورية يحدث فيها انفصام يعلن الانتقال الحتمي إلى

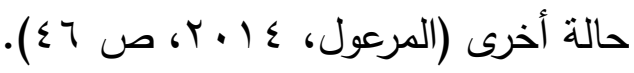

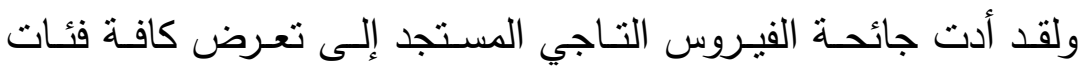

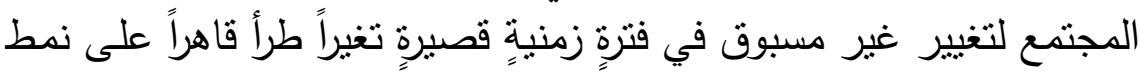

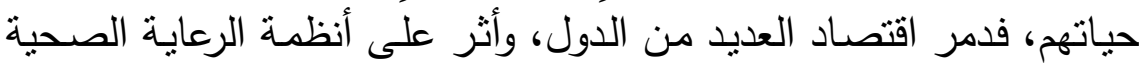
في جميع دول العالم، ومنع التنقلات وأوقف رحالات الطيران، وبات العالم أسيراً لفيروس كورونا (Viswanath \& Monga, 2020, p. 133). وعزز ذلك أيضاً ما تم فرضه على معظد سكان العالم من إجراءات الحجر

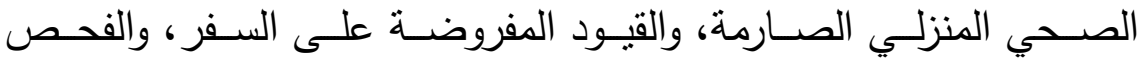
والمراقبة المستمرة، ويُضاف إلبها ذلك القدر الكبير من المعلومات الخاطئة

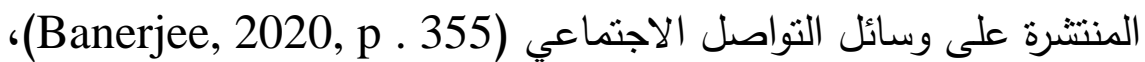

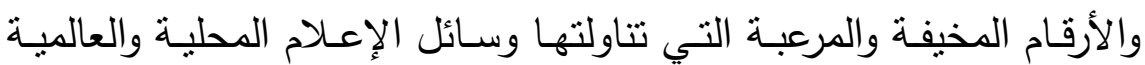

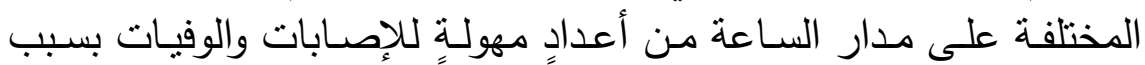

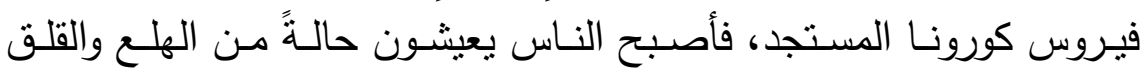
والتوتر على نطاقٍ واسعِ ربما لم تشهده البشرية من قبل على الأقل منذ فترة ليست بقصيرة ( Velavan \& Meyer,2020, p. 53; Zhai \& Du, 2020, p. 87).

\section{الآثار النفسية لجائحة كورونا :}

يعد الأمسن النفسي للفرد من المتطلبات الأساسية للصـحة النفسية التي يحتاج إلبها الفرد كي يتمتع بشخصية إيجابية منزنة ومنتجة، وهو شعور الفرد بتقبل الآخرين له وحبهم له، وبعاملونـه بدفي ومودة وشعوره بالانتهاء

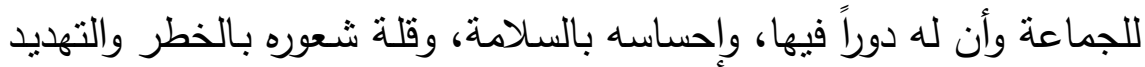

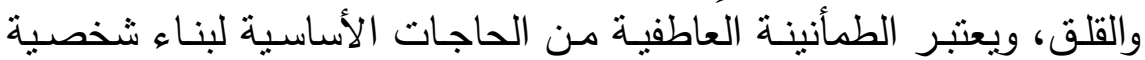


صحية في جميع مراحل الحياة، ابتداءً من الطفولة حتى نهاية حياة الفرد.

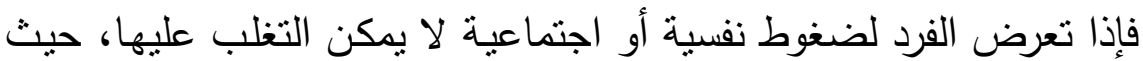

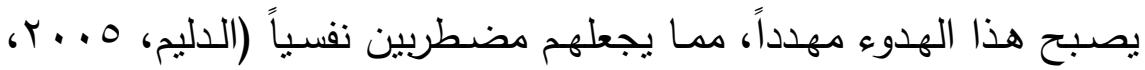

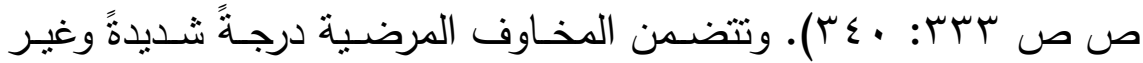
عقلانيةً من الخوف التي تؤثر بدرجةٍ شديدةٍ على أنشطة الطفل الطبيعية، ولنه وبظهر الخوف عند الأطفال من المهد إلى المراهقة، والمخاوف المرضية لدرهية التي تظهر عندهم هي في جوهرهـا اسـتجابات لمثيـرات لأثـياء موجـودة بالفعل في البيئة المباشرة المحيطة، ومع نمو الطفل ودخوله المدرسة ترتبط

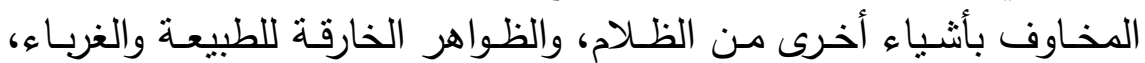
إضافةً إلى الخوف من المستقبل، ويعتمد نمو الخوف المرضي عند الأطفال بالدرجة الأولى على الخبرات المؤلمة التي يتعرض لها الطفل في حياته.

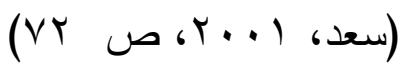

وقد أشارت أغلب الدراسات أن المخاوف التي يتعرض لها الأطفال تؤثز على جميع جوانب نموه المختلفة، كما تؤثر على استجاباته النفسية وتهدد الإدراك الحسي لديه، أي أنها تؤثر على النمو الطبيعي للفرد وتحدث تغييراً

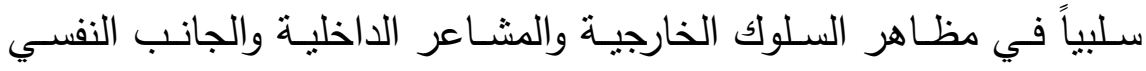

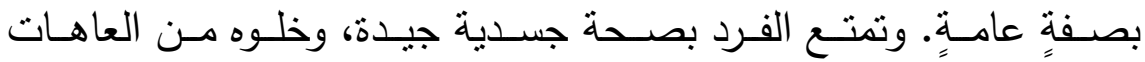

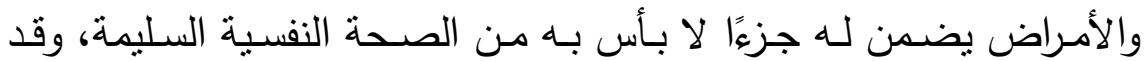

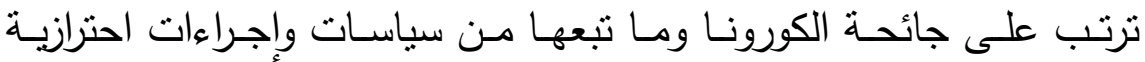
اتخذتها العديد من الدول ومنها سياسـة الإغـلاق، والحجر الصـحي داخل وماتل

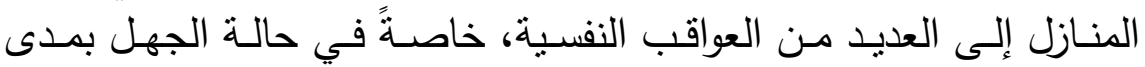

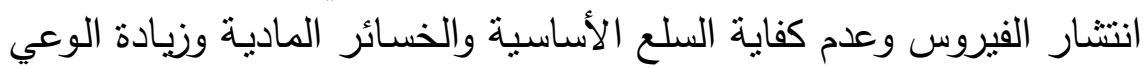

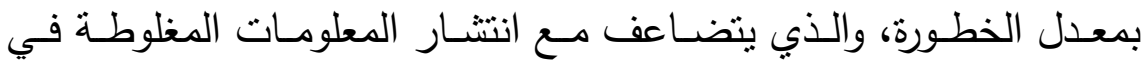
(Singh et al., 2020, p وسائل الإعلام بالمراحل المتقدمة من الجائحة 
153; Brooks at al., 2020, pp 220-233) النفسي والوجداني للأفراد العاديين.

كمـا أكـدت الدراسـات في الجـوائح السـابقة أن التـأثنير النفسي للحجـر

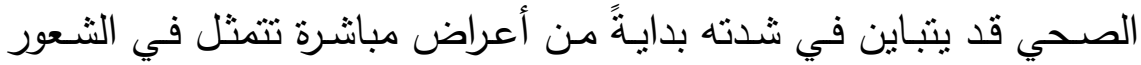

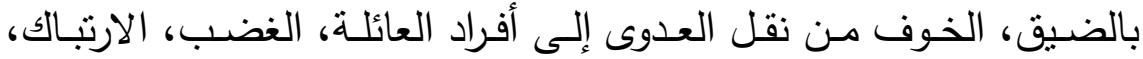

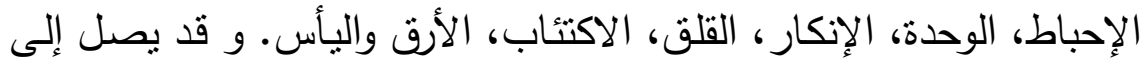

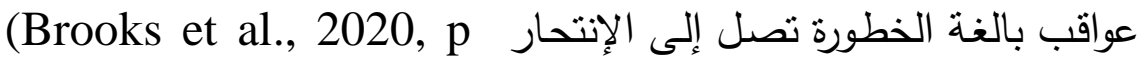

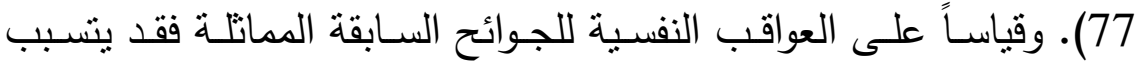
فيروس كورونا المستجد في ظهور المخاوف المرضية وظهور اضطراب ما بعد الصدمة نتيجة لتعرض الأطفال لتفاصيل ومعلومات مقلقة عبر وسائل

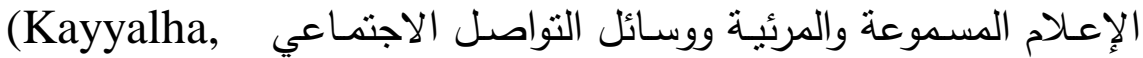
(2020, p 3070; Muris \& Field, 2010, p 142

وقد عايش الأطفال هذه الفترة أزمات وصدمات غير منوقعـة، فيواجـه

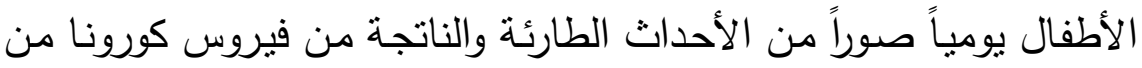

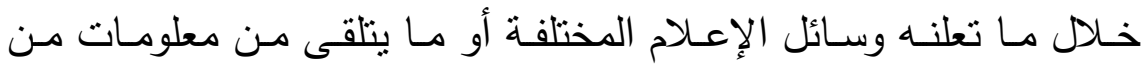

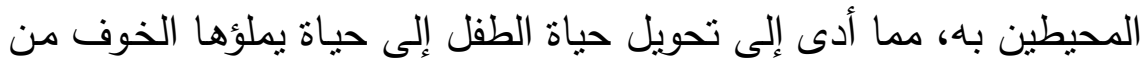

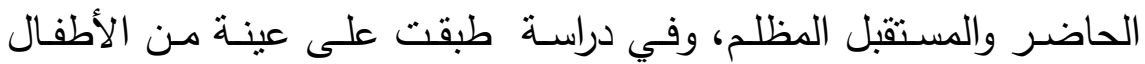
والمراهقين من سن (ستة إلى سبعة عشرة) سنة، والتي اهتمت بدراسة تأثنير

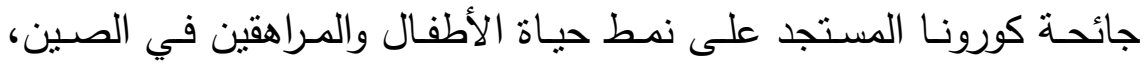

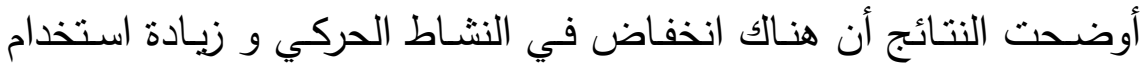

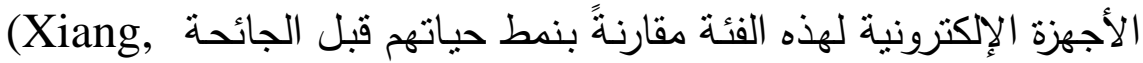
Zhang\& Kuwahara,2020, p 33) 


\section{المجلة العلمية لكلية رياض الأطفال - جامعة بورسعيد}

وترى الباحثة أن شـربحة الأطفال مـن أكثر شـرائح المجتمـع تـأثراً بهذه الجائحة وأكثرها احتياجاً للثقة بالنفس، والمساندة الاجتماعية والنفسية؛ وذلك الك

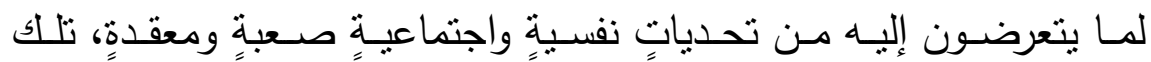
التحديات التي تجعلهم عرضةً بالثعور بالخوف؛ لما بحدث حولهم في عالم مجهول الهوبة بالنسبة لتفكيرهم المحدود وادراكهم للموقف ككل، كما يواجها الأطفال مشكلات نفسية واجتماعية في نفس الوقت. تأثير جائحة كورونا على النمو الاجتماعي للطقل:

الفرد لا بعيث بمعزلٍ منفصلٍ عن المجتمـع بـل هو جزء منهه بيؤثز فيه

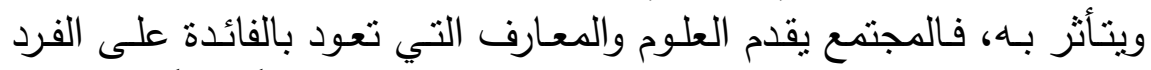

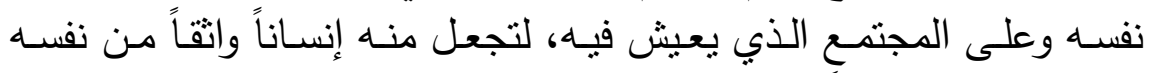
يشتر بإنسانيته قادراً على مواجهة الحياة، ومجابهة المستقبل بكل شجاعةٍ

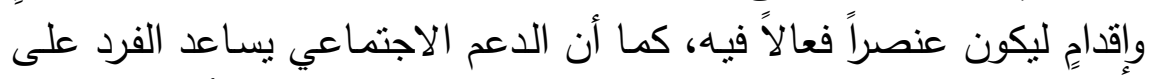

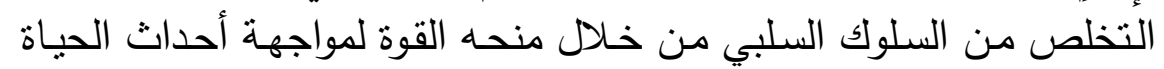

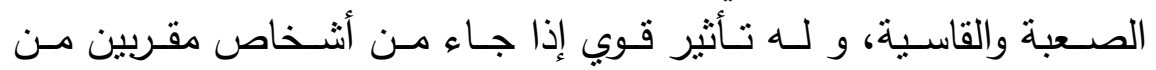
العلاقات الاجتماعية التي تسيطر عليها مشـاعر الحب والثقة، ومن إيمانهم بوجود أشخاص مقربين بمكنهم الوثوق بهم، ومن بستطيع العناية والوقوف في أوقات الأزمـات. بالتـالي ومـن هنـا يصـبح الـدعم حواجز وقائيـة للفرد من الآثار الصحية السلبية التي قد تصاحب أي أزمات، بحيث بخات بخفف من هن

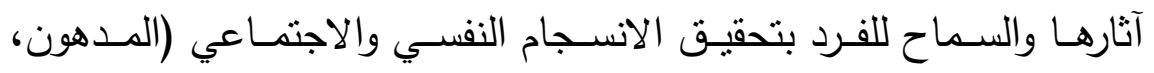
Harel, Shechtman \& 0 Cutrona, 2012, p. 220).

وفي السياق نفسـه نجد أن المصسابين بالمخـاوف الاجتماعيـة يصبحون قلقين مـن احتمـال تقيهم الآخـرين السـلبي لهـ، وهذا مـا قامـت بـه جائحسة 


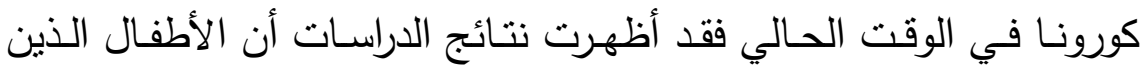

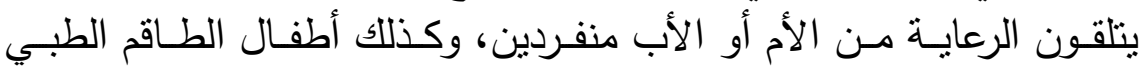

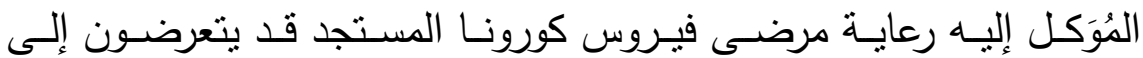

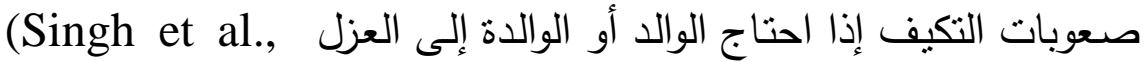
2020, p. 177; Brooks at al., 2020, p. 253; Dubey et al,. 2020, p.1032).

\section{تأثير جائحة كورونا على النمو الانفعالي للطقل:}

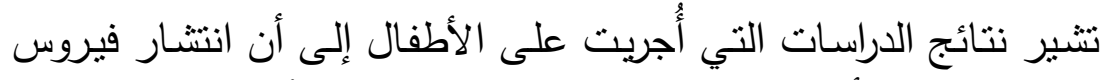

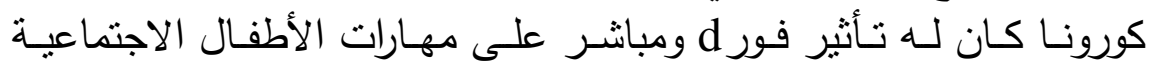
والانفعالية ، وذلك بما اتخذته العديد من دول العالم من إجراءاتٍ إحترازيـةٍ

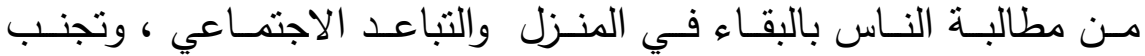

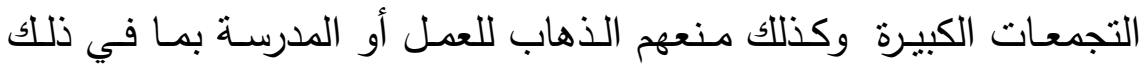

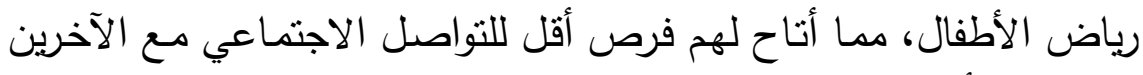

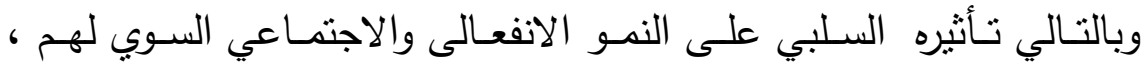

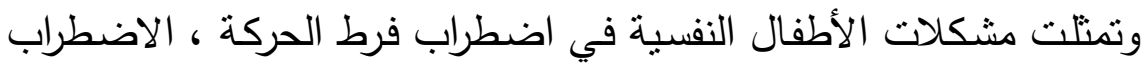
العاطفي ، المخاوف ، القلق الزائد ـ اضطرابات في النوم والأكل .

(Singh et al., 2020, p. 153)

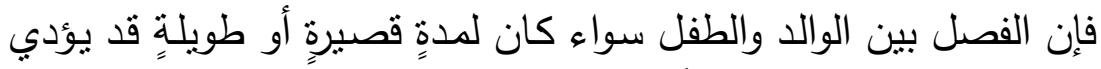

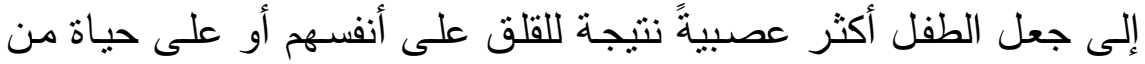
يحبون، وقد تتسبب في عواقب نفسية وخيمة. ومن أهم المقومات الوجدانية الونة

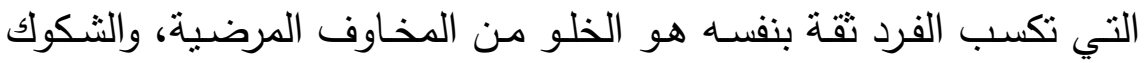
المرضية والوساوس التي يؤدي تسلطها على الثخص إلى فئل فقدان ثقته بنفسها أو اهتزازها، إضـافةً إلى الابتعاد عن التذرع بالنكوص المرضي إلى مراحل 
عمريسة سـابقة من حباة الفرد، ثم إن افتقاد الثقة بالنفس يتسبب ببـث شعور الحزن والاكتئاب المرضـي في نفس الفرد، ذلك أن الفرد الذي لا يجد من بن

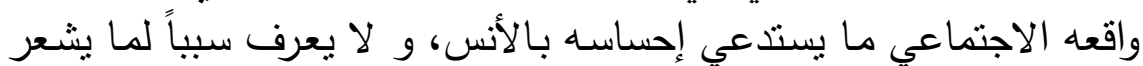
به من حزنٍ دفينٍ داخل أحشائه، فإنه سينتهي في نهايـة المطاف إلى فئ فقدان

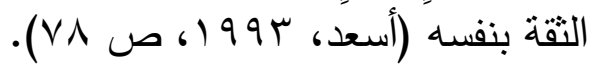

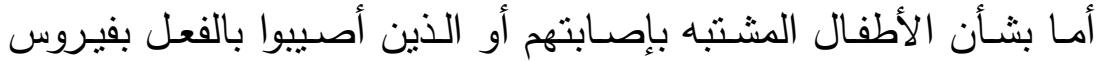
كورونا المستجد و الذين هم بحاجة للعزل أو الحجر المنزلي فإنهم الأكثر بإني

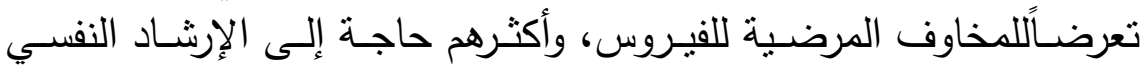
لمواجهة هذه المخاوف و الآثار النفسية الأخرى المترتبة عليها.

(Kayyalha, 2020, p. 3088)

تعقيب

يتضـح مـن العـرض السـابق أن المخـاوف الثــديدة التـي بتعـرض لهـا الأطفال بصفةٍ عامسة وما يتعرضون لهم في الوقت الحالي وبسبب جائحة كورونا المستجد خاصةً، قد يعرض الأطفال إلى مشكلات نفسية واجتماعية

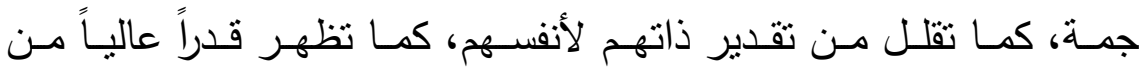
السـوكيات غير السـوبة و تعرضـهم للضـغوط النفسية والمخـاوف المرضية

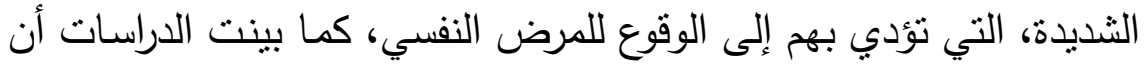

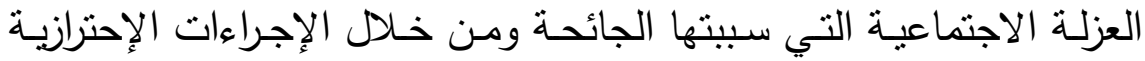

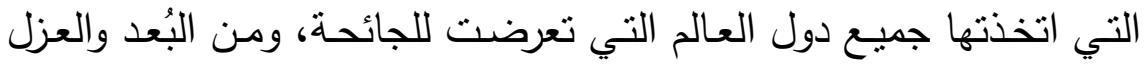

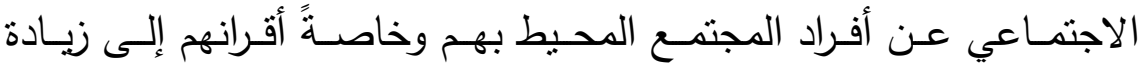
المخاوف الاجتماعية. و قد لاحظت الباحثة أنه لم يكن هنالك برامج اهتمت وحت بعـلاج المخـاوف الناشـئة للأطفـال مـن فيروس كورونـا المستجد (كوفيد 9 (1) أو بتقديم الدعم النفسي لهم بينما اهتمت بعض الدراسات بالكثف عن 
الجائحة وأسبابها وكيفية تعامل دول العالم معها، وعليه يعد البحث الحالي

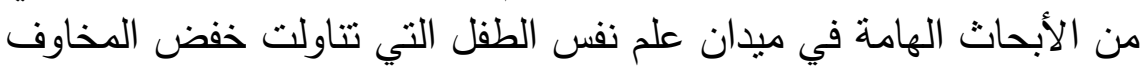

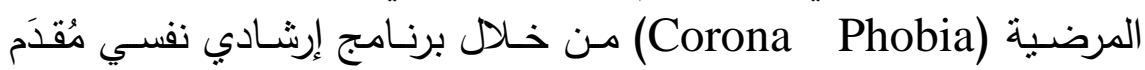

$$
\text { فروض البحث : للأل سن (-9-9). }
$$

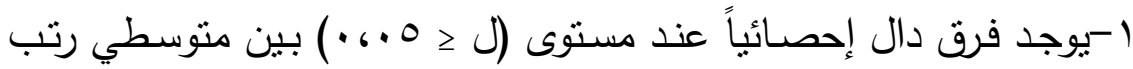

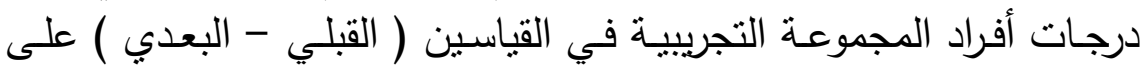

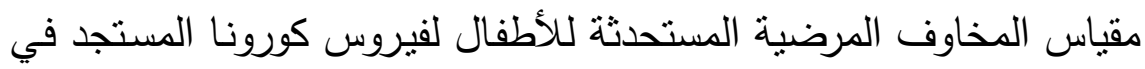

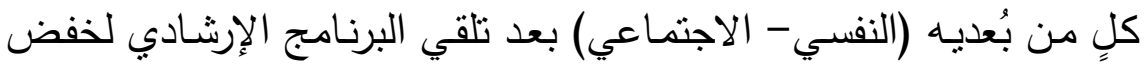
البخاوف في اتجاه القياس البعدي.

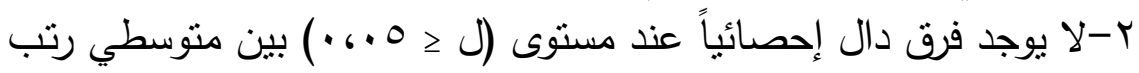

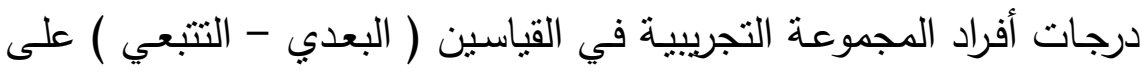

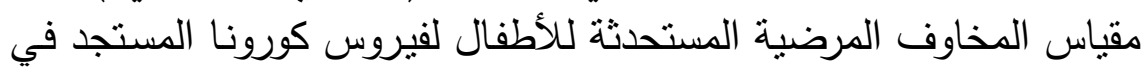

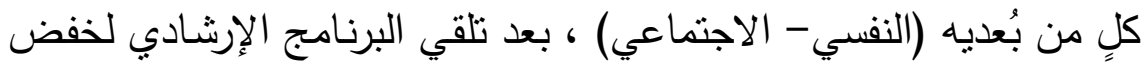
المخاوف بعد مرور شهر من التطبيق .

الإجراءات المنهجية للبحث : أولاًا : منهج البحث:

المنهج المستخدم هو المنهج شبه التجريبي باستخدام التصميم التجريبي

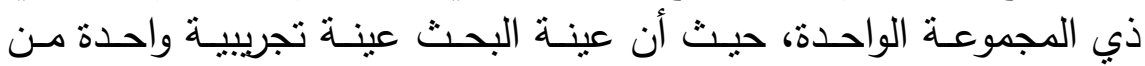

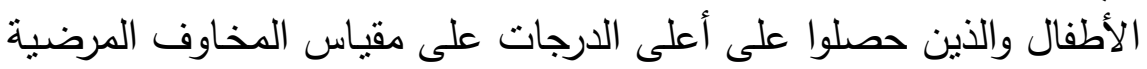

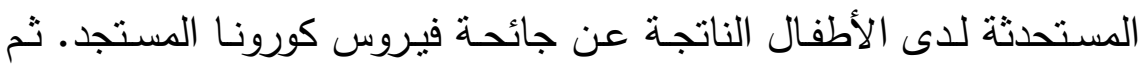


تطبيق البرنامج الإرشـادي للبحث، والقياس البعدي لبيان دلالة الفروق بين القياسين القبلي والبعدي والتتبعي. ثانياً :عينة البحث: أ -عينة البحث الاستطلاعية :

تم تطبيق المقياس على ( • ( ) طفلاً من الأطفال في نفس العمر الزمني للعينة الأساسية(-0-9 ) سنوات؛ وذلك لتطبيق مقياس البحث عليه،م وكذللك جزء من البرنامج الإرشادي المُعَد وذلك لمدة أسبوعين.

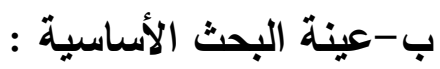

تكونت عينة البحثث من ( • ) أطفالاً من الإنـاث والذكور من أطفال

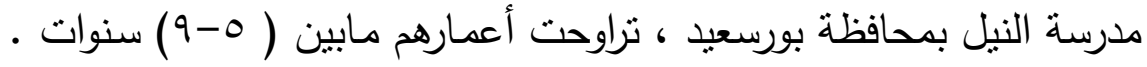
تم تطبيق البرنامج الإرشادي على أفراد عينة البحث التجريبية في الفترة من ون

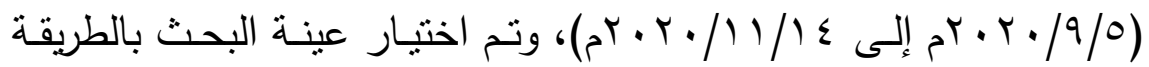
العمدية من الأطفال الحاصلين على أعلى الدرجات على مقياس المخاوف

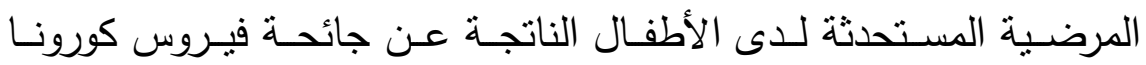

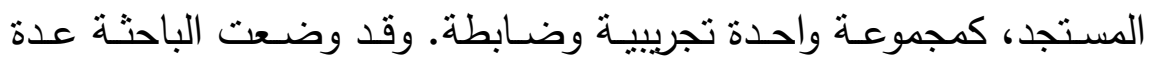
شروط لاختيار العينة: - حصول أفراد العينـة على درجـة عالبـة على مقيـاس المخاوف المرضية المستحدثة لاى الأطفال الناتجة عن جائحة فيروس كورونا المستجد. - أن يكون الطفل خالبـاً مـن أي إعاقـة جسـدية مدكن أن تكـون فيرون عـاملاً مساعداً في وجود المخاوف لدى الطف الطفل .

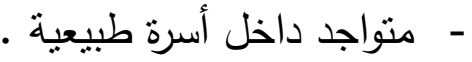




\section{المجلة العلمية لكلية رياض الأطفال - جامعة بورسعيد}

- مستوى اجتمـاعي واقتصـادي واحد ، حيـث تم الاعتمـاد على مجموعـة

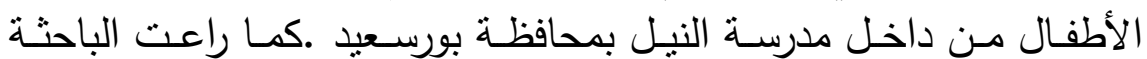
الفـروق الفرديـة بـين الأطفـال عند تـدريب الأطفـال المهـارات الاجتماعيـة

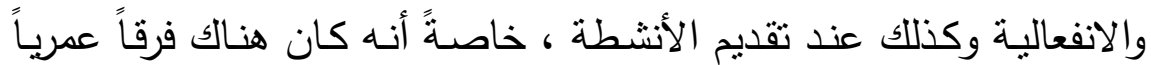

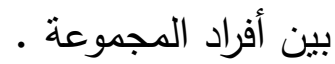
ثالثثاً: أدوات البحث: استخدمت الباحثة الأدوات التالية :

أولاً : مقيـاس المخـاوف المرضـية المستحدثة لدى الأطفـال الناتجـة عن جائحة فيروس كورونا المستجد ( إعداد/ الباحثة ).ملحق رقم(1) الهـف العـام مسن المقيـاس : التعرف على مستوى المخـاوف من فيروس

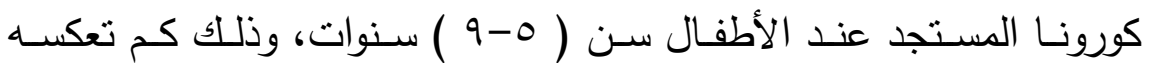
درجاتهم على بنود المقياس ( النفسي - الاجتماعي ) .

\section{وصف المقياس :}

يتكون المقياس من ( • ع) عبارةً موزعةً على بُعدين فرعيين وهما:• البُعد النفسي: وبعبر عن الانفعالات التي يعبر عنها الطفل في سلوكه أثناء الجائحة والتي يمكن أن تتصف بمشاعر الخوف والتوتر ، وبتم تقديرها من جانب الوالدين بحيث توضح مدى انطباق هذه الأعراض على الطفل ،

$$
\text { وعدد عباراته ( • (r) عبارةً. }
$$

• البُعـد الاجتمـاعي: وبعبر عن سـلوك الطفل في المواقف الاجتماعيـة وطـرق إسـتجابته في التعـامالات أثنـاء الجائحسة، وكذللك قدرته على إقامـة علاقات اجتماعية مع الآخرين ، وعدد عباراته ( • ب) عبارةً. 
ويقوم القائم على رعايـة الطفل بإختيار استجابة واحدة من ثالثة بدائل

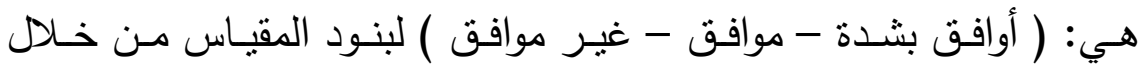
إعطاء وجهة نظرهم فيها ووضع علامة أمام إستجابة واحدة من الإختيارات

\section{مفتاح تصحيح المقياس:}

وقد وزعت درجات الإجابة على فقرات المقياس على النحو التالي: وضعت الباحثة سلماً تدريجياً ثلاثياً حيث وضعت ثثلاثة خيارات لكل فقرة

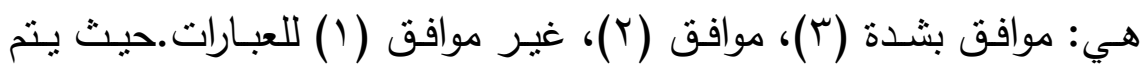

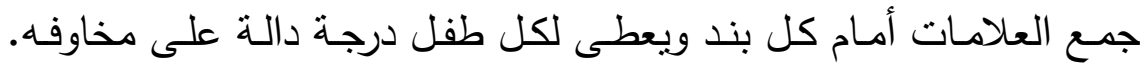
وكلما زادت الدرجة دل ذلك على المخاوف المرضية (Corona Phobia)،

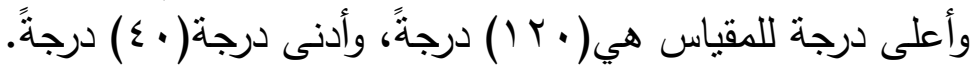
الخصائص السيكومترية للمقياس :

حساب الصدق والثبات لمقباس المخاوف المرضية (Corona Phobia) المستحدثة لدى الأطفال الناتجة عن جائحة فيروس كورونا المستجد (إعداد/

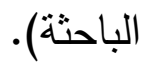

\section{صدق المحتوى (Validity Content):}

للتأكـد مـن صـدن المحتـوى تـم عـرض مقيـاس المخــاوف المرضـية

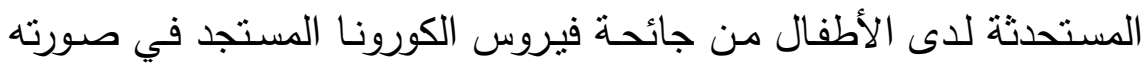
الأوليـة على عددٍ من السـادة المحكمين أعضـاء هيئة التدريس في في مجال الصـحة النفسية؛ وذلك للتعرف على آرائهم في الاختبـار مـن حيـث دقـة هـثة الصياغة اللغوبة لمفرداته وسلامة المضمون، وانتماء العبارات المتضمنة في الاتي كل بُعد لله، وكفاية العبارات الواردة في كل بُعد لتحقيق الهدف الذي وضـع 


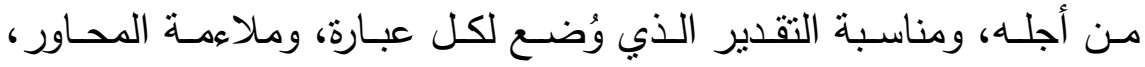
وسلامة المضمون ودقة الصياغة والعرض لكل عبارة، ومناسبة التقدير الذي وفي وُضـع لكل عبارة، وقد قامت الباحثة بـإجراء التعديلات المُشـار إليها على ودئ صـياغة بعض العبـارات، وبذللك يكون قد خضـع لصـدق المحتوى وبـللك

$$
\text { صدق أصبح مكوناً من ( • ع) مفردةً. }
$$

تعتمد هذه الطريقة على الاتساق في أداء الأطفال على فقرات المقياس،

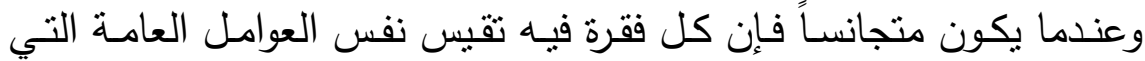
يقيسها المقياس، ويتم حساب الصدق بطريقة معاملات الارتباط بين درجة كل عبارة والدرجة الكلية لمقياس المخاوف المرضبة المستحدثة لدى الأطفال من جائحة فيروس الكورونا المستجد وكانت النتائج كما يلي:

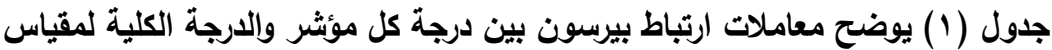

\begin{tabular}{|c|c|c|c|c|c|}
\hline معامل & p & المكون & الارتباط & p & المكون \\
\hline $.515^{* *}$ & 21 & \multirow{8}{*}{ الاجتماعي } & $.660^{* *}$ & 1 & \multirow{8}{*}{ النفسي } \\
\hline $.544 * *$ & 22 & & $.699^{* * *}$ & 2 & \\
\hline $.548 * *$ & 23 & & $.671^{* * *}$ & 3 & \\
\hline $.440^{* *}$ & 27 & & $.671^{* *}$ & 7 & \\
\hline $.554 * *$ & 25 & & $.678^{* * *}$ & 5 & \\
\hline $.545^{* * *}$ & 26 & & $.628^{* * *}$ & 6 & \\
\hline $.445^{* * *}$ & 27 & & $.662^{* * *}$ & 7 & \\
\hline $.405^{* *}$ & 28 & & $.617^{* *}$ & 8 & \\
\hline
\end{tabular}

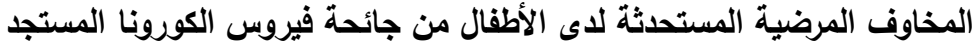


المجلة العلمية لكلية رياض الأطفال - جامعة بورسعيد

\begin{tabular}{|c|c|c|c|c|c|}
\hline الارتباط معامل & p & المكون & الارتباط معامل & p & المكون \\
\hline $.504 * *$ & 29 & \multirow{12}{*}{ الاجتماعي } & $.171^{* *}$ & 9 & \multirow{12}{*}{ النفسي البُعد } \\
\hline $.586 * *$ & 30 & & $.727^{* *}$ & 10 & \\
\hline $.618 * *$ & 31 & & $.671^{* * *}$ & 11 & \\
\hline $.622 * *$ & 32 & & $.626^{* * *}$ & 12 & \\
\hline $.638 * *$ & 33 & & $.612^{* * *}$ & 13 & \\
\hline $.539 * *$ & 37 & & $.766^{* *}$ & 17 & \\
\hline $.504 * *$ & 35 & & $.686^{* * *}$ & 15 & \\
\hline $.586 * *$ & 36 & & $.660^{* * *}$ & 16 & \\
\hline $.464 * *$ & 37 & & $.672^{* * *}$ & 17 & \\
\hline $.482 * *$ & 38 & & $.629^{* * *}$ & 18 & \\
\hline $.484 * *$ & 39 & & $.621^{* *}$ & 19 & \\
\hline $.508 * *$ & 70 & & $.679^{* *}$ & 20 & \\
\hline
\end{tabular}

باسـتقراء الجـدول السـابق يتضــح أن جميـع معـاملات الارتبـاط بـين

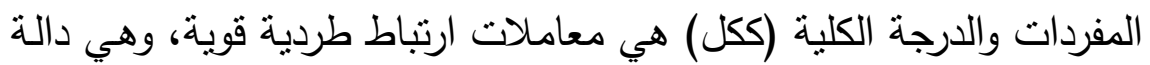

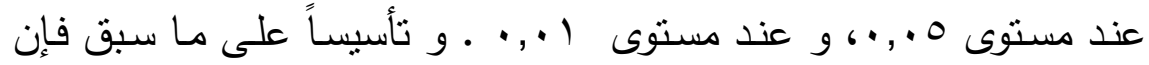

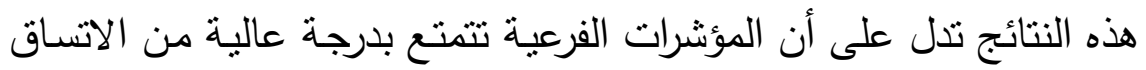

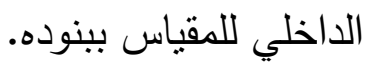


ثانياً: اختبار ثبات مقياس المخاوف المرضية المستحدثة لاى الأطفال من جائحة فيروس الكورونا المستجد:

لحساب ثبات المقياس تم التطبيق على عينة قوامها (0) تتوافر فيها نفس شروط عينة البحث وبعد التطبيق تم حساب الثبات بطريقة : أ- حساب معامل ألفا (حساب الثبات الكلي للمقياس):-

تم حساب ثبات المقياس Reliability باستخدام معامل ألفا لـ كرونباخ

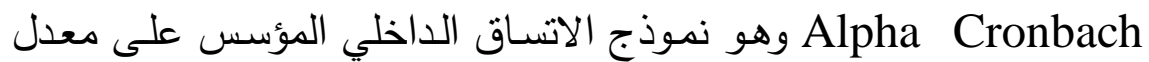
الارتباط البيني بين العبارات، والذي يستخدم لحسباب معامل الثبات التبات الكلي

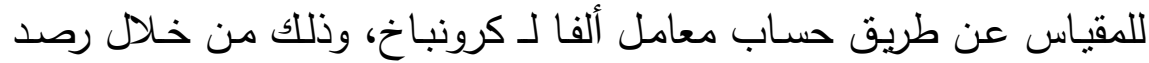
درجات العينة الاستطلاعية لمؤشر كل محور ، وهي كانت كما يلي:-

Alpha Cronbach جدول (ץ) معامل ألفالـ كرونباخ

\begin{tabular}{|c|c|c|c|}
\hline $\begin{array}{c}\text { Cronbach's } \\
\text { Alpha }\end{array}$ & $\begin{array}{c}\text { Cronbach's Alpha } \\
\text { if Item Deleted }\end{array}$ & $\begin{array}{c}\text { Corrected Item- } \\
\text { Total Correlation }\end{array}$ & \\
\hline $0.805^{* *}$ & .710 & .526 & 1 \\
\cline { 2 - 4 } & .739 & .577 & 2 \\
\cline { 2 - 4 } & .710 & .550 & 3 \\
\cline { 2 - 4 } & .610 & .577 & 7 \\
\cline { 2 - 4 } & .610 & .523 & 5 \\
\cline { 2 - 4 } & .636 & .607 & 6 \\
\cline { 2 - 4 } & .638 & .537 & 7 \\
\cline { 2 - 4 } & .638 & .613 & $\mathbf{8}$ \\
\cline { 2 - 4 } & .615 & .379 & $\mathbf{1 0}$ \\
\cline { 2 - 4 } & .613 & .702 & \\
\hline
\end{tabular}


المجلة العلمية لكلية رياض الأطفال - جامعة بورسعيد

\begin{tabular}{|c|c|c|c|}
\hline $\begin{array}{c}\text { Cronbach's } \\
\text { Alpha }\end{array}$ & $\begin{array}{c}\text { Cronbach's Alpha } \\
\text { if Item Deleted }\end{array}$ & $\begin{array}{l}\text { Corrected Item- } \\
\text { Total Correlation }\end{array}$ & المفردة \\
\hline & .639 & .515 & 11 \\
\hline & .638 & .607 & 12 \\
\hline & .638 & .589 & 13 \\
\hline & .612 & .727 & 17 \\
\hline & .639 & .561 & 15 \\
\hline & .636 & .637 & 16 \\
\hline & .638 & .621 & 17 \\
\hline & .638 & .608 & 18 \\
\hline & .639 & .795 & 19 \\
\hline & .639 & .555 & 20 \\
\hline & .638 & .561 & 21 \\
\hline & .639 & $\begin{array}{l}.598 \\
\end{array}$ & 22 \\
\hline & .638 & .599 & 23 \\
\hline & .638 & .618 & 27 \\
\hline & .610 & .515 & 25 \\
\hline & .611 & .331 & 26 \\
\hline & .618 & .713 & 27 \\
\hline & .611 & .318 & 28 \\
\hline & .619 & .377 & 29 \\
\hline & .616 & .776 & 30 \\
\hline & .618 & .711 & 31 \\
\hline & .616 & .710 & 32 \\
\hline & .611 & .389 & 33 \\
\hline
\end{tabular}


المجلة العلمية لكلية رياض الأطفال - جامعة بورسعيد

\begin{tabular}{|c|c|c|c|}
\hline $\begin{array}{c}\text { Cronbach's } \\
\text { Alpha }\end{array}$ & $\begin{array}{c}\text { Cronbach's Alpha } \\
\text { if Item Deleted }\end{array}$ & $\begin{array}{c}\text { Corrected Item- } \\
\text { Total Correlation }\end{array}$ & \\
\hline \multirow{6}{*}{} & .611 & .637 & 37 \\
\cline { 2 - 4 } & .611 & .607 & 35 \\
\cline { 2 - 4 } & .611 & .367 & 36 \\
\cline { 2 - 4 } & .613 & .331 & 37 \\
\cline { 2 - 4 } & .616 & .337 & 38 \\
\cline { 2 - 4 } & .618 & .779 & 39 \\
\cline { 2 - 4 } & .616 & .317 & 40 \\
\hline
\end{tabular}

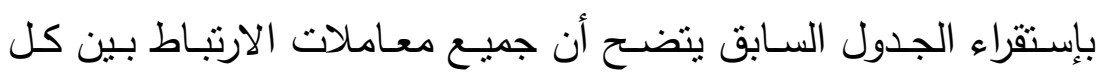

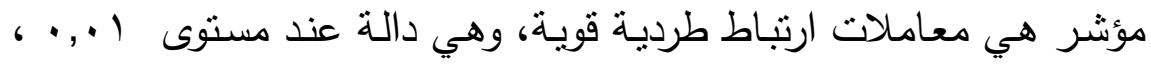

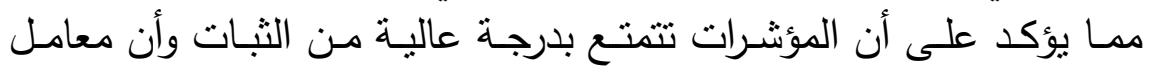

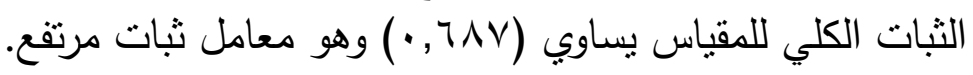
ب-حسـاب ثبـات المقيـاس Reliability باسـخدام التجزئسة النصفية

\section{: Split - Half}

حيث تتمثل هذه الطريقة في تطبيق المقياس مـرة واحدة ثم يُجزَأ إلى لـى

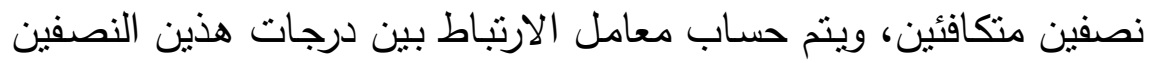

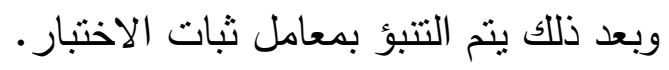

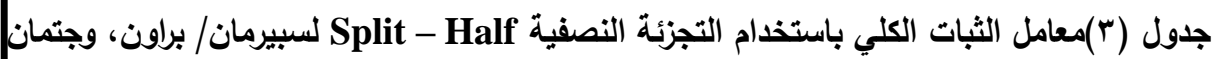

\begin{tabular}{|c|c|c|}
\hline \multirow[t]{2}{*}{ جتمان } & \multicolumn{2}{|c|}{ سبيرمان /براون } \\
\hline & في حالة عدم تساوي نصفي & في حالة تساوي نصفي الاختبار \\
\hline .652 & .621 & .621 \\
\hline
\end{tabular}




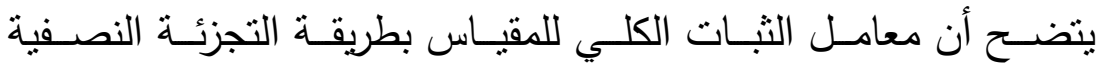

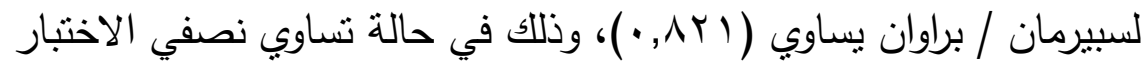

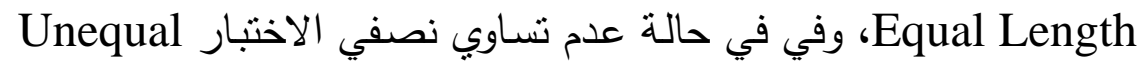

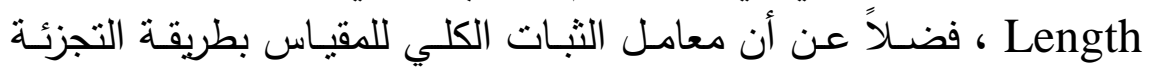

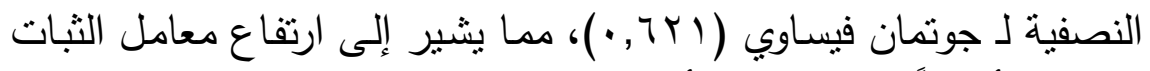

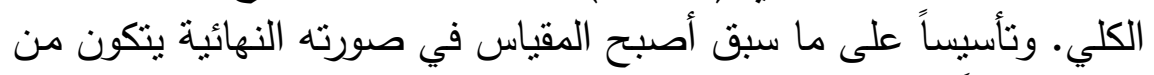

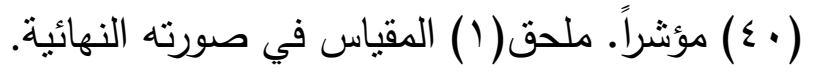
ثانياً : البرنامج الإرشادي ( إعداد/ الباحثة ):

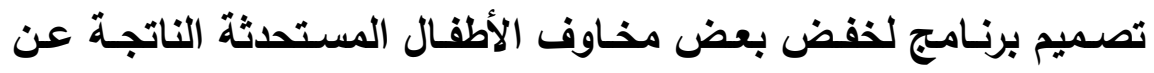

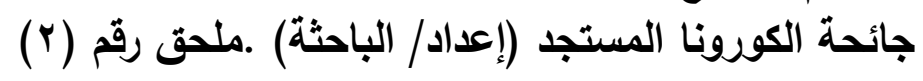
الهذف العام للبرنامج :

يهدف البرنامج إلى خفض المخاوف المرضية (Corona Phobia)

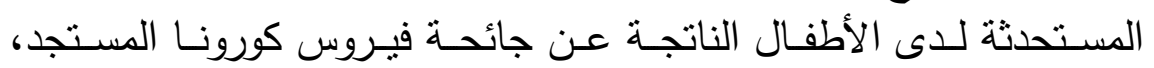

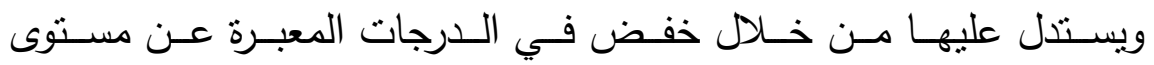

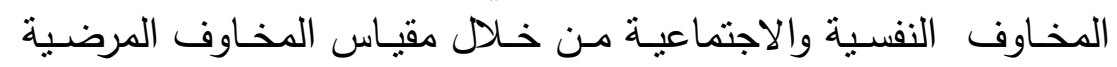

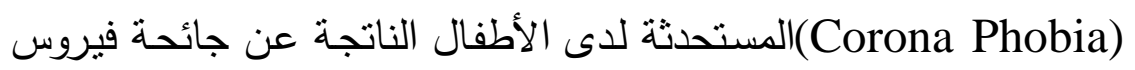

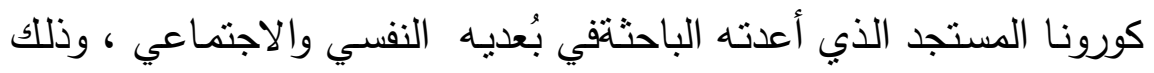

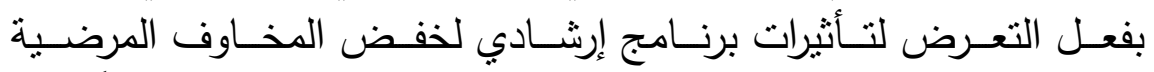

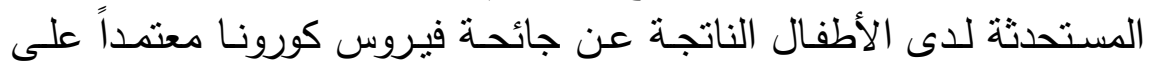

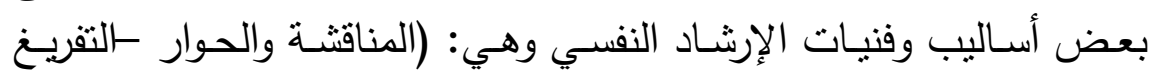

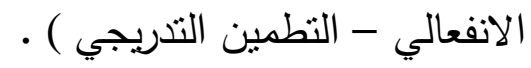




\section{الأهداف الاجرائية للبرنامج:}

تتحقق الأهداف الإجرائية للبرنامج من خلال القيام ببعض الأنشطة داخل

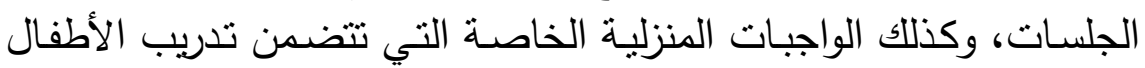

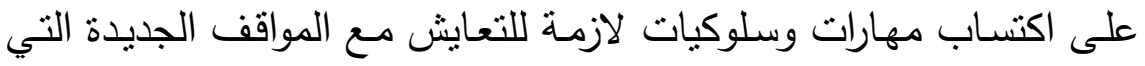

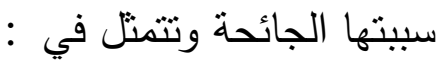
- تعليم الأطفـال بمفهوم الجائحسة، وأسبابها، و طبيعتهـا، وكيفيـة التعامل معها . - تدريب الأطفال على التنفيس الانفعالي. - - تعرف الأطفال على مخاوفهم؛ وكيفية التغلب عليهال

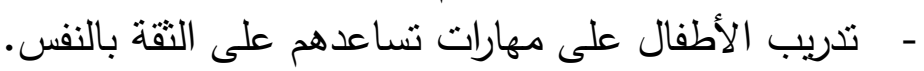

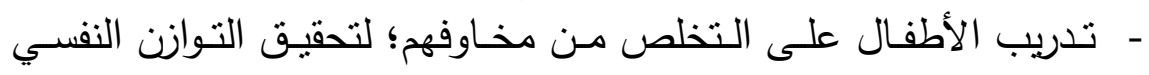

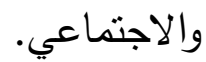

- تدريب الأطفال على التخلص من المشاعر السلبية.

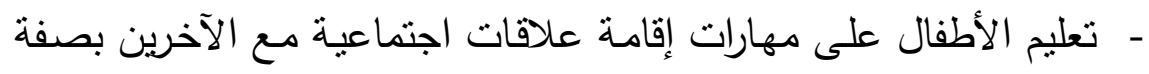
عامة . تصن. - تدريب الأطفال على كيفية ضبط الانفعالات. عينة البرنامج: أطفال سن (0-9) سنوات. نوع الإرشاد: جماعي- فردي.

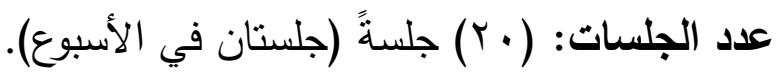

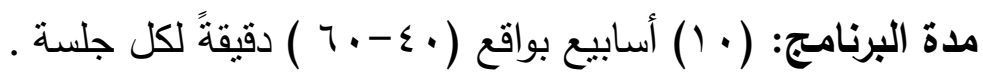
فنيات البرنامج: المناقشة والحوار - التفريغ الانفعالي - التحصين التدريجي

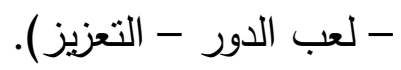




\section{الفتيات المستخدمة في البرنامج :}

- أسلوب المناقشـة والحوار : حيث تم تقديم معلومات للأطفال المشاركين في المجموعة الإرشادية عن بعض المفاهيم كالحديث عن جائحة كورونا

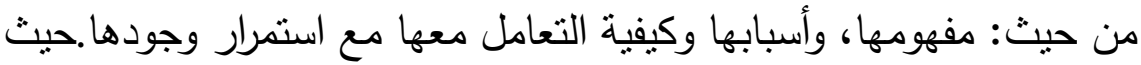

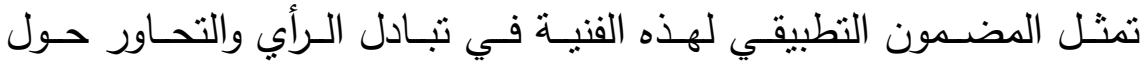

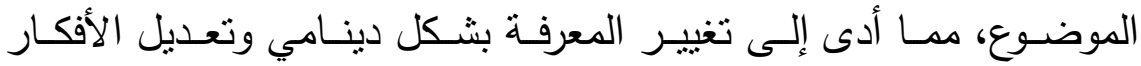
الخاطئة لأعضاء المجموعة الإرشادية.

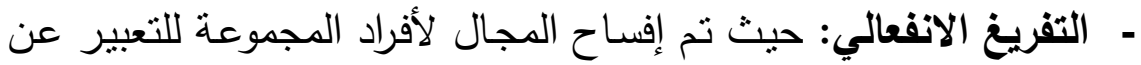

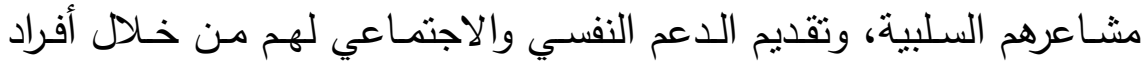

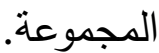

- أسـلوب التطمسين التـدريجي" التحصسين التـدريجي" desensitization

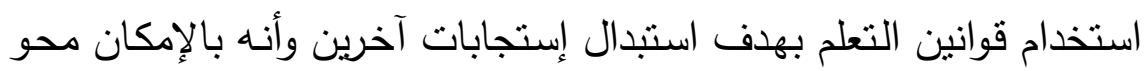

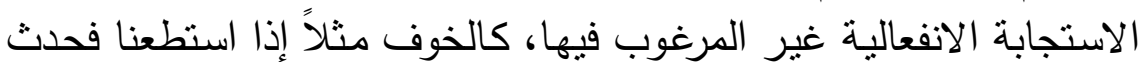

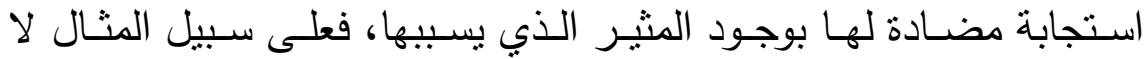

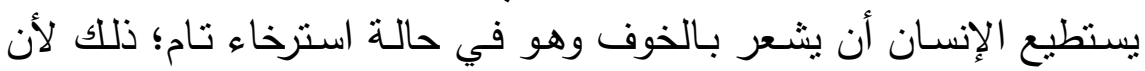

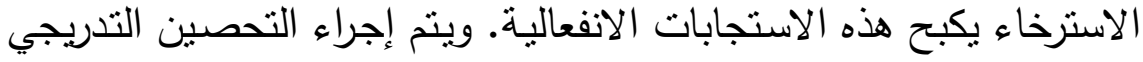

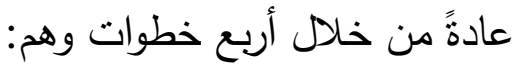
أولاً: التدريب على الاسترخاء العضلي :

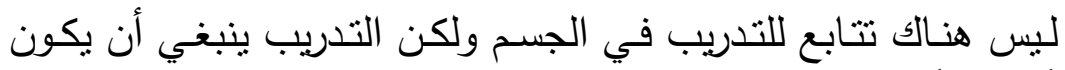

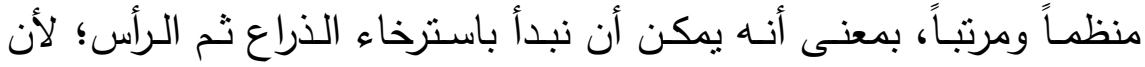

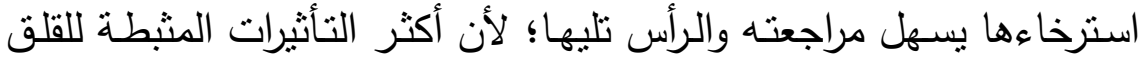

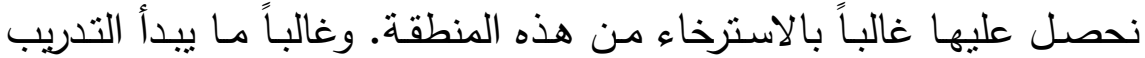


بفقرات قصـيرة، ثم بعـد ذلك سـيجد الفـرد سـهولة في الوصـول إلى حالـة الاسترخاء كاملة عن طريق التدريب المستمر وتكرارها بالمنزل. ثانياً: تحديد المنبهات المثيرة للقلق:

في نفس الوقت الذي يـتم فيـه تدربب الأطفـال على الاسـترخاء يبني الأخصـائي أو المرشـد مـدرجات القلق أو الخـوف المرضـي، وذلك عندما يكون الطفل في حالته العادية بعيداً عن التدربيات؛ للكثف عن استجاباته العادية من خلال المقابلات والاختبارات والمقاييس. ثالثًا : تدريـج المنبهاث المثيرة للقلق :

بعد حصر المنبهات المثيرة للقلق والتي سوف يتم علاجها، تبدأ مرحلة أخرى من العلاج، بحيث يتم وضع قائمة مدرجة من القلق والمخاوف بحيث

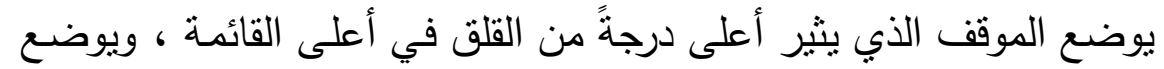
أقلها اسثنارةً في أسفل القائمة. رابعًا:- إجراء عملية التحصين :

هـي تلك الخطوة الأخيـرة في تقليـل الحساسـية التدربجي، والتي تشـتمل على إقران المثيرات التي تبعث القلق بالاستجابة البديلة للقلق (الاسترخاء).

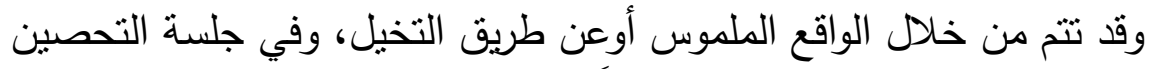

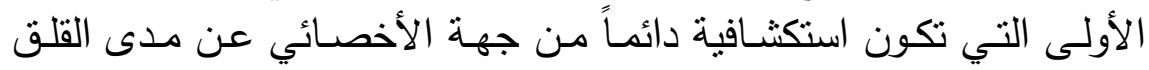

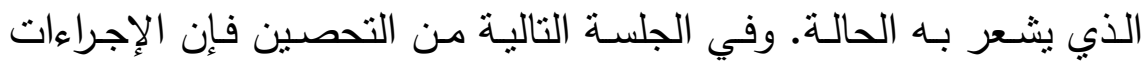

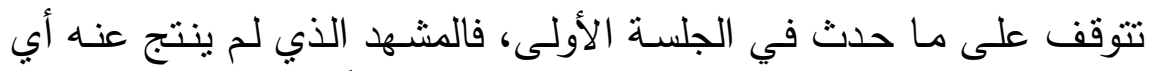

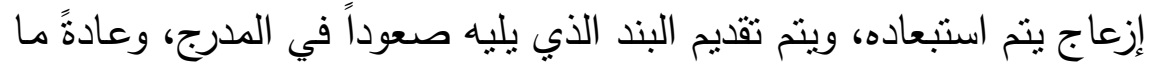

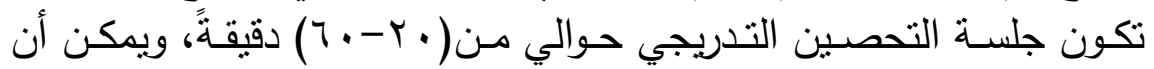
تطول هذه الفترة إذا تطلب ذلك (عبد الحميد، ع . . ب). 


\section{التخطيط العام للبرنامج :}

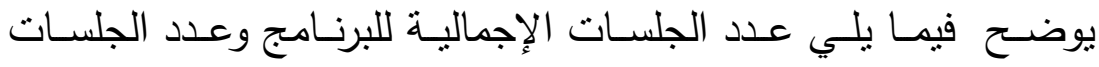

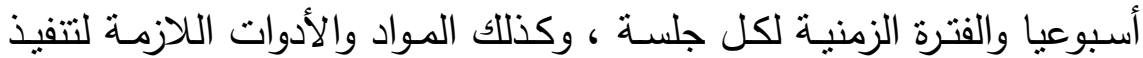

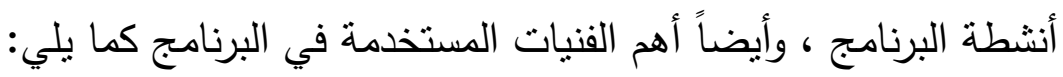
جدول (؛ ) يوضتح التخطيط العام للبرنامج

\begin{tabular}{|c|c|c|c|c|c|}
\hline أهم القتيات & الجلسة & البرنامج & الجلسات & الجلسات & المستخدمة \\
\hline 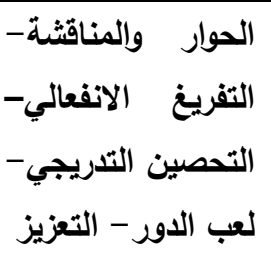 & د ع - + & \begin{tabular}{|c|}
1. \\
\end{tabular} & $r$ & $r$. & مـأقلام- قصصات ملونة \\
\hline
\end{tabular}

ا-الاطلاع على الأدبيات التي تتاولت المخاوف المرضية وجائحة كورونا.

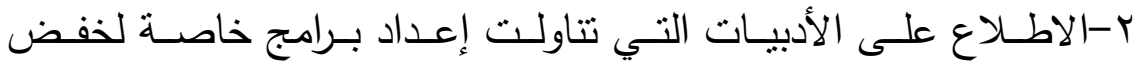
المخاوف المرضية و تحديد المنهج المستخدم وهو المنهج شبه التجربيه.

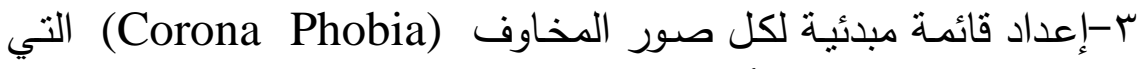
ظهرت على الأطفال من أثز الجائحة والمراد تقليلها لدى الأطفال .

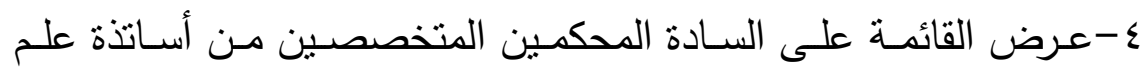
النفس والصحة النفسية. 
ه-إجـراء التعـديلات اللزمـة والوصـول بالقائمـة إلى صـورتها النهائيـة في ضوء آراء المحكمين.

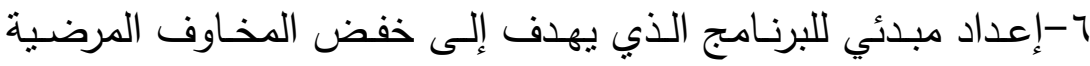
المستحدثة لجائحة كورونا المستجد لدى الأطفال.

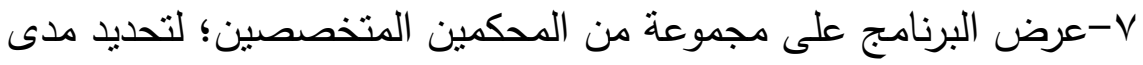

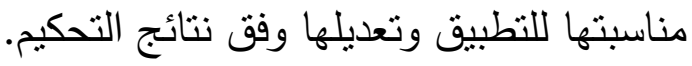

1-إجراء الدراسة الاستطلاعية وحساب الخصائص وفئس السيكومنرية للاختبار. 9-نطبيق مقياس المخاوف المرضية (Corona Phobia) المستحدثة لجائحة كورونا المستجد لدى الأطفال على المجموعة التجريبية كقياس قبلي. • أسبيق البرنامج الإرشادي. 11-تطبيق مقياس المخاوف المرضية (Corona Phobia) المنيقية المستحدثة لجائحة كورونا المستجد لاى الأطفال قياسا بعدياً .

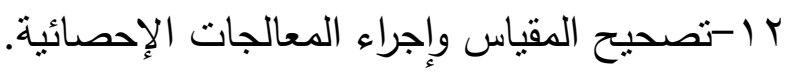
ك ا ا--عرض نتائج البحث ومناقتشتها. ع ا-تقديم مقترحات وتوصيات البحث.

خامساً :الأساليب الإحصائية المستخدمة:

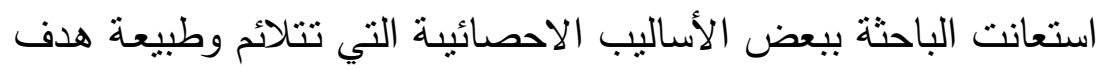

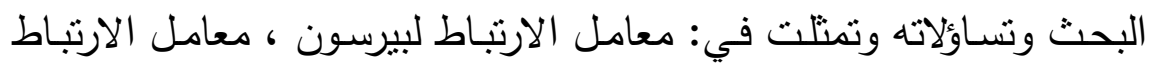

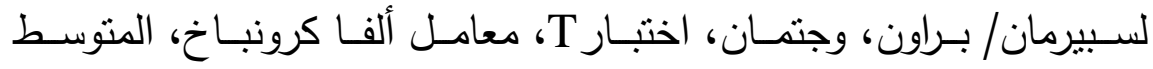

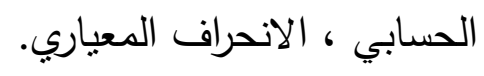
عرض نتائج الفرض الأول ومناقثتها:

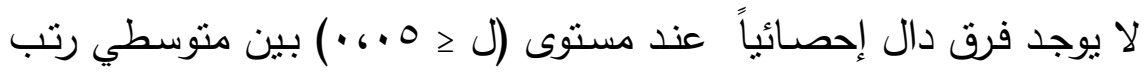

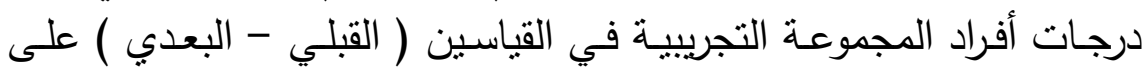


مقياس المخاوف المرضية المستحدثة للأطفال لفيروس كورونا المستجد في كلٍ من بُعديه (النفسي - الاجتماعي) بعد نلقي البرنامج الإرشـادي لخفض المخاوف في اتجاه القياس البعدي.

وللتحقـق مـن صـحة هـذا الفـرض قامــ الباحثة بحسـاب المتوسـطات

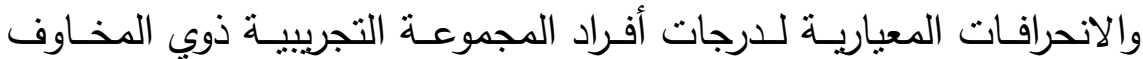

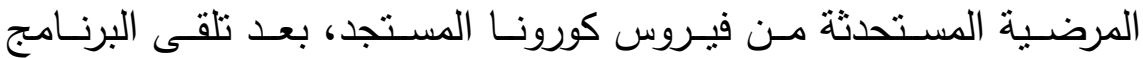
الإرشادي وبين درجاتهم قبل البرنامج على أبعاد مقياس المخاوف المرضية المستحدثة للأطفال لفيروس كورونا المستجد في كلٍ من بُعديـه (النفسي الاجتماعي)، والجدول التالي يلخص هذه النتائج.

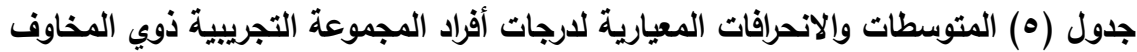
المرضية المستحثثة من فيروس كورونا المستجد في كلٍ من بُعديه (النفسي - الاجتماعي)

\begin{tabular}{|c|c|c|c|}
\hline الانحراف المعياري & المتوسط & نوع الأداء & المكون \\
\hline 3.62 & 49.63 & القبلي & \multirow{2}{*}{ البعد النفسي } \\
\hline 7.09 & 33.25 & البعدي & \\
\hline 1.81 & 51.13 & القبلي & \multirow[t]{2}{*}{ البعد الاجتمـاعي } \\
\hline 8.12 & 34.25 & البعدي & \\
\hline
\end{tabular}

من النتائج التي يلخصها الجدول السابق أن هنالك تحسنا في أداء أطفال المجموعة التجريبية ذوي المخاوف المرضية المستحدثة من فيروس كورونا المستجد بعدياً، ويستدل على ذلك من نتائج مقارنة المتوسطات والانحرافات المعيارية لأداء الأطفال في التطبيقين القبلي والبعدي. 


\section{المجلة العلمية لكلية رياض الأطفال - جامعة بورسعيد}

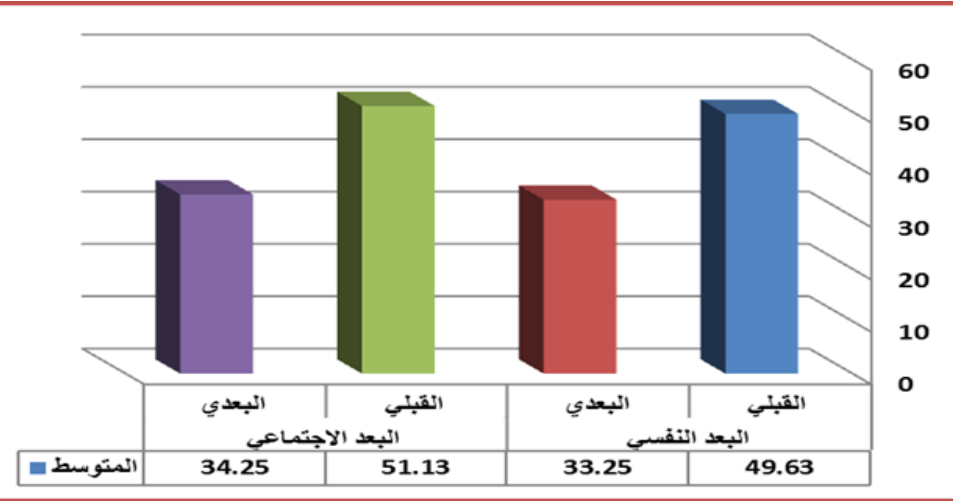

شكل (1) يوضح المتوسطات لارجات أفراد المجموعة التجريبية ذوي المخاوف المرضية

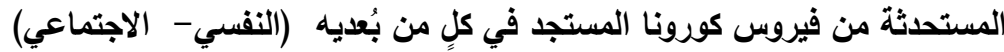
تم تطبيق اختبار وبلكوكسون Wilcoxon Signed Rank Test الذي يسمى اختبار الرتب الإشاري، وهو من الاختبارات اللابارامترية التي تستخدم كبديل لاختبار (ت) للعينتين المرتبطتين من البيانات، وذلك في حالة عدم تحقيق شروط استخدام اختبار ت للقيم المرتبطة وذلك لصغر حجم العينة. والجدول التالي يلخص هذه النتائج.

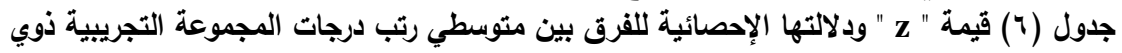

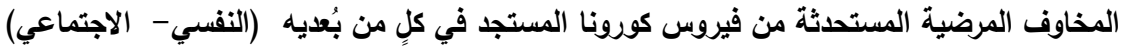

\begin{tabular}{|c|c|c|c|c|c|c|}
\hline 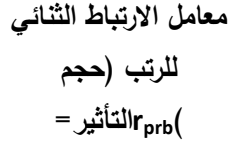 & مستوى الدلالة & إحصائي & الرتب & متوسط الرتب & الإثشارات & المكون \\
\hline \multirow{2}{*}{$\begin{array}{l}0.944 \\
\text { قوي جاً }\end{array}$} & \multirow[t]{2}{*}{.017} & \multirow[t]{2}{*}{2.380} & 35.00 & 5.00 & السالبة & \multirow{2}{*}{ النفسي } \\
\hline & & & 1.00 & 1.00 & الموجبة & \\
\hline \multirow{2}{*}{ قوي جداً } & \multirow[t]{2}{*}{.018} & \multirow[t]{2}{*}{2.366} & 28.00 & 4.00 & السالبة & \multirow{2}{*}{ الاجتماعي } \\
\hline & & & .00 & .00 & الموجبة & \\
\hline
\end{tabular}

* عند مستوى ه.,. 
"z" نتبين من النتائج التي يلخصها الجدول السابق أن قيمة إحصائي

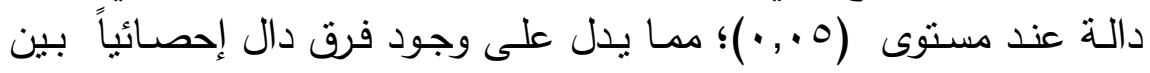

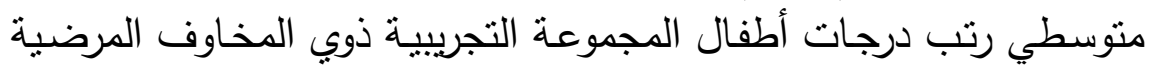
المستحدثة من فيروس كورونا المستجد في التطبيقين القبلي والبعدي في كلٍ البِ

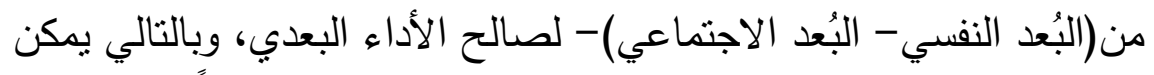

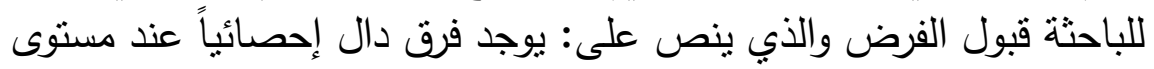

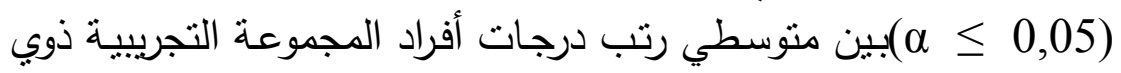

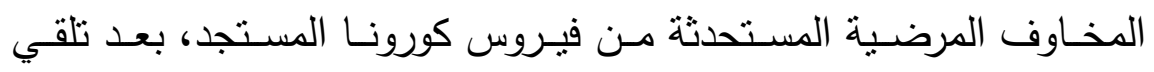

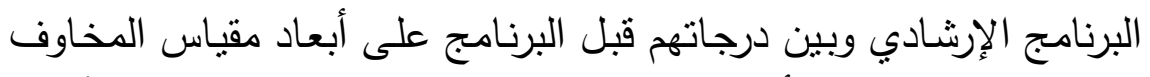

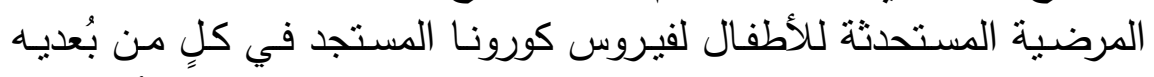

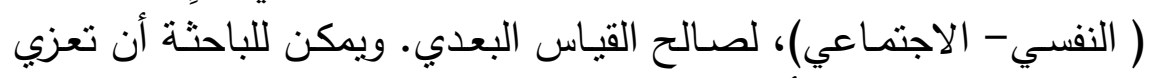

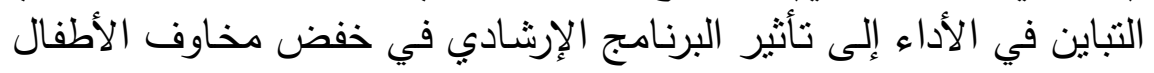

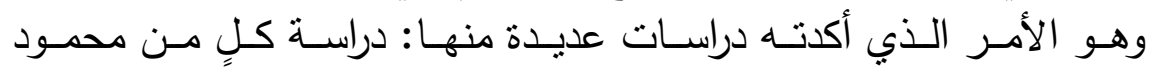

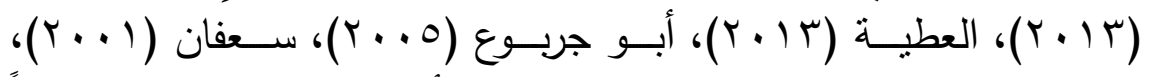

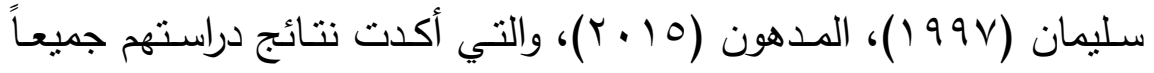

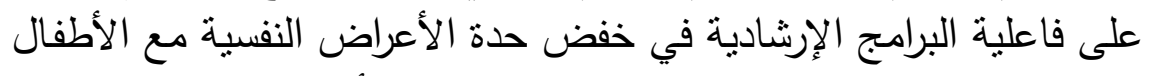
وفي خفض مخاوفهم سواء كانت مخاوف اجتماعية أو نفسية .

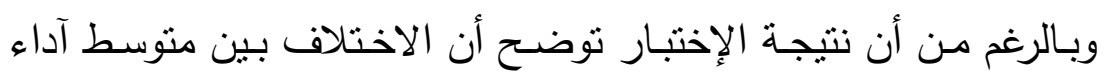

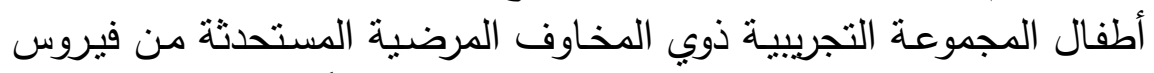

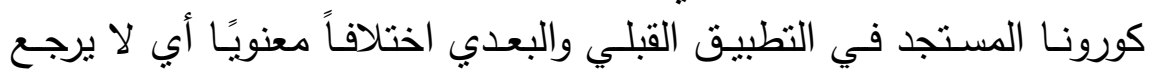

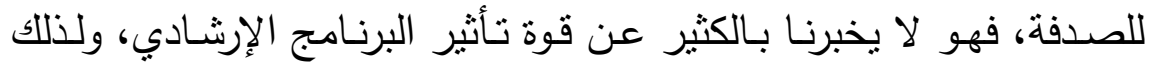

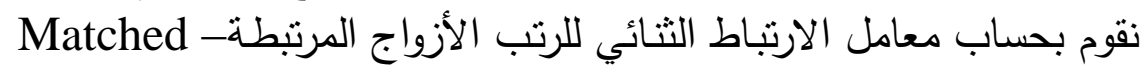


لمعرفة حجم التأثير المتغير Pairs Rank biserial correlation المستقل على المتغير التابح. و يمكن حسابه من المعادلة :

$$
I_{\text {prb }}=\frac{4(T 1)}{n(n+1}-1
$$

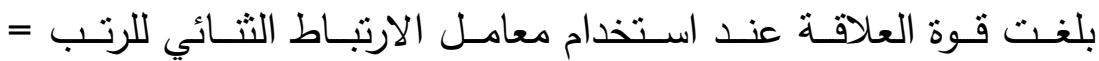

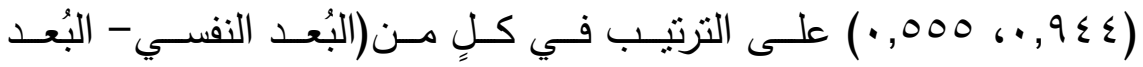

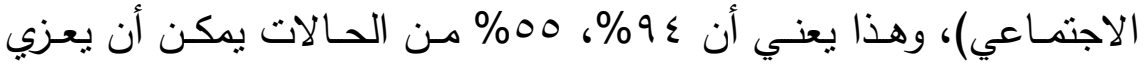

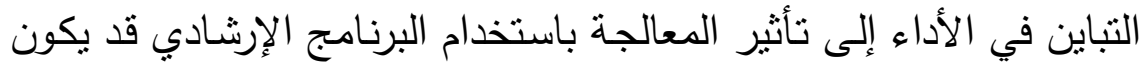
لله أثر كبير في خفض بعض الاد المخاوف المرضية المستحدثة لدى الأطفال

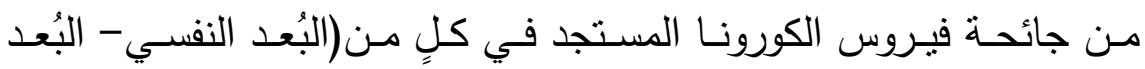

$$
\text { (الاجتماعي). }
$$

ويمكن للباحثة أن تعزي التباين في الأداء إلى تأثثر البرنامج الإششادي

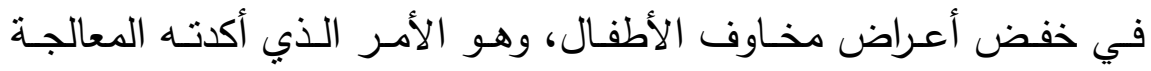

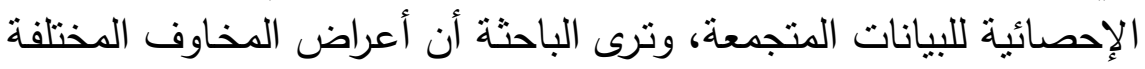

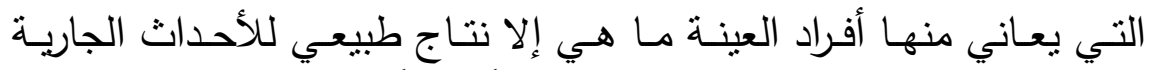

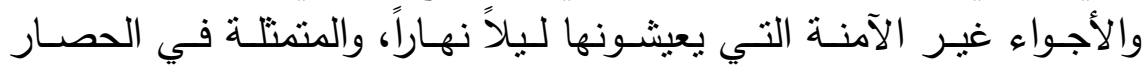

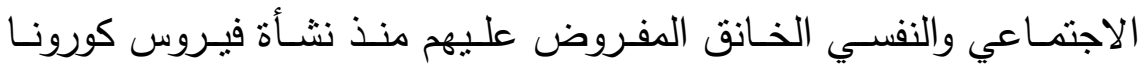

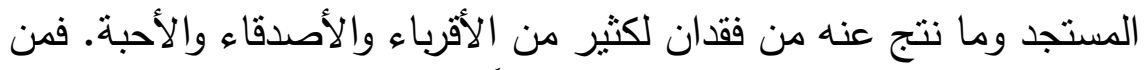

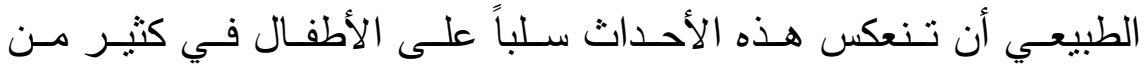

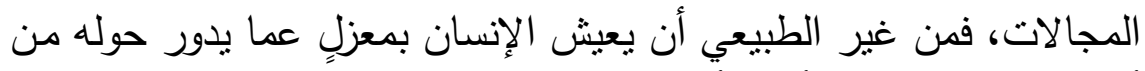

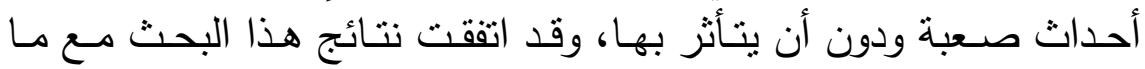

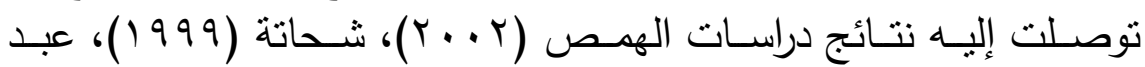

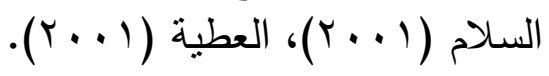


Jiao et al. (2020); Roy et al., (2020); فما اتفقت مع دراسة

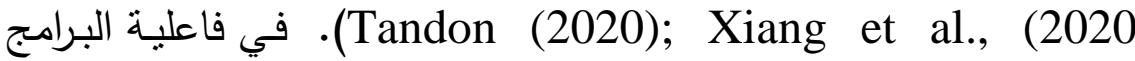
الإرشـادية في خفض المخاوف لدى الأطفال، وكذلك فاعليتها في تتميـة

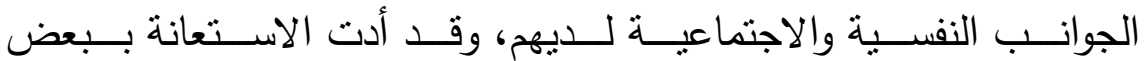

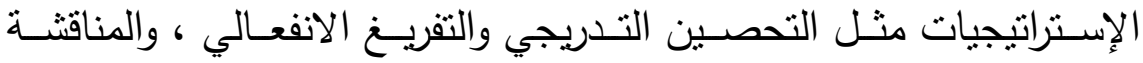

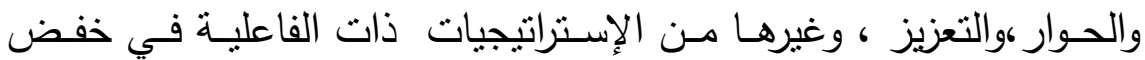

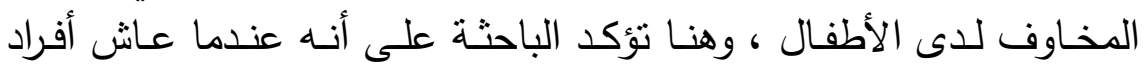

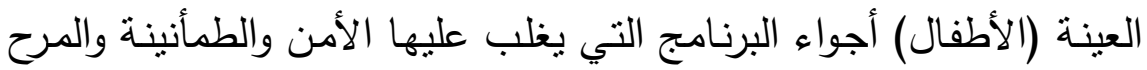

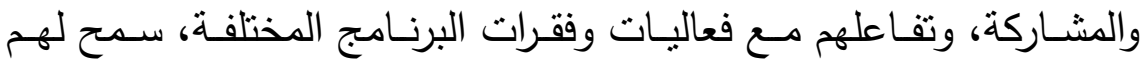

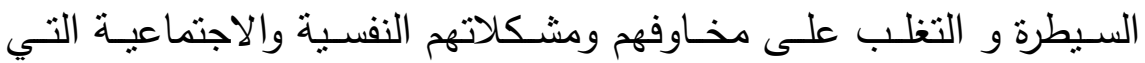

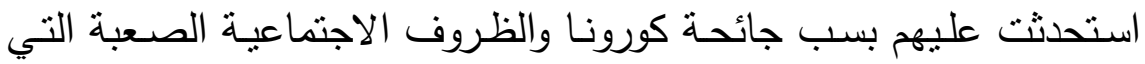

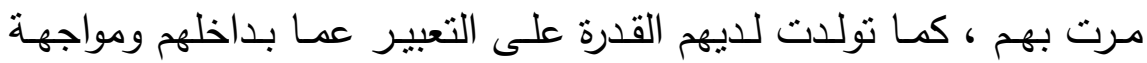

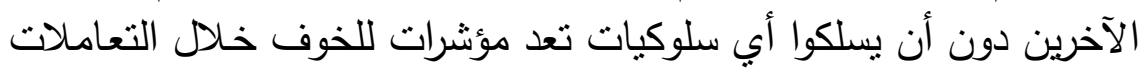

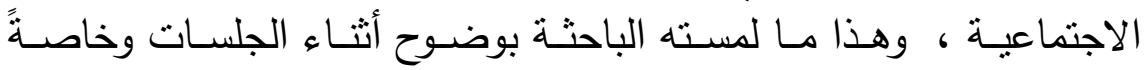
الجلسات المتأخرة منها ـ كما تمنل ذلك التحسن في استجابة الأطفال وتزايد

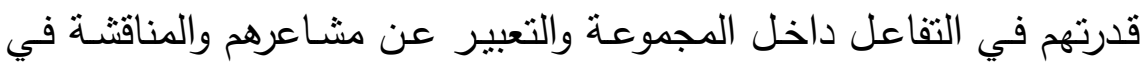

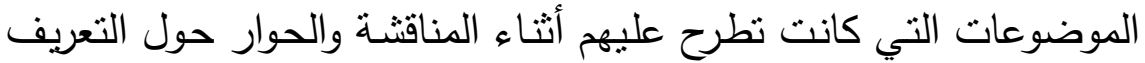

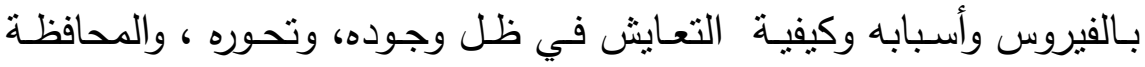

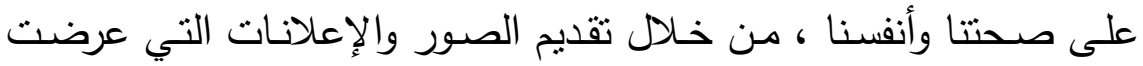

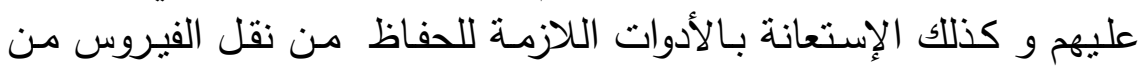

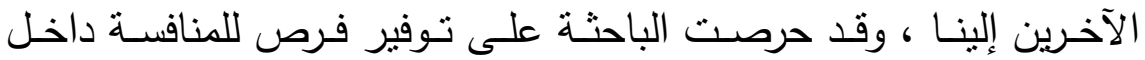

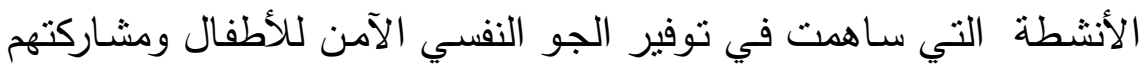

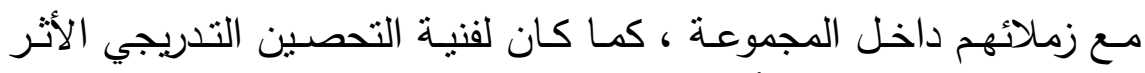

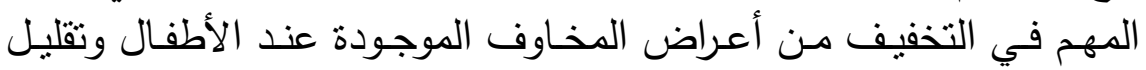


مشـاعر التوتر والقلق الذي كانوا بشـعرون بـه في بدايـة البرنـامج حيثت تم

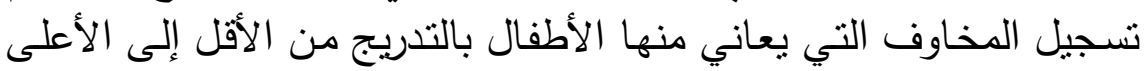

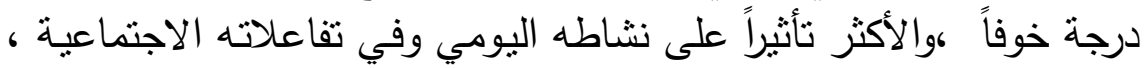
وتدرب الأطفال على الاسترخاء والتنفس بهدوء، والتخيل للمواقف التي تثير لديه الخوف والقلق تدريجياً بدأ بأقلها وانتهاءاً بأكثرها إثارة، وهو في حالة الأب الاسترخاء ومن خلال تكرار هذه الجلسـات في البرنامج والتدريب المنزلي باءي بالبيت، ومن خلال المواجهة الفعالة وتعربضه لمثيرات الخوف ساعد بشكلٍ كبيرٍ على تحوبل انتباه الأطفال إلى اتجاهات إيجابية أكثر ساعدتهم على

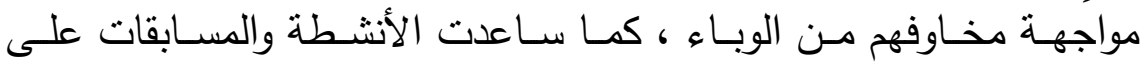

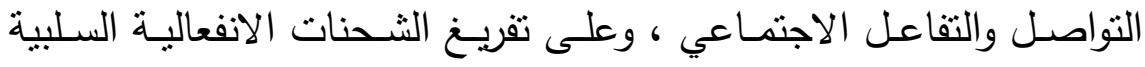

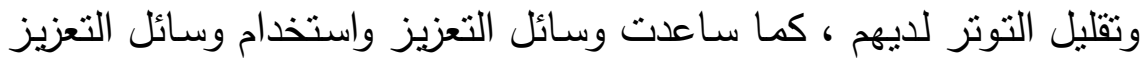

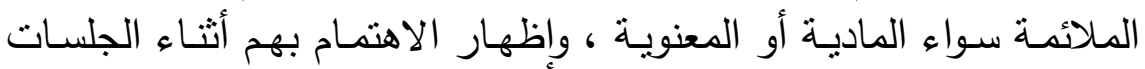

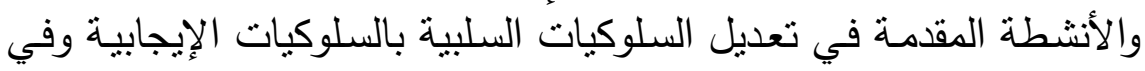

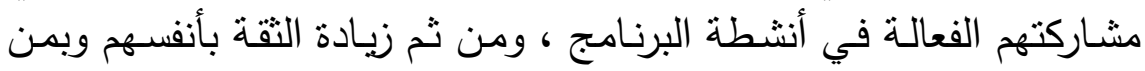

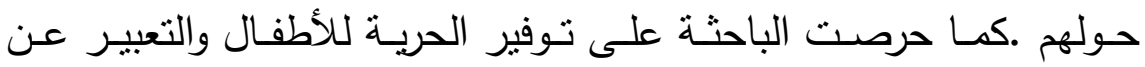
مشاعرهم والتفاعل الإيجابي من خلال حريتهم في اختيار الأنشطة وخاصة وجود فرق في المرحلـة العمريسة بين أفراد المجموعـة وحريتهم في اختيـار أنشطة بديلة تنتاسب معرد في معرد عرض نتائج الفرض الثاني ومناقشتها: ينص الفرض الثاني على أنه لا يوجد فرق دال إحصـائياً عند مستوى

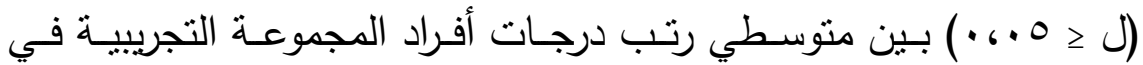
القياسين ( البعدي - التتبعي ) على مقياس المخاوف المرضية المستحدثة

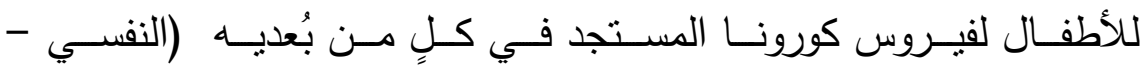


الاجتمـاعي) ، بعد تلقي البرنـامج الإرشـادي لخفض المخـاوف بعد مرور شهر من التطبيق.

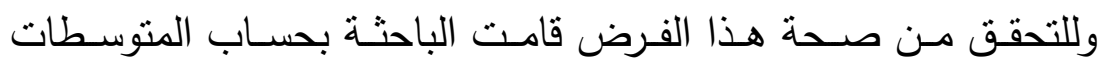

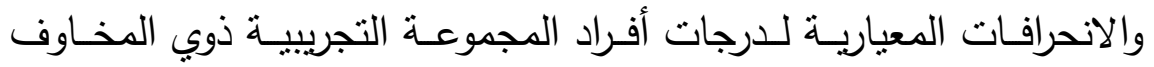

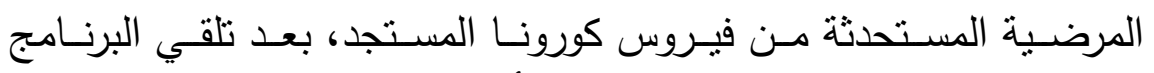

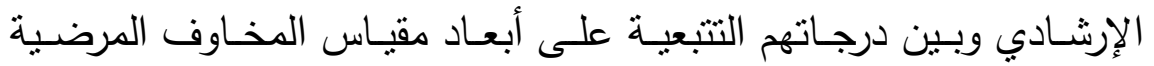

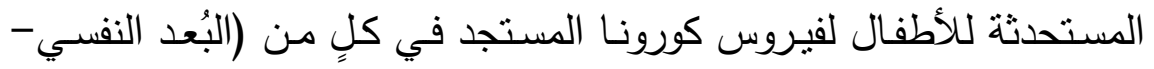

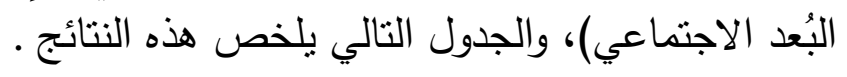

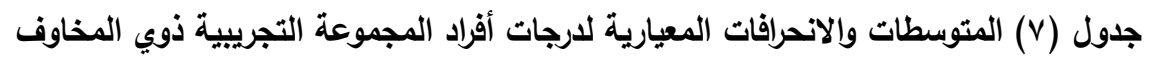
المرضية المستحدثة من فيروس كورونا المستجد في كلٍ من بُعديه (النفسي- الاجنماعي)

\begin{tabular}{|c|c|c|c|}
\hline الانحراف & المتوسط & نوع الأداء & المكون \\
\hline 6.70 & 32.63 & التتبعي & \multirow{2}{*}{ البعد النفسي } \\
\hline 7.09 & 33.25 & البعدي & \\
\hline 7.62 & 34.50 & التتبعي & \multirow{2}{*}{ الاجتماعد } \\
\hline 8.12 & 34.25 & البعدي & \\
\hline
\end{tabular}

يتبين من النتائج التي يلخصها الجدول السابق أن هناك ثبات في أداء

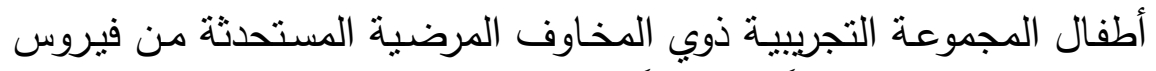

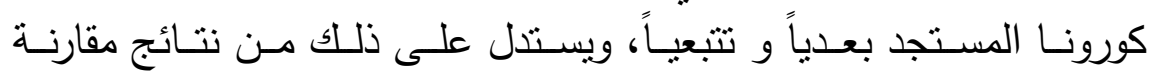

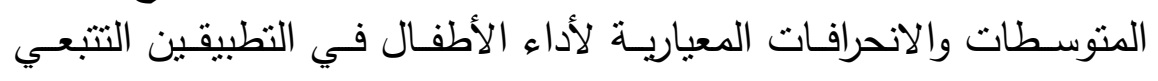
والبعدي. 


\section{المجلة العلمية لكلية رياض الأطفال - جامعة بورسعيد}

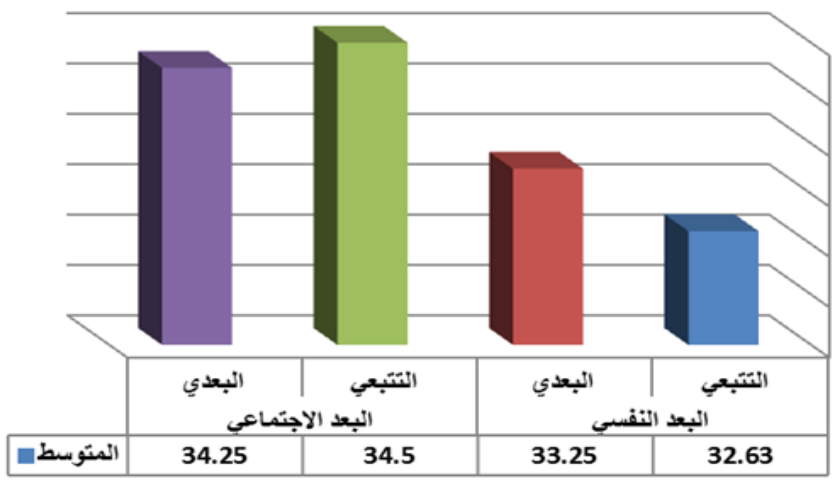

شكل (Y)(المتوسطات لدرجات أفراد المجموعة التجريبية ذوي المخاوف المرضية المستحدثة

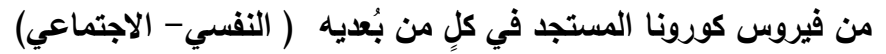

تم تطبيق اختبار ويلكوكسون Wilcoxon Signed Rank Test الذي متي يسمي اختبار الرتب الإشاري، وهو من الاختبارات اللابارامتربة التي تستخدم كبديل لاختبار (ت) للعينتين المرتبطتين من البيانات، وذللك في حالة عدم تحقيق شروط استخدام اختبار ت للقيم المرنبطة وذلك لصغر حجم العينة. والجدول التالي يلخص هذه النتائج. جدول (^) قيمة " z " ودلالتها الإحصائية للفرق بين متوسطي رتب درجات المجموعة التجريبية ذوي

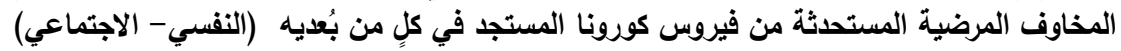

\begin{tabular}{|c|c|c|c|c|c|}
\hline الدلالة & "z" إحصائي & مجموع الرتب & متوسط الرتب & الإشارات & المكون \\
\hline \multirow[t]{2}{*}{.102} & \multirow[t]{2}{*}{1.633} & .00 & .00 & السالبة & \multirow{2}{*}{ النفسي } \\
\hline & & 6.00 & 2.00 & الموجبة & \\
\hline \multirow[t]{2}{*}{.414} & \multirow[t]{2}{*}{0.816} & 14.00 & 3.50 & السالبة & \multirow{2}{*}{ الاجتماعي } \\
\hline & & 7.00 & 3.50 & الموجبة & \\
\hline
\end{tabular}


"z" نتبين من النتائج التي يلخصها الجدول السابق أن قيمة إحصائي

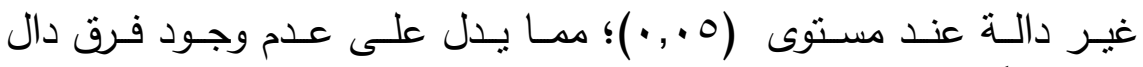

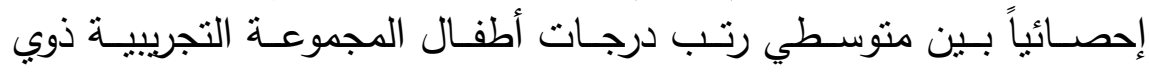
المخاوف المرضية المستحدثة من فيروس كورونـا المستجد في التطبيقين

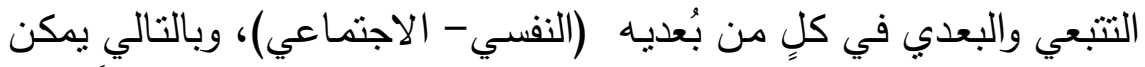

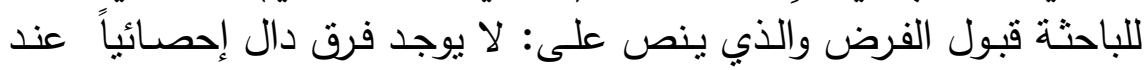
مستوى $(\alpha \leq 0,05)$ بين متوسطي رتب درجات أفراد المجموعة التجريبية

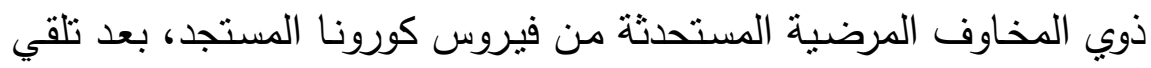

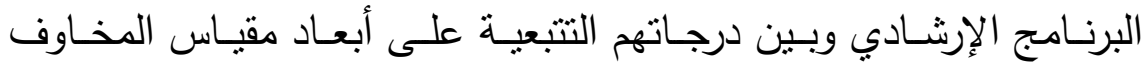

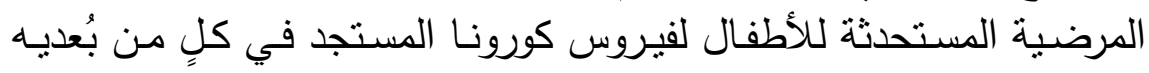

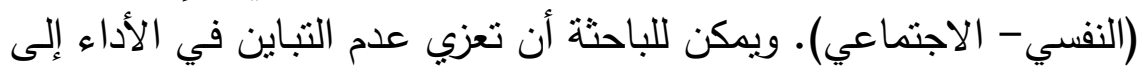

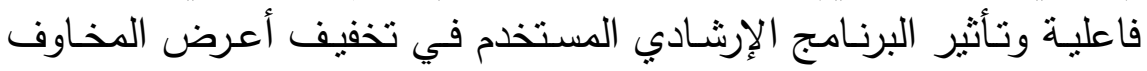

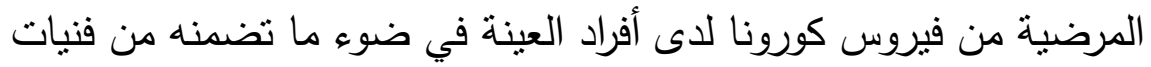

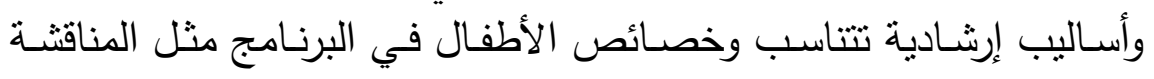

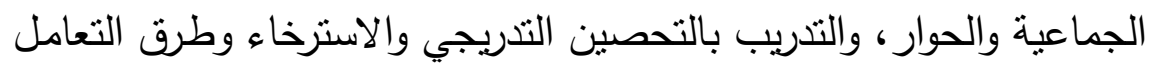

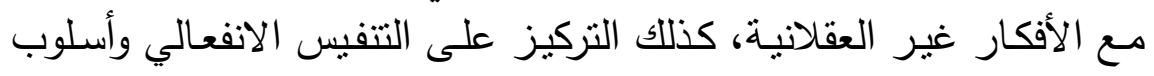

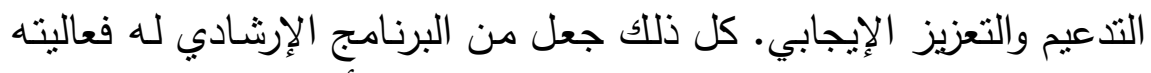

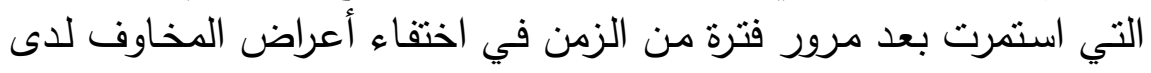

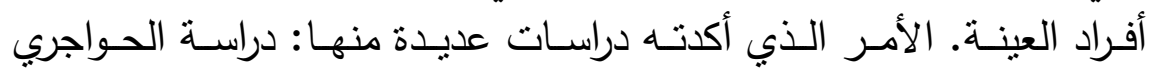

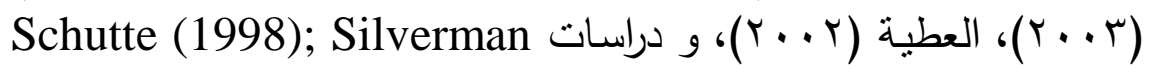
بواء والتي (1998); Last, Hansen \& Franco (1998) بقاء واستمرار أثز البرنامج بعد مرور فترة زمنية وبعد الانتهاء من التعرض التهات

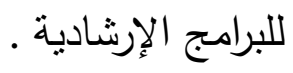


وتؤكد الباحثة أن الاستقرار في هذا الانخفاض يؤكد فاعلية البرنامج في

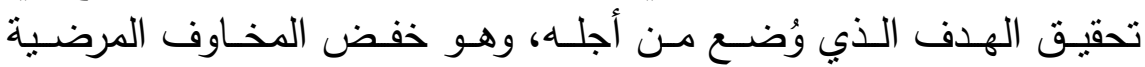

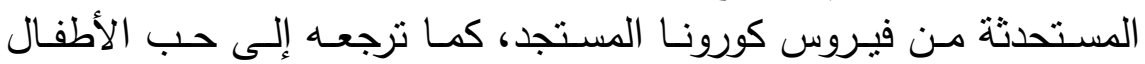

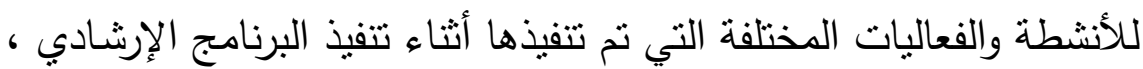

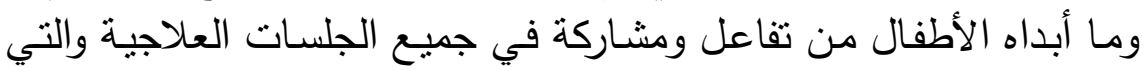
كان لها الأثر في تدعيم السلوكيات الإيجابية في المواقف الحياتيـة المختلفة والتي تثير الخوف لديهم، ومتابعة الباحثة لهم في فترة المتابعة.

وهكذا استطاع البرنامج المستخدم تحقيق الهدف الذي وُضِع من أجله في

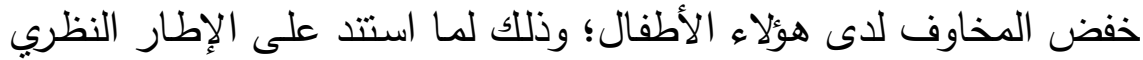
والمنحنى الإنمائي، أكدت الدراسات والبحوث السابقة أنه من أكثر التوجهات الإهات النظربـة إنجاحًا في التطبيـق النفسـي والتربـوي، هـذا بالإضــافة إلـى تقبـل الإسل الأطفال للفنيات المستخدمة وتقهمه وتجاوبهم معها، وقد استمر هذا التأثير

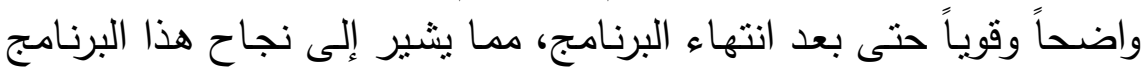
في خفض المخاوف المرضية المستحدثة من فيروس كورونا المستجد لدى الأطفال.

وفي ضوء ذلك تؤكد الباحثة أن المخاوف المرضية لها دوراً هاماً في حياة الأطفال، فتؤثز علبهم بالسلب في أغلب الأحبان، وبنعكس ذلك على دؤى تصرفاتهم وسلوكياتهم حيال أنفسهم ومـع الآخرين، ويترتب على ذلك وجود

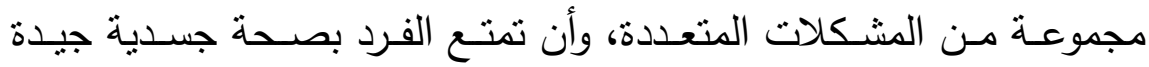
وقدرته على مواجهة الصعاب، وخلوه من المشكلات والأمراض بضمن لله

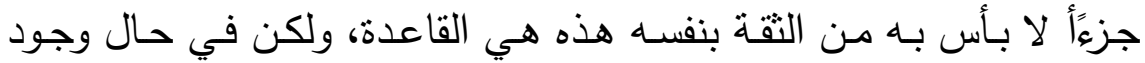
مشكلة معينة في حياتهم فإن درجة التقة التي يتمتع بها الفرد هي التي تحدد دهد

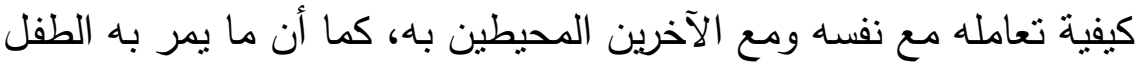




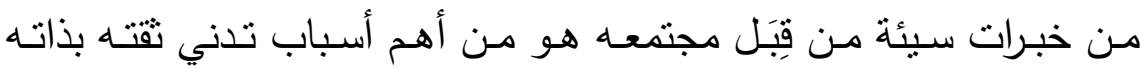

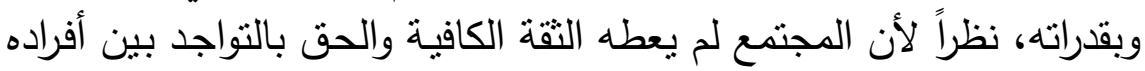

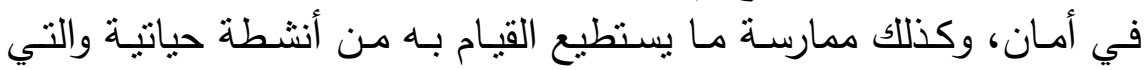

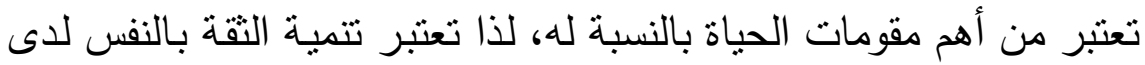

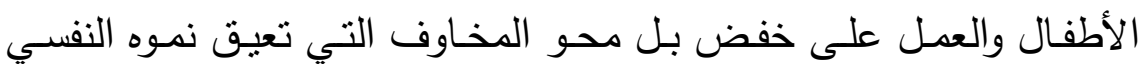

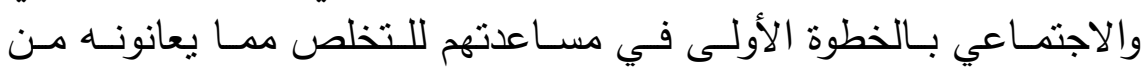

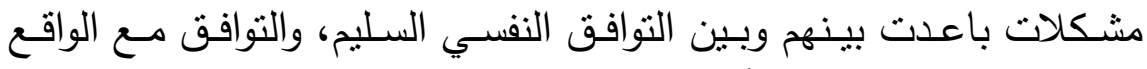
الاجتماعي الذي يعيشه الأطفال بسبب خبراته لتون السيئة التي مروا بها. توصيات البحث: نتيجة لما أسفرت عنه نتائج البحث يمكن للباحثة أن توصي بـ:

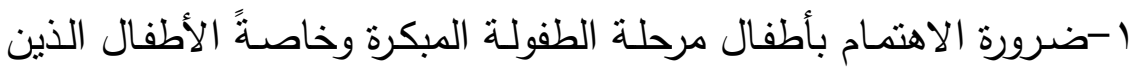

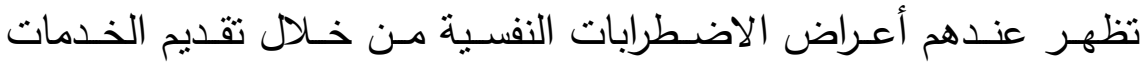
والبرامج الإرشادية.

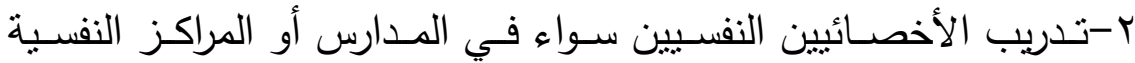
التربوية على فنيات الإرشاد النفسي المنتوعة وأسسه.

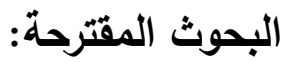
- إجراء دراسـة وصفية مقارنـة لدراسـة المخـاوف مـن فيروس كورونـا بين الذكور والإناث. - إجراء برنامج إرشادي لتتمية التقة بالنفس لدى مصابين كورونا. - - اقتراح برامج ارشـادية لعـلاج مخاوف فيروس كورونـا في مراحل عمريـة مختلفة. - إجـراء دراسـة ميدانيـة لدراسـة الخصـائص النفسـية للأطفـال المصـابين بفيروس كورونا. 


\section{المراجح?}

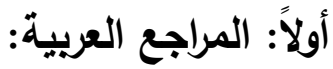

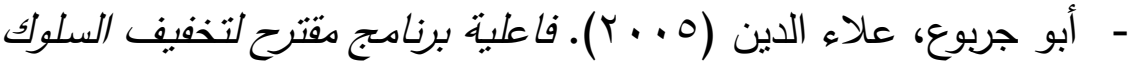
العدواني لدى طلاب الصف التاسع الأساسي بدحافظة غنة (رسالة ماجستير

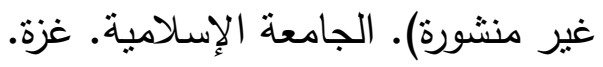

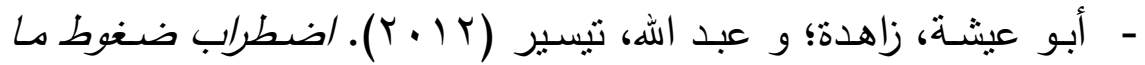

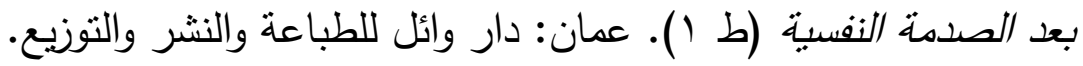

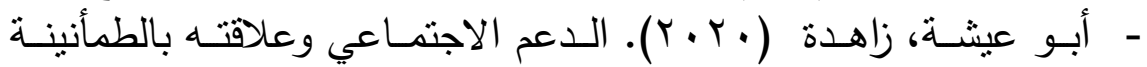
العاطفية والمخاوف المرضية لـ :Covid-19 دراسة مقارنة للبيئتين العربية بالية

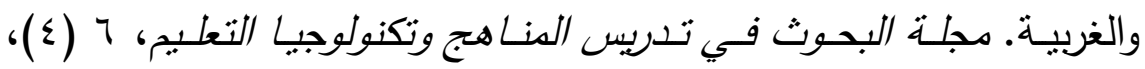
.r. O- I $\leqslant V$

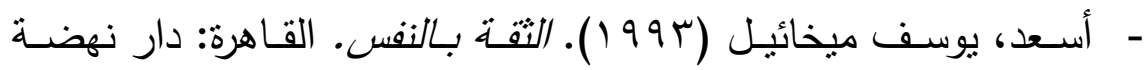

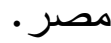

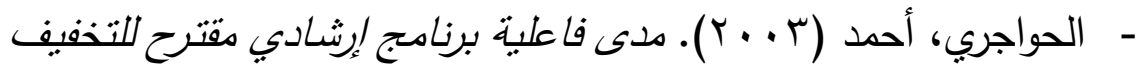

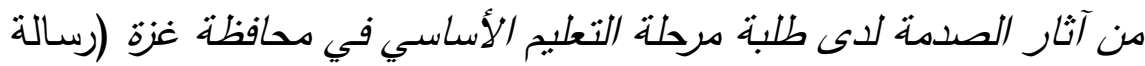

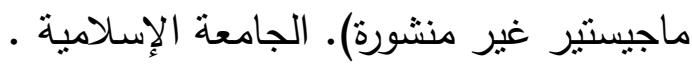

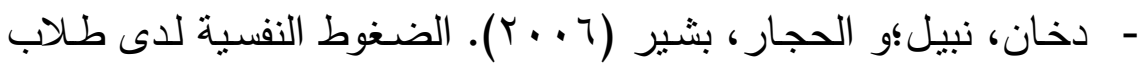

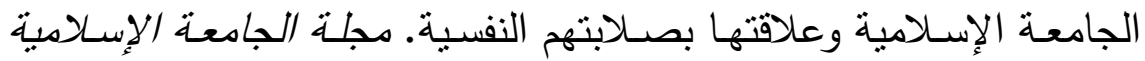

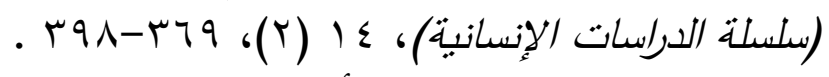

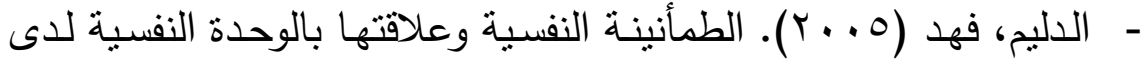

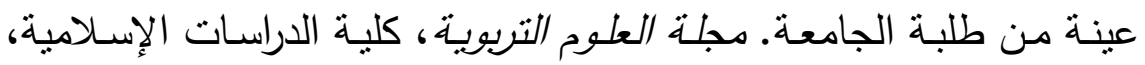

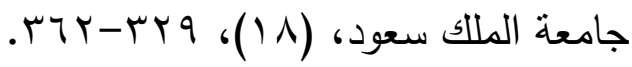


- زهـران، حامـد عبـد السـلام (ب . . ب). دراسـات فـي الصــة النفسـبة والإشاد النفسي. القاهرة: عالم الكتب. مادئ.

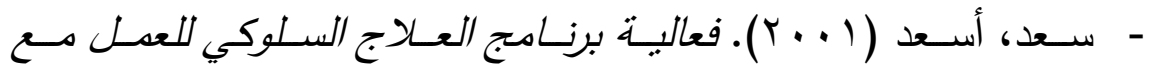
المجدوعات للحد من بعض المخاوف المرضبية الشائعة بين فتبات المدارس لرس الابتدائبة في مرحلة الطفولة المتأخرة (دكتوراه غير منشورة). جامعة عين

- سعفان، محمد أحمد ابراهيم (1 ( . ب). الإشاد النفسي للأطفال. القاهرة: دار الكتاب الحديث. - سـليمان، عبد الرحمن سـيد (99V (1) ). تربية غبر العـادبين وتعلبيهم. القاهرة: مكتبة زهراء الثرق .

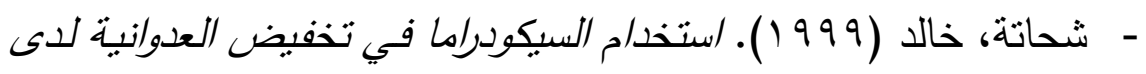
الأطفال اللقطاء مجهولي النسب لسن ما قبل المدرستة (رسالة ماجستير غير

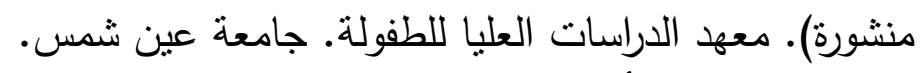

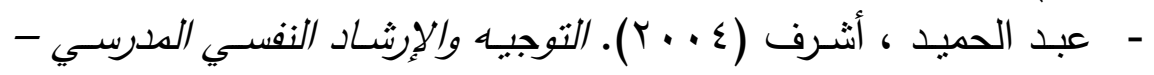
إستراتيجية عدل الأخصسائي النفسي بددارس العـادبين وذوي الاحتباجـات

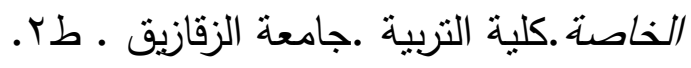

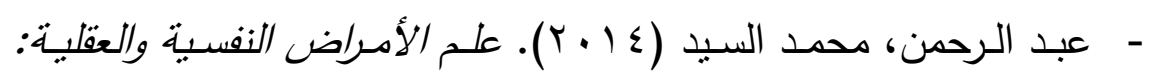
الأسباب- الأعراض - الثشخبص والعلاج. القاهرة: مكتبة زهراء الثرق.

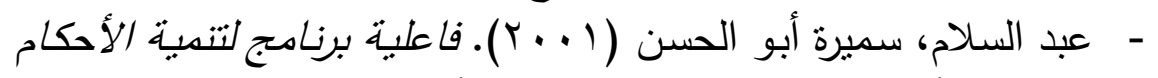

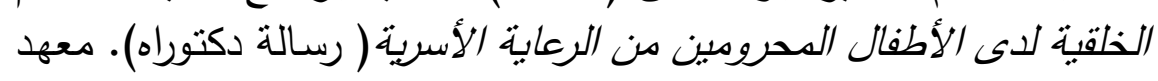
الدراسات والبحوث التربوبة.جامعة القاهرة.

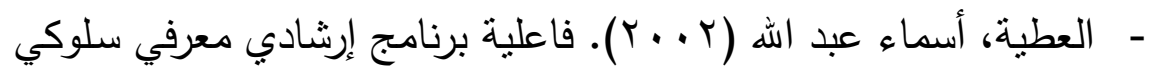

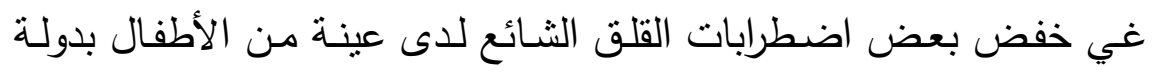

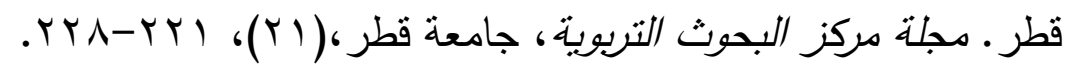




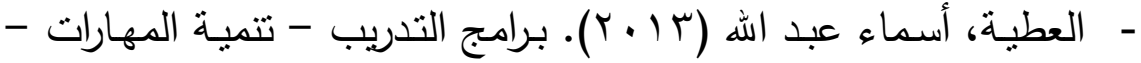

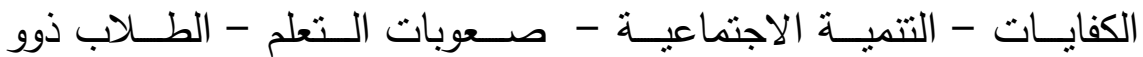

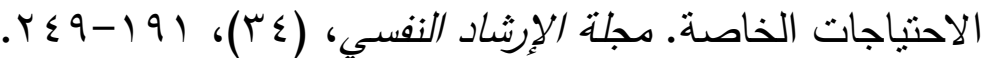

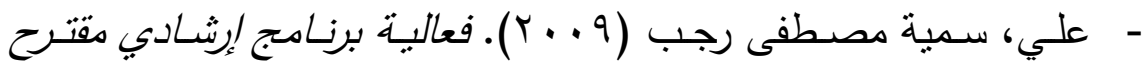
لتنمبية الثقة بالنفس لدى طالبات الجامعة الإسلادبية بغزة ( رسالة ماجستير). الجامعة الإسلامية غزة.

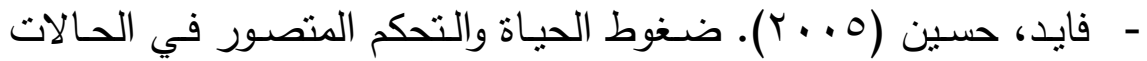

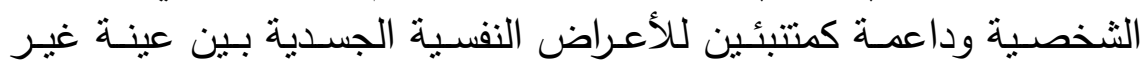
سريرية. مجلة الدراسات النفسية . جمعية علماء النفس المصرية، 10 (1)، (1) . or-o

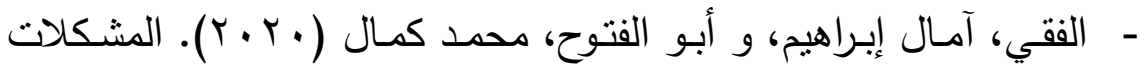

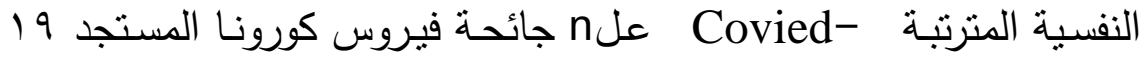
(بحث وصفي استكثـافي لدى عينة من طلاب وطالبات الجامعة بمصر ).

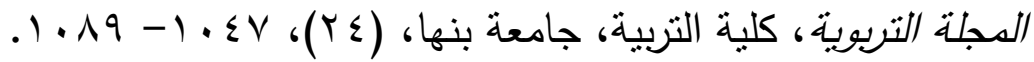

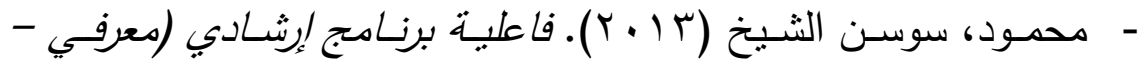
سـلوكي) مقتـرح فـي حفض حدة الخـوف المرضـي مسن المدرسـة ( رسـالة دكتوراه) ـ كلية التربية. جامعة عين فين شمس.

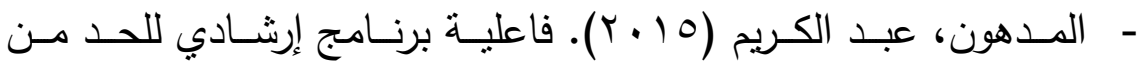

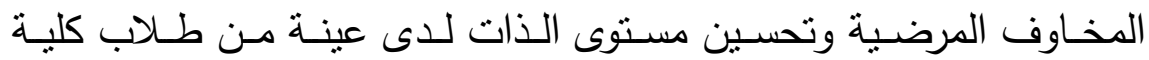

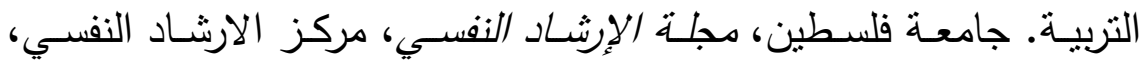

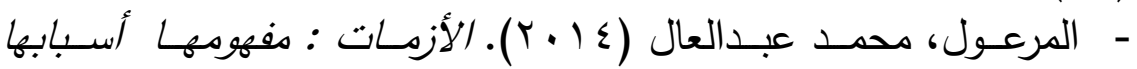
وآثارها ودورها في تعدبق الوطنبة. الرياض: مكتبة القانون والاقتصاد. 
- نحيلي، علي؛ وزوبي، سليمة (1 ( • ب). المخاوف الثـائعة لدى أطفال

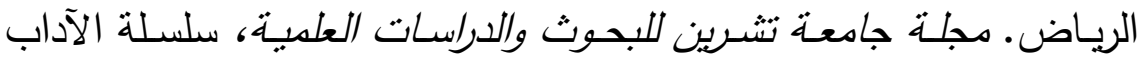

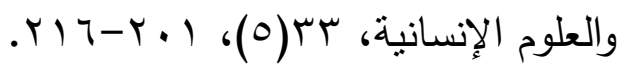

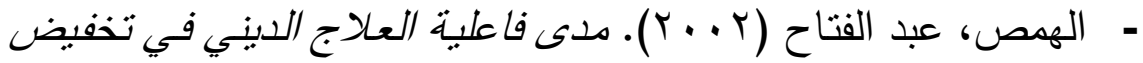
القلق لدى الثـباب الفلسطبني فـي محافظات غزة ( رسالة ماجستير غير

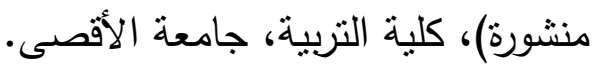
ثانياً: المراجع الأجنبية

- American Psychiatric Association. Task Force on DSM-IV. (2013). Dsm-iv sourcebook (Vol. 1). American Psychiatric Pub.

- Banerjee, D. (2020). The COVID-19 outbreak: Crucial role the psychiatrists can play. Asian journal of psychiatry, 50, 102014.

- Brooks, S. K., Webster, R. K., Smith, L. E., Woodland, L., Wessely, S., Greenberg, N., \& Rubin, G. J. (2020). The psychological impact of quarantine and how to reduce it: rapid review of the evidence. The Lancet.

- Cao, W., Fang, Z., Hou, G., Han, M., Xu, X., Dong, J., \& Zheng, J. (2020). The psychological impact of the COVID-19 epidemic on college students in China. Psychiatry research, 112934.

- Chakraborty, K., \& Chatterjee, M. (2020). Psychological impact of COVID-19 pandemic on general population in West Bengal: A cross-sectional study. Indian Journal of Psychiatry, 62(3), 266. 
- Chan, J. F. W., Yuan, S., Kok, K. H., To, K. K. W., Chu, H., Yang, J., ... \& Tsoi, H. W. (2020). A familial cluster of pneumonia associated with the 2019 novel coronavirus indicating person-to-person transmission: a study of a family cluster. The Lancet, 395(10223), 514523.

- Depoux, A., Martin, S., Karafillakis, E., Preet, R., Wilder-Smith, A., \& Larson, H. (2020). The pandemic of social media panic travels faster than the COVID-19 outbreak.

- Dong, L., \& Bouey, J. (2020). Public mental health crisis during COVID-19 pandemic, China. Emerg Infect Dis, 26(7), 10-3201.

- Dubey, S., Biswas, P., Ghosh, R., Chatterjee, S., Dubey, M. J., Chatterjee, S., ... \& Lavie, C. J. (2020). Psychosocial impact of COVID-19. Diabetes \& Metabolic Syndrome: Clinical Research \& Reviews.

- Epkins, C. C. (1996). Cognitive specificity and affective confounding in social anxiety and dysphoria in children. Journal of Psychopathology and Behavioral Assessment, 18(1), 83-101.

- Haleem, A., Javaid, M., \& Vaishya, R. Effects of COVID 19 pandemic in daily life. Curr Med Res Pract [Preprint]. 2020 [citado 27/4/2020].

- Harel, Y., Shechtman, Z., \& Cutrona, C. (2012). Exploration of support behavior in counseling groups with counseling trainees. The Journal for Specialists in Group Work, 37(3), 202-217. 
- Huang, Y., \& Zhao, N. (2020). Generalized anxiety disorder, depressive symptoms and sleep quality during COVID-19 outbreak in China: a web-based crosssectional survey. Psychiatry research, 112954.

- Jiao, W. Y., Wang, L. N., Liu, J., Fang, S. F., Jiao, F. Y., Pettoello-Mantovani, M., \& Somekh, E. (2020). Behavioral and emotional disorders in children during the COVID-19 epidemic. The journal of Pediatrics, 221, 264.

- Kayyalha, M., Xiao, D., Zhang, R., Shin, J., Jiang, J., Wang, F., ... \& Mandal, P. (2020). Absence of evidence for chiral Majorana modes in quantum anomalous Hallsuperconductor devices. Science, 367(6473), 64-67.

- Kluge, H. H. P., Jakab, Z., Bartovic, J., D'Anna, V., \& Severoni, S. (2020). Refugee and migrant health in the COVID-19 response. The Lancet, 395(10232), 12371239.

- Lai, C. C., Shih, T. P., Ko, W. C., Tang, H. J., \& Hsueh, P. R. (2020). Severe acute respiratory syndrome coronavirus 2 (SARS-CoV-2) and corona virus disease2019 (COVID-19): the epidemic and the challenges. International journal of antimicrobial agents, 105924. - Last, C. G., Hansen, C., \& Franco, N. (1998). Cognitive-behavioral treatment of school phobia. Journal of the American Academy of Child \& Adolescent Psychiatry, 37(4), 404-411.

- Muris, P., \& Field, A. P. (2010). The role of verbal threat information in the development of childhood 
fear."Beware the Jabberwock!". Clinical Child and Family Psychology Review, 13(2), 129-150.

- Prete, G., Fontanesi, L., Porcelli, P., \& Tommasi, L. (2020). The psychological impact of COVID-19 in Italy: Worry leads to protective behavior, but at the cost of anxiety. Frontiers in Psychology, 11, 3022.

- Pulla, P. (2020). Covid-19: India imposes lockdown for 21 days and cases rise.

- Roy, D., Tripathy, S., Kar, S. K., Sharma, N., Verma, S. K., \& Kaushal, V. (2020). Study of knowledge, attitude, anxiety \& perceived mental healthcare need in Indian population during COVID-19 pandemic. Asian Journal of Psychiatry, 102083.

- Schutte, N. S., Malouff, J. M., Hall, L. E., Haggerty, D. J., Cooper, J. T., Golden, C. J., \& Dornheim, L. (1998). Development and validation of a measure of emotional intelligence. Personality and individual differences, 25(2), 167-177.

- Silverman, D. (1998). Qualitative research: meanings or practices?. Information systems journal, 8(1), 3-20.

- Sim, K., \& Chua, H. C. (2004). The psychological impact of SARS: a matter of heart and mind. Cmaj, 170(5), 811-812.

- Singh, S., Dubey, S., Kumar, N., Goyal, M. K., \& Pal,

I. (2020). Psychological Impacts of COVID-19. In Integrated Risk of Pandemic: Covid-19 Impacts, Resilience and Recommendations (pp. 153-168). Springer, Singapore. 


\section{المجلة العلمية لكلية رياض الأطفال - جامعة بورسعيد}

- Sprang, G., \& Silman, M. (2013). Posttraumatic stress disorder in parents and youth after health-related disasters. Disaster medicine and public health preparedness, $7(1), 105-110$.

- Tandon, R. (2020). COVID-19 and mental health: preserving humanity, maintaining sanity, and promoting health. Asian journal of psychiatry.

- Velavan, T. P., \& Meyer, C. G. (2020). COVID-19: A PCR-defined pandemic. International Journal of Infectious Diseases.

- Viswanath, A., \& Monga, P. (2020). Working through the COVID-19 outbreak: rapid review and recommendations for MSK and allied heath personnel. Journal of Clinical Orthopaedics and Trauma.

- Wang, C., Pan, R., Wan, X., Tan, Y., Xu, L., Ho, C. S., \& Ho, R. C. (2020). Immediate psychological responses and associated factors during the initial stage of the 2019 coronavirus disease (COVID-19) epidemic among the general population in China. International journal of environmental research and public health, 17(5), 1729.

- WHO (2020). Statement on the second meeting of the International Health Regulations (2005) Emergency Committee regarding the outbreak of novel coronavirus (2019-nCoV).

- Wu, P., Fang, Y., Guan, Z., Fan, B., Kong, J., Yao, Z., ... \& Hoven, C. W. (2009). The psychological impact of the SARS epidemic on hospital employees in China: 
exposure, risk perception, and altruistic acceptance of risk. The Canadian Journal of Psychiatry, 54(5), 302311.

- Xiang, M., Zhang, Z., \& Kuwahara, K. (2020). Impact of COVID-19 pandemic on children and adolescents' lifestyle behavior larger than expected. Progress in Cardiovascular Diseases.

- Zhai, Y., \& Du, X. (2020). Mental health care for international Chinese students affected by the COVID19 outbreak. The Lancet Psychiatry, 7(4), e22. 


\section{برنامج تدريبي لتنمية مهارة الاستماع لاى عينة من أطفال} الروضة المنبئين بصعوبات تعلم قراعة اللغة العربية * أ.د/ ندا الحسيني ندا يوسف.

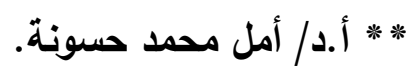

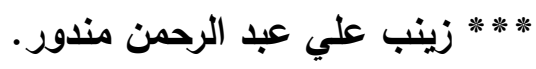

\section{ملخص البحث :}

هدف البحث الحسالي إلى الكثف عن مدى فعاليـة البرنـامج التدريبي

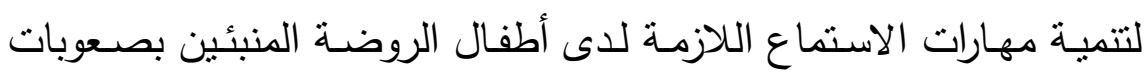
تعلم قراعة اللغة العربية ، وتكونت عينة البحث الحالي من (^) من الأطفال المنبئين بصعوبات تعلم القراءة بروضـة مدرسـة التتبس الابتدائية بمحافظـة بورسـعيد ، واسـتخدم البحـث المـنهج شـبه التجريبـي باسـتخدام التصــميم التجريبـي للمجموعـة الواحدة. وقد تم اسـتخدام مقيـاس مهـارة الاسـتماع المصور (إعداد/ الباحثة)، البرنامج التدريبي لتتمية مهارة الاستماع لدى طفل

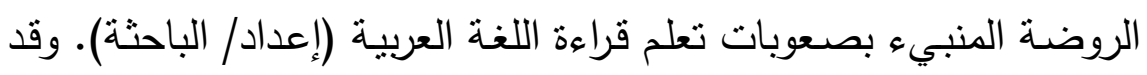

* أستاذ النحو والصرف المتفرغ - كلية الآداب - جامعة بورسعيد. * * أستاذ علم نفس الطقل (الصحة النفسية) ورئيس قسم العلوم النفسية - عميد كلية التربية للطفولة المبكرة - جامعة بورسعيد. * * * باحثة دكتوراه بقسم العطوم النفسية -كلية التربية للطفولة المبكرة - جامعة بورسعيد. 
توصلت نتائج البحث إلى أنه توجد فروق دالة إحصائياً بين منوسطي رتب درجـات أطفـال المجموعـة التجريبيـة (عينـة البحـث) علـى مقيـاس مهـارة الاستماع المصور في القياسين القبلي والبعدي للبرنامج التدريبي، لا توجد فروق دالة إحصائياً بين متوسطى رتب درجات أطفال المجموعة التجريبية (عينة البحث) على مقياس مهارة الاستماع في القياسين البعدي والتتبعي للبرنـامج التـدريبي.ممـا يثـير إلى فعاليـة البرنـامج التـدريبي لتنميـة مهـارة الاستماع لدى أطفال الروضة المنبئين بصعوبات تعلم قراءة اللغة العربية.

\section{A training program to develop the listening skill of kindergarten children who predict difficulties in learning to read Arabic}

Prof. Dr. Nada El-Husseini Nada Youssef. *

Prof. Dr. Aml Mohamed Hassona. **

Zainab Ali Abdel Rahman Mandour. ***

\section{Abstract:}

The aim of the current research is to reveal the effectiveness of the training program to develop the necessary listening skills among kindergarten children who predict difficulties in learning to read the Arabic

* Professor Emeritus Grammar and Morphology - Faculty of Arts University of Port Said.

**Professor of Child Psychology (Ment: Head of the Psychological Science, Faculty of Early Childhood Education - Portsaid University. *** Researcher, Department of Psychological Sciences - Faculty of Early Childhood Education - Portsaid University. 
language، and the current research sample consisted of (8) children who predicted learning difficulties to read in the Kindergarten of Tanis Elementary School in Port Said governorate، and the research was used. Quasiexperimental using single-group experimental design. The illustrated listening skill scale (preparation / researcher) was used, the training program for developing the listening skill of the kindergarten child who predicted difficulties learning to read Arabic (preparation / researcher). The results of the research concluded that there are statistically significant differences between the mean grades of the experimental group children (the research sample) on the scale of listening skill depicted in the pre and post measurements of the training program. There are no statistically significant differences between the mean grades of the experimental group children (the research sample) on A measure of the listening skill in the post and tracer measurements of the training program، indicating the effectiveness of the training program for developing listening skill among kindergarten children who predict difficulties in learning to read Arabic.

\section{الكلمات المفتاحية Keywords}

Training program

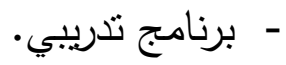

The skill of listening

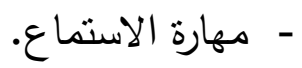


- أطفال الروضنة المنبئين بصعوبات تعلم قراءة اللغة العربية .

Kindergarten children predicting difficulties learning to read Arabic

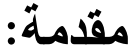

يواجه بعض أطفال الروضنة المنبئين بصسوبات تعلم قراءة اللغـة العربية مشكلات وصسوبات وهم في سبيلهم إلى التعلم نتيجة لعوامل حسية سواء

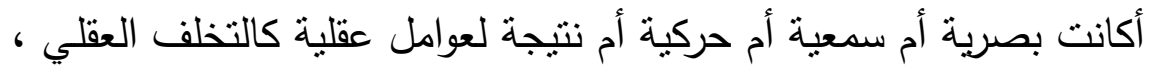

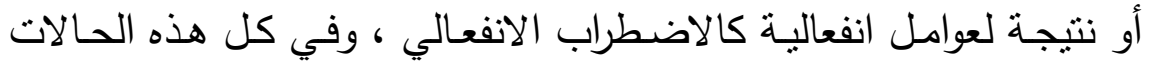
يجب أن يُقدَم للطفل نوعاً من التربية الخاصـة التي تتلاعم مـع نوع الاعاقة

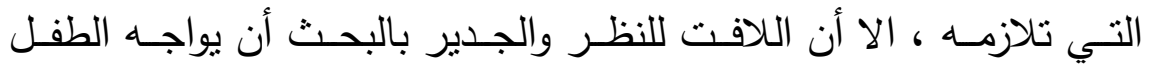
صعوبات أثتاء تعلمه في الوقت الذي لا يمكن فيه أن يصنف ضمن أن أي من

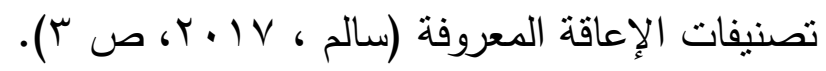

وتمثل مهارات اللغـة العربية الأسـاسية ( الاستماع ، والتحدث ، والقراءة والكتابـة) أسـاسـاً للتعليم والتعلم في المراحل العدربـة المختلفة، وعن طريقها

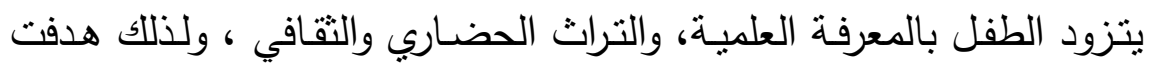

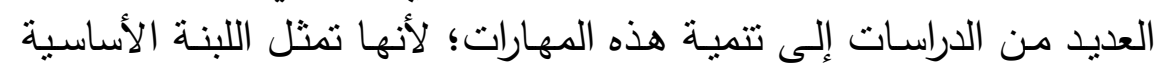

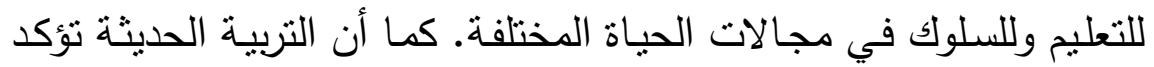

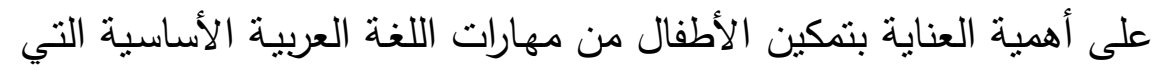

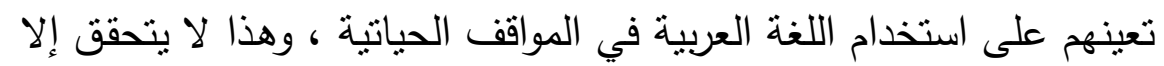

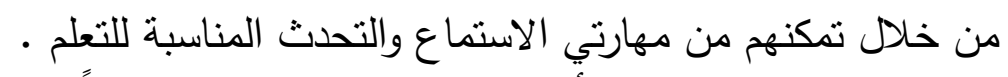

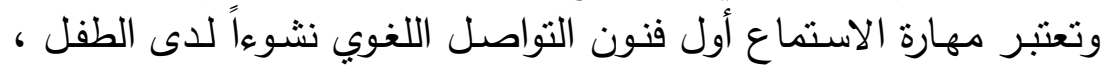
وتشير بعض الدراسـات التي أجريت على سلوك الأجنة في بطون أمهاتهم 
أن الجنين يستجيب للأصـوات الخارجيـة، وربمـا اهتز تفـاعلاً مـن سـماع

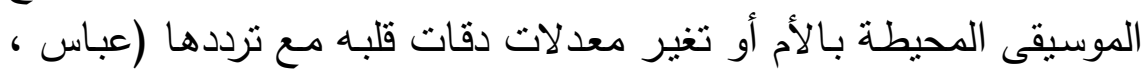

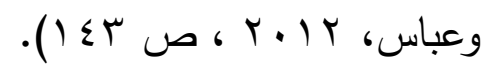

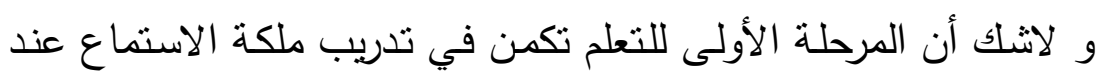

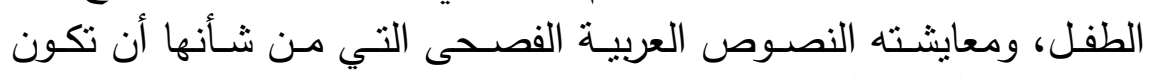

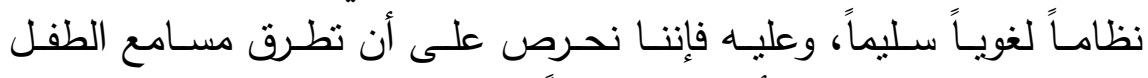

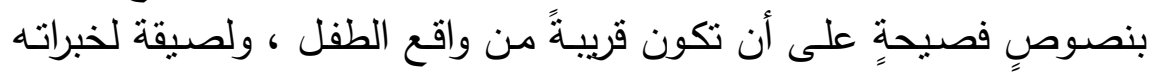

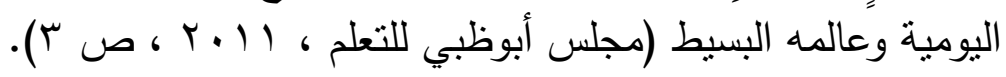

والاستماع شرط أساسي للنمو اللغوي لدى الطفل حيث يكتسب ثروته المته اللغوية عن طريق الربط بين الصوت والصورة، والصوت والحركة، والصوت

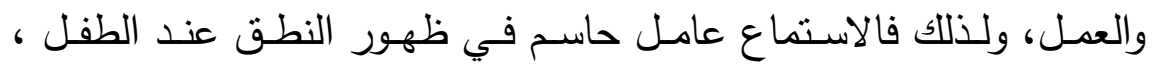

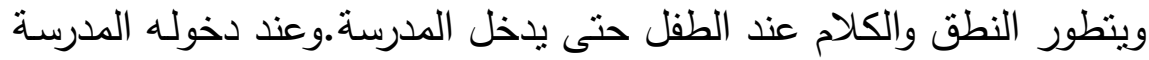

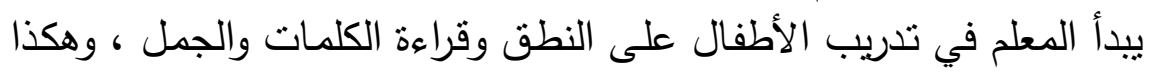

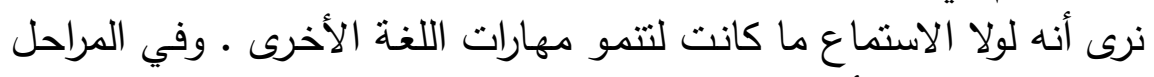

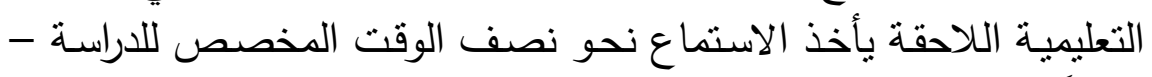

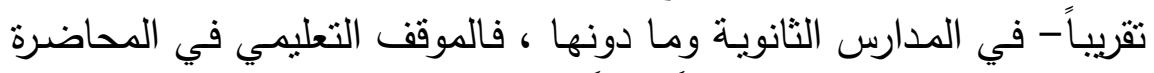

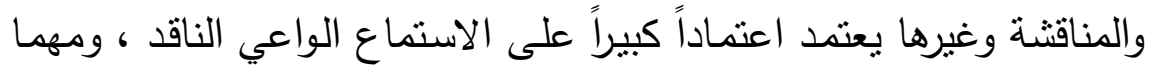

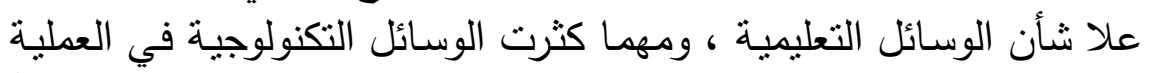

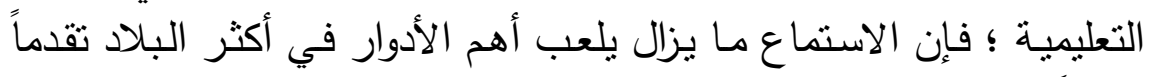

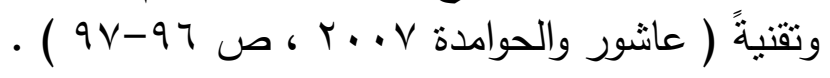

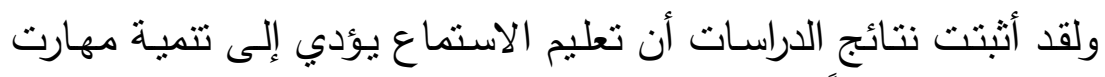

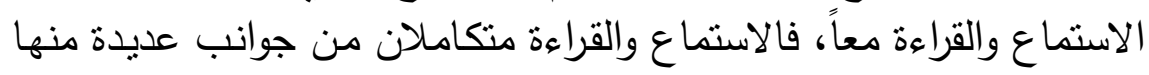

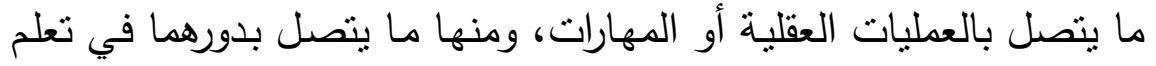


اللغة، فالاستماع بزود الأطفال بالمفردات وتراكيب الجمل التي تقدم أساساً

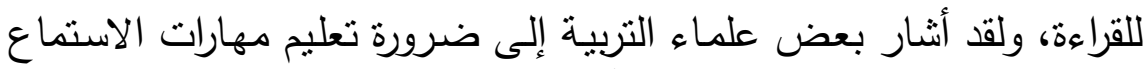

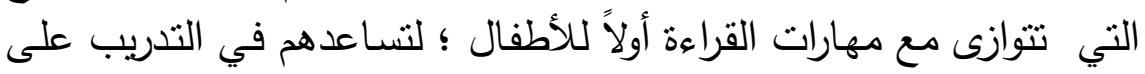

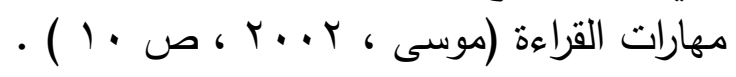

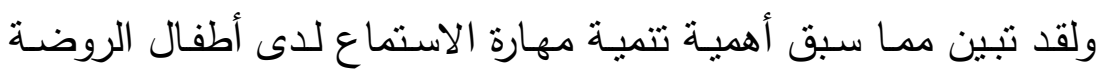

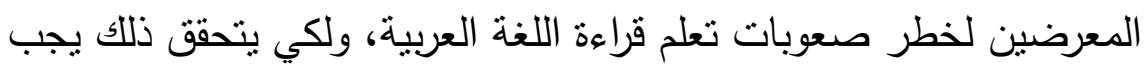

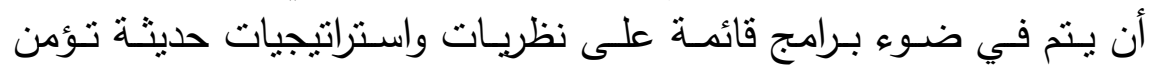
بالفروق الفردية بين المتعلمين وتتيح طرق تعلم متتوعة.

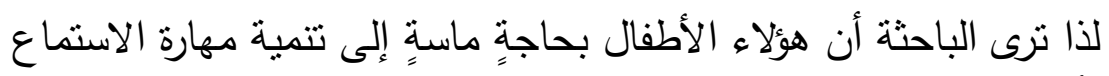
من أجل الحد من صعوبات تعلم قراءة اللغة العربية.

\section{مشكلة البحث: - 2 - مثن}

تشكل قضية الكثف المبكر عن الأطفال المنبئين بصعوبات التعلم أهميةً

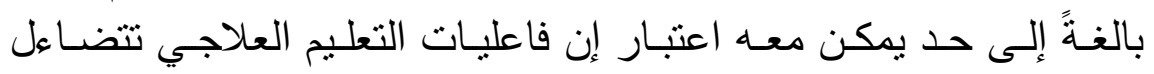

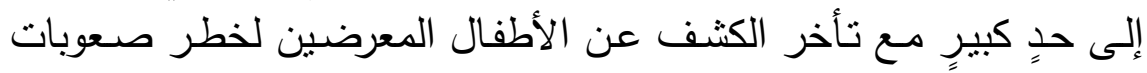

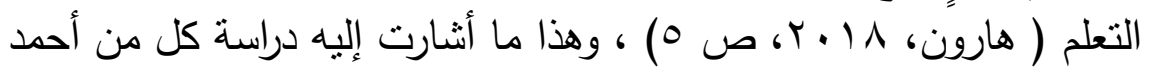

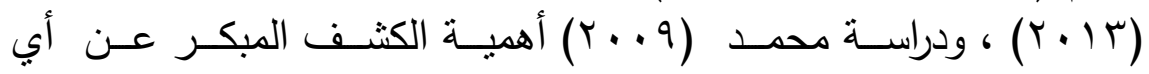

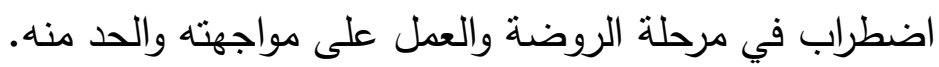
وتتطلق مشكلة البحث الحالي من أهمية مرحلة رباض الأطفال والتي ينمو مروله

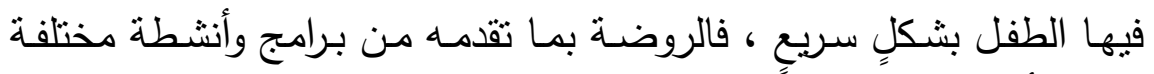

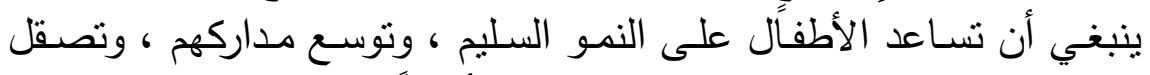
مهاراتهم ، وتتبع حاجاتهم المختلفة وتهيئهم أيضاً للمرحلة اللاحقة. 
وقد لاحظت الباحثة أثناء عملها كمعلمة رباض أطفال أن هناك قصوراً في مهارات الاستماع التي تؤثز بدورها على استعدادات الطفل للقراءة، وأنه في حاجة قبل انتقاله إلى المرحلة اللاحقة إلى اتقان مهارات اللغة العربية الأساسية اللازمة التي تسهل عليه عملية التعلم في تلك المرحلة .

وترى الباحثة أن أسباب هذا القصور قد يكون في قلة توظيف التقنيات الحديثة في تعليم الأطفال التي تيسر من تدربيهم على المهارات الأساسية للغة العربية بعدة أنشطة وطرق مفيدة وحديثة. لاطية.

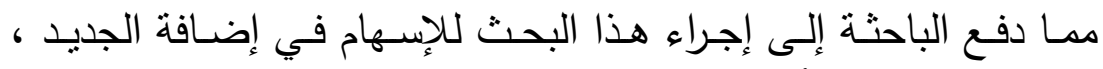

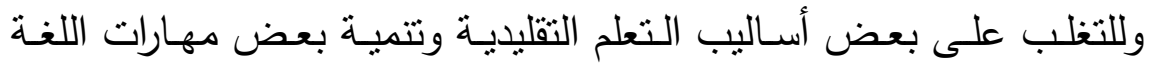
العربية الأساسية لديه.

وفى ضـوء مـا سـبق يحـاول البحـث الحـالى التعـرف على مـدى فعاليـة برنامج تدربيي في تتمية مهارة الاستماع للحد من صعوبات تعلم قراءة اللغة العربية.

وتتمثل مشكلة البحث الحالي في السؤال الرئيس التالي: ما فعالية برنـامج تدريبي في تتمية مهارة الاستماع لدى أطفال الروضـة

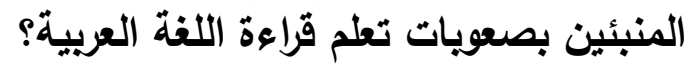
وبتفرع من هذا السؤال الأسئلة الفرعية الآتية: ا ـ ما مهارات الاستماع اللازمة لأطفال مرحلة الروضـة المنبئين بصعوبات تعلم قراءة اللغة العربية؛ مانج

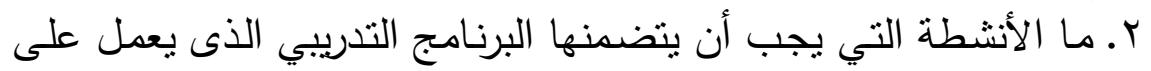

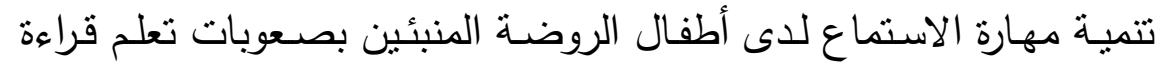
اللغة العربية؟ مهابه 


\section{أهد|ف البحث:}

\section{استهدف البحث الحالي تحقيق ما يلي:}

ا ـ الكثف عن مدى فعاليـة البرنـامج في تتمبـة مهارات الاستماع اللازمـة لطفل الروضة للحد من صعوبات تعلم القراءة باللغة العربية لديه.

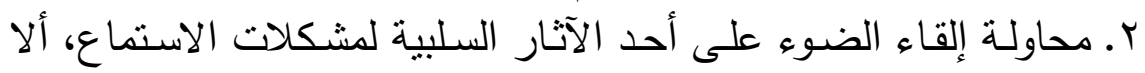
وهي صعوبات تعلم قراءة اللغة العربية، والتي لها نأثير مستقبلي سلبي على إنى تواصل الطفل الاجتماعي والكفاءة الأكاديمية لديه.

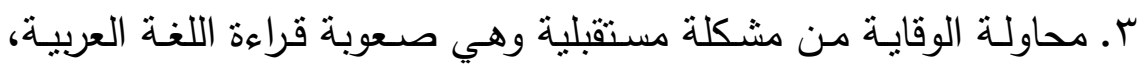

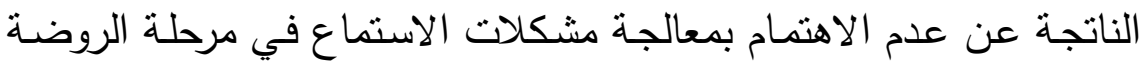

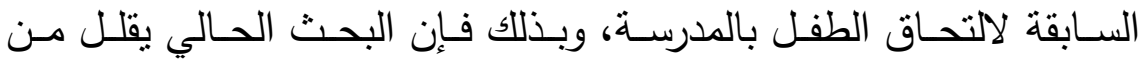
احتمالات هذه الصعوبات لاحقاً. أهمية البحث:

يمكن توضيح أهمية هذا البحث فيما يلي:

ا ـ قد يستخدم هذا البحث القائمين على بـرامج الأطفال ومعلمـات ربـاض الأطفال في تحسين أساليب التعليم برباض الأطفال، وذلك بإعداد نماذج من الأنشطة التعليمبة الحديثة الهادفة. r. كما أن هذا البحث يتتاول مرحلة من أهم المراحل وهي مرحلة الروضة ، الأهية

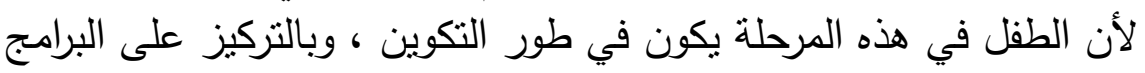
التدريبية الجيدة لاى هؤلاء الأطفال يمكن تتمية بعض هـون مهارات اللغة العربية الأساسية والمحددة بالبحث في مهارة الاستماع لديهم، مما يجعلهم أكثر قدرةً على التواصل مع الآخرين ، وأقل تعرضاً لمشكلات قراءة اللغة العربية. 
r. إمكانية توجيه نظر المعلمات في مرحلة رياض الأطفال إلى ابتكار مهام

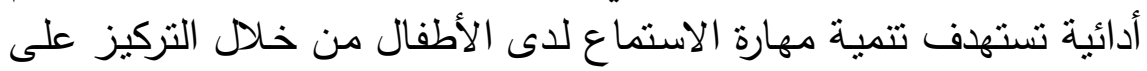
أنشطة البرنامج التدريبي. تصني

\section{محددات البحث:}

المحددات الزمنيـة: تم تطبيق هذا البحث في الفصل الدراسـي الأول من البن

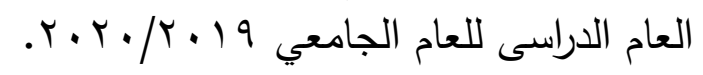

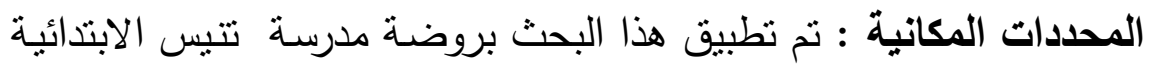

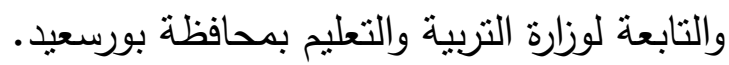

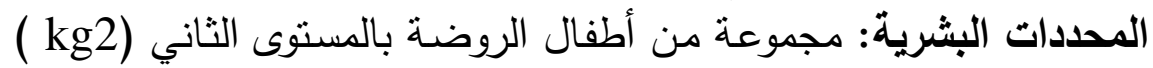
من سن ( 0-7) سنوات والملتحقين بإحدى روضات المنات المدارس التابعة لوزارة

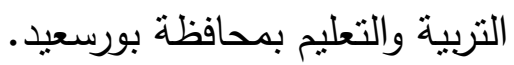
المحددات الموضوعية : اقتصر البحث الحالي على مهارة الاستماع . مصطلحات البحث: - (1)

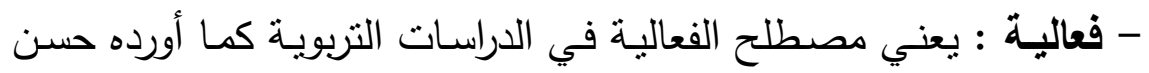

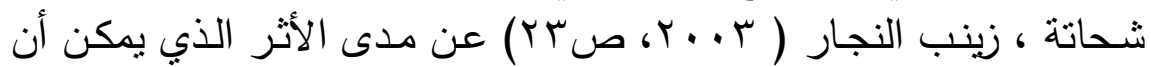

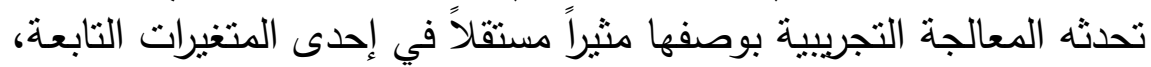

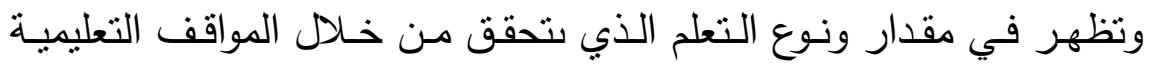
داخل الفصل الدراسي وخارجه.

وتعرفها الباحثة إجرائياً بأنها: التأثنر الجيد والإنيجابي الذي يحدثه البرنامج

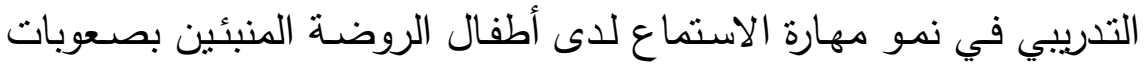
تعلم قراءة اللغة العربية. 
- البرنـامج التدريبي : هو برنامج يقدم للأفراد بهدف تتمية مهاراتهم على لتى

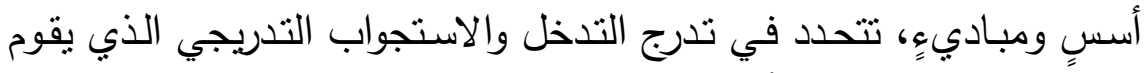
على التدرج في تعليم الأطفال المعرفة والسلوكيات الصحيحة والتي والخاطئة في

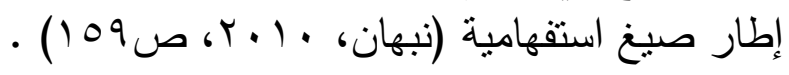
ويُقتصند بالبرنامج التدريبي في البحث الحالي : بأنه برنامج يُقدَم للأطفال

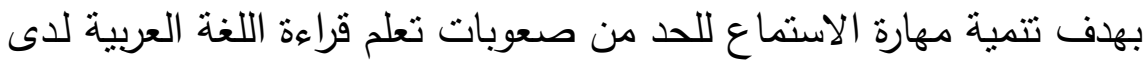
أطفال الروضة المنبئين بها.

- المهارة : هي كل ما يصدر عن المتعلم من سلوك النص أو عمل بظهر

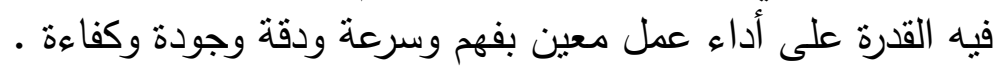

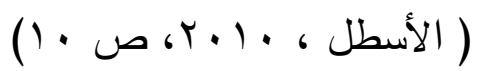

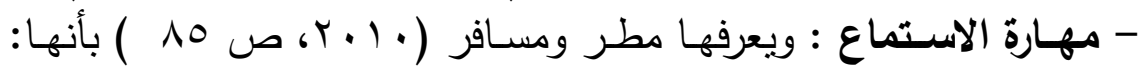

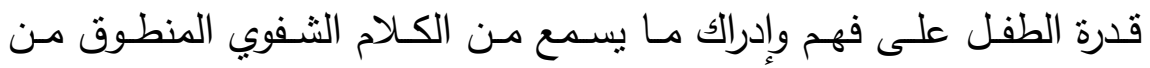

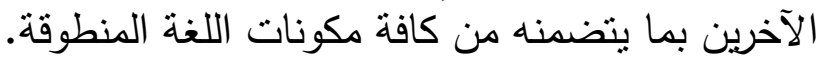

وتعرف الباحثة مهارات الاستماع إجرائياً بأنها: جميع الأداءات التي يقوم

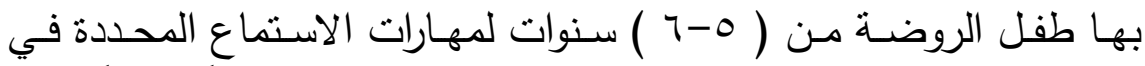

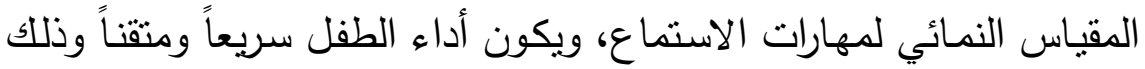

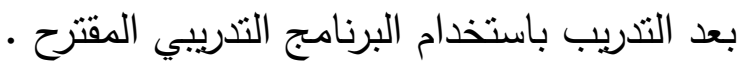

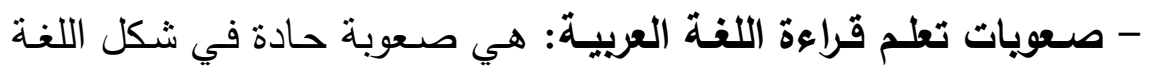

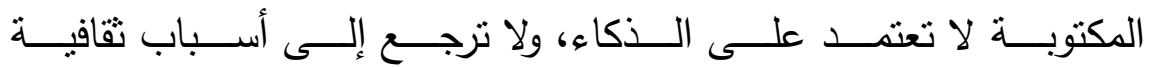

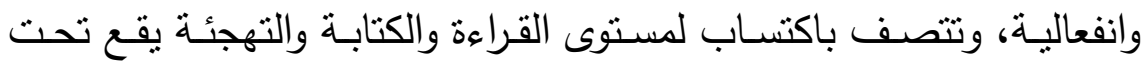

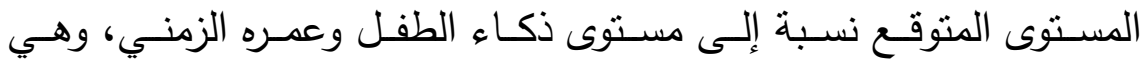
ذات طبيعة معرفية تؤثر على المهارات اللغوية التي تتصل باءل بالثكل الكتابي، 
وبخاصــة الرمــوز البصــرية اللفظيــة والــذاكرة القصــيرة ونظــام الإدرالك

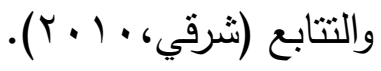

وتعرف الباحثة صعويات تعلم القراءة إجرائياً بأنها :عجز الطفل عن القراءة

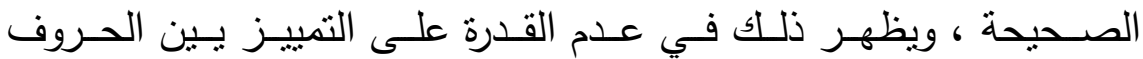
المتشابهة، والتعبير اللفظي غير الصحيح، وصعوبة وفهم وإستيعاب المادة المسـوعة وكذللك المقروءة وإبدال وحذف بعض الحروف مسن الكلمـات ، وعدم القدرة على استرجاع الكلمات المخزنة سابقاً .

- أطفـال الروضـة المنبئين بصسعويات الـتعلم: يعرف بيتمـان Betman

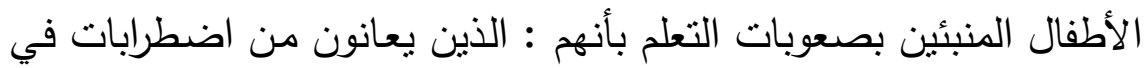

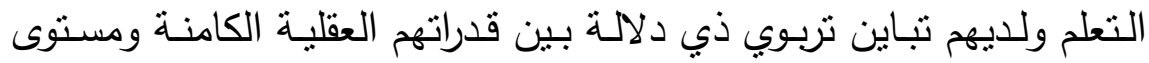

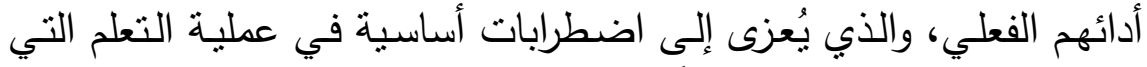
تكون أو قد لا تكون مصحوبةً بقصورٍ واضـحِ في وظيفة الجهاز العصبي

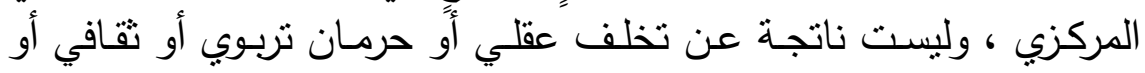

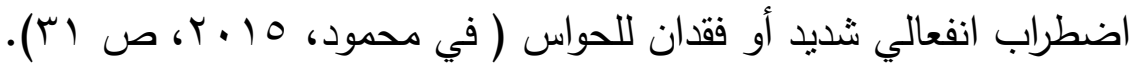
وتعرف الباحثة أطفال الروضـة المنبئين بصـويات التعلم إجرائيـاً بأنهم:

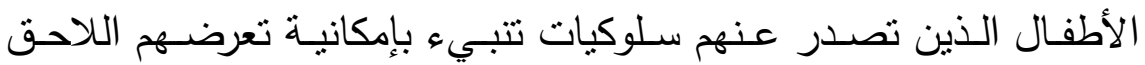

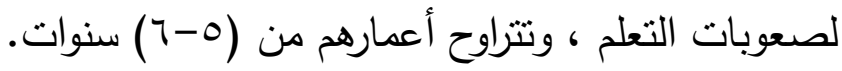

الإطار النظري والدراسات السابقة :

الاستماع مهارة معقدة وهو أكثر تعقيداً من القراءة ، حيث أن القاريء قد

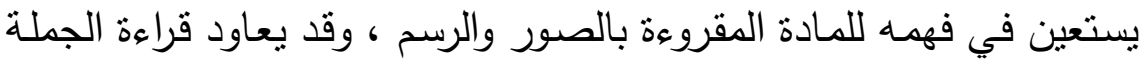

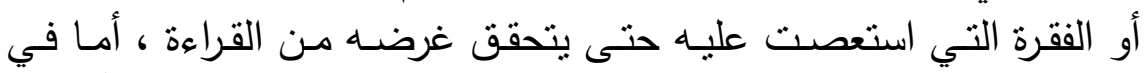

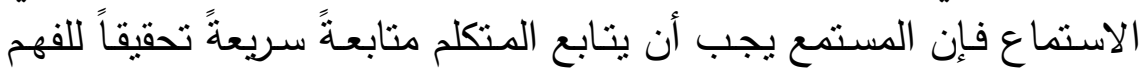


والتحليل ، والتفسير والنقد وهذه عمليات تحتاج إلبي التعليم والتدريب على التى

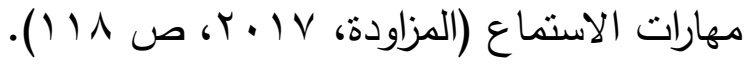

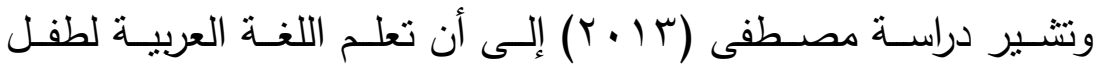
الروضة ينبغي أن يبدأ بالاستماع ، ولذلك يجب الاهتمام بتتميته في مرحلة الروضة والمراحل التالية أيضاً.

: تعريف مهارة الاسثماع :

هو حاسة دن حواس الإنسان التي وهبها الله لله؛ ليستقبل بها عالم اللغة مـن حولـه قـال تعـالى: "والله أخـرجكم مـن بطـون أمهـاتكم لا تعلمـون شـيئًاً وجعل لكم السمع والأبصار والأفئدة لعلكم تشكرون".

فهو يعني التعـرف على الأصسوات، والفهم والتحليـل والتفسير والتطبيـق

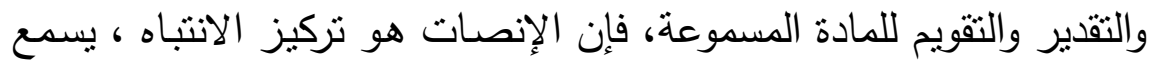

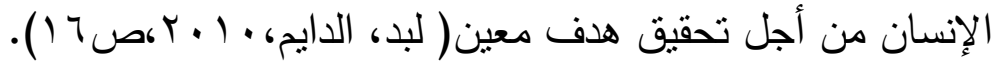

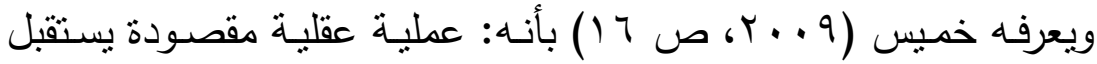
فيها المتعلم المـادة الصـوتية والوعي بها، ومحاولة فهمها وتحليلها ونقدها لتحسين مهاراته التواصلية. مهارات عملية الاستماع : مكات

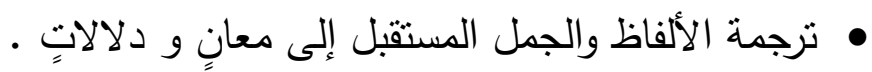
• فهم ما يربد المتحدث توصيله إلى المستمع عبر الإشـارات التي بستعين بـا

معرفـة دلالات الكلمـات والجمـل وطريقة تركيبهـا ، وهذه خطـوة لاحقة لاستقبال الرموز الصوتية وتركيبها في ذهنه ليجعل منها شيئاً ذات معنى. 
معرفة الوظائف المختلفة التي تؤديها الكلمات والجمل ، فمـا الذي يربد

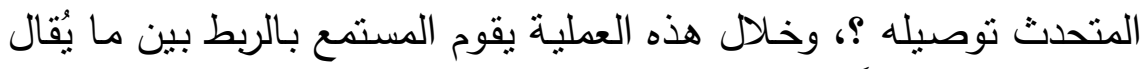

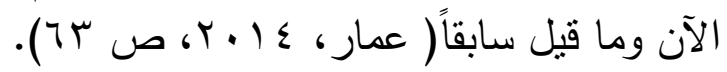

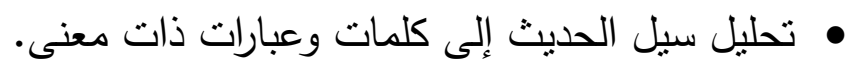
تعرف أقسام الكلام. • الربط بين المنطوق وخلفية المستهع المعرفية. تعرف المضمون البلاغي والوظيفي لمنطوقٍ ما. تفسير دلالات الإيقاع والنبر والتتغيم.

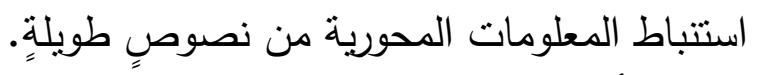
إدراك الأفكار الرئيسة والفرعية.

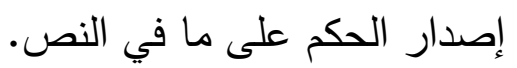

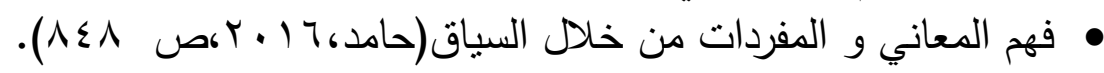
تصنيف مهارة الاستماع : صنف أبو حمرة (10 ب) الاستماع ومهاراته إلى : (أ) الفهم ، ويتفرع عنه المؤثرات الآثية :

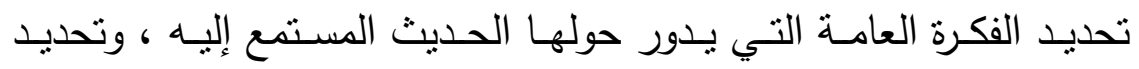

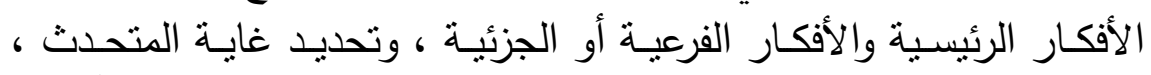

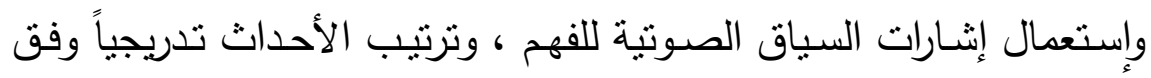
تسلسل ورودها ، بالإضافة إلى فهم معنى الكلمات من السياق. -الاستيعاب، ويتفرع عنه المؤشرات الآتية :

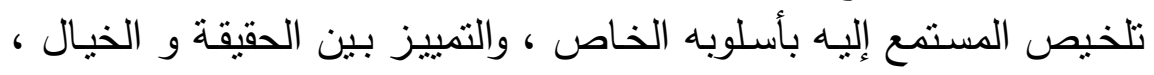
وتحديد العلاقات بين الأفكار المعروضـة ، وتصنيف الأفكار التي تعرض بلته لها المتحدث. 


\section{(ب) التذكر، ويتفرع عنه المؤثرات الآتية:}

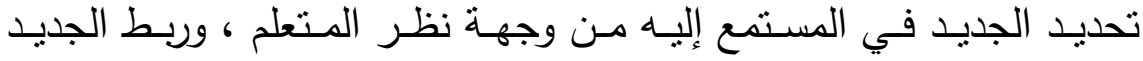

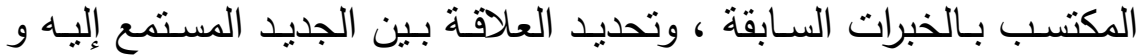

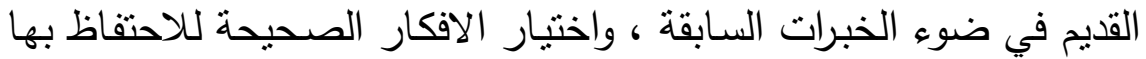

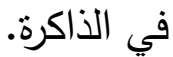

(ج) التذوق ، ويتفرع منه المؤشرات الآتية: تمييز مواطن القوة و الضعف في الحديث ، والحكم على المستمع إليه في ضوء الخبرات السابقة ، وتحديد مدى أهمية الأفكار التي تضمنها الحديث ،

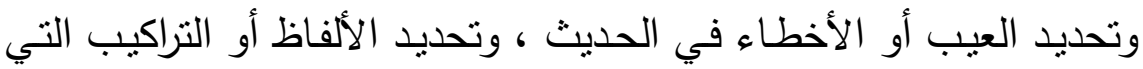

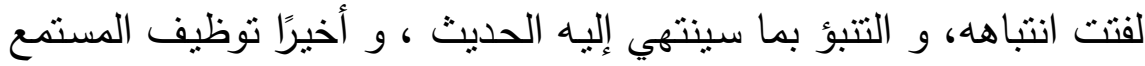

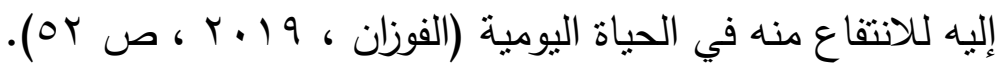
طبيعة عملية الاستماع : بليه

دارت العديد من الآراء التربوية حول طبيعة عملية الاستماع من حيث

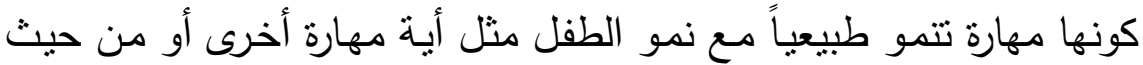

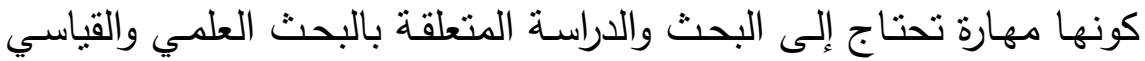

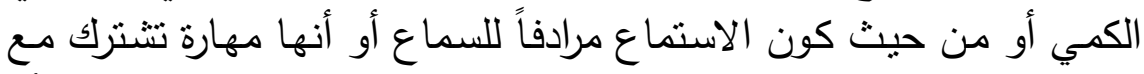

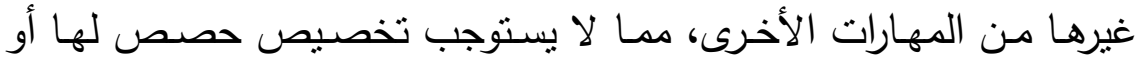

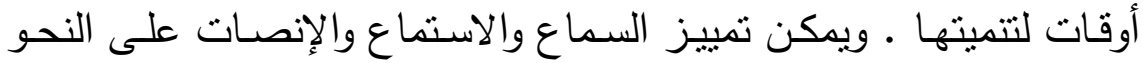

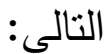
- السـماع: هو كل مـا يطرق الأذن من أصـوات دون انتباه واهتمام لتلك

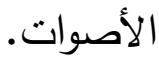


- الاسـتماع :هو إعطـاء اهتمـام وعنايـة لاستقبال الأصــوات والمعلومـات بهدف فهم مضدونها.

- الإنصات: هو أيضاً بيضمن الاستماع ولكن بدرجة أعلى من الاهنمام و

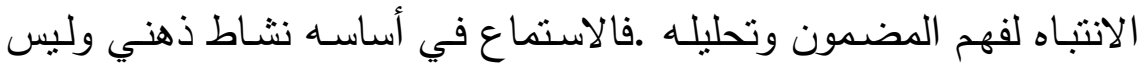

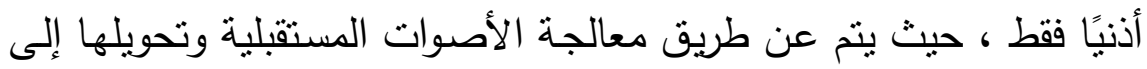

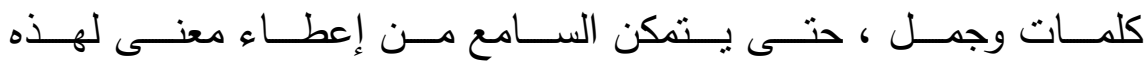

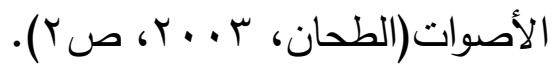

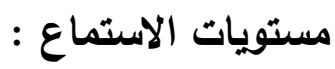

يرى Arif saricoban(1999) أن للاستماع أربعة مستويات هي: ا-مستوى الفهم والانتباه المحدود : ويتوقف المستمع فيه عند حد إدراك

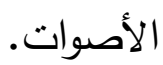
r-فهم الحديث ، واستتناج الأفكار الرئيسية.

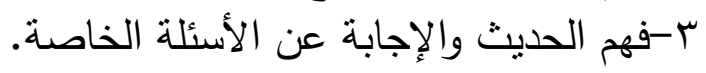

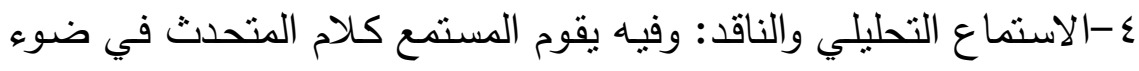

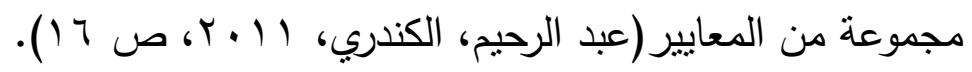

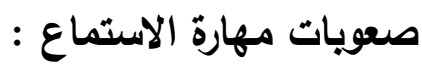
إن تنميـة مهارة الاستماع في تعليم اللغـة العربيـة للنـاطقين بغيرهـا وفقًا

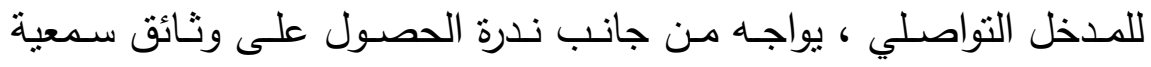

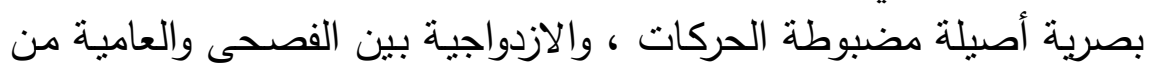

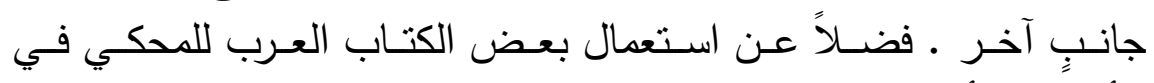
الأجناس الأدبية المختلفة أنسا 
كمـا يؤخذ بالحسبان مسـألة في غايـة الأهميـة ، هـي الاختـلاف بـين

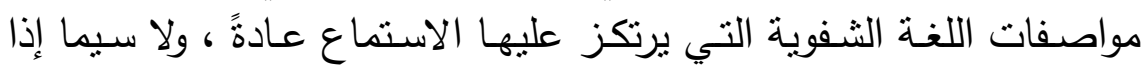

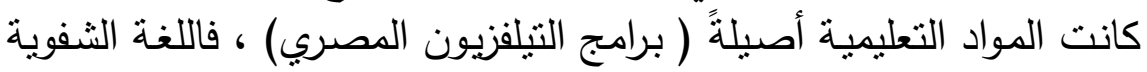

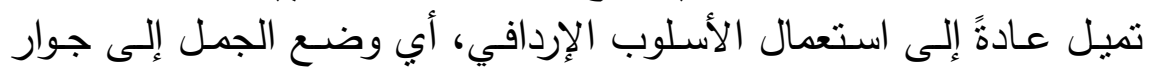

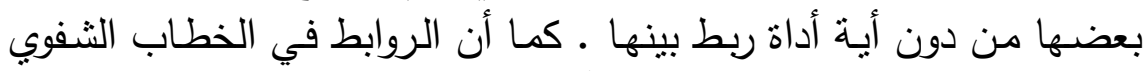

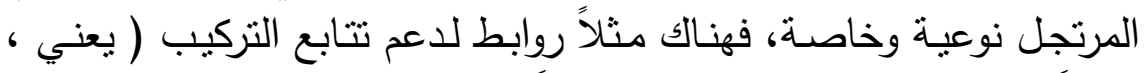

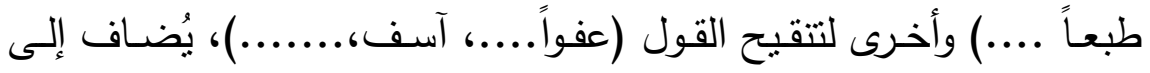

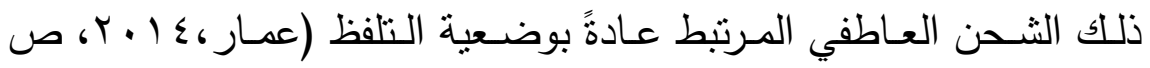
. (77

\section{الأهداف التعليمية لمهارة الاستماع :}

1-تعرف الأصوات العربية، وتمييز ما بينهما من اختلافاتٍ صوتيةٍ حين تشتخدم في الكلام العادي.

r-تعرف الحركات القصيرة والطويلة ، والتمبيز بينهما.

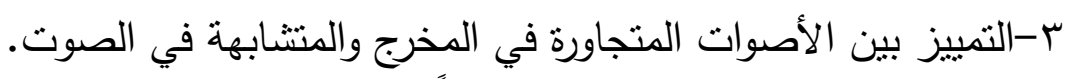
ع -تعرف التشديد والتتوين وتمييزها صنوتياً.

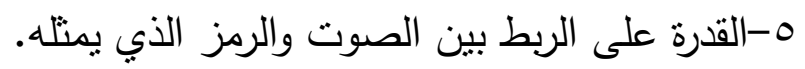

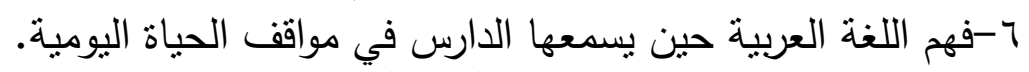
V - V الاستجابة لبعض الأسئلة استجابةً دقيقةً. ^-تنفيذ الأوامر بدقةٍ حين يسمعها أبي دارس. 9-إدراك التغيرات في المعنى الناتجة عن تعديل أو تحويل في بنية الكلمة.

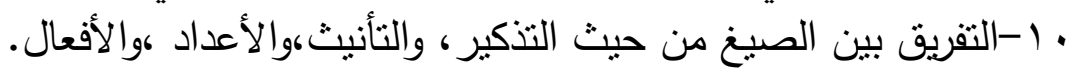

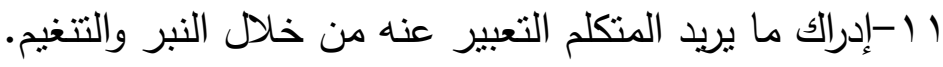


r إ-إدراك نوع الانفعال الذي يسود المحادثة و الاستجابة(التتقاري، عمر،

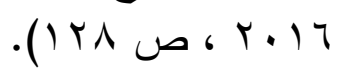

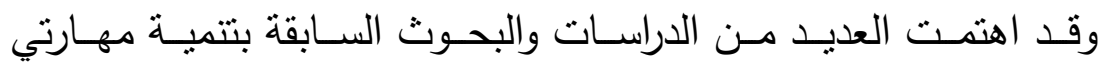

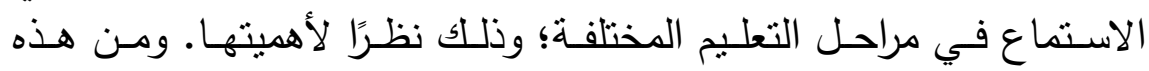

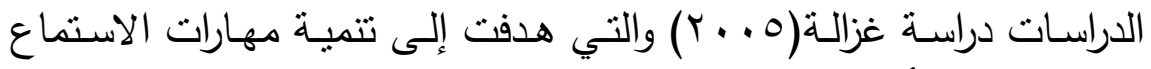

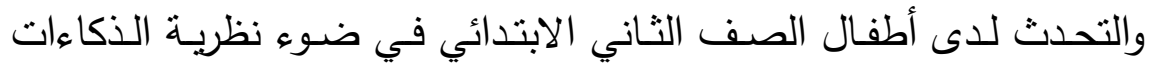

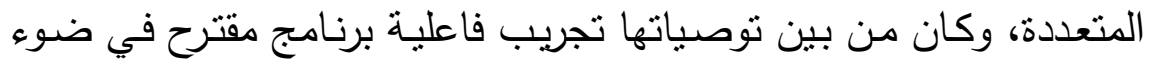

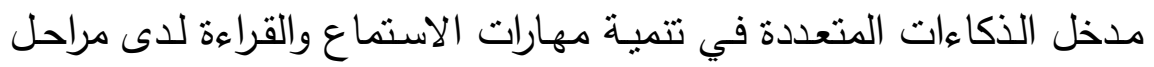
تعليمية مختلفة.

ودراسـة يوسف(9 ه . . ب) والتي هدفت إلى تعرف تأثثير إضـافة مـا وراء

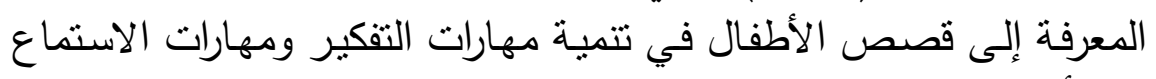
لاى أطفال المرحلة الابتدائية.

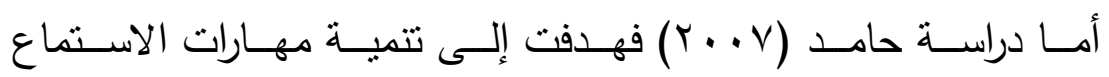

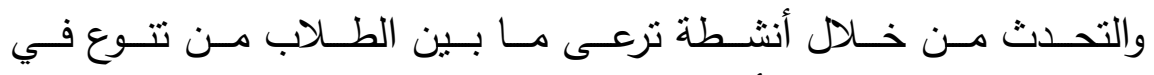

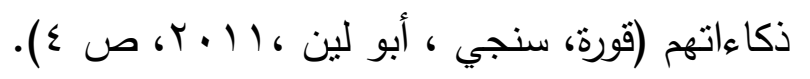
معوقات تنمية مهارة الاستماع: أ-معوقات جسمية : أمئه

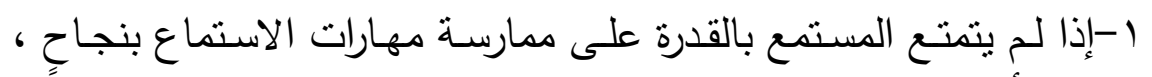

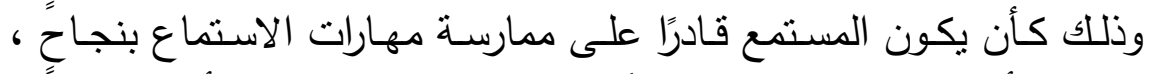

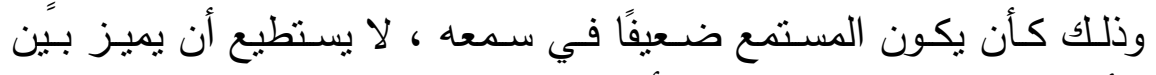

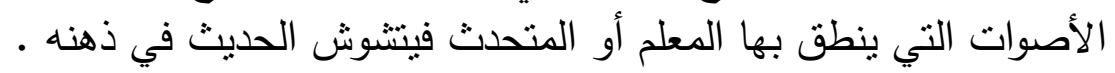


ץ-شعور التعلم بالألم من علة بعانيها تجعله غير قادراً على التركيز ، فلا

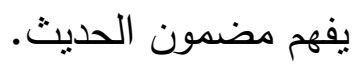

\section{ب-معوقات نفسية وعقلية:}

ا-يعتبر الثرود الذهني من معوقات الاستماع ؛ ذلك لأن المستمع يتبعثر

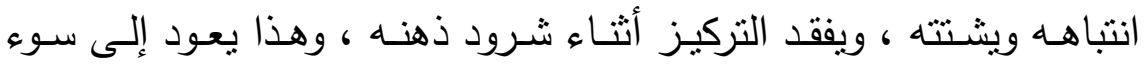

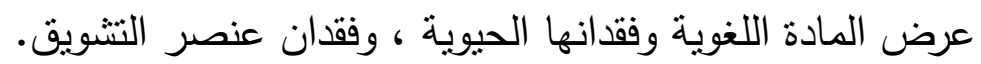

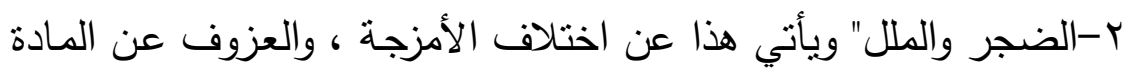

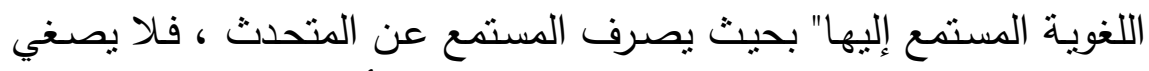

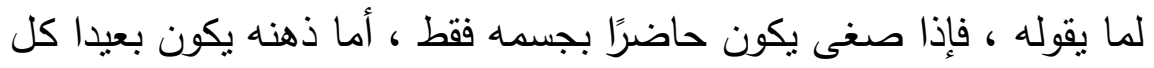

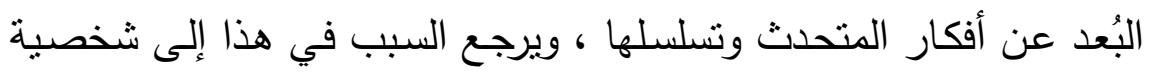
المتحدث ، وطريقة عرضه الفعار للمادة.

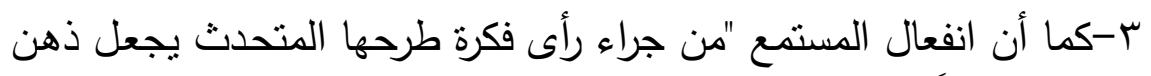

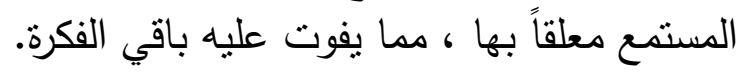

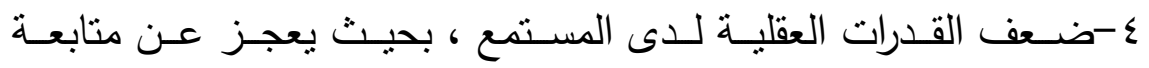

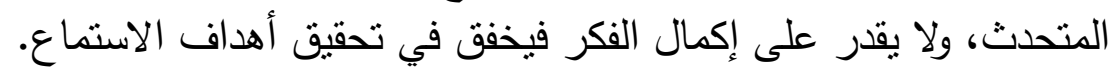

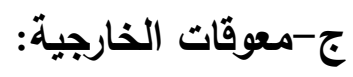

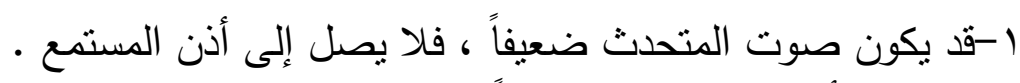

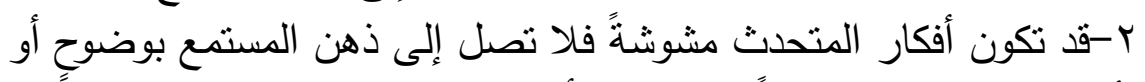
لأن المتحدث كان مشوشاً في عرض أفرار أفكاره.

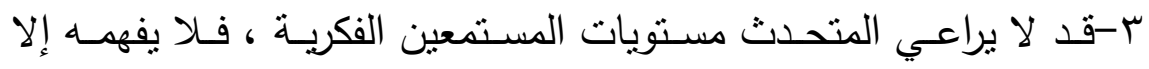

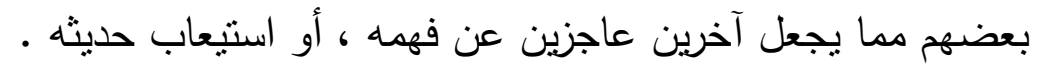

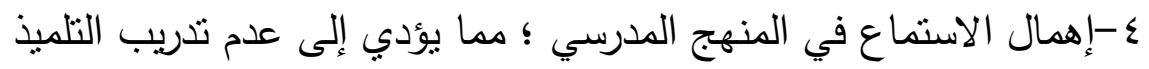

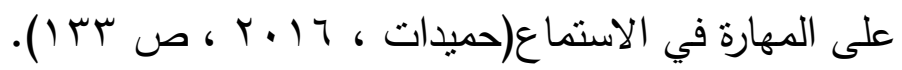


ا.توجد فروق دالة إحصائياً بين متوسطي رتب درجات أطفال المجموعة

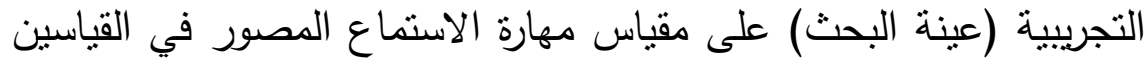
القبلي والبعدي للبرنامج التدريبي. r. لا توجد فروق دالة إحصائياً بين متوسطي رتب لادب درجات أطفال

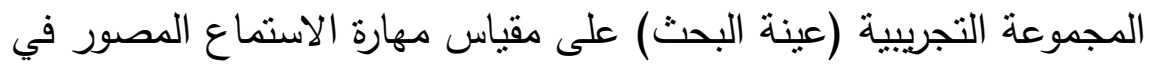
القياسين البعدي والتتبعي للبرنامج التدريبي. الإجراءات المنهجية للبحث: منهج البحث:

تم استخدام المنهج شبه التجريبي باستخدام التصميم التجريبي للمجموعة التهائ

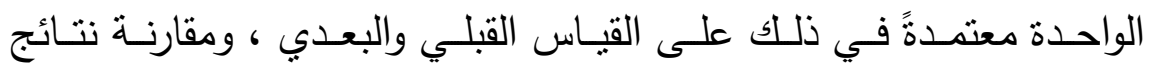

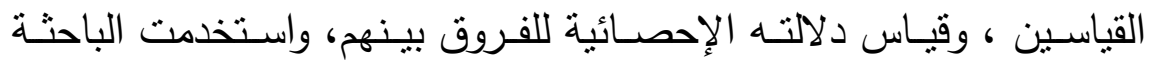

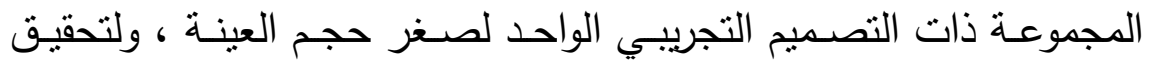

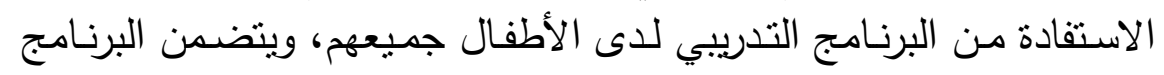

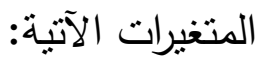
(1) المتغير المستقل: وهو البرنامج التدريبي.

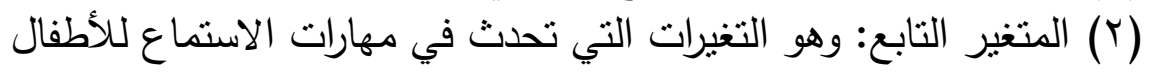
المنبئين بصعوبات تعلم قراءة تعلم اللغة العربية. عينة البحث: - مين اختيرت عينة البحث من الأطفال المنبئين بصعوبات تعلم القراءة بروضة مدرسة التتيس الابتدائية بمحافظة بورسعيد وعددهم (^) أطفالاً. 
اشترطت الباحثة بعض الثروط بالنسبة لاختيار أطفال الروضـة ( عينة

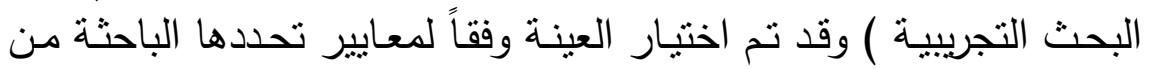
أهمها:

• أن بتراوح العمر الزمني للأطفال ما بين (0- 7 آن سنوات.

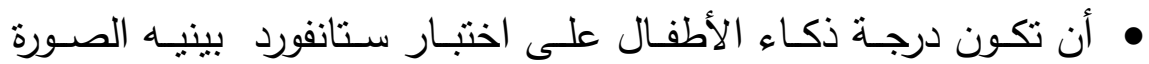

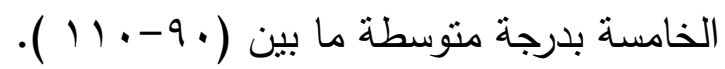

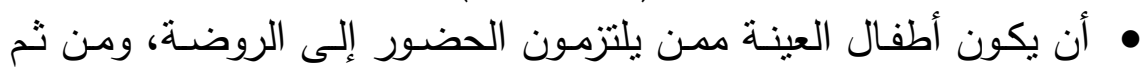

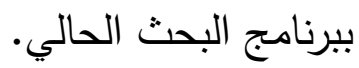
• أن يكونوا من الأطفال ممن لايهم ضعف في مهارات الاستماع، وذلك

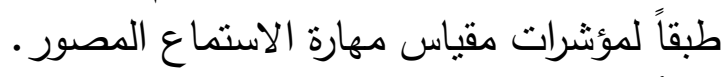
• أن يكون الأطفال من المصنفين من فئة ذوبي صعوبات تعلم القراءة.

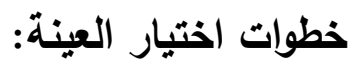
مر اختيار العينة بالخطوات التالية:

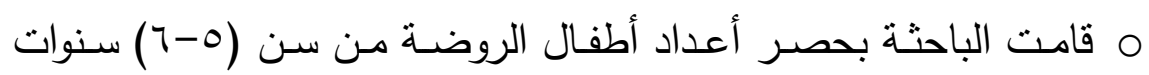

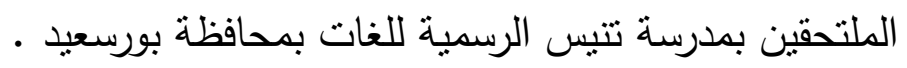

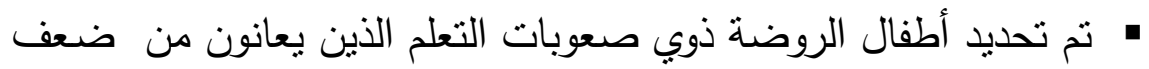

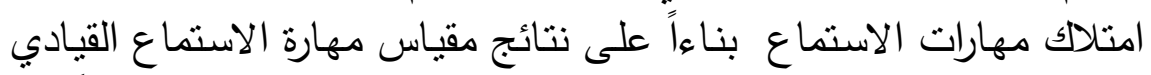

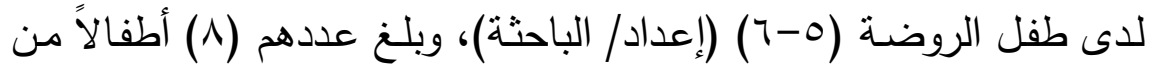
الأكور والإناث. • تم استبعاد الأطفال الذين لا تتطبق عليهح شروط اختيار العينة ، وبذلك

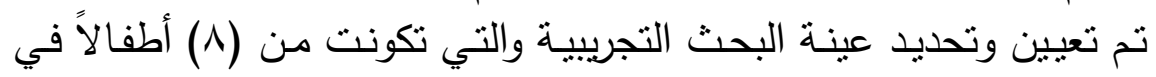

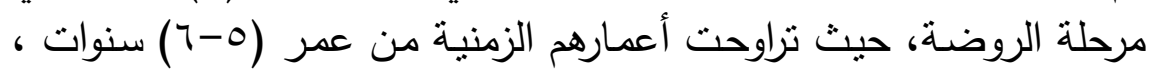
والجدول التالي يوضـح عينة البحث من حيث العدد والنوع. 
جدول رقم ( 1 ) يمثل عينة البحث من حيث العدد والنوع

\begin{tabular}{|c|c|c|}
\hline متوسط العمر & العدد & النوع \\
\hline \multirow{3}{*}{0,0} & $r$ & ذكور \\
\hline & 0 & إناث \\
\hline & $\Lambda$ & مج \\
\hline
\end{tabular}

\section{أدوات البحث:}

استخدمت الباحثة في هذا البحث عددًا من الأدوات التي يمكن أن نساهم في توفير البيانـات التي تقضضيها الإجابـة على أسئلة البحث، وفيمـا يلي

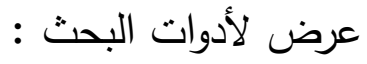

\section{ا ـمقياس مهارة الاستماع المصور:}

تضمن بناء مقياس مهارة الاستماع عدة خطوات يمكن إجمالها فيما يأتي: ) استقراء التراث النظري والاطلاع على بعض المقاييس السابقة. ( تصميم مقياس مهارة الاستماع في صورته الأولية. ح عرض المقياس على مجموعة من الخبراء والمتخصصين في علم النفس ورباض الأطفال لتحكيمه. ) إعداد المقياس في صورته النهائية. (الخصائص السيكومترية للمقياس. وتم بناء مقياس مهارة الاستماع لأطفال الروضـة المنبئين بصعوبات تعلم قراءة اللغة العربية وفقاً لعدد من الخطوات كالآتي: ح تحديد التهدف من المقياس :

صمح هذا المقياس النمائي كوسيلة للكثف عن عن بعض القدرات والمهارات اللغوية الكامنة لدى الطفل في اللغة العربية ، وبيان القدرات والمهارات التي 
تحتاج إلى تطوير مما يساعد الطفل على الاستعداد لتعلم القراءة والحد من خطر التعرض لصعاد تهوبر معات تعلم القراعة في المرحلة اللاحقة.

\section{ح صياغة مفردات المقياس :}

تم صـياغة مفردات المقيـاس في ضـوء مهـارة الاسـتماع المقترح قياسـها

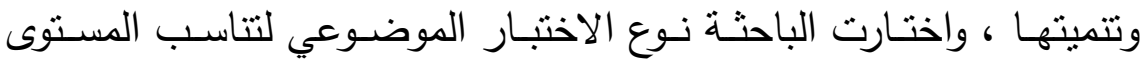

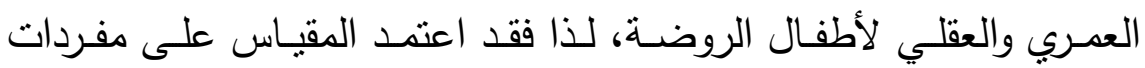

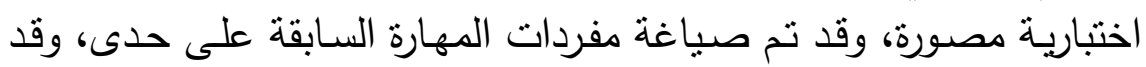

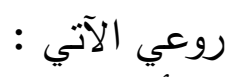

• أن تكون مفردات المهارة واضحةً ومناسبةً لمستوى أطفال الروضة ذوي

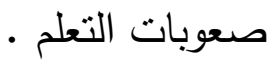
• أن تكـون مفردات المقيـاس خاليـةً مـن المصـطلحات غيـر المألوفـة أو الغامضة أو أن تحمل أكثر من معنى. مفرد

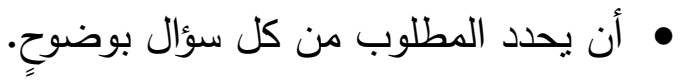
ح صياغة تعليمات المقياس:

تمـت صـياغة تعليمـات المقبـاس حيـث تعتبـر تعليمـات المقيـاس عنصـرًا ضروريًا ، لذا فقد صـاغت الباحثة تعليمات المقياس وراعت فيها الوضسوح

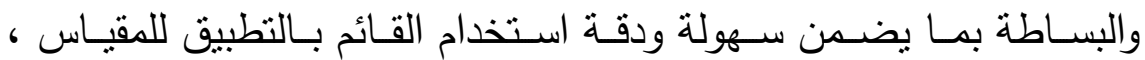

وتضمنت تعليمات المقياس العناصر الآتية: خلق جو نفسي قبل نطبيق المقياس وفي أثنائه. وجود مساعد أو اثثين لمساعدة الأطفال حينما بطبق عليهم المقياس. كتابة بيانات الأطفال في المكان المخصص ده لذلك. قراءة أسئلة المقياس بطربقةٍ جيدةٍ ومبسطةٍ؛ حتى بستطيع الطفل الإجابـة

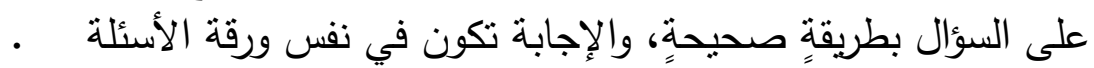


• إذا رغب الطفل في تغيير إجابته ؛ فيجب التأكد منه أنه قد محي إجابته السابقة تمامًا.

عرض المقياس على مجموعة من الخبراء والمتخصصين في علم النفس ورياض الأطفال: - ترضن المقاس

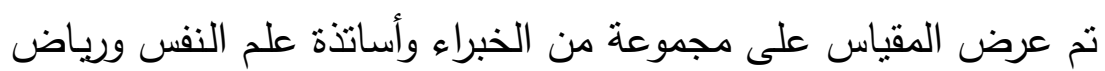

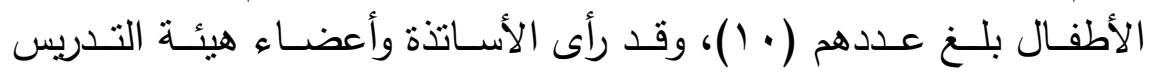

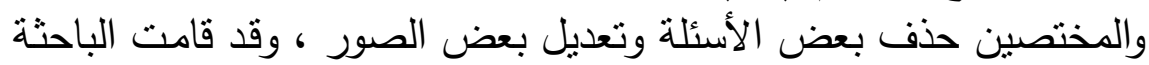
بإجراء التعديلات التي أوصى بهان الهن السادة المحكمون.

إعداد المقياس في صورته النهائية:

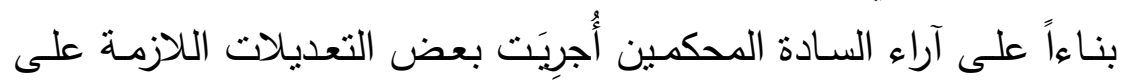
بعض الفقرات وحذف بعضها، ثم وضع المقياس في صورته النهائية . الخصائص السيكومترية للمقياس: أولاً: ثبات المقياس Reliability :

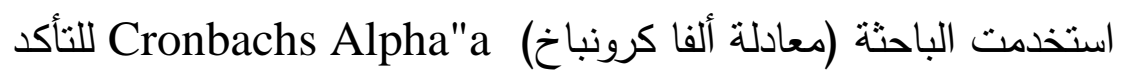

$$
\begin{aligned}
& \text { من ثبات المقياس والجدول التالي يوضح الإجراء الإحصائي : } \\
& \text { جدول (r) }
\end{aligned}
$$

\begin{tabular}{|c|c|c|}
\hline معامل ألفا كرونباخ (ر) & $\underline{E}$ & \\
\hline$*$ * ، $\Lambda \varepsilon$ & $\frac{E}{E}$ & مقياس الاستماع المصور \\
\hline
\end{tabular}

ثبات مقياس مهارة التحدث المصور 


\section{ثانياً: صدق المقياس Validity:

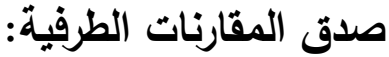

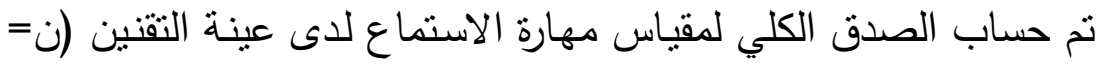

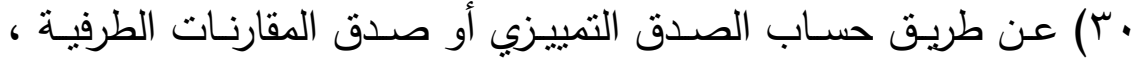
حيث تم ترتيب درجات الأفراد على الدرجة الكلية لمقياس الثعور بالخجل

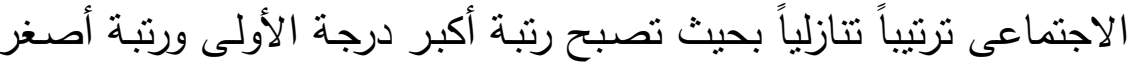

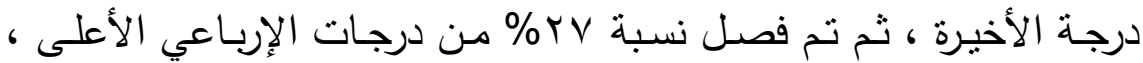

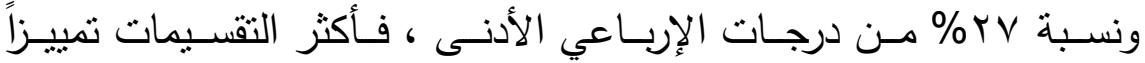
لمستويات الامنياز والضعف هي التي تعتمد على تقسيم درجات الميزان إلى الإنى

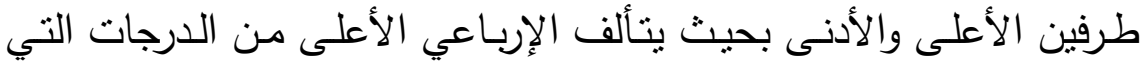

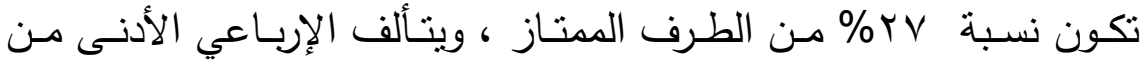

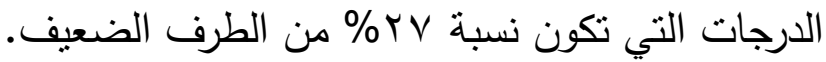

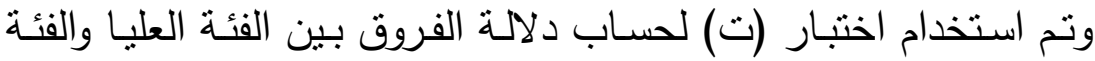

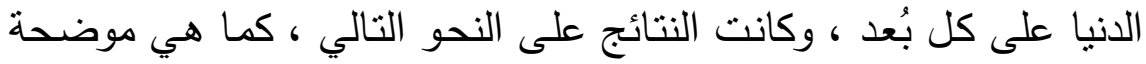

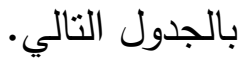

جدول ( آ)

نتائج اختبار "ت" للاراسة الفروق بين متوسطات المجموعة الطرفية لمقياس مهارة التحدث لاى العينة الاستطلاعية

\begin{tabular}{|c|c|c|c|c|c|c|c|c|}
\hline \multirow{2}{*}{ الاحصائية } & \multirow[t]{2}{*}{ قيمة (ت) } & \multicolumn{3}{|c|}{ الفئة الانيا } & \multicolumn{3}{|c|}{ الفئة العليا } & المتغير \\
\hline & & الالانحراف & المتوسط & ن & المعياري & |المتوسط & ن & مقالاستماع \\
\hline$\cdot, \cdots$ & $v, .79$ & $00, \varepsilon 1$ & 1,10 & $\wedge$ & T.TEY & $19, .4$ & 1 & \\
\hline
\end{tabular}


ويتضـح من الجدول السـابق وجود فرق دال إحصـائياً عند مستوى دلالـة

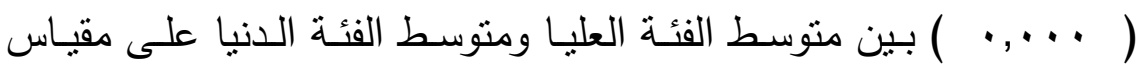
مهارة الاستماع لصـالح متوسط الفئهة العليا لدى العينـة الكلية ، وهذا يدل على الصدق التمييزي لمقياس مهارة الاستماع، مما يشير إلى أن المقياس لديه قدرة مرتفعة على التمييز بين مرتفعي ومنخفضي الاسنماع. r. البرنامج التدريبي لتنمية مهارة الاستماع لاى طقل الروضة المنبيء

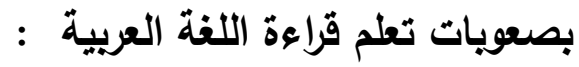

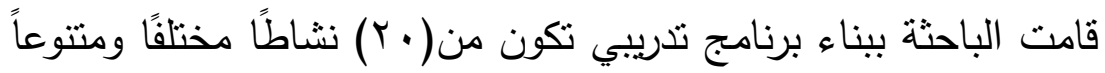

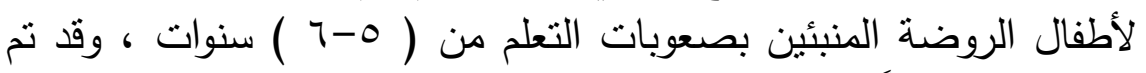

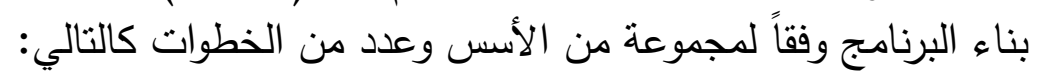
- الحديد الأهداف العامة والفرعية للبرنامج:

يهدف البرنامج التدريبي لطفل الروضة المنبيء بصعوبات التعلم إلى الى تتمية مهارة الاستماع وذلك كالتالي: • تتمية مهارات الاستماع لدى أطفال الروضة المنبئين بصعوبات التعلم. ولتحقيق الأهداف العامة لابد من تحقيق الأهداف الفرعية والتي منها ما يأتي: - ت تمية قدرة الطفل على التمييز السمعي.

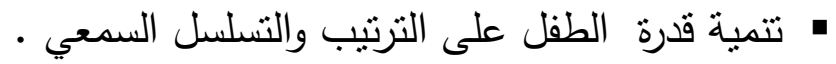
- تتمية قدرة الطفل على الفهم السماعي. 


\section{r . بناء أنشطة البرنامج التـريبي:}

تضمن برنامج البحث ( ب ( ) جلسةً لتمية مهارة الاستماع ، كما تضمنت الجلسات موضوعات محبية ومألوفة للأطفال ولبست جديدة عليهم وتتضمن مثيرات منتوعة وجذابة للطفل ومتوفرة في البيئة المحيطة ، مما يزبد من قدرة الطفل الذاتية على تعلم اللغة واتثراء بيئته اللغوية . وقد روعي أن تكون موضوعات الأنشطة من الموضوعات ذات الاهنهام بالنسبة للأطفال إلى جانب كونها ملائمة ومناسبة للمفاهيم والموضوعات التي يتم تقديمها بشكلٍ متكاملٍ داخل أنشطة البرنامج، بالإضافة إلى كون موضوع النشاط معبرًا عن مجموعة من المهارات والمفاهيم التي تمنثل محور التركيز الرئيسي في أنشطة البرنامج والتي تعتبر المفاهيم الأخرى مفاهيم داعمة لها. ب- إعداد البرنامج في صورته الأولية: • تم تصميم هذا البرنامج بعد إطلاع الباحثة على التراث النظري الخاص بالموضوع وما توفر من برامج بالدراسات السابقة لرياض الأطفال، وما تلقته من تدربيات عملية في دورات وورش عمل في مجال صعوبات التعلم، وخبرة عملية في مجال التعامل مع طفل الروضة من خلال عملها كمعلمة رياض أطفال وتم صياغة عناوين لأفكار الأنشطة من واقع الحياة المحيطة بالطفل، وقد روعي في ذلك محاولة تجسيد الفكرة وتبسيطها وتقربيها للطفل من خلال

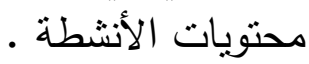

ع -إعداد المواد والموارد المستخدمة:

ونشمل كافة المواد والموارد المستخدمة في تتفيذ أنشطة البرنامج بهدف تعميق استفادة الأطفال من محتوى البرنامج المستهدف تطبيقه ، وقد تم 
الإعداد المسبق لهذه المواد والموارد المستخدمة والتجهيزات التي يتطلبها

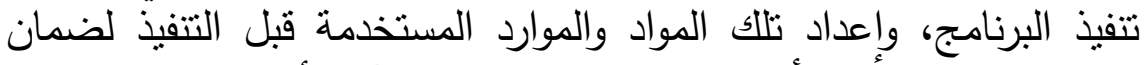

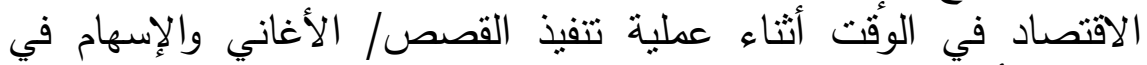

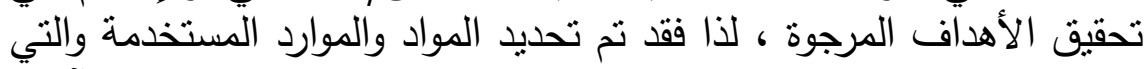

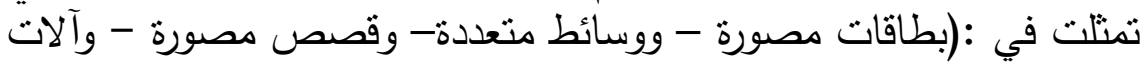
موسيقية). •-إعداد أدوات التقويم : موسئ يستخدم في البرنامج ثلاثة أساليب للتقويم هي : 1 - تقويم قبلي: وهو يتم قبل تطبيق البرنامج وذللك بتطبيق مقياس مهارة

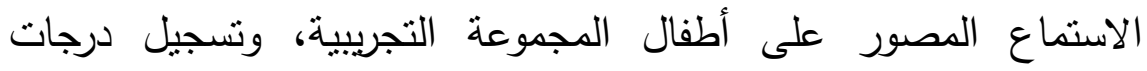
الأطفال على المقياس بهدف تحديد مهارات الاستماع التي تحتاج إلى الى الى التهات تحسينها وتتميتها عند الأطفال.

r - تقويم بنائي: ويتم فيه تقويم الطفل بشكلٍ مستمرٍ منذ بداية البرنامج

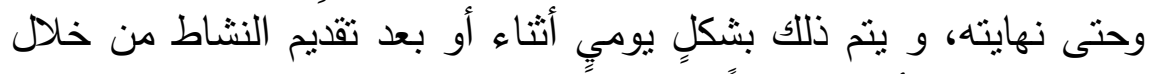
بطاقات تقدم للأطفال يومياً كتطبيق على على النشاط ويمكن تسميتها (بالتقويم

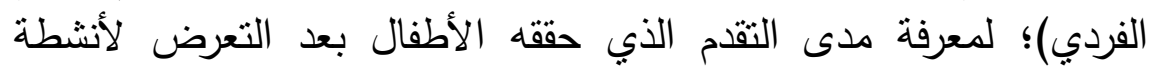

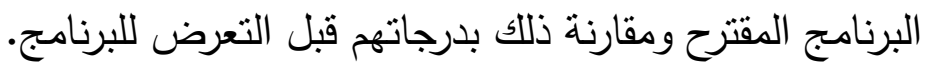

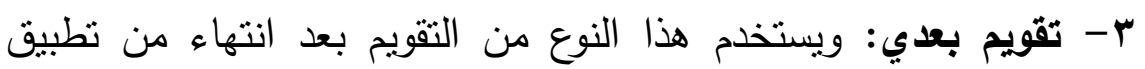

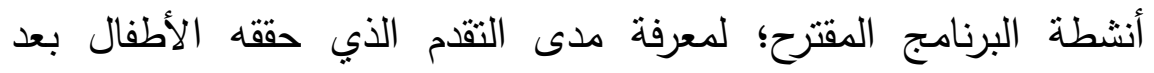

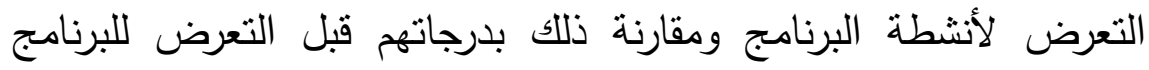

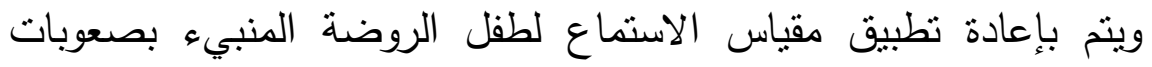
التعلم. 


\section{7 ـ إجراء تجربة استطلاعية لبعض أنشطة البرنامج:}

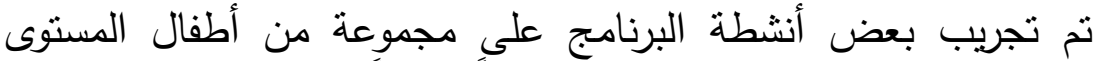

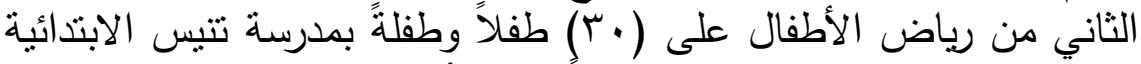

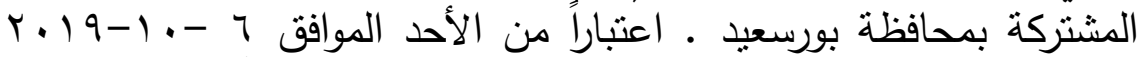

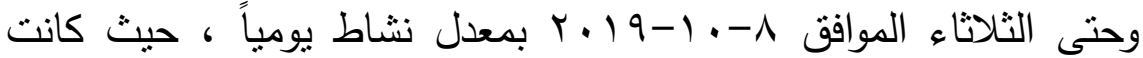

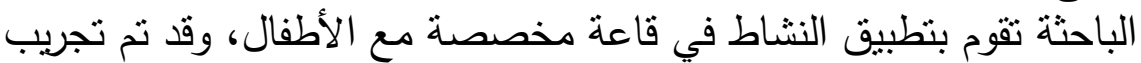
خمس أنشطة بمعدل نشاط واحد لكل مهارة من مهارات البرنامج حتى تمثل المهارات الرئيسة التي تدور حولها أنشطة البرنامج. وفي ضوء ملاحظات الباحثة أثناء تجريب الأنشطة وأداء الأطفال للأنشطة تم الآتي: • تحسين الزمن المناسب لكل نشاط وهو • ب دقيقة. • التأكد من ملاعمة عنوان النشاط والمهارت المستهدف نتميتها لدى أطفاط ألهال الروضة المنبئين بصعوبات التعلم.

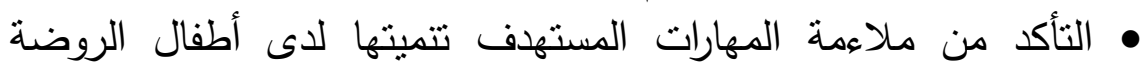

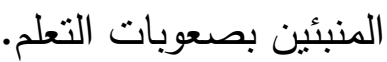
• التأكد من مناسبة المواد والموارد المستخدمة الخاصة بالنشاط.

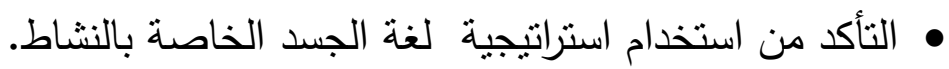
• التأكد من الوضوح والتسلسل المنطقي لإجراءات النشاط. • التأكد من ملاءمة ومناسبة أدوات التقويم لطبيعة أطفال الروضة الراءة المنبئين

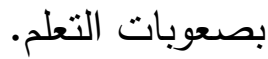
V حيث إنه في ضوء الخطوات السابقة أصبح البرنامج معداً في صورته النهائية . 


\section{الأساليب الإحصائية المتبعة:}

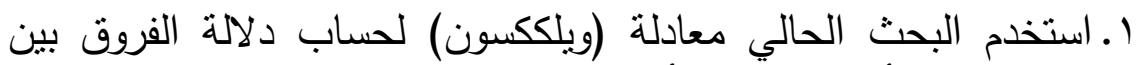

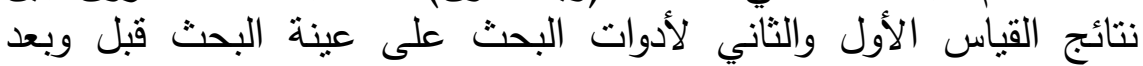

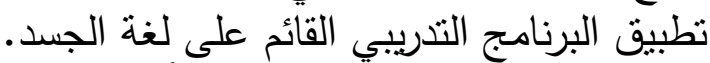

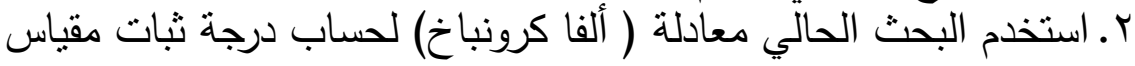
مهارة الاستماع المصور لادى طفل الروضة المنبيء بصعوبات تعلم القراءة. نتائج البحث ومناقشتها: الفرض الأول.... ونتائجه : ينص الفرض الأول للبحث على أنه:

توجد فروق دالة إحصائياً بين متوسطي رتب درجات أطفال المجموعة

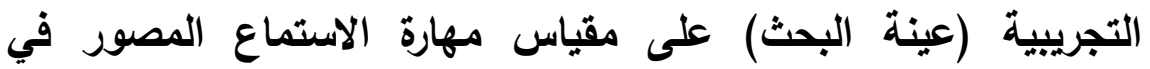
القياسين القبلي والبعدي للبرنامج التدريبي.

وللتحقق من صحة هذا الفرض قامت الباحثة باستخدام اختبار ويلكوكسون

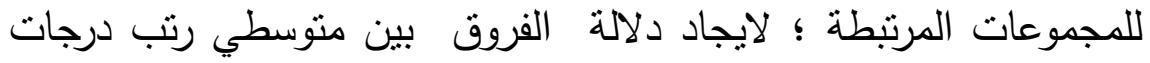

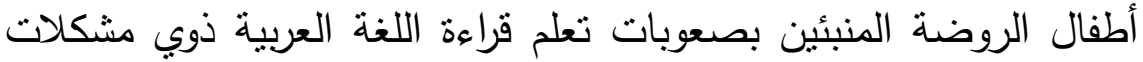

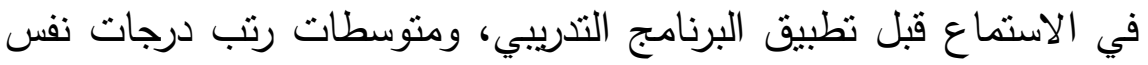

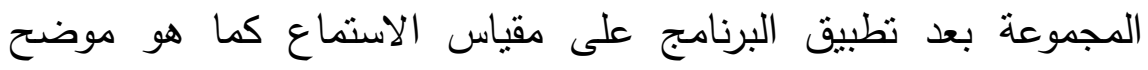
بالجدول النالي: 


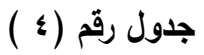

قيمة (Z) ودلالتها الإحصائية بالنسبة للارجات الكلية على مقياس الاستماع المصور للعينة

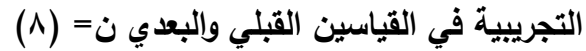

\begin{tabular}{|c|c|c|c|c|c|c|}
\hline \multirow[t]{2}{*}{ مستوى الالاكة } & \multirow[t]{2}{*}{ قيمة (Z) } & & القبلي & \multirow[t]{2}{*}{ العدد(ن) } & \multirow{2}{*}{ فراتج الرتب } & \multirow{6}{*}{ 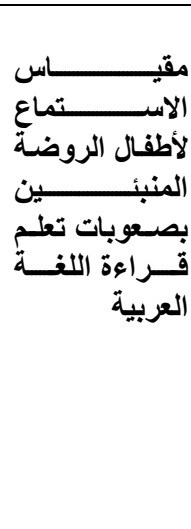 } \\
\hline & & الرجموع & متوسط & & & \\
\hline \multirow[t]{4}{*}{ دالة إحصائياً } & \multirow{4}{*}{$\begin{array}{c}- \\
2.527^{a}\end{array}$} & $00 \cdot 36$ & 4.50 & $8^{a}$ & الموجبة & \\
\hline & & .00 & .00 & $0^{\mathrm{b}}$ & السالبة & \\
\hline & & & & 0 & الرحايدة & \\
\hline & & & & 8 & الكلي الموع & \\
\hline
\end{tabular}

أوضحت النتائج في الجدول السابق رقم ( ع ) دلالة الفروق بين متوسطى القياسين القبلي والبعدي لدى أطفال المجموعة التجريبية على التى مقياس مهارة الاستماع كوعند حساب الفرق بين رتب المجموعتين بلغت قيمة الفروق(2.527a) ، مهي قيمة دالة إحصائياً ، وبيتضح من الجدول الدلالة عند مستوى ( 0. . • لصالح القياس البعدي ، وبذلك تحققت صحة الفرض الأول للبحث.

ويمكن تفسير هذه النتيجة في ضوء البرنامج التذريبي المستخدم الذي

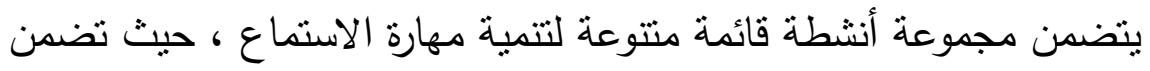

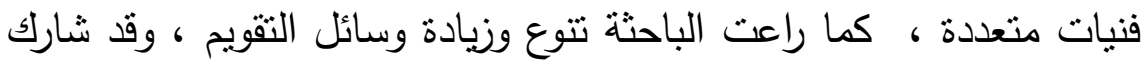

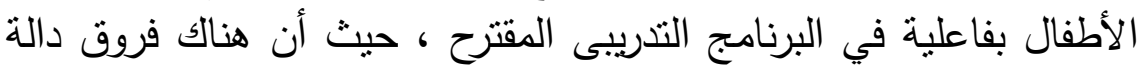
إحصائياً بين منوسطي رتب درجات أطفال المجموعة التجريبية قبل وبعد تطبيق البرنامج لصالح القياس البعدي. 
ومما سبق نجد أن البرنامج له تأثثر إيجابي وفعال في مهارة الاستماع،

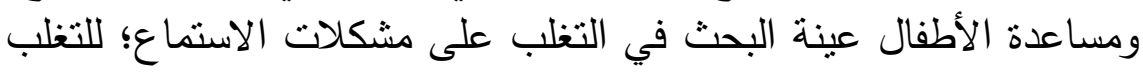
على خطر صعوبات تعلم قراءة اللغة العربية.

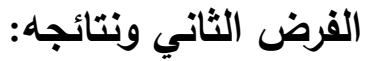
ينص الفرض الثاني للبحث على أنه:

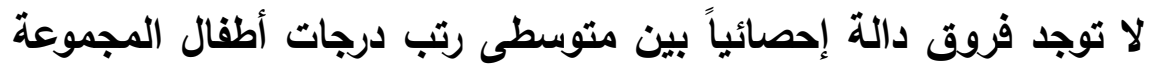

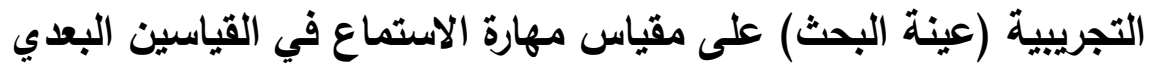
والتتبعي للبرنامـج التدريبي.

وللتحقق من صحة هذا الفرض قامت الباحثة باستخدام اختبار ويلكوكسون للمجموعات المرتبطة لإيجاد دلالة الفروق بين متوسطات رتب رلب المات

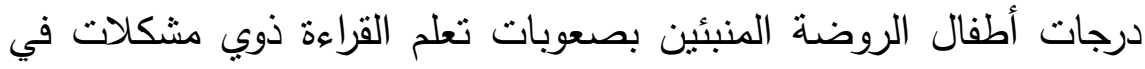

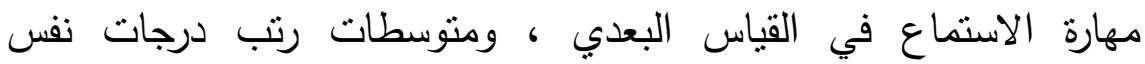

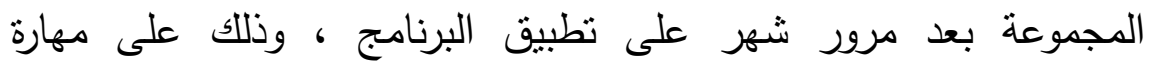

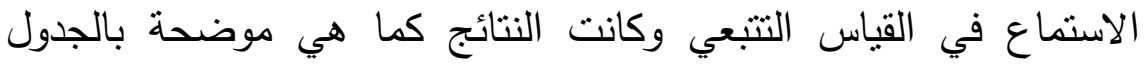

جدول رقم ( ) (ن) التالي: - - n

قيمة (Z) ودلالتها الإحصائية بالنسبة للارجات الكلية على مقياس التحدث المصور للعينة

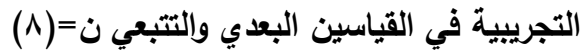

\begin{tabular}{|c|c|c|c|c|c|c|}
\hline \multirow{2}{*}{ مستوى } & \multirow[t]{2}{*}{ قيمة (Z) } & \multicolumn{2}{|c|}{ البعدي/التتبعي } & \multirow[t]{2}{*}{ العدد(ن) } & \multirow{2}{*}{ فروق الرب } & \multirow[b]{3}{*}{ 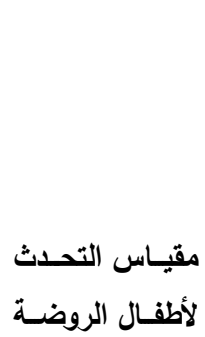 } \\
\hline & & مجموع & متوسط & & & \\
\hline غير دالة 31700 & $\begin{array}{c}- \\
1.000^{\mathrm{a}}\end{array}$ & 1.00 & 1.00 & $1^{a}$ & الموجبة & \\
\hline
\end{tabular}




\begin{tabular}{|c|c|c|c|c|c|}
\hline \multirow[t]{3}{*}{ إحصائياً } & .00 & .00 & $0^{b}$ & الرالبة & \multirow{3}{*}{ 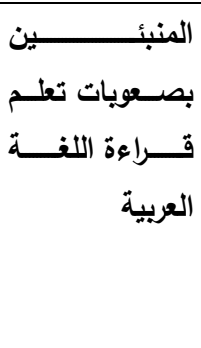 } \\
\hline & & & 7 & المحايدة & \\
\hline & & & 8 & المجموع & \\
\hline
\end{tabular}

يتضـح مـن الجـدول السـابق رقم ( 0 ) عـدم وجـود فـروق دالـة بـين

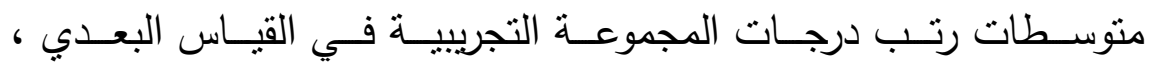
ومتوسطات رتب درجات نفس المجموعة في القباس التتبعي حيث كانت

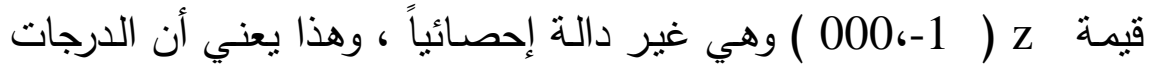

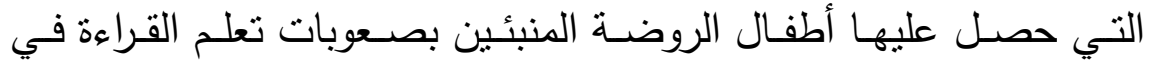
القباسين البعدي والتبتعي كانت متقاربة، مما بدل على استمرار أثز البرنامج التدربيي بالنسـبة لأطفال المجموعـة التجريبيـة فيمـا بعد تطبيـق البرنـامج خلال فترة المتابعة، وبذلك فقد تحققت صحة الفرض الثاني للبحث.

وتزجع الباحثة هذه النتيجة إلى استمرار فعالية البرنامج في تتمية مهارة

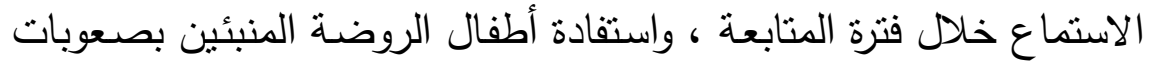
التعلم من الأنشطة المقدمـة في البرنـامج ، والذي ينجم عنه تحسين مهارة الاستماع عند هؤلاء الفئة من الأطفال.

وتتفق نتائج هذا الفرض مع نتائج الدراسات السابقة ومنها دراسة محروس

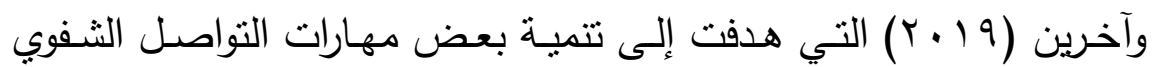
(الاستماع والتحدث) لاى أطفال الروضة، باستخدام إستراتيجية (فكر -زاوج

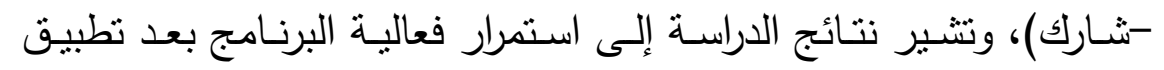
القياس التتبعي. 
ودراسـة الغزولـي (9 ( • ب) والتـي اسـتهدفت تتميـة مهـارتي الاسـتماع

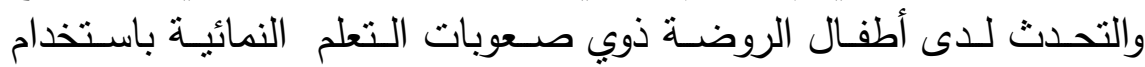

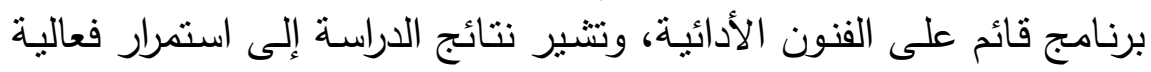
البرنامج بعد تطبيق القياس التتبعي.

\section{مناقشة عامة على النتائج :}

أوضحت نتائج البحث الحالي فعالية البرنامج التدريبي في تتمية مهارة

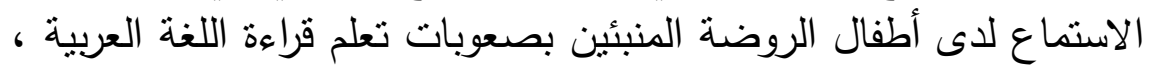

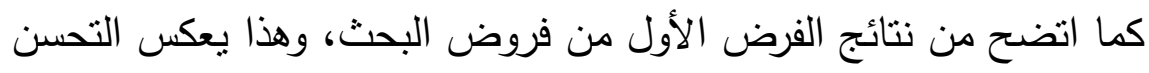

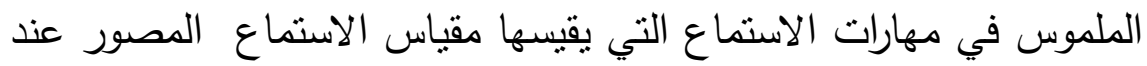
تطبيق البرنامج ، وهذا يدلل على جدوى البرنامج في تحسين مهارة الاستماع.

كما أن مراعاة البرنامج التدريبي لخصائص العينة في إعداد البرنامج قد التداء

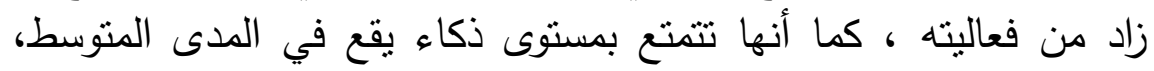

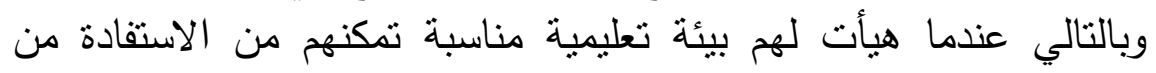

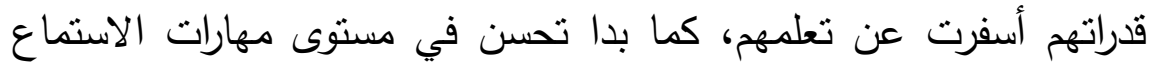
لديهم بعد تطبيق البرنامج.

كما أن ما احتواه البرنامج من فنيات متعددة زاد من وعي الطفل بمهارات

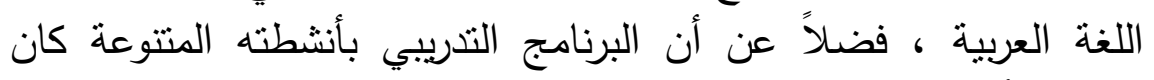

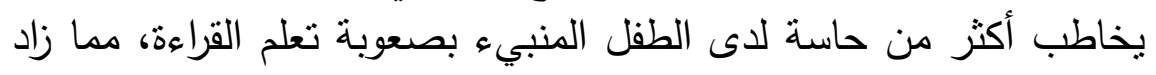
من فعالية البرنامج.

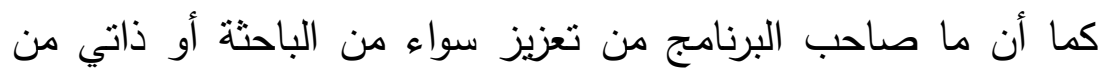

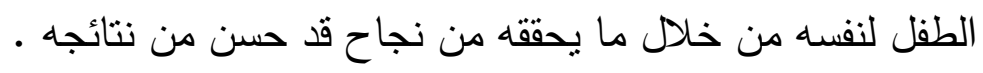


وتتفق هذه النتيجة مع ما قدمه التراث النظري والدراسات السابقة حول

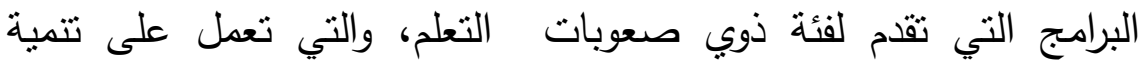
مهارات الاستماع والتحدث، مع ضرورة التأكيد على إنثراء البيئة المحيطة

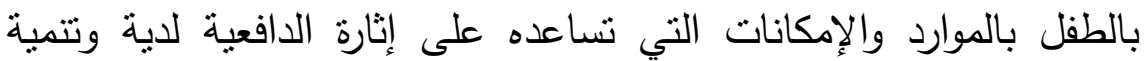
مهاراته اللغوية.

ولعل مرد فاعلية البرنامج إلى استخدام إستراتيجية لغة الجسد والقصة وروح المرح التي غلبت عليها وجعلها في سياق ألعاب تتافسية بين الأطفال مما زاد من انتباههم وحسن وعيهم وإدراكهم.

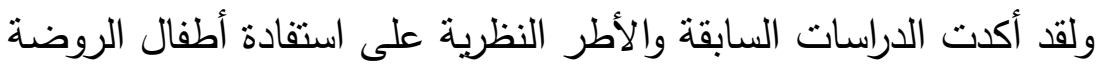

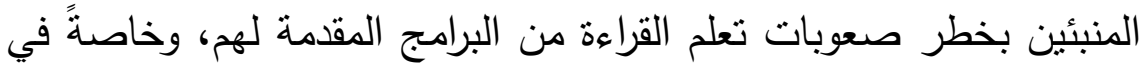

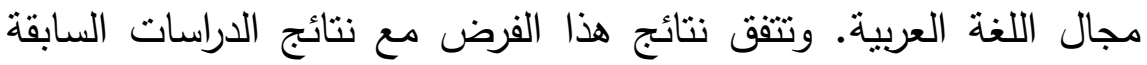

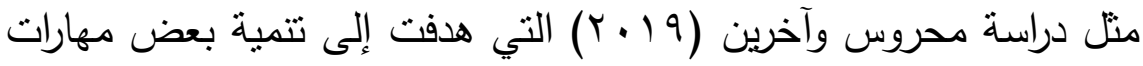

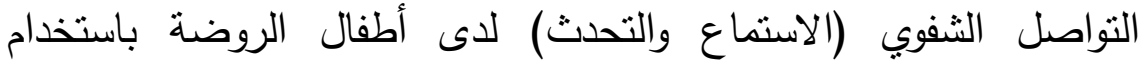
إستراتيجية (فكر -زاوج سثارك).

ودراسة الغزولي (19 (Y) والتي استهدفت تتمية مهارتي الاستماع

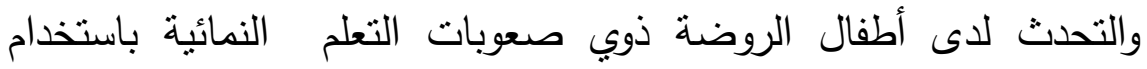
برنامج قائم على الفنون الأدائية .

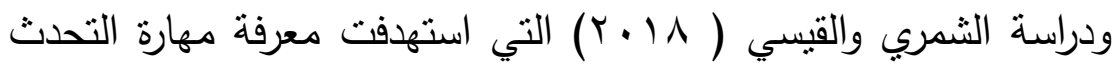

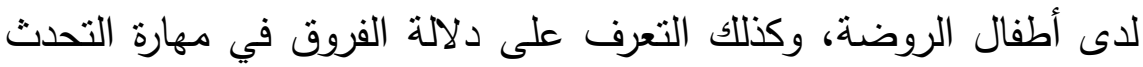

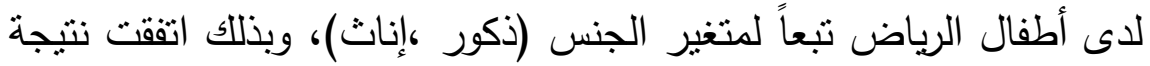

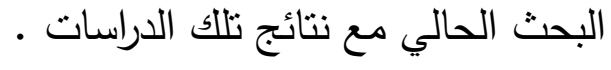


وتتضح فعالية البرنامج التذريبي في الحد من صعوبات تعلم قراءة اللغة العربية في هذا البحث من خلال التحسن الذي طرأ فلى فلى المستوى اللغوي

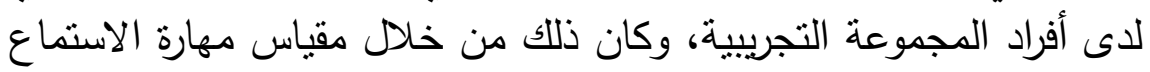

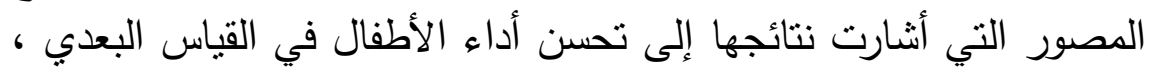

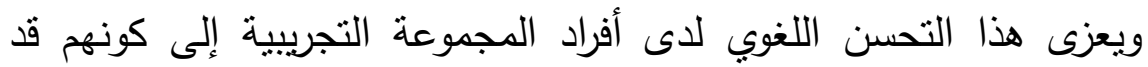

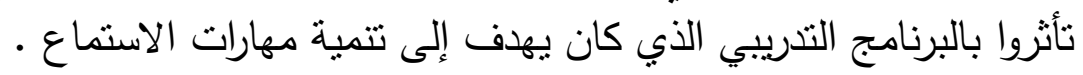

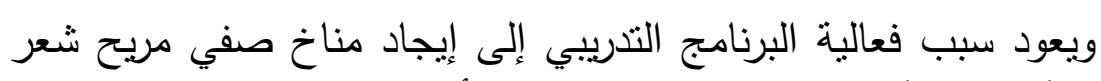
فيه الأطفال بالأمان والحرية في التعبير عن أفكارهم دون خوف البع ، مما سمح

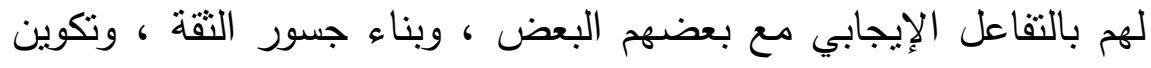

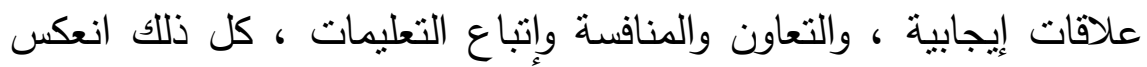

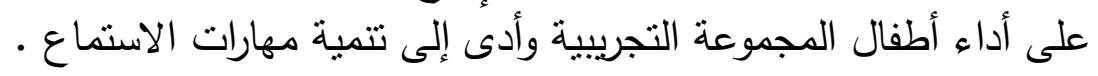

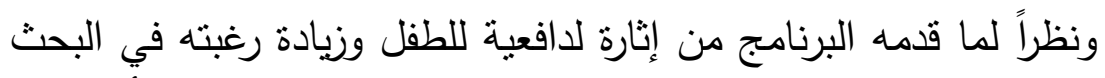

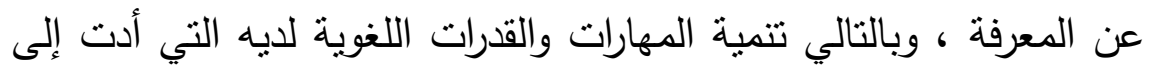

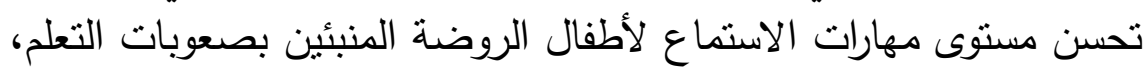

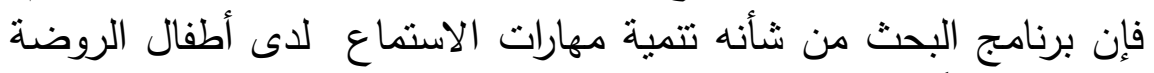

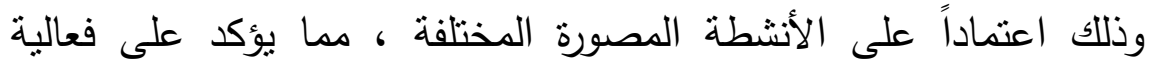
برنامج البحث الحالي.

وترجع الباحثة تحسن أداء الأطفال في مهارات الاستماع نتيجة للبرنامج

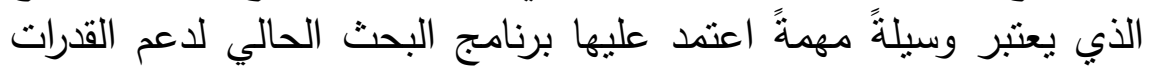
الاستماعية موضوع البحث.

كما تضمنت جلسات البرنامج قصصاً منتوعةً إيجابيةً تعمل على الإنى

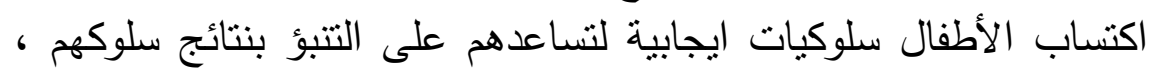

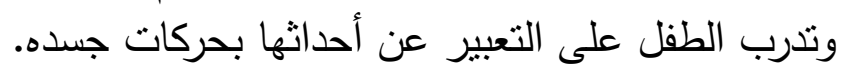


كما اشتملت الجلسات على أنشطة موسيقية مرتبطة بالقصص تساعد

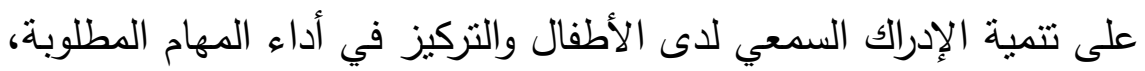
مما بؤدي إلى تحسين مهارات السمع التي بدورها تؤثر على الألى اكتسابه

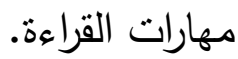

وتفسر الباحثة التحسن في أداء الأطفال بعد البرنامج نظراً لمراعاة

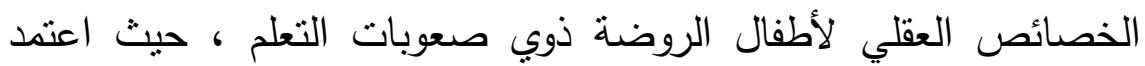

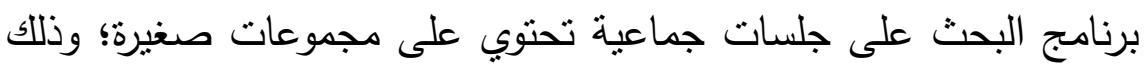

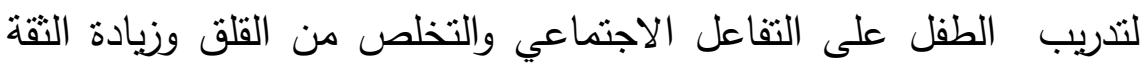

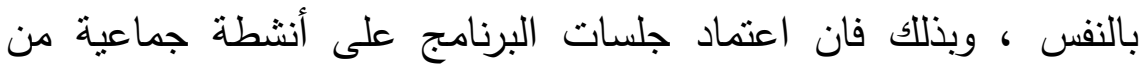

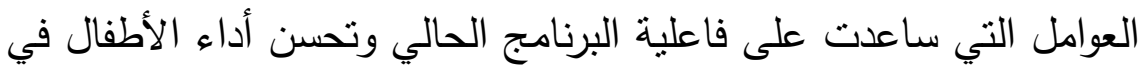

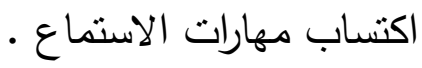

كما ترى الباحثة إرجاء فاعلية البرنامج إلى مراعاته للتدرج الزمني لكل

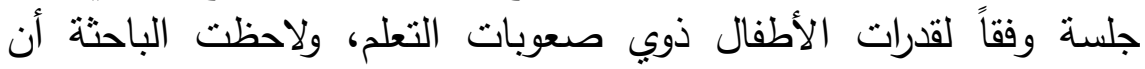

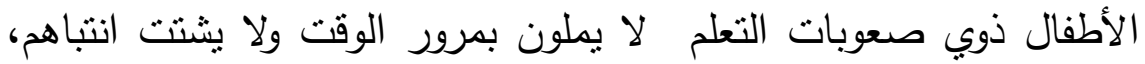

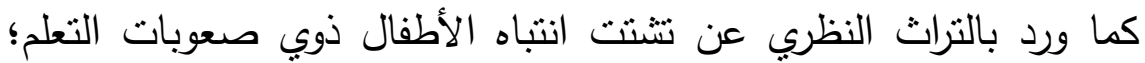
وذلك لأن الجلسات تضمنت أنشطة منتوعة تفعيل دور الطفل بإيجابية الفياه

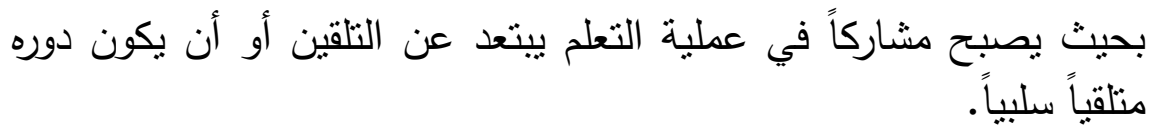

وقد روعي أيضاً في أنشطة البرنامج التتوع والبساطة والاعتماد على فلى

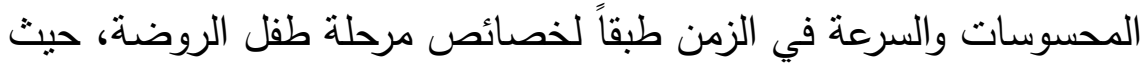

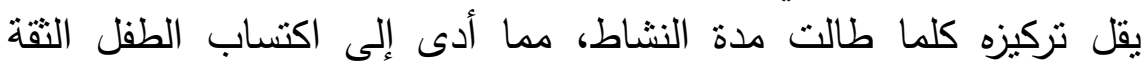
بالنفس وزيادة مستوى دافعيته للتعلم. 
وبذلك تشبر كل نتائج البحث الحالي على أن جميع الفروض التي

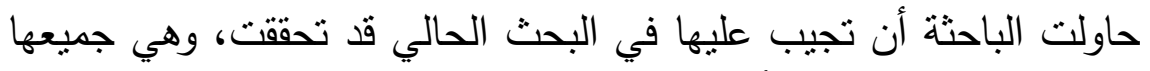

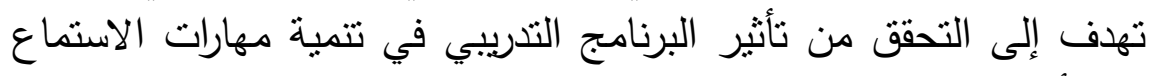

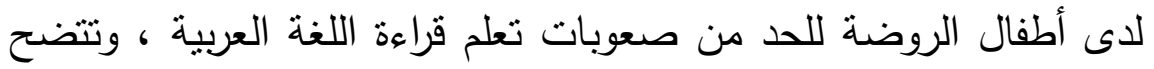

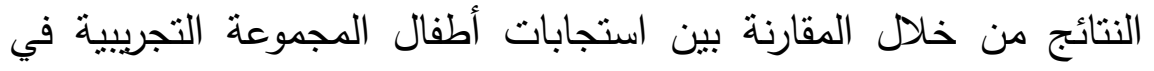
القياس القبلي والبعدي والتتبعي.

وهذه النتائج مفردة ومجتمعة تؤكد فعالية البرنامج المستخدم في ولتئية تلتمية

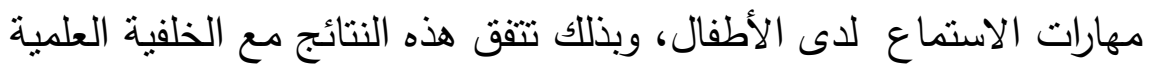

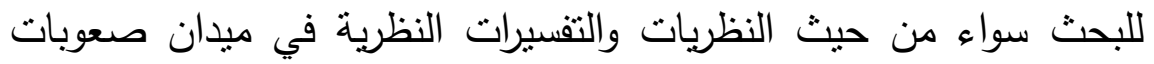

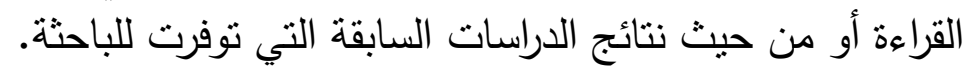

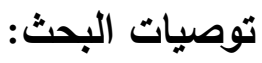

في ضوء ما توصل إليه البحث الحالي من نتائج تثقدم الباحثة بالتوصيات

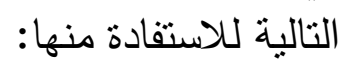

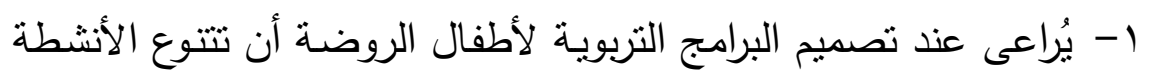

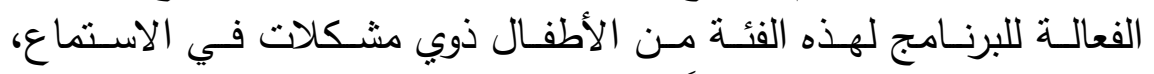

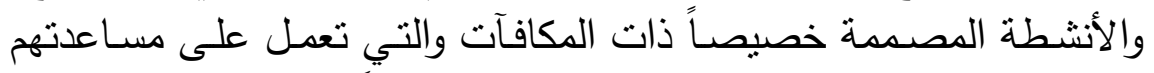

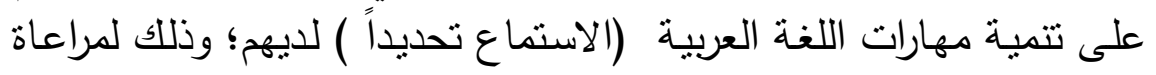
خصائص طفل الروضة. r- البُعد عن طرق التدريس التقليدية التي تعتمد على التلقين دون اعتبار

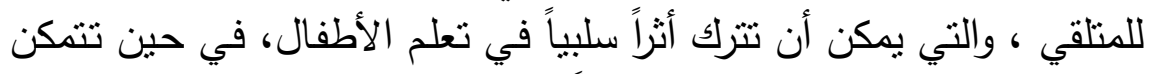

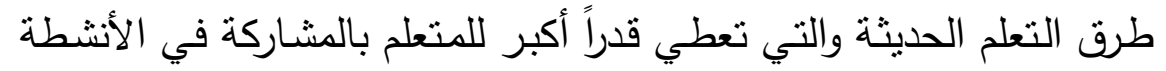
والتي تعتمد على لغة الجسد والتي تتناسب مع لفي هذه الفئة من الأطفال. 


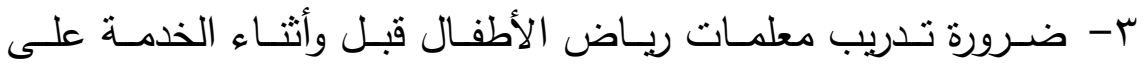
اسـتخدام إسـتراتيجيات متتوعـة في الممارسـات التعليميـة وتصـميم الأنشـطة التعليمبة المناسبة لها. ع- تشجيع معلمات رباض الأطفال على التتوبع في استخدام إستراتيجيات التدريس؛ لمراعـاة الفروق الفرديـة بين الأطفال لجعل كل طفل يتعلم وفق لـق أسلوب التعلم المفضل لديـه، وتمكينهم من انتقاء الأنشطة التي تنتاسب مـع

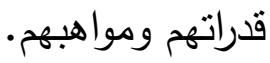
ه- الاهتمـام بعمل نشـخيص مبكر لفئة المضطربين لغويـاً بصفةٍ عامـةٍة

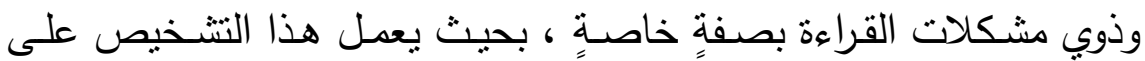
محكات وأدوات تشخيصية متعددة ، من أجل تبسير التّخل المبكر للحد من فن مشكلات هذه الفئة، مما يكون له أثراً بالغاً عن لو تم هذا التخدل فئ في مرحلة منأخرة.

\section{البحوث المقترحة:}

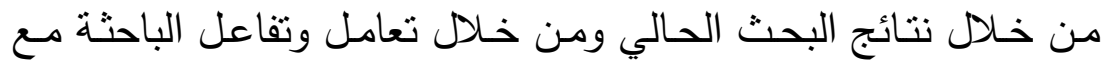
الأطفال ذوي صعوبات القراءة ، فلقد اقترحت الباحثة البحوث الآتية: ا- فعالية برنامج قائم على القصص الإبتكارية للحد من صعوبات التعلم

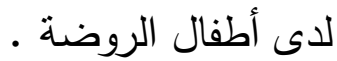
r- فعالية برنامج تدخل مبكر للحد من صعوبات تعلم القراءة لدى أطفال الروضة.

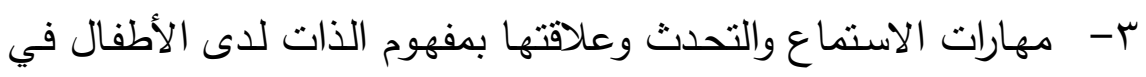
مراحل عمرية منتالية ، دراسة مقارنة بين الذكور والإناث.

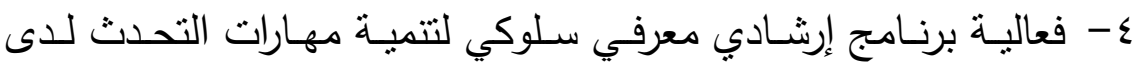
أطفال الروضة ضعاف السمع. 
0- فعاليـة برنـامج تدريبي لتتميـة مهارات الاستماع والتحدث لدى أطفال الروضة المكفوفين.

\section{المراجع}

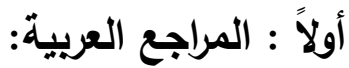

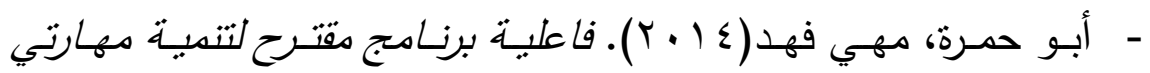

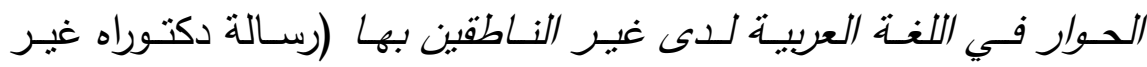
منشورة). جامعة دمشق . كلية التربية.

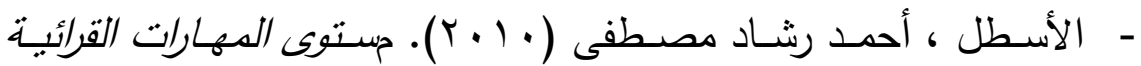
والكتابيـة لـدى طلبـة الصف السـادس (رسـالة ماجستير غير منشـورة ). الجامعة الإسلامية .غزة.

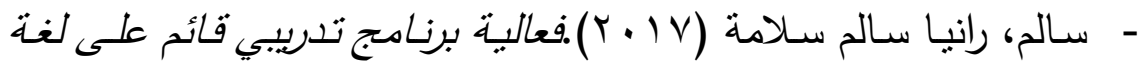

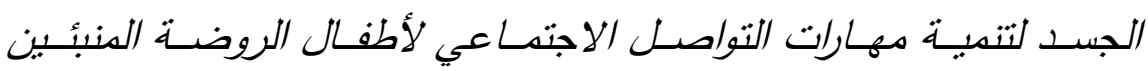

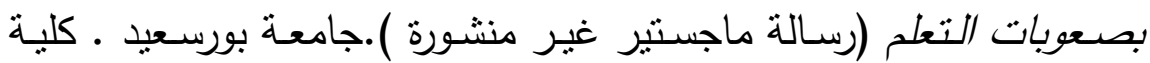
رياض الأطفال.

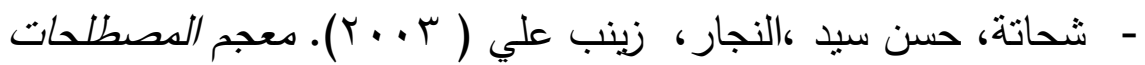
التربوية والنفسية ـ القاهرة: الدار المصرية اللبنانية.

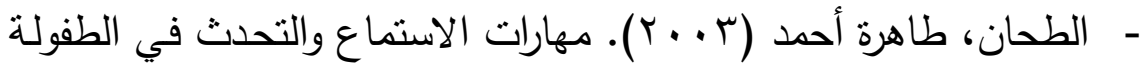

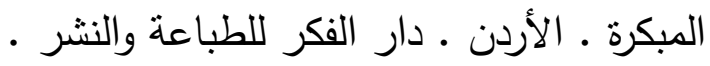

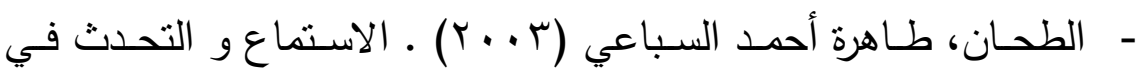

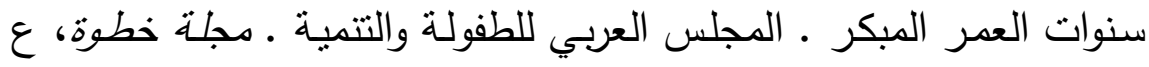
$\cdot(r \cdot)$ 


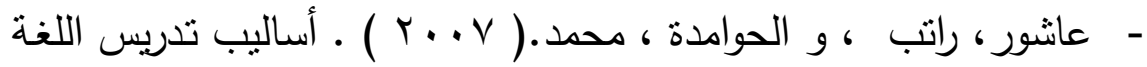

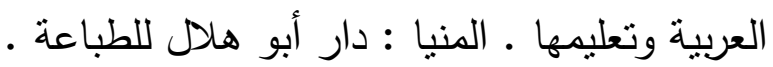

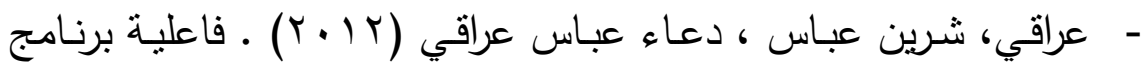

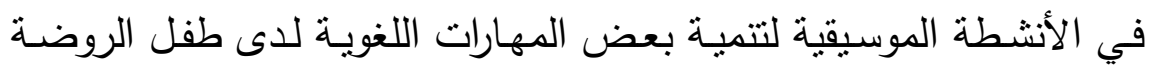

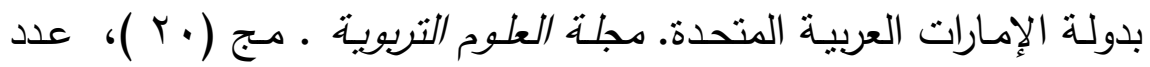
ع أكتوبر

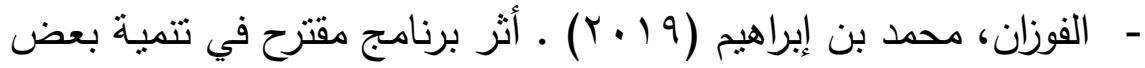

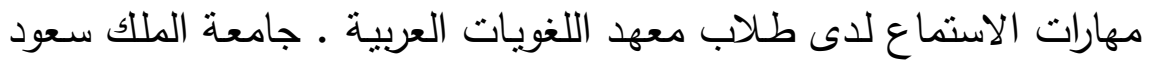

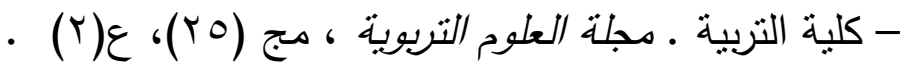

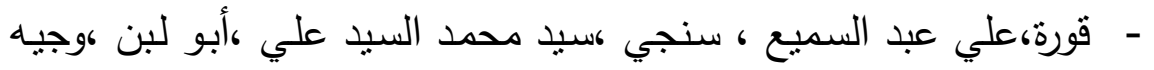

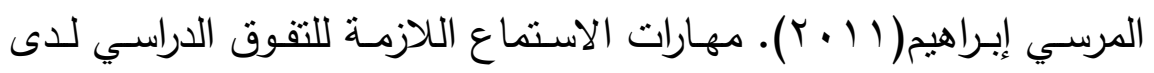

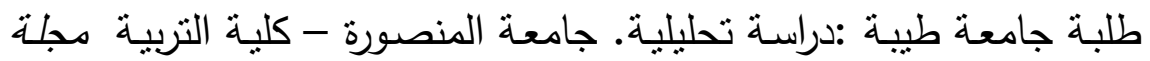

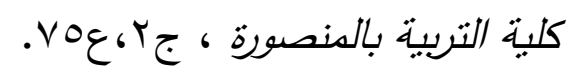

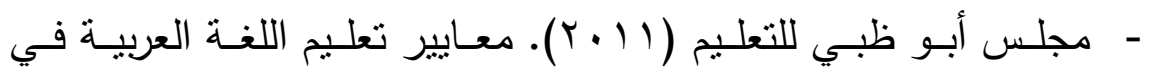

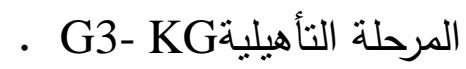

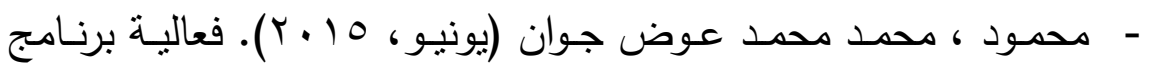
إرشادي معرفي سلوكي للحد من اضطرابات النطق لدى الأطفال المتأخرين

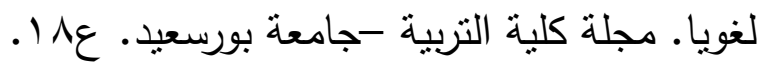

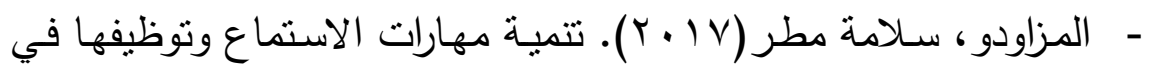

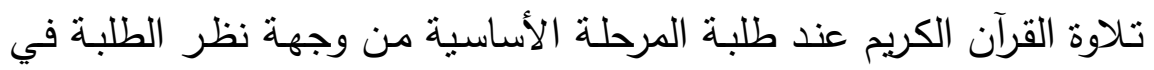


محافظة المفرق. جامعة أسيوط - كلية التربية. مجلة كلية التربية، مسج سب

$$
. \vee \varepsilon^{6}
$$

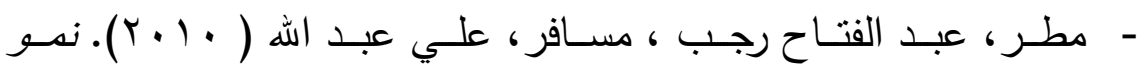
المفاهبم والمهارات اللغوبة لدى الأطفال . الرباض. دار النشر الدولي.

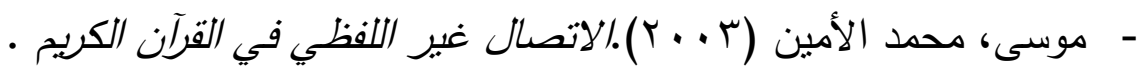

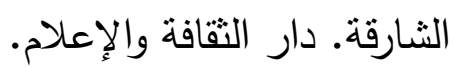

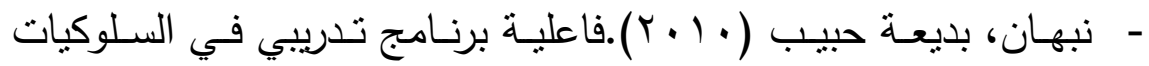
الأمانيـة لتميـة الثقة بـالنفس وتقدير الذات لـدى الأطفـال المعـاقين عقليـاً

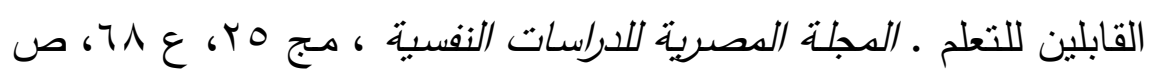

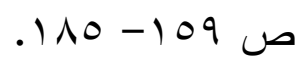

\section{ثانيًا: المواقع الإلكترونية :}

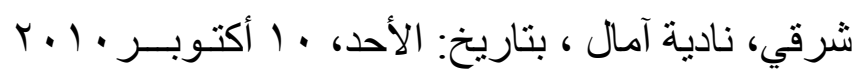

http://www.edutrapedia.illaf.net/arabic/show_article.thtml ?id=628 

فاعلية استخدام القصص الإلكترونية في تنمية بعض المفاهيم المرتبطة بثقافات الشعوب العربية لاى طقل الروضة * د/ سهر عاطف عبد القادر عبد المنعم.*

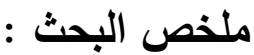

يهدف البحث إلى تتمية بعض المفاهيم المرتبطة بثقافات الثعوب العربية لاى طفل الروضة من خلال إعداد برنامج قصص إلكترونية، وتكونت عينة البحث من ( • 7) طفلاً وطفلةً من أطفال المستوى الثاني لرياض الأطفال والتي تتراوح أعمارهم الزمنية من (0 - 7) سنوات، وقد قسمت على النحو

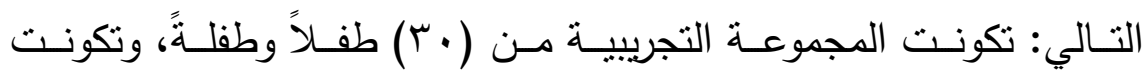

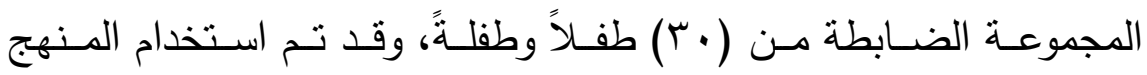
التجريبي، وتحددت أدوات البحث في مقيـاس المفـاهيم المرتبطــة بثقافـات الثـعوب العربية المصور لطفل الروضـة (إعداد الباحثة)، برنـامج قصص إلكترونيـة لتتميـة بعض المفاهيم المرتبطة بثقافات الثـعوب العربيـة لطفل الروضة (إعداد الباحثة)، وقد أسفرت النتائج بأن استخدام برنامج القصص بـد الإكترونية كان له تأثثر إيجابي في تتمية بعض المفاهيم المرتبطة بثقافات الثعوب العربية لطفل الروضة.

* مدرس بقسم الطوم التريوية-كلية التربية للطفولة المبكرة - جامعة الزقازيق. 


\section{المجلة العلمية لكلية رياض الأطفال - جامعة بورسعيد}

\section{The effectiveness of using electronic stories in developing some concepts related to the cultures of Arab peoples for the kindergarten child}

Prepare: Dr. / Sahar Atef Abdel Qader Abdel Moneim. *

\section{Abstract:}

The research aims to develop some concepts related to the cultures of Arab peoples for the kindergarten child through the preparation of an electronic stories program, and the research sample consisted of (60) children and girls from the second level of kindergarten children whose ages range from (5-6) years and was divided as follows The experimental group consisted of (30) children and a girl, and the control group consisted of (30) children, and the experimental method was used, and the research tools were identified in the scale of concepts related to the cultures of Arab peoples. Concepts related to the cultures of Arab peoples for the kindergarten child (the researcher preparation). The results showed that the use of the electronic stories program had a positive effect on the development of some concepts related to the cultures of Arab peoples for the kindergarten child.

*Lecturer, Department of Educational Sciences, Faculty of of Early Childhood Education, Zagazig University. 


\section{الكلمات المفتاحية Keywords:}

- القصص الإلكترونية. Electronic stories -

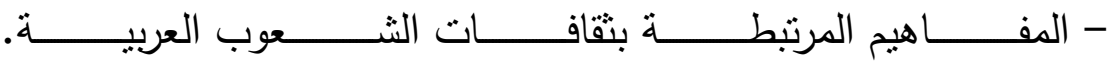

Concepts related to the cultures of Arab peoples

Kindergarten child

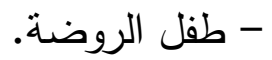

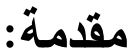

تهتم برامج التعليم بما يحقق التفاعل مع متغيرات المستقبل وتحدياته،

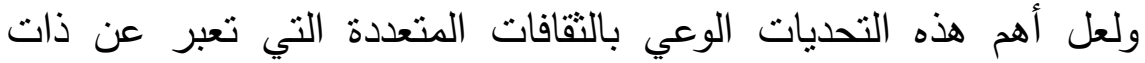
الثعوب وتمثل هويتها وتحدد ملامح شخصيتها، وتعتبر مرحلة الطفولة

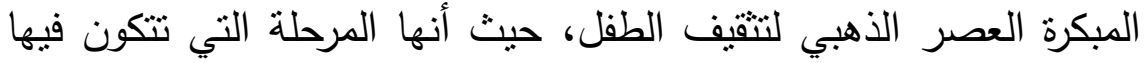

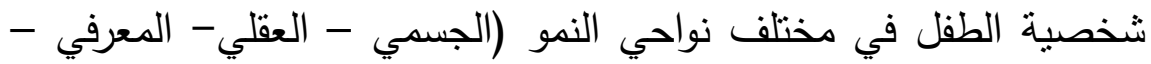
(الاجتماعي).

فالتقافة إحدى الركائز الأساسية في تتشئة الطفل فهي تمده بالقيم والتقاليد

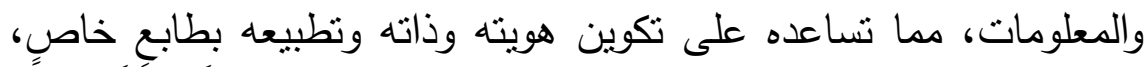
في ضوء ذلك نجد أن الوعي بالثقافات المتعددة برتبط ارتباطاً وثثيقاً بتتشئة

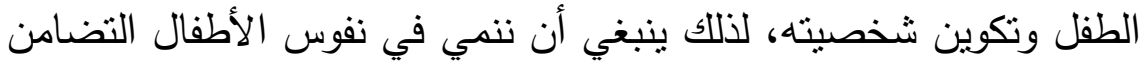

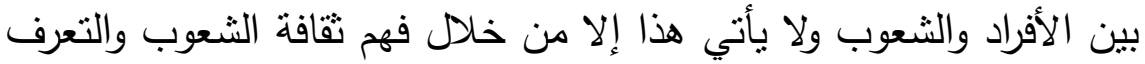

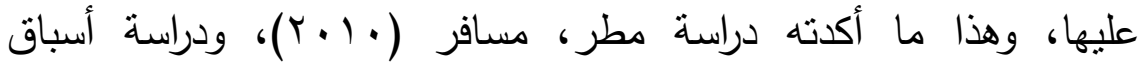

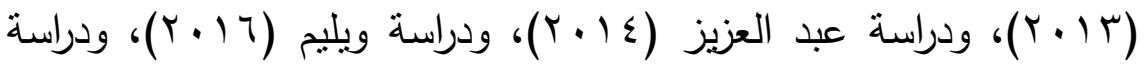

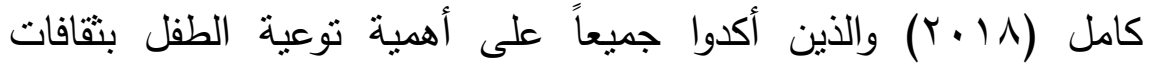

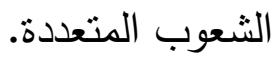


ونظراً لأننا نعيش الآن في عصر التكنولوجيا الرقمية حرص التربويون على توظيف التكنولوجيا في خدمة العملية التعليمية، ونظراً لأن مرحلة

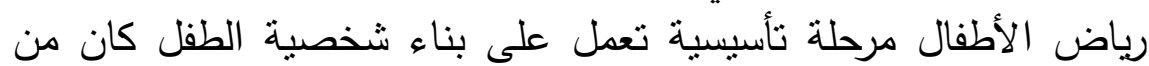

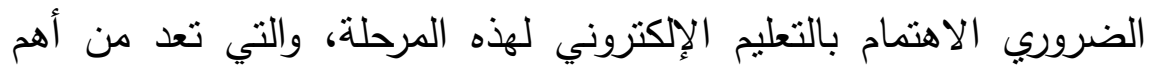
تطبيقاته القصص الإكترونية التي تشهد اهتماماً كبيراً في السنوات الأخيرة؛ لما تتمتع به من مميزاتٍ تربويةٍ وفنيةٍ تيسر فهم الكثير من المفاهيم والحقائق التي يصعب فههها، وفي ضوء ذلك يتضح أن القصة الإلكترونية تساعد في تتمية المفاهيم المختلفة للطفل ومنها المفاهيم المرتبطة بثقافات الشعوب (Engle,2011, p.1)، (Sangra, 2012, p.46)، (عبد الباسط،

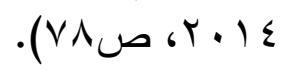

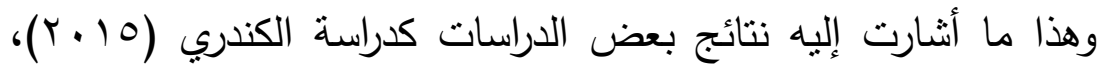

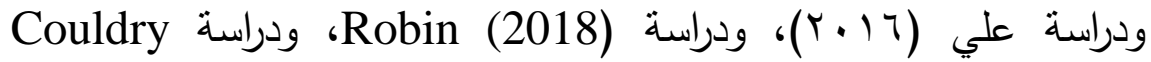

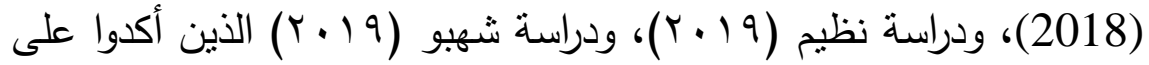
فاعلية القصص الإلكترونية في تتمية العديد من المفاهيم لطفل الروضة، ونها، لللك يسعى البحث الحالي إلى توظيف القصص الإلكثرونية لتتمية المفاهيم المرتبطة بثقافات الثعوب لطفل الروضة.

\section{الإحساس بالمشكنة:}

ينبع الإحساس بالمشكلة من خلال المصادر الآتية:

• من خلال إثراف الباحثة على طالبات كلية التربية النوعية، شعبة رياض فلاض الأطفال في التربية العملي، لاحظت افتقار منهج رياض الأطفال إلى الإلى

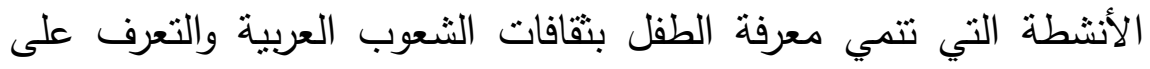
العالم الخارجي من حوله للاستفادة منه، كذللك اعتماد المنهج على التعليم 
التقلبدي، وعدم الاهتمام بالتعلم الإلكتروني على الرغم من التقدم التكنولوجي

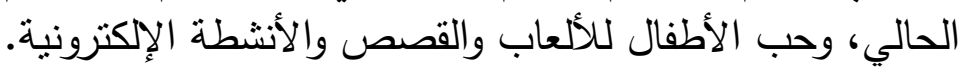

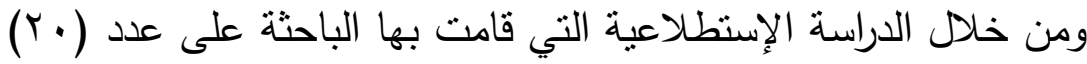
معلمةً من معلمات رياض الأطفال حول مدى استخدام القصص الإلكترونية

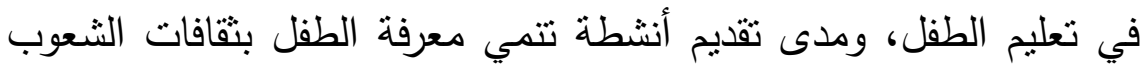

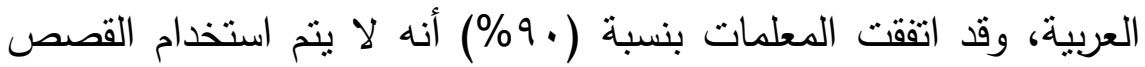
الإلكترونية في تعليم الأطفال بل يستخدموا القصص الورقية التقليدية، كما اتفقت المعلمات بنسبة (90\%) على أنه لا يتم تقديم أنشطة تنمي معرفة

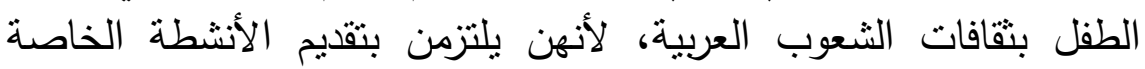

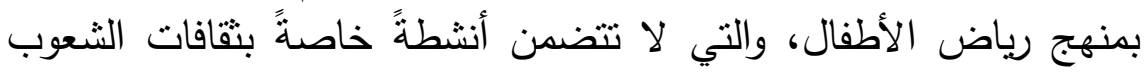
العربية.

• كما توصلت الباحثة بعد الإطلاع على الدراسات السابقة التي تتاولت القصص الإلكترونية وأوصت بتطبيقها مثل دراسة الكندري (10) (10)،

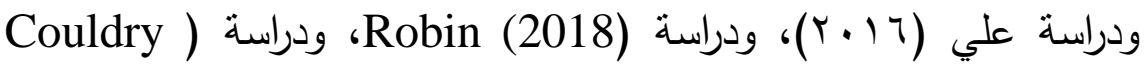

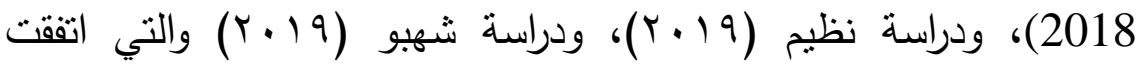
نتائجها على أهمية القصص الإلكترونية كمدخل تعليمي للطفل يعتمد على فلى ودية استخدام التكنولوجيا في التعليم بما يتوافق مع العصر • التصنيه وهذا يؤكد على أهمية تطبيق القصص الإلكترونية في تتمية المفاهيم المرتبطة بثقافات الثعوب العربية.

\section{مشكنة البحث :}

من العرض السابق لمصادر الإحساس بمشكلة البحث، خلصت الباحثة إلى وجود نقص في تتمية بعض المفاهيم المرنبطة بثقافات الثعوب العربية، لذلك كان لابد من وضع أنشطةٍ تعليميةٍ تركز على القصص الإلكترونية 
التي تعد اتجاهاً حديثاً في تعليم وتعلم الأطفال؛ وذلك لتتمية بعض المفاهيم

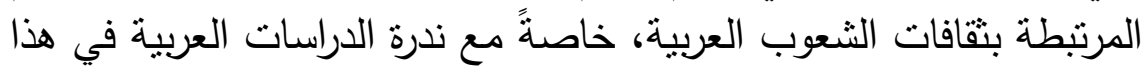
المجال في حدود علم الباحثة. لذلك تم تحديد مشكلة البحث في السؤال الرئيسي التالي: "ما فاعلية استخدام القصص الإكترونية في تتمية بعض المض المفاهيم

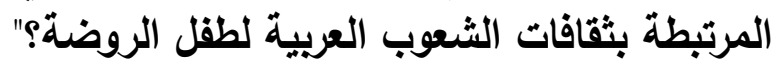
وينبثق من هذا السؤال الرئيسي الأسئلة الفرعية التالية:

ا-ما المفاهيم المرتبطة بثقافات الثعوب العربية التي ينبغي تتميتها لدى

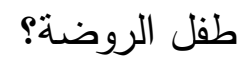

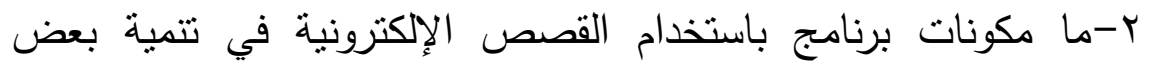

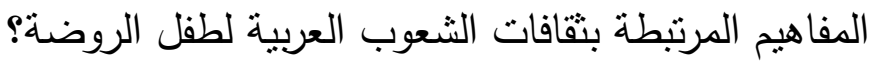
ب-ما فاعلية القصص الإلكترونية في تتمية بعض المض المفاهيم المرتبطة بثقافات الشعوب العربية لطفل الروضة التهب

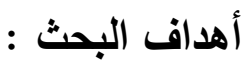

$$
\text { يهدف البحث الحالي إلى : }
$$

1- تحديد المفاهيم المرتبطة بثقافات الثعوب العربية التي ينبغي تتميتها لاعى طفل الروضة. ץ- إعداد مقياس مصور لقياس بعض المفاهيم المرتبطة بثقافات الثعوب العربية لطفل الروضة.

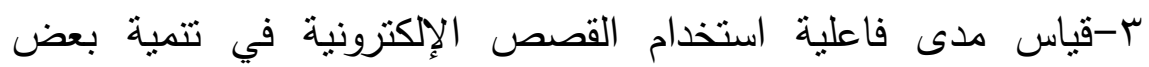
المفاهيم المرتبطة بثقافات الثعوب لطفل الروضة الثنة. 
تتلخص أهمية البحث النظرية في النقاط التالية : • إبراز فاعلية استخدام القصص الإلكترونية في تتمية بعض المفاهيم المرتبطة بثقافات الثعوب العربية. • إلقاء الضوء على أهم المفاهيم المرتبطة بثقافات الثعوبة العبات العربية المتمثلة في (الأعلام- العواصم- العداءلات- نظام الحكم- المعالم- الزئي الثعبى -الأعياد والاحتفالات - الأكلات الثعبية- الديانة). وتتلخص أهمية البحث التطبيقية في النقاط التالية: • تشجيع معلمات الروضة على تصميم القصص الإلكترونية وتوظيفها في تتمية مفاهيم الأطفال. حث القائمين على وضع مناهج رياض الأطفال لتطويرها وربط الطفل

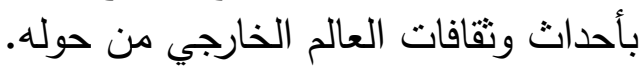
• الخروج عن شكل التعليم التقليدي وربط التكنولوجيا والتعلم التفاعلي في

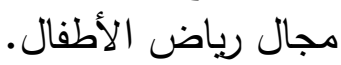
فروض البحث: 1-توجد فروق ذات دلالة إحصائية بين متوسطات درجات أطفال المجموعة التجريبية وأطفال المجموعة الضابطة في القياس البعدي على دلى مقياس

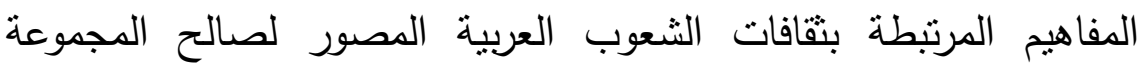
التجريبية ـ العاهية r-توجد فروق ذات دلالة إحصائية بين متوسطات درجات أطفال المجموعة

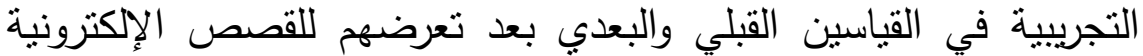

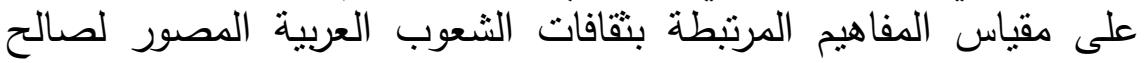

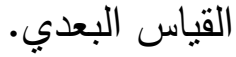


ץ-لا توجد فروق ذات دلالة إحصائية بين متوسطات درجات أطفال المجموعة التجريبية في القياسين البعدي والتتبعي بعد تعرضهم للقصص داته الإكترونية على مقياس المفاهيم المرتبطة بثقافات الثعوب العربية المصور ل لطفل الروضة.

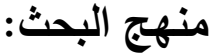

استخدمت الباحثة في البحث الحالي المنهج التجريبي لمناسبته لطبيعة البحث، وذللك باستخدام التصميم التجريبي للمجموعتين (التجريبية، والضابطة) وباتباع القياسات (القبلي، البعدي، التتبعي)؛ لمعرفة نأثير "القصص الإلكترونية" كمتغير مستقل على "المفاهيم المرتبطة بتقافات الشعوب العربية" كمتغير تابع. أدوات البحث:

1- اختبار المصفوفات المتتابعة الملون لجون رافن (إعداد/ حماد، $\cdot(r \cdot .1$

r- استمارة استطلاع رأي لتحديد المفاهيم المرتبطة بثقافات الثعوب العربية المناسبة لطفل الروضة. (إعداد الباحثة) "- مقياس "المفاهيم المرنبطة بثقافات الثعوب العنداد العربية" المصور • (إعداد الباحثة) ع -برنامج القصص الإكترونية. (إعداد الباحثة) مصطلحاث البحث : مصن : تعرفها الباحثة إجرائياً بأنها: • القصص الإلكترونية: "هي قصص يتم تقديمها بواسطة الوسائط

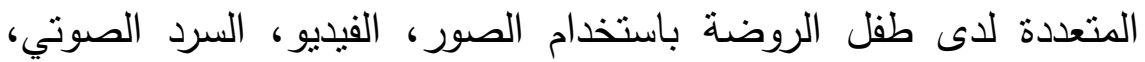


المؤثرات الصوتية، الموسيقى، النصوص، بهذف تتمية بعض المفاهيم المرتبطة بثقافات الشعوب العربية لديه".

• الثقافات المتعددة: "كل ما يميز ثقافة شعب عن ثقافات الثعوب الآخرى من العادات والتقاليد والنظم السياسية والإقتصادية والاجتماعية"، وقد

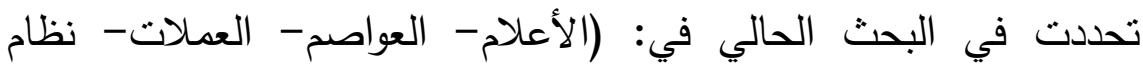

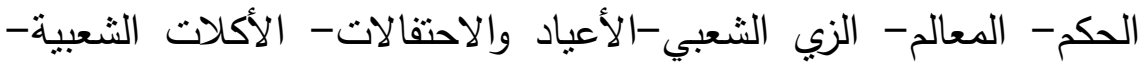
الايانة).

الإطار النظري والدراسات السابقة: يتتاول الإطار النظري للبحث الحالي المحاور التالية: المحور الأول: القصص الإلكترونية (تعريفاتها- أهميتها لطفل الروضـةعناصرها - أنوعها - دورها في تتمية المفاهيم لدى طفل الروضة العنة).

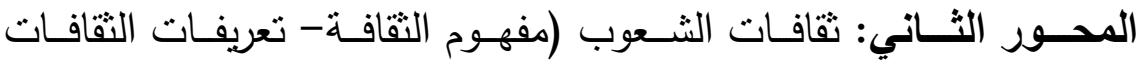

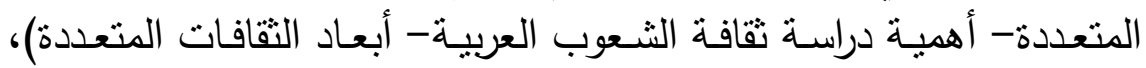

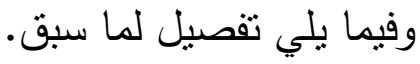
المحور الأول: - - أن

\section{القصص الإكترونية Digital Storytelling}

على الرغم مـن قِدَم روايـة القصـة كفن شـعبي قديم، إلا أن التكنولوجيـا

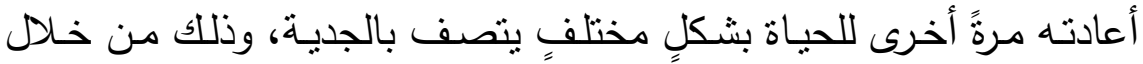

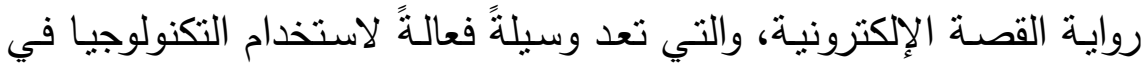

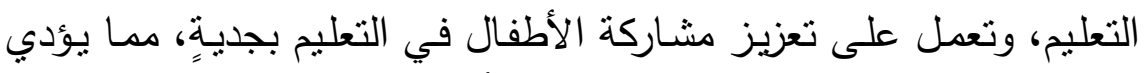

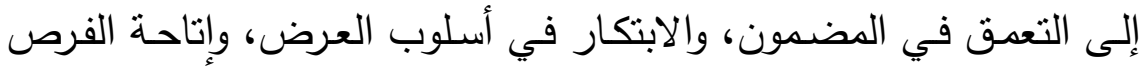


للأطفال للتعبير عن المعارف، والانخراط في المحتوى أكثر جديـةً لأنها

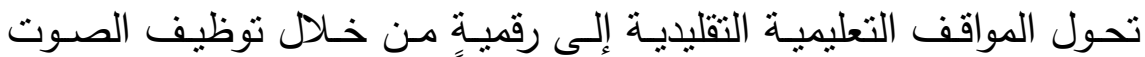
والصورة والحركة فيها، مما يضفي الحياة إلى الموضوع، ويسهم في إيصال المعلومات بطريقةٍ أبسط وأسهل من الطريقة التقليدية.

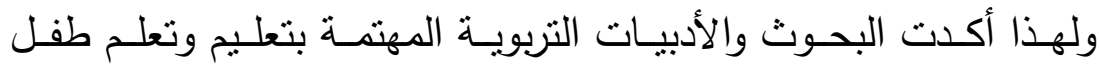

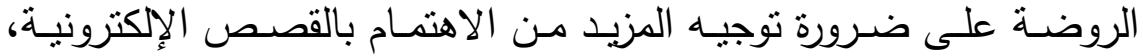
واستخدامها في سنوات الطفولة المبكرة(Susan, ،(Engle, 2011, p.2) .2017, p.7)

لأنها تمنل إغراءاً كبيراً بالنسبة للأطفال في ظل التطور التكنولوجي في التها

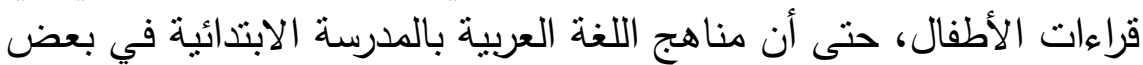

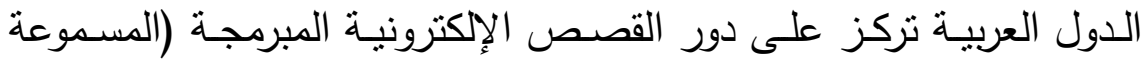

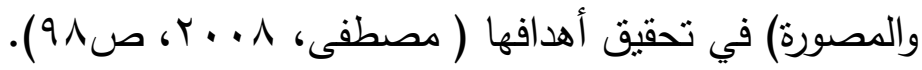

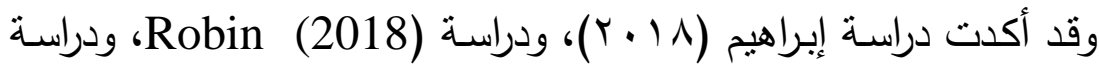

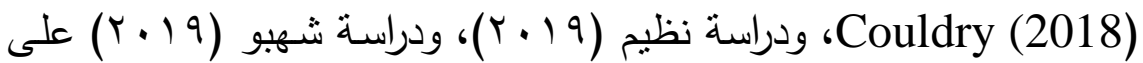
أهمية القصص الإكترونية في تعليم الطفل؛ لأنها تساعد في إكسابه العديد

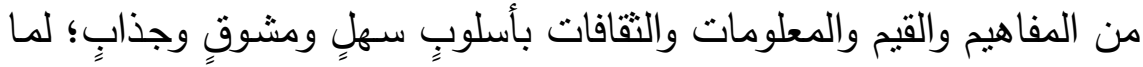

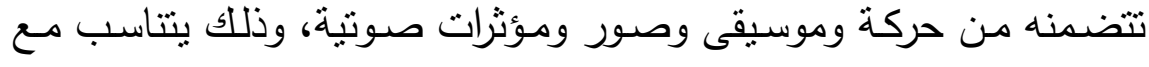

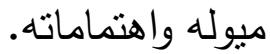

\section{تعريفات القصص الإلكترونية:}

يعنى البحث الحالي بالقصص الإلكترونية لتتمية بعض المفاهيم المرتبطة بثقافات الشعوب العربية لطفل الروضة، لذالك الكن من المهم أن نطرح تعريفاتها من وجهات نظر مختلفة على النحو التالي: 
يعرفها بورت Port (2008, p.20) بأنها: "فيلم صغير يحتوي على

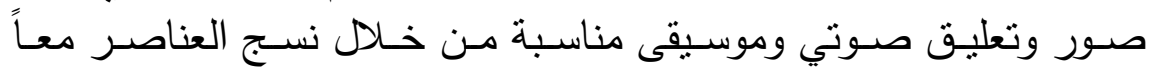

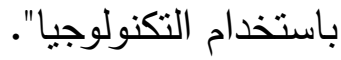

وتعرفها إنجل Engle (2011, p.1) بأنها: "دمج بين الفن القديم لحكاية القصص مع قوة ومميزات التكنولوجيا الإلكترونية الحديثة التي يسهل تعلمهانيا

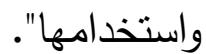

كما بعرفها روبن Robin (2011, p12 بأنها: "قصص بتم تقديمها في صورة إلكترونية باستخدام وسائط متعددة منل الفيديو كامل الحركة بالصوت الصات الفيات

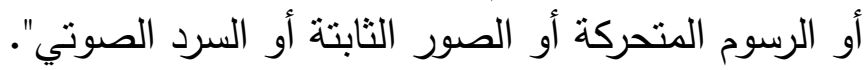

كذلك يعرفها ماثيوس DeNatale (2018, p35 بأنها: "سرد للقصة

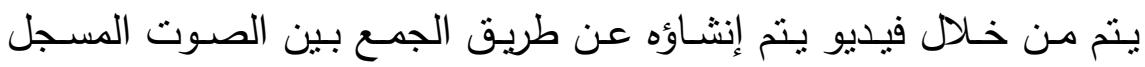

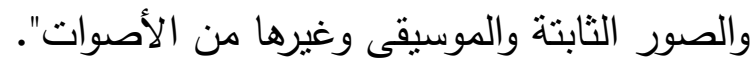

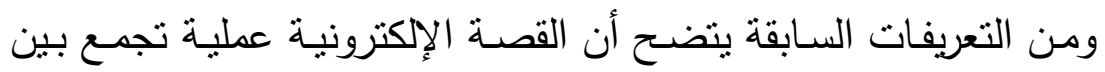

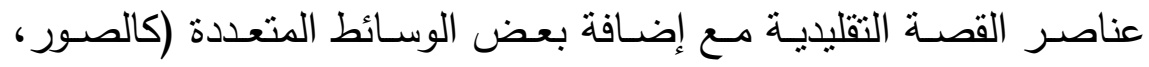

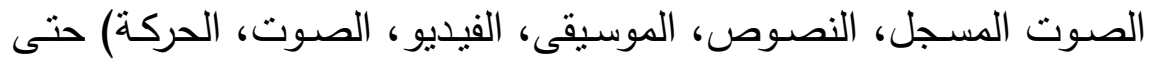

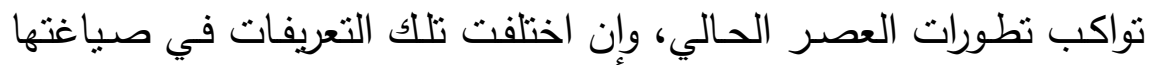

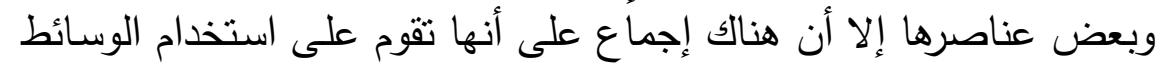

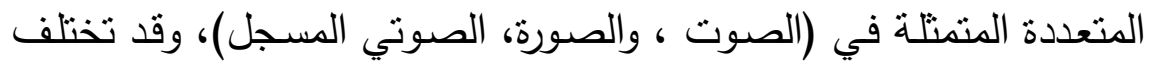

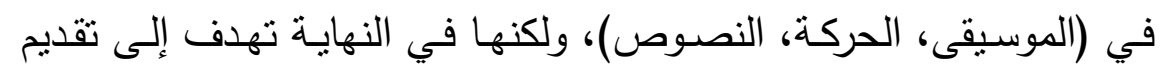
معلومات حول موضوع محدد عن طريق تكنولوجيا الوسائط المتعددة. وفي ضوء ذلك تعرف الباحثة القصص الإلكترونية إجرائياً بأنها: "هي الهي قصص يتم تقديمها بواسطة الوسائط المتعددة لدى طفل الروضة لاهية باستخدام 
الصور ، الفيديو، السرد الصوتي، المؤثرات الصوتية، الموسيقى، النصوص، بهدف تتمية بعض المفاهيم المرتبطة بثقافات الثعوب العربية لديه".

\section{أهمية القصص الإلكترونية لطقل الروضة:}

تسـهم القصـة الإككترونيـة في تدعيم إسـتراتيجيات التعلم المتمركز حول

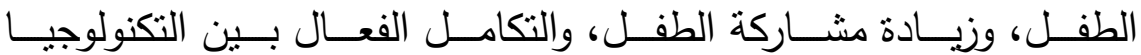
والتعلم (Barrett, 2016, p.650).

فهي من أقدر الأسـاليب التي تعمل على تتمبة شخصية الطفل، وذلك لدورها الهام في إكساب الطفل المفردات اللغوبـة السليمة وتصـيح النطق النق اللغـوي، فيصبح أكثر تحكماً في مخـارج الحروف وأكثر اتقانـاً في نطقه للكلمات، حيث أن الأطفال يميلون إلى القصص بشكلٍ فطري، كما أنها من

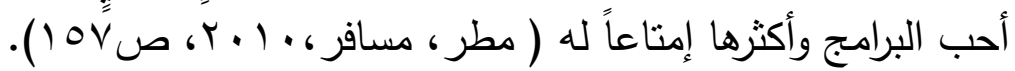

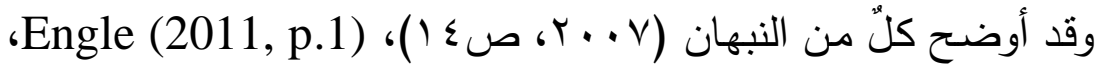
Candreva(2011, p.45) أهمية القصص الإكترونية لطفل الروضة في التالي:

ا - تسـاعد على تتميـة اتجاهـات الأطفـال نحـو التعلم بالتكنولوجيـا داخل الفصل الدراسي. r - تشـاعد على جذب انتباه الأطفال، والمتعـة والإثارة وزيـادة الدافعيـة نحو

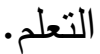
"ا - تمد الطفل بخبرات وتجارب من الحاضر ، وتعدهم لخبرات المستقبل.

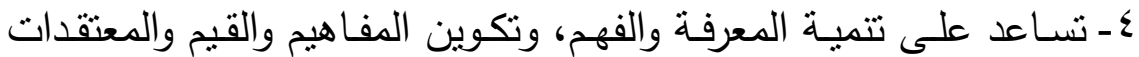
والآراء الفردية. ـ - تسـاعد الأطفال على إنمـاء علاقتهم وفهمهم لغيرهم مـن النـاس الذين بعيشون معهم في بيئنهم. 
7 - تساعد على تتمية مهارات الاستماع والتحدث لاى الأطفال. 人 - نساعد في تتمية الحصيلة اللغوية للكلمات. A- نراعى الفروق الفردية بين الأطفال في أساليب العليم.

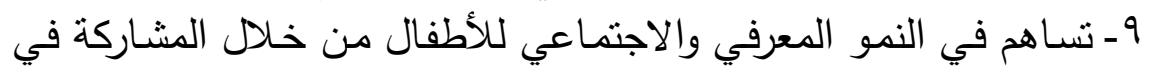
الخبرات.

وبذلك يمكن القول بأن سرد القصص الإكترونية تعد وسيلةً من وسائل

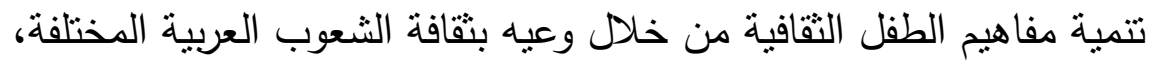

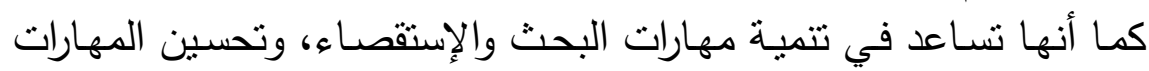

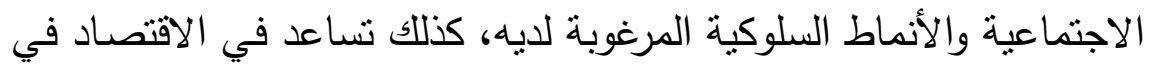

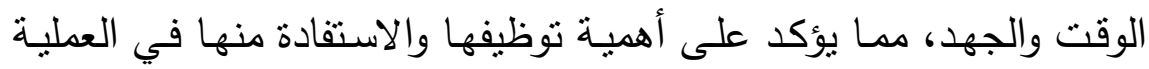

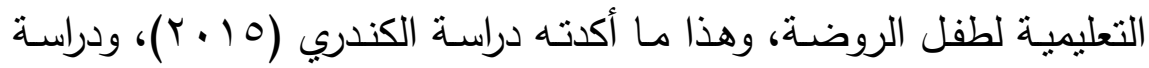

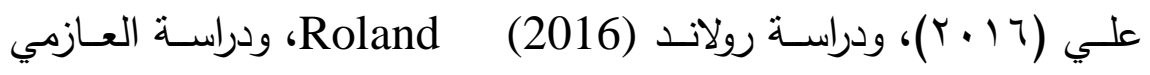
$\cdot(r \cdot 1 \Lambda)$

\section{عناصر القصص الإكترونية:}

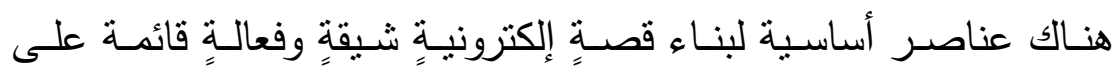

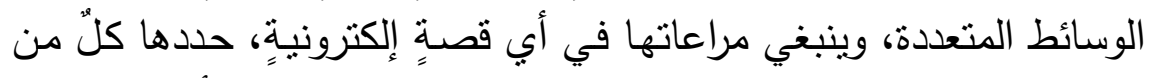
Condy (2012, p.269) Engle (2011, p.4)

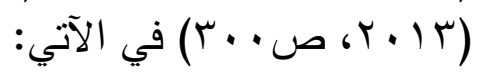

1-وجهة النظر: وهي النقطة الرئيسية في القصص الإلكترونية التي توضح

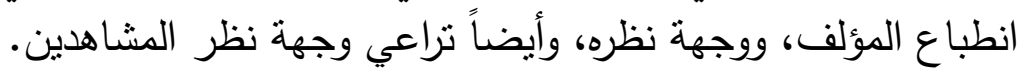

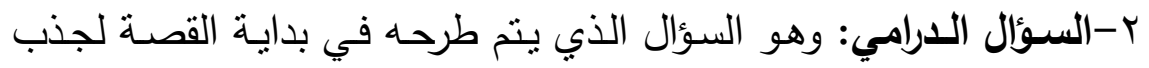

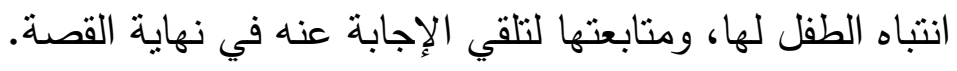


ب-المحتوى الانفعالي: وهو الأحاسيس والمشـاعر التي تحملها القصص

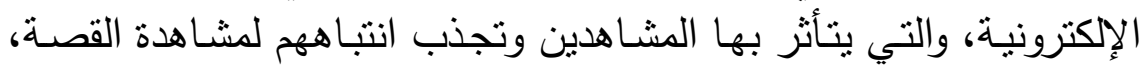

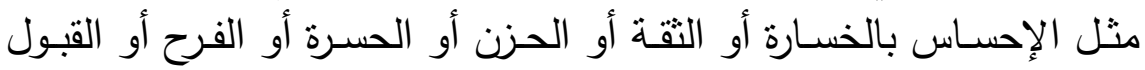

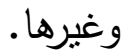

؟-السرد الصوتي: فإنه يساعد المشاهدين على فهم سياق القصة ويشجعهم

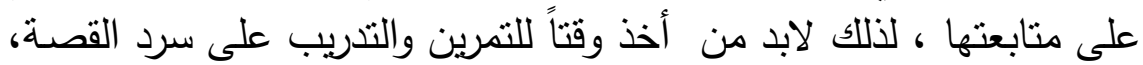
بحيث يمكن القيام بسردها في شكل محادثة، والاختيار الجيد للصوت الصنا المراد

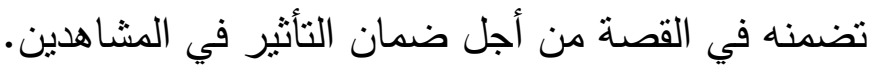

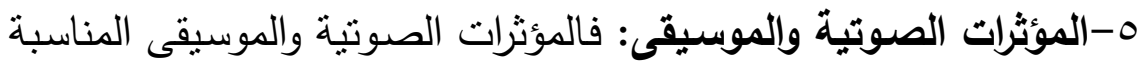

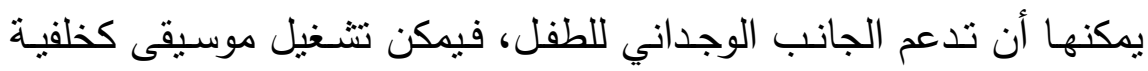

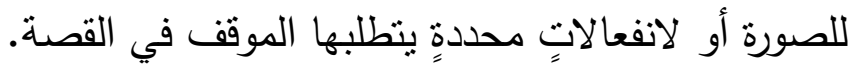

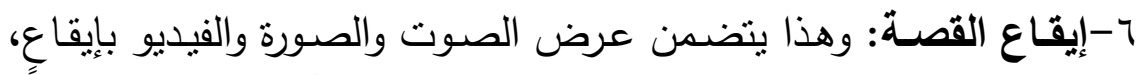
وسرعةٍ مناسبةٍ ، بحيث ينتقل المشاهد من مشهٍِ إلى آخر بتسلسلٍٍ وترتيبٍ منطقي وسرعةٍ مناسبةٍ V- Vالاقتصاد: وذلك بأن تكون القصة اقتصاديةً في الوقت والأحداث، بحيث

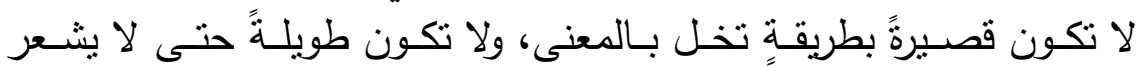
الأطفال بالملل.

أنواع القصص الإكترونية:

تتعدد أنواع القصص الإلكترونية حسب الهدف منها، وقد أوضحها حمزة

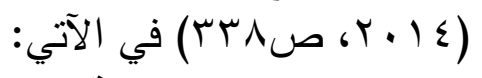

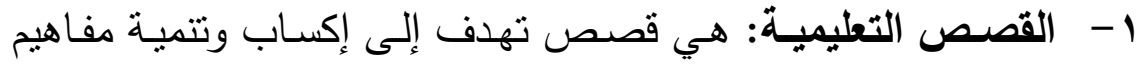
وقيم وسلوكيات معينـة لدى الأطفال، فعادةً تستخدمها المعلمات في تقديم البهات 
المعلومات في مجالاتٍ مختلفةٍ مثل: العلوم، الرياضيات، التربية الصحية

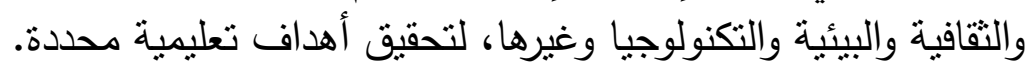
r - القصص الثخصية: وفيها يقوم المؤلف برواية بعض تجاربه الثخصية

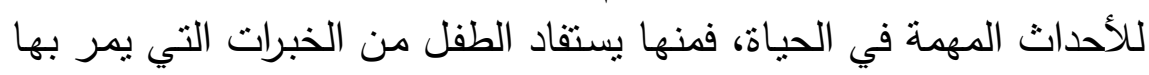

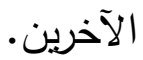

r- القصـص التاريخيـة: وهـي قصص تحكى عن أحداثٍ وشخصياتٍ

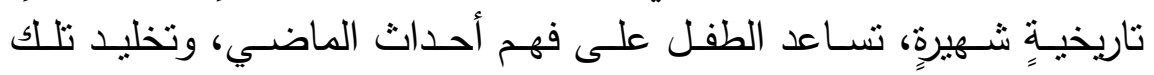

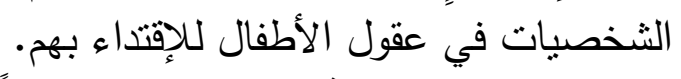
ع - القصص الوصفية: وهي تعرض وصفاً للظواهر والقضايا والمشكلات من حيث المكان، والزمان، والمكونات، والمراحل الإجرائية التي تمر بها.

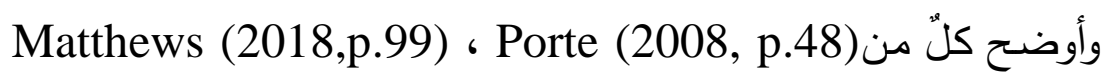
أن أنواع القصص الإلكترونية التي ينبغي تقديمها للأطفال يمكن تصنيفها إلى إن: • القصص الأخلاقية: وتهدف إلى غرس القيم الأخلاقية الحميدة في نفوس الأطفال، وتحبيبهح في الحق ونصرته.

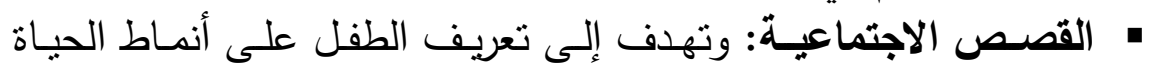

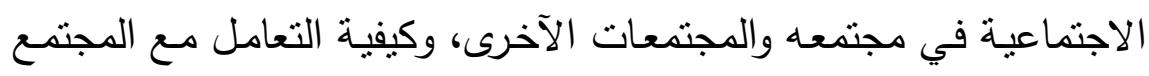
بكافة نواحيه وطبقاته. • القصـص التاريخيـة: وهي التي تعيد سـرد الأحداث التاريخيـة، وتقدم

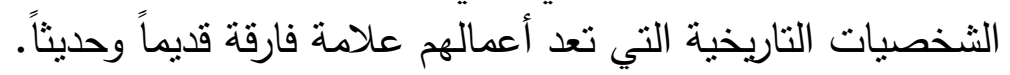

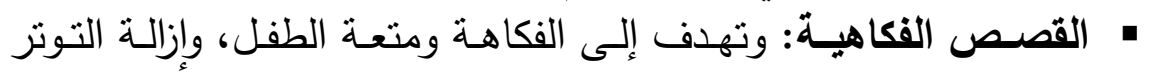
وتجديد النشاط. 
- قصص المغامرات: وتهدف إلى تتمية حب الاستطلاع والإكتشاف، من خـلال عرض حياة بعض الرحالة أو المستكثفين أو استكثـاف نمط حيـاة الناس في المجتمعات الأخرى. • القصص الرمزيـة: وتهدف إلى تقديم العبرة والموعظة للطفل، وتوجيهـه نحو السلوكيات الحميدة، وتتفيره من السلوكيات السيئة.

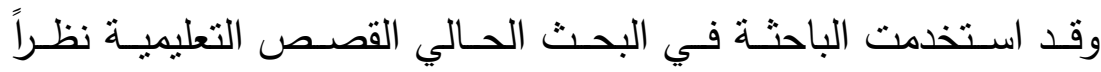

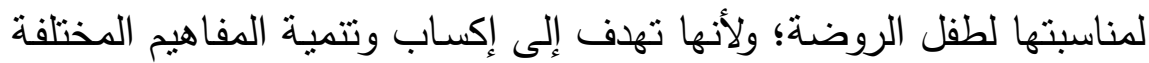

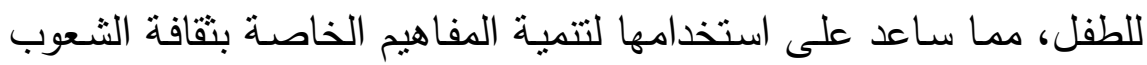

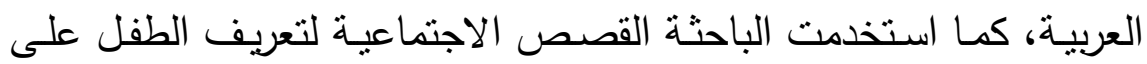

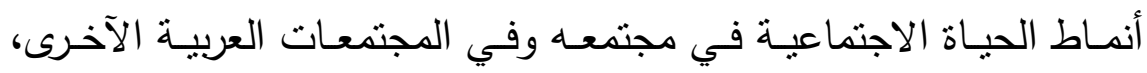

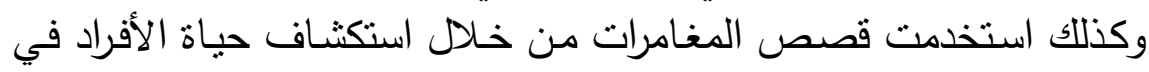

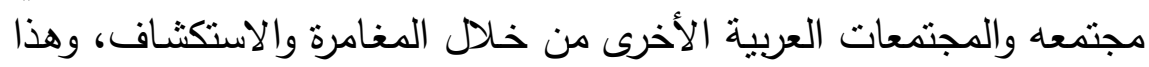

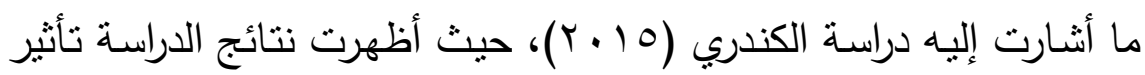

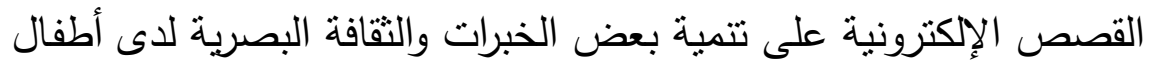
ما قبل المدرسة في دولة الكويت.

دور القصص الإكترونية في تنمية المفاهيم لاى طفل الروضة:

القصـة والتعلم وجهان لعملةٍ واحدةٍ؛ لأن عملية تأليف قصـة هي عملية

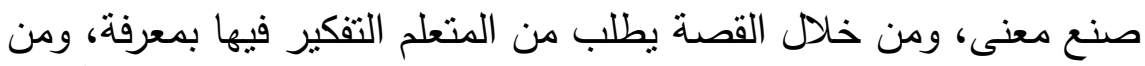

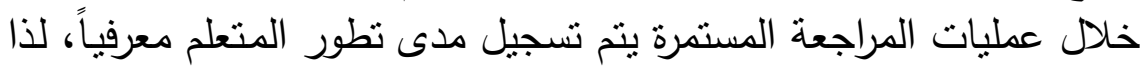

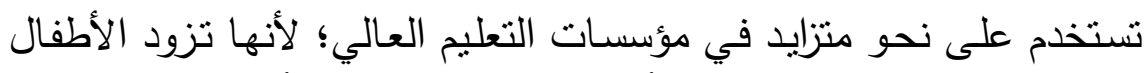

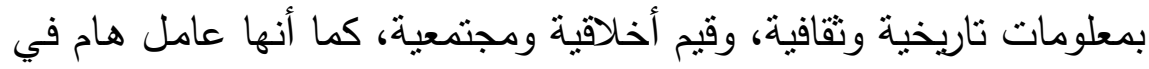

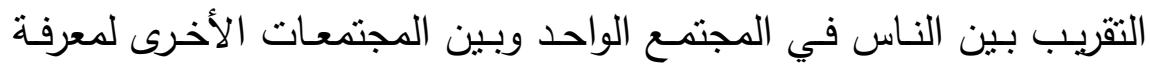


ثقافـة تلك المجتمعـات، مـن خـلال إنشـاء رابطـة مشـتركة بينهم وبين بيئة التعلم (Mahita; Martin, 2010, p.306).

وعلى هـذا فـإن القصـص الإلكترونيـة تسـاعد على تزويــد الأطفـال بالمعلومات والمعارف التي تُضاف إلى خبراتهم، وعنصري النشويق والجذب التب الموجودان بها يساعدان على تيسير فهم الكثير من الحقائق التي تروبها،

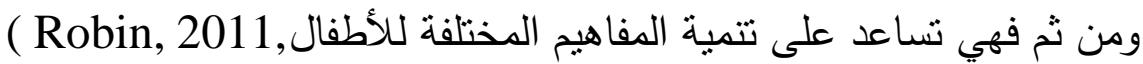
.p.134)

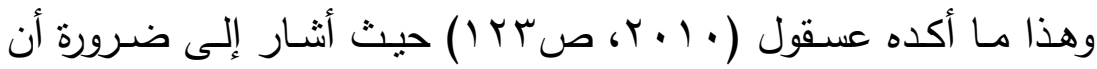
تتضمن القصص الإكترونية معلومات ومفاهيم مختلفة، وجوانب اجتماعية،

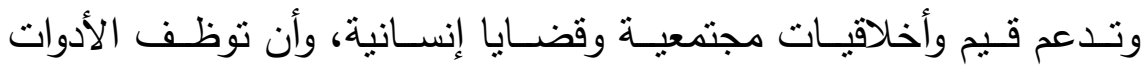
التكنولوجيـة لإنتاجها وعرضـها. وفي هذا إثـارة إلى العلاقة التقاعليـة بين

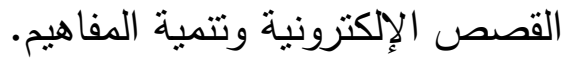

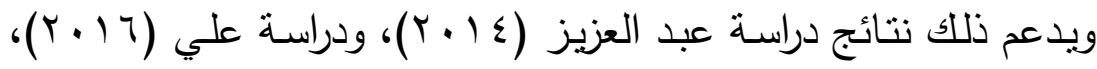

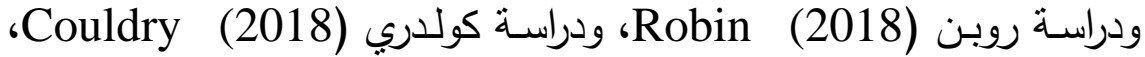

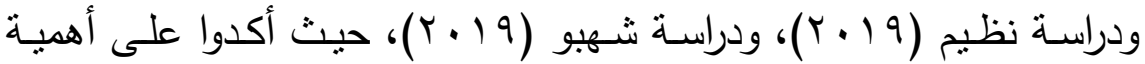
القصص الإلكترونية في تتمية المفاهيم المختلفة لطفل الروضـة، مدا يؤكد على دورها في تتمية المفاهيم المرتبطة بثقافات الثعوب. المحور الثاني : ثقافة الشعوب مفهوم الثقافة: - مفافة الثقافة سمة من سمات الفرد، فهي نتاج طبيعي لتفاعله مع البيئة التي يعيش فيها، فيتشرب قيمها وتقاليدها وعاداتها ومبادئها، وهي ظاهرة خاصة بكل شعب تعبر عن طريقة أفراده في الحياة. وعلى ذلك يتضح أن لكل 
شعب نقافة خاصة به تميزه عن باقي الشعوب، بمعنى أن له أنماط معينة

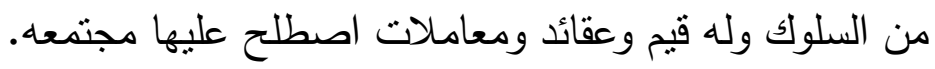

فنتافات الثعوب تتفق جميعاً في ضرورة إثباع الأفراد لحاجاتهم

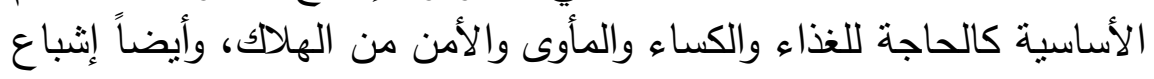

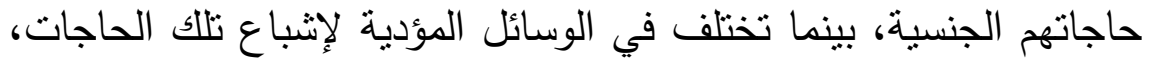
وصور التنظيم الذي تتنهجه الجماعة لتحقيق رغباتها وإنباع التباع حاجاتها.

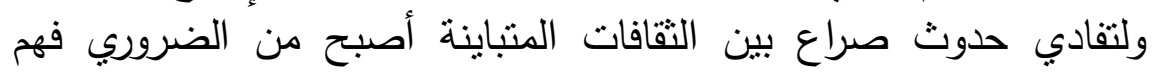
الآخر والتعرف عليه من خلال لغة الحوار بين الثقافات، فهي بمثابة السبيل

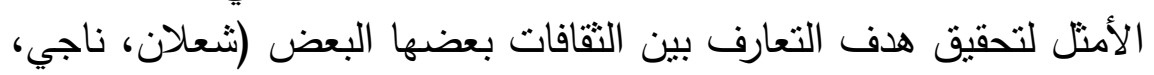

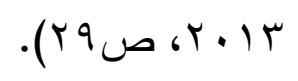

ونظراً لأن مرحلة الطفولة هي العصر الذهبي لتقيف الطفل، وفيها تتكون فيها شخصية الطفل في مختلف النواحي الجسمية والعقلية والاجتماعية والانفعالية. فقد أكدت العديد من الدراسات على أهمية نتمية معرفة طفل

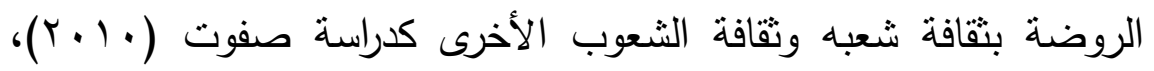

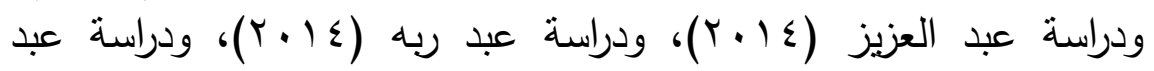

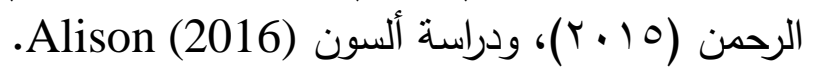
تعريف الثقاقات المتعددة: تعددت تعريفات الثقافات المتعددة، ومنها ما يلي:

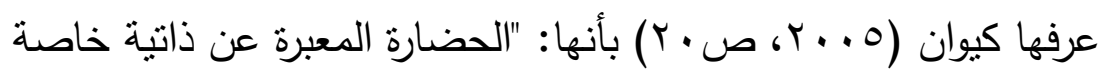

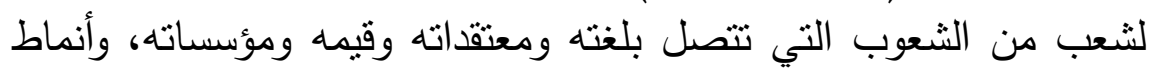

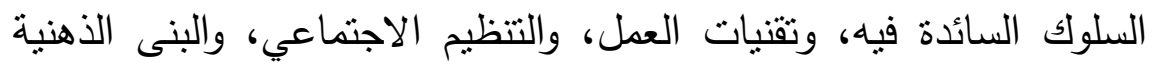
السائدة فيه، ونتاجه الأدبي الفني". 
ويعرفها جوهان ونانسي (John, Nancy (2012, p276) بأنها: "دراسة كافة النظم الثقافية والاجتماعية والدينية لمجموعة من الأفراد والمجتمعات متعددة الجنسيات بغض النظر عن اللون والعرق والدين واللغة والثقافة".

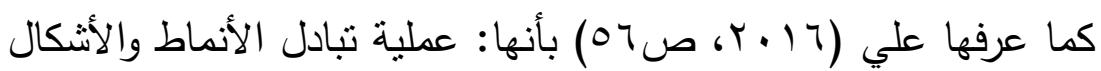
الثقافية المختلفة( عادات - ثقاليد - قيم - معتقدات - أفكار .. إلخ ) التي

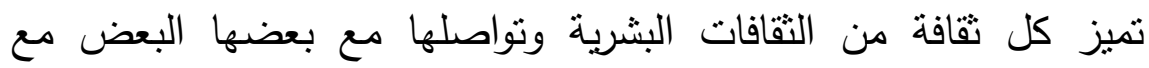

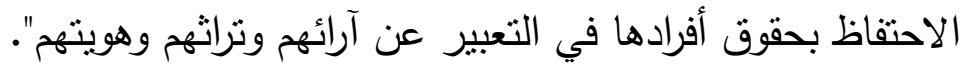

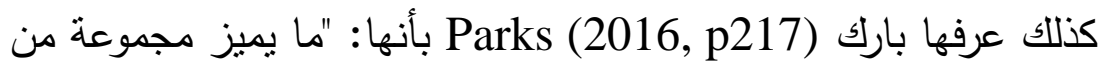

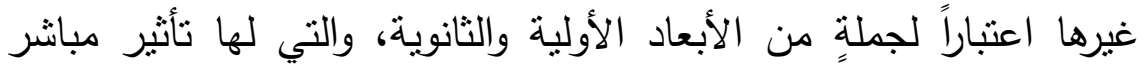

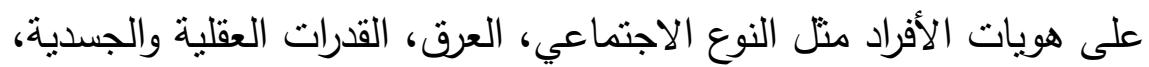

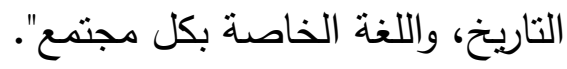

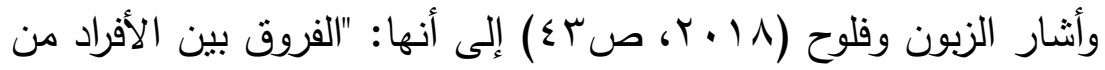

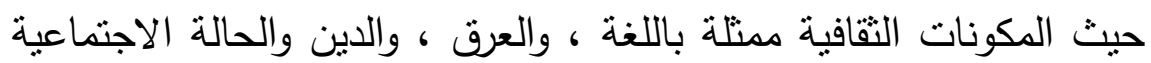
النقافية ، والجنس ، والعمر والقدرات".

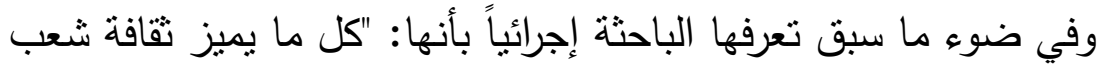

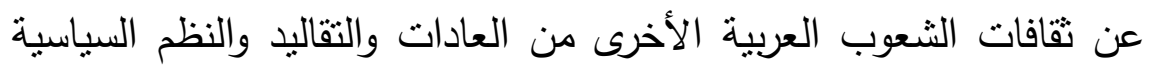
والإقتصادية والاجتماعية"، وقد تحددت في البحث الحالي في العي (الأعلام -

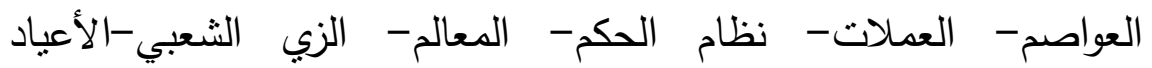

$$
\text { أهمية دراسة ثقافة الآلات الأكلات الثعبية- الديانة). }
$$

يعتبر دراسة ثقافة الثعوب لا غنى عنها في المجتمعات الحديثة، حيث

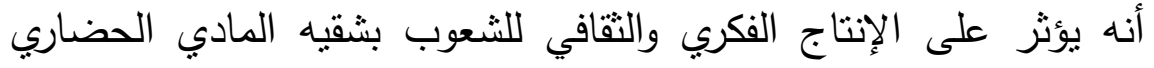


والمعنوي الروحي. فالتعدد الثقافي الخلاق يرتبط بمعاني الإبداع والابتكار والقدرة على التجديد في إطار الوحدة دون تعارض، مما يؤدي إلى تماسك

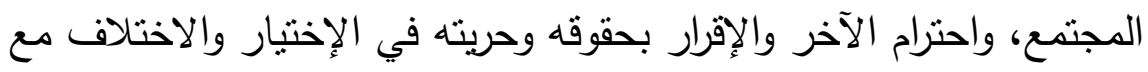
الآخر وتعزيز العلاقات الإيجابية والمشاركة والتفاعل البناء بين مختلف والإني أطياف المجتمع والمجتمعات الأخرى وهذا يحقق ثقافة التعايث السلمي.

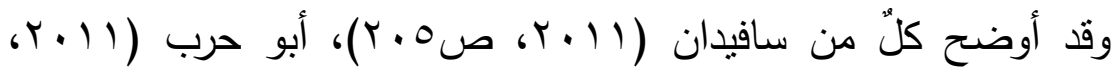

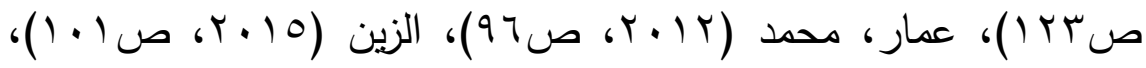
شاكر (10 ( ب، ص191 1) أهمية دراسة ثقافة الثعوب العربية في الآتي: ا - إعداد مواطن قادر على ممارسة الديمقراطية والتسامح وتقبل الرأي الآخر الآعر r - تتمية التواصل والتكامل التقافي ونبذ التعصب.

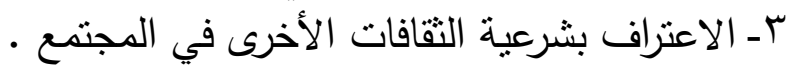
ـ - التعرف على الثقافات والحضارات الأخرى في المجتمع / القيم والعادات • والتقالبد 0ـ الاحترام المتبادل بين الثقافات في المجتمع الواحد. 7- يسمح التعدد الثقافي بعلاقاتٍ وطيدةٍ بين الثقافات الأخرى. ومما سبق ترى الباحثة أن لاراسة ثقافة الثعوب العربية أهمية واضحة بالنسبة لطفل الروضة، وتثمثئ فئي: إعداد طفل قادر على ممارسة الديمقراطية والتسامح وتقبل الرأي الآخر • تحسين احترام الطفل لذاته من خلال الاعتزاز بالتراث الثقافي. تفعيل قيم الإنتماء والمواطنة والتعايش السلمي لدى الطفل. إعداد طفل قادر على الحفاظ على تراث البشرية. تقدير الطفل للتراث الثقافي في بلاده وفي البلاد الأخرى. 
تكوين اتجاهات إيجابية للطفل نحو ثقافته وثقافة الآخرين. نبذ الإرهارب والتطرف والتعصب.

وفي ضوء ما سبق يتضح أهمبة وعي طفل الروضة بمفاهيم ثقافة

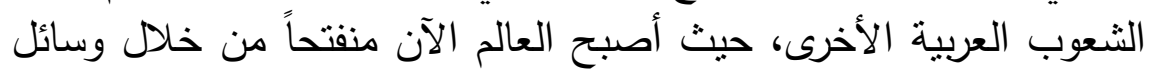

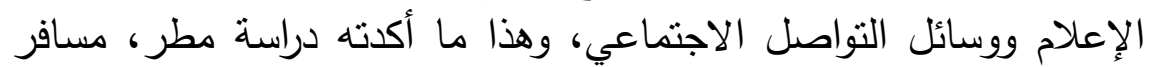

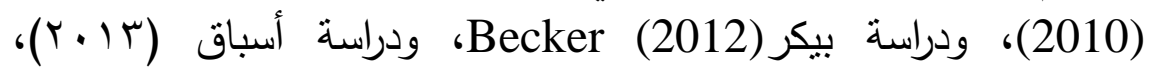

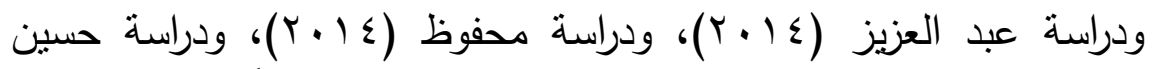

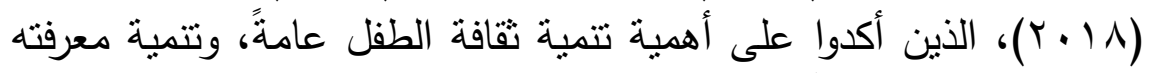
بثقافة الثعوب خاصةً للتعرف على عاداتها وتقاليدها ونظمها الاجتماعية والسياسية والإقتصادية، للتعرف على المنشابه والمختلف مع ثقافة شعبه لكي يقبل الآخر ويستقيد منه بما يتناسب مع ثقافته. أبعاد الثقافات المتعددة:

تتعدد أبعاد الثقافات وفقاً لكل شعب ومجتمع، فمن هذه الأبعاد ما يلي:

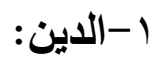

ثمة ارتباط فوي بين الثقافة والدين، فهو يقدم تصوراً لبناء المجتمع الإنساني

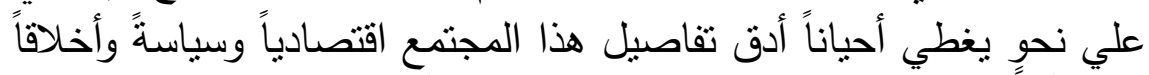

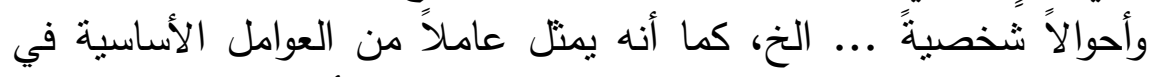
تعبئة ثقافة ما وشحنها بالرموز والمضامين. فمن أشكال التعبير الديني "الثياب" كارتداء الحجاب أو النقاب أو البرقع بالنسبة للمسلمات، والقميص

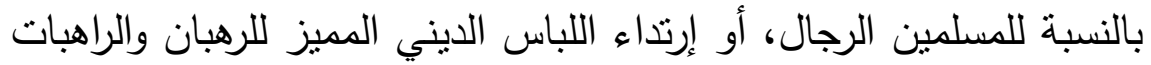
المسيحيات أو ارتداء القلنسوة بالنسبة لليهود، كما نشمل أشكال التعبير الديني "دور العبادة" من مساجد ومآذن وكنائس ومقابر ومدافن ومواقع دينية

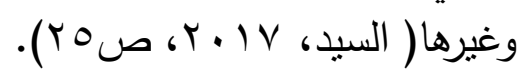




\section{r - القتون والآداب والإعلام ووسائل الاتصالات:}

يؤدي المشهر الذي يشمل الصحافة والكتب والإذاعة والتليفزيون والسينما والإنترنت ومختلف أنواع الأدوات الرقمية دوراً سواء من حيث إبراز التنوع التقافي وتسليط الأضواء عليه أو من حيث نتكيل الأذواق والقيم والرؤى الأى العالمية، ويمكن إجمال أشكال التعبير هذه في الأفلام والمواد المسموعة والمرئية الكتب والأدب برامج الكمبيوتز والخدمات المعلوماتية (بو جلل،

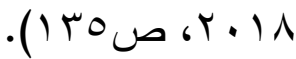

$$
\begin{aligned}
& \text { r-اللغة : }
\end{aligned}
$$

تعد اللغة هي المكون الرئيسي في ثقافة أي مجتمع؛ لأن اللغة في أي مجتمع ليست فقط مفردات بين أفراد المجنمع، ولكنها مكون معرفي لاني

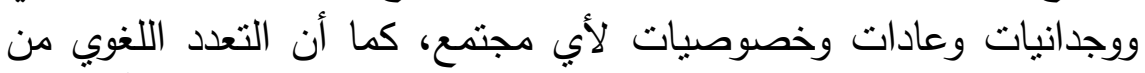
الظواهر الطبيعية في المجتمعات، إذ من الصعب أن تجد مجتمعاً أحادي

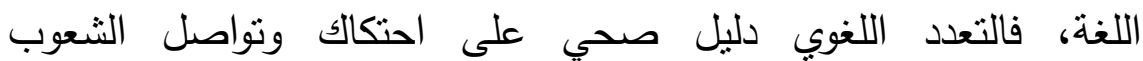
والحضارات والثقافات فيما بينها، وإن اختلفت أسبابه بين اجتماعية وسياسية وتاريخية، لكنه يبقى ظاهرة صحية تحافظ على بقاء واستمرارية أي مجتمع.

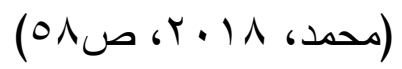

\section{ع - التتوع العرقي:}

علي الرغم من أن مصدر الإنسانية رجل واحد وامرأة واحدة هما آدم

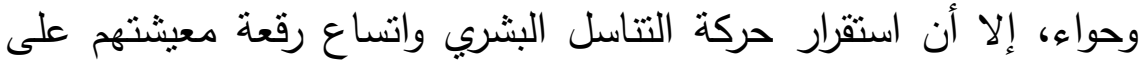

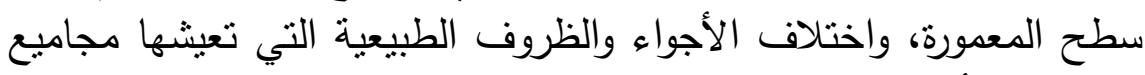
البشر، قد أفرزت حالات من الاختلاف في المظاهر والأشكال بين تلك المجاميع، وهذه أرجح نظربة يفسر بها تعدد الأعراق بين البشر ، والتي فندها

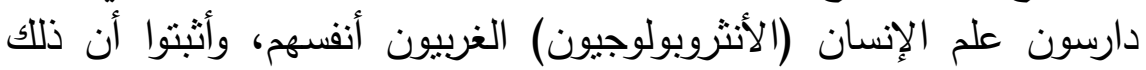


التباين العرقي ليس له أهمية دن حيث تفوق عرق على عرق أو شعب على ألى

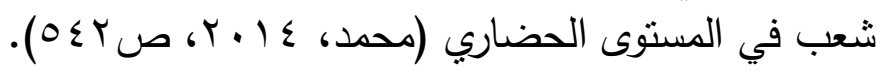

كما أوضح ريسنيك Resnik (2017, p.157) أن الثقافات المتعددة تتكون من:

• الثقافة التنظيمية: وهي تهتم بقيم وسلوكيات الأفراد داخل الدولة، وتميز

$$
\text { دولة عن أخرى. }
$$

• الثقافة الاجتماعية: وهي تنتاول ما يخص المجتمع والعادات والتقاليد والزى والأعياد والمناسبات وأثشهر المأكولات.

• الثقافة الإقتصادية: وهي تثتاول كل ما والثانيات يخص العلاقات الإقتصادية والإستتمار والعملات وعلاقات الدول الإقتصادية.

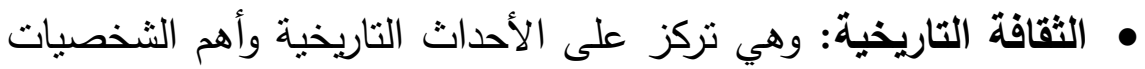
والأماكن الأثرية والتاريخية.

• الثقافة الاينية: وهي تشمل كل ما يخص موضوعات الدين من عادات

$$
\text { وقيم أخلاقية. }
$$

وفي ضوء ذلك تتاولت الباحثة (الأعلام- العواصم- العملات- نظام

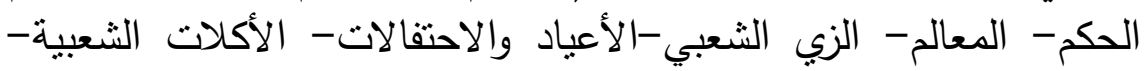
الديانة) كأحد أبعاد مفاهيم ثقافات الثعوب الثعب العربية.

وبشأن هذا الصدد تناولت العديد من الدراسات ثقافات الثعوب من أبعاد

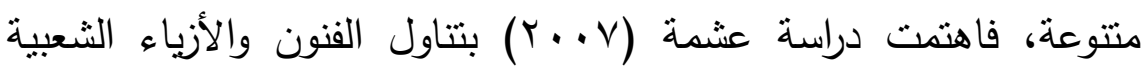
والمناسبات والأعياد، واهتمت دراسة فرحانة (2017)Farhana بتناول النظام السياسي والإقتصادي وأثنهر المهن والصناعات، كما اهتمت دراستة اجويجور Ora Geiger (2017) بتتاول الجوانب التاريخية والسياسية والمعرفية والإقتصادية لكل بلد. 


\section{إجراءات البحث \\ أولاً: منهج البحث :}

استخدمت الباحثة في البحث الحالي المنهج التجريبي لمناسبته لطبيعة

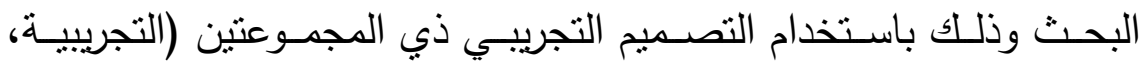
والضـابطة)، وباتبـاع القياسـات (القبلي، البعدي، التتبعي)؛ لمعرفـة تأثير

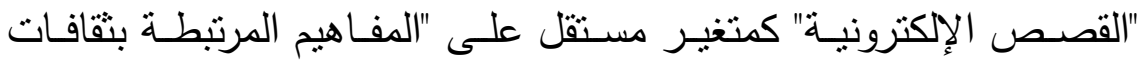
الشعوب العربية" كمتغير تابع. ثانياً: مجتمع وعينة البحث :

يتمثل مجتمع البحث في جميع الروضـات بإدارة غرب الزقازيق التعليمية

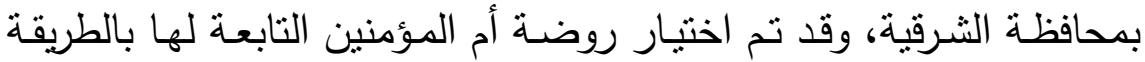

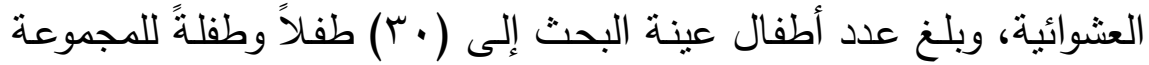

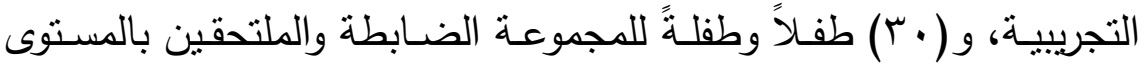

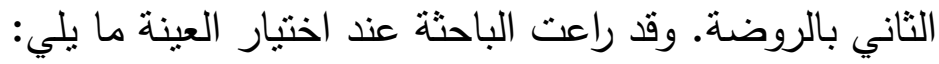

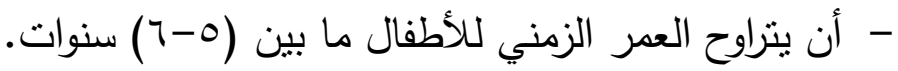

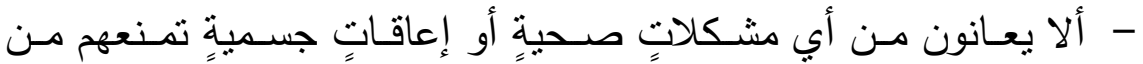
الحضور إلى الروضة.

- التزام الأطفال بالحضور إلى الرونى الروضة وللبرنامج الكُقَدَم لهم.

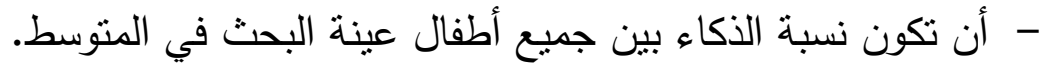

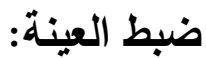
أ- تجانس عينة البحث: البه:

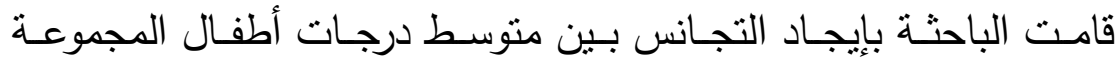

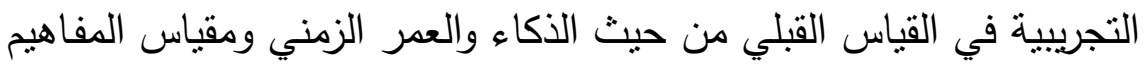

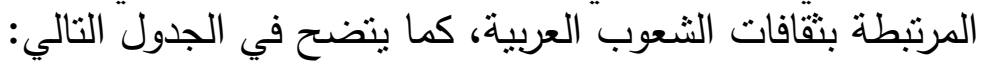




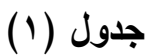

التجانس بين أطفال المجموعة التجريبية من حيث الأكاء والعمر الزمني ومقياس

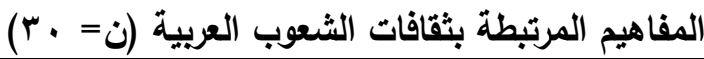

\begin{tabular}{|c|c|c|c|c|}
\hline معامل الإلتواء & الإنحراف المعياري & الوسيط & المتوسط & المتغيرات \\
\hline$\cdot, \vee \cdots$ & ג & $M \cdot, 0$ & $11 r, 0$ & - - الذكاء - - اء \\
\hline$\cdot, \cdot \leq \xi$ & $r q, \varepsilon$ & $0, \vee 9$ & $7, r$ & - العمر الزمني \\
\hline$\cdot, \ldots r$ & TVT, & $\leqslant 9$ & $\varepsilon 9,01$ & - المقياس \\
\hline
\end{tabular}

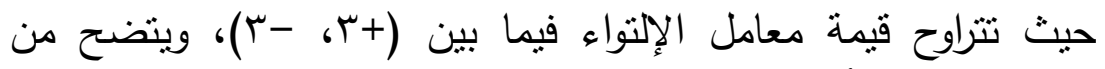
جدول (1) تجانس أفراد العينة من حيث الذكاء والعدر العراء الزمني والمقياس.

$$
\text { ب- تكافؤ عينة البحث : }
$$

قامت الباحثة بإيجاد دلالة الفروق بين متوسطات درجات أطفال

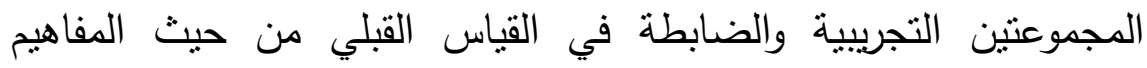
المرتبطة بثقافات الثعوب العربية، كما يتضح في الجدول التالي: جدول (r)

التكافؤ بين أطفال المجموعة التجريبية والمجموعة الضابطة في القياس القبلي من

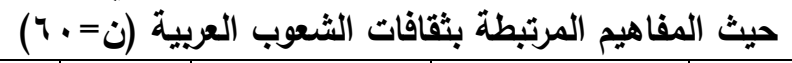

\begin{tabular}{|c|c|c|c|c|c|c|}
\hline \multirow[t]{2}{*}{ مستوى الالالة } & \multirow[t]{2}{*}{ ا"تبار } & \multicolumn{2}{|c|}{ الض الضموعة } & \multicolumn{2}{|c|}{ التجريبية } & \multirow[t]{2}{*}{ المتغيرات } \\
\hline & & r & $r_{p}$ & ع & م 1 & \\
\hline غير دالة & $\cdot, Y Y$ & r, Yo & $\leqslant \Lambda, 0$ & Y,Y & 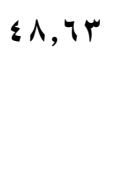 & الثرتبطة بثقافات \\
\hline
\end{tabular}




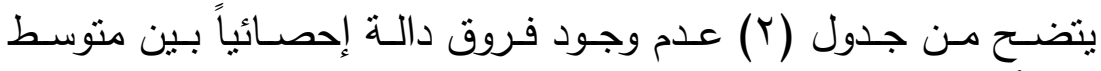

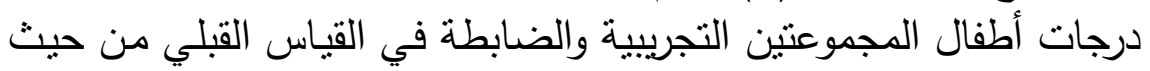

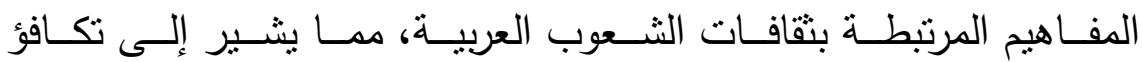
المجموعتين التجريبية والضابطة. ثالثاً: أدوات ومواد البحث : 1-اختبار المصفوفات المتتابعة الملون لجون رافن (إعداد/ حماد، م . . ب).

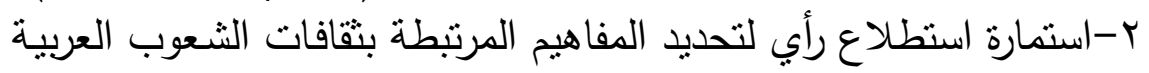
المناسبة لطفل الروضة. (إعداد الباحثة) r-مقيـاس "المفـاهيم المرتبطـة بثقافـات الثـعوب العربيـة" المصـور • (إعداد الباحثة) ع-برنامج القصص الإكترونية. (إعداد الباحثة) أولاً:اختبـار المصـفوفات المتتابعـة الملـون لجـون رافـن (إعـداد/ حمـاد، $:(r . . \Lambda$ أ- وصف الاختبار:

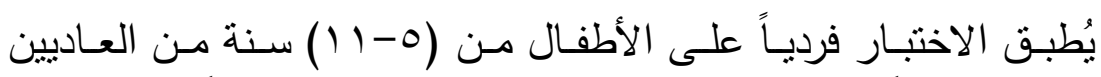

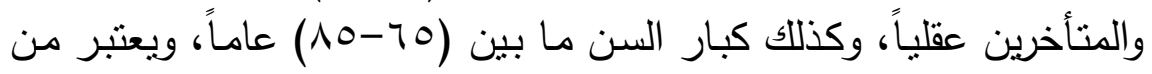
الاختبارات عبر الحضارية الصالحة للتطبيق في مختلف البيئات والثقافات.

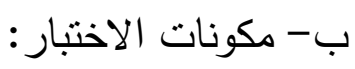

يتكون من ثلاث مجموعات (AB) - (A) - (B)، وتحتوي كل مجموعة

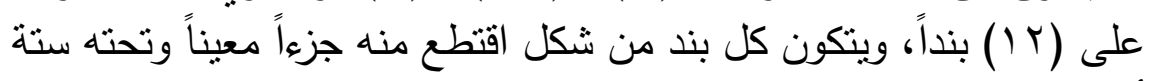

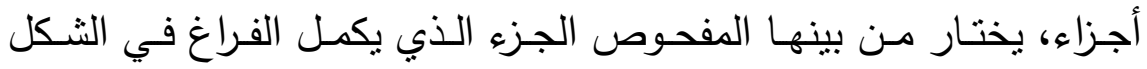
الأساسي، وقد استخدمت الألوان كخلفية لكي تجعل الاختبار وبنوده أكثر 
تشـويقاً ووضـوحاً وإثارةً لانتبـاه الأطفال، وتتمثل مجموعات الاختبـار فيما يلي:

1- المجموعة (A): والنجاح فيها يعتمد على قدرة الفرد على إكمال نمط

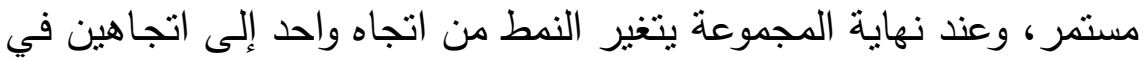

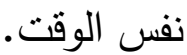
r- المجموعـة (AB): والنجـاح فيهـا يعتمـد على قدرة الفـرد على إدراك الأشكال المنفصلة في نمط كليى على أساس الارتباط المكاني.

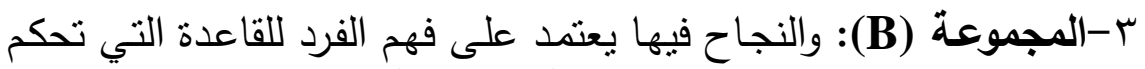

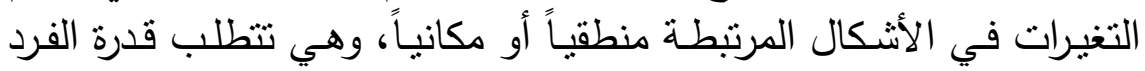

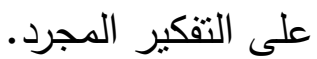
ج- الخصائص السيكومترية للاختبار:

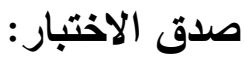

تم حساب معاملات الارتباط بين اختبار المصفوفات المتتابعة الملونـة

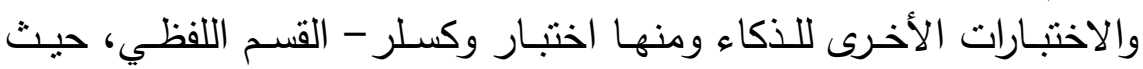

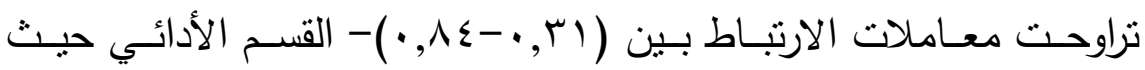

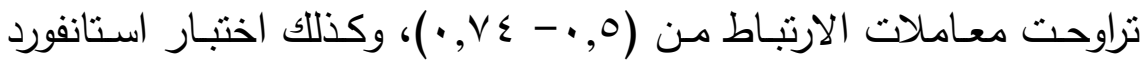

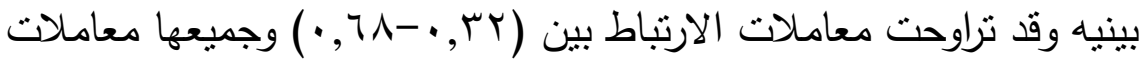

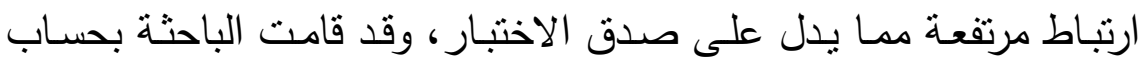

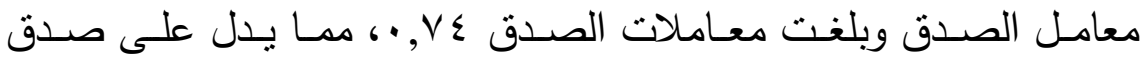

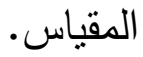




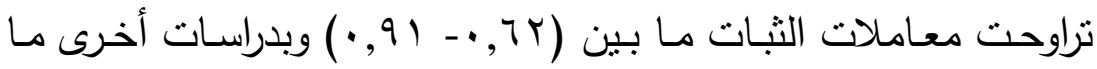

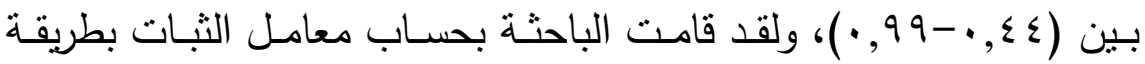

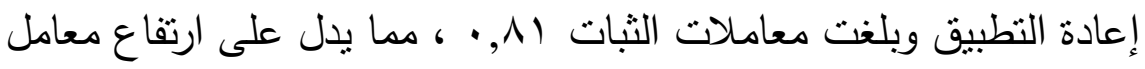
ثبات الاختبار .

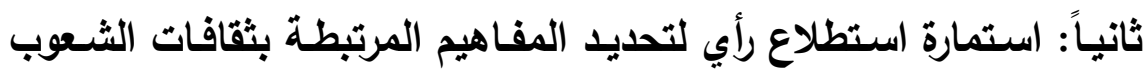
العربية المناسبة لطقل الروضة. (إعداد الباحثة)

هدفت استمارة استطلاع الرأي إلى تحديد أهم المفاهيم المرتبطة بثقافات الثعوب العربية المناسبة لطفل الروضة.

وقد استفادت الباحثة في إعدادها من أطر نظرية وأبحاث سابقة اهتمت التهات

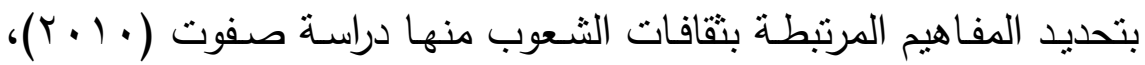

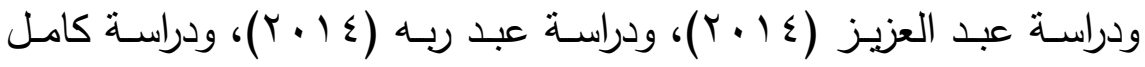

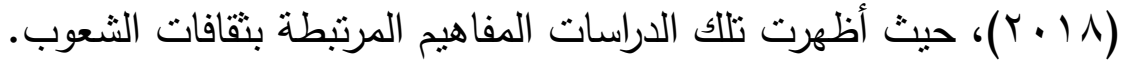
وفي ضـوء ذلك أعدت الباحثنة استمارة استطلاع رأي متضـمنة ثمانيـة

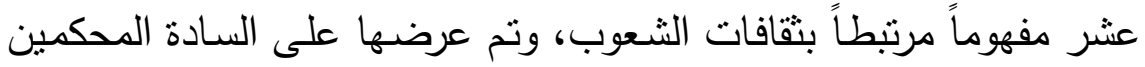

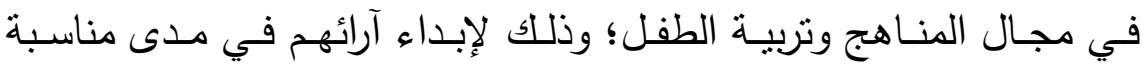

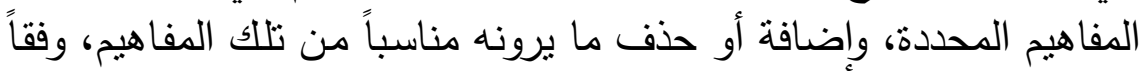
للتقدير الثنائي (مناسب/ غير مناسب).

وقد استبعدت الباحثة المفاهيم التي حصلت على نسبة اتفاق أقل من

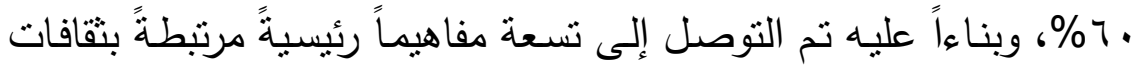

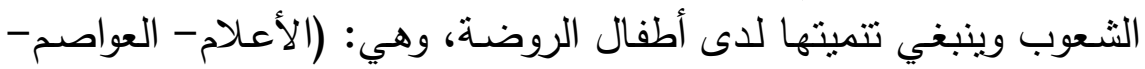


العهـلات- نظـام الحكم - المعـالم - الـزي الثـعبي -الأعيـاد والاحتفـالاتالأكلات الشعبية- الديانة).

ثالثـاً: مقبـاس "المفـاهيم المرتبطـة بثقافـات الثـعوب العربيـة" المصـور . (إعداد الباحثة)

$$
\text { مقياس المفاهيب المرتبية بثقافتات }
$$

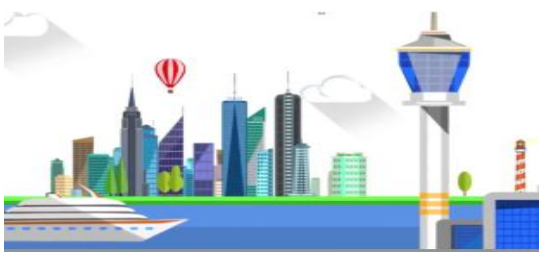

• الهرف من المقياس:

يهدف المقياس إلى قياس مدى قدرة أطفال الروضنة في المستوى الثاني

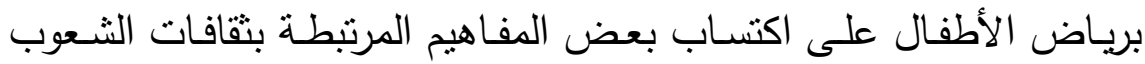

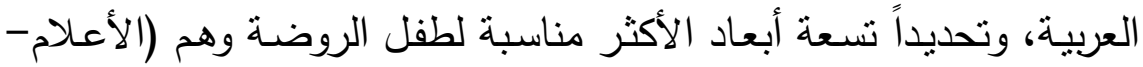

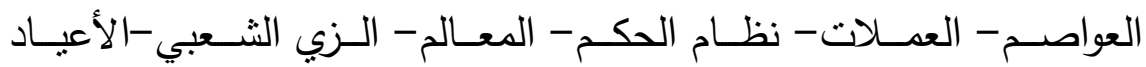

$$
\text { • والاحتفالات- الأكلات الثعبية- الديانة). }
$$

ا - الإطسلاع على البحوث والدراسـات السـابقة والمراجـع العربيـة والأجنبية

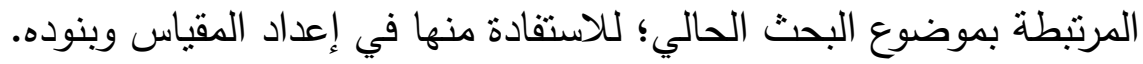

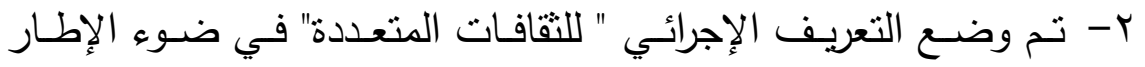
النظرى والدراسات السابقة في حدود علم الباحثة. 
ب-قامت الباحثة بالإطلاع على عددٍ من المقاييس والإستبيانات التي تمت الاستفادة منها والاستعانة بها في تصميم المقياس وبنوده منل: استبيان ثقافة الطفل للمفتي (9 ( . ب) وقد استفادت الباحثة من هذا المقياس في صياغة

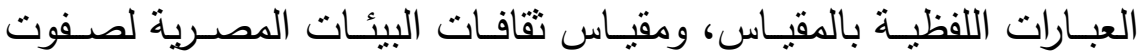

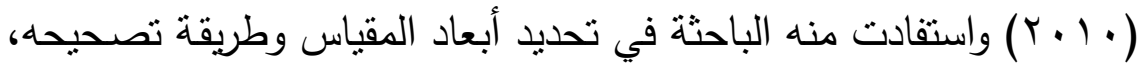

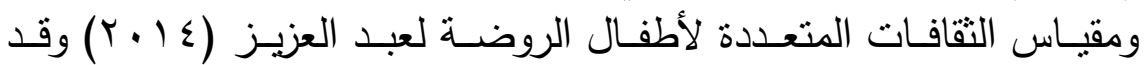
استفادت منه الباحثة في تحديد بعض المفاهيم المرتبطة بثقافات الثعوب، ومقياس لعبد ربه (ع ( • (Y) وقد استقادت منه الباحثة في تصميم المقياس،

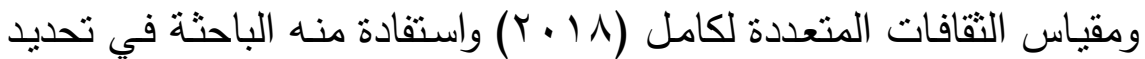
بعض عبارات المقياس ومراعاة اتساقها مع أبعاده وطريقة القياس. ع-راعـت الباحثة في تصـميم المقبـاس ارتبـاط الصـورة بالعبـارات داخـل الموقف الواحد. ه-راعت الباحثة في تصميم المقياس أن تكون بنوده مرتبطة ببيئة ومجتمـع الطفل 7-تم تقسيم المقياس إلى خمسة أجزاء: الجزع الأول: المواقف من (ا-هنم) والتي تقيس بُعد (الأعلام). وفيما يلي عرض أحد مواقف المقياس الخاصة بهذا البُعد:
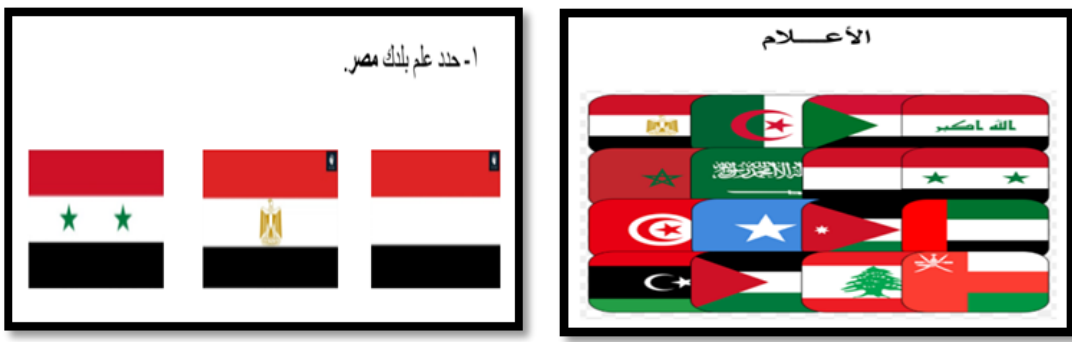
المجلة العلمية لكلية رياض الأطفال - جامعة بورسعيد

الجزء الثاني: المواقف من (7- • () والتي تقبس بُعد (العواصم).

وفيما يلي عرض أحد مواقف المقياس الخاصة بهذا البُعد:
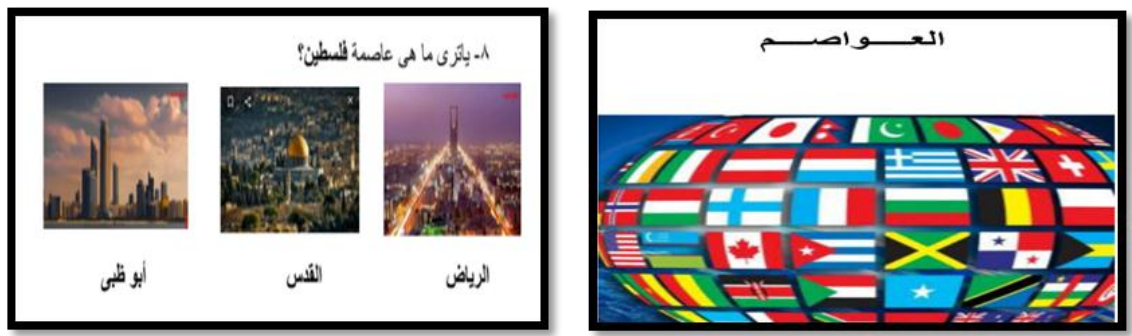

الجزء الثالث: المواقف من (1 (1-0 ) والتي تقيس بُعد (العملات).

وفيما يلي عرض أحد مواقف المقياس الخاصة بهذا البُعد:
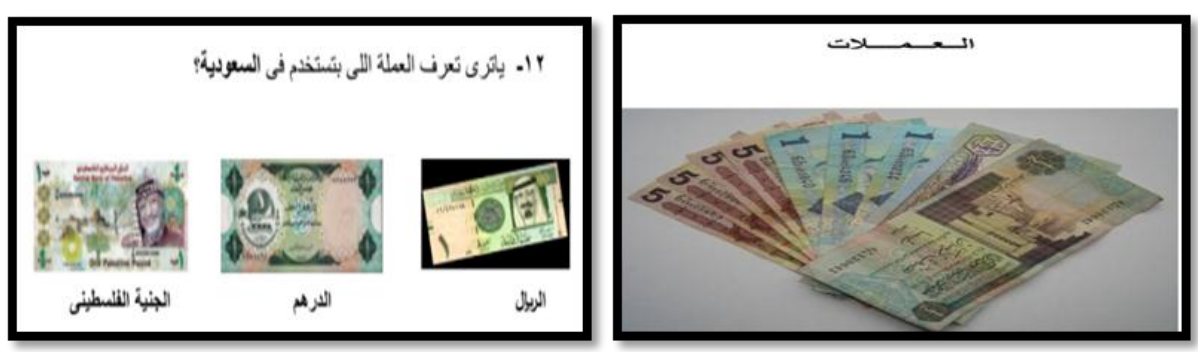

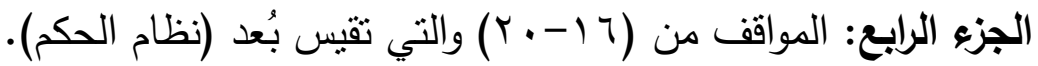
وفيما يلي عرض أحد مواقف المقياس الخاصة بهذا البُعد:
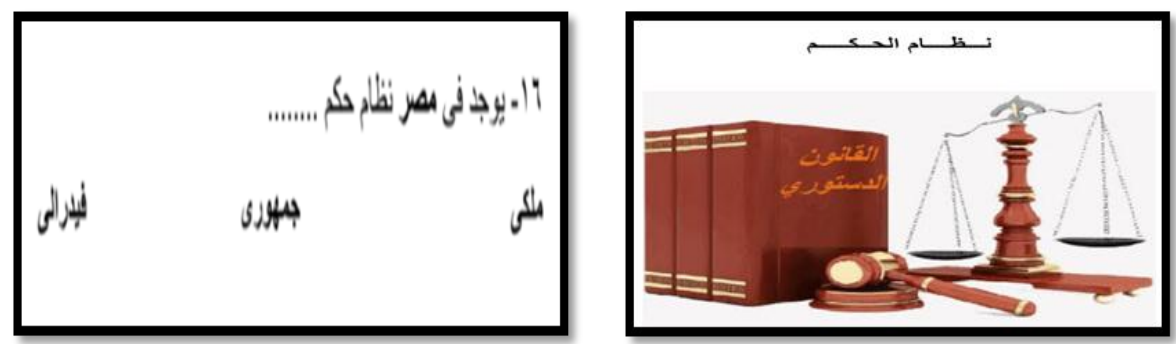
المجلة العلمية لكلية رياض الأطفال - جامعة بورسعيد

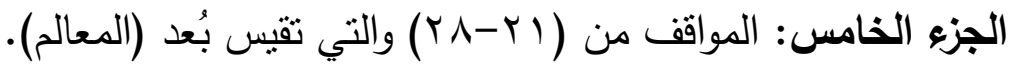
وفيما يلي عرض أحد مواقف المقياس الخاصة بهذا البُعد:
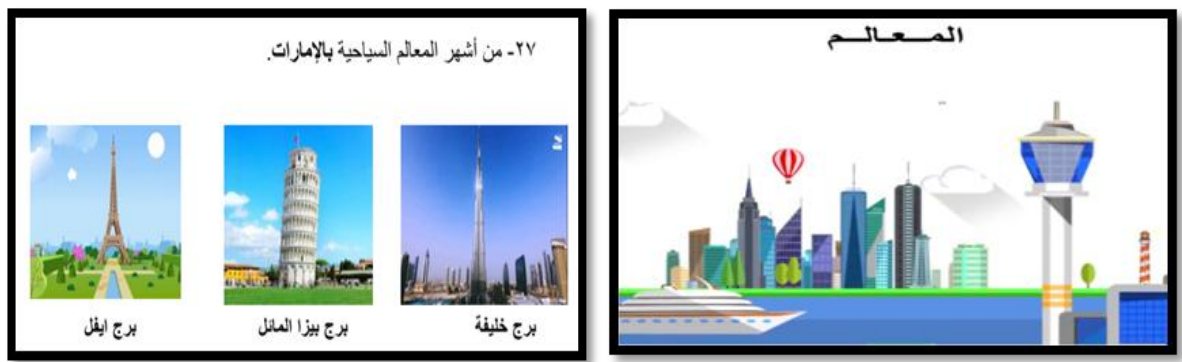

الجزء السادس: المواقف من (و (-جr) والتي تقيس بُعد (الزي الثعبي). وفيما يلي عرض أحد مواقف المقياس الخاصة بهذا البُعد:
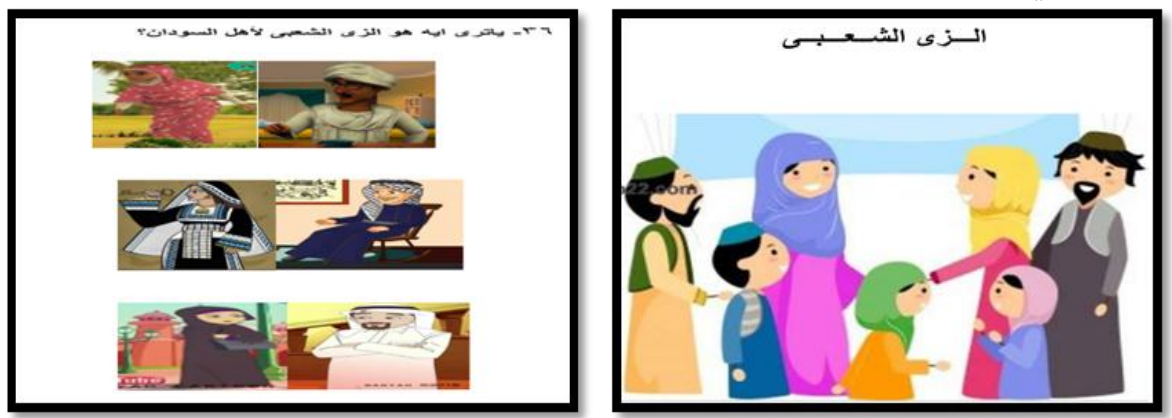

الجزء السابع: المواقف من (rv - ع ؛ ) والتي تقيس بُعد (الأعياد والاحتفالات). وفيما يلي عرض أحد مواقف المقياس الخاصة بهذا البُعد:

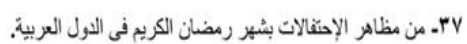
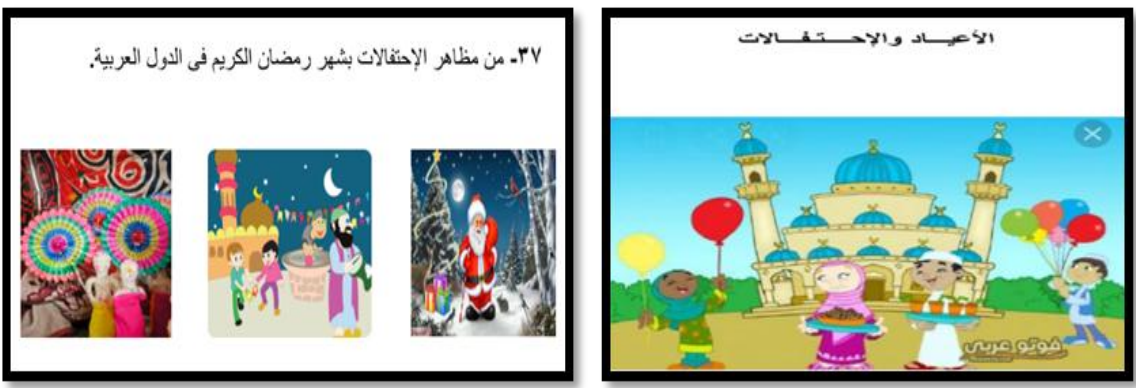

$(1.07)$ r. r. العدد ( السابع عشر ) أول يوليو - آخر ديسمبر 


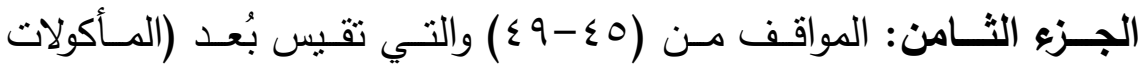
•الثعبية). وفيما يلي عرض أحد مواقف المقياس الخاصة بهذا البُعد:

9. بـ من أنشر الأكلاث الثُبية بالسودان.

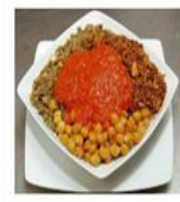

الكثرى

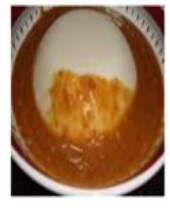

العصبدة - n

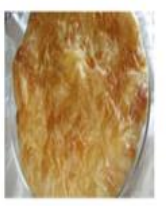

الفطبر المنلتت

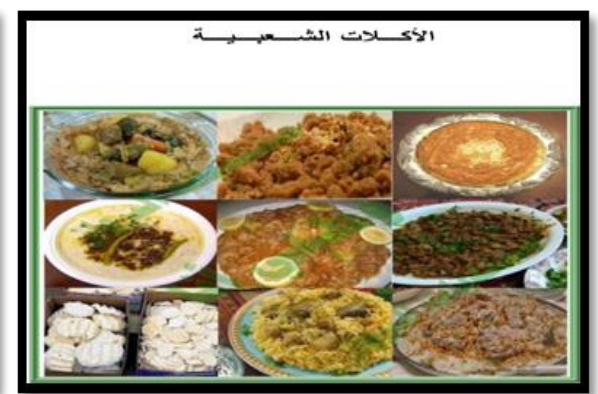

الجزء التاسع: المواقف من ( •0-ــ) والتي تقيس بُعد (الديانة)

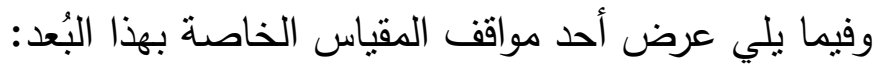
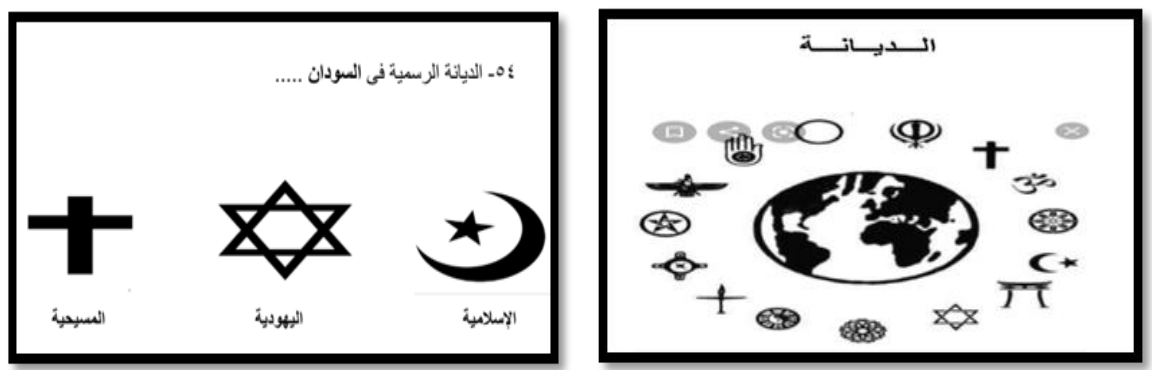

وفي كل جزءٍ من تلك الأجزاء يتم عرض الموقف على الطفل مصحوباً

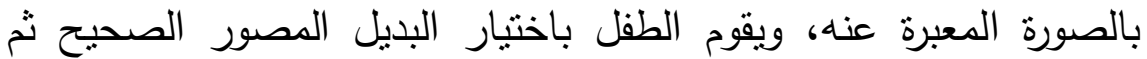
ينتقل إلى الموقف الذي يليه، فيما عدا الجزء الرئه الرابع فهو لفظي.

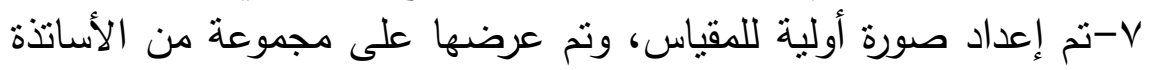

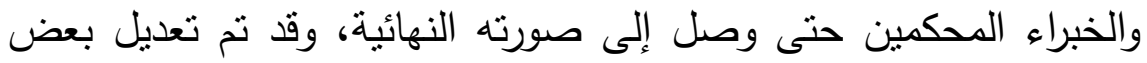
مواقف المقياس من قِبَّل الخبراء والمحكمين على النحو التالي: 


\section{المجلة العلمية لكلية رياض الأطفال - جامعة بورسعيد}

\begin{tabular}{|c|c|c|}
\hline الموقف بعد التعديل & الموقف قبل التعديل & رقمث \\
\hline حدد علم بلدك مصر . & ضمهورية مصر العربية. & -1 \\
\hline 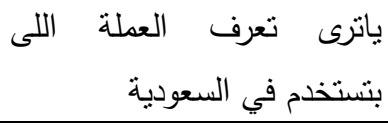 & ما هي عملة السعودية؟ & $-1 Y$ \\
\hline من أثهر المعالم السياحية في & خلى من هذه الصور يمثل برج & $-r V$ \\
\hline
\end{tabular}

\section{طريقة تطبيق المقياس:}

- يتم تطبيق المقياس عن طريق المقابلة الفردية لكل طفل على حدى، وقد استعانت الباحثة ببعض الزميلات في مجال عملها لمساعدتها في تطبيق المقياس. زمن تطبيق المقياس: يسـتخرق تطبيـق المقيـاس حوالي . ب دقيقةً (حيـث تم تحديـد زمـن تطبيـق المقياس في ضوء التجربة الإستطلاعية لأدوات البحث).

تعليمات المقياس:

- تعرض الباحثة البطاقة المصورة المكونة للمقياس على الطفل مع توجيه

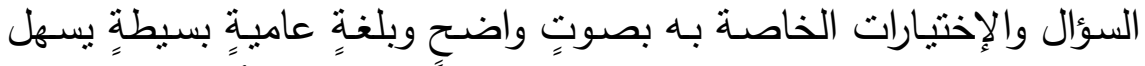

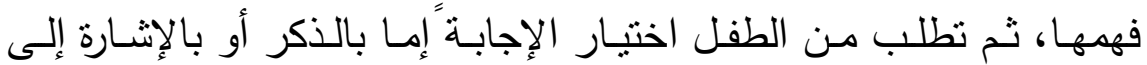
الصورة المعبرة عن إجابته. 


\section{طريقة تصحيح المقياس:}

- في حالة اختيار البديل المصور الخطأ، بأخذ درجةً واحدةً.

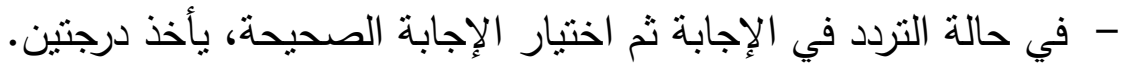

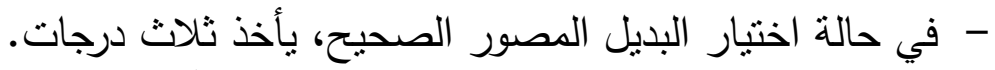

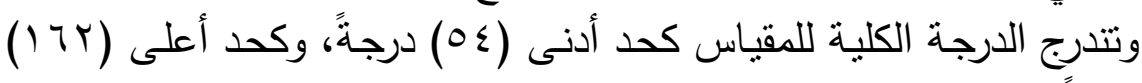
درجةً.

الخصـائص السـيكومترية لمقيـاس المفـاهيم المرتبطـة بثقافـات الشـعوب

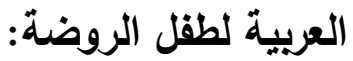

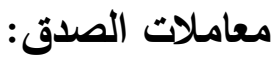
1 - 1 - صدق المحكمين:

قامـت الباحثنة بعرض المقيـاس على مجموعـة مـن الخبـراء المحكمـين

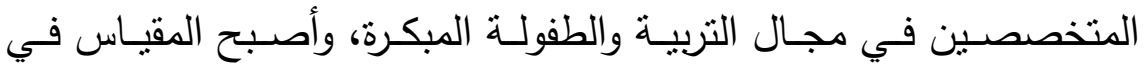

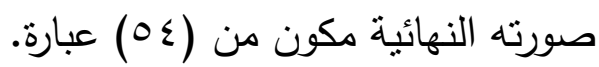

ثم قامت الباحثة بإيجاد معاملات صدق المحكمين لكل عبارة باستخدام معادلة "لوش"، وكانت تتراوح بين (T9 ,. إلى . ., 1)، وهذا يشير إلى اتفاق المحكمين على صدق عبارات المقياس وصـانلاحيتها للتطبيق على ولى أطفال

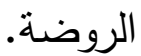

r- صدق الاتساق الداخلي (التجانس الاخلي) :

تم حسـاب الصـدق للمقياس المصدور بحسـاب معـاملات الارتبـاط بـين

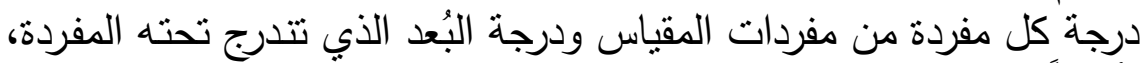

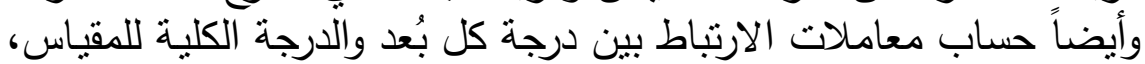




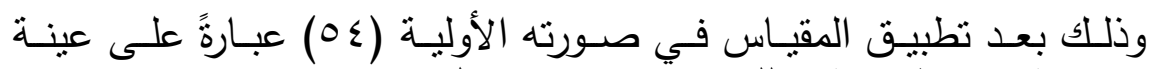

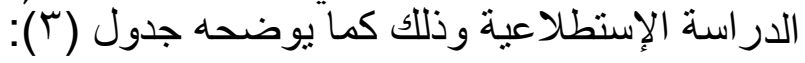

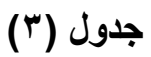

معاملات الارتباط بين درجة كل مفردة ودرجة البُعد الأي تتتمي إليه المفردة $(r \cdot \dot{r})$

\begin{tabular}{|c|c|c|c|c|c|c|c|}
\hline \multicolumn{2}{|l|}{ نظام الحكم } & \multicolumn{2}{|l|}{ العملات } & \multicolumn{2}{|l|}{ العواصم } & \multicolumn{2}{|l|}{ الأعلام } \\
\hline معامل الارتباط & رقم & معامل الارتباط & رقم & معامل الارتباط & رقم & معامل الارتباط & رقم \\
\hline$* *,, \vee \vee r$ & 17 & $* *, \Lambda, \mu$ & 11 & $* *,, \vee \vee \wedge$ & 7 & سץ, ד, ש** & 1 \\
\hline$* *, \wedge \neg 1$ & 18 & $* *, \wedge, q$ & it & $* *$, , $\wedge$ Y & V & $*, \Sigma \wedge \mu$ & r \\
\hline سז, • * * & 11 & $* *,, O V Y$ & rا & $*, \varepsilon, r$ & $\wedge$ & $* *, \wedge r \varepsilon$ & r \\
\hline$* *, \vee \vee \wedge$. & 19 & $* *, V Y r$ & $1 \varepsilon$ & $*, \varepsilon \ldots$ & 9 & $* *, \wedge \wedge \wedge$ & $\varepsilon$ \\
\hline$* *,,\rceil \wedge \wedge$ & $r$. & $* *, 707$ & 10 & **, & 1. & $* *,, \wedge 01$ & 0 \\
\hline
\end{tabular}

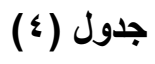

معاملات الارتباط بين درجة كل مفردة ودرجة البُعد الأي تتتمي إليه المفردة

$$
\text { ( } r \cdot=)
$$

\begin{tabular}{|c|c|c|c|c|c|}
\hline \multicolumn{2}{|c|}{ الأعياد والاحتفالات } & \multicolumn{2}{|c|}{ الزي الثعبي } & \multicolumn{2}{|l|}{ المعالم } \\
\hline معامل الارتباط & رقم & معامل الارتباط & رقم & معامل الارتباط & 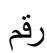 \\
\hline **, ๆ & rv & ס ט ד, •* & rq & $* *,,\rceil \leq \Lambda$ & Y) \\
\hline$* *, 794$ & r & $* *$, , & r. & $* *$, o $\vee \wedge$ & Yr \\
\hline$* *, 0 \vee 0$ & q & $* *$, , o $\vee \wedge$ & ו & r*, r , & rr \\
\hline$* *, 7 r q$ & $\varepsilon$. & $* *, \neg \leqslant \Lambda$ & ry & *. & $r \varepsilon$ \\
\hline$* *, V \backslash 1$ & \&1 & $* *, r q 9$ & سץ & ס ש • * * & ro \\
\hline$* *,, o \vee V$ & $\varepsilon r$ & $* *, 07 r$ & ع & $* *, \leqslant \wedge \neg$ & ru \\
\hline$* *, 0 \wedge r$ & $\varepsilon$ & $* *, 0 \wedge 9$ & o r & $* *, 0 \wedge 9$ & rV \\
\hline$* *,, 7 \leq \varepsilon$ & $\varepsilon \varepsilon$ & $* *,, \Sigma \wedge \uparrow$ & דy & $* *, 07 r$ & rᄉ \\
\hline
\end{tabular}




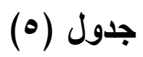

معاملات الارتباط بين درجة كل مفردة ودرجة البُعد الذي تتنمي إليه المفردة (ن=r)

\begin{tabular}{|c|c|c|c|}
\hline \multicolumn{2}{|l|}{ الايانة } & \multicolumn{2}{|c|}{ الأكلات الثعبية } \\
\hline معامل الارتباط & رقم & معامل الارتباط & رقم \\
\hline$* * *, \Lambda \cdot r$ & 0 . & ***,,$V T V$ & $\leqslant 0$ \\
\hline$* *, \wedge \cdot q$ & 01 & $* *,, V \cdot r$ & $\varepsilon 7$ \\
\hline$* *, 0 V Y$ & Or & $* *$, * Y Y O & $\varepsilon V$ \\
\hline$* *, V Y Y$ & or & ***,, 717 & $\varepsilon \wedge$ \\
\hline$* *, 707$ & o & $* *, 0 \wedge \uparrow$ & $\leqslant 9$ \\
\hline
\end{tabular}

جدول (ఛ) (ך)

معاملات الارتباط بين درجة كل بُعد والارجة الكلية للمقياس (ن= • ب)

\begin{tabular}{|c|c|c|c|}
\hline معامل الارتباط & البُعد & معامل الارتباط & البُعد \\
\hline$* *, 799$ & ז-الزي الشعبي & $* *, \wedge \mid r$ & 1-الأعلام \\
\hline$* * \ldots, V r_{0}$ & V-الأعياد والاحتفالات & $* *, 701$ & r-العواصم \\
\hline$* *, \vee \vee 70$ & ^-الأكلات الثعبية & $* *, 74$ & ب-العملات \\
\hline ***, ฯ Ү & 9-الديانة & $* * \cdot, 7 \leq 1$ & ع -نظام الحكم \\
\hline & & $* * ., 799$ & ه-المعالم \\
\hline
\end{tabular}

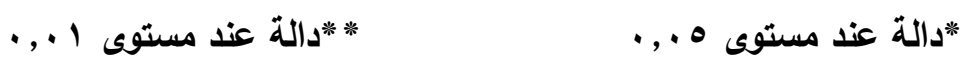

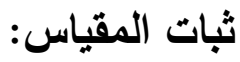

1 - معامل الثبات (ألفا) بطريقة كرونباخ :

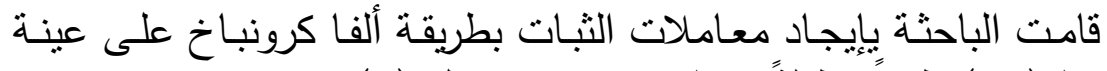

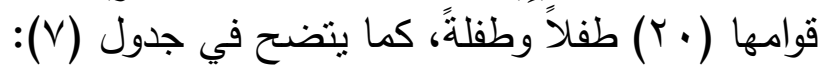




\section{جدول (v)}

معاملات الثبات(ألفا)لمقياس المفاهيم المرتبطة بثقافات الثعوب العربية

لطقل الروضة بطريقة كرونباخ

\begin{tabular}{|c|c|}
\hline معامل الثبات & الأبعاد \\
\hline$\cdot, \wedge \wedge$ & 1- الأعلام \\
\hline.,$\wedge 7$ & r- العواصم \\
\hline.,$\wedge \mathrm{V}$ & ب- العملات \\
\hline$\cdot$, , & ع - نظام الحكم \\
\hline$\cdot, \wedge \wedge$ & 0- المعالم \\
\hline$\cdot, \wedge 7$ & 7- الزي الشعبي \\
\hline$\cdot, \wedge \wedge$ & V- الأعياد والاحتفالات \\
\hline$\cdot, \wedge 0$ & 1- الأكلات الثعبية \\
\hline$\cdot, \wedge 9$ & 9- الديانة \\
\hline$\cdot, \wedge \wedge$ & - الدرجة الكلية \\
\hline
\end{tabular}

يتضح من جدول (V) ارتفاع قيمة معامل الثبات مما يدل على ثبات

r - بريقة إعادة الاختبار:

قامت الباحثة بإيجاد معاملات الثبات بطريقة إعادة التطبيق بفاصلٍٍ زمني

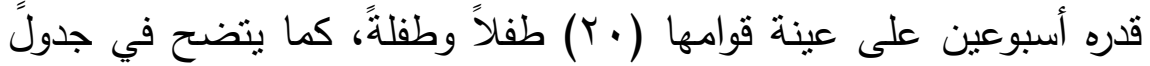




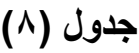

معامل الثبات لمقياس المفاهيم المرتبطة بالثقافات المتعددة لطقل الروضة بطريقة إعادة الاختبار بالفتان

\begin{tabular}{|c|c|}
\hline معامل الثبات & الأبعاد \\
\hline$\cdot, 90$ & 1- الأعلام \\
\hline$\cdot, 9 \leq$ & r- العواصم \\
\hline$\cdot, 90$ & r- العملات \\
\hline., 94 & ع- نظام الحكم \\
\hline., $9 \varepsilon$ & 0- المعالم \\
\hline., 94 & ד- الزي الثعبي \\
\hline., 94 & V- الأعياد والاحتفالات \\
\hline., 91 & ^- الأكلات الشعبية \\
\hline .,94 & 9- الديانة \\
\hline$\cdot, 9 \leq$ & - - الدرجة الكلية \\
\hline
\end{tabular}

يتضح من جدول (^) ارتفاع قيمة معاملات الثبات مما يدل على ثبات

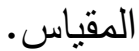

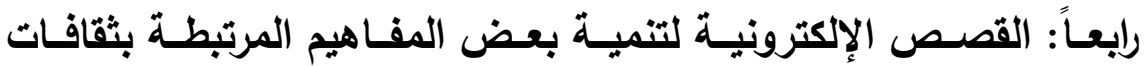

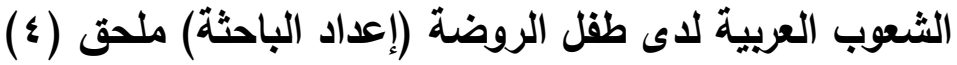

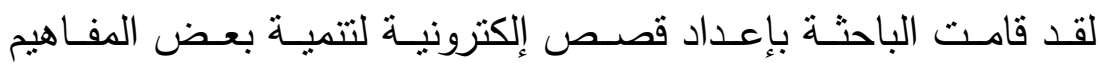
المرتبطة بثقافات الثعوب العربية لاى طفل الروضة. - الهدف العام للقصص الإكترونية:

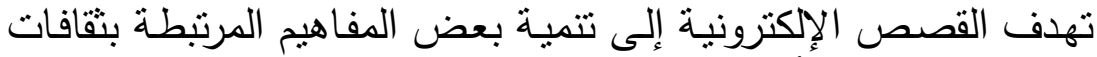

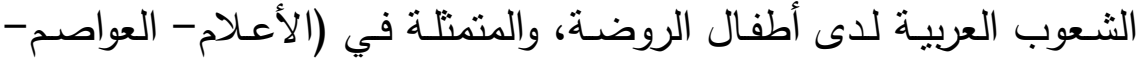


العملات - نظام الحكم - المعالم - الأزيـاء الثعبية- الأعياد والاحتفالاتالأكلات الثعبية- الديانة).

- معاييز إعداد القصص الإلكترونية:

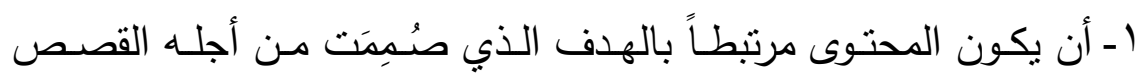
الإلكترونية.

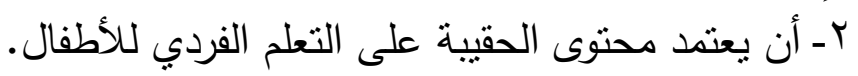

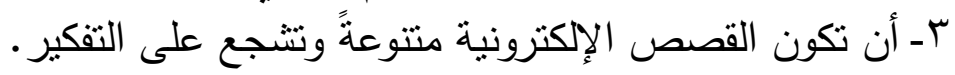

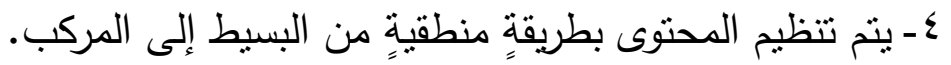

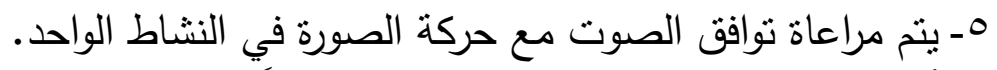
7- أن يتتوع التقويم في القصص الإلكترونية وفقاً لمستويات الأنشطة. - مكونات القصص الإلكترونية:

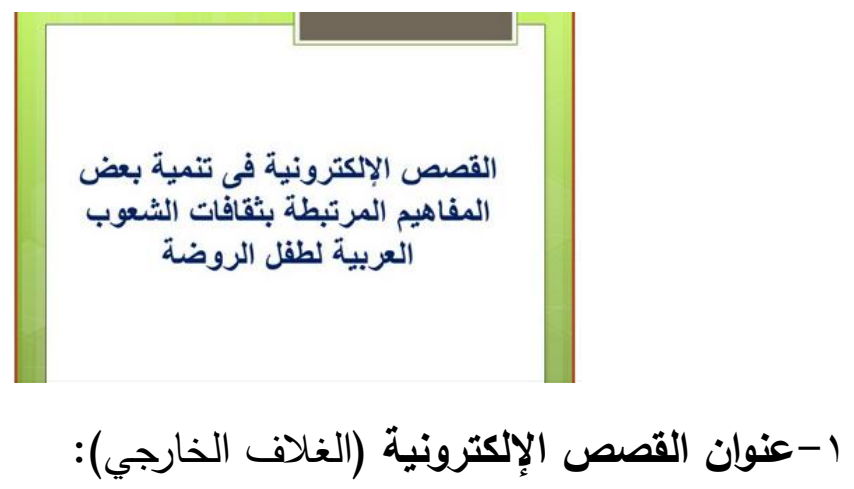

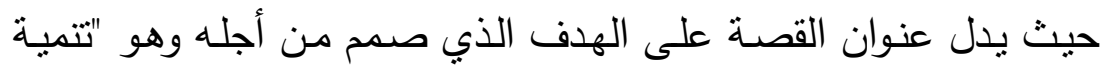

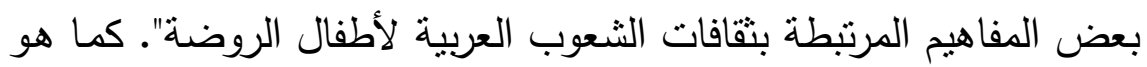
موضح على النحو التالي: 
ץ-المقدمة: وتتضمن شاشة تعبر عن أبعاد القصص الإلكترونية. كما هو

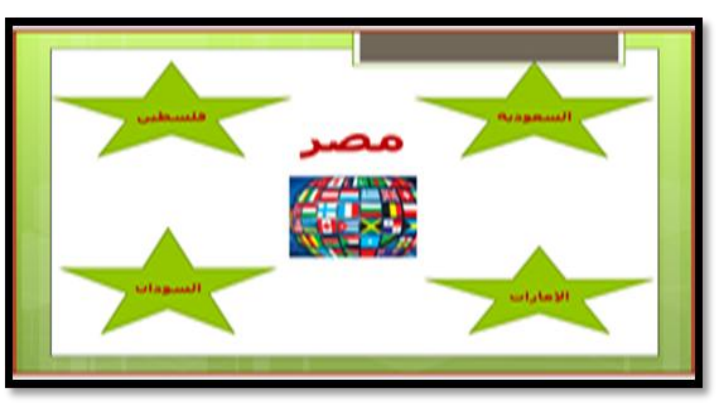

بالصورة:

ب-الأنثـطة التمهيديـة: لقيـاس مسـتوى الأطفـال قبـل البـدء في النشـاط،

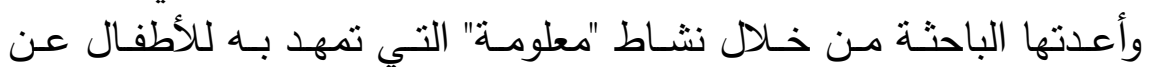
موضوع النشاط.

צ-القصص الإلكترونية: والتي تم إعدادها من خلال برامج الكمبيونز ، وقد تم إعدادها في ضـوء احتياجات الأطفال وتتوعت بحيث تشهم في تتميـة بعض المفاهيم المرتبطة بثقافات الثـعوب العربية لطفل الروضـة. كما هو موضتح على النحو التالي:

نماذج لبعض القصص الإلكترونية:

قصة "الحافلة العجيبة في مصر" قصة "كرميلة في الأهرامات"
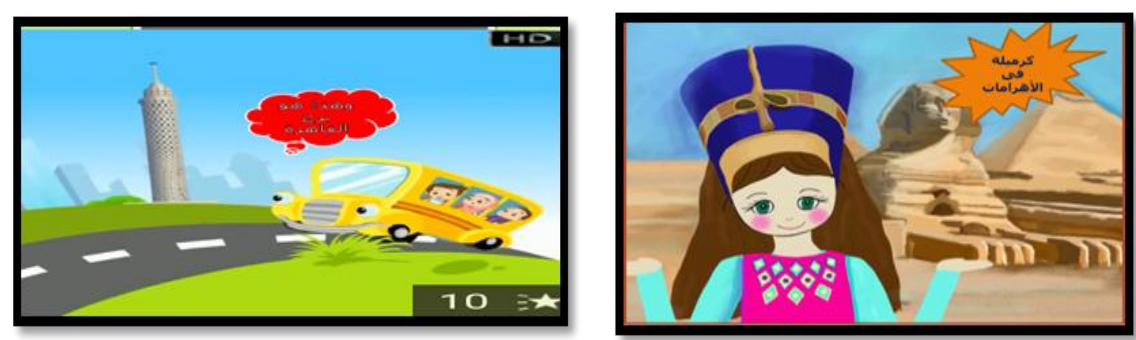
المجلة العلمية لكلية رياض الأطفال - جامعة بورسعيد

$$
\text { قصة "رحلة إلى فلسطين" }
$$

قصة "محمد في السعودية"
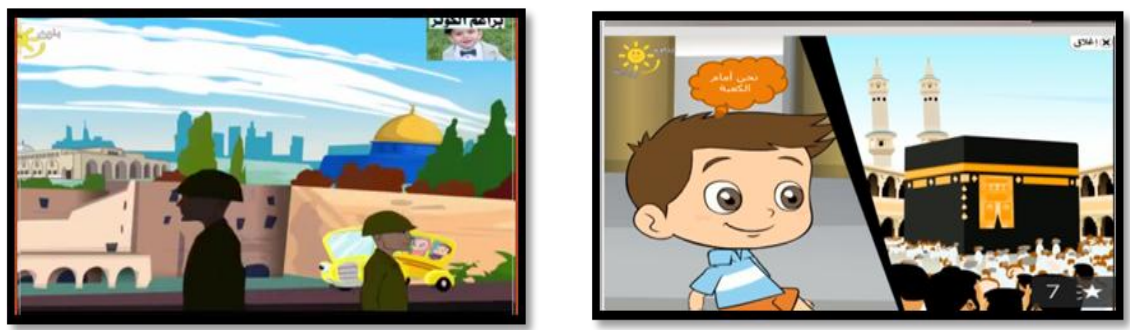

قصة "سارة في السودان"

قصة "دانية في دبي"
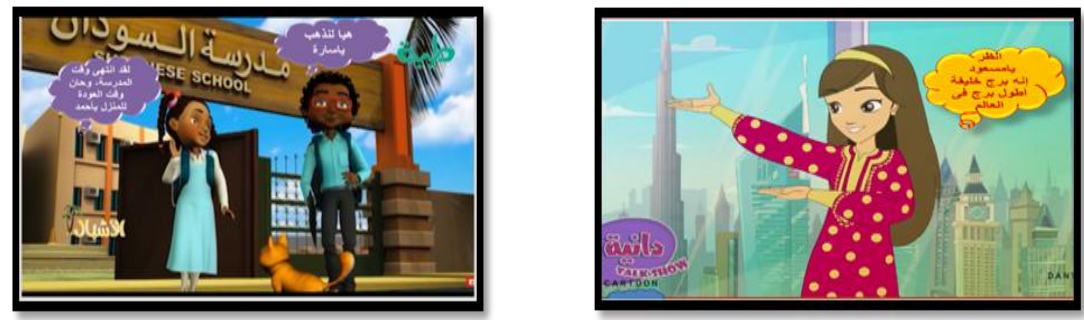

ه-أساليب التقويم: تتوعت وسائل التقويم المستخدمة على النحو التالي:

أ- تقـويم قبلـي: للتعـرف على الخلفيـة التعليميـة للطفل ومسـتوى تقكيـره

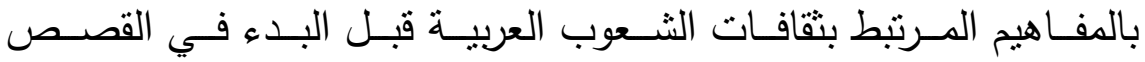
الإلكنرونية مـن خـلال "مقياس المفاهيم المرتبطة بثقافات الثـعوب العربية المصور " لطفل الروضة.

ب-تقويم مرحلي: وهو تقويم مصساحب للقصص الإلكترونيـة منذ بدايتها

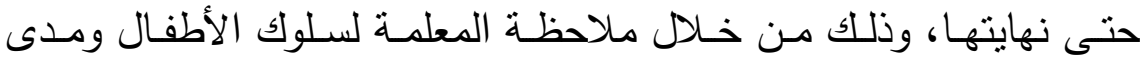


استجابتهم أثناء ممارسة أنشطة القصص الإلكترونية والتعرف على جوانب القوة والضعف، وكذلك من خلال التطبيقات التربوية التي يمارسونها الأطفال عقب كل نشاط.

ج-التقويم البعدي: ويتمثل في إعادة تطبيق مقياس " المفاهيم المرتبطة

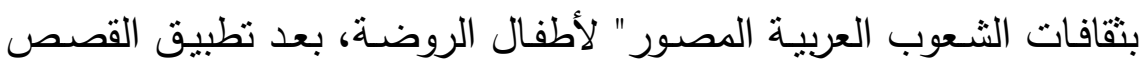

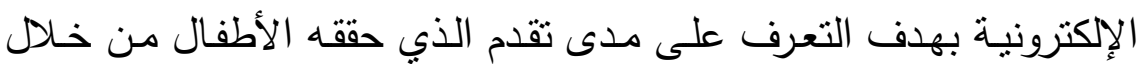
مقارنة درجاتهم قبل تطبيق القصص الإلكترونية وبعد التطبيق.

وفيما يلي عرض لبعض نماذج أنشطة التطبيقات التريوية الخاصة بالقصص الإلكترونية.
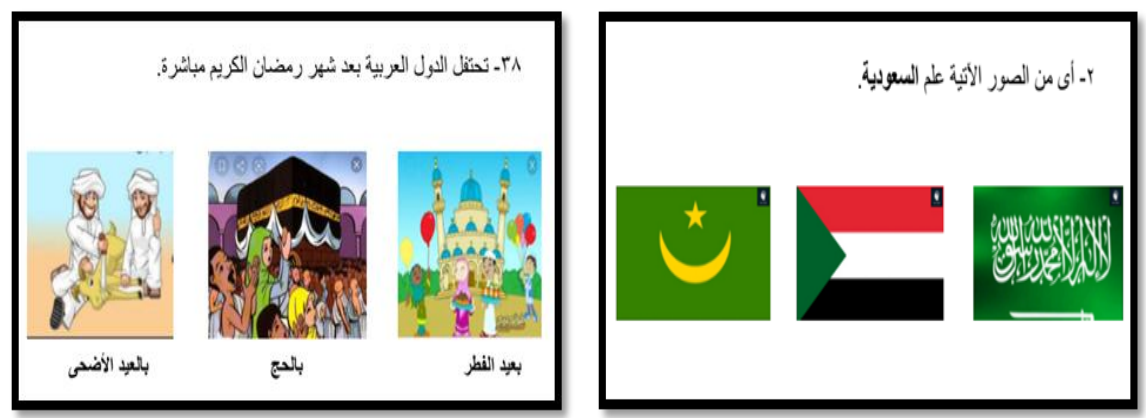

- القلسفة التربوية للقصص الإكترونية:

تتبثث الفلسفة التربويـة للقصص الإلكترونيـة مـن أهميـة استثمار التقدم

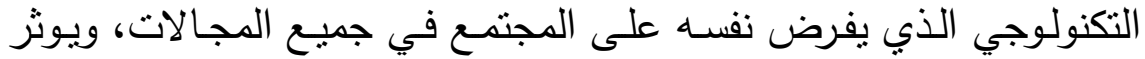

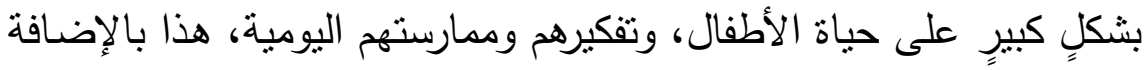
إلى ظهور عدد من النظريات التربويـة والنفسية التي تعتمد على تصلى تصميم 
البرمجيات التعليمية المختلفة، والتي تسهم بدورها في تتمية الجوانب العقلية

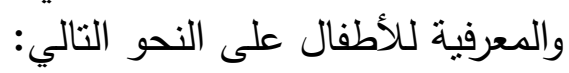

وقد تبنت الباحثة النظرية الاتصالية للتعلم والمعرفة "لسيمينز"، حيث أنها

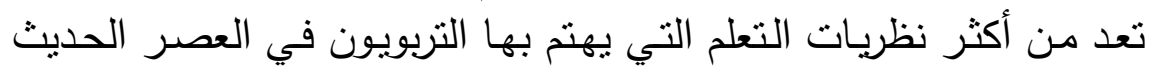

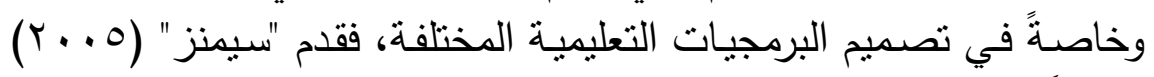
نظريـةً تسعى إلى أن توضـح كيفيـة حدوث التعلم في البيئات الإلكترونيـة

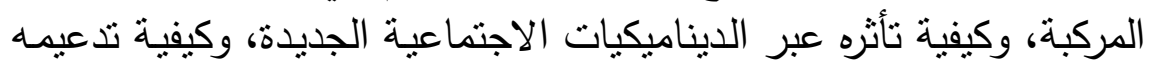

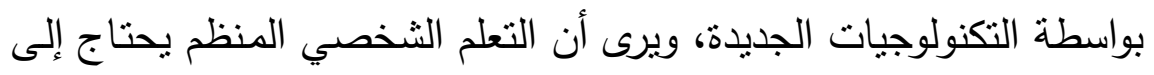
مجموعة من المهام المتكاملة من المعلمة والطفل.

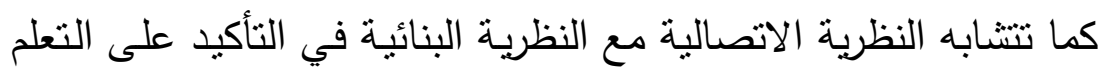

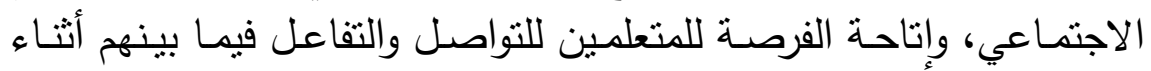

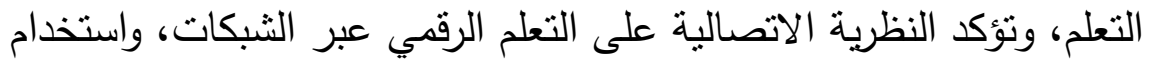
أدوات تكنولوجيا الحاسب والإنترنت في التعليم.

- الإستراتيجيات التعليمية المستخدمة في تطبيق القصص الإكترونية:

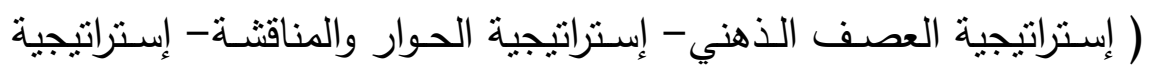
التفكير الابتكاري- إستراتيجية التعلم الذاتي).

- خطوات تصميم القصص الإكترونية: تم تصميم القصص الإلكترونية وفقاً للخطوات التالية: أ- مرحلة التحليل:

حيـث قامـت الباحثتة بتحديـد احتياجـات الأطفـال وفقـاً للمرحلـة العمريـة

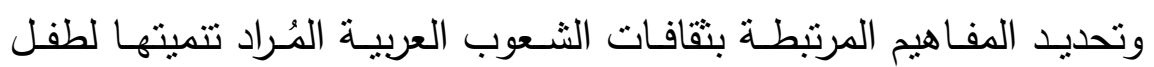


الروضــة وفقاً لإسـتطلاع آراء الخبـراء والمحكمين، وتم تحديد الهدف مـن القصص الإككترونية، وتحديد الفئة المستخدمة.

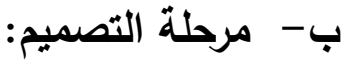

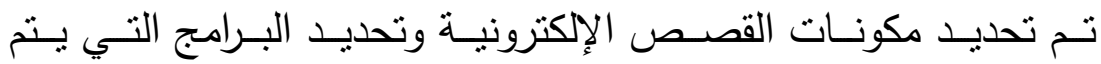

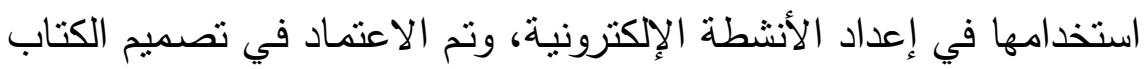

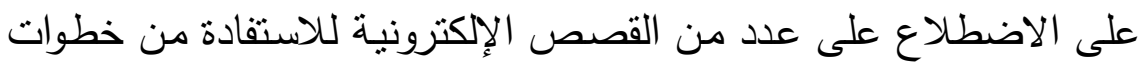
تصميمها والإستراتيجيات المستخدمة في تقديمها على النى النحو التالي:

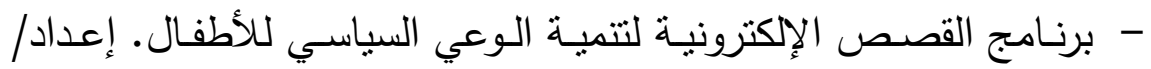

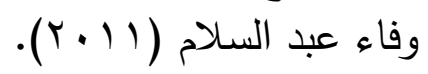

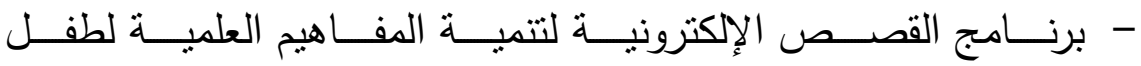

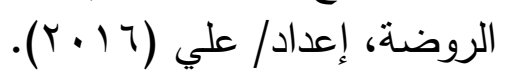

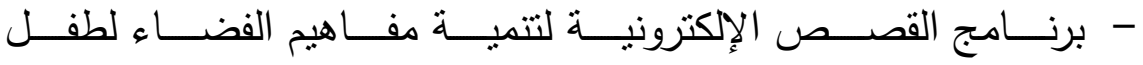

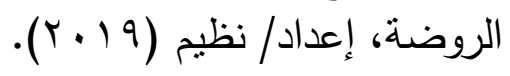

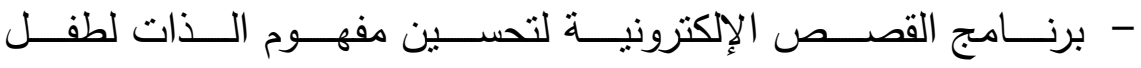

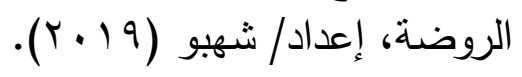

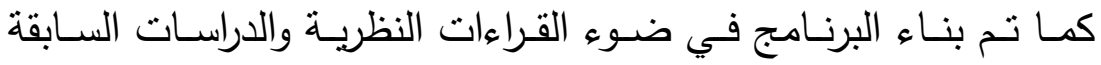

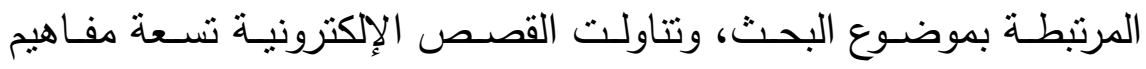

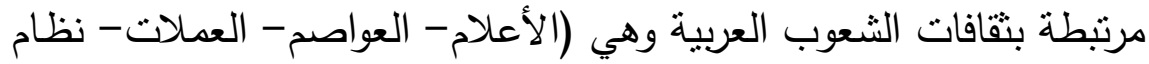
الحكم- المعالم- الأزياء الثعبية- الأعياد والاحتفالات - الأكلات الثربة الثعبيةالايانة). 


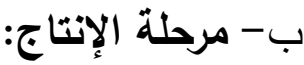

تم إعداد وتجهيز المحتويات لإنتاج القصص الإككترونية مثل (الصسور

الثابتة والرسـوم والصسور المتحركة والفيديو والصـوت المصـاحب للشاشـات

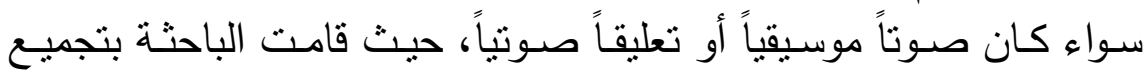

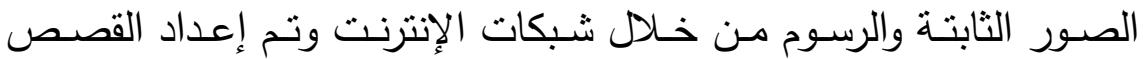

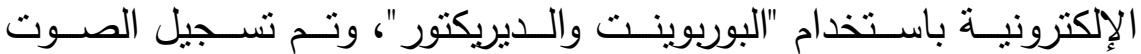

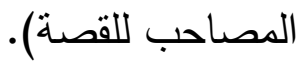

ج-مرحلة التقويم البنائي للقصص الإكترونية: قامت الباحثة بإجراء تقويم (قبلي- مرحلي- نهائي) وإعداد التطبيقات

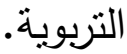

وفيمـا يلـي عرض لإحدى القصص الإلكترونيـة لتنميـة بعض المفـاهيم المرتبطة بثقافات الثعوب العربية لطقل الروضة الإنة:

$$
\text { نشاط: (·) (1) }
$$

عنوان النشاط: قصة "مغامرات سعيد ساعي البريد". الههف العام: تتمية معرفة الطفل بالمفاهيم المرتبطة بثقافة دولة لئة الإمارات.

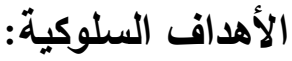

- أن يتعرف الطفل على أشهر معالم الإمارات.

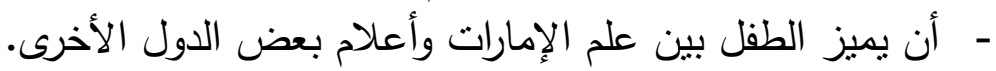
- أن يذكر الطفل عاصمة الإمارات. - أن - أنعرف الطفل على أنثهر المدن الإماراتية. - أن يتعرف الطفل على عملة الإمارات. 
- أن يتعرف الطفل على نظام الحكم في الإمارات. - - أن يذكر الطفل أثنهر الأكلات الإماراتية. - - أن يذكر الطفل الديانة الرسمية للإمارات.

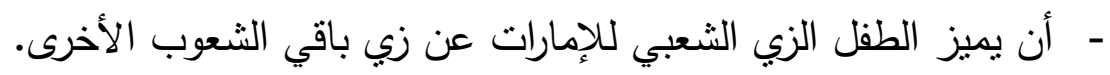
- أن يتعرف الطفل على اهنمامات شعبها. - - أن يثرى خيال الطفل وتفكيره. - أن يتدرب الطفل على التعلم باستخدام الحواس (السمع - البصر ) من الطن خلال القصص الإلكترونية. - أن يمارس عملياً استخدام القصص الإلكتة.

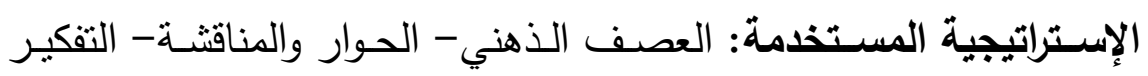
الابتكاري. مكان النشاط: قاعة الوسائط المتعددة. زمن النشاط: ـ 9 دقيقة.

الأدوات المستخدمة: جهاز كمبيونز أو حاسب شخصـي- شاشــة عرض-

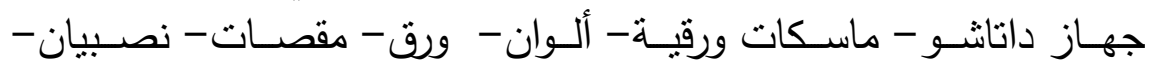
كانسون - أسطوانات (CD). خطوات تثفيذ النشاط:

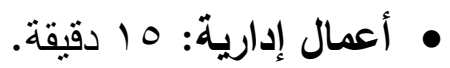
• فترة التهيئة: 10 د دقيقة. حيث تصطحب الباحثة الأطفال إلى غرفة الوسائط المتعددة، وتشاعد كل طفل في فتح جهاز الكمبيوتر الخاص بـه، وفتح القصنة الإلكترونية، وتبدأ

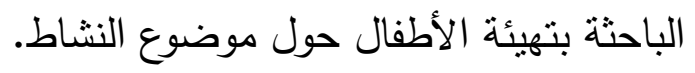




$$
\text { • الممارسات: (· م دقيقة). }
$$

تطلب الباحثة مـن الأطفال فتح النافذة الرئيسية للقصص الإلكترونيـة

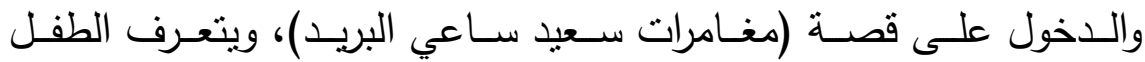
بالصوت والصورة على أثهر المعالم الموجودة بالإمارات، وعاصمتها وأثهر

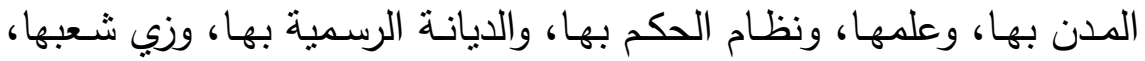

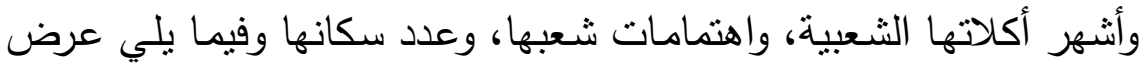
لبعض مشاهد قصة مغامرات سعيد ساعي البريد:
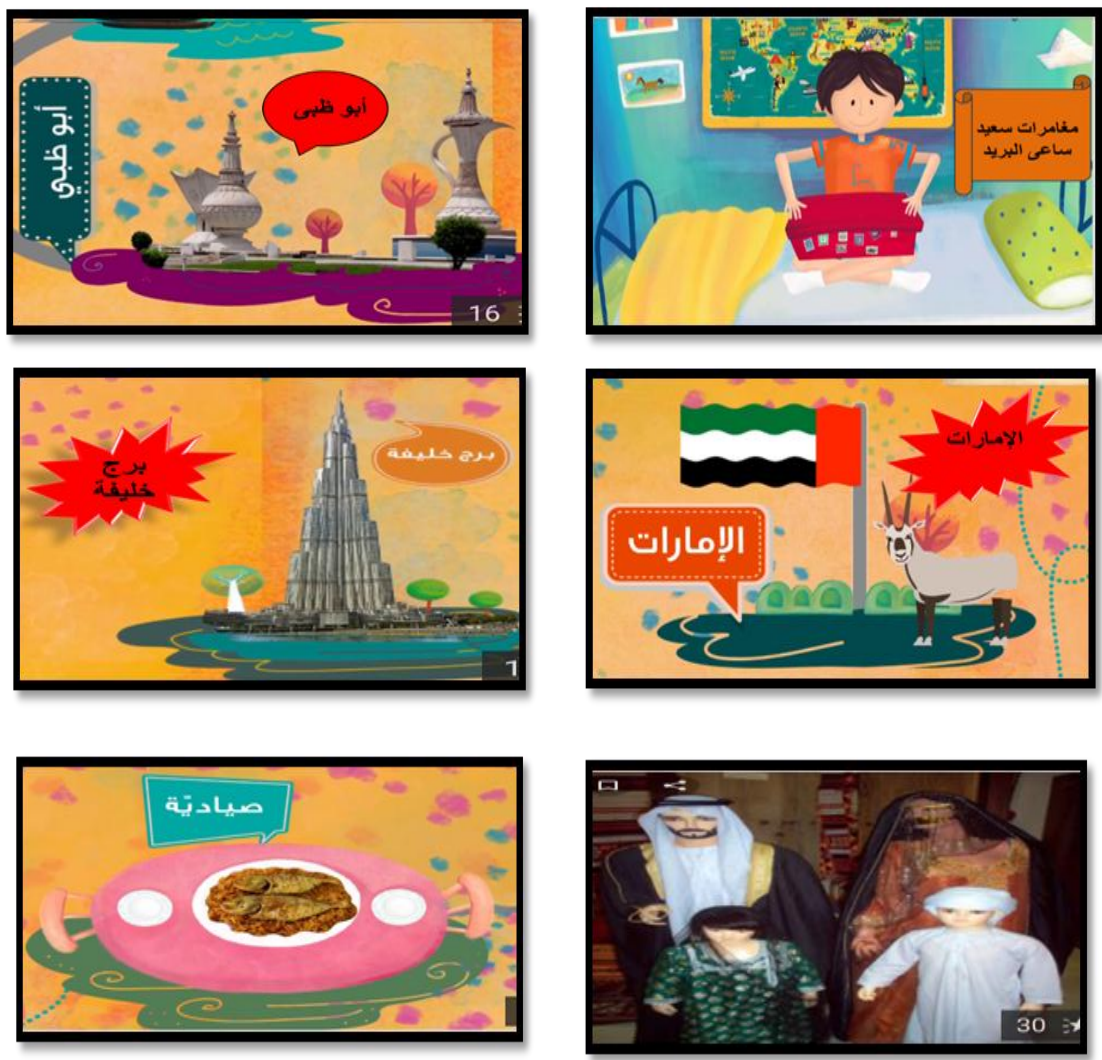


\section{• ختام النشاط: 10 دقيقة.}

تتاقش الباحثة كل طفل فيما استمع إليه وشاهده، وتتيح الفرصـة للأطفال

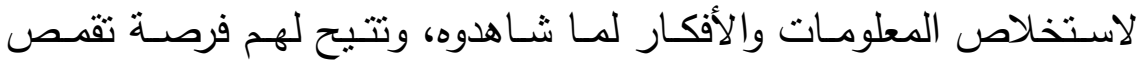

شخصية أحد أبطال القصة. لاصنات

$$
\text { التقويم: (·r دقيقة) }
$$

تتاقش الباحثة الأطفال في مدى استفادتهم من النشاط، ثم تطلب منهم

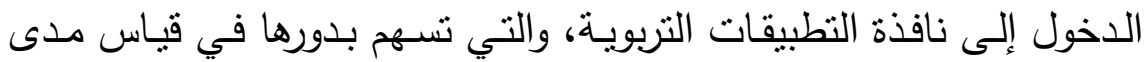

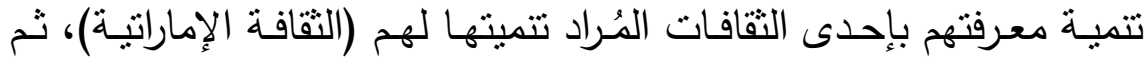

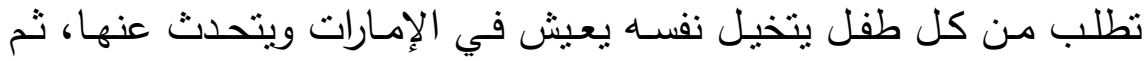

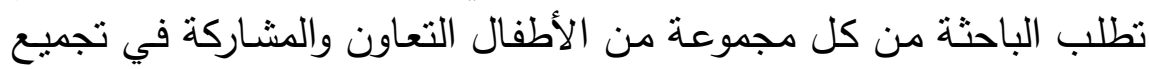

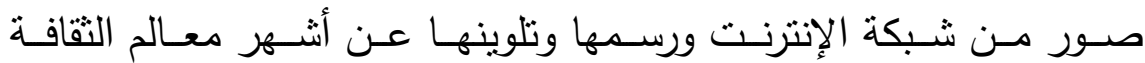

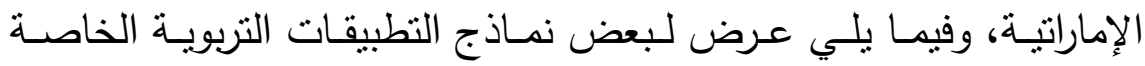
بقصة "مغامرات سعيد ساعي البريد".
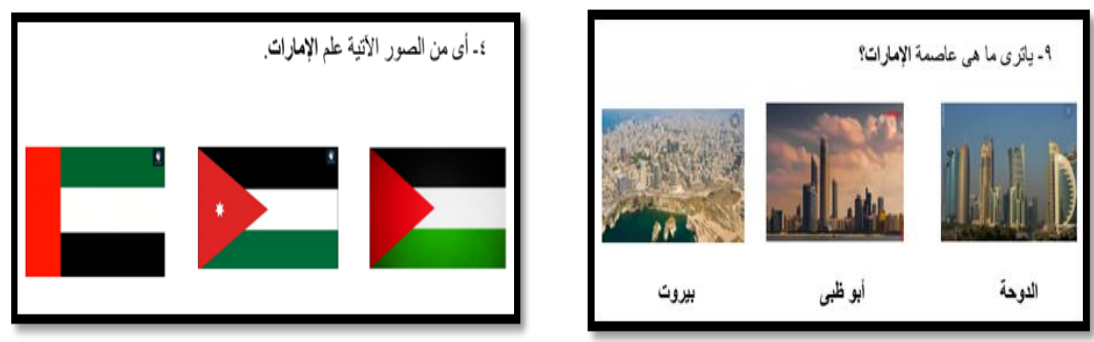

- التجرية الإستطلاعية الأولى:

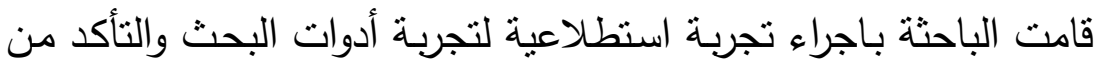
صلاحيتها في القياس، حيث قامت بتطبيقها على عينة قوامها (· ب) طفلاً 
وطفلةً من مجتمع البحث ومن دون عينة البحث الأساسية لإجراء معاملات

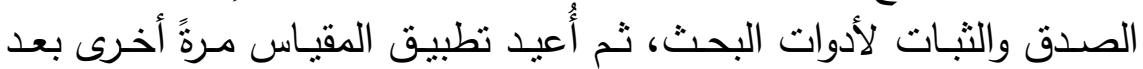
(0) 10 يوماً للتحقق من ثبات المقياس. - التجرية الإستطلاعية الثانية:

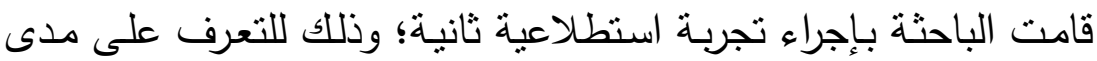

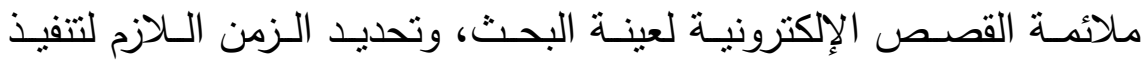
القصص، وقامـت الباحثـة بتـدريب ثلاثـة مـن الـزميلات المسـاعدات مـن معلمات الروضة والمتخصصات في مجال الطفولة؛ لمساعدتها في ملاحظة الناهنة

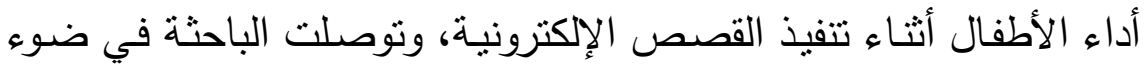
نتائج التجربة الإسنطلاعية الثانية إلى ملائمة القصص الإلكترونية للأطفال

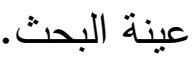

\section{-}

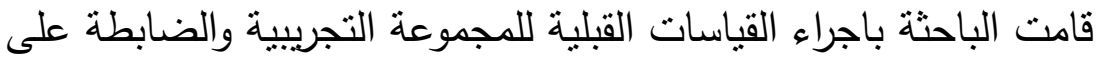

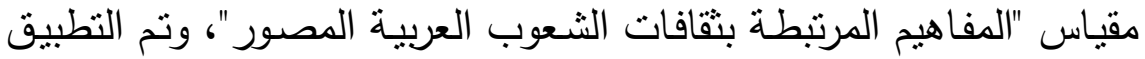

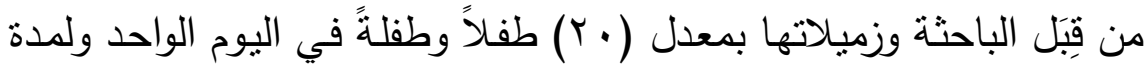

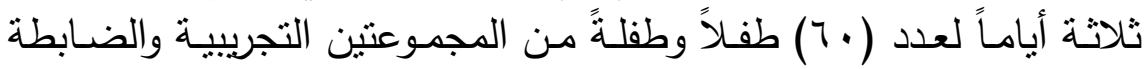
لمدة r ساعات يومياً.

\section{- تطبيق القصص الإلكترونية:}

قامت الباحثة بتطبيق القصص الإلكترونيـة والتي تتــاول تسعة مفـاهيم

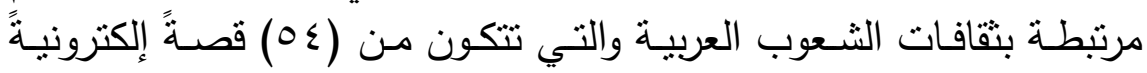

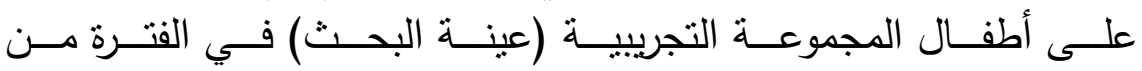




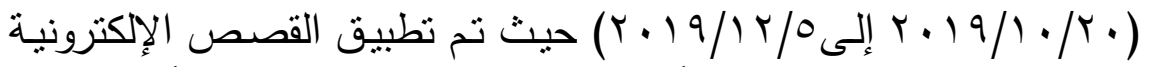

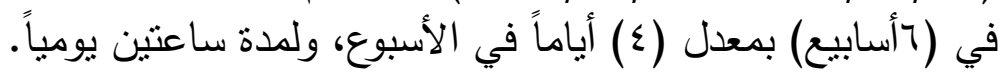

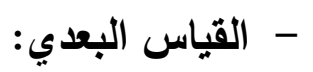

بعـد الانتهـاء مـن تطبيـق القصـص الإلكترونيـة قامـت الباحثـة بـإجراء البـاء

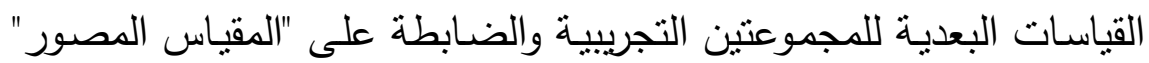

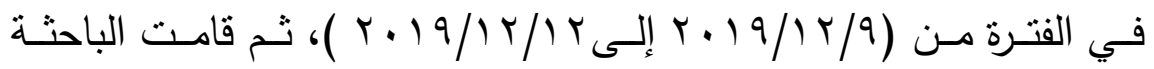
بإجراء المعالجات الإحصائية، وتم التطبيق من قِبَل الباحثة وزميلاتها بمعدل

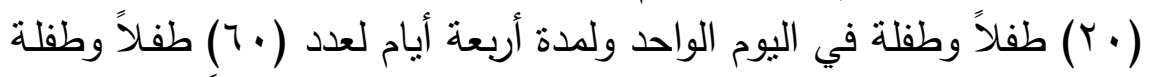

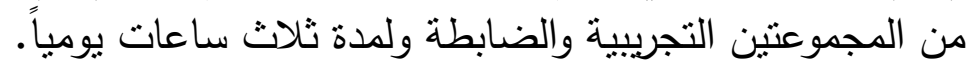

\section{- القياس التتبعي: -}

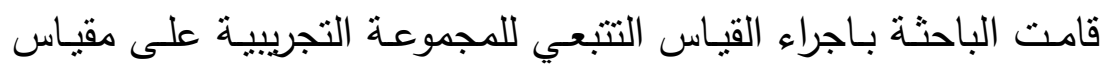

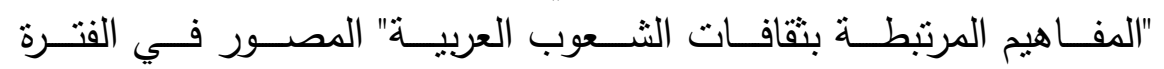

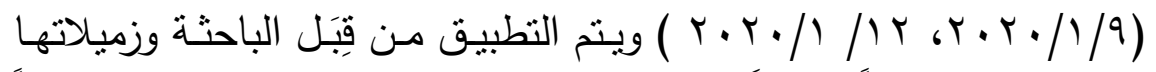

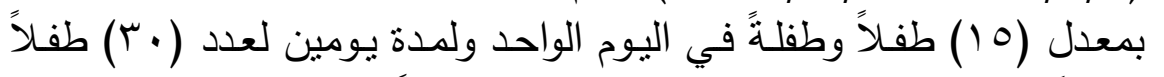

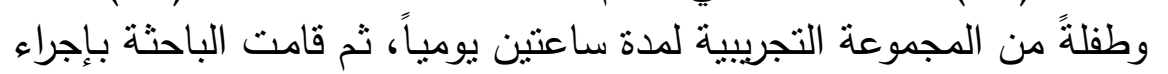
المعالجات الإحصائية.

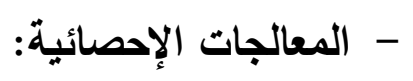
1-اختبار لاوش المات الإحس r-معامل الارتباط لسبيرمان ع-معامل "ألفا كرونباخ". ع -اختبار "ت" لحساب دلالة الفروق بين المتوسطات. 
المجلة العلمية لكلية رياض الأطفال - جامعة بورسعيد

جدول (9) البرنامج الزمني لإجراء البحث

\begin{tabular}{|c|c|c|c|c|c|}
\hline \multicolumn{2}{|c|}{ التاريخ } & المكان & العينة & الهلف & \multirow[t]{2}{*}{ الإجراءات } \\
\hline إلى & من & & & & \\
\hline 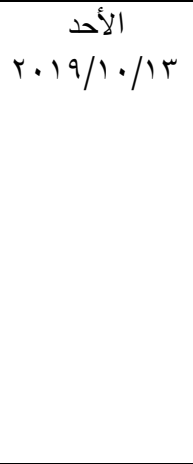 & 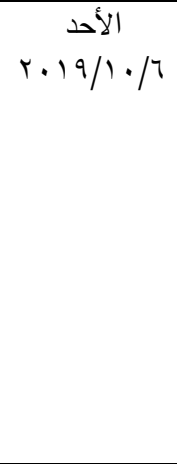 & الروضة & 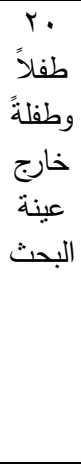 & 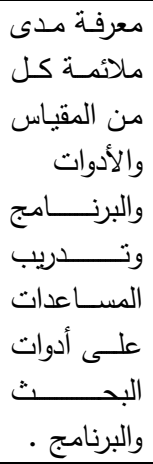 & 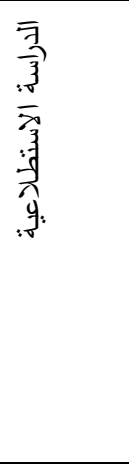 \\
\hline $\begin{array}{c}\text { الأربعاء } \\
\text { r 19/1/17 }\end{array}$ & 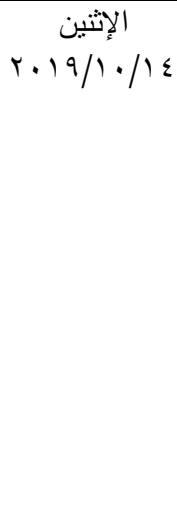 & النشاطر & "طلوفلاًٌ & 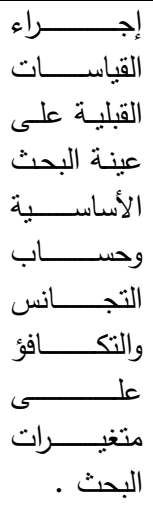 & القباس \\
\hline 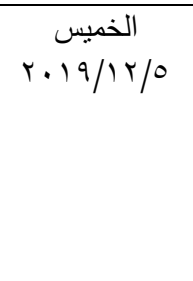 & 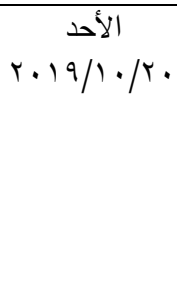 & والنارج & 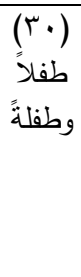 & 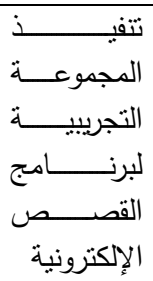 & تطبيق \\
\hline
\end{tabular}


المجلة العلمية لكلية رياض الأطفال - جامعة بورسعيد

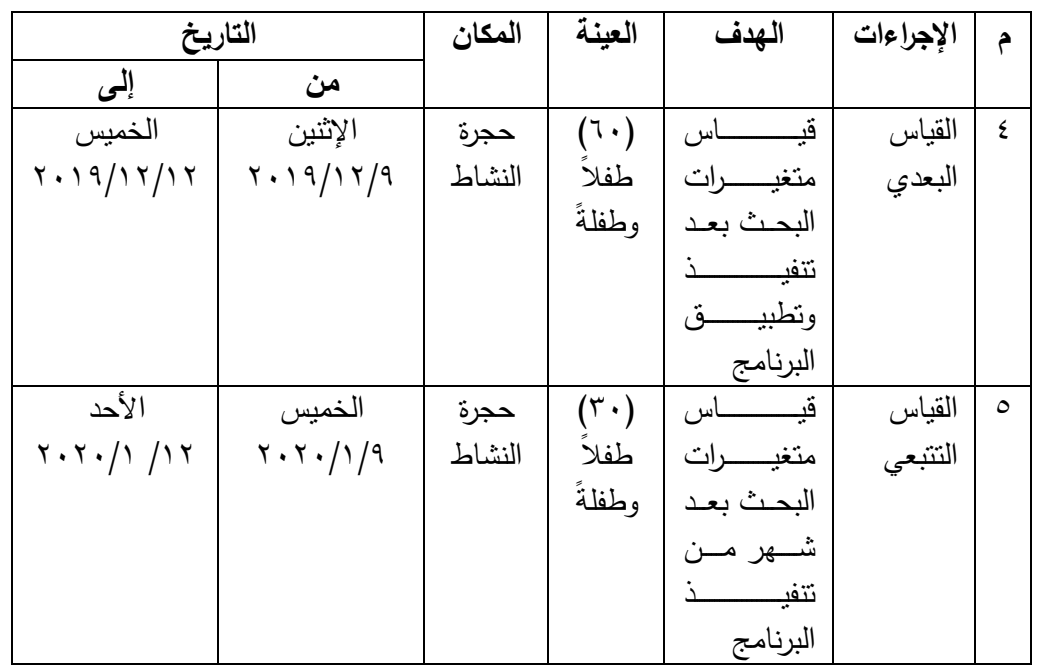

تفسير ومناقشة النتائج :

نتائج القرض الأول وتفسيره :

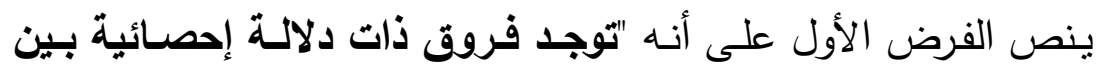

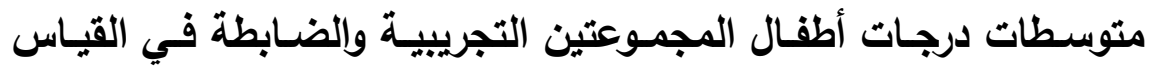

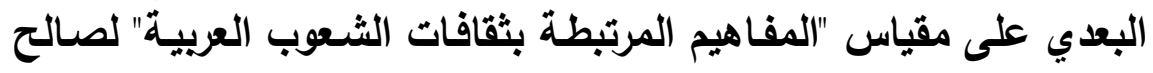
المجموعة التجريبية ".

للتحقق مـن صـحة هذا الفرض استخدمت الباحثة اختبـار "ت" لإيجـاد

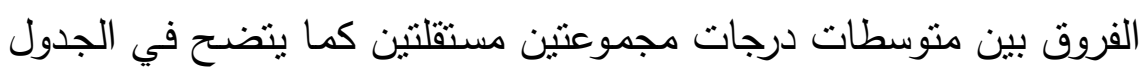

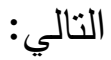




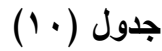

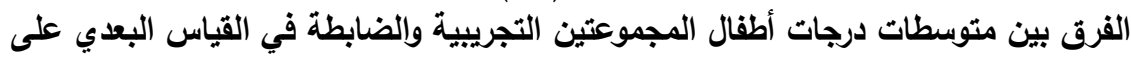

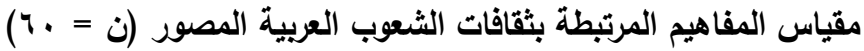

\begin{tabular}{|c|c|c|c|c|c|c|c|}
\hline \multirow[b]{2}{*}{ النتيجة } & \multirow{2}{*}{ مستوى الدلاية } & \multirow[t]{2}{*}{ 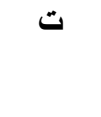 } & \multicolumn{2}{|c|}{ ضابطة (·" (r) } & \multicolumn{2}{|c|}{ تجريبية (· · ) } & \multirow[t]{2}{*}{ المتغيرات } \\
\hline & & & $r \varepsilon$ & $t^{\beta}$ & $1 \varepsilon$ & ק & \\
\hline دالة & $\cdot, \cdot 1$ & $\varepsilon, 7 \wedge$ & 1,1 & $r, r$ & 1,19 & $\varepsilon, V$ & ا -الأعلام \\
\hline دالة & $\cdot, \cdot 1$ & $0, V Y$ & 1,19 & $r, 0$ & 1,0 & $\varepsilon, 1$ & ب_العو اصم \\
\hline دالة & $\cdot, \cdot 1$ & $7, \cdot T$ & I,Tr & $r, 0$ & $\cdot, \wedge \Gamma$ & $\varepsilon, r$ & r_العملات \\
\hline دالة & $\cdot, \cdot 1$ & $7,1 Y$ & $\mid, Y_{1}$ & $r, r$ & $1, \ldots$ & $\varepsilon_{61}$ & ع ــنظام \\
\hline دالة & $\cdot, \cdot 1$ & $V, 00$ & $1, r$ & $\varepsilon, \cdot$ & $\cdot, 1 / 7$ & 0,9 & 0ـالمعالم \\
\hline دالة & $\cdot, \cdot 1$ & $7,1 \leq$ & $1, Y Y$ & $r, 0$ & $\cdot, V r$ & 0,1 & الــالزى \\
\hline دالة & $\cdot, \cdot 1$ & $V, 01$ & $1, \cdot r$ & $r, 1$ & $\cdot, \wedge \wedge$ & $\varepsilon, 9$ & $\begin{aligned} \text { والإحتفالات } \\
\text { والأعياد }\end{aligned}$ \\
\hline دالة & $\cdot, \cdot 1$ & $7,0 \leqslant$ & $1, \cdot r$ & $Y, \Lambda$ & $\cdot, \wedge 9$ & $\varepsilon, \varepsilon$ & الثـالأكلات \\
\hline دالة & $\cdot, \cdot 1$ & $9, Y 7$ & $1, \cdots$ & $1, Y$ & $\cdot, 9 \mathrm{~V}$ & $\varepsilon, 1$ & 9 \\
\hline دالة & $\cdot, \cdot 1$ & $1 \varepsilon, 94$ & $r, r \Lambda$ & $r_{0, \Lambda}$ & $\varepsilon, \wedge \varepsilon$ & $\sum 1,9$ & - الكلية \\
\hline
\end{tabular}

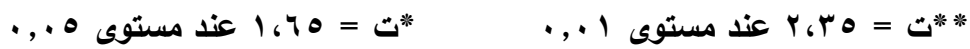

يتضـح مسن الجـدول السـابق وجـود فـروق ذات دلالــة إحصـائية بـين

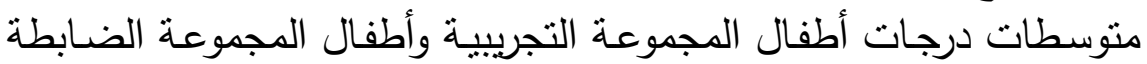


في القياس البعدي على مقياس المفاهيم المرنبطة بثقافات الثـوب العربية

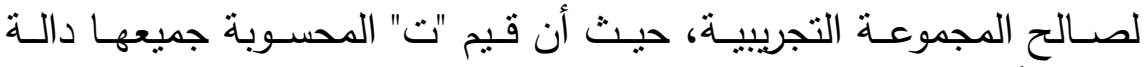

إحصائياً عند مستوى ( .، . .

تفسير نتائج الفرض الأول :

أظهرت النتائج صحة الفرض الأول الذي ينص على "وجود فروق ذات دلالـة إحصـائية بـين متوسـطات درجـات أطفـال المجمـوعتين التجريبيـة والضابطة في القياس البعدي لمقياس المفاهيم المرتبطة بثقافات الثـعوب

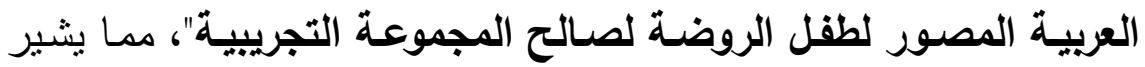
إلى فاعلية البرنامج المقترح في تحقيق أهدافه، وهو مـا قد يرجع للأسباب التالية:

• نجاح القصص الإككترونيـة لتتميـة بعض المفاهيم المرتبطة بثقافات الثـوب العربيـة لطفل الروضـة، حيث تعرض أطفال المجموعـة التجريبيـة

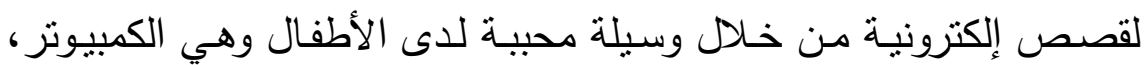
وكذلك تطبيقات التربوية التي تساعد على التأكد من نمو معارف ومعلومات

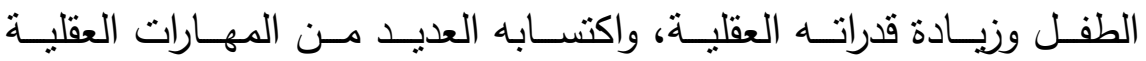
والسلوكيات الذهنية التي يمكن أن يستدعيها عندما يمر بمواقف أو خبرات

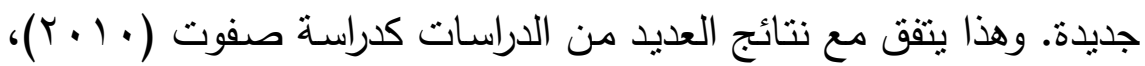

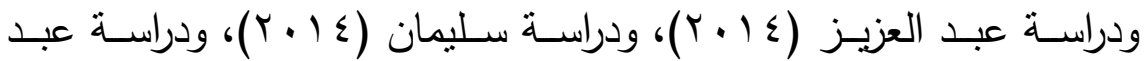

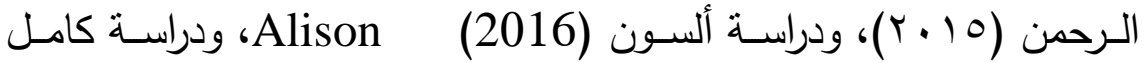

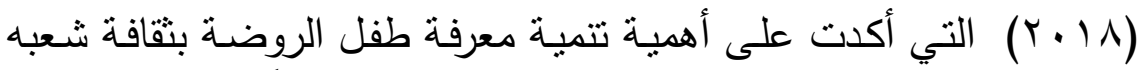

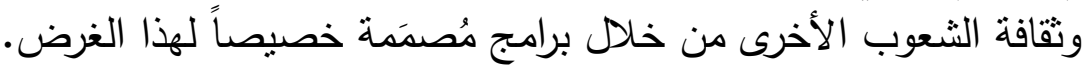
• كذللك ساهم البرنامج في مساعدة الأطفال على التعلم باستخدام الحواس مـن خـلال القصص الإلكترونيـة والتطبيقات التربوبـة المصـحوبة بالصـوت 


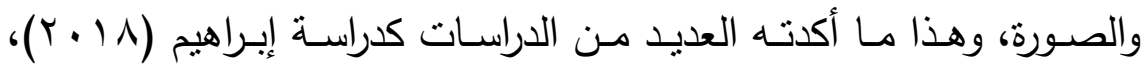

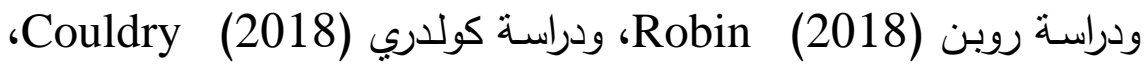

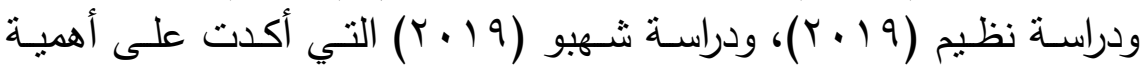

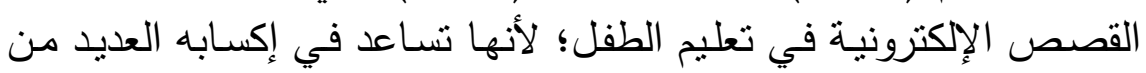

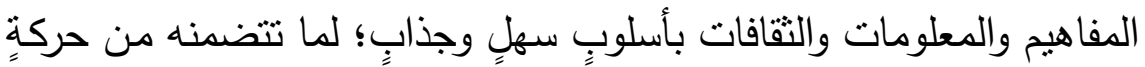

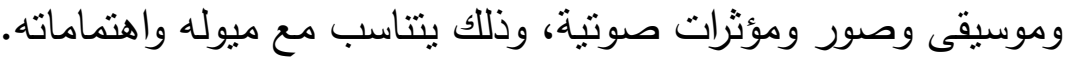
• كذللك سـاهت القصص الإلكترونية في الارتقاء بمستوى الأطفال في

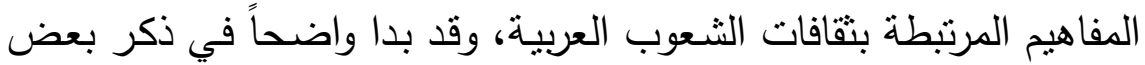

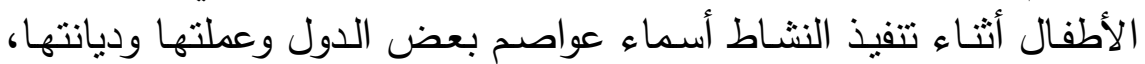

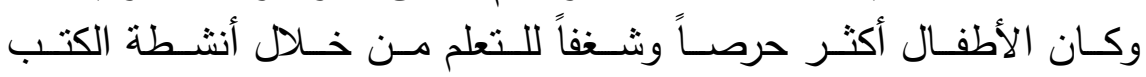
الإلكترونية.

• ما ظهر تقدماً ملحوظاً على الأطفال في استخدام أجهزة الحاسب الآلي الإلي والتعامل مـع أنشطة الكتب الإلكترونيـة بشكلٍ جيدٍ وزيـادة دافعيـة الأطفال

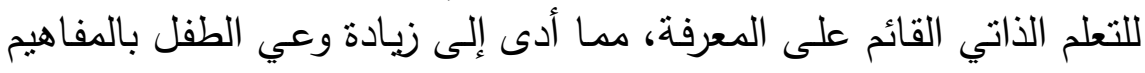

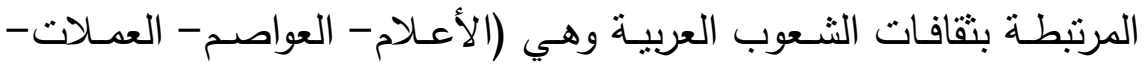

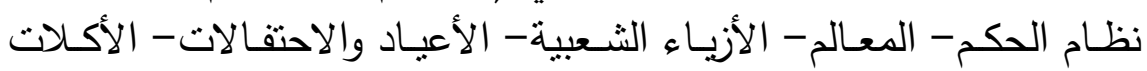
الثعبية- الديانة).

وتخلص الباحثة إلى تحقق صحة الفرض الأول والذي ينص على: "وجود

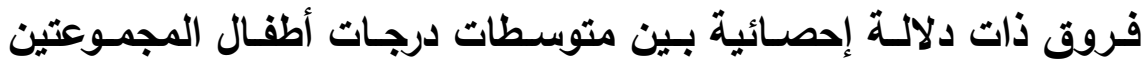

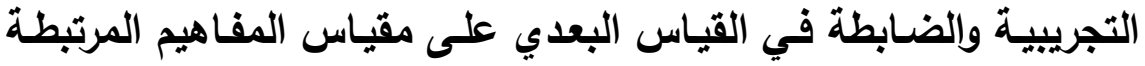
بثقافات الثعوب العربية المصور لصالح المجموعة التجريبية". 


\section{نتائج الفرض الثاني وتفسيره:}

ينص الفرض الثاني على أنها "توجد فروق ذات دلاتلة إحصائية بين

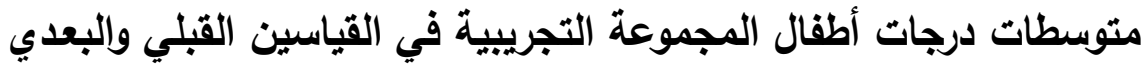

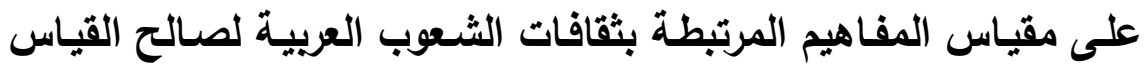

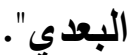

وللتحقق مـن صـحة هذا الفرض استخدمت الباحثة اختبـار "ت" لإيجـاد

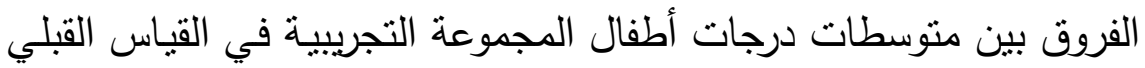

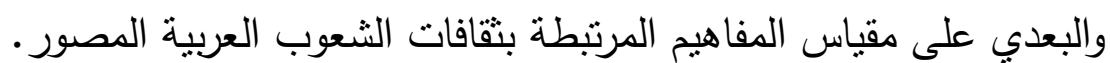

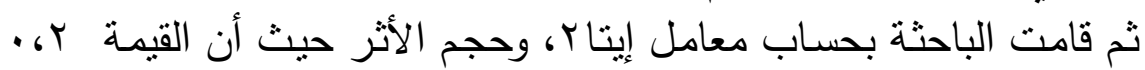

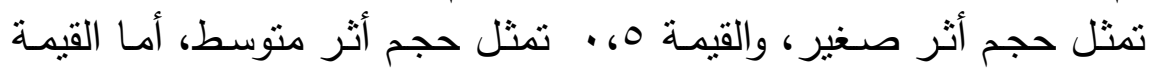

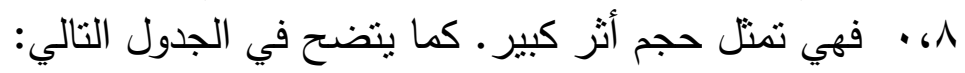
جدول (11)

الفروق بين متوسطات درجات أطفال المجموعة التجريبية في القياسين القبلي والبعدي

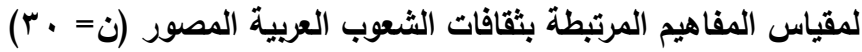

\begin{tabular}{|c|c|c|c|c|c|c|c|}
\hline \multirow[t]{2}{*}{ الأثج } & \multirow[t]{2}{*}{ ايتام } & \multirow[t]{2}{*}{ اتجاه الالالة } & \multirow[t]{2}{*}{ مستلوي } & \multirow[t]{2}{*}{ "تيمة } & \multicolumn{2}{|c|}{ القياسين القبلين } & \multirow[t]{2}{*}{ المتغيرات } \\
\hline & & & & & مج ح & م ف & \\
\hline متوسط & $\cdot$ & فألقياس اتجاه & $\cdot, \cdot$, & $\gamma, \cdots$ & $1, r \lambda$ & 1,174 & 1- الأعلام \\
\hline متوسط & $\cdot, \mathrm{VV}$ & في ألقياس & $\cdot, \cdot 1$ & $9, \wedge \uparrow$ & $1, r^{9}$ & $T, \Gamma T$ & ז- العواصم \\
\hline كبير & $\cdot, \wedge$ & فالقياس اتجاه & $\cdot, \cdot, 1$ & $1 \cdot, \cdot 9$ & $1, Y Y$ & T,YT & بـ العملات \\
\hline
\end{tabular}


المجلة العلمية لكلية رياض الأطفال - جامعة بورسعيد

\begin{tabular}{|c|c|c|c|c|c|c|c|}
\hline \multirow[t]{2}{*}{ الأثز } & \multirow[t]{2}{*}{ معامل } & \multirow[t]{2}{*}{ اتجاه الدلالة } & \multirow[t]{2}{*}{ مستوى الالالة } & \multirow[t]{2}{*}{ "قيمة" } & \multicolumn{2}{|c|}{ القياسين القبلي } & \multirow[t]{2}{*}{ المتغيرات } \\
\hline & & & & & مج ح & م ف & \\
\hline متوسط & $\cdot, V I$ & التي التياس & $\cdot,+1$ & $\Lambda, 7 \mu$ & $1, T_{1}$ & $r, \cdot T$ & ع الحكم \\
\hline كبير & $\cdot, \wedge 0$ & التي اتجياه & $\cdot, \cdot 1$ & 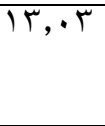 & $\cdot, \wedge 7$ & $Y, \cdot T$ & هـالمعالم \\
\hline كبير & $\cdot, \wedge \varepsilon$ & التي اتجاه & $\cdot, \cdot 1$ & Tr, $\leq 7$ & $\cdot, 94$ & $r, I T$ & الثـالزبي \\
\hline متوسط & $\cdot, \mathrm{VO}$ & في التياس اتجاه & $\cdot, \cdot 1$ & $9,0 V$ & $1, Y V$ & T,YT & والاحتفالات \\
\hline كبير & $\cdot, \wedge r$ & في التّباس البّاه & $\cdot, \cdot 1$ & $11, \wedge \varepsilon$ & 1,49 & $r, Y T$ & الشعبية الأكلات \\
\hline كبير & $\cdot, \wedge T$ & في التّباس البجاه & $\cdot, \cdot 1$ & $11, \lambda r$ & 1,49 & $r, \Lambda$ & 9-الديانة \\
\hline كبير &., $9 \leq$ & في التياس التجاه & $\cdot, \cdot 1$ & YY,VA & $\varepsilon, \vee q$ & 19,94 & الكلية الدرجة \\
\hline
\end{tabular}

ت = 1, 1, 1, عند مستوى 0., .

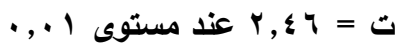

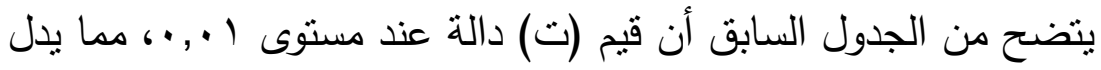

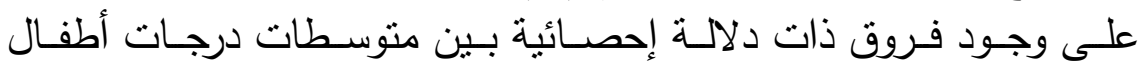
المجموعة التجريبية في القياسين القبلي والبعدي على دلى أبعاد مقياس المفاهية البهات المرتبطة بثقافات الثعوب العربية المصور لصالح القياس البعدي. 


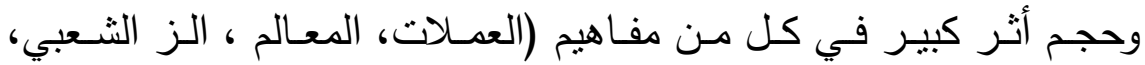

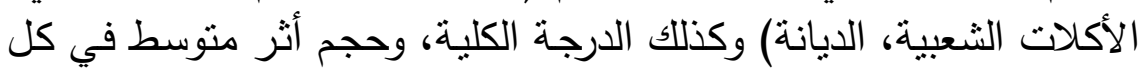
من مفاهيم (الأعلام، العواصم، نظام الحكم، الأعياد والاحتفالات) وحتر).

وقد قامت الباحثة بايجاد نسبة التحسن بين متوسطات درجات أطفال

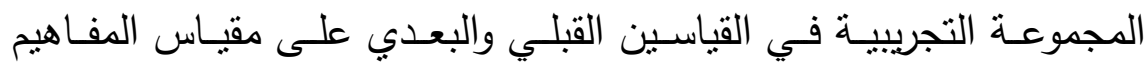
المرتبطة بثقافات الثعوب العربية المصور ، كما يتضح في الجدول التالي:

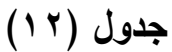

نسبة التحسن بين متوسطات درجات أطفال المجموعة التجريبية في القياسين القبلي

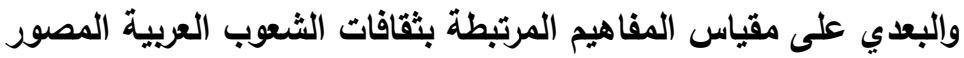

\begin{tabular}{|c|c|c|c|}
\hline نسبة التحسن & القياس القبلي & البعدي & المتغيرات \\
\hline$\% \Upsilon \wedge, r$ & $r, q$ & $\varepsilon, V$ & 1-الأعلام \\
\hline$\% 07,1$ & 1,1 & $\varepsilon, 1$ & r - العواصم \\
\hline$\% \circ Y, V$ & $T, \cdot T$ & $\varepsilon, \Gamma$ & بـ- العملات \\
\hline$\% \leqslant 9, \vee$ & T,. T & $\varepsilon, 1$ & ـ ـ-نظام الحكم \\
\hline$\%$ \%r,ᄉ & $r, q$ & 9.0 & 0ـ-المعالم \\
\hline$\% \leqslant 1,1$ & $r, \cdot$ & 0,1 & דـ الزي الثعبي \\
\hline$\% \leqslant \varepsilon, \wedge$ & $Y, Y$ & $\varepsilon, 9$ & V-الأعياد والاحتفالات \\
\hline$\% \circ Y, Y$ & r, & $\varepsilon, \xi$ & 1_-الأكلات الشعبية \\
\hline$\% \neg \Lambda, r$ & $1, r$ & $1, \varepsilon$ & 9-الديانة \\
\hline$\% \leqslant \vee, \varepsilon$ & TY & $\varepsilon 1,9$ & ـالارجة الكلية \\
\hline
\end{tabular}


ويوضح جدول (Y M) نسب التحسن الملحوظ في جميع المفاهيم المرتبطة

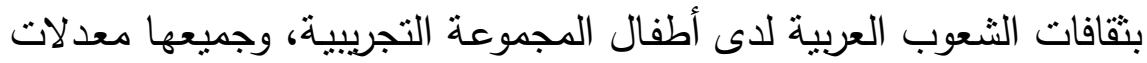

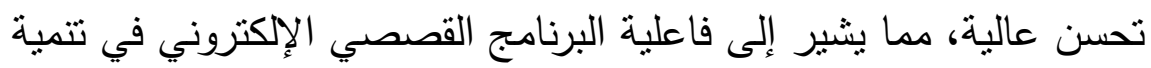
تللك المفاهيم لدى طفل الروضة.

\section{تفسير نتيجة الفرض الثاني :}

ترجيع الباحثة تفوق المجموعـة التجريبيـة في القياس البعدي عن القيـاس القبلي إلى : ترجى :

1- تعرض أطفال المجموعـة التجريبية للقصص الإلكترونية التي هدفت

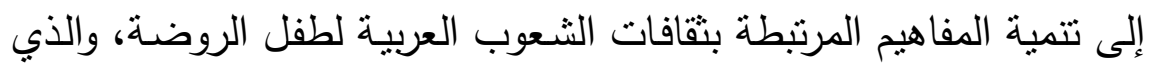

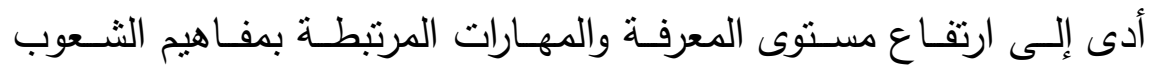

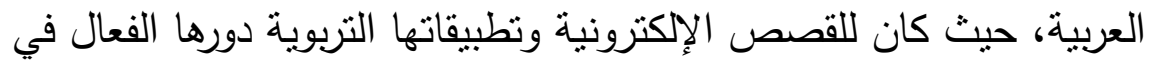

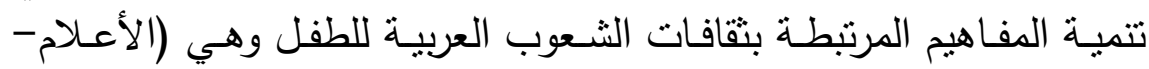

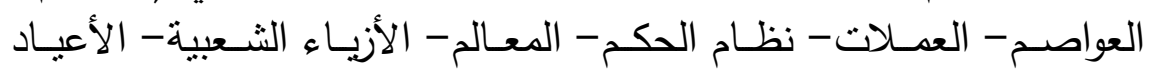

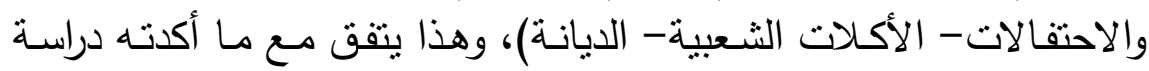

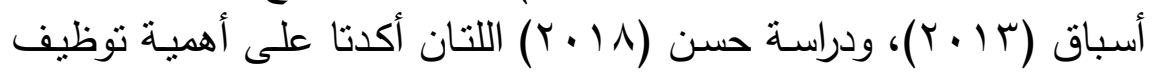

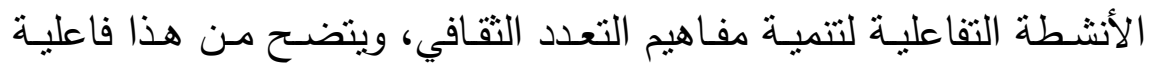

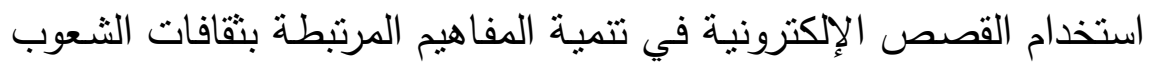

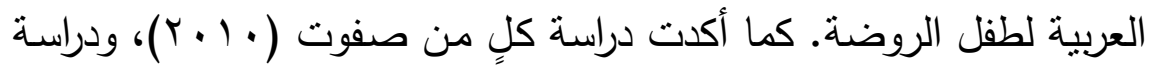

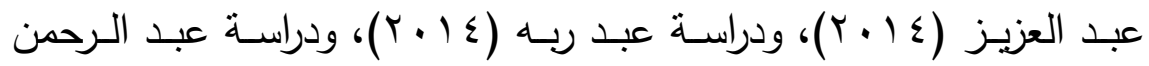

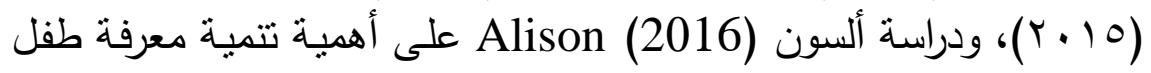

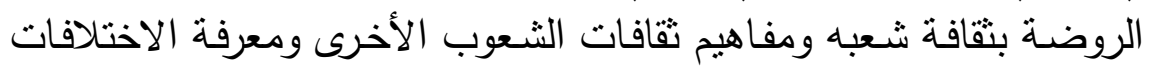
بينهم لحمايته من التأثير السلبي لتطورات العولمة. 
r- التجاوب مـع أسئلة الأطفال، واستجابتهم حول المفاهيم التي تعلمونها

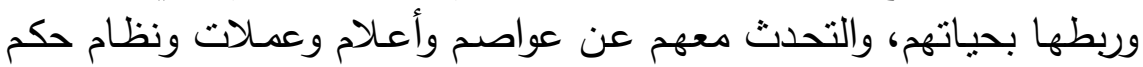
ومعالم وزي وأعياد وأكلات وديانة بعض ولته الدول.

r- مناسبة القصص الإلكترونية المتضمنة بالبرنامج للخصائص النمائية لطفل الروضة.

ع- استخدام الباحثة أساليب متعددة من أجل تتجيع الطفل حيث كان هذا

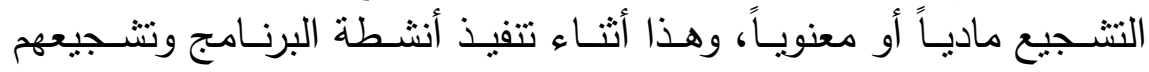
باستمرار على أدائهم ومشاركتهم في الأنشطة.

ه- استخدام العديد من الأدوات والوسائل التعليمية والتي استخدمها الطفل بنفسه، مما ساعد على شعور الطفل بالإنجاز وزيادة رغبته في المشاركة في الإني جميع أنشطة البرنامج.

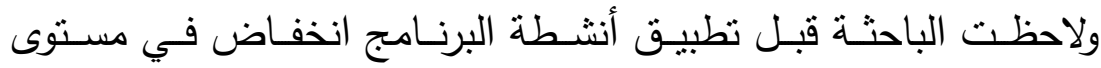

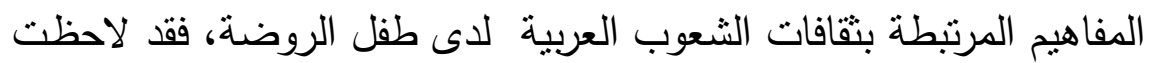

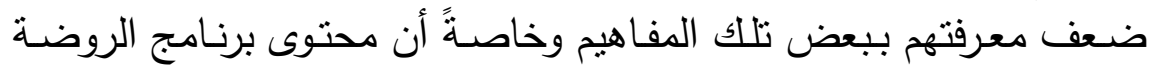
يفتقر إلى تللك المفاهيم. كذللك لاحظت الباحثة أثناء تطبيق البرنامج أصبح

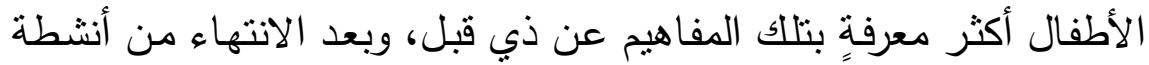

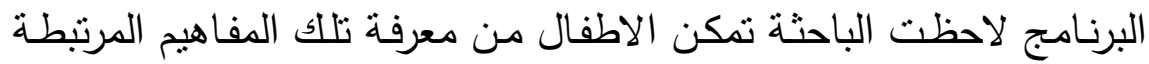
بثقافات الثعوب العربية بشكلٍ كبيرٍ ، والتمييز بينها بشكلٍ أفضل من من مرحلة

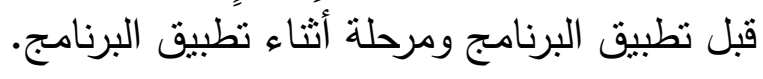

وتخلص الباحثة مما سبق إلى تحقق صحة الفرض الثاني والذي ينص

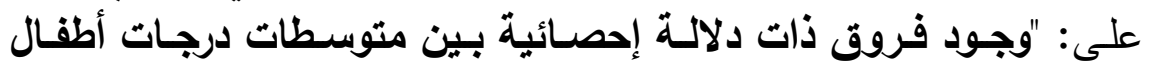


المجموعة التجريبية في القياسين القبلي والبعدي على مقياس المفاهيم المرتبطة بثقافات الثعوب العربية المصور لصالح القياس البعدي".

\section{نتائج الفرض الثالث وتفسيره :}

ينص الفرض الثالث على أنه "لا توجد فروق ذات دلالة إحصائية بين

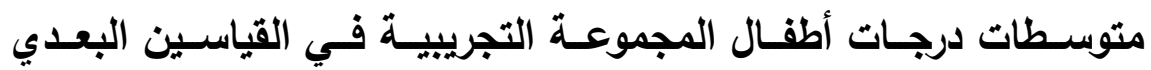

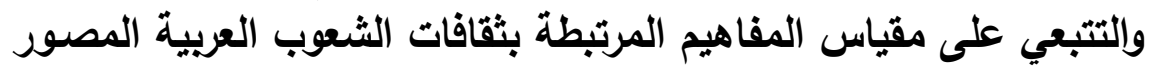

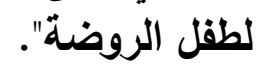

وللتحقق من صحة هذا الفرض استخدمت الباحثة اختبار "ت" لإيجاد

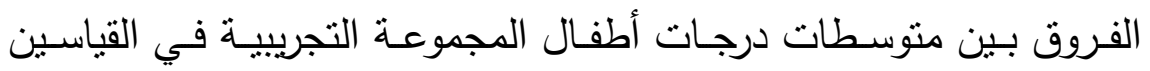

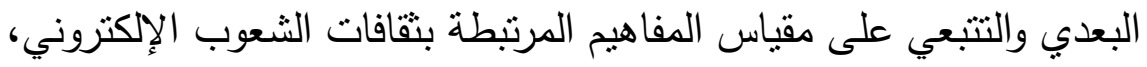
كما يتضح في الجدول التالي:

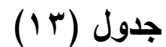

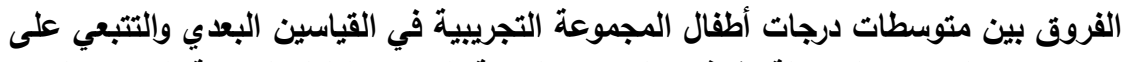

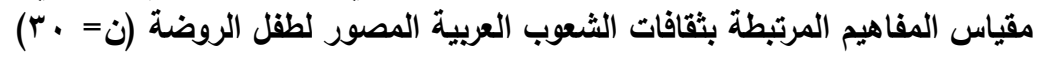

\begin{tabular}{|c|c|c|c|c|}
\hline \multirow{2}{*}{ الدالة } & \multirow[t]{2}{*}{ "تيمة } & \multicolumn{2}{|c|}{ الفرق بين القياسين البعدي } & \multirow[t]{2}{*}{ المتغيرات } \\
\hline & & ميج ح ف & م ف & \\
\hline - & $1, \cdots$ & $\cdot, \mathrm{VA}$ & $\cdot, 1 Y$ & 1- الأعلام \\
\hline- & .,OY & $\cdot, \mathrm{v}$ & $\cdot, \ldots 7$ & ץ- العواصم \\
\hline- & $1, \cdots$ & $\cdot, V_{1}$ & $\cdot, 10$ & r- العملات \\
\hline- & $1, \cdots$ & $\cdot, \vee \vee 9$ & $\cdot, M$ & ـ - نظام الحكم \\
\hline- & $\cdot, 0 \times 1$ & • & $\cdot, \ldots 7$ & ه-المعالم \\
\hline
\end{tabular}


المجلة العلمية لكلية رياض الأطفال - جامعة بورسعيد

\begin{tabular}{|c|c|c|c|c|}
\hline \multirow{2}{*}{ الدالة } & \multirow[t]{2}{*}{ "تيمة } & \multicolumn{2}{|c|}{ الفرق بين القياسين البعدي } & \multirow[t]{2}{*}{ المتغيرات } \\
\hline & & مج ح ف & م ف & \\
\hline - & $\cdot, \leqslant 9$ & $\cdot, V T$ & $\cdot, \cdots 7$ & צ-الزي الشعبي \\
\hline - & $1, \ldots$ & $\cdot, V_{1}$ &., 10 & 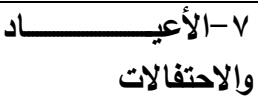 \\
\hline- & $1, \ldots$ & $\cdot, \vee \wedge \wedge$ & $\cdot, 1 \pi$ & 1-الأكلات الشعبية \\
\hline - & $\cdot, V Y$ & 1,01 & $\cdot, r$. & 9-الايانة \\
\hline - & אוr & $1, \Gamma \varepsilon$ & $\cdot$, ro & -المقياس ككل \\
\hline
\end{tabular}

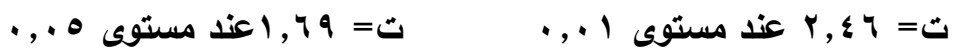

يتضح من الجدول السابق عدم وجود فروق ذات دلالة إحصائية بين

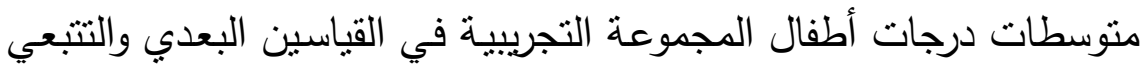

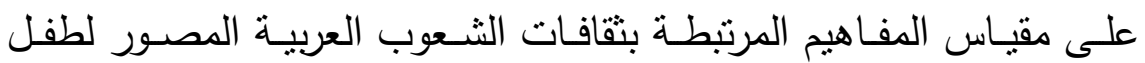

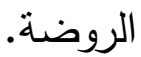

\section{تفسير نتيجة الفرض الثالث:}

تثبير نتائج الفرض الثالث إلى عدم وجود فروق دالة إحصائياً بين

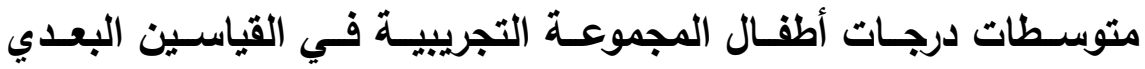

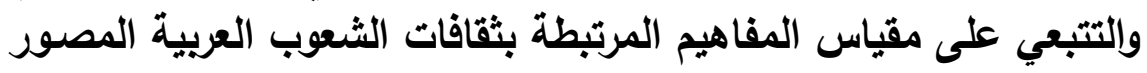

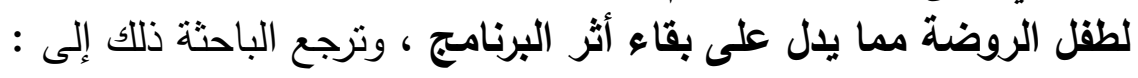
برنامج القصص الإلكترونية بالإضافة إلى الخبرات المباثرة التي تتيحها الأنشطة المصاحبة من خلال التطبيقات التربوية المتنوعة. 
بالإضافة إلى الخروج عن النمطية في تقديم الأنشطة وخاصة من حيث

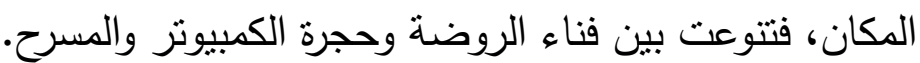

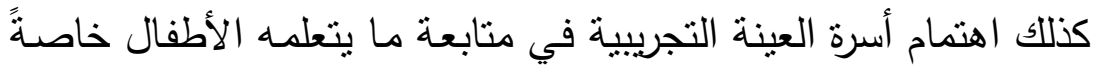

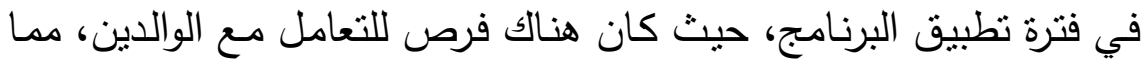

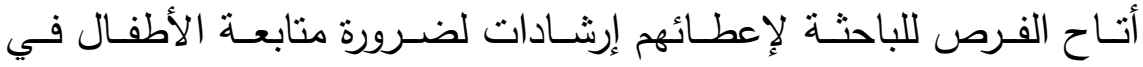

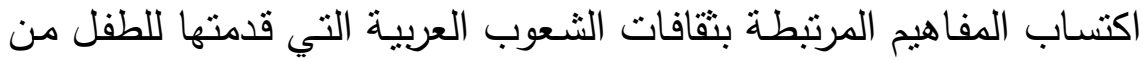
خلال القصص الإلكترونية، والتعرف على بقاء أثزها مما يحقق صحة هذات التها

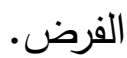

تبسيط المعلومات للطفل، وتدرجها من السهل إلى الصعب.

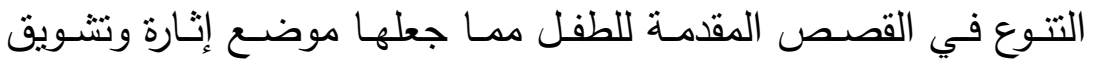
للطفل.

مراعاة خصائص الطفل واحتياجاته وقدراته عند تقديم أنشطة البرنامج. مواظبـة أطفـال العينـة على الحضـور إلىى الروضــة طـوال مدة تطبيـق

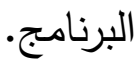
ومما سبق تستخلص الباحثة أن برنامج المقترح الذي صممته الباحثة

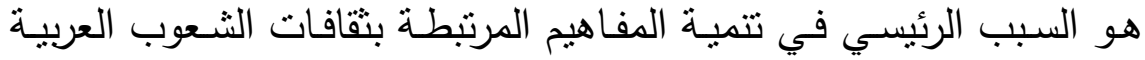

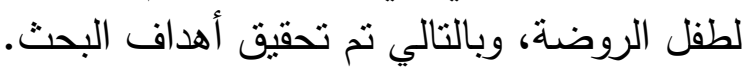

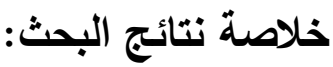
من خلال البحث تحققت جميع الفروض، وكانت النتائج كالتالي:

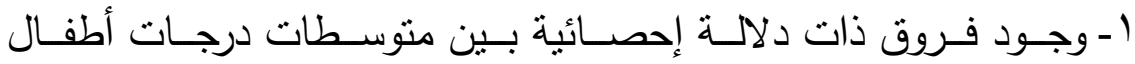

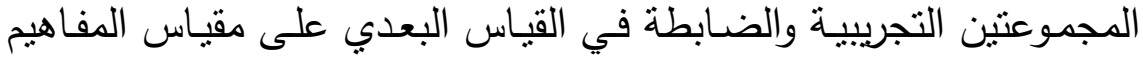

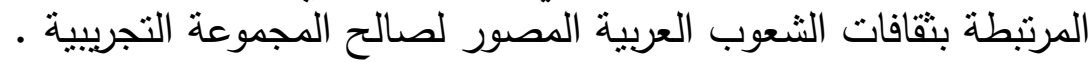


ץ- وجـود فـروق ذات دلالــة إحصـائية بــين منوسـطات درجـات أطفـال

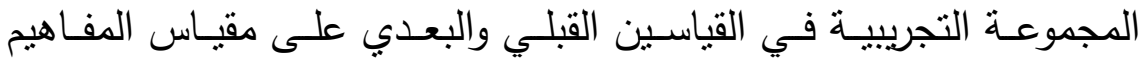
المرتبطة بثقافات الثعوب العربية المصور لصالح القياس البعدي. r- عدم وجود فروق ذات دلالـة إحصـائية بين متوسطات درجات أطفال

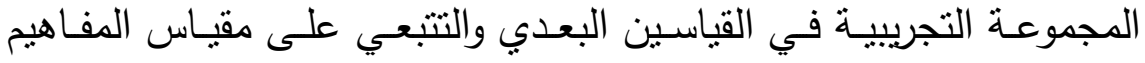
المرتبطة بثقافات الثعوب العربية المصور لطفل الروضة.

\section{التوصيات والمقترحات :}

1-تدريب معلمات الروضات على استخدام الوسائط المتعددة والتكنولوجية

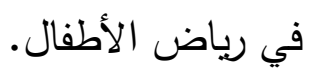

r-تفعيل دور القصص الإكترونية في تعليم وتعلم الأطفال.

ب-الاهتمـام بالأنشطة التي تتمسى تقافـة الطفل الخاصـة بشعبه والخاصـة

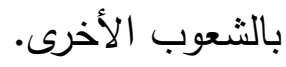
ع -الاهتمام بالأنشطة المحببة للطفل واستثمارها في عملية التعلم. المراجع

أولاً : المراجع العربية :

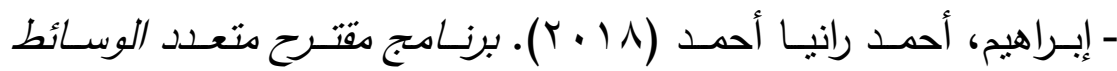

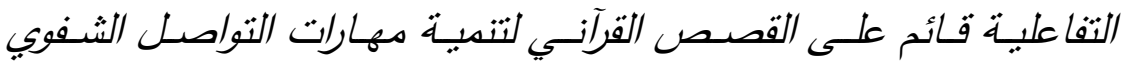
والاستعداد للقـراءة لـدى أطفال الربـاض ( رسـالة دكتوراه غيـر منشـورة). جامعة المنصورة، كلية التربية. 
- أبو حرب، يحيى حسين (11 + (1). توجهات في المنهج التربوي.الكويت

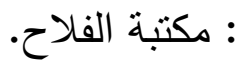

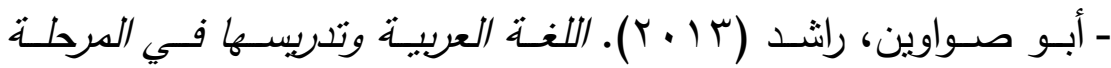
الأساسية الدنبا وتطبيقاتها الصفية هوان غزة: مكتبة الطالب.

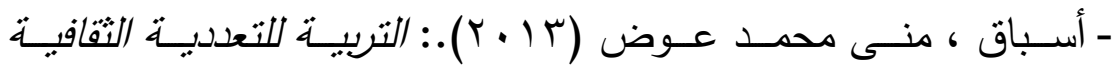
وانعكاستها على تتشئة الطفل الدصري في مرحلة رياض الأطفال ( رسالة دكتوراه غير منشورة). كلية رياض الأطفال. جامعة الإسكندرية.

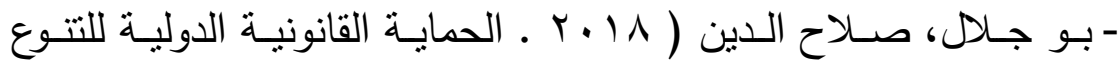

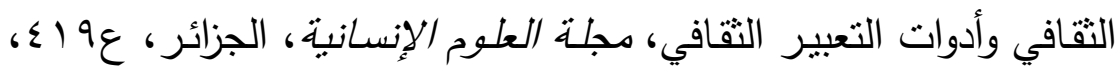
$. r) \cdot-\mid V \wedge$

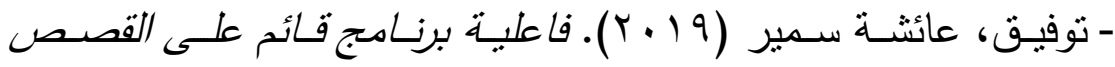

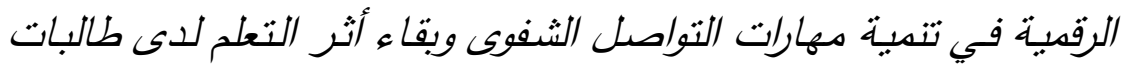
الصف الرابع الأساسسي بغزة( رسالة ماجستير غير منشورة) كلية التربية، جامعة الأزهر - غزة.

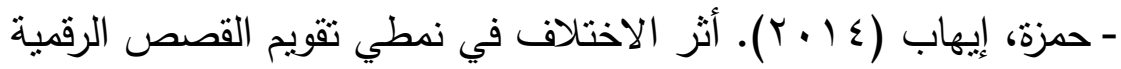

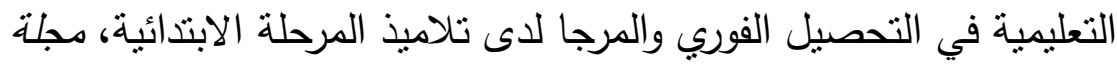

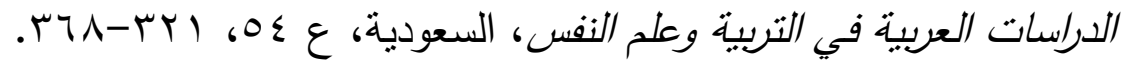

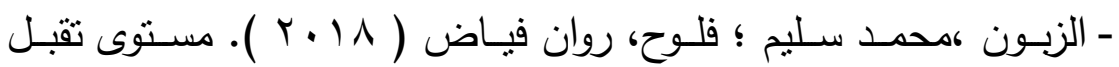

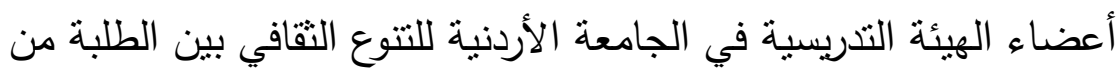

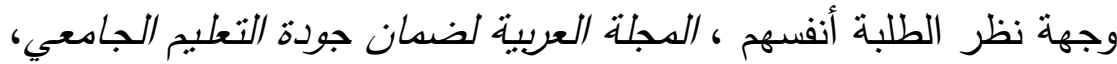
(1) (1) 
- الزين، أميمة سميح ( 10 ـ ) ). التتوع الثقافي إثراء إنساني أم صدام

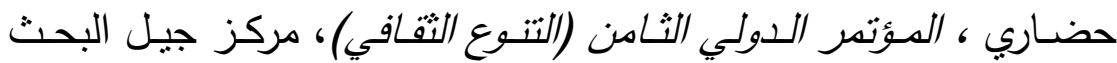
العلمي، لبنان، طرابلس. - سافيدان، باتريك ( 11 ( ب ). الدولة والتعدد الثقافي (ترجمة: المصطفى حسوني)، دار بقل للنشر • بانس

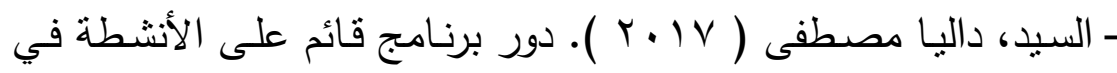

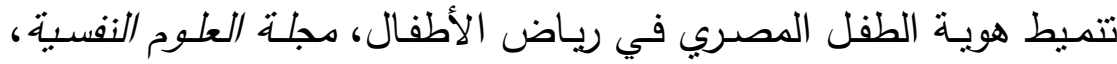
r r

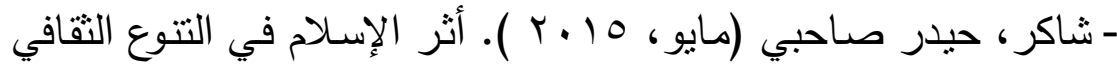

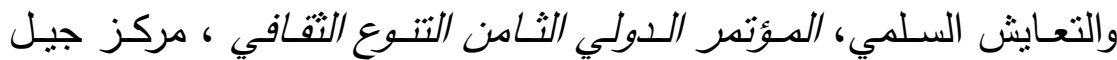

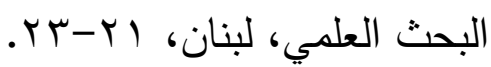

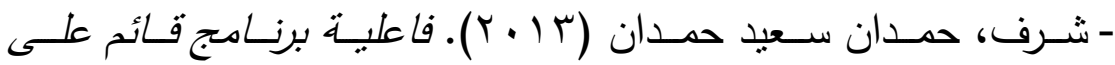
القصص الإككترونيـة في تنميـة بعض مهارات الاستما ع لـدى تلاميذ

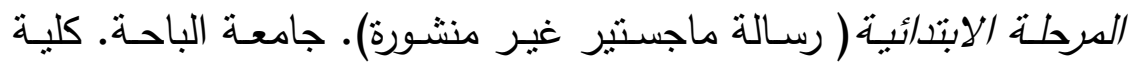

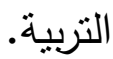

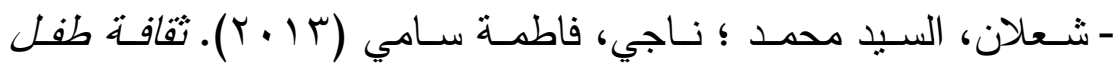
الروضة. القاهرة: دار الكتاب الحديث.

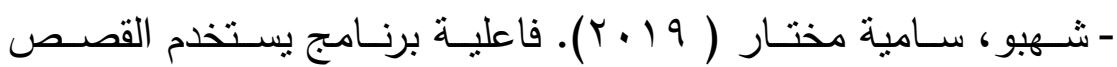

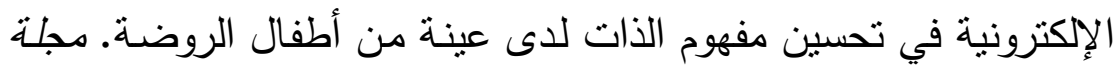

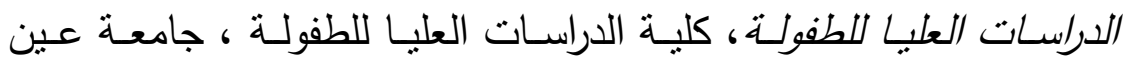

$$
\text { شمس، r }
$$


- صـفوت، حنـان ( ( + (Y). فاعليـة برنـامج مقتـرح باســتخدام الألعـاب

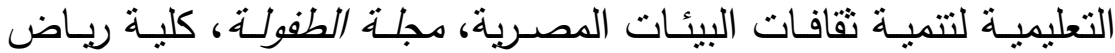

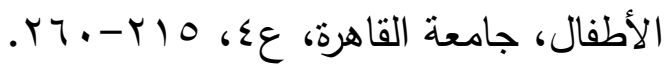

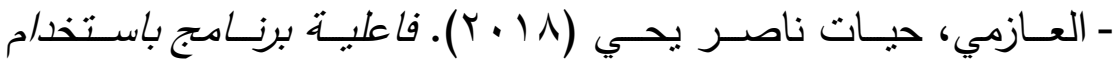
القصص الإلكترونية في تندبة الحصبلة اللغوبية والذكاء الاجتماعي لدى أطفال الروضـة ( رسـالة ماجستير غير منشـورة). جامعـة جنوب الوادي. كلية التربية.

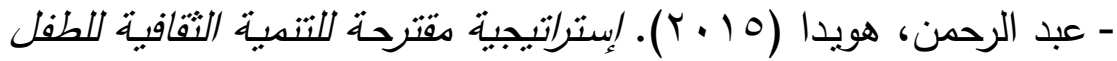
المعسري (رسـالة دكتوراه غبـر منشـورة). كليـة الدراسـات العليـا للتربيـة. جامعة القاهرة.

- عبد العزيز ، رشا فؤاد توفيق (ع ا • r). التربية الفنية والموسيقية كمدخل لتتميـة المفاهيم المرتبطة بثقافات الثـعوب لطفل الروضـة، مجلـة البحث العلمي في التربية، مصر ،

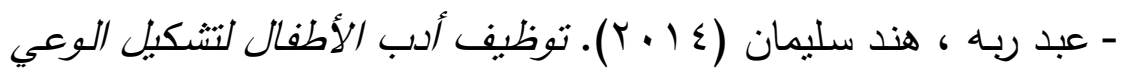
بالثقافـات المتعددة لـى طفل الروضـة ( رسـالة ماجسـتير غير منشـورة). كلية رباض الأطفال . جامعة القاهرة. - عسقول ، محمد عبد الفتاح ( • ( . )، الوسائل والتنكنولوجيا في التعلبم بـبن الإطلار الفلسفي والإطلار التطبيةقى الطبعـة الثانيـة) . غـزة. مكتبـة الطالب.

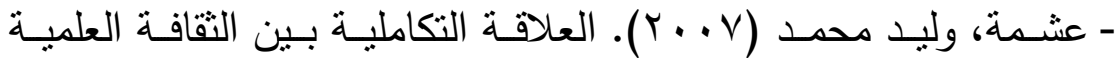
والإعـلام والتعليم الموجـه للطفل العربي، المهؤتمر الإفلبيهي الأول "الطفل 
العربي في ظل المتغبرات المعاصرة گro-r ب بناير"، كلية البنات، مركز البحوث والدراسات والخدمات المتكاملة، 77.

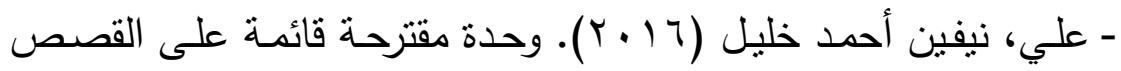
الإككترونية في تتمية بعض المفاهيم العلمية لدى أطفال الروضـة، مجلة اهلة

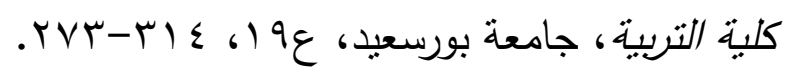

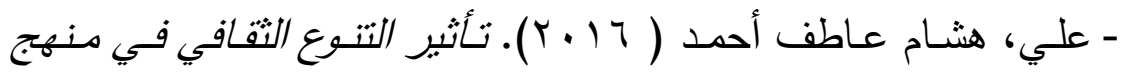

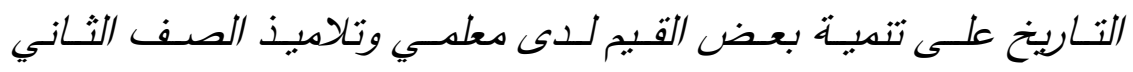
الإعدادي( رسالة دكتوراه غير منشورة ). جامعة عين شمس. كلية التربية.

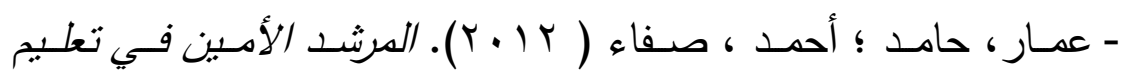

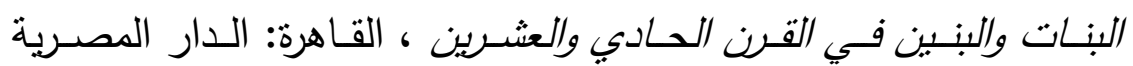
اللبنانية.

- كامـل، عـلا حسن (1 ( • ب). فاعليـة كتب الأطفـال الإلكترونيـة لتتميـة

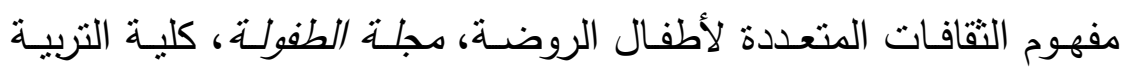

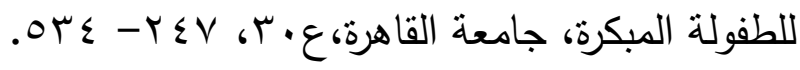

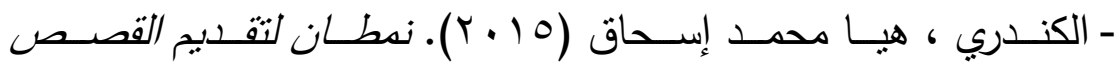
الإككترونبية وأثرها على تنمية بعض الخبرات والثقافة البصرية لدى أطفال

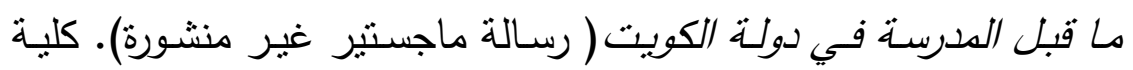

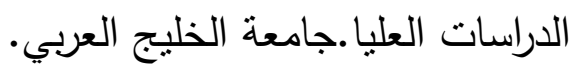

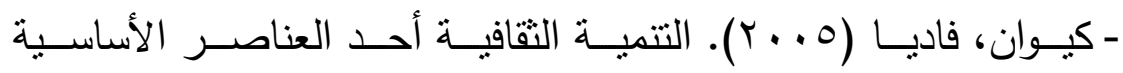
للإستراتيجية الإنمائية نحو سياسـة ثقافية عربية للتتميـة، المنظمة العربية

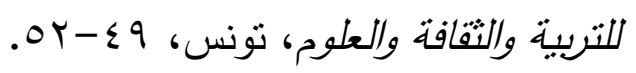




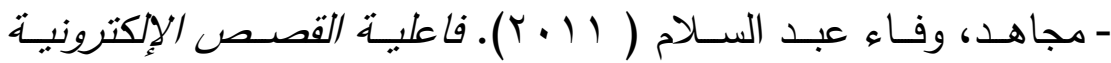
التفاعلية في تندبة الوعي السباسـي للأطفال ( ماجستير غير منشورة) . معهد الدراسات التربوية. جامعة القاهرة.

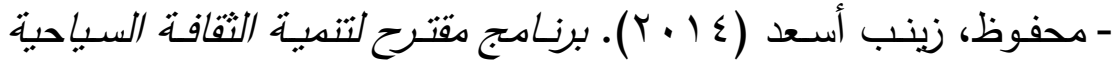

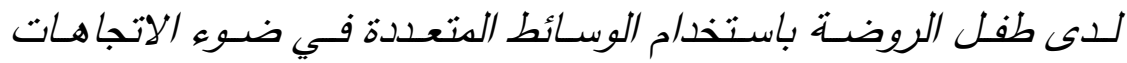

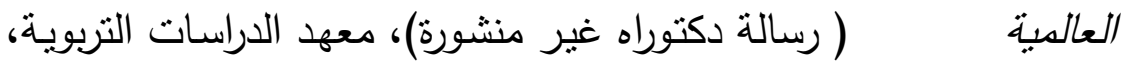

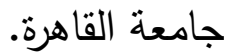

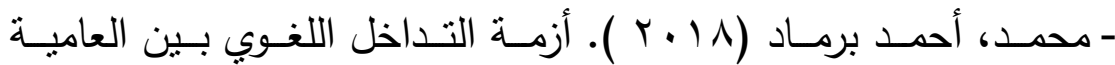

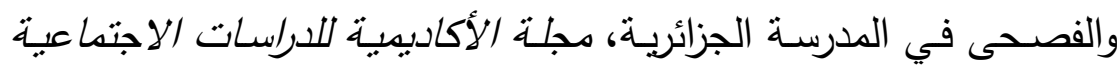

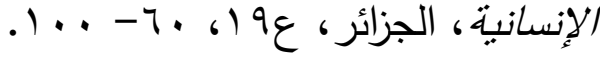

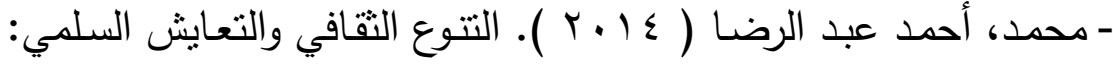

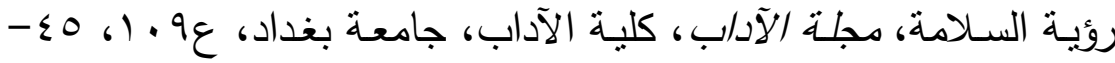
.9 .

- مصطفى،فهيم (1 . . r). مهارات القراءة الإلكترونية وعلافتها بتطويب

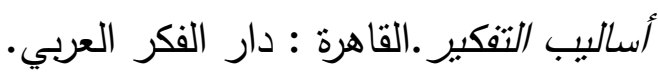
- مطر ، عبد الفتاح رجب ؛ مسافر، علي عبد الله ( • ب)، ندو الدفاهيب

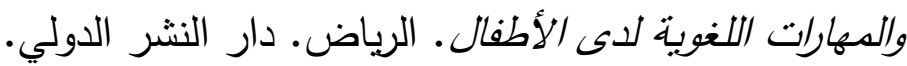

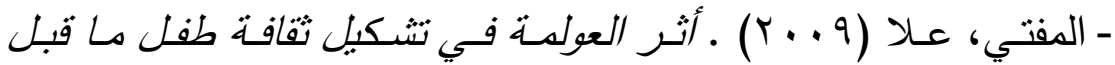
الددرسة ( دكتوراه غير منشورة ). كلية البنات. جامعة عين شمس.

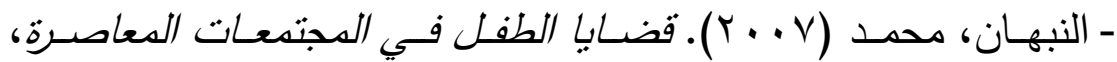

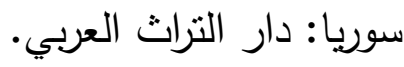


- نظيم، آلاء كمال (9 1 ـ r). أثر استخدم القصص الإلكترونية التفاعلية

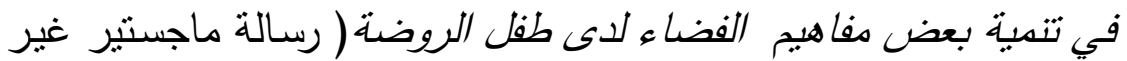
منشورة). كلية التربية للطفولة المبكرة. جامعة المنيا.

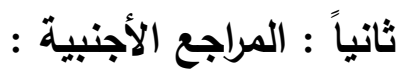

- Abdullah,A.(2009): Multicultural Education in Early Childhood Issue and Challenges Cice Hiroshima University, Journal of International cooperation in Education, 12(1), 159-175.

- Alison,G.(2016): Teaching Cultural Awareness Using the Four Skills, Master of Arts in Teaching Degree at the school for international training, Brattleboro, Vermont.

- Barrett,H. (2016): Reaearching and evaluating digital storytelling as adeep learning tool, Proceedings of Society for Information technology and teacher education international coference, 647-654.

- Becker,B. (2012): The Transfer of Cultural Knowledge in the Early Childhood: Social and Ethnic Disparities and the Mediating Role of Familial Activities, European Sociological Review, Volume 26, Issuel, 39-45.

- Borg,F. (2017): Economic in equality and sustainability preschool children's views of the economic situation of other children in the world: Early child Development and Care, 99. 
- Candreva,C. (2011): Digital storytelling in Kindergarten: Merging Literacy, Technology, and Multimodality.

- Condy,J. et.al.(2012): Pre-Service student's Pperceptions and experiences of digital storytelling in diverse classrooms, Turkish Online Journal of Educational Technology, 11(3), 278-285.

- Couldry,N. (2018): Digital Storytelling media research and democracy: conceptual choices and alternative futures, USA: Peter lang Publishing, Inc.

- Engle, A. (2011): Digital storytelling, USA: McGraw Publishing.

- John,w. , Nancy, p. ( 2012): The Greenwood Dictionary of Education, Second 'Edition , Santa Barbara, California , Denver, Oxford, England.

- Matthews, G.(2018): Digital storytelling: Tips and Resources, Boston, Simmons College.

- Ora Geiger (2017): Values and Ideology of aculture as reflected in its kindergarten singing, scientific research.

- Parks,J. (2016): Hatch early learning, The importance of teaching Multiculturalism\& Diversity.

- Porte, B.(2008): Digital storytelling, USA: Adobe Systems Incorporated. 
- Resnik,J. (2017): Multicultural Education- Good for Business but Not for the state? The IB Curriculum and Global Capitalism, British Journal of Education Studies, 57(3), 217-244.

- Robin, B. (2011): Digital storytelling Hands- ons $L a b$ : The Educational uses of digital storytelling, Austin.

- Roland,B. (2016): Digital Stories in the classroom, School Art, Vol.7, Issue105, 7-26 .

- Sangra,A.(2012): Building an Inclusive Definition of E-Learning: An Approach to the Conceptual framework, The International Review of Research in Open and Distance Learning, 13(2), 145-159.

- Susan Randoloph (2017): Digital storytelling gifted students, little river elementary shool, March, 28, 2.

- William,S. (2016): This Guy is Japanese stuck in a white man's body, A discussion of meaning making, identity slippage, and cross-cultural adaptation, Journal of Multilingual and multicultural development, 22(1), 30-65. 

برنامج قائم على خرائط التفكير الإلكترونية في تنمية مهارات

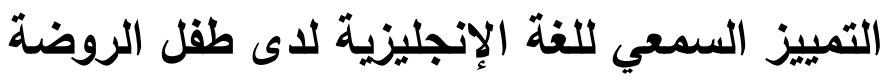

" أ.د/ جيهان محمود البسيوني."

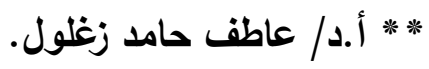

* * * * آية محمد عبد الباقي جودة.

\section{ملخص البحث :}

استهدف البحث الحالي قياس فاعلية برنامج قائم على إستراتيجية خرائط

التفكير الإكترونية في تتمية مهارات التمييز السمعي للغنة الإنجليزيـة لدى طفل الروضة، ولتحقيق هذا الهدف استخدمت الباحثة المنهج التجريبي ذي التصميم شبه التجريبي من خلال مجموعتين المجموعة الضابطة والمجموعة التجريبية، ونكونت العينة من( • ب) طفلاً وطفلةً من أطفال روضـة الحديدي

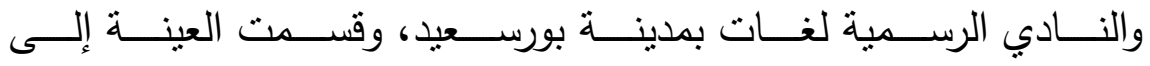
مجموعتين:المجموعـة التجريبيــة وقوامهــا(0 1 ) طفـلاً وطفلـةً ،والمجموعـة الضابطة وقوامها (0 1 ) طفلاً وطفلةً، واستخدمت الباحثة أيضاً قائمة مهارات

* أستاذ مناهج وطرق تدريس اللغة الإنجليزية -كلية التربية- جامعة بورسعيد.

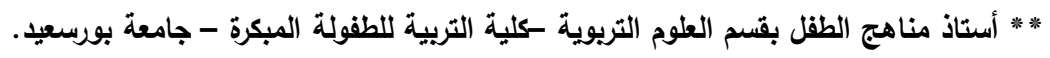
*** * *احثة دكتوراه بقسم العلوم التريوية -كلية التربية للطفولة المبكرة - جامعة بورسعيد. 
التمييز السمعي للبرنـامج للغنة الإنجليزيـة (إعداد الباحثة)، اختبار الذكاء المصور الذي وضعه "أوتيس -لينون" (إعداد مصطفى كامل)، والاختبار الإلكتروني المصور لقياس مهارات التمييز السمعي للغة الإنجليزية (إعداد الباحثة)، والبرنامج القائم على إستراتيجية التفكير الإلكترونية لتنمية مهارات

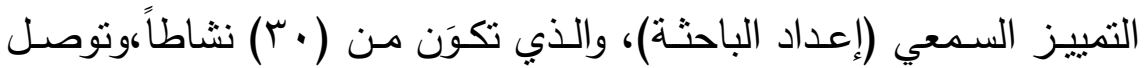
البحـث إلى أنـه توجد فروق دالـة إحصـائياً بين متوسطي درجـات أطفال المجموعة التجريبية في التطبيقين القبلي والبعدي لاختبار مهارات التمبيز السمعي للغـة الإنجليزية لدى طفل الروضـة لصالح التطبيق البعدي، توجد

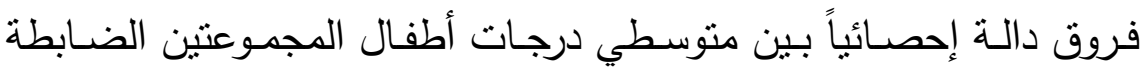
والتجريبيـة في التطبيـق البعـدي لاختبـار مهـارات التمييـز السـمعي للغــة

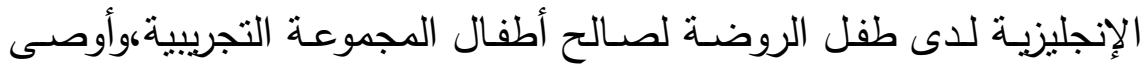
البحث بتنمية مهارات التمييز السمعي للغـة الإنجليزية باستخدام إستراتيجية خرائط التفكير الإلكترونية لطفل الروضة. 


\section{A program based on electronic thinking maps in} developing the auditory discrimination skills in English for kindergarten children

Prof.Dr/Jehan Mahmoud El-Bassuony. *

Prof.Dr / Atef Hamed Zaghloul. **

Aya Mohamed Abdel Baky Sayed Gouda. ***

\section{Abstract:}

The current research aimed to measure the effectiveness of a program based on the electronic thinking maps strategy in developing auditory discrimination skills in English in a kindergarten child, and to achieve this goal the researcher used the experimental approach with a quasi-experimental design through two groups, the control group and the experimental group, and the sample consisted of (30) children and girls. Of the children of AlHadidi Kindergarten and the Official Language Club in Port Said, the sample was divided into two groups: the experimental group consisting of (15) children and a girl, and the control group consisting of (15) children and girls. The researcher also used a list of skills Auditory discrimination for the program in English (the

* Professor of Curricula and Methods of Teaching English Language Faculty of Education - Port Said University.

** Professor of Child Curriculum, Department of Educational Sciences, Faculty of Education Early Childhood - Port Said University. *** Researcher, Department of Educational Sciences - Faculty of Early Childhood Education - Port Said University. 
researcher's preparation), the visual intelligence test developed by "Otis-Lennon" (Mustafa Kamel's preparation), the electronic video test to measure auditory discrimination skills in English (the researcher's preparation), and the program based on the electronic thinking strategy to develop auditory discrimination skills (Preparation of the researcher), which consisted of (30) activities, and the research found that there are statistically significant differences between the mean scores of the children of the experimental group in the pre and post applications to test the auditory discrimination skills in English in the kindergarten in favor of the post application, there are statistically significant differences between the mean The scores of the children of the control and experimental groups in the post application of the test of auditory discrimination skills in English in the kindergarten for the benefit of the children of the experimental group. The research recommended the development of auditory discrimination skills in English using the electronic thinking maps strategy for the kindergarten child.

الكلمات المفتاحية Keywords:

Electronic Thinking Maps خرائط التفكير الإلكترونية.

$$
\text { -مهارات التمييز السمعي للغة الإنجليزية. }
$$

Hearing discrimination skills in English

Kindergarten child

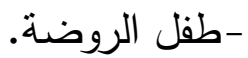




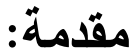

الطفولة هي أغلى وديعة من ودائع الله للإنسان فهي أمانة الأجيال، ولها

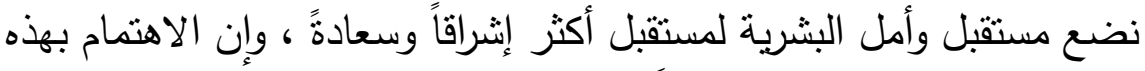

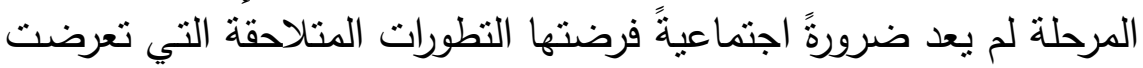

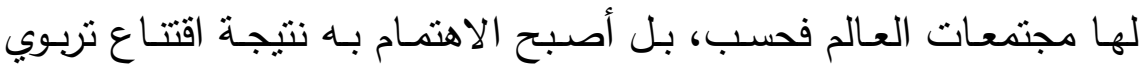
ونفسي وإدراك لأهمية هذه المرحلة من العمر .

إن النمو اللغوي لطفل ما قبل المدرسة يتحدد في زيادة قدراته الاستماعية

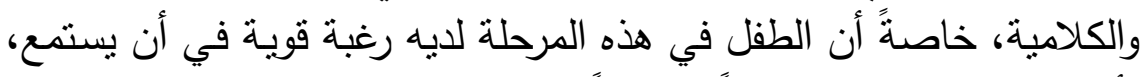
وأن يتكلم ويحقق بذللك تقدماً ملحوظاً من الناحية اللغوية.

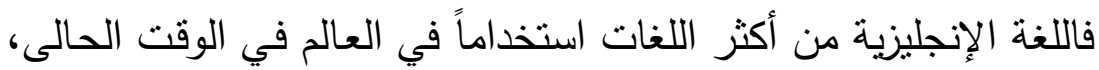

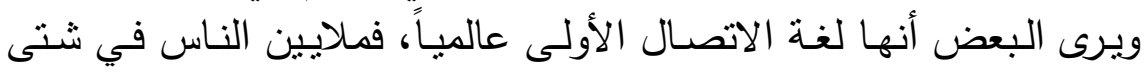

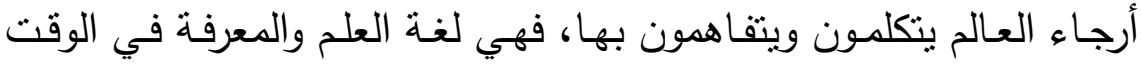

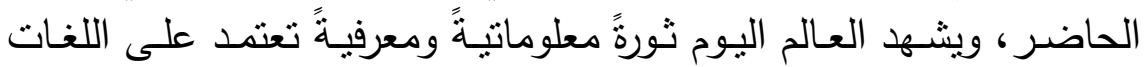

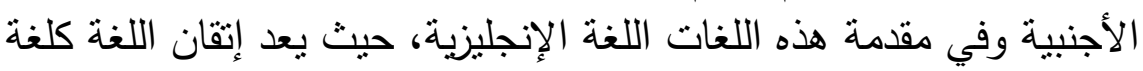

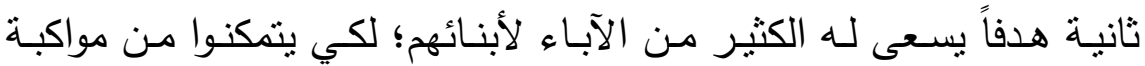

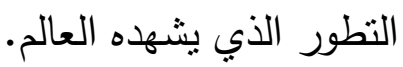

وكي يـتم تتميـة مهارات التمييز السـمعي للغــة الإنجليزيـة لـدى أطفـال

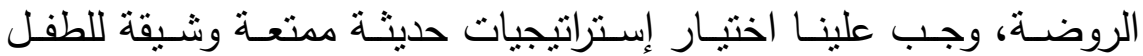

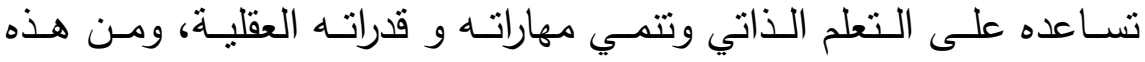

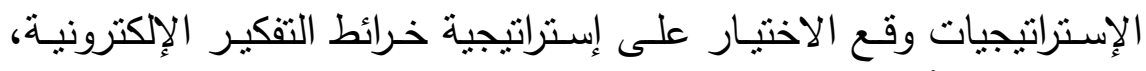

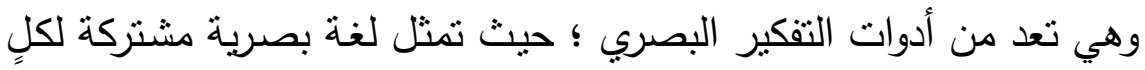
من الطفل والمعلمة. من ادوات 


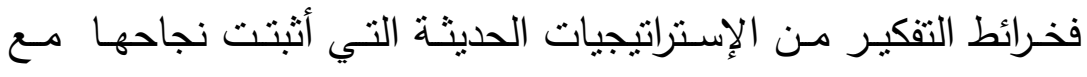

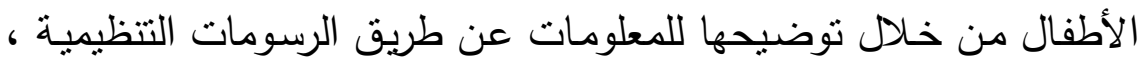
Hickie (2006) Madiri (2008) Sunseri Sومن هذه الدراسـات (2011) ، كما أثبتت العديد من الدراسات فاعلية إستراتيجية خرائط التفكير

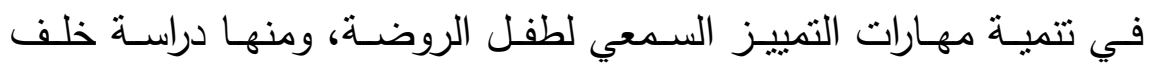

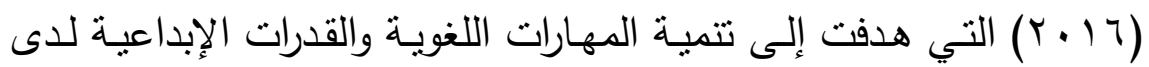

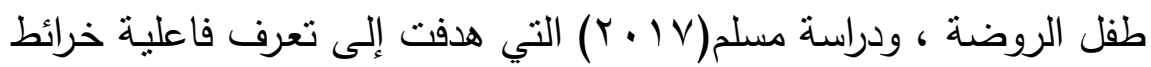
التفكير كإستراتيجية في تكوين بعض المفاهيم البيولوجية لدى طفل الروضة.

\section{مشكية البحث:}

بـدأ الاحسـاس بمشكلة البحث من خـلال تتفيذ المعلمـة لأنشـة اللغـة الإنجليزيـة في مرحلة ربـاض الأطفال ، حيبث لاحظت الباحثة ضعفاً في مهارات التمييز السمعي للغة الإنجليزية لإى العديد من أطفال المرحلة؛ مدا يعرضـهم إلى الضـف الأكاديمي مستقبلاً، وللتأكد من وجود هذه المشكلة الإنة

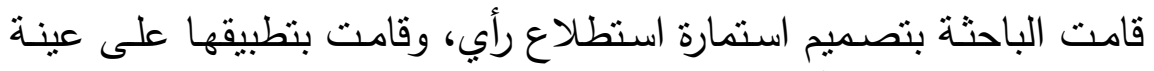

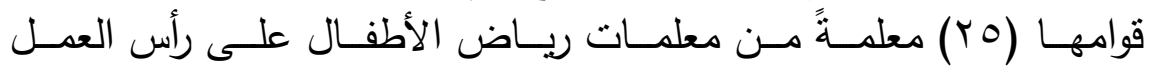

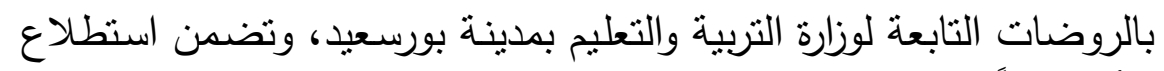

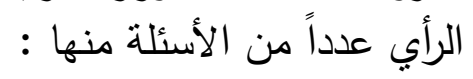

ما الصعوبات التي تواجه الأطفال في التمبيز السمعي للغة الإنجليزبة؟ مانه مالوقت الذي يستغرقه الأطفال لتذكر أنشودة موسيقية للغة الإنجليزية؟ هل بستطيع الطفل سرد قصة قصيرة للغة للغة الإنجليزبة بعد سماعها؟ كيف يميز الطفل الكلمات المتشابهة في النطق؟ • كيف يميز الطفل بين حروف اللغة الإنجليزبة المنشابهة في النطق؟ 


\section{وقد أوضحت نتائج الدراسة الاستطلاعية ما يلي:}

-أشـارت 00 \% من المعلمات استخدامهن للإستراتيجيات التقليدية مثل:

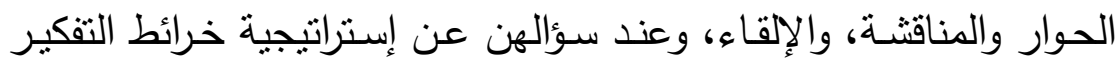

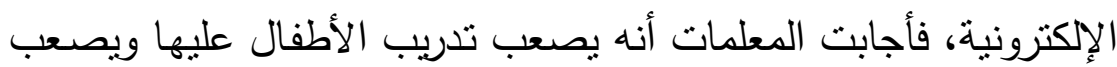
على المعلمات تتفيذها.

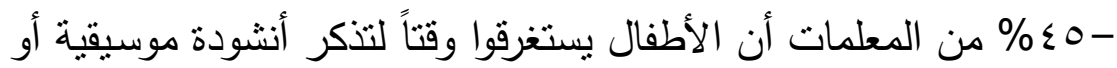
قصة للغة الإنجليزية.

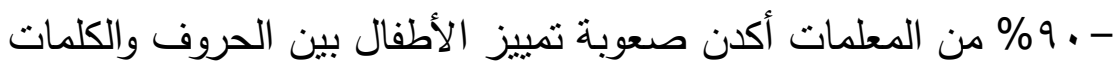
المنتابهة للغة الإنجليزية.

ومن خلال ما سبق فإن مشكلة البحث تتمثل في تتمية مهارات التمييز

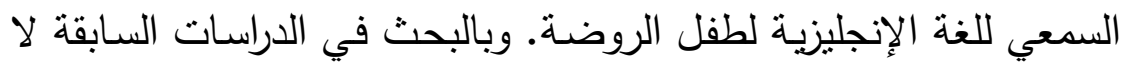

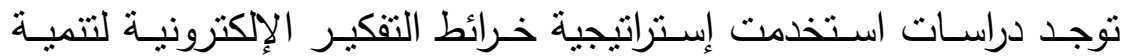
مهارات التمييز السمعي للغة الإنجليزية لطفل الروضة. ويحاول البحث الحالي الإجابة عن السؤال الرئيس التالي :

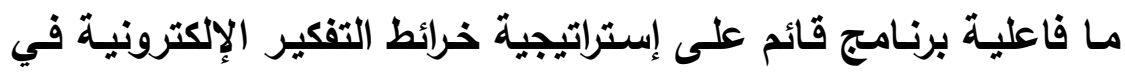

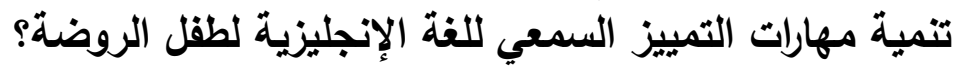

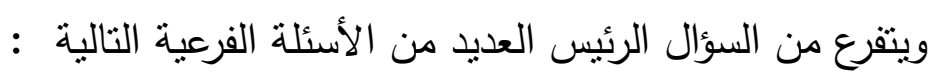

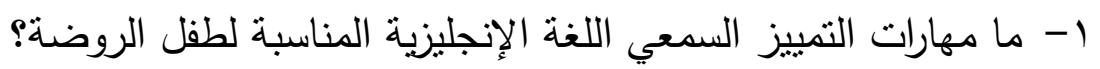

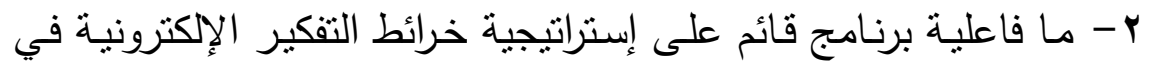

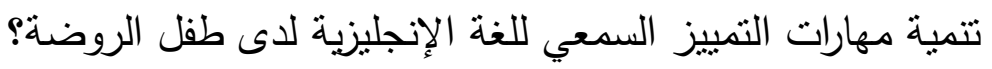




\section{هدف البحث:}

يهدف البحث الحالي إلى تتمبـة مهارات التمبيز السمعي للغـة الإنجليزيـة لـى طفل الروضـة باسـخدام برنـامج قائم على إسـراتيجية خرائط التفكير

$$
\text { أهمية البحثث: الإكتية. }
$$

الأهمية التظرية:

ا-تحديد مهارات التمبيز السمعي للغة الإنجليزية المناسبة لطفل الروضة.

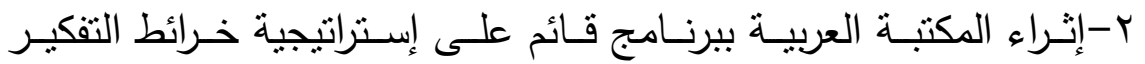

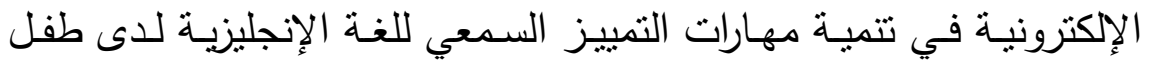
الروضة.

\section{الأهمية التطبيقية :}

ا ـ افادة معلمات الروضة في تتمية مهارات التمبيز السمعي للغة الإنجليزبة لطفل الروضة. r. إمداد القائمين على رعاية وتربية طفل الروضة ببرنامج مُصدَم في ضوء

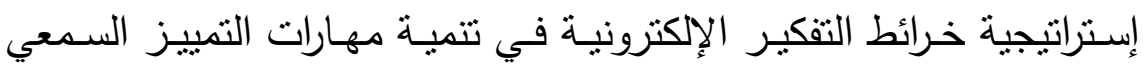
للغة الإنجليزية لطفل الروضة. م. قياس فاعلية برنامج قائم على إستراتيجية خرائط التفكير الإلكترونية في الإني تتمية مهارات التمبيز السمعي للغة الإنجليزية لطفل الروضة. 
- الحدود البشرية: نتمثل في أطفال الروضـة للمستوي الثاني من (0-7) سنواث. - الحـدود المكانيـة: يطبـق البحـث في روضــة مدرسـة الحديـدي والنـادي الرسمية للغات، وهي إحدى روضات الأطفال التابعة لوزارة التربية والتعليم بمحافظة بورسعيد.

- الحـدود الموضـوعية: بعض مهـارات التمبيز السـمعي للغــة الإنجليزبـة لطفل الروضة و باستخدام خرائط التفكير الإلكترونية.

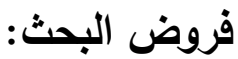

1- توجد فروق دالـة إحصـائياً بين متوسـي درجـات أطفـال المجموعـة التجريبية في التطبيقين القبلي والبعدي لاختبار مهارات التمبيز السمعي للغة الإنجليزية لدى طفل الروضة لصالح التطبيق البعدي. r - توجد فروق دالة إحصـائياً بين متوسطي درجات أطفال المجموعتين

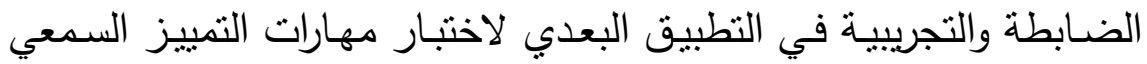
للغة الإنجليزية لدى طفل الروضة لصالح أطفال المجموعة التجريبية. مصطاح اتبث: البحث: - خرائط التقكير الإلكترونية:

يعرفها Hyerle(2009,p13 على أنها: تتظيمات خطية منظمة ومترابطة تستخدم لتقديم المعرفة بأنماط متتوعة بصورة تسهم في إكسابها وتتميتها .

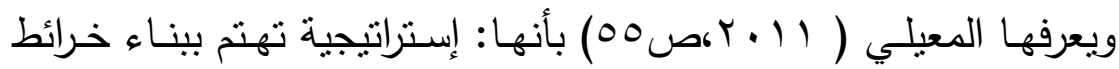
التفكير بأدواتٍ حديثةٍ تستند على تطبيقات الحاسب وتسمح بإنشـاء روابط بـاء 
تشعبية للنص والرموز داخل الخربطة، و إنشـاء خرائط فرعية والربط بين عناصر المعرفة وتوفير روابط لمصادر المعرفة.

وأضاف Himmele (2017,p.127) Hyerle (2014,p. 27) أن خرائط التفكير تتضمن ستة أنواع من المهارات المعرفية كما ذكر بنيامين، والتي يتم تقسيمها إلى مهارات تفكير عليا ودنيا ، تتضمن المهارات الدنيا (المعرفة ،الفهم ،التطبيق)، بينما تتضمن المهارات العليا (التحليل، التركيب، - التقوبم) من خلال التعريفات السابقة تعرفها الباحثة إجرائيًا:

هـي أداة مـن أدوات التفكيـر البصـري، وهنـاك ثمانيـة أنـواع مـن خـرائط

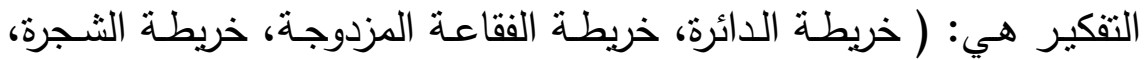
خربطة التدفق، خربطة الدعامة، خريطة الجسر ، وخربطة الفقاعة، خريطة حربطة التدفق المتعددة).

- مهارات التمييز السمعي للغة الإنجليزية: يعرفها مدكور (V . . . بأنها : مهارة من مهارات الاستماع، وتشمل على

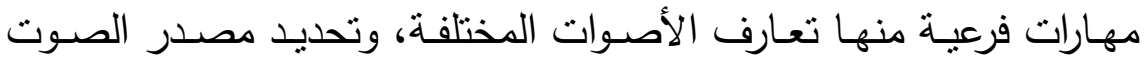
والتمبيز بين النغمات الصوتية، وإعادة سرد القصة.

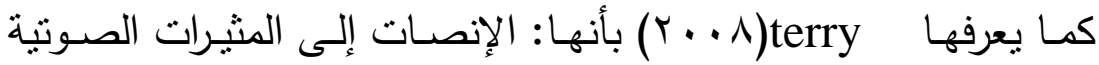

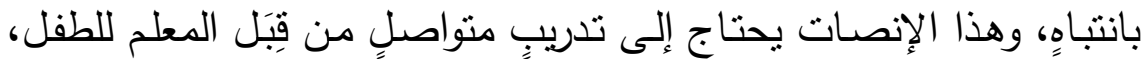
وبخاصة إذا عرف مدى ضيق الانتباه وقصر مدته في نفس الوقت. ويذكر أبو حطب(1 (1 ب) بأنها: القدرة على تمييز شدة الصوت وارتفاعه

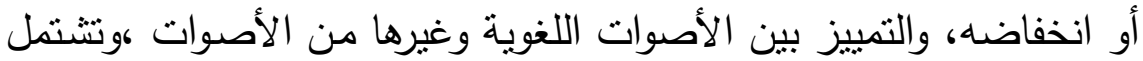


هـذه القـدرة أيضـاً على التمبيـز بـين الأصــوات الأسـاسـية وبـين الكلمـات المنشابهة والمختلفة.

وتعرفها الباحثة إجرائيـاً: درجة الطفل في الاختبار المُعَد؛ لقياس قدرته

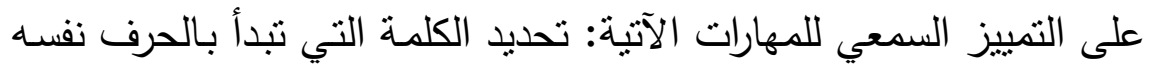
الذي تبدأ به الكلمة المسموعة، تحديد الكلمات المنتـابهة في النطق، تمبيز

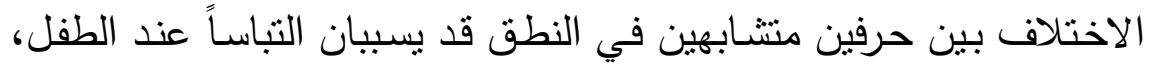
التمبيـز بـين الكلمتين المتشـابهتين في عـدد الحـروف الصــوتية ، تمييـز الكلمات الموزونة.

الإطار النظري والدراسات السابقة : أولاً :إستراتيجية خرائط التفكير الإلكترونية:

تسـاعد خرائط التفكير الأطفال على أن يصبحوا بنـائين وقادرين على تكوبن صسلاتِ واضـحةٍ بـين التفكير والمعنى والتعلم؛ لذلك تسـاعد خرائط التفكير المعلـم و الطفل على بنـاء المعرفة، تسـاعد أيضـاً خرائط التفكيـر الأطفال على إنشـاء محتوى خاص بهم، خلق التعاون بين الأطفال داخل

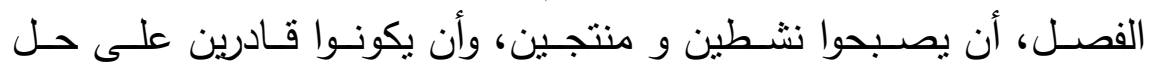
المشكلات (Hyrle, 2009,p30). أهمية خرائط التفكير:

واتفق كلٌ من (Holz Idon,2003; Man,2004; Abuowda,2014) على أنه تكمن أهمية خرائط التفكير في أنها:

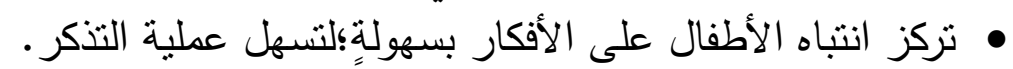
• تساعد على حرية التفكير والإستكشاف، تبادل المعلومات بينهم. 
توفر تغذيـة راجعة للأفكار والمعاني المعقدة، ممارسـة العمليات العلميـة المختلفة.

تسمح بتغبير وتطوبر الأفكار والتعبير عنها بطربقةٍ مفهومةٍ.

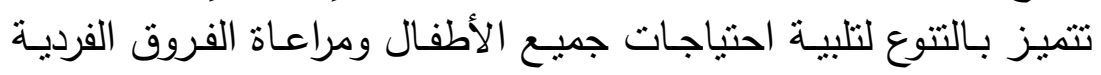

المعرفـة المنظمـة على إيجـاد العلاقـات والتـرابط بينههـا وبين المفـاهيم بينهم. الموجودة. تساهم في تتمية مهارات التفكير المختلفة. تستخدم كأدوات تعلم،وأدوات تقييم. تساهم في الربط بين خبرات التعلم السابقة،والخبرات الحالية. تساهم في تتمية بعض المهارات الاجتماعية كالتعاون. وأضاف ( Gibbs(2010,p.85 أن أهمية خرائط التفكير ، تتمنل في: بقاء أثز التعلم. • مناسبة لجميع المراحل العمرية. تسهل عملية التفكير الإبداعي. ربط المفاهيم الجديدة وتمبيزها عن المفاهيم المنتابهة. تساعد على التفاعل بين المتعلمين وبذلك تدعم التعلم التفاعلي.

وتؤكد على ذلك دراسة Lopez (2011,p.30) التي استخدمت خرائط التفكير الإلكترونية في تطوير اللغة الأكاديمية لمتعلمي اللغة الإنجليزبة من دأن خلال استطلاعات الرأي والمقابلات، وجد Lopez أن تأثير خرائط التفكير على دارسي اللغة الإنجليزية كان له تأثيراً كبيراً خاصةً في اللغة الأكاديمية. 
ومن خـلال مـا سـبق ترى الباحثة أن مسن فوائد وأهميـة إسـتراتيجية خرائط

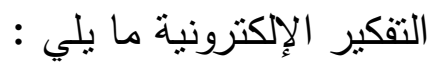
( ) تساعد على مراعاة الفروق الفردية من الأطفال. r) تسهل على الأطفال تذكر المعلومات بطريقةٍ بسيطةٍ. r) الوصول إلى حلول إبداعية من نتاج عقل الطفل نفسه. §) تعمل على إعمال العقل واستخدام قدراته الذهنية. خصائص خرائط التفكير الإلكترونية: وبرى Hyrle( 2004,p.66 بأن خصائص خرائط التفكير هي: () الثبات : الثكل الذي يتكون منه كل خريطة فريد وثابت، ويعكس المهارة المعرفية التي يتم تحديدها. ب) المرونة : المهارة المعرفية والرسم الأولي للخريطة، يتسم بالمرونة يؤدي لهائ إلى عددٍ لا حصر لله من الطرق التي يمكن أن تتمو بها الخريطة.

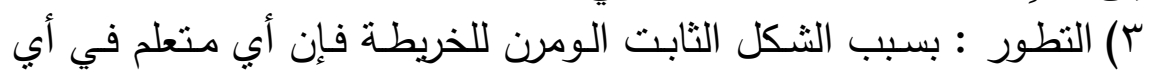
سن يمكن أن يبدأ بورقةٍ بيضاءٍ، ويرسم خريطة ليعرض أفكاره.

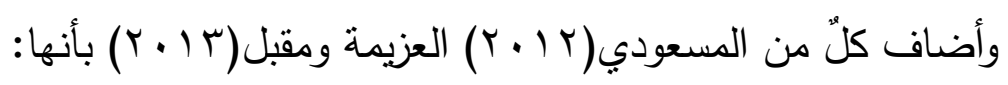

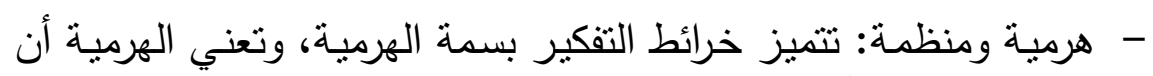
المفاهيم أكثر شمولاً تأتي في قمـة الخريطة، وتعلو عـى المفاهيم والقضـايا الأقل شمولاً. - مترابطـة: يجـب أن يكون هنـاك ترابط بـين المفـاهيم والأفكـار المدرجـة بالخربطة، وهذا الترابط يكون عبر الوصلات الخطية والأسهم التي تصاحبها عبارات. 
- تكامليـة:حيث أن المفـاهيم والأفكـار المدرجــة ضــمن الخربطــة تعدـل لتتكامل في توضيح موضوع محد. - شـمولية:حيث نشتمل على الأفكار والمفاهيم الرئيسية التي جـاعت في مضمون الموضوعات بشكلٍ شاملٍ. ومسن خـاللال مـا سـبق توضــح البحثـة أن أهـم خصــائص خـرائط التفكيـر

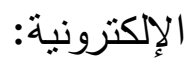

\section{• وضوح المفاهيم الرئيسية.}

• سهولة استرجاع المعلومات عن طريق رسم الخريطة. • جذب انتباه الأطفال. • مرونتها لتراعي الفروق الفردية بين الأطفال. أنواع خرائط التفكير الإلكترونية:

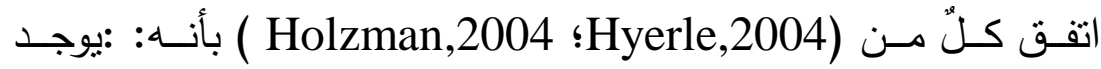
ثمانيـة أنمـاط لخـرائط التفكير وهـي خربطـة الدائرة،خربطـة الفقاعة،خربطـة

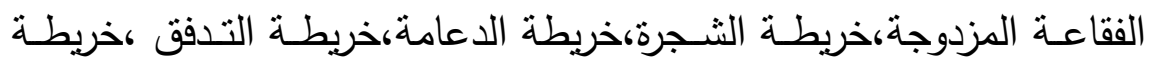
التدفق المتعدد،وتتدرج تحت كل منها مهارات فرعية وهي: - مهارات التركيز(Focusing Skills): - تحديد المشكلات. - صياغة الأهداف.

r - مهارات جمع المعلومات(Information Gathering Skills) - الملاحظة. - صياغة الأسئلة. 
(Remembering Skills) ب- مهارات التذكر

$$
\text { - - الترميز. - }
$$

ومن أنواع خرائط التفكير الإلكترونية الني تم استخدامها في البحث:

وحددها كلٌ من Hyerle,2004؛ Holzman,2004؛

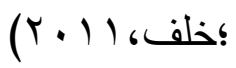

• خريطة الدائرة Circle Map: وهي تستخدم للبحث عن السباق، غالباً

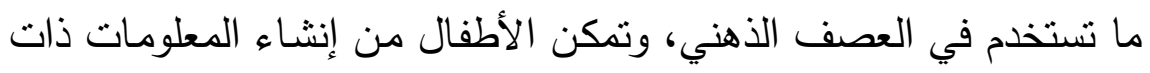

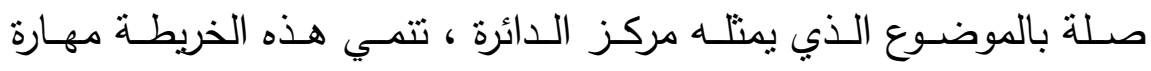
التعريف والتحديد.

-الأسئلة التي تعبر عن خريطة الدائرة:

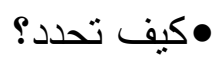

$$
\begin{aligned}
& \text { • ما تعرف عن الفكرة أو الثئ ؟ } \\
& \text { •ما المحتوى ؟ ترف } \\
& \text { • ما هو إطارك المرجعي ؟ } \\
& \text { وتساعد خريطة الدائرة علي : }
\end{aligned}
$$

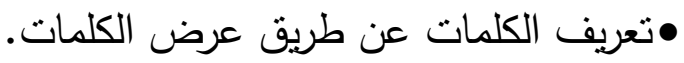

•تحديد نقطة البدء والانطلاق.

•التركيز على شيء واحد فقط لجذب أنظار الأطفال. 


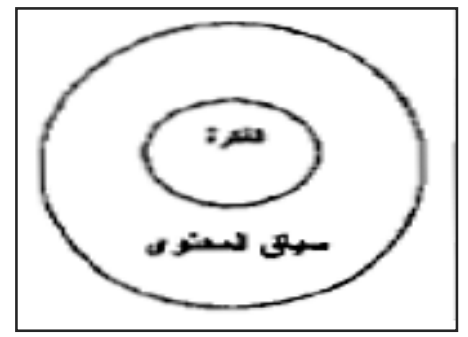

\section{شكل (1) يوضح خريطة الدائرة}

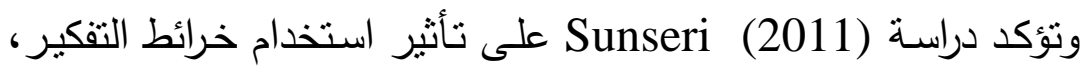
ومن أهم هذه الخرائط خربطة الدائرة التي لديها القدرة على التكوين اللغوي

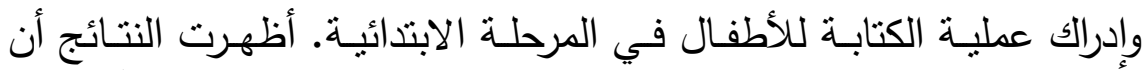

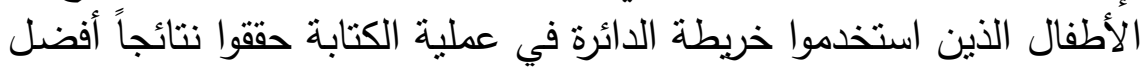

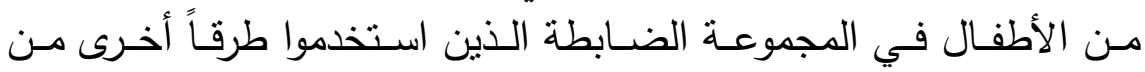
الرسومات التتظيمية.

ومثال على ذلك فقد استخدمتها الباحثة في تحديد الحروف المشتركة في

الكلمات الآتبة :

\section{Skirt - T.Shirt - Shirt}

$$
\text { Van - Man - fan }
$$

• خريطة الفقاعة: : تم تصميمها لعملية الوصف، وتستخدم هذه الخربطة

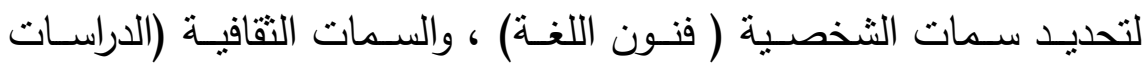
الاجتماعيـة) ، والخصائص (العلوم) أو الصفات (الرباضيات) ، تتمي هذه الخربطة مهارة الوصف والصفات. والهات. - الأسئلة التي تعبر عن خريطة الفقاعة: كيف تصف هذا الثيء • أي الصفات / الخصائص تكون أفضل في وصف هذا الثيء؟ 


\section{وتساعد خربطة الفقاعة على :}

وصف الخصائص باستخدام الصفات.

• الإمداد بالتفاصيل الوصفية للكتابة.

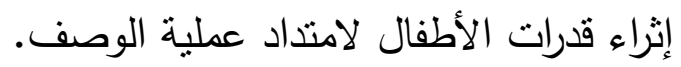

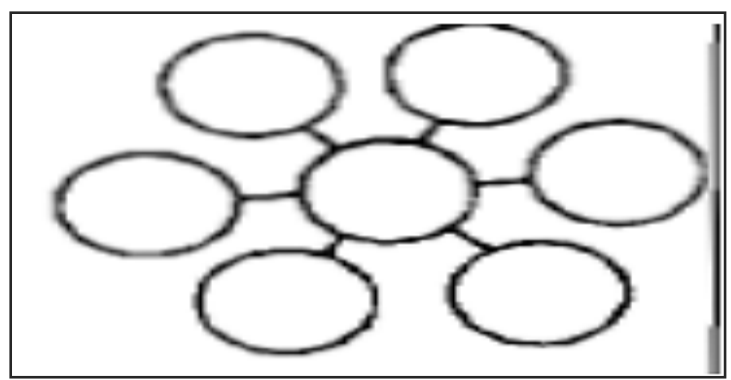

شكل(Y) يوضت خريطة الفقاعة

وتثبت دراسة (2016) من خلال تطبيق إستراتيجية خرائط التفكير

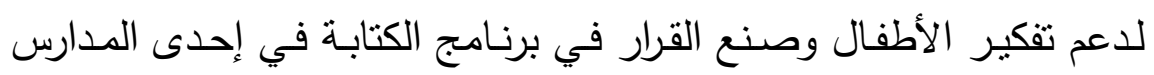

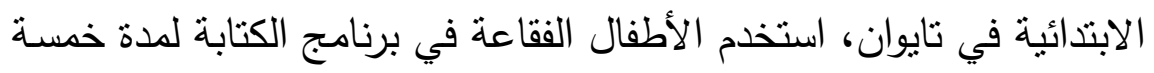
مرات على مدار أسبوعين. أثنتت الدراسة فعالبة خرائط التفكير في تسـهيل وإثراء عملية الكتابة، تقديم الأفكار لكتابة المقالات. مدات. وقد استخدمت الباحثة هذه الخربطة في أنشطة متعددة، ومثال على ذللك عندما قامت بتقديم حرف F في وسط الخريطة ومن حولها كلمات تبدأ

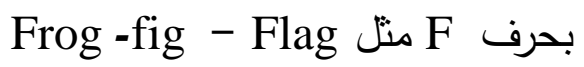
First - Fan

• ريطة الدعامة: تستخدم لتحديد العلاقات بين الجزء والكل أو بين الجزء والأجـزاء الأصــر ، حيـث تدعم هذه الخربطة الإسـتـلال المنطقي والفهم لكيفية تحديد الحدود المادية،تمي هذه الخريطة مهارة الكل والجزء. 


\section{- الأسئلة التي تعبر عن خريطة الاعامة:}

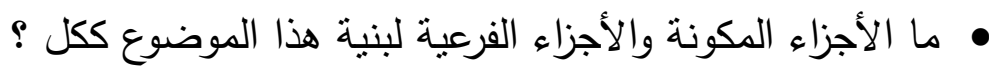
وتساعد خريطة الدعامة على : فهم العلاقات بين الكل والجزء. وضع إطار للفهم. تحليل الأهداف بعد قراءة موضوع معين.

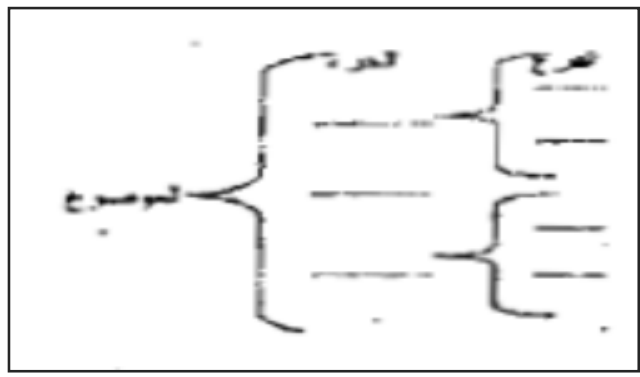

\section{شكل(r) يوضح خريطة الاعامة}

وتؤكد دراسة Innovative(2001) على أثز خريطة التذفق في تدريس

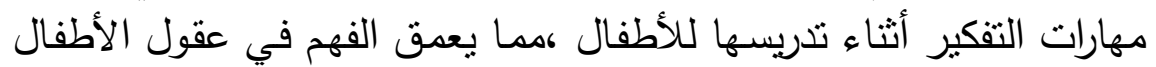
أثناء تتظيمهم للمعلومات المختلفة ضمن إطار جديد. ومثال على ذلك:

استخدمت الباحثة هذه الخريطة في أكثر من نشـاطٍ، منها وضـع كلمـة وتحتها كلمات لآخر حرف وهو Y Family وهما Bicycle - Funny - Young 
• خريطة الجسر Bridge Map : توفر مساراً مرئياً لإنشاء وتفسير

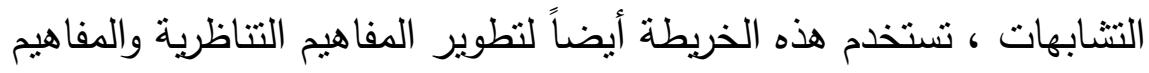
المجازية المحتوى، تتمي هذه الخريطة مهارة المتشابهات والمتتاظرات. -الأسئلة التي تعبر عن خريطة الجسر:

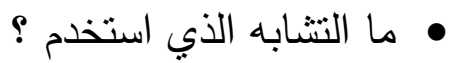

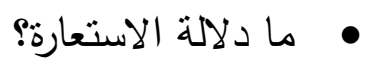
- وتساعد خربطة الجسر على: • فهم التتاظرات والتشابهات.

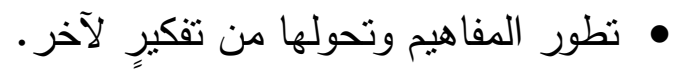
• ت تعزيز فهم العلاقة بين الأشياء.

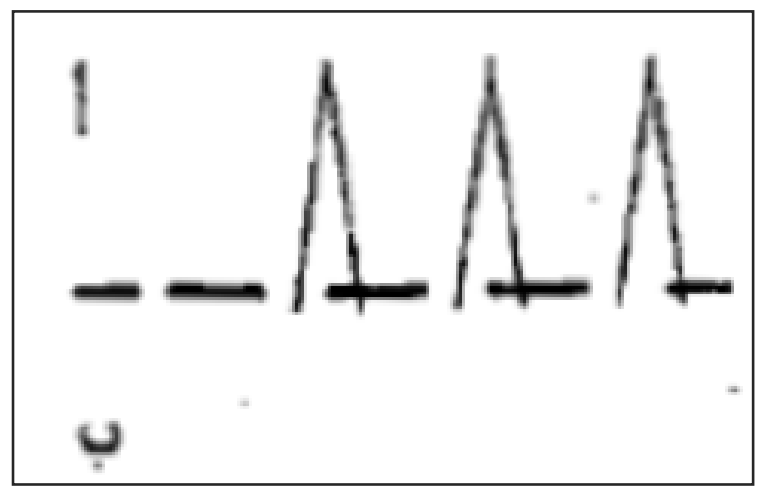

شكل(؛ ) يوضح خريطة الجسر

فكل واحدة من خرائط التفكير نتوافق مع إحدى عمليات التفكير، و يكون

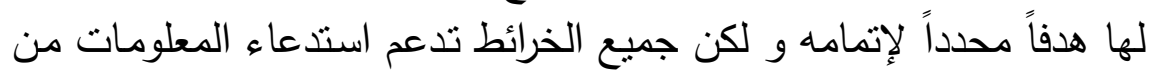
خلال التصور المرئي (Aikman,2014,p55). 
قدمتها الباحثة للأطفال عن طريق عرض بعض الأفعال وعكسها مثل Happy,Sad-Thin,Fat- Tall,Short

أيضاً منل On,In,Under,

وترى الباحثة أن خرائط التفكير مرنة بحيث يمكن استخدام كل خريطة

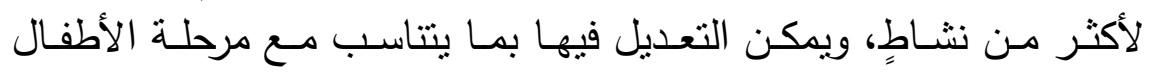
العمرية والفروق الفردية.

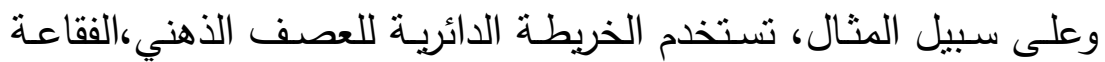
للوصف، الفقاعة المزدوجة للمقارنة والتباين، خريطة الدعامة تستخدم لتحليل

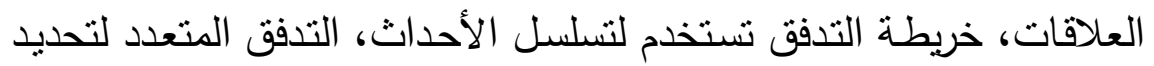

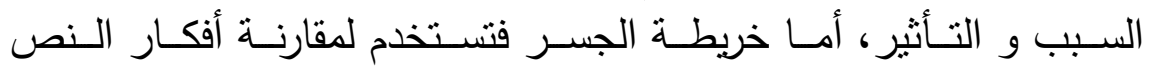
والتصنيف.

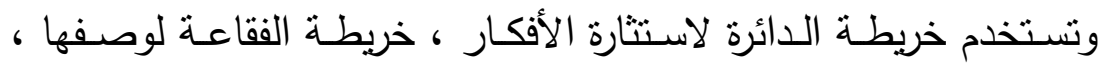

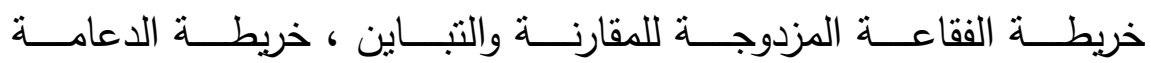

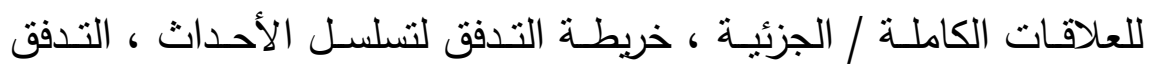

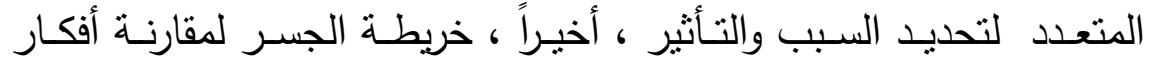
النص (Murbiyan,2015,p.589).

وأُجري Omar \& Albakri (2016) دراسة حالة في إحدى المدارس حيث قاموا باستخدام خرائط التفكير في تدريس اللغنة الإنجليزيـة، وأظهرت النتائج أن خرائط التفكير فعالة في تعليم اللغة الإنجليزية.

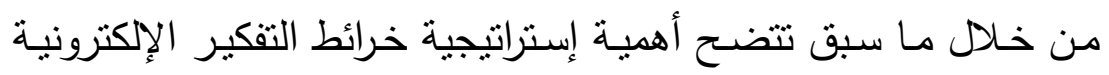

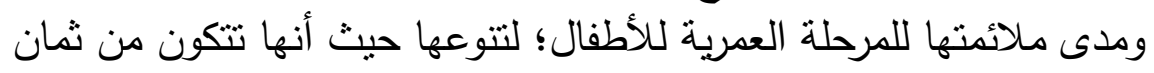

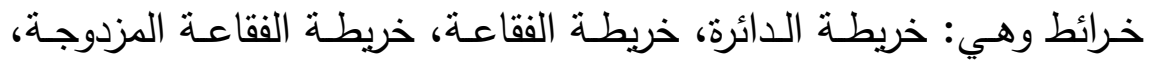


خربطـة الثــرة،خريطة التـدفق، خريطـة التـدفق المتعـدد. ولكـل خربطـة

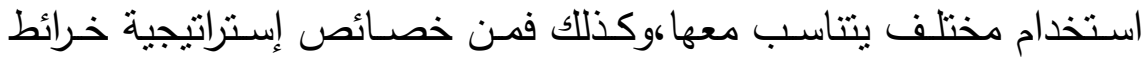
التفكير الإلكترونية المرونة، والتطور ، والتكامل وهذا ما يتتاسب مع مرحلة رياض الأطفال

فإستراتيجية خرائط التفكير الإلكترونية تهنم بجميع حواس الطفل حيث أن الطفل يتعلم من خلال حواسه، وتساعده على ربط الأفكار والتذكر عند رسم الخربطة ـ وهناك العديد من الدراسات التي أثبتت فعالية إستراتيجية خرائط التفكير الإلكترونيـة في تتميـة مفردات اللغـة الإنجليزيـة لدى طفل الروضـة وكافة الصفوف.

ثانياً : مهارات التمييز السمعي للغة الإنجليزية:

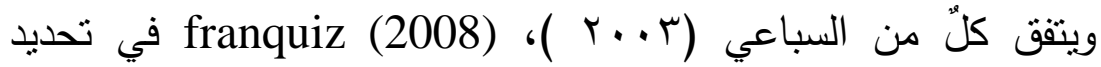

أهمية مهارات التمييز السمعي للغة الإنجليزية للطفل في النقاط الآتية : ا- تتمية قدرة الطفل على تمبيز الأصوات والحروف والكلمات تمبيزاً صحيحاً.

r - تتمبة الذاكرة السمعية وتدريبها على الاحتفاظ بالمعلومات لمدةٍ أطول.

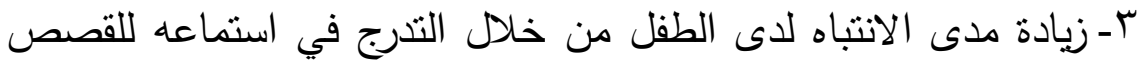
للغة الإنجليزية. ـ - إثراء حصيلة الطفل اللغوبة بالعديد من الكلمات والجمل البسيطة للغة الإنجليزبة. 0ـ تتمية القدرة على تتبع المسموع، والتدريب على فهم المسموع في سرعةٍ ودقةٍ .

T- مساعدة الطفل في التخيل، وكذلك على تتظيم أفكاره لصورةٍ مرتبةٍ ومتسلسلةٍ ماعلة 


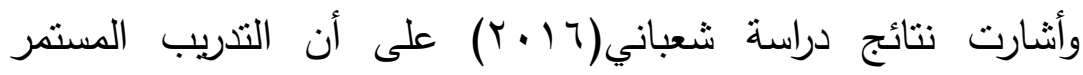
والمكثف لمهارات التمبيز السمعي لطفل الروضة يساعده في تعلم المهارات اللغوبة المختلفة.

وأكدت دراسة محمد (Y ( r r) على أنه يوجد فروق ذات دلالة إحصائية لصالح المجموعة التجريبية أثز برنامج في الأنشطة اللغوية قائم على المدخل الدرامي لتتمية بعض مهارات التمبيز السمعي للغة العربية لطفل الروضة.

عمليات التمييز السمعي للغة الإنجليزية:

$$
\text { : الانتباه }
$$

هو عملية تركيز الشعور في شيء مثير سواء أكان هذا المثير حسياً أم معنوياً ، وأثارت الدراسات بأن عدد قليل جداً من الأطفال يستطبعون التركيز لمدة عثرين ثانية دون تشتت تركيزهم وانتباههم إلى مثثرات أخرى.

$$
\text { : القهم }
$$

التواصل الثفوي بين المتحدث والمستمع لا بد أن يقوم على فكرة موجودة في ذهن المتكلم يربد توصيلها أو بثها في عقل المستهع ؛ ليقوم المستمع بمشاركة المتكلم فيها ويتبادلان الآراء وطرح وجهات النظر ، و يقوم المستمع بعد عملية إرسال الرسالة مباشرةً بعدة عملياتٍ منها تفسير شفرة الرسالة

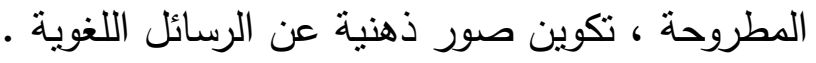

$$
\text { ب- التقويم : n }
$$

هي العملية الثالثة من عمليات الاستماع، حيث ثأتي هذه العملية بعد تركيز الانتباه على الرسالة ، ومحاولة فهها على وجهها الصحيح ، كما أن عملية التقوبم تتضمن إصدار أحكام موضوعية حول كافة جوانب عملية 
التواصل من مناسبة الرسالة المقدمة، تمكن المتحدث، وضوح الرسالة

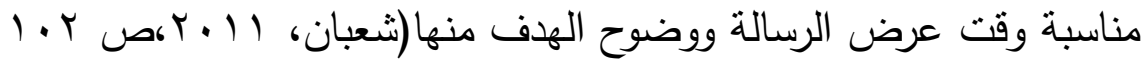
( $1.0-$

عناصر التمييز السمعي : يتكون من عدة عناصر و هي :

ا - المتحدث: ويعد أحد العناصر المهمة والرئيسة في عملية الاستماع ، إذ

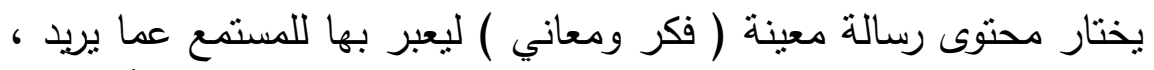
و تتوقف فاعلية الاستماع على مجموعة من العوامل المتصلة بها وأهمها ما يلي : (سرعة المتحدث ، لهجته ، درجة انفعاله ، مكانته ) .

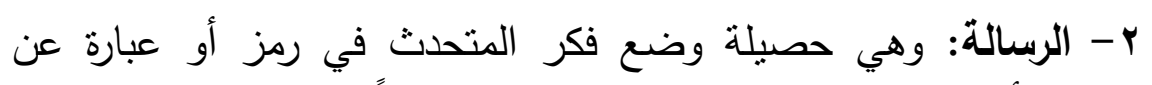

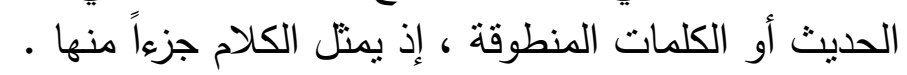

أما باقي المعاني فتكمن خارج الكلمات المنطوقة، وخاصةً في طريقة

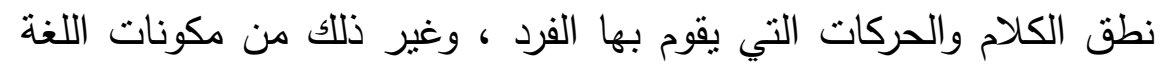
غير اللفظية. وتؤثز طبيعة الرسالة على عملية الاستماع من زوايا عديدة

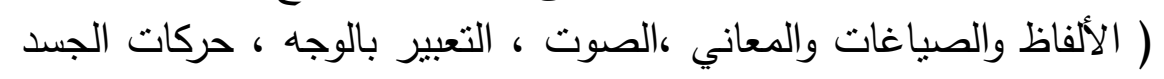
والأبدي )

ب- المستمع : وهو الطرف الأساسي في عملية التواصل . و هو الذي

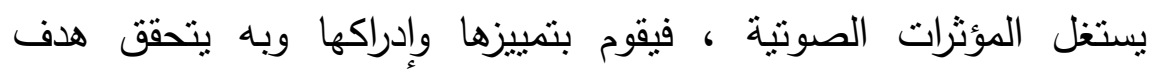
المتحدث من عملية الإرسال.

ع - الإدراك: عملية تفسير المعلومات الواردة، وتكوين المفاهيم والتصورات ، وهو مرتبط بكل مظاهر النشاط الذهني للإنسان ، ومن ثم تأثيره المباشر 
وغير المباشر على استجابات المستمع والتقوبم ، وتدوين ملاحظات عن موضوع الاستماع.

ه - الظروف البيئية: تؤثز البيئة التي يتم فيها الاستماع على مدى فاعلية

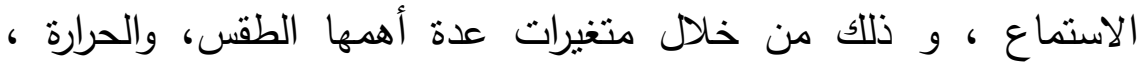
والضوضاء، والمقعد المستخدم للجلوس.

צ- التشويش: و هو مجموعة من العوامل التي تؤدي إلى ظهور اختلافات

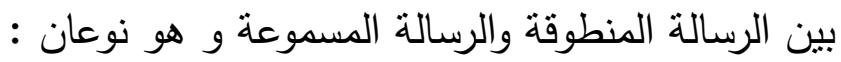
أ- تشويش ميكانيكي : ويعني أي تغير أو أي تداخل فني يطرأ على إرسال الإشارة في رحلتها إلى مصدر المعلومات إلى الهُف الذي الذي يريد المتحدث الوصول إلبه.

ب- تشويش دلالي : ويحدث عند توافر ظروف معينة منل: وجود أسباب

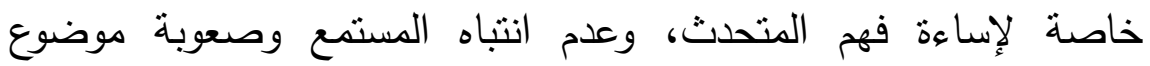
الحديث.

- رجع الصدى : وبتمثل في مجموعة الاستجابات اللفظية وغير اللفظية بين طرفي عملية الاستماع ، وتمثل الأساس لاستمرار التفاعل في عملية

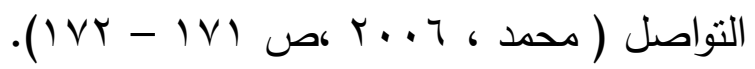

وأكدت على ذلك دراسة Neslihan (2020) أن التمبيز السمعي عند الأطفال لا يتأثز بالمتغيرات المختلفة منت الجنس والسن والبيئة. مهارات التمييز السمعي للغة الإنجليزية: حدد عبد العاطي(9 + . †) مهارات التمبيز السمعي في: أ- إدراك معاني الكلمات وتذكر تلك المعاني واستتناج معاني الألفاظ الصعبة من السياق عند السماع. 
ب- فهم الأفكار، وإدراك العلاقة فيما بينها.

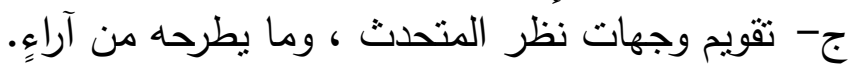
د- تدريب الطفل على تلخيص ما سمعه. هـ - التدريب على تذكر الخبرات السابقة وربطها بالخبرات الحالية.

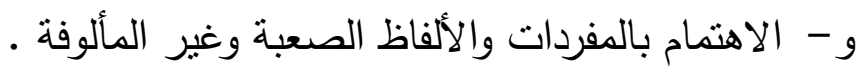
ز - التدريب على استخراج اهم العناصرالواردة في المادئ المادة المالوفة المسموعة، و كذللك استخراج الأهداف والنتائج.

ح- تدريب الأطفال على كيفية تدوين الملاحظات في أثناء الاستماع. ط- التدريب على حسن الإصغاء والاستجابة الفعالة ومتابعة المتحدث •باهنماحٍ

وحدد ( 2007,p.63 Gavin Reid) مهارات التمييز السمعي: • تحديد الكلمة التي تبدأ بالحرف نفسه الذي تبدأ به الكلمة المسموعة. • تحديد الكلمات المنتابهة في النطق. تمييز الاختلاف بين حرفين متتابهين في النطق قد يسبيدان التباساً عند الطفل. • التمييز بين الكلمتين المتتابهتين في عدد الحروف الصوتية ـ • تمييز الكلمات الموزونة.

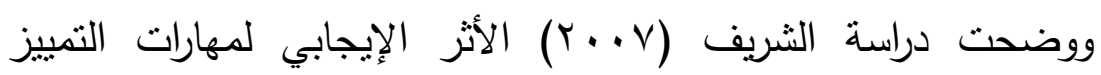

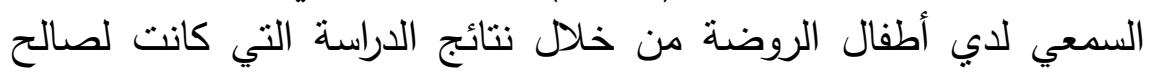
المجموعة التجريبية.

وأثنتت نتائج دراسة Kabesh) فعالية خرائط التفكير في تتمية

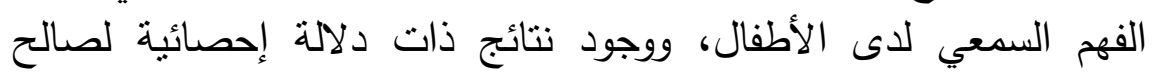
المجموعة التجريبية. 
مبررات اختيار إستراتيجية خرائط التفكير الإلكترونية لتنمية التمييز السمعي للغة الإنجليزية:

ا-تهنم خرائط التفكير الإلكترونية بجميع حواس الطفل السمع والبصر،

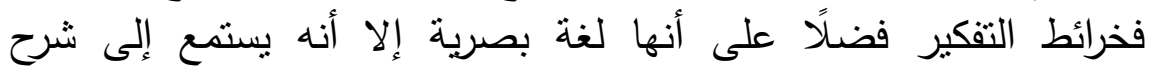

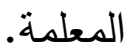

r-تسهر خرائط التفكير في تكوين رويةِة متكاملةٍ حول موضوعات وأنشطة المهارات اللغوية، فخريطة الثجرة لجسئة لبكم الإنسان.

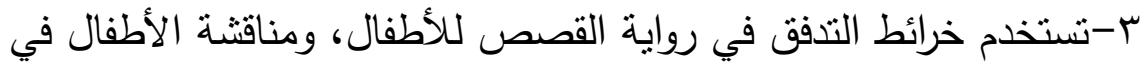
أحداث كل مشهد، وطرح الأسئلة وتحفيز الأطفال على روايتها وتهات ومنليد أصوات الثخصيات. ع-تساعد خرائط التفكير الأطفال على رؤية كيفية ربط الكلمات والأفكار بعضها البعض.

ه-إستراتيجية خرائط التفكير تنبي لدى الطفل معلومات مسبقة

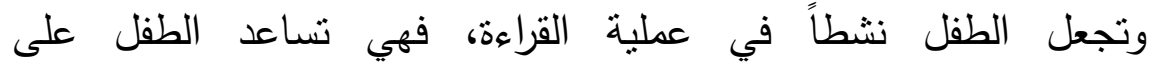

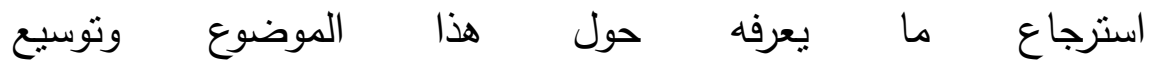
معرفته (Hyerle,Curtis,2004p. 91).

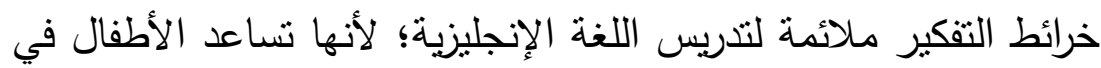

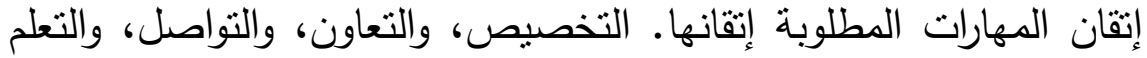

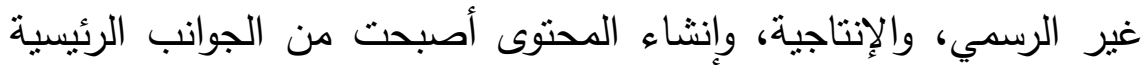
المطلوب من تلاميذ اللغة الانجليزية إتقانها.

(McLoughlin\&Lee, 2008,p.55; Redecker \& Punie,2013, p.23)

تساعد خرائط التفكير الأطفال أن يصبحوا بنائيين وقادرين على تكوين صلات واضحة بين التقكير والمعنى والتعلم. لذلك تساعد خرائط التفكير 
المعلم والطفل على بناء المعرفة. تساعد أيضاً خرائط التقكير الأطفال على التى

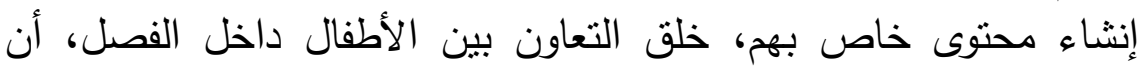
يصبحوا نشطين ومنتجين، وأن يكونوا قادرين لتعان على حل المشكلات. (Hyrle, 2009,p30)

يمكن استخدام خرائط التفكير في جميع مستويات الصفوف مع العديد من فئن

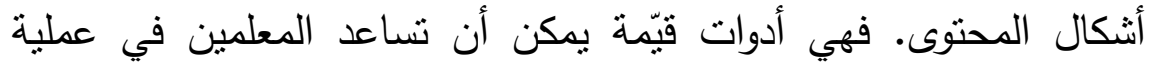

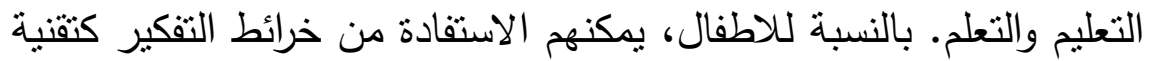
جديدة يمكن استكثافها في أي مادةٍ أو مهارٍ إلى جانب اللغة النها الإنجليزية.

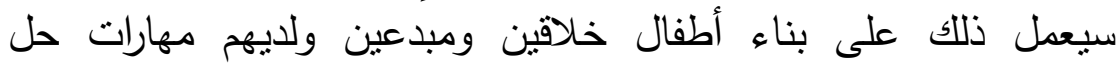
المشكلات (Long \& Carlson, 2011p.68).

\section{الإجراءات المنهجية للبحث: أولاً: منهج البحث:}

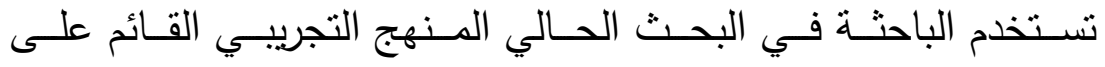
المجمـوعتين المتكـافئتين الضـابطة والتجريبيـة؛ وذلك لقيـاس مدى فاعليـة الفية

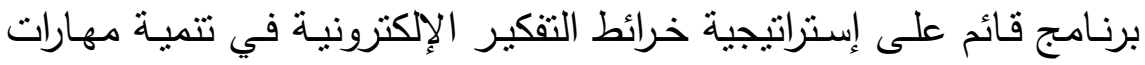

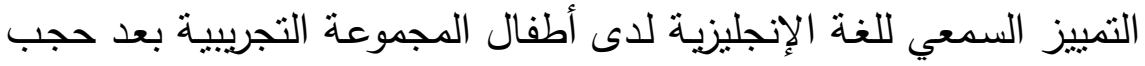
أطفال المجموعة الضابطة وعدم تعرضهم للمتغير المستقل. عينة البحث: - مئم

تم اختيار عينة البحث بعد إجراء اختبار القدرة العقلية (إعداد أوتيس -

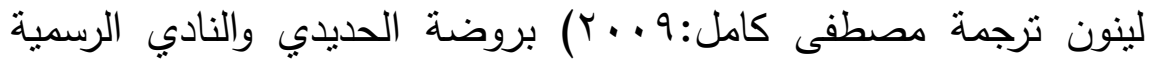

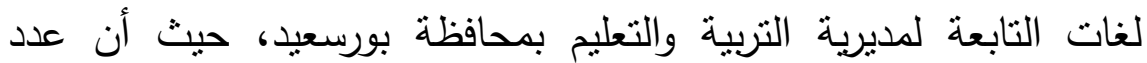

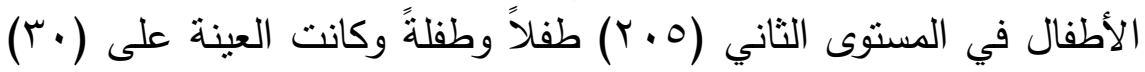




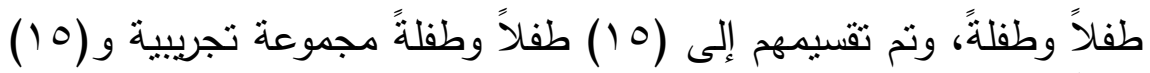

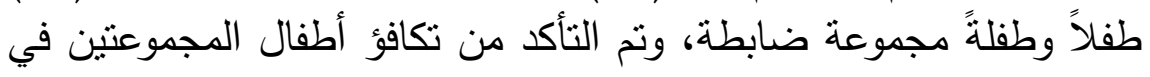
المتغيرات التالية: (أ) - مستوى الأكاء.

(ب) - الــدرجات القبليـة علــى اختبــار مهـارات التميـز الســعي للغــة

$$
\text { أدوات البحث: }
$$

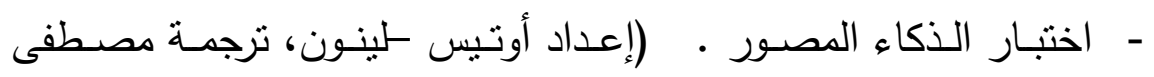

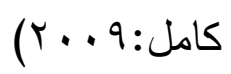

- قائمة مهارات التمبيز السمعي للغة الإنجليزية. (إعداد الباحثة)

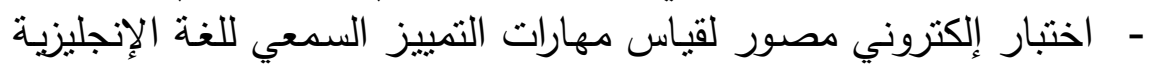
لاى طفل الروضة.(إعداد الباحثة)

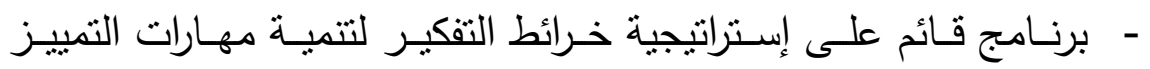
السمعي للغة الإنجليزية لدى طفل الروضة. (إعداد الباحثة)

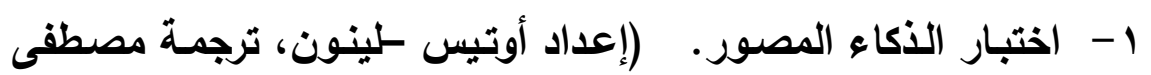
كامل: 9 ( . (

وتم استخدام هذا الاختبار لتحديد مدى قدرات الأطفال العقلية، ويركز

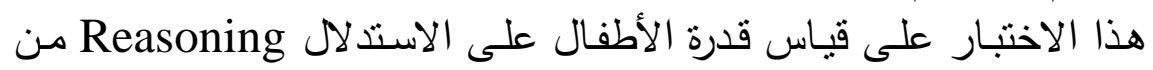

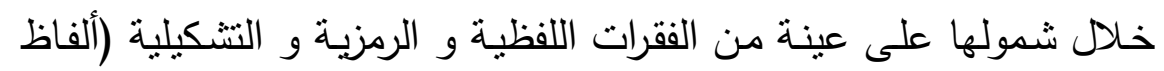

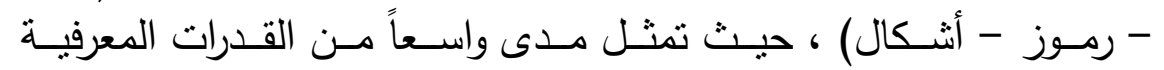

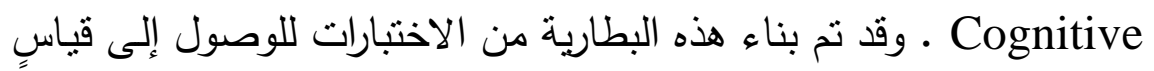

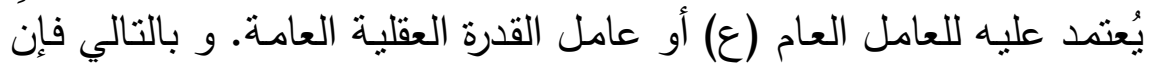

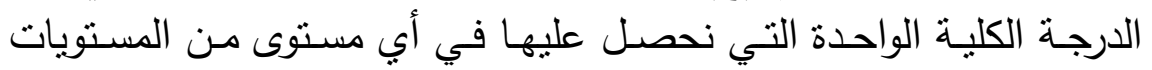


المكونة للبطارية ، تلخص أداء الطفل على مجموعة من المواد الاختيارية ، ثم انتقاؤها على أساس إسهامها في تقدير العامل العام لدى الطفل . ويتكون الاختبار من بس مفردة، وبتم تقسيم الاختبار على ثلات أقسام، حيث يتم تجميع كل قسم على حدى، وأعلى درجة يمكن للطفل الحصول

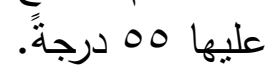

r - قائمة مهارات التمييز السمعي للغة الإنجليزية:

بعـد الإطـلاع على المراجع والدراسـات السـابقة قامـت الباحثة بتصـميم

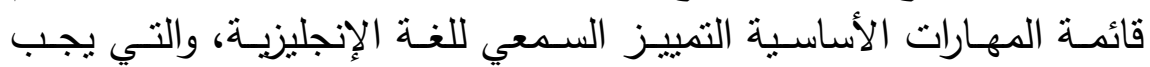
تتميتها لدى أطفال الروضة وهي: التهي: بتعرف على الأصوات المختلفة في البيئة. يعيد سرد القصة التي حكيت له. يصف الثخصيات التي وُرِد ذكرها في القصة. تحديد الكلمات المنشابهة في النطق. تمبيز الاختلاف بين حرفين متشابهين في النطق قد يسببان التباساً عند الطفل . • التمبيز بين الكلمتين المتشابهتين في عدد الحروف الصوتية . • تمبيز الكلمات الموزونة.

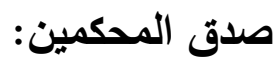
تم عرض قائمة المهارات الأساسية للتمبيز السمعي للغة الإنجليزية على مجموعة من السـادة المحكمين المتخصصبين في المناهج وطرق التدربس، ورياض الأطفال، للنأكد من صدق الاستمارة. 


\section{وذللك من خلال إبداء آرائهم حول:}

مدى وضوح المهارات التي تنضمنها القائمة. ملاعمة المهارات مع المرحلة العمرية لأطفال الروضة.

وجـاءت آراء المحكمسين بالمواققة على العبـارة الأولى والثانيـة، وتعديل

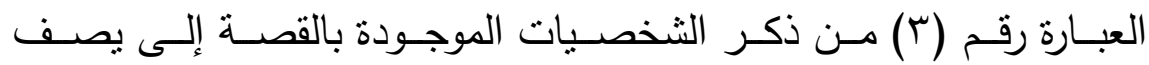

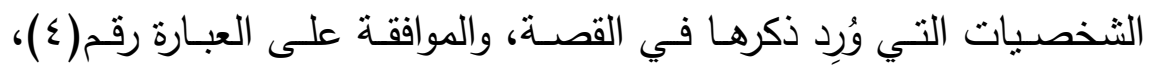
وتعديل العبـارة رقم (0) تحديـد الحروف المنتــابهة في النطـت إلى تمبيـز الاختلاف بين حرفين منشابهين في النطق قد يسببان التباساً في النطق، وتم فئ حذف العبارة رقم (7) وإضافة عبارتين، وبذلك أصبحت عدد المفردات (v). ب- اختبـار إلكترونـي مصسور لقيـاس مهـارات التميـز السـمعي للغـة الإنجليزية لاى طقل الروضة:

\section{اللهدف من الاختبار : أه}

يهدف بناء هذا الاختبار إلى قياس مدى فاعلبة مهارات التمبيز السمعي

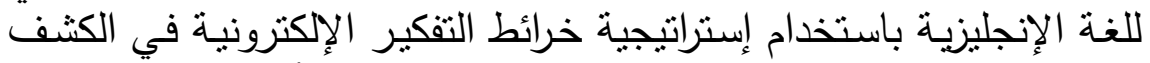

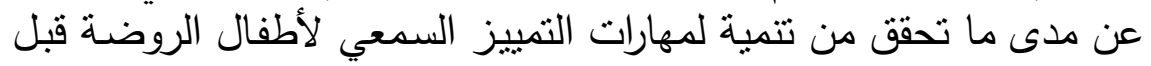
وبعد البحث كمؤشر على مدى فاعلية البرنامج. • بناء الاختبار وتحديد مفرداته: واعتمد بناء الاختبار على الخطوات التالية: أ- تحديد عدد المفردات:

تـم تحديـد عـدد المفـردات في كل مسـتوى مـن مسـتوبات ( التذكر -

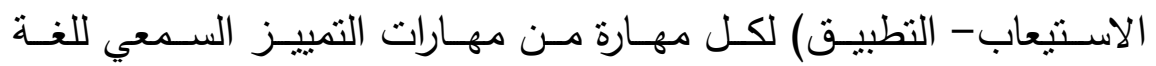
الإنجليزية. 


\section{ب- تحديد نوع المفردات:}

اعتمدت الباحثة في تحديد نوع مفردات الاختبار على: - الأهداف المقاسة والمستوبات المعرفية المراد قياسها. - خصائص طفل الروضة.

وقد تم اسـتخدام نوعـان مـن الأسـئلة الموضـوعية ومنهـا( الاختبـار مـن متعدد - توصبل)، وذلك للأسباب الآتية:

مـا يميزز هذا النـوع مـن الأسـئلة سـرعة الاسـتجابة، وسـهولة التصـحيح، بالإضافة إلى أنها ثتمتع بمعدلات صدق وثبات عالية.

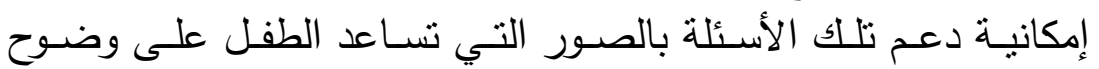
الأسئلة، وبالتالي سهولة الإجابة عليها.

\section{حساب صدق الاختبار:}

وبُقصد بصدق الاختبار : قدرة الاختبـار على قياس مـا وُضِعَ من أجله، أي قياس مؤشر صدق بنود الاختبار وارتباطها بالهدف العام من الاختبار

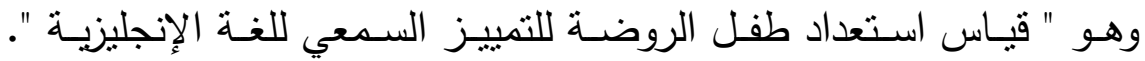
وقامت الباحثة بقياس صدق الاختبار بالطرق التالية:

\section{: (1) صدق الأساتذة المحكمين}

قامت الباحثة بعرض الاختبار وما يشمله من مفردات بصورته المبدئية

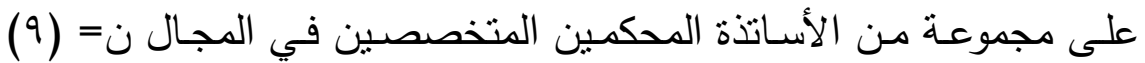
محكمين، وذلك لإبداء الرأي حول مالائمسة بنود الاختبار وسـامة الصياغة

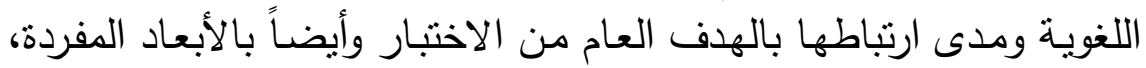
وقد تراوحت النسبة المئوبـة لآراء الخبراء حول الموافقة على مفردات وأبعاد

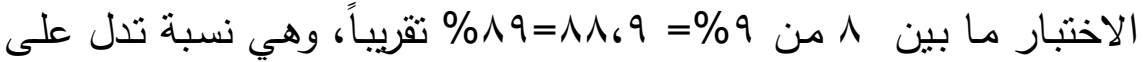


صدق الاختبار وما اشتمله من بنود، وقد قامت الباحثة بإجراء التعديلات

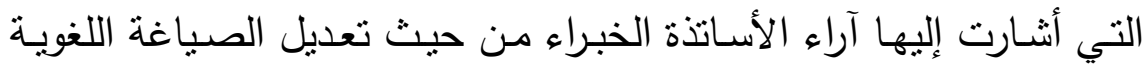
لبعض المفردات، وحذف البعض منها؛ لأنه يؤدي نفس المعنى بالتشـابه مـع بنود أخرى أو التبديل بين بنود الأبعاد المفردة.

$$
\text { (ب) الاتساق الاخلي: }
$$

لحساب صدق الاتساق الداخلي للاختبار قامت الباحثة باستخدام طريقتين: ا- تم تطبيـق الاختبـار على عينـة التقنين وعددها (0) (1 ) طفـلاً وطفلـةً بالمستوى الثاني بمرحلة رياض الأطفال، حيث قامت الباحثة بحساب معامل ارتباط بيرسون (ر) بين درجة كل عبارة والدرجة الكلية للاختبار • بلاه

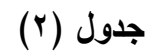

معامل الارتباط بين درجة كل مفردة والارجة الكلية للمقياس (ن " عينة التقتين"

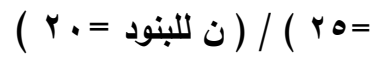

\begin{tabular}{|c|c|c|c|}
\hline معامل الارتباط بالدرجة الكلية & العبارة & معامل الارتباط بالدرجة الكلية & رقبم \\
\hline$* *$, * $\wedge \leq 7$ & 11 & $1 * * .6911$ & 1 \\
\hline$* * .99 \mathrm{rV}$ & Ir & $* * .69 . r$ & $r$ \\
\hline$* *$, , $\wedge \wedge \wedge$ & $1 \%$ & $* *, ، \wedge \wedge \wedge$ & $r$ \\
\hline$* *$. * $\wedge \vee ५$ & $1 \varepsilon$ & $* *$ * . $\wedge 9$. & $\varepsilon$ \\
\hline$* * .69 .9$ & 10 & $* *$ * ‘ $\wedge \vee 1$ & 0 \\
\hline$* * .99 r$ & 17 & 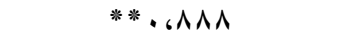 & 7 \\
\hline$* * .90 \%$ & 18 & $* * \cdot, \Lambda \cdot V$ & $\mathrm{~V}$ \\
\hline$* * ., 190$ & 11 & $* * .991 \leq$ & $\Lambda$ \\
\hline$* *, ، \wedge \wedge \vee$ & 19 & $* * .9 \vee r$ & 9 \\
\hline$* * .997$ & $r$. & ***، & 1. \\
\hline
\end{tabular}


يتضح من جدول (Y) ما يلي: تراوحت معاملات الارتباط بين درجة كل

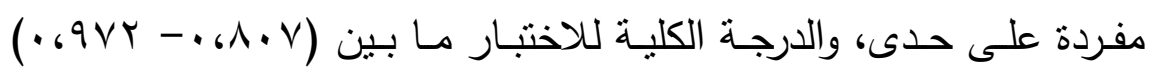

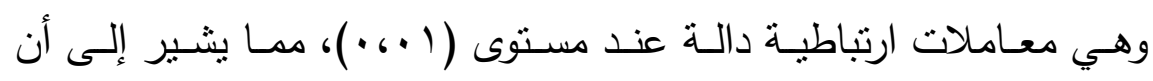
مفردات الاختبار تتمتع بدرجةٍ عاليةٍ من الصدق.

جدول (r) ثبات أبعاد الاختبار بطريقة ألفا كرونباخ (ن = ه r)

\begin{tabular}{|c|c|}
\hline معامل الارتباط & 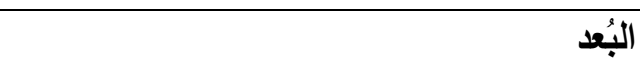 \\
\hline$* * \cdot ، \wedge 9 \vee$ & البُعد الأول: ( تمييز الحروف الساكنة ) \\
\hline$* * 69.7$ & البُعد الثاني: ( تمييز الحروف المتحركة ) \\
\hline$* * .9911$ & البُعد الثالث: ( تمييز الكلمات التي تبلأ بنفس ) \\
\hline$* * . ، 199$ & البُعد الرابع: (تمييز الحروف الموزونة) \\
\hline$* *, 91$. & خامس: ( تحديد الكلمات ) \\
\hline
\end{tabular}

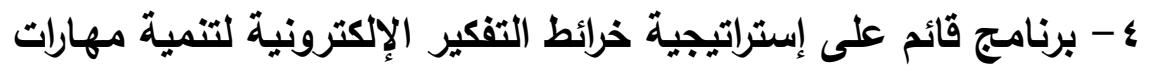
التمييز السمعي للغة الإنجليزية لاعى طقل الروضئة خلئية

الهدف العام للبرنامج: تتمية بعض مهارات التمييز السمعي للغة الإنجليزية لدى طفل الروضة باستخدام إستراتيجية خرائط التفكير الإكترونية.

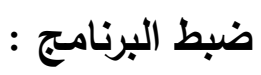

تتميـة بعض مهارات التمييز السمعي للغـة الإنجليزيـة للدى طفل الروضــة

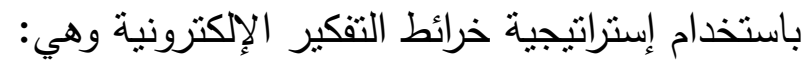
( ) بيزيز الحروف الساكنة. r) (Y تمبيز الحروف المتحركة. 
r) تمبيز الاختلاف بين الحروف الساكنة والمتحركة. ع) تمبيز الكلمات التي تبدأ بنفس الحرف.

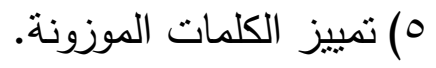
7) تمبيز الحروف الصيز لمامنة. ) تحديد الكلمات. (V ضبط البرنامج

قامـت الباحثة بإعداد برنـامج قائم على خرائط التفكير الإلكثرونيـة في تتمبـة مهـارات التمبيـز السـمعي للغـة الإنجليزبـة، وللتأكد مـن صــلاحيته وضبطه اعتمدت الباحثة على جانبين هما:

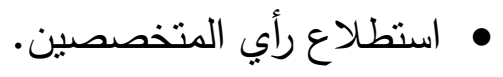
• إجراء تجربة استكثافية.

استطلاع رأي المتخصصين:

تم عرض البرنامج على مجموعة من السادة المحكمين المتخصصين في

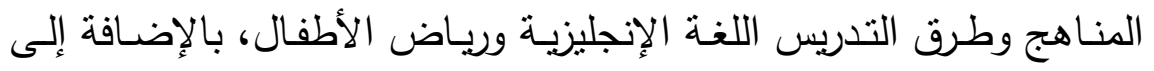

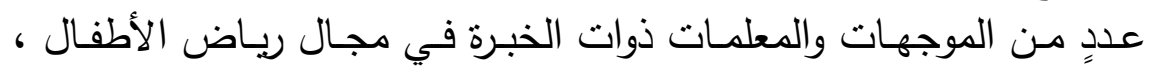
وذلك لإبداء آرائهم حول مدى ملائمة البرنامج من حيث: - أساسيات البرنامج. - المادة التكوينية المكتوبة. - تنوع الوسائل التعليمية. - مناسبة ترتيب عرض موضوعات البرنامج. - الأهداف السلوكية للمحتوى الخاص بكل مهارة. - الأنشطة المتضمنة لتحقيق الأهداف المقصودة. 


\section{- التدريبات المتضمنة في البرنامج. - الاختبارات البنائية.}

وفيما يلي عرض لآراء المحكمين وملاحظاتهم والتي أُجرِيت التعديلات في ضوئها، فقد أجمع المحكمون على: - ' أن البرنامج قد التزمت فيه الباحثة بأساسيات إعداده.

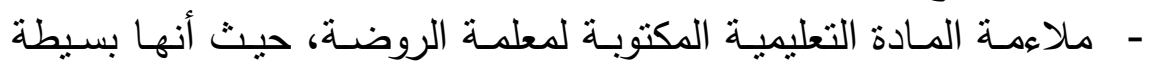
وسهلة ويمكن للمعلمة فهمها وتقديمها للأطفال.

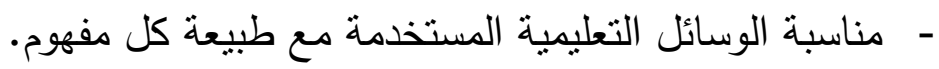
- - مناسبة ترتيب عرض موضوعات البرنامج من البسيط إلى الأكثر تعقيداً.

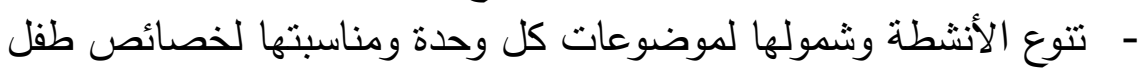

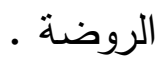

إجراعات تثفيذ البرنامهج:

بعد إعداد أدوات البحث والتأكد من صدقها وثباتها وصـلاحيتها للتطبيق

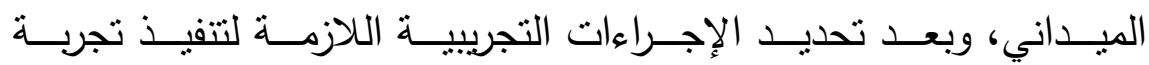
البحث،اتبعت الباحثة الخطوات الآتية في إجراءات البحث.

أولاً:إجراءات قبل التطبيق:

أ- التطبيق القبلي لأدوات البحث:

بعد تحديد الباحثة لعينة البحث قامت بعقد مقابلات للتعرف على الطفل والوالدين والمعلمين والهرف من نلك المقابلات: - التعرف على الطفل. - جمع بعض المعلومات عن قدرات الأطفال. 


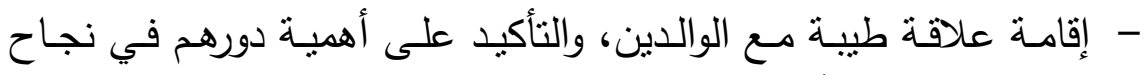
البرنامج من خلال الأنشطة المنزلية التي تقدمها المعلمة للوالدين.

\section{ب- إعداد قاعة التطبيق:}

نظراً لعدم توافر بعض الإمكانات في الروضـة، فقامت الباحثة بتوفير

وتتظيم الإمكانات اللازمة لتنفيذ البرنامج حيث قامت الباحثة بما بلي:

• إعداد الوسـائل والأدوات التعليمية المتضمنة في كل مهارةٍ من مهارات التهات

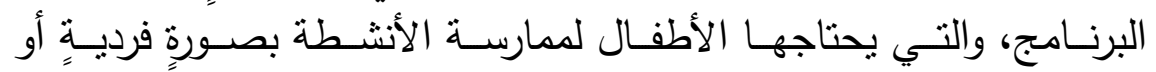
جماعيةٍ.

تجهيز قاعة الكمبيوتز وتحميل البرنامج على الأجهزة؛ لتمكين الأطفال من الاستفادة من الأنشطة.

تجهيز مجموعـة مـن الجوائز كأسـلوب لتعزيـز نشـاط الأطفال بصـورةٍ

منتظمةٍ.

\section{التطبيق البعدي للبرنامج :}

بعد الانتهاء من تطبيق برنامج مهارات التمييز السمعي للغـة الإنجليزبـة على أطفال المجموعة التجريبية ، تم تطبيق اختبار مهارات التمبيز السمعي الإني على المجموعة التجربيية، وحثت الباحثة كل طفل على التزكيز ومحاولة

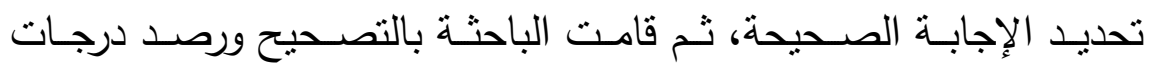

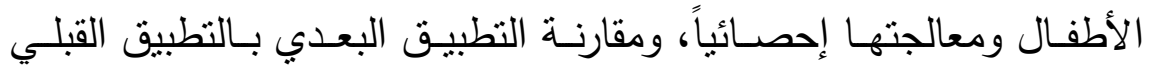

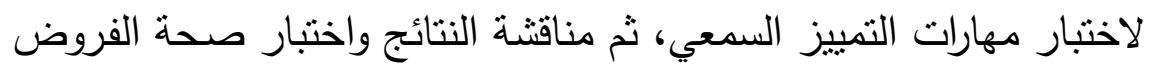
وتفسيرها. 
توجـد فـروق دالـة إحصـائياً بـين متوسـطي درجـات أطفـال المجموعـة التجريبية في التطبيقين القبلي والبعدي لاختبار مهارات التمييز السمعي للغة الإنجليزية لاى طقل الروضة لصالح التطبيق البعدي.

ولاختبار صحة الفرض قامـت الباحثة باستخدام اختبـار (ت Test T) وذلك بحسـاب قيم ( المتوسـط العـام م، والإنحـراف المعيـاري ع ، ودرجـة الفروق ف ويمكن توضيح هذا الإجراء الإحصائي في الجداول التالية:

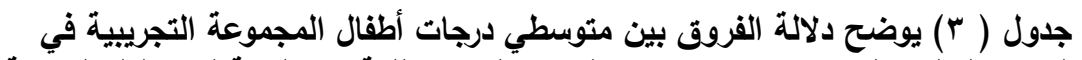

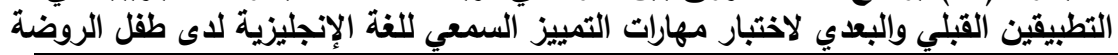

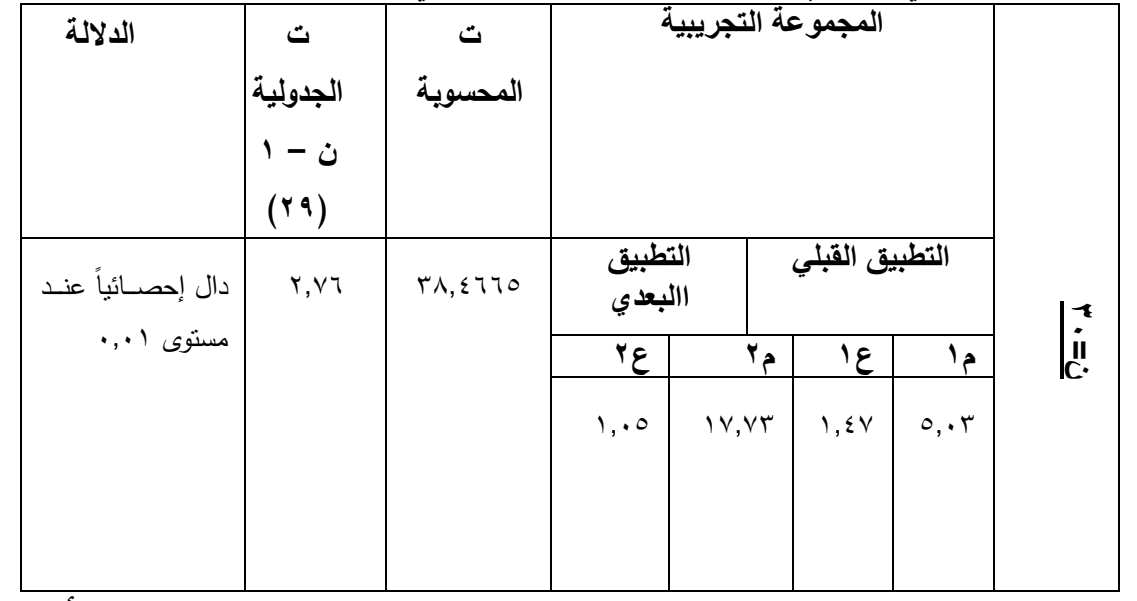

كما قامت الباحثة بحسـاب درجـة الفروق بين متوسطي درجـات أطفال

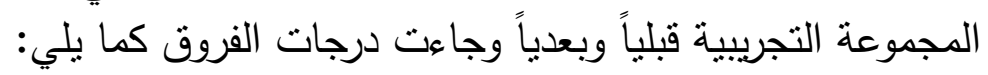


جدول (ع ) يوضح درجة الفروق بين متوسطي درجات أطفال المجموعة التجريبية قبلياً وبعدياً على الأبعاد المفردة للاختبار

\begin{tabular}{|c|c|c|c|}
\hline درجة الفروق & متوبطي درجات المجموعة & المجموعة التجريبية درجات & الأبعاد \\
\hline$\cdot, \wedge \neg+$ & r r, & $1, r v$ & التميزيز \\
\hline
\end{tabular}

وهكذا من خلال جدول (ع) بتضح للباحثة وجود فروق دالة إحصائياً بين

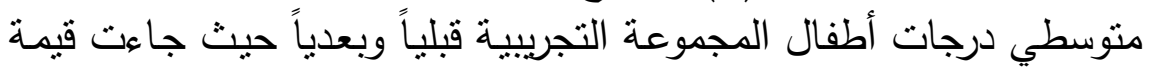

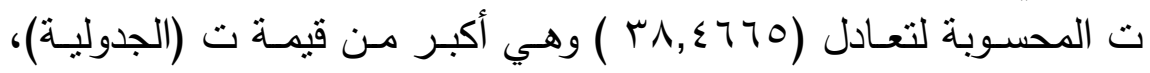

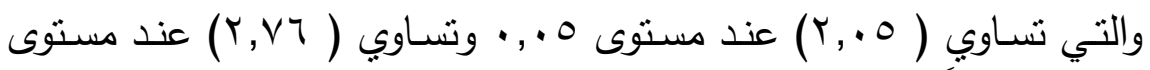

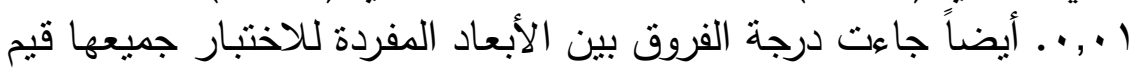

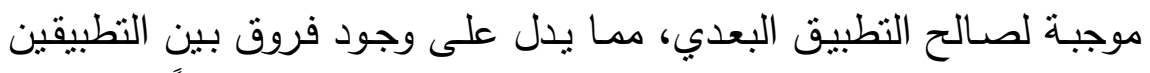

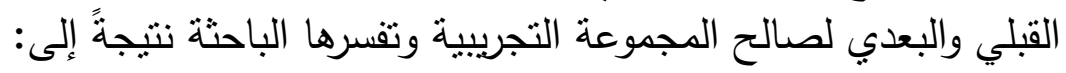

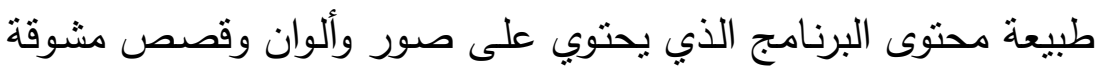

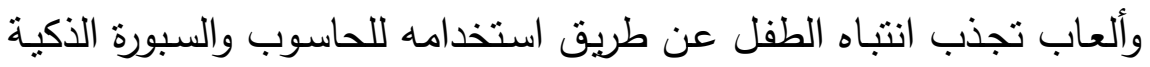

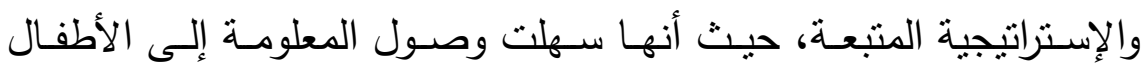

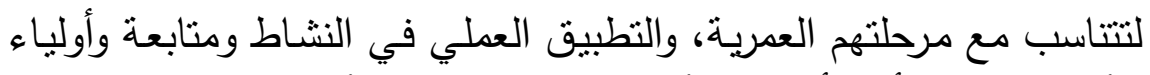

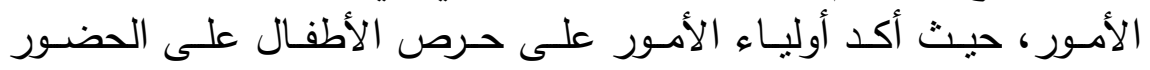

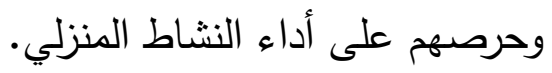

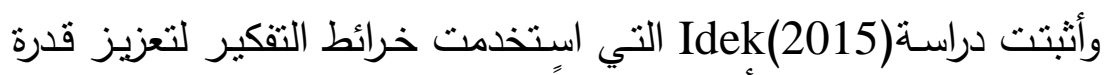

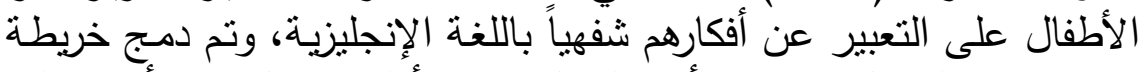

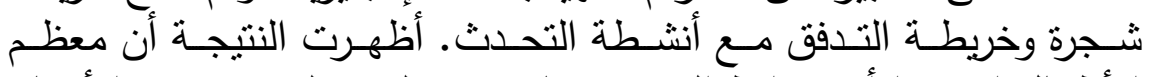

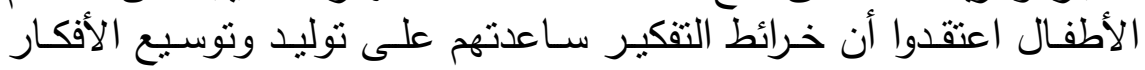


والتعبير عنها شفوياً، فشعر الأطفال بمزيدٍ من الثقة وكان المحتوى الخاص بهم أكثر تتظيماً ودقةًا.

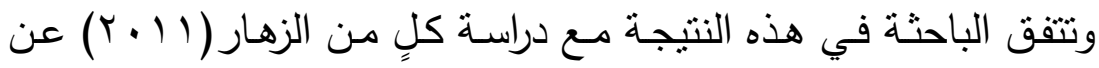

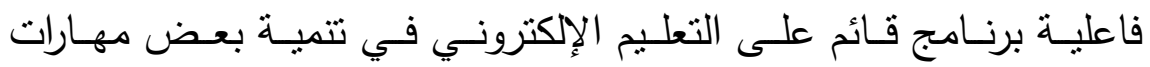

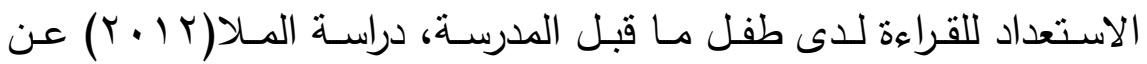
فاعلية الخرائط الذهنية في تتمية الاستعداد القرائي للأطفال المتفوقين عقلياً

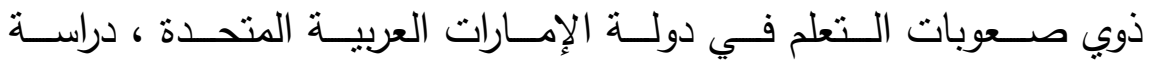

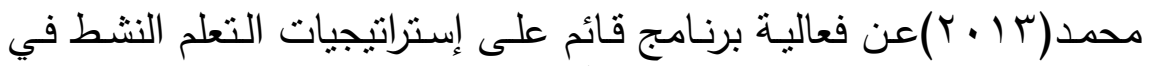

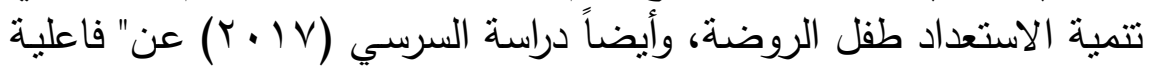
إستراتيجية القراءة التشاركية في تتمية الاستعداد القراءة لدى عينة من أطفال الروضة على وجود فروق ذات دلالة إحصائية بين متوسطي درجات أطفال

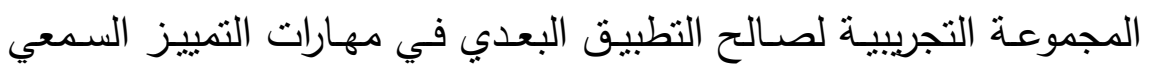
للغة الإنجليزية لطفل الروضهة.

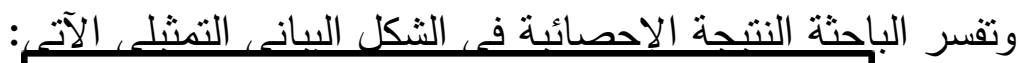

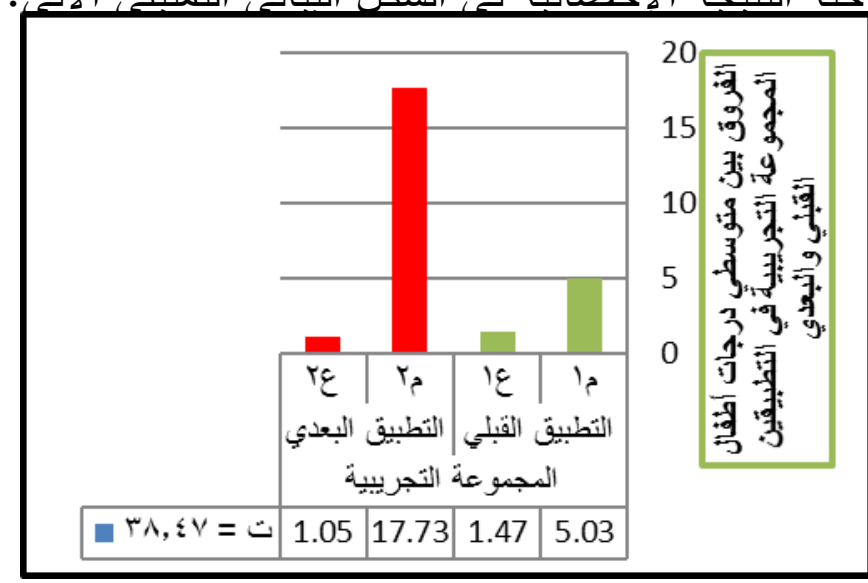

شكل (•) يوضح الفروق بين متوسطي درجات أطفال المجموعة التجريبية في التطبيقين القبلي والبعدي 


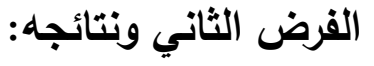

ينص الفرض الثاني على أنه:

توجد فروق دالـة إحصـائياً بيلن متوسطات درجـات أطفـال المجمـوعتين

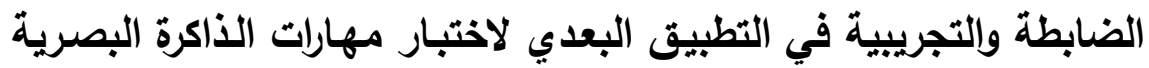
للغة الإنجليزية لاى طفل الروضة لصالح الطفالئ الطفال المجموعة التجريبية.

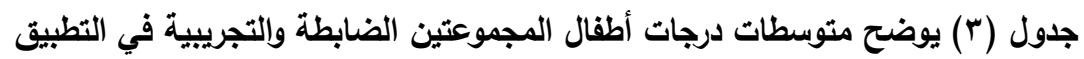

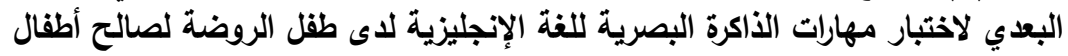

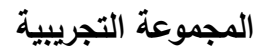

\begin{tabular}{|c|c|c|c|c|c|c|c|}
\hline الدلالة & 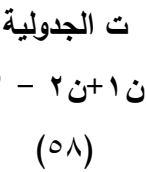 & ت المحسوية & \multicolumn{4}{|c|}{ التطبيق البعدي } & \\
\hline إحصائيًا & r,T & $r V, r \wedge 9 r$ & \multicolumn{2}{|c|}{ المجموعة التجريبية } & \multicolumn{2}{|c|}{ الضجموعة } & \\
\hline & & & $r \varepsilon$ & $r^{p}$ & $1 \varepsilon$ & م & \\
\hline ا •, مسوىى & & & $1, .0$ & IV,VT & $1,0 r$ & $0,1 T$ & \\
\hline
\end{tabular}

وهكذا من خلال جدول ( 0) بيضح للباحثة وجود فروق دالة إحصائياً بين متوسطي درجات أطفال المجموعتين الضابطة والتجريبية بعدياً، حيث

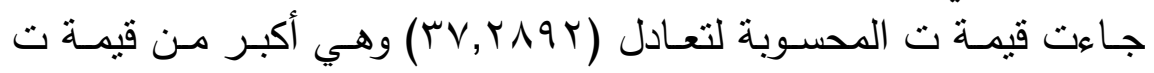

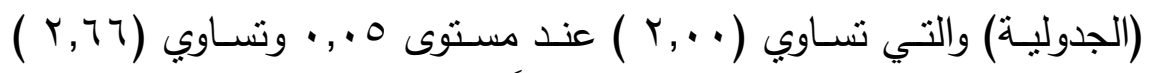

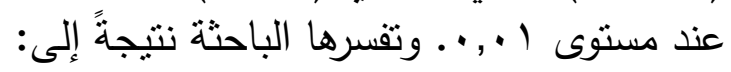

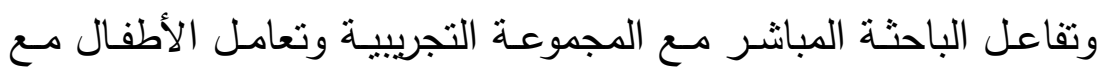

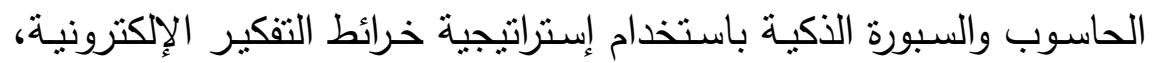

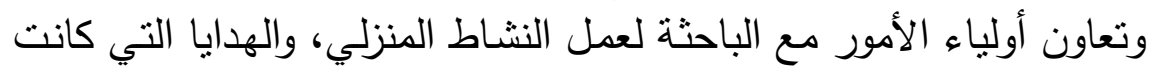


تقدمها الباحثة للأطفال أسهم في اكتساب الأطفال مهارات التمبيز السمعي للغنة الإنجليزيـة، وفاعلية البرنامج ووضوح مفرداته وتتوعها، ووجود تطبيق

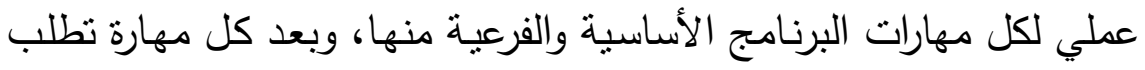

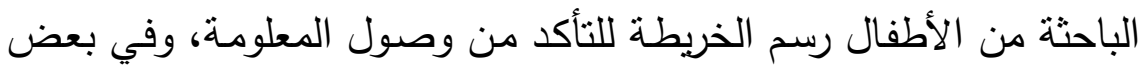
الأحيان كان الأطفال يقوموا بتلوين الخرائط ، وحلهم للاختبار والكتابة على الإنى

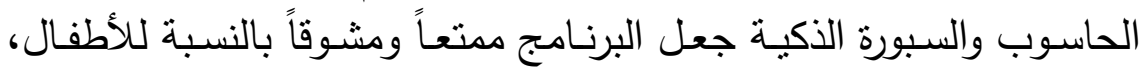
وبذلك جاءت درجات أطفال المجموعة التجريبية في التطبيق البعدي علي

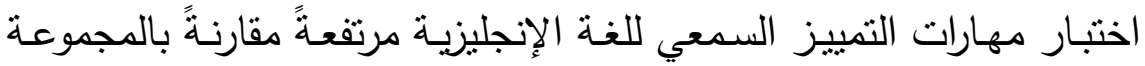
الضابطة نتيجة لعدم تعرض أطفال المجموعة الضابطة لأنشطة البرنامج. وتثفـق الباحثة في هـذه النتيجـة مـع دراسـة فرحسات( ( 1 • ب)، ودراسـة

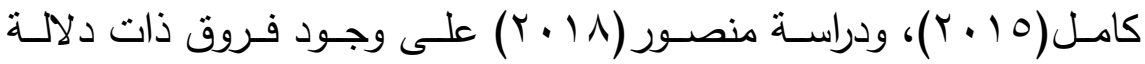
إحصائية بين المجموعتين التجريبية والضابطة لصالح المجموعة التجريبية.

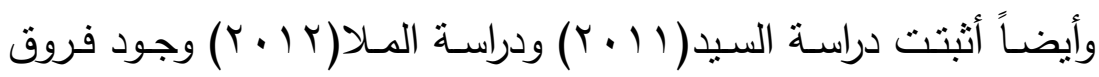
ذات دلالـة إحصـائية بين أطفال المجمـوعتين التجريبيـة والضــابطة لصـالح المجموعة التجربيبة. وتفسر الباحثة النتيجة الإحصائية في الثكل البياني التمثيلي الآتي: 


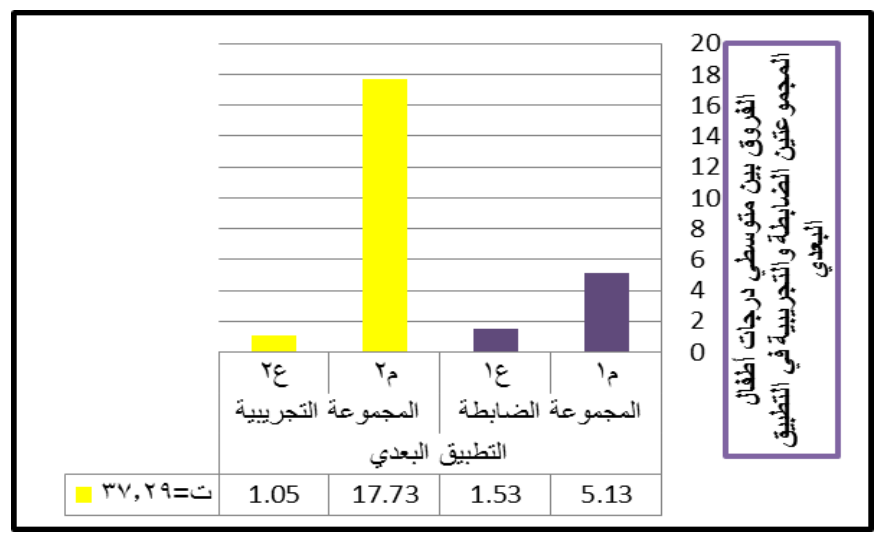

شكل (†) يوضح الفروق بين متوسطي درجات أطفال المجموعة الضابطة والتجريبية في التطبيقين القبلي والبعدي أطفال المجي

\section{توصياث البحث :}

في ضوء نتائج البحث الحالي توصي الباحثة بما يلي: - ت تدريس مهارات التمييز السمعي للغة الإنجليزية؛؛ لما لها من أثرٍ إيجابيٍ لدى طفل الروضة. - اسـتخدام إسـتراتيجيات جديـدة وعلى رأسـها إسـتراتيجية خـرائط التفكيـر الإلكترونية؛ لجذب انتباه الأطفال عن طريق السبورة الذكية ورسم الأطفال لها وتلوينها. - ت تـوفير دورات تدربييـة للمعلمـات عـن كيفيـة تـدربس مفـردات باللغــة البحوث الإنجليزية بصورةٍ صحيحةٍ.

ـ فعاليـة إستراتيجية خرائط التفكير الإلكترونيـة في تتميـة المفاهيم العلميـة للغة الإنجليزبة لدى طفل الروضة إنسية. - استخدام الألعـاب الإلكترونيـة في تتميـة مهارات الاستعداد القرائي للغـة لإنة الإنجليزبة لدى الأطفال ذوي صعوبات التعلم الأكاديمي. 
- فعالية إستراتيجية خرائط التفكير في تتمية المفاهيم الجغرافية لدى طفل

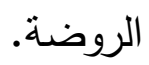

المراجع

\section{أولاً : المراجع العربية:}

- أبو حطب،فؤاد(1 ( • ب).القدرات العقلبة .القاهرة:مكتبة الأنجلو المصرية. - أبو صواوين، راشد (T . . r). تتمية مهارات التواصل الثفوي. القاهرة: إيتراك للنشر والتوزبع.

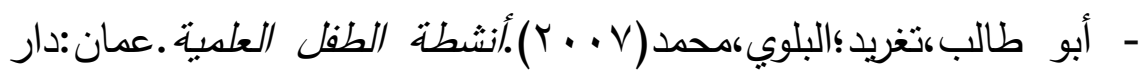
المسبرة.

- خلف،أمل (ابريل، | ( • (Y).فاعلية خرائط التفكير في تتمية المهارات اللغوبة والقدرات الإبداعية لدى طفل ما قبل المدرسة.الجمعية المصرية

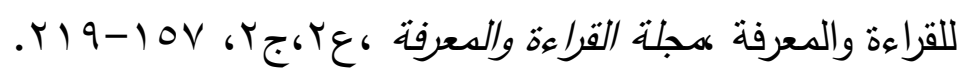

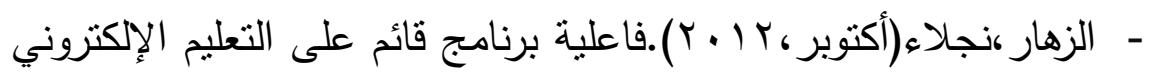
في تتمية بعض مهارات الاستعداد للقراءة لدى طفل ما قبل

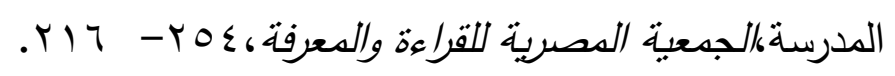
- السباعي،خديجة (ع . . ץ). صعوبات التعلم. القاهرة: مكتبة النهضة الحديثة. 


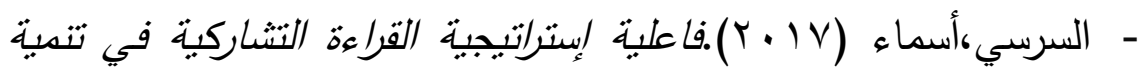
الاستعداد القراءة لدي عبنة من أطفال الروضنة (رسالة ماجستير). معهد الدراسات العليا للطفولة. جامعة عين شمس. - الثربف،سحر(V) . . r).دور البيئة في إكساب الأطفال بعض مهارات الاستعد/د للقراءة (رسالة ماجستير) •جامعة الملك سعود. - شعباني،مليكة( ا ( ب).دور الألعاب التربوية في اكتساب مهارة الاستماع وتتمية مهارة التمبيز السمعي لطفل الروضة. المؤسسة العربية للإستشارات العلمبة وتنمبة الموارد البشربية.ع عه، ا - اس. - العاطي،أحمد (9 . . r). الطفل ومهارات القراءة. الكويت: دار الكتاب الحديث. - عبد الباري،شعبان (11 (r). مهارات الاستماع النشط. القاهرة: دار المسيرة للنشر والتوزيع.

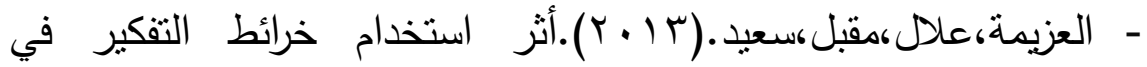
تدريس مادة الاقتصاد علي تمية الفهم والاتجاه لدى طالبات الصف الثاني الثانوي الأدبي بمحافظة عدن، المجلة العربية لتطوبر التفوق، الجمهورية

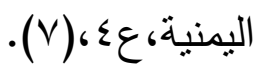

- محمد،أماني(r I • r).فعالية برنامج قائم على استراتيجيات التعلم النشط

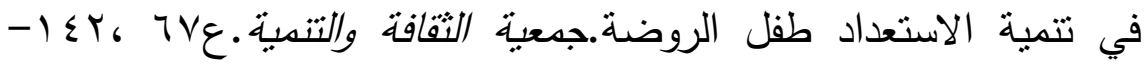


- محمد،كمال (Y ( + (Y).كفاءة برنامج في الأنشطة اللغوية قائم على المدخل الدرامي لتتمية بعض مهارات التمبيز السمعي والبصري للغة العربية بمرحلة رباض الأطفال،الجمعية المصرية للقراءة والمعرفة،مجلة القراءة

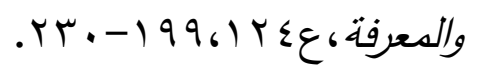
- مدكور ،علي (V . . r). طرائق تدربس اللغة العربية . عمان: دار المسيرة للنشر والتوزبع. - المسعودي،محمد(Y ( • ץ). طرائق التدربس.عمان،الأردن:دار الرضوان للنشر

- مسلم، الثيماء (YV) • (Y).فاعلية خرائط الثفكبر كاسترتبجية في تكوبن بعض المفاهبم البيبولوجية للى طفل الروضتة (رسالة ماجستير). كلية البنات .جامعة عين شمس - الملا، شيخة (Y ( (Y).فاعلية الخرائط الذهنبة في تنمبة مهارات الاستعداد القرائحي للأطفال المتفوقين عقلبًا ذوي صعوبات التعلم في دولة الإمارات العربية المتحدة (رسالة دكتوراه)كلية رياض الأطفال.جامعة القاهرة.

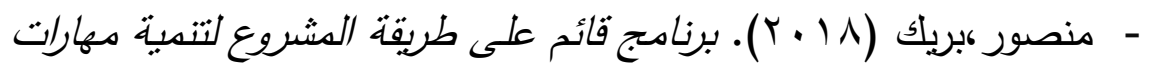
الاستعداد للقراءة للى أطفال الروضة ذذي صعوبات التعلم(رسالة ماجستير).كلية التربية للطفولة المبكرة. جامعة القاهرة. 


\section{ثانياً : المراجع الأجنبية:}

- Alikhan, N. (2014). Thoughts on thinking maps: A new way to think.

- Davin, R. \& van Staden, C.,) 2005). The Reception Year: Learning through Play. Second Edition. Johannesburg, Heinemann Publishers, 82.

- Fan, Y. S. (2016). Thinking Maps in Writing Project in English for Taiwanese Elementary School Students. Universal Journal of Educational Research, 4(1), 36-57. - Franquiz, P. (2014). The Impact of Abuse and Learning Difficultis on Emotion Understanding in Late Childhood and Early. Journal of Genentic, 301-317

- Hickie, K.M. (2006). An examination of student performance in reading/language and mathematics after two years of thinking maps: implementation in three Tennessee schools. Unpublished Doctoral Dissertation. East Tennessee State University, Johnson City (Tennessee), United States of America.

- Himmele, P., \& Himmele, W. (2017). Total participation techniques: Making every student an active learner. ASCD.

- Holzman, S. (2006). Thinking maps: Strategy-based learning for English language learners (and others!). 
Aiming High. Santa Rosa, CA: Sonoma County Office of Education.

- Hyerle, D. (2004). Thinking Maps as a transformational language for learning.

- Hyerle, D. (2009). Visual tools for transforming information into knowledge (2 Ed.).Thousand Oaks, CA: Corwin Press.

- Hyerle, D. (2014). Thinking Maps: A visual language for learning. In Knowledge cartography (pp. 73-87). Springer, London.

- Idek, S. (2015). Thinking maps as a tool in developing oracy in English language learning. . Teaching for Excellence, 21(8). 1-2,

- Kabesh, M. (2016). The Effectiveness of Thinking Maps in Developing Secondary Students' listening Comprehension. CDELT Occasional Papers in the Development of English Education, 62(1), 113-142.

- Long, D., \& Carlson, D. (2011). Mind the map: How thinking maps affect student achievement. Networks, 13(2), 1-7.

- Madiri, S. (2008). A study on the perceptions and attitudes of teachers and pupils to thinking maps. Unpublished master's thesis. Bedfordshire University, Luton, England. 
- Murbiyan, A. (2015). The use of thinking maps to improve the writing skill of grade VIII students at SMPN 2 SRANDAKAN in the academic year of 2014/2015. Unpublished Master's Thesis. Yogyakarta State University, Yogyakarta, Indonesia

- Neslihan, D. (2020). Analysis of preschoo 1 period children Listening skill .World journal of Education ,p79-87

- Redecker, C. and Punie, Y. 2013. The future of learning 2025: developing a vision for change. Future Learning, Vol. 1, pp. 3-17.

- Sunserim A. B. (2011). The impact of Thinking Maps on elementary students' expository texts (Unpublished doctoral dissertation). San Francisco State University, California. 
فاعلية استخدام مسرح الامى في تتمية الوعي الغذائي

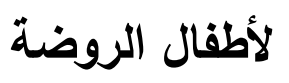

* د يوسف محمد كمال يوسف. *

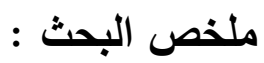

يهدف البحث الحالي إلى تتمية الوعي الغذائي لأطفال الروضة في عمر (0 - 7 ) سنوات وذلك من خـلال استخدام مسرح الدمى، وتكونت عينة

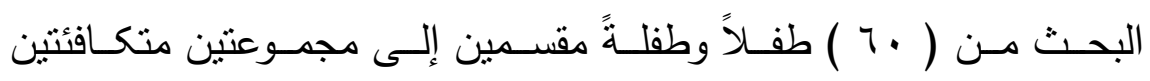

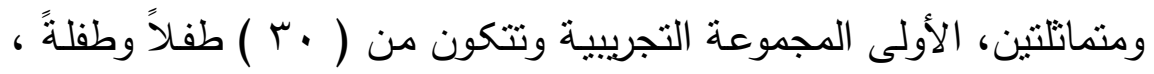

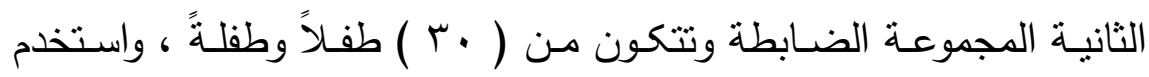
الباحث المنهج التجرببي، وتحددت أدوات البحث الحالي في استبيان(مُحكَّم) لجمع معلومات وبيانات عن مسرح الدمى والوعى الغذائي لأطفال الروضة، ولي،

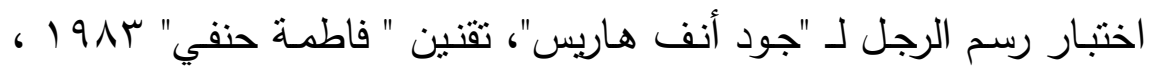

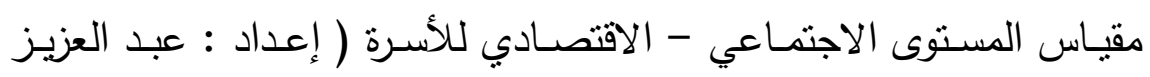
السيد الثخص،990 (199)، مقياس الوعي الغذائي المصور لأطفال الروضـة

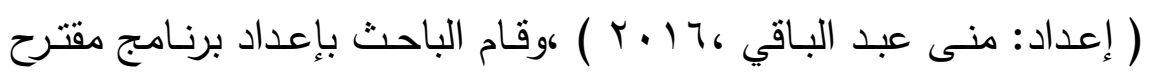

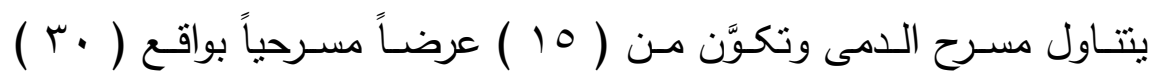
* مدرس أدب الطقل بقسم العلوم الأساسية-كلية التربية للطفولة المبكرة - جامعة بني سويف. 
جلسةًَ، واستمر تطبيق البرنـامج لمدة ( • ( ) أسـابيع، وتوصلت أهم نتائج البحث الحالي إلى فاعلية وكفاءة برنامج البحث في تنمية الوعي الغذائي

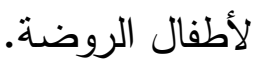

\section{The effectiveness of using Puppet Theater in developing nutritional awareness for kindergarten children}

Prepare: Dr / Youssef Mohamed Kamal Youssef. *

\section{Abstract:}

The current research aims to develop the nutritional awareness of kindergarten children at the age of (5-6) years through the use of puppet theater, and the research sample consisted of (60) children and girls divided into two equal and identical groups, the first is the experimental group and it consists of (30) children and girls. The second control group consists of (30) children and girls. The researcher used the experimental method. The current research tools were identified in a questionnaire (refereed) to collect information and data on puppet theater and the nutritional awareness of kindergarten children, the man's drawing test for "Good Nose Harris", the codification of "Fatima Hanafi" 1983, the measure of the socio-economic level of the family

*Lecturer of Child Literature, Department of Basic Sciences, Faculty of Education Early Childhood - University of Beni Suef. 
(prepared by: Abdel Aziz Al-Sayyid Al-Person, 1995), the Scale of Food Awareness of Kindergarten Children (Prepared by: Mona Abdel-Baqi, 2016), and the researcher prepared a proposed program dealing with puppet theater and consisted of (15) theatrical performances. By (30) sessions, the implementation of the program continued for (10) weeks, and the most important results of the current research reached the effectiveness and efficiency of the research program in developing nutritional awareness of kindergarten children.

\title{
الكلمات المفتاحية Keywords:
}

\author{
Puppet Theater \\ Food awareness \\ Kindergarten children
}

$$
\text { - - مسرح الدمى. - أطفال الرعي الغذائي. }
$$

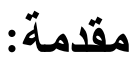

تهتم الدول المتقدمة بمرحلة الطفولة المبكرة؛ لأنها الفترة الحاضنة لأطفال

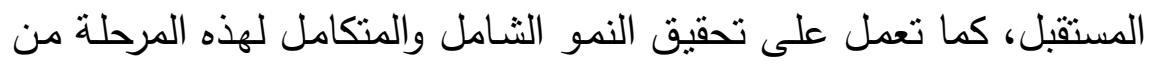

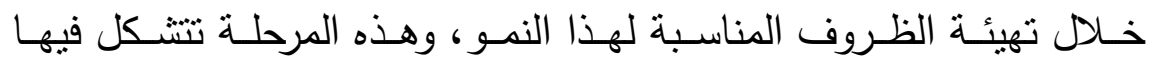

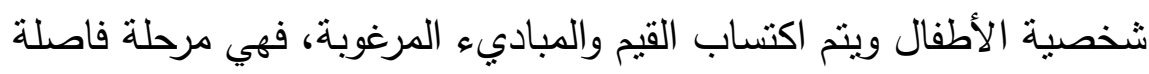

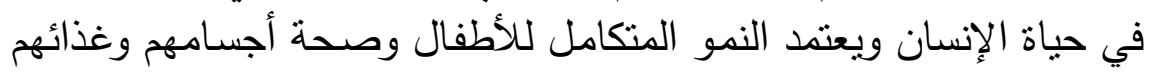

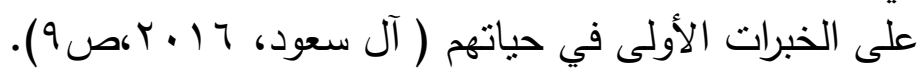


وبكوِن الأطفال معرفتهم وثقافتهم الخاصة بالغذاء من خلال ما بحيط بهم من مؤثراتٍ وما يمارسونه ويُمارَس أمامهر يومياً، فإذا نشأ الأطفال في بيئة

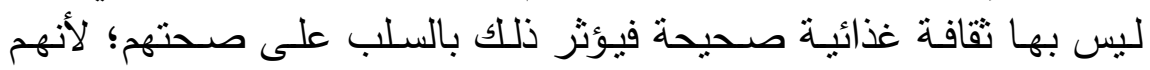
سيكتسبون عادات غذائية غير سليمة، وبعتبر تدربب الأطفال على العادات

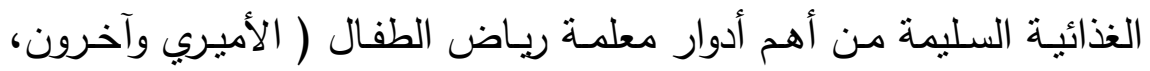

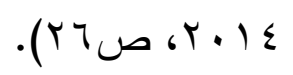

وبمتد مسرح الدمى إلى العصور الفرعونية القديمة في مصر ، حيث تم

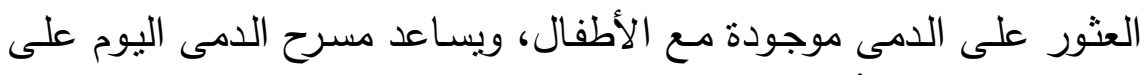

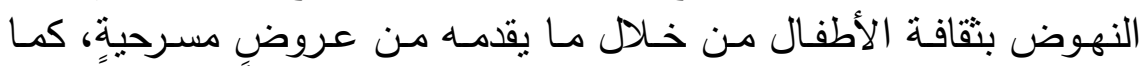

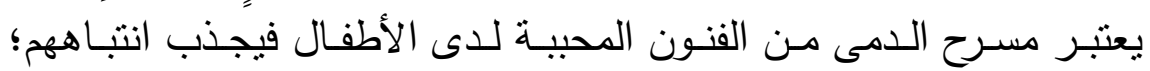

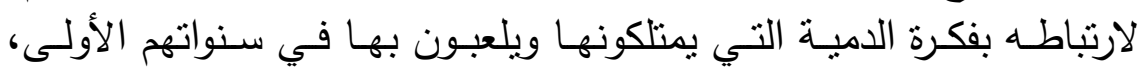

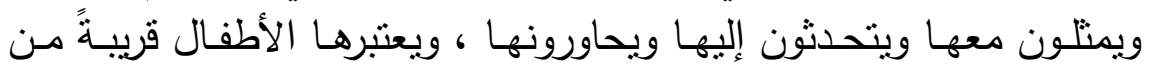

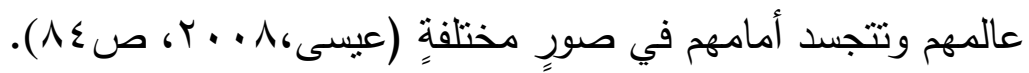
وبسـعى الباحـث في هـذا البحـث إلىى تتميـة الـوعي الغـذائي لأطفـال

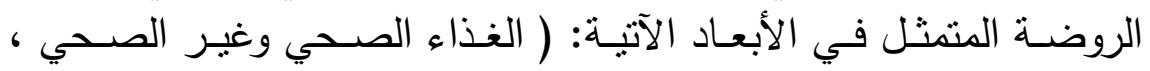

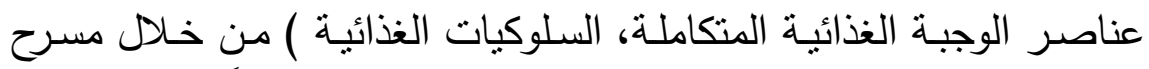

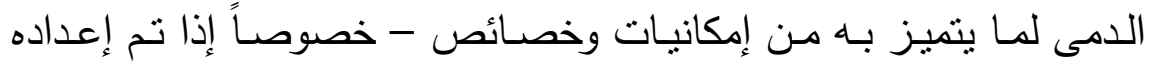
بالثكل الجيد- فله القدرة على محاكاة واقع أطفال الروضة واهنه اهنماماتهم؛ لما

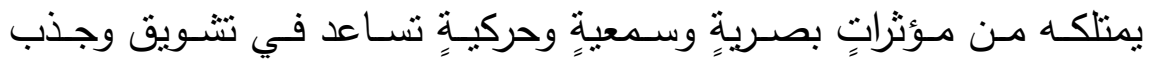

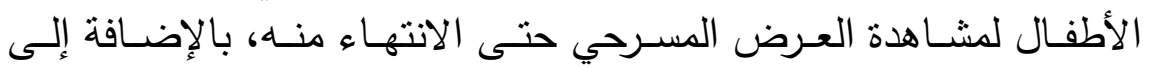

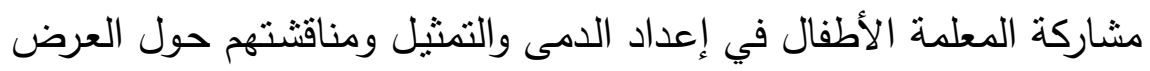
المسرحي قبله وفي أثنائه وبعد الانتهاء منه بساعد في تتمبة الوعي الغذائي 


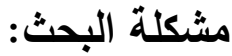

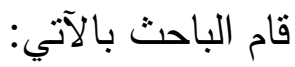

- الإطلاع على البحوث والدراسات الخاصة بمتغيرات البحث الحالي. - إجـراء دراسـة اسـتطلاعية للوقوف على فاعليـة مسـرح الـدمى في تتميـة الوعي الغذائي لأطفال الروضة تهنة تضمنت:

أ. زيـارات متكررة لعددٍ من الروضـات في محافظلة القليوبية ( التي تخضـع لإشراف وزارة التربية والتعليم) منها روضة خالد بن الوليد، روضنة عمر بن الخطاب، روضة العمار الابتدائية.

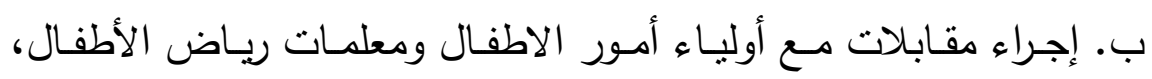
وموجهي رياض الاطفال، والأطفال أنفسهم؛ وذلك لمعرفة مبولهم وقدراتهم

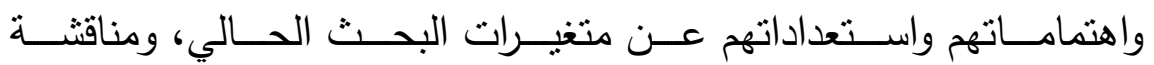
المتخصصين حول موضوع البحث. وخلصت الدراسة الاستطلاعية إلى:

ـ أهمية مسرح الدمى في تتمية الوعي الغذائي لأطفال الروضة.

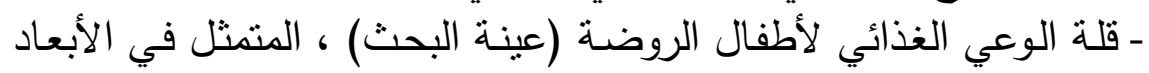
الآتية: (الغذاء الصحي وغير الصحي ، عناصر الوجبة الغذائية المتكاملة، السلوكيات الغذائية). ويمكن تحديد مشكلة البحث في السؤال الرئيسي الآتي: مـا فاعليـة اسـتخدام مسـرح الـدمى فـي تتميـة الـوعي الغـائي لأطفـال الروضة ماع 


\section{ويتقرع منه الأسئلة الفرعية الآتية:}

- مـا الخصــائص العامـة لمسـرح الــمى لتتميـة الـوعي الغــائي لأطفـال

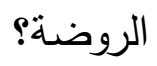

- كيف ننمي الوعي الغذائي لأطفال الروضة من خلال مسرح الدمى؟

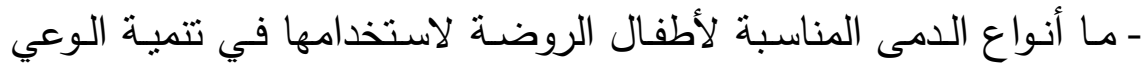

$$
\text { أهمية البحث : الديهي }
$$

ـ الاهتمام بمسرح الدمى، وأطفال الروضة؛ وما لهما من أهميةٍ بالغةٍ في حياة الطفل في هذه المرحلة. - يساعد هذا البحث معلمات رياض الأهد الطفال لاستخدام واستثمار مسرح

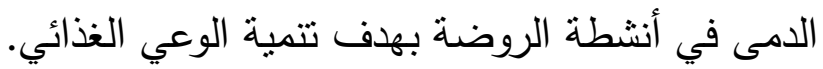
- يعتبر هذا البحث تدعيماً للاراسات والأبحاث التي التئي تتاولت مسرح الطفل

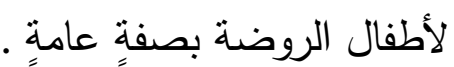
- قد تستقيد وزارة التربية والتعليم من نتائج هذا البحث في إعداد برام برامج

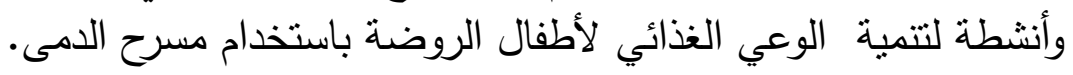
أهداف البحث : يهدف البحث الحالي إلى : -التعرف على فاعلية البرنامج المُصدَح باستخدام مسرح الدمى لتتمية الوعي الغذائي لأطفال الروضة. - التعـرف على الـمىى المناسـبة لأطفـال الروضـة لانستخدامها في تتميـة الوعي الغذائي لديهم. 


\section{حدود البحث: \\ وتثمنل في :}

- الحـدود البشـرية : يقتصـر البحـث على أطفـال الروضــة مـن (0-7) سنواث. - الحدود المكانية : يقتصر هذا البحث على الروضات التابعة لوزارة التربية والتعليم (روضـة خالـد بـن الوليد، التابعـة لمدرسـة خالـد بـن الوليد للتعليم الأساسي ) بمحافظة القليوبية . - الحدود الزمانية : تم تطبيق البحث لمدة شهرين ونصف من بداية الترم

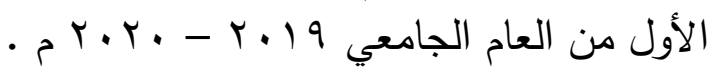
- الحدود الموضوعية: عروض مسرحية لدمى عن أنواع الغذاء . فروض البحث:

أ- لا توجد فروق ذات دلالة إحصائية عند مستوى I +., · بين متوسطات درجات أطفال المجموعة التجريبيـة والضـابطة على مقيـاس الوعي الغذائي المصور لأطفال الروضة قبل تعرض المجموعة التجريبية للبرنامج المُصمَم باستخدام مسرح الدمى لتنمية الوعي الغذائي.

ب- توجد فروق ذات دلالـة إحصسائية عند مسـتوى I + , · بين متوسطات درجات أطفال المجموعـة التجربييـة والضـابطة على مقيـاس الوعي الغذائي المصور لأطفال الروضة بعد تعرض المجموعة التجربيية للبرنامج المُصمَم

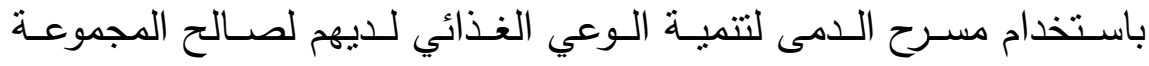
التجريبية.

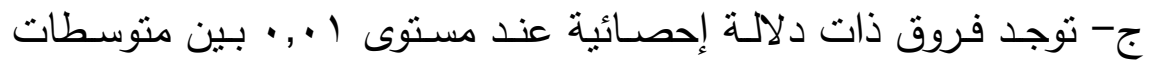

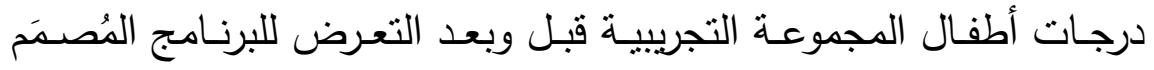




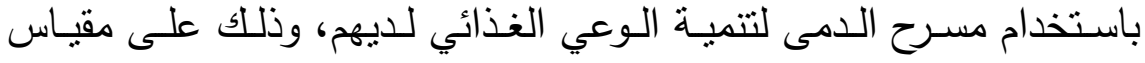

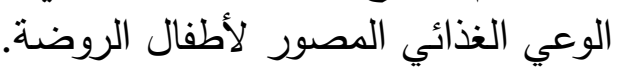

\section{مصطاث البحث: :}

يعرف الباحث المصطلحات الآتية إجرائياً بأنها:

- فاعلية: القدرة علي إحداث الأثر الكبير في تحقيق النتائج المرجوة من

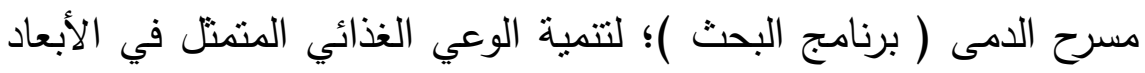

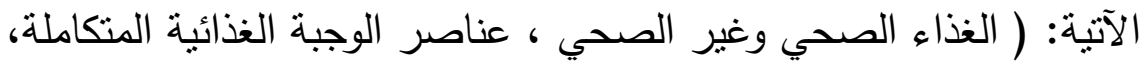
السلوكيات الغذائية )، لأطفال الروضة الغية عينة البحث.

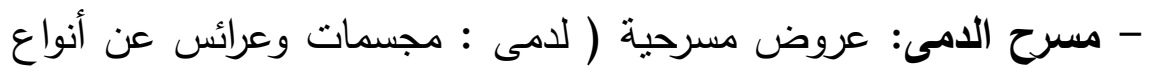

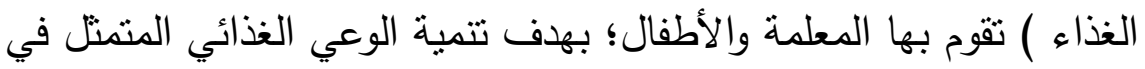

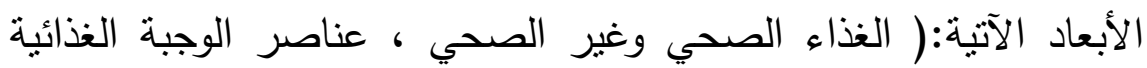
المتكاملة، السلوكيات الغذائية ) لأطفال الروضية.

- الوعي الغذائي: مساعدة أطفال الروضة على اكتساب المعلومات

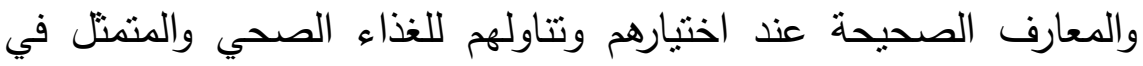

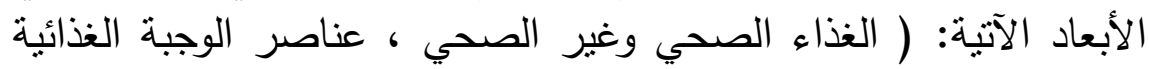
المتكاملة، السلوكيات الغذائية ). الإطار النظري : (1) - (1)

يتتاول الإطار النظري للبحث الحالي المحاور التالية:

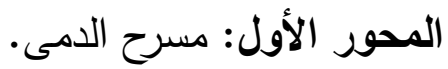

المحور الثاني: إكساب الوعي الغذائي لطفل الروضـة، وفيما يلي تقصيل لما سبق. 


\section{المحور الأول: مسرح الامى :}

• أهمية مسرح الامى لأطفال الروضة:

- يسـاعد على تجسبد الفكرة والثخصية بشكلٍ مسموعٍ وملموسٍ بالنسبة

للطفل.

- تمنل شخصية الدمية عالماً خاصاً للطفل.

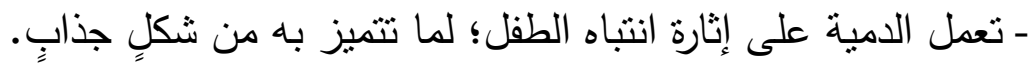

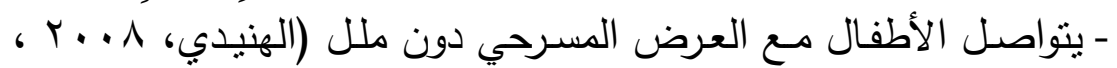

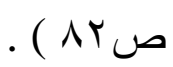

- تساعد الدمى في تيسير العملية التعليمية.

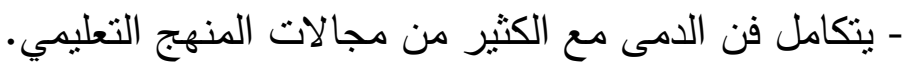
- تتمي الدمى التفكير الإبداعي واستخدام الخيال للأطفال. - إتاحة الفرصة للأطفال لاختيار مواقف من الإبل الحياة . - تقدم الدمى فرصاً عديدةً لحل المشاكل. - تحقق الدمى المتعة والبهجة.

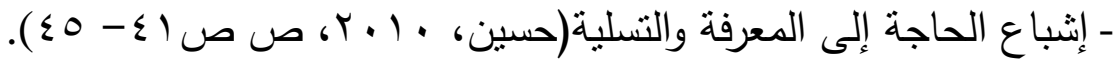
• أنواع الامى المناسبة لأطفال الروضة: أ- عرائس العصا: وهي من أبسط أنواع العرائس، ويتم تثبيت عصا بظهر

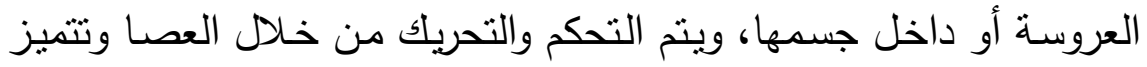
بسهولة تصنيعها من ثمار الخضراوات والفاكهة. ب- عرائس اليد: وهي عرائس القفاز ( الجوانتي ) وتعتبر من أكثر أنواع الفاعه

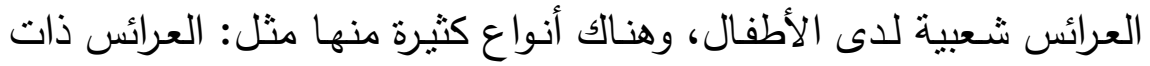

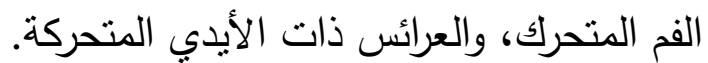




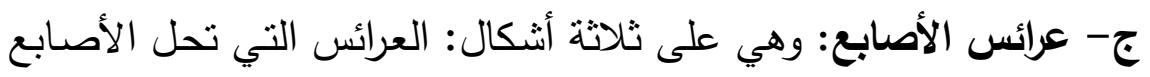

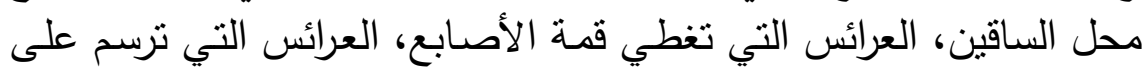

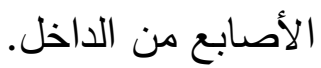
د - العروسـة ذات الوجهين: وهي من العرائس التي لها متعـة خاصـة، لها

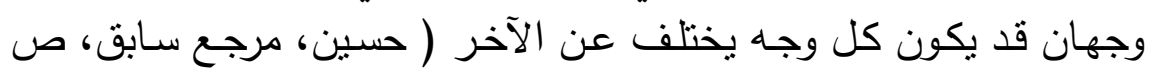

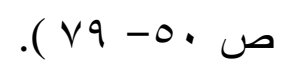

• الاعتبارات التي يجب الأخذ بها عند استخدام مسرح الدمى لأطفـال الروضة:

- يجب أن تتناسب ملابس الدمية في الطول والعرض.

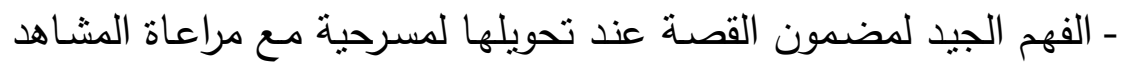
والحوار والثخصيات وغيرها من العناصر.

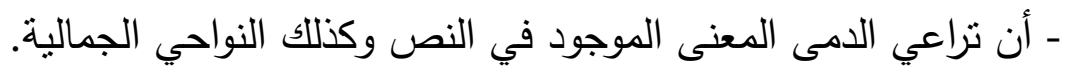

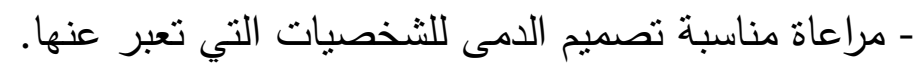
- حسن استغلال الإمكانات المتاحة ومراعاة الاعتبارات الفنية والتكنيكية

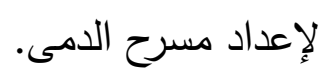

- تحريك الدمى بالثكل المناسب المتوازن حتى لا يتشتت الأطفال.

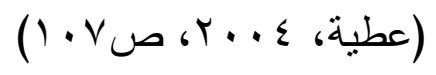

كما أن هناك مجموعة من الاعتبارات الواجب مراعاتها، فيما يلي : - أن تعبر المناظر المستخدمة عن الأحداث والمكان التي يدور فيها مسرح - اختيار الألوان المناسبة سواء في الملابس أو المناظر لتحقيق الاتساق والانسجام. 
- مراعاة التتاسق بين أحجام الأشياء بعضها إلى بعض، فيؤخذ في الاعتبار

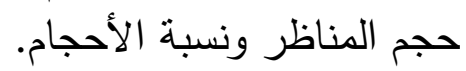
- تصـميم الـدمى مـن الخامـات المختلفـة والمنـاظر التـي تعطيها التشـويق والحيوبة. تهية - مناسبة الارتفاع وفتحة المسرح لأسلوب العرض وعدد الأطفال.

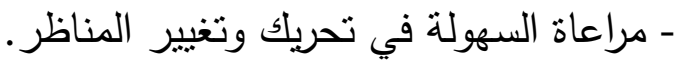

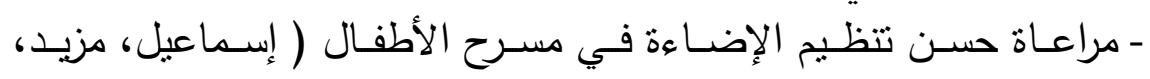

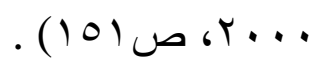

المحور الثاني : إكساب الوعي الغذائي لأطفال الروضة: يوفر الوعي الغذائي لأطفال الروضـة المهارات الحياتية والأساليب التي لئي

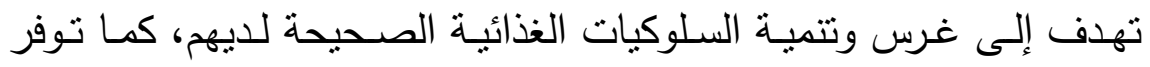

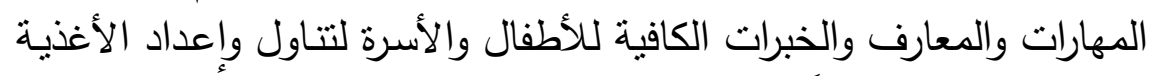

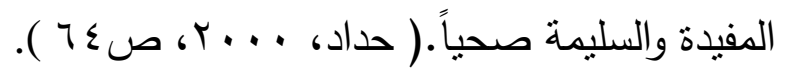
• الثروط الواجب توافرها في الغذاء المُقدَم لطقل الروضة: - أن يكون خالياً من المواد الضارة والسامة.

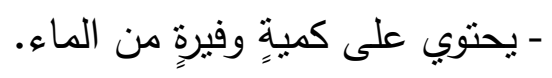

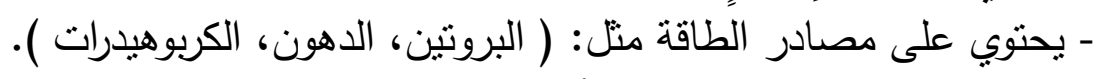

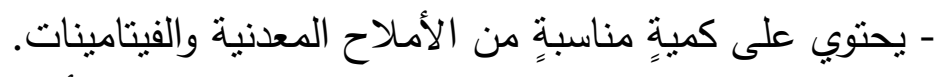

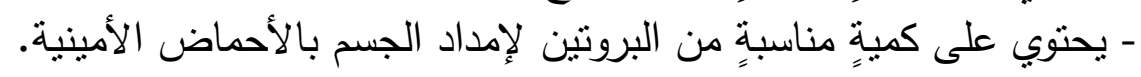

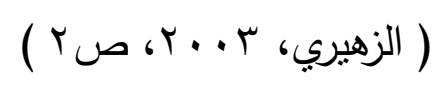


السمات الهامة المرتبطة بإكساب الوعي الغذائي لأطفال الروضة:

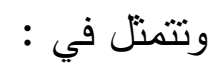

- يرتبط الغذاء بمعانٍ مختلفةٍ : حيث يرتبط الغذاء بمواقف خاصة بالأطفال

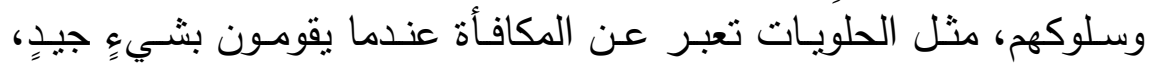

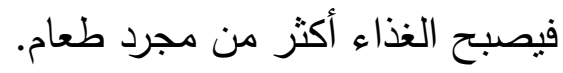
- التواصل: تثميز هذه المرحلة بالمشاركة والحوار والاستمتاع بتتاول الغذاء الغداء مع العائلة، الأصدقاء والمعلمات. ـ الفضول: يتجه الأطفال في هذه المرحلة إلى كثرة الأسئلة عن الأسباب.

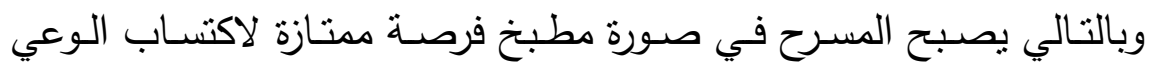
الغذائي من خلال المشاركة والتجربة بأنفسهم في إعداد الغذاء.

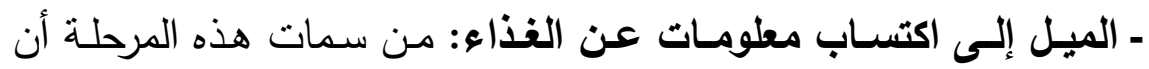
الأطفال يكتسبون بشكلٍ عادٍ معلومات عن الطعام وعن الأطعمـة المغذيـة

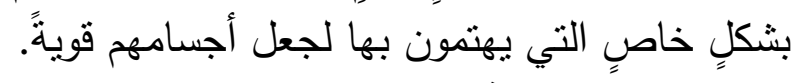

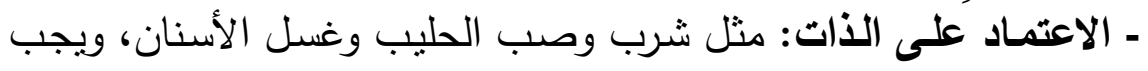

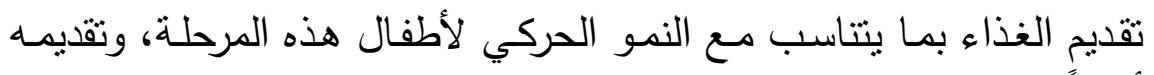

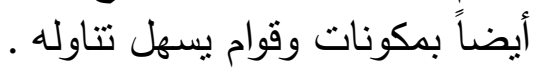

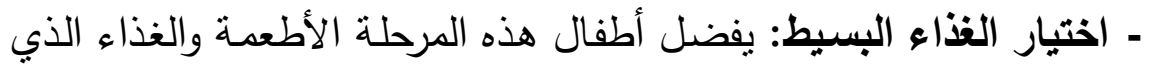

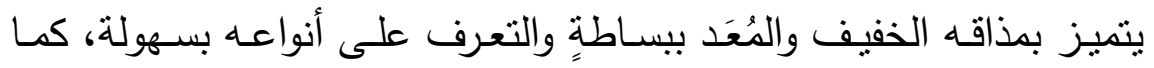

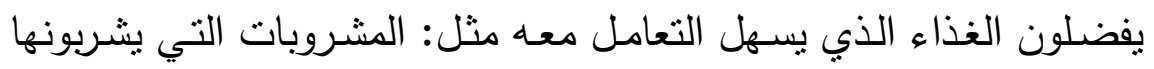
(علب العصير أو في كوب) ، الخضراوات والفواكه المقان التطعة.

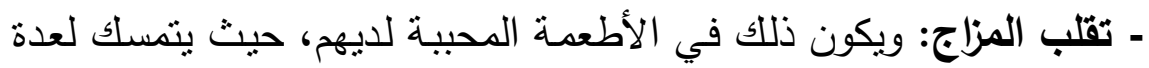

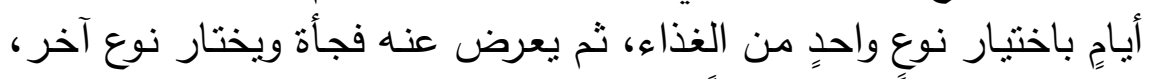
وهذا السلوك لا يعتبر تذبذباً ولكنه طبيعي لهذه المرحلة، ويكون الاختيار 
والتتوع في البداية محدوداً، ثم بعد ذلك يزبد الأطفال من اختبارهم وتتوعهم

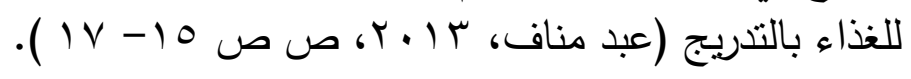

يجب اتباع العوامل الآثية عند إكساب أطفال الروضة الوعي الغذائي: - فهم ومعرفة المواقف التي يقوم بها الأطفال عند ممارستهم للسلوك الغذائي الصحيح.

- تدربب الأطفال على السلوك الغذائي الصحيح المناسب لقدراتهم. (Bobbi, Fisher, 1998, pp. 154-159)

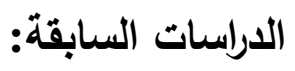

\section{أولاً: دراسات تناولت مسرح الامى:}

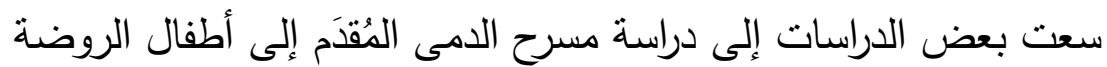

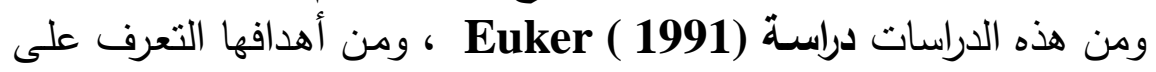

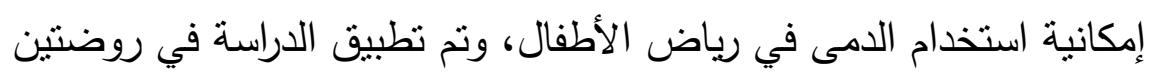

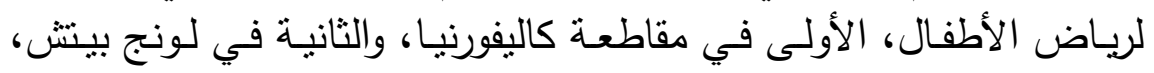

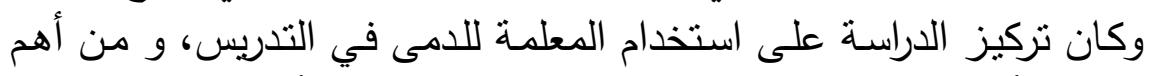

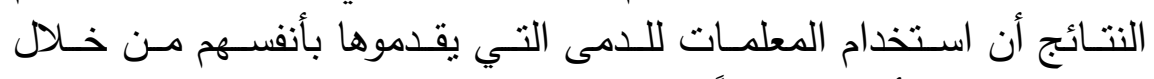

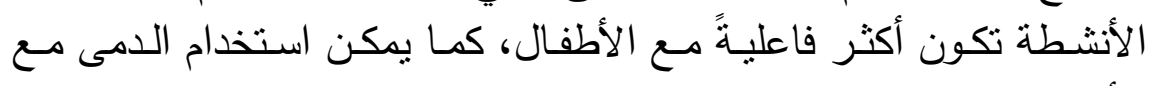

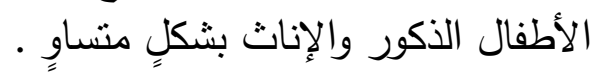

- دراسـة (1995) Deniger : هدفت إلى استخدام مسرح الدمى داخل

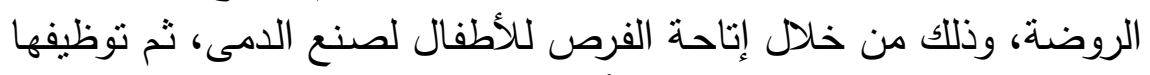

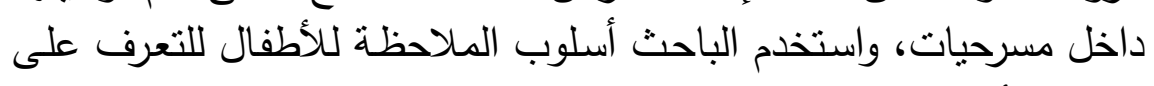

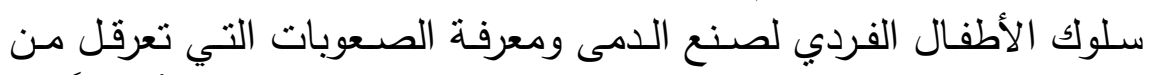
التخطيط لتفعيل مسرح الدمى، وتكونت عينة الدراسة من الاست ( 1 ) أطفالاً في 


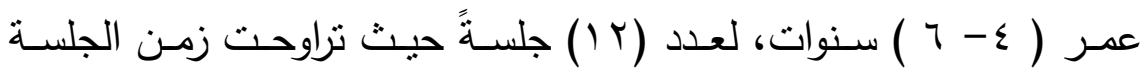

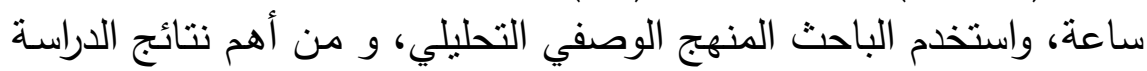

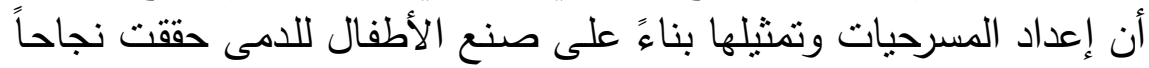

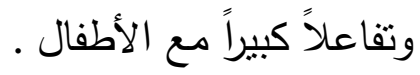

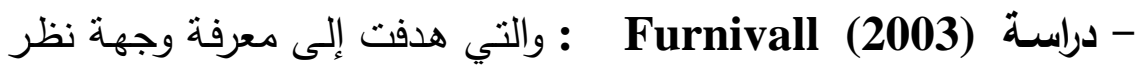

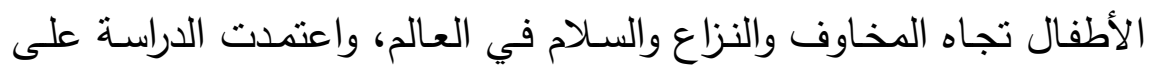

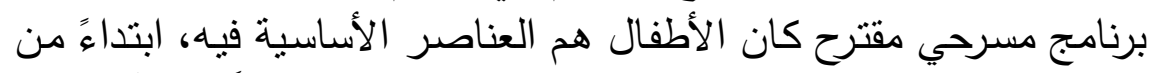

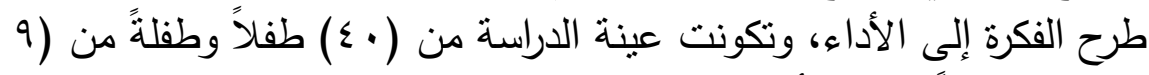

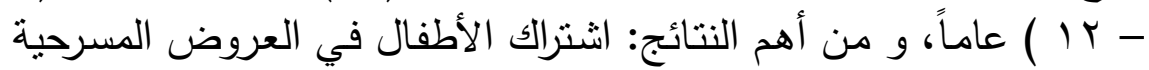

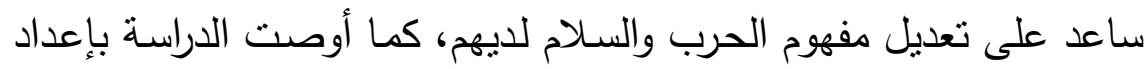

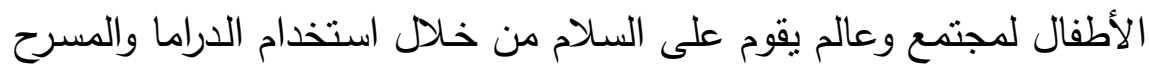
داخل الفصل الدراسي.

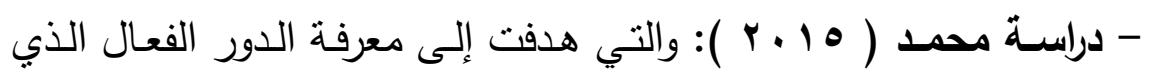

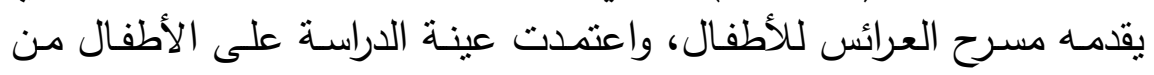

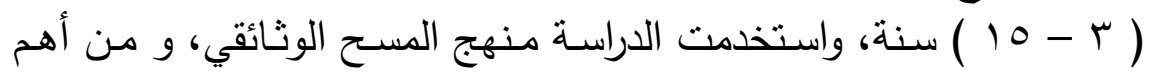

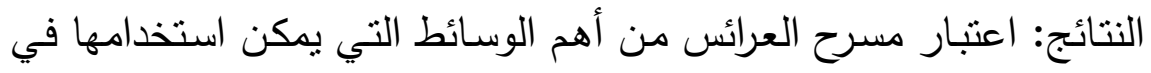

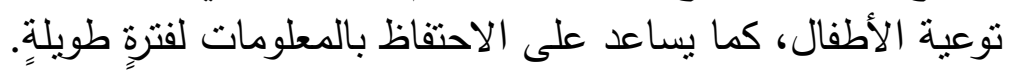

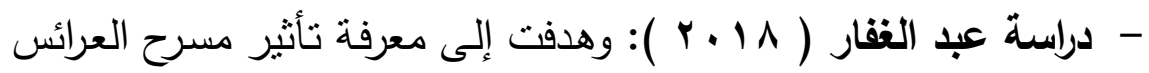

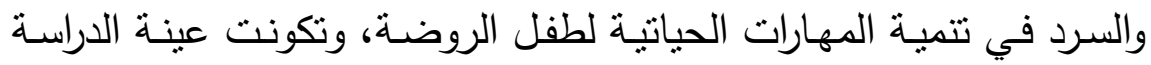

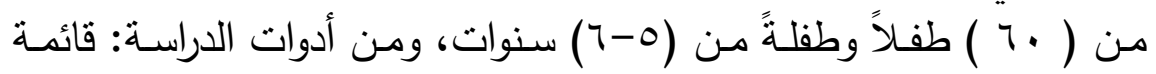

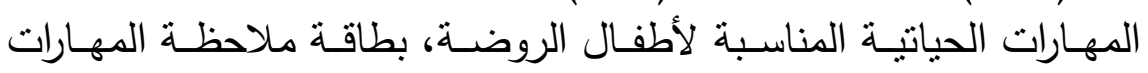

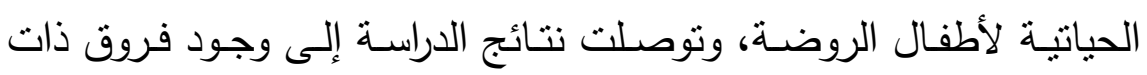

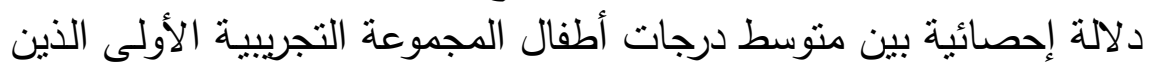


استخدموا نمط مسرح العرائس ومتوسط درجات أطفال المجموعة التجريبية الثانيـة الذين اسـتخدموا نمـط السـرد في التطبيـق البعدي لبطاقـة ملاحظـة

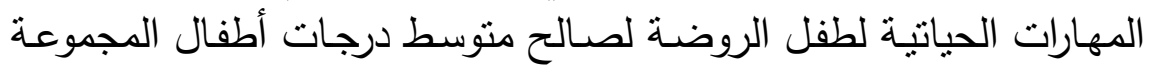
التجريبية الأولى.

- دراسـة عثمـان ( 9 ( ب ب): هـدفت إلـى التعـرف والتحقـق مـن فاعليـة

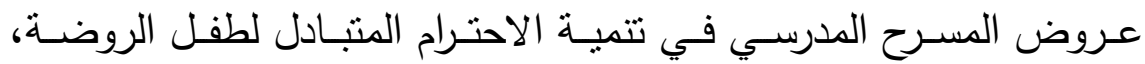

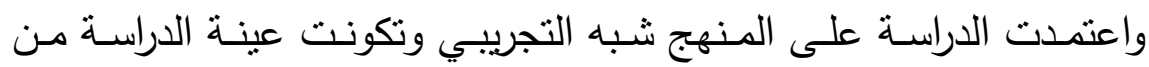

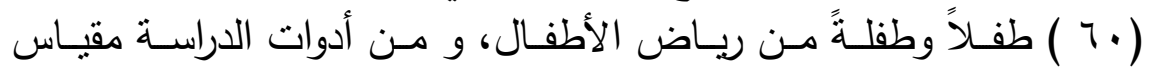

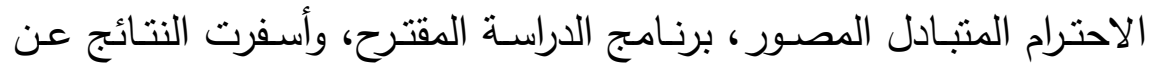
فعاليـة البرنـامج المسرحي لتميـة الاحترام المتبـادل لأطفال الروضـة لصـالح المجموعة التجريبية.

- دراسـة يونس ( 19 • r): هدفت إلى معرفة كفاءة العروض المسرحية

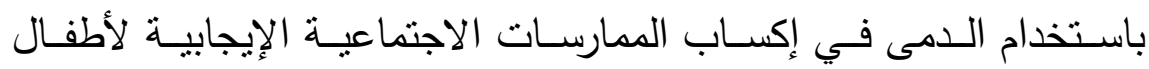
الروضــة، ومسن أدوات الدارسـة: مقيـاس مصــور للسـلوكيات الاجتماعيـة

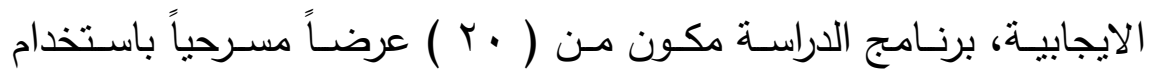
الدمى، وتكونت عينة الدراسة من ( المنهج التجريبي ذو المجموعتين، و من أهم النتائج وجود فروق ذات دلالة إحصـائية بين متوسط درجات المجموعة التجريبية الضـابطة في الاختبار البعدي لصالح التجريبية.

ثانياً : دراسات تثاولت الوعي الغذائي لأطفال الروضة: من ضدن هذه الدراسـات دراسـة Weker (2000) : مالتي هدفت إلى معرفة النمط الغذائي لأطفال الروضـة بدولـة بولندا، و مـن أدوات الدراسـة: قياسات أنثرومتربة (خاصة بالجلد، الطول والوزن)، استبانة عن تقييم الغذاء 


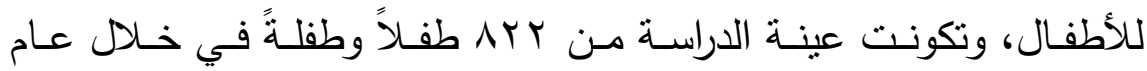

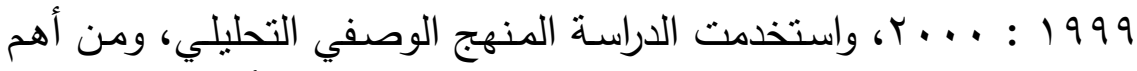

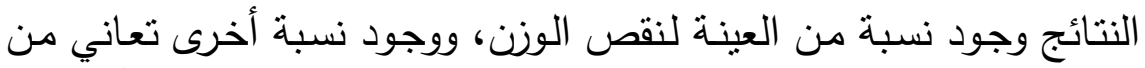

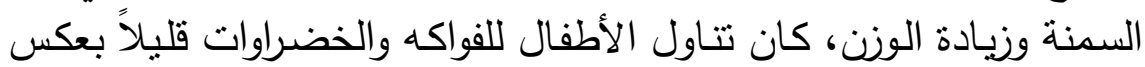

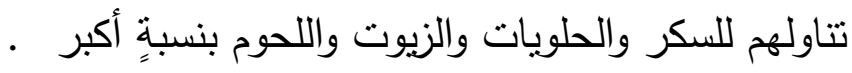

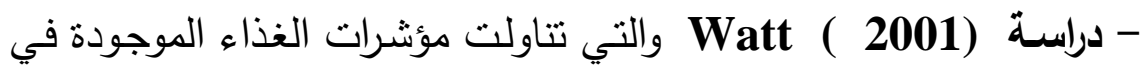
رياض الأطفال في بريطانيا، و من أهداف الدراسـة تقييم الوجبات والثراب

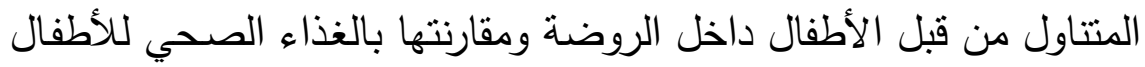

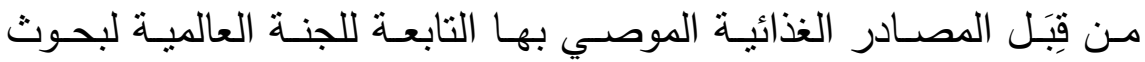

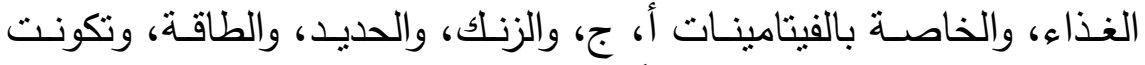

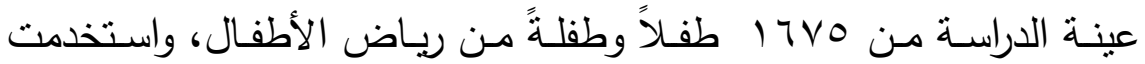

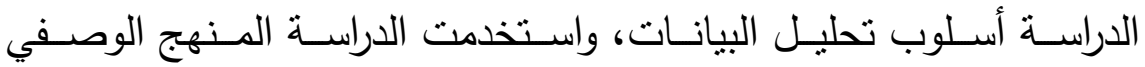

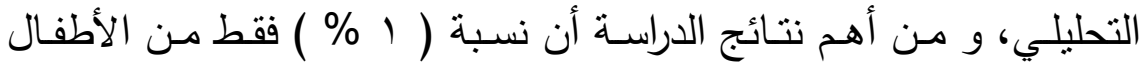

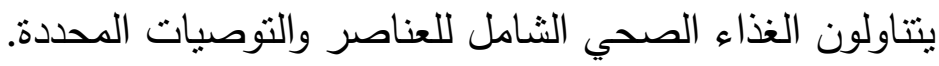
- دراسـة Tada (2002) : حيث هدفت إلى معرفة الحالة الغذائية عند

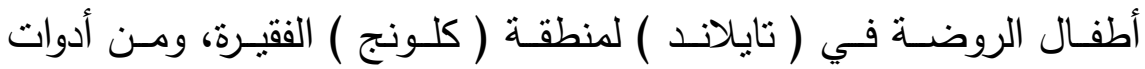

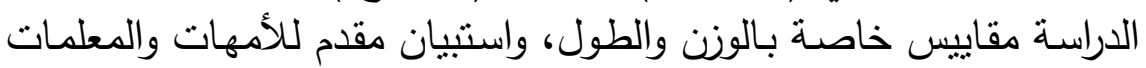

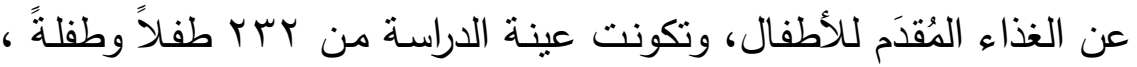

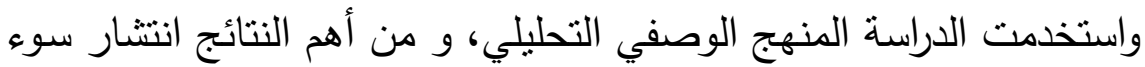

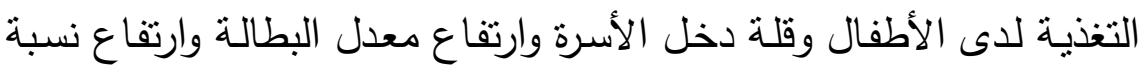
الأمية .

- دراســة الجمـال ( ؟ . . ب): والتـي هدفت إلى إعـداد برنـامج لمشـرفات

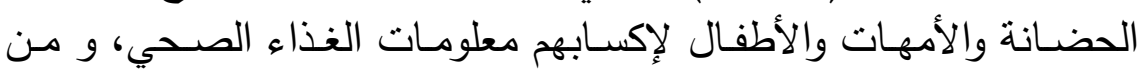


أدوات الدراسـة اختبـار رسـم الرجـل للـذكاء، اســمارة الســلوك الصـحي :

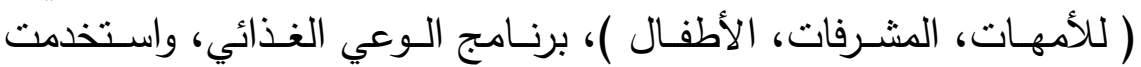

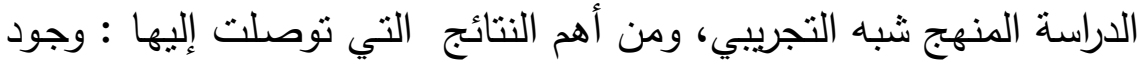
فـروق ذات دلالــة إحصـائية بـين متوسـطات درجـات المجموعـة التجريبيـة والضابطة بعد تطبيق البرنامج لصالح التطبيق البعدي.

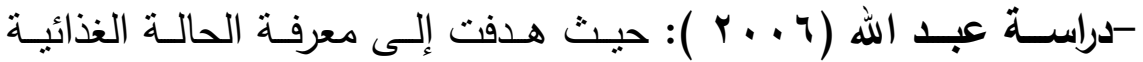
والصحية للأطفال في عمر ( r-7) سنوات، و من أدوات الدراسـة استبانة

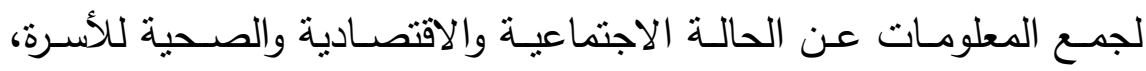
مقاييس للوزن والطول، جداول تحليـل الأغذيـة المُقدَمَة من منظمـة الصـحة

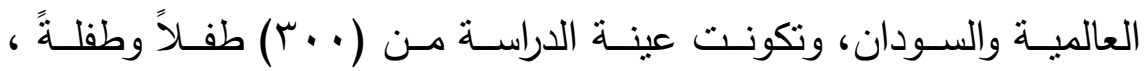

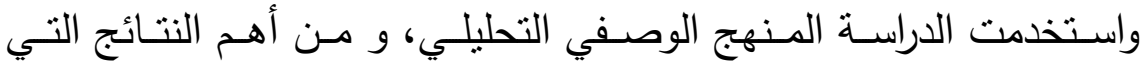

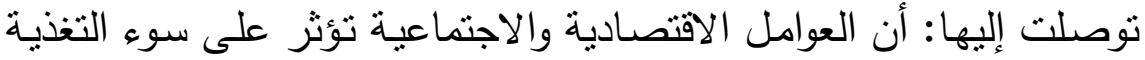

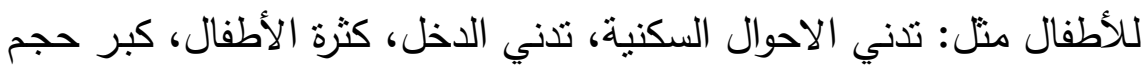
الأسرة، زواج الإناث في سن مبكرة، تدني المستوى التعليمي.

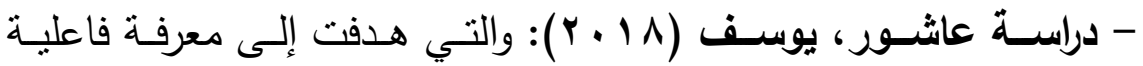
الأنثـة القصصية الإلكترونيـة والحسية لإكسـاب الثقافة الغذائيـة لأطفال

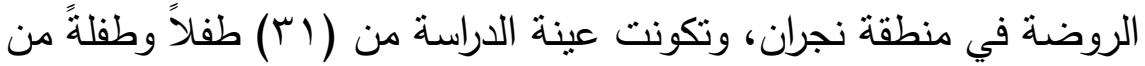

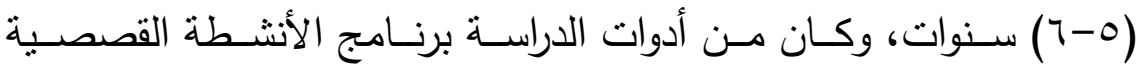

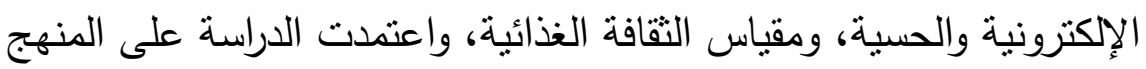
شبه التجريبي ذي المجموعة الواحدة، و من أهم النتائج التي توصلت إليها

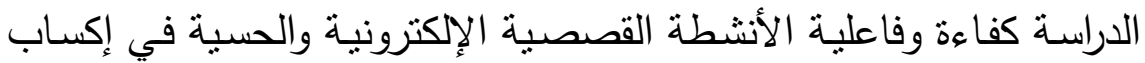

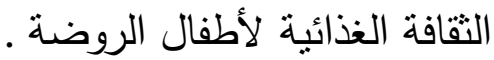


- دراسة تزكو، الحسين (1^ ـ ب): والتي هدفت إلى معرفة كفاءة الأنشطة

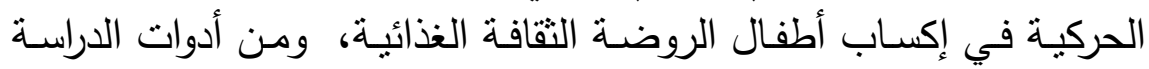

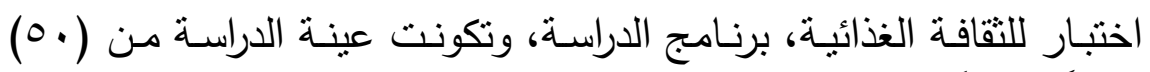

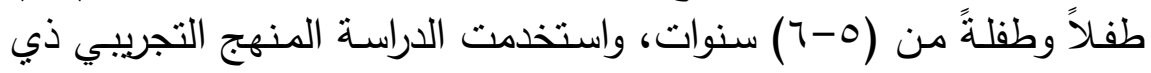

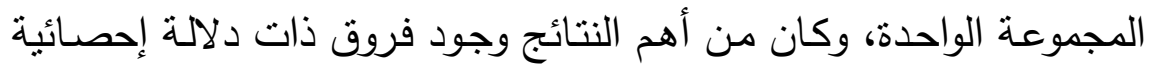

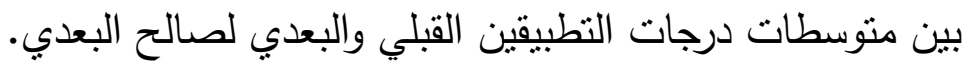

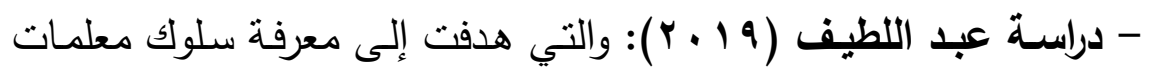

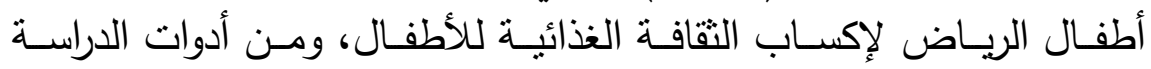

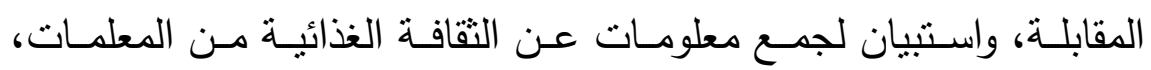

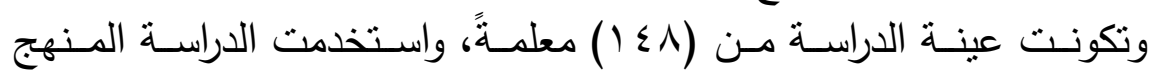

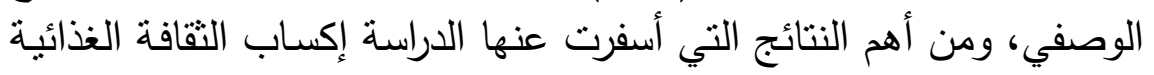

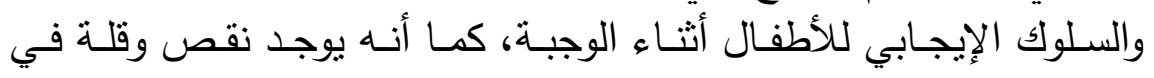
البرامج التدريبية الخاصة بالتقافة الغذائية للأطفال.

\section{تعقيب على الاراسات السابقة:}

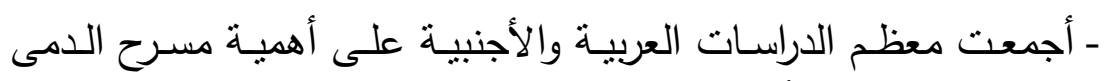

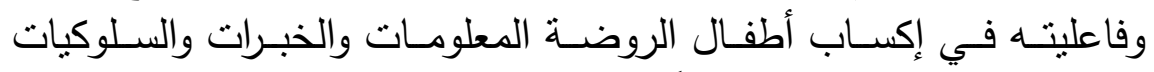

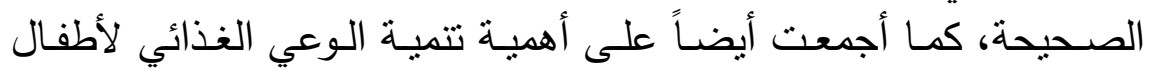

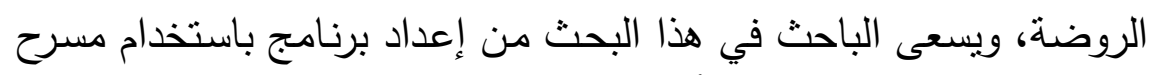

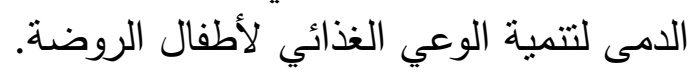
- جاءت نتائج الدراسات السابقة (العربية والأجنبية) لتصف لأنف وتحلل استخدام

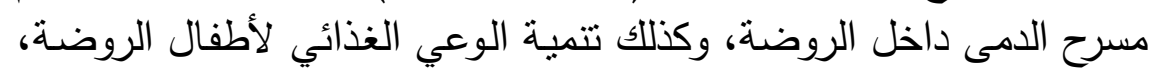
ولكن باختلاف موضوعات الدراسة. 
- ولقد تمثلت الاسـفادة من إطلاع الباحث على الدراسـات السـابقة في المسـاهمة في تحديـد مشـكلة البحـث وأهميتهه، وكذللك في إعداد وتطبيـق برنامج البحث الحالي. إجراءات البحث : أولاً: منهج البحث:

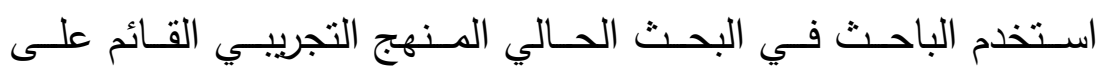
المجموعتين ( الضـابطة ،التجريبية) لمناسبته لطبيعة البحث؛ وذلك لمعرفة مـدى فاعليـة اسـتخدام مسـرح الـدمى فـي تتميـة الـوعي الغـذائي لأطفـال الروضة.

والجدول التالي يوضح التصميم التجريبي المتبع في هذا البحث: جدول رقم (1)

يوضح التصميم التجريبي المتبع في هذا البحث

\begin{tabular}{|c|c|c|c|}
\hline الاختبار البعدي & $\begin{array}{c}\text { المعالجة } \\
\text { Treatment }\end{array}$ & الاختبار القبلى & نوع المجموعة \\
\hline 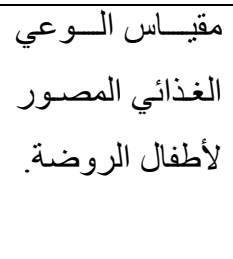 & 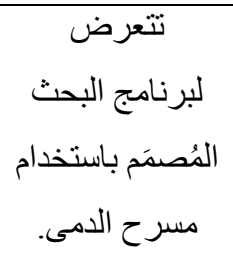 & 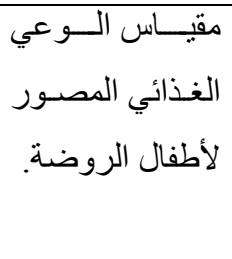 & $\begin{array}{l}\text { المجموعة } \\
\text { EXP. } \\
\text { Group }\end{array}$ \\
\hline 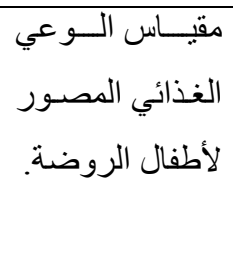 & 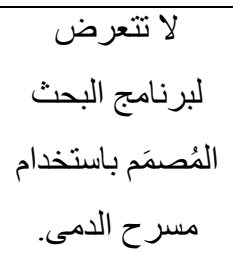 & 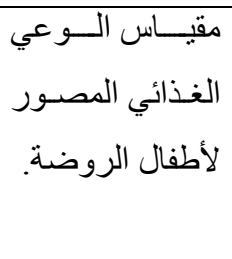 & $\begin{array}{c}\text { المجموعة } \\
\text { Group } \\
\text { cont. }\end{array}$ \\
\hline
\end{tabular}




\section{ثانياً: مجتمع وعينة البحث :}

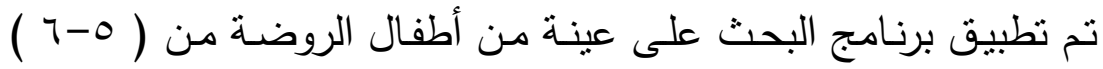

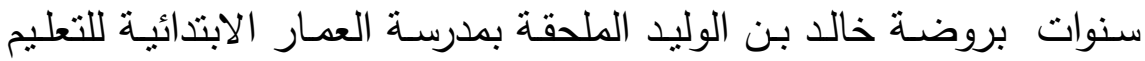
الأساسي، التابعة لإدارة طوخ التعليمية بمحافظة القليوبية.

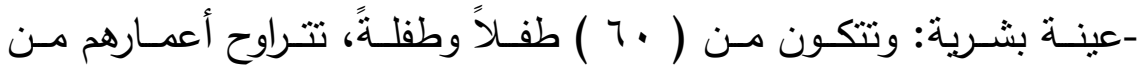

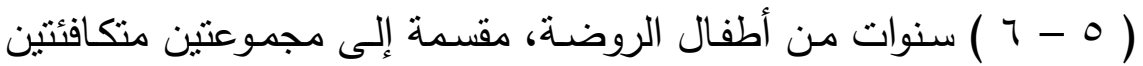

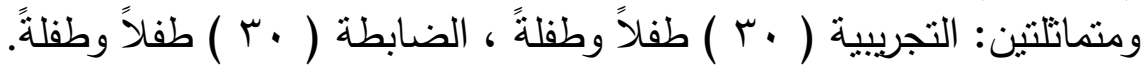

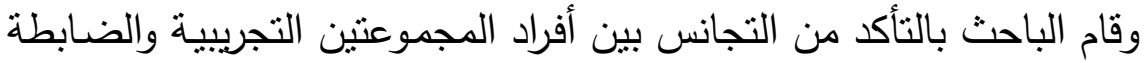

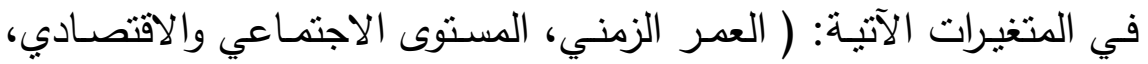

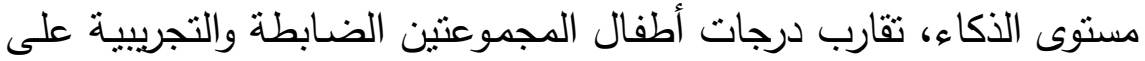
مقيـاس الـوعي الغـذائي المصـور لأطفــال الروضـــة قبـل تطبيـق البرنـامج

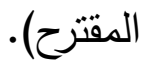
- العمر الزمني: الجدول التالي يوضح التجانس بين المجموعتين في العمر الزمني باستخدام اختبار ( ت الزير ).

جدول (Y) يوضح التجانس في العمر الزمني بالثهور باستخدام اختبار T.test

\begin{tabular}{|c|c|c|c|c|c|c|}
\hline \multirow{2}{*}{ مستوى } & \multirow{2}{*}{ قيمة(ت) } & \multicolumn{2}{|c|}{ 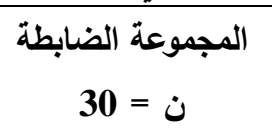 } & \multicolumn{2}{|c|}{ المجموعة التجريبية } & \multirow[b]{2}{*}{ المتغير } \\
\hline & & الانعراف & المستوسط & الانحراف & الحستوسط & \\
\hline دالة & $\cdot, V Y$ & $r, \Lambda$. & $T V, I T$ & $r, 0$ & $77,0 \leq$ & بالثهور \\
\hline
\end{tabular}


يتضح من الجدول السابق عدم وجود فروق دالة إحصائياً بين متوسطات المجموعتين في العمر الزمني. ثالثثاً: أدوات البحث :

ا-اختبار رسم الرجل "جود أنف هاريس"، تقنين فاطمة حنفي (r/9 1) ). r-مقياس المستوى الاجتماعي - الاقتصادي للأسرة. ( إعداد: عبد العزبز هاريز السبد الثخص، (1990) ب-مقيـاس الوعي الغذائي المصـور لأطفال الروضـة. ( إعداد: منى عبد

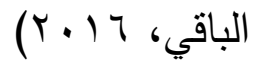
؟-البرنامج القائم على مسرح الدمى. (إعداد الباحث)

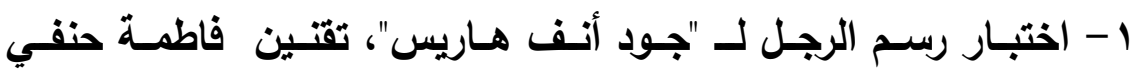

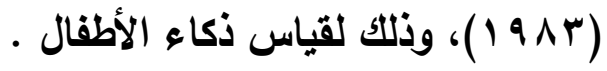

مـن مبـررات اسـتخدام الاختبـار : اسـتخدمته العديد مـن الدراسـات العربيـة

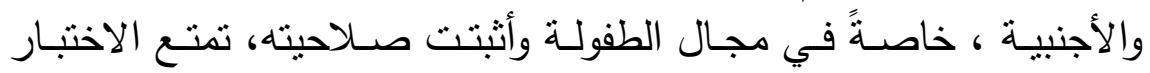
بدرجة ثباتٍ وصدقٍ عاليةٍ مطمئنة إلى حدٍ كبيرٍ ، يصلح تطبيقه على البيئة

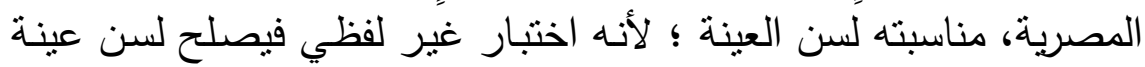

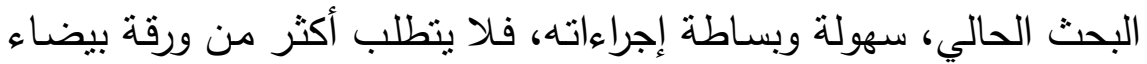
وقلم رصـاص، غير مكلف، لا يعتمد على المهارة الفنيـة في الرسم، يمكن فئن

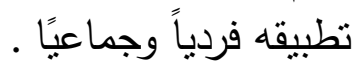

- مستوى الذكاء: الجدول التالي يوضح التجانس بين المجموعتين في نسبة الذكاء 
جدول (ץ) يوضح التجانس بين المجموعتين في نسبة الذكاء

\begin{tabular}{|c|c|c|c|c|c|c|}
\hline \multirow{2}{*}{ مستوى } & \multirow{2}{*}{ قيمة(ت) } & \multicolumn{2}{|c|}{ 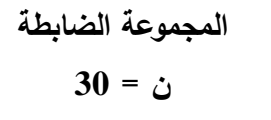 } & \multicolumn{2}{|c|}{ المجموعة التجريبية } & \multirow{2}{*}{ المتغير } \\
\hline & & الانحراف & الحستوسطي & الانحراف & الحستوسط & \\
\hline غير دالة & $\cdot, 7 \leqslant$ & $\varepsilon, 19$ & $9 \wedge, 9$ & $\varepsilon, r$ & $9 \wedge, r$ & الذكبة \\
\hline
\end{tabular}

يتضح من الجدول السابق تجانس المجموعتين من حيث نسبة الذكاء. r-مقياس المستوى الاجتماعي - الاقتصادي للأسرة( إعداد: عبد العزيز

$$
\text { (السيا (الشخص، 0 } 999 \text { 1) ). }
$$

مبررات استخدام المقياس : استخدام العديد من الدراسـات العربية السـابقة لهذه الاستمارة، وقامت معظم هذه الدراسـات بحسـاب قيمـة الصدق والثبات

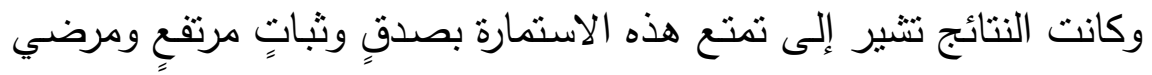
ومطمئن إلى حدٍ كبيرٍ

- المستوى الاجتمـاعي والاقتصـادي: الجدول التالي بوضـح التجانس بين المجموعتين في المستوى الاجتماعي الاقتصادي. جدول (ץ) يوضح التجانس بين المجموعتين في المستوى الاجتماعي الاقتصادي

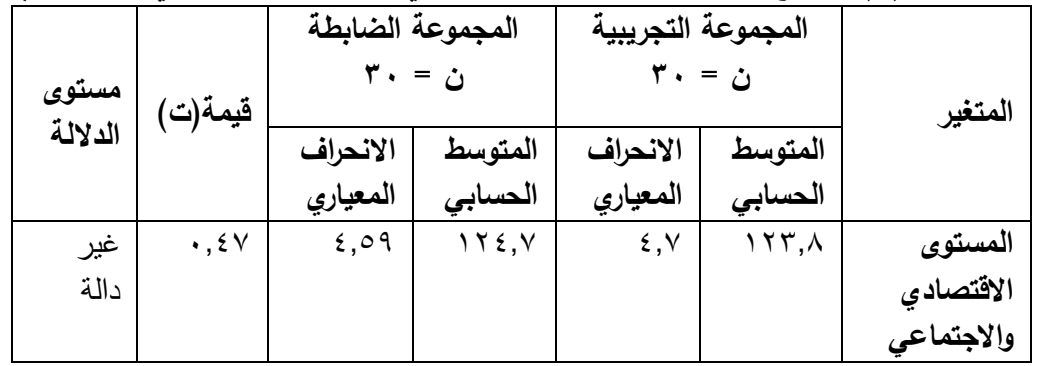


يتضــــ مـن الجــول الســابق تجـانس المجمــوعتين فـي المسـتوى

$$
\text { الاجتماعي - الاقتصادي. }
$$

r- مقياس الوعي الغذائي المصور لأطفال الروضة ( إعداد: منس عبد

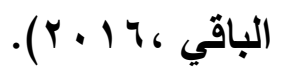

مبررات استخدام المقياس: مناسبة المقياس لسن عينة البحث الحالي؛ لأنه

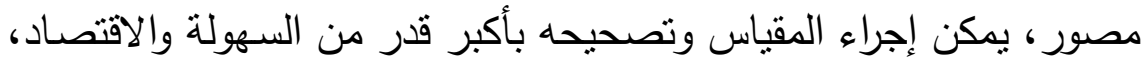

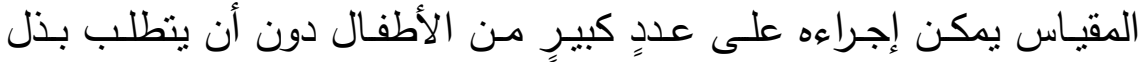

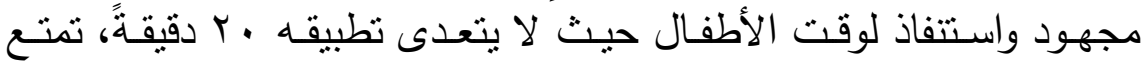

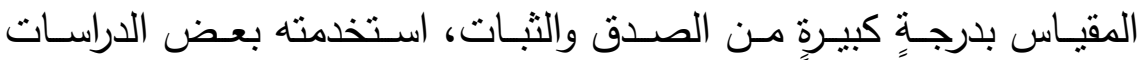

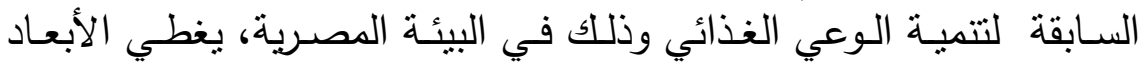

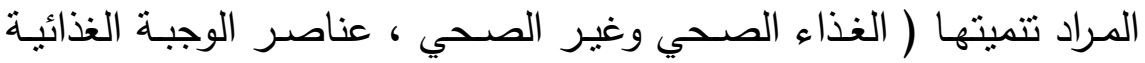
المنكاملة، السلوكيات الغذائية ).

ثبات المقياس: - (مقاس

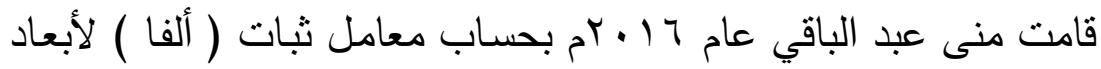

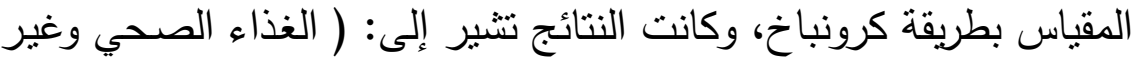

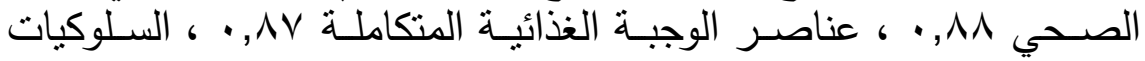

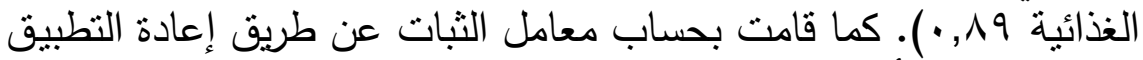

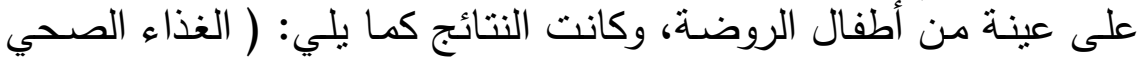

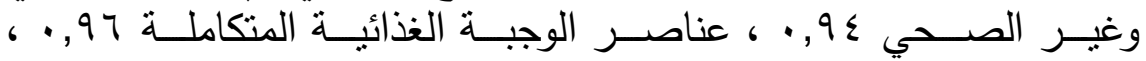

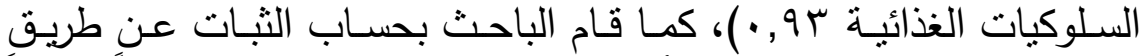

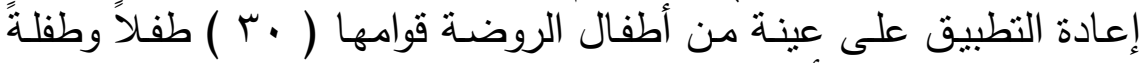

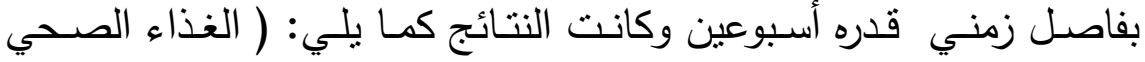

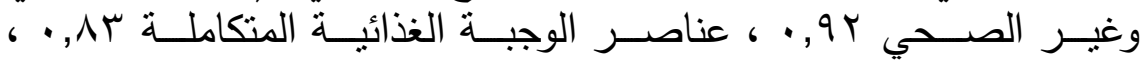
السلوكيات الغذائية •^, • )، وجميعها تذل على ثبات المقياس بدرجةٍ كبيرةٍ. 
قامت منى عبد الباقي عام 17 ـ بام بحساب صدق المقياس عن طربق حساب صدق المحكمين لكل موقفٍ من مواقف المقياس، وقد زادت نسـ

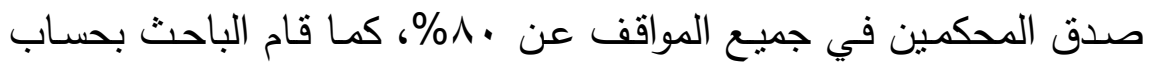
صـدق المقيـاس مـن خـاللال الصــدق الظـاهري ( المتعلـق بـالمظهر العـام للمقياس)، وتم التأكد من ذلك في الدراسـة الاستطلاعية، كمـا تم حسـاب

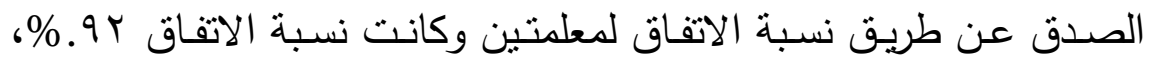
وتؤكد هذه النتائج المرتفعة مصداقية وثبات المقياس للتطبيق على العينة . - تقارب درجات المجموعتين ( التجريبية والضـابطة ) على مقياس الوعي الغذائي المصور لأطفال الروضة، والجدول التالي يوضح ذلك.

جدول (ء) يوضح التقارب بين المجموعتين في أبعاد الوعي الغذائي ( التطبيق القبلي )

\begin{tabular}{|c|c|c|c|c|c|c|}
\hline \multirow{2}{*}{ مستوى الالالة } & \multirow{2}{*}{ قيمة(ت) } & \multicolumn{2}{|c|}{ المجموعة الضابطة } & \multicolumn{2}{|c|}{ المجموعة التجريبية } & \multirow{2}{*}{ البندا الأبعاد } \\
\hline & & الانحراف & المتوبط & الانحراف & المتوبط & \\
\hline غير & $\cdot, \leqslant 0$ & $r, Y \wedge$ & $1 \cdot, 7$ & $r, V q$ & $1 \cdot, \varepsilon$ & الصغذاء الصحي \\
\hline غير & $\cdot, \varepsilon r$ & $\cdot, 99$ & $Y, V \leq$ & $\cdot, \wedge \neg$ & $r, \wedge r$ & الوناصر الغذبة المتكاملة \\
\hline غيز & • & $1, \leqslant 4$ & $r, . q$ & ו, & $r, q r$ & السلوكيات الغذائية \\
\hline
\end{tabular}




\begin{tabular}{|c|c|c|c|c|c|c|}
\hline \multirow{2}{*}{ الدلالة } & \multirow{2}{*}{ قيمة(ت) } & \multicolumn{2}{|c|}{ المجموعة الضابطة } & \multicolumn{2}{|c|}{ المجموعة التجريبية } & البند \\
\hline & & الانمراف & المتوسط & الانحراف & المتوسط & الأبعاد \\
\hline غير & $\cdot, r \wedge$ & $\mu, \wedge$ & 17,8 & ^^, & $17, .7$ & الدرجة الكلية \\
\hline
\end{tabular}

وبتضح من الجدول السابق تكافؤ وتقارب وتماثل المجموعتين التجريبية

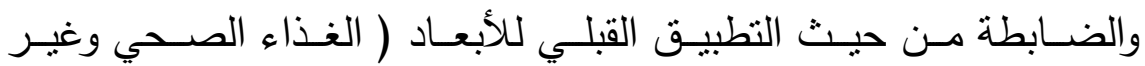
الصحي، عناصر الوجبة الغذائية المنكاملة، السلوكيات الغذائية ). ع - البرنامج القائم على مسرح الدمى. (إعداد الباحث) في ضـوء نتـائج الدراسـات السـابقة والإطـار النظـري للبحـث الحسالي تم

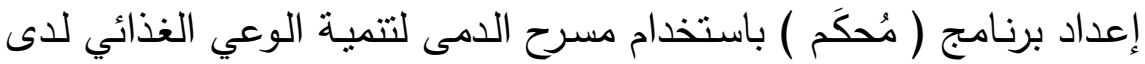

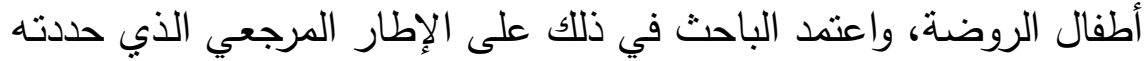

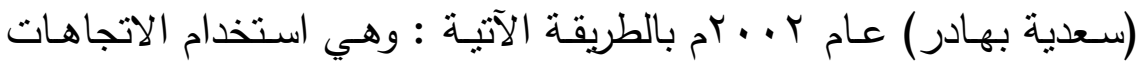
والأساليب العلمية المعاصرة ، وذلك من خلال الإجابة على خمسة تساؤلات تحدد أبعاد الإطار المرجعي العام للبرنامج الحالي وهي:

\section{: To Who? ? : لمن البرنامج}

وتتضـدن الإجابـة على هذا السؤال التحديد الدقيق للمستقيدين مـن هذا البرنامج وهم أطفال الروضة ، والتي تتراوح أعمارهم بين (0-7) سنوات.

: Why? : : لماذا البرنامج :

لتتمية الوعي الغذائي المتمنل في الأبعاد الآتية: ( الغذاء الصحي وغير

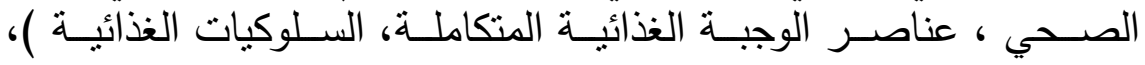

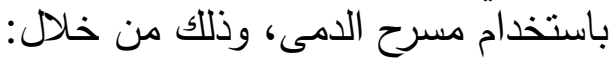


- مستوى المعرفة الغذائية: ويتضمن إكساب الأطفال معارف ومعلومات

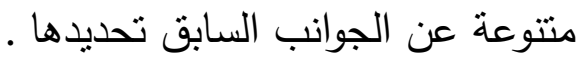

- مستوى الوعي الغذائي: وبتضمن إكساب الأطفال الوعي الغذائي الصحي لجوانب الغذاء المحددة سابقاً.

- مستوى الاتجاهـات والميول والقيم الغذائيـة: ويتضــن إكسـاب الأطفال اتجاهات وميول وقيم نحو الغذاء لتتاول الصحي والمفيد منه. - مستوى المهارات المرتبطة بالغذاء: ويتضمن إكساب الأطفال المهارات المرتبطة بالغذاء اللازمة للحفاظ على صحتهم.

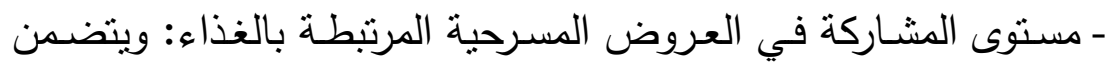
إتاحة الفرص للأطفال للمشاركة بايجابية في العروض المسرحية . ل.

\section{: What ? : ماذا : :}

والمقصود بهذا السؤال ما الذي يمكن تقديمه للمستقيدين من هذا البرنامج حتى يحقق البرنامج فاعليته في تتمية الوعي الغذائي لدى عينة البحث.

واعتمـد برنـامج البحث الحـالي على مجموعـة مـن العـروض المسرحية باسـتخدام الدمهى، ويتكون البرنـامج من (10) عرضـاً مسرحياً لكل عرضٍ مسرحي جلسـتين( جلسـة لإعداد العرض المسـرحي مـع الأطفـال، والجلسـة

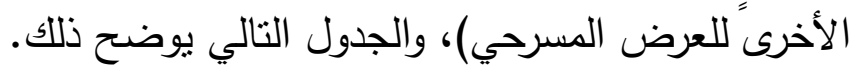




\section{جلول ( )}

العروض المسرحية لتنمية جوانب الوعي الغذائي لأطفال الروضة

\begin{tabular}{|c|c|c|c|}
\hline رقم الجلسة & العرض المسرحي & الجأبفال المُراد تتميته & م \\
\hline$r \cdot 1$ & الجسم السليم في الغذاء & \multirow{5}{*}{ الغذاء الصحي وغير } & \multirow{5}{*}{1} \\
\hline$\varepsilon, r$ & الغذاء الصحي وغير & & \\
\hline 760 & غذائي دوائي. & & \\
\hline$\Lambda, V$ & الخضراوات والفواكه. & & \\
\hline $1 \cdot 69$ & الغذاء النظيف. & & \\
\hline $1 r_{6} 11$ & العناصر الغذائية الأساسية. & \multirow{5}{*}{ عناصر الوجبة الغذائية } & \multirow{5}{*}{$r$} \\
\hline $1 \leq 61 \pi$ & الهرم الغذائي. & & \\
\hline $17 \cdot 10$ & نحن الفيتامينات. & & \\
\hline 11.18 & مكونات الغذاء الصحي. & & \\
\hline$r \cdot 619$ & صحي ولذيذ. & & \\
\hline r 6 G & آداب الطعام. & \multirow{5}{*}{ السلوكيات الغذائية } & \multirow{5}{*}{$r$} \\
\hline$T \leq 6 r$ & الجراثيم لبست أصدقاءنا & & \\
\hline ry, ro & الغذاء الآمن. & & \\
\hline Y^ ، $r V$ & ت ت ت ت اول الغذاء. & & \\
\hline$r \cdot 6 q$ & غسل الفواكه والخضراوات & & \\
\hline
\end{tabular}




\section{سع : : كيف ؟ ? :}

وتتضمن الإجابة على هذا السؤال تحديد الفنيات والإستراتيجيات التربوية

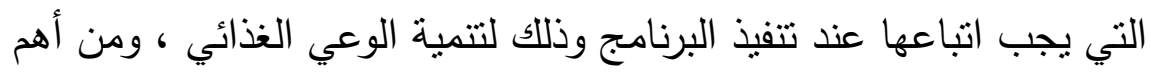

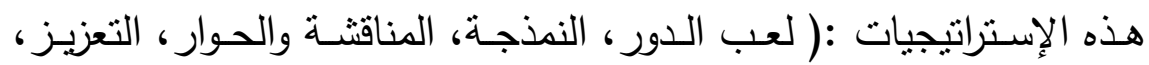
التغذية الراجعة).

ولقد روعي في طرائق التعليم والتعلم (في برنامج البحث) ما يلي : - مدى تتوعها في تقديم المفاهيم والأنشطة المختلفة.

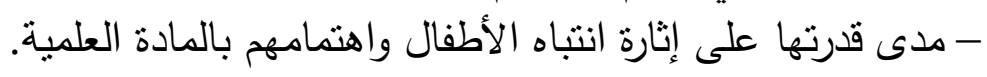

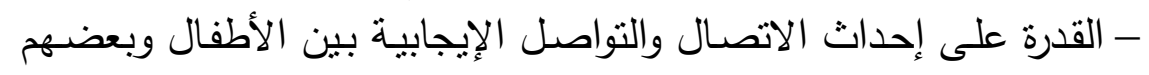
وبين المعلمة.

- مناسبتها للأهداف ومحتوى التعلم وطبيعة نمو الطفل وتفكيره. - محتوى التعلم يتيح فرص تتمية الوعي الغذائي.

\section{س : When ? : متى}

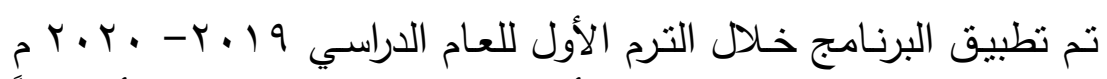

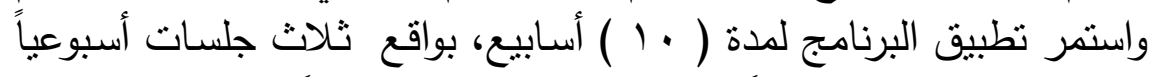

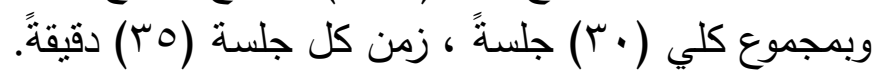

تقويم البرنامج: يتم ذلك طبقاً للآتي:

- التقويم المرحلي : حيث يتم تقويم كل جلسة على حدى بعد كل عرض مسرحي، ويتم ذلك عن طريق : 
ا- جانب نظري : عن طريق الأسئلة والمواقف والمشكلات التي تعرضها المعلمة على الأطفال وذلك( قبل العرض المسرحي وفي أثنائه وبعده ).

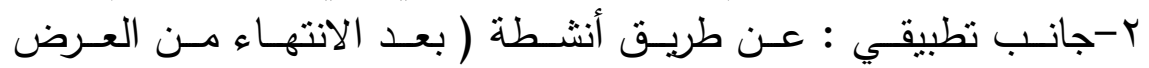
(المسرحي)

- التقويم التهائي: وذلك بالتطبيق البعدي لمقياس الوعي الغذائي المصور على أطفال المجموعة التجربيية. المعالجات الإحصائية المستخدمة في البحث : تم استخدام ما يلي : -المتوسط الحسابي. -الانحراف المعباري.

- T.test اختبار تفسير ومناقشة التتائج : نتائج الفرض الأول وثفسيره :

ينص الفرض الأول على أنه "لا توجد فروق ذات دلالة إحصائية عند

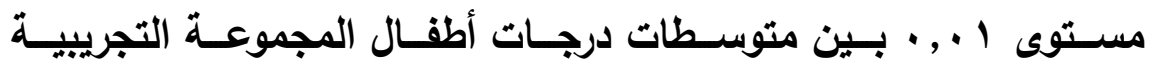

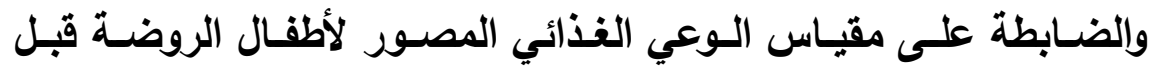

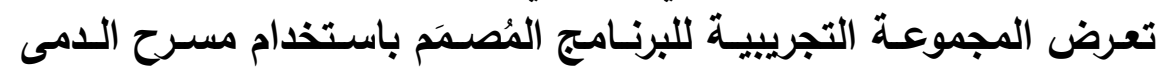
لتنمية الوعي الغذائي ".

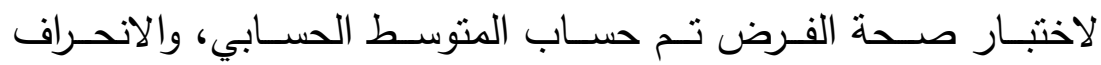
المعياري، وحساب قيمة (ت) للمجموعنين: التجريبية والضـابطة، وذلك على مقبـاس الـوعي الغذائي المصـور لأطفـال الروضـة قبـل تعـرض المجموعـة 
التجريبية لبرنـامج البحث، وبعد رصد النتائج وتحليلها توصـل الباحث إلى النتائج التي تتضح في الجدول التالي:

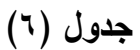

يوضح عدم وجود فروق ذات دلالة إحصائية بين متوسطات درجات أطفال المجموعة

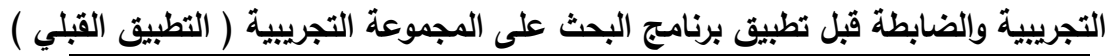

\begin{tabular}{|c|c|c|c|c|c|c|}
\hline \multirow{2}{*}{ مستوى الدلالة } & \multirow{2}{*}{ قيمة(ت) } & \multicolumn{2}{|c|}{ 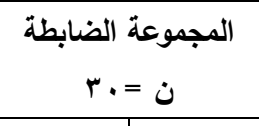 } & \multicolumn{2}{|c|}{ المجموعة التجريبية } & \multirow{2}{*}{\begin{tabular}{|l} 
البنداد المقاسة \\
\end{tabular}} \\
\hline & & الانحراف & الحستوسط & الانعراف & المستوسط & \\
\hline غير & $\cdot, \leqslant 0$ & $r,{ }^{\prime} \wedge$ & $1 \cdot, 7$ & $r, v q$ & $1 ., \varepsilon$ & الصحي \\
\hline غير & .,$\leqslant r$ &., 99 & $r, V \varepsilon$ & • & $r, \wedge r$ & الوالئة \\
\hline غير & ه ז, • & $1, \leqslant 4$ & $r, . q$ & r, & r,qr & السلوكيات \\
\hline غير & $\cdot, \mu \wedge$ & $r, \cdot \Lambda$ & 17,8 & $r, \uparrow \wedge$ & $17, .9$ & الارجة الكلية \\
\hline
\end{tabular}

ويتضح من الجدول السابق عدم وجود فروق ذات دلالة إحصائية بين متوسطات درجات أطفال المجموعة التجربيية والضـابطة قبل تطبيق برنامج البحث على المجموعة التجريبية من حيث التطبيق القبلي للأبعاد ( الغذاء

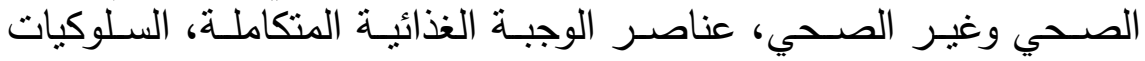
الغذائية ) وكذللك الدرجة الكلية. 


\section{نتائج الفرض الثاني وتفسيره:}

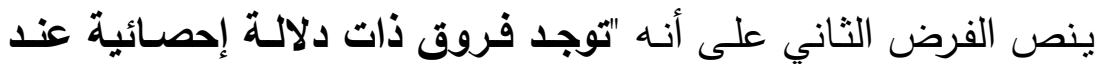

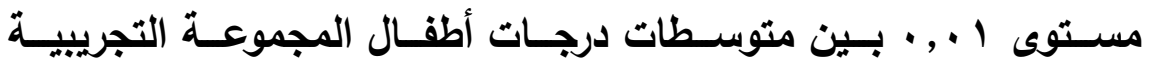

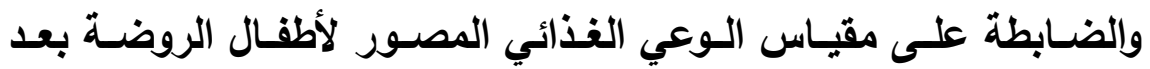

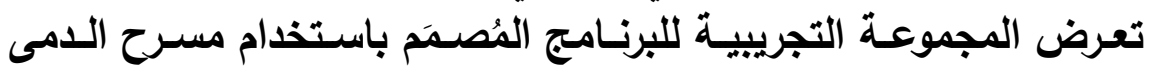

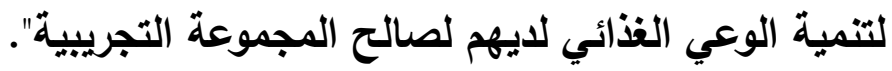
لاختبار صحة الفرض تم حساب المتوسط الحسابي، والانحراف المعياري،

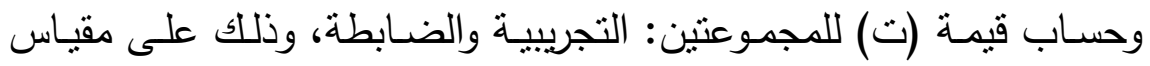

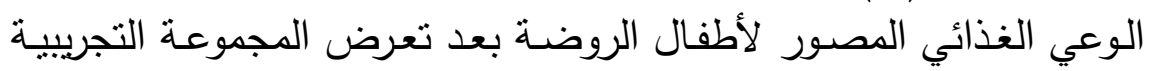

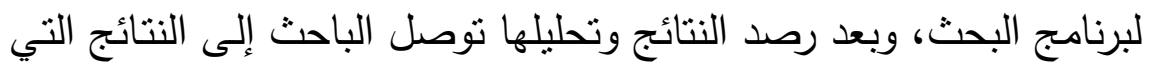
تتضح في الجدول التالي:

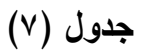

يوضح الفروق بين المجموعتين التجريبية والضابطة في الوعي الذذائي للقياس البعدي، وذلك الكيان على أبعاد مقياس الوعي الغذائي لأطفال الروضية

\begin{tabular}{|c|c|c|c|c|c|c|}
\hline \multirow{2}{*}{ مستوى الالالة } & \multirow{2}{*}{ قيمة(ت) } & \multicolumn{2}{|c|}{ (المجموعة الضابطة } & \multicolumn{2}{|c|}{ 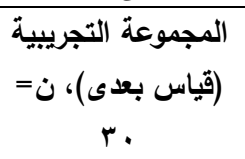 } & البند \\
\hline & & الانحراف & المثتوبط المسابي & الانحراف & المتوسط الحسابي & الأبعاد \\
\hline دالة عند & $1 \varepsilon, .9$ & $r, \varepsilon$. & $1 \cdot, v$ & 0,97 & $r V, \varepsilon V$ & الغذاء الصحي الصحي \\
\hline دالة عند & IY,Y & $1, Y 7$ & $r, 1 r$ & $1, r r$ & $v, 1 v$ & الوجاصبة الغذائية \\
\hline
\end{tabular}




\begin{tabular}{|c|c|c|c|c|c|c|}
\hline \multirow{2}{*}{ مستوى الالالة } & \multirow[t]{2}{*}{ قيمة(ت) } & \multicolumn{2}{|c|}{ (قاس المبوعة الضابطة } & \multicolumn{2}{|c|}{ 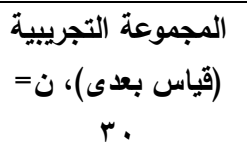 } & البند \\
\hline & & الانحراف & المثوسط & الانحراف & المتوبط & الأبعاد \\
\hline دالة عند & $1 \varepsilon, 07$ & וצ & $r, r r$ & $1, \leqslant 1$ & $\Lambda, \varepsilon \vee$ & السلوكيات \\
\hline دالة عند & $1 \wedge, \wedge 7$ & $r, r v$ & $I V, \cdot V$ & 7,70 & $\& 1,7$ & الارجة الكلية \\
\hline
\end{tabular}

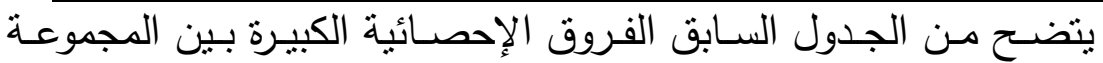
التجريبية والضابطة لصالح المجموعة التجريبية في الأبعاد: (الغذاء الصدي الصئي

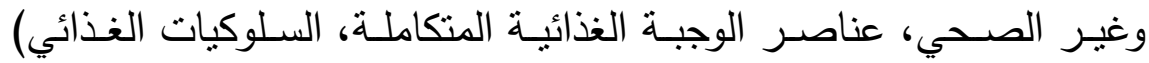
وكذلك الدرجـة الكليـة للمقياس، حيث أن مستوى الدلالـة دال إحصـائياً عند مستوى 1 •, •• لكل بُعد من الأبعاد والدرجة الكلية.

ويمكن أن نرجع هذا العائد والتحسن الإيجابي الذي طرأ على أطفال

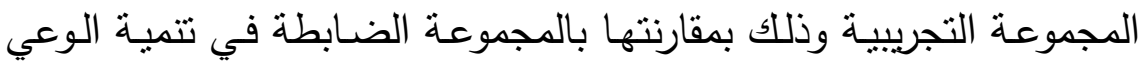

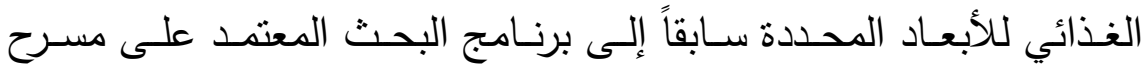

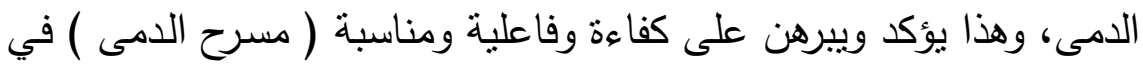

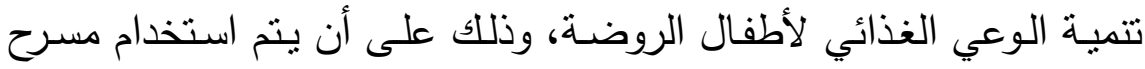

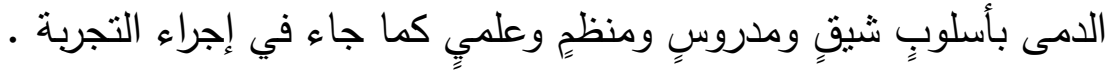

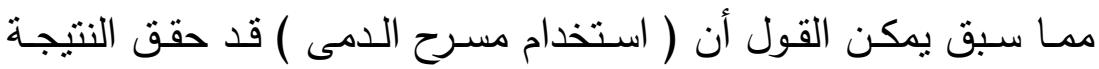

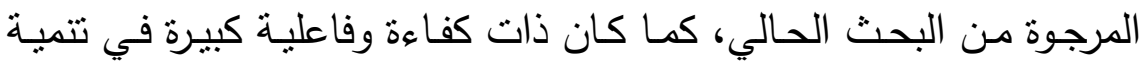
الوعي الغذائي لأطفال الروضة. 


\section{نتائسج الفرض الثالث وتفسيره :}

ينص الفرض الثالث على أنه "توجد فروق ذات دلالـة إحصـائية عند

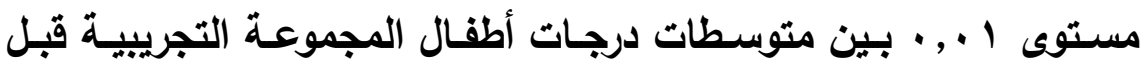

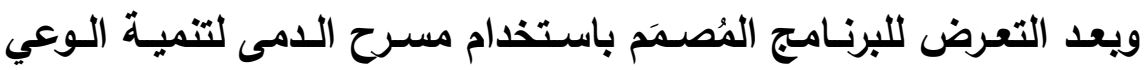

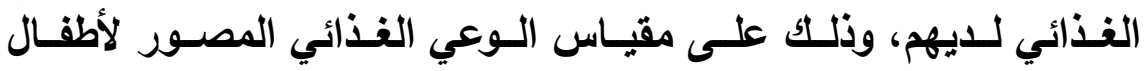
الروضة".

لاختبار صحة الفرض تم حساب المتوسط الحسابي، والانحراف المعياري،

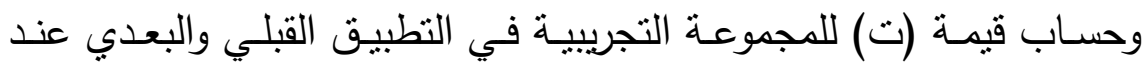
مسـتوى I + , · ، وذلـك على مقيـاس الـوعي الغـذائي المصـور لأطفـال الروضة، وبعد رصد النتائج وتحليلها توصل الباحث إلى النتائج التي تتضح

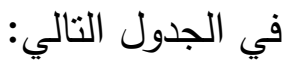

$$
\text { جدول (^) }
$$

يوضح الفروق بين التطبيق القبلي والبعدي للمجموعة التجريبية على أبعاد مقياس

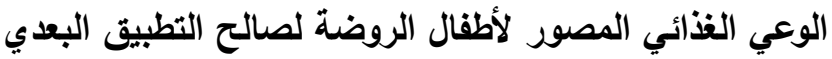

\begin{tabular}{|c|c|c|c|c|c|c|}
\hline \multirow[t]{2}{*}{ مستوى الالالة } & \multirow[t]{2}{*}{ قيمة(ت) } & \multicolumn{2}{|c|}{ 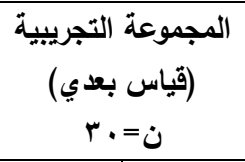 } & \multicolumn{2}{|c|}{ 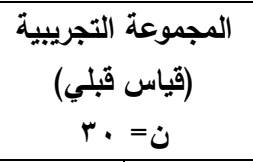 } & \multirow{2}{*}{ الأبند } \\
\hline & & الانحراف & المتوبط & الانحراف & الحتوبط & \\
\hline دالة عند & $1 \varepsilon, O r$ & 0,97 & $r V, \varepsilon V$ & $r, \vee q$ & $1 \cdot, \varepsilon$ & الصذاء \\
\hline دالة عند 1 ., . & 10,0 & $1, Y r$ & $v, 1 v$ & $\cdot, \wedge 7$ & $r, \wedge r$ & عناصر \\
\hline
\end{tabular}




\begin{tabular}{|c|c|c|c|c|c|c|}
\hline \multirow{2}{*}{ مستوى الالالة } & \multirow[t]{2}{*}{ قيمة(ت) } & \multicolumn{2}{|c|}{ 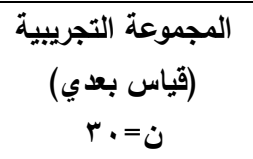 } & \multicolumn{2}{|c|}{ 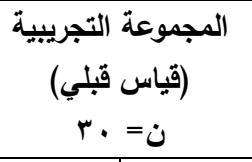 } & \multirow{2}{*}{$\begin{array}{l}\text { الإبند } \\
\\
\end{array}$} \\
\hline & & الانحراف & المتوسط الحسابي & الانحراف & المتوسط الحسابي & \\
\hline & & & & & & المغذائية \\
\hline دالة عند ا ـ, • & $1 \leq, 9 V$ & $1, \leqslant 1$ & $\Lambda, \varepsilon \vee$ & 1, & $r, q r$ & السلوكيات الغذائية \\
\hline دالة عند 1 ., •. & 19,11 & 7,70 & $\varepsilon r, 1$ & ז צ & $17, .7$ & الارجة \\
\hline
\end{tabular}

يتضح من الجدول السابق الفروق الإحصائية الكبيرة بين التطبيقين القبلي

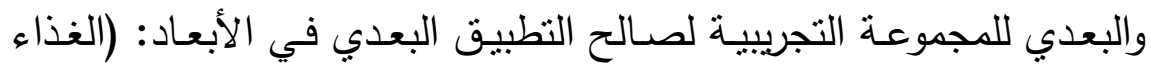

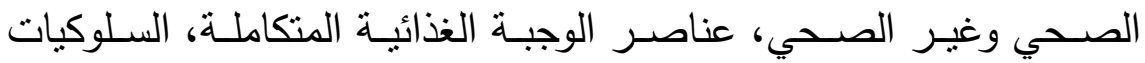

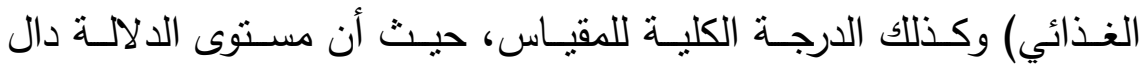
إحصائياً عند مستوى I + , . لكل بُعد من الأبعاد والدرجة الكلية.

ويمكن أن نرجع مدى التحسن الذي طرأ على أطفال المجموعة التجريبية إلى فاعليـة مسـرح الدمى في تتميـة الوعي الغذائي للأبعاد المحددة سـابقاً لأطفال الروضة، وذلك من خلال العروض المسرحية المقدمة للأطفال.

\section{خلاصة نتائج البحث:}

تتضح نتائج البحث كالتالي: أ- لا توجد فروق ذات دلالـة إحصسائية عند مستوى I ل , · بين متوسطات درجات أطفال المجموعة التجربيبـة والضـابطة على مقيـاس الوعي الغذائي 
المصور لأطفال الروضة قبل تعرض المجموعة التجربيية للبرنامج المُصدَم باستخدام مسرح الدمى لتتمية الوعي الغذائي.

ب- توجد فروق ذات دلالـة إحصـائية عند مسـتوى I + , · بين متوسطات درجات أطفال المجموعـة التجريبيـة والضـابطة على مقيـاس الوعي الغذائي المصور لأطفال الروضة بعد تعرض المجموعة التجربيية للبرنامج المُصدَم باسـتخدام مسـرح الـدمى لتتميـة الـوعي الغـذائي لـديهم لصــالح المجموعـة التجريبية.

ج- توجد فروق ذات دلالـة إحصـائية عند مسـتوى I + , ب بين متوسطات

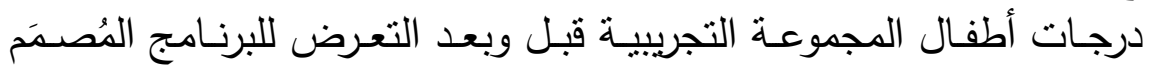
باسـخدام مسـرح الـدمى لتنميـة الـوعي الغذائي لـديهم، وذلك على مقيـاس

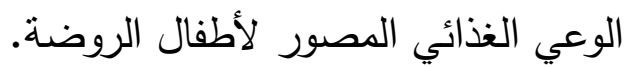

\section{التوصبات والمقترحاث :}

من خلال نتائج البحث الحالي يوصي الباحث بالآتي :

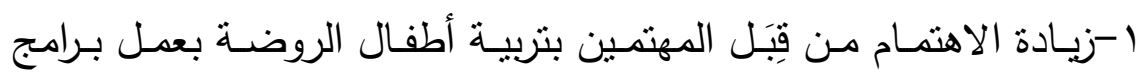
ومناهج قائمة على استخدام مسرح الدمى في تتمية الوعي الغذائي.

r- ضرورة التأكيد على أهمية مسرح الدمى في مرحلة رياض الأطفال، وما

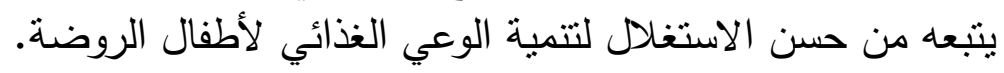




\section{المراجع}

\section{أولاً : المراجع العربية :}

- أبراجية، عبير عثمان أحمد (9 (1) ـ استخدم عروض المسرح المدرسي

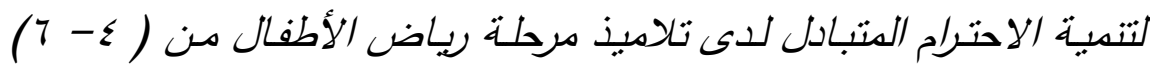

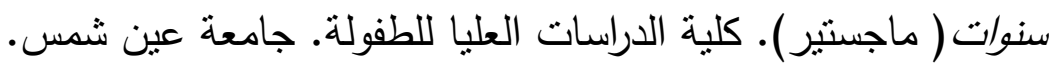

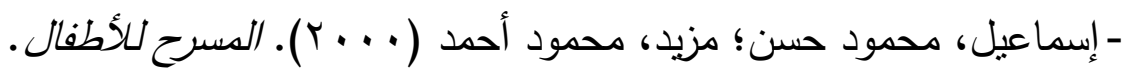

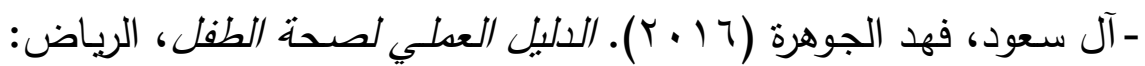
مكتب التربية لدول الخليج.

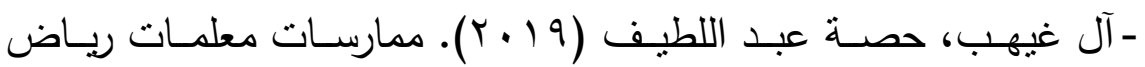

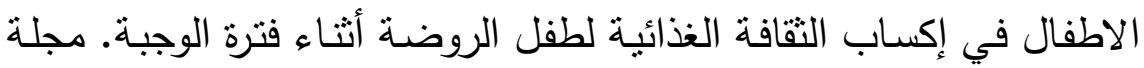

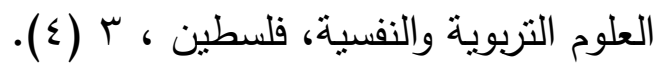

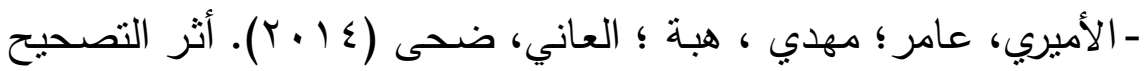

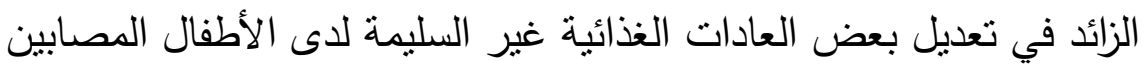

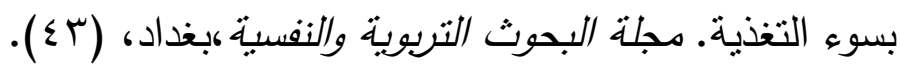

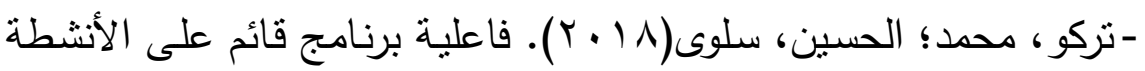

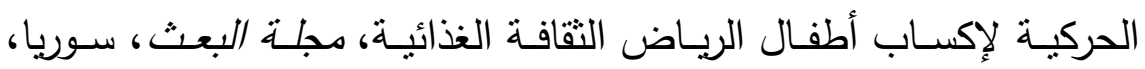
$\cdot($ r $) \leq.$

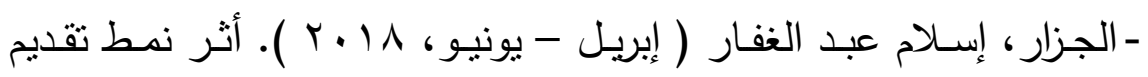

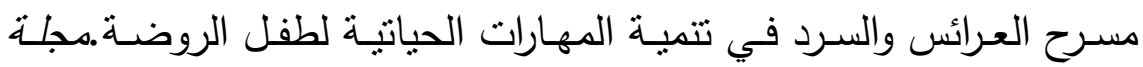

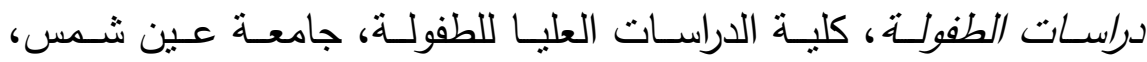

$$
\cdot(v q) \text { r) }
$$




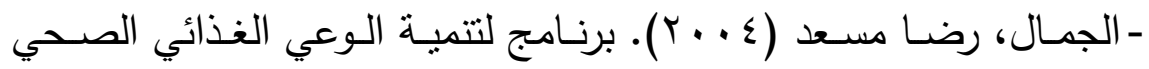

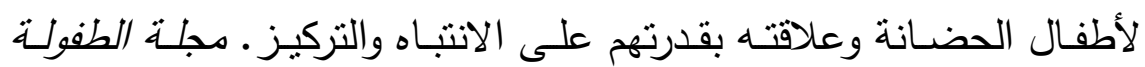

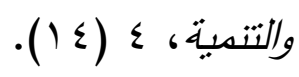

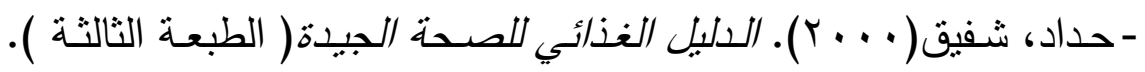
لبنان: نوفل للنشر والتوزيع. - حسين، كمـال الدين حسين ( • ( • ب). مقدمسة في مسـرح ودرامـا الطفل لرياض الأطفال . مطبعة العمرانية للأوفست.

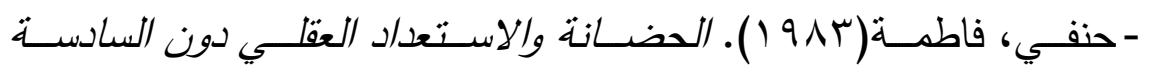
( ماجستير). كلية البنات. جامعة عين شمس.

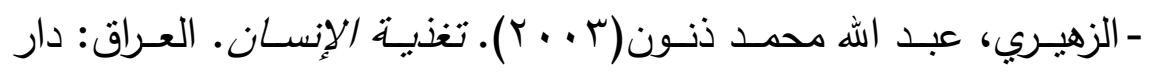
الحكمة.

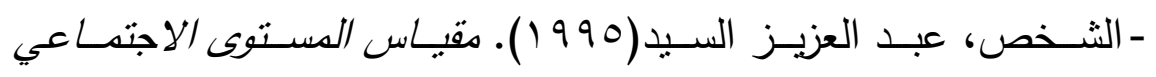
والاقتصادي للأسرة،" دلبل المقياس " ـ القاهرة: مكتبة الأنجلو المصرية.

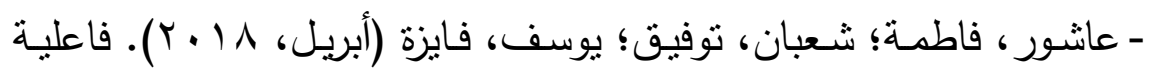
استخدام الأنشطة القصصية الحسية والإكترونية في إكساب الثقافة الغذائية

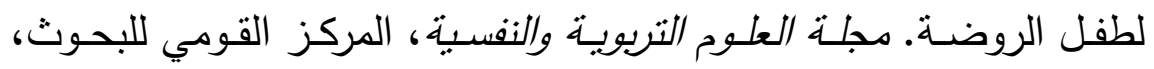
فلسطين، ب ( • ( ). - العبادي، إيمان يونس إبراهيم(9 (1) ـ ب). فاعلية عروض مسرحية باستخدام

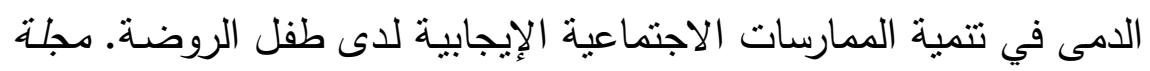

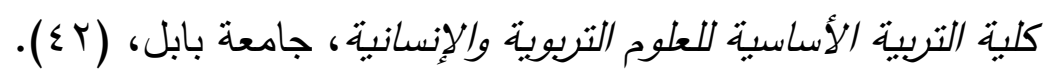


- عبد الباسـط، روحيـة محمـ (10 ـ ب). الـدور الفعـال الذي يقدمـه مسـرح العرائس للطفل.مجلة دراسات الطفولة. كلية الدراسات العليا للطفولة. جامعة

$$
\text { عين شمس، } 11 \text { ا (7) (7). }
$$

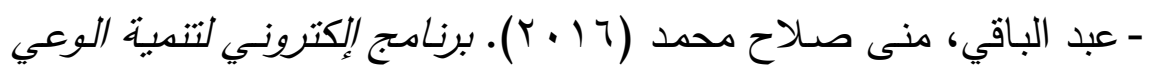
الغذائحي لطفل الروضة (ماجستير). كلية رباض الأطفال .جامعة القاهرة.

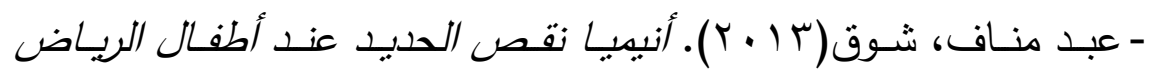
وعالقتها ببعض المتغيرات ( ماجستير غير منشورة). كلبة التزبية للبنات.

$$
\text { جامعة بغداد. }
$$

- عطبـة، طلارق جمال الدين(ع . . r). مدخل إلـى مسرح الطفل . القاهرة: مؤسسة طيبة للنشر والتوزبع.

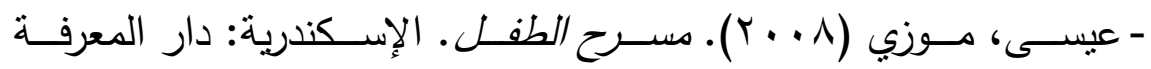
الجامعبة.

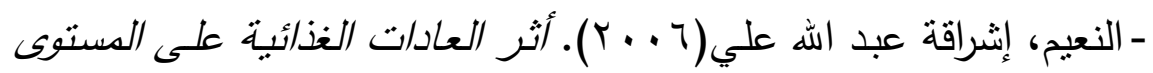
الغذائي والصحي للأطفال في مرحلة ما قبل المدستة (دكتوراه ).كلية التربية. جامعة الخرطوم.

- الهنيدي، منال عبد الفتاح (ی . . r). التربية الفنبة لطفل الروضـة . عمان: دار المسيرة.

\section{ثانياً : المراجع الأجنبية :}

- Deniger,M (1995). An Ethnographic study of the use of puppetry with children's group, Dissertation abstracts international, 51 (9). 
- Euker,f (1991). The use of puppetry in southern California kindergarten classrooms. Dissertation abstracts international,30 (31).

- Fisher, Bobbi (1998). Joyful learning in Kindergarten: Revised Edition,New York, Heinemann'.

- Furnivall. Sara Lynne (2003). The children's theater for peace, A portrait of possibility Exploration of conflict in children's lives, Canada: M.E.D York University،.

- Tada -Y, Chamroonsawasdi - K (2002). Nutritional status of the preschool children of the (Klong) Toey Slum, a sean Institute for health Development, Mohjdol University, Thailand،33(3),627-73.

- Watt - R, plimley - W (2001). The development of a national Oral health Promotion Program for preschool children in England,department of Epidemiology and Public health, University College, London, UK ‘Int - dent - J. 51(5), $334-8$.

- Weker - Hj, Klemar-M, Czyk - W (2000). Nutrition of preschool age children 'General considerations and assessment of child nutrition, Institut matki; Dziecka, zaklad zywienia (01 - 211) Warszawa, u1. Kasprzaka 17 a Rocz- panstw - Zakl - Hig.51(4): 385 - 92. 

فاعلية استخدام إستراتيجية قائمة على نظرية التعلم المستندة إلى الدماغ على تنمية مهارات الحس العددي والتقكير البصري

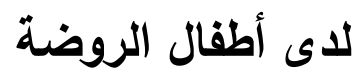

* د/ إيمان لطفي عبد الحكيم خليفة.

ملخص البحث :

هدف البحث الحالي إلى التعرف على فاعلية استخدام إستراتيجية قائمة

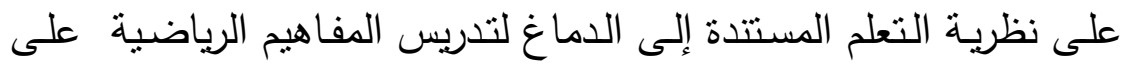

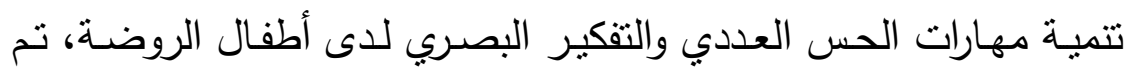

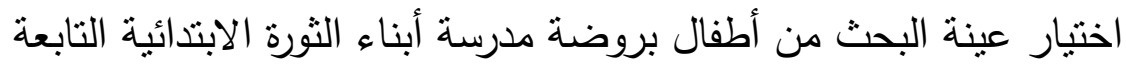

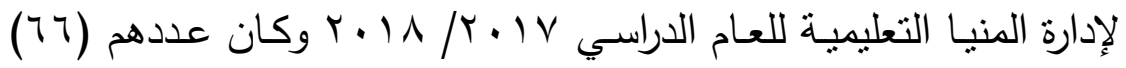

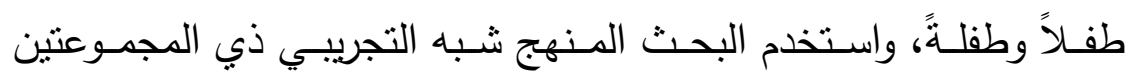
"الضابطة و التجريبية" حيث المجموعة الضابطة درست بالطريقة المعتادة و المجموعة التجريبية والتي درست باستخدام الإستراتيجية القائمـة على نظريـة التعلم المسـتندة إلى الـدماغ ، ولتحقيـق هـدف البحـث تـم إعـداد إستراتيجية قائمة على نظريـة التعلم المستتدة إلى الدماغ لتدريس المفاهيم الرياضـية، واختبـار الحس العـدي لأطفــال الروضــة ،واختبـار التفكيـر

* مدرس المناهج بقسم العلوم التربوية بكلية التربية للطفولة المبكرة - جامعة المنيا. 
البصـري لأطفال الروضـة. وتوصـلت نتائج البحث إلى وجـود فرق دال إحصائياً بين منوسطي درجات أطفال المجموعة الضابطة ( التي درست وده بالطريقـة المعتـادة ) و المجموعـة التجريبيـة ( التـي درسـت باسـتخدام الإستراتيجية القائمة على نظرية التعلم المستندة إلى الدماغ) في التطبيق البعـدي لاختبـار الحس العـددي لصـالح أطفــال المجموعـة التجريبيـة، وجود فرق دال إحصائياً بين منوسطي درجات أطفال المجموعة الضـابطة ( التي درست بالطريقة المعتادة ) و المجموعـة التجريبيـة (التي درست باستخدام الإستراتيجية القائمة على نظرية التعلم المستتدة إلى الدماغ) في

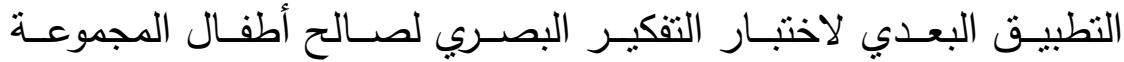
التجريبية ، مما يشير إلى فاعلية استخدام إستراتيجية قائمـة على نظريـة التعلم المستتدة إلى الدماغ لتدريس المفاهيم الرياضية على تتمية مهارات الحس العددي والتفكير البصري لدى أطفال الروضة.

The effectiveness of using a strategy based on learning theory based on the brain on developing numerical sense skills and visual thinking among kindergarten children.

Prepare: Dr. / Iman Lotfi Abdel Hakim Khalifa. *

*Lecturer of Curriculum, Department of Educational Sciences, Faulty of Early Childhood Education - Minia University. 


\section{Abstract:}

The aim of the current research is to identify the effectiveness of using a strategy based on brain-based learning theory to teach mathematical concepts on developing numerical sense skills and visual thinking among kindergarten children. The research sample was chosen from children in the Children of the Revolution Primary School of the Minya Educational Administration for the academic year 2017/2018. Their number was (66) boys and girls, and the research used the quasiexperimental approach with two groups "control and experimental" where the control group studied in the usual way and the experimental group studied using the strategy based on the theory of brain-based learning. To achieve the goal of the research, a strategy based on the theory was prepared Brain-based learning for teaching mathematical concepts, numerical sense test for kindergarten children, and visual reasoning test for kindergarten children. The results of the research concluded: There was a statistically significant difference between the mean scores of the children of the control group (which was studied in the usual way) and the experimental group (which was studied using the strategy based on the brain-based learning theory) in the post application of the numerical sense test for the benefit of the children of the experimental group. Statistically significant between the mean scores of the children of the 
control group (which was studied in the usual way) and the experimental group (which studied using the strategy based on the theory of brain-based learning) in the post application of the visual reasoning test for the benefit of the children of the experimental group, which indicates the effectiveness of using a strategy based on theory Brain-based learning to teach mathematical concepts to develop numerical sense skills and visual thinking in kindergarten children.

Brain based learning theory

الكلمات المفتاحية Keywords: - نظرية التعلم المستتدة إلى الدماغه

Numerical sense skills

Visual thinking

$$
\text { - - - مهارات التفكير البصري. }
$$

مقدمة: - مقا

أصبح الاهتمام بالثروة البشرية من الضروريات الحتمية لتقدم المجتمعات

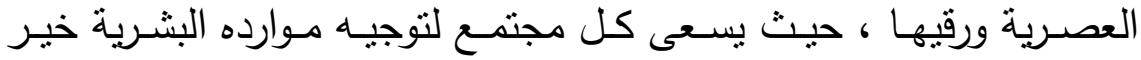

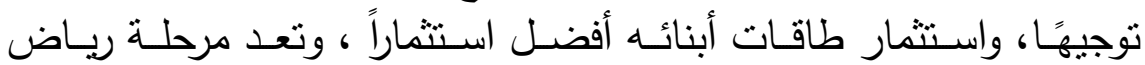

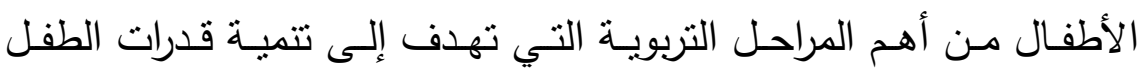

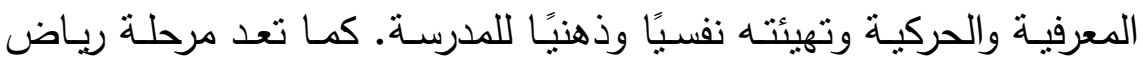

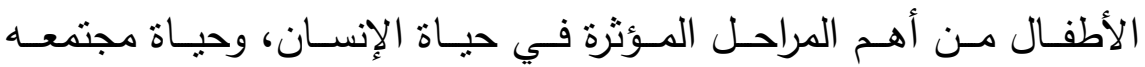

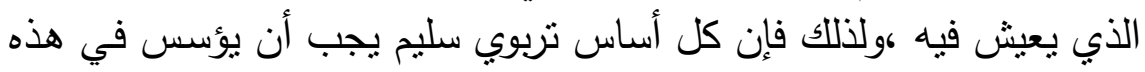

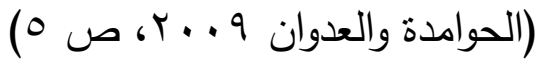

المرحلة الدي ل 


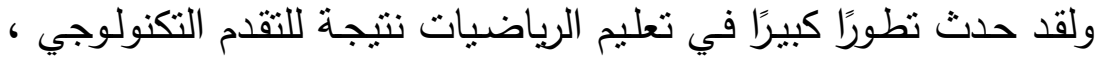
وأدى ذلك إلى تغيير في محتوى الرياضيات وأسـاليب تعليمها في المراحل العدرية المختلفة بما يتتاسب ومتغيرات هذا العصر ، وقد حظي العي الإحساس

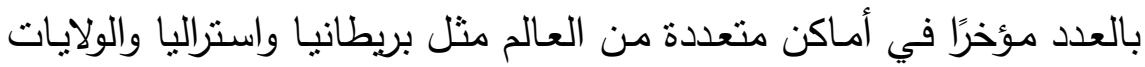

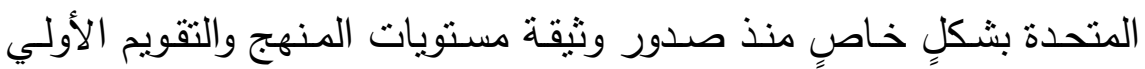
بواسطة المجلس القومي لمعلمي الرباضيات NCTM التي جاء فيها أن تعلـم الرياضـيات هـو نشـاط موجـه نحـو تتميـة الحس العـددي باسـتخدام الأنشطة الإئرائية ( NCTM,2000,13 ).

والحس العددي هو ذلك الجزه الهام في الرياضيات الذي بركز على النظام العددي ويهدف إلى تتمية الإدراك العام لدى الطفل للعدد والعمليات

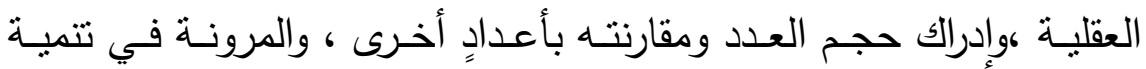
إسـتراتيجيات متعددة للحسـاب الذهني والتقدير التقريبي ، واختيـار العلامـة بـا

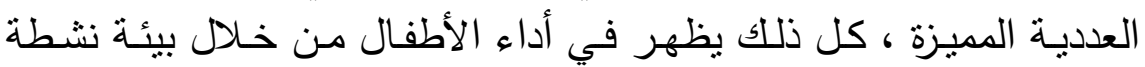
وبنية رياضية تشسم بـالترابط بين طرائق الحسـاب المختلفة (كامل r بـ . . ،

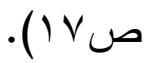

كمـا أن مهارات الحس العددي من المهارات الهامـة التي يجب تتميتها

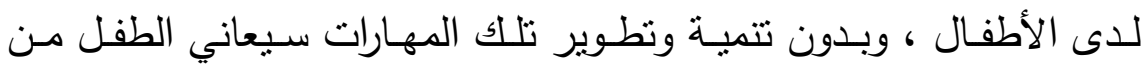
صعوبات في فهم وتطبيق المهارات العدديـة والتي تعد ضـرورية في الحياة اليومية ، فلا بد من حث الأطفال وتشتجيعهم على التفكير في التعامل مـع

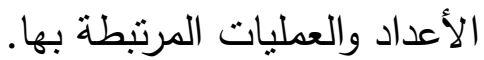

ونظراً لأهمية الحس العددي فقد أجريت بعض الدراسـات التي أظهرت

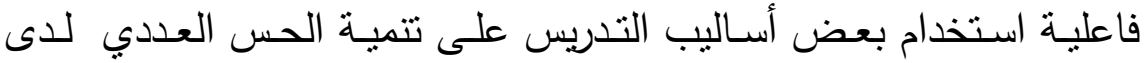

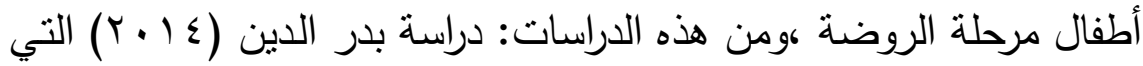


أظهرت فاعليـة برنـامج لتتميـة مهارات الحس العددي لـدى الأطفـال ذوي

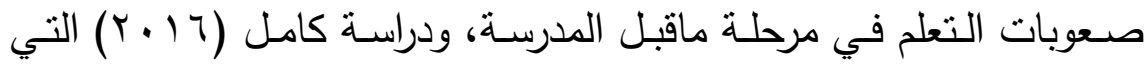

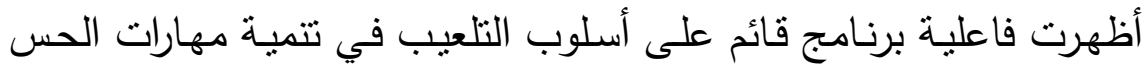
العددي لدى طفل الروضة.

وتعدد نظريـة التعلم المسـتند إلىى الدماغ أسـلوبًا أو منهجـاً شـاملاً للتعليم والتعلم ، حيث يجعل الاطفال أكثر إنتاجـاً والمعلمين أقل احباطـاً ،ويغير نظرة المعلمين إلى أطفالهم ،كما أن هذه النظرية تستتد إلى تركيب ووظيفة

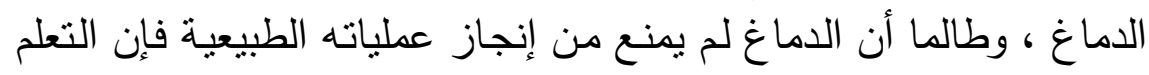

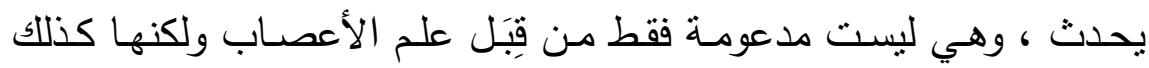

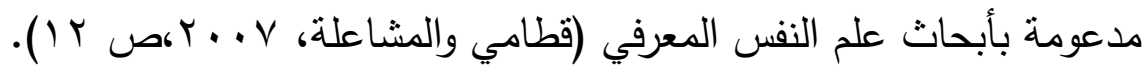

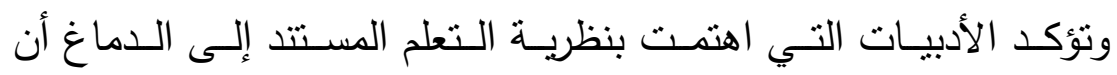
المعلمين الذين يتفهون طبيعة الدماغ البشري بكفاءةٍ يمكن أن يسهموا في الني

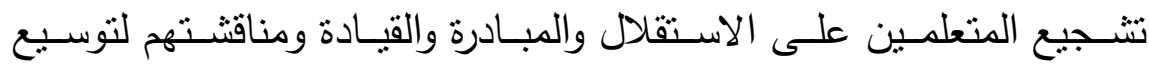
استجاباتهم ، وتشـجيعهم على التفاعل مـع بعضـهم البعض ، وعلى تقدير

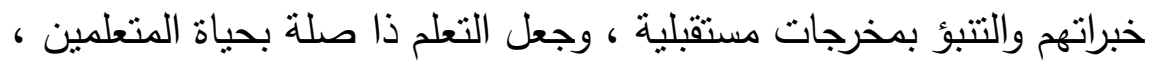

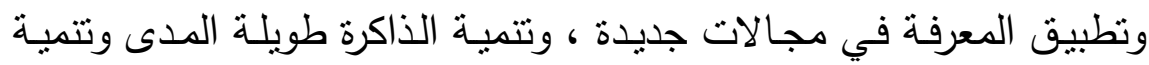

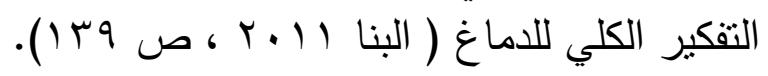
ونظربـة التعلم المستتد إلى الدماغ تركز بشكلٍ رئيسٍ على وظائف عمل الدماغ وتتظيم عملياته وتعلمه والابتعاد عن العشوائية أثتاء التعلم ، فتركز على إدخال المعلومات وموضوعات التعلم بأسلوب يجعل الطفل يكمل بين وظـائف نصـفي الـدماغ الأيمـن والأيسـر بشـكلٍ مناسـبِ يمكنـه مـن الفهـم والاستيعاب ، واعمال مهارات التفكير في معالجة المعلومات والتفاعل معها لها 
بشكلٍ تدريجي وفقاً للوظائف التدريجية لعمل الدماغ ، ثم تمكنه في النهاية من تحقيق أهداف التعلم ( Sousa, 2006, 37 ) بنَّي

كمـا تؤكد العديـد مـن الدراسـات التربويـة على أهميـة التدريس باسـتخدام

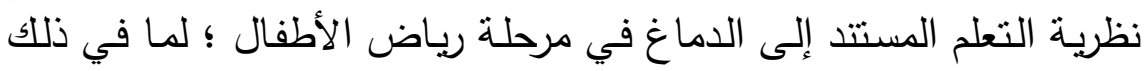
من تسهيل إكساب الأطفال للمعرفة وتخفيف القلق وإحداث الاستقرار النفسي فئهي والاجتماعي وإنجاز المهام التربوية بدقة وسهولة (الروفلي، V V • r، r). وقد أظهرت الدراسـات والبحوث السـابقة فاعليـة البـرامج والإسـتراتيجيات القائمـة على نظريـة التعلم المسـتندة إلىى الـدماغ في تـدريس الرياضـيات

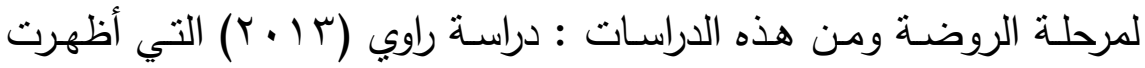
فاعلية برنامج قائم على التعلم المستتد إلى الدماغ في تتمية مهارات التفكير

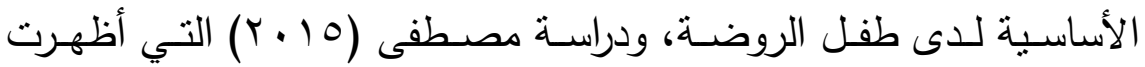

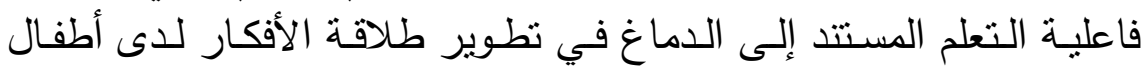
الروضة.

وفي ضـوء ذلك يتبين قلـة الدراسـات والبحوث السـابقة التي اسـتخدمت

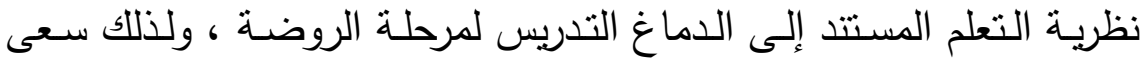

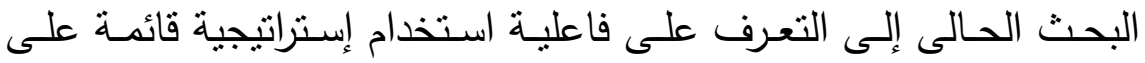
نظربـة التعلم المستتد إلى الدماغ للتدريس في مرحلـة الروضـة على تتميـة مهارات الحس العددي.

مـن ناحيـة أخـى تُعـد عمليـة الإبصـار عند الإنسـان عمليـة لا تقتصـر

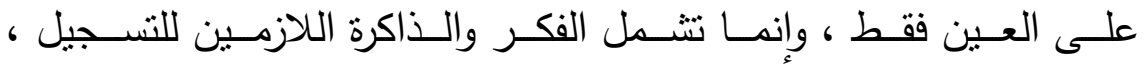
والترتيب ، والمقارنـة ـ فعمليـة التدريب تعد ضـرورية للعين من أجل تتميـة

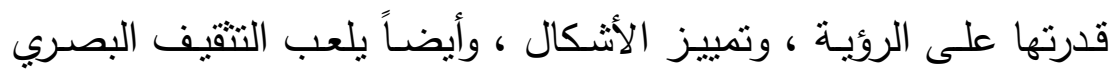


(Visual Illiteracy )

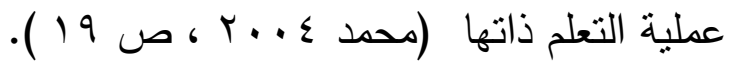

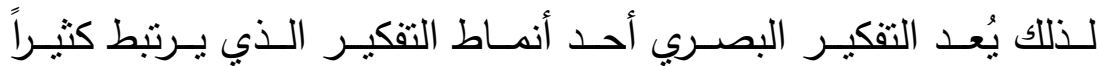

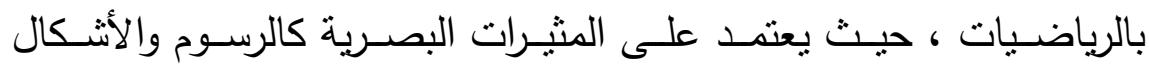

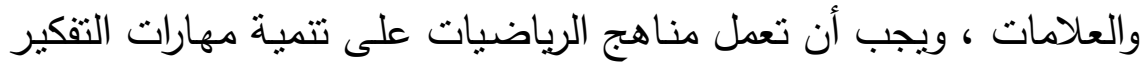

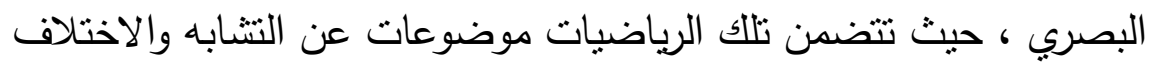

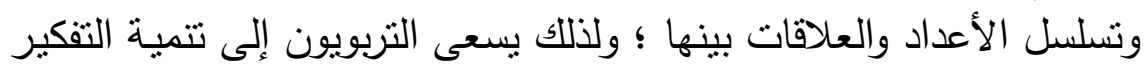

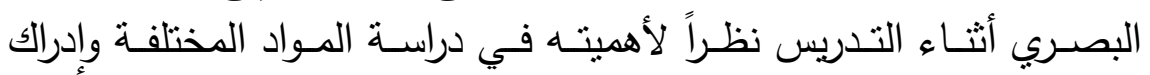

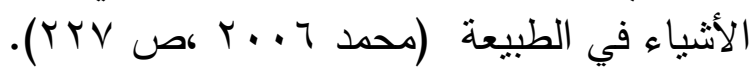

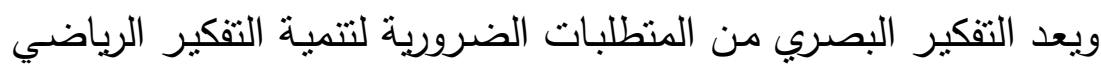

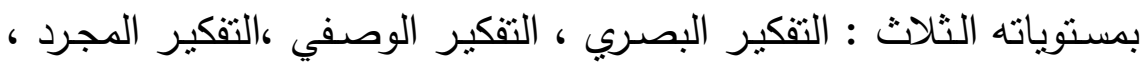

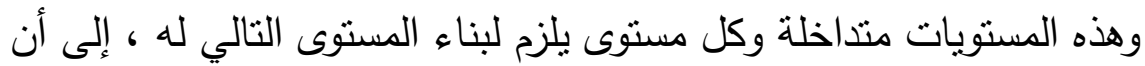

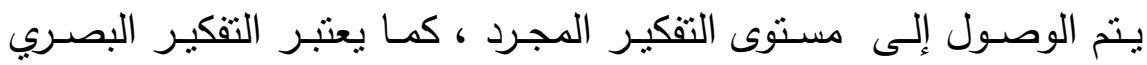

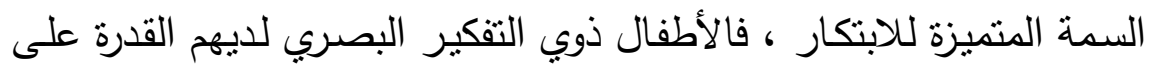

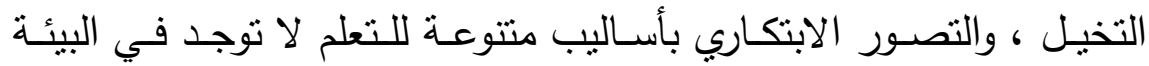

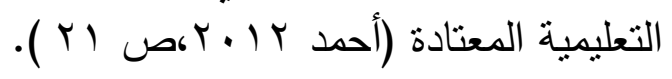

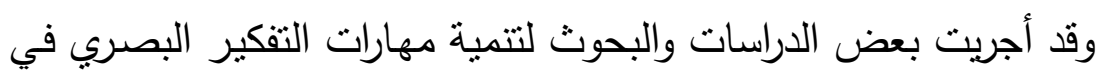

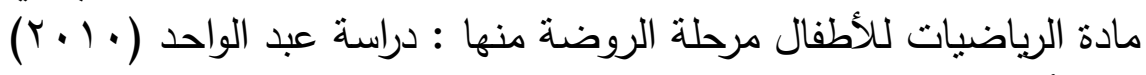

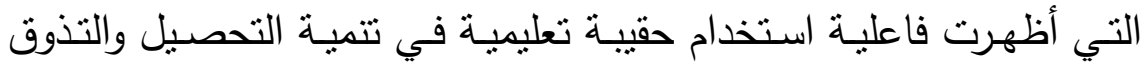

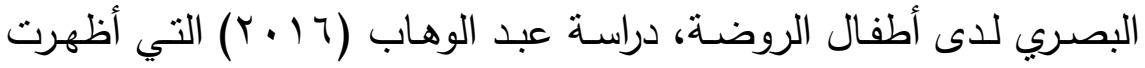
فاعلية برنامج إلكتروني مقترح في تتمية مهارات الذاكرة البصرية للأطفال في مرحلة الروضة. 
كما أجريت بعض الدراسات والبحوث التي أظهرت فاعلية استخدام نظرية

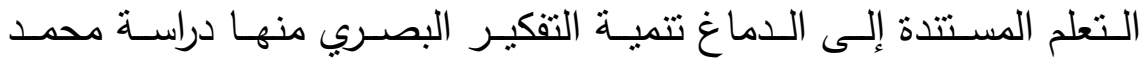
(T ( ا (Y) التي أظهرت فاعلية تصميم بصري تعليمي بالوسائط المتعددة قائم على نظربة التعلم المستتدة إلى الدماغ في تتمية مهارات التفكير البصري بهي بهي في مادة التقنيات التربوبة لدى طالبات الفرقة الثالثة بكلية التربية ، ودراسـة راضـي (T 1 • r) التي أظهـرت فاعليـة إسـتراتيجية تدربسية مقترحسة للتعلم

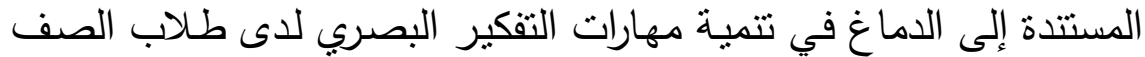

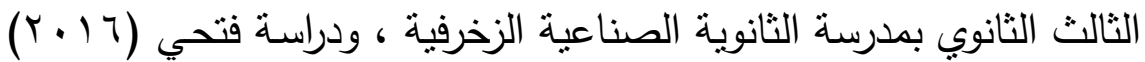

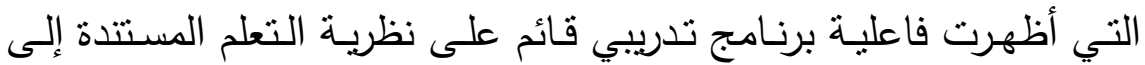
الدماغ في تتمية المرونـة المعرفيـة والتفكير البصـري في الفيزيـاء ومهارات

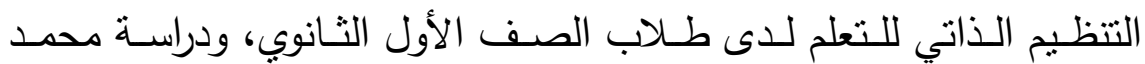

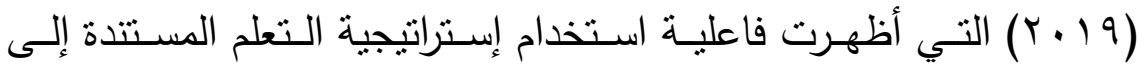

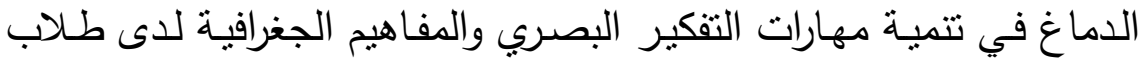

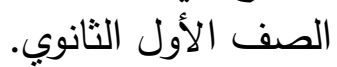

في ضوء ذلك يتبين الحاجة إلى التعرف على فاعلية استخدام إستراتيجية قائمسة على نظريـة التعلم المستندة إلى الدماغ للتدريس على تتميـة التفكير

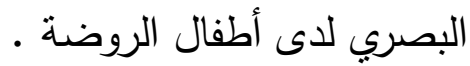

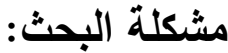

هناك عدة عوامل أدت إلى الإحساس بمشكلة البحث، وهي: ا- من خلال قيام الباحثة بدراسة استطلاعية في بعض الروضات الملحقة بالمدارس بمدينة المنيا تبين عدم اهتمام مرحلة الروضة بتتمية مهارات الحس العددي والتفكير البصري لدى الأطفال. 
r- قلة الأبحاث والدراسات السابقة التي اهتمت بإستراتيجية التدريس القائمة

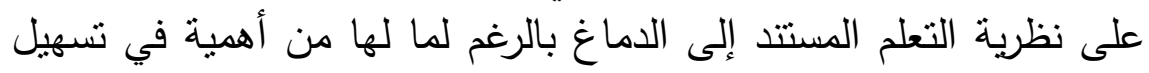

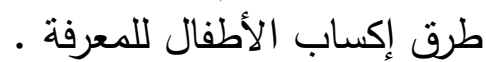

وفي ضوء حدود البحث تحددت مشكلة البحث الحالي في الإجابة عن

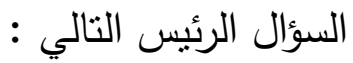

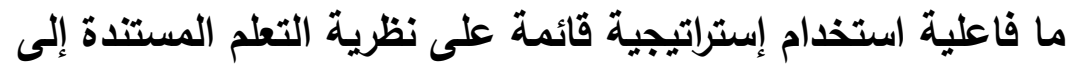

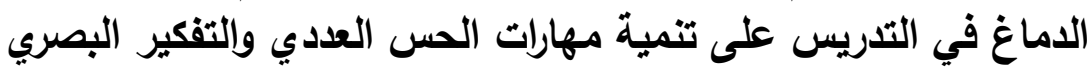

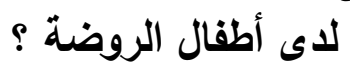

يتقرع منه السؤالين التاليين :

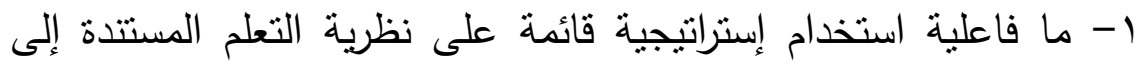

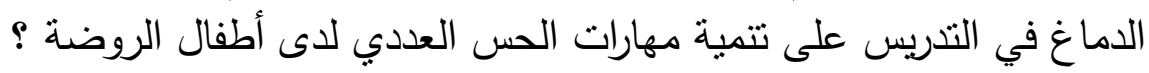

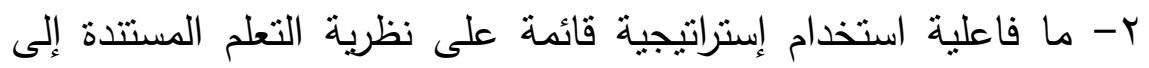
الدماغ في التدريس على تتمية التفكير البصري لدى أطفال الروضة أنة أهداف البحث:

$$
\text { يهدف البحث الحالي إلى التعرف على: }
$$

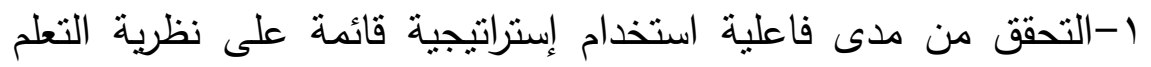

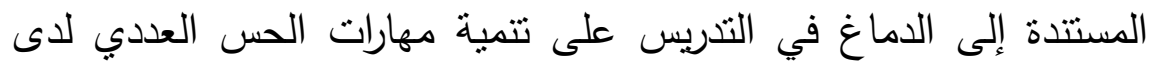
أطفال الروضة.

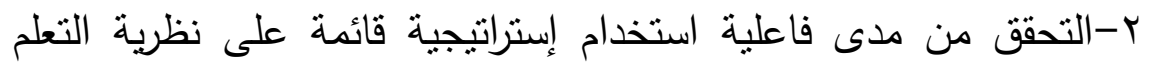
المستتدة إلى الدماغ في التدريس على نتمية التفكير البصري لإى أطفال الروضة. 
1- تتاول المتغيرات التالية: نظرية التعلم المستتدة إلى الدماغ و الحس

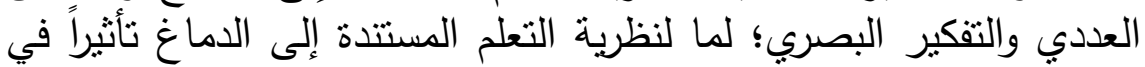

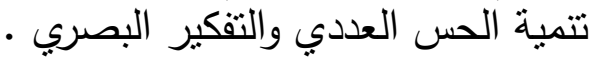

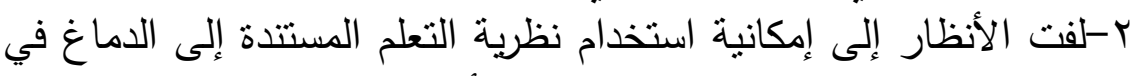
تتمية الحس العددي والتفكير البصري لانى أطفال الروضة. • الأهمية التطبيقية:

تقديم الأدوات التعليمية وأدوات القياس التي تقيد المعلمات في التطبيق على عينات أخرى كالتالي: 1-أوراق عمل طفل الروضة باستخدام الإستراتيجية القائمة على نظرية

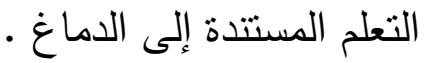
r-دليل المعلمة لتوضيح ليفية استخدام الإستراتيجية القائمة على نظرية

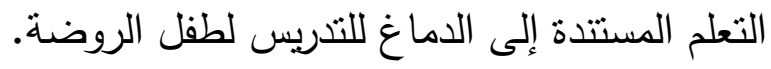
r-اختبار لقياس مهارات الحس العددي لدى طفل الروضة.

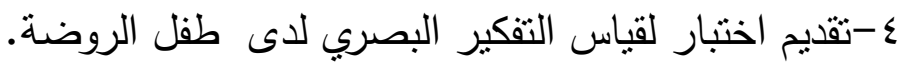

$$
\text { اقتصر البحث الحالي : }
$$

1-مجموعة البحث من أطفال الروضة بروضة مدرسة أبناء الثورة الابتدائية

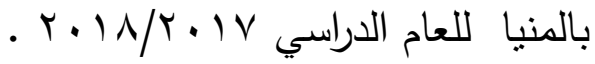


ץ-الأعداد من ا إلى • ا والدائرة، والمتلث، والمربع، والمستطيل بمقرر

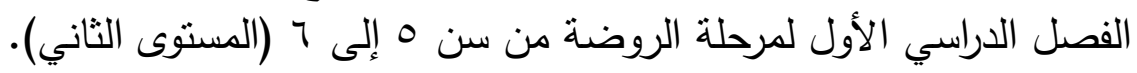

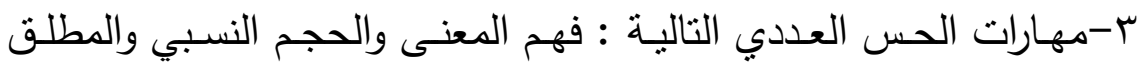

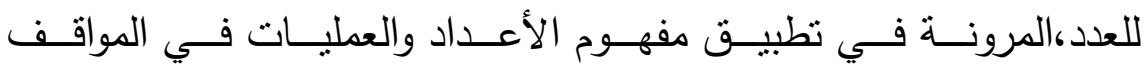
الحسابية،التعبير بالأعداد عن علاقات ممنلة بنماذج بـان بصرية.

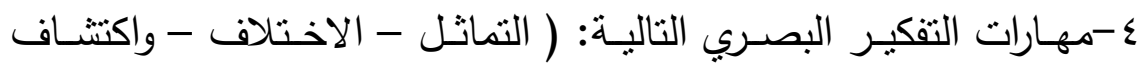
تسلسل النمط). مصطاحات البحث:

\section{: Effectiveness الفاعلية}

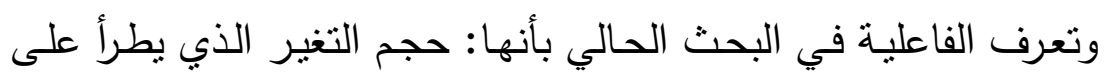

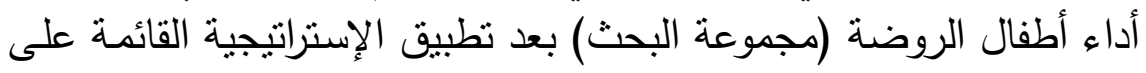

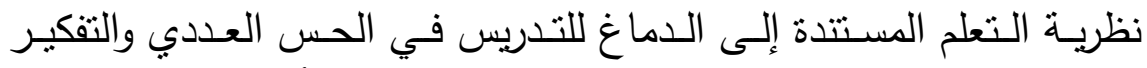

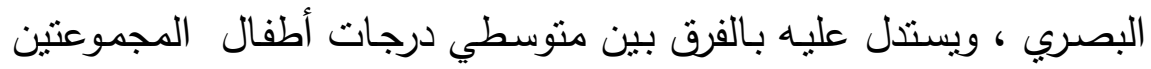

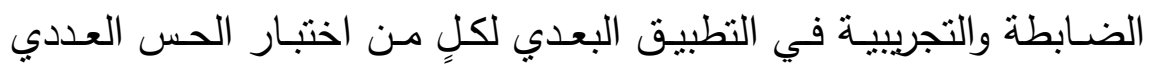

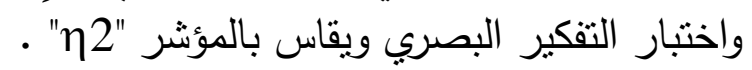

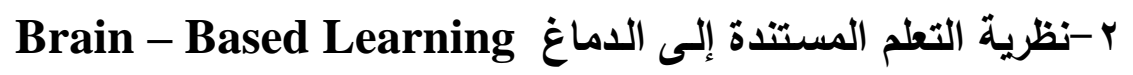
:Theory

تعرف نظرية التعلم المستتدة إلى الدماغ في البحث الحالي: التعلم الذي

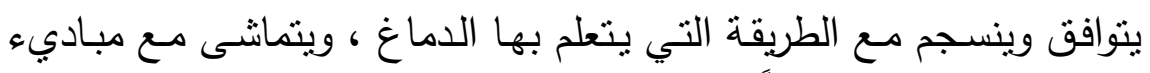

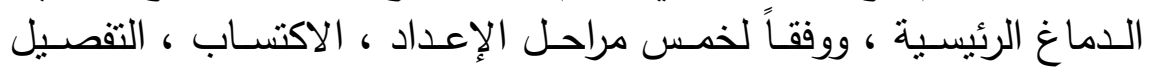
(الإسهاب ) ، تكوين الذاكرة ، التكامل الوظيفي. 


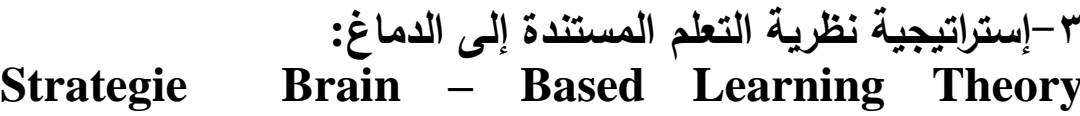
وتعرف إستراتيجية نظرية التعلم المستتدة إلى الدماغ بأنها: مجموعة من

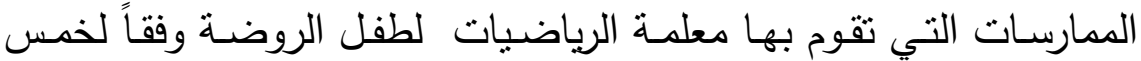
مراحل هي : الإعداد ، الاكتساب ، التفصيل (الإسهاب ) ، تكوين الذاكرة ، التكامل الوظيفي.

\section{ع -الحس العددي Numerical Sense :}

ويعرف الحس العددي في البحث الحالي بأنه: قدرة طفل الروضـة على فهم المعنى والحجم النسبـي والمطلـق للعدد،والمرونـة في تطبيـق مفهوم

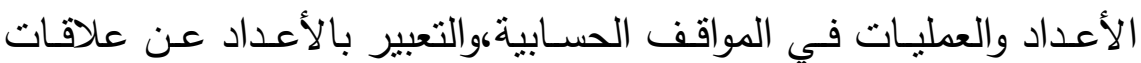
ممنلـة بنمـاذج بصـرية، والذي يُقاس بمقدار مـا يحصـل عليـه الطفل مـن درجات في اختبار الحس العددي المستخدم في البحث. لئه

\section{: Visual thinking التفكير البصري}

ويعرف التفكير البصري في البحث الحالي بأنه: نمط من أنماط التفكير

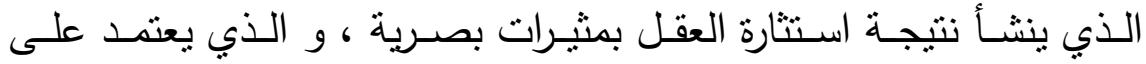
مجموعة من العمليات العقلية ، منمتلة في قدرة طفل الروضنة على إدراك

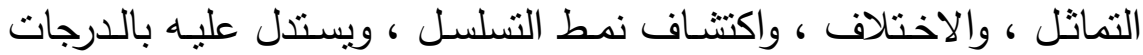
التي يحصل عليها الاطفل في اختبار التفكير البصري المُعدَ لهذا الغرض.

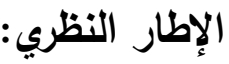
نتتاول في هذا الجزء ثلاثة محاور هي: المحور الأول: نظرية التعلم المستتد إلى الدماغ، والمحور الثاني:الحس العددي، والمحور الثالث:التفكير

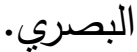




\section{المحور الأول: نظرية التعلم المستند إلى الدماغ :}

وتعد نظرية التعلم المستتد إلى الدماغ أسلوباً أو منهجاً شاملاً للتعليم التها

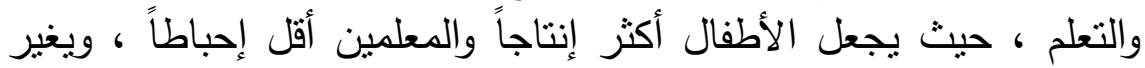

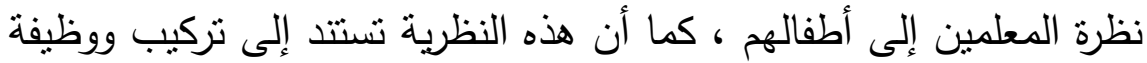

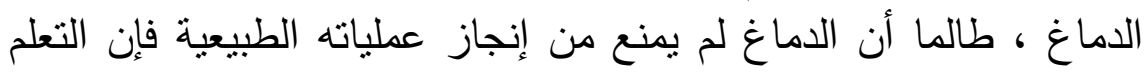

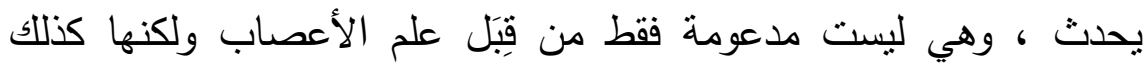

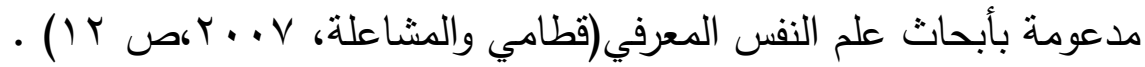

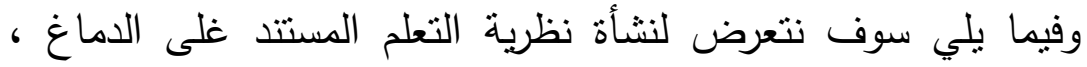
ومفهوم نظرية التعلم المستتدة إلى الدماغ ،ومباديء نظرية التعلم المستتد

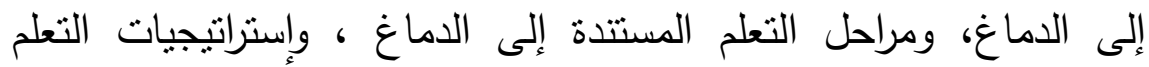

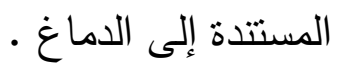

1-نشأة نظرية التعلم المستند إلى الاماغ :

نتيجة الاهتمام العلمي المتزايد بدراسة المخ البشري من قِبَّل علماء

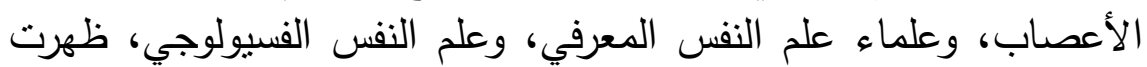

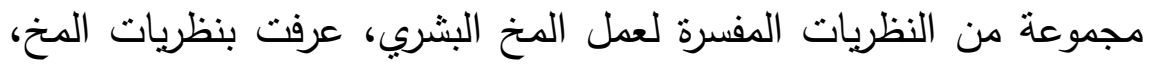

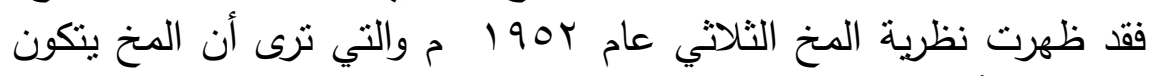

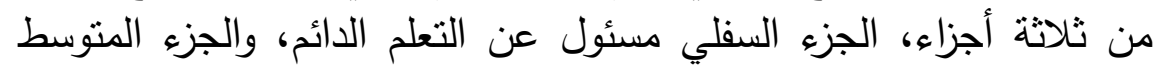

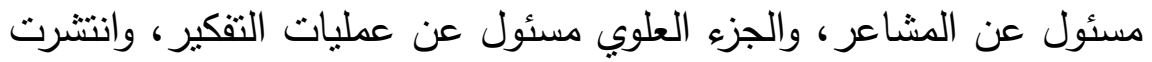

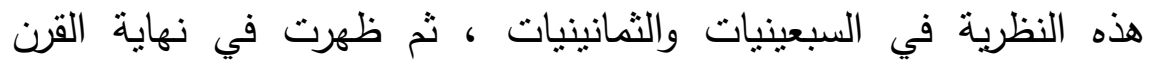

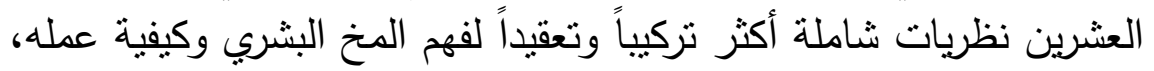

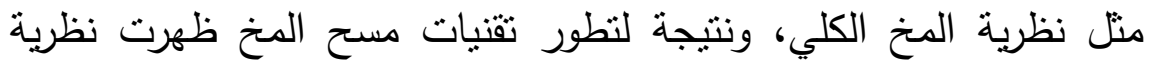

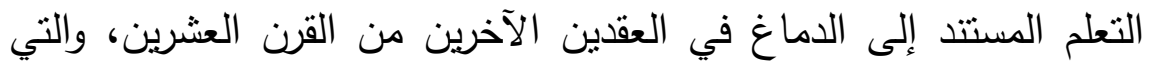
تسمى نظرية التعلم مع حضور الذهن، وهي تؤكد على أن كل فرد قادر الأن 
على التعلم، إذا توفرت لله بيئة التعلم النشطة الحافزة للتعلم، والتي تتيح له

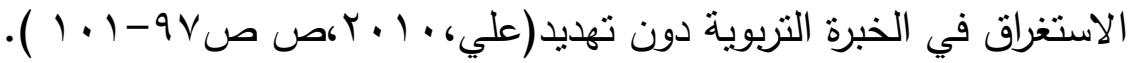
ץ-مفهوم نظرية التعلم المستندة إلى الدماغ :

\section{Brain - Based Learning Theory}

تعرف نظرية التعلم المستتدة إلى الدماغ بأنها: هي تلك " العمليات التي

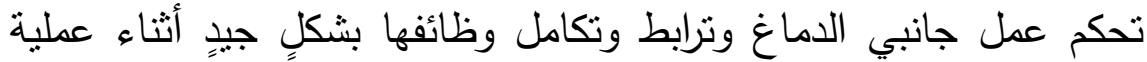
التعلم ، فيعمل الجانب الأيمن على معرئل معرفة الكليات والعموميات وإدراكها

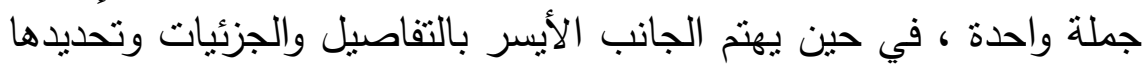

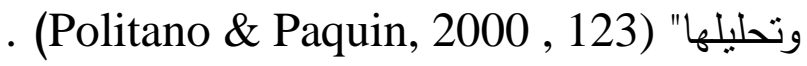

وتعرف على أنها: تلك النظرية التي تهتم بقيام الدماغ بوظائفه الطبيعية

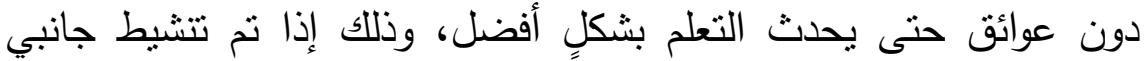

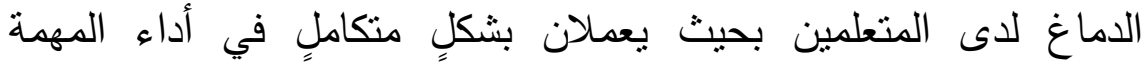

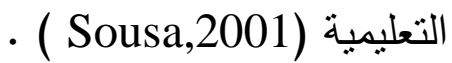

وتُعرف بأنها: " أسلوب أو منهج شامل للتعليم - التعلم يستتد إلى على إنى

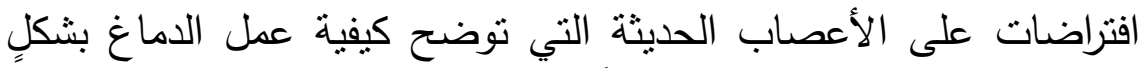

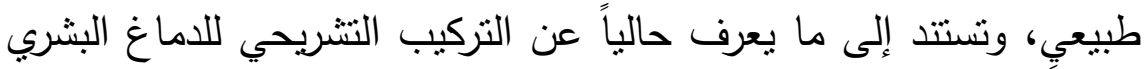

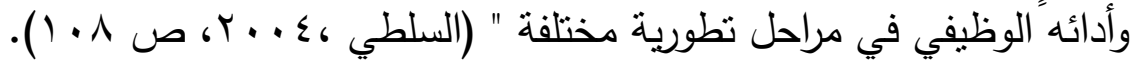
r - مباديء نظرية التعلم المستثد إلى الاماغ :

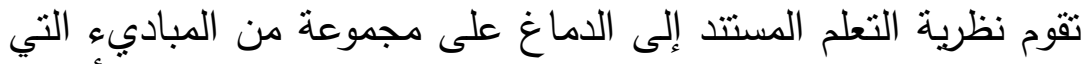

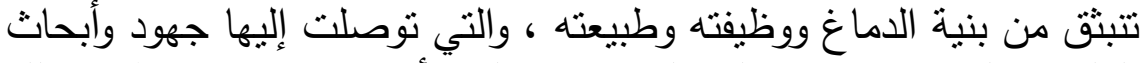

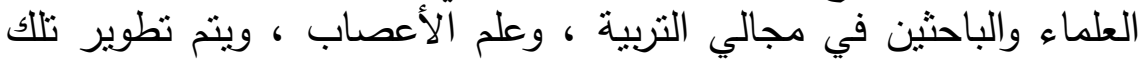

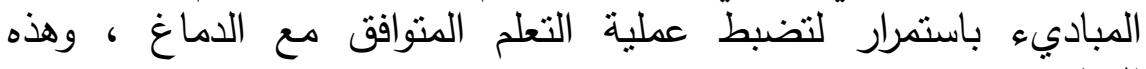
المباديء هيء لبيء 
أ - الدماغ جهاز حيوي ، الجسم والدماغ والعقل وحدة دينامية واحدة :

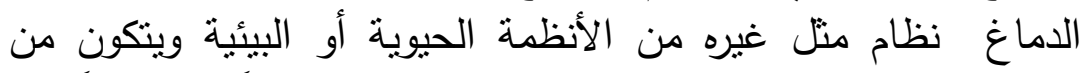

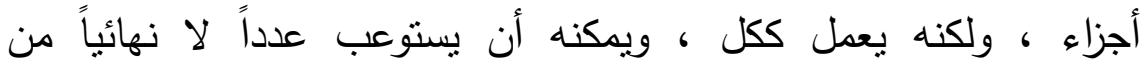

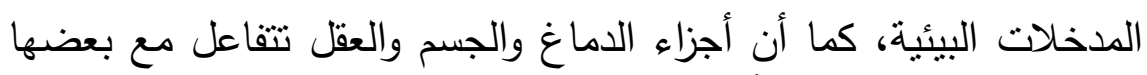

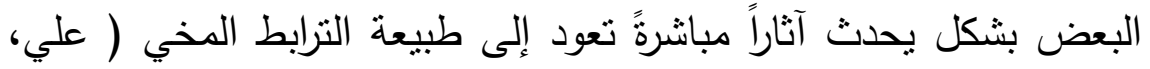

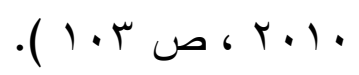

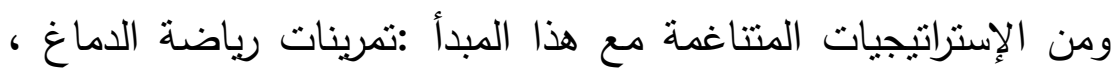

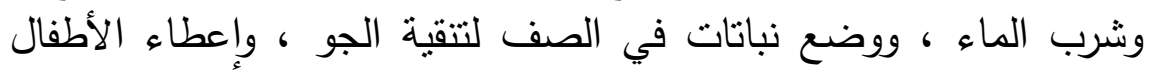

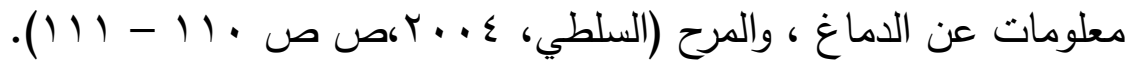
ب - الاماغ / العقل اجتماعي :

الاماغ يتغير بصورةٍ مستمرٍ طالما كان الإنسان حياً ، حيث تبدأ حياة

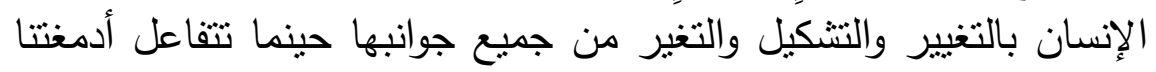

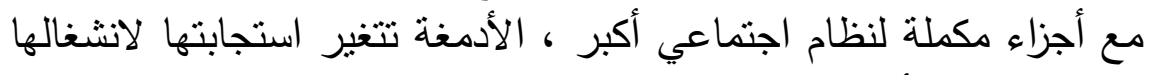

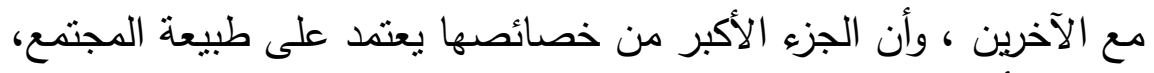

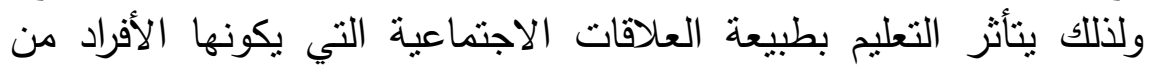

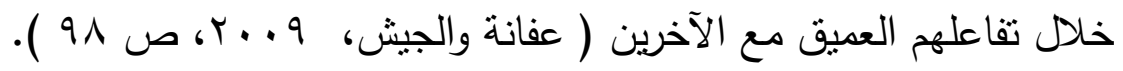

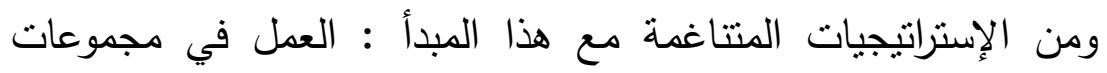

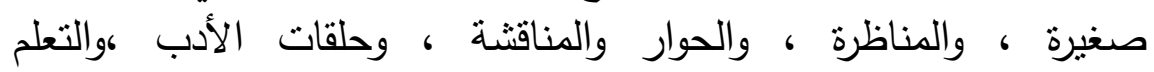

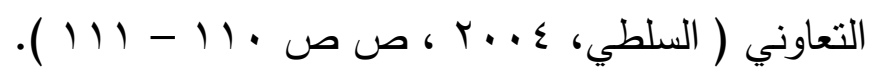
ج- البحث عن المعنى فطري:

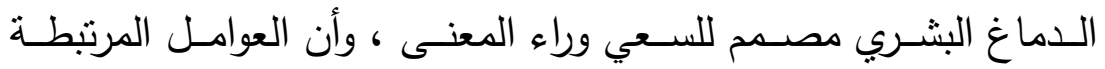
بتكوين المعنى هي : الترابط ، الانفعالات ، والسياق ، فالترابط من وظائف 


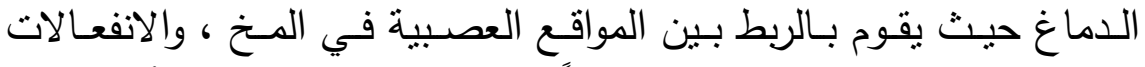

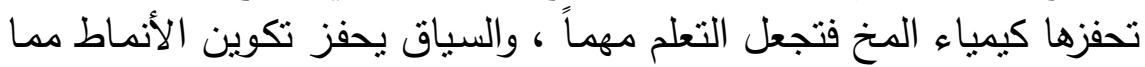

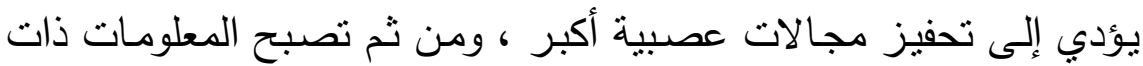

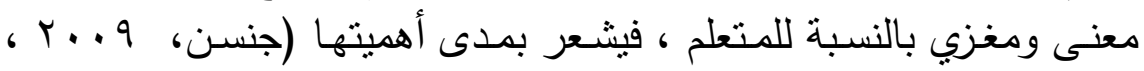

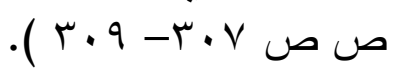

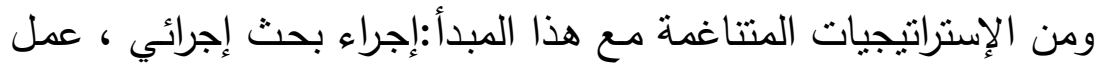

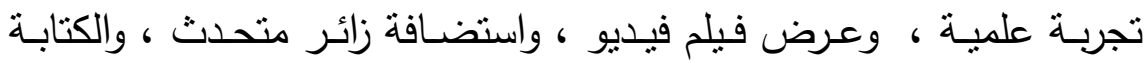

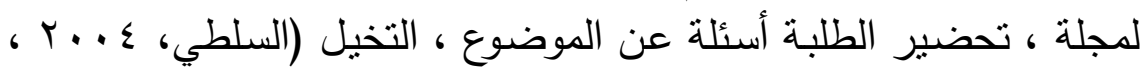
ص ص س (1) ).

هـ - البحث عن المعنى يتم من خلال التنميط أو النمذجة :

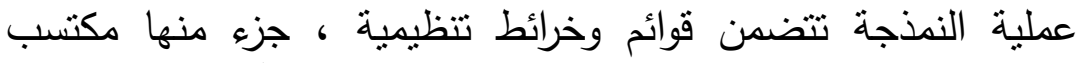

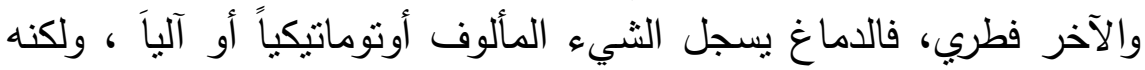

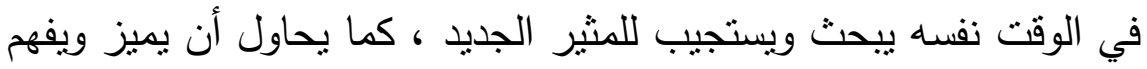

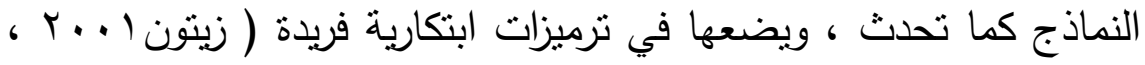

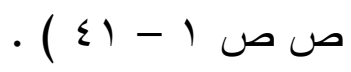

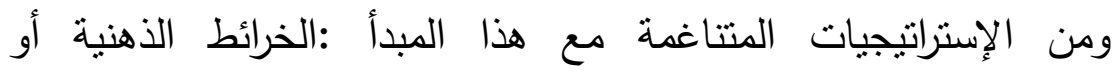

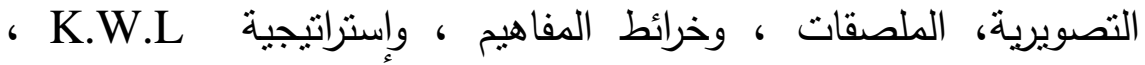

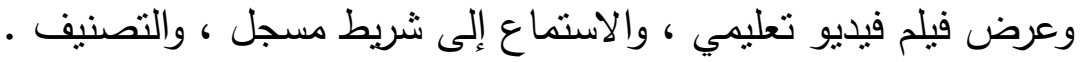

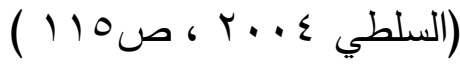

و - الانفعالات والعواطف مهمة وضرورية من أجل التنميط والنمذجة : العواطف والانفعالات مهمة جداً في التعلم واتخاذ القرارات ، وأن كل ما لـأ

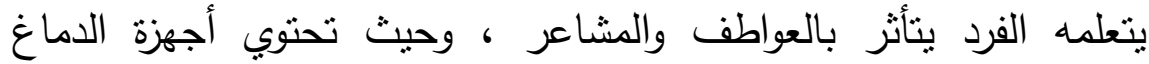


البشري على تقدير الذات ، والحاجة إلى التفاعل الاجتماعي حتى يحدث

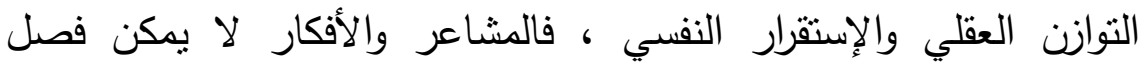
بعضهما عن بعض في الدماغ ذي الجانبين ، ومن هنا فإن تأثير العواطف

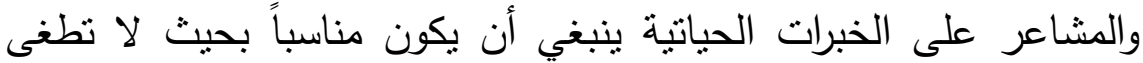

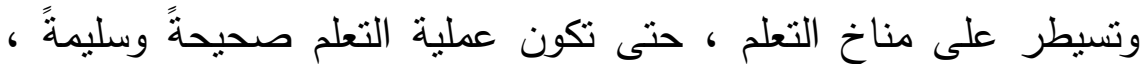
فالتفكير لا يمكن فصله عن المناخ العاطفي الذي يدفع الفرد إلى التفكير في جو مربح يعطيه المنطقية في العمل . Connell,2009, p30) ؛ عفانة

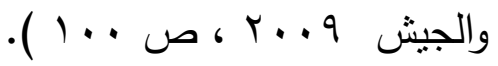

ومن الإستراتيجيات المتتاغمة مع هذا المبدأ: لعب الأدوار ، ورواية نكتة أو طرفة ، والمسرح ، وإتاحة الفرصة التعبير عن المشاعر ، وتدريب الإسترخاء ، وكتابة التقارير الذاتية ، والمشي والحركة ، والسؤال عن عن وانه

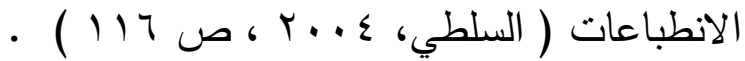
ح سيعالج الدماغ الكليات والجزئيات بشكلٍ متزامنٍ : جانبي الدماغ يوجد بينهما تفاعل وتتاغم فيما يقومان به من أنشطة لا سيما في الثخص السليم ، والتمبيز بين جانبي الدماغ الأيمن والأيسر لا يمثل الحقيقة المطلقة، حيث بشير مبدأ كلية الدماغ إلى أنه يدرك الكليات

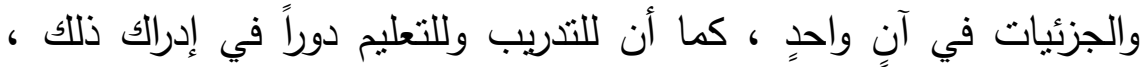
والجسم الجاسيء هو المسؤول عن العمليات المشتركة للجانبين فهو الذي يعمل علي ربط الأجزاء في الجانب الأيسر من الدماغ ، ليقوم الجانب الأيمن بدوره في بناء الكليات ، كما بقوم الجانب الأبسر من الدماغ بتفتيت

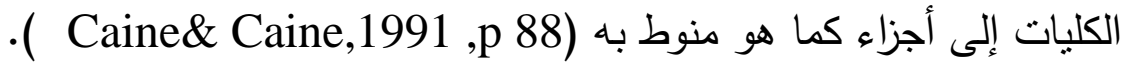
ومن الإستراتيجيات المتتاغمة مع هذا المبدأ: الخرائط الذهنية ، المنظم

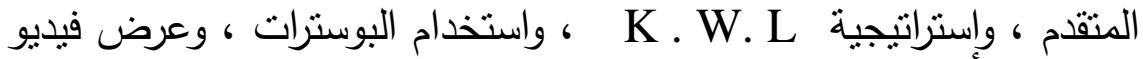


تعليمي ، والموسيقى ، والحركة ، ووضع صور ومخططات على الحائط ، واستقراء المزايا والسلبيات ، والمجموعات التعاونية الصغيرة ، وتعليم

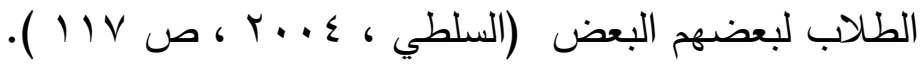

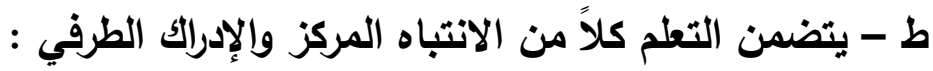

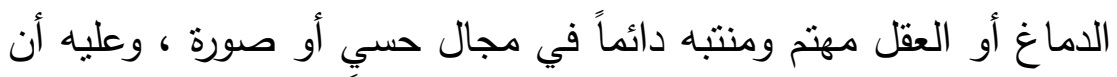

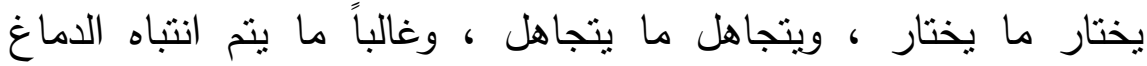

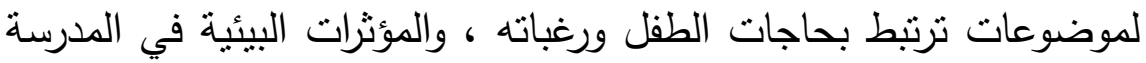

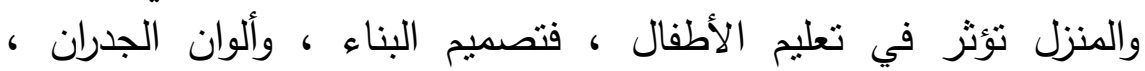
والملصقات ، والجرس ، ووسائل الإعلام ، والمواقف العاطفية كلها عوامل

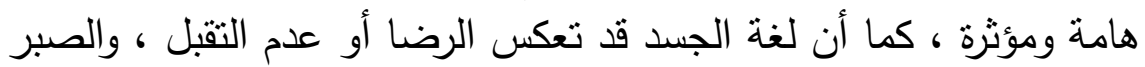

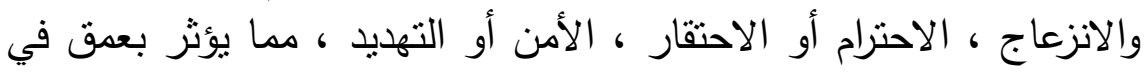

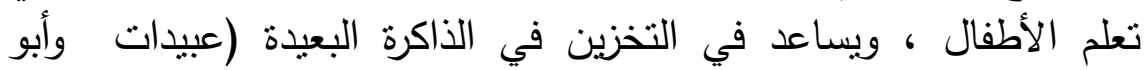

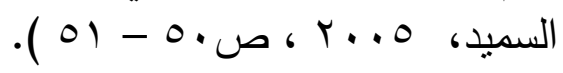

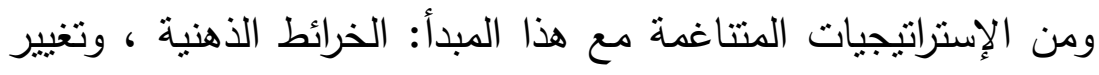

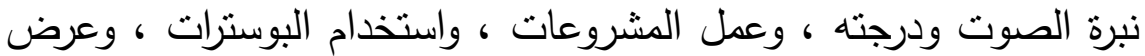

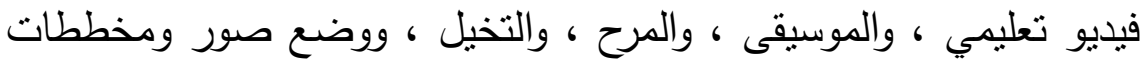

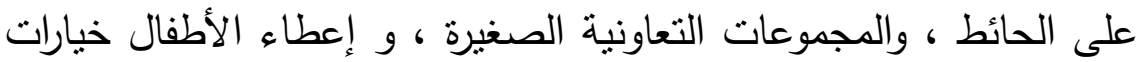

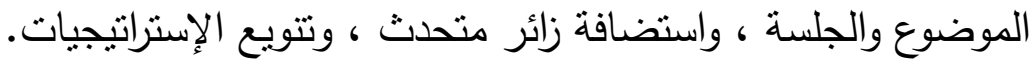

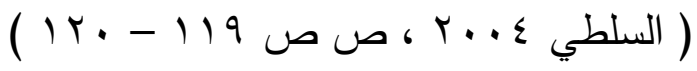
ك- التعلم يتضمن دائماً عمليات الوعي واللاوعي:

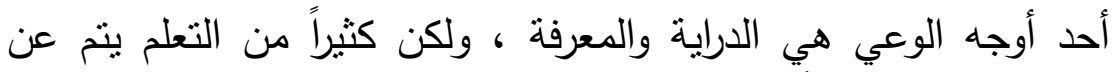

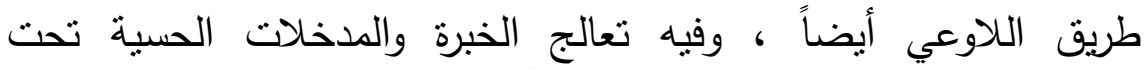

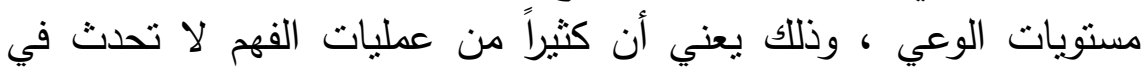


الفصل ، وقد تحدث خلال ساعات أو أسابيع أو شهور لاحقة ، فيجب على

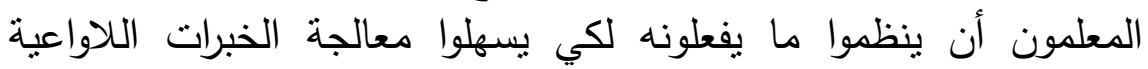

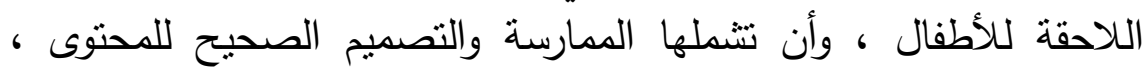

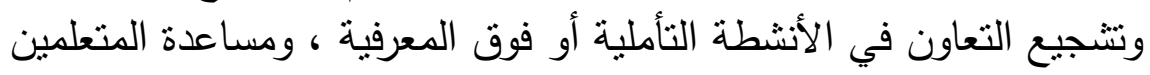

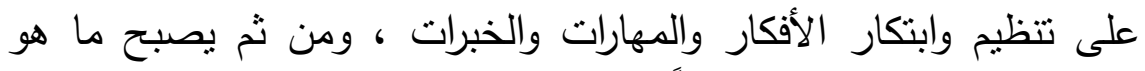

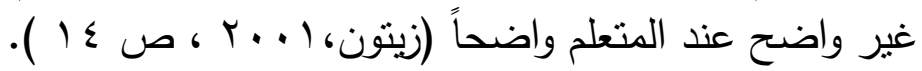

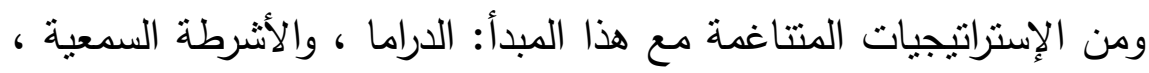

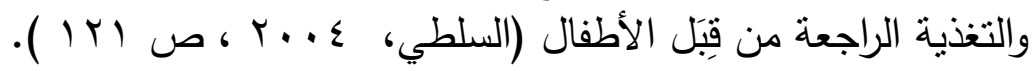
م - لاينا على الأقل طريقتان لتنظيم الذاكرة :

الذاكرة مجهزة بيولوجياً لتسجيل كامل الخبرات ذات المعنى ، وغير ذات

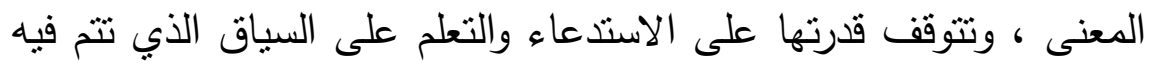

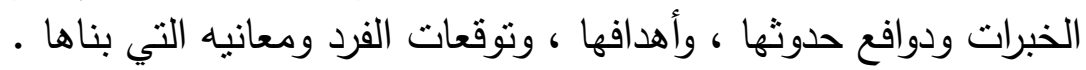

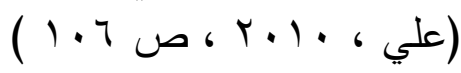

وللذاكرة عدة أنظمة ويمكن إيجازها كالتالي :

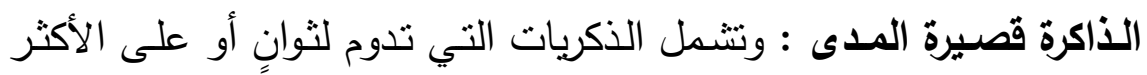

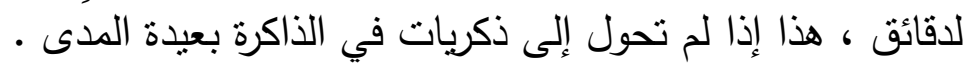

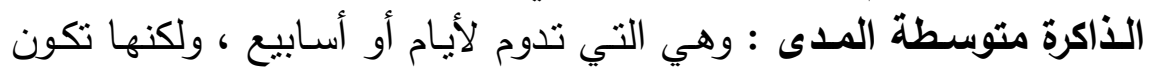

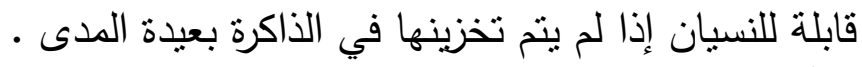

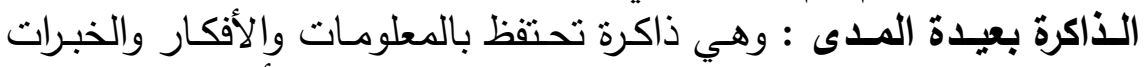

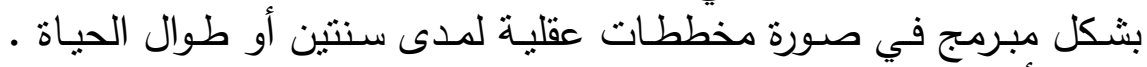

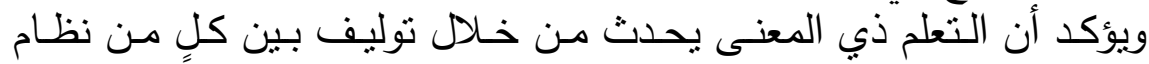

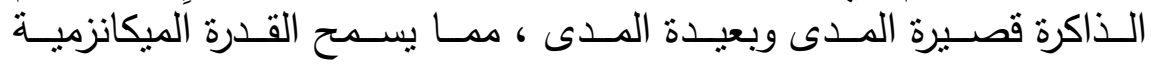

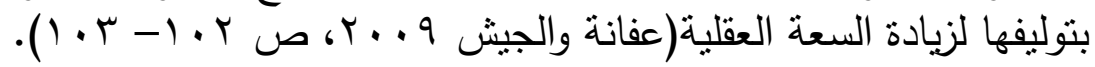


ومن الإستراتيجيات المنتاغمة مع هذا المبدأ:المنظمات المتقدمة ، تغيير

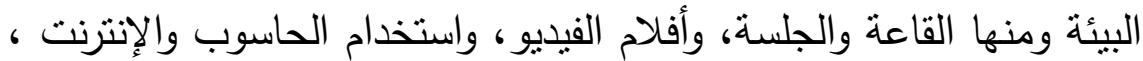

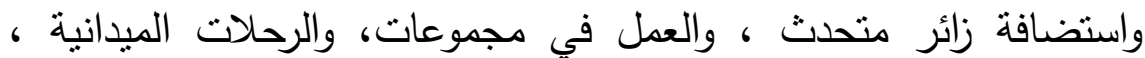

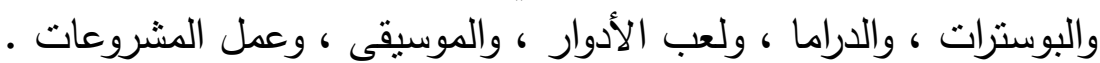

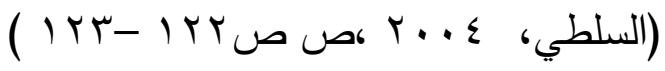

\section{ن - التعلم عملية متطورة ومستمرة:}

الدماغ على الرغم من أنه شديد التعقيد ، إلا أنه لله إمكانيات هائلة

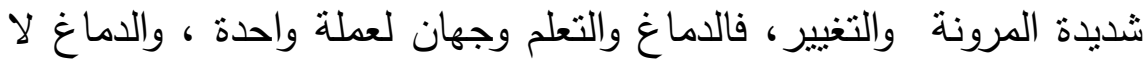
ينمو بمجرد الغذاء والحماية ، ولكن أيضاً من خلا وجل الخبرات الحية التي وني تقود إلى روابط عصبية وإفرازات كيماوية ، ويؤكد على أن عمل الدماغ يستمر مدى الحياة ما دام الإنسان يفكر ، وبالتالي فإن دماغه بينمو .

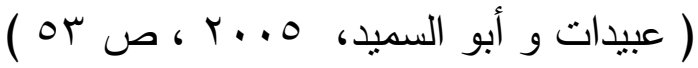

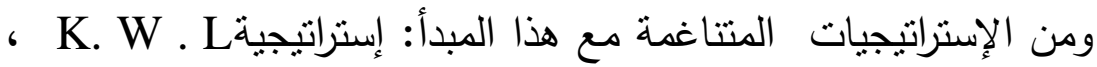

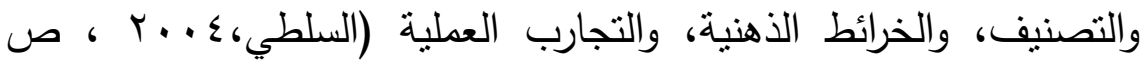
- ( I Y $\varepsilon$

\section{ش - ياعم التعلم المعقد بالتحدي ويكف بالتهديد :}

تعلم الدماغ يتم بشكلٍ أفضل ، ويقوم بعمل نرابطات عصبية متعددة عندما تكون بيئة التعلم مفعمة بالتحدي والمخاطرة ، ويكف تعلم الدماغ

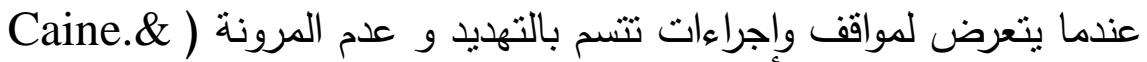

$$
\text { -( Caine, } 1991 \text {,p } 91
$$

ومن الإستراتيجيات المنتاغمة مع هذا المبدأ :طرح مشكاتلت واقعية ومناقشتها ، وإعطاء خيارات ، واستضافة زائر ، وتغيير البيئة ، والعمل في هي 
مجموعات ، والدراما ، والموسيقي ، والتعلم الذاتي ، والحاسوب (السلطي،

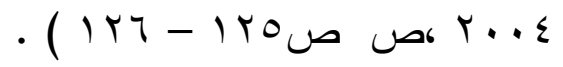
ك - كل دماغ منظم بطريقةٍ فريدةٍ : كانة

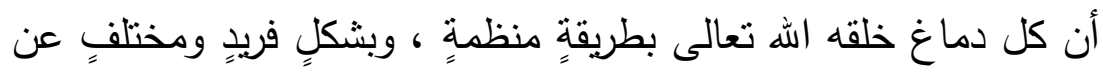

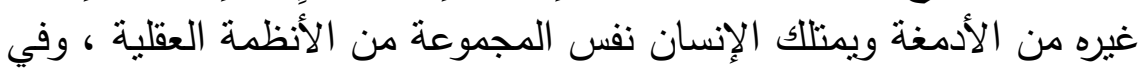

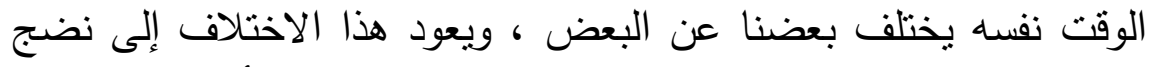

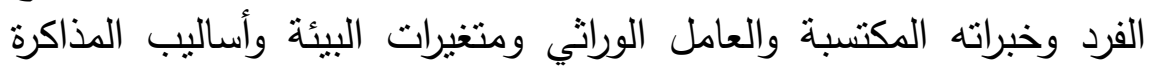

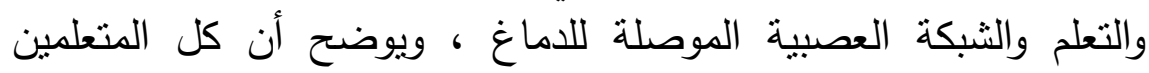

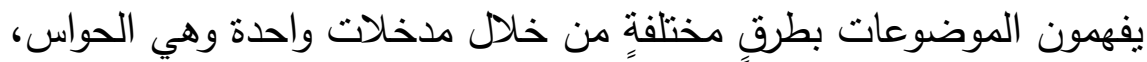

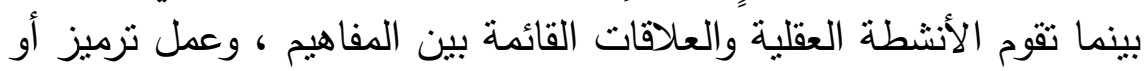

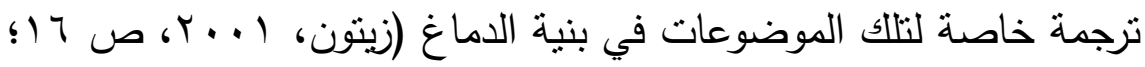

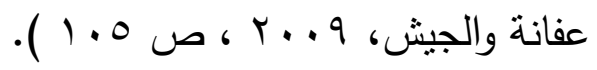

ومن الإستراتيجيات المتتاغمة مع هذا المبدأ: عمل بحوث حسب اختيار

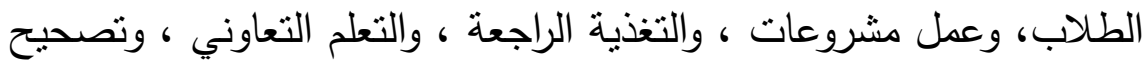

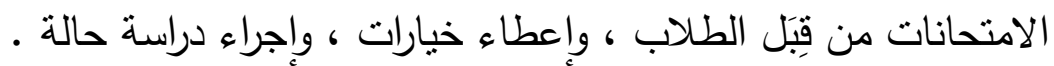

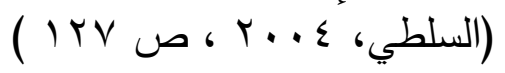
تتلخص مباديء ومسلمات التعلم المستتد إلى الدماغ في خمس مباديء

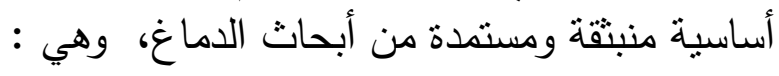

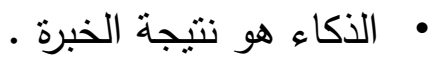

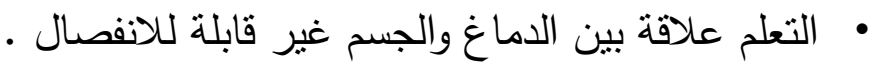

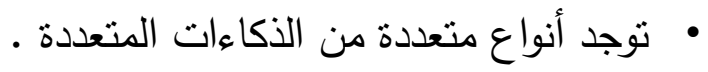

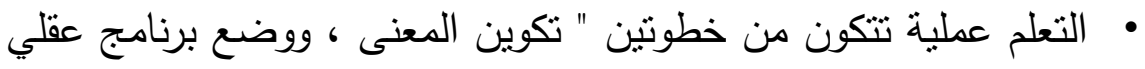

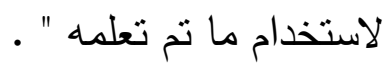


الثخصية تؤئز على التعلم والأداء (كوفاليك وأولسن، ع . . ب ،ص ص $\cdot(r-1$

كما توجد عناصر منسجمة مع المباديء السابقة لترجمة نتائج أبحاث

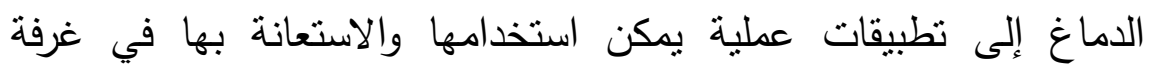

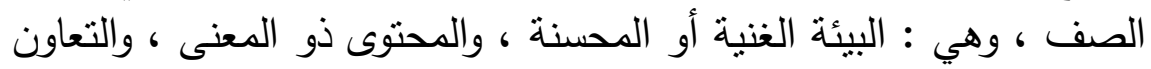

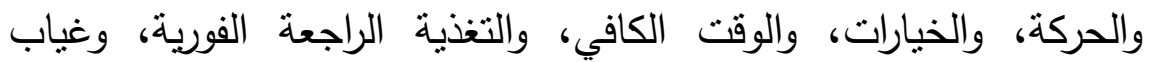

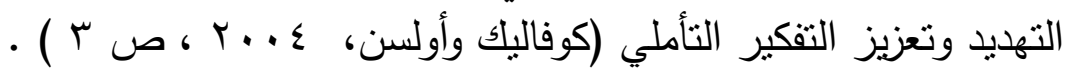

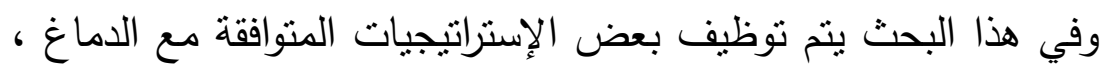
والتي تستعين بها المعلمة في التخطيط للتدريس بالنموذج التدريسي التئي القائم

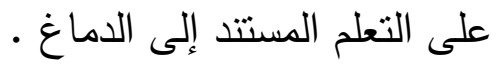
r- مراحل التعلم المستتدة إلى الدماغ:

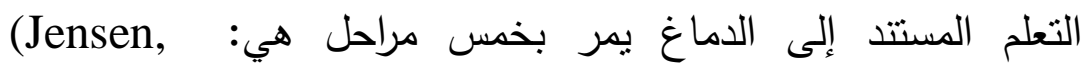

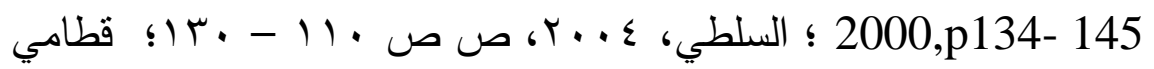

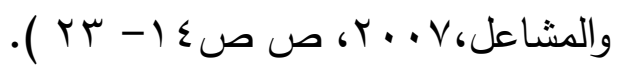
المرحلة الأولى : الإعداد Preparation

وتتنتمل هذه المرحلة على فكرة عامة عن الموضوع وتصور ذهني

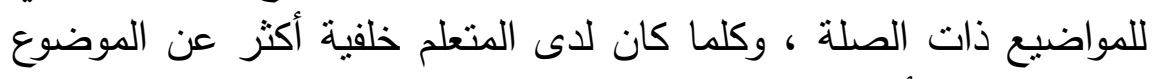

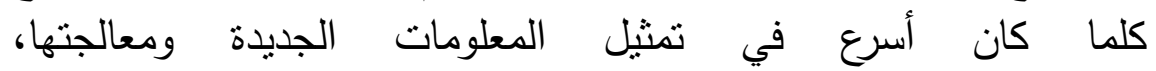
وهذا يتطلب من المعلمة القيام بالأدوار التالية :

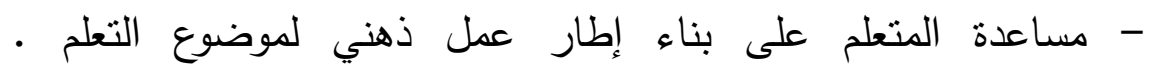

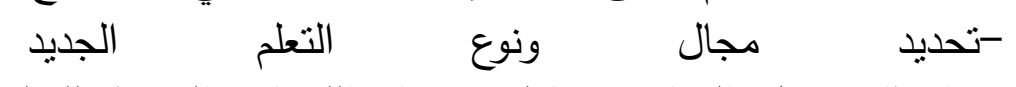
- استثارة عمل الدماغ ونشاطه لإعداد اللوحات اللازمة للتعلم الجديد. 
- تتظيم صورة ذهنية كلية منظمة في علاقات منترابطة

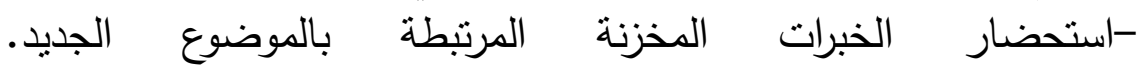
-مساعدة المتعلم على تطوير إستراتيجيات تمثيل ذهني للمعلومات الجديدة.

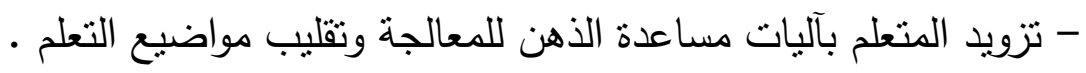

\section{المرحلة الثانية : الاكتساب Acquisition}

وتؤكد هذه المرحلة على أهمية تشكيل ترابطات عصبية نتيجة الخبرات الأصيلة والمترابطة ، وكلما كانت المدخلات منرابطة كانت التهلت الترابطات

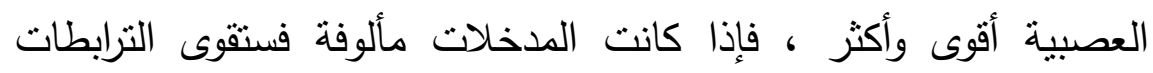

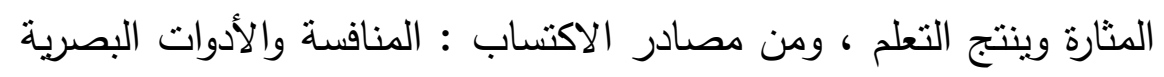

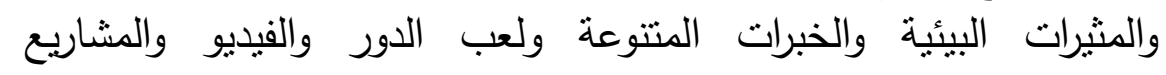
الجماعية، وتؤكد هذه المرحلة على الخبرة القبلية . وهذا يتطلب من المعلمة القيام بالأدوار التالية : -تنشيط الدماغ لاستحضار الترابطات والمحاور • -مساعدة المتعلم على بناء روابط ذهنية جديدة.

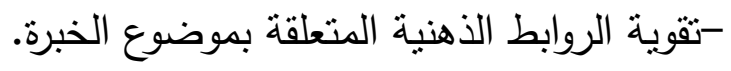
-إثارة مواقف المنافسة والمستحقات الذهنية البيأئية.

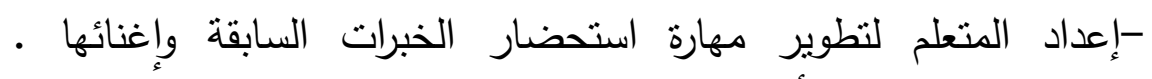
- تتشيط تفاعل مباشر أو غير مباشر في المواقف البيئية لزيادة الروابط.

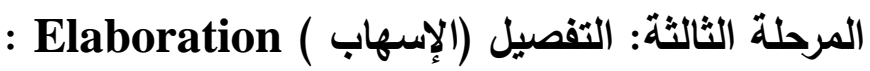

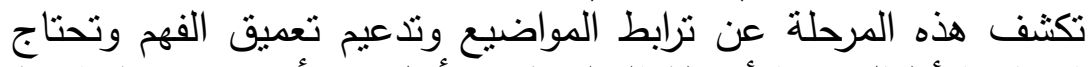

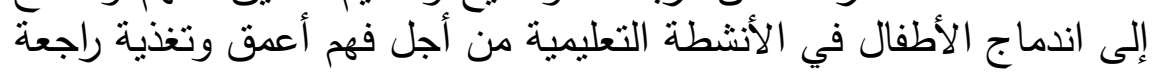

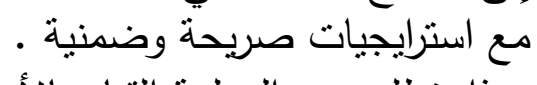
وهذا يتطلب من المعلمة القيام بالأدوار التالية: 
-تعميق الفهم عن طريق مواقف التفصيل والتوسيع بالخبرات المترابطة عصبياً وذهنياً.

-التأكد من وجود الترابطات العصبية اللازمة لدى المتعلم .

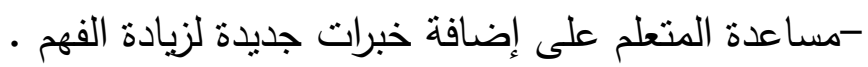

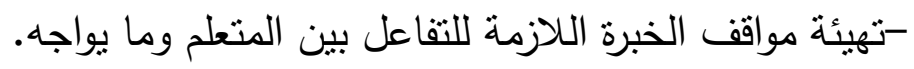

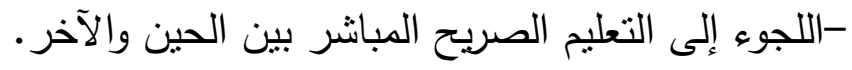
-التزويد بالتغذية الراجعة اللازمة. - إتاحة الفرصة للمتعلم لممارسة عمليات التصنيف، التهة والفحص، والتحليل. - تقديم أنشطة مختلفة يلعب فيها أدواراً مختلفةً .

المرحلة الرابعة : تكوين الأكرة Memory Formation :

وتهدف هذه المرحلة إلى تقوية التعلم واسترجاع المعلومات بشكلٍ أفضل

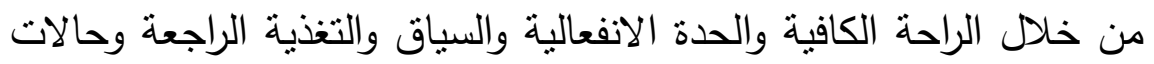
التعلم والتعلم القبلي، مما يساعد على الرافي عمق المعالجة الدماغية والتعلم الأفضل الأعلم التعل

وهذا يتطلب من المعلمة القيام بالأدوار التالية :

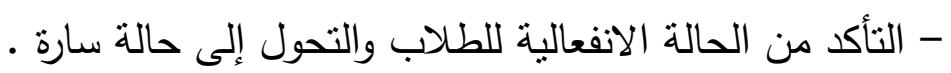

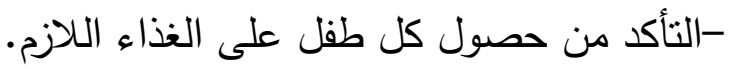

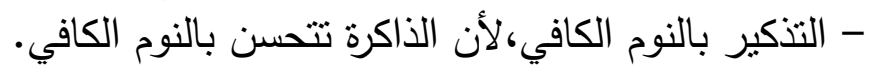

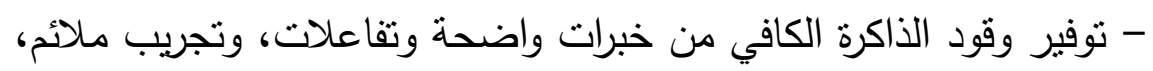

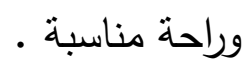

المرحلة الخامسة : التكامل الوظيفي Functional Integration: وفي هذه المرحلة يتم استخدام التعلم الجديد بهدف تعزيزه لاحقاً والتوسع فيه، 
ويتم تطوير الثبكات العصبية الموسعة أو الممتدة من خلال تكوين ترابطات وتطوير ترابطات صحيحة وتقوية الترابطات . وهذا يتطلب من المعلمة القيام بالأدوار النالية : - تقديم التعلم وفق ترابطات عصبية مناسبة . - تزويد المتعلم براحة كافية تساعده على إدراك الروابط المناسبة . - تنظيم الخبرات كي تكون منظمة على صورة شبكات تتاسب الثبكات

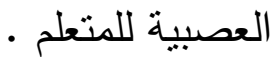
- تزويد المتعلم بالتغذية الراجعة التي تسهل عليه إدراك العلاقات العصبية

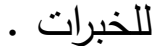
- توضيح الهدف أمام المتعلم لزيادة وتسهيل حدوث ترابطات عصبية

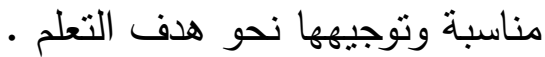
ع - استرتيجيات التعلم المستندة إلى الدماغ :

عرفنا مما سبق أنه لكي تكون بيئة تعليمية مستتدة إلى الدماغ، فإن هذا يتطلب مجموعة من الإستراتيجيات التعليمية ، وفيما يلي نتتاول بعض إنس الإستراتيجيات التعليمية التي تم الإستعانة بها في التخطيط للتدريس

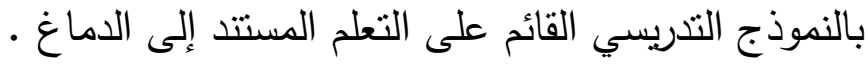

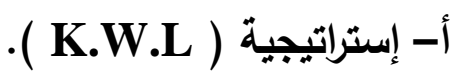

إن هذه الإستراتيجية تتسجم وتتتاغم مع عمل الدماغ ، وتفيد في تحديد

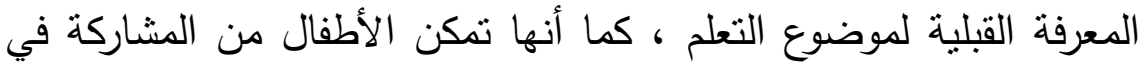

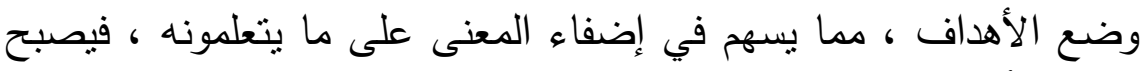
تعلمه أفضل وتزداد فرصة تخزين المعرفة وسهولة تذكرها (السلطي،

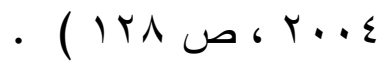


ويتضح مما سبق أن إستراتيجية (K.W.L) ) تؤكد نشاط المتعلم في تكوين المعنى ، وتهدف إلى تتشيط معرفة الأطفال السابقة لتكون نقطة التهة الانطلاق ومحور الإرتكاز؛ لما يتضمنه من موضوع التعلم من معارف

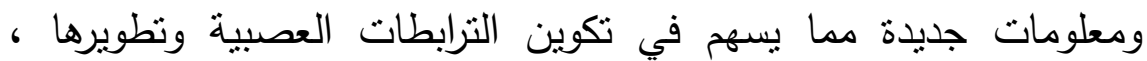

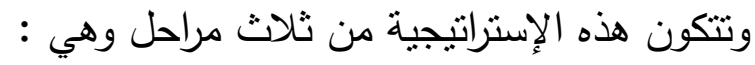
-المرحلة الأولى( K ( K ) : يحدد الطفل ما يعتقد أن يعرفه عن الموضوع .( What I Know? ) -المرحلة الثانية (W) : يحدد الطفل ما يريد أن يعرفه عن الموضوع .(What I Want to Know? )

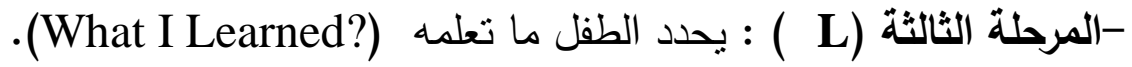

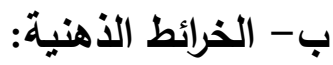

تعددت التعريفات التي تتاولت مفهوم الخرائط الذهنية نذكر منها: تعرف الخربطة الذهنية بأنها " ثقنية رسومية قويه نزود الفرد بمفاتيح تساعده

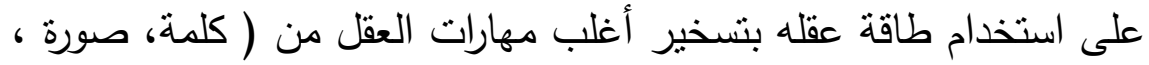

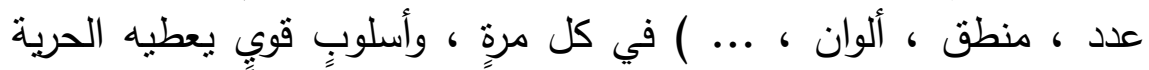

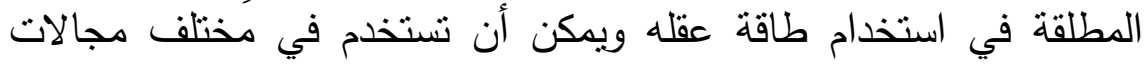

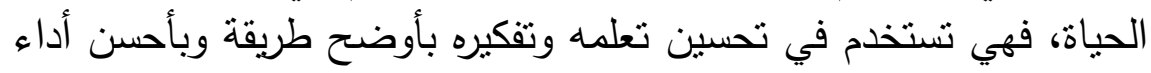

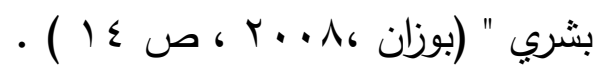
وتعرف بأنها " خريطة إبداعية تمثل روية الطفل للمادة الدراسية والعلاقات

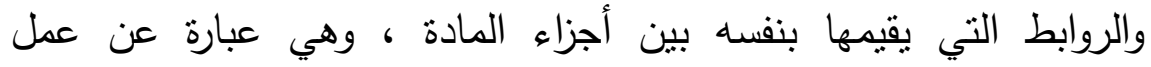
ملاحظات ومذكرات خاصة وليس مجرد أخذ ملاحظات (عبيدات و و أبو

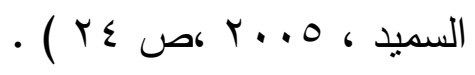


وأيضاً تعرف بأنها: إستراتيجية مرئية تعبر عن رؤية المتعلم للمادة

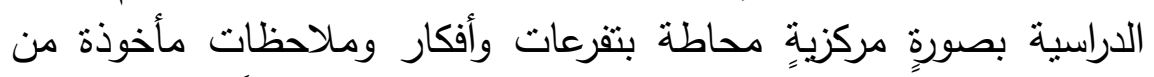
معلومات معطاة، فيتم الدمج بينهما بروابط وأسهر معتمداً على بلى الأشكال والألوان والرموز والصور؛ لإثارة كل الطاقات الكامنة لدى المتعلم وتوليد

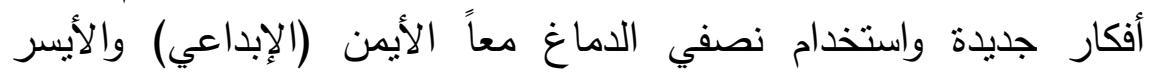

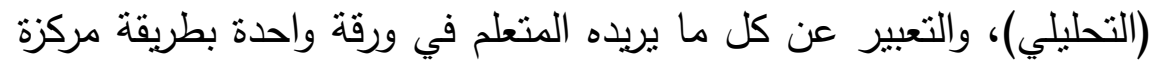

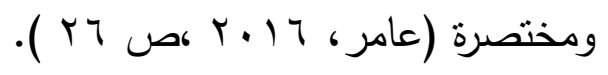

ومن خلال العرض السابق للتعريفات المختلفة التي تتاولت الخرائط الذهنية يمكن استخلاص النقاط التالية : • تشير معظم التعريفات إلى أن الخرائط الذهنية أنثكال تخطيطية نوضح

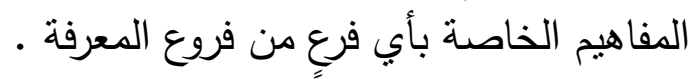

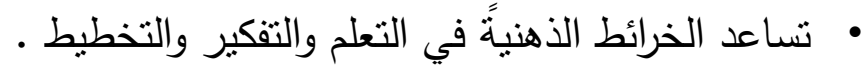
• تعتمد الخرائط الذهنية على الرسم والكتابة، مما يساعد على على سهولة

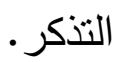
• الخريطة الذهنية أداة فكرية مكتوبة ووسيلة يستخدمها الدماغ لتتظيم الأفكار .

وفي ضوء ما سبق، تعرف الخرائط الذهنية في البحث الحالي بأنها:

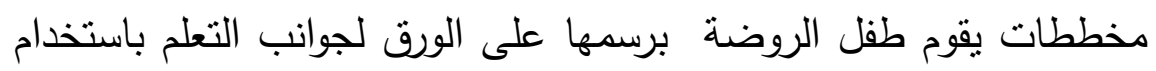

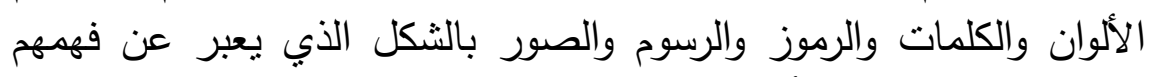

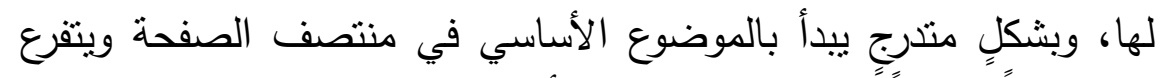

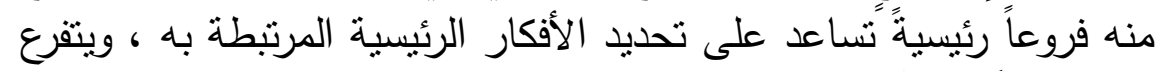
منها فروعاً ثانويةً أخرى على حسب أنس الأفكار وطبيعتها. 


\section{ج- التعلم التعاوني :}

وبعد التعلم التعاوني أحد الإستراتيجيات المنتاغمة مع الدماغ و يعرف التعلم التعاوني بأنه " أسلوب تعليمي يقوم على تتظيم الصف، حيث يقسم الأطفال إلى مجموعاتٍ صغيرةٍ ، تتكون كل منها من أربعة أفراد - على

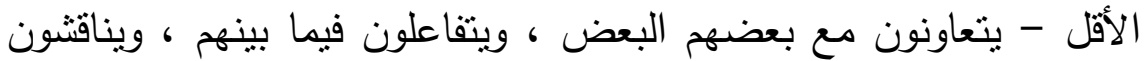

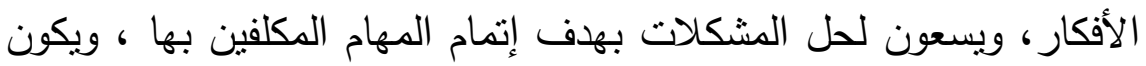

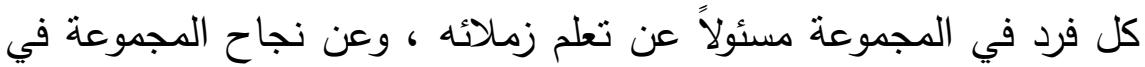

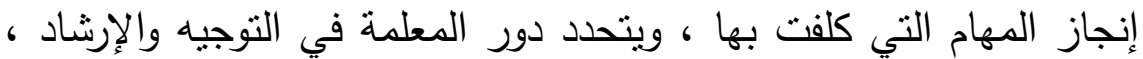
وتتجيع الأطفال والإجابة عن أسئلته وتوزبع الأدوار على كل طلى في في

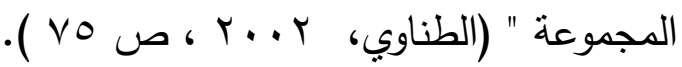

" فكر ، زاوج ، شارك " هي: إحدى إستراتيجيات التعلم التعاوني التي تشجع على المشاركة الفردية وتتاسب جميع المراحل الدراسية وكافة الفصول وتعتمد على تفكير الأطفال من خلال ثلاث خطوات محددة كالتالي(الثمري

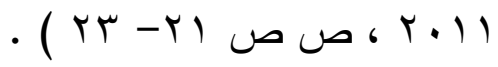

- فكر: حيث يفكر الأطفال بشكلٍ مستقلٍ في السؤال الذي تم طرحه من قِبَل المعلمة، بهدف تشكيل وصياغة أفكارهم الخاصة. - زاوج : حيث يتم تجميع الأطفال في أزواج لمناقشة أفكارهم، وتسمح هذه الخطوة للأطفال بالتعبير عن أفكارهم وأفكار الآخرين.

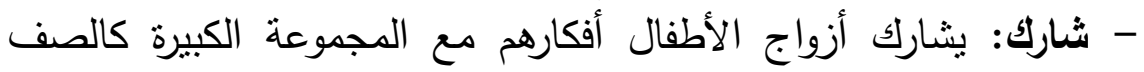

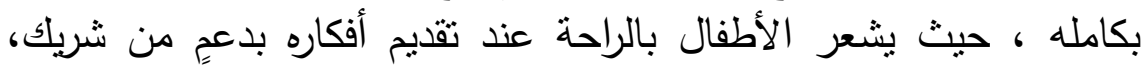
بالإضافة إلى أن الأفكار تصبح أكثر دقةً بعد مرورها بهذه المراحل. بالهاه 
وتعد إستراتيجية العصف الذهني منتاغمة ومنوافقة مع الدماغ ، أنتير وتولا أفكاراً إبداعيةٍ عند المتعلمين من خلال مواجهة المتعلم بمشكلة أو إثارته بموقف حياتي أو حدث تعليمي معين ، وتعتمد هذه الإستراتيجية على

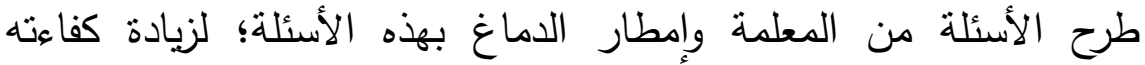

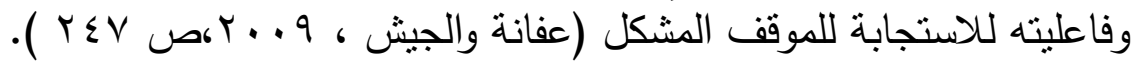
ويمكن استخدام هذه الإستراتيجية لتوليد الأفكار في أي وقت لأي مادة

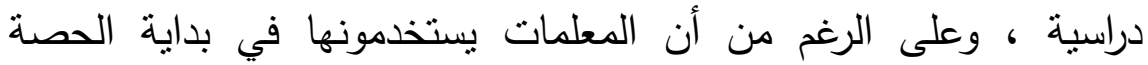
الدراسية إلا أنه من المفيد استخدامها بعد انتهاء التعلم حيث يكون الأطفال

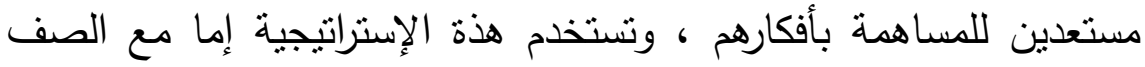

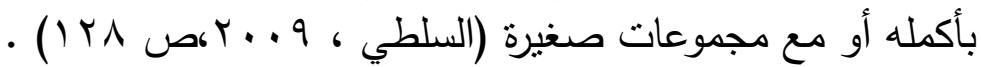

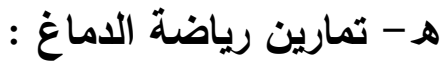

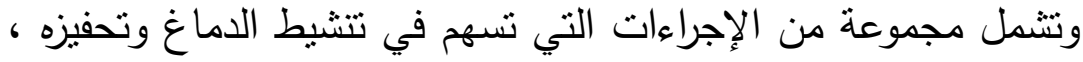
وتحسين عمل الذاكرة ، وتتضمن مجموعة من الحركات الجسدية السريعة

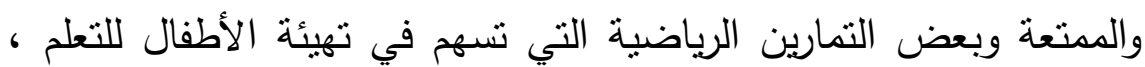

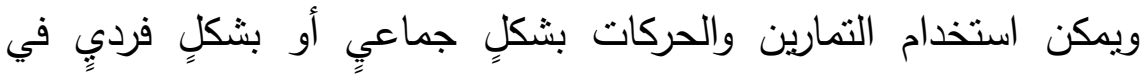

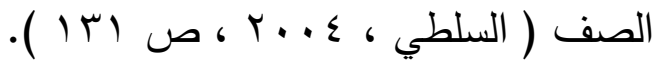

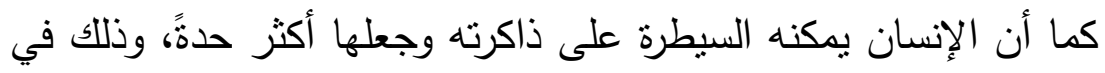

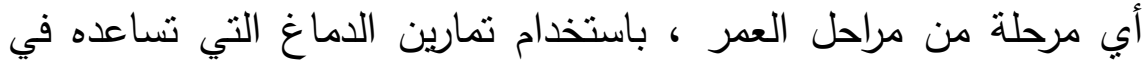

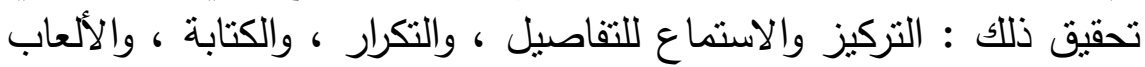

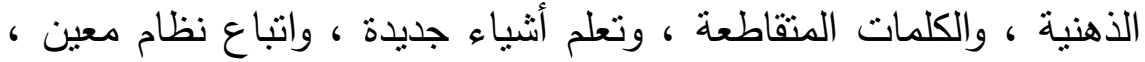

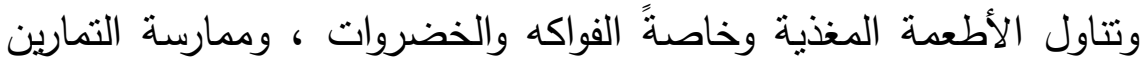


الرياضية والتي نزيد من نسبة الأكسجين في الدم (كمال، با ـr ، ص

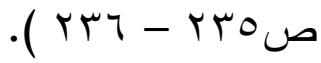

المحور الثاني: الحس العددي Numerical sense skills :

وسنحاول فيما يلي إلقاء الضوء على مفهوم الحس العددي ،وأهمية تتمية

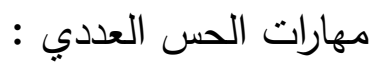
1-مفهوم الحس العددي:

يعرف الحس العددي بأنه "الحدس الجديد حول الأعداد وعلاقتها، ومرونة

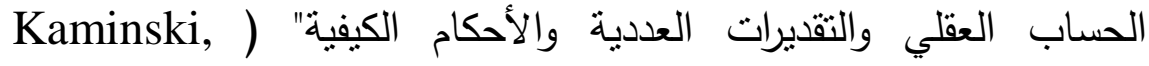
.(2003,p25

كما يعرف بأنه هو "المرونة الفكرية في التعامل مع الأعداد من حيث: إدراك معنى العدد وعلاقته بالأعداد الأخرى والقدرة على الفئ أداء العمليات

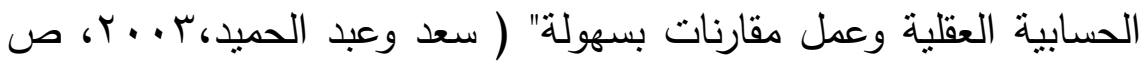

. (rTr r-أهمية تنمية مهارات الحس العددي:

قد اتفق عدد من التربوبين على أهمية اكتساب الأطفال لمفهوم العدد

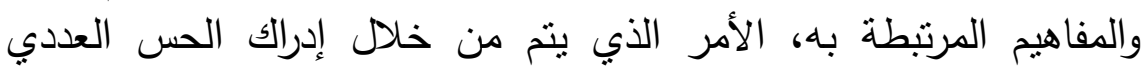

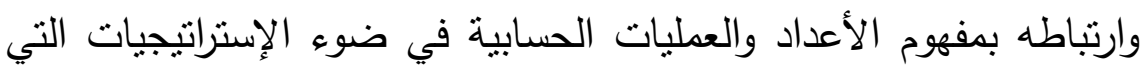

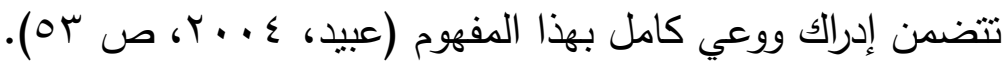
وعدَّ التربويون نقاطاً متعددةً توضح أهمية الحس العددي كما سيتضح فيما

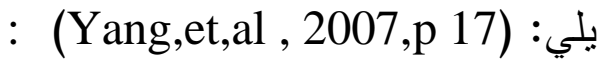


- يَيني الحس العددي لدى الأطفال الإدرالك العميق والبصيرة، إضافةً إلى إلى

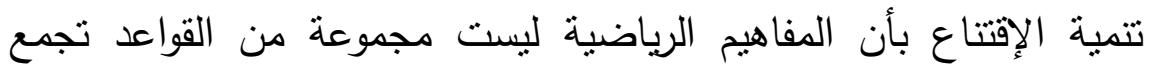

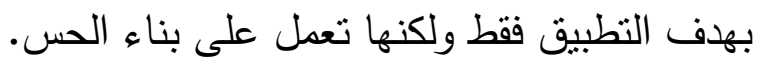

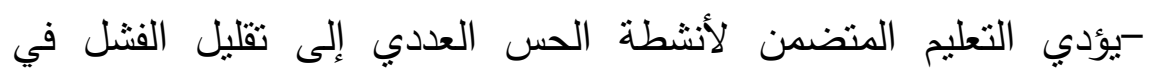
المفاهيم الرياضية بصورةٍ واضحةٍة. - يقلل الحس العددي من الصعوبات التي تواجه المتعلمين في حل تدريبات المفاهيم الرياضية. - يزيد الحس العددي من ثقة المتعلم في نفسه، ويبث فيه الطمأنينة والراحة

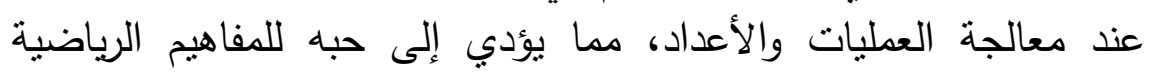

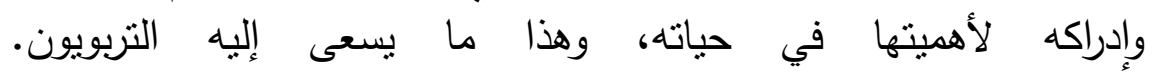
- يساعد الحس العددي في استيعاب المفاهيم الرياضية من خلاد فيلهي تحسين

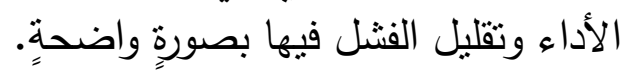
- يعمل الحس العددي على تحسين تحصيل الأطفال في المفاهيم الرياضية حيث أثتتت كثير من الدراسات وجود ارتباط ذات دلالة إحصائية بين الحين الحياضية التحصيل والحس العددي. -يشجع الحس العددي المتعلمين على اكتشاف المفاهيم المتعلقة بالأعداد

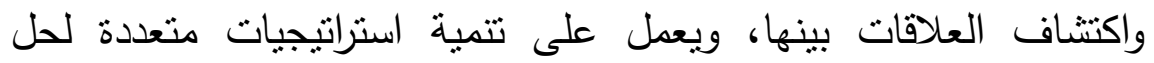

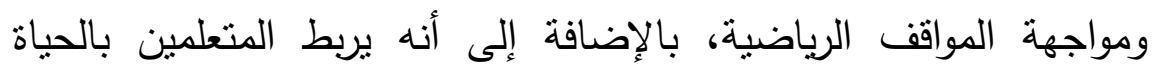

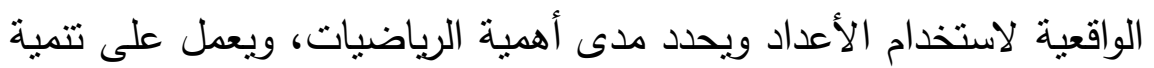
التفكير الرياضي لدى المتعلمين. - ييني الحس العددي الكفاءة الذهنية والقدرة الحسابية والمتعة عند التعامل مع المنظومة العددية. 


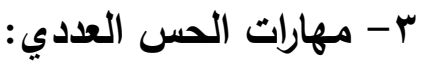

بينت دراسة جاي ودوجلاس أن الحس العددي يضم مهارات عديدة ترتبط بالحس المشترك حول الأعداد، وتلك المهاب المهارات هي: ا ـ الفهم الجيد لمعاني الأعداد.

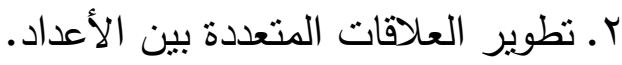
r. إدراك الكم النسبي للعدد.

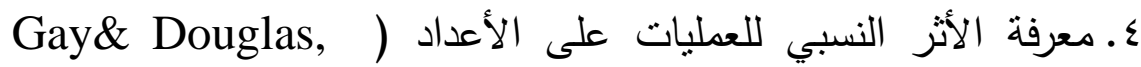
1997,p 27).

كما أثنار رييز ويانج أن للحس العددي مهارات وهي: ا ـ التمييز بين الأعداد والمقارنة بينها. r r انتقاء واستخدام العلامات العددية المميزة.

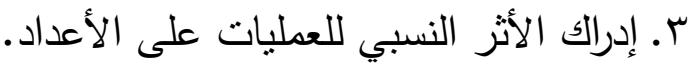

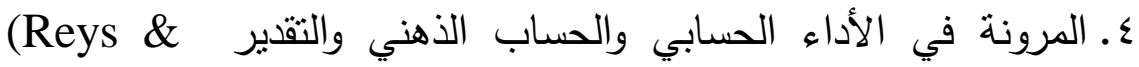
Yang,1998,p 228) وصنف المنوفي مهارات الحس العددي فيما يلي: ا ـ الوعي بالأعداد واستخداماتها في الحياة من حولنا. r. اختيار العملية المناسبة. r. اختيار العلامات العددية الإرشادية وتوظيفها لإصدار الحار أحكام عددية. ـ ـ إدراك الكم المطلق والنسبي للأعداد.

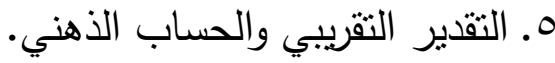

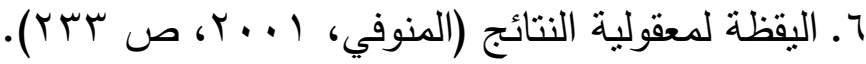


واستخدم فيها عبد العال مهارات الحس العددي التالية: ا ـ إدراك الكم المطلق والنسبي للعدد. r r إدراك الأثر النسبي للعمليات على الألى الأعداد. r. إدراك العلامة العددية المميزة واستخدامها.

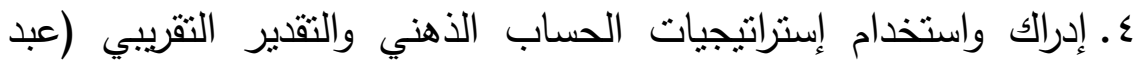

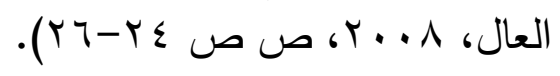
ومن خلال ماسبق تم تحديد مهارات الحس العددي التالية:

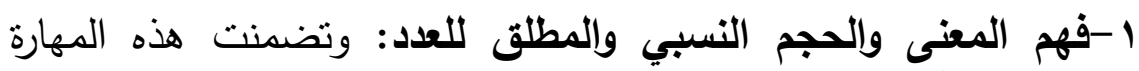

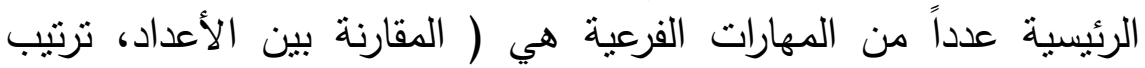

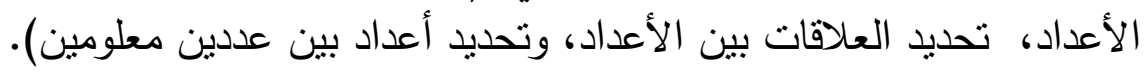
r-المرونة في تطبيق مفهوم الأعداد والعمليات في المواقف الحسابية:

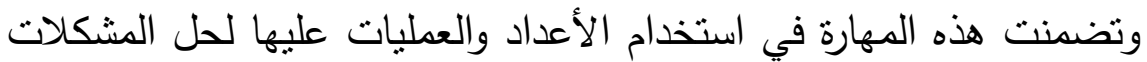

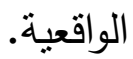

r-التعبير بالأعداد عن علاقات ممثلة بنماذج بصرية: تضمنت هذه

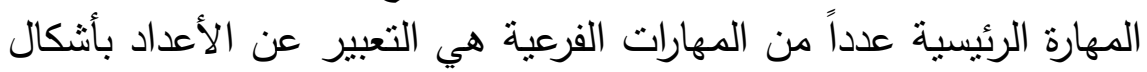
بصرية والتعبير لفظياً أو في شكل مصور عن العبلاقات التعات بين الأعداد.

\section{المحور الثالث: التفكير البصري Visual thinking :}

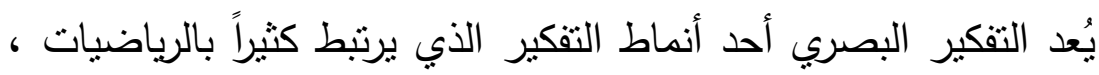

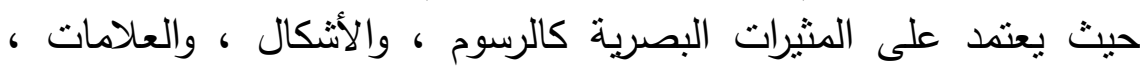

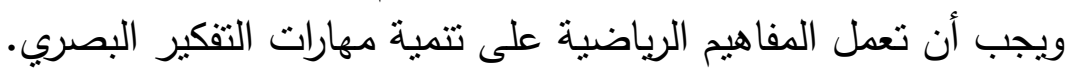

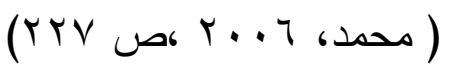


وفيما يلي سوف يتم التتاول بشيءٍ من التفصيل لكلٍ من مفهوم التفكير

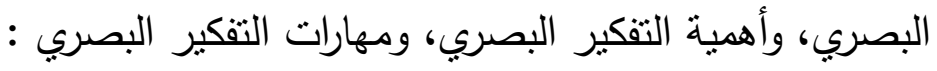

1-التقكير البصري :

يعرف التفكير البصري بأنه : نمط من أنماط التفكير الذي ينشأ نتيجة

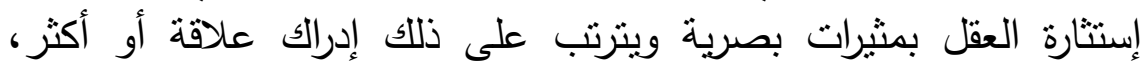

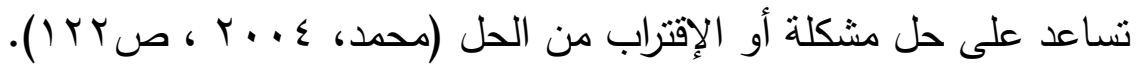

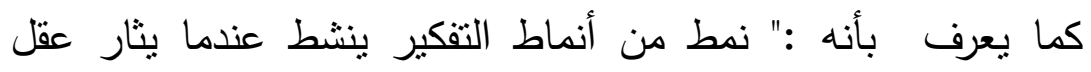

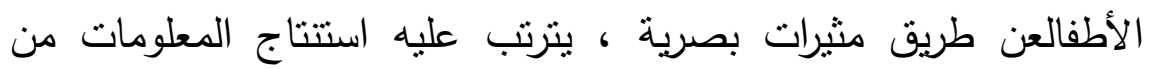

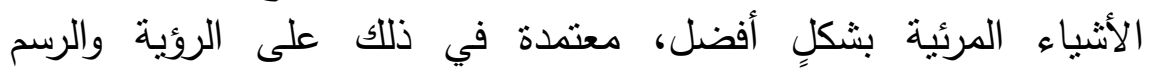

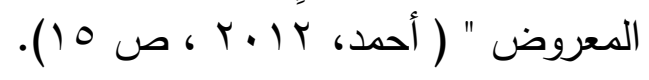
r-أهمية التفكير البصري: ترجع أهمية التفكير البصري بالنسبة للمتعلم إلى :

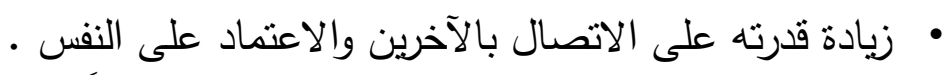

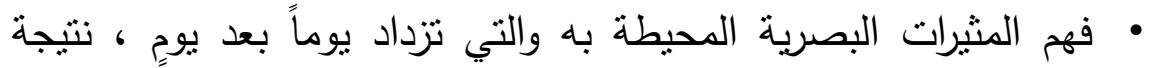

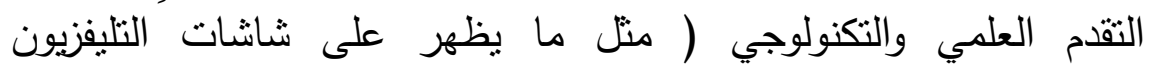
والكمبيوتز ....الخ )، وبالتالي تزداد صلته بالبيئة المحيطة بهاه.

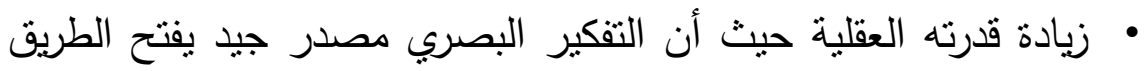

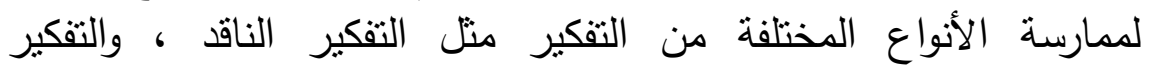
الابتكاري.

• يزيد من شعور المتعلم بالتقة بالنفس ( محمد، ع . . ب ، ص بr ). 
أيضاً ترجع أهمية التفكير البصري في العملية التعليمية ؛ لما لها من فن

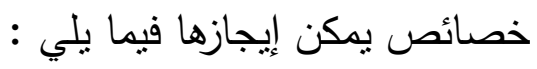

• يساعد على التعلم النشط حيث تعمل على تضمين المتعلم في عملية

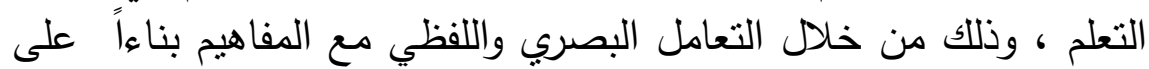

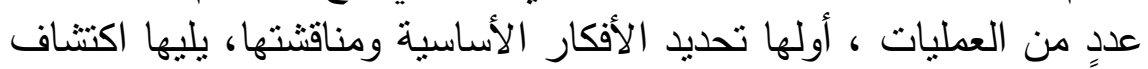
العلاقات، والتعبير عنها، واستتناج الارتباطات بينها ومحاولة تبسيطها، وباستكمال الثبكات البصرية ، فإن المتعلم يكون على وعي وفهم كامل لهذه

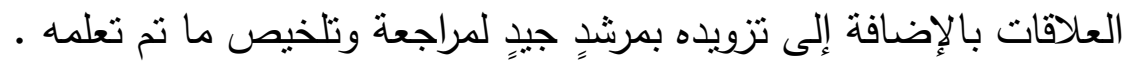

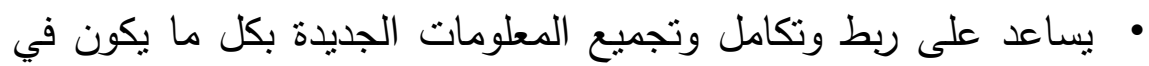
حصبلة المتعلم المعرفية . • يساعد على التذكر واسترجاع المعلومات السابقة .

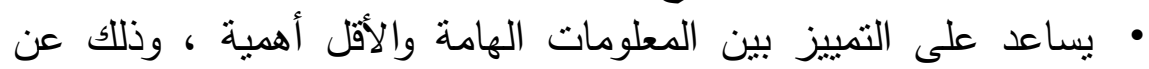

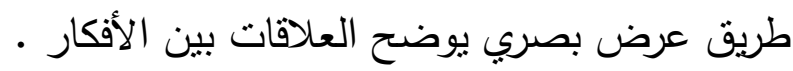
• يثير الدافعية لاى الأطفال وبشجعه على توظيف ما تعلمه بطريقةٍ فعالةً، حيث أن الأطفال الذي ينظم معلوماته في إطار مفاهيمي واسع ، يمكن أن أن فئس يجمع معلومات مثرابطة وكثيرة في وقت أقل ويستطيع أن يوظفها في

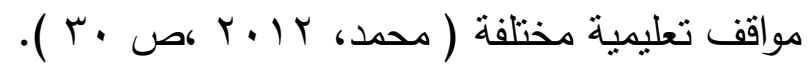

كما ترجع أهمية التفكير البصري لما له من المميزات التي تساعد الطفل

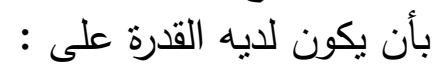

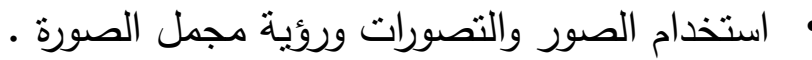

• استبعاب الفكرة ككل مرة واحدة ، ثم مله الأجزاء .

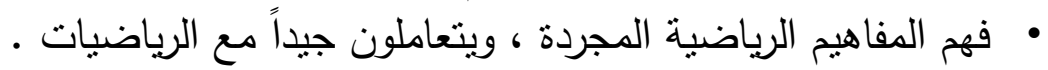
• استخدام الحدس في الوصول للحلول الصحيحة . 
• حل المشكلات على نحوٍ إيداعي من خلال إيجاد حلول غير عادية ل المشكلات المل

• • التواصل لابتكار العديد من المنتجات القابلة للاستخدام •

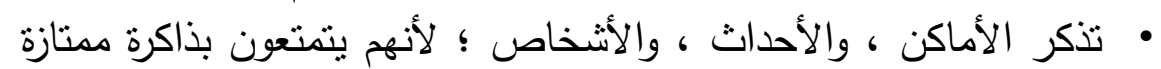
وطوبلة المدى. توكر الأكن.

• التفكير ثلاثي الأبعاد ، حيث بإمكانه تكوين علاقات بالفراغ . • فهم الهندسة ، والفيزياء ، والرسوم البيانية .

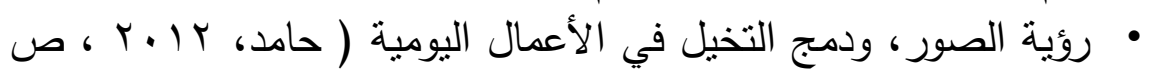

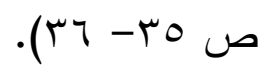
ب-مهارات التفكير البصري : بان

تتاولت الدراسات والبحوث المتعددة موضوع التفكير البصري من حيث تتميته من خلال تدريس الرياضيات، وتبنت هذه الدراسات والبحوث مهات مهارات

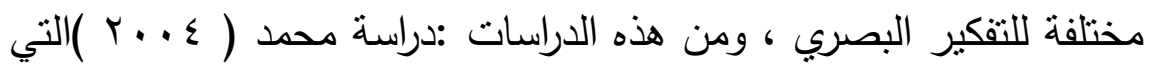

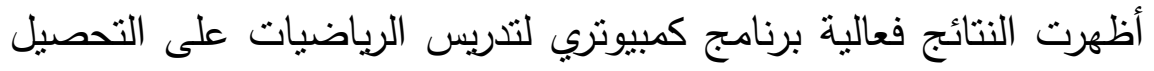

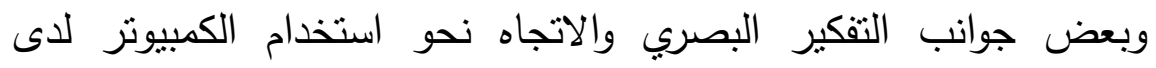

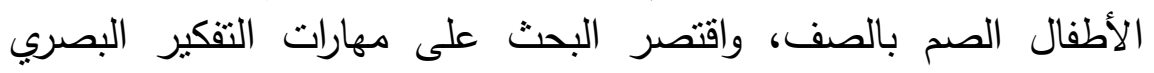
التالية ( إدراك التماثل ، إدراك الاختلاف ، اكتشاف الهُ النمط ). ودراسة محمد ( T . . T ) التي أظهرت فاعلية استخدام الألعاب التعليمية

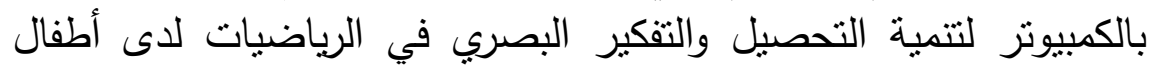

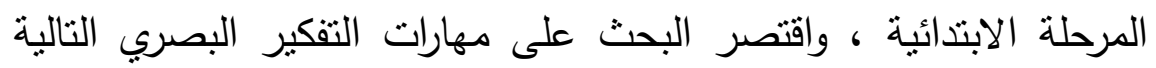

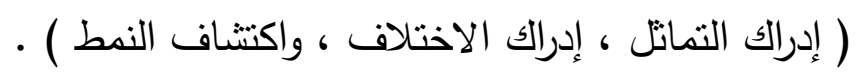

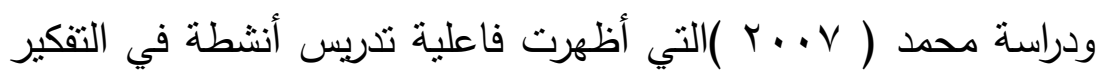

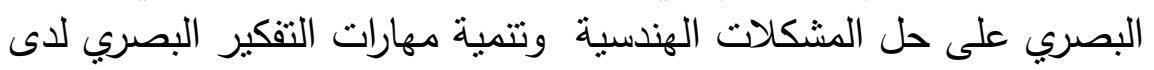




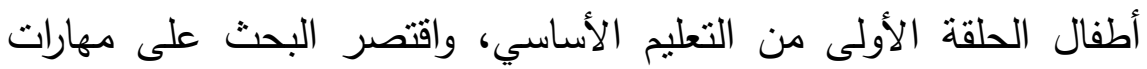

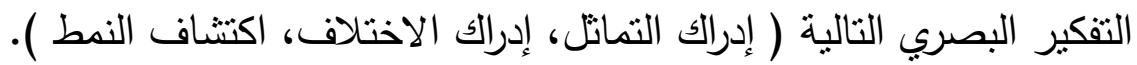

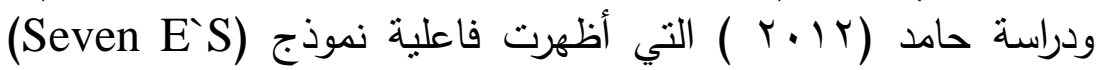

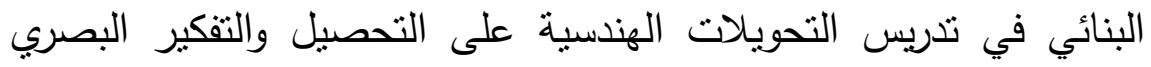

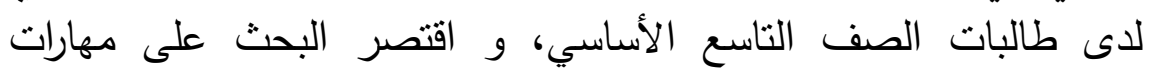

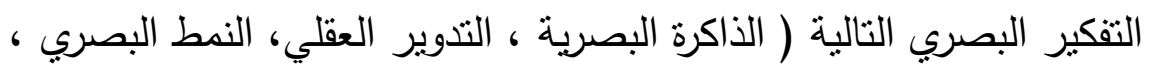
الاستد لال البصري).

من خلا العرض السابق أمكن التوصل إلى مهارات التقكير البصري

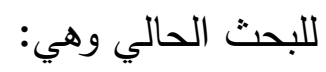

مهارة إدرالك التماثل: وهي قدرة الطفل على تحديد الأشكال أو أجزاء من

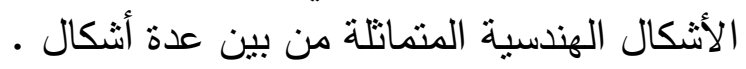
• مهارة إدراك الاختلاف: هي القدرة على تحديد الأشكال أو عناصر

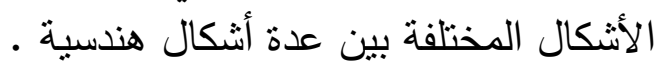

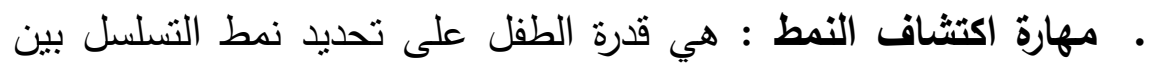
الأعداد أو الأشكال ، وتكملة التشلسل وفقاً للنمط الذي يكتشفه .

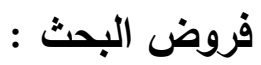

من خلال الدراسات والبحوث السابقة تم صياغة فروض البحث الحالي التالية: - الت خن

ا - يوجـد فـرق دال إحصـائياً بــين متوســـي درجـات أطفــال المجموعـة

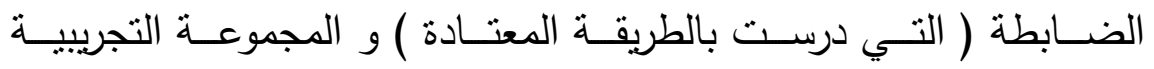

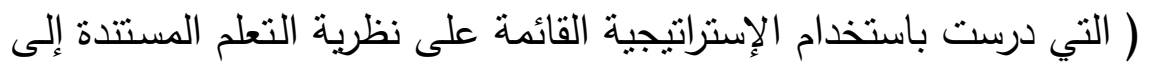

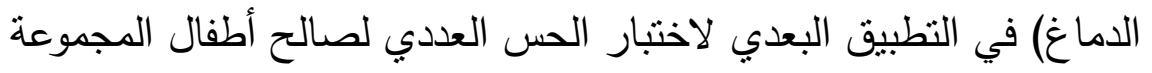
التجريبية. 
ب- بوجـد فـرق دال إحصـائياً بـين متوسـطي درجـات أطفـال المجموعــة

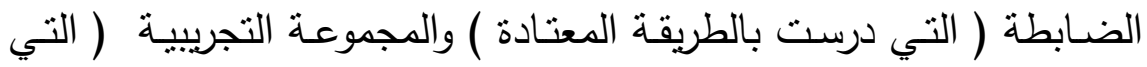

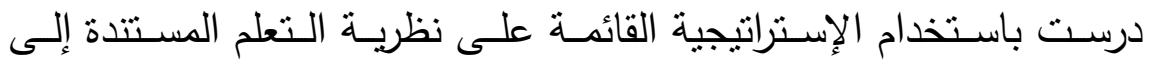

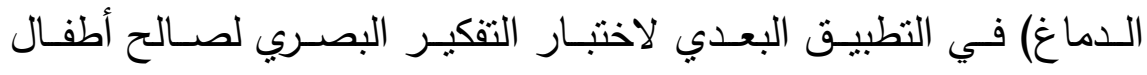
المجموعة التجريبية.

$$
\text { إجراءات البحث : }
$$

سار البحث الحالي تبعاً للإجراءات التالية: أولاً: إعداد اختبار الحس العددي لأطفال ما قبل المدرسة: مر إعداد اختبار الحس العددي بالخطوات التالية: 1- تحديد الهرف من الاختبار: تتمية مهارات الحس العددي لاى أطفال الروضة. r - إعداد الصورة الأولية للاختبار:

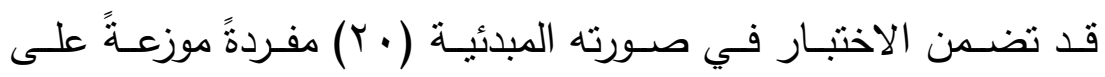

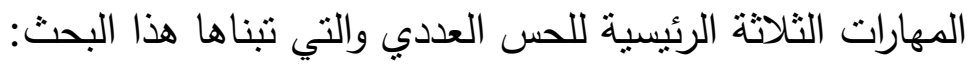

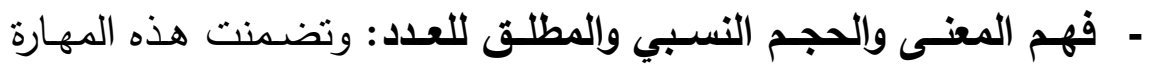

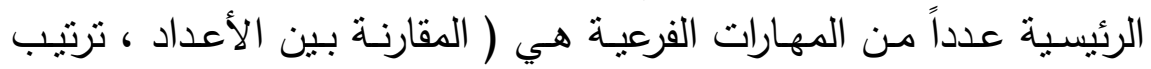

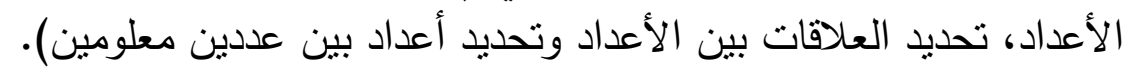
- المرونـة في تطبيق مفهوم الأعداد والعمليات في المواقف الحسـابية:

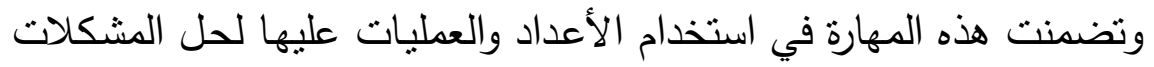

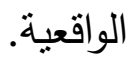




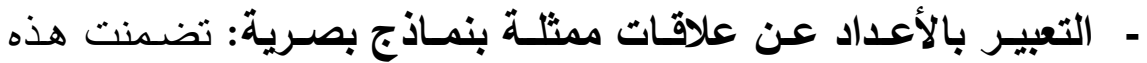

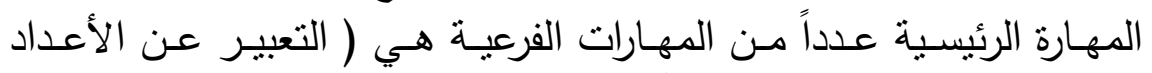

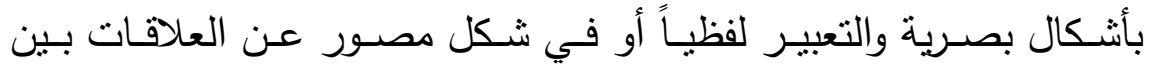
الأعداد).

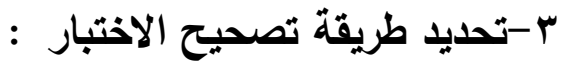

تم تحديد طريقة تصحيح الاختبار بحيث تعطى كل مفردة في الاختبار

$$
\text { درجةً واحدة. }
$$

\section{ع -تحديد صدق الاختبار:}

للتأكد من صدق الاختبار تم عرضـه على مجموعة من الاهبار: أساتذة المناهج

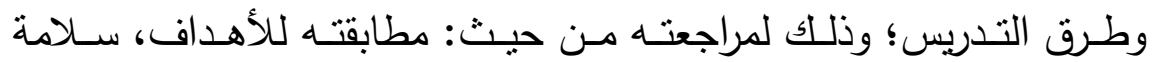

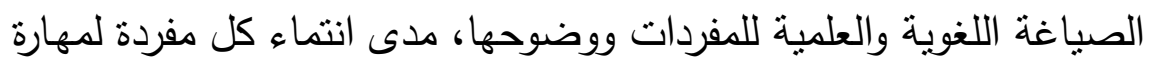

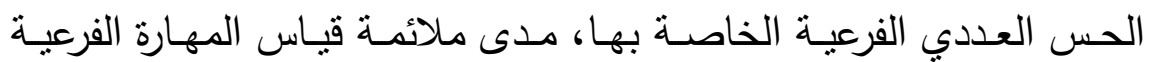

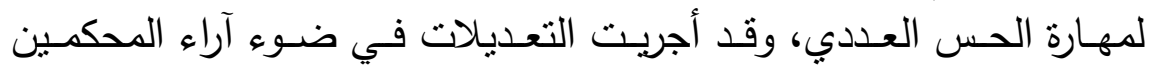
وأصبح الاختبار في صورته النهائية .(ملحق الهن الهن )

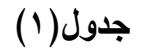

يوضح توزيع مفردات اختبار الحس العددي على مهاراته

\begin{tabular}{|c|c|c|c|}
\hline أرقام المفردات & المهارات الفرعية & المهارات الرئيسية & p \\
\hline$r \cdot r \cdot 1$ & -المقارنـــة بـــين الأعــــاد،ترتيب & فهـــم المعنــى والحجـــ & 1 \\
\hline $1,0, \varepsilon$ & الأعـــاد، تحديــــــالقاتــات بــين & النسبي والمطلق للعدد. & \\
\hline$q \cdot \wedge, V$ & الأعداد، تحديد أعداد بين عددين & & \\
\hline 1 . & معلومين. & & \\
\hline
\end{tabular}


المجلة العلمية لكلية رياض الأطفال - جامعة بورسعيد

\begin{tabular}{|c|c|c|c|}
\hline أرقام المفردات & المهارات الفرعية & بارات الرئيسية & r \\
\hline $\begin{array}{l}1 r_{6} 1 r_{6} 11 \\
1061 \varepsilon\end{array}$ & - استخدام الأعداد والعمليات عليها & 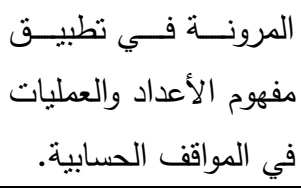 & r \\
\hline $\begin{array}{c}11.1 V_{6} 17 \\
r \cdot 619\end{array}$ & والتعبير عن الأعداد بأشكال بصرية & 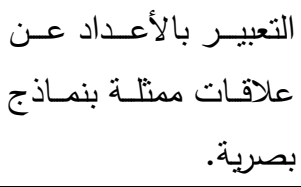 & r \\
\hline r. & & المجموع & \\
\hline
\end{tabular}

-التطبيث الاستطلاعي للاختبار:

تم تطبيق الاختبار على عينة استطلاعية تكونت من ( ب ب) طفلاً وطفلةً بروضـة مدرسـة أبناء الثورة الابتدائية؛ وذلك لحسـاب صدق عباراته وثبات المقياس، وزمن الإجابة عليه. - صدق مفردات الاختبار :

تم حسـاب صسدق صسدق مفردات الاختبار بايجـاد معامـل الارتباط بين

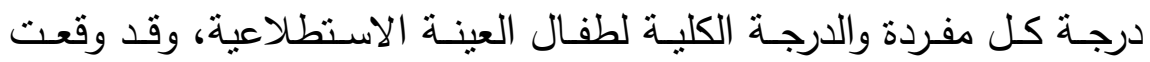

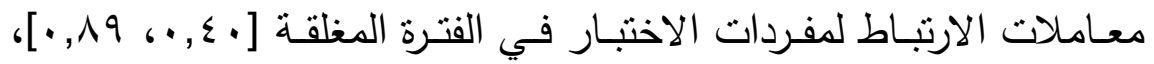
وبالتالي فان جميع معاملات الارتباط موجبة مما بشير إلى صدق مفردات

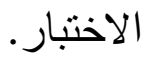

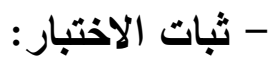

تم حساب ثبات الاختبار باستخدام "معادلة ألفا للثبات" معادلة كرونباخ

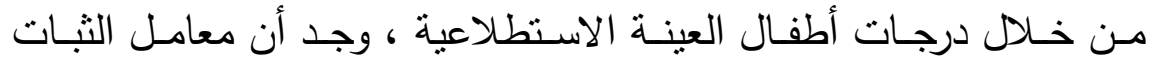
للمقياس = 
تم حساب زمن الإجابة عن مفردات الاختبار عن طريق رصد زمن إجابة

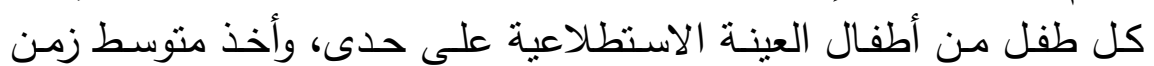
الإجابة على مفردات الاختبار ،وكان الزمن اللازم ( • الإ) دقيقةً. ثانياً : إعداد اختبار التفكير البصري:

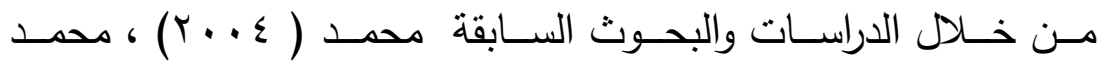

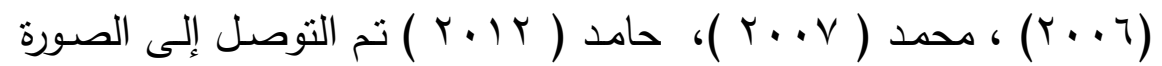

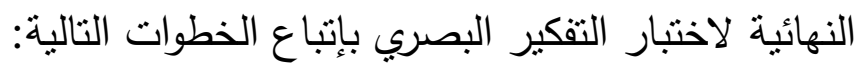
1 - تحديد الهدف من الاختبار:

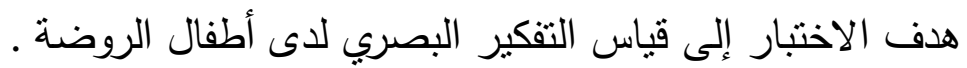
r - تحديا مهارات التفكير البصري: تم تحديد المهارات التي تمثنل التفكير البصـري وهي: إدراك التماثل ، التهل

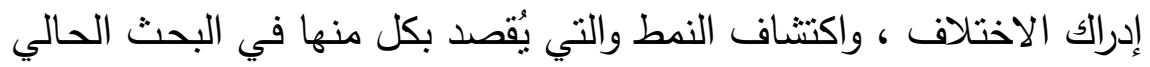
ما يلي: مهارة إدرالك التماثل، مهارة إدراك الاختلاف، مهارة اكتشاف الفهد النمط. r- إعداد الصورة الأولية للاختبار : مهارة إنسات

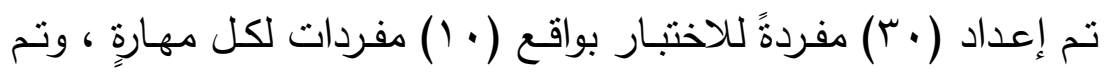
صياغة المفردات في صورة اختيار من متعدد. ع - تعليمات الاختبار :

هدفت تعليمات الاختبار إلى مساعدة الأطفال على الإجابة عن مفردات

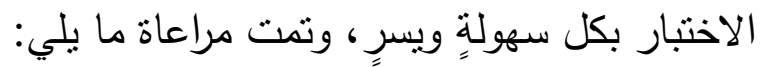
- أن تكون التعليمات قصيرةً ومبانشرةً 


\section{- - توضيح الغرض من الاختبار. - - وصف مختصر للاختبار.} - الإشارة إلى ضرورة الإجابة عن كل مفردة من مفردات الاختبار . ه-طريقة تصحيح الاختبار: تم تحديد درجة واحدة لكل إجابة صحيحة عن كل مفردة من مفردات اختبار التفكير البصري. 1-تحديد صدق الاختبار :

للتأكد من صدق الاختبار تم عرضسه على مجموعة من أساتذة المناهج

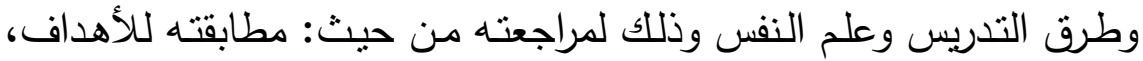
سلامة الصياغة اللغوية والعلمية للمفردات ووضوحها، مدى انتماء كل مفردة للبُعد الذي تقيسه، وقد أجريت التعديلات في ضوء آلاءرية آلاء المحكمين وأصبح

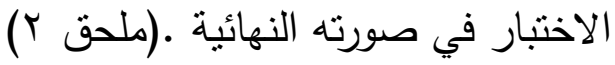

التطبيق الاستطلاعي للاختبار:

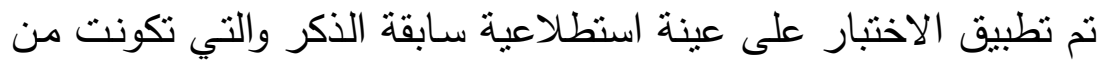

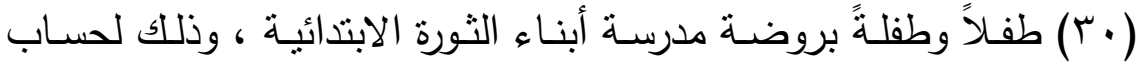
صدق عباراته، وثبات المقياس، وزمن الإجابة عليه.

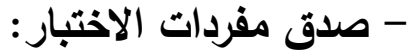

تم حساب صدق صدق مفردات الاختبار بإيجاد معامل الارتباط بين

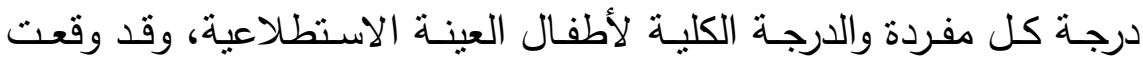

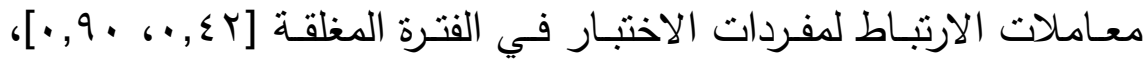
وبالتالي فإن جميع معاملات الارنباط موجبة مما يشير إلى صدق مفردات

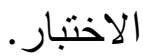




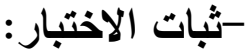

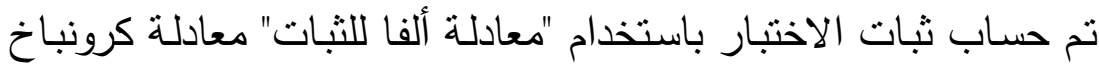

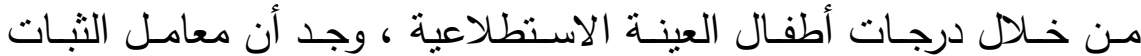

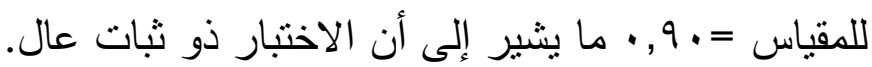

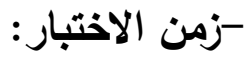

تم حساب زمن الإجابة عن مفردات الاختبار عن طريق رصد زمن إجابة

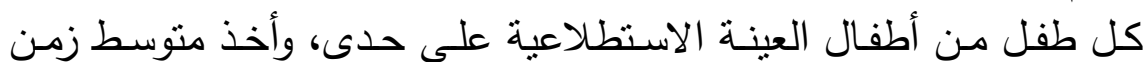
الإجابة على مفردات الاختبار ،وكان الزمن اللازم ( • ع) دقيقةً.

ثُالثاً:إعداد أورلق عمـل الطفل ودليلـل المعلمـة للتـدريس لأطفـال الروضــة باستخدام الإستراتيجية القائمة على نظرية التعلم ودلئ المستندة إلى الدماغل تم التوصـل إلـى الصـورة النهائيـة لأوراق عمـل الطفل ودليـل المعلمــة

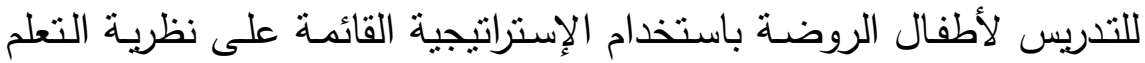
المستتدة إلى الدماغ بإتباع الخطوات التالية: 1-تحديد الأهداف العامة : تم تحديد الأهداف العامة فيما يلي: - تتمية الحس العددي لاى أطفال الروضة. - تتمية التفكير البصري لدى أطفال الروضة الروية . r-تحديد الأهداف الخاصة:

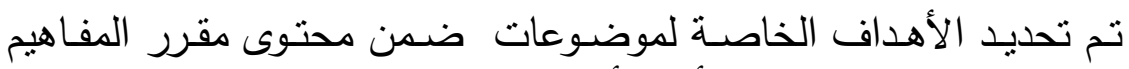

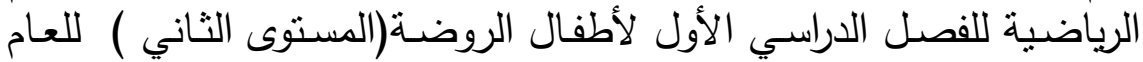

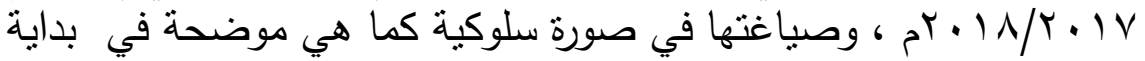

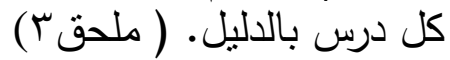


r-تحديد الاجراءات المتبعة للتدريس باستخدام الإستراتيجية القائمسة على المئي

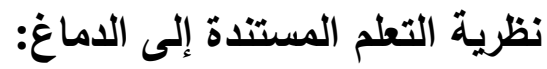

في ضـوء المراحل الخمسـة التي تستتد إليها نظريـة التعلم المستتدة إلى

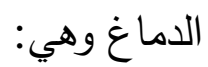

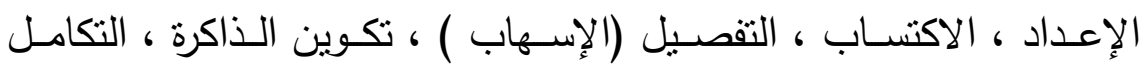

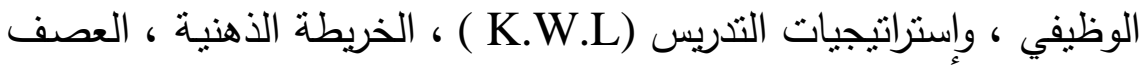

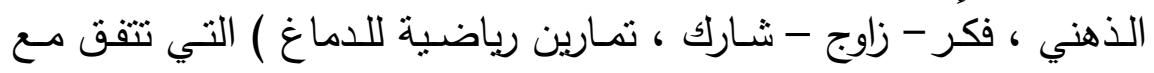
التعلم المستتد إلى الدماغ ، تم تلعديد الاجراءات المتبعة للتدريس باستخدام الإستراتيجية القائمة على نظرية التعلم المستتدة إلى الدماغ العاغ.

ع -تحديد الوسائل والمواد المستخدمة للتدريس: تم استخدام الوسائل والأدوات التعليمية التالية :

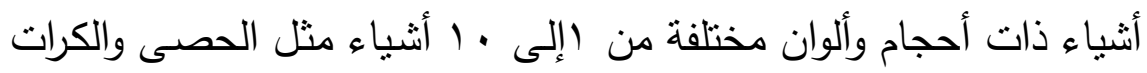

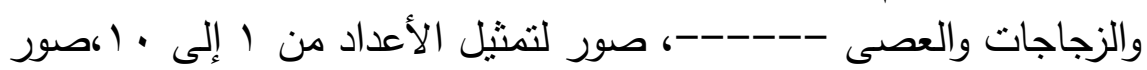
لدوائر ومنتلثات ومربعات ومستطيلات ، أوراق عمل للطفل. ه-تحديد أساليب التقويم : تم تقويم التدريس من خلا ثثلاث مراحل هي : -التقويم القبلي : تم تطبيق اختبار الحس العددي واختبار التفكير البصري

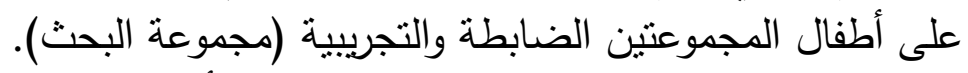

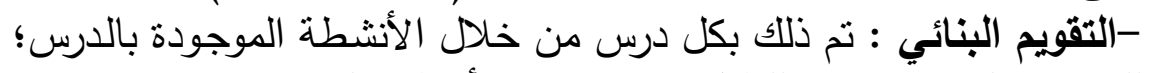

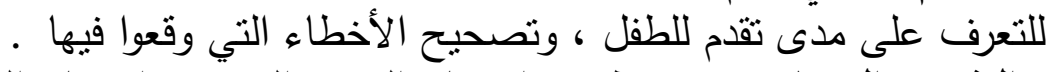

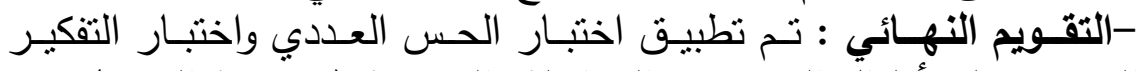
البصري على أطفال المجوعتين الضابطة والتجريبية (مجموعة البحث). 
צ-إعداد الصورة الأولية لأوراق عمل الطقل:

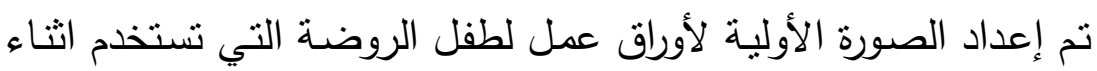

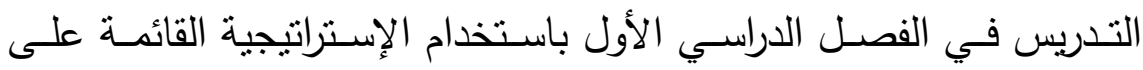

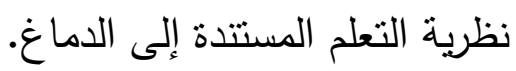
V - إعداد الصورة الأولية لدليل المعلمة:

تم إعداد دليل المعلمة لتسترشد بـه المعلمة عند التدريس للفصل الدراسي

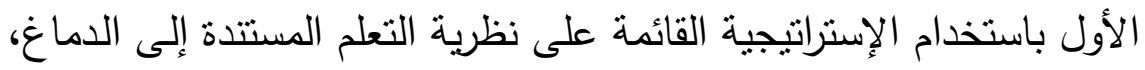

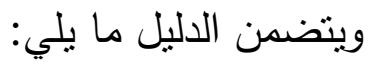
-مقدمـة عن نظريـة التعلم المستتدة إلى الدماغ من حيث تعريفها وأهمية استخدامها.

-خطوات استخدام الإستراتيجية القائمسة نظرية التعلم المستتدة إلى الدماغ

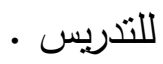
- أهداف تدريس موضوعات البحث المتضمنة بهذا الدليل .

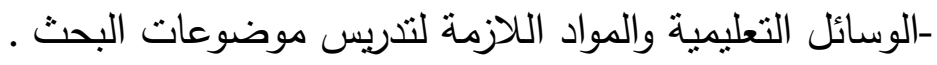
-كيفية تدريس كل درس من موضوعات البحث وفقا للإستراتيجية القائمة

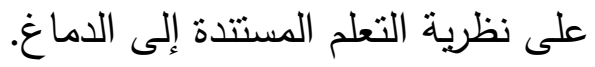

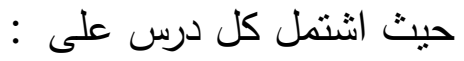

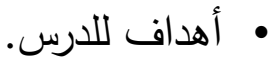
• الوسائل والمواد المستخدمة.

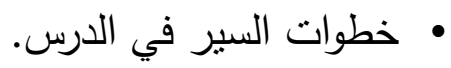

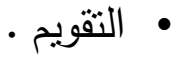


1- الصورة النهائية لاليل المعلمة وأوراق العمل :

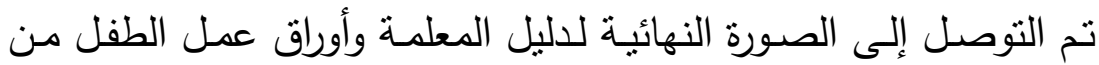

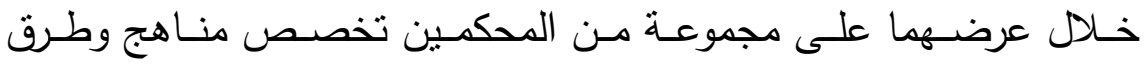
التدريس؛ وذلك للتعـرف على آرائهم وملاحظــاتهم حـول : مـدى مناسـبة الأهداف السلوكية لكل درس ،ارتباط الأهداف بالمحتوى،مناستبـة الوسيائل

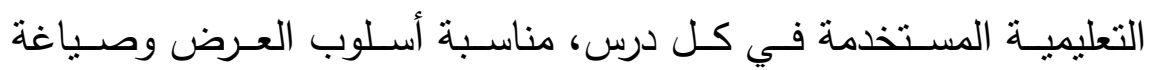

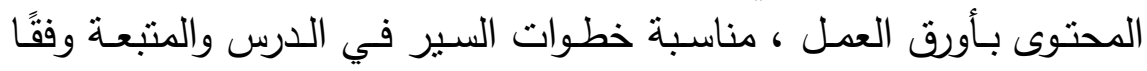

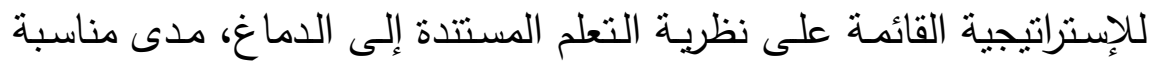
أساليب التقويم المتبعة.

وقد أثنار السادة المحكمون إلى إعادة صباغة بعض الأهداف السلوكية ،

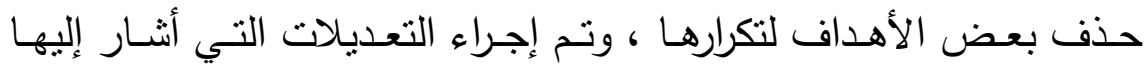

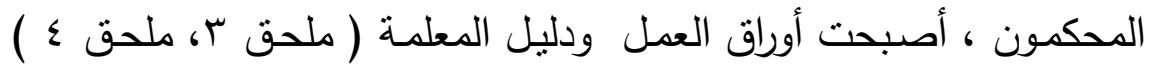
قابلين للتطبيق على أطفال الروضة أراف العمل ودموعة البحث التجريبية) . رابعاً:اختيار عينة البحث وتقتيمها إلى مجموعتين : تم اختيار عينة البحث من أطفال بروضـة مدرسـة أبناء الثورة الابتدائية

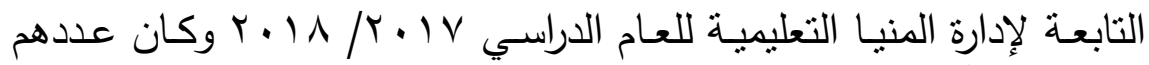
(7 (7) طفلاً وطفلةً وتم تقسيمهم إلى مجموعتين:

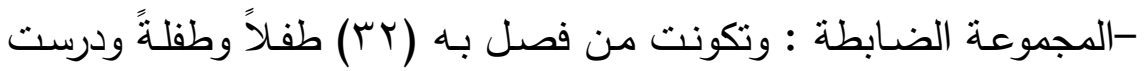
بالطريقة المعتادة. - المجموعة التجريبية: وتكونت من فصل بـه (ع بـ) طفلاً وطفلةً ودرست باستخدام الإستراتيجية القائمة على نظرية التعلم المستندة إلى الدماغ فله 
وتم ضبط المتغيرات الآتية التي يحتمل أن تؤثر على نتائج البحث وذلك

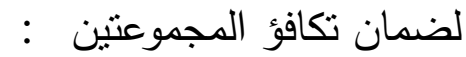

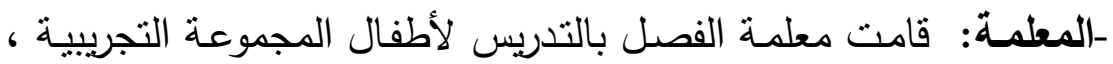

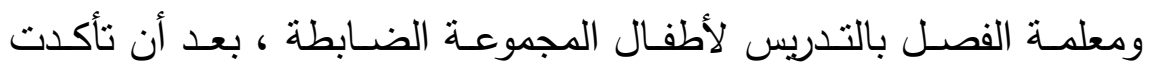

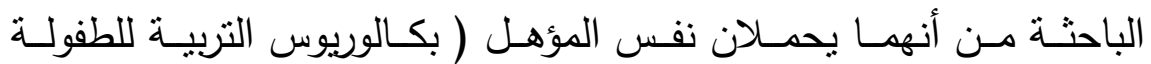

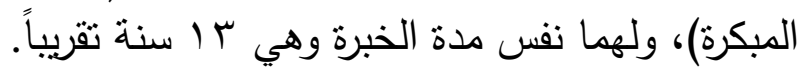

-مهارات الحس العددي السـابقة: للتأكد من تكافؤ المجموعتين من حيث

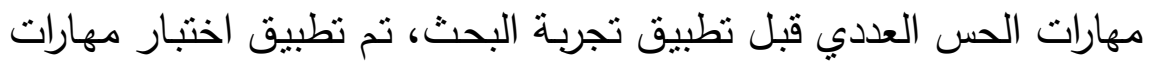

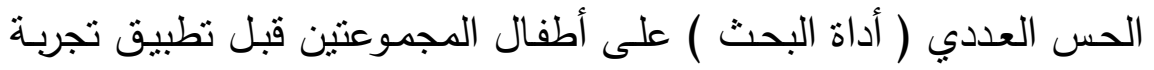

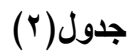
البحث، والجدول التالي يوضتح ذلك.

يوضح دلالة الفرق بين متوسطي درجات أطفال المجموعتين الضابطة والتجريبية في التطبيق

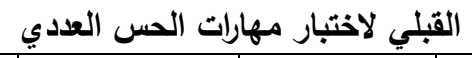

\begin{tabular}{|c|c|c|c|c|c|}
\hline دلالة & 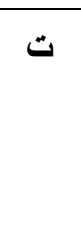 & الانحراف & المتوسط & عدد الأطفال & البيان \\
\hline \multirow[t]{2}{*}{ غير } & \multirow[t]{2}{*}{ r } & דוד, & $1, \wedge V$ & r & الضابطة \\
\hline & & , & $1, V \varepsilon$ & $\Gamma \varepsilon$ & التجمروعة \\
\hline
\end{tabular}

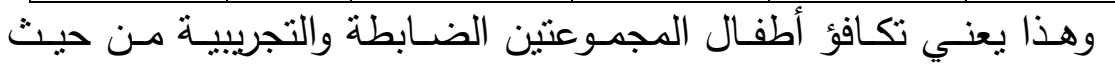
مهارات الحس العددي قبل إجراء تجربة البحث. 


\section{التفكير البصري السابق: - الت}

للتأكد من تكافؤ المجموعتين من حيث التفكير البصري قبل تطبيق تجربة

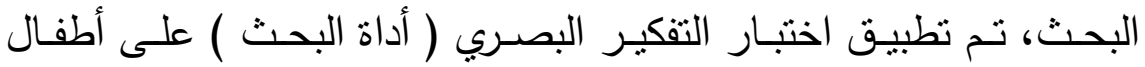
المجموعتين قبل تطبيق تجربة البحث، وجدول (r) يوضح ذلتك.

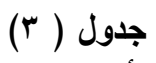

يوضح دلالة الفرق بين متوسطي درجات أطفال المجموعتين الضابطة والتجريبية في التطبيق التبري

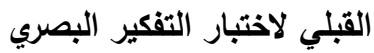

\begin{tabular}{|c|c|c|c|c|c|}
\hline دلالة & $ت$ & الانحراف & المتوسط & علد الأطفال & البيان \\
\hline غير & , rV &, $0 \leqslant$ & $r, 79$ & Tr & المجموعة الضابطة \\
\hline دالة ل & & ,95 & r, & $r \varepsilon$ & المجموعة التجريبية \\
\hline
\end{tabular}

وهذا يعني تكـافؤ أطفـال المجمـوعتين الضـابطة والتجريبيـة مـن حيـ إثبـ التفكير البصري قبل إجراء تجربة البحث. خامساً: تطبيق تجرية البحث:

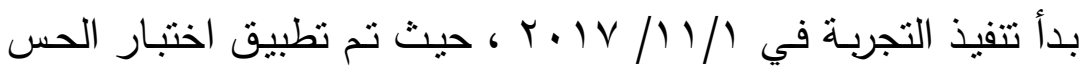

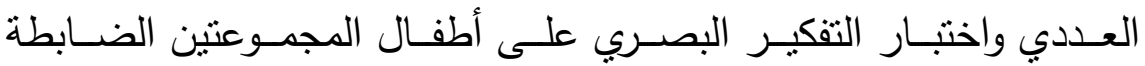

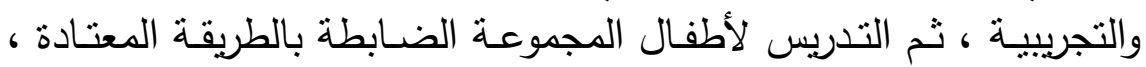

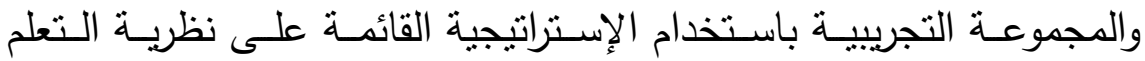

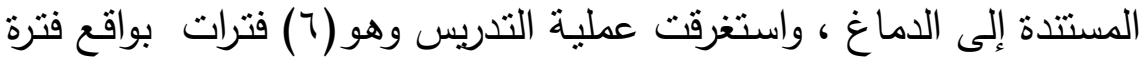




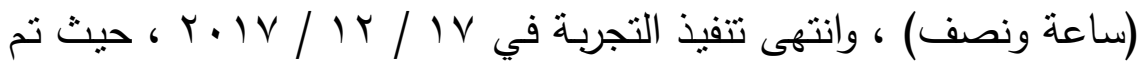
إعادة تطبيق اختبار الحس العددي واختبار التفكير البصري على التهى أطفال المجموعتين الضابطة والتجريبية.

\section{نتائج البحث وتحليلها وتفسيرها :}

أولاً: نتائج تطبيق اختبار مهارات الحس العددي:

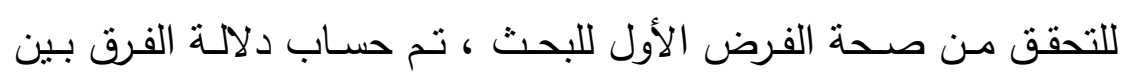

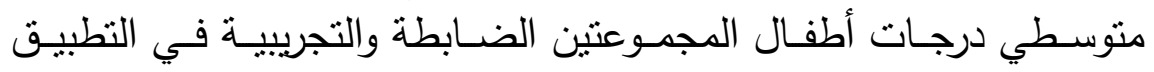

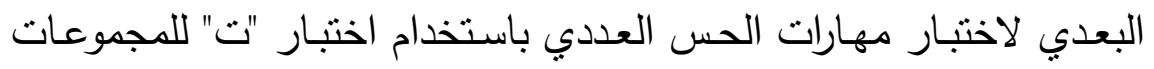

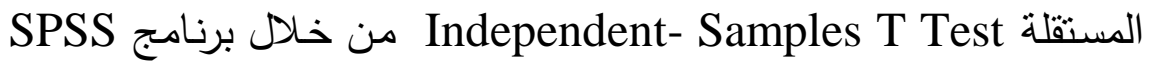

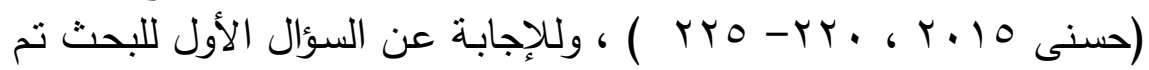

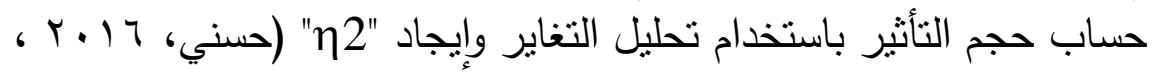

$$
\text { ص صو r ) . }
$$

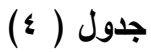

دلالة الفرق بين متوسطي درجات أطفال المجموعتين الضابطة والتجريبية في التطبيق البعدي لاختبار مهارات الحس العدادي الضعابطي

\begin{tabular}{|c|c|c|c|c|c|c|c|}
\hline $\begin{array}{l}\text { دلالة } \\
\eta 2\end{array}$ & $\eta 2$ & دلالة & 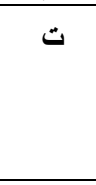 & $\begin{array}{c}\text { المعياري } \\
\text { المراف } \\
\text { المعاف }\end{array}$ & المتوسط & |لأطفال & البيان \\
\hline \multirow[t]{2}{*}{ كبير } & \multirow[t]{2}{*}{ r } & \multirow{2}{*}{ دالة دمنوى } & \multirow[t]{2}{*}{$r \varepsilon, T$} & $1,7 V$ & $0,1 V$ & Tr & الضابطة \\
\hline & & & & $1,0 \mathrm{~V}$ & $1 \varepsilon, q \vee$ & $r \varepsilon$ & التجريبية \\
\hline
\end{tabular}




\section{من جدول (ع) يتبين لنا أن:}

-الفرق بين متوسطي درجات أطفال المجموعتين الضـابطة والتجريبية في

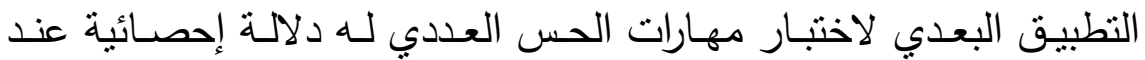

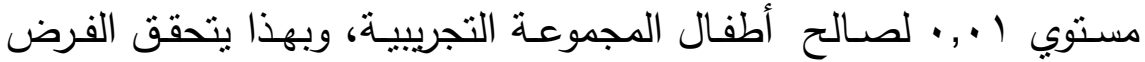
الأول للبحث ، وهذا يـدل على ارتفاع مسـتوى أطفال المجموعـة التجريبيـة

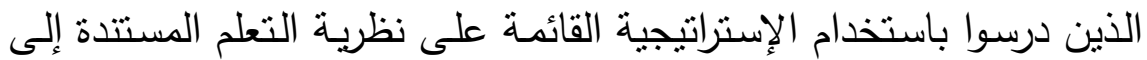
الدماغ في مهارات الحس العددي عن مستوى نظرائهم أطفال المجموعـة الضابطة الذين درسوا بالطريقة المعتادة . -حجم التـأثير للمتغيـر المسـتقل (الإسـتراتيجية القائمسة على نظريـة التعلم

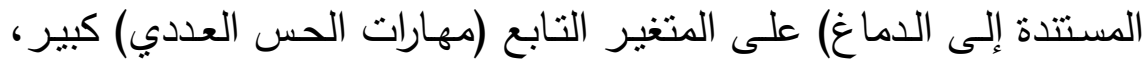
وهذا يـدل على فاعليـة اسـتخدام الإسـتراتيجية القائمسة على نظريـة التعلم المستتدة إلى الدماغ في تتمية مهارات الحس العددي لدى أطفال الروضـة ،

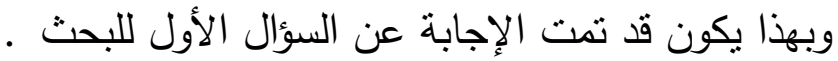

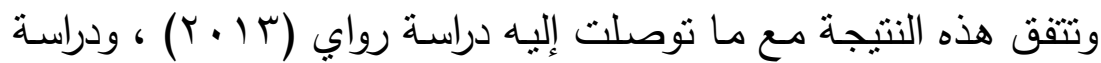

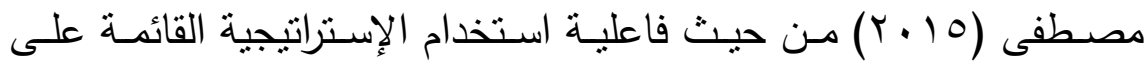
نظرية التعلم المستتدة إلى الدماغ في التدريس . وارتفـاع مسـتوى أطفـال المجموعـة التجريبيـة الـذين درسـوا باسـتخدام

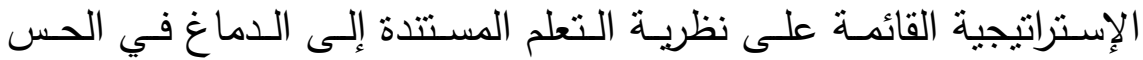
العـددي عـن مسـتوى نظـرائهم أطفـال المجموعـة الضـابطة الـذين درسـوا بالطربقة المعتادة، يرجع إلى : عادئ - طبيعة الإستراتيجية القائمة على نظرية التعلم المستندة إلى الدماغ إنى ، التي

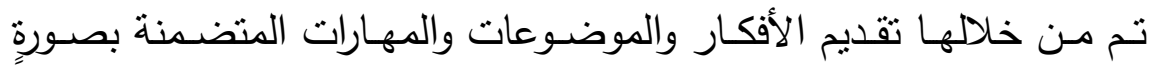
منظمة. 
- استخدام الإستراتيجية القائمة على نظرية التعلم المستتدة إلى الدماغ إتاحة

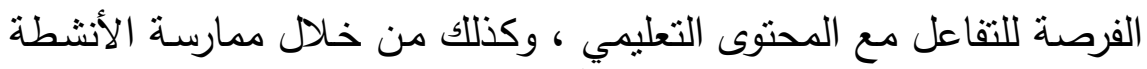

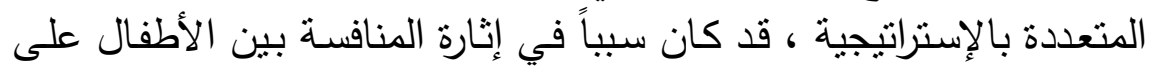

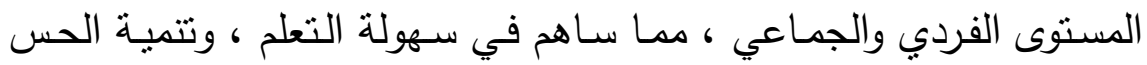
العددي.

-دور الوسيط الذي قامت بـه المعلمة في الإستراتيجية القائمة على نظرية

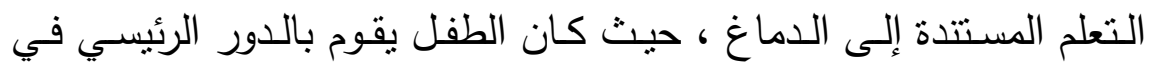
الخبرات التعليمية والوسائل التي تمكنه من إنجاز المهام واحراز النجاحات ، التهات التهات

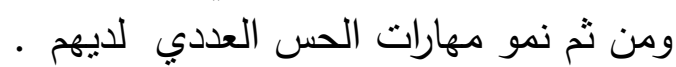
-التقويم المستمر قبـل وأثتـاء وبعد التدريس باستخدام الإسـتراتيجية وتقديم التغذية الراجعة المستمرة للأطفال. ثانياً: نتائج تطبيق اختبار التفكير البصري:

للتحقق من صـحة الفرض الأول للبحث ، تم حسـاب دلالـة الفرق بين

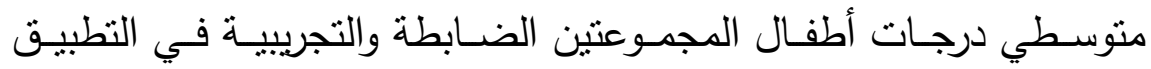

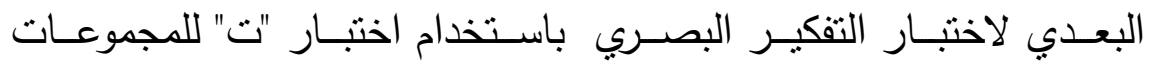

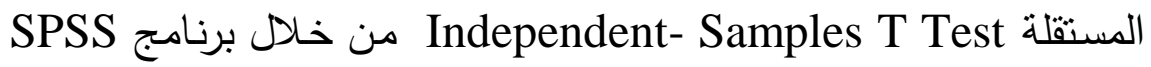

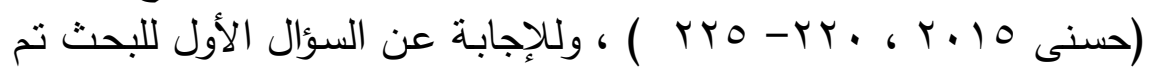

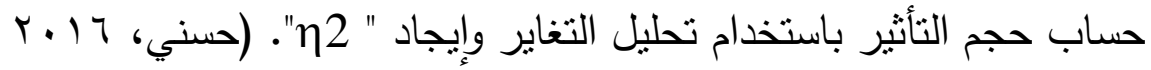

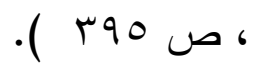




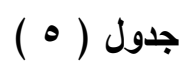

دلالة الفرق بين متوسطي درجات أطفال المجموعتين الضابطة والتجريبية في التطبيق

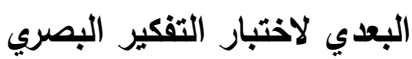

\begin{tabular}{|c|c|c|c|c|c|c|c|}
\hline دلالة & $\eta^{2}$ & دلالة & ت & الانحراف & المتوسط & |لأطفال & البيان \\
\hline \multirow[t]{2}{*}{ كبير } & \multirow[t]{2}{*}{,$\wedge \varepsilon$} & \multirow{2}{*}{ دالة عند } & \multirow[t]{2}{*}{$r 9,79$} & , & $7, .9$ & rr & المجموعة الضابطة \\
\hline & & & & r,IV & $r r, r q$ & $r \varepsilon$ & التجريبية \\
\hline
\end{tabular}

-الفرق بين متوسطي درجات أطفال المجموعتين الضـابطة والتجريبية في

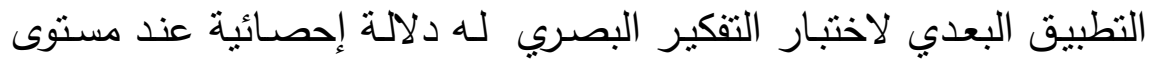

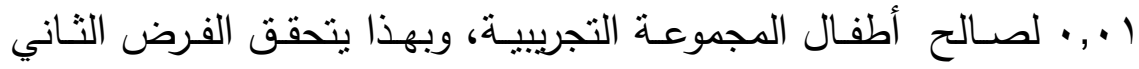

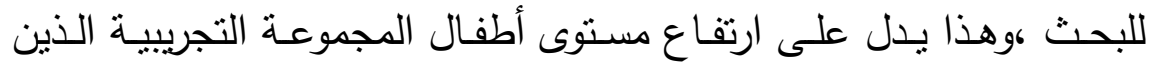

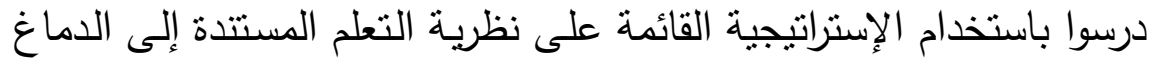

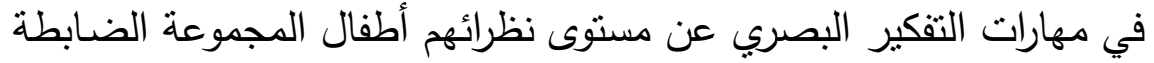

$$
\text { الذين درسوا بالطريقة المعتادة . }
$$

-حجم التأثثر للمتغير المستقل (الإسـتراتيجية القائمسة على نظريـة التعلم

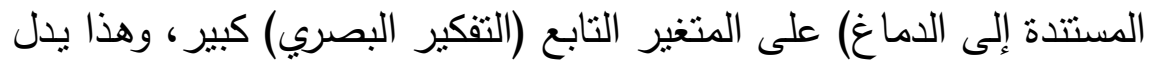

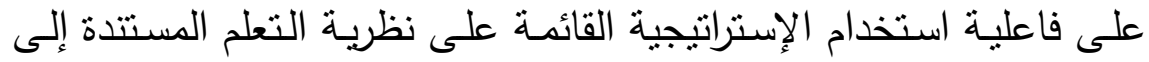

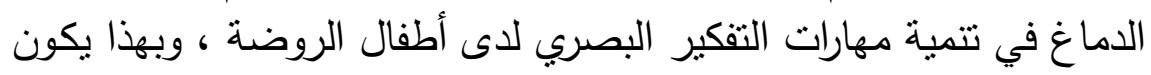

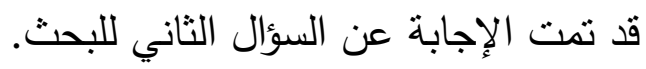




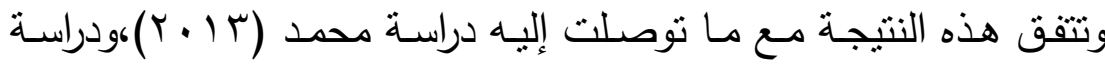

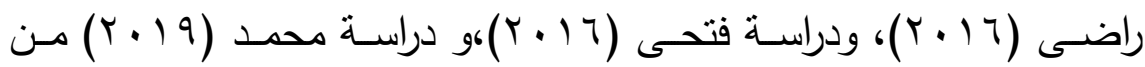

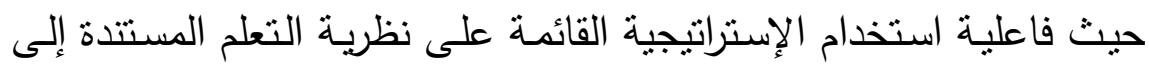

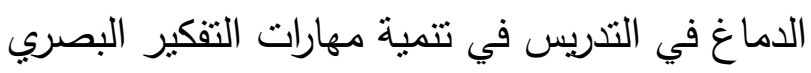

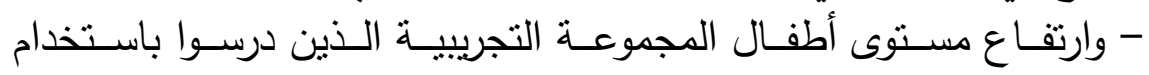

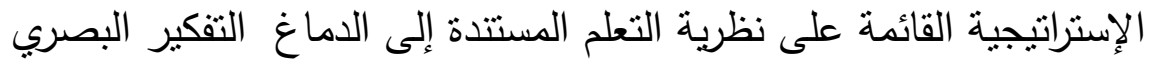

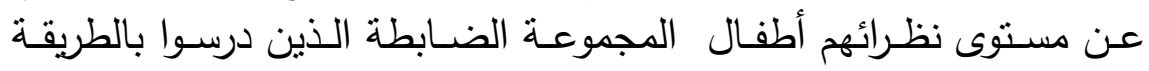

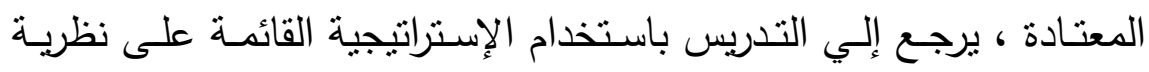

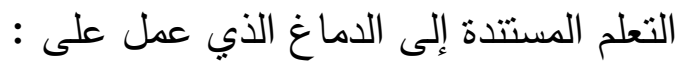

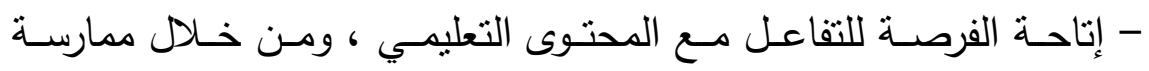
الأنشطة المتعددة بالإستراتيجية عمل على إكساب الأطفال الفيل مجموعة البحث

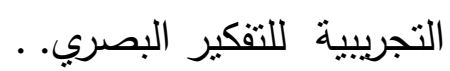
-استخدام الصور والرسوم التوضيحية وتركيز المعلمة على إكساب المعرفة

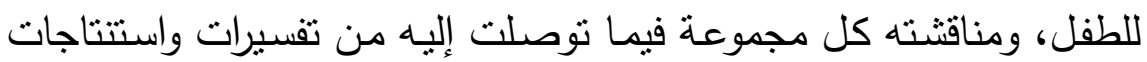

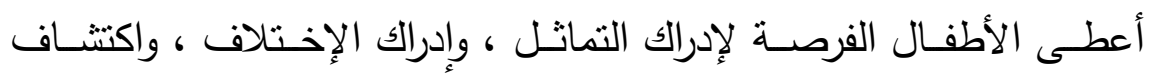

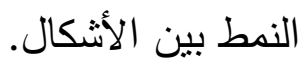
توصيات البحث:

في ضوء نتائج البحث الحالي يمكن تقديم التوصيات التالية:

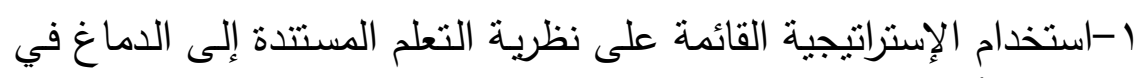

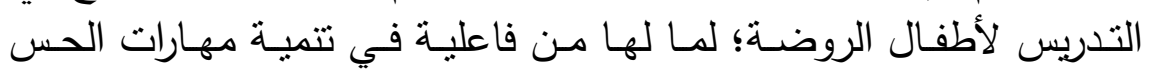

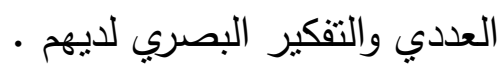


r- تـدريب الطالبـات المعلمـة بكليـة التربيـة للطفولـة المبكرة على استخدام الإستراتيجية القائمة على نظرية التعلم المستتدة إلى الدماغ في في التدريس.

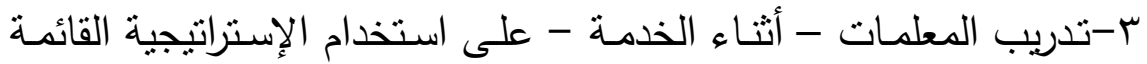
على نظرية التعلم المستتدة إلى الدماغ في التدريس .

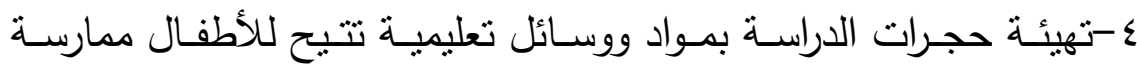

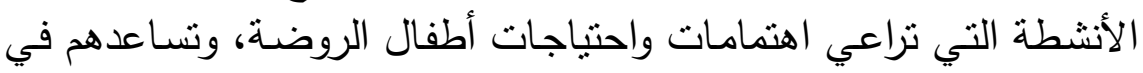
تتمية مهارات الحس العددي والتفكير البصري الدئي لديهم. البحوث المقترحة: - اته

في ضوء نتائج البحث يمكن اقتراح البحوث التالية:

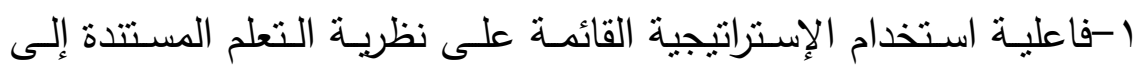

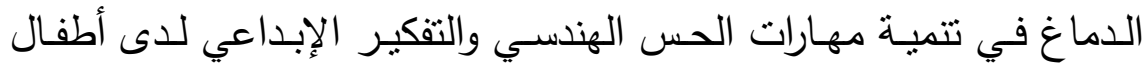

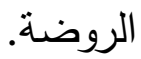
ץ-المقارنة بين أثز استخدام الإستراتيجية القائمة على نظرية التعلم المستتدة

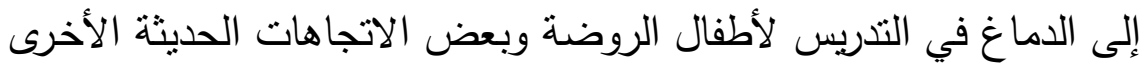

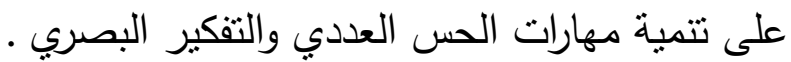

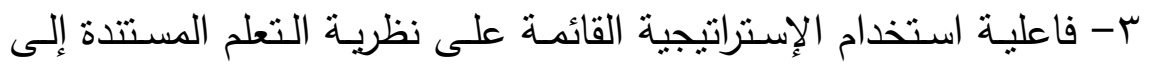

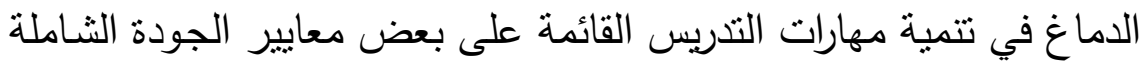
لاى معلمات أطفال الروضة. 


\section{المراجح?}

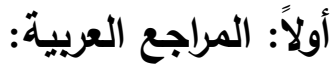

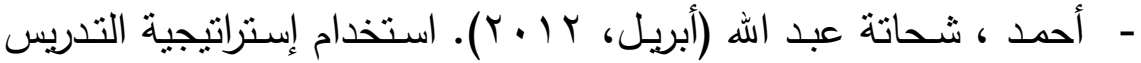

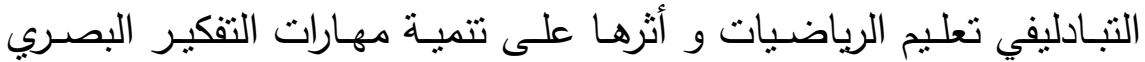

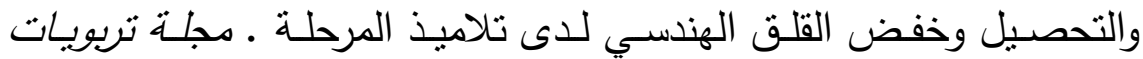
الرياضيات. الجمعية المصرية لتربويات الرياضيات ، كلية التربية ، جامعة لرية

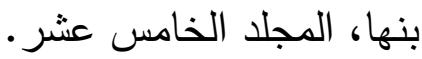

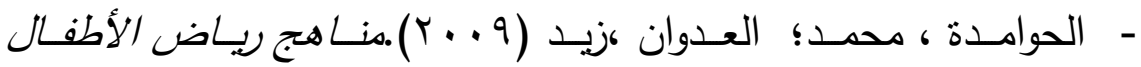

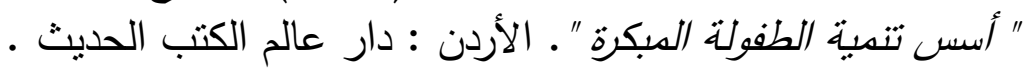

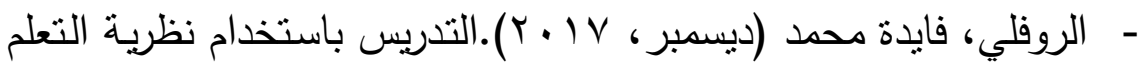

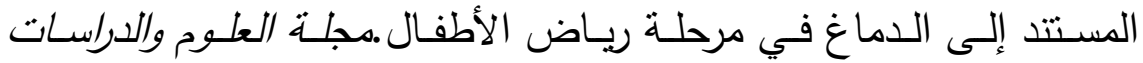

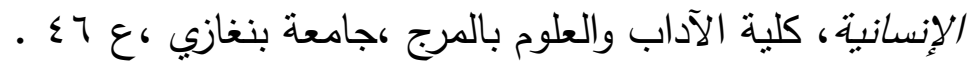

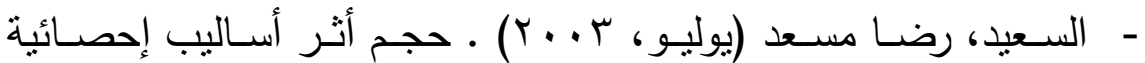

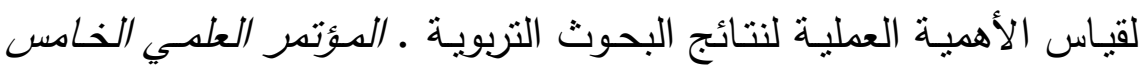

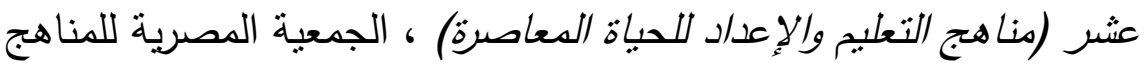

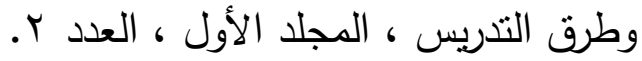

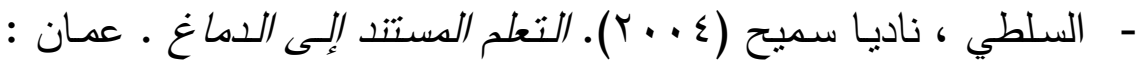
دار الميسرة للنشر والتوزيع الطباعة.

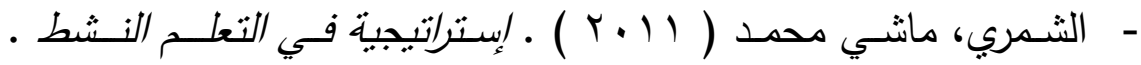

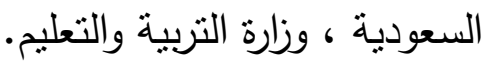

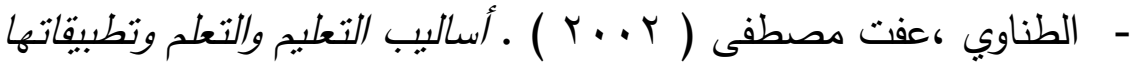

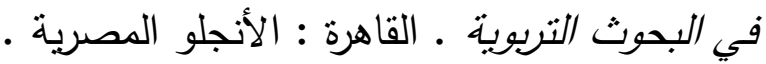




\section{المجلة العلمية لكلية رياض الأطفال - جامعة بورسعيد}

- المنوفي، سعيد جابر ( ( . . ب).الحس العددي وبعض المتغيرات المرتبطة

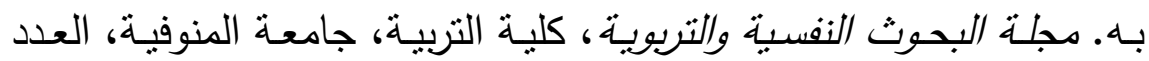

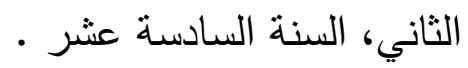

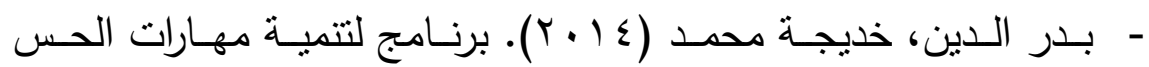
العددي لدى الأطفال ذوي صعوبات التعلم في مرحلة ماقبل المدرسة.المجلة

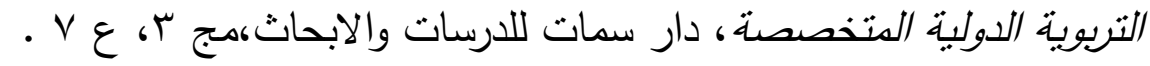

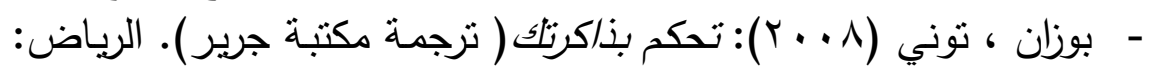
مكتبة جرير •

- جينسن، أيربك (9 r). التعلم المبني على العقل (ترجمة مكتبة جرير).

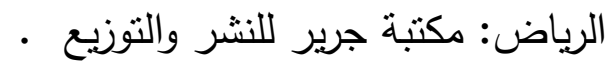

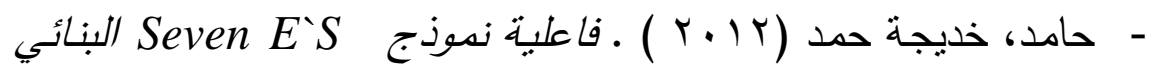

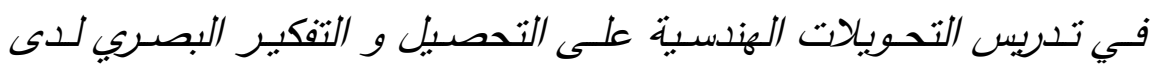

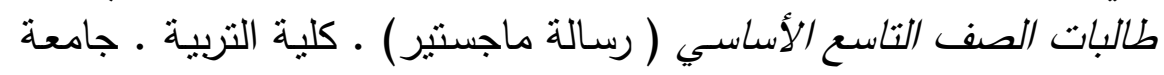
السلطان قابوس • سلطنة عمان. - مسني ، محمد ربيع (10 ( م) : الإحصاء والتحلبل الإحصائي باستخدام • SPSS حسني ، محمد ربيع (T ( • Y). الإحصاء والتحلبل الإحصائي باستخدام

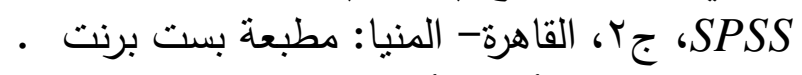

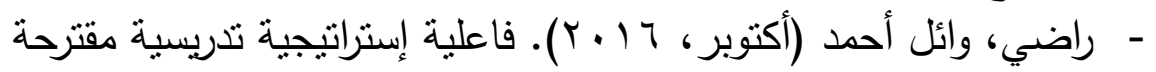

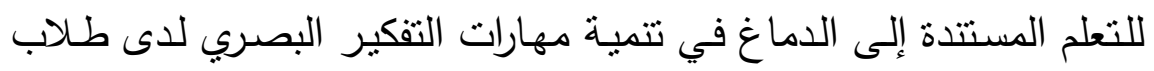

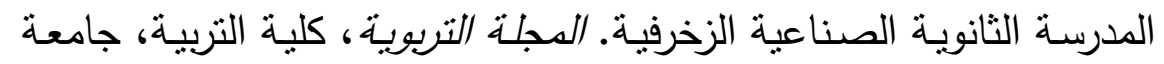

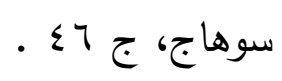

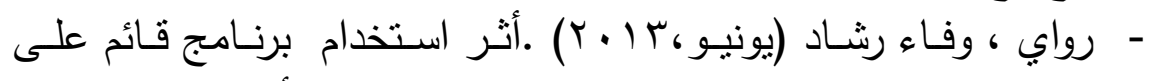

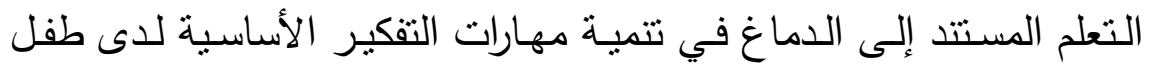


الروضـة. دراسات عربية في التربية وعلم النفس،رابطة التربويين العرب،ع

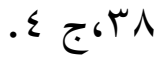

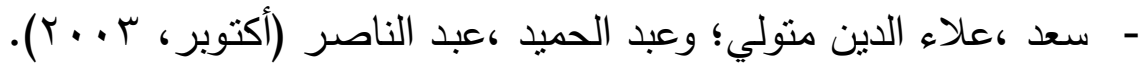

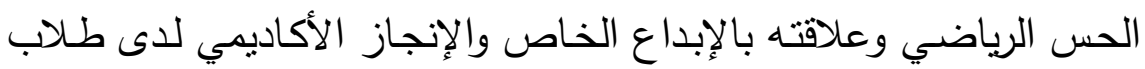

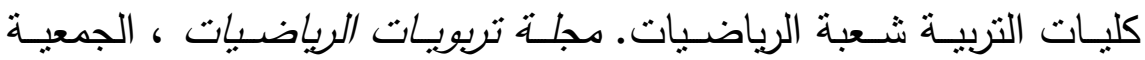

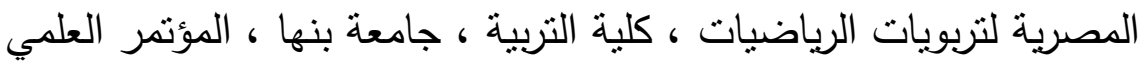
- شحاتة ،حسن ؛ والنجار ، زينب (r . . ץ). معجم الدصطلحات التربوية

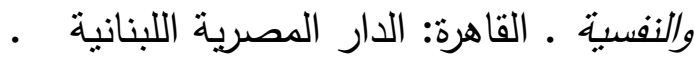

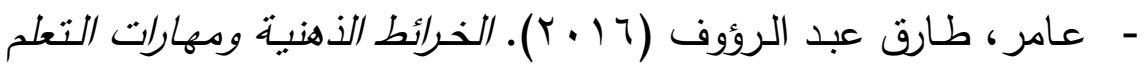
طربقك إلى بناء الأفكار الذكبة ( الطبعة الثانية). القاهرة: المجموعة العربية

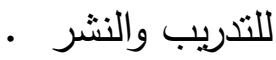

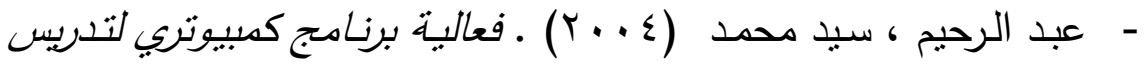

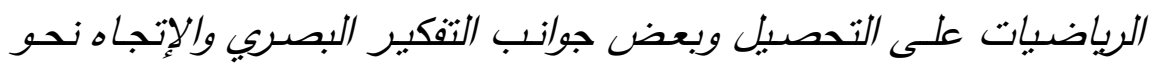

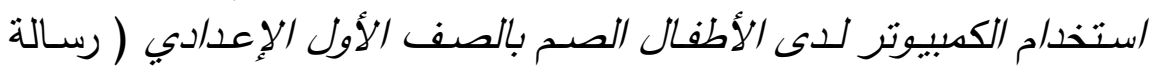

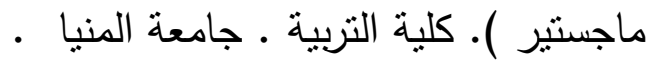

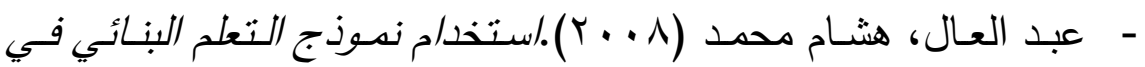

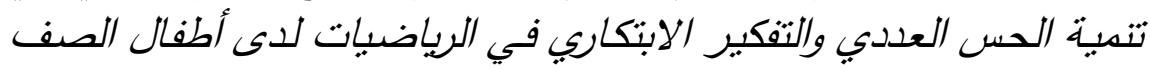

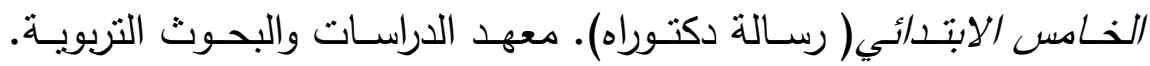
جامعة القاهرة .

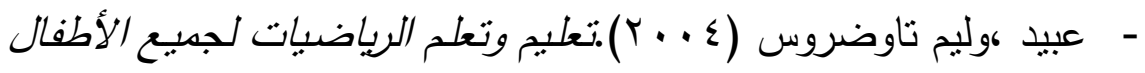

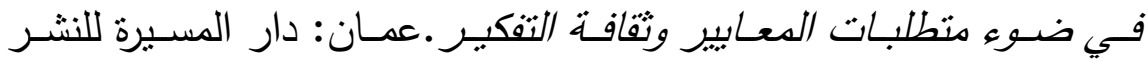

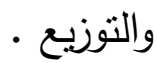




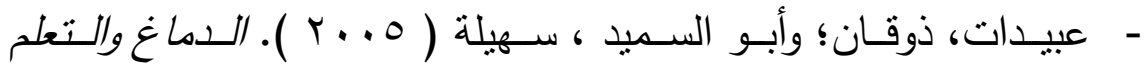
والتفكبر • عمان : ديبونو للطباعة والنشر والتوزيع.

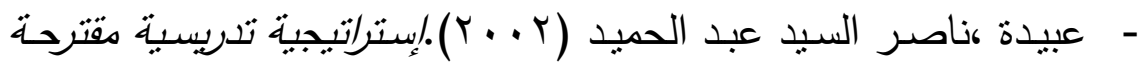
لتنمبية الحس العددي وأثرها على الأداء الحسابي لأطفال الصف الخامس الابتدائسي( رسالة ماجستير) . كلية التربية. جامعة المنوفية.

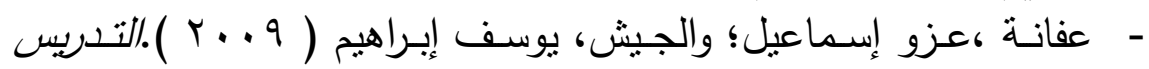
والتعلم بالدماغ زي الجانبين . عمان :دار التقافة للنشر والتوزيع.

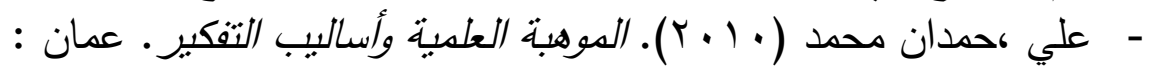
ديبونو للطباعة والنشر والتوزيع.

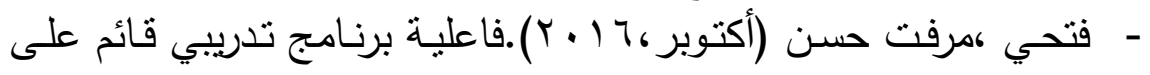

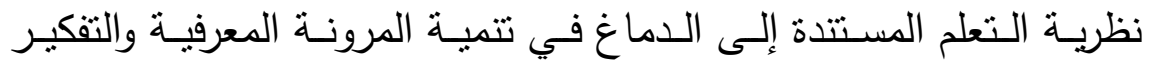

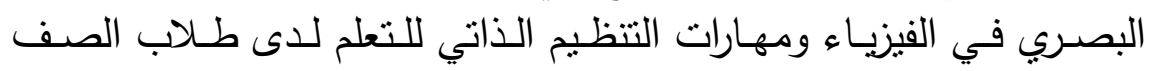
الأول الثانوي • دراسات تربوبة واجتماعبة ،كلية التربية ، جامعة حلوان ،مج . $\varepsilon$ \&

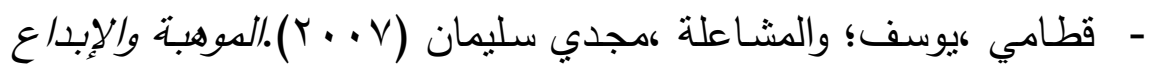

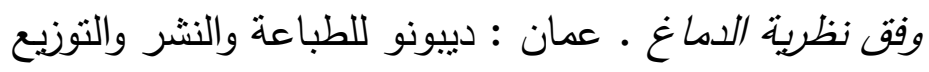

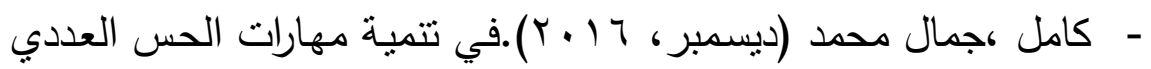
لدى طفل الروضـة في ضوء برنامج قائم على أسلوب التلعيب. مجلة كلبة التية رياض الأطفال ، كلية رياض الأطفال، جامعة بورسعيد،ع م 1 ـ

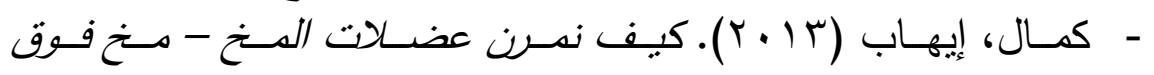
العادة.القاهرة: دار الخلود للنشر والتوزيع.

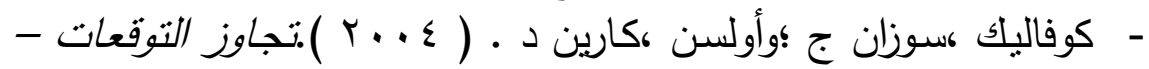
دلبل المعلم لتطبيق أبحاث الدماغ في غرفة الصف ، الكتاب الأول، رجمة (مدارس الظهران الأهلية) ، الرياض : دار الكتاب التربوي للنشر والتوزيع. 


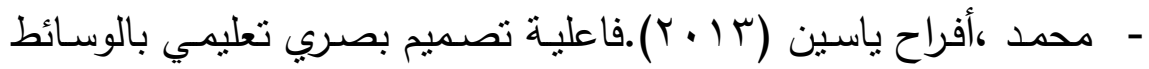

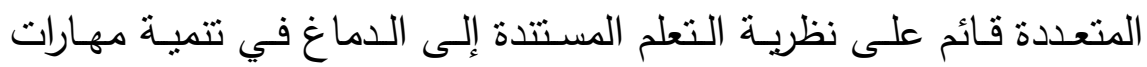
التفكير البصري في مادة التقنيات التربوية ـ مجلة العلوم التربوبية والنفسية ،

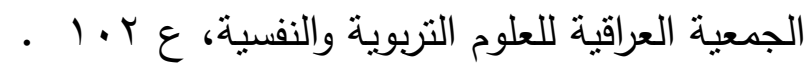

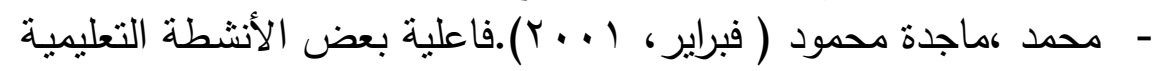

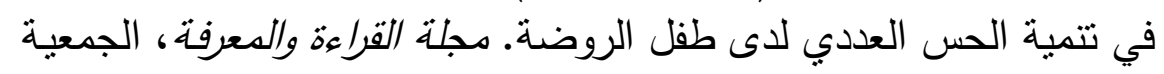

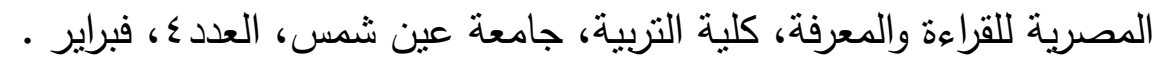

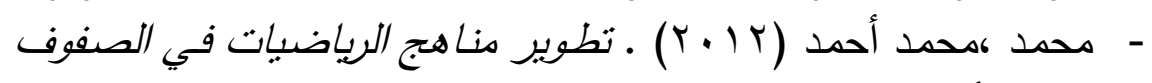
ف - - V في تعلبم الرباضيات و تعلمها (رسالة دكتوراه). كلية التربية ـ جامعة عين

- محمد ،مديحة حسن (فبراير ، ع . . ب) • برنـامج مقترح في الرباضبيات

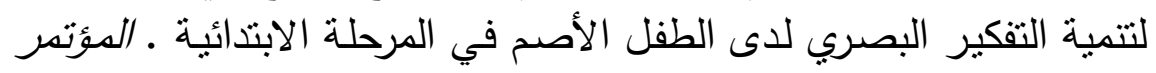
العلدسي السـنوي (الرباضـيات المدسبية : معـابير ومسـتوبات) ، الجمعيـة

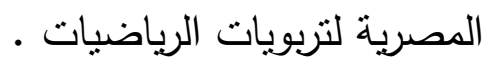

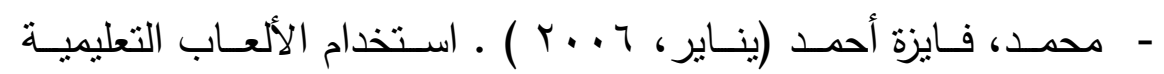
بالكمبيوتر لتتمية التحصيل و التفكير البصري في الرياضيات لدى أطفال المرحلة الابتدائية ـ المجلة التربوبية ، كلية التربية ، جامعة سوهاج ، العدد

- محمد، نيفين محمد (ديسمبر ، 9 1 ـ ب).أثر استخدام إستراتيجية التعلم المستتدة إلى الدماغ في تتمية مهارات التفكير البصري والمفاهيم الجغرافية

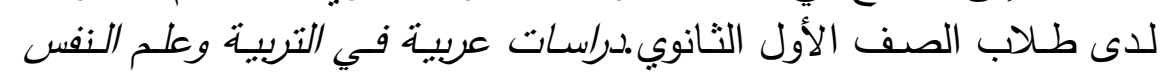

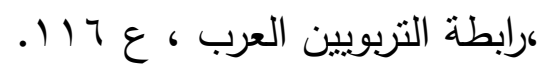




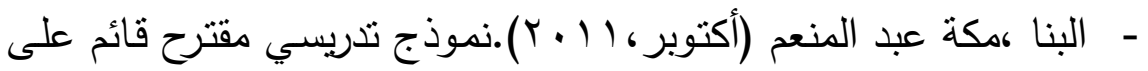

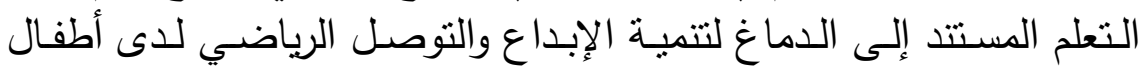

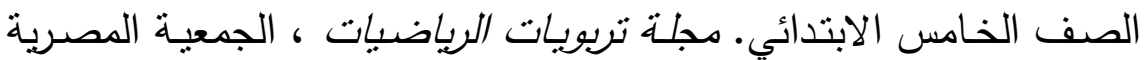

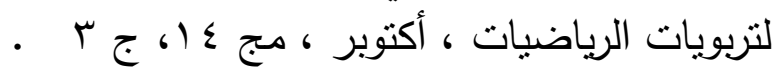

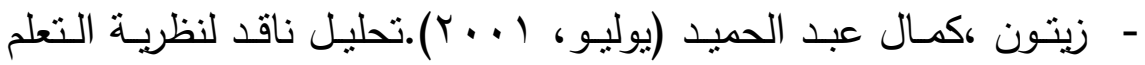

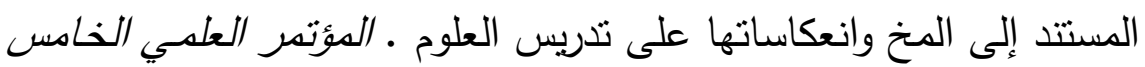

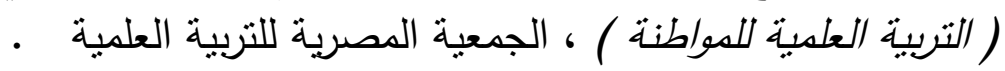

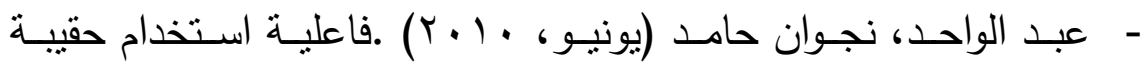

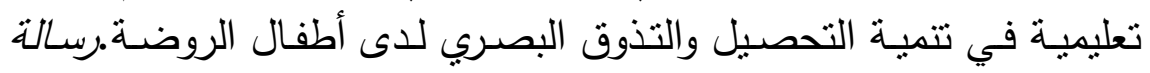

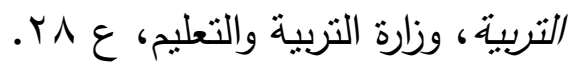

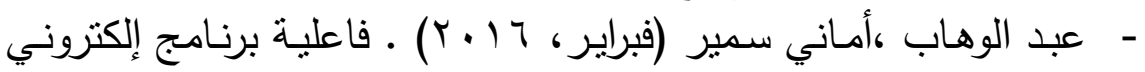

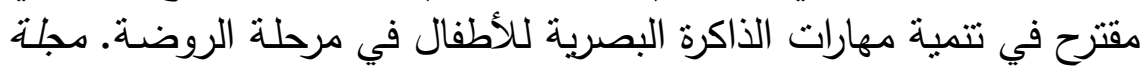

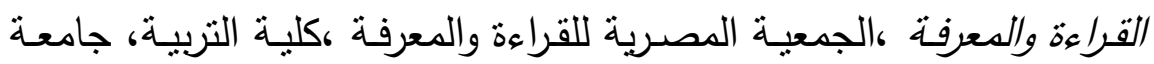

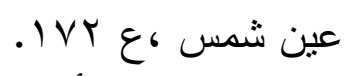

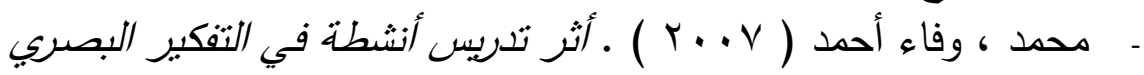

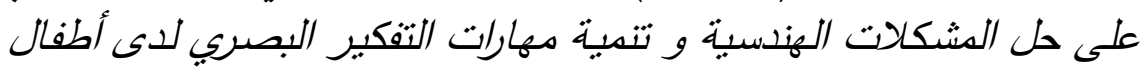

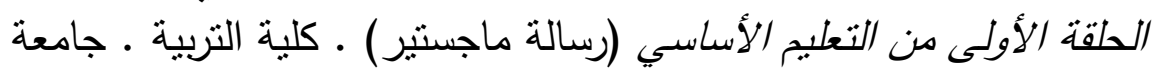

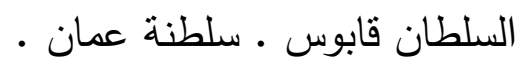
-مصطفى ،هيام صلاح (10 م ب) أثر التعلم الدستند إلى الدماغ في تطوبير طلاقة الأفكار لدى أطفال الروضة (رسالة ماجستير ) .كلية الدراسات العليا.

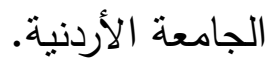




\section{ثانياً: المراجع الأجنبية :}

- Caine, R.N. \& Caine, G.(1991):Making Connection : Teaching and Brain, Alexandria, VA: ASCD.

- Connell ,J (2009):The Global Aspects of Brain Based Learning , ERIC:EJ868336.

- Gay, S. \& Aichele, D.(1997): Middle School Student's Understanding of Number Sense Related to Percent, School Science and Mathematics, Vol. 97,No1,. - Jensen , E.,(2002):Brain - Based Learning , Academic Press Inc. Alexandria, Virginia.

- Kaminiski,B.,(2003): Promoting Pre-Service Teacher Education Students' reflective practice in Mathematics, Asia pacific of teacher Education. Vol 31. No. 1.

- National Council for Accreditation of Teacher Education(2000) :"Performance - based Accreditation Standards", from : Available online at :http://www.ncate.org

- -Politano,C \& Paquin,(2000):"Brain - Based Learning with Class ." Winnipeg ; portage \& Main press.

- -Reys, R.E. \& Yang, D. C,( 1998): "Relationship between computational performance and number sense among sixth and eight grade students in Taiwan", Journal for Research in mathematics Education, Vol.26,No 2. 
- -Sousa,D.(2006) :How the Brain Learning :a classroom Teacher's Guide .(2nd Ed.). Thousand Oaks ,CA: Crown Press, Inc .

- -Yang, D.C. , Lin, E. \& Neng, M., ,( 2007):"A study of the performance of 5 th grade in number sense and its relationship to achievement in mathematics, International Journal of Science and Mathematics Education., Vol .99,No 3. 

فاعلية برنامج قائم على مدخل ريجيو إميليا في تنمية عملية التصنيف للمعاقين ذهنياً المدمجين برياض الأطفال

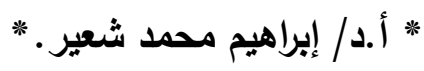

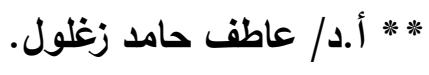

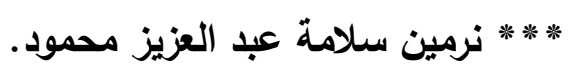

\section{ملخص البحث :}

يهدف البحث إلى الكثف عن فاعلية برنامج قائم على مدخل ريجيو

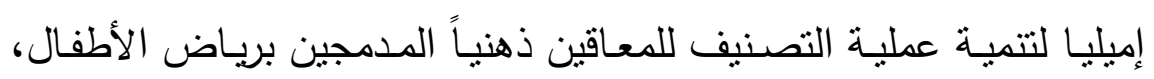

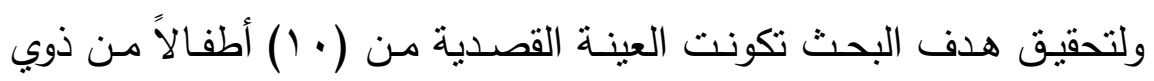
الإعاقة الذهنية المدمجين بروضـات محافظة بورسعيد من خلال ( اختبار

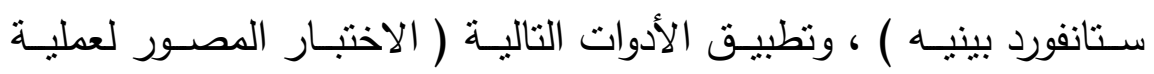

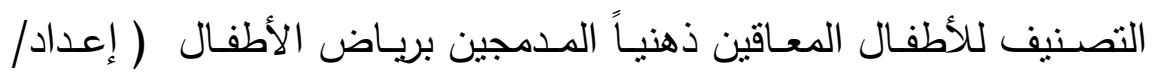
الباحثة ) ، برنامج أنشطة لتتمية عملية التصنيف للأطفال المعاقين ذهنياً

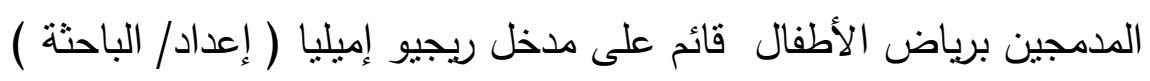

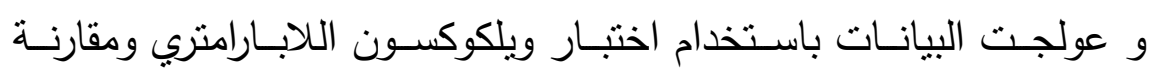

" أستاذ المناهج وطرق التدريس-كلية التربية- جامعة المنصورة.

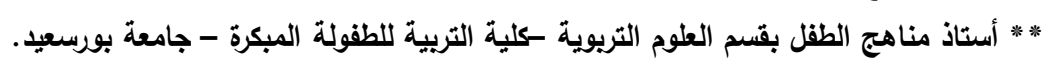

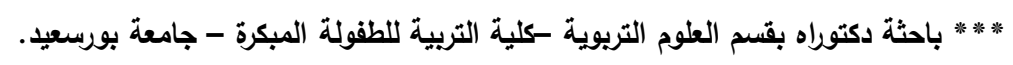


متوسطي رتب درجات الأطفال بين التطبيقين القبلي والبعدي على الاختبار المصسور للتصـنيف ، وأظهرت النتائج فاعليـة البرنـامج القائم على مدخل

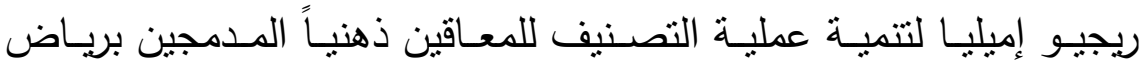

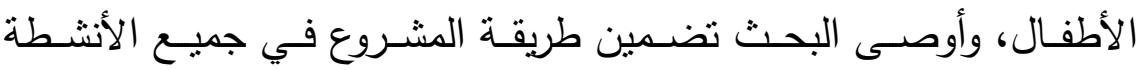
المقدمـة للطفل ذوي الإعاقـة الذهنيـة البسـيطة المـدمين بريـاض الأطفـال

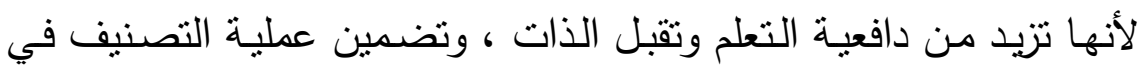
الأنشطة المقدمة للطفل ذوي الإعاقة الذهنية.

The effectiveness of a program based on the Reggio Emilia approach in developing the classification process for the mentally handicapped who are integrated into kindergarten

Prof.Dr/ Ibrahim Mohammed Shoair. *

Prof.Dr / Atef Hamed Zaghloul. **

Nermin Salama Abdel Aziz Mahmoud. ***

\section{Abstract:}

The research aims to reveal the effectiveness of a program based on the Reggio Emilia approach to developing the classification process for the mentally

* Professor of Curricula and Teaching Methods - Faculty of Education Mansoura University.

** Professor of Child Curriculum, Department of Educational Sciences, Faculty of Education Early Childhood - Port Said University. *** Researcher, Department of Educational Sciences - Faculty of Early Childhood Education - Port Said University. 
handicapped who are integrated into kindergartens, and to achieve the goal of the research, the intended sample consisted of (10) children with intellectual disabilities who were integrated into the kindergartens of Port Said Governorate through (the Stanford-Binet test), and the application of tools The following (illustrated test of the classification process for mentally handicapped children integrated into kindergarten (the researcher's preparation), a program of activities for developing the classification process for mentally handicapped children who are integrated into kindergartens based on the Reggio Emilia approach (the researcher's preparation) and the data were processed using the Wilcoxon non-parametric test and a comparison of the average grades of children The results showed the effectiveness of the program based on the Reggio Emilia entrance to the development of the classification process for the mentally handicapped who are integrated into kindergarten, and the research recommended that the project method be included in all activities provided to the child with mild intellectual disability integrated in kindergarten because it increases motivation Learning and self-acceptance, and including the classification process in the activities provided to the child with disabilities Mentality. 


\section{الكلمات المفتاحية Keywords:}

- مدخل ريجيو إميليا Entrance to the Reggio Emilia Classification process - عملية التصنيف

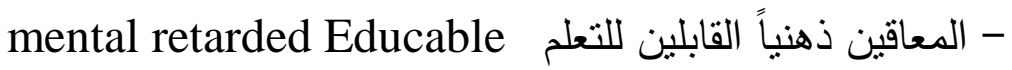

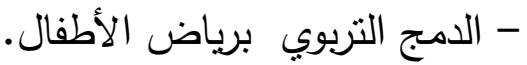
Educational Inclusion in kindergarten

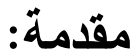

يعد الأطفال أمـل كل أمسة في التقدم و العنايسة بهـم و تقديم كافـة

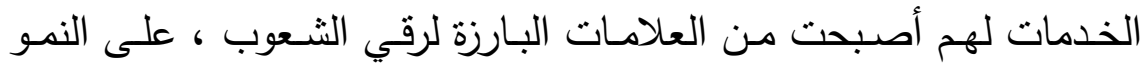

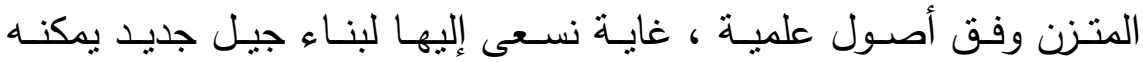
النهوض بالأمة و تحقيق آمالها.

ولمرحلة ريـاض الأطفال أهمية خاصـة بالنسبة للطفل ، فهي المرحلـة

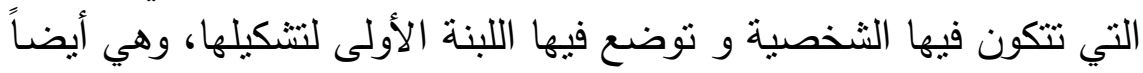

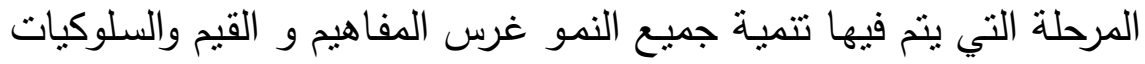

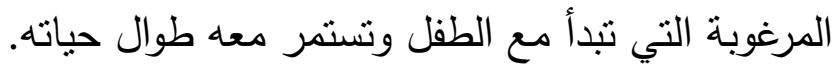

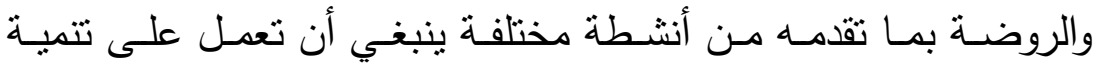

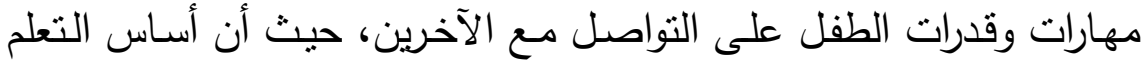

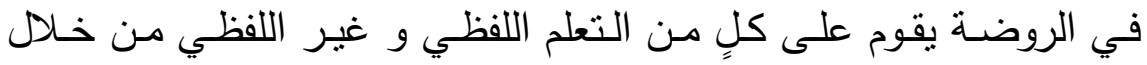

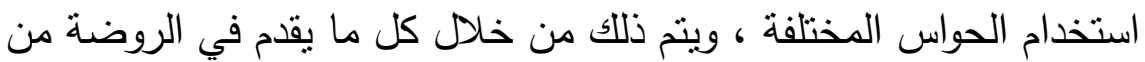

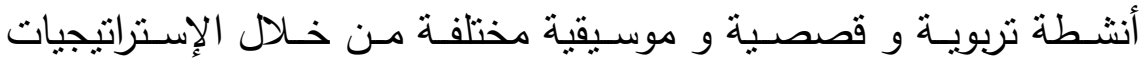

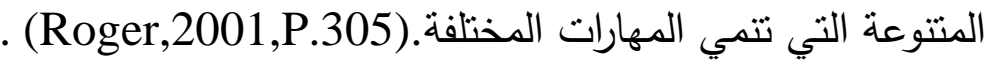


وهناك فئة من الأطفال بنبغي أن تحظى باهتماٍٍ خاصٍ نظراً لطبيعتها

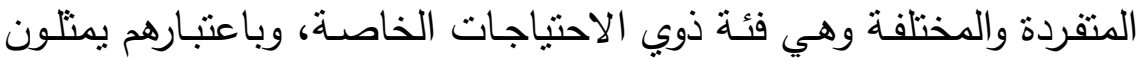

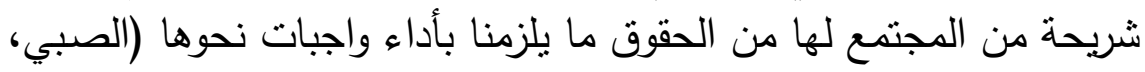

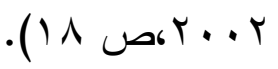

وقد أصبح الدمج من أهم الاتجاهات الحديثة في التربية الخاصـة، فهو

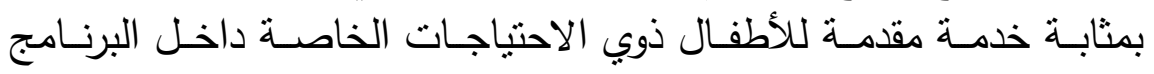

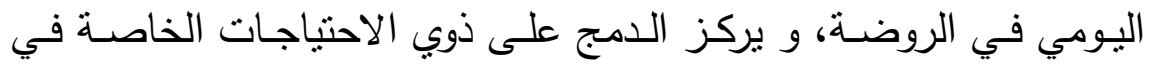

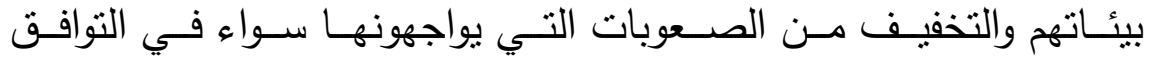

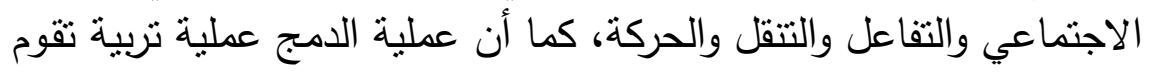

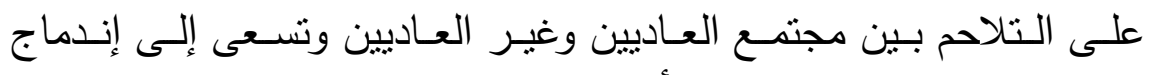

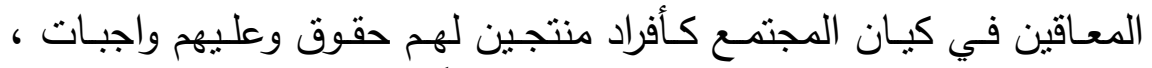

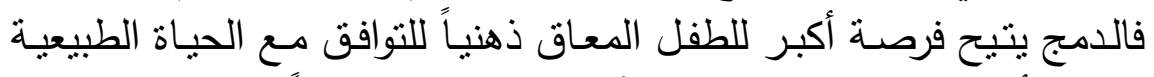

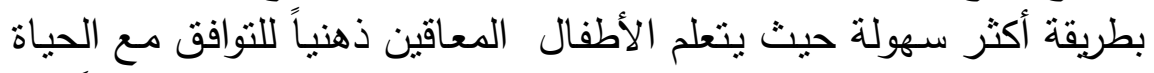

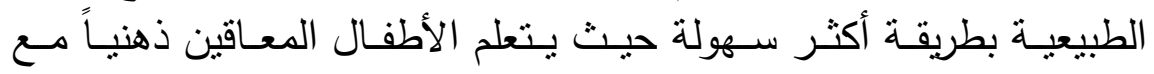

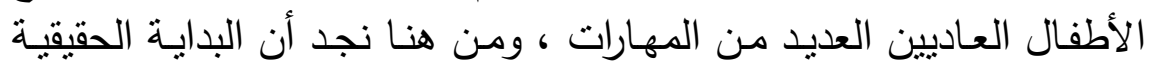
للطفل المعاق ذهنياً تكون في نظام الدمج الذي يفجر الدئ جميع الطاقات الكامنة لديه.

ومن جانبٍ آخر نجد أن الاهتمام بتربية وتعليم الأطفال المعاقين ذهنياً

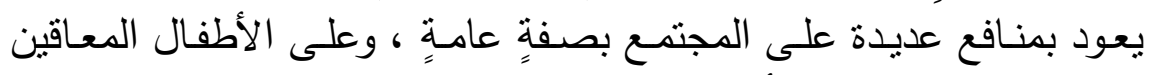

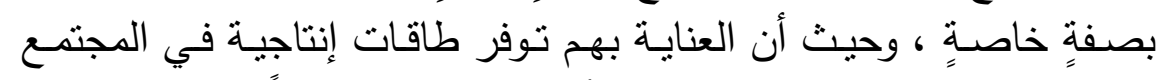

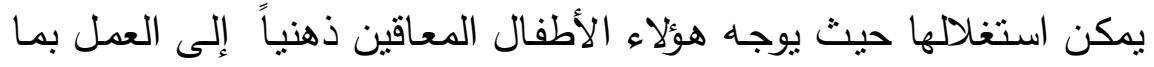

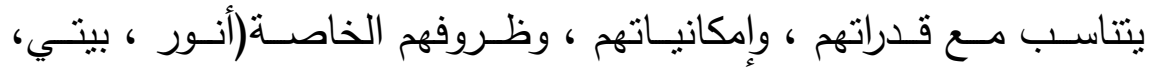
. (r T R R r... 
ولذلك لابـد مـن تتميـة عمليـة التصـنيف وقدرة الأطفال المعـاقين ذهنبـاً

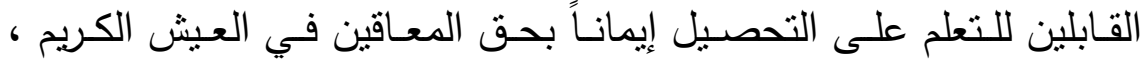
ومحاولة مشاركتهم في أنشطة كغيرهم من الأسوياء ، فالدمج يساعد الطفل

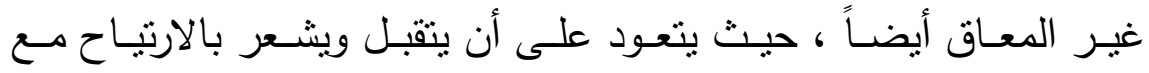
أثخاص مختلفين عنـه. وقد أوضحت نتائج الكثير مـن الدراسـات كدراسـة

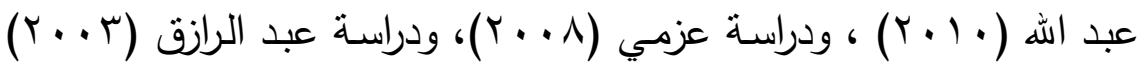
على إيجابيـة الأطفال العـاديين عندما يجدون فرصـة للعـب مـع الأطفال

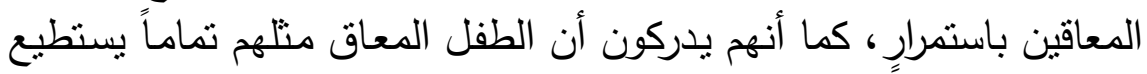

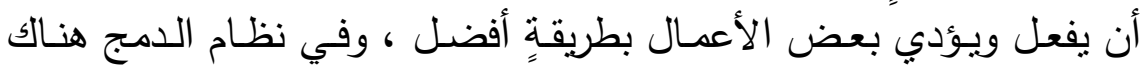

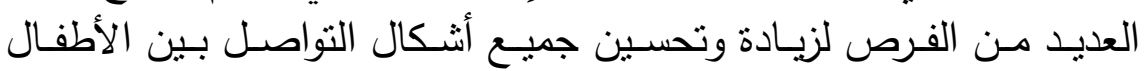
العادبين ، وأقرانهم المعاقين.

تعد طريقة ريجيو إميليا Reggio Emilia من أكثر الطرق التربوية التي ذاع صيتها في شتى أرجاء العالم، و لقد انطلقت بوادر هذه الطريقة

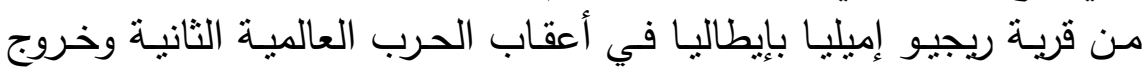
الألمان من إيطاليا، وتعتمد ريجيو إميليا على التربية في المرحلة الابتدائية وتربية طفل ما قبل المدرسة ، وبرجع الفضل في تأسيس هذه الطريقة للمعلم لوريس مالاجوزي Loris Malaguzzi والذي كان يعمل معلماً بقرية ريجيو

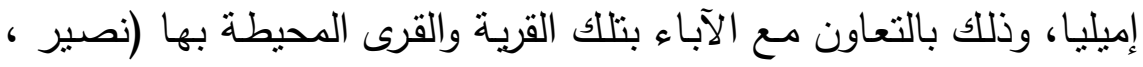

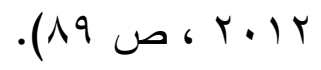

وتتبنى هذه الطربقة التطور العقلي للأطفال عن طريـق التركيز المنظم

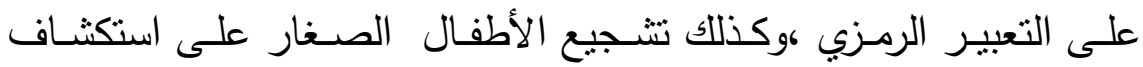
بيئته و التعبير عن أنفسهم عن طريق جمع ما يتوافر لهم من طرق التعبير والتواصل و اللغات المعرفية أياً ما كانت هذه الطرق: كلمات أو حركات أو هن 
رسومات أو تلوين أو عمل التماثيل أو اللعب بخيال الظل أو اللعب الدرامي

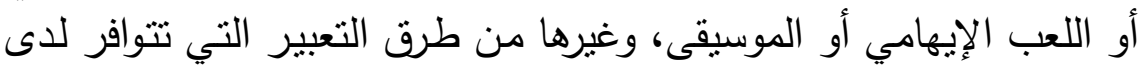

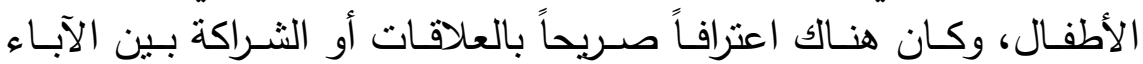

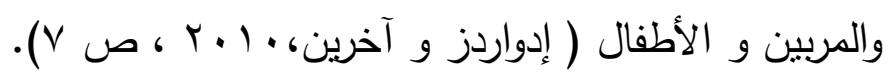

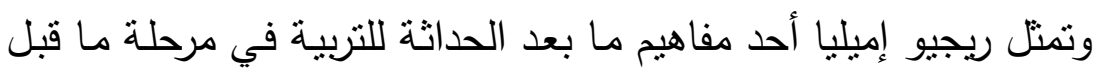

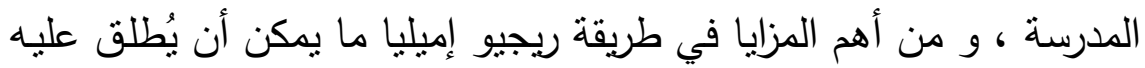

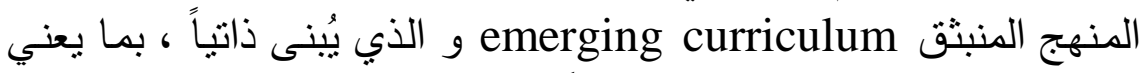

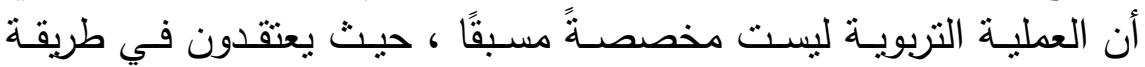

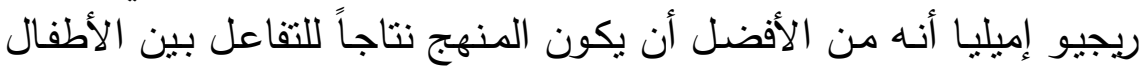

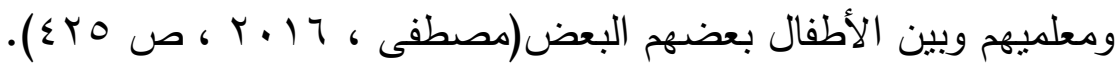

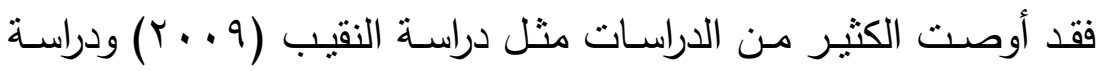

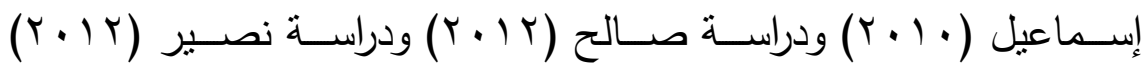

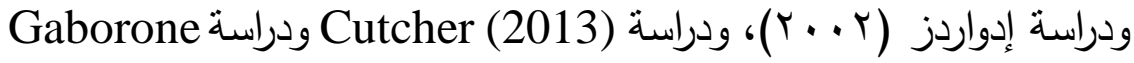

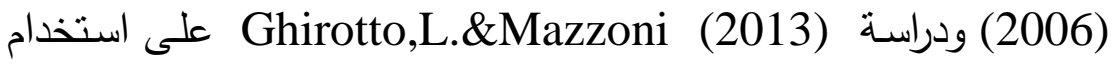
منهج ريجيو إميليا حتى يكتسب المتعلمون المفاهيم والمهارات بشكلٍ ذي معنى.

وترى الباحثة أنه على مـا تقدم فهناك حاجة ماسـة لدعم وتفعيل الدمج

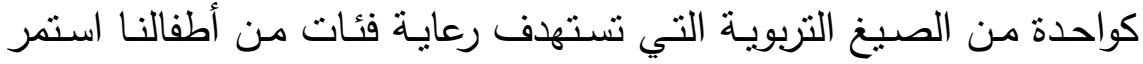

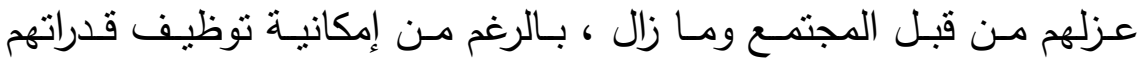
وطاقاتهم والاستفادة منها بما يعود عليهم ، وعلى أسرهم ومجتمعهم بعوائد كبيرة.

ويرى بعض التربويون أن دمج الأطفال ذوي الإعاقة في رياض الأطفال

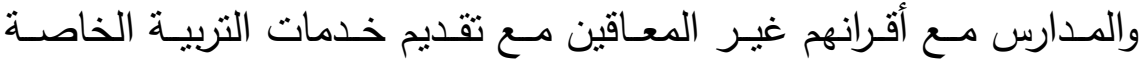


والخدمات المساندة، بهذف الإقلال من عزل الأطفال ذوي الإعاقة، وذلك

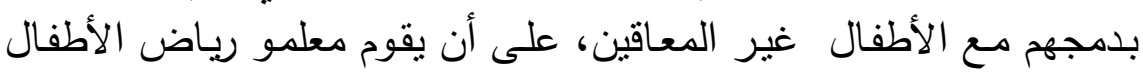

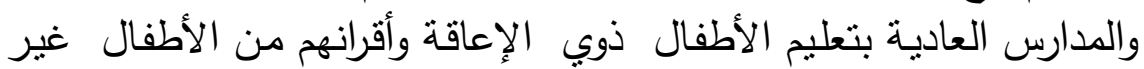

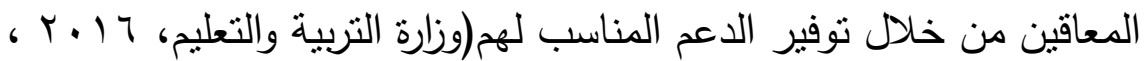
ص 0)

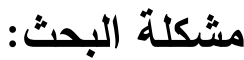

تتضح مشكلة البحث في أن نظام الدمج يتم تطبيقه في رياض الأطفال

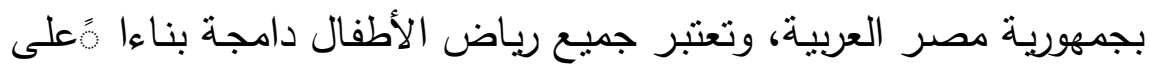

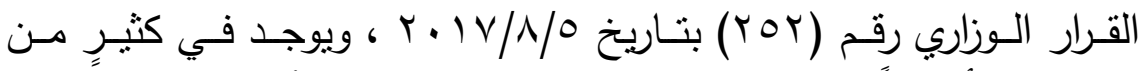

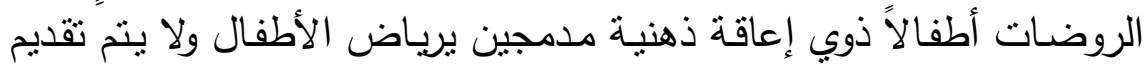

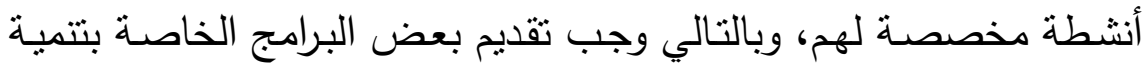

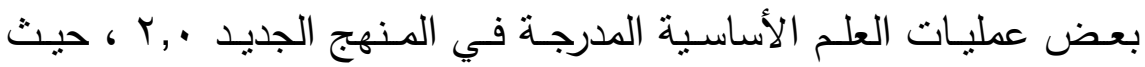

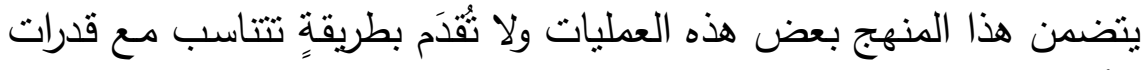

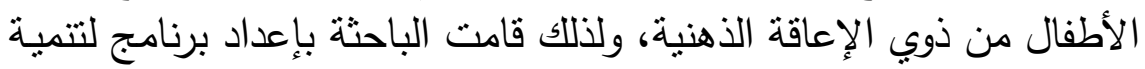

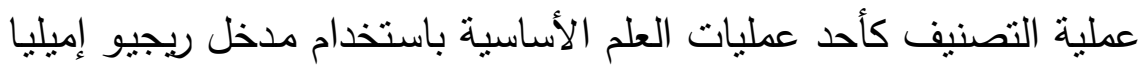
المعتمد على طريقة المشروع.

وتوجد بعض المؤشرات العلمية التي تؤكد على ألهى أهميـة الاهتمـام بتتميـة

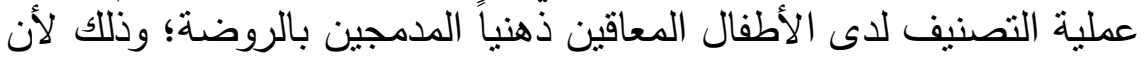

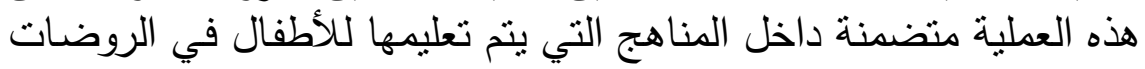

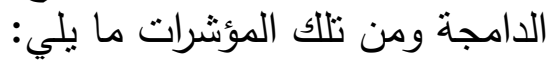

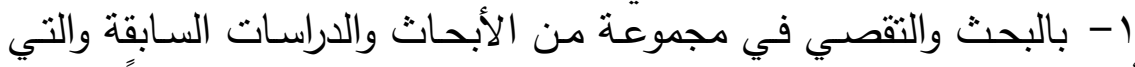

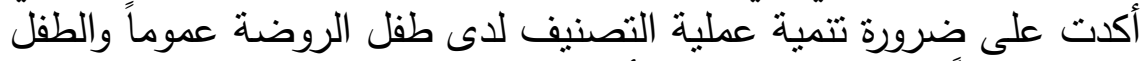

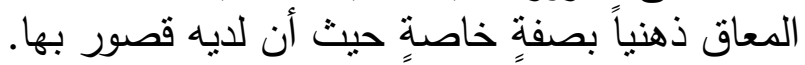


r- بـالإطلاع على الأدبيـات والدراسـات السـابقة الخاصـة بمـذل ريجيو إميليا والتي تتاولت تطبيق تجربة ريجيو إميليا في رياض الإن الأطفال في الدول

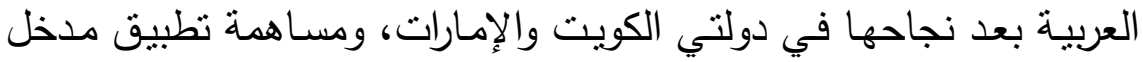

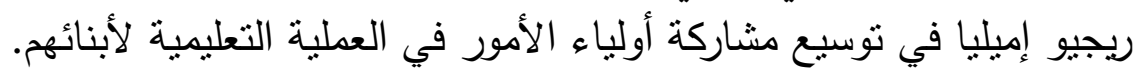

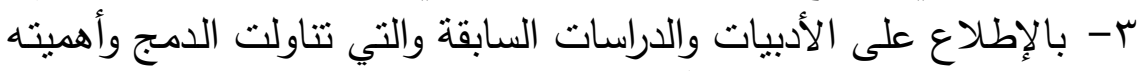

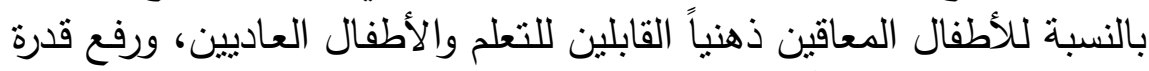

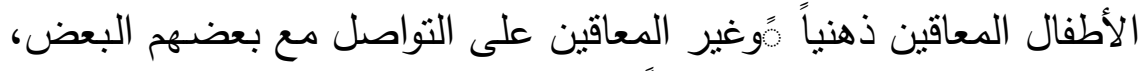

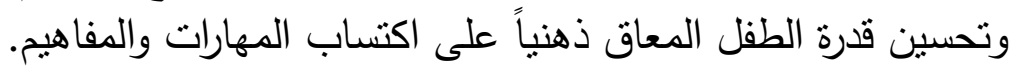

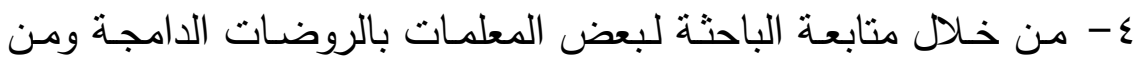

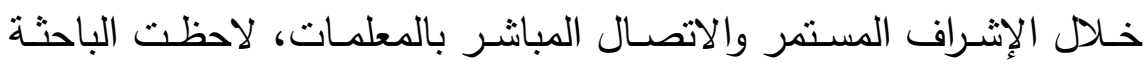

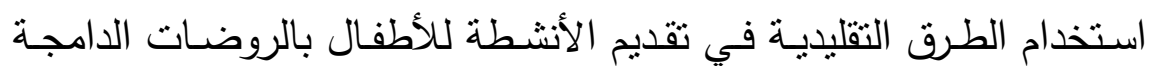

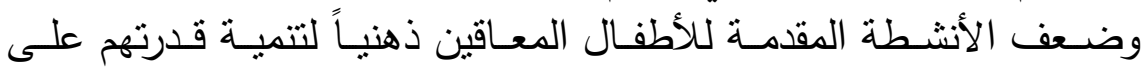
التحصبل الأكاديمي و قلة المعلومات لدى المعلمات عن الطرق المناسبة لتقديم الأنشطة للأطفال المدمجين.

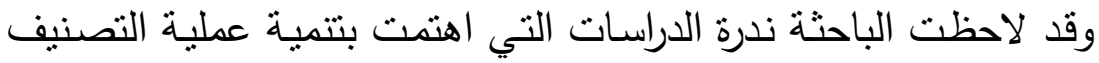

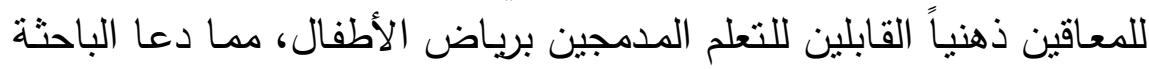
إلى التطرق لموضوع البحث. وتتحدد مشكلة البحث في الإجابة على السؤال الرئيس التالي:

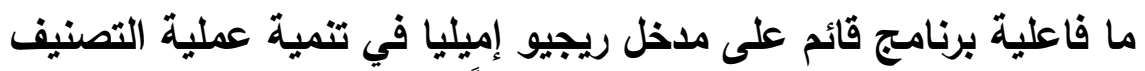

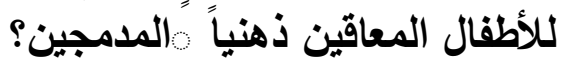

$$
\text { ويتفرع من السؤال الرئيس عدداً من الأسئلة الفرعية وهي: }
$$

ا - مـا العمليات الفرعية للتصنيف الواجب التبون تتميتها لدى الأطفال المعاقين

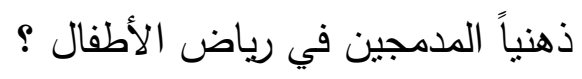


ץ- ما أنشطة البرنامج المقترح القائم على مدخل ريجيو إميليا لتتمية عملية

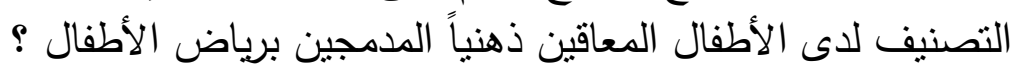

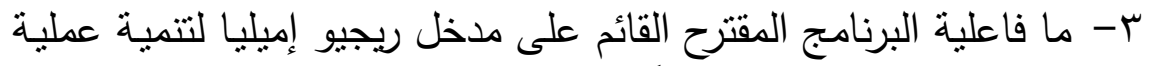

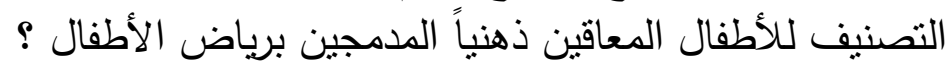

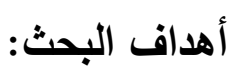

\section{يهذف البحث الحالي إلى ما يلي:}

"الكثف عن فاعلية مدخل ريجيو إميليا في تتمية عملية التصنيف للأطفال

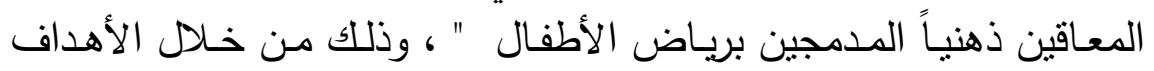
الفرعية التالية:

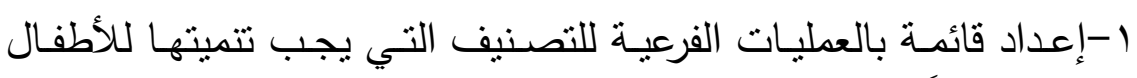

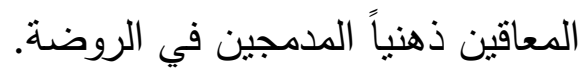
r-إعداد اختبار مصسور لقياس المدين فمليـة التصنيف للأطفال المعاقين ذهنياً المدمجين في الروضة.

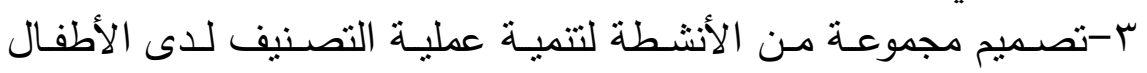
المعاقين ذهنياً المدمجين بالروضة باستخدام مدخل ريجيو إميليا.

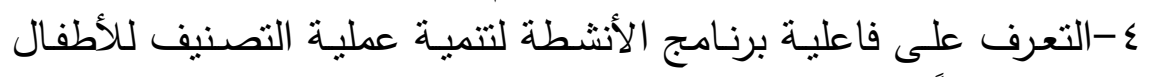

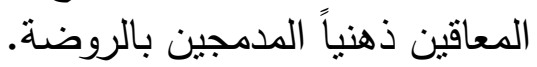

\section{أهمية البحث:

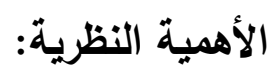

1- تفيـد مخططي المنـاهج بمرحلـة ريـاض الأطفـال في إعـداد أنشـطة تعليمية للأطفال ذوي الإعاقة الذهنية المدمجين في رياض الئن الأطفال. 
ץ-تحديد عمليات التصنيف الفرعية التي يمكن تتميتها للطفل المعاق ذهنياً المدمج في رياض الأطفال. ب-قد يسهرم هذا البحث في تبصير معلمات رباض الأطفال بأهمية تتمية

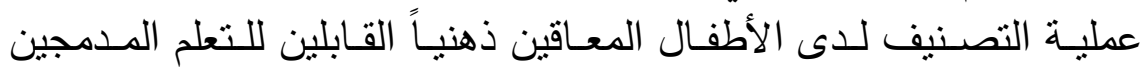
بالروضة.

ع-قد يسهم البحث بإلقاء الضوء على مدخل ربجيو إميليا وإكانية تطبيقه في رياض الأطفال الدامجة. هـقلة عدد الدراسات التي أُجريت فِي في مجال الأطفال المعاقين ذهنياً لتتمية عملية التصنيف مستخدمة مدخل ريجيو إميليا ، وذلك من خـلال مراجعة الاهـ

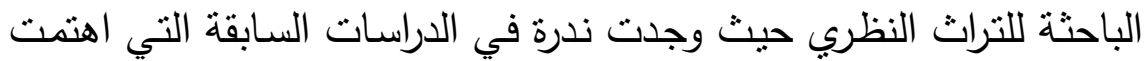
بموضوع البحث ، وذلك في حدود علم الباحثة.

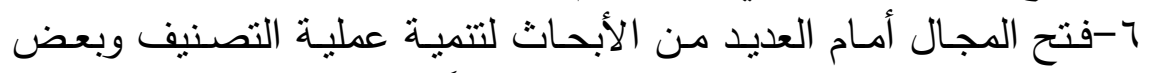
عمليات العلم الأساسية للأطفال المعاقين ذهنياً المدمجين. الأهمبة التطبيقية : ا-تقديم برنـامج أنشـة لتنميـة عمليـة التصـنيف في ضـوء مـخل ريجيو

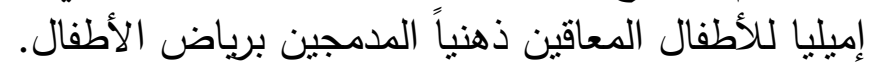
ب -قد تقبد نتائج البحث بعض مخططى ومؤلفي المناهج للأطفال المعاقين ذهنياً تَبِعض الأنشطة الخاصة بتتمية عملية التصنيف المُصدَمة في ضوء مدخل ريجيو إميليا. ب-قد تفيد نتائج البحث بعض أخصائي و معلمي المعاقين ذهنياً مَبكيفيـة تصميم الأنشطة في ضوء مدخل ريجيو إميليا . 
التزم البحث الحالي بالحدود التالية:

-الحدود البثرية: تم التوصل إلى عينة البحث من خلال تحديد الأطفال

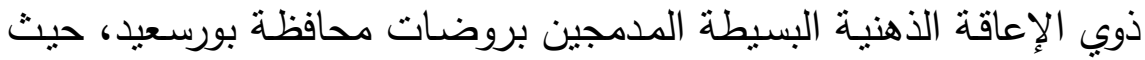

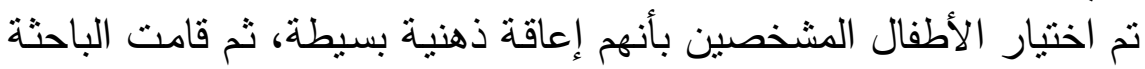

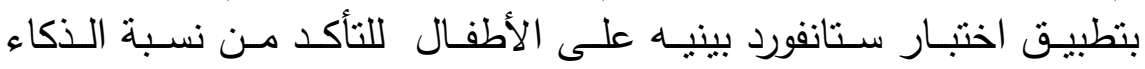

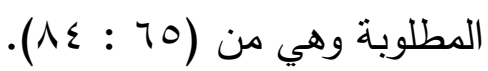

وبذلك توصلت الباحثة إلى العينة القصدية وعددها ( • () أطفالاً، وهم

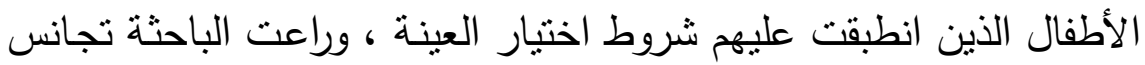

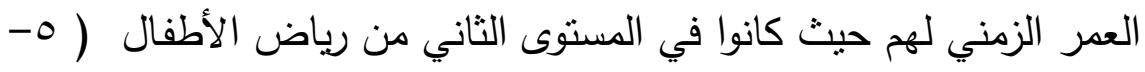
(الجدود ) منوات.

-الحدود المكانيـة: تم تطبيق البحث على الأطفال المعاقين ذهنياً القابلين

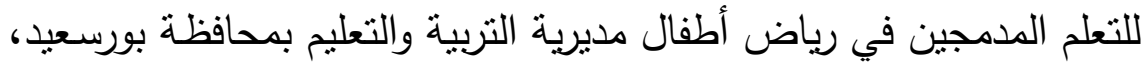

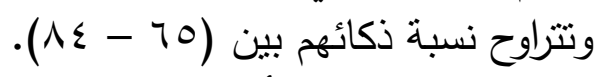

-الحدود الزمنية: بدأت التجربة من منتصف شئه (هر سبتمبر واستمرت لمدة

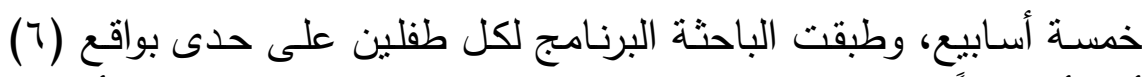

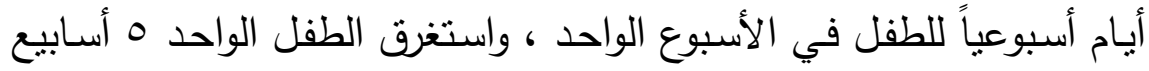

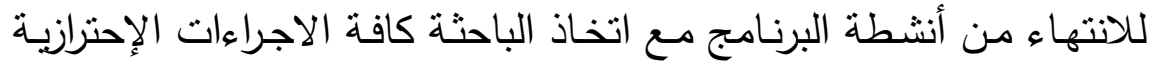

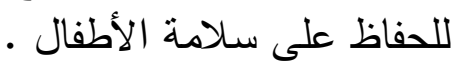

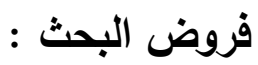

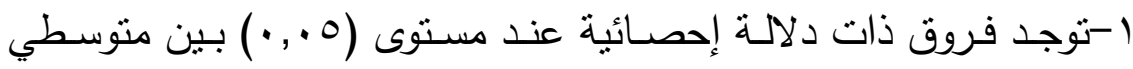

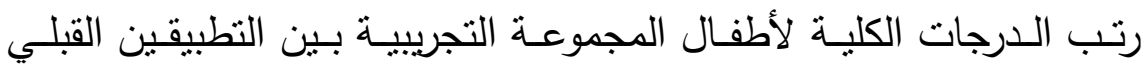


والبعدي على اختبار عملية التصنيف المصور للأطفال ذوي الإعاقة الذهنية المدمجين برياض الأطفال لصالح التطبيق البعدي. r-البرنامج المقترح القائم على مدخل ريجيو إميليا فعال في تتميـة عمليـة

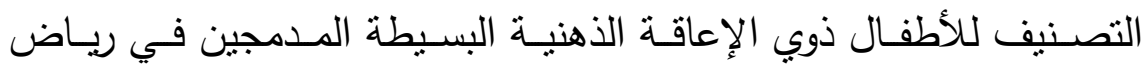
- الأطفال مصطاح البحث: أ- منهج ريجيو إميليا: جاء في الموسوعة الحرة ويكيبديا (Wikipedia,n.d) أن طريقة ريجيو إمبليا تقوم على مجموعة من المباديء منها:

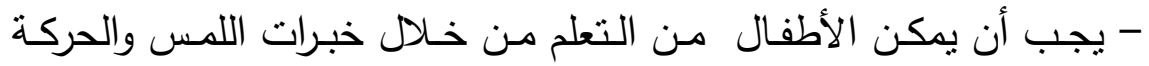

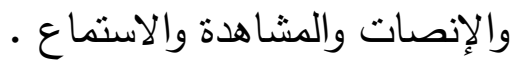
- للأطفال علاقات مع أقرانهم، وكذلك مع الأشياء المادية المحيطة بهم في العالم الذي يجب أن يسمح لهم باكنشافه.

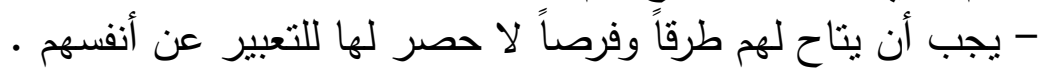
تعرفـه عيسـى بأنـه " مـنهج غيـر عـادي قـائم على أسس نظريـة كثيرة شملت نظريتي بياجيه وفيجوتسكي ، وذلك للبرامج المؤسسة في ريجيو إميليا بشمال إيطاليا ، والمنهج يقوم على المشروعات ، والتي تمثل في الحقيقية المفهوم المركزي الذي بدور حوله مدخل ربجيو إميليا ، حيث بتعلم الأطفال

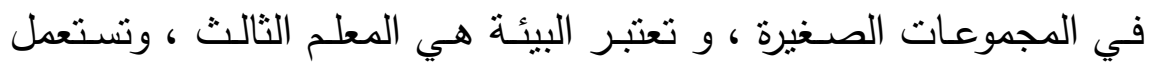

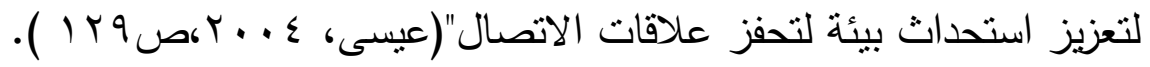
وتعرفه الباحثة إجرائياً بأنه: منهج يعتمد على الثراكة بين المعلم وأولياء

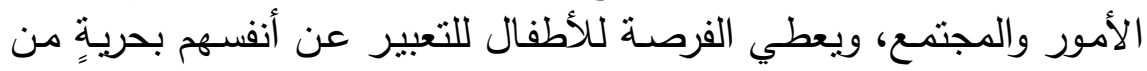
خلال استخدام التعبير الرمزي، ويتم هذا من خلال ما يتوافر لهم من طرق 


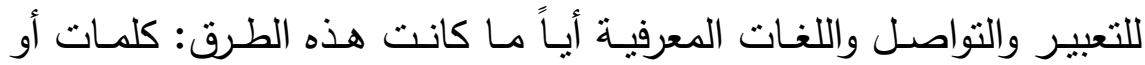

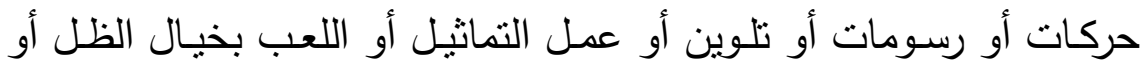

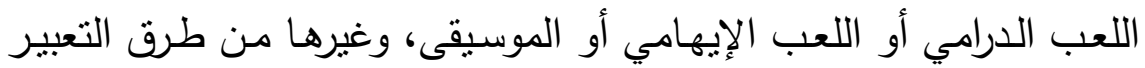

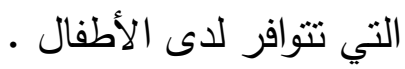

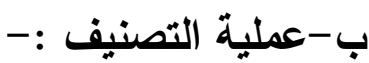

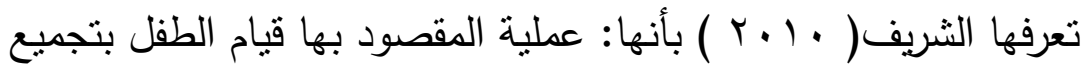

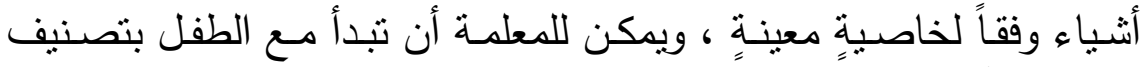

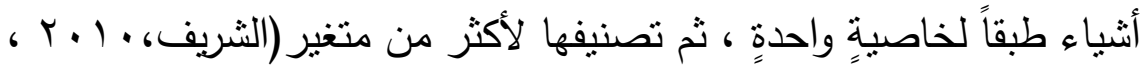
• ص (

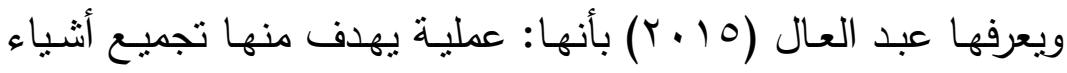

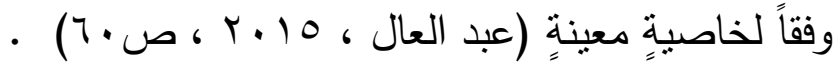

ومن التعريفات السابقة تعرف الباحثة التصنيف إجرائياً على أنه :هي اعي هي

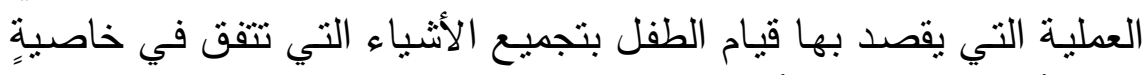

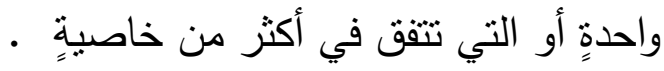

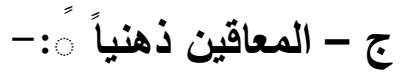

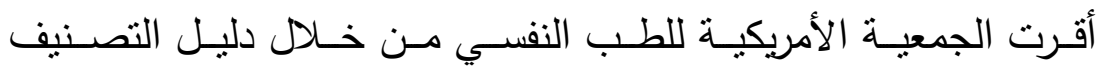
التشخيصية والإحصائي للأمراض النفسية و الذهنية Dsm- IV وجود ثناثة

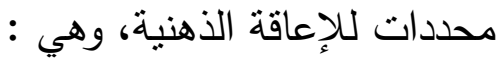
- أداء عقلي دون المتوسط ونسبة الذكاء (• ( أو أو أقل على أحد المقاييس الفردية للأطفال. - قصسور في السـوك التكيفي للطفل ، وذللك في إثتين على الأقل مـن المجالات الآتية : 


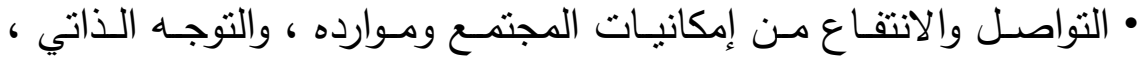
والمهارات الأكاديمية الوظيفية ، العمل ، الفراغ ، الصحة ، الصئة السلامة. • أن يحصل ذلك خلال فترة النمو أي قبل سن ^ 1 سنة(عبد الله ، ع . .

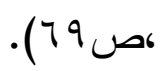

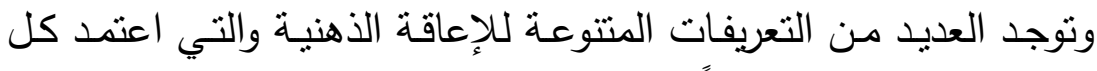

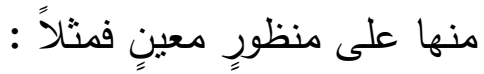
أمن الجانب الطِّي : تمعِي تعريفها على أنه حالة من عدم التوازن الكيميائي

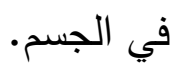
r-مـن الجانب الاجتمـاعي : تم تعريفها على أنها نقص المستوى الثقافي والتمكن من التفاعل مع الآخربن •

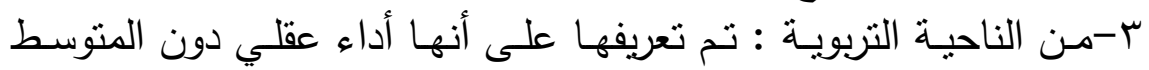
ويظهر متزامناً مع القصور في السلوك التكيفي للفرد من خلال فترة النمو.

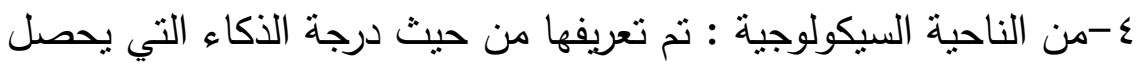

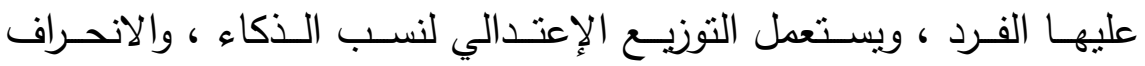

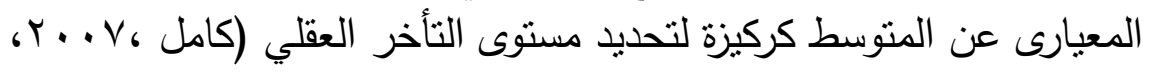

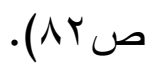

وتعرفه الباحثة إجرائياً بأنـه: وجود انخفاض واضـح في القدرة العقليـة العامـة للطفل، بالإضـافة إلى وجـود ضـف مصداحب في سـوكه التكيفي

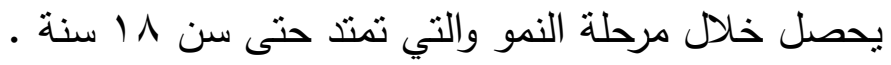

$$
\text { : دالدمج) }
$$

يوجد مساران أساسيان في تتظيم تعليم ذوي الاحتياجات الخاصة هما :نظام العزل و نظام الدمج وسوف نتناول في هذا البحث نظام الدمج فقط . 
الإطار النظري والدراسات السابقة :

المحور الأول: مدخل ريجيو إميليا :

نشأة منهج ريجيو إميليا :

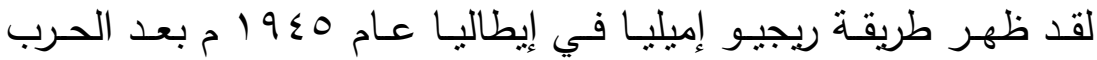

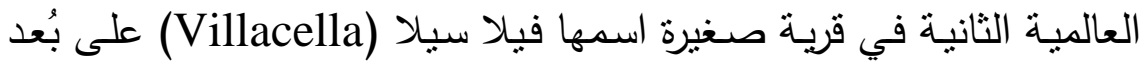

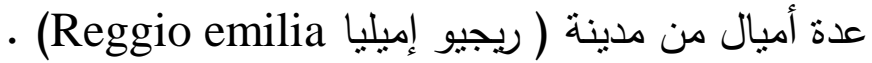

وهي مدينة إيطالية تقع في شمال إيطاليا تطوع فيها المواطنون والأهل

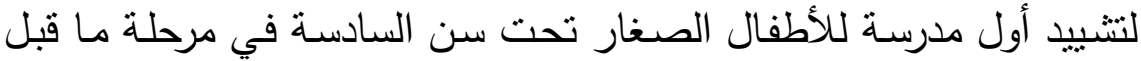

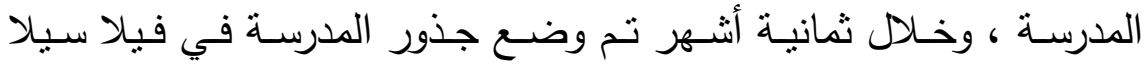

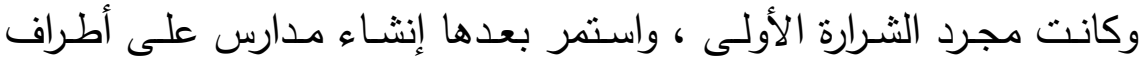

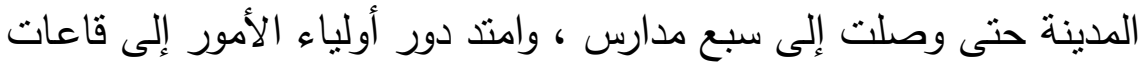

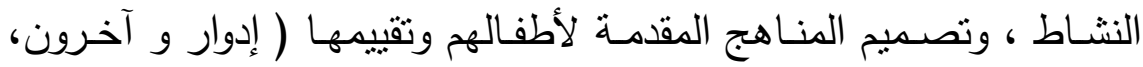

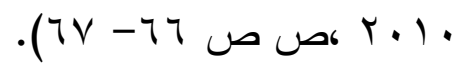

وقد انضم إلى المنطوعين لوريس مالاجوزي (Lures Malaguzzi)

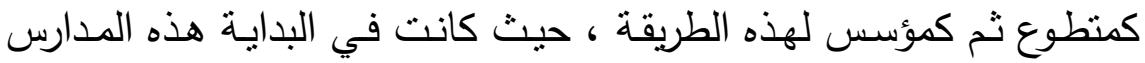

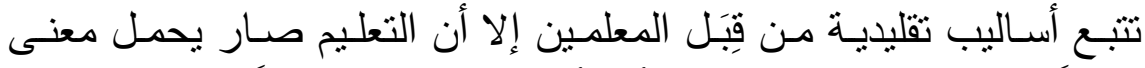

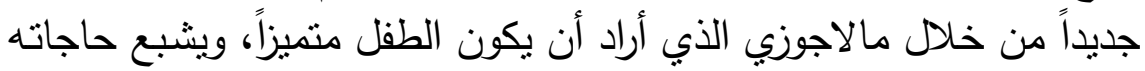

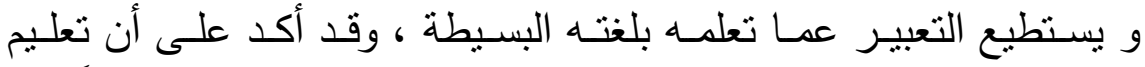

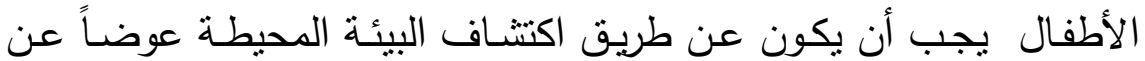

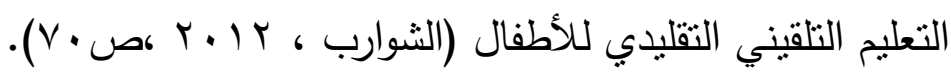

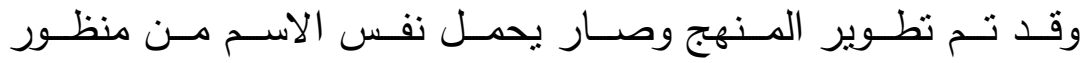
المتخصصين ، وأنشأت المنظمة الإيطالية (ريجيو إميليا) عام ع9 99 المن 
أجل خدمة ورعاية النظرية التربوية وراء هذا الاتجاهر Hendrek , Joanne

$$
\text { ( , 2012,pp } 26-13
$$

وعلى المستوى العربي أقامت الجمعية الكوينيـة مؤتمرهـا الدولي الأول

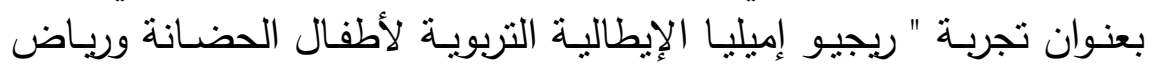

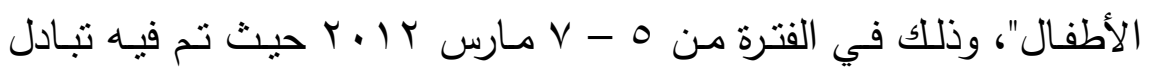

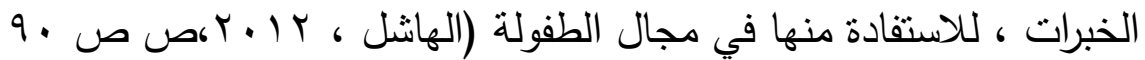

$$
\text { . ( } 9 \vee-
$$

\section{: The Reggio Emilia Approach تعريف منهج ريجيو إميليا}

تعرفه عيسى بأنه " منهج غير عادي قائم على أسس نظرية كثيرة شملت

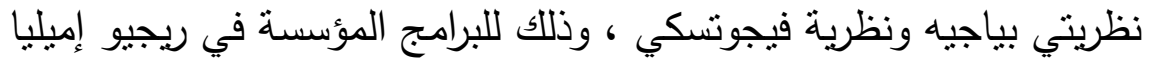

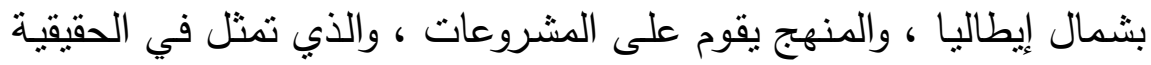
المفهوم المركزي الذي يدور حوله مدخل ريجيو إميليا ، حيث يتعلم الأطفال

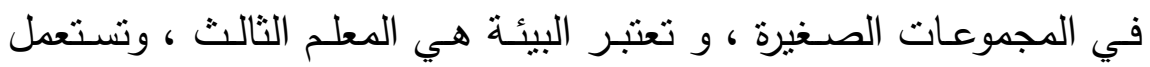

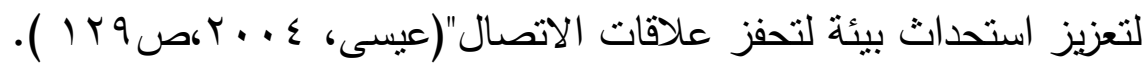

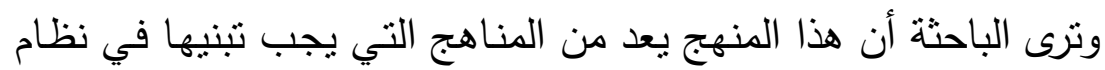

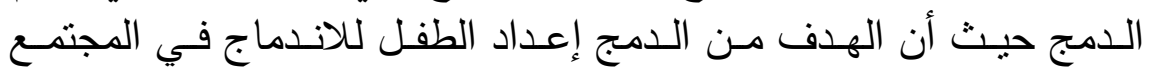

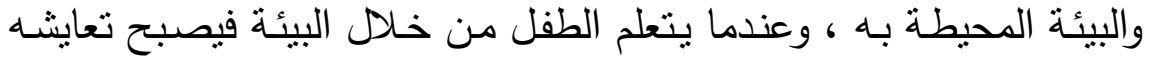

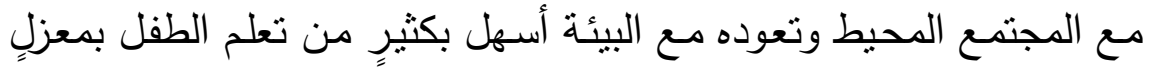

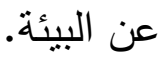

ومن أهم الأصسول الفلسفية و المعالم الأساسية التي قام عليها منهج

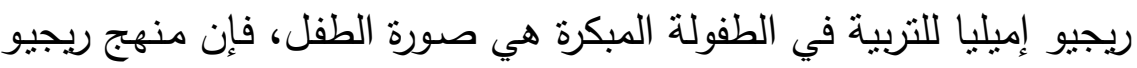

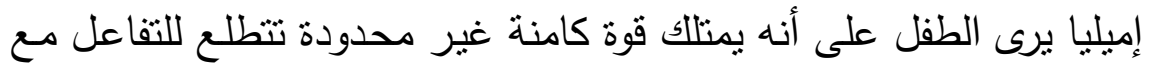

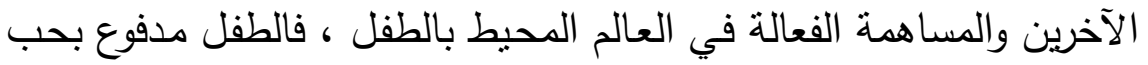




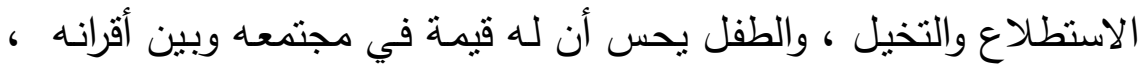
ولخص هيويت (2001 ) مewett المعالم الرئيسية لنظرة منهج ريجيو إميليا للطفل فيما يلي: هيلي

\section{- الطقل كصاحب حقوق : The Child as having rights -}

وذللك حيث يتمنل الاعتقاد الأساسي لمنهج ريجيو إميليا الذي تبنى عليه نظرتها للطفل في أنه صاحب حقوق و ليس احتياجات ، ومن ثم فالطفل الطيل صـاحب الحقوق يجب أن تتوفر لـه الفرص لينمسي ذكاءه، وكذللك لتهيئنه للنجاح الذي يجب أن يدركه بل إن الأمر يصل بهم في ريجيو إميليا ليطلقوا

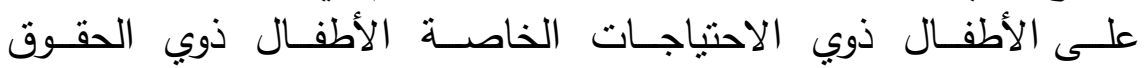

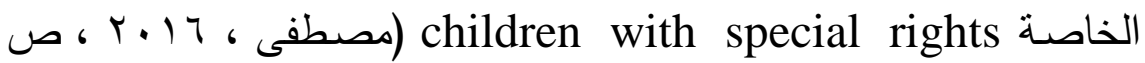

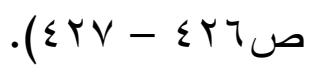

\section{الخصائص الرئيسية لمنهج ريجيو إميليا:}

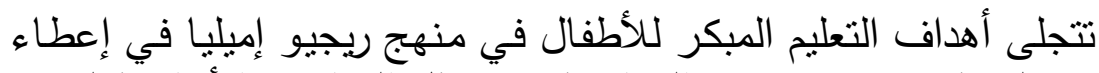

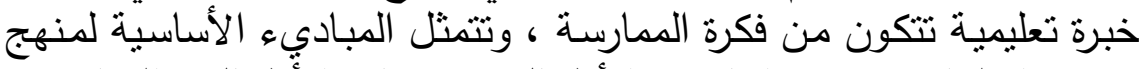

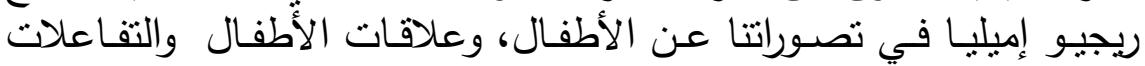

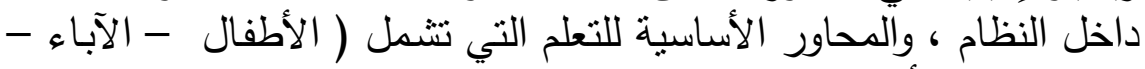

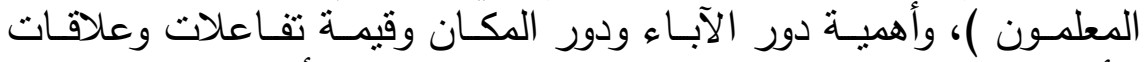

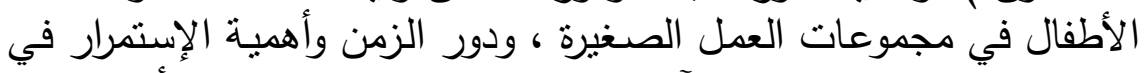

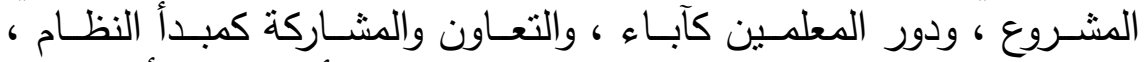

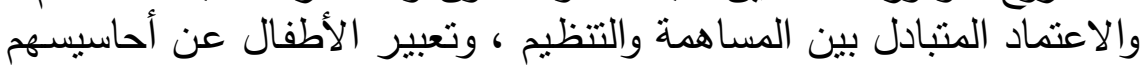

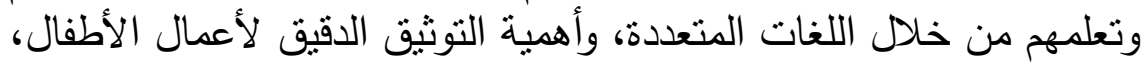
ووضع المدخل نتيجة العمل و المشروعات.

(Jo,AnnBrower,2005,p80; Johan Hindrek ,2010; pp 17-24 ) 


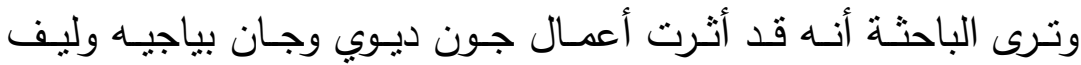

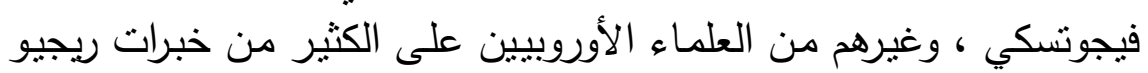

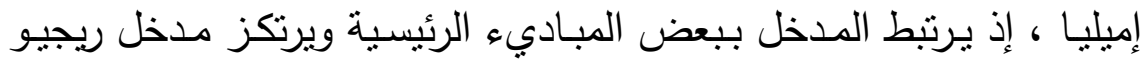

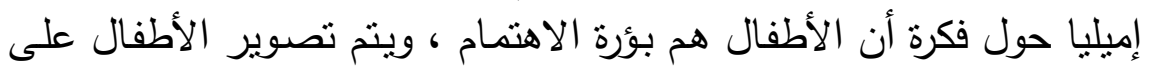

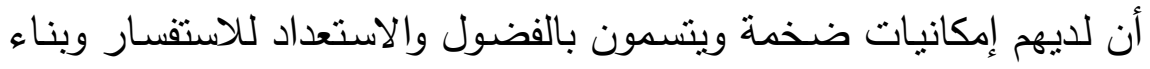
معارفهم ويتم ذللك من خلال التفاعل فيما بينهم وبين بيئتهم . وتتمثل الخصائص الرئيسية لمنهج ريجيو إميليا كما يأتي:

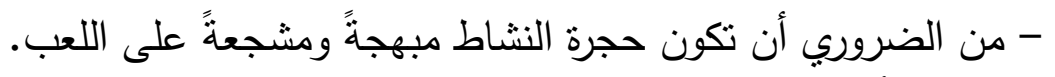

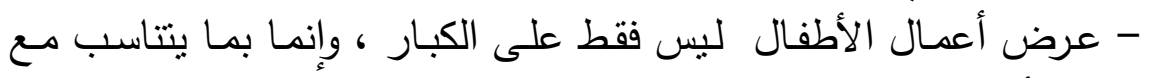

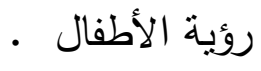

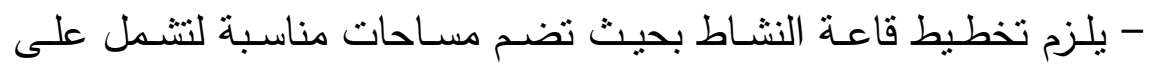
مناضد متتوعة ومراكز تعلم متتوعة ومركز للعب الدرامي.

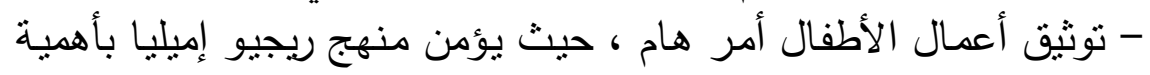

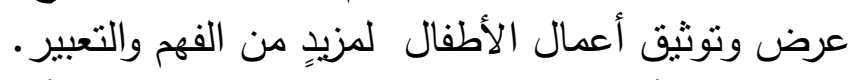

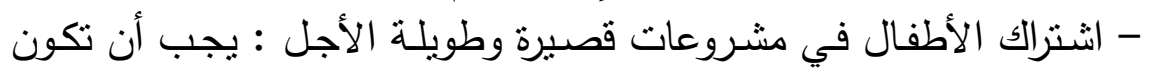

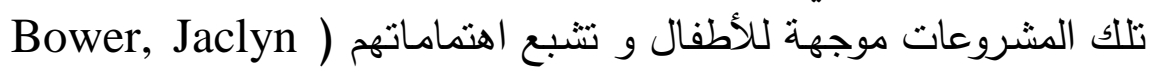

$$
\text { .(,2014,p28 }
$$

\section{المحور الثاني: عملية التصنيف:}

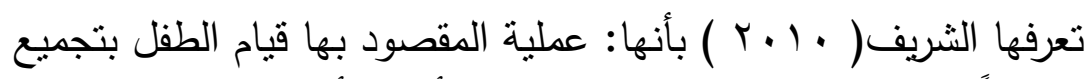

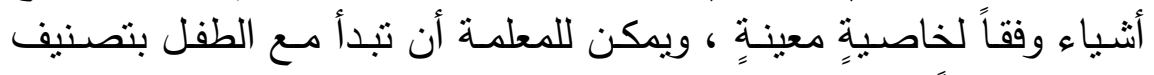

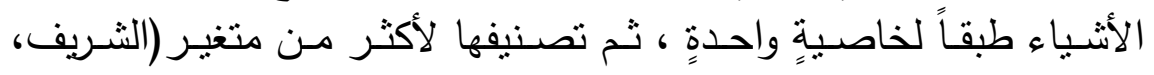

$$
\text { . (r^9 ( r.). }
$$




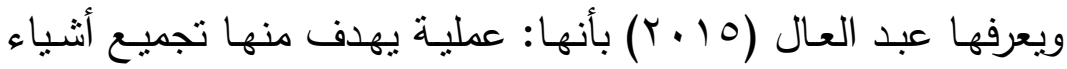

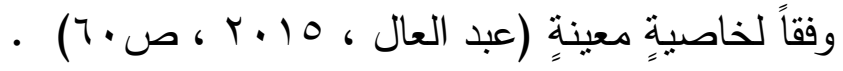

ومن التعريفات السابقة تعرف الباحثة التصنيف إجرائياً على أنه :هي العملية التي بقصد بها قيام الطفل بتجميع الأشياء التي تشترك في خاصية واحدة أو التي تساهم في أكثر من خاصبة ل .

\section{ويتناول التصنيف أشكالاً متعددةً :}

أ- تصنيف شكلي : يكون معبار الحكم فيه على خواص حسية للشيباء مرتبطة ارتباطاً دقيقاً بعملية الإدراك مثل : (اللون - الثكل - الحجم). ب- تصنيف وظيفي : يكون معيار الحكم فيه على عدة استعمالات الثيء. ج- تصنيف وجداني : يكون معيار الحكم فيه على خاصية وجدانية تحكم

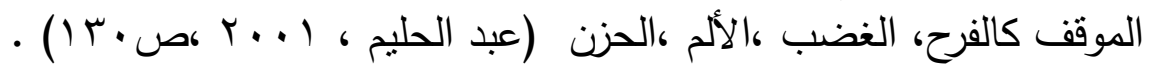
تحليل عملية التصنيف:

تشتمل عملية التصنيف العمليات الفرعية التالية:

- التصنيف وفقاً لخاصيةٍ واحدةٍ كتجميع الأثياء ذات الثكل الدائري.

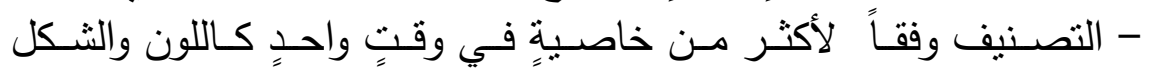

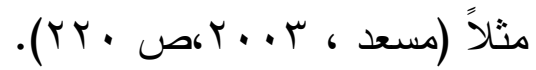
المحور الثالث: المعاقين ذهنياً " إن: تعريف الإعاقة الذهنية:

ليس من السهل إيجاد تعريفاً واحداً للإعاقة الذهنية يكون مقبولاً لمختلف المهتمين في مجال التربية الخاصة ، وذللك لأسباب متعددة منها: 
1-أن الإعاقة الذهنية في أغلب الأوقات ليست شيئاً نتمكن أن نمسكه أو

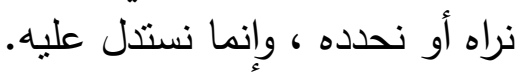

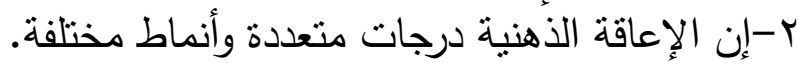

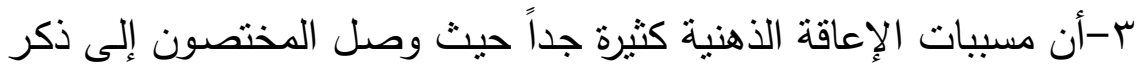
ع أن مثبياً وما زالت هناك أسباب كثيرة أخرى مجهولة.

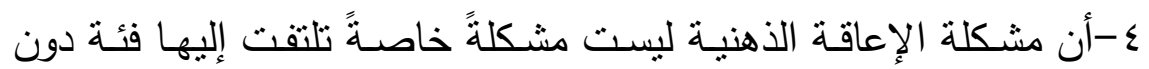

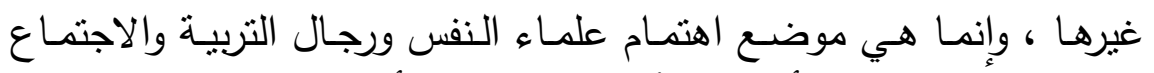

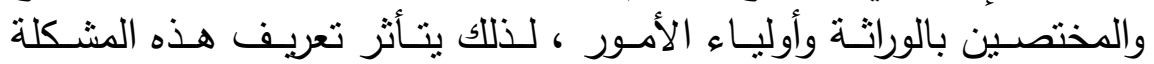

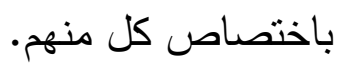

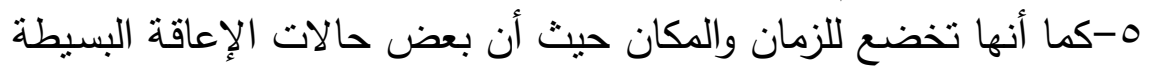

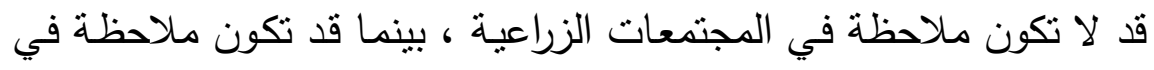

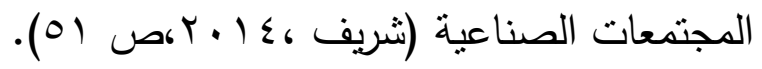

وتعرف الجمعيـة الأمريكيـة للإعاقـة الذهنيـة (AAMR) بأنها: إعاقـة

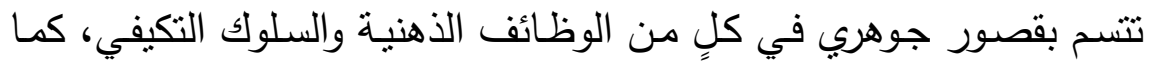

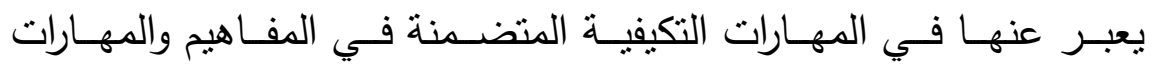

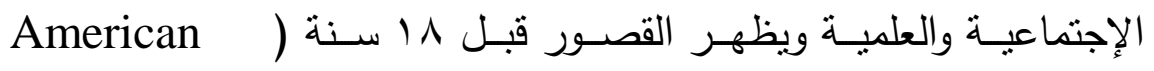
.(Association on Mental Retardation,2000

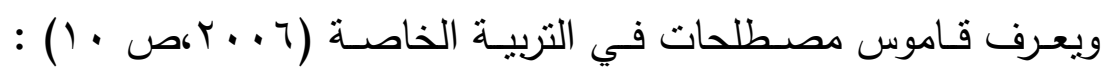

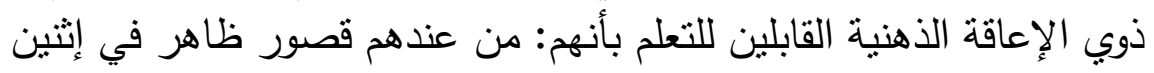

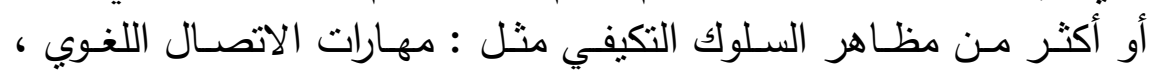

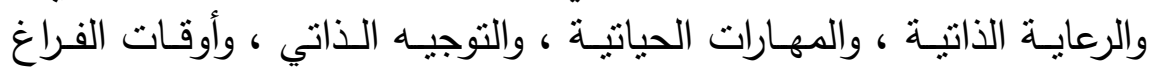
والعمل ، هذا بالإضافة إلى تركيزهم على التني الواضح في المقدرة الذهنية 
( أقل من ه V درجة) ، ويتضح في مراحل العمر النمائية منذ الميلاد وحتى

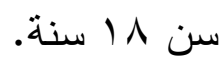

وترى الباحثة أن هناك مجموعة مجموعة من الأسس العامة التي يجب التباء

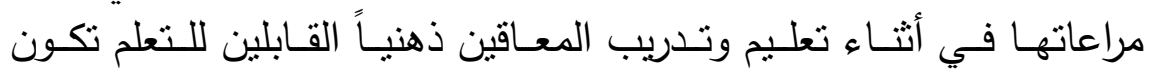
كالتالي : مراعاتي

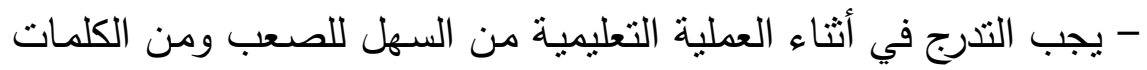

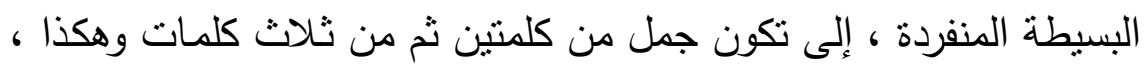

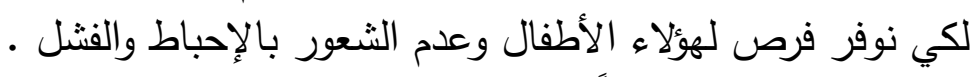

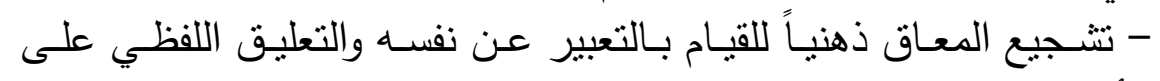

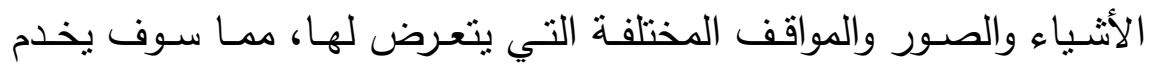

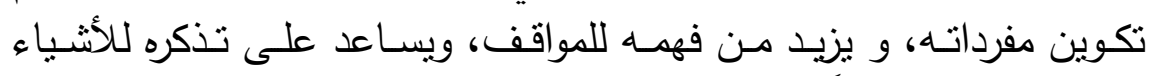
و تعرفه عليها وأيضاً تكوين المفاهيم.

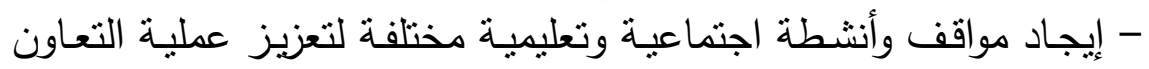

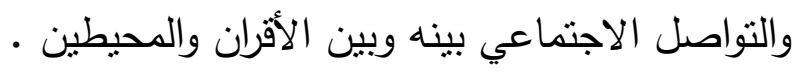

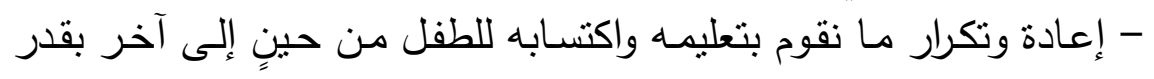

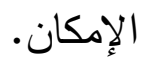
- أن نقوم بإكساب مهارة التواصل اللفظي والمهارة الإجتماعية على مراحل

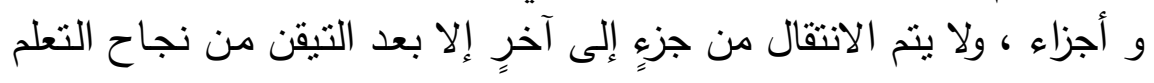

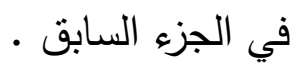
- استعمال أكثر من مثير بيئي وأكثر من أسلوب لتوصبل مفهوم محدد للطفل لزيادة التكيف الاجتماعي لديه التئ.

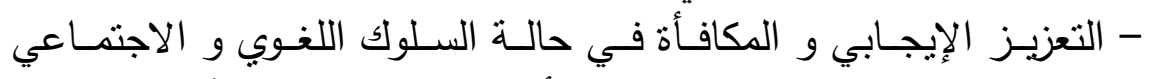

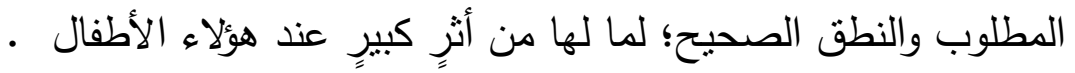


- مراعاة وجود فترات راحة بعد كل مرحلة والتي تليها، وعدم الانتقال إلى المرحلة التالية إلا بعد التأكد من أخذ قسطٍ وافرٍ من الراحة والاستجمام.

\section{المحور الرابع : اللمهج :}

وينقسم نظام الدمج الى نوعين :

$$
\text { ب-الدمج الجزئي }
$$

وسوف أنتاول فيما يلي الدمج الكلي الذي تتاوله البحث الحالي : وفيما يلي تقوم الباحثة بعرض أنواع الدمج الكلي التي أجمع عليها العديد

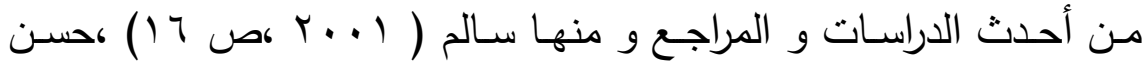

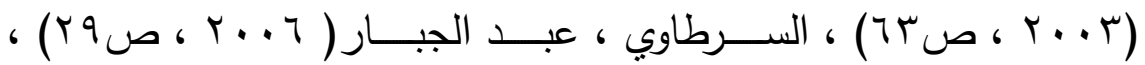

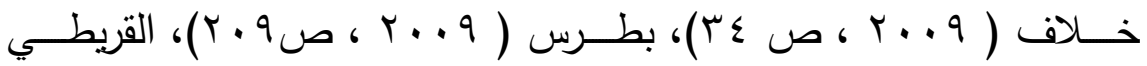

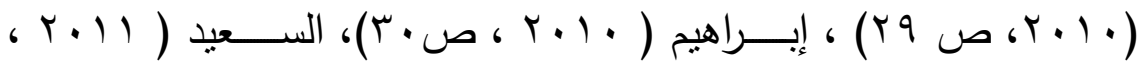

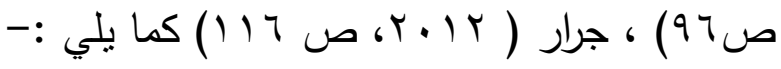

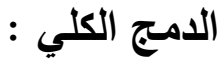
هناك نوعان من الدمج الكلي وهما كالتالي: ا-اللدمج الكامـل دون إثـراف أو توجيـه : وبذهب الطفل في هذا النظلام إلى إحدى الروضات المجاورة إلى منزل الطفل في فصول عامة مـع أقرانه غير المعاقين ولا بتلقى أى خدمات خاصة أو برامج خاصة بـه. r -الامـج الكامل في فصول عامة مع ضرورة تقديم خدمات مساعدة لتلبية

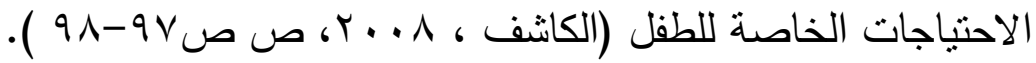


وقـد أصــدرت وزارة التربيــة والتعلـيم المصــرية القـرار الــوزاري رقـم

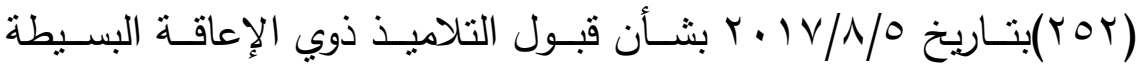
بمدارس التعليم العام، والذي ينظم عملية قبول الأطفال ذوي الإعاقة الذهنية البسيطة، والذي تم تحديد درجة الإعاقة الذهنية التي تقبل بالمدارس العادية

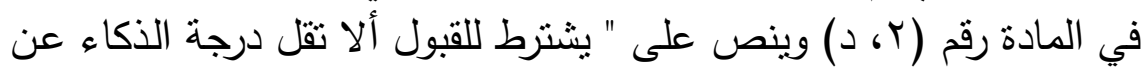

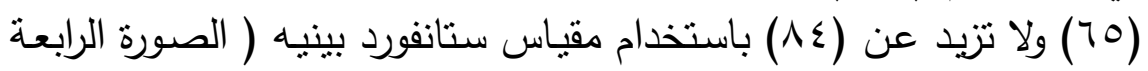

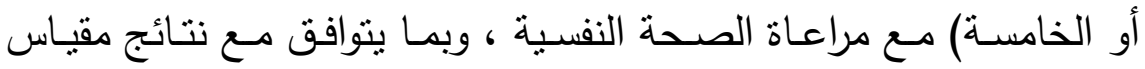

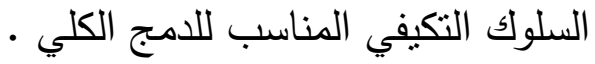

ويوضح القرار أن الإعاقة الذهنية تتضمن جميع المتلازمات التي تتدرج

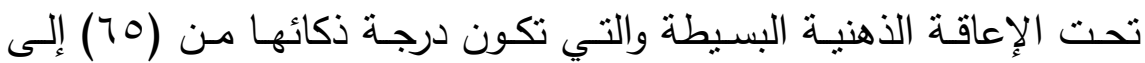
(^乏) على مقيـاس سـانفورد بينيـه ( الصـورة الرابعـة أو الخامسـة)، وأيضـاً بطيئوا التعلم هم التلاميذ الذين يكون التحصيل الدراسي لديهم منخفضاً في

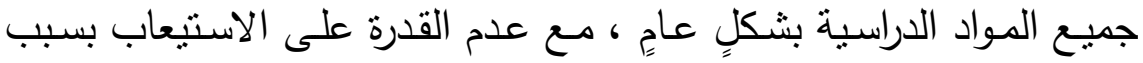

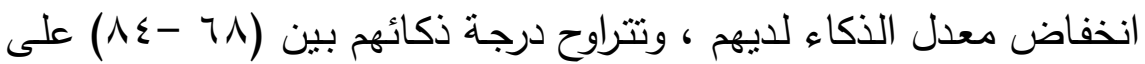
مقياس ستانفورد بينيه ( الصورة الرابعة أو الخامسة).

الإجراءات المنهجية للبحث:

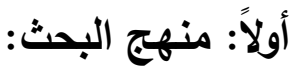
يستخدم البحث الحالي كلا مَمن: أ- المنهج الوصفي التحليلي : الذي يقوم بوصف ما هو كائن وتفسيره ،

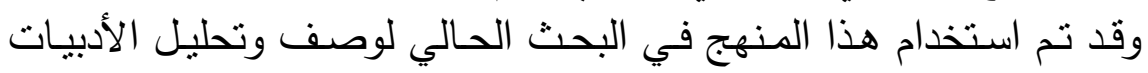

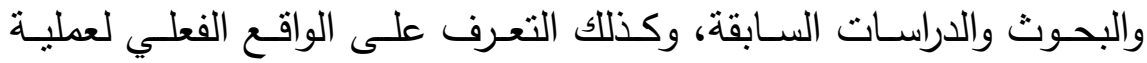
التصنيف لدى الأطفال ذوي الإعاقة الذهنية المدمجين برياض الأطفال. 
ب - المـنهج شبه التجريبـي : وهو المنهج الذي بستخدم التجربـة في

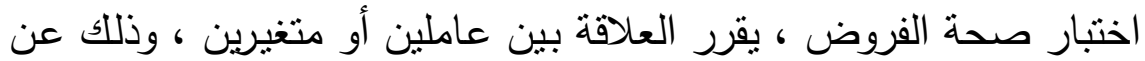
طريق دراسـة المواقف التي ضبطت كل المتغيرات مـا عدا المتغيرات التي تهتم الباحثة بدراستها ، وعليه فقد تم استخدام هذا المنهج في البحث الحالي للكثف عن تأثير بين المتغيرين الإثنين: -متغير مستقل: مدخل ريجيو إمبليا.

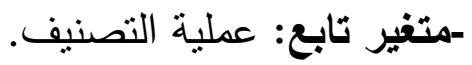
وتـم ذلك باسـتخدام التصــميم التجريبـي ذي المجموعـة الواحـدة واختبـار (وبلكوكسون ) كأسلوب إحصائي؛ لحساب الفروق بين متوسطي التطبيقين القبلي والبعدي لعينة البحث. مجتمع وعينة البحث: - مجتمع البحث: الأطفال المعاقين ذهنياً المدمجين برياض أطفال محافظة بورسعبد.

- عينة البحث: تم اختار عينة عمدية من الأطفال المعاقين ذهنياً المدمجين في رياض الأطفال بالروضات الدامجة، وعددهم عثرة روضات على مستوى المحافظة، وتكونت المجموعة من عشرة أطفالاً معاقين ذهنياً المدمجين عبارة عن مجموعة واحدة تجربيية. - تم عمل تجربة استطلاعية شملت (7) أطفالاً معاقين ذهنياً مدمجين؛ بغرض التقنين العلمي لاختبار عملية التصنيف المصور ، وللتحقق من التكافؤ في التطبيق القبلي تم استخدام مقياس ستانفورد بينيه للتأكد من نسبة

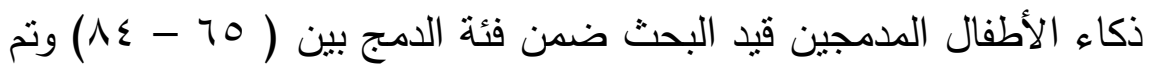
تحديد معامل السهولة والصعوبة للاختبار ، تم استخدام وبلككسون كأحد 
اختبارات الإحصاء اللابارامترى وفق عينة البحث والبالغ عددها ( (1 ) أطفال معاقين ذهنياً مدمجين برياض الأشياء الأطفال . أدوات البحث:

أ- إعداد قائمة ببعض عمليات التصنيف الفرعية التي تندرج تحت عملية التصنيف :-

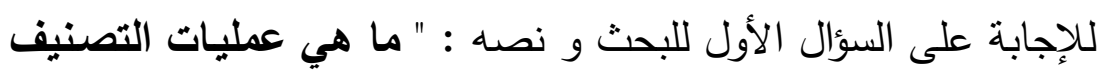

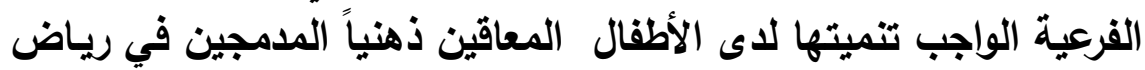

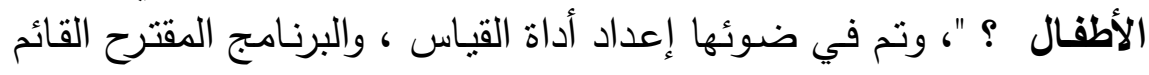

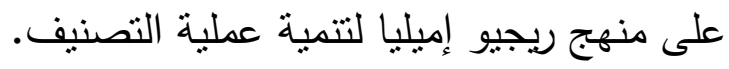

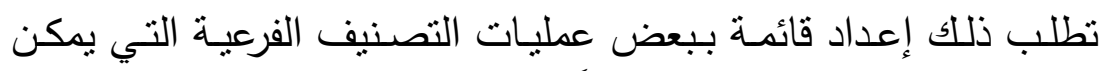

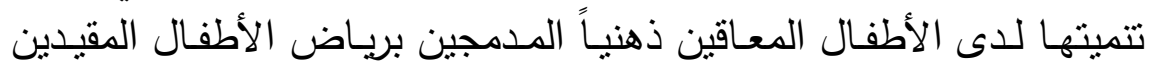

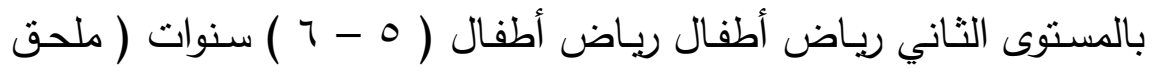
رقم ( ) الصورة النهائية لقائمة ببعض اطفال عمليات التصنيف الفرعية.

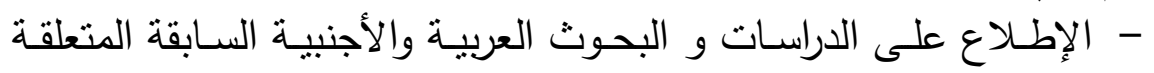

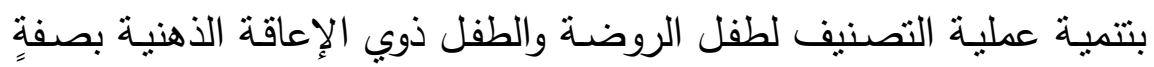

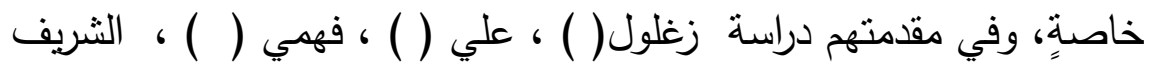

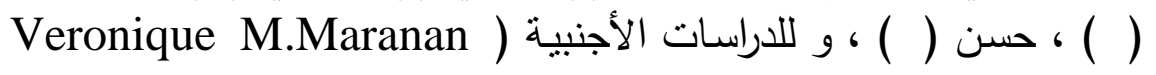
•(2017) (Erin Miles2010

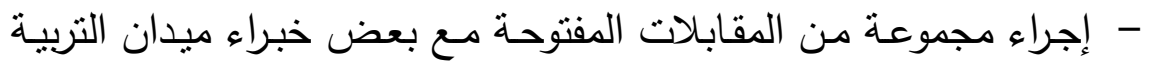

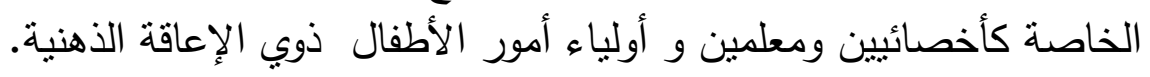

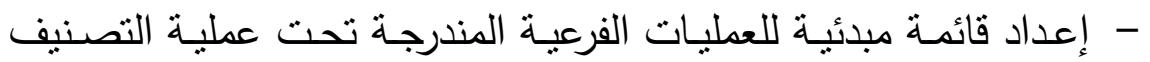

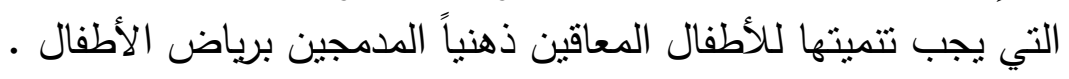


- ضبطط القائمسة مـن خلال عرضـها على مجموعـة مـن السـادة المحكمين المتخصصين في مناهج وطرق تدريس الإعاقة الذهنية ، التربية الخاصـة ، الذهية

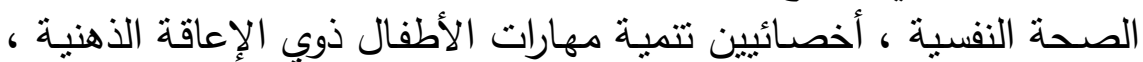

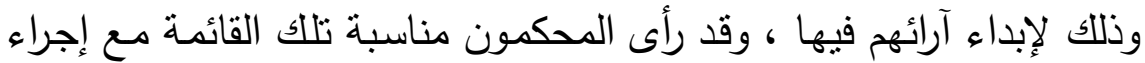
بعض التعديلات البسيطة في ضوء آرائهم منل إعادة ترتيب بعض العمليات الفرعية ذات العلاقة ببعضها.

- إعداد الصورة النهائية لقائمسة عمليات التصنيف الفرعية الواجب تتميتها

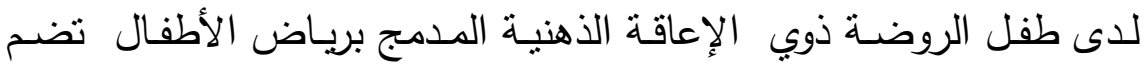

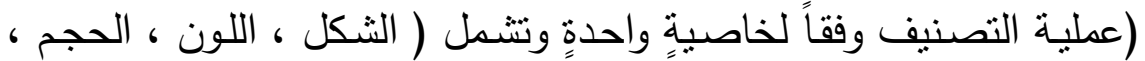

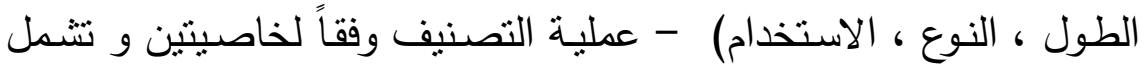
( الشكل ، اللون - الثكل ، الحجم - الثكل ، الطول - اللون ، الحجم -

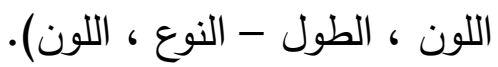
ب-إعداد البرنـامج المقترح لتنميـة عمليـة التصنيف لـى الطفل المعاق

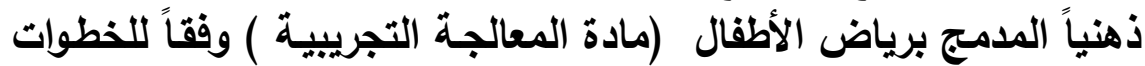
التالية :- دهية

ا ا-تحديـد أسـس البـرامج التربوبـة الفعالـة المقدمـة للأطفـال ذوي الإعاقـة الذهنية التي التزمت بها الباحثة في البحث الحالي وشملت ما يلي :• الأسس القلسفية : حيث يستند البرنامج إلى النظرية البنائية الإجتماعية البهية التي نـادى بها بياجيهـ ، فيجوتسكي ، ديوي وغيرهم ، التي انبتقـ أفكار لوريس مالاجوزي منها(Malaguzzi , Loris , 1994 - 2011 ,p 55).

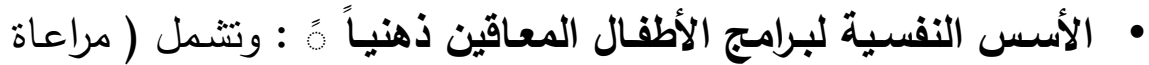

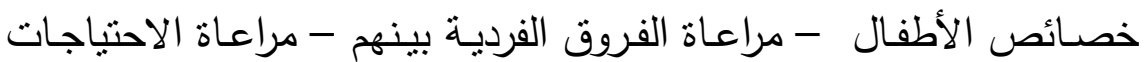
الخاصة بكل طفل ) ( الاصهل 
• الأسس الاجتماعية لبرامج الأطفال ذوي الإعاقة الأهنية وتتمل ( البيئة

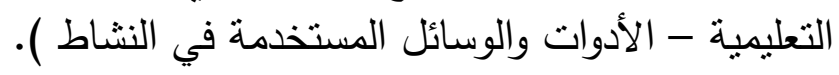

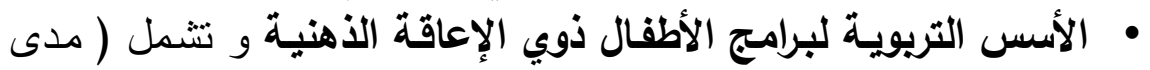

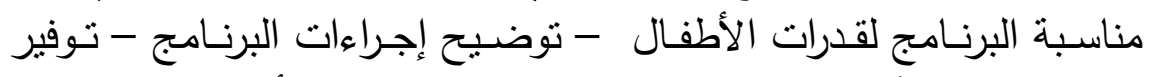

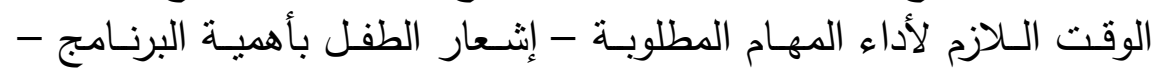

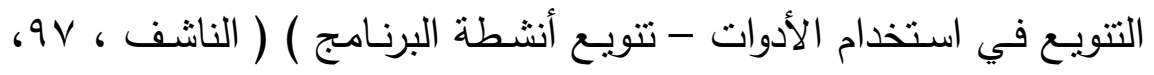

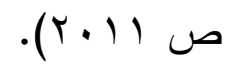

• الاتجاهات الحديثة : في بناء برامج الأطفال ذوي الإعاقة الذهنية.

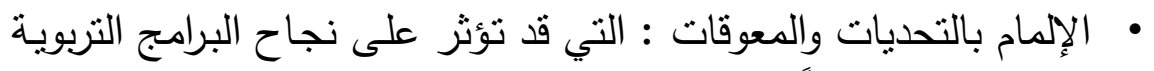
لبلأطفال المعاقين ذهنياً . ץ - تحديد الأهداف العامة للبرنامج في ضوء الهدف الرئيسي للبحث و هو " تتمية عملية التصيف باستخدام برنامج قائم على مدخل ريجيو الأيو إميليا ". r-تصميم البرنامجج : n ويتضمن البرنامج العناصر التالية :

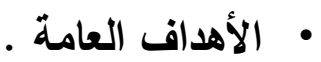

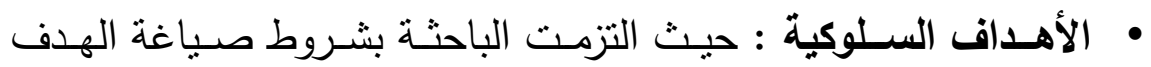

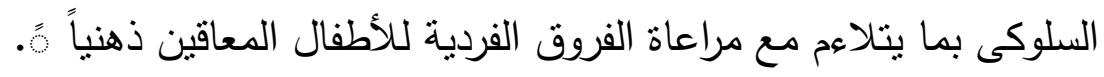

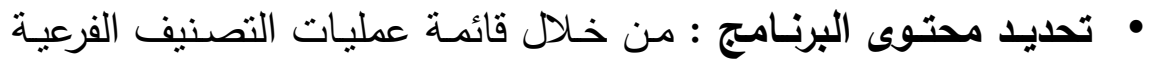
• الإسـتراتيجيات والطرق التدريسية المسـتخدمة في البرنـامج : حيث

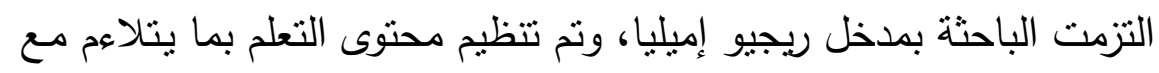

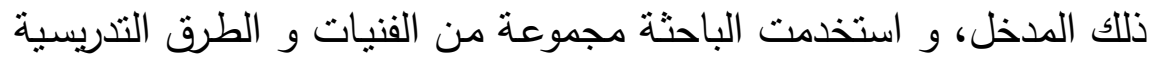

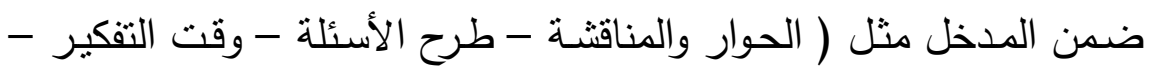




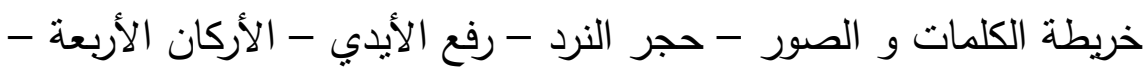

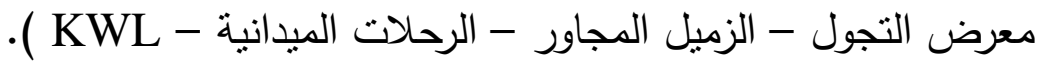

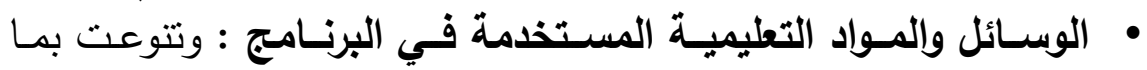

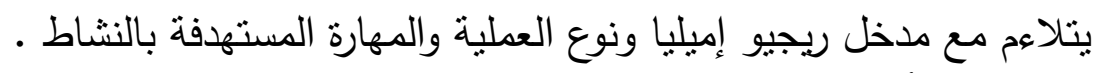

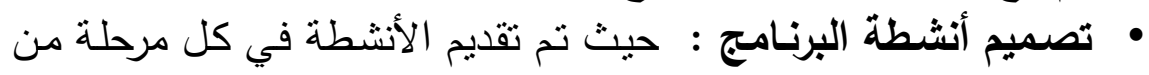

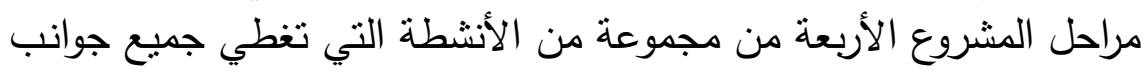

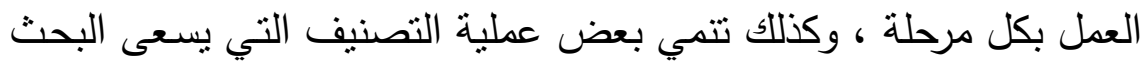

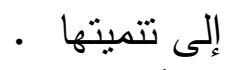
• أسـاليب التقويم المستخدمة في البرنـامج : تنوعت مـا بين التقويمات

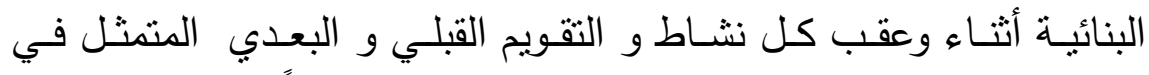

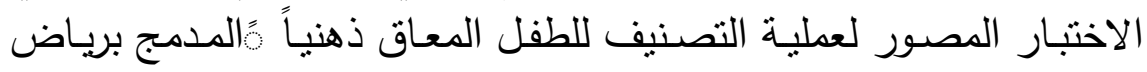
- الأطفال الأنبار المبنة • كيفية السير في البرنامج : نم إعداد دليل للبرنامج •

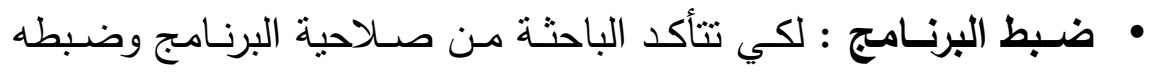
اعتمدت على : أنى

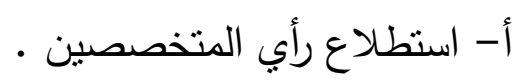
ب-إجراء التجربـة الاستطلاعية : قامـت الباحثة بتطبيـق بعض الأنشطة

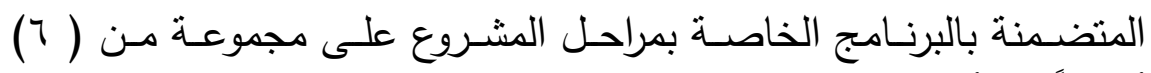

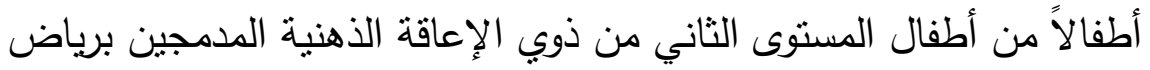

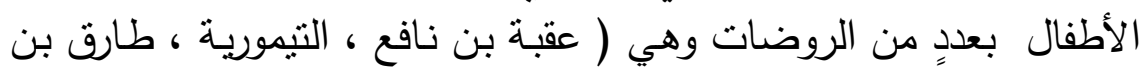

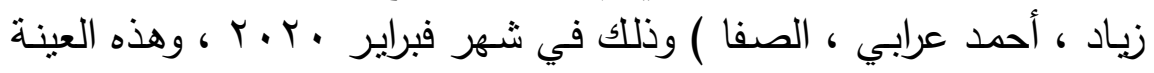

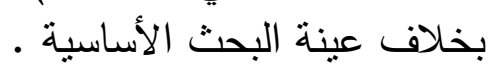
ج - إعداد اختبـار مصـور لقياس عمليـة التصـنيف للطفل المعـاق ذهنيـاً المدمج برياض الأطفال وفقاً للخطوات التالية: 
ا-تحديـ الهـف مسن الاختبـار : يهدف الاختبـار إلى قياس مدى تتمبـة

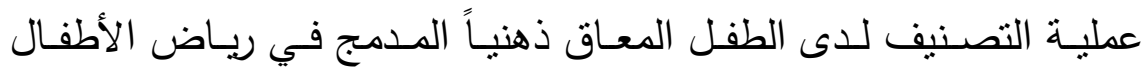
المقيدين بالمستوى الثاني ريـاض أطفال حيـث نسبة ذكائهم على مقيـاس

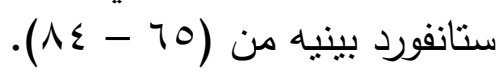

r -تحليل محتوى وحدات البرنامج وإعداد جدول المواصفات .

ب-بنـاء الاختبـار وتحديــ مفرداتـه مسن خـلال الإطـلاع علـى الاختبـارات

والاراسات التالية : ماءليات

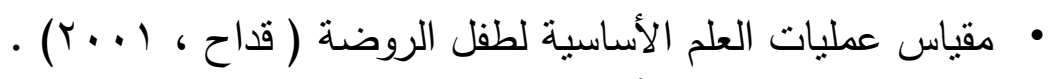
• اختبار عمليات العلم الأساسية.

Test of Basic and Integrated Process Skills (Miles , 2010) • اختبار عمليات العلم الأساسية .

Science Basic Process Skills Test (M.Mranan, 2017)

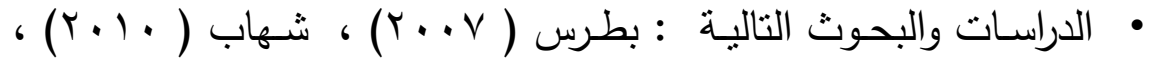

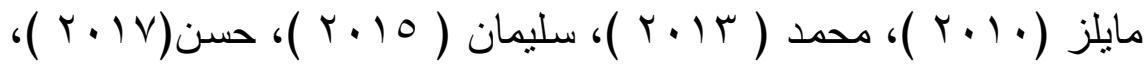

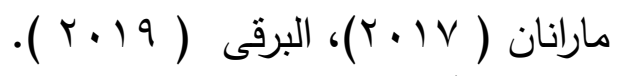
ع -صياغة مفردات الاختبار : في ضوء العمليات الفرعية للتصنيف التي تم تحديدها تم صـياغة عبارات مصـورة لقياس هذه العمليات الفرعيـة وتكون

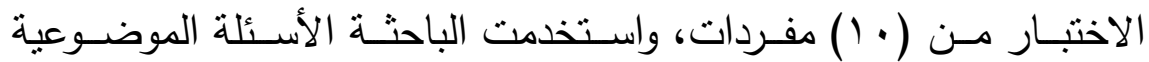

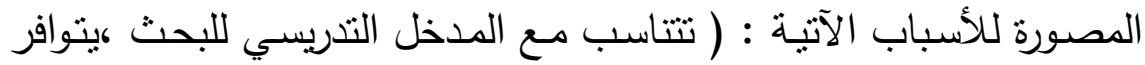
فيها عناصـر الموضـوعية والصـدق والثبات والتمييز ، تعطي صـورة دقيقة

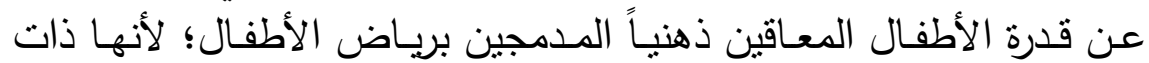

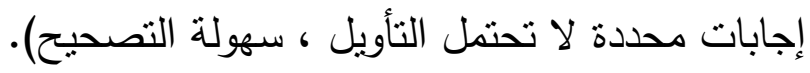
0-تقدير درجات الاختبار . 
ج-صسياغة تعليمـات الاختبـار : أعدت الباحثة مجموعـة مسن التعليمـات

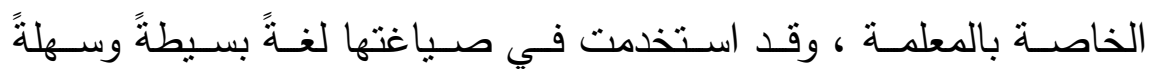
وواضحةً، وهذه التعليمات توضح للمعلمة كيفية عرض الاختبار على الطفل وحل وكيفية تسجيل درجات الطفل وحسابها.

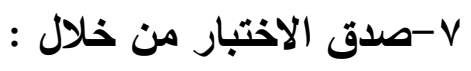

• الصدق الظاهري : وهو وضوح الهدف من الاختبار و وضوح مضمونه

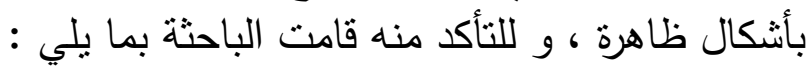

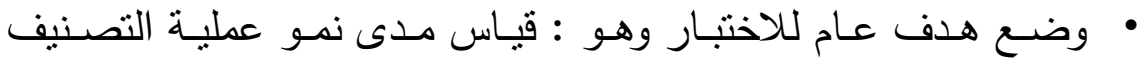

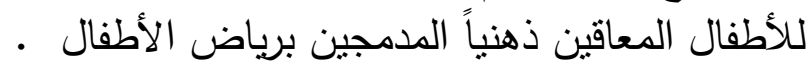
• مراعـاة صـياغة مفـردات الاختبـار موضـحة لعمليـة التصـنيف المُـراد

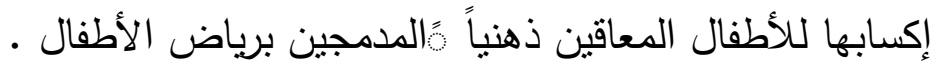
• صدق المحكمين : فقامت الباحثة بعرض الاختبار في صورته الأولية

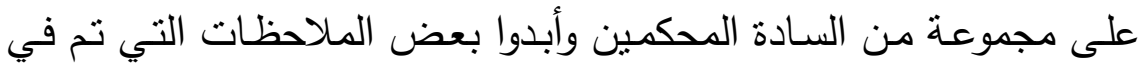

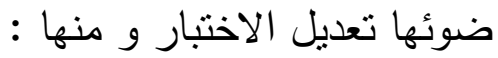

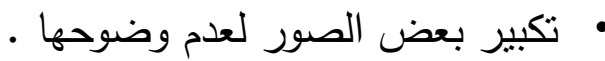

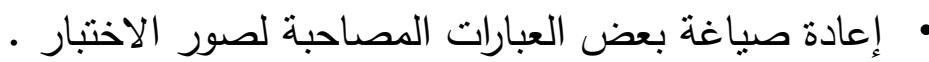
• صياغة العبارات بصيغة المفرد لأنها تطبق بصورةٍ فرديةٍ.

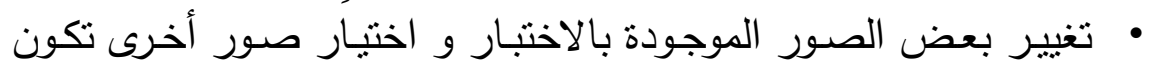
أكثر وضوحاً أمًاً 1-التجربة الاستطلاعية للاختبار بغرض تحديد : • حساب معامل ثبات الاختبار : استخدمت الباحثة معادلة كيودر ريتشارد

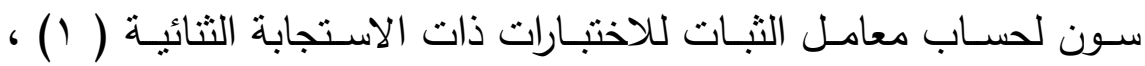
(صفر) لكل مفردة من المفردات ، و كان معامل ثبات كيودر ريتشارد سون 


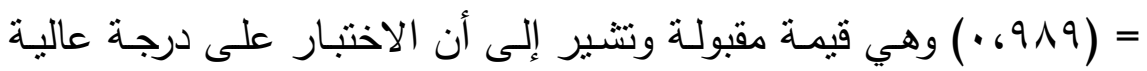
من الثبات.

• ســاب زمسن تطبيـق الاختبـار : ونظراً لأن الاختبـار مقدم للأطفال

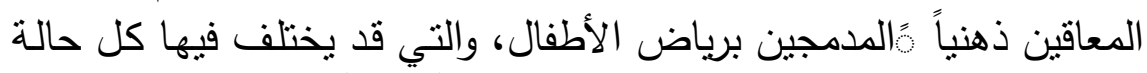

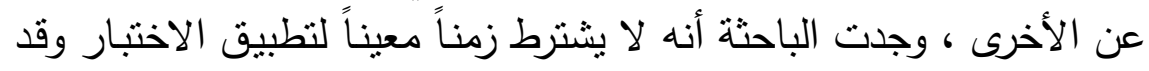

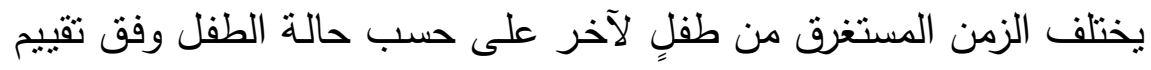

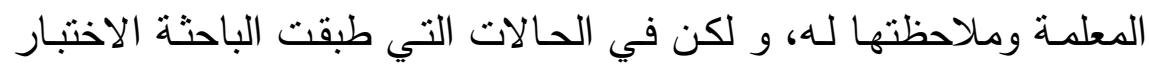

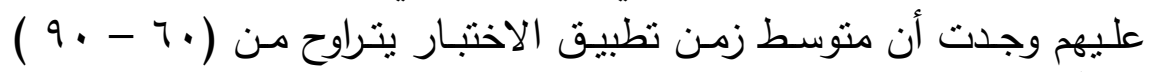

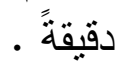

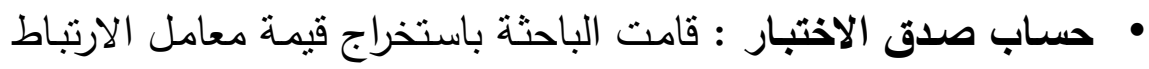

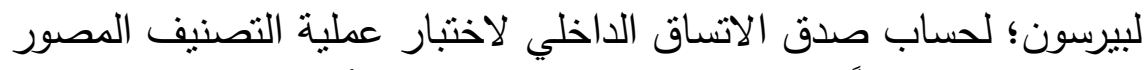

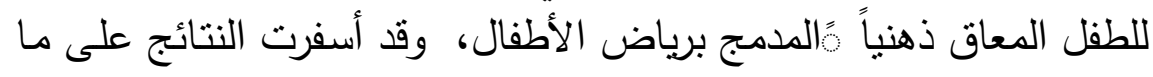

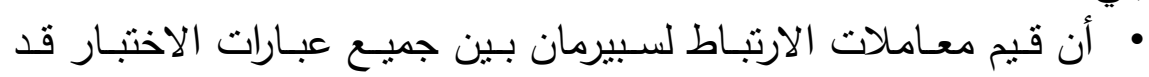

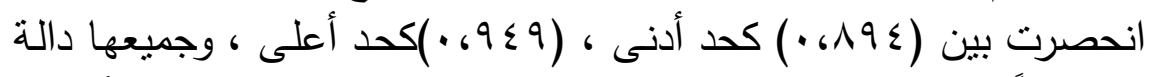

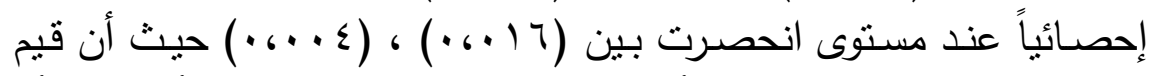

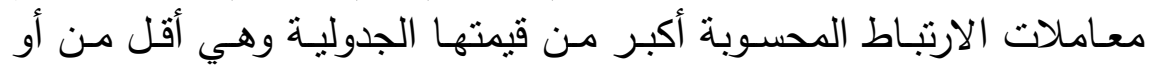
تساوى (0.، •) ، مما يدل على صدق الإتساق الداخلي للاختبار .

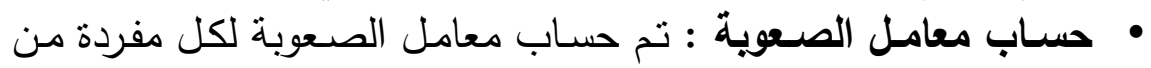

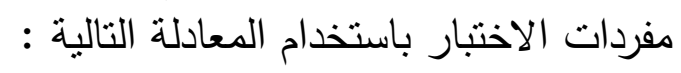

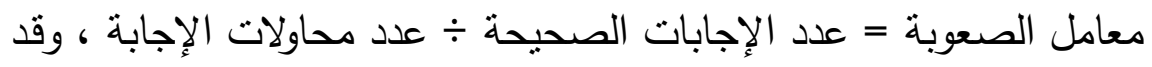

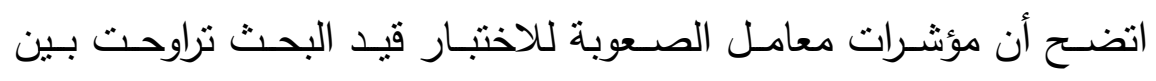

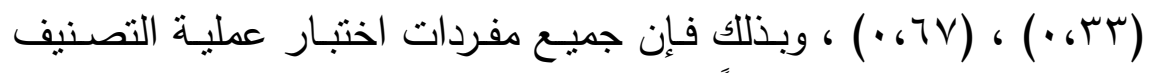

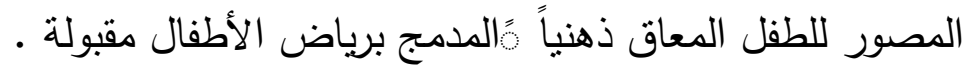


9-الصورة التهائية للاختبار : في ضوء النتائج التي قد تم الحصول عليها بعد تطبيـق التجربـة الاسـتطلاعية للاختبـار ، وبعد تقنينه بحسـاب صـدقه وثباته و إجراء التعديلات في ضوء آراء السادة الخبراء المحكمين ، توصلت بهات

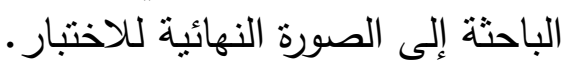

\section{د - البحث التجريبي : \\ - التصميم التجريبي :}

هدف البحث الحـالي إلى تتميـة عمليـة التصـنيف لدى الطفل المعـاق ذهنياً ًالمدمج برياض الأطفال القائم على مدخل ريجيو إميليا ، ولذلك استخدمت الباحثة تصميم المجموعة التجربيية الواحدة ذات التطبيق القبلي والبعدي ، واختارت الباحثة ذلك التصميم التجريبي؛ لاختبار أثز برنامج قائم على مدخل ريجيو إميليا ( متغير مستقل) على عملية التصنيف ( متغير

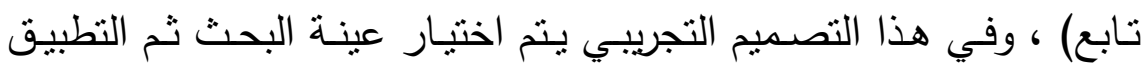
القبلي لأدوات البحث، و بعد ذلك يتم التطبيت البعدي للأدوات ، وبذلك يتم حساب الفروق و دلالتها بين التطبيقين القبلي والبعدي للمجموعة التجريبية ، بدوبية وتقييم مدى فعالبة البرنامج المُعَد باستخدام مدخل ريجيو إمبليا لتتمبة عملية

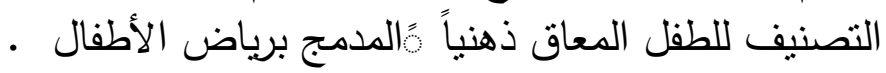
- تحديا أفراد البحث وضبط تجاتسها :

تم التوصـل إلى عينـة البحث مـن خـلال تحديد الأطفال ذوي الإعاقة

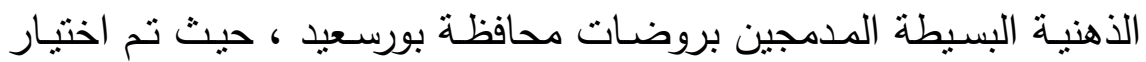
الأطفال المشخصين بأنهم إعاقة ذهنية بسيطة ، ثم قامت الباحثة بتطبيت

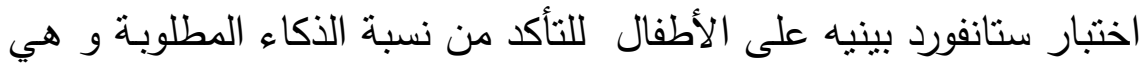

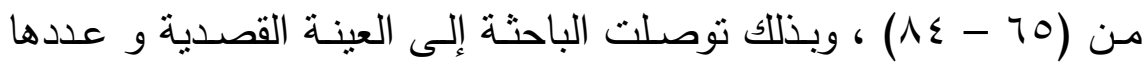




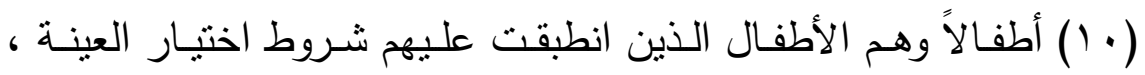
وراعت الباحثة تجانس العدر الزمني لهم حيث كانوا في المستوى الثناني من

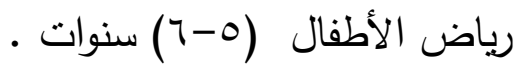
- إجراعات تنفيذ البحث :

بعد إعداد أدوات البحث و التأكد من صـدقها و ثباتها و صـاحيتها

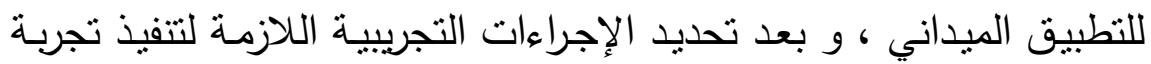

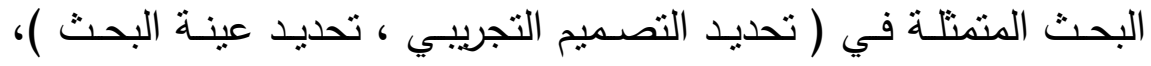
اتبعـت الباحثـة الخطـوات الآتيـة فـي إجـراءات تتفيـذ البحـث ( المعالجـة - التجربيبة)

أولاً : إجراءات قبل تطبيق البرنامج و تتضمن : - التطبيث القبلي لأدوات البحث . - إعداد قاعة التطبيق ثانياً : إجراءات تطبيق البرنامهج :

بدأت التجربـة من منتصف شـهر سبتمبر واستمرت لمدة خمس أسـابيع و طبقت الباحثة البرنامج لكل طفلين على حدى بواقع ( 7 ) أبام أسبوعياً للطفل في الأسبوع الواحد ، واستخرق الطفل الواحد م أسـابيع للانتهاء من

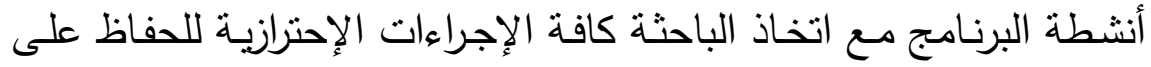

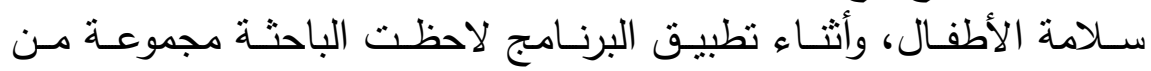

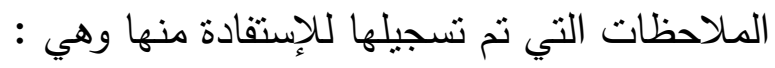

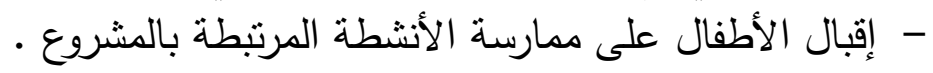

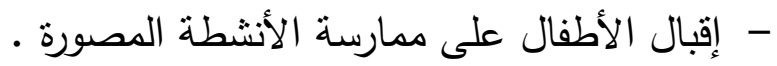




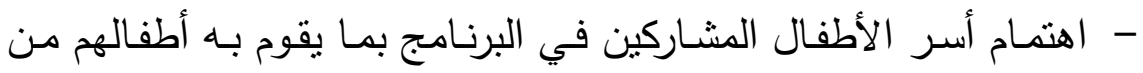

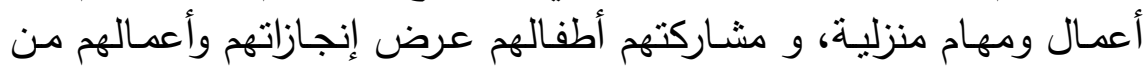

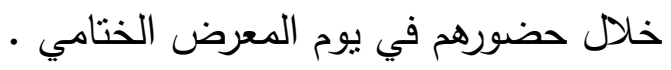

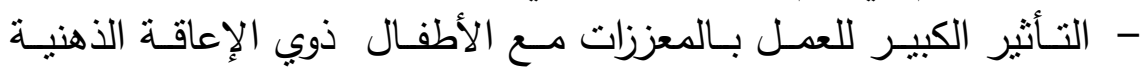
البسيطة؛ و ذللك للإستجابة لتنفيذ التعليمات و الأوامر .

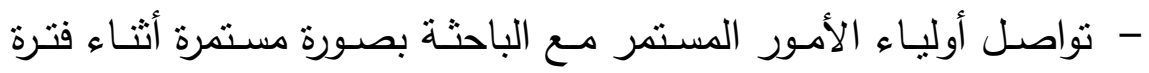

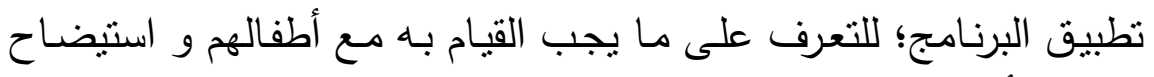
بعض الأنشطة المنزلية . لمنامك

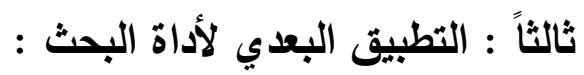

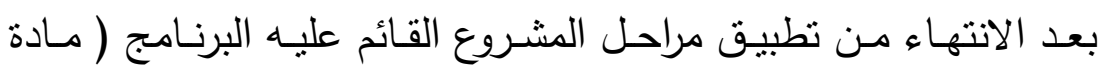

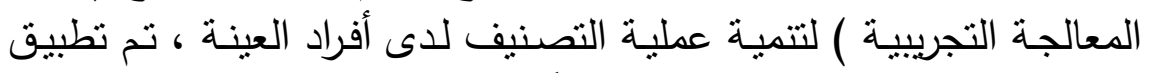

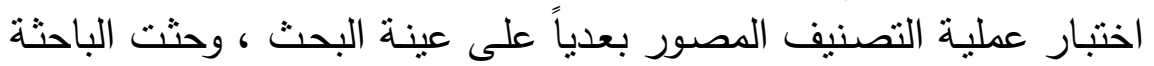

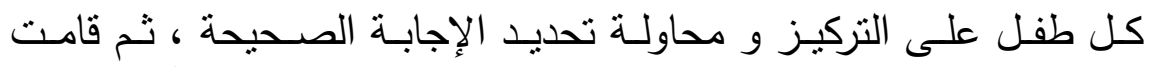

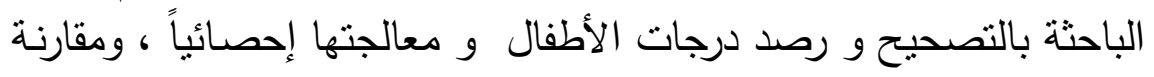
التطبيـق البعدي بـالتطبيق القبلـي لكـلا الاختبـارين ، ثـم مناقثــة النتـائج واختبار صحة الفروض و تفسيرها. الأساليب الإحصائية المستخدمة :

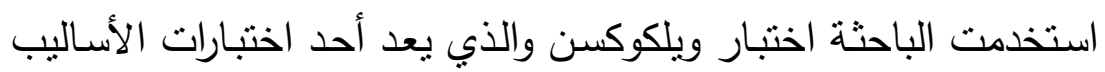

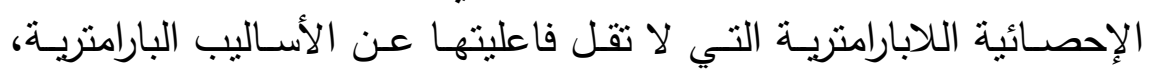

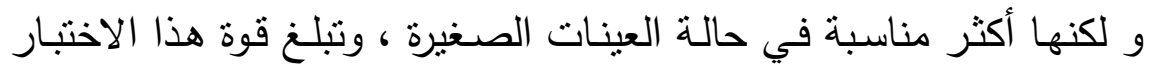

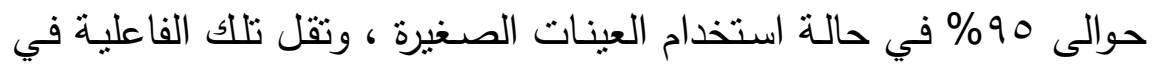
حالة العينات الكبيرة . 
نتائج البحث :

اختبار صحة الفرض الأول:

ينص الفرض الأول على أنه:

" يوجد فروق ذات دلالـة إحصائية عند مستوى (ع • ، · ) بين متوسطي

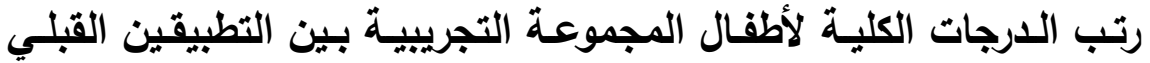
والبعدي على اختبار عمليـة التصنيف المصدور للأطفـال ذوي الإعاقة الأهنية المدمجين برياض الأطفال لصالح التطبيق البعدي ".

وللتحقق من صحة هذا الفرض استخدمت الباحثة اختبار رتب الإشارة لوبلكوكسون لدلالـة صحة الفروق القياسين القبلي و البعدي لاختبار عملية التصنيف ، و يوضتح الجدول التالي ما توصلت إليه النتائج :

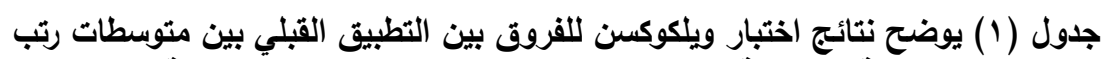

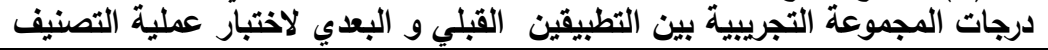

\begin{tabular}{|c|c|c|c|c|c|c|c|c|c|}
\hline \multirow{2}{*}{ مستوى الدلاية } & \multirow{2}{*}{ قيمة Z } & \multicolumn{2}{|c|}{ مجموع الرتب } & \multicolumn{2}{|c|}{ متوسط الرتب } & \multicolumn{2}{|c|}{ عدد الرتب } & \multirow{2}{*}{ وحدة } & \\
\hline & & + & - & + & - & + & - & & \\
\hline$\cdot, \cdots \varepsilon$ & $r, \wedge \leqslant \wedge-$ & $00, \ldots$ & صفر & $0,0$. & صفر & 1. & صفر & الدرجة & التصنيف \\
\hline
\end{tabular}

ويتضــح مـن الجـدول السـابق وجـود فرق دال إحصـائيا مَعند مسـتوى

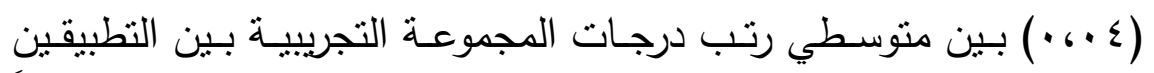
القبلي و البعدي لاختبار عملية التصنيف المصور للأطفال المعاقين ذهنياً المدمجين برباض الأطفال لصالح التطبيق البعدي ، حيث أن قيمة (z) 


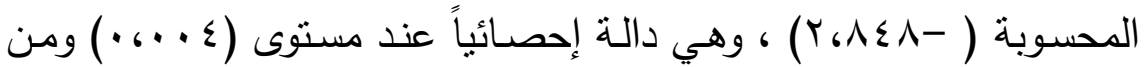
ثم يتضح صحة الفرض الأول. تفسير و مناقشة التتائج المتعلة بالفرض الأول:

أظهرت نتيجة صحة الفرض الأول وجود فرق ذي دلالة إحصـائية عند مستوى (ع · . • ) بين متوسطي رتب درجات أطفال المجموعة التجريبيـة بـين التطبيقين القبلي و البعـدي على اختبـار عمليـة التصـنيف المصـور للأطفال ذوي الإعاقة الذهنيـة المدمجين برياض الأطفال لصـالح التطبيق

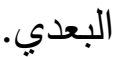

وقد ترجح الزبـادة في درجات أفراد المجموعة التجربيية للتطبيق البعدي لاختبـار عمليـة التصنيف المصـور للأطفال ذوي الإعاقة الذهنبـة البسيطة المدمجين برياض الأطفال إلى : الإنى ا-تضمين عملية التصنيف خلال مراحل العمل بالمشروع. r-استخدام فنيات تدربسية متتوعة تتمي عملية التصنيف في البحث. ب-تحديد دور كل من المعلمة والطفل خلال إجراءات المشروع لتتمية عملية

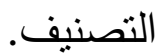
צ-تحديد عددٍ كافٍ من الممارسات لكل هدف فرعي على حدى. ه-الأنشطة المنزلية التي كان يؤديها الأطفال مع أولياء أمورهم في المنزل في كل نشاط أدى إلى تتمية عملية التصنيف . • اختبار صحة القرض الثاني: ينص الفرض الثاني على أنه: "البرنامـج المقترح القائم على مدخل ريجيو إميليا فعال في تنمية عمليـة

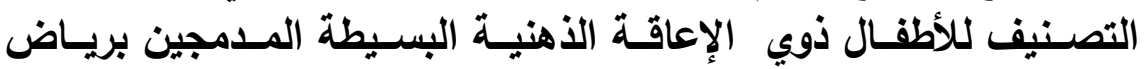


الأطفال " ، وتم التأكد من الفعالية من خلال استخدام معادلة حجم الأثر

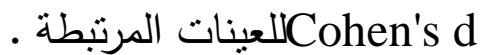

\section{قيمة فرنبطه

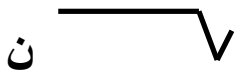

حيث Z هي قيمة Z الناتجة من اختبار ويلكوكسون ، ن هو عدد أفراد

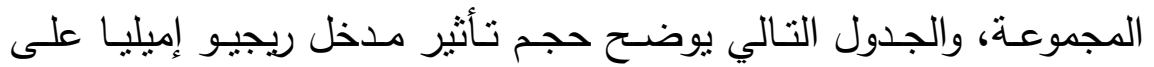
عملية التصنيف . جدول (ץ) يوضح حجم التأثير لاستخدام مدخل ريجيو إميليا لتنمية عملية التصنيف للأطفال المعاقين ذهنياً المدمجين برياض الأطفال

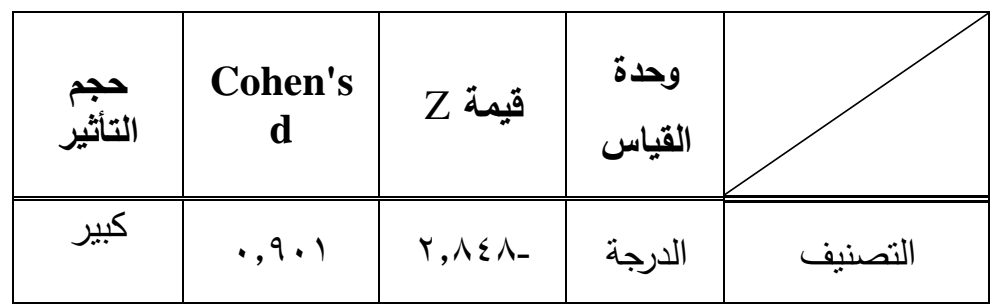

ويتضح من الجدول السابق أن قيمة حجم التأثير تساوي (•9، • · بالنسبة

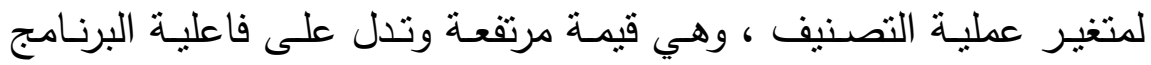

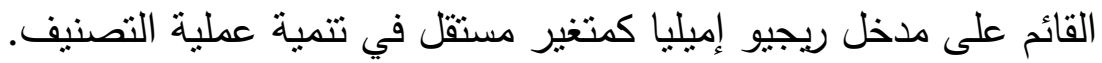
تفسير ومناقشة النتائج المتعلقة بالفرض الثاني: أظهرت نتائج اختبار صحة الفرض الثاني ما يأتي :

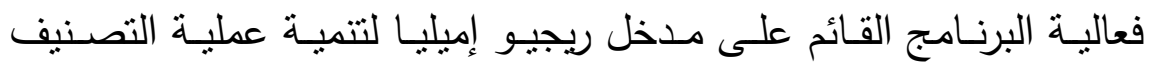

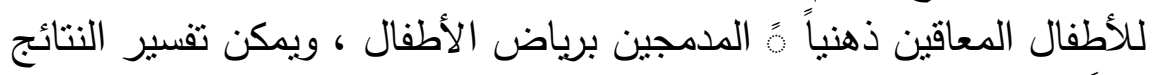
وفقاً لما يلي: 
ا-وجود علاقة ارتباطية بين مدخل ريجيو إمبليا وتتميـة عملية التصنيف لكأطفال المعاقين ذهنياً المدمجين برباض عاضة الأطفال.

r-استخدام الباحثة لفنيات تدربسية ساهمت في تتمية عملية التصنيف.

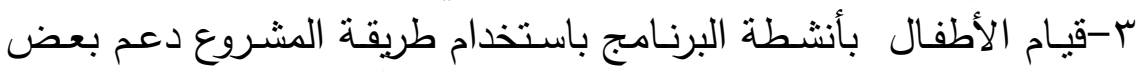

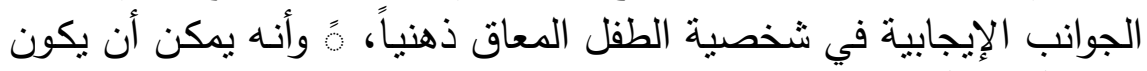

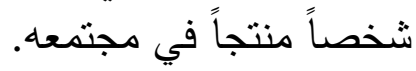
ع -استخدام الباحثة لأساليب التعزيز ، مما أثر إيجابيا في دافعية الأطفال للتعلم.

هذا وأوضـحت نتائج البحث أن البرنامج القائم على مدخل ربجيو إميليا كمتغير مستقل له تأثير كبير وفعال في تتمية عملية التصنيف المستهدفة في البحث الحالي ( كمتغير تابع) • توصيات البحث : في ضوء نتائج البحث الحالي توصي الباحثة بما يلي : ا ـ تضمين تعليم بعض عملية التصنيف في الأنشطة المقدمة للطفل ذوي

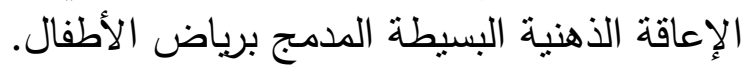

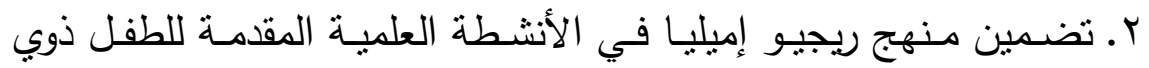
الإعاقة الذهنيـة البسيطة المدمجين برياض الأطفال، حيث تسـهم في تعلم الأطفال بصفةٍ عامةٍ و الطفل المعاق ذهنياً بصفةٍ خاصة.

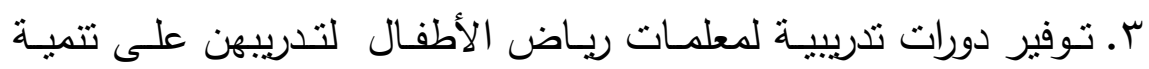

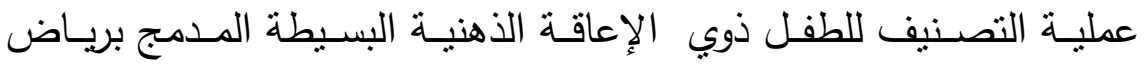
الأطفال. 
ع. توفير دورات تدريبية لمعلمات رباض الأطفال لتدربيهن على استخدام مـنهج ريجيـو إميليـا لتنميـة عمليـة التصـنيف للطفـل ذوي الإعاقـة الذهنيـة البسيطة المدمجين برياض الأطفال.

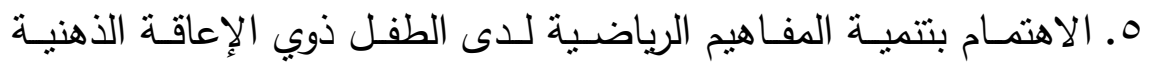
البسيطة من خلال استخدام منهج ريجيو إميليا. 7 ـ ضــرورة تـوفير بـرامج إرشـادية متخصصـة لأوليـاء أمسور الأطفـال ذوي

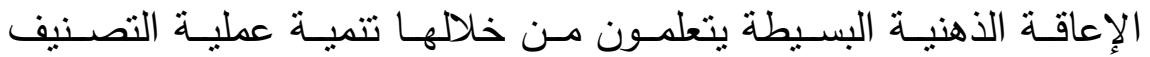
لأبنائهم.

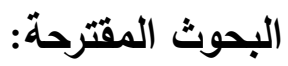
تقترح الباحثة بعض البحوث المستقبلية كما يلي: ا ـ برنامج تدربيي لمعلمات الروضـة لتتمبة عملية التصنيف للطفل المعاق ذهنياً المدمج برباض الأطفال باستخدام منهج ريجيو إميليا. r ـ تتميـة عمليـة التصـنيف للطفل ذوي الإعاقة الذهنيـة البسيطة باسـتخدام الحقائب التعليمية. م. برنـامج إرشـادي لأوليـاء أمـور الأطفـال ذوي الإعاقـة الذهنيـة البسـيطة المدمجين برياض الأطفال لتتمية المفاهيم العلمية والرباضية باستخدام منهج الإهي ريجيو إميليا. ع. برنـامج كمبيوتري قائم على الألعاب التعليميـة لتتميـة عمليـة التصنيف

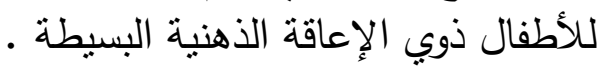




\section{المراج?}

\section{أولاً : المراجع العربية:}

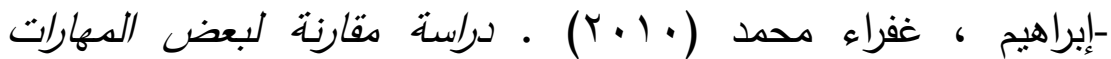
الإجتماعية لدى الأطفال المعاقبن عقليًا القابلبن للتعلم بددارس الدمج و دواسه

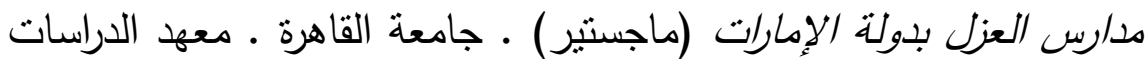
التربوبة.

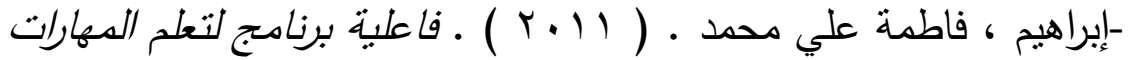
اللغوبة في ضوء مدخل الذكاءات المتعددة في تنمبة الكفاءة الاجتماعية للى

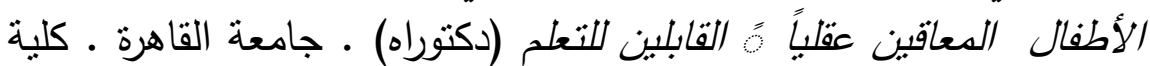
الدراسات العليا.

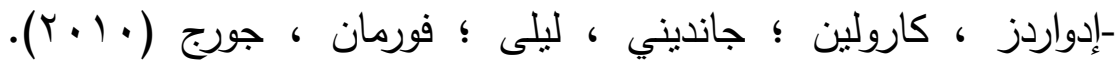
الأطفال ولغاتهم المئة مدخل ريجيو إمبليا تنأمالت متطورة ـ ( ترجمة ليلى كرم الدين ، مراجعة علي عاشور الجعفر ) . الكويت : الجمعية الكويتية لتقدم الطفولة العربية.

-البرقي ، إيمان فؤاد محمد (19 ( I ) ) . تتمية بعض مهارات العلم و الاتجاهات العلمية لدى طفل الروضة باستخدام أنشطة STEM .

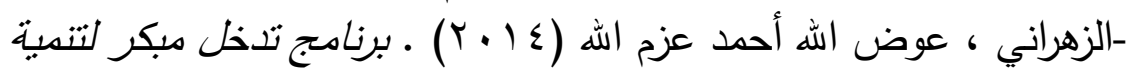
بعض المهارات اللغوبة لدى الأطفال ذوي الإعاقة العقلية المصحوبة بالثلل الدماغي (ماجستير) • جامعة عين شمس • كلية التربية.

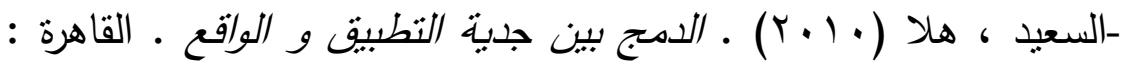
دار الأنجلو المصرية. 


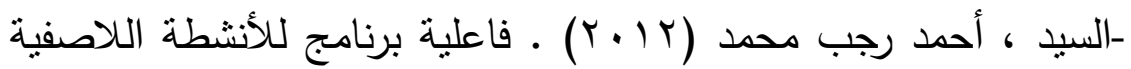

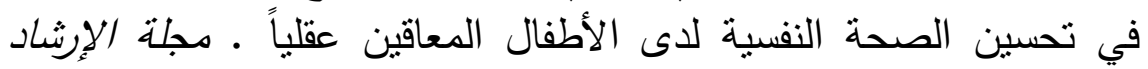

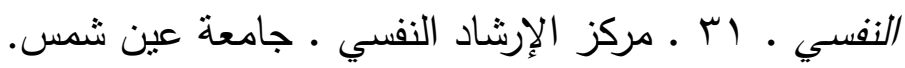

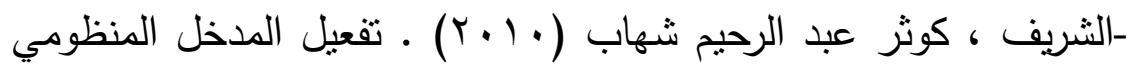

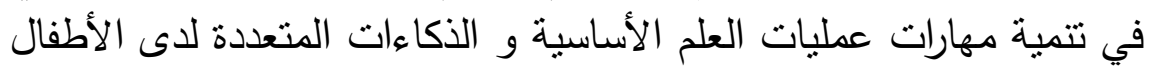

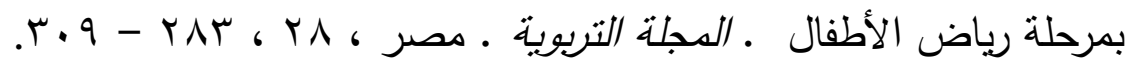

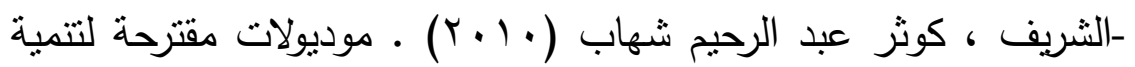

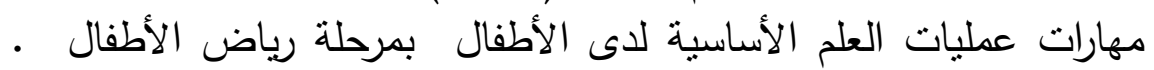

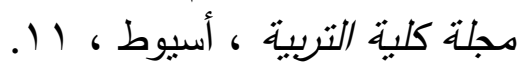

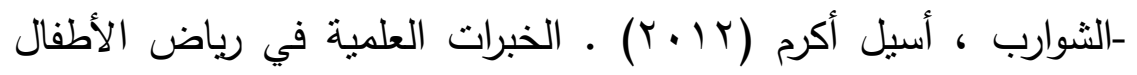

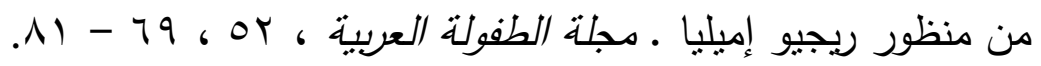

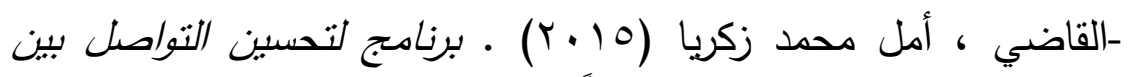

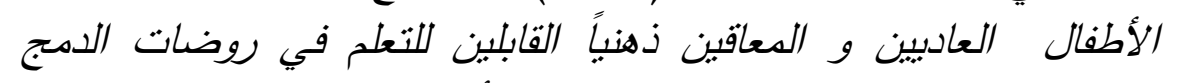

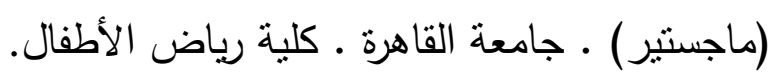

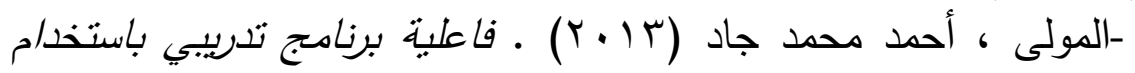

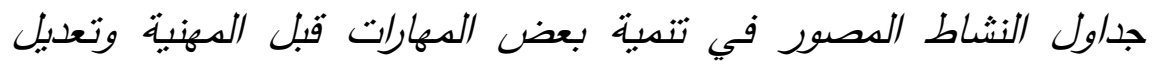

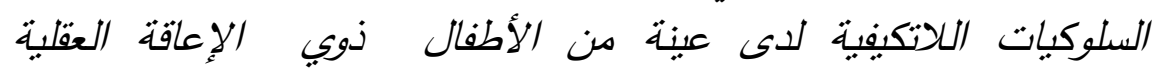
(دكتوراه). جامعة عين شمس ـ كلية التربية.

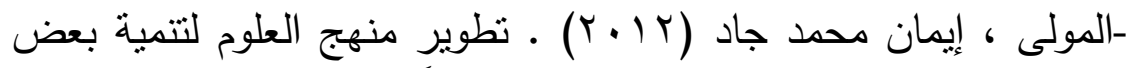

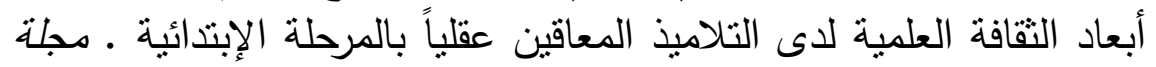

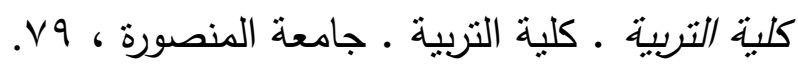

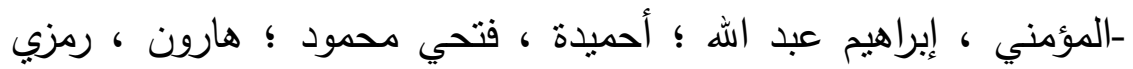

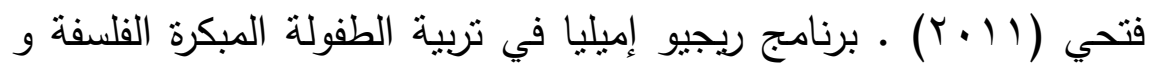


المباديء و التضمينات التربوية ـ مجلة دراسات العلوم التربوية ـ الأردن ، م

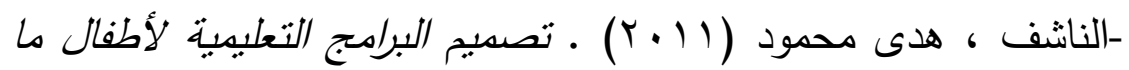
قبب المدرسة ( الطبعة الثانية) ـ القاهرة : دار الكتاب الحديث. .

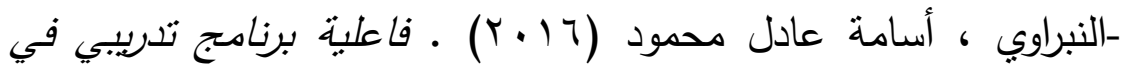
تحسبن قراءة العقل وأثره على الكفاءة الاجتماعبية للى الأطفال ذوي الإعاقة العقلية البسبطة (دكتوراه) . جامعة بنى سويف ـ كلية التربية.

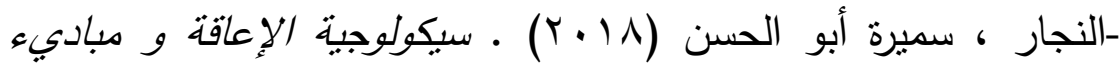
التربية الخاصتة ـ جامعة القاهرة ـ معهد الدراسات التربوية.

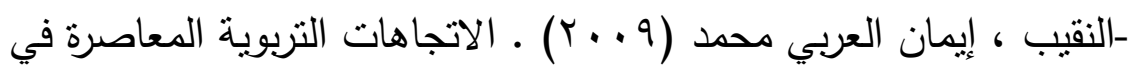
تربية طفل رياض الأطفال تجربة ريجيو إميليا في إيطاليا . مجلة كلية

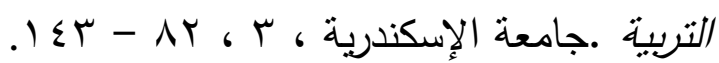

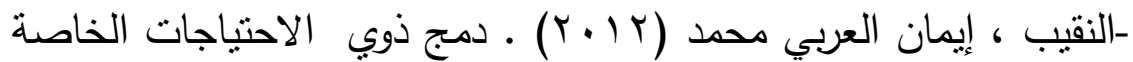

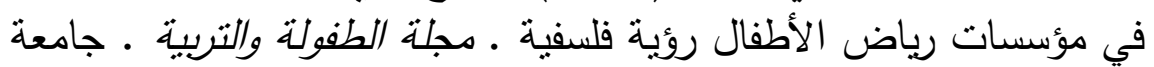
الإسكندرية ، مؤسيات 11

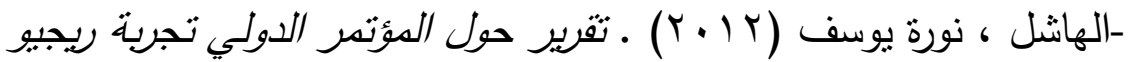

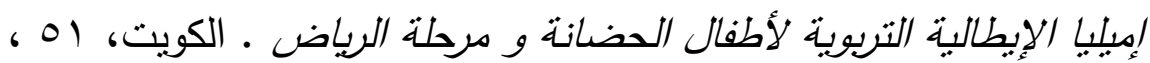
$.1 .-19$

-بدر، إسماعيل ( • ( • ب). مهارات السلوك التكبفي لذوي الإعاقة العقلية . الرياض : مكتبة الزهراء للنشر والتوزيع.

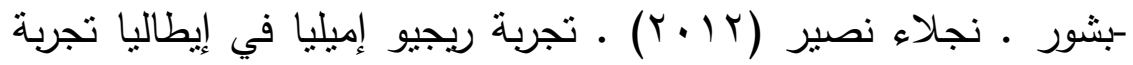

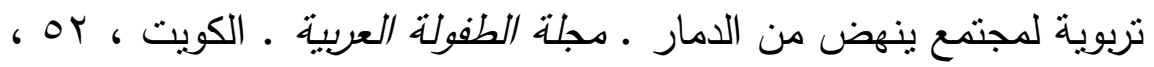
.1. - - 19 


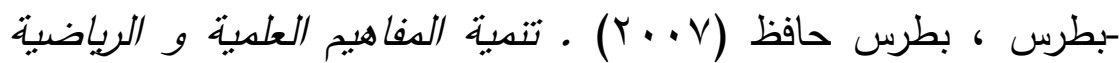
لطفل الروضة ـ ـ عمان : دار المسيرة. -بطرس ، بطرس حافظ (9 ، . ب ) ) سيكولوجية الدمج في الطفولة المبكرة . عمان : دار المسيرة للنشر .

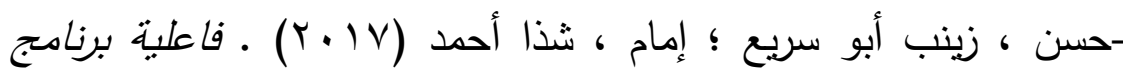

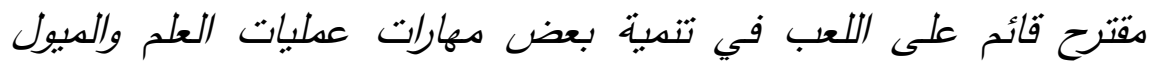

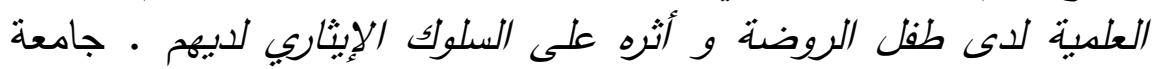
حلوان ـ كلية التربية.

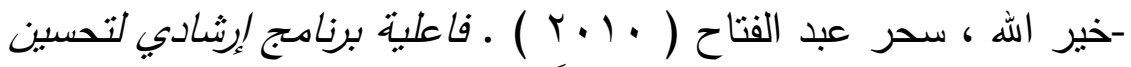

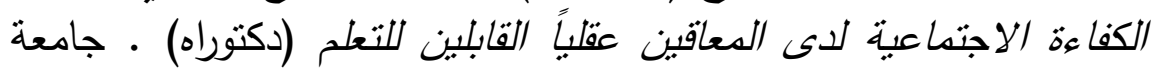
بنها ـ كلية التربية.

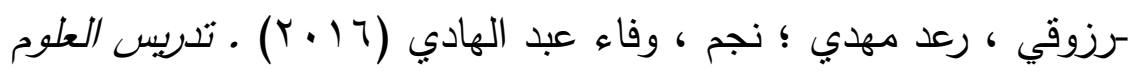

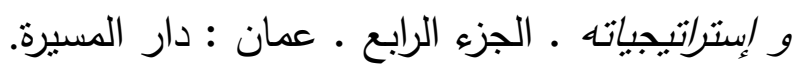

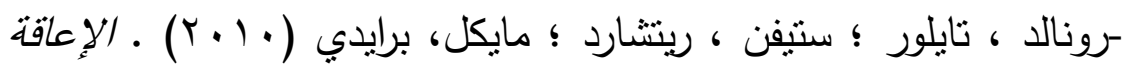

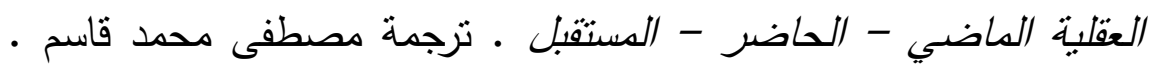
عمان : دار الفكر ناشرون و موزعون.

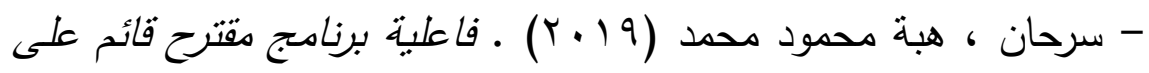

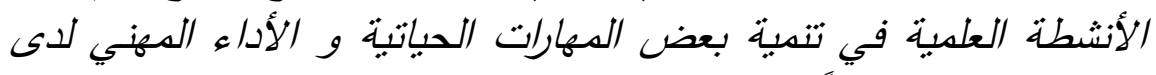

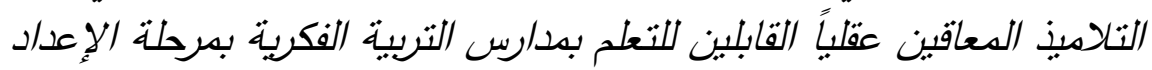

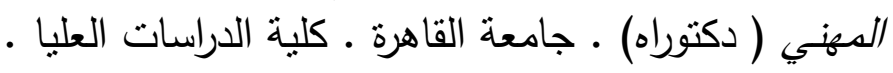




\section{ثانياً : المراجع الأجنبية:}

- Abd el Fattah . Marwa . (2014) . Realizing a progressive pedagogy a comparative case study of two science Reggio Emilia preschool in San Francisco. Published M A Thesis. Stanford University . From http://catalog . Stanford . Edu / view /10670122 .

- Akben , N , (2014) . Impoving Science Process Skills in science and technology course activities using the inquiry method. International Resaearch. Journal of Library and Information Science . India vol.

- AlGhofail.Jawaher.(2015). Reggio Emilia Study Tour. Arab Childhood Journal. Kuwait 64

- Ardejewska , Kathie , Coutts Pamela . (2013). Teachers who support Reggio - Exploring Their under standings of the philosophy . Australian Journal of Early Childhood . 29 . P.P. 17-23 .

- Baxter , Christian . (2010) . Making connections early childhood teachers re - creat meaning contextualizing Reggio Emilia pedagogy . Master's . Retrieved from proquest dissertations and theses available at : http://www.research online . Mq. Edu $\mathrm{au} / \mathrm{vita} / \mathrm{acces} /$ servies/download/mq:8/ds3. 
- Bower , Jaclyn Morris . (2014) . Montessori Method and Reggio Emilia approach and science in kindergarten compared and contrasted . Research Starters Education 2 From ( www.young childrens learning . Ecsd . Net) .

- Brown , Karr . (2011) . The Reggio Emilia Approch. (p.p. 1-1) . Great Neck Publishing.

- Burns , Marcia V.lewis Alishal . (2016) . How the project approach challenges young children . Gifted Child Today, V 39 n 3 p 140-144.

- Buyuktaskapu , S. , Celikoz , N. \& Akman , B. (2012) .The Effects of constructivist sciece teaching program on scientific proseccing skills of 6 years old children . Eduction and Science . 37 (165) . P. P. 275-292 .

- Chung - Hee , C. (2010) . The Effects of Science Activities using nofication literature on preschool children's scientific process skills . Attitudes and comcepts , Korean Journal of child studies , 31 . P.P. 167-191 .

- De Kock , Jill . (2015) . Science in early children a prrogram inspired by Reggio Emilia Approach . ACE papers . 30 . P.P. 117-133 From http://www.research gate .net/ publication /229901424 .

- Dijana, Hristovska, Snezana Javanova - Mitkovska, practical. (2010). Strateguies to improve learning and 
Achievements of pupils with special educational needs in Elementry school. Social and Behavioral Sciences . Vol . 2. I .2.Issue2 .p.p.2911 - 2916 .

- Galini , Rekalidou\& Efthymia , Penderi . (2010) . Acollaborative Action Research Project in the kindergarten perspectives and challenges for teacher development through evaluation process . New Horizons Education . Oct 2010 . Vol . 58 Issue 2 , P . P. 18-33

- 18-33

- Gandinin , Lio . (2012) . Foundations of the Reggio Emilia Approach in J.Hendric (Ed) Next steps toward teaching the Reggio way accepting the challenge to change (2nd ed) . P.p.13-26 . Upper Saddle River . N.J .person/ Merill/ prentice . Hall . Available at : http://www.pearson highered .com /program/HendrickNext-Steps- Toward-Teaching- the Reggio - way accepting.

- Glassman , Michael, Whaley , Kimberlee. (2013). Dynamic Aims. The use of long term projects in early childhood classroom in light of Reggio Emilia's Educational philosophy . Child development . 2From : http://ecrp.illinois.edu/v2nl/index.html .

- Hall, Claire .(2013) . Implementing a Reggio Emilia Inspired Science. The Impact on Early Childhood 
Teachers professional role. Published. M A thesis. Edith Cowan University . Perth Austra lia . From http://ro.ecu.edu.au/theses//1082/

- Hendrick , Joanne. (2012) . Reggio Emilia and American schools telling them apart and putting them togeather-can we DO IT? INJ. Hendrick ED.NEXT steps towards teaching the Reggio Way . 2nd . Ed . P.p.p. 3849. Upper Saddle RIVER .Pearso Merrill Prentice Hall from http://www.paper back swap.com/next-step-towardjoanne-hendrick/book/013049657/

- Huppert , J. s. Michal Lomask \& R . Lazawitz . (2010) . Computer Simulations in the high school : students cognative stages. Science process skills and acadimic achievment in microbiology. International Journal of Science Education .24/8. P. P. 803-821

- Hutchings, Lynn, V. olser, Richard . (2008) . A School Design to support the enclusion of student with disablilties. New Jerrsy . Councel on Developmental Disablities . P . 19 .

- Idiege, Kimson Joseph, Ja, Cecilia, Ugwu .(2017) . Development of Science Students and pupils. An oppinion Internatiuonal Journal of Chemistry Education Vol . (2) . P.P 13-21 . 
- Kuru , N . , \& Ahman , B . (2017) . Examining The Science Process Skills of preschoolers with regards to teachers and children variables . Education and Science, 42 . P .P . 269-279 .

- M. Maranan, Vernique . (2017) . Basic Process Skills and attitude toward science to an enhanced student cojnitive performance. Laguna State Polytechnin University . Sanpablo city campus . Master .

- Malaguzzi ,L .(1998 a) . History, ideas and philosophy . Inc . Edwards, L .Gandi , G . For - man (Eds). The hundred languages of children : The Reggio Emilia approach to early child hood education. Advanced reflections .(2nd ed). Nor Wood, NJ : Ablex Publishing . - Miles ,Erin . (2010) . In-Service Elementary teachers familiarty interest conceptual knowledge, and performance on science process skills . Master . Southern Linois University Carbondale. 

فاعلية برنامج تدريبي قائم على استخدام القصص في تنمية مهارة الدافعية للإنجاز لاى أطفال الروضة

* أ.د / كمال الدين حسين محمد حسين.

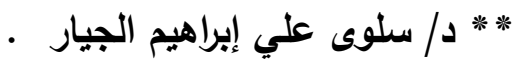

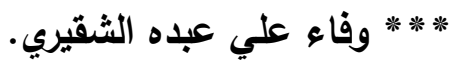

ملخص البحث :

يهدف البحث إلى التحقق من مدى فاعلية برنامج تدريبي قائم على استخدام القصص في تتمية مهارة الدافعية للإنجاز لدى أطفال الروضـة ، اعتمـد البحث على المنهج شبـه التجريبي القائم على المجموعـة الواحدة وتضمنت عينة البحث ( 10 ) طفلاً وطفلةً بالمرحلة العمرية من (0- 1 ( 1 ) سنوات من الذكور والإناث بالمستوى الثاني( kg2 ) بأكاديمية Rainbow Kids البحــث الحـالي : مقيـاس الدافعيـة للإنجـاز (إعـداد الباحثـة)، البرنـامج

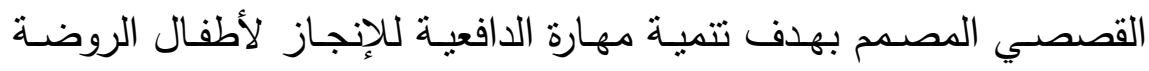
( إعداد الباحثة ) • وتوصلت نتائج البحث إلى أنه: توجد فروق ذات دلالة إحصـائية بـين متوسـطي رتب درجـات أطفـال الروضــة ( عينـة البحـث

* أستاذ الأدب المسرحي والدراسات الثعبية - كلية التربية للطفولة المبكرة - جامعة القاهرة. * * مدرس الإعلام وثقافة الأطفال - كلية التربية للطفولة المبكرة - جامعة بورسعيد.

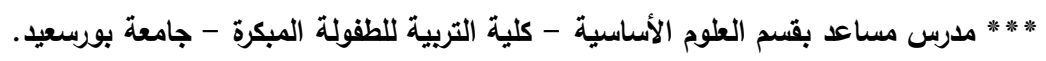


التجريبيـة ) على مقيـاس الدافعيـة للإنجـاز لأطفـال الروضـة مـن (0-7) سـوات فـى القياسـين القبلـي والبعـدي للبرنـامج التـدريبى لصـالح القيـاس البعدي،لا توجد فروق ذات دلالــة إحصـائية بـين متوسطي رتب درجـات أطفال الروضــة ( عينـة البحث التجريبيـة ) على مقياس الدافعيـة للإنجاز لأطفال الروضة من (0-7) سنوات فى القياسين البعدي والتتبعي للبرنامج التدريبي ، ممـا يـلـ على فاعليـة البرنـامج التـدريبي القـائم على استخدام

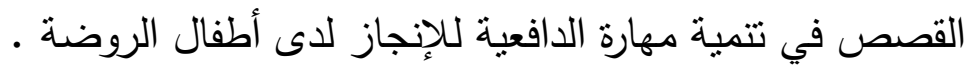
The effectiveness of a training program based on the use of the motivation to achieve achievement among a sample of kindergarten children

Prof. Dr. Kamal El-Deen Hussein Mohamed Kamal. *

Dr. Salwa Ali Ibrahim El. Gayyar. **

Wafaa Ali Abdo El- Shokery. ***

\section{Abstract:}

The aim of the research is to verify the effectiveness of a training program based on the use of stories in developing the skill of motivation for achievement among kindergarten children. The research relied on the semi-

* Professor of Theatrical Literature and Popular Studies - Faculty of Early Childhood Education - Cairo University.

** Lecturer, of Media and Children's Culture - Faculty of Early Childhood Education - Port Said University.

*** Assistant Lecturer, Department of Basic Sciences - Faculty of Early Childhood Education - Port Said University. 
experimental approach based on one group. The research sample included (15) children in the age group (5-6) years of age. Male and female students at the second level (kg2) at the Rainbow Kids Academy in Port Said governorate, and the researcher used the following tools in the current research: The Motivation Achievement Scale (the researcher's preparation), the story program designed with the aim of developing the skill of motivation for achievement for kindergarten children (the researcher preparation). The results of the research concluded that: There are statistically significant differences between the average grades of kindergarten children (the experimental research sample) on the motivation to achievement scale for kindergarten children from (5-6) years in the pre and post measurements of the training program in favor of the post measurement, there are no significant differences A statistic between the average grades of kindergarten children (experimental research sample) on the achievement motivation scale for kindergarten children from (5-6) years in the post and tracer measurements of the training program, which indicates the effectiveness of the training program based on the use of stories in developing the skill of motivation for achievement among kindergarten children.

الكلمات المفتاحية Keywords:

Training Program

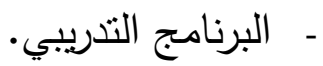




\section{Stories}

Motivation for achievement Kindergarten children

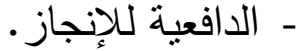

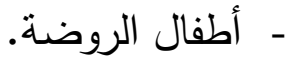

مقدمة: - مقا

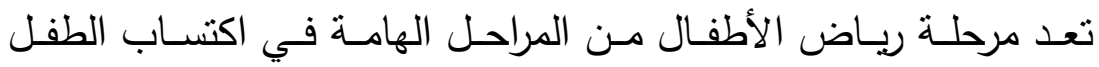

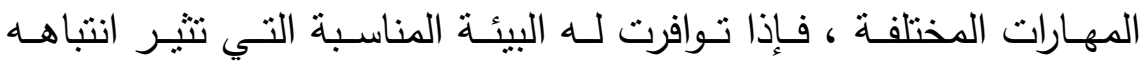

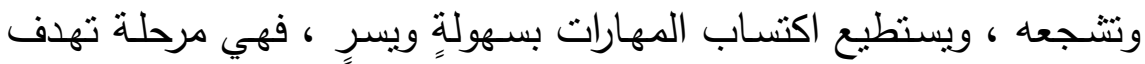

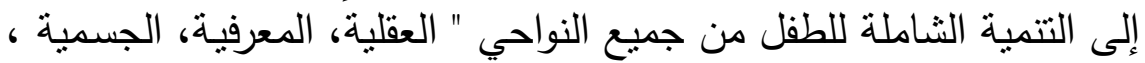
الحركية ، الانفعالية، الاجتماعية ، الخلقية".

وتعتبر الدافعية للإنجاز من المهارات الهامة التي يجب تتميتها في مرحلة

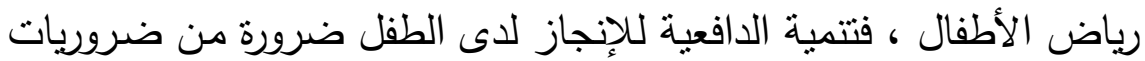

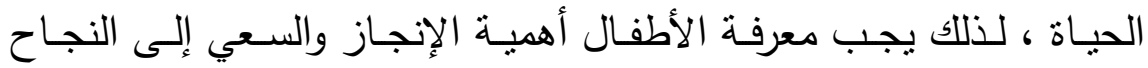
والمثنابرة لتحقيتق الأهداف ، فقدرة الطفل على الإنجاز بطريقـة صحيحة الإنة

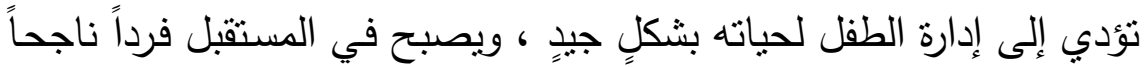

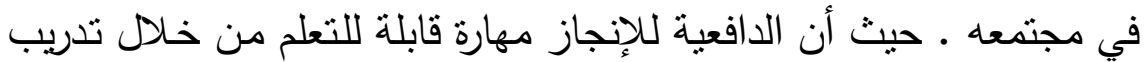

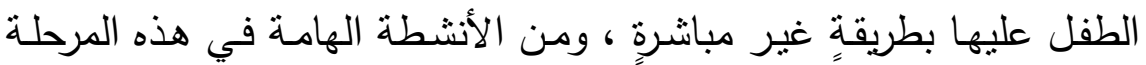
القصص حيث أنها تساعد على تتمية المهارات المختلفة. فالقصص من أكثر الأنشطة الممتعة للطفل ، فالقصة تعمل على تتمية

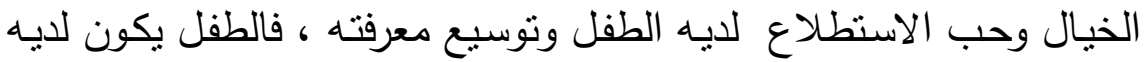

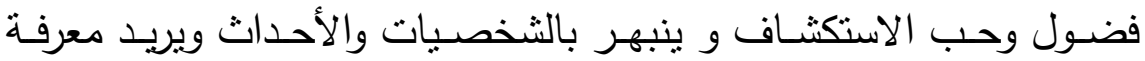

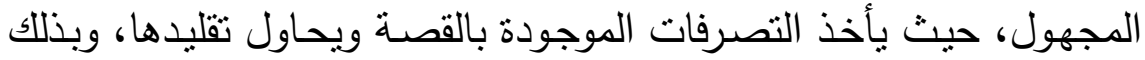
تتحسن قدرته على التواصل مع الآخرين والاندماج معهم ، وتدفعه للإنجاز 
مـن خـلال أفعـال الثخصـيات الموجـودة بالقصـة، ومـن هنـا بتضــح دور القصص في تتمية الدافعية للإنجاز لدى أطفال الروضة . ل

\section{مشكية البحث:}

بـدأ الإحسـاس بمشـكلة البحـث مـن خـلاه الزبـارات الميدانيـة المتكـررة

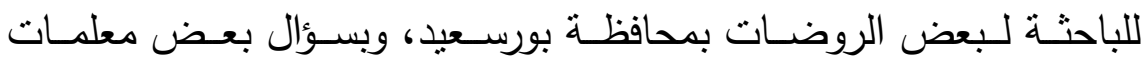
الروضة عن أهم المشكلات التي تواجهم عند التعامل مـع طفل الروضـة ،

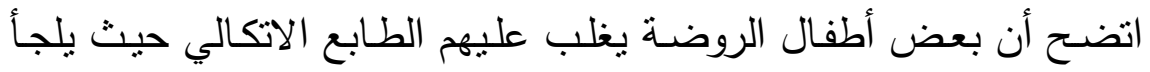

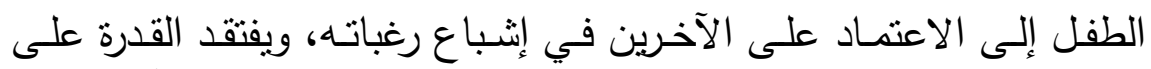

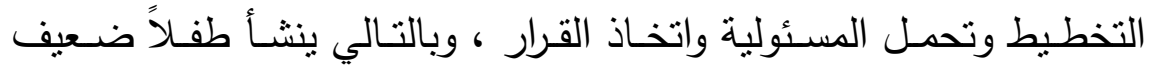
الشخصية غير قادراً على تحقيق أهدافه ، ويعتمد على الآخرين وخاصـةً

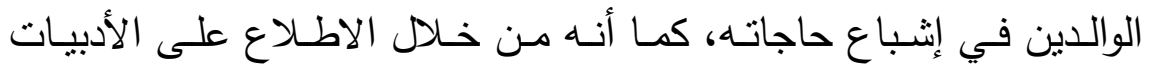

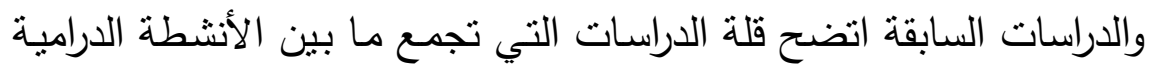
ومهارات السـوك القبادي لدى طفل الروضـة، وبذلك يمكن تحديد مشكلة البحث من خلال الاجابة عن السؤال الرئيس التالي:

مافاعلية البرنامـج التدريبي القائم على استخدام القصص لتنمية الدافعية

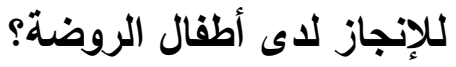

ويتقرع من هذا السؤال الرئيس سؤالين وهما :

ا - ما فاعلية البرنامج التدربيي القائم على استخدام القصص لتتمية الدافعية للإنجاز لدى أطفال الروضة r - ما التصور المقترح للبرنامج التدربيي القائم على استخدام القصص في تتمية مهارة الدافعية للإنجاز ؟ ماحج 
أهداف البحث:

استهدف البحث الحالي تحقيق ما بلي:

- التعرف على فاعلية البرنامج التدريبي القائم على القصص في تتمية

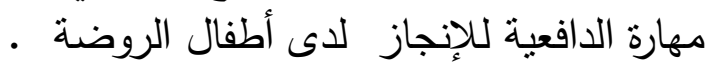
- تصميم برنامج مقترح لتمية بعض مهارة الدافعية للإنجاز لدى أطفال

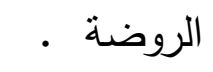
أهمية البحث: - 2 - 20 يمكن توضيح أهمية هذه البحث فيما بلي:

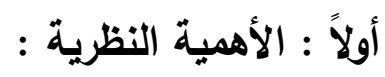

ا - يستمد هذا البحث أهميته في إظهار مدى أهمية القصص لأطفال الروضة في مرحلة هامة وحاسمة في حياة الطفل وهي مرحلة رياض

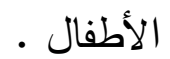
r- دعم المكتبة العربية بدراسة حول القصص و الدافعية للإنجاز في مرحلة رباض الأطفال دمال ثانيًا : الأهمية التطبيقية : ا - قد توجه البحث نظر العاملين والمتخصصين في مجال رياض الأطفال

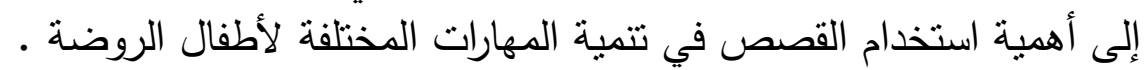

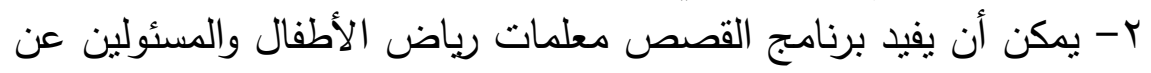
إعداد وتربية الأطفال في استخدام وسائط تعليمية جديدة .

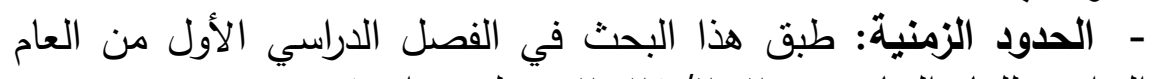

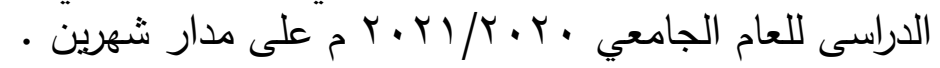


- الحدودالمكانية : طبق هذا البحث ضمن البرنامج اليومي في قاعات حضانة Rainbow Kids الخاصة بمحافظة بورسعيد. - الحدود البشرية: مجموعة من أطفال الروضة بالمستوى الثاني (kg2 ) والملتحقين بأكاديمية Rainbow Kids الخاصة بمحافظة بورسعبد. - الحدود الموضوعية : اقتصر البحث الحالي مفهوم القصة وأهميتها

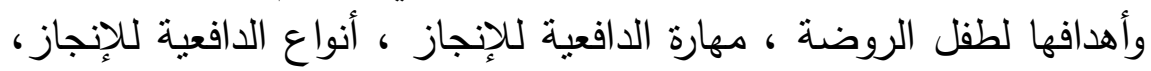
تتمية الدافعية للإنجاز عند الأطفال ، العوامل المؤثزة في تتمية دافعية

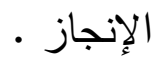

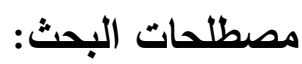

تعرف الباحثة المصطلحات إجرائياً كما يلي :

- Training Program البرنامج التدريبي

مجموعة من الأنشطة المخططة المتتوعة التي تهدف إلى إكساب الأطفال مجموعة من المهارات.

\section{: Stories القصص -}

فن من فنون الأدب التي تقوم الباحثة بروايتها للأطفال ؛ لتتمية المهارات

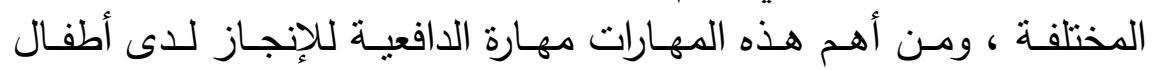
الروضة.

\section{: Skill المهارة}

أداء نشـاط معين والتمكن من إنجازه بدقـة ومهارةٍ في أقل مـا بمكن من

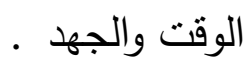




\section{: Motivation for achievement الدافعية للإنجاز-}

هي الرغبة القوية لدى الطفل في السعي للوصول إلى هدفٍ معينٍ وتحقيق النجاح

الإطار النظري والدراسات السابقة : المحور الأول : القصص وطقل الروضة : مفهوم القصة :

تعـرف بأنها: شـكل مـن أثنكال الأدب فيـه جمـال ومتعـة ، لهـا قواعد

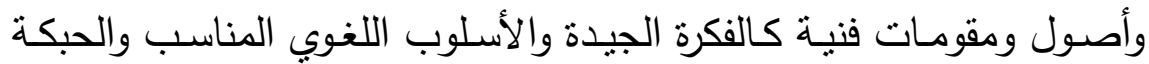

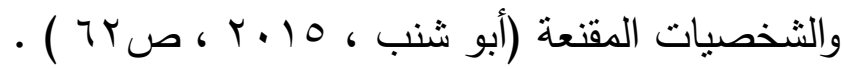

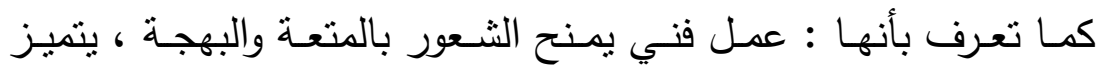

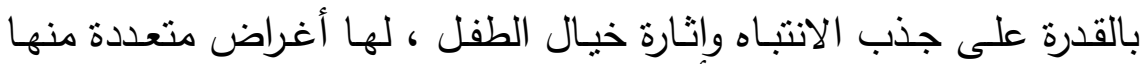

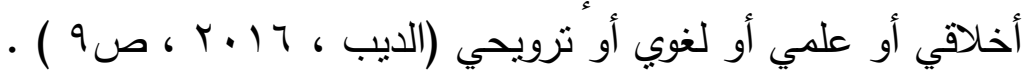

وفي إطار ذللك تقوم الباحثة بصياغة تعريف للنشاط القصصي إجرائياً:

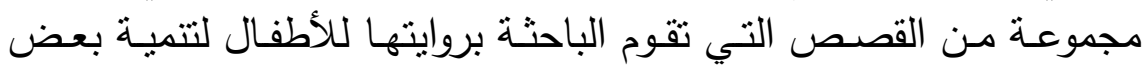

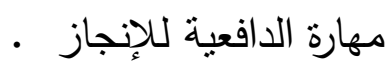
أهداف رواية القصة للطقل :

• تدريب الأطفال على مهارات التواصل منل " الحديث والإنصات " .

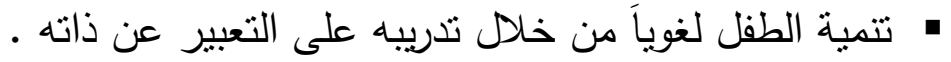

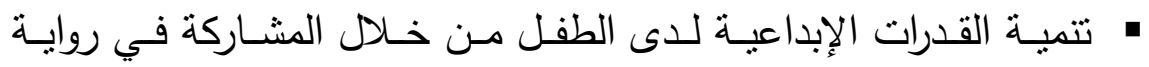
القصة. 


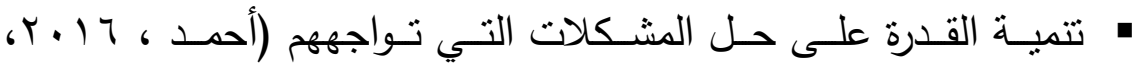
- (199) أهمية القصة للطقل :

تدريب الطفل على استعمال فكره وخياله .

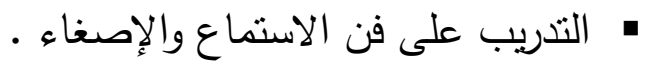

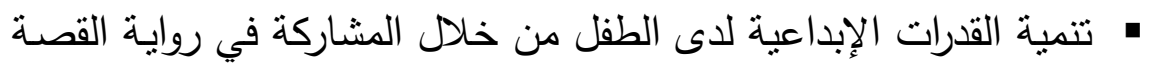

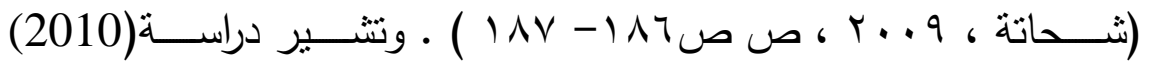
Kang, Ling Yun

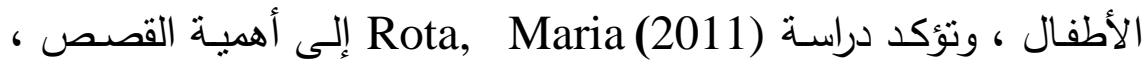
حيث تساعد الطفل في عملية صنّع القرار، وتلبيـة الاحتياجات السلوكية والاجتماعية.

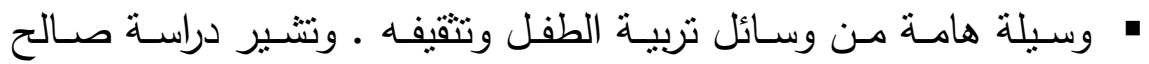

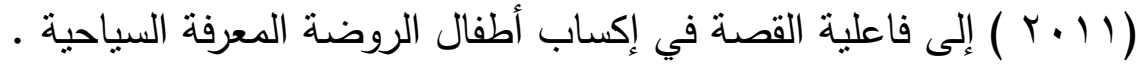

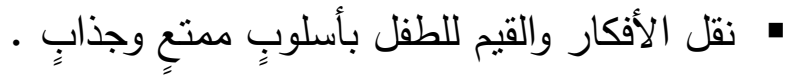

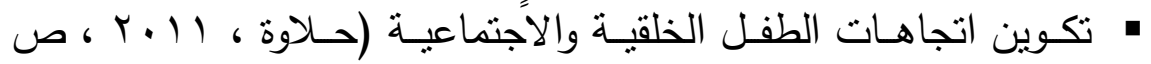

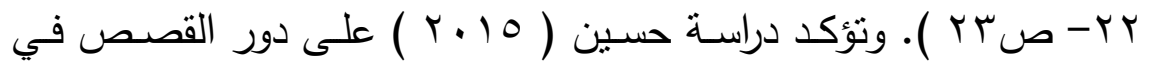

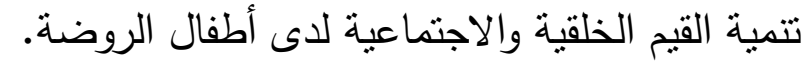

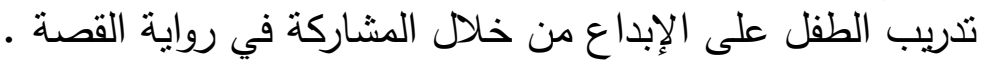

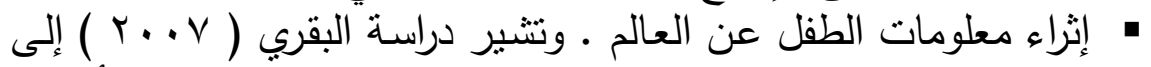

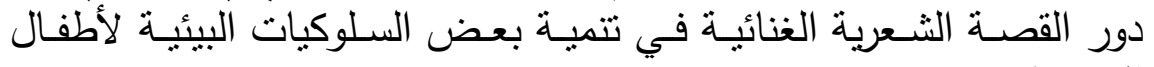
الروضة الرئة • ت تخخل السرور في نفوس الأطفال .

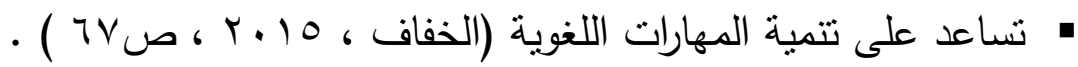


وتتبير دراسة Jamjoom, Saja(2014 إلى أن رواية القصص تساعد في اكتساب مفردات لغوية جديدة للأطفال ، وتؤكد دراسة

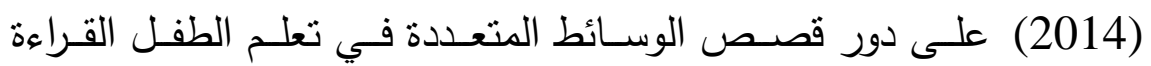
والكتابة .

المحور الثاني : مهارة الدافعية للإنجاز : مفهوم الدافعية للإنجاز :

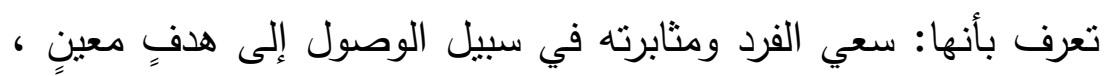

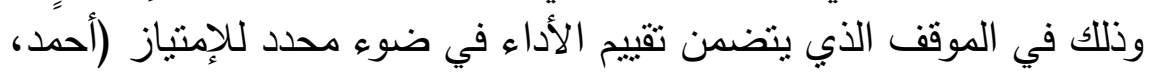

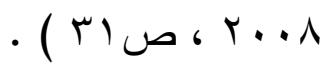

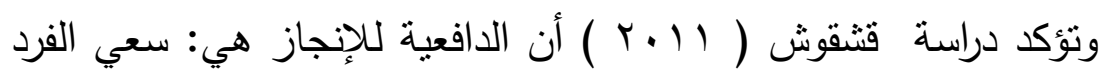
تجاه تحقيق ذاته من خلال ما ينجزه وما يحققه من الأهداف ـ الإنهاز

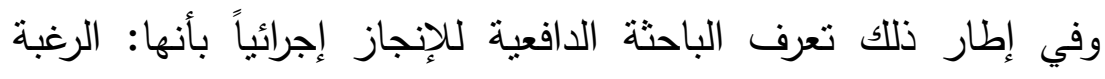

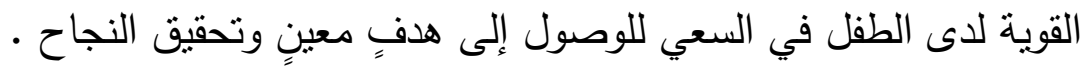
أنواع الافوفية للإنجاز :

• دافعية الإنجاز الذاتية : وهي التي تتضمن تطبيق المعايير الثخصية

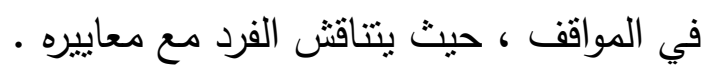

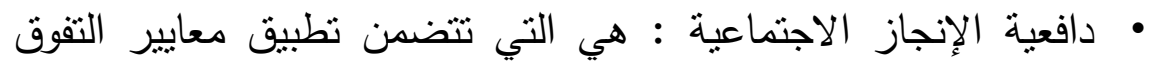

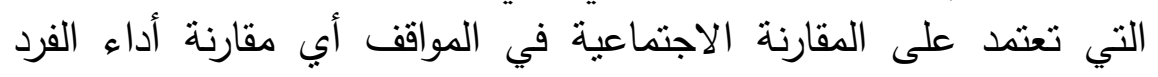

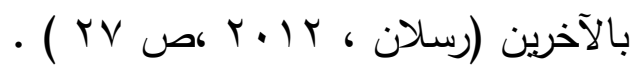
تنمية الدافعية للإنجاز عند الأطفال : هنالك مجموعة من الأساليب لإثارة الدافعية عند المتعلمين : لإعله : 
• إعطاء الحوافز المادية منل قطعة الحلوى ، الحوافز المعنوية منل المدح والثاء .

• استخدام أساليب التهيئة المحفزة عند بداية النشاط . توظيف الأساليب التكنولوجية في إنارة فضول الأطفال وتنشويقهم •

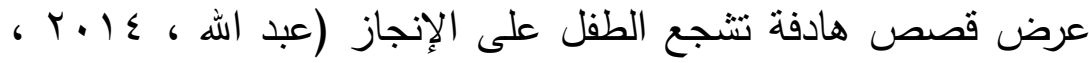

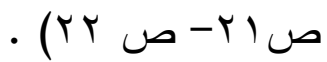
وتؤكد دراسة (2012) Mokrova لدى أطفال ما قبل المدرسة . (2012 العوامل المؤثرة في تنمية دافعية الإنجاز : - الأسرة : الجماعة الأولى التي ينتمي إليها الطفل ، فهي تلعب دوراً

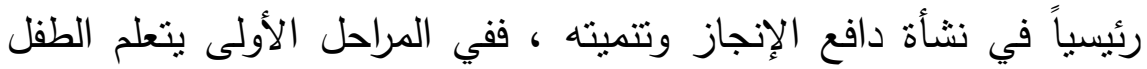

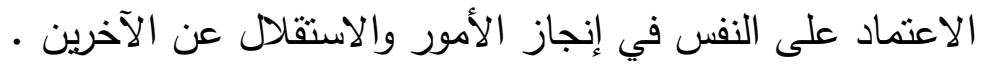
- مجتمع ما قبل المدرسة : حيث تلعب البيئة المحيطة بالأسرة دوراً أساسياً الأنياً

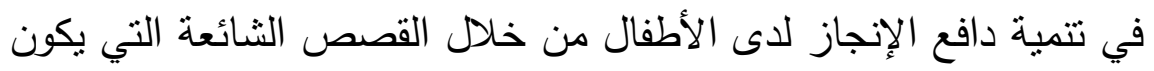
لها دور هام في تتمية دافع الإنجاز .

- المدرسة : تعمل المدرسة على تتمية دافع الإنجاز من خلا الإله الاهتمام

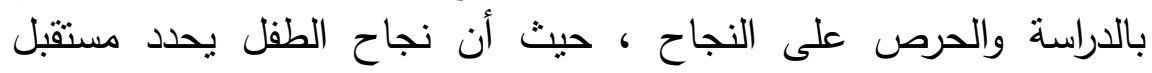

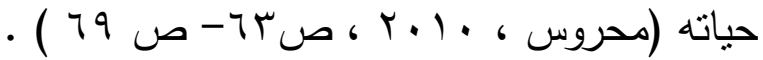

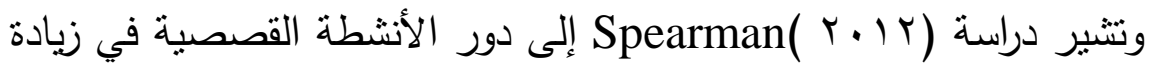

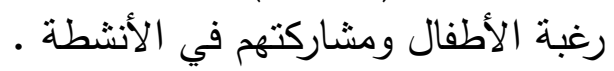


الإجراءات المنهجية للبحث:

وفيما يلي عرض لهذه الاجراءات:

- منهج البحث:

تتطلـب طبيعـة البحـث الحـالي وتحقيـق أهدافـه اسـتخدام المـنهج شـبه التجريبي باستخدام التصميم التجريبي للمجموعة الواحدة ، معتمدة في ذلك ولك على القباس القبلي والبعدي ومقارنـة نتائج القياسين ودلالته الإحصـائية،

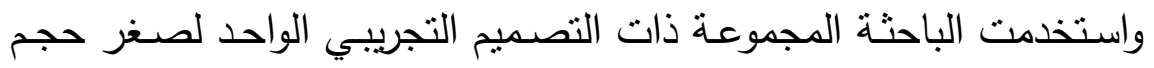
العينـة ، ولتحقبـق الاسـقادة مـن البرنـامج القصصـي لـى عينـة مـن أطفال الروضة ، وبتضمن ذلك المتغيرات التالية:

أ).المتغيز المستقل Independent Variable وهو برنامج تدريبي قائم على استخدام القصص للدى أطفال الروضـة من من

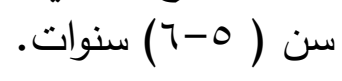

ب).المتغير التابع Dependent Variable وهو تتمبـة مهارة الدافعيـة للإنجاز للدى أطفال الروضـة من سن ( 0-7) سنواث.

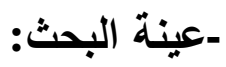

تم اختيار عينة البحث الأساسية بطريقة عشوائية بيلغ عددها ( 10 ) طفلاً وطفلةً بالمستوى الثاني بأكاديمية Rainbow Kids الخاصة بمحافظة بورسعيد. 


\section{التجانس بين أطفال الروضة ( عينة البحث التجريبية):}

قامـت الباحثـة بحسـاب معامـل التجـانس داخل عينـة البحـث مـن حيــث (العمر الزمني ، نسبة الذكاء، درجة انخفاض الدافعية للإنجاز ) كما يتضح

$$
\text { بالجدول التالي رقم (1). }
$$

جدول (1)

يمثل مدى تجانس عينة البحث من حيث

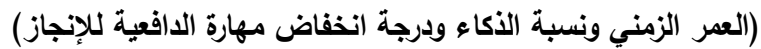

\begin{tabular}{|c|c|c|c|c|c|}
\hline مستوى الدلالة & كا2 & $\overline{\mathrm{Df}}$ & $\begin{array}{c}\text { الانحراف } \\
\text { Std. } \\
\text { Seviation }\end{array}$ & $\begin{array}{l}\text { الحتوسطي } \\
\text { Mean }\end{array}$ & المتغيرات \\
\hline 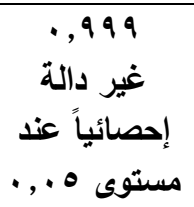 & $\cdot, \leqslant \ldots$ & 7 & $r 1.1$ & $0, \varepsilon$ & الزمني \\
\hline مستوى & r,rrr & 1. & $\varepsilon, . \leqslant 979$ & $9 \wedge, \varepsilon$. & الذكاء \\
\hline 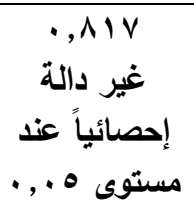 & r, ז & $\mathrm{V}$ & $r, \mu l \leq 90$ & $19, r r$ & لدرازة \\
\hline
\end{tabular}

ويتضح من الجدول السابق أن قيم (كاب ) غير دالة ، وهذا معناه أنه لا

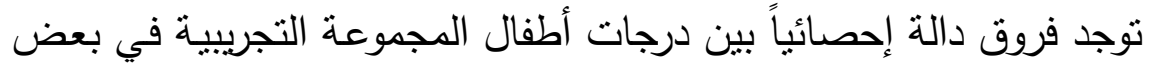

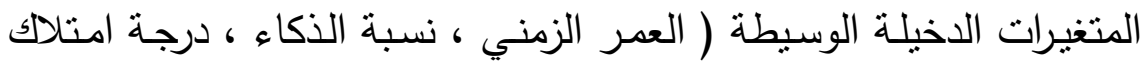
مهارة الدافعية للإنجاز )، مما يثير إلى تجانس هوله هؤلاء الأطفال. 
- توجد فروق ذات دلالــة إحصـائية بـين متوسطي رتب درجـات أطفال الروضـة ( عينـة البحث التجريبيـة ) على مقياس الدافعية للإنجاز لأطفال الروضة من (0-7) سنوات في القياسين القبلي والبعدي للبرنامج التدريبي لصالح القياس البعدي. - لا توجد فروق ذات دلالة إحصائية بين متوسطي رتب درجات أطفال

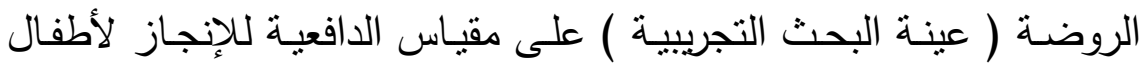

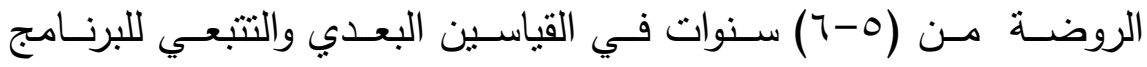
التدريبي. - التروض

\section{ثالثًا: أدوات البحث:}

ا-مقيـاس الدافعيـة للإنجـاز لـدى أطفـال الروضـة مـن سـن ( 0- 7) سنوات (إعداد الباحثة ): - الهرف من المقياس :

يهدف المقياس إلى قياس فاعلية البرنامج التدريبي القائم على استخدام

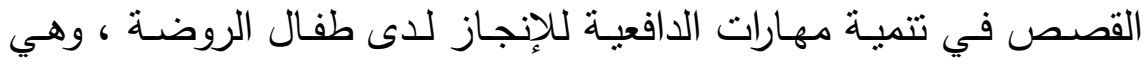

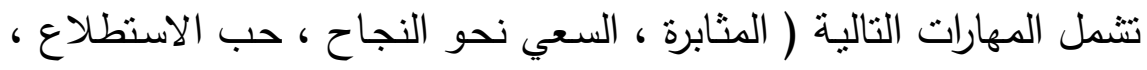

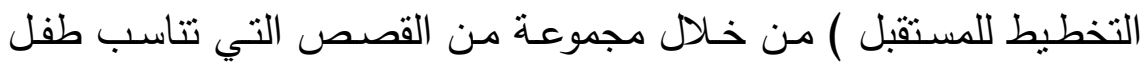
الطفل.

وقد مرت عملية إعداد المقياس بالخطوات التالية: (1)(استقراء التراث النظري والإطلاع على بعض المقاييس السابقة : 


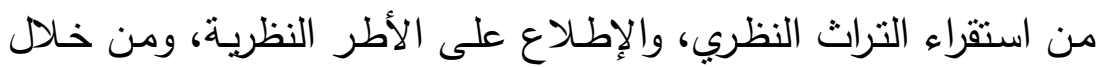

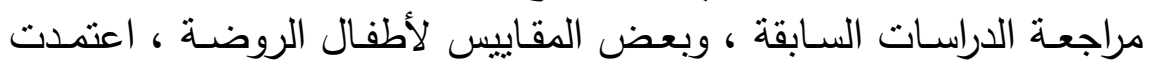
الباحثة في بنائها للمقياس على مصدرين الإنة وبن أساسيين هما:

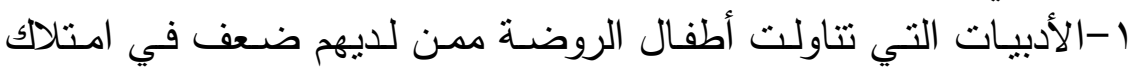

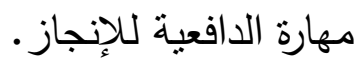

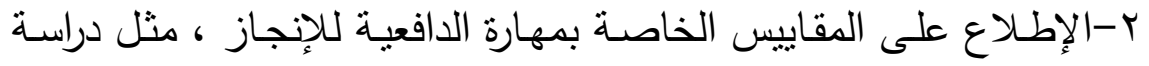

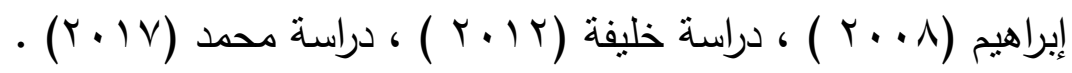

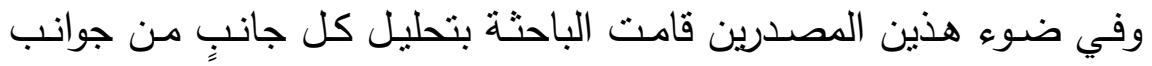

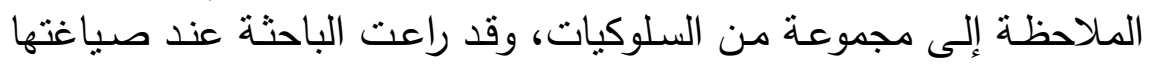

$$
\text { أن }
$$

-تتضمن كل عبارة سلوكاً واحداً فقط يقوم به الطفل. -تصاغ في جمل بسيطة يسهل على على المعلمة فهمها. - تستخدم عبارات قصيرة وواضحة. (r)

يتكون المقياس من مجموعـة مـن المفردات التي تعبر عن سلوكيـات يؤديها الطفـل في المواقف المختلفة، وقد بلغ عدد المفردات ( • عـ مفردةً.

$$
\text { (ب) صياغة مفردات المقياس: }
$$

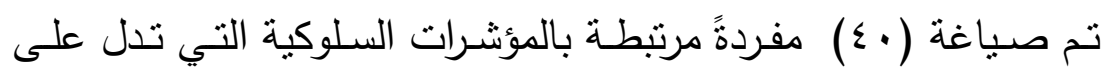

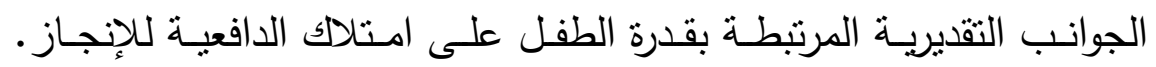

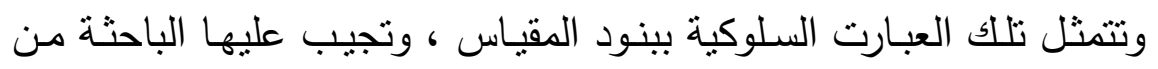
واقع خبرتها وملاحظتها للطفل في مواقف التفاعل الاجتماعي المختلفة ولفئ بينها وبينه من جهة ، وبين الطفل وأقرانه من جهة مولة أخرى. 


\section{( ( ) صياغة تعليمات المقياس:}

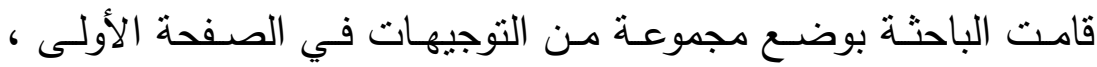

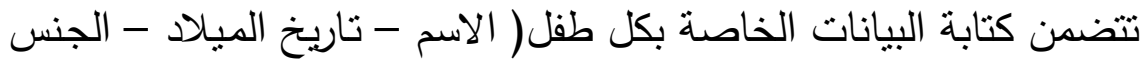
- تاريخ الملاحظة).

\section{(0) تحديا معايير تصحيح المقياس:}

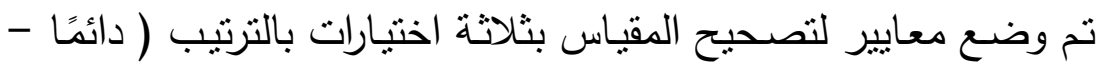
أحيانًا - نادرًا )، ويحصل معاير الطفل على درجات هذه الإستجابات بترتيب موازٍ

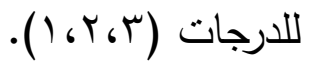

وقد قامت الباحثة بالتعبير عن ذلك كما يلي:

ا-يعطى الطفل درجة واحدة على كل علامة تحت عمود " نادرًا. "

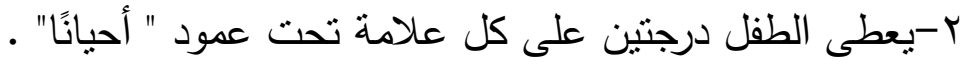

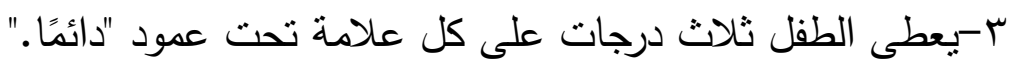
وتقوم المعلمة:

• وضع علامة (ل) تحت عمود "نادرًا" في حالة عدم قيام الطفل بإظهار

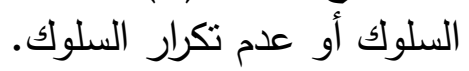
• وضع علامة (ل) تحت عمود "أحيانًا" في حالة نكرار السلوك أكثر من مرة. • وضـع علامـة (ل) تحت عمود "دائمًا" في حالة تكرار السلوك بصفةٍ مستمرة.

(7) عرض المقياس على مجموعة من الخبراء والمتخصصين في علم النفس ورياض الأطفال:

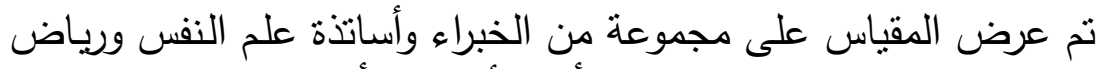

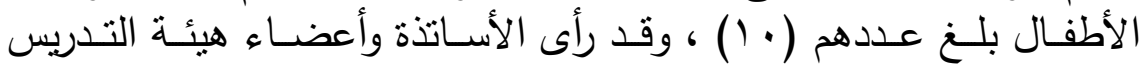


والمختصين حذف بعض المفردات وتعديل الصياغة لبعضهـا ، وقد قامت

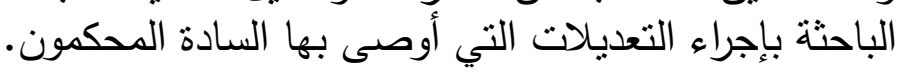
: إعداد المقياس في صورته التهائية (V) بناءًا على آراء السـادة المحكمين أجريت بعض التعديلات اللازمـة على بعض المفردات وحذف بعضها، ثم تم وضع المقياس في صورته النهائية. الخصائص السيكومترية للبطاقة: : Reliability أولاً: ثبات المقياس قامت الباحثة بحساب ثبات المقياس بطريقتين كالتالي: ا - معامل ألفا ( كرونباخ):

استخدمت الباحثة (معادلة ألفا كرونباخ Cronbachs Alpha"a (لقياس

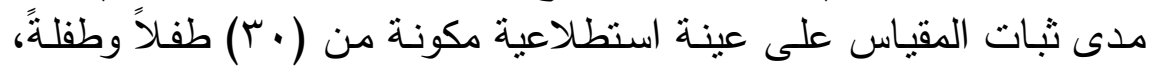
وقد تم استبعادها من العينة الأساسية للبحث والجدول التالي يوضـح الإجراء الإحصائي:

$$
\text { جدول (r ) }
$$

معاملات ثبات مفردات مقياس الاففية للإنجاز لأطفال الروضة

$$
(r \cdot=\dot{u})
$$

\begin{tabular}{|c|c|c|}
\hline كعامل ثبات ألفا & عدد المفردات & مقياس الأطفال الرعية للإنجاز \\
\hline *, , $\wedge \vee r$ & $\varepsilon$. & الثبات الكلي للبطاقة \\
\hline
\end{tabular}


ومن بيانات الجدول السابق يتضـح أن مفردات مقياس الدافعية للإنجاز

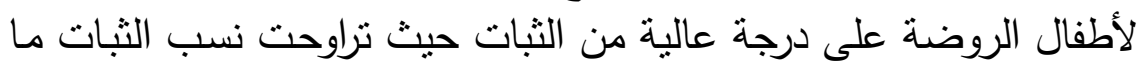

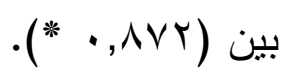

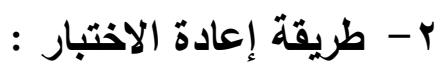

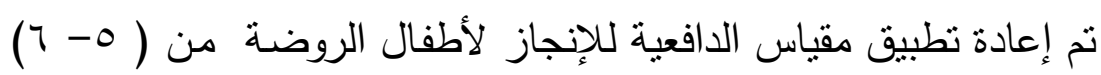

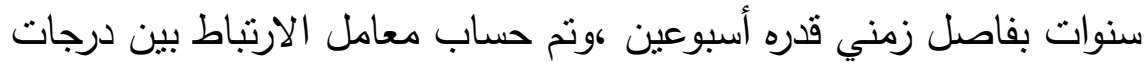

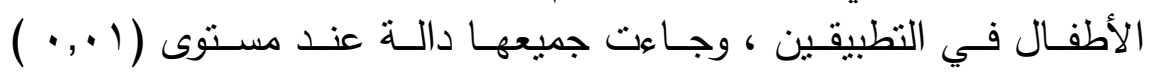
والجدول التالي يوضح ذلك:

جدول (r)

معاملات ثبات مفردات مقياس الدافعية للإنجاز لأطفال الروضة بإعادة الاختبار

\begin{tabular}{|c|c|c|}
\hline الالالة الإحصائية & معامل الارتباط & مقياس الدافعية للإنجاز لأطفال \\
\hline$\cdot, \cdot 1$ & $\cdot, \wedge \wedge 1$ & الدرجة الكلية للبطاقة \\
\hline
\end{tabular}

ثانيًا : صدق المقياس Validity:

لتحديد مدى صدق محتوى المقياس ، استخدمت الباحثة في دراستها

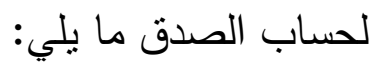
ا -الصدق التمييزي ( المقارنة الطرفية) :

تم حسـاب الصـدق الكلي لمقيـاس الدافعيـة للإنجـاز للدى عينـة التقنـين

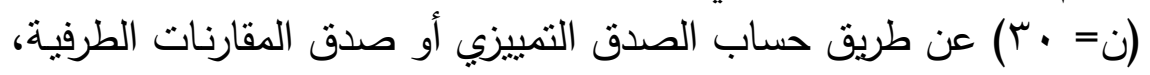
حيث تم ترتيب درجات الأطفال على الدرجة الكلية لمقياس الدئ الدافعية للإنجاز

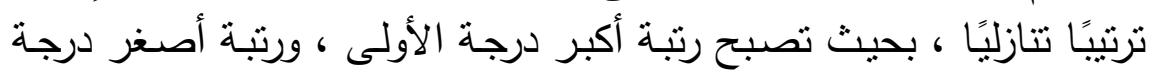


الأخيرة ،ثم تم فصل نسبة YrV مسن درجات الإربـاعي الأعلى ، ونسبة

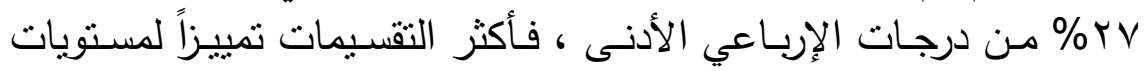
الامتياز والضـف هي التي تعتمد على تقسيم درجات المبزان إلى طرفين الأعلى والأدنى ، بحيث يتألف الإرباعي الأعلى من الدارجات الدات التي تكون

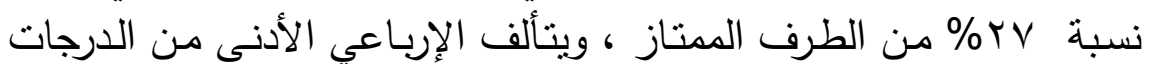
التي تكون نسبة rv\% من الطرف الضعيف.

وتـم اسـتخدام اختبـار (ت) لحسـاب دلالـة الفروق بين الفئة العليـا والفئة

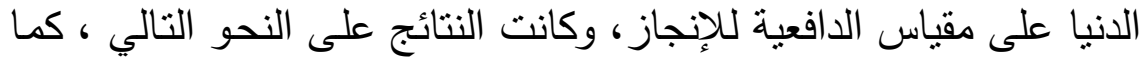
هي موضحة بالجدول التالي:

\section{جدول ( ع ( )}

نتائج اختبار "ت" لاراسة الفروق بين متوسطات المجموعة الطرفية لمقياس الافوعية للإنجاز لاى العينة الاستطلاعية مئوات الميوعة

\begin{tabular}{|c|c|c|c|c|c|c|c|c|}
\hline \multirow{2}{*}{ الإحصائية } & \multirow[b]{2}{*}{ قيمة (ت) } & \multicolumn{3}{|c|}{ الفئة الانيا } & \multicolumn{3}{|c|}{ الفئة العليا } & المتغير \\
\hline & & الانحراف & المتوسط & $\dot{ن}$ & الانحراف & المتوسط & ن & مقياس \\
\hline$\cdot, \ldots$ & $11, \cdot 7 V-$ & $1, r$. & rV,Tr & $\wedge$ &., 700 & 14,0 . & $\wedge$ & الأطفال \\
\hline
\end{tabular}

ويتضــح مـن الجـدول السـابق وجـود فـرق دال إحصـائياً بمسـتوى دلالـة

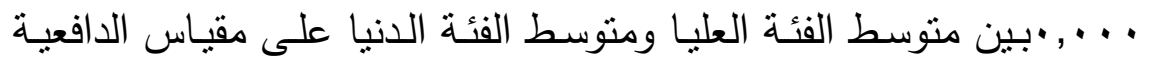

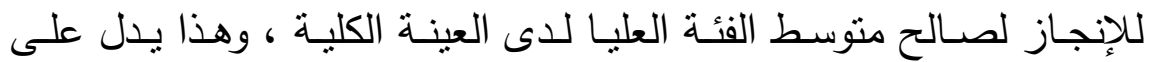
الصدق التمبيزى للمقياس، مدا يشير إلى أن مقياس الدافعيـة للإنجاز لديـهـ قدرة مرتفعة على التمبيز بين مرتفعي ومنخفضي الدافعية للإنجاز • 


\section{إجراءات تطبيق المقياس:}

تم تطبيق المقياس على مجموعة من أطفال الروضة بالمستوى الثاني

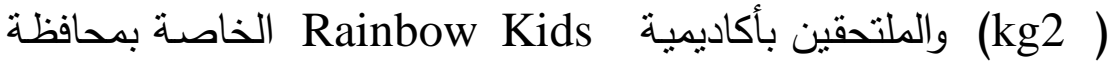

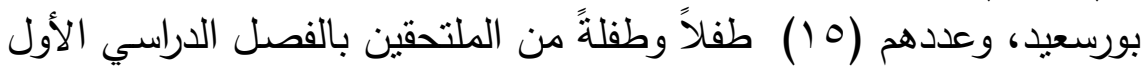

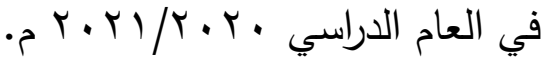

$$
\begin{aligned}
& \text { تفريغ البيانات ومعالجتها إحصائياً: }
\end{aligned}
$$

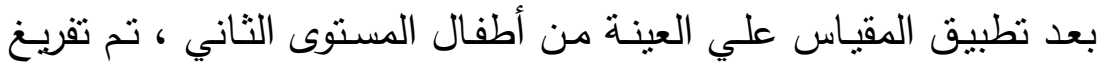

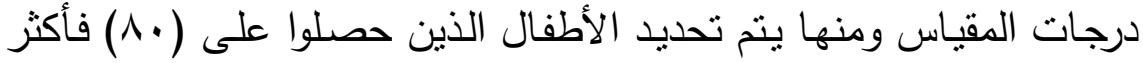
من الدرجة النهائية للمقياس ويتم تفريغها في جداول خاصة. - البرنامج التدريبي القائم على القصص في تنمية مهارة الدافعية للإنجاز

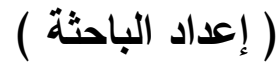

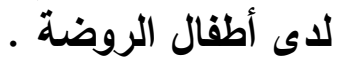

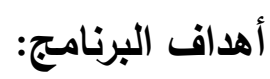

الهـف العام مـن البرنـامج: تتميـة بعض مهارات الدافعية للإنجاز لأطفال

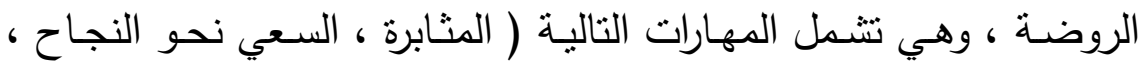

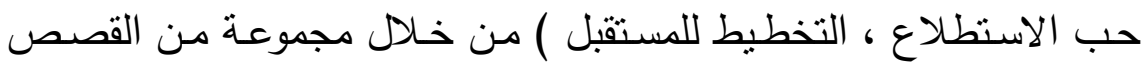
التي تتاسب طفل الروضة. الأهداف الخاصة للبرنامج:

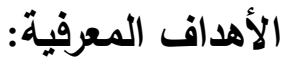

-أن بعرف الطفل أهمية المحاولة للوصول إلى الهدف.

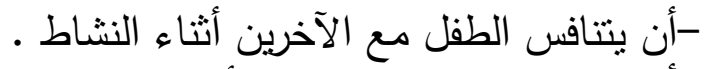

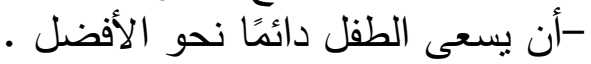


-أن يذكر الطفل أهمية التخطيط في حياته . -أن يتتاقش الطفل مع الباحثة في الأحداث التي تثير فضوله الته في القصة. الأهداف المهارية :

-أن يجيب الطفل على الأسئلة التي تدور حولها القصة.

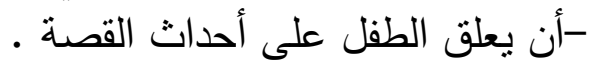

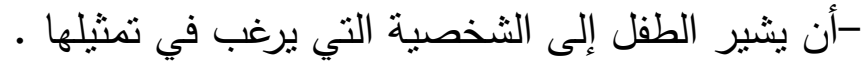
-أن يمثل الطفل دور الثخصية التي أعجبته في القصة فئة الأهداف الوجدانية : -أن يبدي الطفل رغبته في المشاركة في النشاط القصصي.

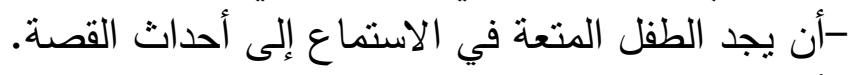

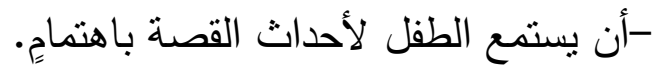

-محتوى البرنامج :

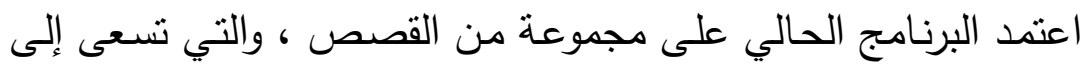

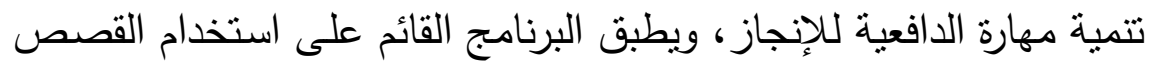

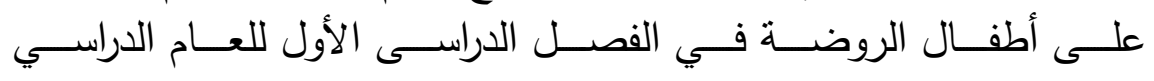
$\cdot r \cdot r / r \cdot r \cdot$

- الوسائل والأدوات المستخدمة في البرنامج : بطاقات قصص ، قصص إلكترونية ( Photoshop) ، مجسمات. -نوع القصص المستخدمة في البرنامج:

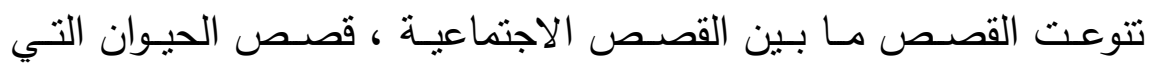
تتاسب طفل الروضة. 
- أساليب التعلم المستخدمة :

$$
\begin{aligned}
& \text { - الحوار والمناقتشة . } \\
& \text { - النمذجة. } \\
& \text { - لعب الأدوار - لعند العزب - } \\
& \text {-التعزيز الإيجابي. }
\end{aligned}
$$

نموذجين من القصص المستخدمة في البرنامج :

1 -قصة لوسي وإختبار الطيران :

المهارة المستهدفة : مهارة الدافعية للإنجاز .

المهارة الفرعية : السعي نحو النجاح.

محتوى القصة:

كـان يـا مكان يـا سـادة يـا كرام ولا يحلى الكـلام إلا بـذكر النبـي عليـه

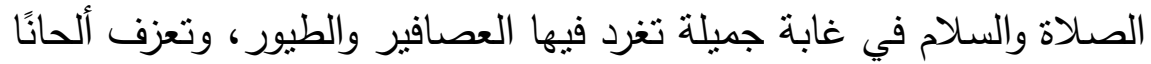

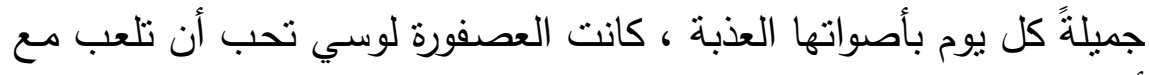

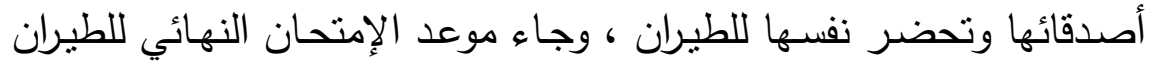

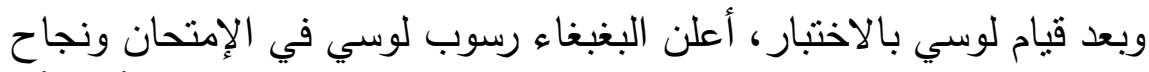

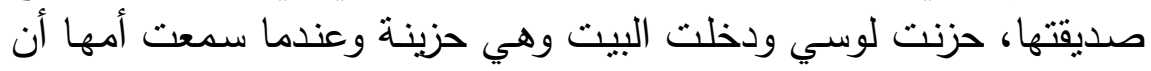

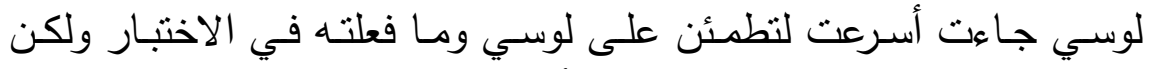

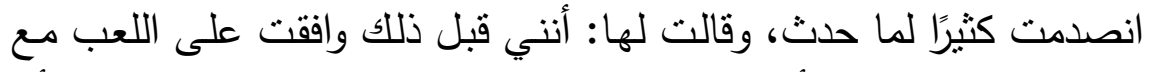

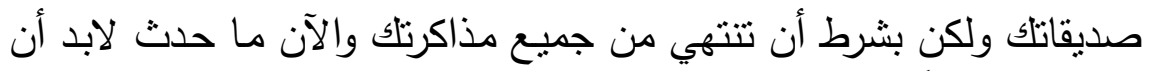

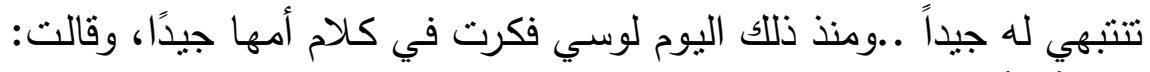

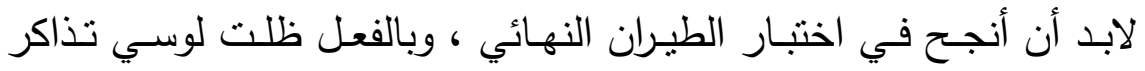


دروسها وفي أوقات الفراغ فقط تلعب مـع صديقتها، إلى أن جاء اليوم التي تتتظـره منـذ فترة وقامـت بإعـادة الاختبـار وأعلن البغبغـاء فوزهـا واجتيازهـا لاختبار الطيران بجدارة، فقرحت الأم بها كثيرًا؛ لأنها اجتهدت وفعلت ذلك ألك

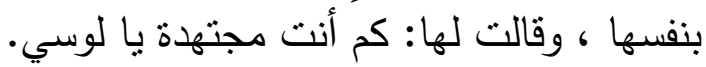
r - قصة فوفو الكسلان المهارة المستهدفة : تتمية مهارة الدافعية للإنجاز . المهارة القرعية : مهارة التخطيط للمستقبل. محتوى القصة :

كان يوجد حيـوان كسـول لا يحب الحركـة في غابـة يسـود فيهـا الحـب

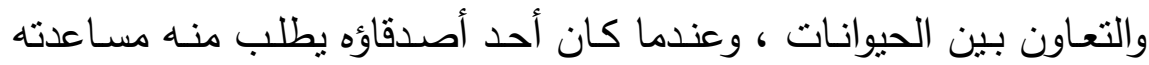
كان يرد: بأنني كسلان: كيف لي أن أساعد أحد وأنا في هذه الحالة؟، وفي

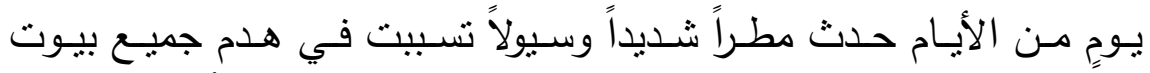
الحيوانات بما فيهم بيت الكسـلن ، ولم يمر وقت كبير إلى أن فكر جميع الحيوانـات بإعـادة بناء بيوتهم مرة أخرى حتى بيتمكنوا مـن النوم ، وتدفئة

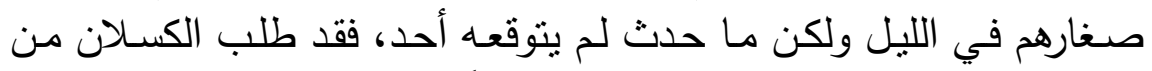

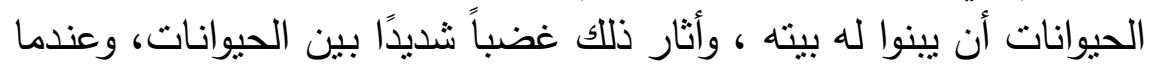
وجد الكسـلان صغاره لا تقوى على برد الليل فقرر في نفسه أن يقوم ببناء بيت لصغاره ؛ حتى لا يموتوا من شدة البرد وبالفعل قام ببناء نصف البـ لبيت في مدة طوبلة ، وعندما رأى الحيوانات ذلك قرروا أن يساعدوه ما دام فوفو أصبح نشيطاً وبحتاج إلى مساعدتتا، وبالفعل انتهى البيت ومنذ ذلك اليوم أصبح فوفو الكسـلان نشبطاً يحب الحركة ، ومسـاعدة زملائه وهتف بين 
أصـدقائه قـائلاً : لقد تعلمـتُ درسـاً وشكر أصـدقاءه على وقـوفهم بجانبـهـ وأصبح صغاره فخورين به. الأساليب الإحصائية المتبعة:

1-استخدم البحث الحالي معادلة (ويلككسون) لحسـاب دلالة الفروق بين

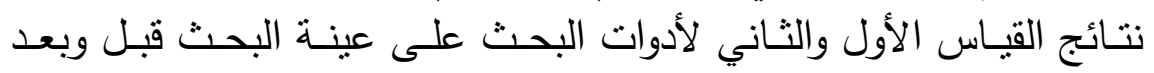

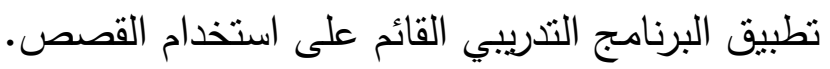

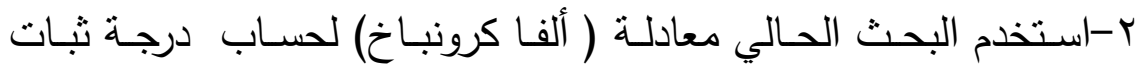
مقياس الدافعية للإنجاز لدى أطفال الطفال الروضة. r-معامل ارتباط بيرسون لحساب صدئ لإن مقياس درجة ثبات مقياس الدافعية الروضة لكإِنجاز لاى أطفال الروضة. ع -استخدمت البحث الحالي معامل مربع إيتا ( n2 ) لحساب لإن حجم الأثر

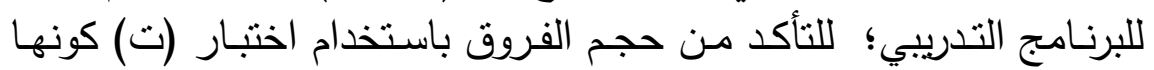
فروق حقيقية تعود لمتغيرات البحث. :تتائج البحث :

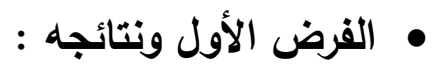
ينص الفرض الأول على أنه:

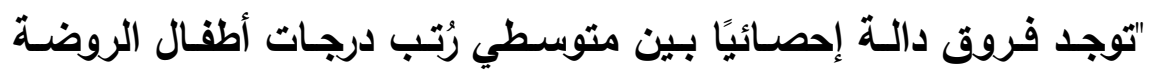

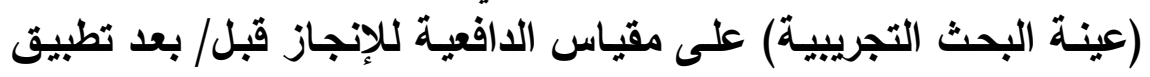

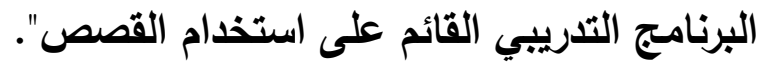

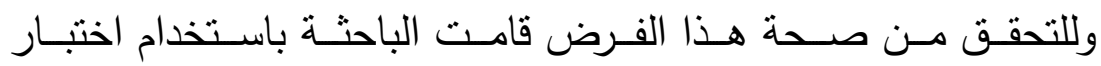

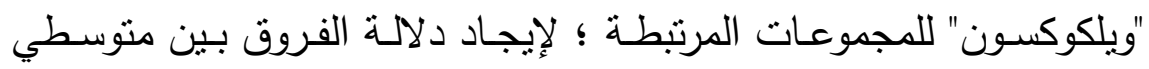


رتب درجات أطفال الروضة قبل تطبيق البرنامج التدريبي ، ومتوسطي رتب درجات نفس المجموعة بعد تطبيق البرنامج على مقياس الدافعية للإنجاز كما هو موضح بالجدول التالي:

جدول (ن)

متوسط ومجموع الرتب الموجبة والسالبة وقيمة (Z) ودلالتها الإحصائية للعينة التجريبية بين

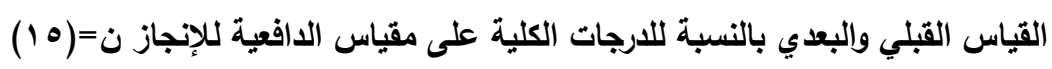

\begin{tabular}{|c|c|c|c|c|c|c|}
\hline \multirow[t]{2}{*}{ مستوى الدلاية } & \multirow{2}{*}{ قيمة } & \multicolumn{2}{|c|}{ القبلي/البعدي } & \multirow[t]{2}{*}{ العدد (ن) } & \multirow{2}{*}{ فروق الرتب } & \multirow{6}{*}{ لالألانجاز } \\
\hline & & مجموع & منوسط & & & \\
\hline \multirow{4}{*}{ عالة إحصائياً" } & \multirow{4}{*}{$\begin{array}{c}- \\
a,\{\mid r\end{array}$} & $I^{r}, \ldots$ & $\wedge, \ldots$ & 10 & الموجبة & \\
\hline & & & & • & السالبة & \\
\hline & & & & . & الرحايدة & \\
\hline & & & & 10 & المجموع & \\
\hline
\end{tabular}

ويتضح من الجدول السابق وجود فروق ذات دلالة إحصائية عند مستوى (ألهى

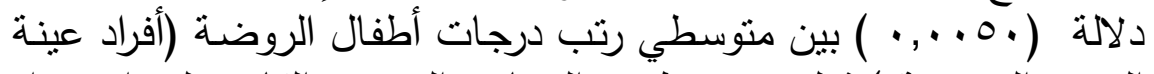
البحث التجريبية ) قبل وبعد تطبيق البرنامج التدريبي القائم على استخدام

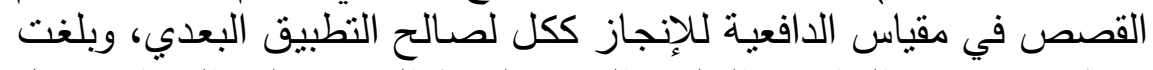

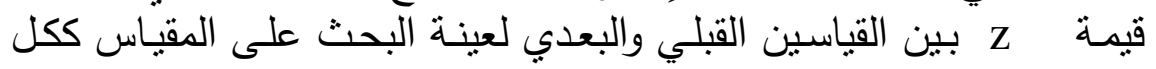

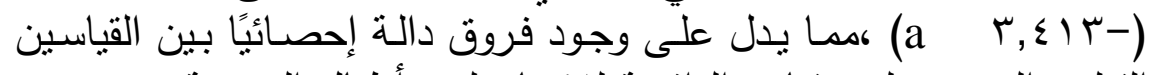

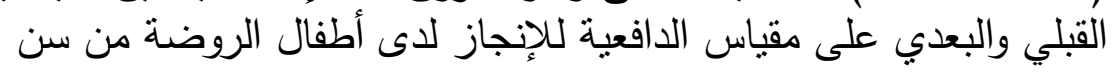




\section{6 -5 )سنوات) أفراد عينة البحث التجربيية.}

ويمكن تفسير هذه النتيجة في ضوء استخدام القصص في تتمية مهارة

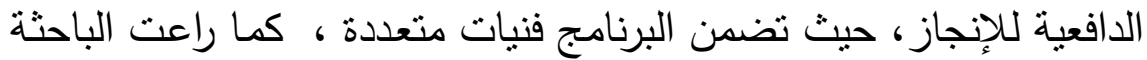

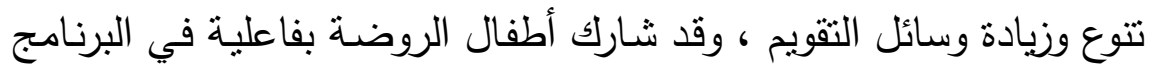

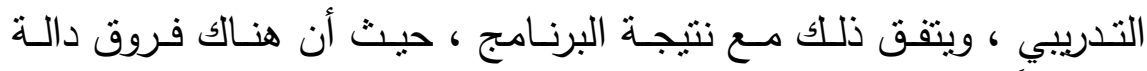

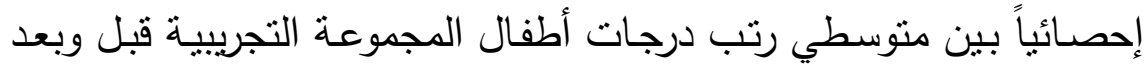
تطبيق البرنامج لصالح التطبيق البعدي.

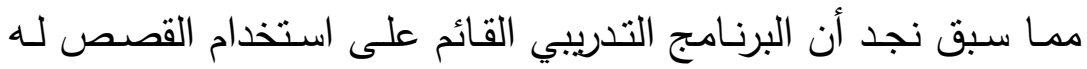

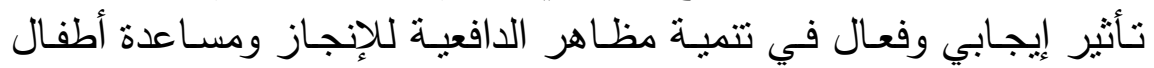

$$
\text { الروضة (عينة البحث التجريبية). }
$$

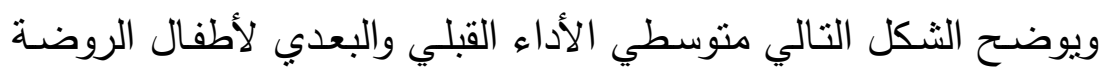

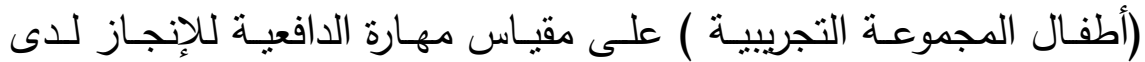

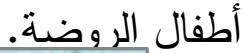

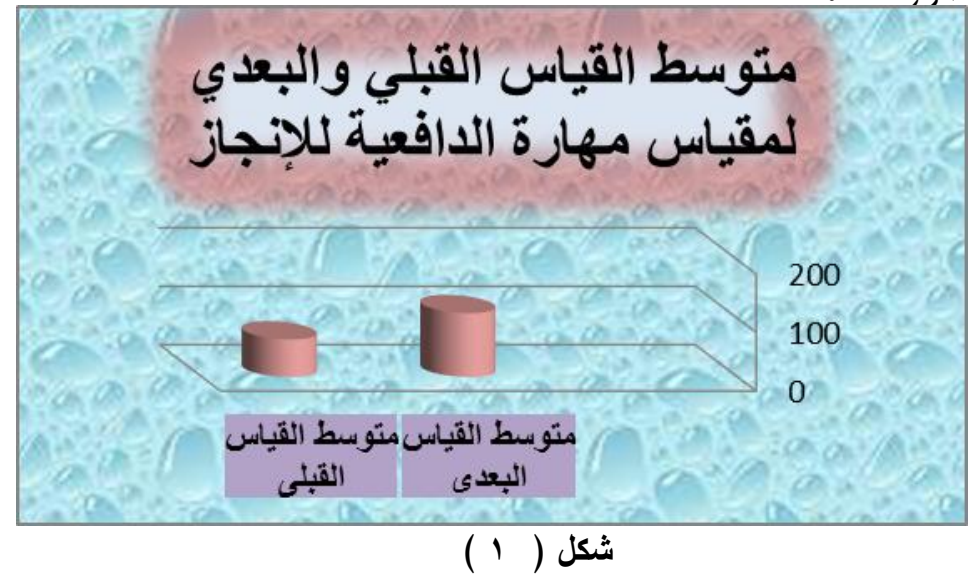

دلالة الفروق بين متوسطي درجات أطفال الروضة في القياس القبلي والبعدي لمقياس مهارة الدافعية للإنجاز 
كمـا قامت الباحثة بإيجاد نسبة التحسن بين القياسين القبلي والبعدي

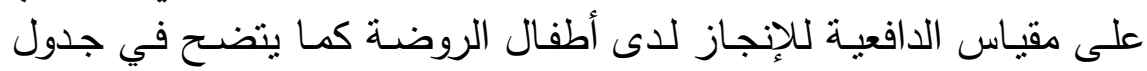

$$
\text { جدول (7) }
$$

نسبة التحسن بين القياسين القبلي والبعدي على مقياس الدافعية

$$
\text { للإنجاز لدى أطفال الروضنة الفئي ولبعي }
$$

\begin{tabular}{|c|c|c|c|}
\hline نسبة & متوسط القياس & متوسط القياس & مقياس الدافعية للإنجاز \\
\hline$\%$ & $1, .94$ & צ & \\
\hline
\end{tabular}

ومن نتائج الجدول السابق ( †) نجد أن البرنامج لله تأثير إيجابي وفعال في تتميـة الدافعية للإنجاز لدى أطفال الروضـة حيث بلغت نسبة التحسن

\section{تفسير نتائج الفرض الأول:}

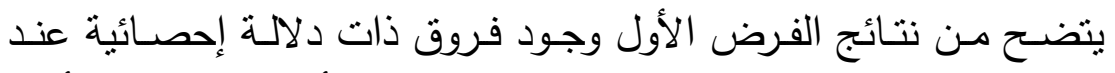
مستوى دلالة (0 . . . •) بين متوسطي رُتب درجات أطفال الروضـة (أفراد

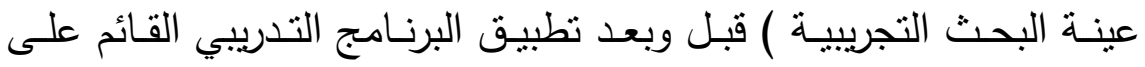

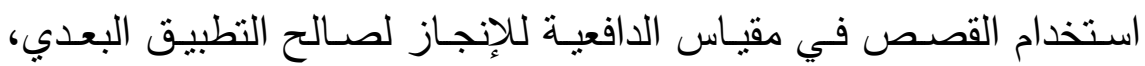
وبلغت قيمة Z بين القياسين القبلي والبعدي لعينة البحث على المقياس ككل

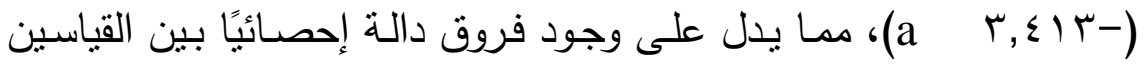

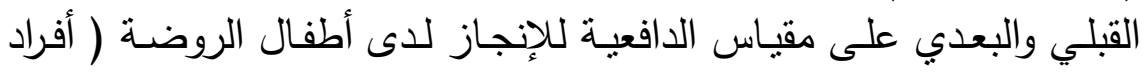
عينة البحث التجريبية). 
حيث تشير نتائج جدول ( 0 ) إلى تفوق أطفال المجموعـة التجريبية

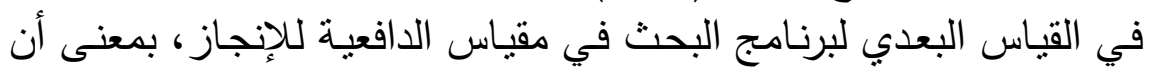

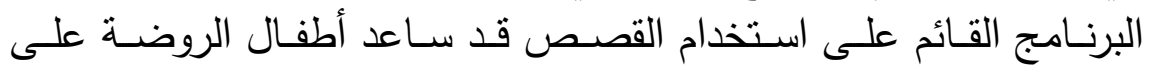
الدافعية للإنجاز لدى أطفال الروضة.

كما يتضـح من الجدول ( 7) نسبة التحسـن لأطفال الروضـة قبل وبعد تطبيق برنامج القصص على مقياس الدافعية للإنجاز ، وهذا ما يوضح بدوره لإهاه مدى النجاح الذي حققته القصص في تتميـة الدافعيـة للإنجاز لـى أطفال الروضة.

وقد بلغت نسبة التحسن قبل وبعد تطبيق البرنامج القائم على استخدام

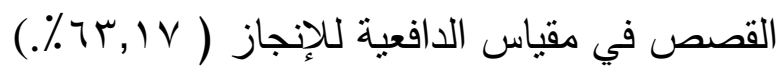

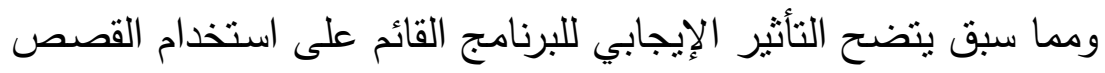

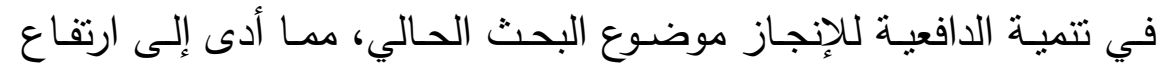
درجات أطفال الروضــة في القباس البعدي على مقياس الدافعيـة للإنجاز لأطفال الروضة من ( حيث قامت الباحثة بتطبيق المقياس تطبيقًا بعديًا بعد الانتهاء من تطبيق

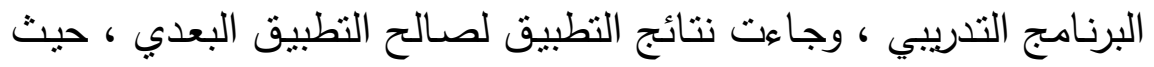
اشتمل البرنامج المقترح على مجموعة منتوعة من القصص التي سـاعدت في تتمية مهارة الدافعية للإنجاز لدى أطفال الروضة.

ومسن القصـص التـي تـم تطبيقهـا على أطفـال الروضــة قصـة " لوسـي واختبار الطيران " والتي هدفت إلى تتمية مهارة السعي إلى النجاح ، وقصة

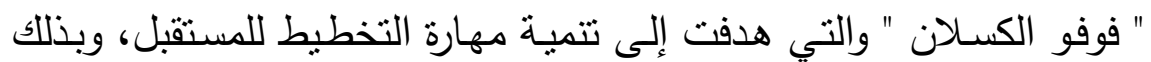
يتم تتمية مهارة الدافعية للإنجاز لدى أطفال الروضنة. 


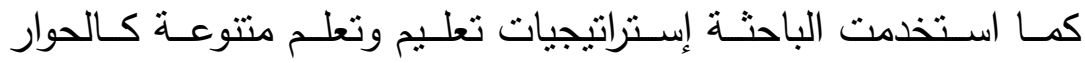

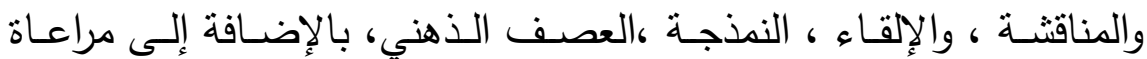

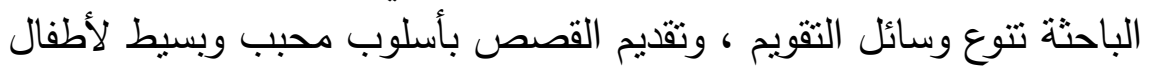
الروضة في جو من المرح والسعادة.

ومما سبق يتضح التأثير الإيجابي للبرنامج التدريبي القائم على استخدام

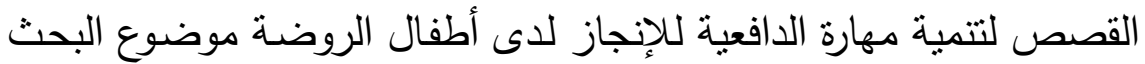

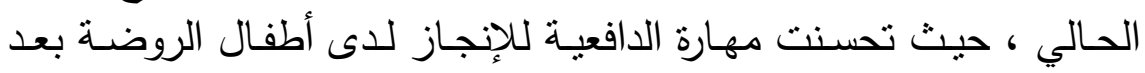

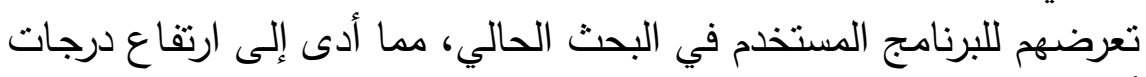

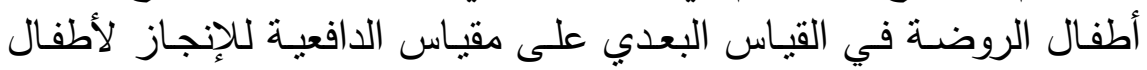

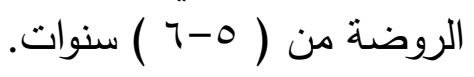

كما توصلت الباحثة في البحث الحالي إلى ارتباط الأنشطة القصصية

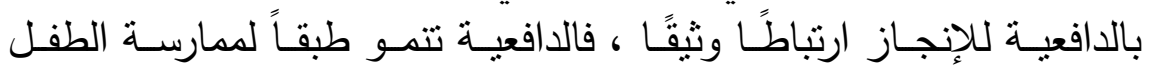

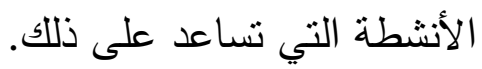

ويتفق ذلك مع نتيجة البرنامج ، حيث أن هناك فروق دالة إحصائيًا بين

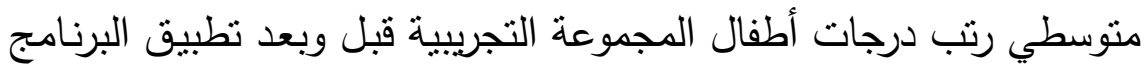
لصالح التطبيق البعدي.

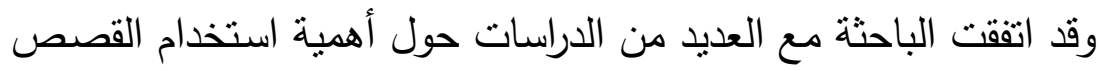

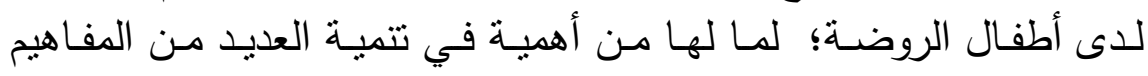

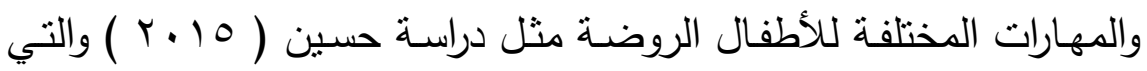

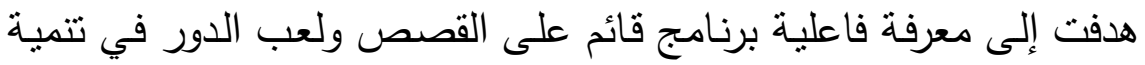

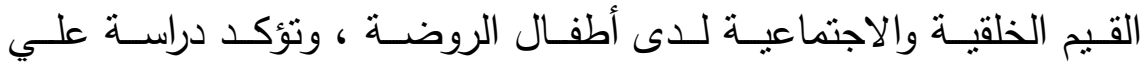

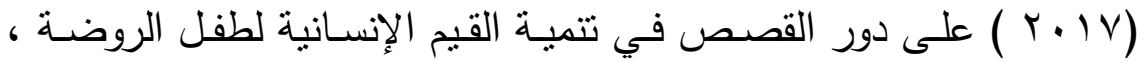

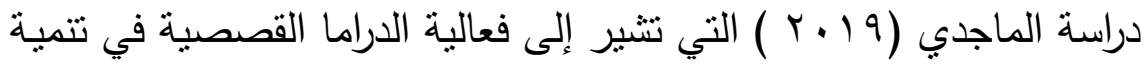


بعض مظاهر السلوك الايجابي لدى طفل الروضـة ، وتتشير دراسـة دياب

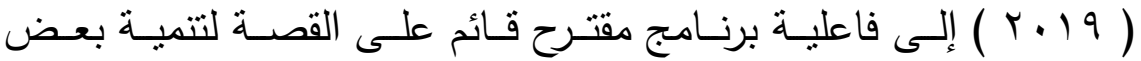

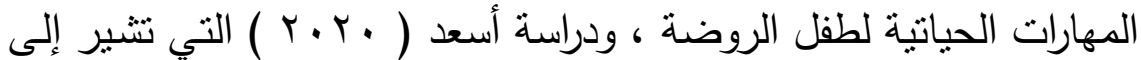
فاعلية برنامج قائم على القصص الفنية لتتمية بعض القية القيم الأخلاقية لطفل

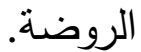

ومما سبق نجد أن البرنامج التدريبي القائم على استخدام القصص لـأله تأثثير إيجـابى وفعـال في تتميـة مهارة الدافعيـة للإنجـاز ومســاعدة أطفال الروضة (عينة البحث التجريبية ).

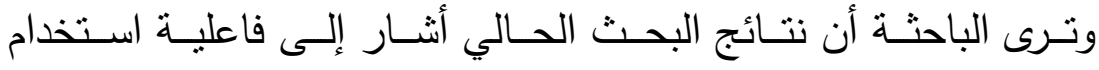

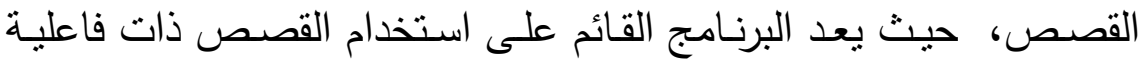

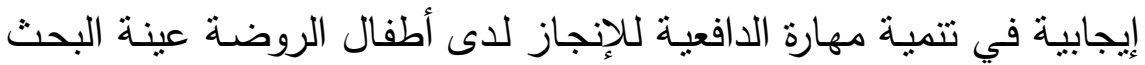

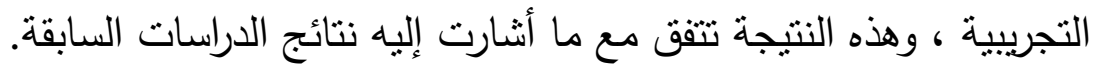

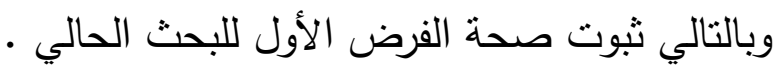

• الفرض الثاني ونتائجه: ينص الفرض الثاني على أنه: " لا توجد فروق دالة إحصائيًا بين متوسطي رتب درجات أطفال الروضـة

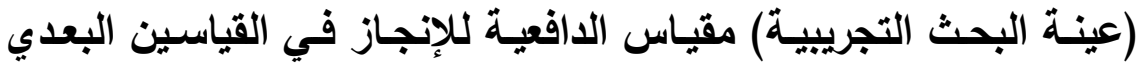

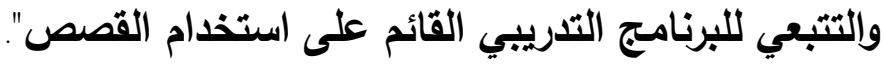

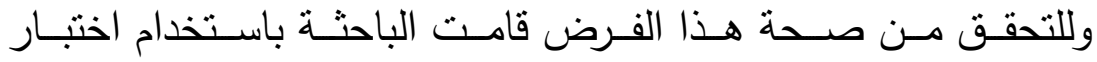
ويلكوكسون للمجموعات المرتبطة لإيجاد دلالة الفروق بين منتسطي رتب

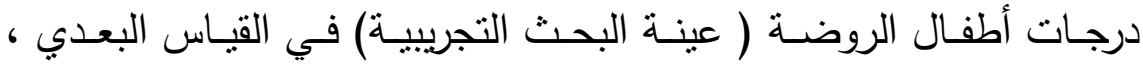

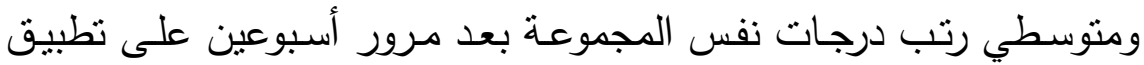


البرنامج التدريبي المقترح القائم على استخدام القصص في القياس التتبعي، وكانت النتائج كما هي موضحة بالجدول التالي: جدول (v)

متوسط ومجموع الرتب الموجبة والسالبة وقيمة (Z) ودلالتها الإحصائية للعينة التجريبية بين القياس البعدي والتتبعي بالنسبة للارجات الكلية على مقياس الإلفية ولإية للإنجاز

$$
(10)=0
$$

\begin{tabular}{|c|c|c|c|c|c|c|}
\hline \multirow[t]{2}{*}{ مستوى } & \multirow[t]{2}{*}{ قيمة } & \multicolumn{2}{|c|}{ البعدي/التتبعي } & \multirow[t]{2}{*}{ العدد (ن) } & \multirow{2}{*}{ فروق الرتب } & \multirow{7}{*}{ لالإنقية } \\
\hline & & مجموع الرتب & متوسط & & & \\
\hline \multirow{5}{*}{ غير دالة آل } & \multirow{5}{*}{$\begin{array}{c}- \\
1, \ldots\end{array}$} & $1, \ldots$ & $1, \ldots$ & $b_{1}$ & الرتب & \\
\hline & & & & & الموجبة & \\
\hline & & $\cdot, \cdots$ & $\cdot, \cdots$ & . & السالبة & \\
\hline & & & & $1 \varepsilon$ & الرثبث & \\
\hline & & & & 10 & المجموع & \\
\hline
\end{tabular}

ويتضـح من الجدول السـابق عدم وجود فروق ذات دلالة إحصـائية بين

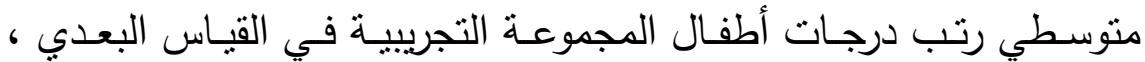
ومتوسطي رتب درجات نفس المجموعة في القياس التتبعي حيث كانت قيمة ل ل -1.000a) الدرجات التي حصل عليها أطفال المجموعة التجريبية في القياسين البعدي والتتبعي كانت متقاربة، مما يدل على استمرار أثر البرنامج بالنسبة لأطفال المجموعة التجريبية فيما بعد تطبيق البرنامج خالل فترة المتابعة. 
ويوضـح الثـكل التالي متوسـات الأداء في القياسين البعدي والتتبعي لأطفال الروضـة ( عينـة المجموعة التجريبية ) على مقياس مهارة الدافعيـة ل الإنجاز

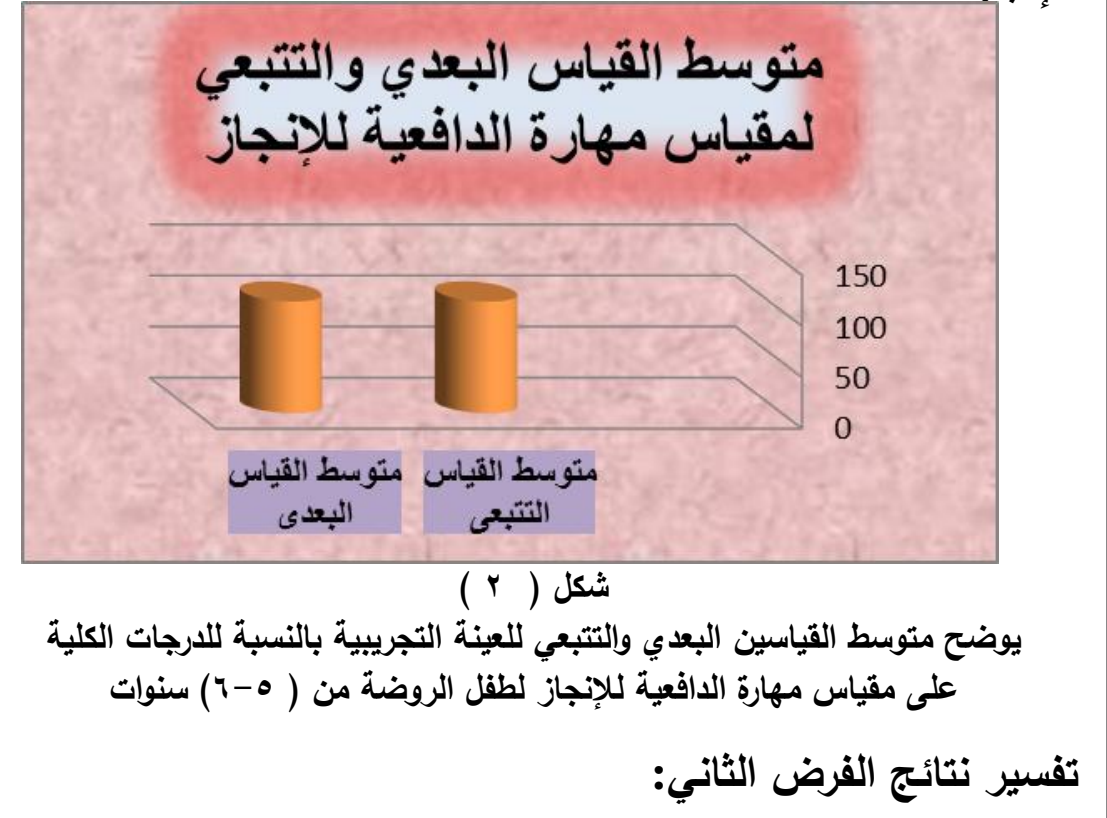

لقد أوضـحت نتائج الفرض الثاني للبحث على عدم فروق ذات دلالـة إحصائية بين متوسطي رتب درجات أطفال الروضـة في القياسين البعدي لمقياس الدافعية للإنجاز لطفل الروضة من ( حيث أكدت نتائج البحث الحالي على فعالية البرنامج التدريبي القائم على القى القي استخدام القصص ، وانعكاس ذلك إيجابياً على تتمية مهارة الدافعية للإنجاز لدى أطفال الروضة عينة البحث التجريبية مع استمرار هذا الأثر الإيجابي للبرنامج خلال فترة المتابعة. 
وترجـع الباحثة نتيجـة هذا التحسن بشـكل كبير إلى جلى التسات البرنـامج

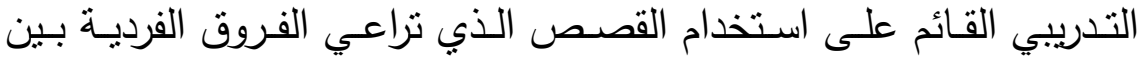

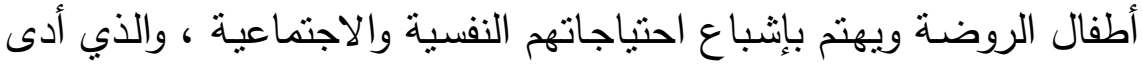
إلى استمرار أثزه بعد مرور فتزة زمنية قدرها أسبوعين ، وأيضاً تقديم الباحثة الفئة

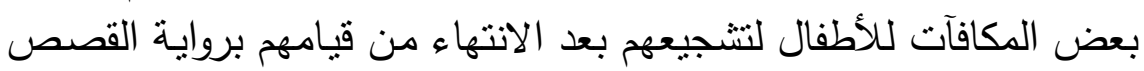

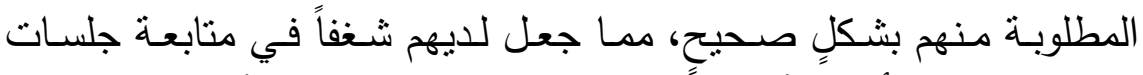

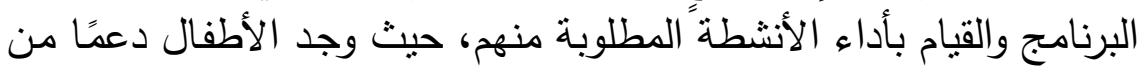

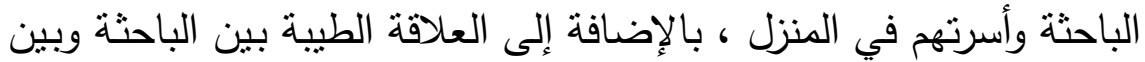

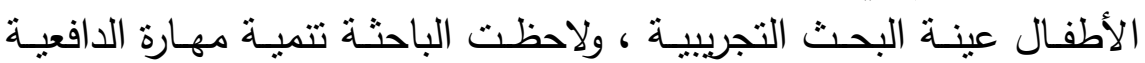

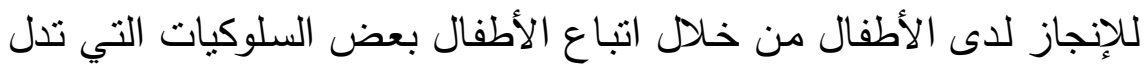

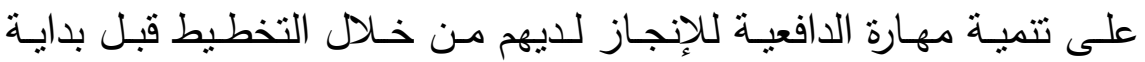

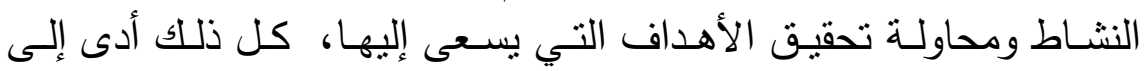

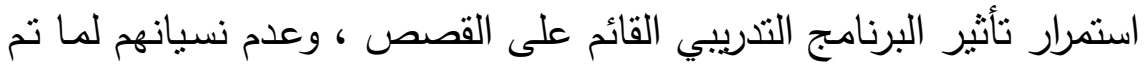
اكتسابه من مهارات ، وبذللك فقد تحققت صحة الفرض الثرائ الثاني للبحث.

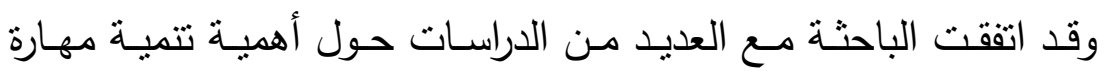

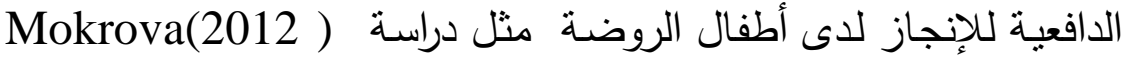

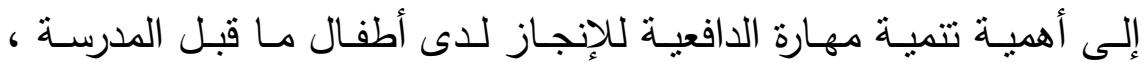

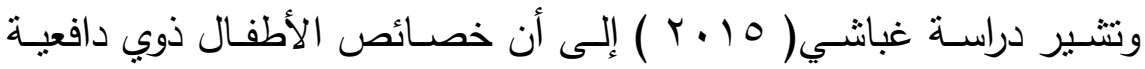

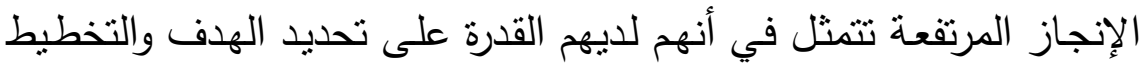

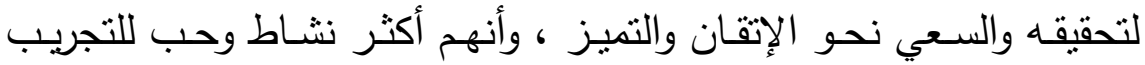

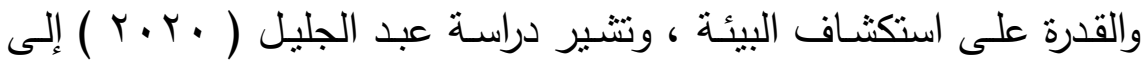

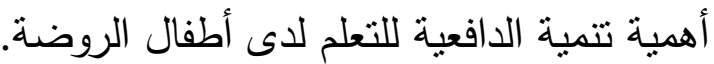




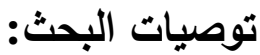

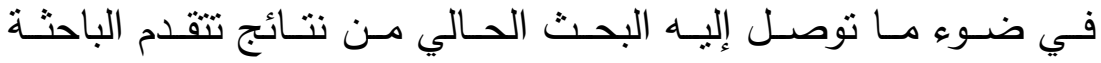
بالتوصيات التالية للاستفادة منها:

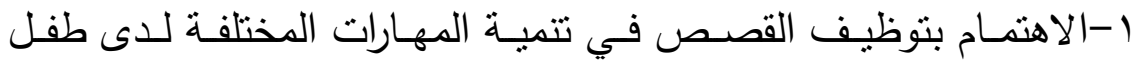

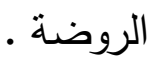

r-ضرورة الاهتمام بمهارة الدافعية للإنجاز في مرحلة الطفولة لما لها من دور بالغ الأهمية. r- توعية معلمات الروضة بأهمية استخدام القصص داخل الروضة.

\section{المراجع}

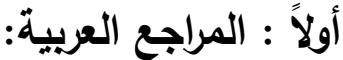

- إبراهيم ، صـلاح محمد (1 . . ب ) . فاعلبية برنـامج لبعض المهارات

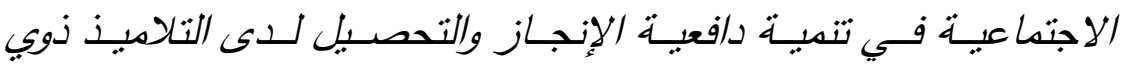

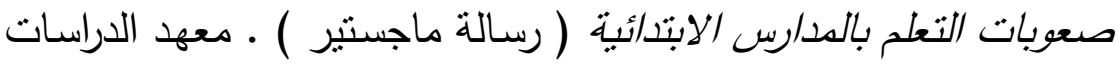
التربوية · جامعة القاهرة.

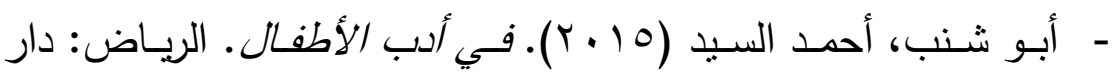

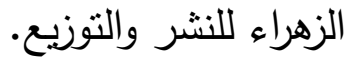

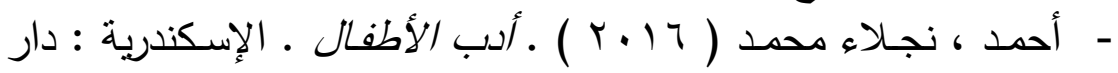

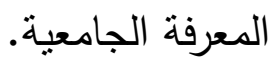

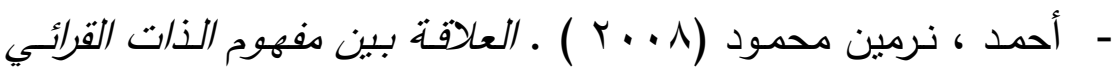

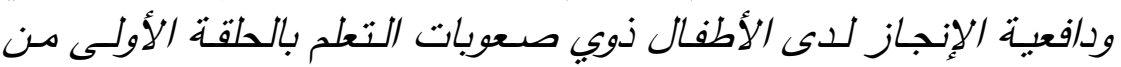

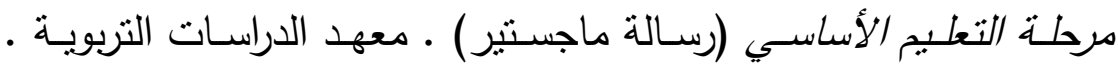
جامعة القاهرة. 


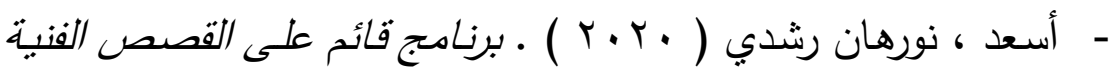

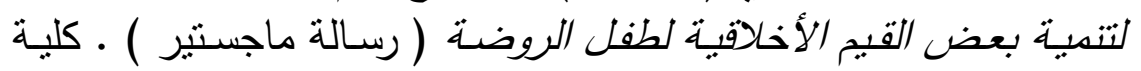

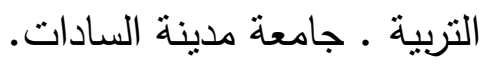

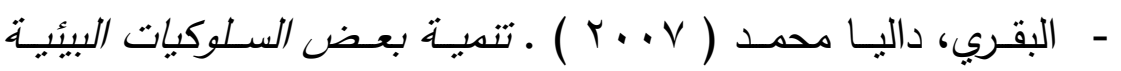

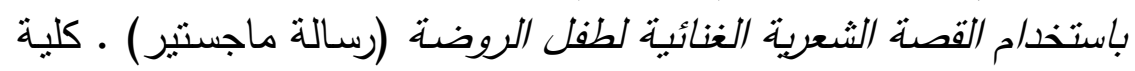
رباض الأطفال • جامعة القاهرة

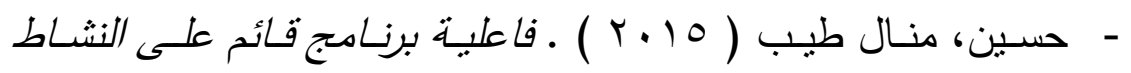

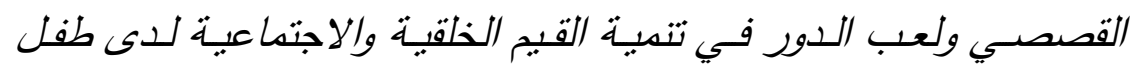
الروضة (رسالة ماجستير) ـ كلية العلوم التربوية ـ جامعة الإسراء.

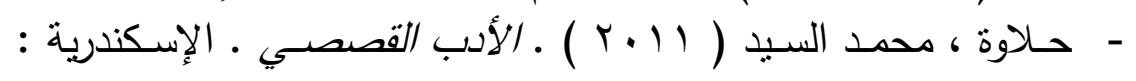

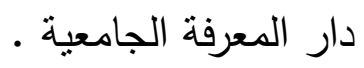

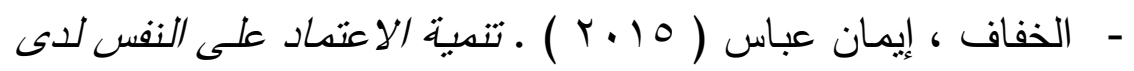

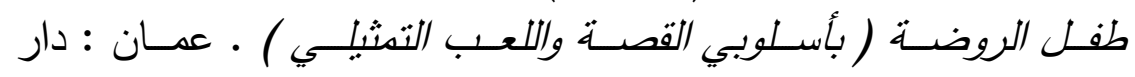

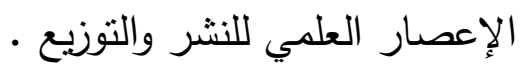

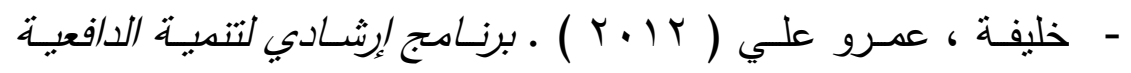

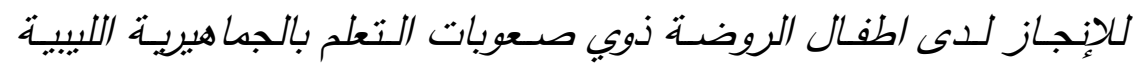

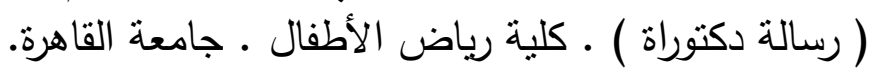

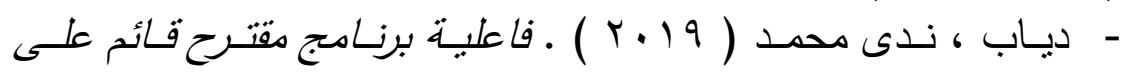
القصة لتنمبة بعض المهارات الحباتية لطفل الروضة ( رسالة ماجسنير )

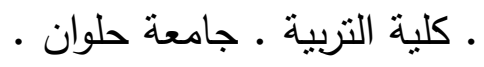

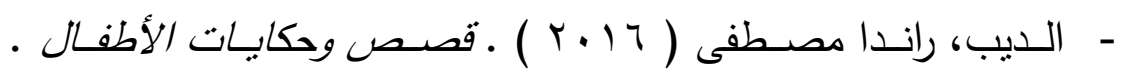
الاسكندرية : دار المعرفة الجامعية. 


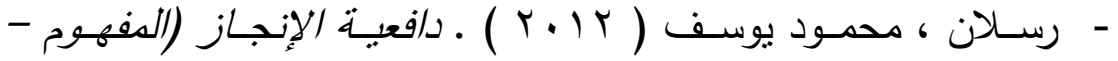

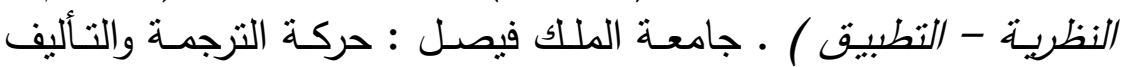
والنشر

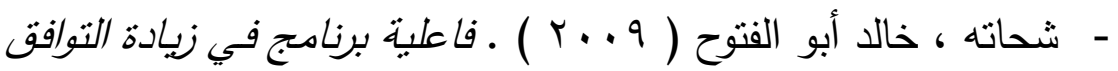
النفسـي والاجتهـاعي لـدى الأطفال الصــم باسـتخدام فنبـات السـبكودراما

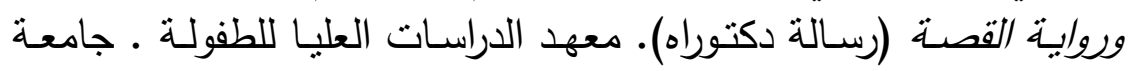
• عين شمس وله

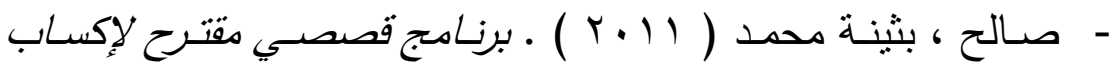

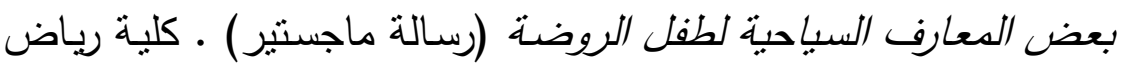
الأطفال . جامعة الإسكندرية. - عبد الجليل ، إسراء أحمد ( . . . . ) . فاعلبة برنامج مقترح باستخدام

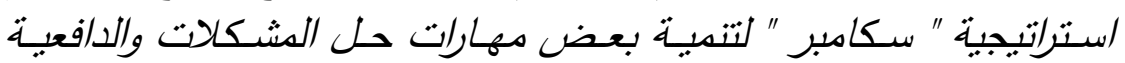
للتعلم للدى أطفال الروضـة ( رسـالة ماجستير ) ) كليـة التربيـة ـ جامعـة سوهاج.

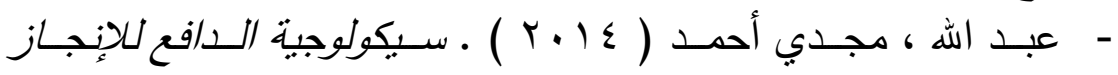
( دراسة عامة مقارنة ) · الإسكندرية : دار المعرفة الجامعية .

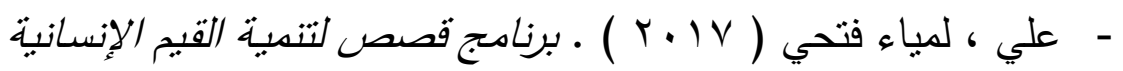

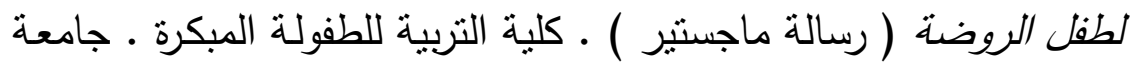
القاهرة . مان

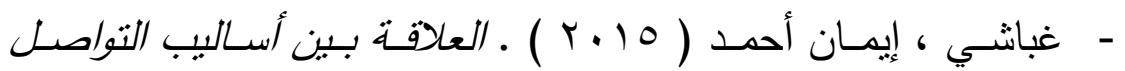

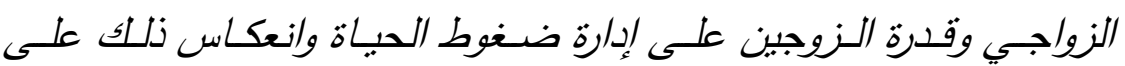

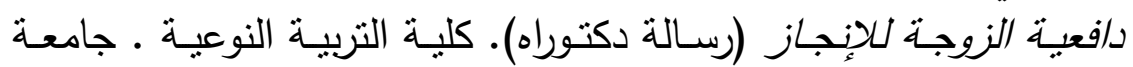
بورسعيد. 


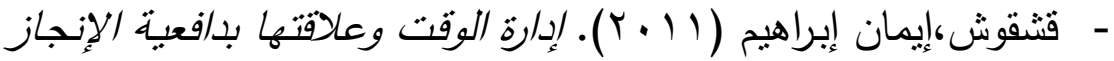

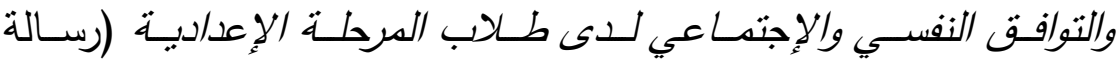
ماجستير) ـ كلية الإقتصاد المنزلي . جامعة المنوفية.

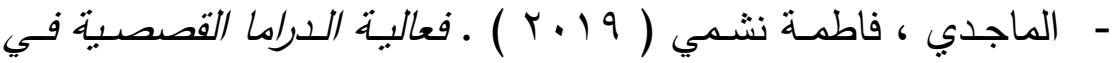

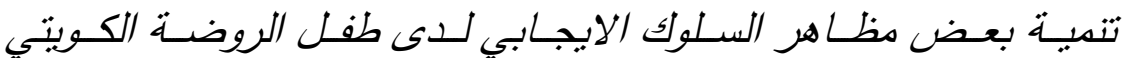
( رسالة ماجستير ) ) ـ كلية التربية النوعية ـ جامعة بنها.

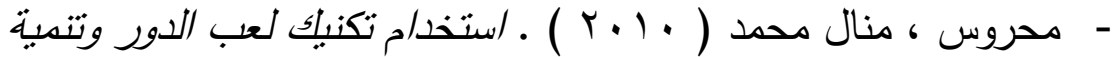
دافعية الإنجاز • كفر الثيخ : المكتب الجامعي الحديث.

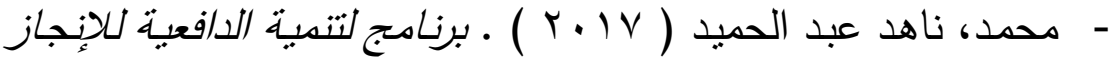
لدى أطفال الروضشة ذوي صعوبات التعلم الموهوبين (رسالة ماجستير) . كلية التربية للطفولة المبكرة ـ جامعة القاهرة ـ

\section{ثانيًا: المراجع الأجنبية:}

- Jamjoom, Saja M.K. (2014). Story Reading and Literary Arabic Vocabulary Acquisition in Kindergarten. Ph.D., Northwestern University, United States.

- Kang, Ling Yun. (2010). Research on story activity in kindergarten during 100 years' early childhood education reformation in china. East China Normal University, United States.

- Rota, Maria. (2011). Use of Social Stories with Students in an Inclusive Kindergarten Classroom: An 
Action Research Study. Ed.D, University of Rochester, United States.

- Spearman, Brenda R. (2012). The Effects of Using Dramatic Play on Students' Interest in Pleasure Reading. Ed.D., Northcentral University, United States Arizona.

- Zhou, Ninger. (2014). Effects of multimedia story reading on preschoolers' vocabulary learning, story comprehension and reading engagement. Ph.D, Purdue University, United States. 


\section{A Training Program Based on Brain Gym to Develop Auditory and Visual Memory in English Language for Kindergarten Children Predictive of Learning Difficulties}

Prof. Dr/ Aml Mohamed Hassona. *

Prof.Dr/Jehan Mahmoud El-Bassuony. **

Rania Salem Salama Salem. ***

\section{Abstract:}

The research aimed to measure the effectiveness a training program based on brain gym for developing auditory and visual memory in English language among kindergarten children predictive of learning difficulties in English language. Battery diagnostic measures for the difficulties of "social and emotional" behavior (Prepared by: Fathi El Zayat). The quasi-experimental approach was used by the one-group method, and the research tools included a pre- and post-auditory-visual memory scale (prepared by the researcher). The researcher used a training program based on brain gym to develop auditory / visual memory in English language among kindergarten children predictive of learning difficulties (prepared by

* Professor of Child Psychology (Ment: Head of the Psychological Science, Faculty of Early Childhood Education - Portsaid University.

** Professor of Curricula and Methods of Teaching English Language Faculty of Education - Port Said University.

*** Researcher, Department of Psychological Sciences - Faculty of Early Childhood Education - Portsaid University. 
the researcher) to be applied to a sample of (15) children, male and female, at the second level of kindergarten stage. The results of the research have proven the effectiveness of the training program based on brain gym in developing memory (audio - visual) in English language among kindergarten children who predictive of difficulties in learning English language.

\section{Research Terminology:}

- Training program.

-Brain gym.

- Auditory / visual memory.

- Kindergarten children predictive of difficulties in learning English language.

\section{Introduction:}

Learning disabilities is an important topic in the field of special education, and it has received a tremendous amount of attention from specialists and researchers. This may be due to the size of the problems and challenges that students face in different educational stages as a result of learning difficulties. This is in addition to the ambiguity of this concept and the difficulty of distinguishing it from other categories of special education and the categories that are similar with them, 
such as academic delay and slow learning. Most children who have learning difficulties had difficulties in learning reading, writing and mathematics, and they had impairment of long-term memory (retention and recall) in controlling concepts (Hammadena, 2017).

In this field, different strategies, styles, and methods have been developed to educate and train people with learning difficulties and to develop their abilities and skills. One of such methods is the brain gym developed by researchers Dennison \& Dennison in the mid-seventies of the twentieth century. It is based on early intervention with the aim of integrating body movements with the mind and learning through a series of exercises designed to help learners create coordination between their brains and bodies in an integrated manner. It also aims to Creating a balance between the left and right hemispheres of the brain, improving the flow of Dopamine and Norepinephrine, increasing blood flow to the prefrontal cortex, and improving memory and academic skills such as reading, writing, counting, mathematical skills, as well as social skills, such as social communication, forming relationships and social competence (Brain Gym International, 2011). 
In this regard, the study of Andrea (2012) aimed to verify the effectiveness of brain gym activities on the academic participation of children with learning difficulties, through research based on experimental evidence in the effect of brain gym movements on such children's behaviors necessary to complete the task. The results will help practitioners to accept or reject brain gym as an effective activity to improve children's academic behaviors, in the wake of the latest educational legislation, as there have been new educational methods applied in the school system. One of the methods that were implemented is the Educational Kinesiology Program based on a program called "Brain Gym". This study has shown some positive effects on the percentage of behaviors needed to complete the task with brain gym activities.

The results of a research study by Dorothea Paige (2003), Witzlar, Germany, conducted in a school district, concluded that children who did brain gym activities read faster, made fewer mistakes, and had a better understanding of the test material than the two comparison groups (Brain) Gym Journal, Aug. 2003). 
Patrick Le Maire (2002) pointed out that memory is a cognitive process through which learning and retrieval of what has been learned and gained from previous experiences is done. The first process takes place by receiving information to process it in working memory and then storing it in long-term memory. The second process is retrieval and extraction of information stored in long-term memory to short-term memory to use it (Elsayed \& Rakza, 2020, 81).

The researcher believes that memory (auditory - visual) is one of the important skills that must be studied as one of the psycho-linguistic skills, as the weakness of memory or the decrease in the ability to retrieve information is one of the deficiencies of the child predictive of difficulty in learning. It is worth noting that this difficulty does not appear in the child's ability to remember things that happened a long time ago, i.e. longterm memory, but the problem lies in the weakness of short-term memory.

The use of brain gym for children predictive of learning difficulties to develop auditory and visual memory in English language may result in an improvement in the level of their visual and auditory memory, especially if 
this use is done in a systematic and effective method in an organized program, which is what the current research tries to look in and consider.

\section{The Research Problem:}

Based on the researcher's experience with the reality of kindergartens during her work as a kindergarten teacher and direct contact with children, and based on the importance of English language as one of the necessary requirements for children's adaptation to modern progress in education, and in light of some previous Arabic literature that emphasized the effectiveness of early intervention to develop the child's auditory and visual memory and the extent of the effectiveness of the programs presented to improve these capabilities, the researcher could emphasize the importance of auditory and visual memory for kindergarten children in general, and those who are predictive of learning difficulties in particular.

The researcher sought to study the strength and weakness points of the cognitive channels of kindergarten children who are predictive of difficulties in learning English language, with the aim of diagnosing those points 
and seeking to improve and develop weaknesses by developing and designing a program to treat deficiencies in the auditory and visual memory of children (the research sample).

This was done through open interviews with some kindergarten teachers and mothers of children. The interviews were conducted with the aim of getting acquainted with the views of the teacher and the mother on the cognitive abilities that the child lacks and that limits creativity among children predictive of learning difficulties while interacting with the teacher and peers. Through these interviews, it was revealed that the child's level of auditory and visual memory in English language has been low. In addition, open interviews were held with some of the children predictive of learning difficulties to determine the visual and auditory abilities which they lack and which affect memory in learning English language.

In view of the foregoing, and with the researcher's observation that there are no local studies and research that have dealt with this topic, as this area lacked previous studies and research, and with the importance of developing treatment strategies that help reduce auditory 
and visual memory difficulties in English language among kindergarten children who are predictive of learning difficulties and improve their academic performance in English, it has been revealed that training programs based on brain gym may be effective in developing auditory and visual memory in English language in kindergarten children who are predictive of learning difficulties.

Therefore, the current research attempts to answer the following main question:

What is the effectiveness of a training program based on brain gym in developing auditory and visual memory skills in English language among kindergarten children who predictive of learning difficulties?

This main question is divided into the following sub-questions:

1)What are the training activities that can develop the memory (audio - visual) in English language for kindergarten children who predictive of learning difficulties? 
2)What are the differences between the scores of kindergarten children who are predictive of learning difficulties in the pre and post measurement of memory (auditory - visual) in English language?

3)What are the differences between the scores of kindergarten children who are predictive of learning difficulties in the post and follow-up measurement of memory (auditory - visual) in the English language?

\section{The Research Objective:}

In general, the research aimed to measure the effectiveness of a training program based on brain gym to develop memory (audio-visual) in English language in kindergarten children to reduce the difficulties of learning English language, in addition to knowing the extent to which the auditory and visual memory skills of children improved after applying the program later.

\section{Importance of the Research:}

- The importance of the current research comes through dealing with an important aspect of the educational process, which is to reveal the effectiveness of brain gym in developing auditory and visual memory in English 
language among kindergarten children who are predictive of learning difficulties.

- The results of this research may contribute to raising the level of cognitive awareness of kindergarten teachers and counselors about the benefit that might stem from brain gym in their interaction with children who are predictive of learning difficulties and improving the level of auditory and visual recollection skills in English language.

\section{Methodological Procedures of the Research:}

\section{First: The Research Sample:}

The current research sample consisted of (15) kindergarten children who predictive of difficulties in learning English language at the age of (5-6) years. The sample was intentionally chosen from the Kindergarten of Port-Said Official Language School in Port-Said Governorate, and homogeneity among the children of the study sample was taken into account by observing the following:

1- The chronological age of all children of the sample ranges between (5-6) years.

2- IQ scores should not be less than (90-110) on the Stanford-Binet Intelligence, the fifth edition. 
3- The children have obtained the highest score in the difficulty scale, prepared by (Fathi Mustafa Al-Zayat).

4- The children of the sample are those who are obligated to attend the kindergarten, as this facilitates their commitment to attend and hence, to the current study program.

5- None of children of the sample may suffer from obvious health problems or disabilities, so as not to affect their performance in the program.

Based on the previous conditions, the study sample was determined (15) boys and girls (9) males, and (6) females. Data were collected on the chronological age of the sample members from the lists of the school administration.

\section{Second: Research Methodology:}

The quasi-experimental approach, one-group design, was used to investigate the effectiveness of a training program based on brain gym for developing auditory and visual memory in kindergarten children predictive of learning difficulties. 


\section{Third: Research Instruments:}

The researcher prepared the following tools:

1.A scale of auditory and visual memory in English language for kindergarten children who predictive of learning difficulties (prepared by the researcher).

2.A program based on brain gym for developing auditory and visual memory among kindergarten children who are predictive of learning difficulties (prepared by the researcher).

3.A scale of auditory and visual memory in English language for kindergarten children who predictive of learning difficulties, the scale consists of two dimensions as follows:

\section{The first dimension: (Auditory memory):}

It refers to the ability of a kindergarten child to remember a series of auditory stimuli, and to arrange them and organize them in a sequence, such as arranging English letters or numbers.

\section{The second dimension: (Visual memory):}

It refers to the ability of a kindergarten child to remember a series of visual stimuli.

The scale was codified in terms of validity and reliability as follows: 


\section{Stability of the scale:}

The researcher used (Cronbach's Alpha Coefficient) to measure the reliability of the scale on a pilot sample consisting of (30), which was excluded from the main sample of the study. The following table shows the statistical procedure:

Table (1)

Demonstrates stability coefficients for the auditory and visual memory scale using Cronbach's alpha

\begin{tabular}{|l|l|}
\hline $\begin{array}{l}\text { Dimensions of } \\
\text { Psycholinguistic Skills }\end{array}$ & $\begin{array}{l}\text { Scale of Cronbach Alpha } \\
\text { Coefficient }\end{array}$ \\
\hline $\begin{array}{l}\text { The first dimension: auditory } \\
\text { memory }\end{array}$ & 0.911 \\
\hline $\begin{array}{l}\text { The second dimension: } \\
\text { visual memory }\end{array}$ & 0.980 \\
\hline Overall Score & 0.905 \\
\hline
\end{tabular}

From the previous table, It is evident that the general reliability coefficient for the scale dimensions is high, reaching $0.905 *$ for the total scale items. This indicates that the scale has a high degree of stability that can be relied upon in the field application of the research according to the Nunnalle Scale, which adopted 0.70 as 
the minimum stability.

\section{Validity of the scale:}

\section{Terminal comparisons validity:}

The scale was applied to the rationing sample $(\mathrm{N}=30)$ of kindergarten children who are predictive of learning difficulties and were not included in the final application of the scale in order to calculate the differences between the highest and lowest quartiles (27\%) of the children's scores, using the T-test shown in the following table:

\section{Table (2)}

Results of the T-test to study the differences between the averages of the peripheral groups of the auditory and visual memory scale of the pilot sample

\begin{tabular}{|l|l|l|l|l|l|l|l|l|}
\hline & \multicolumn{3}{|c|}{ Higher Quadrant } & \multicolumn{3}{c|}{ Lower Quadrant } & & \\
\cline { 2 - 7 } Variable & $\mathrm{N}$ & Mean & $\begin{array}{c}\text { Standard } \\
\text { Deviation }\end{array}$ & $\mathrm{N}$ & Mean & $\begin{array}{c}\text { Standard } \\
\text { Deviation }\end{array}$ & $\mathrm{T}$ & $\begin{array}{c}\text { Level of } \\
\text { significance }\end{array}$ \\
\hline $\begin{array}{l}\text { Auditory } \\
\text { visual } \\
\text { memory as } \\
\text { a whole }\end{array}$ & 8 & 8.750 & 0.462 & 8 & 5000 & 0.000 & 22.913 & 0000 \\
\hline
\end{tabular}

From the previous table, it is evident that there is a statistically significant difference at the level (0.001) 
between the highest and the lowest quartiles on the auditory and visual memory scale in favor of the mean of the highest quartile of the total sample. This indicates the differential validity of the auditory and visual memory scale, indicating that the scale has a high ability to distinguish between high and low memory. Thus, the researcher made sure that the auditory and visual memory scale has a high degree of stability on the pilot sample of the current research.

First: A program based on brain gym to develop auditory and visual memory in English language among kindergarten children who are predictive of learning difficulties.

The researcher designed and implemented a set of (30) training sessions based on brain gym, and the activities were formulated to cover all visual and auditory memory skills of the subject of the study. The activities were designed to develop such skills while properly employing kindergarten children who are predictive of learning difficulties. 


\section{The program build-up steps:}

The program was built with the following steps:

\section{(1) The general objective:}

The development of auditory and visual memory in English language among kindergarten children predictive of learning difficulties

\section{(2) Sub-goals:}

-Development of the child's ability of auditory recollection.

-Development of the child's ability visual recollection Procedural objectives.

\section{After completing the program, the child should be able to:}

-Retell three or more unrelated words as heard from the teacher, in the same order.

-Retell three sounds in the same order after hearing them from the teacher.

-Imitate the number of repeats of a sound up to three 
times.

-Retell five non-serial numbers after the teacher in the same order.

- Retell three sounds related to three pictures in front of them, and when each picture is displayed, the child speaks up the sound.

-Mention three actions a person took in three different places through a story that was presented to them.

-Mention four details in a picture that was shown to them for five seconds when asked verbally.

-Imitate four drawings, from memory, displayed for 10 seconds.

-Recall and remember things delayed after 5 seconds: Two stimuli are shown, then hidden and returned in a group.

-Point to things that have been seen before.

-Mention the names of four pictures of four people s/he remembers that were shown to them successively, a separate action for each person. 
-Execute commands and instructions presented to them acoustically.

Second: Building sessions and activities of the program based on brain gym:

In light of the goals that the program seeks to achieve, (30) training sessions have been determined aimed at developing auditory and visual memory to reduce learning difficulties in English language.

\section{Third: Preparing tools of evaluation :}

Three instruments of evaluation are used in the program:

1)Pre-evaluation: This is conducted before applying the program by applying the auditory and visual memory scale to the children of the experimental group, then recording the children's scores on the scale in order to determine the memory difficulties in their English language.

2)Formative evaluation: in which the child is evaluated continuously from the beginning of the program until its end. This is done on a daily basis during or after presenting the activity through cards presented to children 
daily as an application to the activity. It can be called (individual evaluation) to observe the progress made by children after undergoing the brain gym program and compare that to their scores before undergoing it.

3)Post evaluation: It is used after completing the application of the brain gym program to find out the progress achieved and compare that with the scores of children before undergoing the program. The auditory and visual memory scale is applied to children again.

\section{Research Hypotheses:}

Based on the research problem and objectives, the researcher determined the following hypotheses for the research:

1. There are statistically significant differences between the two means of the experimental group children's score ranks (the experimental study sample) on the auditory and visual memory scale in English language among kindergarten children who are predictive of learning difficulties before / after the application of the brain gym program in favor of the post-measurement.

2. There are no statistically significant differences between the two means of the experimental group 
children's score ranks (the experimental study sample) on the auditory and visual memory scale in English language among kindergarten children who are predictive of learning difficulties in the post and follow-up measurements.

\section{Research Findings:}

The hypotheses formulated were tested with the aim of ensuring the effectiveness of the brain gym strategy in developing psych-linguistics skills among gifted kindergarten children prone to learning difficulties in English language.

\section{Findings of the First Hypothesis: Discussion and Interpretation:}

The first hypothesis of the research states that:

"There are statistically significant differences between the two means of the experimental group children's score ranks (the experimental study sample) on the auditory and visual memory scale in English language among kindergarten children who are predictive of learning difficulties before / after the application of the brain gym program in favor of the post-measurement".

To verify the validity of this hypothesis, the researcher used the Wilcoxon Test for Correlated Groups to find the 
significance of the differences between the two means of score ranks of kindergarten children predictive of learning difficulties before applying the program and the two means of score ranks of the same group after applying the program, as shown in the following table:

\section{Table (3)}

The mean and sum of the negative and positive ranks and the $Z$ value between the pre and post measures on the psycholinguistic skills scale as a whole by Wilcoxon method

\begin{tabular}{|c|c|c|c|c|c|c|}
\hline Skills & \begin{tabular}{|} 
Rank of \\
the \\
Psycho- \\
Linguistic \\
Skills \\
Variable
\end{tabular} & \multirow[t]{2}{*}{$\begin{array}{l}\text { Number } \\
(\mathrm{N})\end{array}$} & \multicolumn{2}{|c|}{$\begin{array}{c}\text { Pre/post } \\
\text { Measurement }\end{array}$} & \multirow[t]{2}{*}{ Z Value } & \multirow[t]{2}{*}{$\begin{array}{l}\text { Statistical } \\
\text { Significance }\end{array}$} \\
\hline \multirow{5}{*}{$\begin{array}{l}\text { Auditory } \\
\text { / visual } \\
\text { memory }\end{array}$} & & & $\begin{array}{l}\text { Ranks } \\
\text { Mean }\end{array}$ & $\begin{array}{l}\text { Ranks } \\
\text { Total }\end{array}$ & & \\
\hline & $\begin{array}{c}\text { Negative } \\
\text { Ranks }\end{array}$ & 0.0 & 0.00 & 0.00 & \multirow[t]{4}{*}{-3.424} & \multirow[t]{4}{*}{0.001} \\
\hline & \begin{tabular}{|c|} 
Positive \\
Ranks
\end{tabular} & 15 & 8 & 120 & & \\
\hline & $\begin{array}{l}\text { Neutral } \\
\text { Ranks }\end{array}$ & 8 & & & & \\
\hline & \begin{tabular}{|c|} 
Total \\
Summation
\end{tabular} & 15 & & & & \\
\hline
\end{tabular}

According to the previous table, it becomes clear that there are statistically significant differences at the level of significance $(0.001)$ between the mean ranks of children who are predictive of learning difficulties in the study 
sample before and after the application of the program on the auditory and visual memory scale as a whole, used in the current study, in favor of the post application. The values of $\mathrm{Z}$ between the pre and post applications of the current study sample reached $(-3.424)$.

\section{Interpretation and discussion of the findings of the first hypothesis :}

It is evident, from the previous table, that there are statistically significant differences between the score ranks of the experimental group before and after applying the program on the auditory and visual memory scale in English language as a whole.

The findings of the research showed that there was an improvement in both auditory and visual memory of the members of the experimental sample after applying the training program to them. The improvement in visual memory is due to the program's containment of memory improvement strategies that are represented by (repetition - chuncking - mind maps).

During the application, the researcher has also taken into account the clarity of the presented visual stimuli, the arrangement of the presentation, the division of everything presented into categories, in addition to taking into account the number of the presented visual stimuli so that they do not exceed more than seven. The researcher 
also took into account the time of presentation of the stimuli so that it took less than 10 seconds. These stimuli contributed to increasing and improving the attention span of the children of the study sample, which contributed to improving visual memory.

As for the auditory memory, the findings showed a strong effect of the current program, as the program included training in auditory memory on a number of training tasks that helped improve this pattern of memory. The training program included two strategies to improve memory (repetition and coding), as well as the combination of new information and previous information for the child, which contributes to improving memory efficiency. Program activities in this component included renaming known solid models, recounting a group of words after being presented by the teacher, recounting sounds in the same order, and retelling a sentence.

The auditory memory training has taken into consideration improving the child's ability to make generalizations through the use of auditory memory to retain directions and instructions, improving the child's ability to follow related commands and instructions, retransmitting a verbal message to another person outside the classroom, and remembering a home address in detail including the street name and number, and the house 
number, in addition to retelling a phone number. Repetition is one of the important means of training in skills and emphasizing behaviors. The current research was not only limited to using this technique for instructions and explanation, but also extended to the use of the technique of repetition of activities.

The researcher attributes these differences also to the brain gym used in this research, where the auditory and visual memory deficiency in English language - which kindergarten children who are predictive of learning difficulties suffer from - is an important factor affecting memory deficiency in English language. Memory deficiency is reflected in the child's deficiency in both auditory and visual recollection, which in turn affects the ability of these children to satisfy their needs or desires to learn English language. It also reflects on the ability to recall and remember auditory and visual information. This affects the ability of these children to follow instructions and recall relevant information in English language. Hence, the preparation of the current program, including many objectives and activities based on brain gym, has become urgent. Consequently, the researcher sought to prepare the program in a way that suits the capabilities of children who are predictive of learning difficulties to achieve the objectives of the current research. The objectives of the program were applied to the members of the experimental group, which 
contributed to finding statistically significant differences between the mean scores of the experimental group children before and after the application of the program on audio and visual memory in favor of the post measurement.

The researcher believes that the choice of brain gym and the use of its techniques contributed to the development of auditory and visual memory among the children of the experimental group. Brain gym had an important role in increasing children's motivation to participate in the sessions and activities of the training program. In addition, brain gym affected the auditory and visual memory of these children "the experimental study sample."

\section{The findings of the second hypothesis: discussion and interpretation:}

The second hypothesis of the research states that "There are no statistically significant differences between the two means of the experimental group children's score ranks (the experimental study sample) on the auditory and visual memory scale in English language among kindergarten children who are predictive of learning difficulties in the post and follow-up measurements". 
To verify the validity of this hypothesis, the researcher used the Wilcoxon parametric test to detect the significance of the differences between the pre and follow-up measurements of the research sample. Table (4) illustrates the findings.

\section{Table (4)}

The mean and sum of the negative and positive ranks and the $Z$ value between the post and follow-up measures of the Wilcoxon Auditory Scale

\begin{tabular}{|c|c|c|c|c|c|c|}
\hline \multirow{6}{*}{$\begin{array}{l}\text { Scale of } \\
\text { auditory } \\
\text { and } \\
\text { visual } \\
\text { memory } \\
\text { as a } \\
\text { whole }\end{array}$} & \multirow{2}{*}{$\begin{array}{l}\text { Ranks of the } \\
\text { variable of the } \\
\text { auditory and } \\
\text { visual memory } \\
\text { scale }\end{array}$} & \multirow{2}{*}{\begin{tabular}{|l} 
Numbe \\
\\
N
\end{tabular}} & \multicolumn{2}{|c|}{$\begin{array}{l}\text { Follow-up \& } \\
\text { post } \\
\text { measurement }\end{array}$} & \multirow[t]{2}{*}{ Z-valu } & \multirow[t]{2}{*}{ Significance } \\
\hline & & & $\begin{array}{l}\text { Ranks } \\
\text { Mean }\end{array}$ & $\begin{array}{l}\text { Ranks } \\
\text { Total }\end{array}$ & & \\
\hline & Negative Ranks & 0.0 & 0.00 & 0.00 & 0.000 & 1.000 \\
\hline & Positive Ranks & 15 & & & & \\
\hline & Neutral Ranks & 0 & & & & \\
\hline & $\begin{array}{l}\text { Total } \\
\text { Summation }\end{array}$ & 15 & & & & \\
\hline
\end{tabular}


The previous table shows that there are no statistically significant differences between the two means of score ranks of children who are predictive of learning difficulties in the study sample after applying the program and after a month of post-measurement on the auditory and visual memory scale as a whole, which is used in the current research. The values of $\mathrm{Z}$ between the post and follow-up measurements of the study sample on the scale as a whole reached $(0.000)$.

\section{Interpretation of the second hypothesis findings:}

From the previous table, it is evident that there are statistically significant differences between the scores of the experimental group in the post and the follow-up measure on the auditory and visual memory scale as a whole. The researcher attributes these differences to the training program based on brain gym used in the current research. This is due to the continuing effect of brain gym on the research sample in the total score of the auditory and visual memory scale in the post and follow-up measurement.

The researcher believes that the use of brain gym has contributed to improving the child's motivation to accomplish the activities required of them. The diversity 
in the use of the audio and visual stimuli included in the training program led to the motivation of the child to pay attention to these stimuli more positively and to improve their performance in terms of memory.

During the implementation of the training program, the researcher took into account the transition of the effect of auditory/visual improvement during the child's reception of auditory and visual stimuli to improvement of reception and grasp of verbal instructions addressed to them. The child's ability to receive verbal vocabulary, which the researcher uttered during doing the training program activities, has increased.

The findings of the current research demonstrated the effectiveness of the program based on brain gym in developing auditory and visual memory in kindergarten children who are predictive of learning difficulties, as evidenced by the results of the two hypotheses. This reflects the tangible improvement in auditory and visual recollection that the auditory and visual memory scale measures after implementing the program. This indicates the utility of the program in developing auditory and visual memory. 
Thus, all the findings of the current research indicate that the two research hypotheses that the researcher tried to answer in the current research have been fulfilled. All of them aim to verify the effectiveness of brain gym in developing auditory and visual memory in kindergarten children who predictive of learning difficulties. The findings are evident through a comparison between the responses of the children of the experimental group in the pre- post and follow-up measurements.

These results confirm the effectiveness of using brain gym in developing auditory and visual memory in English language among kindergarten children who are predictive of learning difficulties. Based on the above, and by accepting the two research hypotheses, the training program based on brain gym has done well in developing auditory and visual memory in English language among kindergarten children who are predictive of learning difficulties.

\section{Recommendations and Proposals:}

Based on the foregoing, the researcher can mention the following recommendations and suggestions: 
1.Holding special courses for ordinary teachers who teach children who are predictive of learning difficulties in English language periodically to familiarize them with children with learning difficulties and how to deal with them.

2.Designing special programs for children predictive of learning difficulties who suffer from weakness and limitations in auditory and visual memory in English language.

3.Conducting more research and studies dealing with memory (especially successive auditory and visual memory) in English language for children who are predictive of learning difficulties in different environments other than the one in which this study was conducted in order to generalize the findings to a larger possible sample.

\section{Suggested Research:}

1. Conducting a study dealing with the effectiveness of brain gym in developing working memory in children predictive of learning difficulties.

2. Conducting a study that deals with the importance of brain gym in helping to teach English to children who are predictive of learning difficulties in the surrounding community. 
3. Conducting a study dealing with training kindergarten teachers to develop audiovisual memory for kindergarten children.

\section{Bibliography}

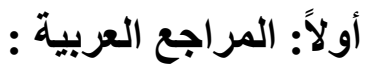

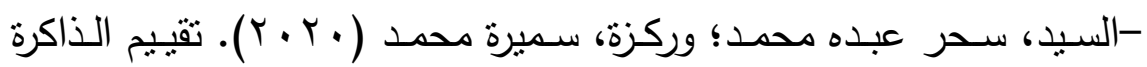

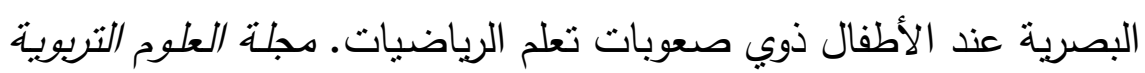

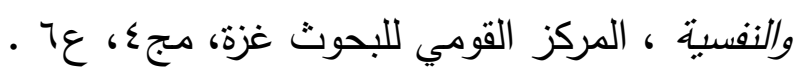

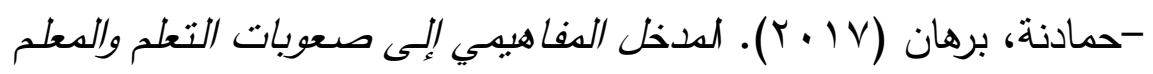
والأسرة. المملكة العربية السعودية: مكتبة الرشد.

\section{Second: Foreign Resources:}

-Andrea, Goodwin Watson, B.A (2012). The Effect of Brain Gym on On-Task Behavior for Children with Disabilities, Master of Arts in School Psychology, the Faculty of the Graduate School of Stephen F. Austin State University, IJMI Number: 1507360.

-Brain Gym International.(2011). Edu-K Style ide: The Style and Standards of Educational Kinesiology. Ventura، California, U.S.A.

-Brain Gym Journal, Aug.( 2003). Volume XVII, No. 2. 

فاعلية برنامج إثرائي متكامل لتنمية الإدراك الحسي ومهارات

التفاعل الاجتماعي لاى أطفال اضطراب التوحد (دراسة ميدانية) * د أندريا أنور أيوب البزنط.

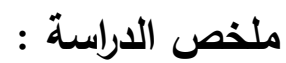

هدفت الدراسة الحالية إلى التحقق من مدى فاعلية برنامج إثرائي متكامل فـي تتميـة الإدراك الحسـي ومهـارات التقاعـل الاجتمــاعي، مثـل مهـارة التواصل الاجتمـاعي، الاستقبال، التقليد، التعاون، وتكونت عينـة الدراسـة

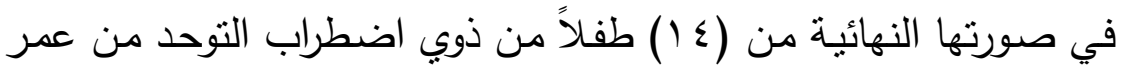
( ( - T) سنوات، وتم تقسيمهم إلى مجموعتين، كل مجموعة (V) أطفالاً

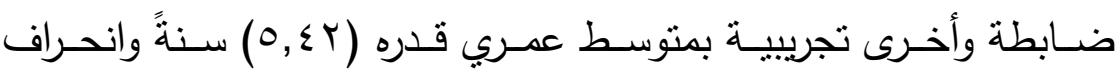

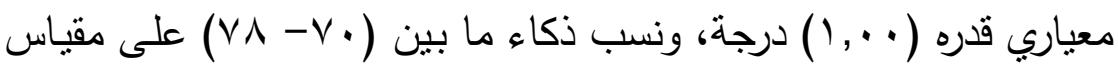
جـوودارد. واسـتخدم الدراســة الحسالي مقياسـي مهـارات الإدراك الحسـي

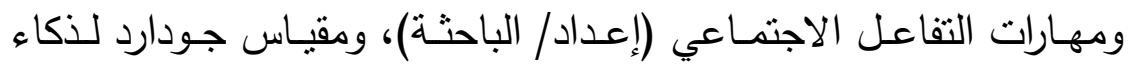
الأطفال ذوي اضطراب التوحد ومقياس كارز ، وكذللك البرنـامج التدريبي المتكامـل (إعداد/ الباحثة) والـذي اسـتمر على مـدار (بس) جلسـةًة لمـدة ثلاثة شهور • وتوصلت الدراسة الحالية إلى النتائج التالية: فاعلية برنامج

* مدرس بقسم العلوم النفسية- كلية التربية للطفولة المبكرة - جامعة دمنهور. 
إثرائسي متكامـلـ فـي تتميـة مهـارات الإدراك الحسـي ومهـارات التفاعـل الاجتمـاعي للطفل التوحدي، فحقق الأطفال تحسن في مهارات الإدراك الحسي ( الحركي والبصـري والسـعي واللمسي والثــي والتذوقي)، وفي مهـارات التفاعـل الاجتمـاعي (مهـارة التواصـل الاجتمـــي واعلاعـتقبال والتقليد والتعاون)، وعدم وجود فروق ذات دلالة إحصائية بين رتب أفراد

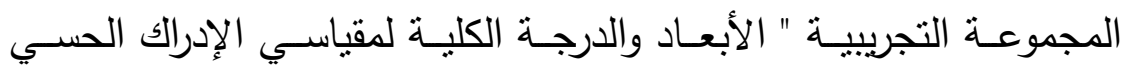
ومهارات التفاعل الاجتماعي " بين القياس البعدي والتتبعي.

Effectiveness of Integrated enrichment program in development of sensory perception and social interaction skills by children with autism disorder

Prepare: Dr. / Andria Anwar Ayob Albzand. *

\section{Abstract:}

The aim of the current study is to verify the effectiveness of an integrated enrichment program in developing sensory perception and social interaction skills, such as the skill of social communication, reception, imitation, cooperation. The study sample in its final form consisted of (14) children with autism from the age of (4- 6) years, and they were divided into two groups, each group (7) children were control and the

*Lecturer, Department of Psychological Sciences- Faculty of Education Early Childhood - Damanhour University. 
other experimental, with an average age of (5.42) years and a standard deviation of (1.00) degrees, and intelligence ratios between (70- 78) on the Gooddard scale. The current study used the two scales of perceptual skills and social interaction skills (preparation / study er), Goddard scale of intelligence of children with autism and the Cars scale, as well as the integrated training program (preparation / study er), which lasted over (33) sessions for a period of three months. To the following results: The effectiveness of an integrated enrichment program in developing the perceptual skills and social interaction skills for the autistic child, so the children achieved improvement in the perceptual skills (movement, visual, auditory, tactile, olfactory and taste), and in social interaction skills (the skill of social communication, reception, imitation and cooperation), and the absence of Statistically significant differences between the ranks of the experimental group members, "dimensions and total degree of the two scales for perceptual perception and social interaction skills" between post-measurement and tracking.

الكلمات المفتاحية Keywords:

Aرنامج إثرائي متكامل. An integrated enrichment program

Sensory perception

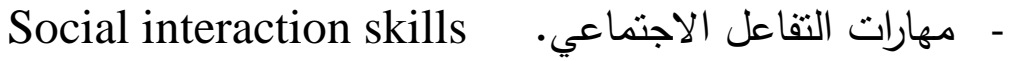

- Children with autism disorder - 


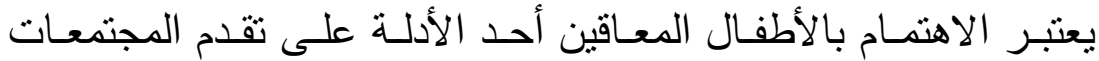

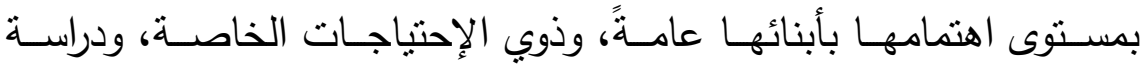

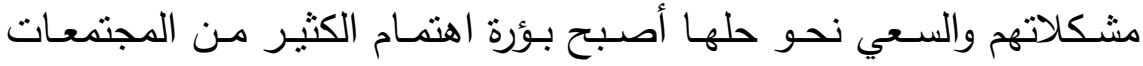
الدولية؛ لأنهم جزءًا من القوى البشرية فيه، ويقدر اهتمام هذه المجتمعات التهات

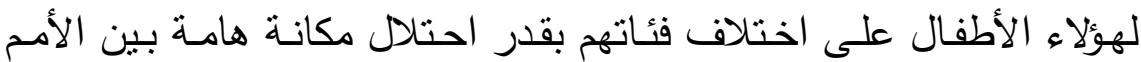

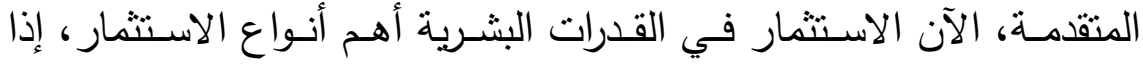

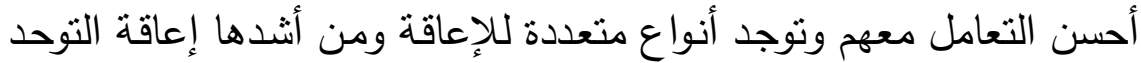
التي تصيب الطفل في مراحل النمو الأولى. والاتجاه الحديث في التعامل مع الأطفال التوحديين يأخذ بعين الاعتبار الطرق والأساليب والبرامج العلاجية السلوكية الموجهة لزيادة القدرات والتقليليل

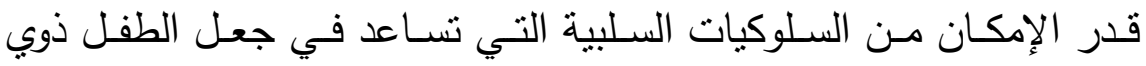

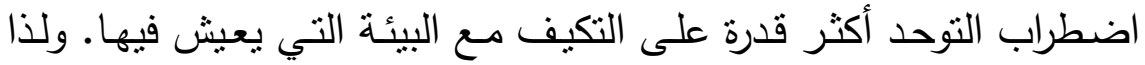

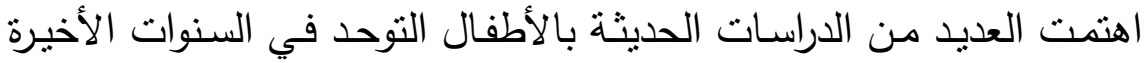

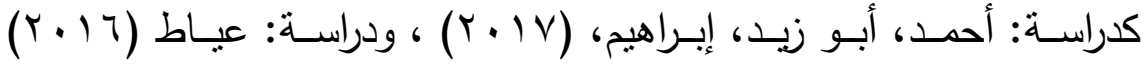
ودراسة ، Evans (2004)

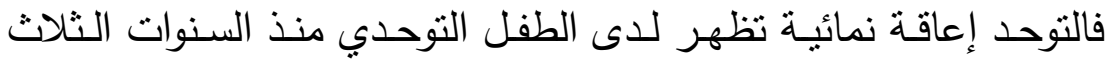

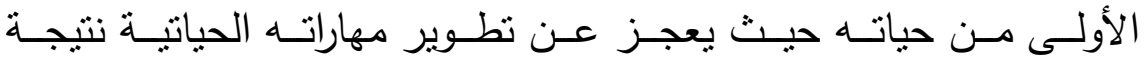
للاضطرابات العصبية التي تصيبه مما تؤثر على تواصله ، كما تقل قدرته

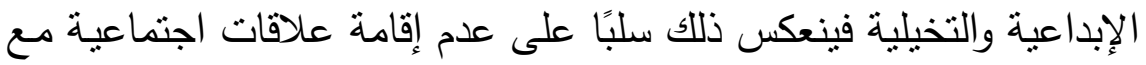

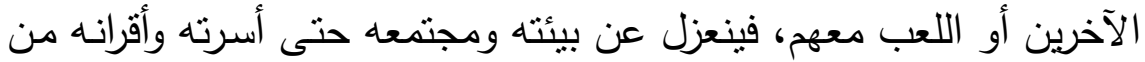

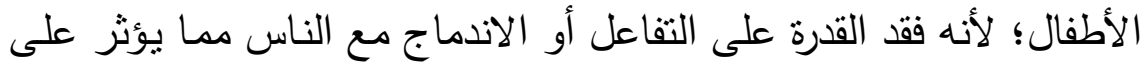

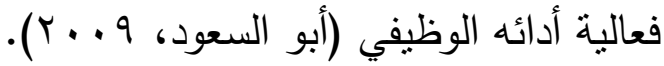


وأصبح اضطراب التوحد هو ثاني أكثر الإعاقات انتشـارًا، ولا يسبقه في

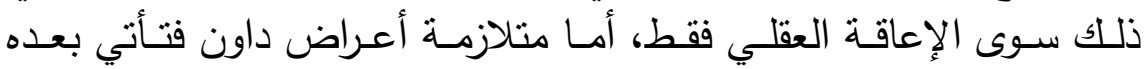

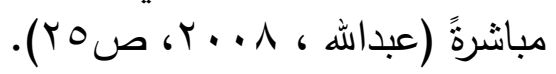

تقدر نسبة التوحد الثديد عالميًا بحوالي (0) من كل ( . . . . 1) مولوداً، وإذا أخذنا في الاعتبار التوحد المصساحب بإعاقةٍ عقليةٍ شديدةٍ من الذكور

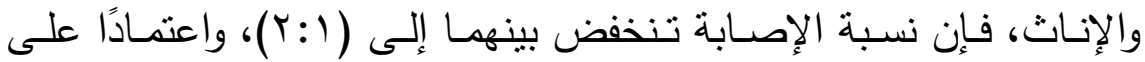
محكات كانر التشخيصسية إلى أن نسبة الإصـابة باضطراب التوحد ثقدر

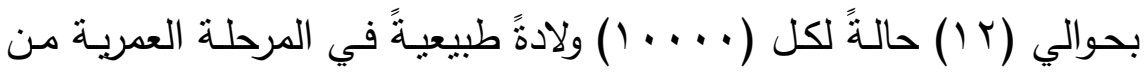

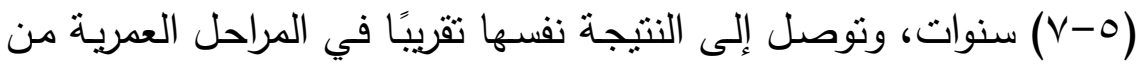

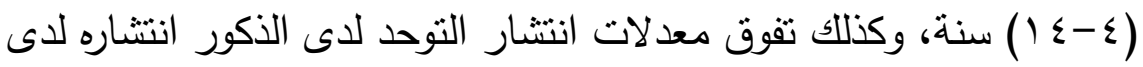

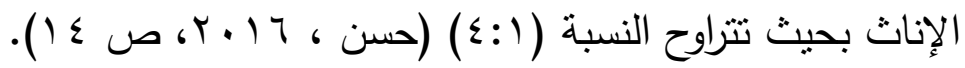

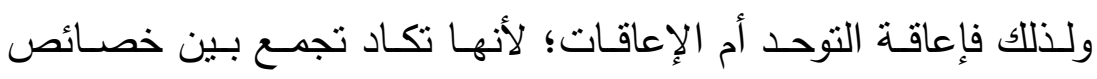
ومظاهر كافة الإعاقات الأخرى، فالأطفال التوحديون حواسهم سليمة ولكنهم يبـدون كمـن لا يســع ولا يـرى ولا يــكلم وكـأنهم معـاقون سـمعيًا وبصـريبًا

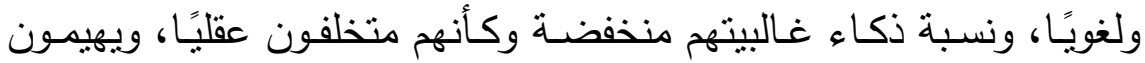
بخيالهم في عالم صنعوه غالبيتهم بأنفسهم وكأنهم معاقون فكريًا، وحركاتهم

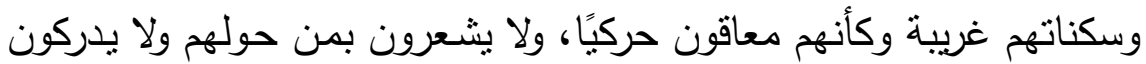

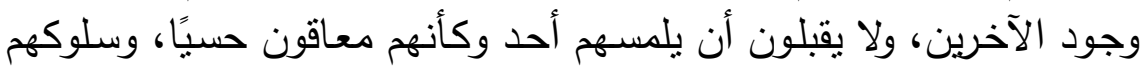

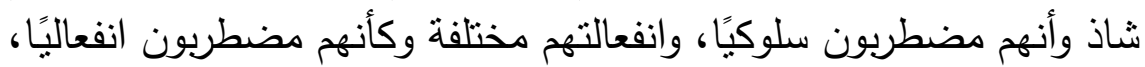

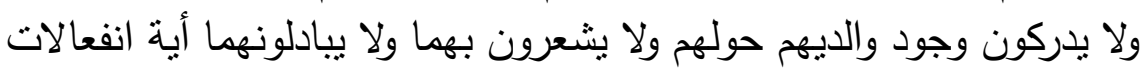

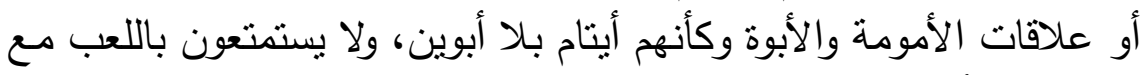

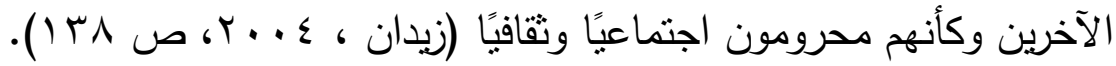


وظهرت مفاهيم مختلفة لاضطراب طيف التوحد في العقود الأخيرة تسلط الضوء على التشوهات الإدراكية الحسية كأساس مميز لهذا الاضطراب، فقد لإهراب وصف بعض الباحثين منل Rasmussen, Rats اضطراب طبف التوحد بأنه اضطراب في الحواس بدلاً من العجز الاجتماعي حيث تعمل الحواس في عزله، ويكون الدماغ غير قادراً على تتظيم المثيرات بطريقة مجدية، فقد

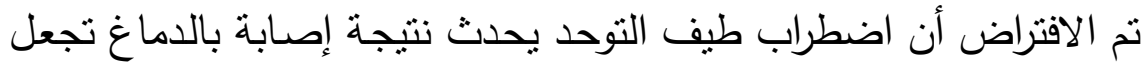
الأطفال يدركون المدخلات من العالم الخارجي بطريقةٍ مختلفةٍ عن الأطفال

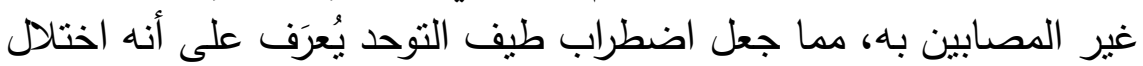
وظيفي للحواس واضطراب في التكامل الحسي في الدماغ حيث نكون غير قادرةً على تتظيمها واعطاء معنى لها (Bogdasbing ,2003, p 25 ) . وتُعد أول من قامت باكتشاف الصلة بين العمليات الحسية وسـلوك الأطفـال ذوي الاحتياجـات الخاصــة، وقـد صـممت أدوات ثقيـيم الوظائف الحسية ذي الاختلال الوظيفي وعرفت بأنه العملية التي يتم فيها تسـيل وتعديل وتمبيز الأفراد الأحاسيس المستقبلة من خلال إثراء النظام

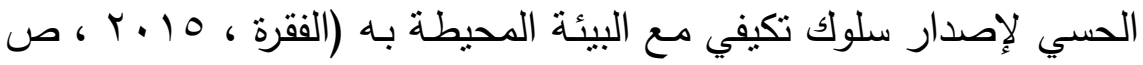
(r)

ويوجد علاقة قوبة بين تكامل الوظائف الحسية (النظام الحسي) والتوحد،

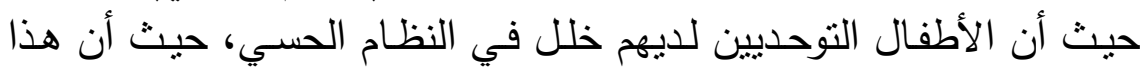
الخلل لديهم قد يكون نقص تفاعل أو زيادة التفاعل في حاسة واحد أو أكثر. وعدم قدرة الأطفال على الاستماع وتسـيل الملاحظات والمعلومـات أثتاء الدراسـة تكون مثالاً على قصسور الوظلئف الحسية (التكامل الحسي)؛ لأن

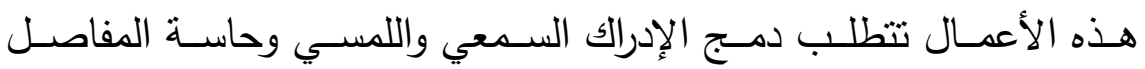
والعضالات، وعندما يكون هناك خلالًا نرى أن الطفل كثير التعثر وهو يمثي وهي 
أي يسقط كثيراً على الأرض، حيث يصعب عليه التحكم في الحركات مثل

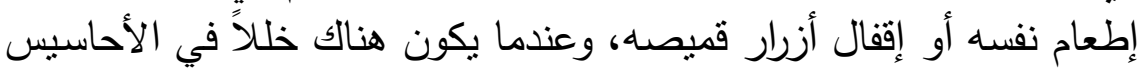

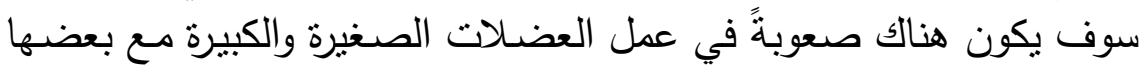

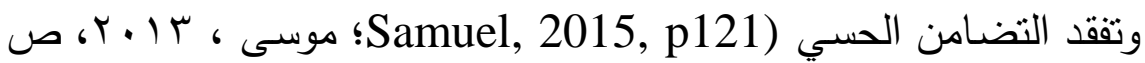

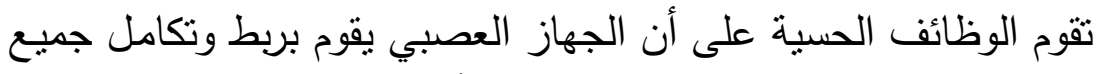

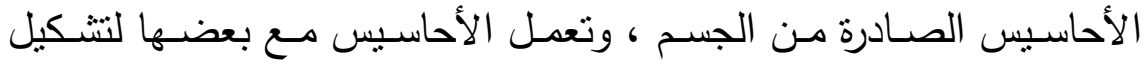

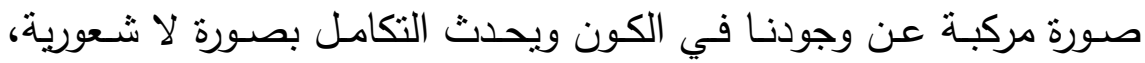

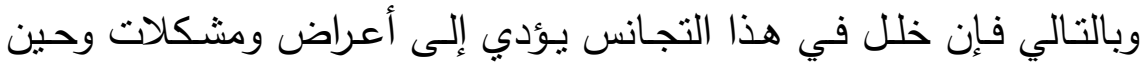

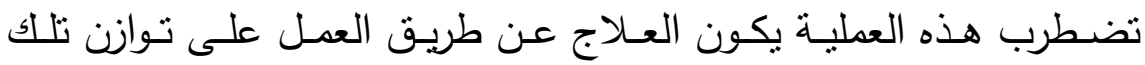

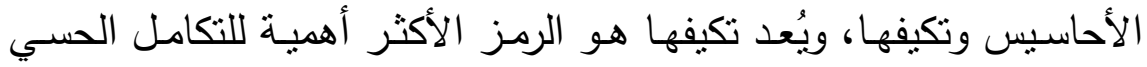

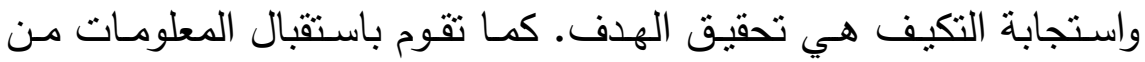

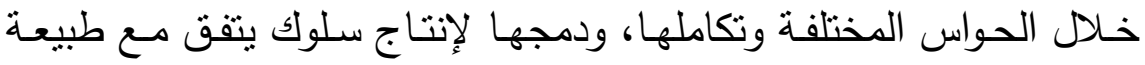

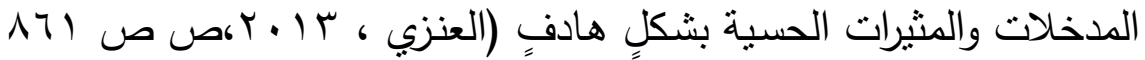

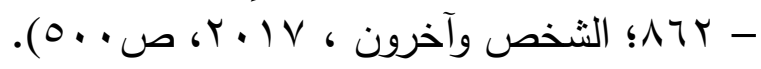

وتوضـح الدراسـات معانـاة طفل التوحد من العجز في الإدراك والتفاعل

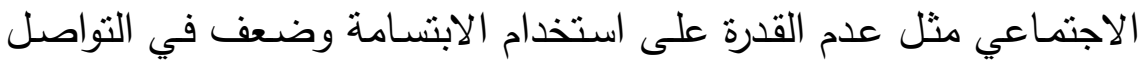

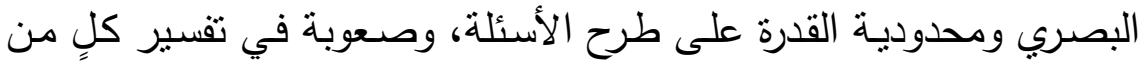
الإثارات الاجتماعية اللفظية وغير اللفظية، وتعبيرات الوجه وعدم التعاطف، عدم التقليد، ضعف في تفسير اللغة، وصسوبة في تبادل الإنية الخبرات العاطفية

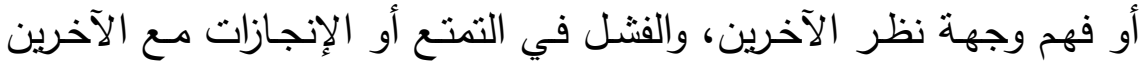

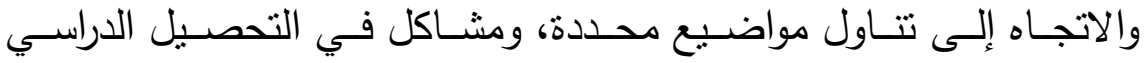
والمهني، ومشـاكل القلق في مرحلةٍ لاحقةٍ مـن التطور ، وفي فرص ومل التعلم 
والاستقلالية، وجود القوالب النمطية وتدمير الممتلكات، والعدوان، وقلة قبول الأقران وعزلة اجتماعية،وهذا يؤدي إلى إقامـة علاقات مُرضية بين الأقران

والعائلة) (Khodabakhshi, Ahmad \& Mokhtar, 2014, p45)

وأثـارت دراسـة السـعدي( ( . . Y، ص 0؛ ) إلـى أن الأطفـال التوحديين يواجهون صسعوبات في جوانـبٍ متعددةٍ لدى تواصلهم مسع الآخرين داخل فيل المنزل والمدرسة، وكذلك في المجتمع المحيط بهم وتنلخص نلاك الصعوبات

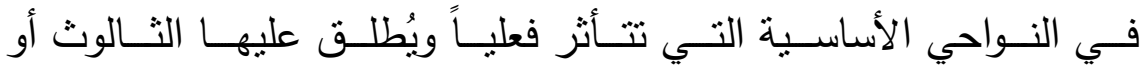

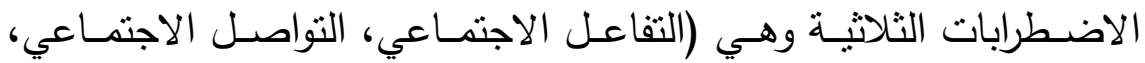
اللعب التخيلي)

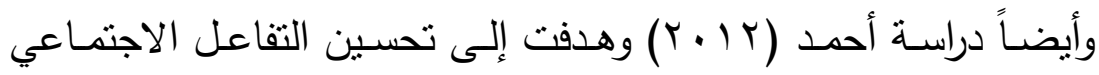
لاى عينة من الأطفال التوحديين وخفض سلوكاياتهم المضطربة من خلال برنـامج قائم على مفـاهيم نظريـة العقله وأسـفرت النتائج على أنى مفـاهيم

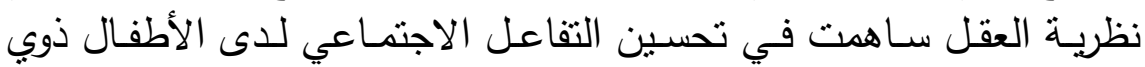
اضطراب التوحد وخفض سلوكياتهم المضطربة .

وأكدت دراسـة العباط (T ( ا Y) على أهمبـة التدريب على التواصـل غير

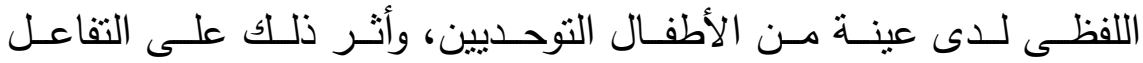

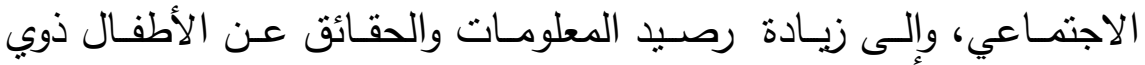
التوحد سـواء في عمليـة التعرف عليهم أو كيفيـة تقديم الخدمات والفنيات المناسبة لهم . لمون وهنالك منـاهج لعـلاج مهارات التفاعل الاجتمـاعي المقترحة وتشـمل هذه

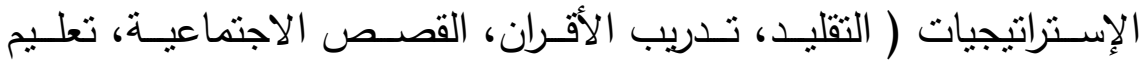
المهارات الاجتماعيـة، الإدراك الاجتمـاعي في مجموعـات)، والمثـاركة في

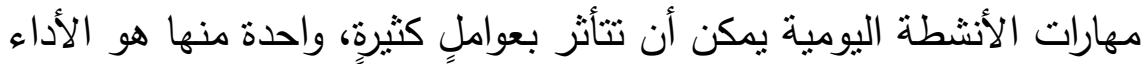


الحسي، ويلعـب التطـور الحسي والحركي دوراً هامـاً في تعليم الأطفـال الصغار ، وعادةً ما يستخدمون المهارات الحسية والحركية لاستكثـاف البيئة،

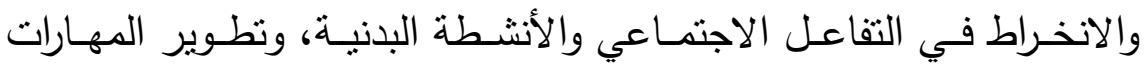
الأكاديمية الأساسية (Khodabakhshi, 2014,pp 45-39) ومـن خـله الدراسـات السـابقة اتضــح أن مشـكلة الأطفــال التوحـديين

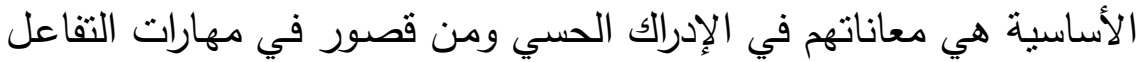

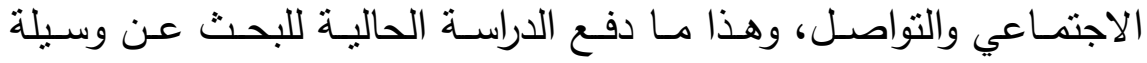

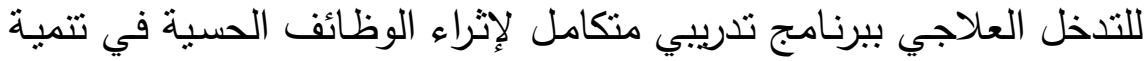

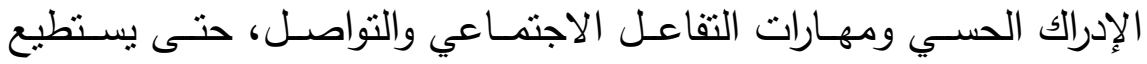

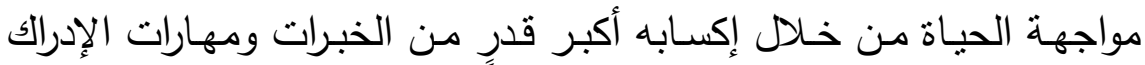

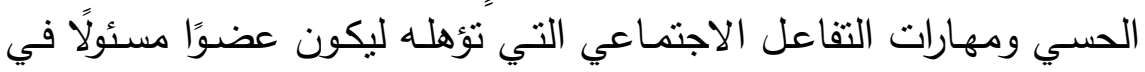

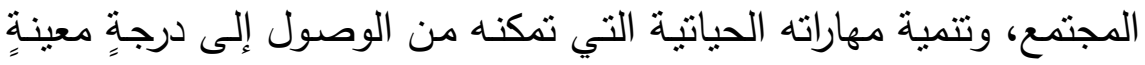

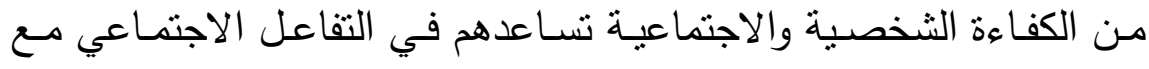

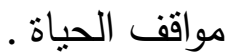

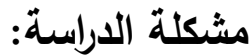

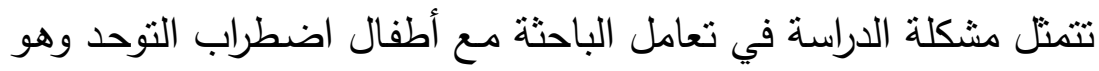

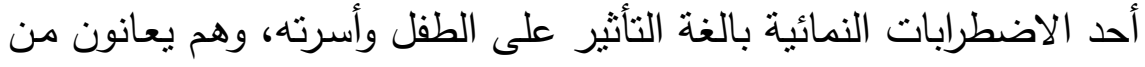

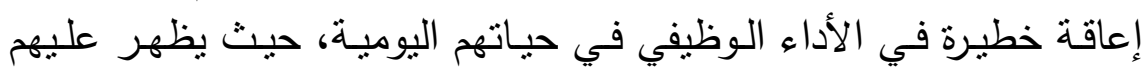

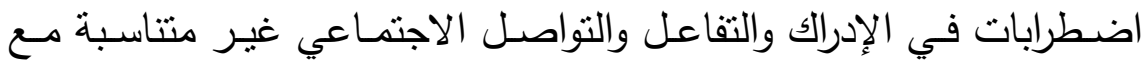

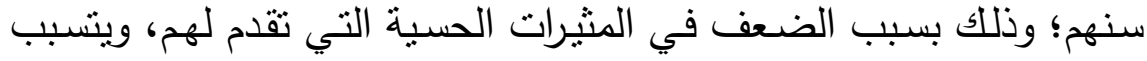

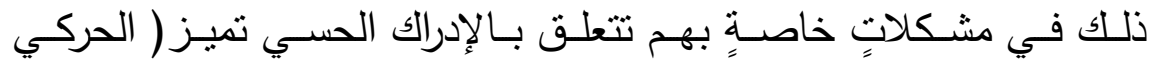

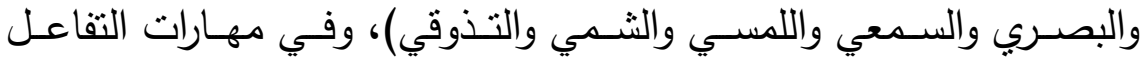

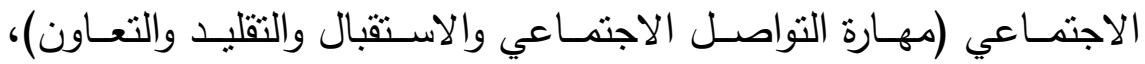


وبالمهـارات الاجتماعبـة لـديهم مثـل (التواصــل الاجتمــاعي - صــعوبة الاستقبال - صعوبة مهارات التقليد ـ التعاون مسع الآخر)، مـع مراعاة ندرة

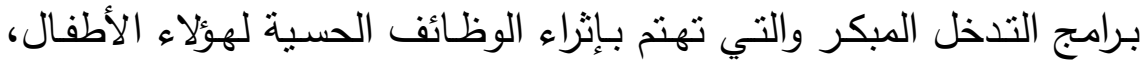

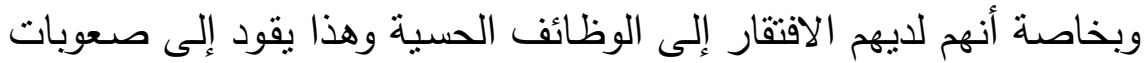

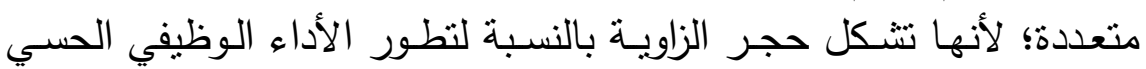
السـليم الذي يتطلب تآزر الجهاز العصبي والمركزي وترابطهه مـع الجهاز العضلي، ومـن هنـا جـاءت فكرة الدراسـة الحالية والذي يهدف إلى التدخل ببرنامج علاجي إثرائي متكامل في تتمية مهارات الإدراك الحسي والتفاعل

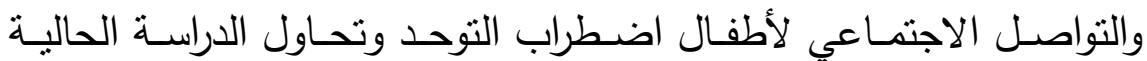
الإجابة عن السؤال التالي : ومن هنا تتبع مشكلة هذه الدراسة التي يمكن صياغتها في التساؤل الرئيسي

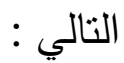

ما فاعلية برنامج إثرائي متكامل في تنمية الإدراك الحسي والتفاعل

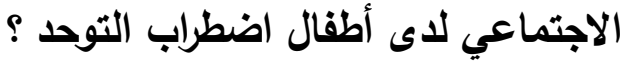

وبذلك يمكن أن ينبثق من التساؤل الرئيسي عدة تساؤلات فرعية ونتبلور فيما ا-هل يؤدي التدخل العلاجي للبرنامج القائم على إثراء الوظائف الحسية إلىى تحسـين مهـارات الإدراك الحسـي تميـز ( الحركي والبصـري والسـمعي واللمسي والثمي والتذوقي) ومهارات التفاعل الاجتماعي متمثلة في مهارات

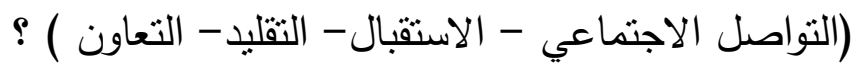
r-هل بستمر أثز البرنامج في العلاج بعد الانتهاء من تطبيقه في تحسين مهارات الإدرالك الحسي ومهارات التقاعل الاجتماعي؟ بعدي 


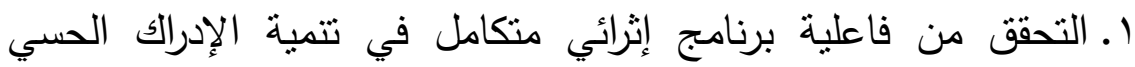

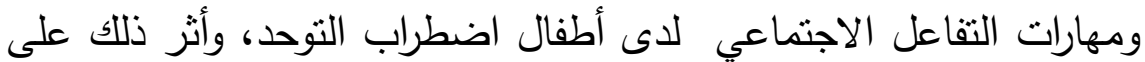

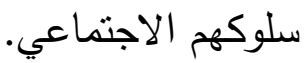
r. التحقق من إمكانية استمرار فاعلية برنامج إثرائي متكامل في تتمية

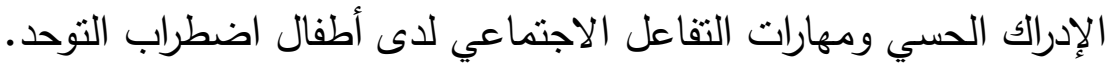

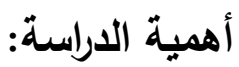

تتمثل أهمية الدراسة في الاستفادة من الإنشطة الإثرائية المتكاملة لإثراء

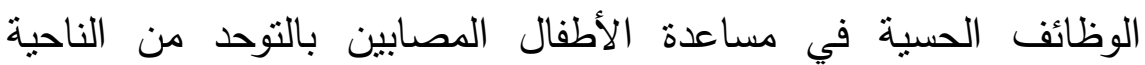
الإدراكية والاجتماعية والمعرفية واللغوية والحركية من خلال توجيه الأنشطة

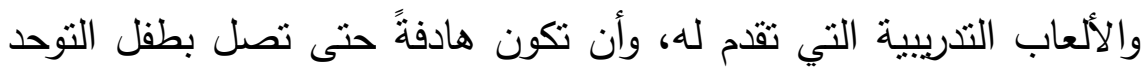

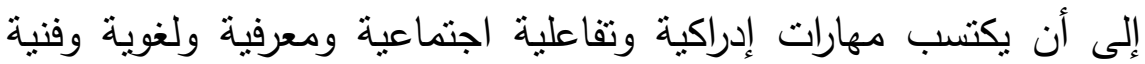
وحركية بطرق أكثر قرباً وواقعيةً من عالم الطفل التوحدي.

وترجع أهمية الدراسة إلى :

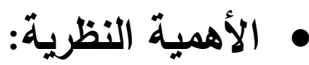

1- تعتبر هذه الدراسـة إضـافةً إلى التـراث النظـري في متغيرات الدراسـة

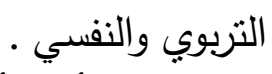
r-مساعدة أسر أطفال التوحد والأخصائيين بفنيات إثراء الوظائف الحسية التي تساعد على خفض حدة بعض مشاكل الأطفال التوحديين على مهارات الإدراك الحسي والتفاعل الاجتماعي. 
ب-تعالج ظاهرة مهمة تعكس آناراً سلبيةً على جميع جوانب شخصية أطفال التوحد وأسرهم.

\section{• الأهمية التطبيقية:}

1-إمداد الباحثين والآباء والأخصائيين والمعنيين بأطفال ذوي الاحتياجات

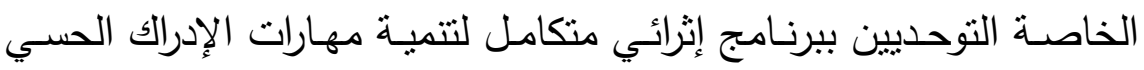

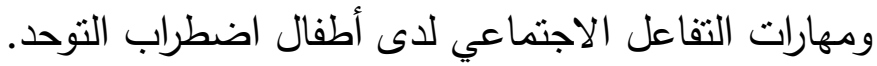

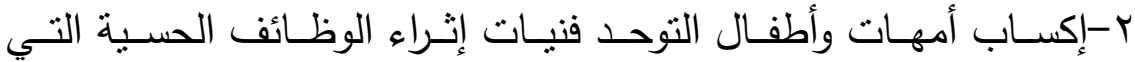

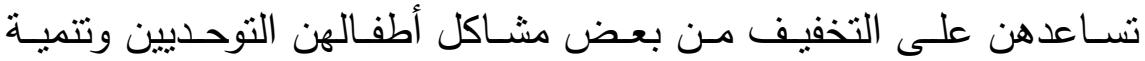

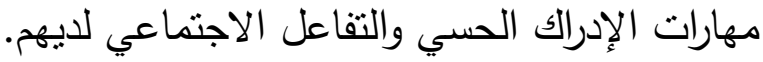

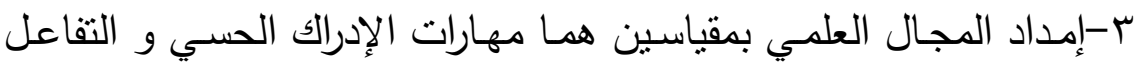

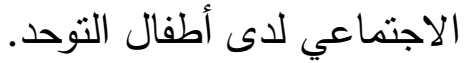

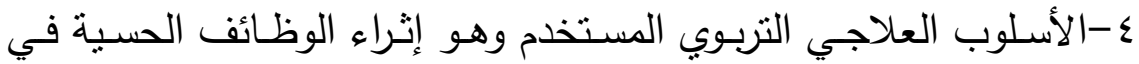

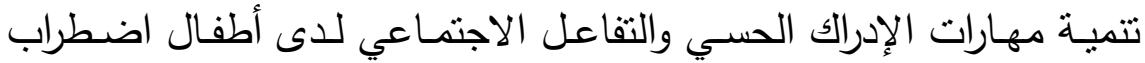

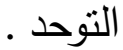

ه-الاسـتفادة مـن النتائج وتوصيات الدراسـة وتوظيفهـا في مراكز التربيـة

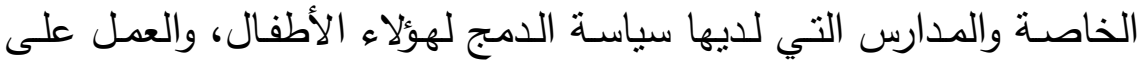

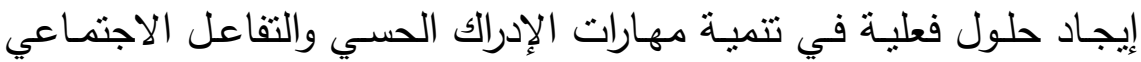
بقدر الإمكان أثثاء تطبيق البرامج التربوية.

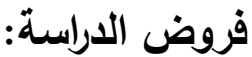

ا-توجد فروق ذات دلالــة إحصـائية بـين متوسـي رتب درجـات أطفال

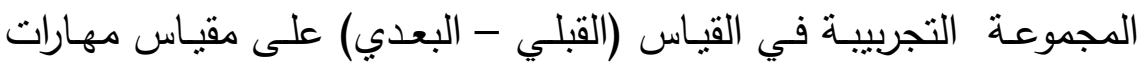


الإدراك الحسـي و مقيـاس مهارات التفاعل الاجتمـاعي (للأبعـاد والدرجـة الكلية) لصالح القياس البعدي. r-توجد فروق دالة إحصائياً عند منوسط رتب التب درجات أفراد المجموعتين

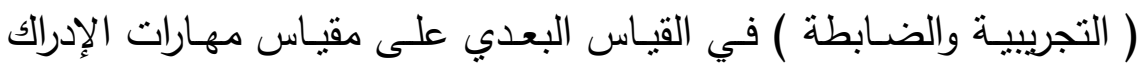

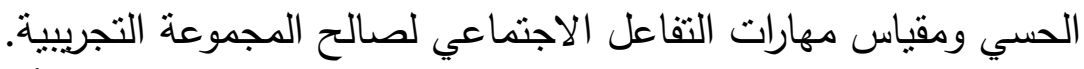

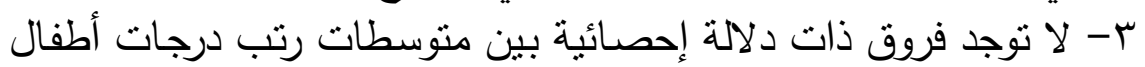

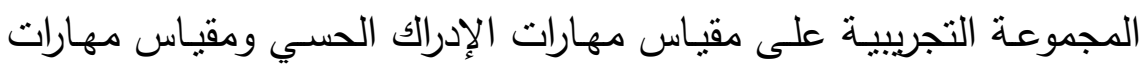
التفاعل الاجتماعي (للأبعاد والدرجة الكلية) في القياسين البعدي والتبني. مصطلحات الدراسة:

- Autistic disorder اضطراب التوحد:

يعرف اضطراب الذاتوية بأنه: اضطراب نمائي عصبي يظهر عادةً قبل

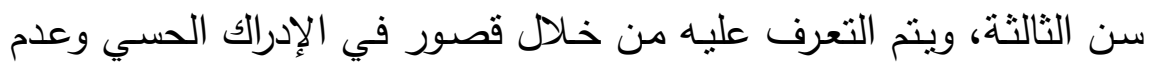

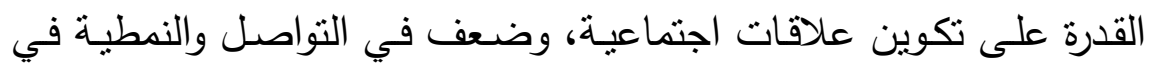

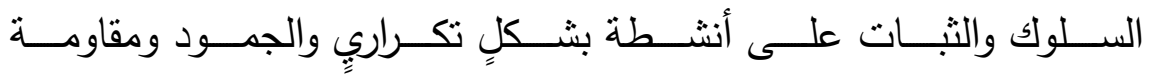
التغير (Katherine, 2015, p9).

وقد حددت الباحثة أطفال اضطراب التوحد إجرائيًا في الدراسـة الحالية

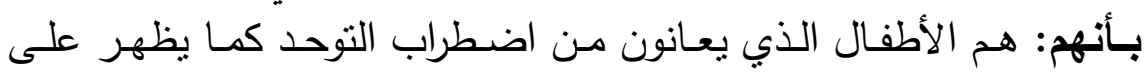

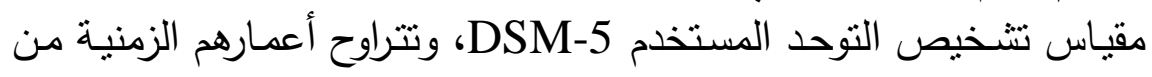

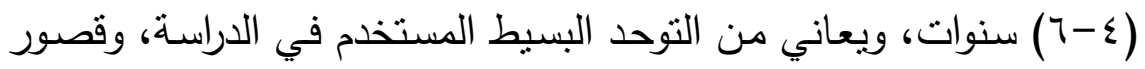

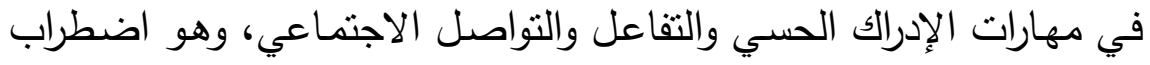

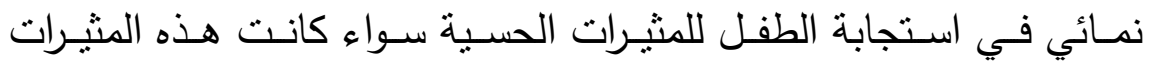

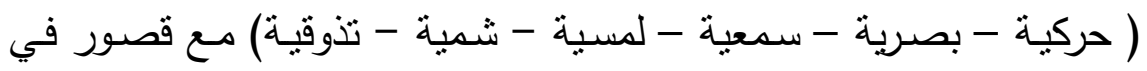
الإدراك والتقاعل الاجتماعي في مهارات ( الاتصـال - الاستقبال - التقليد- 


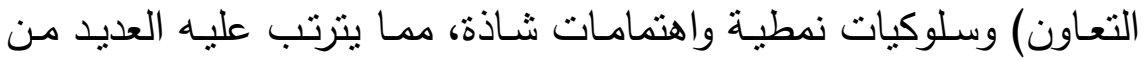

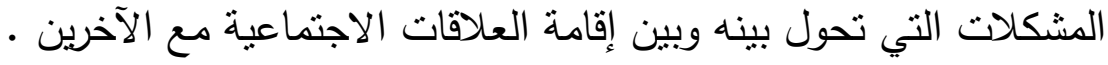

\section{- The Effectiveness الفاعلية -}

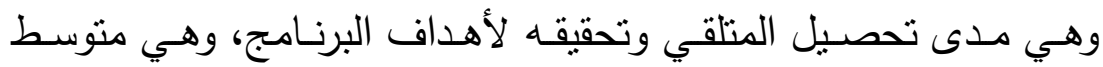

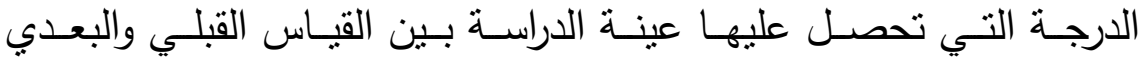
والتتبعي، وأن الفاعلية هنا هي النشاط الإيجابي الذي يتم فيه التفاعل بين الأطفال والموقف) (Black , 1972, p25)

\section{Integrated enrichment البرنـامج الإثرائـي المتكامسل -} :program

هو برنامج مخطط ومنظم في ضوء أسس علمية وتربوية تستند إلى مبدأ

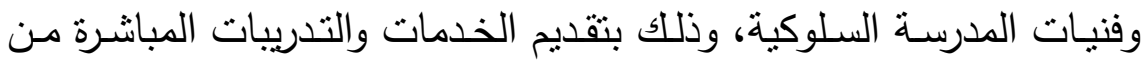

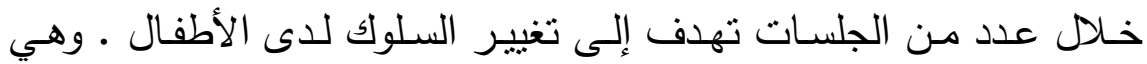

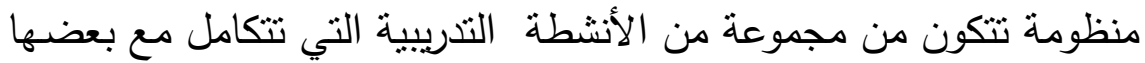
البعض وتتفاعل تفاعلاً وظيفياً محققة لأهدافها المحددة ( بهادر ، 997 19 19 ص ص r r (r)

وقد حددت الباحثة البرنـامج إجرائياً بأنـه: هو مجموعة من اللقاءات

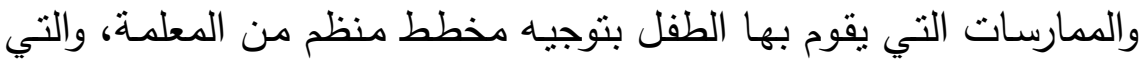

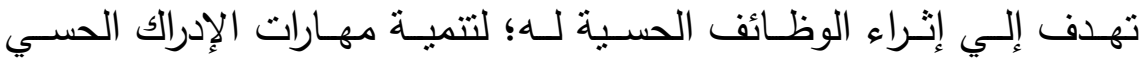

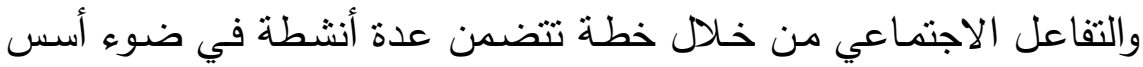

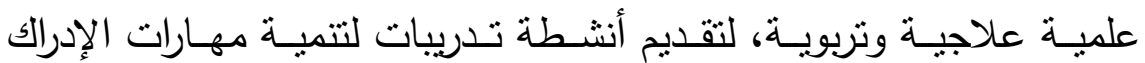

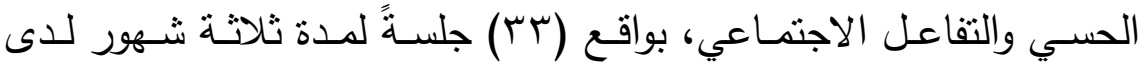
أطفال اضطراب التوحد البسبط من خـلاع التدريب المباشر على على الأنشطة لتكوين مهارات تصبح سلوكاً معتاداً عليه. 


\section{- الإثراء الحسي Enrichment sensory:}

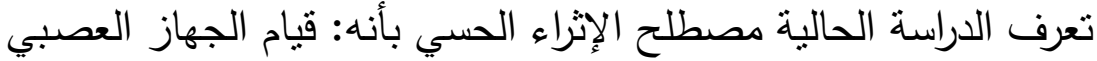
والمركزي لاى طفل التوحد بالوظائف الحسية في تتظيم المعلومات الحسية، بما يساعد على شعور الطفل بجسده والمثيرات التي تحيط بـه، واستقبال

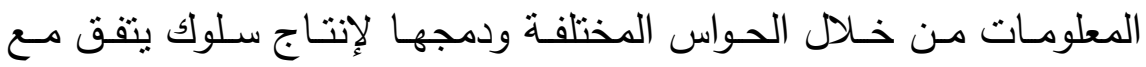
طبيعة المدخلات والمثيرات الحسية بشكلٍ هادفٍ.

وقد حددت الباحثة الإثراء الحسـي إجرائيًا في الاراسـة الحالية: بأنها

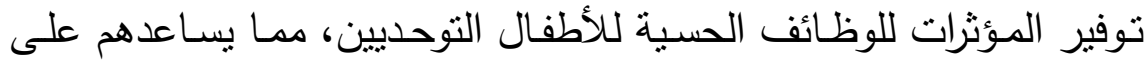
إدراك وتتظيم المعلومات الحسية الآتية من جسمه ومن البيئة المحيطة، مما

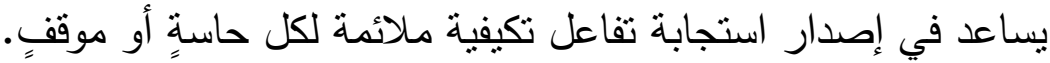
- الإدراك الحسي Sensory Perceptual -

يعـاني بعض الأطفال ذوي اضطراب طيف التوحد مـن مشكلات في

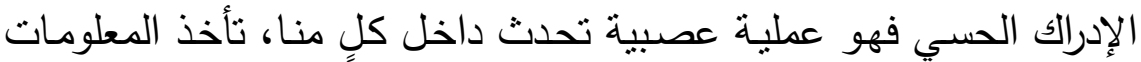

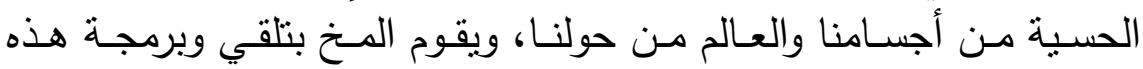

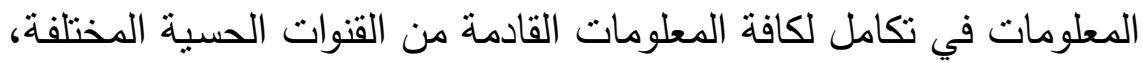

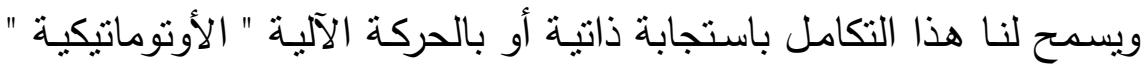

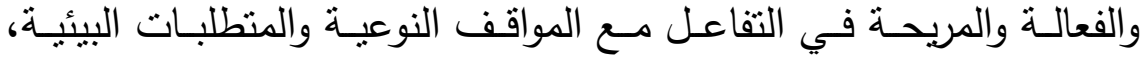
وتتواصل عملية الإدراك الحسي طالما استمر الجهاز العصبي المركزي في النضج (Turkjngton, 2007, p19).

وقد حددت الباحثة مهارات الإدراك الحسي إجرائيًا في الدراسـة الحالية بأنها: الدرجة التي يحصل عليها الأطفال التوحديين على مقياس مهارات الإلهات الإدراك الحسي المستخدم في الدراسة الحالية. 
- Social communication skills مهارات التفاعل الاجتماعي

تعـرف الدراســة الحاليـة مصــلـح مهـارات التفاعـل الاجتمــاعي بأنهـا:

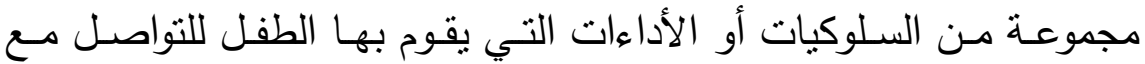
الآخرين في المواقف المختلفة وتعكس شخصية الطفل، وتساعده في بناء علاقات اجتماعية إيجابية، وتمكنه من مواجهة المواقف الحياتية المختلفة، وتساعده في حل المشكلات.

وقد حددت الباحثـة مهارات التفاعل الاجتمـاعي إجرائيًا في الدراسـة

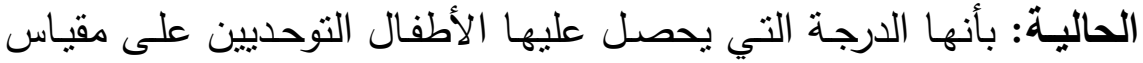
مهارات التفاعل الاجتماعي المستخدم في الدراسة الحالية.

وسوف تقتصر الدراسة الحالية على مهارات التفاعل الاجتماعي الآتية:(مهارة التواصل الاجتماعي، مهارة الاستقبال، مهارة التقليد، مهارة التعاون).

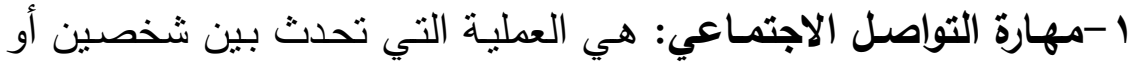
أكثر وتتضمن التأثير المتبادل والاستجابة المتبادلة للأشخاص في الماعي المواقف

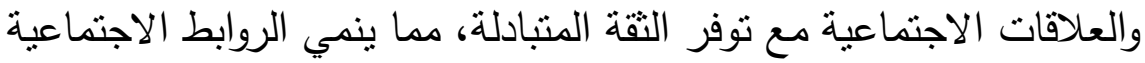
المختلفة. ب-مهـارة الاستقبال: هي قدرة الفرد على استقبال الرسـئل اللغويـة المرئية والمسموعة وفهمها وتحليلها والربط بينهما. ب-مهارة التقليد: هي الوسيلة غير اللفظية التي تساعد الطفل التوحدي في وفي التها.

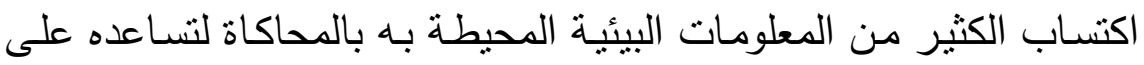

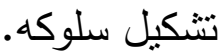
ع -مهـارة التعـاون: هي العمليـة التي بقوم فيها الأفراد بأنشطة مترابطـة ومتشابهة في صورة جماعية بغرض تحقيق أهداف مشتركة بينهم. 


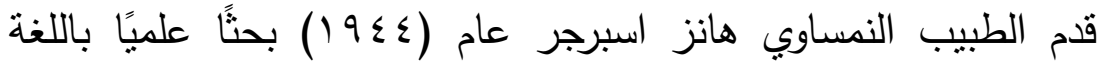
الألمانية وصف فيه مجموعة من الأطفال كانوا يعانون من اضطراب سماه

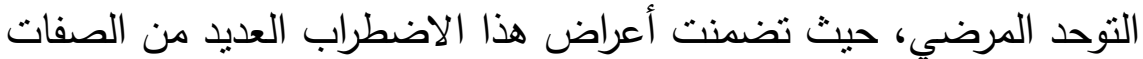

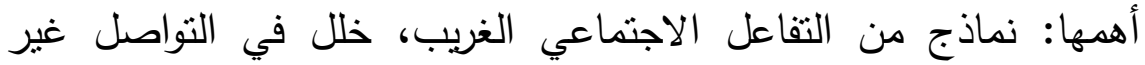
اللفظي، ضعف في فهم ومشاعر واحتياجات الآخرين. وأصدرت الجمعية

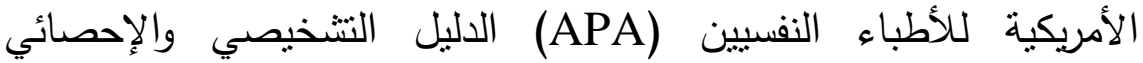

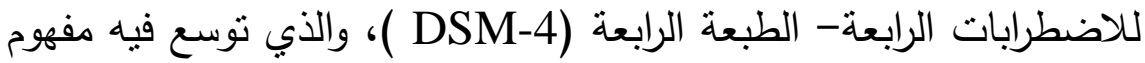
الاضطرابات النمائية الثاملة بحيث أصبحت تضم اضطرابات طيف التوحد

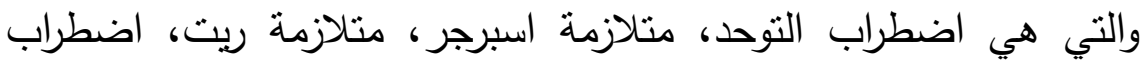

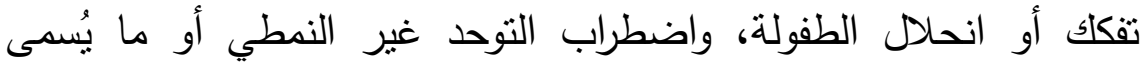
بالاضطراب النمائي الثامل غير المحدد، وأخيرًا أصدرت الجئر الجمعية الأمريكية للأطباء النفسيين (APA) الدليل النتخيصي والإحصائي للاضطرابات

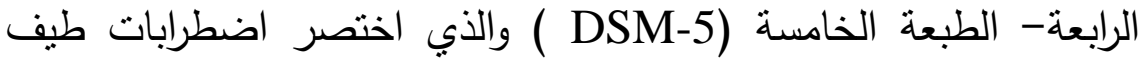

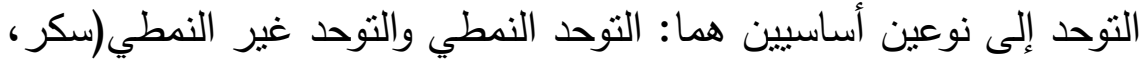

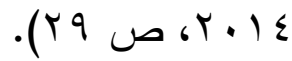
• ت تعريف التوحد:

ترى الجمعية الأمريكية للتوحد أن اضطراب التوحد يظهر في مظاهره

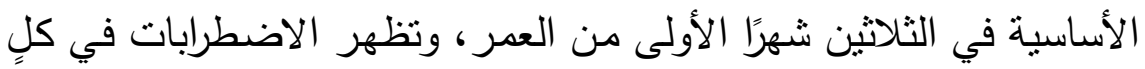
من الاستجابة للمثيرات الحسية، نسبة النمو، والتطور وما يتبعها، النطق، التهان اللغة، والقدرات المعرفية، والقدرات المرتبطة بالناس، والأحداث والأثنياء.

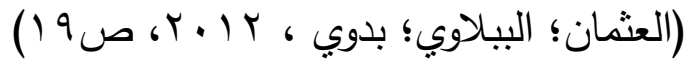


تعـرف الجمعيـة الأمريكيـة التوحد بأنـه: عبـارة عـن اضـطراب معقد في

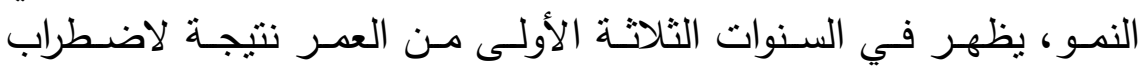

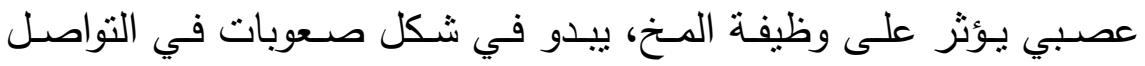
اللفظي وغير اللفظي، والتفاعل الاجتماعي، وأنشطة اللعب. (Vidya, 2004, pp2-3)

يعرف الدليل التشخيصسي والإحصسائي الخـامس للاضطرابات العقلية

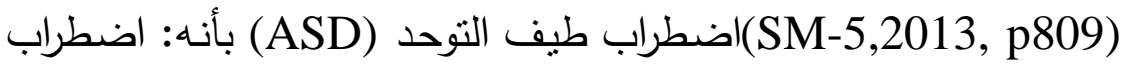

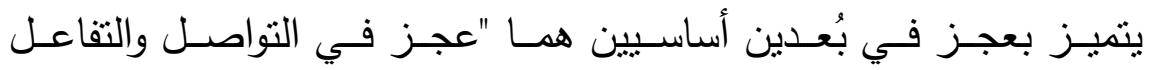

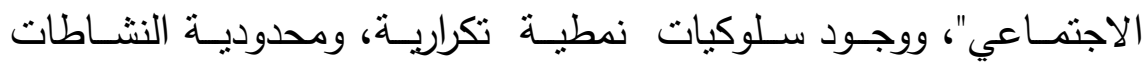
والاهتمامـات، على أن تبدأ هذه الأعراض في الظهور في فترة نمو مبكرة

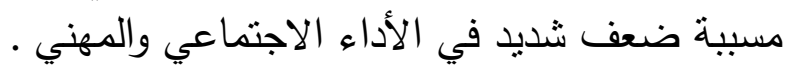
يعرفه سلامة (0 . . ب، ص • r) بأنه: حالة تصيب بعض الأطفال عند

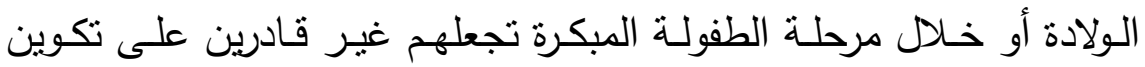

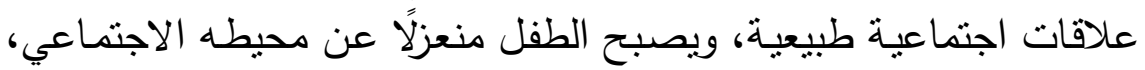
ويتقوقع في عالم منغلق يتصف بتكرار الحركات والنشاطات .

وبعرفه (1995) Howlin ملى أنه: مصطلح بُطلق على أحد

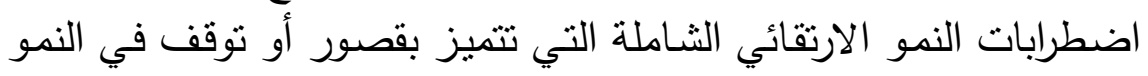

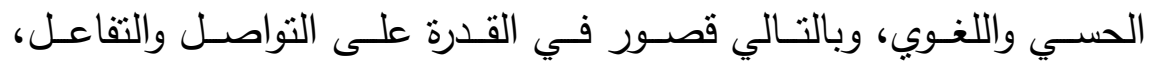
والتخاطـب والـتعلم، والنمـو المعرفي والاجتمـاعي، وتصـاحب ذلـك نزعـة انسحابية انطوائية، وانغلاق على الذات مع جمود عاطفي وانفعالي، واندماج المُصاب في حركات نمطية عشوائية غير هادفة لفترة طويلة (حبي، إبراهيم،

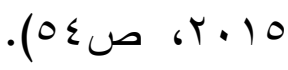


وبنـاءًا عليـه بمكن تعربف التوحد في الدراسـة الحاليـة بأنـه: "اضطراب

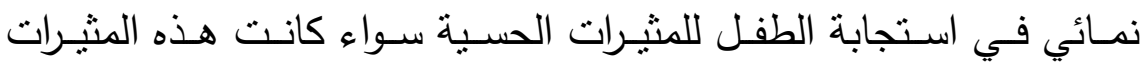
( حركية - بصـرية - سمعية - لمسية - شمية - تذوقية) مسع قصور في الإدراك والتفاعل الاجتماعي في مهارات ( الاتصـال - الاستقبال - التقليد-

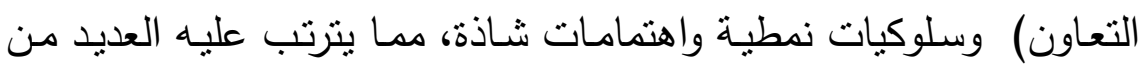
المشكلات التي تحول بينه وبين إقامة العلاقات الاجتماعية مع الآخرين". • أسباب التوحد: وسوف يتم عرض هذه الأسباب كالتالي : -أسباب نفسية وأسسرية: وجد أن آباء الأطفال المصسابين بالتوحد يتسمون

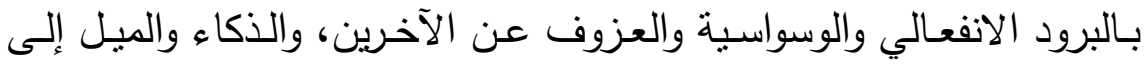
النمطيـة، ونتيجـة لهـا الجمـود العـاطفي والنفعـالي في شخصـية الوالـدين

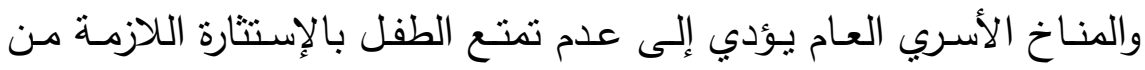

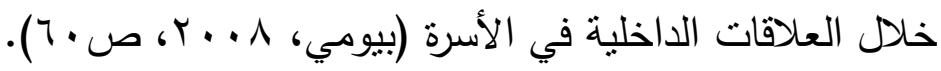
ـالعوامسل البيوكيميائيــة: أنسه لـوحظ فـي بعـض الدراسـات ارتفــاع معـدل

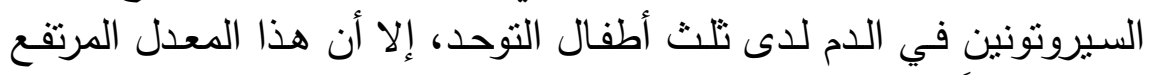
لوحظ أيضـاً في ثلث الأطفال المتخلفين عقليًا إلى درجـة شديدة (الجلبي، الحئ

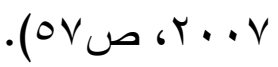

- العوامل الجينية: أوضحت بعض الدراسات أن كروموسوم (Fragil X) يعتبر شكلاً وراثياً حديثاً مسبباً للتوحد والتخلف العقلي وصعوبات التعلم وله دور في حدوث مشكلات سلوكية منل النشاط الزائد، وهذا الكروموسوم يكون

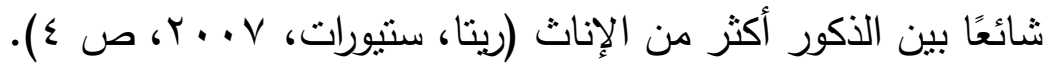


-المضـاعفات الولاديـة قبـل الـولادة: ثُؤكد الدراسـات والتحاليل الطبيـة على التى

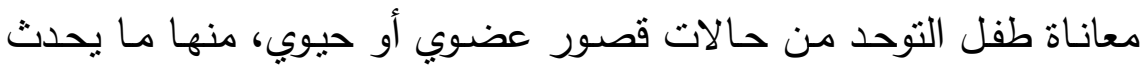

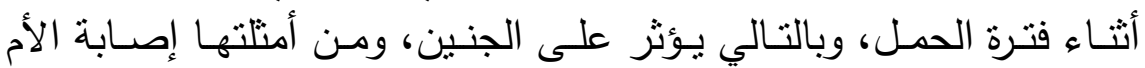

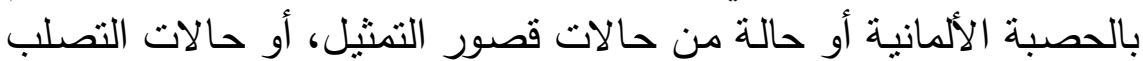

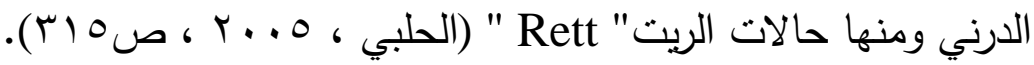
-خلل في الجهاز العصبي المركزي: أنثار البعض إلى أن هناك خلل في

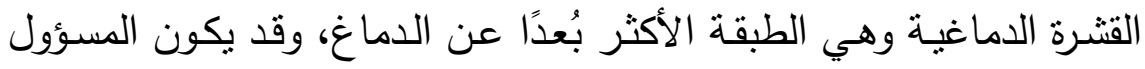
عن الاختلال الوظيفي اللفظي والإدراكي . -تأثير الفيروسـات في حدوث التوحد: أشـارت البحوث والدراسات الأكثر

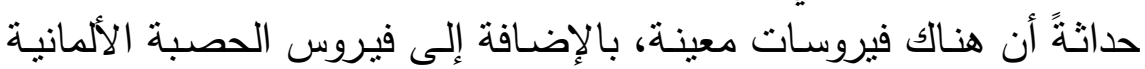

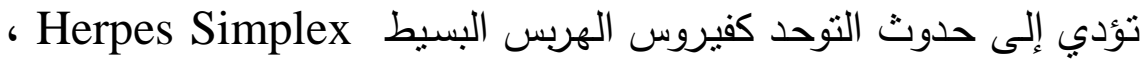
بالإضافة إلى فيروس عراك الخلايا"Thcytomegalo Virus" .

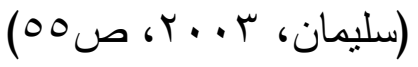

تتعدد أعراض وخصائص أطفال التوحد وتختلف درجتها وفقاً للأسباب

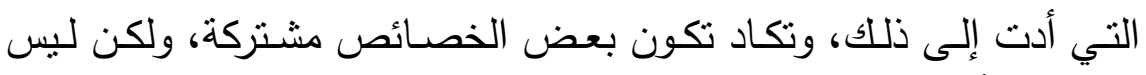

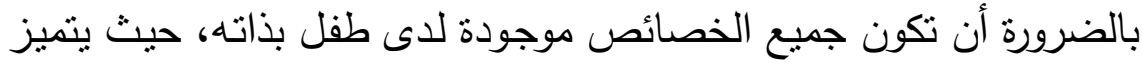

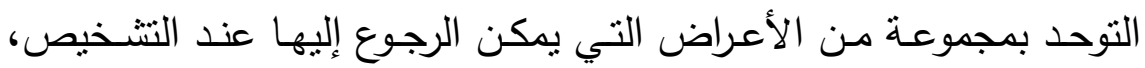
وتتمثل هذه الأعراض فيما يلي:

1 - القصور في التفاعل الاجتمـاعي: أكدت نتائج الدراسات مثل عبد الله

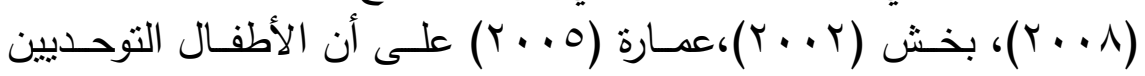
لديهم ميل للانسـابية، وعدم التفاعل الاجتمـاعي والسلبية تجاهـاه الآخرين. 
ويمكن تحديد القصور بثلاثة مجالات هي: (التجنب الاجتماعي / اللامبالاة

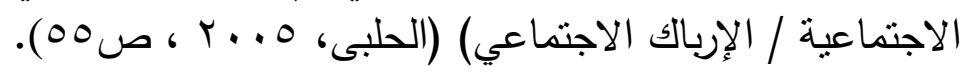

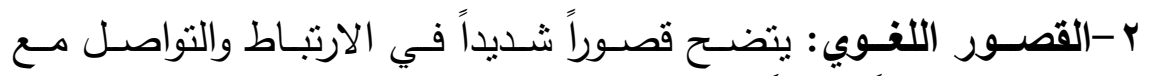

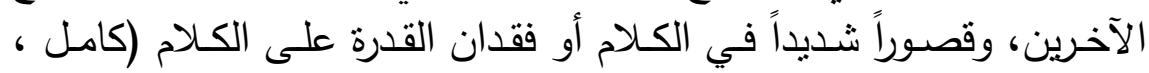

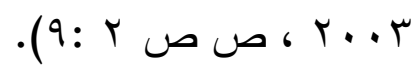
r-الخصـائص المعرفيـة: ويتمثل ذلك في عدم قدرتهم على إجراء حوار

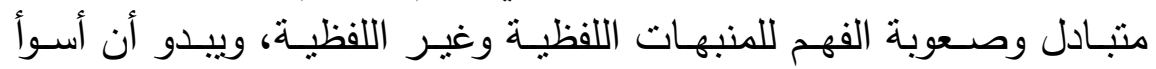

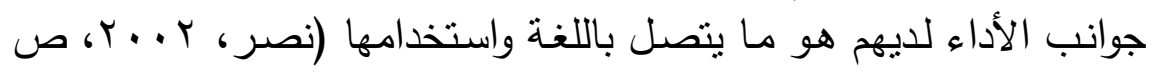

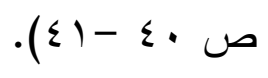

ع -السـلوكيات والاهتمامـات والنشـاطات: يلعب الأطفال التوحديين بشكلٍ

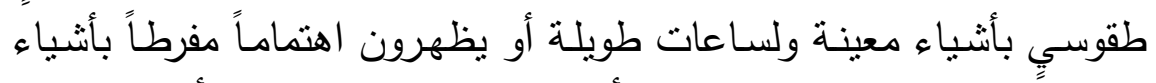

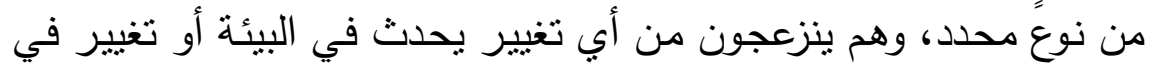
الروتين، كما يحافظون على التماتل، ولديهم مقاومة شديدة للتغير أو التنقل. (Daniel , James, Kauffman,Pand, 2003, p 89)

\section{تعقيب الباحثة:}

يمكن تصنيف أهم أعراض التوحد فيما يلي: أعراض أساسية للأطفال

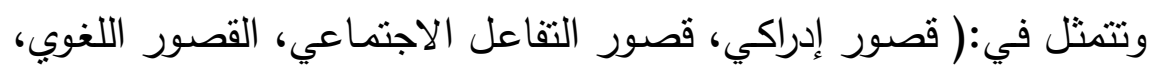

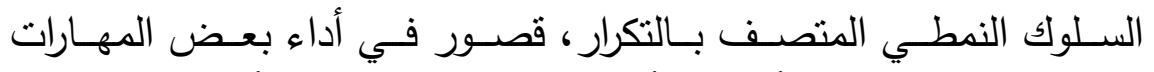

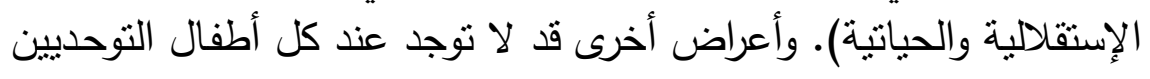

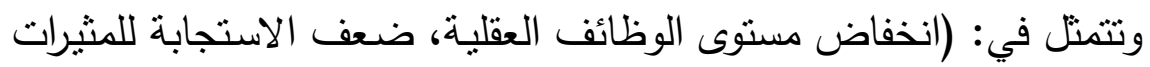

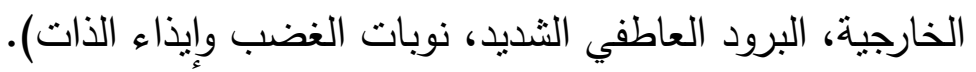




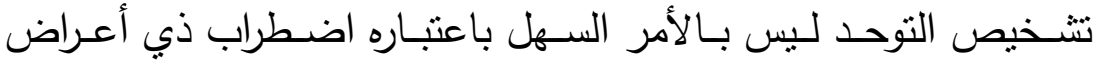
مختلفة من فرد لآخر ؛ وذلك لعدم وجود الاختبـارات الطبيـة التي تطبـق

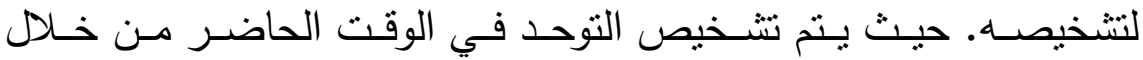
الملاحظة المباشرة لسلوك الطفل بواسطة مختص معتمد، وعادةً مـا يكون

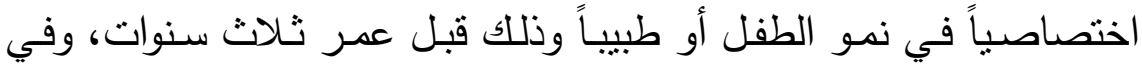

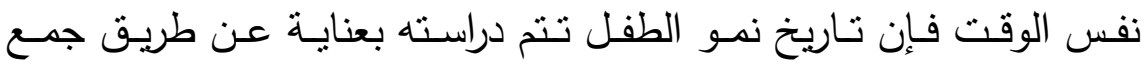

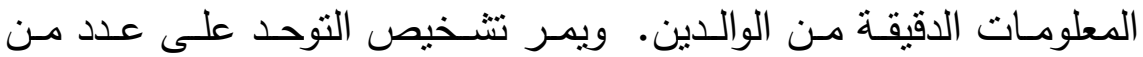

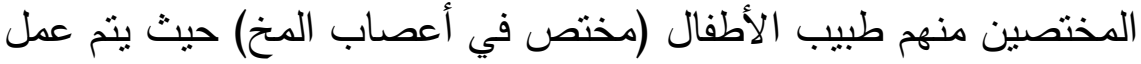

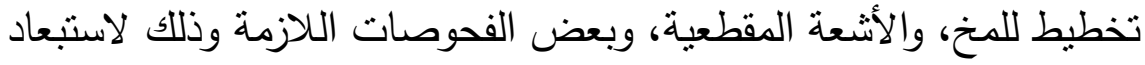

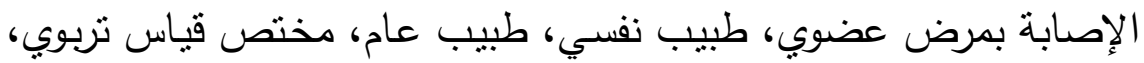

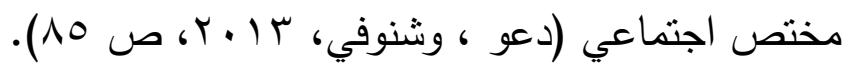

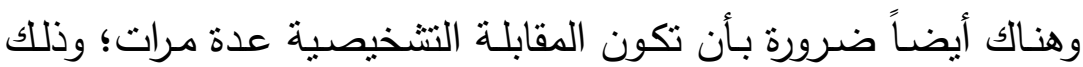
لاستبعاد بعض الأسباب الممكن علاجها وتحديد مدى حدة الاضطراب المابل بالإضافة إلى تحديد الطرق العلاجية المناسبة.

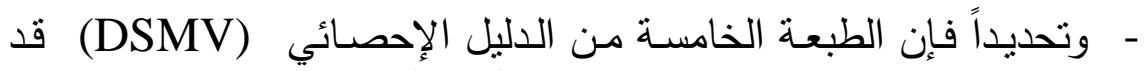

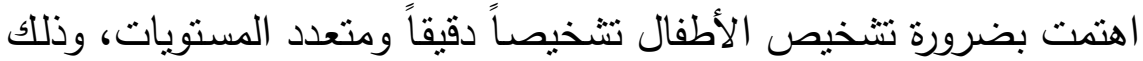

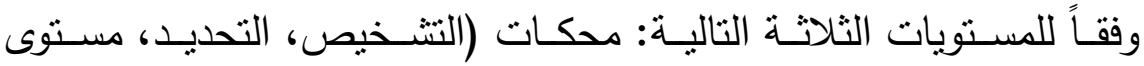

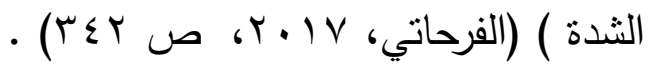

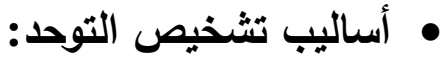

1-التشخيص الطبي: يتم بإجراء بعض الفحوصـات التي يقررها الطبيب

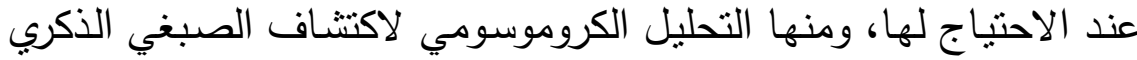


الهش (X-Fragile) والتخطبط الكهربائي للمخ (IEG) وأثنعة الرنين

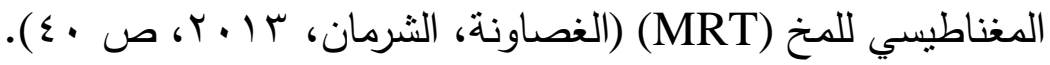
r-التشخيص النفسي: بشير ستفانتوس أنه يتضمن تقيم القدرات العقلية

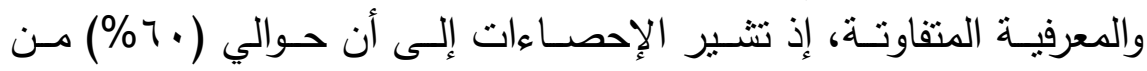

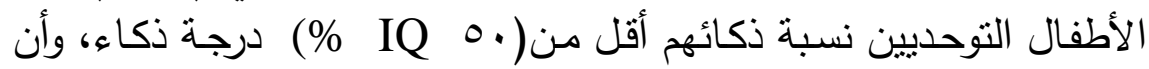

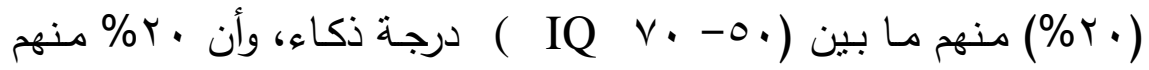
حصلوا علي درجة ذكاء (• (V) فما فوق (Stefanatos, 2002, p195). r-التثخيص الاجتماعي: أنه يتضمن قدرة الطفل التوحدي على الانخراط

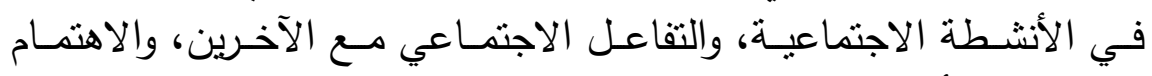

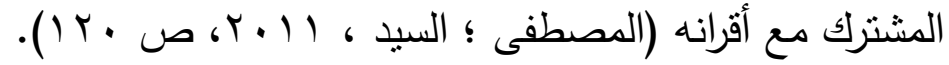
ع -التقييم التريوي: من خلال استخدام التقييم الرسمي باستخدام الملاحظة

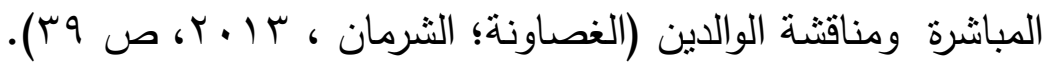

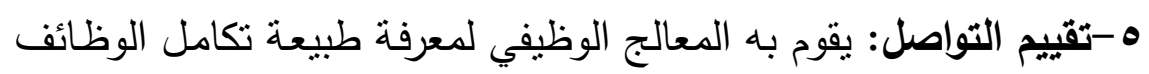

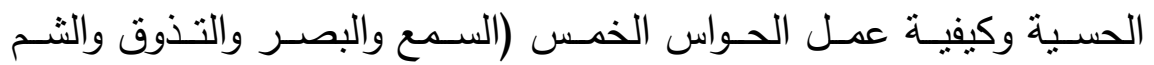

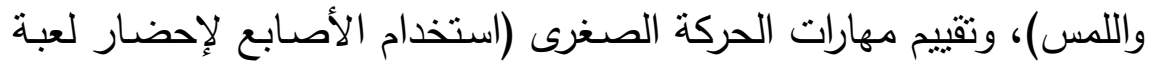

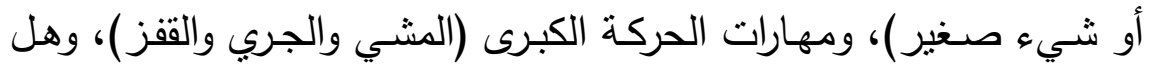

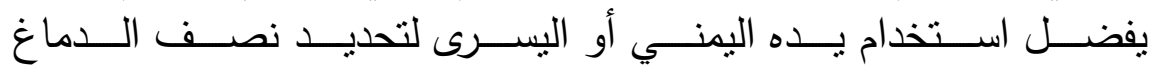

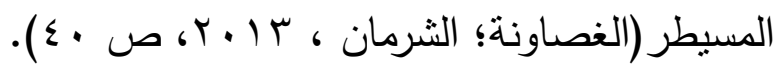

.

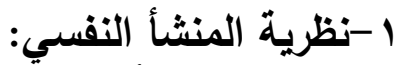

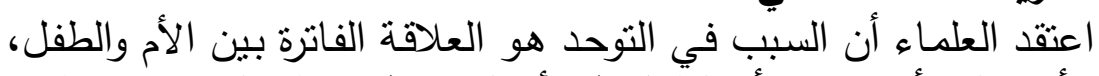

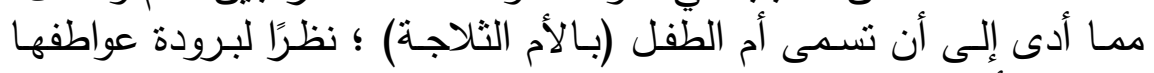

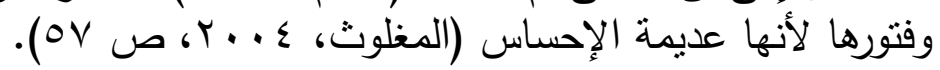


ولا يرجع السبب في ذلك للأم فقط بل إلى الأب أيضاً، فقد كان الوالدان

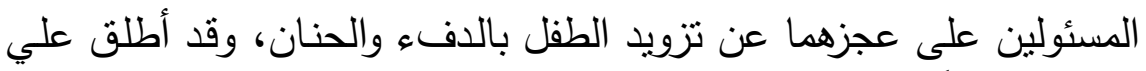

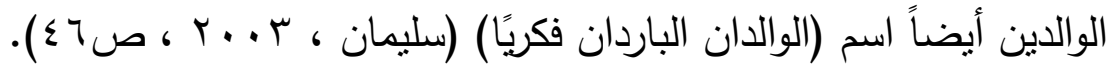

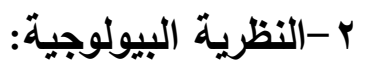

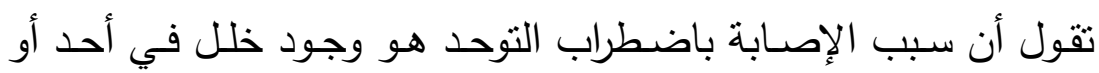

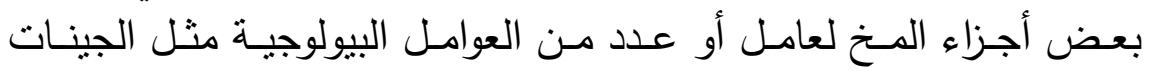

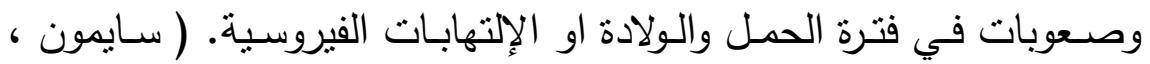

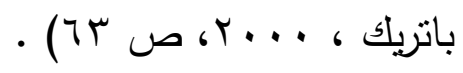

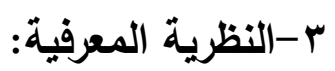

تقول أن الأطفال ذوي اضطراب التوحد لديهم مشكلات معرفية تؤثز على

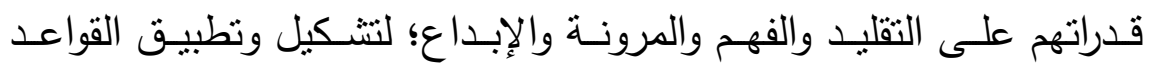

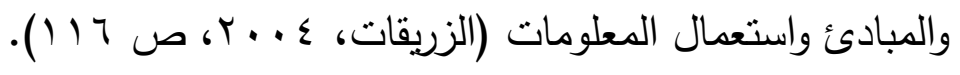
ع -نظرية الكلي (النظرية الصينية):

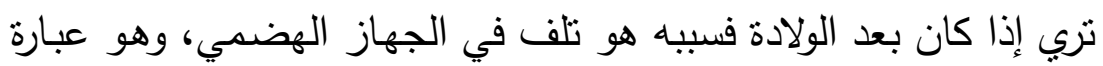

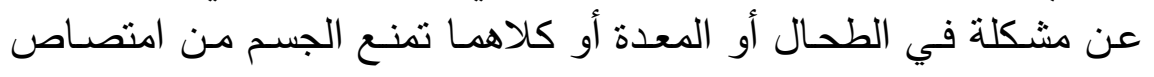

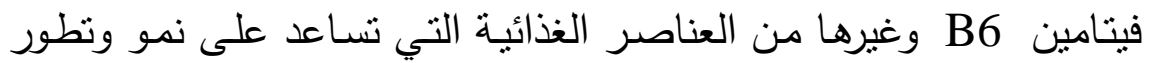

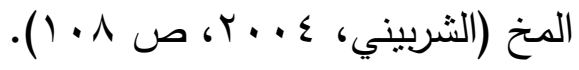

$$
\begin{aligned}
& \text { ه-السموم والتلوث البيئي: }
\end{aligned}
$$

ذكر بأول شاتوك (Shattock, 2008, p2) أن المواد السامة تساهم في

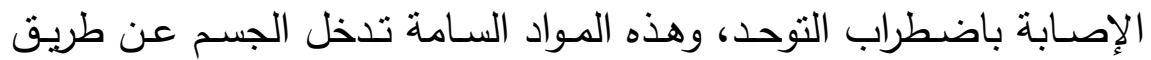
(لقاح MMR ضد الحصبة الألمانية والحصبة، التهابات الغدة النكافية، 


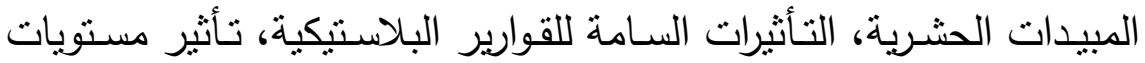

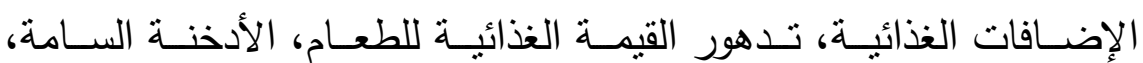

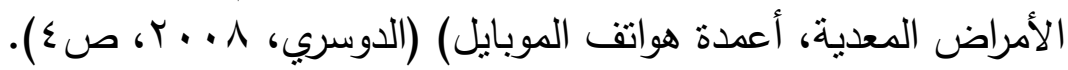

צ-نظريات المخ:

وتستند على اعتقاد أن المرضى الذين يصابون بتلف مكنسب في فص الذص الفي

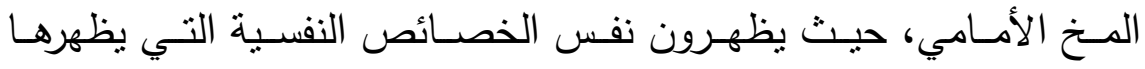

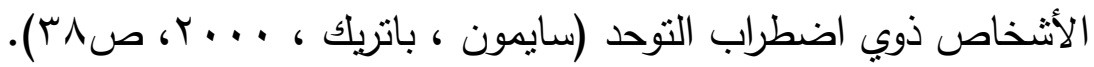

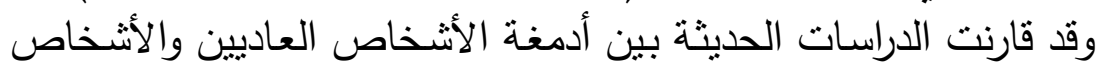

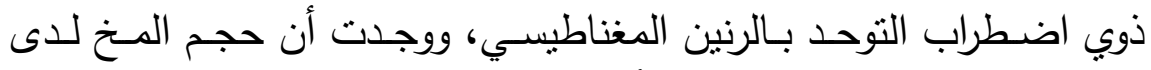
الأشخاص ذوي اضطراب التوحد أكبر من العاديين في مناطق المنخ التالية:

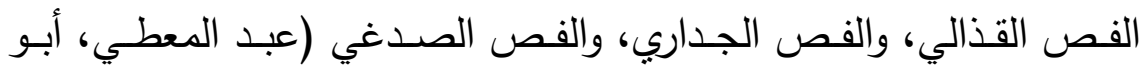

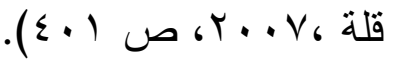

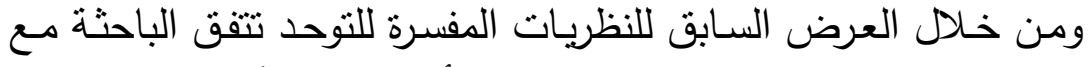

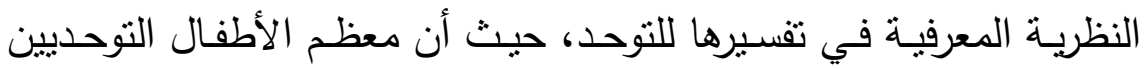

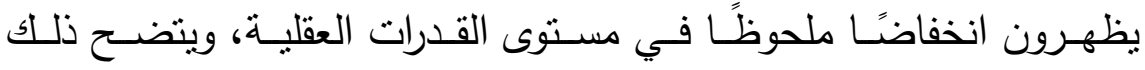
الانخفاض في الضـف في القدرة على التركيز على مثيـرٍِ محددٍ ولفترةٍ كافيةٍة، وكذلك الضعف في إدراك المعلومات وتفسيرها ومعالجتها، والضعف الضفي في التفكير والتمبيز والتصنيف. وكيف. • الأساليب العلاجية للتوحد: 1-برامج تعتمد على الاتجاه الفسيولوجي :

تقوم هذه البرامج على التغيرات الفسيولوجية التي يمكن أن يحدثها العلاج التهاج

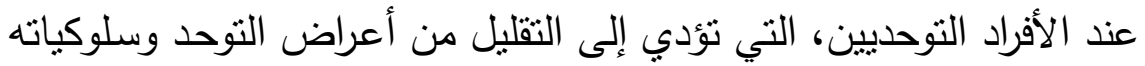


ومنها: ( العلاج بالأدوبة، العلاج بهرمون السيكرتين، العلاج بالفيتامينات المتعددة، العلاج الغذائي، برامج التكامل السمعي، برنامج التكامل الحسي،

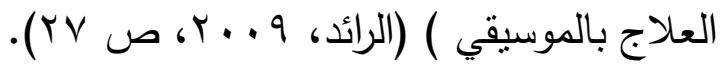

$$
\begin{aligned}
& \text { ץ -برامج العلاج المعتمدة على المهارات: }
\end{aligned}
$$

تقوم البرامج على افتراض أن الأطفال التوحديين بعانون من صعوبات بالغـة في عدد من المهارات، مما يحد من تفاعلهم من الآخرين. لذللك تم

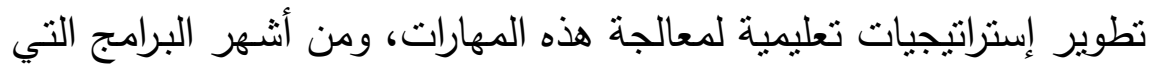
سعت إلى تطوبر المهارات مـا يلي : ( نظام التواصل المعتمد على تبـادل

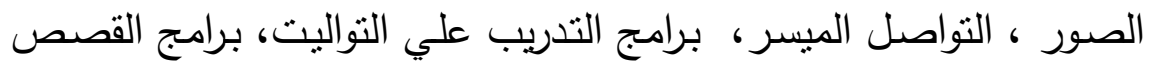

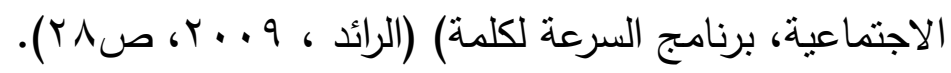

ب-البرامج التريوية نلأطفال التوحديين:

تقوم على الأساس على استخدام إجراءات تعديل السلوك التي يقوم على ألى أسس موضوعية، وليس على انطباعات ذاتية وتعديل السلوك لا بضـع اللوم

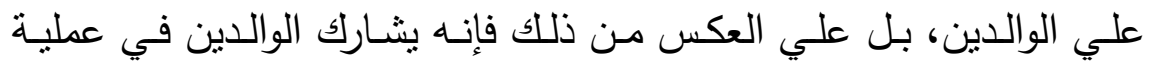

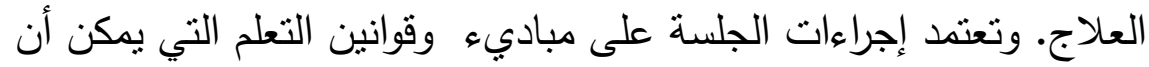

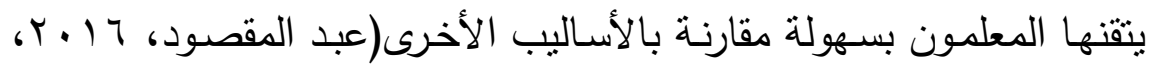

$$
\text { ص ( ) }
$$

ع -التدخل بالتكامل الحسي:

تتبنى الدراسـة الحاليـة المـدخل العلاجي القـائم على العـلاج السـلوكي والإثراء الحسي وذلك للمبررات التالية: (أسلوب يمكن قياس مدى نجاحه أو فنثله، هذا الأسلوب لا يهتم بأسباب التوحد، هذا الأسلوب يعتمد على تتمية الإدراك ومهارات التفاعل الاجتماعي ). 
ه-أمثلة للبرامج العلاجية المبنية علي أسس علمية ومنها :

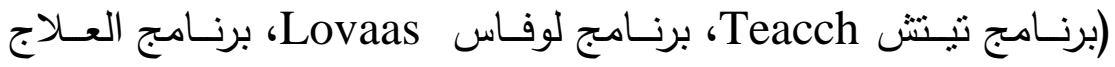

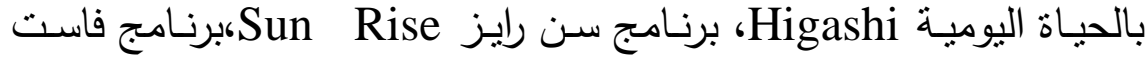
فورورد Fast For Word).

\section{المحور الثاني: الإثراء الحسي Enrichment sensory:}

تعرف الدراسـة الحالية مصطلح الإثراء الحسي (إثراء الوظائف الحسية،

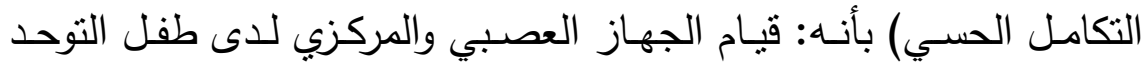

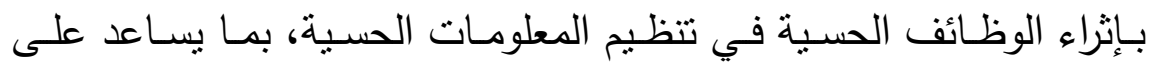

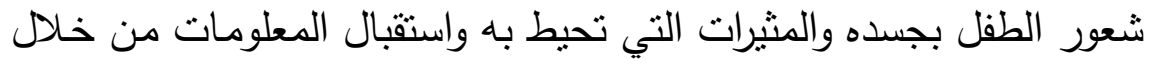

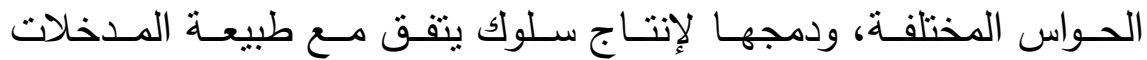
والمثيرات الحسية بشكلٍ هادفٍ.

\section{مصطلح الإثراء الحسي Enrichment sensory :}

الإثراء الحسي: هو إثراء الوظائف الحسية وهي عملية عصبية بيولوجية

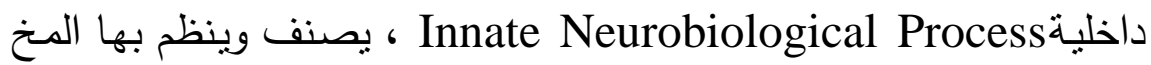

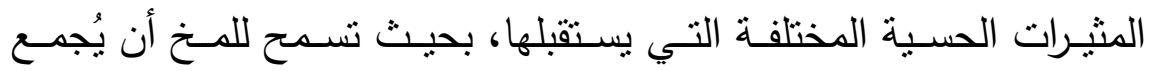

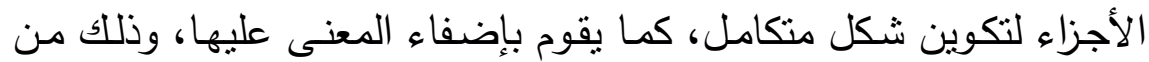

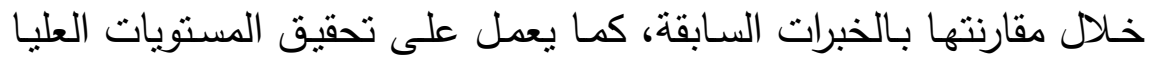

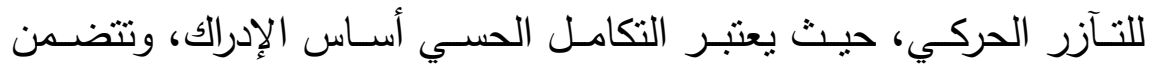

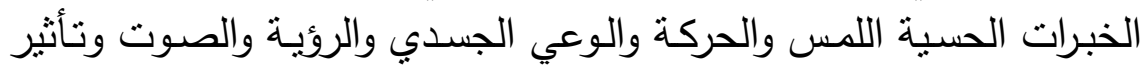

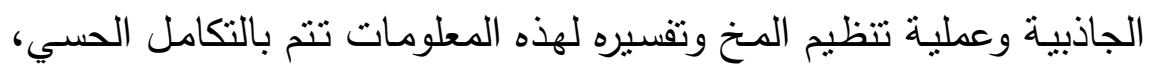

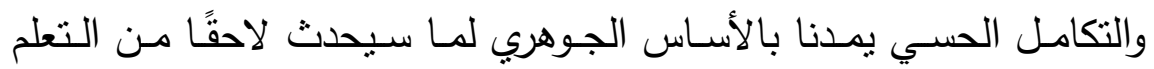

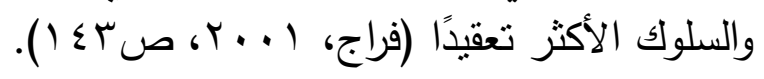




\section{المجلة العلمية لكلية رياض الأطفال - جامعة بورسعيد}

وعرفت إيرس (2005) Ayres إثراء الوظائف الحسية بأنه: العملية التي فيها يسـجل، ويعدل، ويميز الأفراد الأحاسيس المستقبلة مـن خـلاعل النظـام الحسي، والأنظمة الحسية لإنتاج سلوك تكيفي هادف ردًا على البيئة .

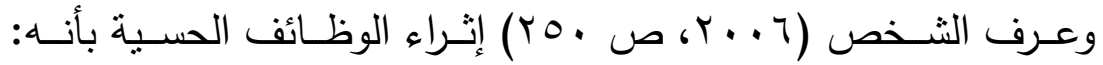

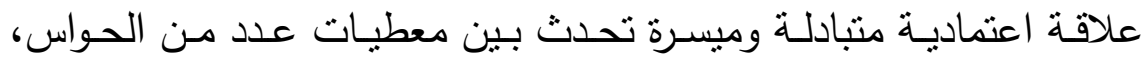
بحيث يمكن أن تؤدي إلى معالجة حسية أكثر دقة وأشمل وأهم من تلاك التي تقوم بها حاسة واحدة بمفردها.

هو عملية عصبية طبيعيـة تتلقى المعلومات من كلٍ من الجسد والبيئة

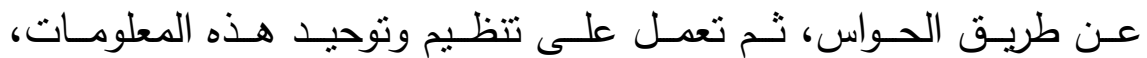

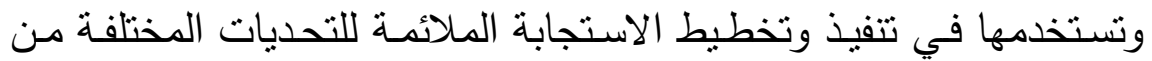

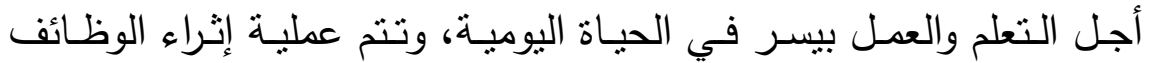
الحسبة العصبي نتيجة استقبال الإنسـان للمعلومـات مـن الحواس المختلفـة وإرسالها إلى الدماغ ثم معالجتها وإعطاء الاستجابات المالائمة لها.

(Sharon, 2010, p20)

وبعرف إثراء الوظـائف الحسية بأنه :القدرة على دمـج المعلومات الواردة من مختلف الحواس وتتظيمها بشكل يعطي معنى محدداً وواضحاً، وبالتالي

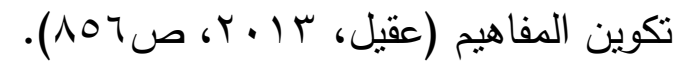

يعرف إبراهيم (ی . . ب) إثراء الوظائف الحسية بأنه: قدرة الدماغ على دمـج ومعالجـة المعلومـات التي ينتم تلقيها مـن أنظمـة الحس المسئولة عن الابصـار والسمع والتذوق والرائحة والحرارة والألم وموقع الجسم من خـلانل

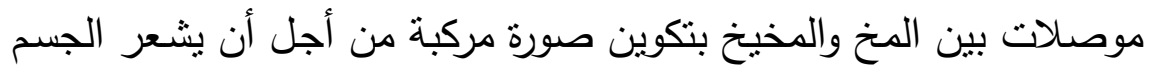

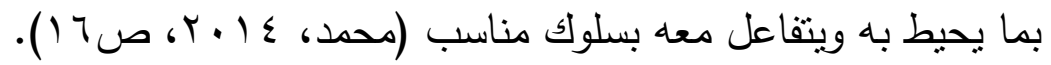


هو استثارة الطفل التوحدي بمدخلات حسبة (سمعية، بصرية، لمسية، شمية، ذوقية، حركية) بحسب حاجة الطفل للتخفيف من فرط حساسية مثير

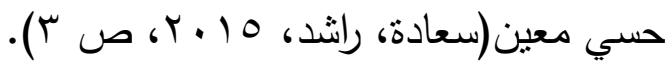

يعتبر من العلاجات التي استخدمت منذ سنوات عديدة من قبل أخصائي

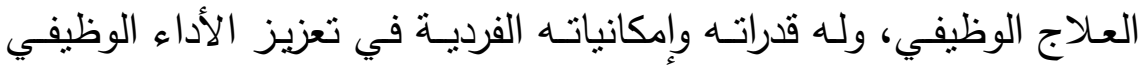
للأطفـال، حيـث يوصـف باعتبـاره مـنهج لتعزيـز قدرة الدماغ على تلى تتظيم المـدخلات الحسـية لاســتخدامها فـي السـلوكيات التفاعليـة مـع الأثـياء والآخرين (Davies, 2007 , p177).

يتم تتطور الوظائف الحسية / التكامل الحسي لدى معظم الأطفال من خلال نشاطات الطفولة العادية، ولكن التكامل الحسي لا بتطور كما يجب بفاعليةٍ لدى بعض الأطفال، فعندما تكون العملية غير منظمةً فإن عدداً من فن لهن المشاكل في التعلم والتطور والسلوك بتظهر ( كامل، ب . . r، ص 0ــ). ولذلك نقوم مـع الأطفال التوحديين بعملية إثراء الوظائف الحسية لديهم، وهي عملية مقصودة وهذا ما يقوم به البرنامج التدربي المنكامل القائم على إنى

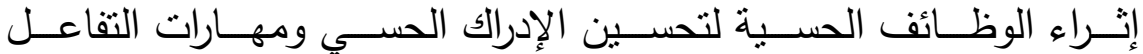
الاجتماعي.

والمعالجـة بـالإثراء الحسـي/ التكامـل الحسـي هـي عـلاج حسـي حركي

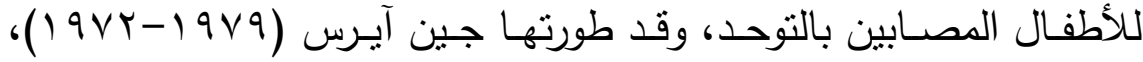
والتي تؤكد فيها على العلاقة بين الخبرات الحسية والأداء السلوكي الحركي،

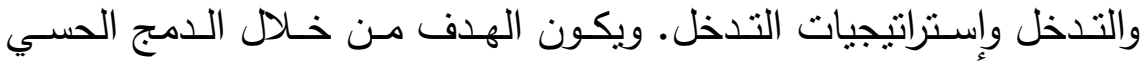
تحسين النظام العقلي، لتنظيم ودمج وتكامل المعلومات من البيئة والتي تزود

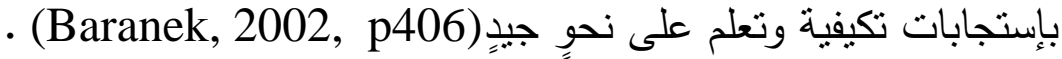


مما سبق يتضح من تعربفات إثراء الوظائف الحسية أن تعربفات الباحثين تتفق مع بعضها إلى حدٍ كبيرٍ ويتحدد في أنه "استثارة طفل التوحد بمدخلات حسية وتتظيمها من أجل أن بشعر طفل التوحد بما بحيط به" .

وتعرف الباحثة إثراء الوظائف الحسية بأنه: "قدرة طفل التوحد على تتظيم

المعلومات الحسية وتكاملها، بما يساعد على شعور الطفل بجسده والمثيرات التي تحيط به واستقبال المعلومات من خلال إثراء الحواس المختلفة وتكاملها ودمجها؛ لإنتاج سلوك يتفق مس طبيعة المدخلات والمثيرات الحسية بشكلٍ هادف:

\section{المحور الثالث: الإدراك الحسي Sensory Perceptual :} • مفهوم الإدراك الحسّي:

أدّا الإدراك الحسّي (بالإنجليزيـة: Sensory Perception) فهو نشـاط يتركز في نقل المعلومات الضـرورية للعيش بين الكائنات الحيـة، والتعرف على العالم الخارجي والداخلي من خلا المثيرات الحسيّ. ( Patrizia, 2012)

\section{• شروط حوادث الإدراك الحسي:}

لابد من توفر عدة عوامل أساسية وهي: الهدف أو الثيء المُراد إدراكه: منثل رؤية جسم بألوان معينة، أو سماع صوت معين، أو شم رائحة معينة. -الأعضاء الحسبة الداعمة للإدراك: منل العين أو الأذن أو الأنف. -الشعور الناجم عن عملية الإدراك: منث الرؤية أو السماع أو الثم . -التعرف على الهـف وإدراكهـ: من خـلال تشكل الصـورة المرئية أو تميز الصوت الصادر والتعرف عليه أو معرفة الرائحة التي تعرضت لعملية الثمّ. 
-آلية حدوث الإدراك الحستّي في الجسم: عندما يحدث تفاعل بين البشر

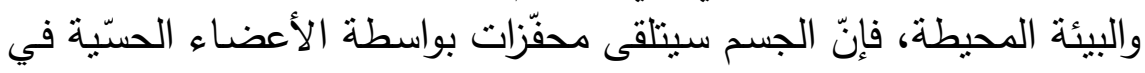

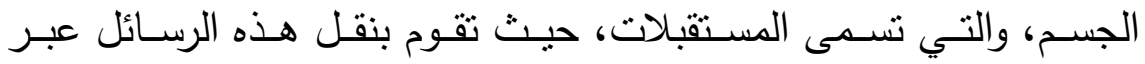

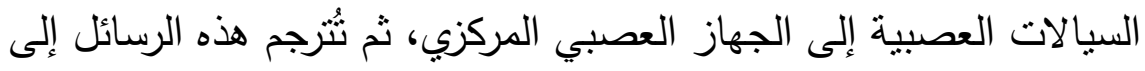

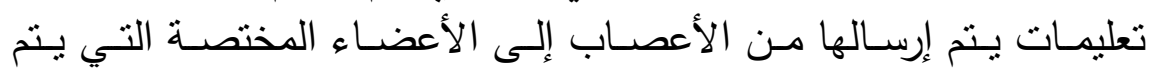

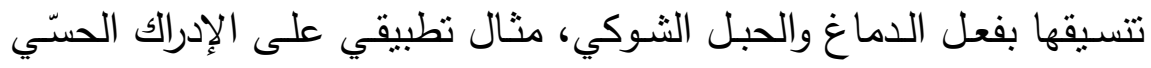

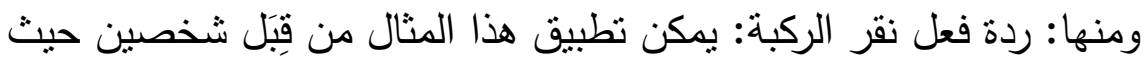
يقوم أحدهما بالجلوس على الطاولة، والاسترخاء مع إغلاق العينين، ثم الثم يقوم

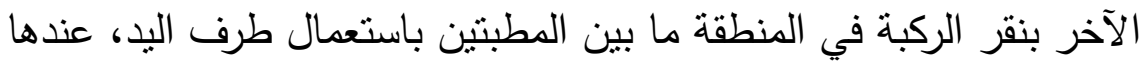
سيلاحظ حدوث ردة فعل مفاجئة للركبة (Patrizia, 2012). • مدخلات الإدرالك الحسي:

عبارة عن أنشطة حركية وحسية تساعد الأطفال على تتظيم المعلومات

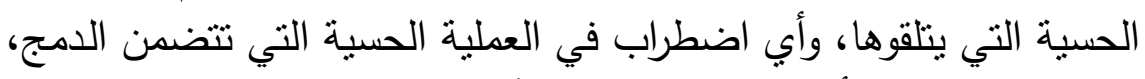

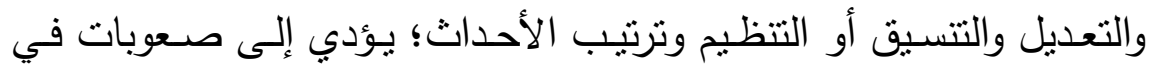
(Sharon, 2010, التعلم وتتمية السلوك المناسب للعمر الزمني للطفل وتئل $\cdot(\mathrm{p} 20$

فالاهتمامات الحسية الحركية من المكن أن تكون في الغالب ملمحاً ذا

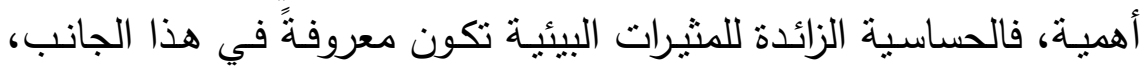

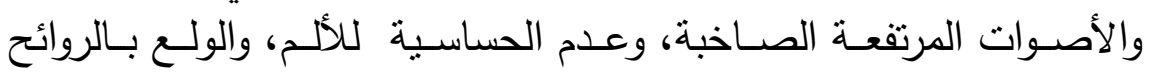

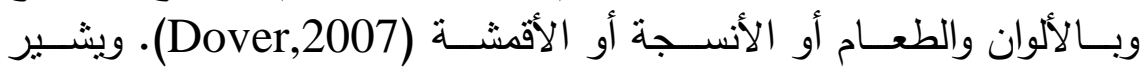

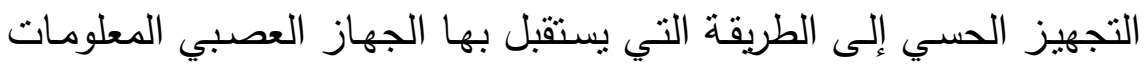

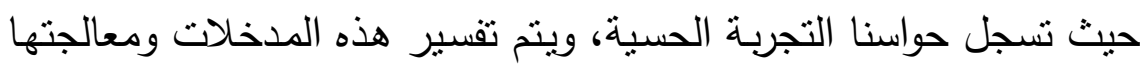


ودمجها في الدماغ لنحصل على صورة منكاملة عن الثيء الذي نتعلمه أو نتعامل معه (Humphry,2002).

ومن المتتاقضات لدى التوحديين هي تفاعلاتهم المترددة وغير المناسبة مع المثير، فمثلًا قد يبدي طفل التوحد عدم تفاعل وعدم اهتمام بمدى منتوع

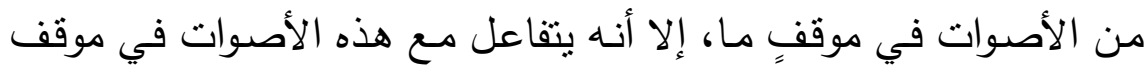

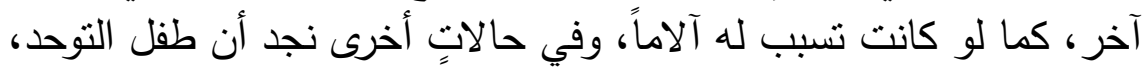

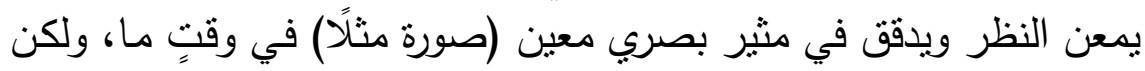
قد ينصرف عن هذا المثير في وقت آخر ، كما لو كان هذا المثير البصري

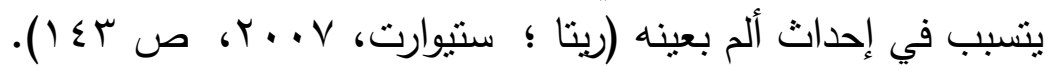
• وظائف الإدراك الحسي هنالك وظيفتين رئيسيتين هما:

ا ـ المستقبلات الحسية تستجيب في حالة الإثارة الزائدة والخطر حتى يتولد الوعي بالدماغ بمقار الخطر القادم، وهذا أمر مهم لمعرفة مصدر الخطر . r. المستقبلات الحسية تستجيب لجميع المعلومات حول البيئة حتى نستطيع

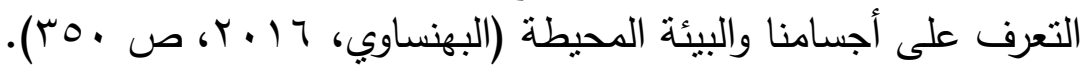
• SPD مصطلح اضطراب المعالجة الحسية إن

وقد اسـتخدم مصطلح اضـراب المعالجـة الحسية (SPD) في الدليل

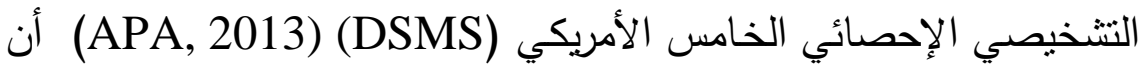
هذا المصطلح أدرج بالفعل كفئة أو اضطراب مستقل وهو يعينه أنه خلل في

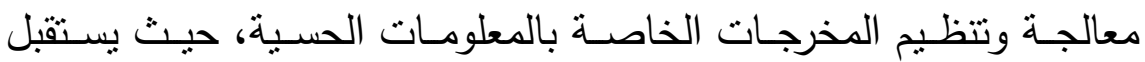

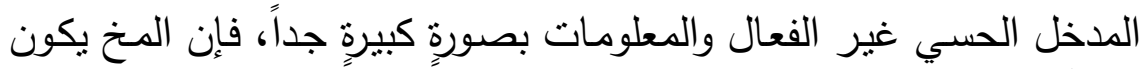

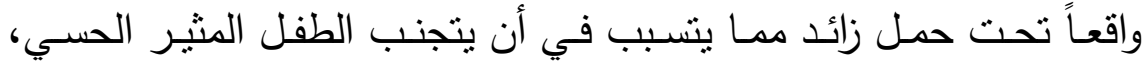
والعكس صحبح في أنه عندما يكون استقبال المعلومات بصورةٍ صغيرةٍ فانِ 


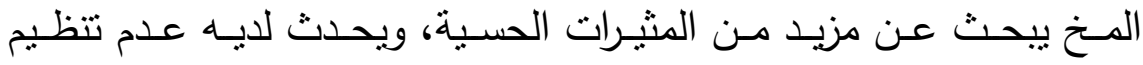

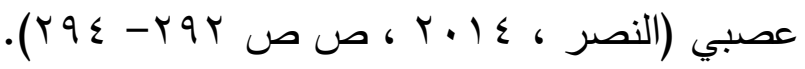

• اضطراب التمييز الإدراك الحسي (SDD) :

يثـير هـا الاضـطراب إلىى عـدم القدرة على التمبيـز بـين الأحاسـيس المتثـابهة في واحد أو أكثر مـن الأنظمسة الحسية مثنل اللمس، الرؤيسة،

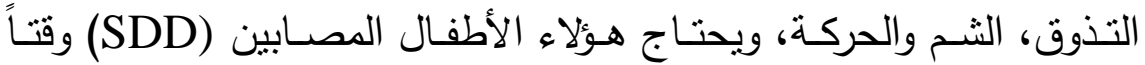

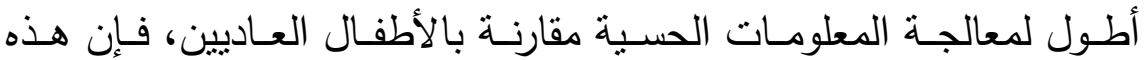
الصعوبة تجعلهم يبدون منأخرن من الناحية الإدراكية، مما يؤدي إلى أنماط سلوكية سلبية والتي تعيقهم في الفصل الدراسي وأثتاء اللعب، حيث تظهر منهر لديهم مشكلات تتعلق بالثقة بالنفس.

ويعد اضطراب الوظـائف الحسية عدم قدرة الدماغ على دمـج ومعالجة معلومات معينة يتم تلقيها من أنظمة الحس وخلل في العلاقة المستمرة بين السلوك وعمل الدماغ، لذا قد تظهر بعض السلوكيات التي قد تبدو غريبة ولا نجد لها تفسير منطقي واضـح أو سبب ظاهري. هذه السلوكيات تؤثر

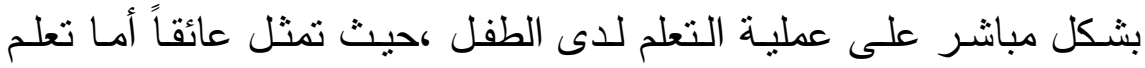
الطفل و اندماجه في البيئة التعليمية المتواجد فيها. فـلا يستطيع التواصل لئل الجيد مـع المـربين و المدرسين و أيضـاً مـع زمالئه داخل الفصـل الدراسـي

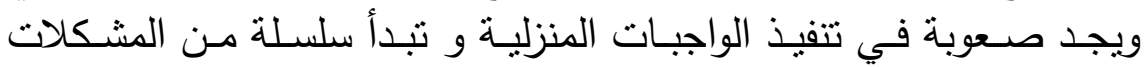

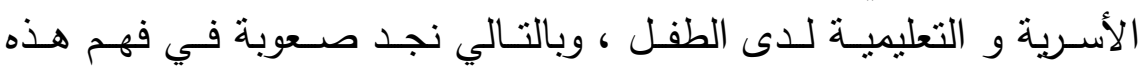

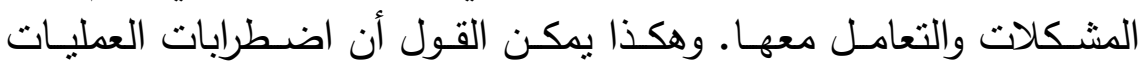
الحسية لدى الطفل لها تأثنر مباشر و قوي على تعلمهـ، الأمر الذي يحتاج إلى تدخل متخصص في معرفة هذه الاضطرابات و وضـع خطة علاجيـة لها للتقليل من الآثار السلبية لها على الطفل، ولقد تم ملاحظة أن الأطفال 
الذين لديهم مثنل هذه المشـاكل يمكن أن يبدوا مميزين في أثنياء أخرى

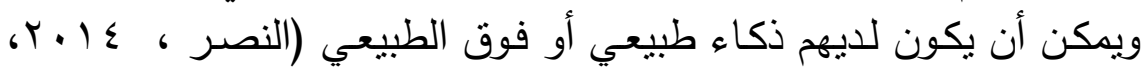

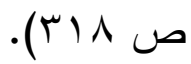

وأثنار (Beth, Kristie, Moya, Megan, Lorrie, 2011, p 76) إلى أن الأطفال الذين يعانون من ضعف المعالجة الحسية منل أطفال طيف

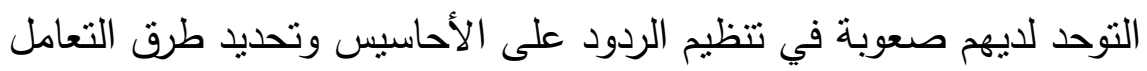

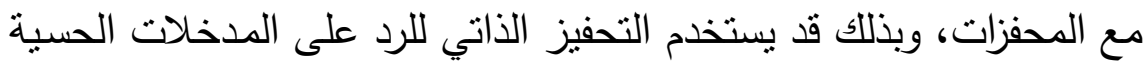

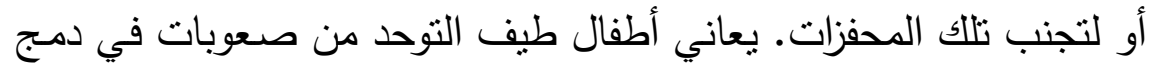
الخبرات الحركية والحسية، ولذلك من المهم التخخل العلاجي لهؤلاء الأطفال

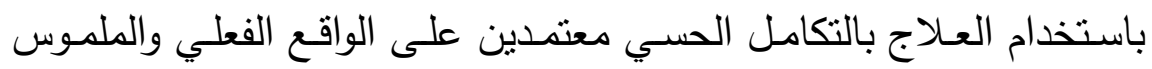
لطبيعته وخصائص أطفال التوحد لأنهم يختلفون عن الأطفال العاديين.

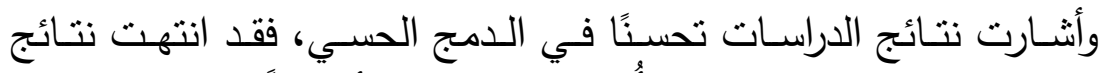

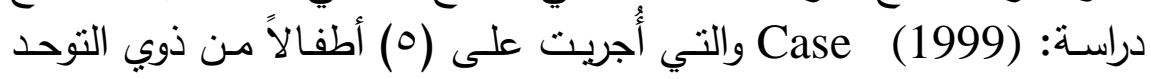

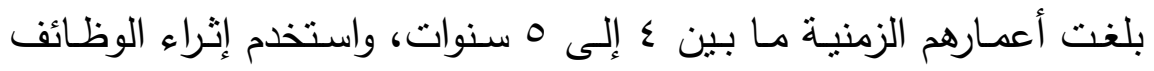

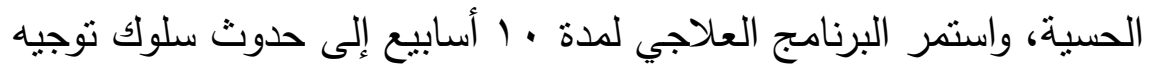

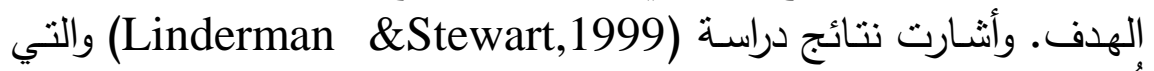

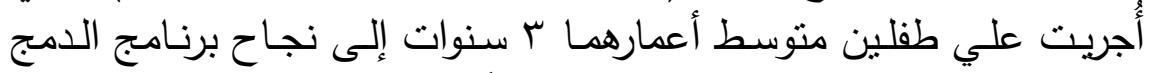

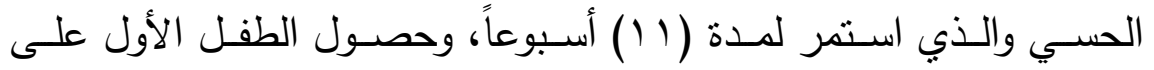

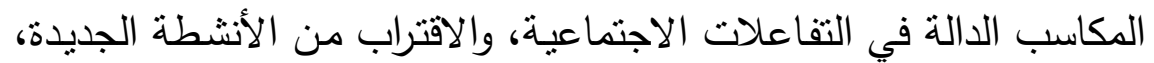

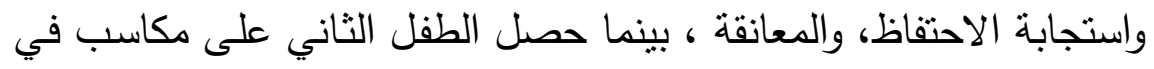

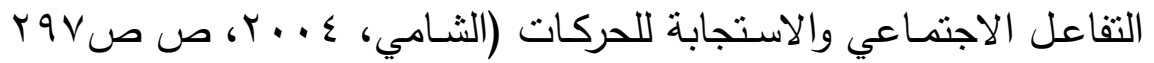
. (rq1- 
• دور الإدراك الحســي فـي عـلاج الاضــراب فــي مهــارات التقاعـل

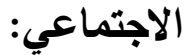

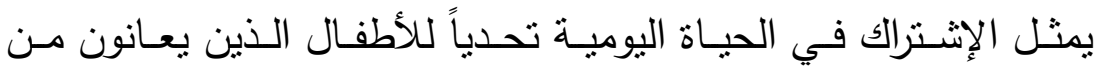
اضطرابات طيف التوحد (ASD) المشاركة والمهارات في الأنشطة اليومية يمكن أن تتأثز بعوامل كثثرة، واحدة منها هو الأداء الحسي. ويلعب التبار التطور

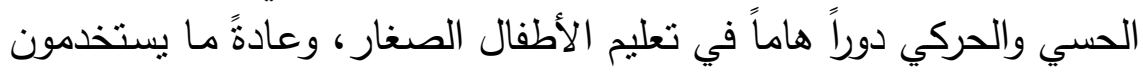

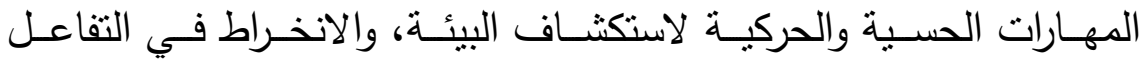
الاجتماعي والأنشطة البدنية، وتطوير المهارات الأكاديمية الأساسية.

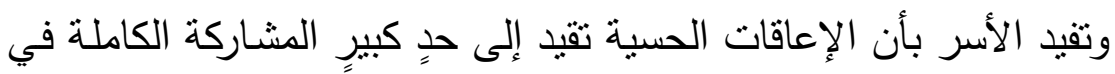

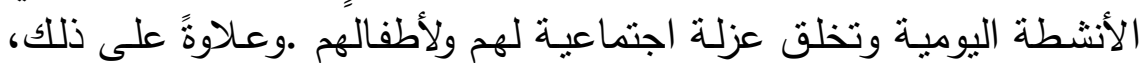

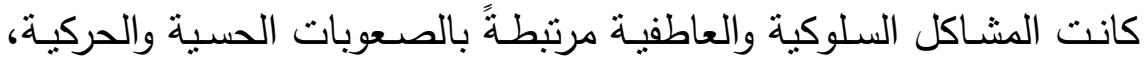

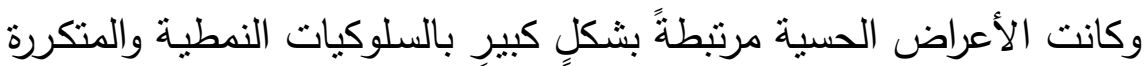

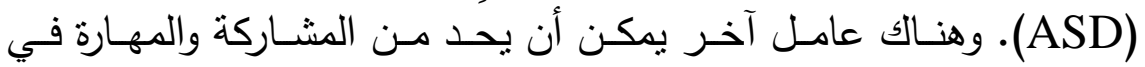

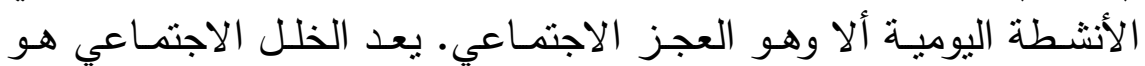

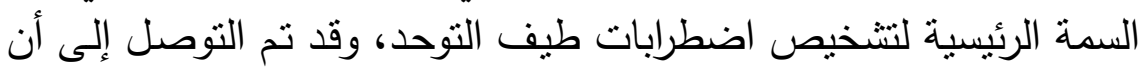

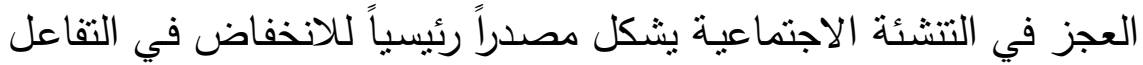

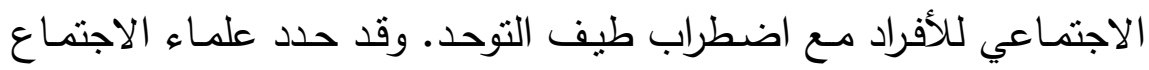
المهارات الاجتماعيـة كسلوكيات محددة تؤدي إلى التفـاعلات الاجتماعيـة السليمة ( Khodabakhshi, Mokhtar,2014, p36)

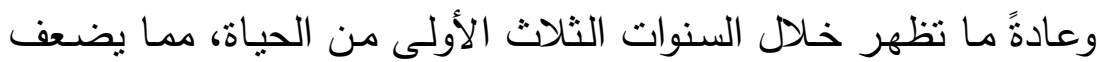

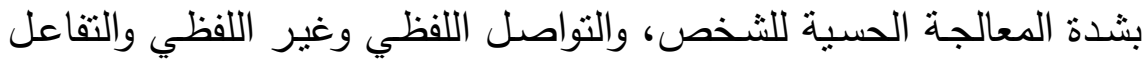

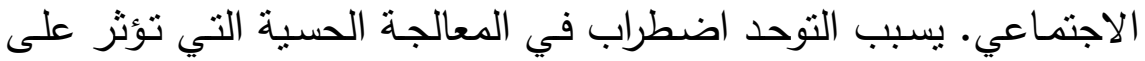

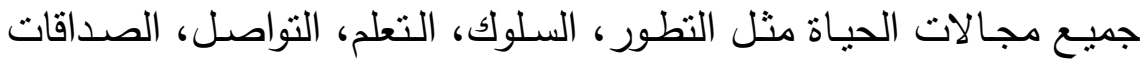




\section{المجلة العلمية لكلية رياض الأطفال - جامعة بورسعيد}

واللعب. ويبرز هذا الهدف كيف يسـاعد العلاج المتكامل من خـلا إثراء الوظائف الحسية في تحسين مهارات الرعاية الاجتماعية والرعاية الذاتية في

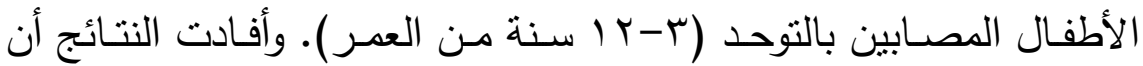
العلاج بالإثراء الحسي لمدة ثلاثث مرات أسبوعياً لمدة ثلاثنة أشهر يساعد في الإني

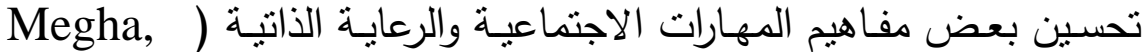
pooja, 2015, p7)

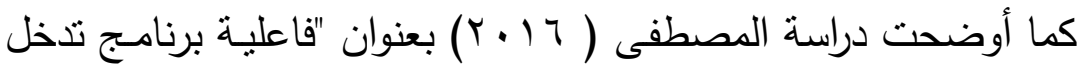

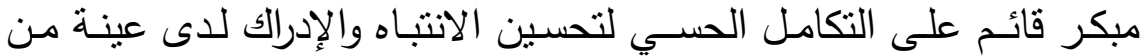
الأطفال ذوي اضطراب التوحد". وهدفت الدراسـة إلى تتمية الانتباه والإدراك

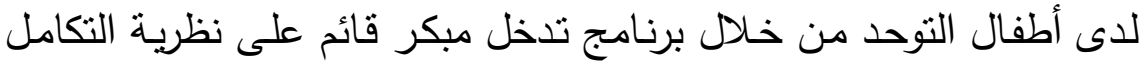

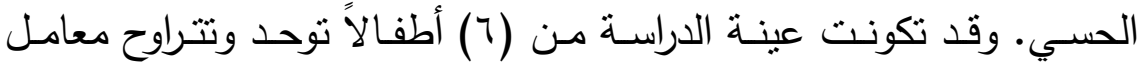

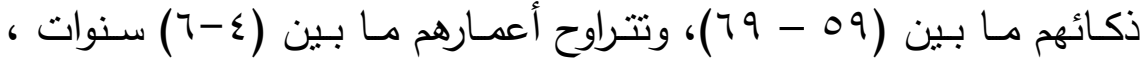
ونسبة اضطراب التوحد لديهم منوسطة. وقد أسفرت النتائج عن وجود فروق

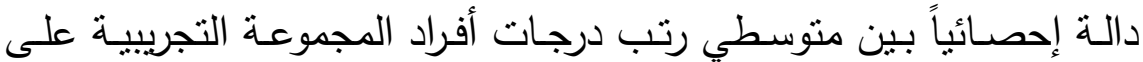
مقياس تقدير الانتباه لدى أطفال التوحد والدرجة الكلية للمقياس في القياسين القبلي والبعدي، وعدم جود فروق دالة إحصائياً بين متوسطي رتب درئ درجات

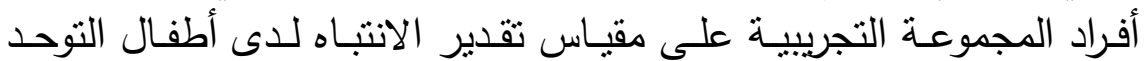
والدرجة الكلية للمقياس في القياسين القبلي والتتبعي. مما سبق يوضح أن مهارات الإدراك الحسي لله دور هام يتمثل في نلبية الاحتياجات الحسية للأطفال التوحديين، ممـا يسـاعدهم على إثراء الإدراك

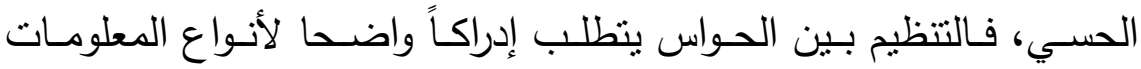
الحسية التي يتلقاها الطفل، وكذلك توافر عتبة حسية محددة نساعد على تسجيل المعلومة بشكل صحيح والاستجابة بردود أفعال مناسبة، كما تثطلب قدرة من الثخص على تحديد مـا هي المعلومات الحسية المهمهة، ومن ثم 
تتظيم الإستجابة وتتفيذها، وهذه الخطوات المتكاملـة والمتسلسلة لا تتوافر لاى الطفل التوحدي لأن يعمل تحت مستويات عالية جداً من الإثارة. المحور الرابع: مهارات التفاعل الاجتماعي : تعد مهارات التفاعل الاجتماعي من المهارات المهمة في حياة الطفل،

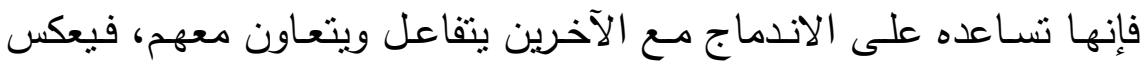

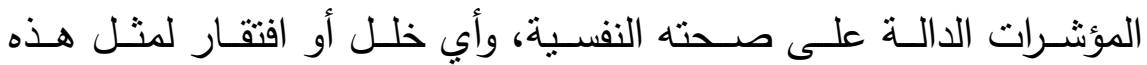

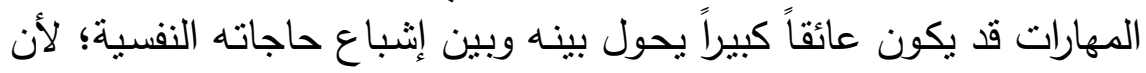

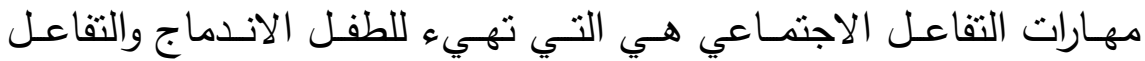
بالصورة الإيجابية.

\section{• تعريف مهارات التقاعل الاجتماعي:}

تعريفات تتاولتها على أنها خبرات أو أنماط سلوكية متعلمة ومنها ما يلي:

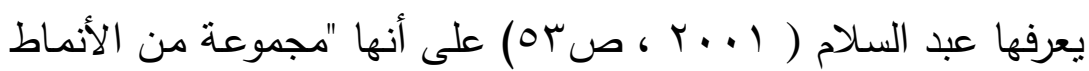

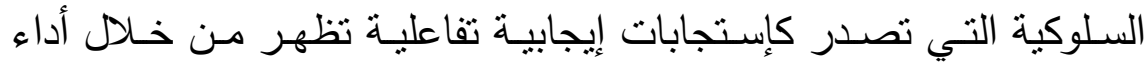

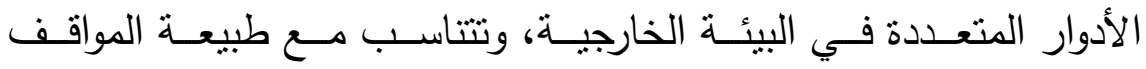
الاجتماعية التي يتم التعرض لها، وتتفق مـع القيم، والمعايير الاجتماعية ولية

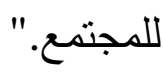

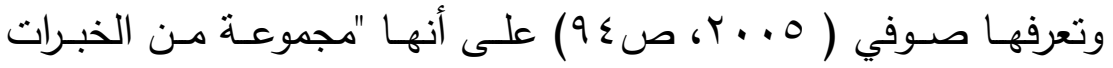

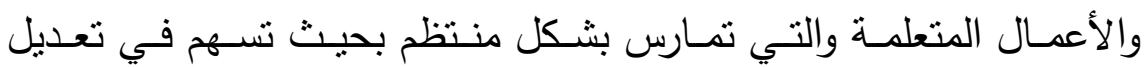

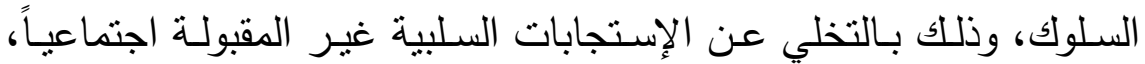

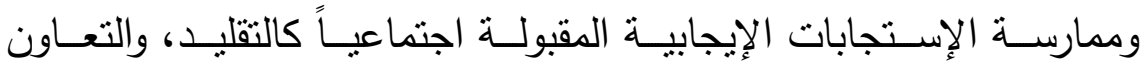
والمشاركة." ومثاريـ الإن 
ويرى (Spinser) هي "المكونـات المعرفية للعناصـر السلوكية اللززمـة للحصول على نتائج إيجابية عند التفاعل الاجتماعي، مما يؤدي إلى إصدار

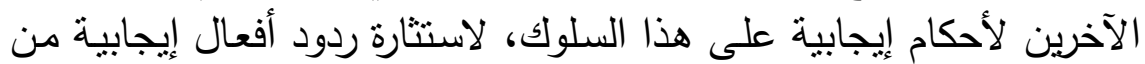

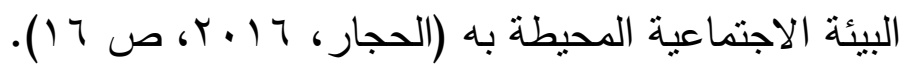

• تعريفات تناولت مهارات التفاعل الاجتماعي على أنها قدرة ومنها:

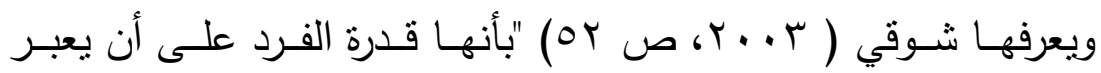
بصورة لفظية وغير لفظية عن مشاعره ، وآرائه وأفكاره للآخرنن، وأن ينتبه

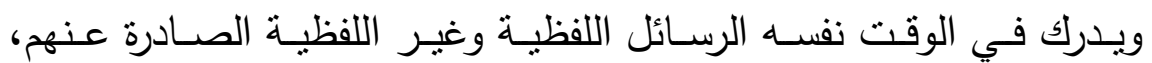
ويفسرها على نحو يسهر في توجيه سلوكهم حيالهم، وأن يتصـرف بصـورة ملأئمسة في مواقف التفاعل الاجتمـاعي معهم، ويتحكم في سلوكه اللفظي وغير اللفظي فيها وبعدله كدالة لمنطلباتها على نحو بسـاعد على تحقيـق أهدافه. وعير

وترى شاش (r · . r أن مهارات التقاعل الاجتماعي ما هي إلا حركات

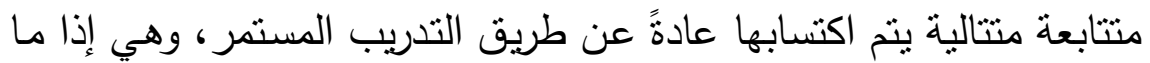

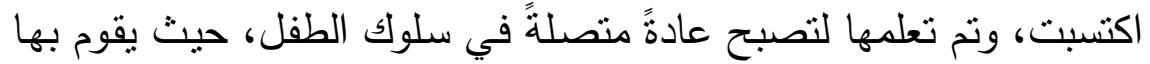

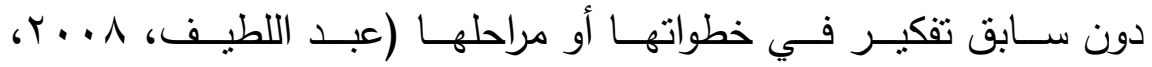

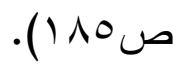

مـن خـلال التعريفات السـابقة لمهارات التفاعل الاجتمـاعي يتضـح عدم اتفاق الباحثين على تعريف محدد لمفهوم مهارات التفاعل الاجتماعي، فقد عرفها بعض الباحثين على أنها القدرة على المبادأة بالتفاعل مع الآخرين، والآخر حدد مفهوم مهارات التفاعل الاجتماعي بأنها حركات متتابعة متتالية يتم اكتسابها عادة ـُعن طريق التدريب المستمر • وعلى أنها أيضـاً مجموعة 
من الخبرات والأعمال المتعلمة والتي تمارس بشكل منتظم بحيث تسهم في

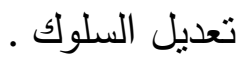

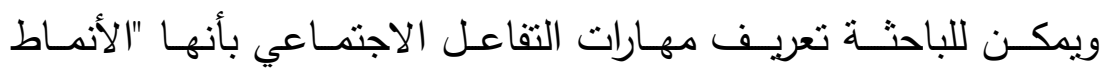

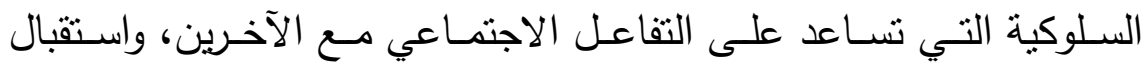

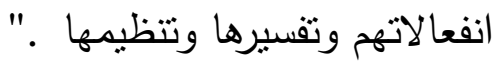
• مكونات مهارات التفاعل الاجتماعي: -نموذج موريسون:

الذي يرى أن مهارات التفاعل الاجتماعي تتضمن ثلاثة مكونات رئيسية وهي:(المكونات التعبيرية وهي:محتوى الحديث ،المهارات اللغوية ، المهارات

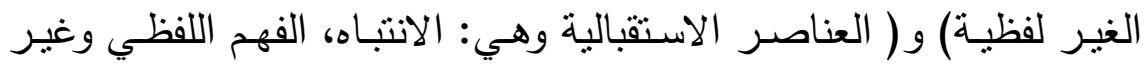

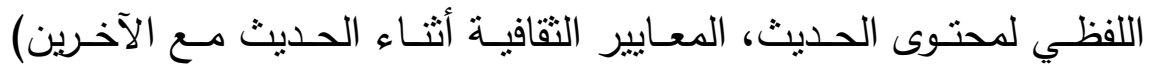
و (الإتزان التفاعلي ويشمل: توقيث الاستجابة، نمط الحديث بالدور ، التدعيم

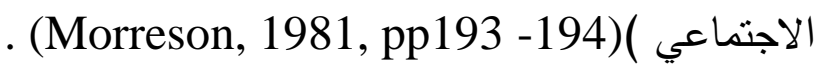
- نموذج (1989) مكونات مهارات التفاعل الاجتماعي: هـي مهارات اتصـال اجتمـاعي وتتقسم إلى ثلاتـة أقسـام هـي مهارات:

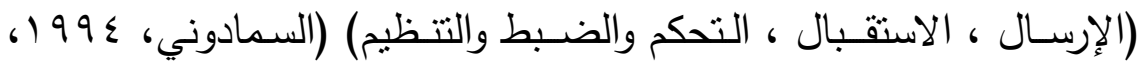

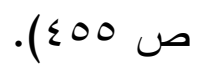

\section{: Merrel (1993)}

يشير هذا النموذج إلى أن مهارات التفاعل الاجتماعي تتضمن المكونات التالية:

- التفاعل الاجتماعي: ويشمل مهارة الطفل في التعبير عن نفسه والاتصال الثخصي مع الآخرين، ومهارته في تكوين صداقات دهات دائمة. 
- الاستقله الاجتماعي: ويشمل مهارة الطفل في أداء الواجبات المختلفة

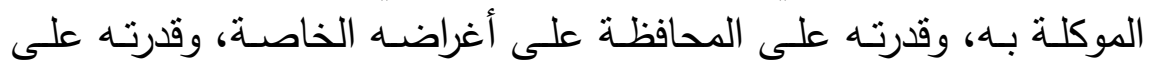
الدفاع عن حقوقه.

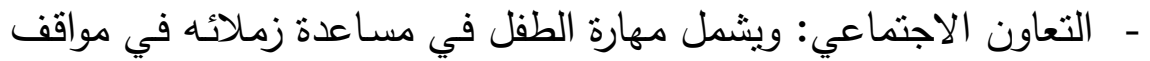

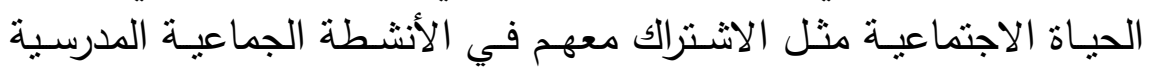
لإتمام عملٍ ما. - الضبط الذاتي: ويشمل النصام الضياع الطفل وامتثاله للتعليمات واتباع القواعد الاجتماعية في الأسرة والمدرسة على حدٍ سواء.

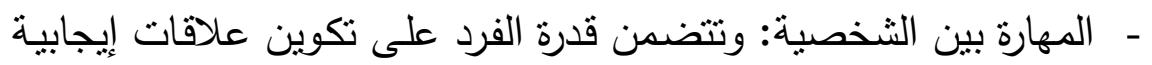

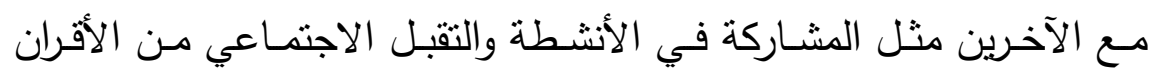

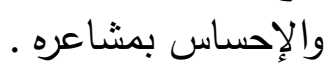

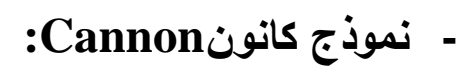

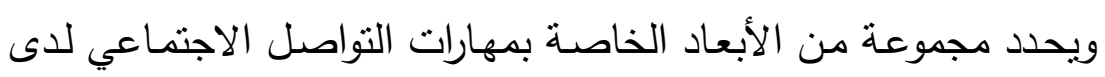

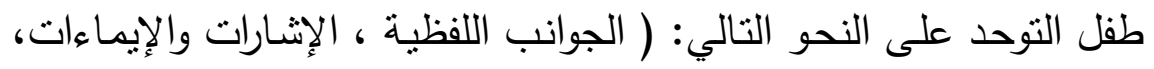

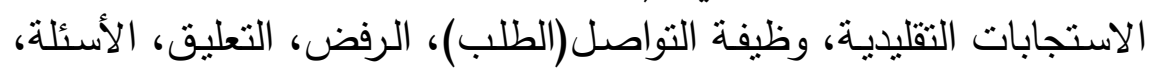
الانتباه المترابط، تواصل العين) (Cannon, 2006, p80). ومما سبق سوف تتبنى الدراسة نموذج موريسون - نموذج ريجو - نموذج ميلر - نموذج كانون. • أهمية مهارات التفاعل الاجتماعي:

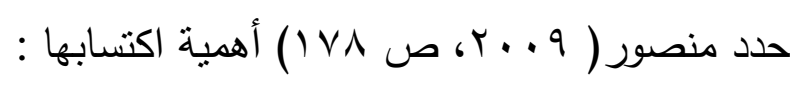
- تقيد في التغلب على مشكلاتهم وتوجيه تفاعلهم مع البيئة المحيطة بهر. 
- تساعد اكتساب هذه المهارات على استمتاعهم بالأنشطة وتحقيق إثباع الحاجات النفسية. - تساعد اكتسابها على تحقيق قدرٍ كبيرٍ من الاستقلال الذاتي والاعتماد

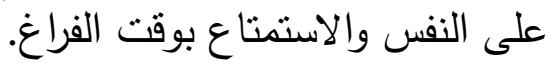

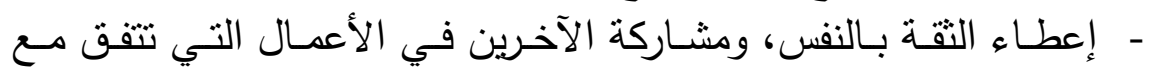
قدراتهم وإمكاناتهم. - تنساعدهم على التفاعل مـع الرفاق والابتكار والإبداع في حدود طاقاتهم الذهنية الجسمية. - تكون مخرجًا لهم من جو الفثل الذي يحيط بهم في مجال التعليم. • التدريب على مهارات التفاعل الاجتماعي:

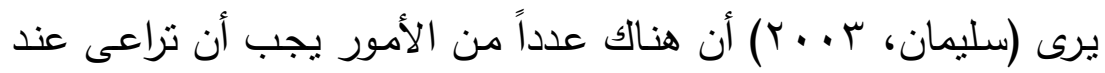

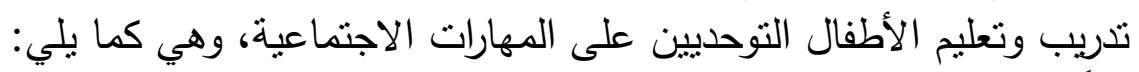
أولاً:- تقسيم عملية التدريب إلى مراحل متعددة.

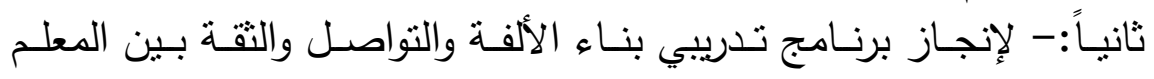
والطفل. ثالثاً:- نتظيم البيئة التعليمية بشكلٍ جيدٍ، واستثمار عناصر البيئة الطبيعية

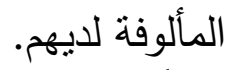
رابعاً:- علينا استخدام المحسوسات والمشاهدات في تعليم الطفل مثل الفيديو والرسومات. خامساً:- فترات التدريب قصبرة؛ وذلك لأن الطفل غالباً ليس لدية فترة انتباه طويلة. سادساً:- مشاركة الأسرة في عملية التدريب وخصوصاً الأم؛ لأنه بياعد في

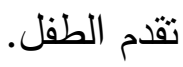




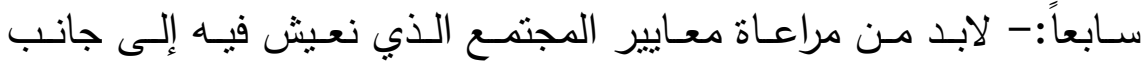

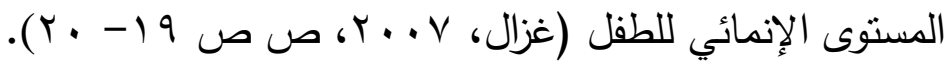
• النظريات المفسرة للمهارات الاجتماعية:

\section{أولاً: النظرية السلوكية:}

تتظر إلى السلوك على أنه وحدة معقدة يمكن تحليلها إلى وحدات أبسط

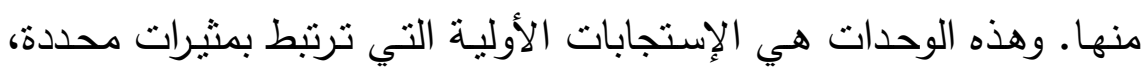
والعلاقة التي تربط بين المثيرات واستجابتها هي علاقاتة الإنة موروثة أبي سابقة

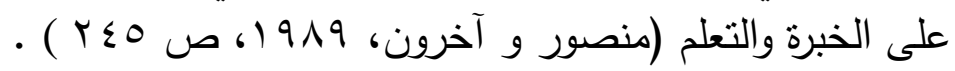

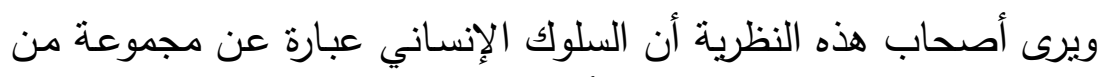

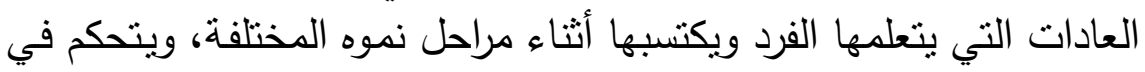

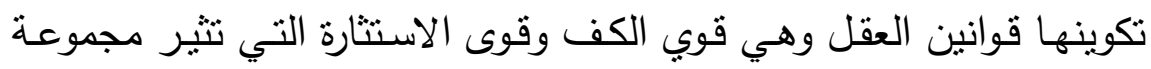

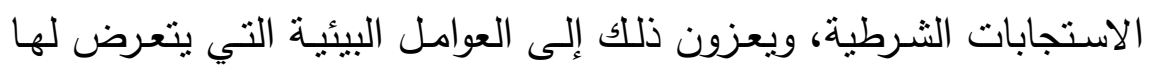

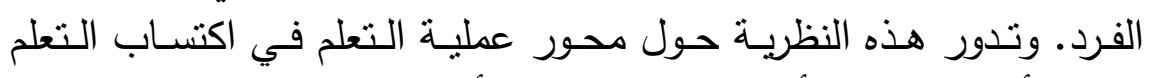

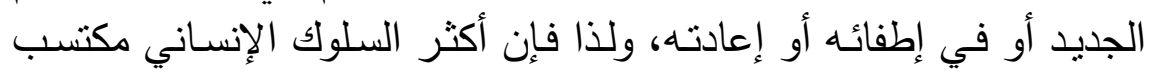

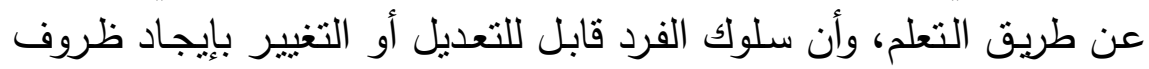
وأجواء تعليمية معينة.

\section{ثانياً: نظرية التعلم الاجتماعي:}

يرى باندورا أن كل من البيئات الخارجية والداخلية للفرد تعمل في صورة الإنه

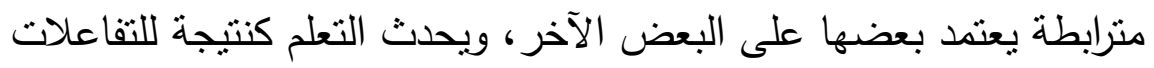

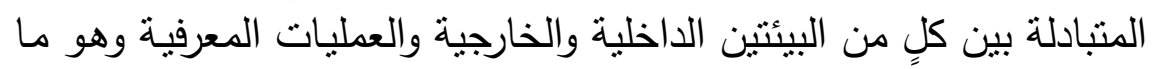

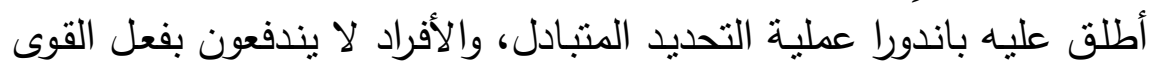

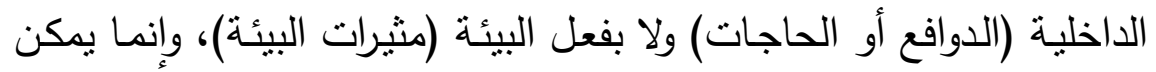


تفسير الأداء النفسي في صسورة تفاعل متبـادل بين المحددات الثخصية

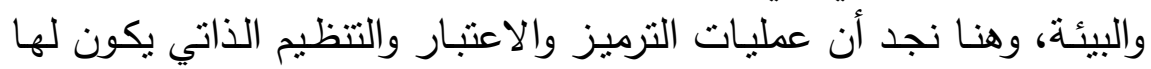

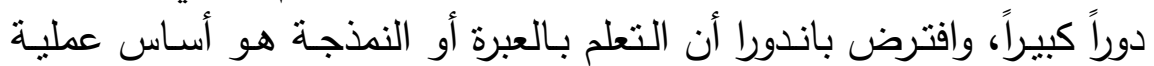

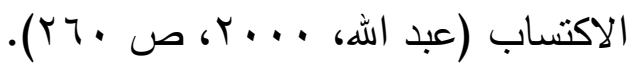

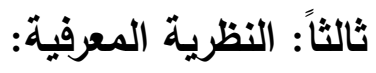

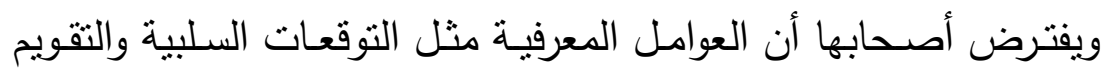

الذاتي هي الأسباب الأساسية لقصور مهارات التفاعل الاجتماعي (عبد الله،

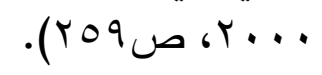

يؤكد إمري (Emery أن لكل منا عدة افتراضات تتطوي على النى

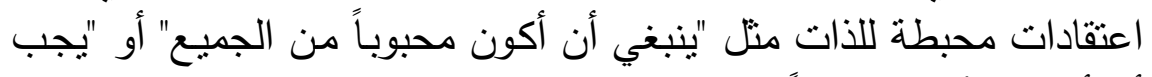

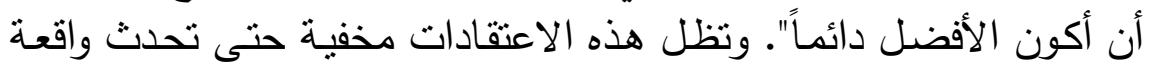

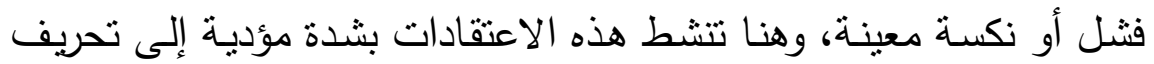

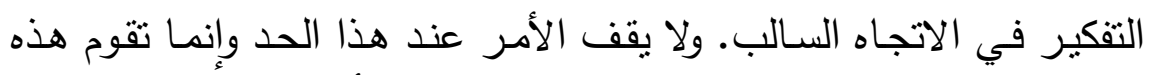

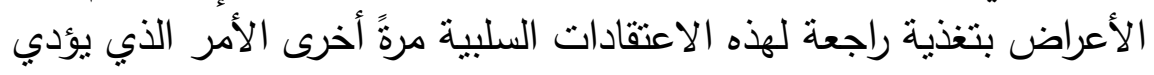

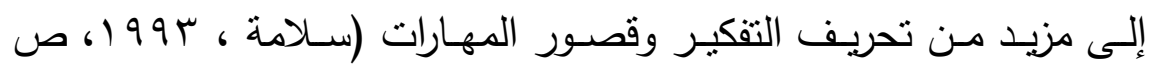

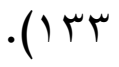
• القصور في مهارات التفاعل الاجتماعي لأطفال التوحد فيما يلي: (1) (1) مهارة التقليد:

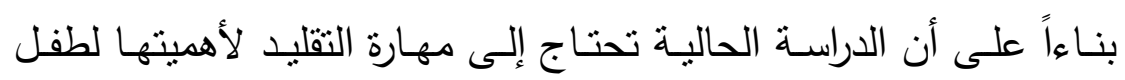

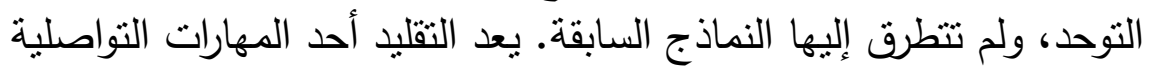

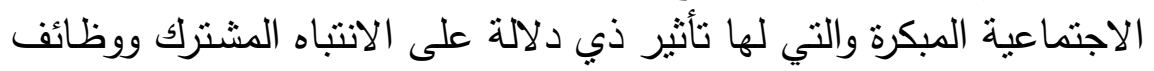

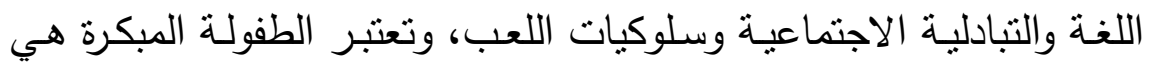


فترة نمو التقليد والتي تتيح للطفل القدرة على تعلم سلوكيات جديدة من خلال المالاحظـة، وتعتبـر أداةً هامـةً جداً في التتعلم والتطـور السـريع لسـلوكيات الطفل

واقترح روجرز وبننجتون Rogers , Penningto (1991) أن التقليد ربمـا يكـون الصـعوبة الأساسية لـدى الأطفـال التوحديين مدـا بعـوق نمـو

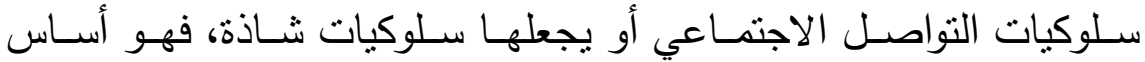
للاضـطرابات الاجتماعبـة والتواصـلية والوجدانيـة وقصــور اللعـب الرمـزي

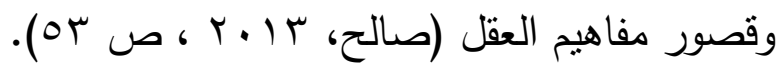
والتقليد مـن المهـارات الهامـة واللازمـة في نمـو الطفل وتعلمـه، فبدون المحاكاة لن يتعلم الطفل التقاعل الاجتماعي مع المحيطين، ويستخدم الطفل

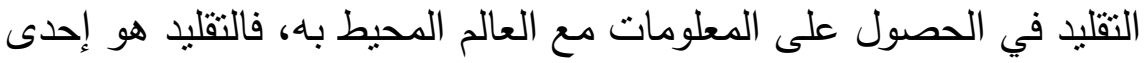
الأشكال الرئيسية للاتصـال الانسـي، والطفل لا يتعلم التقليد ولكن التقليد

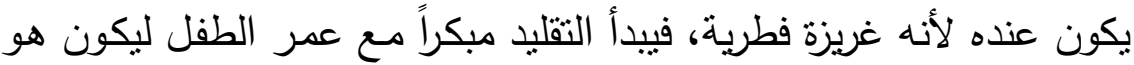
الوسيلة غير اللفظية في اكتساب الكثير من المعلومات البيئية المحيطة بـه هـيه

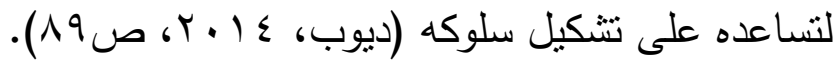
(Y) مهارة التواصل الاجتماعي:

فانخفـاض مسـتوى مهـارات التواصـل الاجتمــــي يجعـل الفـرد غيـر قـادراً

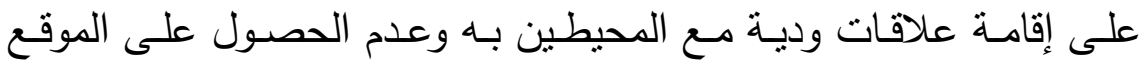
المناسب في العمل والمكانـة الملائمسة بين الزملاء، وصسعوبة في الإفصساح

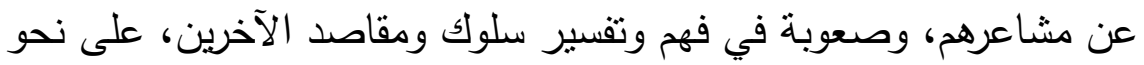

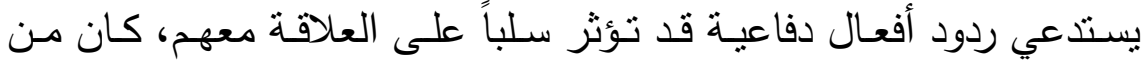
الممكن تجنبها في حالة الفهم الدقيق لسلوكهم، وكذلك تفاقم الثعور بالفشل، 


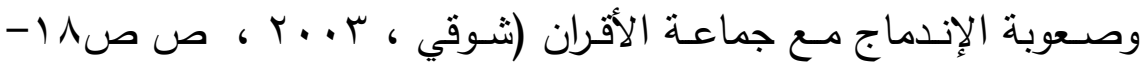

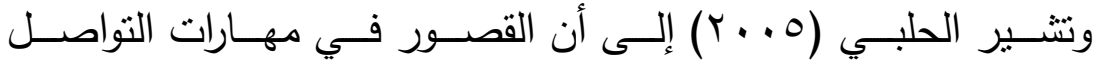
الاجتمـاعي لأطفال التوحد يمكن تحديده بثلاثة مجـالات هي: ( التجنـب الاجتماعي، اللامبالاة الاجتماعية، الإرباك الاجتماعي).

وتعد مهارات التواصل الاجتماعي الأساس الذي يتكيء عليه الطفل من

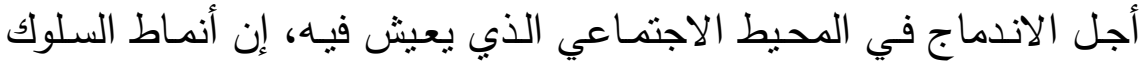
الاجتماعي غير المناسب تظهر عادةً عند أطفال التوحّد بشكلٍ ملحوظٍ قبل

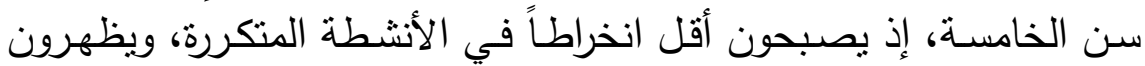

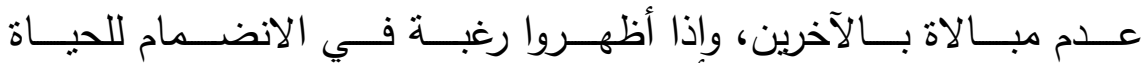

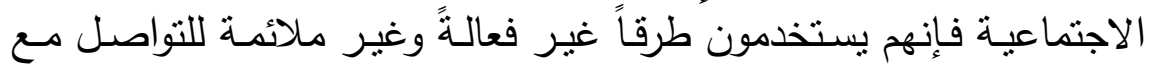
الآخرين Wing (1979) وبعد سن الخامسة تتمثل أهم المشكلات لدى وعلى الأطفال التوحدّيين في عدم مشاركتهم اللعب الجماعي التعاوني مـع الأطفال الآخرين، وفي الإخفاق في إقامة علاقات اجتماعية، وكذلك الإخفاق في فهم

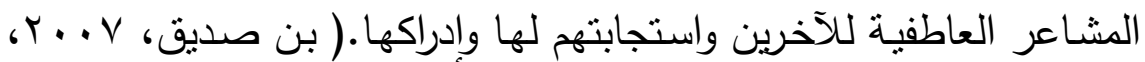

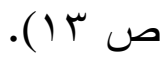
(ب) مهارة التعاون: (ب)

الطفل كائن اجتماعي يعتمد في نموه وبقائه على التفاعل مع الآخرين، وهـو يعيش منـذ الـولادة في وسط اجتمـاعي ويسـتحيل عليـه البقاء خـارج

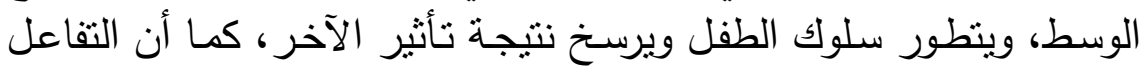

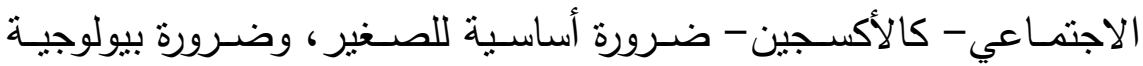

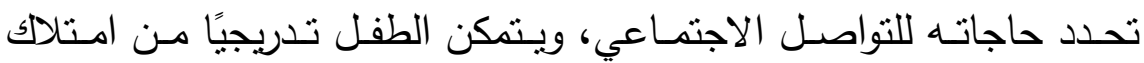
الوسائل الضرورية للحياة، ومن إدراك مفاهيم الخطأ والصواب، وتعلم طريقة ولهئ 
اللبـاس وطريقة الطعام والقواعد الصـحيحة، وكل مـا هـو مفيد في نكيف

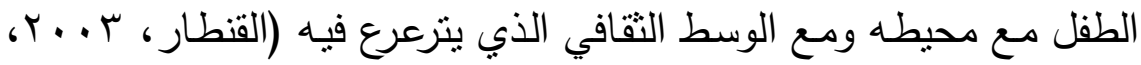
ص (1) ( )

وبعاني الطفل التوحدي من قصورٍ في التعاون الاجتماعي إذا ما قورن بغيره من الأطفال الأسوياء والأطفال المتأخرن عقليًا من غير المصن المصابين

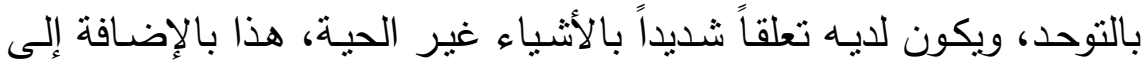

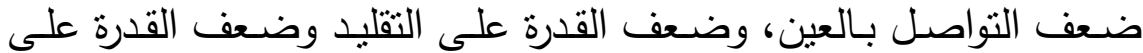

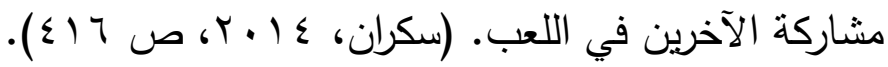
فمهارة التعاون الاجتمـاعي يصسب اكتسـابها بشكلٍ تلقائي وبسهولةٍ من

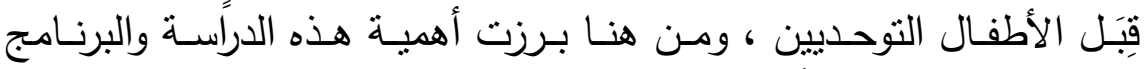

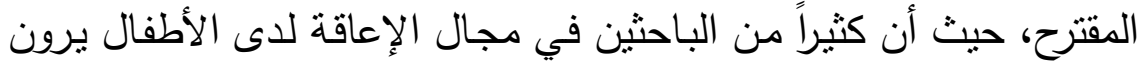
أن المشكلة الجوهربة التي يعانيها هؤلاء الأطفال التوحديون هي الإعاقة في الإني

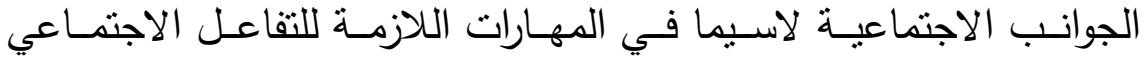

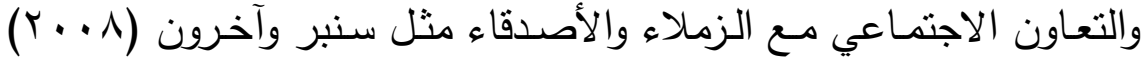

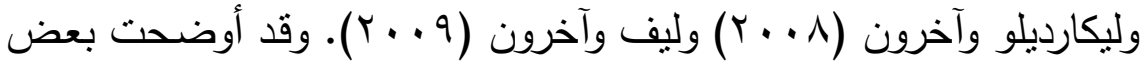
الدراسات أن القصور في مهارات التفاعل الاجتماعي لدى أطفال التوحد يعد ولدون

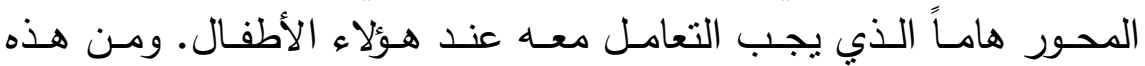

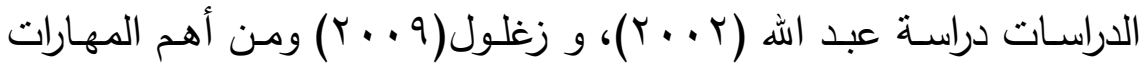
التي أكدت عليها الدراسات وأوصت دراستها عند التعامل مـع هؤلاء الأطفال

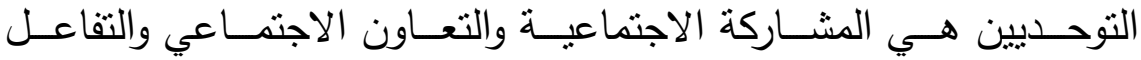

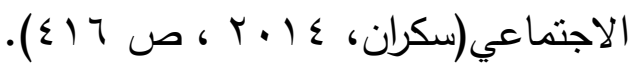
وللتعـاون الاجتمـاعي أنمـاط متعددة : منها التعـاون (التلقائي، التقليدي،

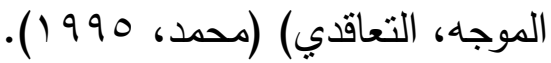




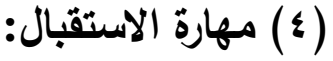

إن الأطفال الذين يعانون من ضعف في مهارات اللغة سوف يعانون من

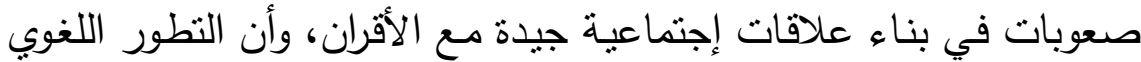

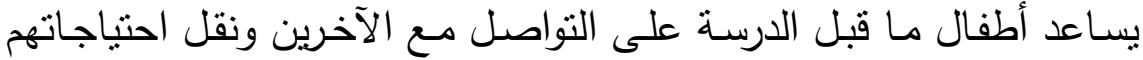
إليهم، وأن التطور السليم للغة الاستقبال يؤدي إلى عدم الإحباط والسبطرة

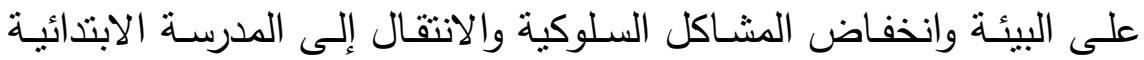

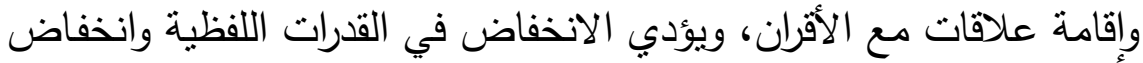

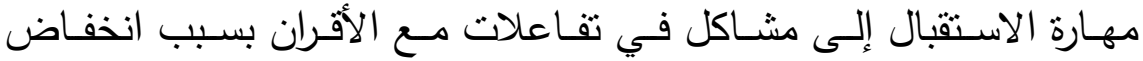

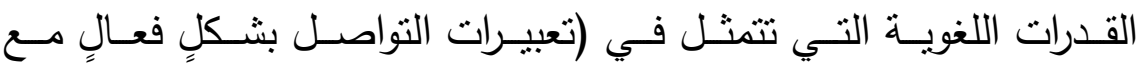
الأقران(Barbara, 2012, p72).

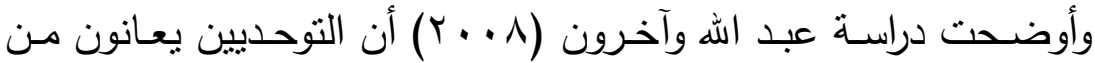

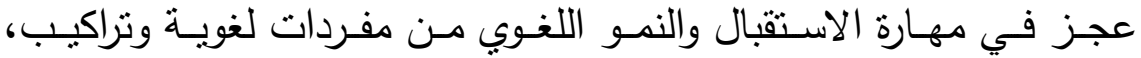

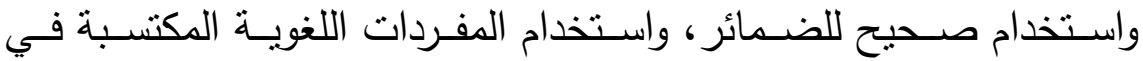
النواصل ذي المعنى.

وكذللك بحثت دراسة كوري (2012) Cory E,et al بعنوان " اللغة الاستقبالية والتعبيريـة كمتنبيء للسـلوكيات المتكررة والمقيدة عند الأطفال

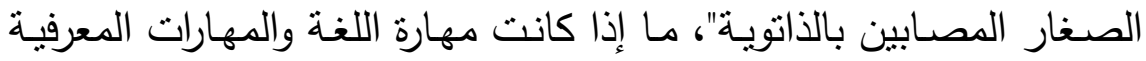

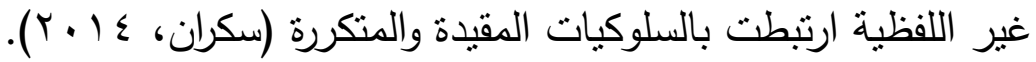

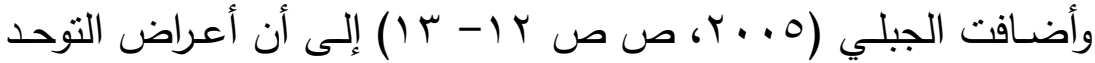

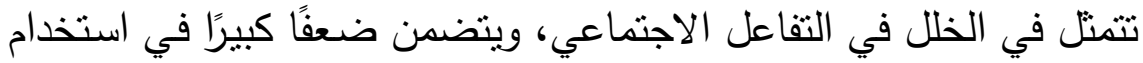
السلوك غير اللفظي ونقصًا في التواصل بالعينين والوجها وعدم التمايز أو الو

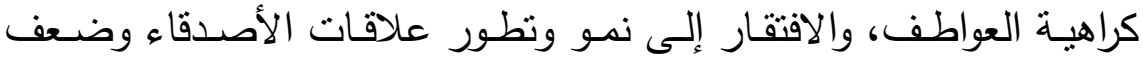
استجابته لهم واهتمامهم بهم . 
مما سبق يتضح لنا تصور برنامج تدريبي قائم على الإثراء الحسي لتحسين الإدراك ومهارات التفاعل الاجتماعي لدى لندئ أطفال التوحد.

الإجراءات المنهجية للاراسة :

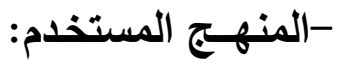

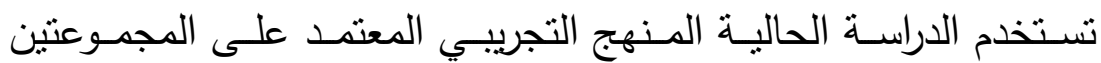

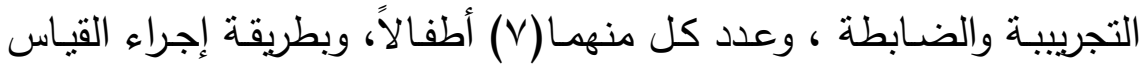

$$
\text { - مجتمع الدراسةة: }
$$

تكونت مجتمع الدراسة للعينة الأساسية من (ب0) طفلاً وطفلةً من ذوي

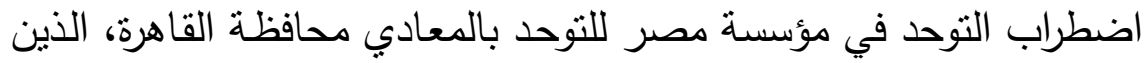

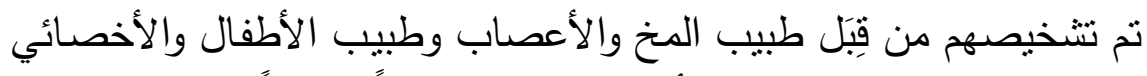

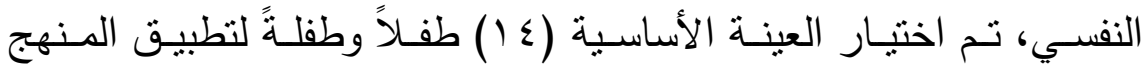

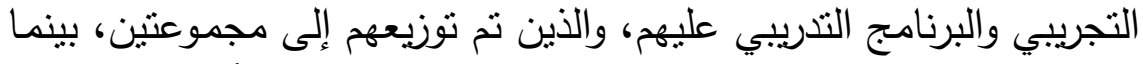

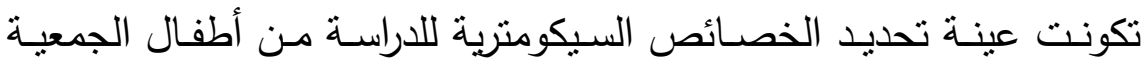

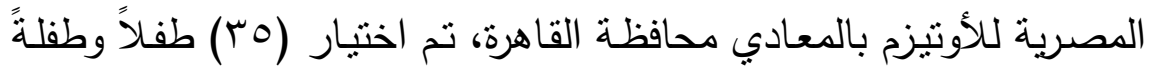
منهم كعينة استطلاعية للتحقق من أدوات الدراسة.

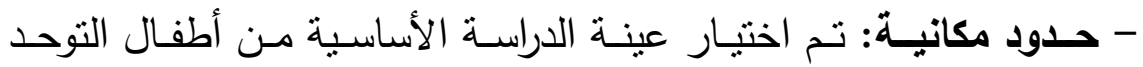
المسجلين في مؤسسة مصر للتوحد بالمعادي بمحافظة القاهرة.

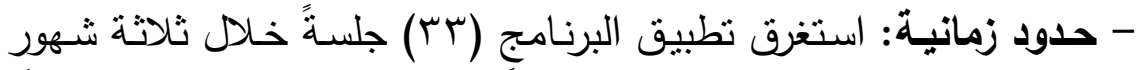

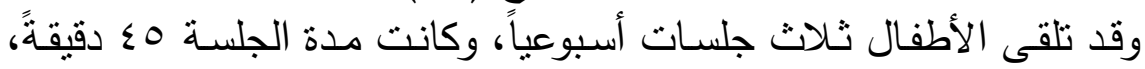

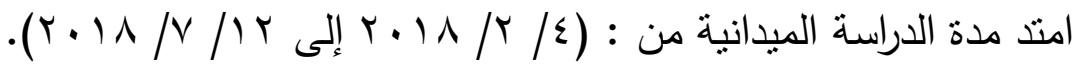


قامت الباحثة باختيار عينة من الأطفال الذين يعانون من التوحد، وقد

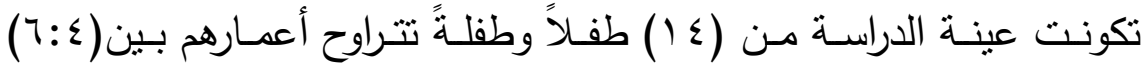

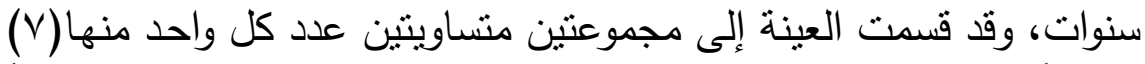

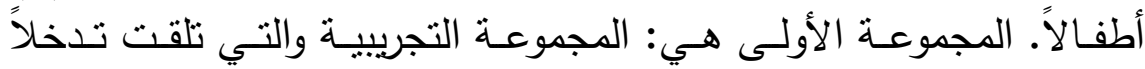

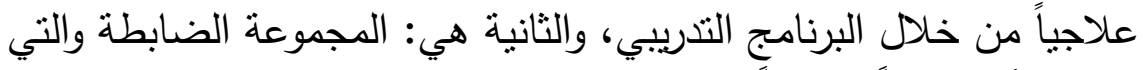
لم تتلق أي تدخلاً علاجياً.

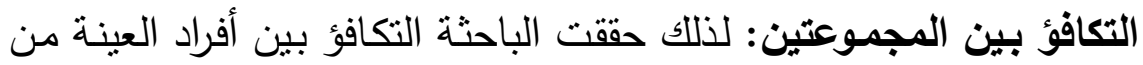

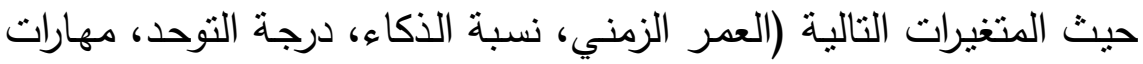
الإدراك الحسي، مهارات التفاعل الاجنماعي). (1) (1) مواصفات اختيار العينة:

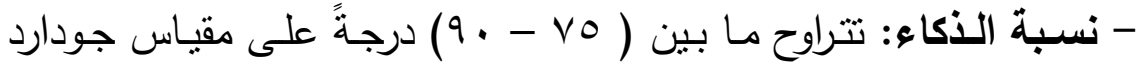
لللكاء (إعداد/ جودارد).

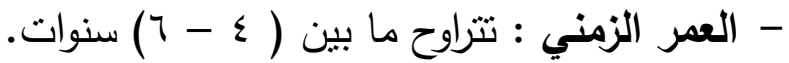

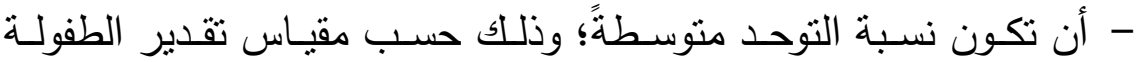
. (كارز) - أن يعـانون مسن قصسور في مهارات الإدراك الحسي ومهارات التفاعل الاجتماعي. - أن تكون أفراد العينة من المنتظمين في الحضور إلى المركز ولا يغيبون لفتراتٍ طويلةٍة. - الخلو من تعدد الإعاقات بمعنى ألا يصاحب الاضطراب أبي إعاقة.

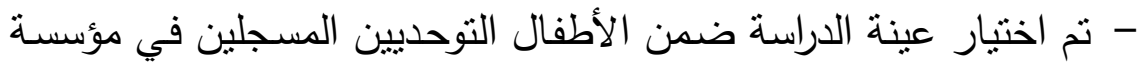
مصر للتوحد بالمعادي بمحافظة القاهرة. 
- وقد كان اختيار الباحثة لهذا المؤسسة لعدة أسباب منها:

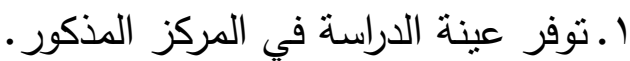

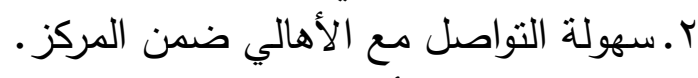

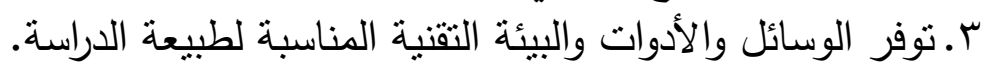

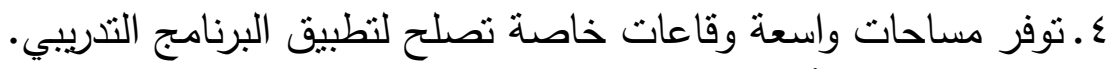

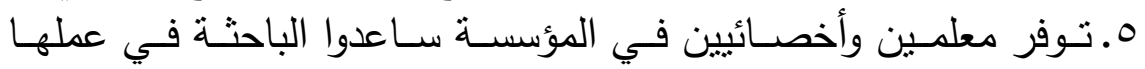
وتطبيقها للبرنامج. T. تقرير طبي معتمد بتشخيص حالة التهن الطفل.

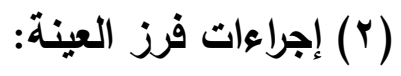

نم اختبار عينة الدراسة من مؤسسة مصر للتوحد وفق المعايير المعتمدة

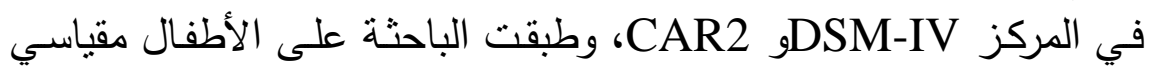

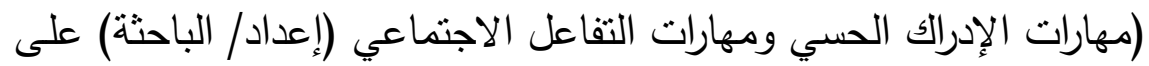

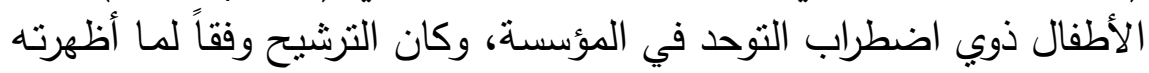

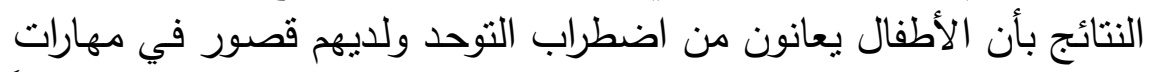

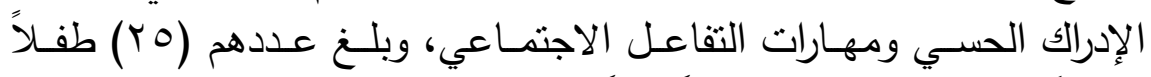

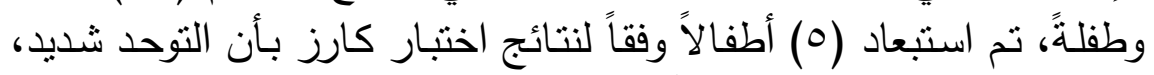

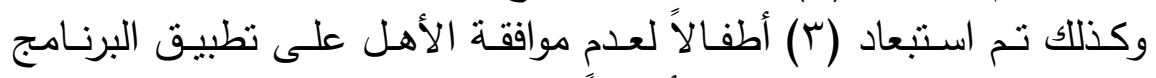

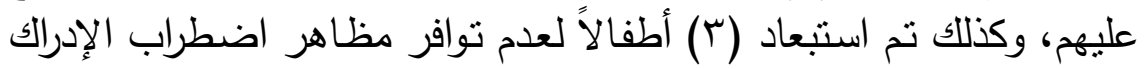

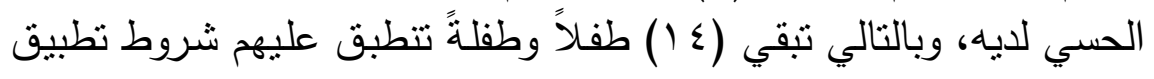
الدراسة.

\section{(r) عينة الخصائص السيكومترية:}

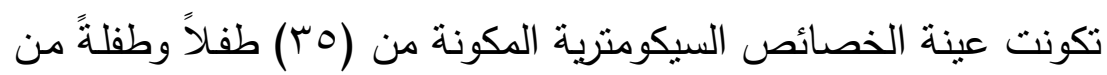
الأطفال التوحديين الملتحقين بثلاثة مراكز هم: (مركز كيان للتوحد بالحدائق التهن 
القبة والجمعيـة المصرية للأوتيزم بالمعادي ومركز سيتي بكارتياس مصر

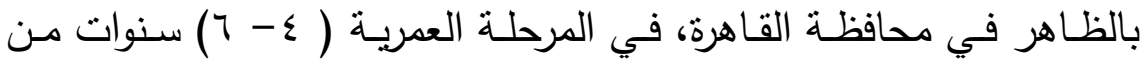

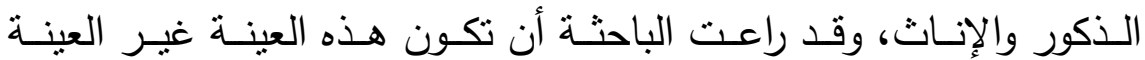

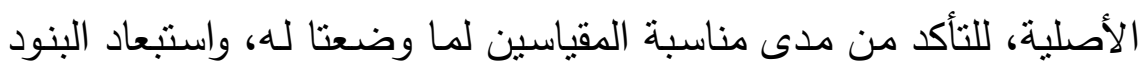

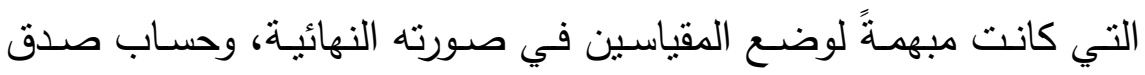
وثبات المقياسين، وبعد تطبيق المقياسين للمجموعة الاستطلاعية. ( ) عينة الدراسة الأساسية:

تتكون عينة الدراسة في صورتها النهائية من(ع ( ) طفلآ وطفلةً من ذوي الونها

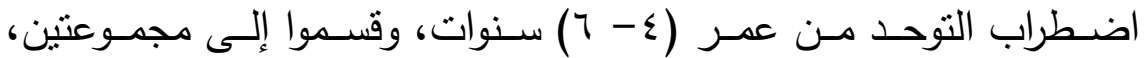

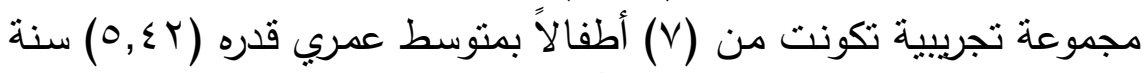

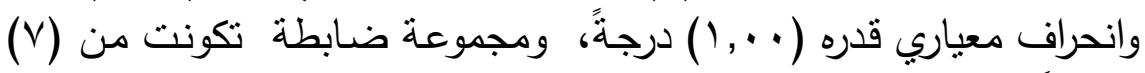

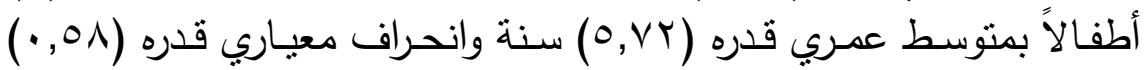

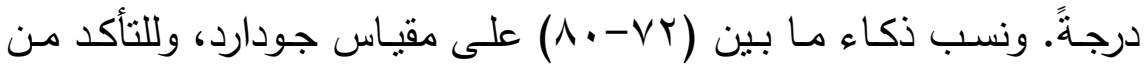

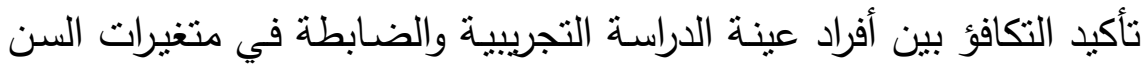

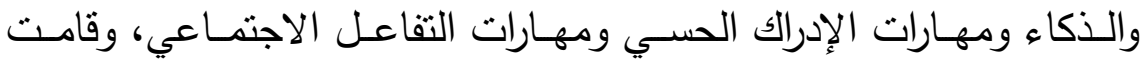

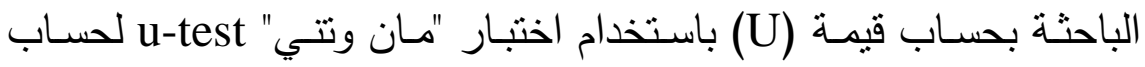
دلالة الفروق بين درجات افراد المجموعة التجريبية والضـابطة. والجدولين التاليين (1-1) يوضحان ذلالك. 
جدول (1) يوضح التكرارات والنسب المئوية حسب متغيرات الدراسة حسب المجموعتين

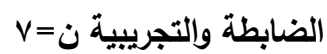

\begin{tabular}{|c|c|c|c|c|c|}
\hline \multicolumn{2}{|c|}{ المجموعة الضابطة ن V= } & \multicolumn{2}{|c|}{ المجموعة التجريبية ن= V= } & & .1 \\
\hline النسبة & التكرار & النسبة & التكرار & & 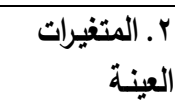 \\
\hline$\% \bullet V, Y$ & $\varepsilon$ & $\% \diamond V, Y$ & $\varepsilon$ & ذكور & r. جنس أطفال \\
\hline$\% \leqslant Y, \wedge$ & $r$ & $\%\{\curlyvee, \wedge$ & $r$ & إناث & العينة \\
\hline$\% 1 \ldots$, & $\mathrm{V}$ & $\% 1 \ldots$ & $\mathrm{V}$ & العيــــــة & ع. المجمــوع \\
\hline
\end{tabular}

تم توزبـع العينـة حسب الجدول ( 1 () بنـاءً على متغبرات الدراسـة حسبب المجموعتين الضابطة والتجريبية. جدول ( r r ) يوضح متوسطات درجات أفراد المجموعة التجريبية والضابطة في القياس القبلي

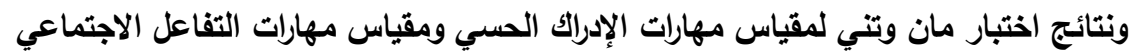

\begin{tabular}{|c|c|c|c|c|c|c|c|c|}
\hline \multirow[t]{2}{*}{ مستوى الالالة } & \multirow[t]{2}{*}{ قيمة Z } & \multirow[t]{2}{*}{ قيمة U } & \multicolumn{2}{|c|}{ الضابطة المجوعة } & \multicolumn{2}{|c|}{ 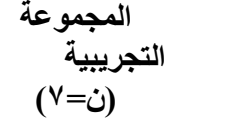 } & \multirow[t]{2}{*}{ المتغيرات } & \\
\hline & & & متوسط الرتب & الرتب & متوسط الرتب & مجرثوع & & \\
\hline غير & $\cdot, \wedge ґ \wedge$ & 1,0 & T,r. & r.,0. & $\varepsilon, \vee \cdot$ & rr,o. & السن & \\
\hline غال & $1, Y 71$ & 7,0 & $\varepsilon, \Gamma$. & r1,0. & $7, V$. & r,o & الأكاء & \\
\hline غال & $\cdot, \leqslant Y \leqslant$ & $1 \cdot, 0$ & $0,1$. & ro,o. & $0,9$. & $r 9,0$ & لرجة التوحد & \\
\hline غال & 1,701 & 7,9 & $0,7$. & Yr, & 0,70 & $r o, \Lambda$ & الإجة الكلية & 1 \\
\hline غال & $1,7 \leq 1$ & $V, r$ & $0, \varepsilon$. & Yr,, & $0,0 \mathrm{~V}$ & YY.7 & اللارجة الكلية & \\
\hline
\end{tabular}


يتضح من الجدول السابق (Y) عدم وجود فروق بين منوسطات درجات

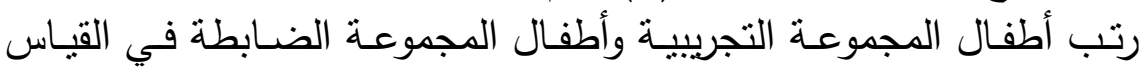

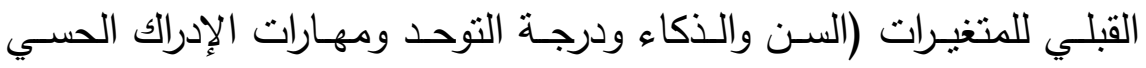

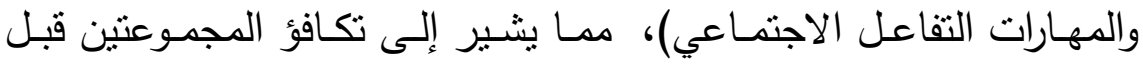
تطبيق البرنامج. رابعاً: أدوات الدراسة: البرنات

ا-مقياس مهارات الإدراك الحسي للد أطفال اضطراب التوحد ( إعداد/

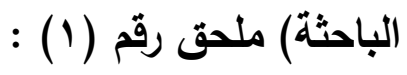
أ- الهرف العام من المقياس:

التعرف على مستوى اضطرابات في مهارات الإدراك الحسي للأطفال التوحديين، وذللك كما تعكسه درجاتهم على المقياس . ب- الأهداف الخاصة للمقياس:-

كثـف قصــور مهـارات الإدراك الحسـي بوجـهِ خـاصٍ أمـراً فـي غايسة

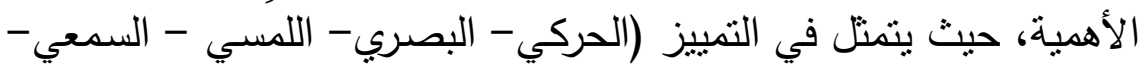

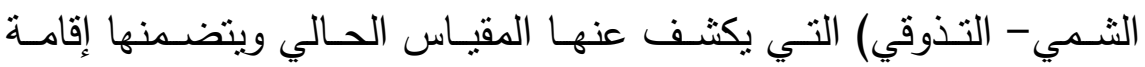
العلاقات والتفاعلات الاجنماعي. ج- مصادر المقياس: ا الإطلاع على التراث السيكولوجي والكتابات النظرية التي تناولت مهارات الإدراك الحسي عند الأطفال ذوبي اضطراب التوحد بصفةٍ خاصةٍة. r- الإطلاع على المقاييس التي صيغت لملاحظة وقياس مهارات الإدراك

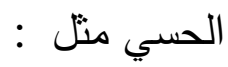




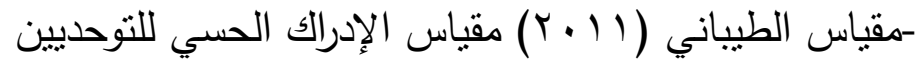
The Miller Assessment for Preschoolers (Miller,1988) include test for ( stereognosis, tactile perception and vestibular function). SIPT ( Ayres,1989) publisher Westren Psychological Service. Autism Diagnostic Observation Schedule.(ADOS) bLord.Rutter, Goo-do, Heemsbergen, Jardan, Mawhood and Schopler, 1989.

\section{د - وصف المقياس :}

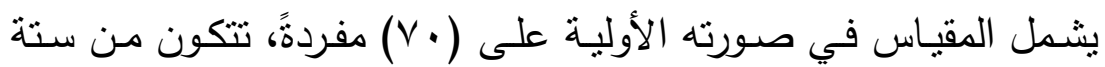

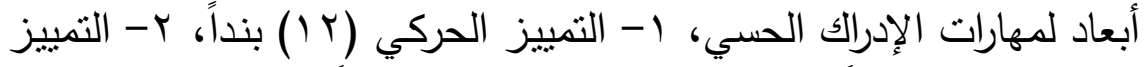

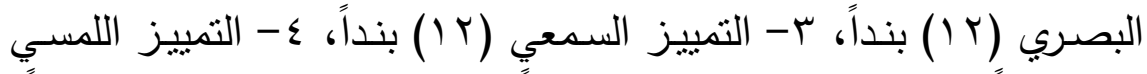

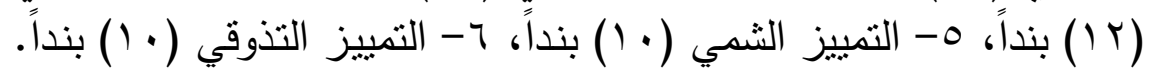

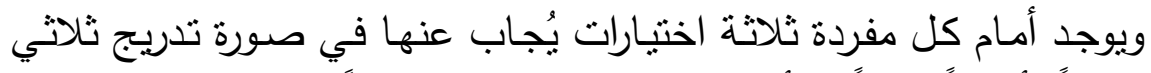

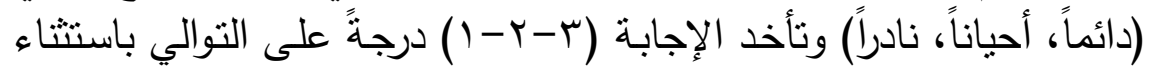

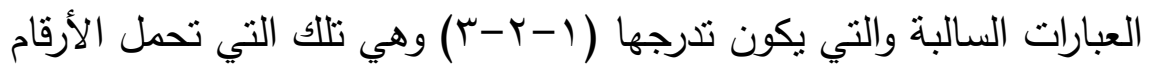

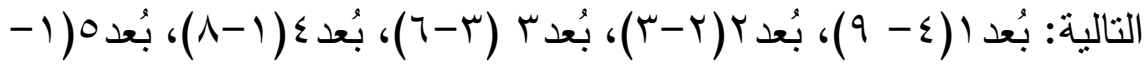

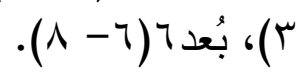

ويتكون المقياس من عبارات موجبة وعبارات سالبة، ويقوم الأخصائيون

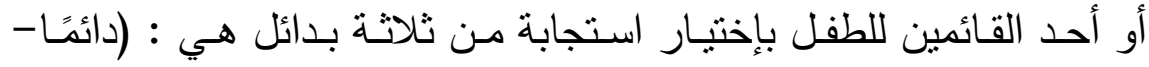

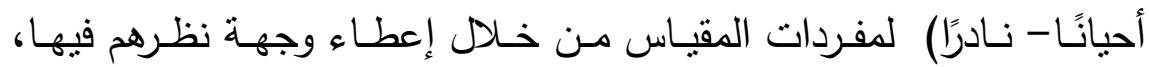
ووضع علامة (ل) أمام الإستجابات واحدة فقط من بين الخانات. 


\section{المجلة العلمية لكلية رياض الأطفال - جامعة بورسعيد}

\section{هـ - طريقة تصحيح المقياس:}

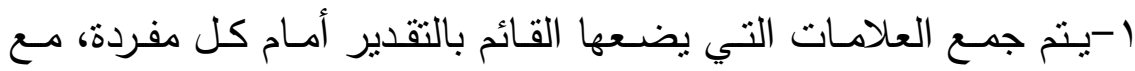

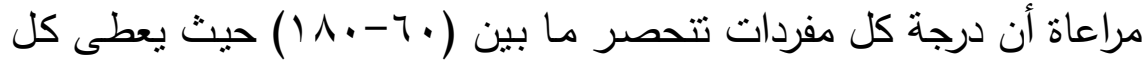

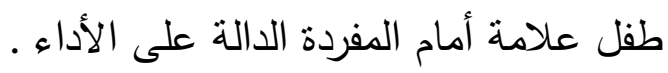

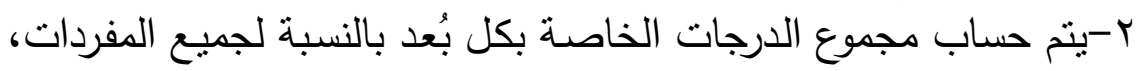

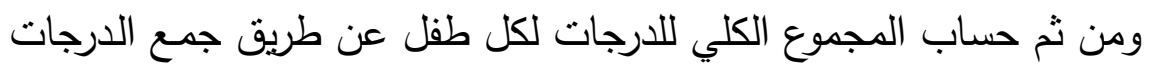
الخاصة بكل بُعد.

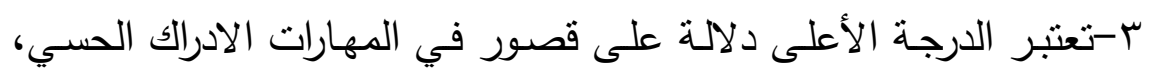

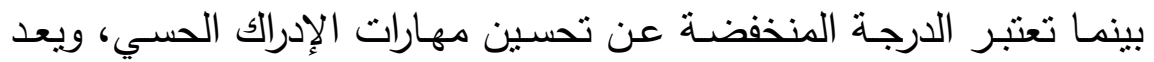
الطفل بحاجة إلى برامج علاجية إذا ارتفعت درجته عن نصف الإدف الدرجة الكلية

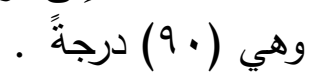

الخصائص السيكومترية للمقياس:

\section{أولاً : صدق المقياس:}

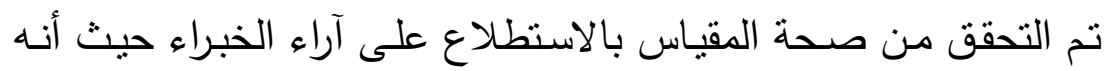

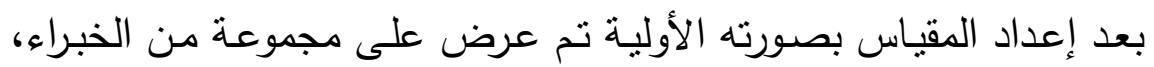

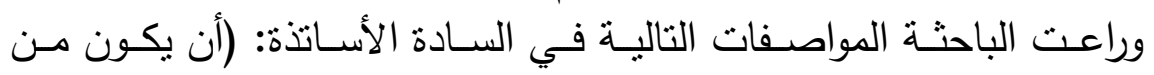

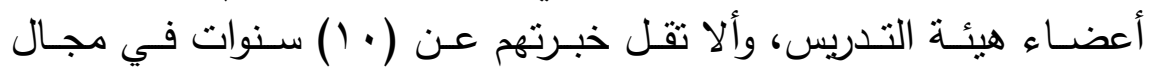

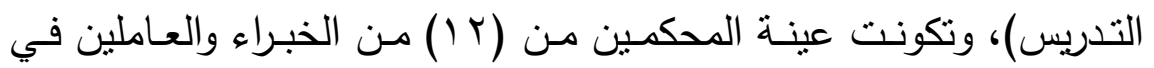

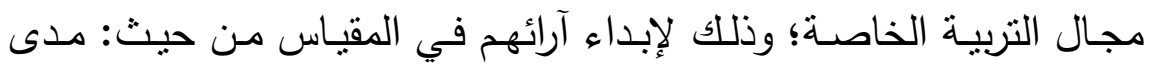

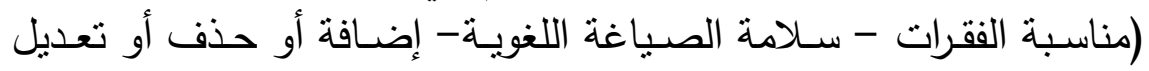

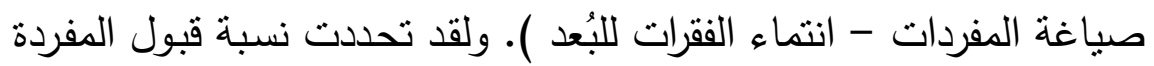

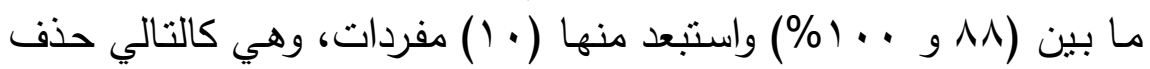

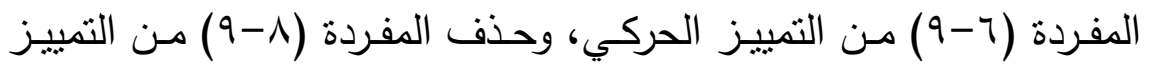


البصـري، وحذف المفـردة (0- • ( ) مـن التمييز السـعي، وحذف المفردة

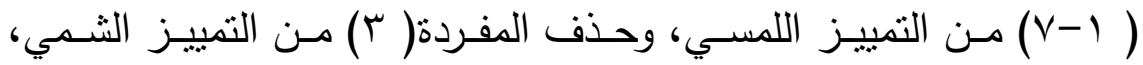
وحذف المفردة( r) من التمبيز التذوقي. ولذلك لسببين الأول: لم تحظ هذه المفردات على نسبة القبول المحددة، والثاني: لبعض التحفظات الأخلاقيـة التي أبداها المحكمون وأيضاً تعديل (7) مفردات من بنود المقياس كما هو موضح في ملحق( () • وبالتالي استقر على تضمين المقياس ( • 7) مفردةًا وتتراوح درجات المقياس ككل من ( • ؟- . 1 1) لكل بُعد درجة خاصسة بـه تتراوح من ( ( - • ب) بعد تعديل المقياس بناءً على ماحظظات المحكمين، وبـذلك تتـوافر دلالـة الصـدق الظـاهري للمقيـاس مـن خـلال نسـب الاتفـاق المرتفعة بين المحكمين في تقدير مدى مناسبة الأبعاد وعباراته التي تقيسها، وتم استخدام معادلة لوشي لحساب صدق المحكمين حيث ثّم الإبقاء على مئى الأبعاد كلها والتي اتفق عليها مـا يزيد عن ( •9\%) مـن المحكمين، وتم

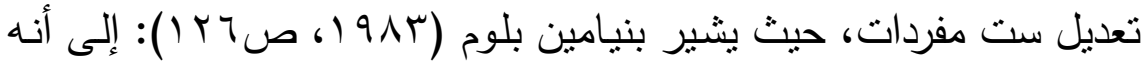

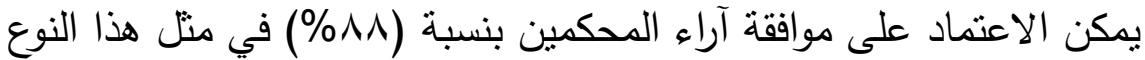

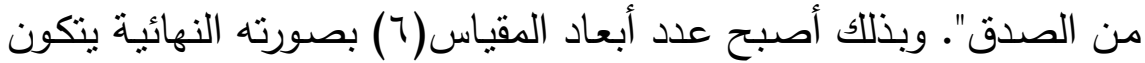
كل بُعد من ( (1) مفردةً. تم توضيح النسب المئوية لاتفاق المحكمين وقيمة لوشي على مفردات مقياس الإدراك الحسي في ملحق (1). r - بدق المحك :

قامت الباحثة بحسـاب معامل الارتباط بين الدرجـة الكليـة على مقيـاس مهارات الإدراك الحسي لدى الأطفال التوحديين ومقياس الطيباني (1)

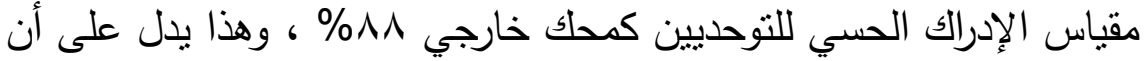

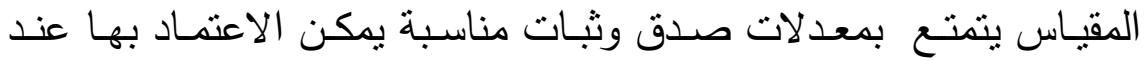

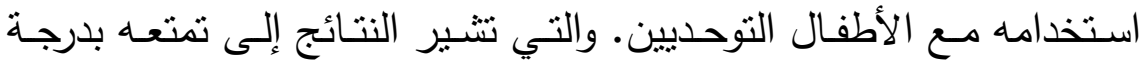


عالية من الصدق والثبات، وعليه تم حساب صدق المحك لدرجات مقباس

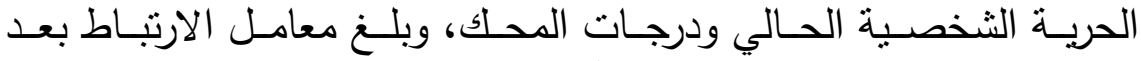

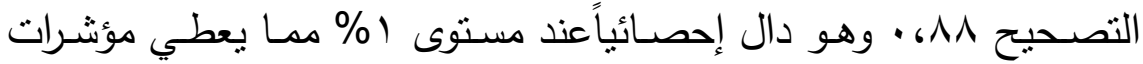
قوية لصدق المحك بما يؤكد تمتع المقياس بمستوى مناسب من الصدق. ثانياً: ثبات المقياس: ا -الثبات باستخدام معامل ألفا لكرونباخ: تسـتخدم معادلـة ألفـا لكرونبـاخ وهـي طربقة معدلـة مـن معادلـة كودر

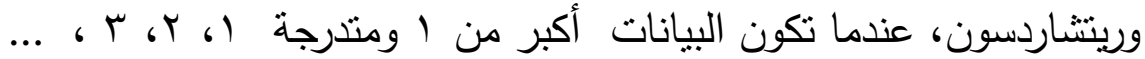
ولقياس ثبات عبارات المقياس قامت الباحثة بحساب معامل ألفا لكرونباخ للعينة الاستطلاعية للاراسة وبلغ عددها (مب)، وقد تم استبعادها من العينة

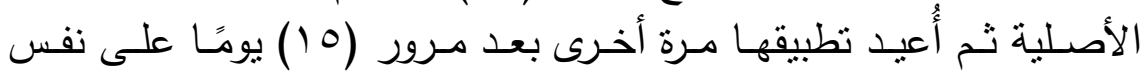

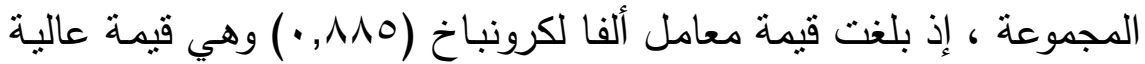
جدًا تبين ثبات عبـارات الأداة وصسلاحيتها لتحليل وتقسير نتائج الدراسـة، ومن هنا فالمقياس يتمتع بدرجة عالية من الثبات يمكن الاعتماد عليه في

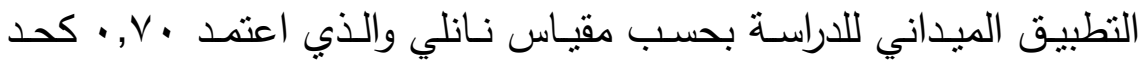

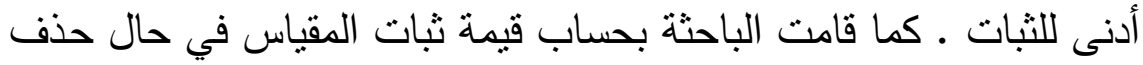
كل مفردة، ويوضح جدول (ع) معامل ثبات كل مفردة من مفردات المقياس

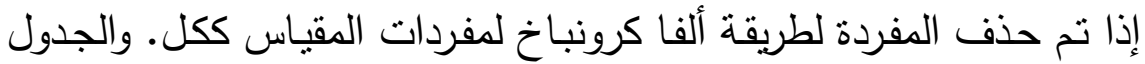

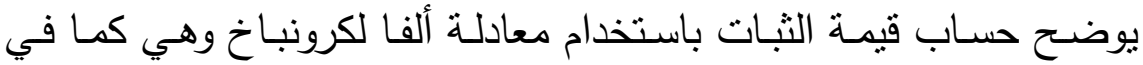
الجدول أدناه وهو: دال عند مستوى دالة عند ا ب. .. . 


\section{المجلة العلمية لكلية رياض الأطفال - جامعة بورسعيد}

جدول (؛ ) معاملات ثبات مقياس الإدراك الحسي للأطفال اضطراب التوحد

\begin{tabular}{|c|c|c|c|c|c|c|c|c|c|c|c|}
\hline \multicolumn{2}{|c|}{ تذوقي } & \multicolumn{2}{|c|}{ شـــي } & \multicolumn{2}{|c|}{ لمسي } & \multicolumn{2}{|c|}{ سمعي } & \multicolumn{2}{|c|}{ بصسري } & \multicolumn{2}{|c|}{ حركي } \\
\hline الثبات & ر/م & الثبات & رلم & الثبات & ر/م & الثبات & ر/م & الثبات & ر/م & الثبات & ر/م \\
\hline •, & 1 &., 794 & 1 & $\cdot, V \vee r$ & 1 & 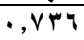 & 1 & $\cdot, \vee \vee \vee \neg$ & 1 &., 799 & 1 \\
\hline$\cdot, \vee \wedge q$ & $r$ & $\cdot, \mathrm{V}, \mathrm{O}$ & $r$ & $\cdot, V \ldots$ & r & $\cdot, \vee \curlyvee \wedge$ & $r$ & $\cdot, \vee \vee \vee \neg$ & $r$ & 4, & $r$ \\
\hline$\cdot, \vee \wedge \varepsilon$ & $r$ & $\cdot,\rceil \wedge \wedge$ & $r$ & ש & $r$ & $\cdot, \vee \vee \vee q$ & $r$ & $\cdot, \vee \vee \vee q$ & $r$ & $\cdot, I V V$ & $r$ \\
\hline$\cdot, \vee \wedge \varepsilon$ & $\varepsilon$ & $\cdot, V \cdot r$ & $\varepsilon$ &., 79. & $\varepsilon$ & $\cdot, v \leq q$ & $\varepsilon$ & $\cdot, \vee \vee ৭$ & $\varepsilon$ &., $74 V$ & $\varepsilon$ \\
\hline$\cdot, V T V$ & 0 & $\cdot, v, r$ & 0 & $\cdot, \vee \ldots$ & 0 & $\cdot, V \leq 0$ & 0 & $\cdot, V \vee V$ & 0 &., 770 & 0 \\
\hline$\cdot, V_{1} \cdot$ & 7 & $\cdot, T \wedge Y$ & 7 &., 799 & 7 & $\cdot, V M I$ & 7 & $\cdot, \vee \wedge 0$ & 7 & $\cdot, 7 \wedge 1$ & 9 \\
\hline$\cdot, V T_{1}$ & V & $\cdot, v \cdot v$ & $\mathrm{~V}$ &., 799 & $\mathrm{v}$ & $\cdot, V \leq \leq$ & V & $\cdot, \vee \vee \vee$ & $V$ & $\cdot, \uparrow \wedge$. & V \\
\hline$\cdot, \vee \wedge \varepsilon$ & $\Lambda$ & $\cdot, \vee \cdot \varepsilon$ & $\Lambda$ & $\cdot, V Y r$ & $\Lambda$ & $\cdot, \vee \vee 1$ & $\Lambda$ & $\cdot, \nabla \wedge r$ & $\Lambda$ & $\cdot, T \vee Y$ & $\wedge$ \\
\hline$\cdot, \vee \vee 94$ & 9 & $\cdot, V \cdot V$ & 9 & $\cdot, V Y$. & 9 & $\cdot, \vee \sim \wedge$ & 9 & $\cdot, \vee \vee \vee 1$ & 9 &.,$T \vee r$ & 9 \\
\hline$\cdot, \mathrm{V} \bullet 0$ & 1. & $\cdot, \vee \wedge \wedge$ & 1. &., 797 & 1. & $\cdot, V R V$ & 1. & $\cdot, \vee \vee \vee \varepsilon$ & 1. & ד & 1. \\
\hline
\end{tabular}

جدول (•) معاملات ثبات بين درجة كل بُعد والدرجة الكلية لمقياس مهارات الإدراك الحسي

\begin{tabular}{|c|c|}
\hline معامل الثبات & مهارات الإدراك الحسي \\
\hline$\cdot, v \leq 0$ & الحركية \\
\hline$\cdot, \vee \wedge \vee$ & البصرية \\
\hline$\cdot, v \circ r$ & السمعية \\
\hline •, & المسية \\
\hline •, vrr & الشمية \\
\hline$\cdot, V \leq r$ & التذوقية \\
\hline
\end{tabular}

ثالثثاً: الاتشاق الداخلي لأبعاد المقياس : أجري التحقق من ثبات الاتساق الداخلي بحساب معامل ارتباط بيرسون بين درجات كل فقرة من فقرات المقياس والدرجة الكلية للمقياس الذي تتتمي 
إلبـه الفقرة، والجدول يوضـح معـاملات الارتبـاط بـين كل فقرةٍ مـن فقرات المقياس والدرجة الكلية للمقياس. وفيما يلي قيم معامالات الارتباط ومستوى

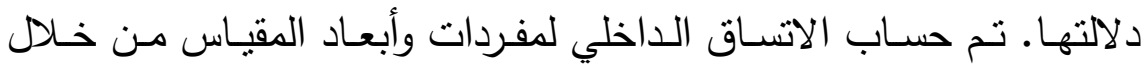
حساب قيم معامالات الارتباط بين درجات أفراد العينة على مفردات المقياس الاست ومجموع درجاتهم على البُعد الذي تنتـي إلبـه، ويوضـح جدول (7) نتائج الاتساق الداخلي على النحو التالي: جدول (†) معاملات الارتباط بين درجة كل مفردة ومجموع درجات البُطد الذي ينتمي إليه لمقياس الإدراك

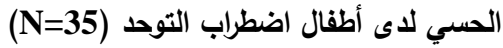

\begin{tabular}{|c|c|c|c|c|c|c|c|c|c|c|c|}
\hline \multicolumn{2}{|c|}{ تذوقي } & \multicolumn{2}{|c|}{ شـــي } & \multicolumn{2}{|c|}{ لمسي } & \multicolumn{2}{|c|}{ سمعي } & \multicolumn{2}{|c|}{ بصسري } & \multicolumn{2}{|c|}{ حركي } \\
\hline الثبات & ر/م & الثبات & ر/م & الثبات & ر/م & الثبات & ر/م & الثبات & ر/م & الثبات & ر/م \\
\hline$\cdot, V \backslash r$ & 1 & • & 1 & $\cdot, V \otimes r$ & 1 &., 719 & 1 & $\cdot, V \leq Y$ & 1 & $\cdot, V \cdot r$ & 1 \\
\hline$\cdot, 70 \leq$ & $r$ &., 007 & $r$ & $\cdot, 7$, & $r$ &., $07 V$ & $r$ & $\cdot, V \otimes r$ & $r$ & $\cdot, Y \cdot Y$ & $r$ \\
\hline., 019 & $r$ & $\cdot, 0 \cdot V$ & $r$ & $\cdot, 7 \cdot 1$ & $r$ & $\cdot, \neg \wedge \vee$ & $r$ & •, THV & $r$ &., 71. & $r$ \\
\hline .,OH & $\varepsilon$ & •,OH & $\varepsilon$ & $\cdot, \vee \vee ৭$ & $\varepsilon$ & $\cdot, \diamond \vee \wedge$ & $\varepsilon$ & $\cdot, 7.1$ & $\varepsilon$ & $\cdot, \vee \vee \neg$ & $\varepsilon$ \\
\hline$\cdot, \vee Y P$ & 0 &., $7 r q$ & 0 & $\cdot, \vee \cdots$ & 0 & $\cdot, \leqslant \wedge \leqslant$ & 0 & $\cdot, V Y Y$ & 0 &., 791 & 0 \\
\hline$\cdot, \vee \cdot Y$ & 7 & $\cdot, 7 \cdot \varepsilon$ & 7 & • & 7 & •,OHY & 7 & $\cdot, \mathrm{T} \odot \mathrm{V}$ & 7 &., $79 \leq$ & 7 \\
\hline$\cdot, V R r$ & V &., 700 & V & $\cdot, V \leq r$ & $\mathrm{~V}$ & $\cdot, Y \cdot V$ & $\mathrm{~V}$ & , T०Y & $\mathrm{V}$ & $\cdot, V \cdot V$ & V \\
\hline$\cdot, 0 \times q$ & $\Lambda$ & $\cdot, 7 / 1$ & $\Lambda$ & סצו, & $\Lambda$ & $\cdot, \vee \cdots$ & $\Lambda$ & $\cdot, \leqslant \vee q$ & $\Lambda$ & $\cdot, 7 \cdot \varepsilon$ & $\Lambda$ \\
\hline$\cdot, 0 \leqslant r$ & 9 & \& & 9 & $\cdot, \vee \wedge)$ & 9 & $\cdot, \diamond \wedge \vee$ & 9 &., 011 & 9 & $\cdot, \leqslant \leq$. & 9 \\
\hline • ד & 1. & $0,0 \leq 7$ & 1. &., $7 \circ V$ & 1. & $\cdot, 0 \diamond \wedge$ & 1. & $\cdot, 0 \leq V$ & 1. & $\cdot, V R r$ & 1. \\
\hline
\end{tabular}

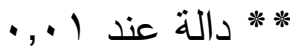

جدول(7) نجد أن هنـاك علاقات ارتباطيـة موجبـة ذات دلالـة إحصسائية بين درجات أفراد العينة على مفردات كل بُعد من الأبعاد الستة، والدرجة هونة

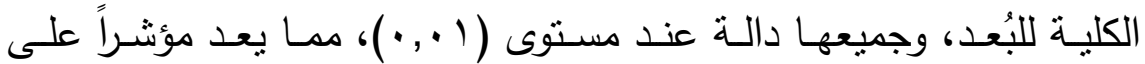
الاتساق الداخلي لكل بُعد. كما تم حساب قيم معاملات الارتباط بين مجموع 


\section{المجلة العلمية لكلية رياض الأطفال - جامعة بورسعيد}

درجـات كل بُعـد مـن الأبعـاد السـنة، ويوضـح جدول(V) نتائج معـاملات الارتباط. جدول (V) معاملات الارتباط بين درجة كل بُعد والدرجة الكلية لمقياس الإدراك الحسي

\begin{tabular}{|c|c|}
\hline معامل الارتباط & مهار ات الإدراثك \\
\hline$* *, \wedge \varepsilon q$ & الحر| \\
\hline$* *, V Y \Lambda$ & البص \\
\hline$* *, \wedge 91$ & الس - - الس \\
\hline$* *, 9 \leq$. & $\ddot{a}$ \\
\hline$* *, V Y Y$ & الث \\
\hline$* *, \wedge \varepsilon 1$ & التذوقية \\
\hline
\end{tabular}

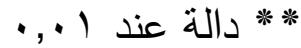

ومـن الجدول (V) نجد أن هنـاك علاقـات ارتباطيـة موجبـة ذات دلالـة

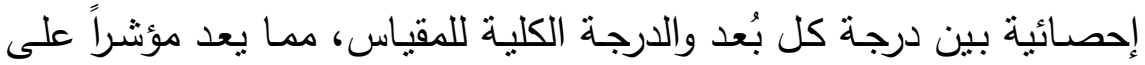
تشبع المقياس بالسمة المراد قياسها وهي(مهارات الإدراك الحسي). r - مقيـاس مهـارات التفاعـل الاجتمـاعي لـدي أطفـال اضـطراب التوحــ

$$
\text { أ إعداد/ الباحثة) ملحق(ب) : البدف العام من المقياس: }
$$

التعرف على مستوى العلاقات والتفاعلات الاجتماعية للأطفال التوحديين وذللك كما تعكسه درجاتهم على المقياس. ب-الأهداف الخاصة للمقياس:-

كثف قصور مهارات التفاعل الاجتماعي بوجه خاص في (التواصلـ الاستقبال - التقليد- التعاون) الاجتماعي التي يكثف عنها المقياس الحالي. 


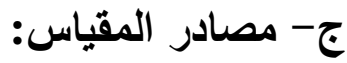

تم إعداد المقياس واثتقاق أبعاده والتحقق من صدقه وثباته، وذلك من

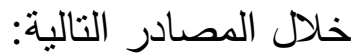

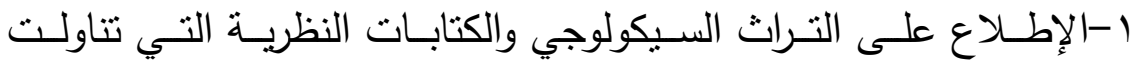

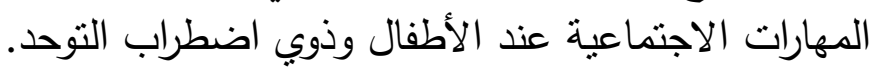

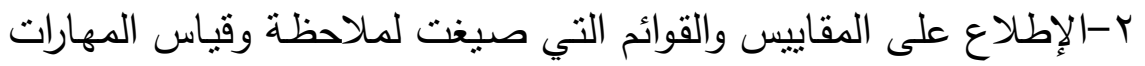

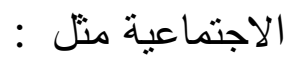

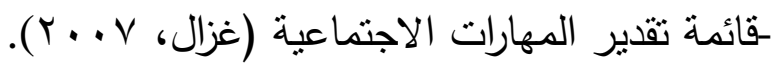
- The childhood Autism Rating مقياس تقدير التوحد الطفولي فهارعة الاجني Scale (CARS)

جداول الملاحظـات التشخيصية للتوحد Diagnostic Observation Schedule.(ADOS) by Lord. Rutter, Goo-do, Heemsbergen, Jardan, Mawhood and Schopler,1989. Autism Descriptors Checklist (ADC) by قائمة أوصاف التوحد

Fridman, Wolf and Cohen,1983. - مقياس جيليام للتوحد 2013 . (GARS) د - وصف المقياس :

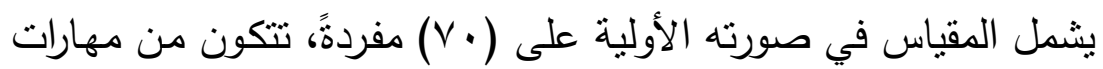

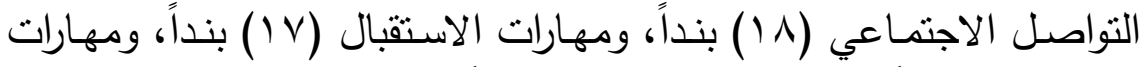

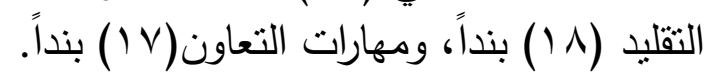

ويوجد أمام كل مفردة ثلاثة اختيارات يُجاب عنها في صورة تدريج ثلاثي

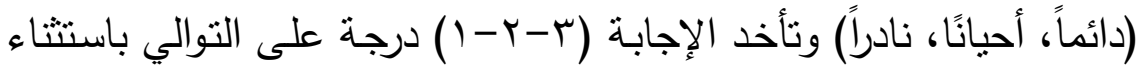




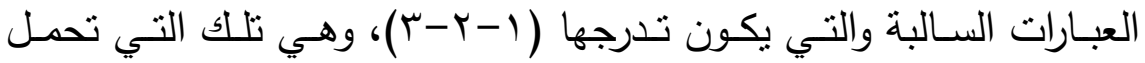

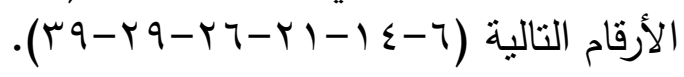

وبعد عرض المقياس على مجموعة من الخبراء وتكونت عينة المحكمين

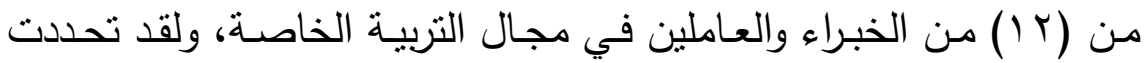

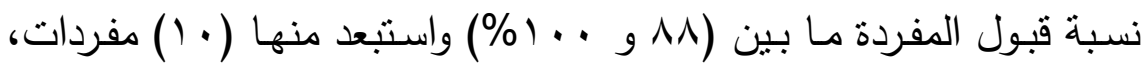

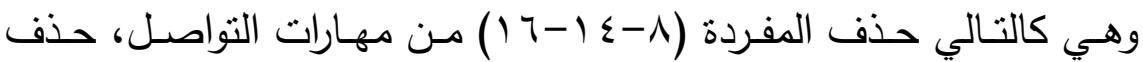

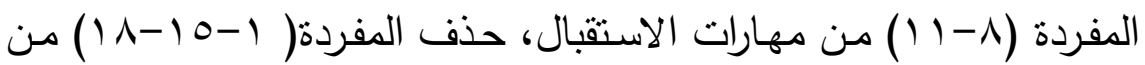

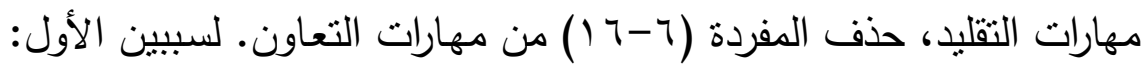
لم تحظ هذه المفردات على نسبة القبول المحددة، والثاني: لبعض التحفظات

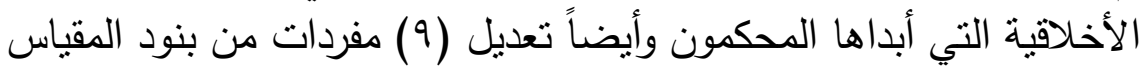

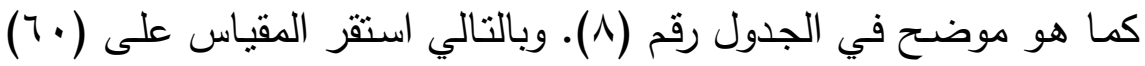

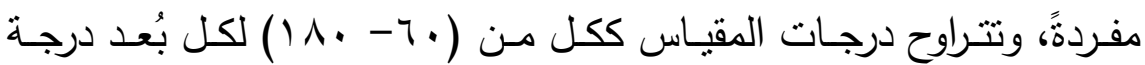

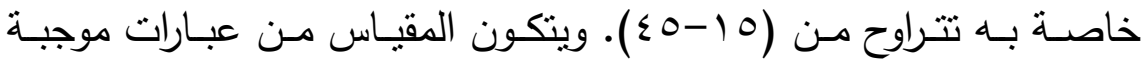

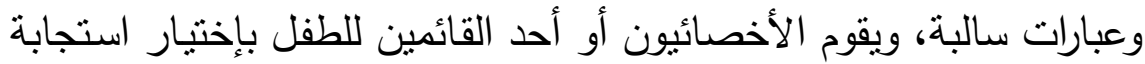

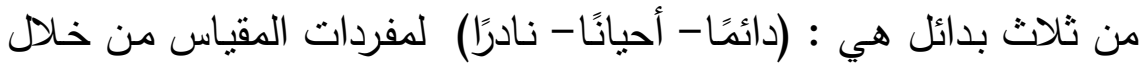

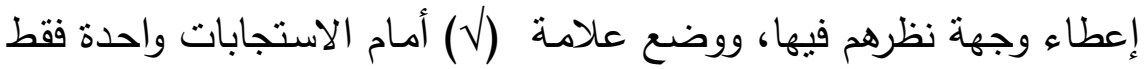

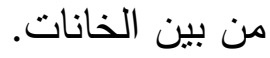
هـ - طريقة تصحيح المقياس:

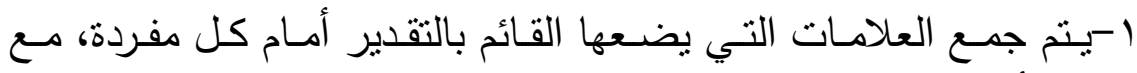

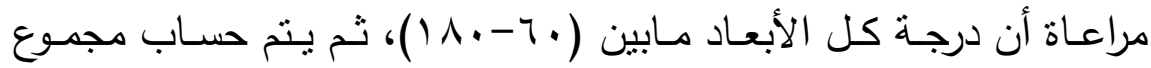

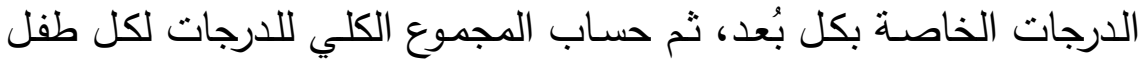

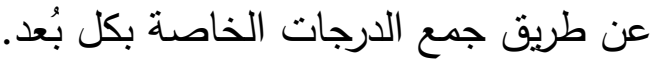




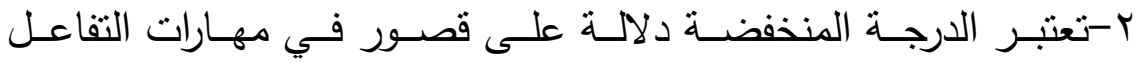

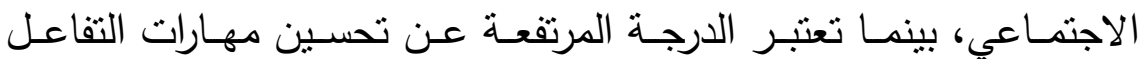

الاجتماعي.

الخصائص السيكومترية للمقياس:

أولاً : صدق المقياس:

تم التحقق من صحة المقياس بالاستطلاع على آراء الخبراء، تم عرض المقياس على مجموعـة من السـادة المحكمين، وراعت الباحثة المواصفات التاليـة في السـادة الأسـاتذة: أن يكون مسن أعضـاء هيئة التدريس وألا تقل

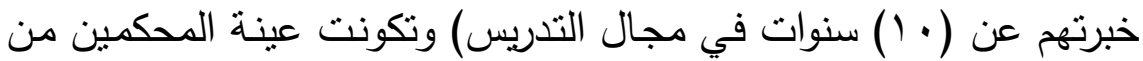

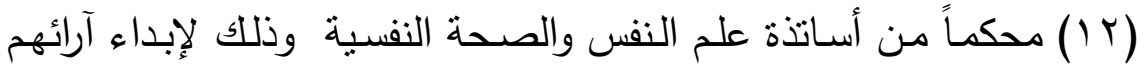
في: (مدى مناسبة الفقرات، مدى سلامة الصياغة اللغوبة لفقرات المقياس ، إضـافة او حذف أو تعديل فقرات يرونها مناسبة، مدى انتماء كل فقرة من من مناءه الفقرات للبُعد). - وتم تعديل المقياس بناءً على ملاحظات المحكمين، وتم توضبح ذلك في

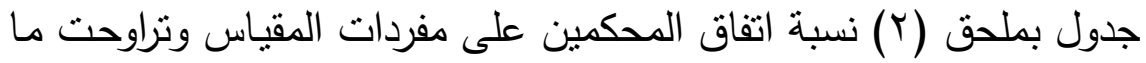

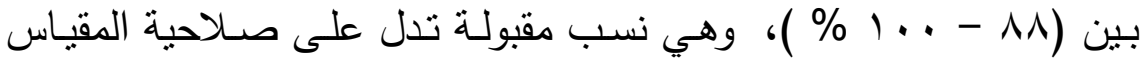
بعد أن تم تعديل بعض العبـارات، وبذللك تتـوافر دلالـة الصـدق الظـاهري للمقياس، والجدول التالي يوضـح مدى اتفاق واختلاف السادة أعضاء هيئة

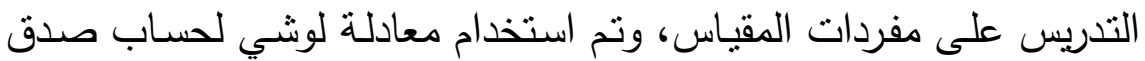
المحكمين حيث ثّم الإبقاء على الأبعاد كلها وهي (ع) والتي اتفق عليها ما

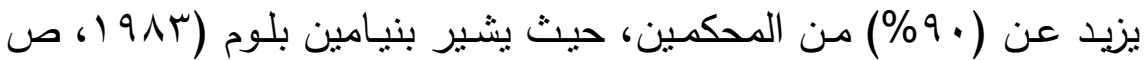

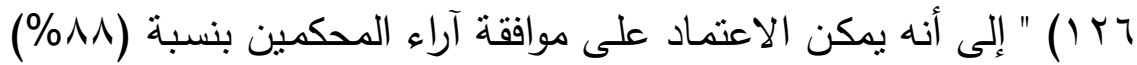


في مثل هذا النوع من الصدق". ولتوضيح أبعاد المقياس والعبارات الدالة

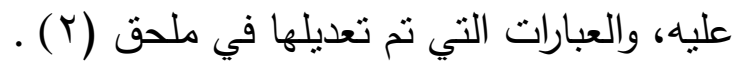

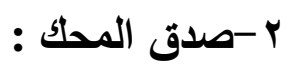

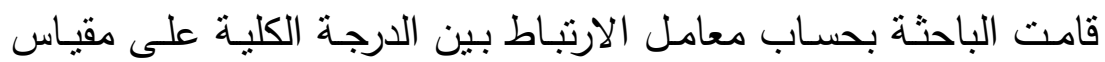

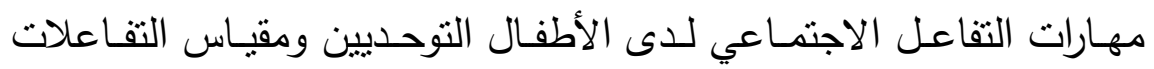

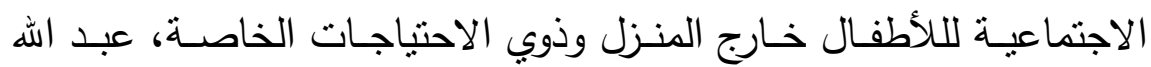

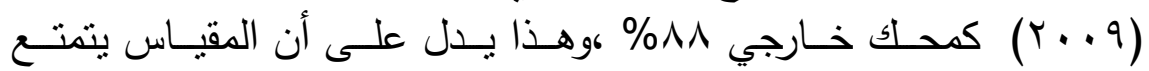

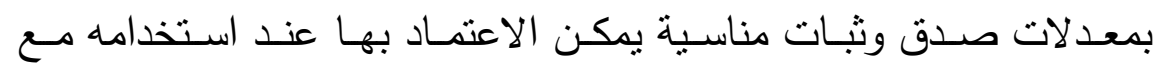
الأطفال التوحديين.

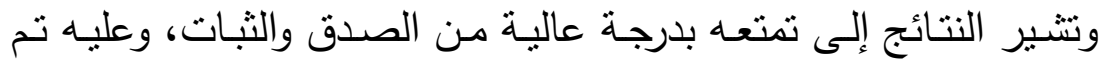

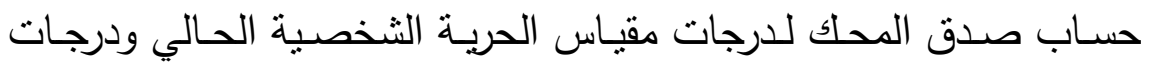

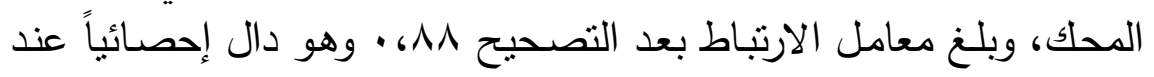

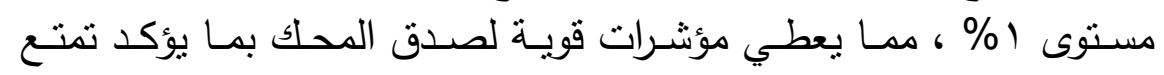
المقياس بمستوى مناسب من الصدق.

\section{ثانياً: ثبات المقياس :}

1-الثبات باستخدام معامل ألفا لكرونباخ:

تسـتخدم معادلـة ألفـا لكرونبـاخ وهـي طريقـة معدلـة مـن معادلـة كودر

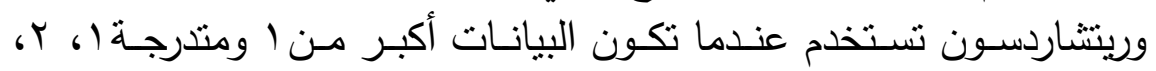

ولقياس ثبات عبارات المقياس قامت الباحثة بحساب معامل ألفا لكرونباخ

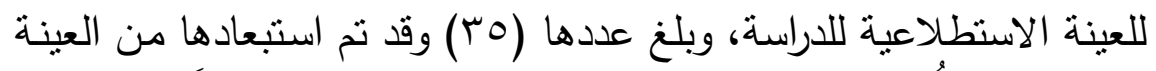

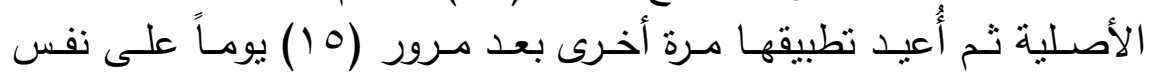




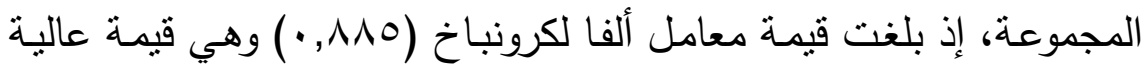
جدًا تبين ثبات عبارات الأداة وصلاحيتها لتحليل وتفسير نتائج الدراسة، وهو يتمتع بدرجة عالية من الثبات يمكن الاعتمـاد عليه في التطبيق الميداني

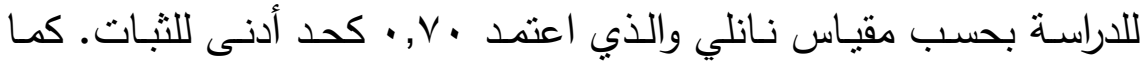
قامت الباحثة بحساب قيمة ثبات المقياس في حال حذف كل مفردة ويوضح جدول (^) معامل ثبات كل مفردة من مفردات المقياس إذا تم حذف المفردة

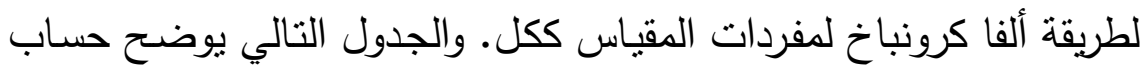
قيمة الثبات باستخدام معادلة ألفا لكرونباخ (Cronbach Alpha) وهي كما

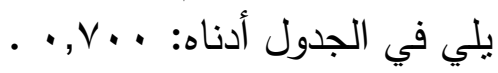

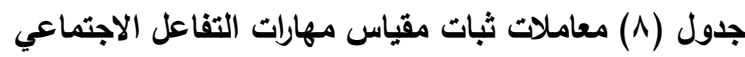

\begin{tabular}{|c|c|c|c|c|c|c|c|}
\hline \multicolumn{2}{|c|}{ التعاون } & \multicolumn{2}{|c|}{ التقليا } & \multicolumn{2}{|c|}{ الاستقبال } & \multicolumn{2}{|c|}{ التواصل الاجتماعي } \\
\hline م/الثبات & المفردة & م/الثبات & المفردة & م/الثبات & المفردة & م/الثبات & المفردة \\
\hline$\cdot, V \vee r$ & $\leqslant 7$ & $\cdot, 7 V r$ & M & $\cdot, \vee \wedge r$ & 17 & •, Vry & 1 \\
\hline$\cdot, \mathrm{V} \cdots$ & $\leqslant V$ & $\cdot, 7 \vee r$ & rr & $\cdot, \mathrm{V} \vee 1$ & 18 & $\cdot, \vee Y \wedge$ & $r$ \\
\hline$\cdot, t \vee r$ & $\varepsilon \wedge$ &., $7 \vee 7$ & r & $\cdot, \vee \vee \varepsilon$ & 11 & $\cdot, \vee r q$ & $\mu$ \\
\hline., 79. & $\leqslant 9$ &., $79 r$ & $r \varepsilon$ &., $87 r$ & 19 & $\cdot, \vee \leq \varepsilon$ & $\varepsilon$ \\
\hline., 791 & 0 . & $\cdot, \mathrm{V} \cdot \mathrm{0}$ & ro & $\cdot, \vee \wedge q$ & r. &,$V \leq 0$ & 0 \\
\hline., 799 & 01 & $\cdot, 7 \wedge \wedge$ & צ & ., $\vee 9 \varepsilon$ & YI & .,VMl & 7 \\
\hline$\cdot, V Y Y$ & Or & $\cdot, V \cdot r$ & $\mu v$ &,,$\vee \vee \varepsilon$ & Yr & ., & V \\
\hline., 799 & Or &.,$\vee 01$ & $\mu \wedge$ &., 799 & $r r$ & $\cdot, \vee \vee 7$ & $\Lambda$ \\
\hline$\cdot, V Y$. & $0 \leqslant$ & $\cdot, \vee \mu \wedge$ & rq & $\cdot, 7 \vee 7$ & $r \leqslant$ & $\cdot, \vee \vee \vee \neg$ & 9 \\
\hline., 797 & 00 & $\cdot, V \mu V$ & $\varepsilon$. &., $7 \vee V$ & ro & $\cdot, \vee \vee q$ & 1. \\
\hline$\cdot, \vee_{1}$ & 07 & $\cdot, v r q$ & $\& 1$ &., 778 & Yq & $\cdot, \vee \vee 94$ & 11 \\
\hline$\cdot, V \cdot V$ & OV & $\cdot, V \Psi \varepsilon$ & $\varepsilon r$ &., 770 & $r V$ & $\cdot, \vee \vee V$ & Ir \\
\hline$\cdot, V \cdot \varepsilon$ & $0 \wedge$ & $\cdot, \vee 01$ & $\varepsilon r$ & $\cdot, 7 \wedge 1$ & $r \wedge$ & $\cdot, \vee \wedge \bullet$ & ir \\
\hline$\cdot, V \cdot V$ & 09 & $\cdot, V \leq \varepsilon$ & $\leqslant \varepsilon$ & $\cdot, 7 \wedge$. & rq & $\cdot, V 7 V$ & $1 \varepsilon$ \\
\hline$\cdot, \vee \backslash \wedge$ & 7. & .,VH. & $\leqslant 0$ & $\cdot, \vee \vee 7 V$ & $r$. & $\cdot, V \cdot r$ & 10 \\
\hline
\end{tabular}


جدول (9) معاملات ثبات بين درجة كل بُعد والدرجة الكلية لمقياس مهارات

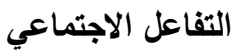

\begin{tabular}{|c|c|}
\hline معامل الثبات & المهارات \\
\hline$\cdot, V \cdot \theta$ & التواصل الاجتماعي \\
\hline$\cdot, V q V$ & الاستقبال \\
\hline$\cdot, V \otimes r$ & التقليد \\
\hline$\cdot, V Y O$ & التعاون \\
\hline
\end{tabular}

ثالثاً: الاتساق الداخلي لأبعاد المقياس :

أُجري التحقق من ثبات الاتساق الداخلي بحساب معامل ارتباط بيرسون

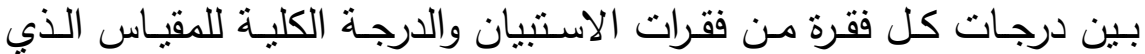

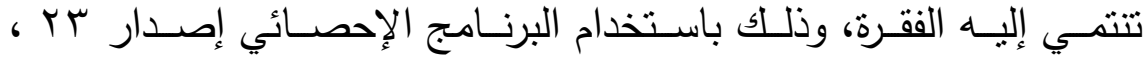
والجدول التالي يوضـح معاملات الارتباط بين كل فقرة من فقرات المقياس الاس والدرجة الكلية للمقياس. وفيما يلي قيم معامالات الارتباط ومستوى دلالتها، ويوضح جدول ( • () نتائج الاتساق الداخلي على النحو التالي:

جدول ( • 1) معاملات الارتباط بين درجة كل مفردة ومجموع درجات البُعد لمقياس (N=35)

\begin{tabular}{|c|c|c|c|c|c|c|c|}
\hline \multicolumn{2}{|c|}{ التعاون } & \multicolumn{2}{|l|}{ التقليد } & \multicolumn{2}{|l|}{ الاستقبال } & \multicolumn{2}{|c|}{ التواصل الاجتماعي } \\
\hline م/الارتباط & المفردة & م/الارتباط & المفردة & م/الارتباط & المفردة & م/ الارتباط & المفردة \\
\hline$* * .6701$ & $\varepsilon 7$ & $* *, 019$ & $\mu_{1}$ & $* *, V$, & 17 & $* *,, 70 \mathrm{~V}$ & 1 \\
\hline$* * .67 \vee 0$ & $\varepsilon V$ & $* *, 0 N_{1}$ & $r r$ & $* *,, 0 \wedge V$ & IV & $* *, 70 r$ & $r$ \\
\hline$* * .67 \ldots$ & $\varepsilon \wedge$ & $* *$, , VY० & $r r$ & $* *, 001$ & 11 & $* *$, , $₹ \vee q$ & $r$ \\
\hline$* *,, v \bullet r$ & $\varepsilon 9$ & $* *, V \cdot Y$ & $r \varepsilon$ & $* *,, \leq \leqslant$. & 19 & $* *, 011$ & $\varepsilon$ \\
\hline$* * .67$. & 0 . & $* *, V R Y$ & ro & $* *, V R r$ & $r$. & $* *,, 0 \leq V$ & 0 \\
\hline$* * .67 \cdot 1$ & 01 & $* *, V \leq Y$ & $r q$ & **, צr & YI & $* *, V I r$ & 7 \\
\hline$* * .67 \wedge 1$ & Or & $* *,, V \otimes r$ & $r v$ & $* *, 919$ & YY & $* *, 70 \leq$ & $\mathrm{V}$ \\
\hline$* *$. .V१q & or & $* *$ *, TrV & $r \Lambda$ & $* *, 07 \mathrm{~V}$ & $r T$ & $* *, \neg \uparrow \wedge$ & $\Lambda$ \\
\hline
\end{tabular}


المجلة العلمية لكلية رياض الأطفال - جامعة بورسعيد

\begin{tabular}{|c|c|c|c|c|c|c|c|}
\hline \multicolumn{2}{|c|}{ التعاون } & \multicolumn{2}{|l|}{ التقليا } & \multicolumn{2}{|l|}{ الاستقبال } & \multicolumn{2}{|c|}{ التواصل الاجتماعي } \\
\hline$* * .67 \%$. & $0 \leq$ & $* *,, 7,1$ & rq & $* *,, \curlyvee \wedge \vee$ & $r \leqslant$ & $* *, 007$ & 9 \\
\hline$* *$. เ $7 \leq \varepsilon$ & 00 & $* *, V, Y$ & $\varepsilon$. & $* *,, \diamond \vee \wedge$ & ro & $* *, 0, V$ & 1. \\
\hline$* *, ، \Delta \wedge \wedge$ & 09 & $* *,, Y, Y$ & $\leqslant 1$ & $* *,, \leq \wedge \leq$ & rq & $* *,, O H r$ & 11 \\
\hline$* *$. 6V70 & OV & $* *, \eta 1$. & $\varepsilon r$ & $* *,, O H Y$ & rV & $* *$, ๆ & Ir \\
\hline$* *,, Y \cdot Y$ & $0 \wedge$ & $* *,, \vee Y q$ & $\varepsilon r$ & $* *$ *, Y ४ & rA & $* *,, 7, \leq$ & ir \\
\hline$* *$, , $7 r q$ & 09 & $* *, 791$ & $\leqslant \varepsilon$ & $* *, \vee \vee \wedge 1$ & rq & $* *, 100$ & $1 \leq$ \\
\hline$* *,, 701$ & 7. & $* *,, 79 \leq$ & $\leqslant 0$ & $* *,, 7 \circ V$ & $r$. & $* *$ *, イ & 10 \\
\hline
\end{tabular}

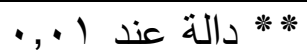

ومسن جدول( • () نجـد أن هنـالك علاقـات ارتباطيـة موجبـة ذات دلالـة

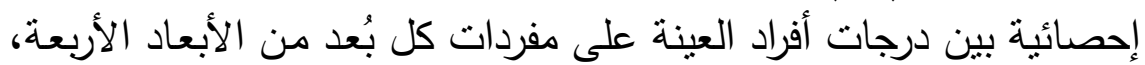
والدرجة الكلية للبُعد، وجميعها دالة عند مستوى ( ( . • )، ممـا بعد مؤشـراً على الاتساق الداخلي لكل بُعد. كما تم حساب قيم معامالات الارتباط بين

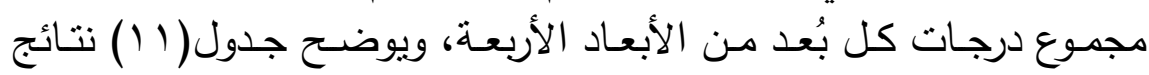
معاملات الارتباط بين درجة كل بُعد والدرجة الكلية. جدول (11) معاملات الارتباط بين درجة كل بُعد واللرجة الكلية لمقياس

\begin{tabular}{|c|c|}
\hline معامل الارتباط & المهارات \\
\hline$* *, \wedge \leq q$ & التواصل الاجتماعي \\
\hline 6**,, $\vee Y \wedge$ & الاستقبال \\
\hline$* *,, \wedge 91$ & التقليد \\
\hline$* *,, 9 \leq$. & التعاون \\
\hline
\end{tabular}

* * دالة عند 1 (, • 
ومـن الجدول(1) (1) نجد أن هنـاك علاقات ارتباطيـة موجبـة ذات دلالــة

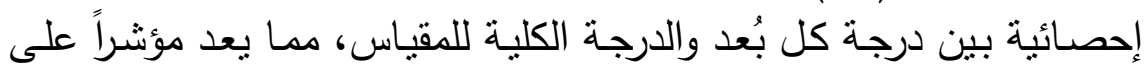
تشبع المقياس بالسمة المراد قياسها وهي (المهارات الاجتماعية).

$$
\text { أ- الهـف منهار جوادارد (إعداد/ جوادارد) ملحق رقم (r): }
$$

تقييم الذكاء الأدائي، غير اللفظي وهو ملائم للأعمار من سن (r,0: ^)

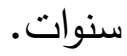
ب-وصف الاختبار :

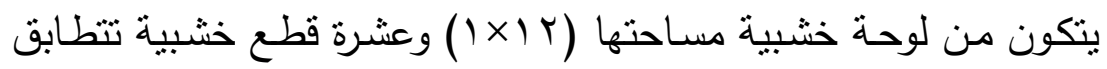

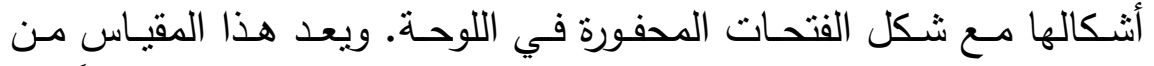

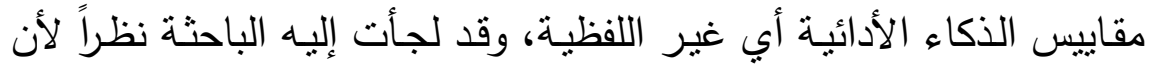

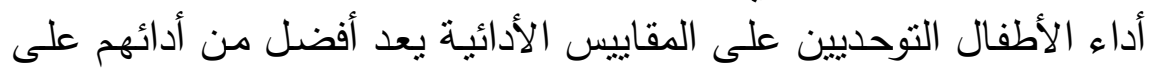

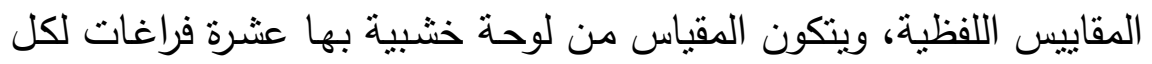

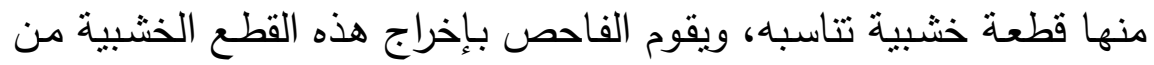

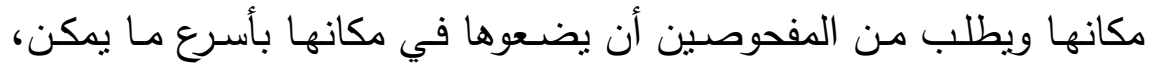

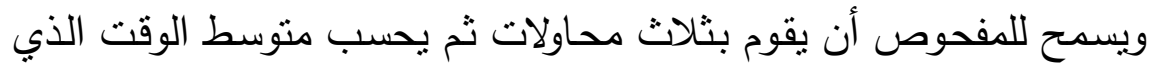

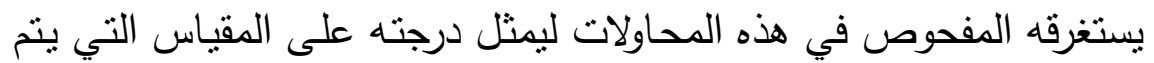
في ضوئها تحديد نسبة ذكائه وذلك بالرجوع إلى دليل الاختبار (عبد اللاه،

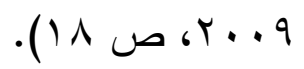


ع -مقياس تقدير التوحد الطقولي: إعداد( إريك سكويلر) تعريب وتقنين

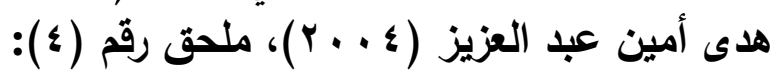
1- الهرف من المقياس:

يستهدف هذا المقياس تقدير التوحد الطفولي في ضـوء خمس عشـرة مهارة، وتعتبر جوانب أساسية تميز هذا الاضطراب والدرجات المحددة لكل فئل منها.

•-البرنامج الإثرائي المتكامل ملحق رقم (•):

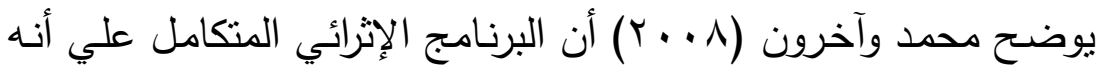

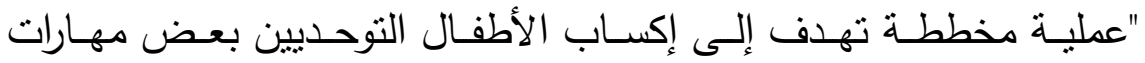

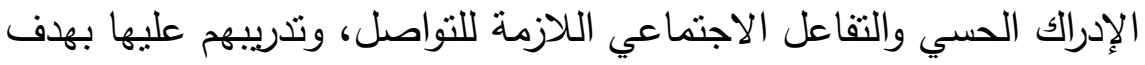

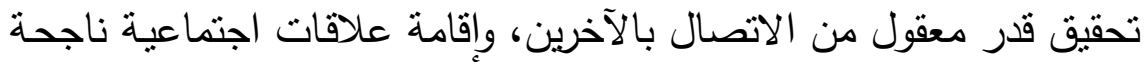

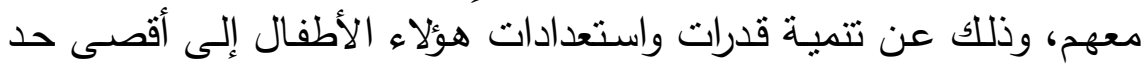

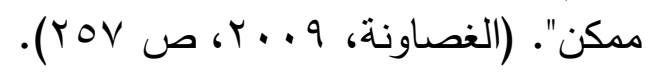

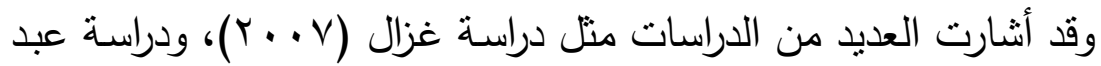

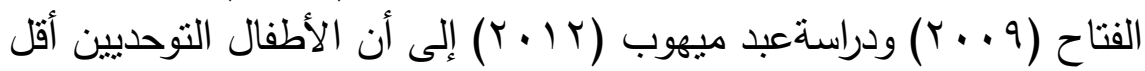

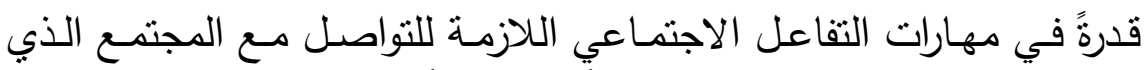

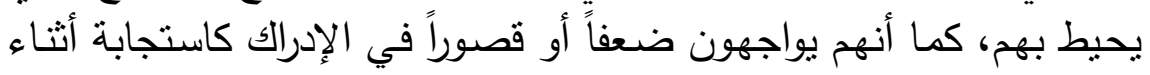

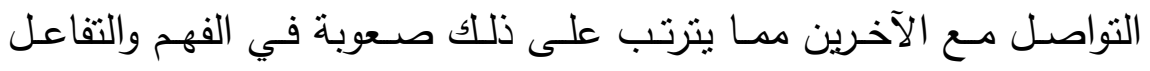
الاجتماعي. تم توضيح النسبة المئوية لآراء المحكمين في عناصر البرنامج التدريبي

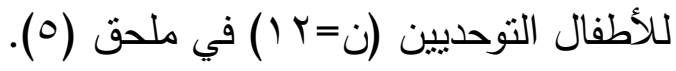




\section{المجلة العلمية لكلية رياض الأطفال - جامعة بورسعيد}

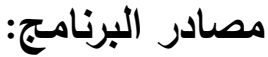

اعتمدت الباحثة في بناء محتوى البرنامج على مصادر عديدة هي: ا-بعض البـرامج المسـتخدمة في الدراسـات السـابقة التـي تتاولت بـرامج

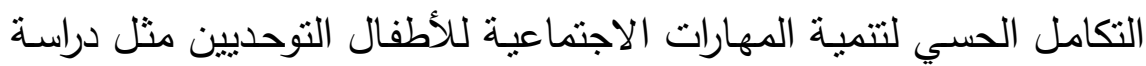

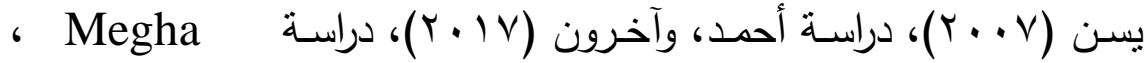
. Parham (2015) Pooja (2015) r-من خلال الإطار النظري للاراسة.

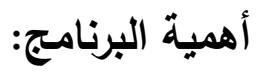

في اهتمامه بعينة من الأطفال التوحديين والذين يعانون من قصور في

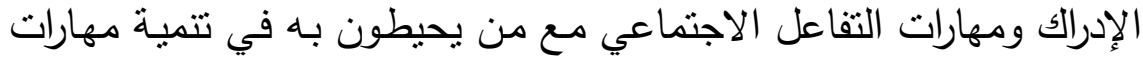

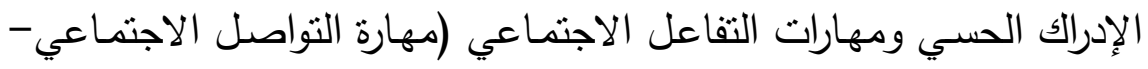

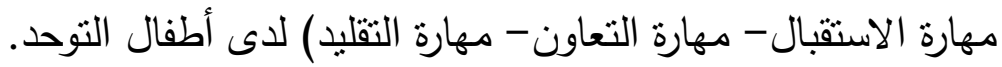

\section{الأهداف العامة من البرنامج:}

يقوم البرنـامج الإثرائي المتكامل على الإثراء الحسي، ويهدف البرنـامج

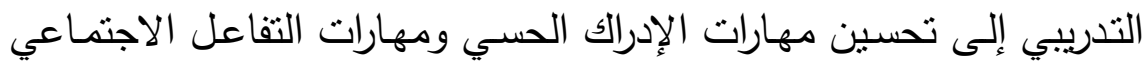

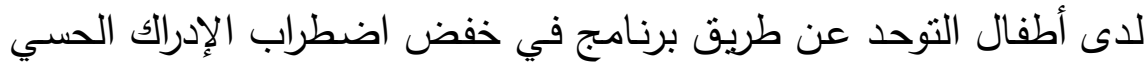

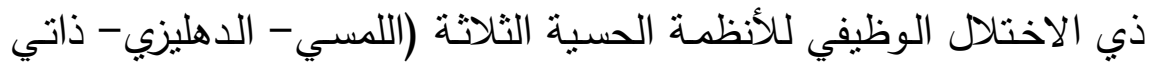
التحفيز) ومهارات التفاعل الاجتماعي لدى الأطفال التوحديين.

\section{الأهداف الفرعية : - الفية}

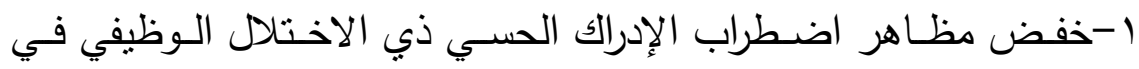
النظام اللمسي والمتمتلة في الدفاع اللمسي وتتمل ما يلي: (عدم التفاعل 
مع الألعاب اللمسية مثل (المعجون - الصلصال - الألوان، عدم الانتباه لمن

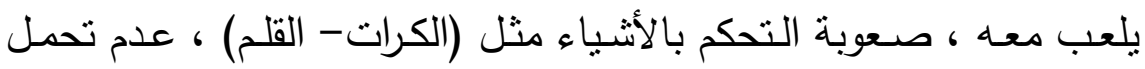

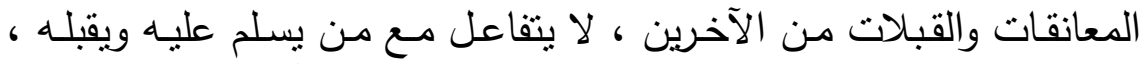

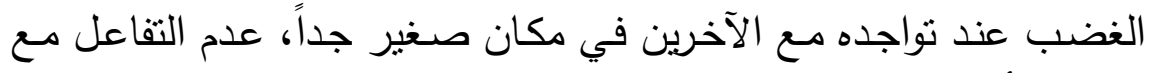
الآخرين أثثاء الألعاب اللمسية).

r-خفض مظـاهر اضـطراب الإدراك الحسي ذي الاختنال الـوظيفي في

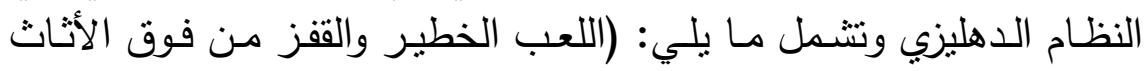

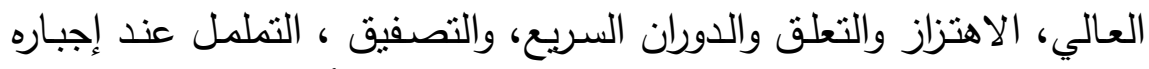

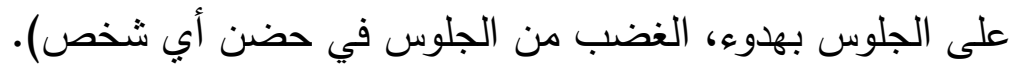

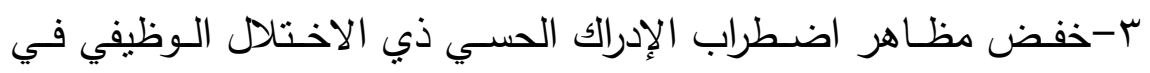

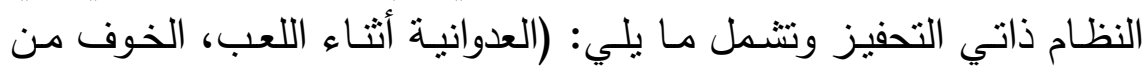

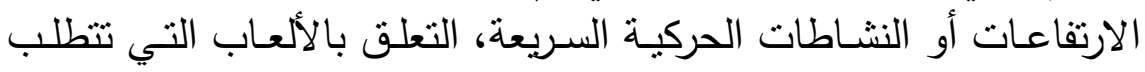

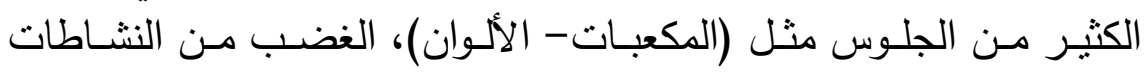

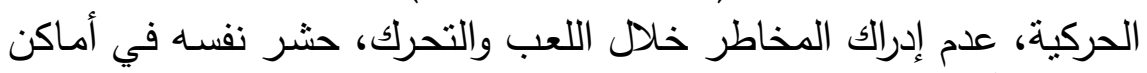
ضيقة جداً).

\section{الأهداف الإجرائية للبرنامج :}

في نهاية البرنامج ينبغي أن يكون الطفل قادراً على الإنى: 1 - الانتباه للأصوات التي تحدث فجأة في محيطه. r- يعبر عن جوعه بإيماء مناسب.

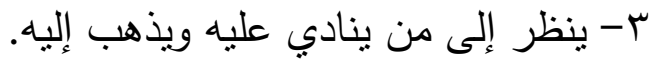
ع- يستجيب عند سماع اسمه. 0- يمد يده بالسلام عند الاسنقبال أو الوداع. 
7- يطابق بين الصوت والصورة المطلوبة منه. V- يستمتع بالألعاب الجماعية منل شند الحبل.

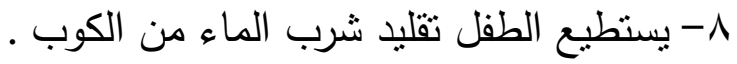

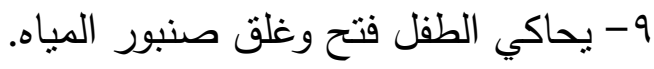

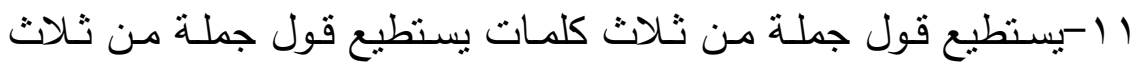

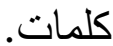
11 ا - يشير إلى شخصية في القصة عندما يطلب منه ذللك.

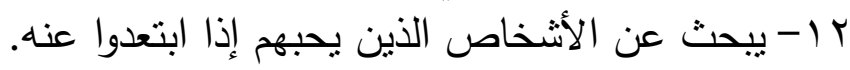
ז ا - يستخدم الطفل إحدى وسائل البدء الاجتماعي.

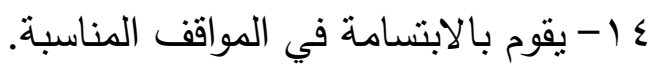
1 1 - يقوم الطفل بتقليد التصفيق بالاليد.

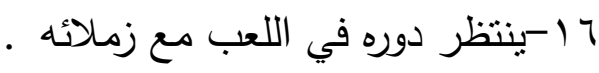

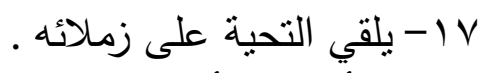

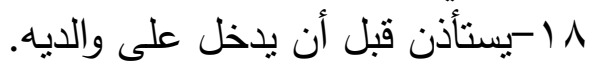
الأسس التي يستند عليها البرنامج :

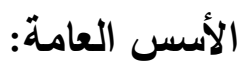

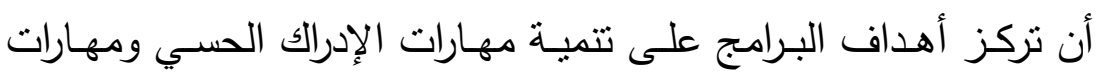
التفاعل الاجتماعي لدى الأطفال التوحديين عن طريق تتمية الإدراك الحسي التهي

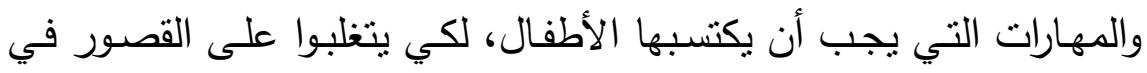
مهارات التفاعل الاجتماعي.

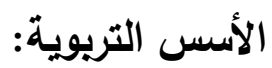

يستند البرنامج التدريبي على النظرية السلوكية، وأن الفرد يتعلم السلوك الأوك

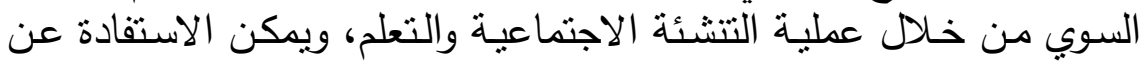




\section{المجلة العلمية لكلية رياض الأطفال - جامعة بورسعيد}

طريق تعزيز السلوك السوي المتوافق عليه والتخلص من السلوك غير السوي

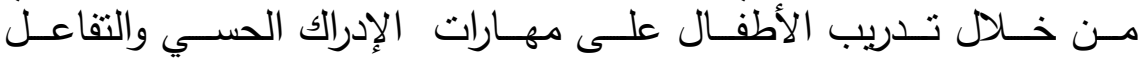

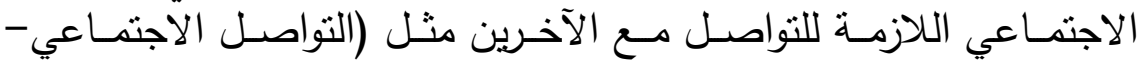
الاستقبال - التقليد - التعاون).

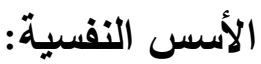

إتاحة الفرصة الكافية لجميع الأطفال للمشاركة كل حسب قدراته وإمكانياته،

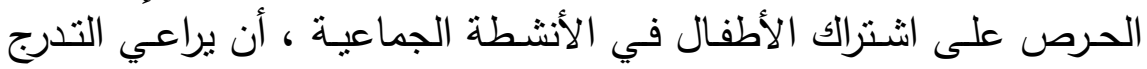

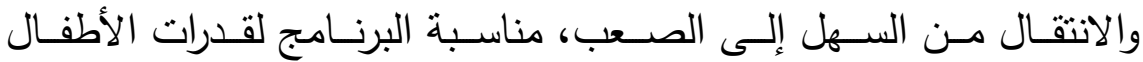

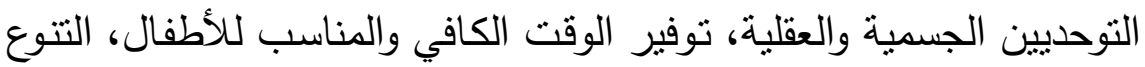
في تقديم أنشطة البرنامج، استخدام المعززات، مراعاة الفروق الفردية.

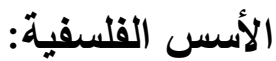

يقوم البرنامج على بعض الأسس الفلسفية في تربية الأطفال مثل نظريـة بياجيه، ونظرية إريكسون، ونظرية باندورا.

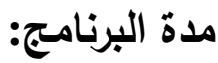

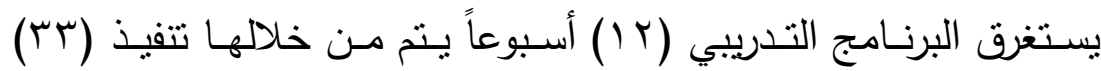

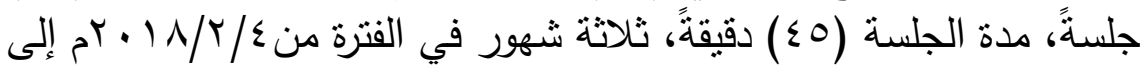
. $11 / 0 / 7$ تخطيط للبرنامج:

تم توضيح شكل تصور تخطيطي للبرنامج التدريبي المستخدم في الدراسة في ملحق (0). 
الأســاليب والقنيـات المســتخدمة فـي البرنــامج: ( التعزيـز "إيجـابي سلبي"،الحث، النمذجة، التشكيل، التقليد التبادلي) في ملحق (0). - الاستراتيجيات والفنيات المستخدمة في البرنامسج:

ا - فنيات نظام ويلبرغر: (استخدام المرآة- الضغط العميق - أنشطة لزيادة

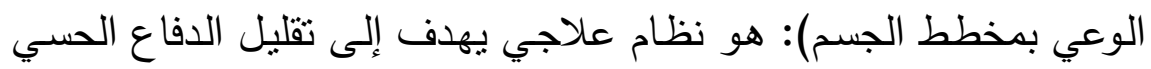

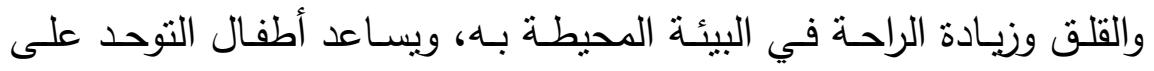

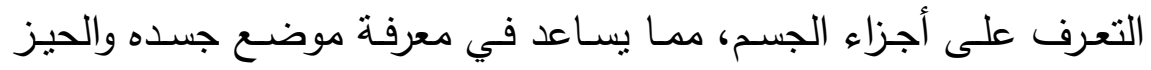
الثخصي لله وللآخرين.

r-فنيـات الحميـة الحسية: (نشاطات دهليزية وذاتيـة التحفيز - النشاطات

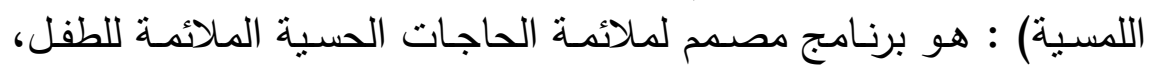

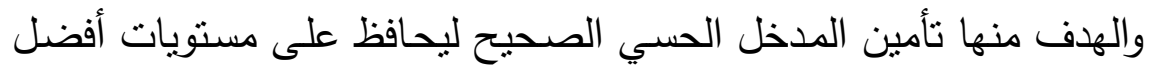

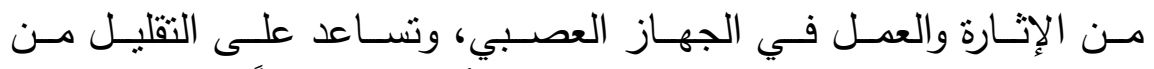

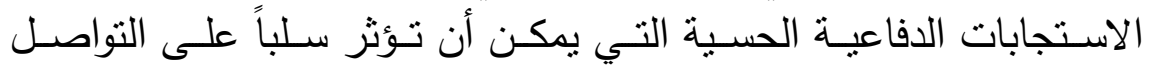
الاجتماعي. r-أنشطة التنبيه: هي أنشطة مضبوطة بصورة أدق لتمنع الإثارة الزائدة،

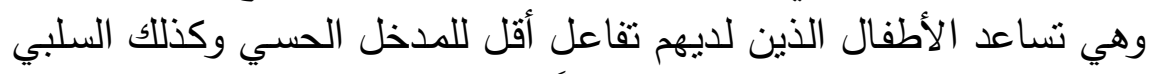
والذي لديه لا مبالاة ليصبح أكثر تركيزاً وانتباهًا. ع - فنيات التهائة والتظيم: هي تقنية تساعد أطفال التوحد الذي يعاني من

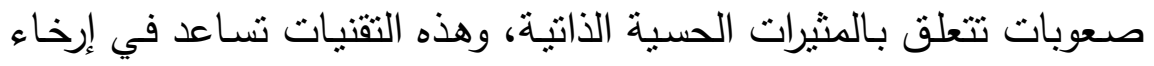

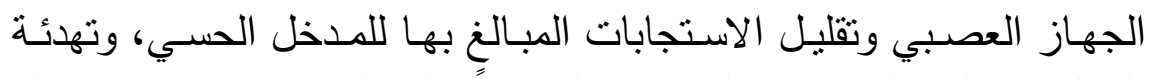
الطفل ذي النشاط الحركي الزائد وتجعله قادراً على التحكم في حواسـه بشكل التهل 
أفضل، وبالتـالي زيـادة الانتبـاه والتركيز عند الطفل (الفقرة، 0 ـ ب ؟، ص

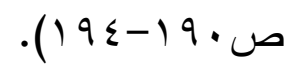

\section{تقييم البرنامج:}

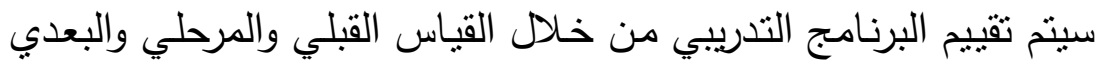

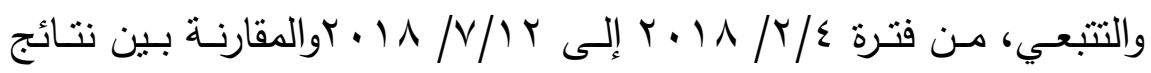

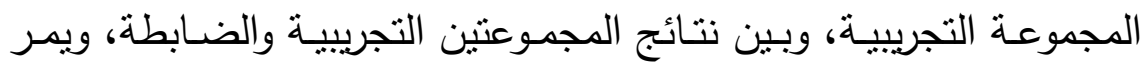

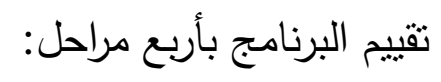

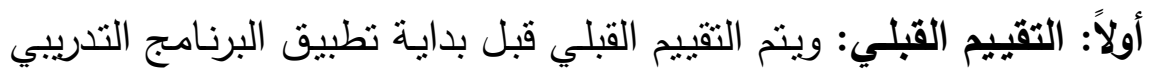

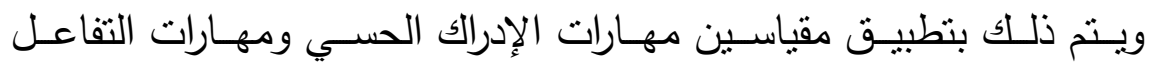

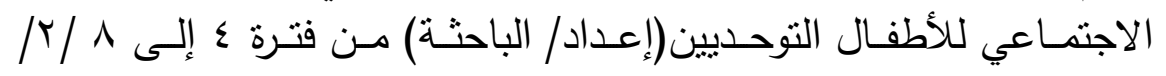
. r. 11 ثانيـاً: التقيـيم المرحلي : ويتم في نهايـة كل جلسـة من جلسـات البرنامج،

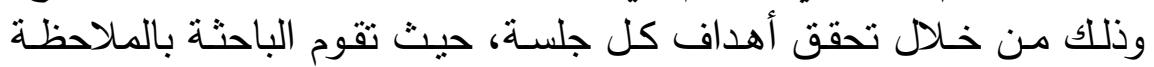

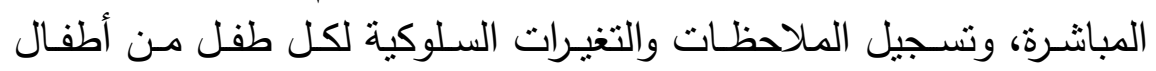

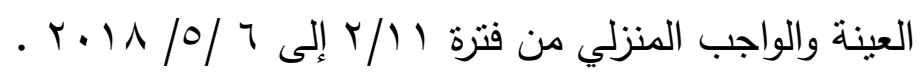
ثالثاً: التقييم البعدي: ويتم بتطبيق مقياسي مهارات الإدراك الحسي ومهارات

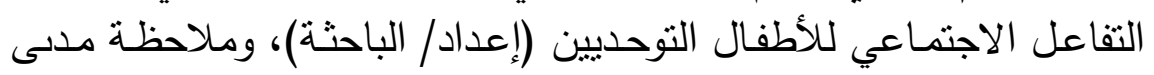

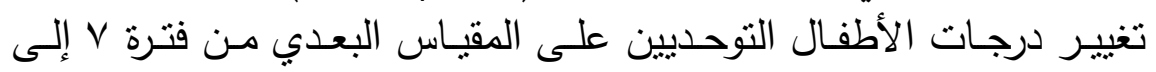

$$
\text { r. } r 110 / 1 \text {. }
$$

رابعاً: التقييم التتبعي: يتم تطبيق مقياسي مهارات الإدراك الحسي ومهارات

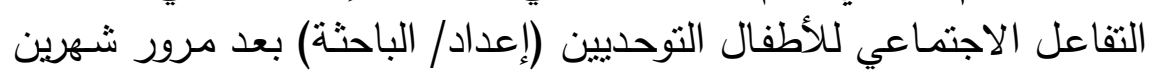

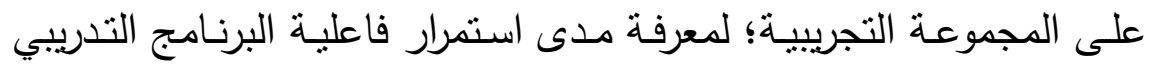


المستخدم، حيث تمـت المقارنـة بين نتائج القياس التتبعي ونتائج القياس

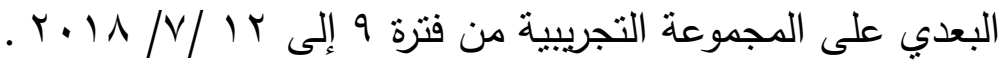

$$
\text { r-دراسة الحالة: ملحق رقم (؟) : }
$$
أ- الهُف من دراسة الحالة:

وصـف المشـكلة - مصـادر دراســة الحالـة: دراسـة الحالــة للأطفــال ذوي الاحتباجات الخاصة "غير العاديين" (إعداد/الباحثة). خامساً: الأساليب الإحصائية المستخدمة:

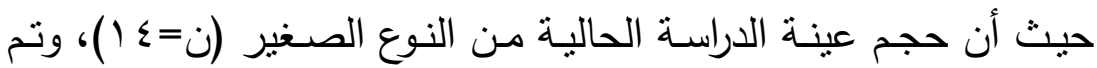

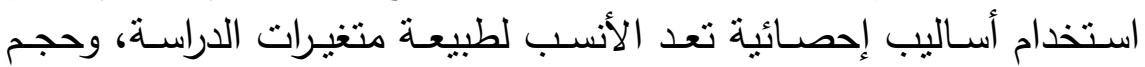
العينة لاستخلاص النتائج واختبار صحة الفروض وقد تمنلت الانس هذه الأساليب

- المتوسط الحسابي (Mean) بهدف مقارنة المتوسطات الحسابية. - الانحراف المعياري (Std. deviation) لمعرفة مدى النتتت المطلق للقيم حول أوساطها. - معادلة سبيرمان - براون(Spearman-Brown) - اختبار مان وتنينى Mann- Whitney ، وذلك لحساب دلالة الفروق بين متوسطات درجات المجموعتين (التجريبية والضابطة) المستقلتين.

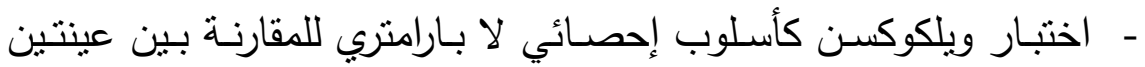
مرتبطين. - معامل ألفا كرونباخ Coronbach-Alpha مغيـة التحقق من ثبات المقاييس. - معادلة كوهين لحجم التأثير - معائر 


\section{نتائج الاراسة وتفسيرها ومناقشتها :}

نتائج الفرض الأول وتفسيرها ومناقشتها :

ينص الفرض الأول على أنها: " توجد فروق ذات دلالـة إحصـائية بين

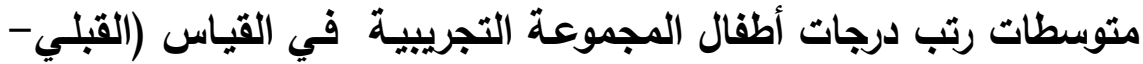

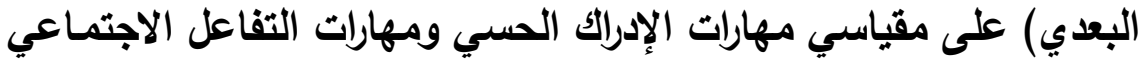
(الدرجة الكلية والأبعاد) لصالح القياس الإلى البعدي.". وللتحقق من صحة الفرض قامت الباحثة بالآتي:

1-بالإحصــاء الوصـفي: " المتوسطات والانحرافـات المعياريـة لكل مـن

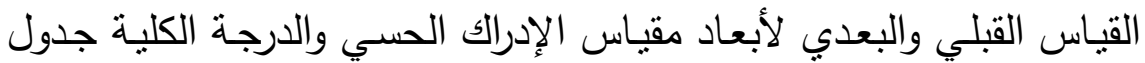

\begin{tabular}{|c|c|c|c|c|}
\hline \multicolumn{2}{|c|}{ القياس البعدي } & \multicolumn{2}{|c|}{ القياس القبلي } & \multirow{2}{*}{ 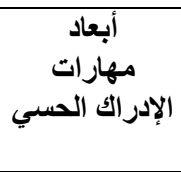 } \\
\hline 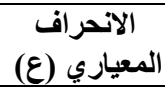 & المتوسط (م) & 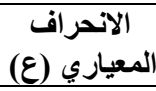 & $\begin{array}{c}\text { المتوسط } \\
\text { (م) }\end{array}$ & \\
\hline$\cdot, \wedge 9$ & $1 \cdot, 1$ & $\cdot, \wedge 9$ & $r \cdot r$ & التمييز الحركي \\
\hline$\cdot, v_{1}$ & Ir,r & $\cdot, \vee_{0}$ & YY,O & التمييز البصري \\
\hline$\cdot, \wedge r$ & 11,0 & $\cdot, \vee \wedge$ & $r 1, r$ & التمييز السمعي \\
\hline$\cdot, \wedge 9$ & $1 \cdot, r$ & $\cdot, \wedge 9$ & $r \cdot, 1$ & التمييز اللمسي \\
\hline$\cdot, \vee \wedge$ & $1 Y, 1$ & $\cdot, v \leq$ & YY,Y & التمييز الشمي \\
\hline$\cdot, \wedge \varepsilon$ & 11,1 & $\cdot, \vee \vee q$ & $r, r$ & التمييز التذوقي \\
\hline$T$ & 71 & $1, v 9$ & IYA & الارجة الكلية \\
\hline
\end{tabular}

ويتضح ذلك بالثكل (1) الفروق بين المنتوسطات لكل ٍِن القياس القبلي والبعدي لأبعاد الإدراك الحسي والدرجة الدرو الكلية. 


\section{المجلة العلمية لكلية رياض الأطفال - جامعة بورسعيد}

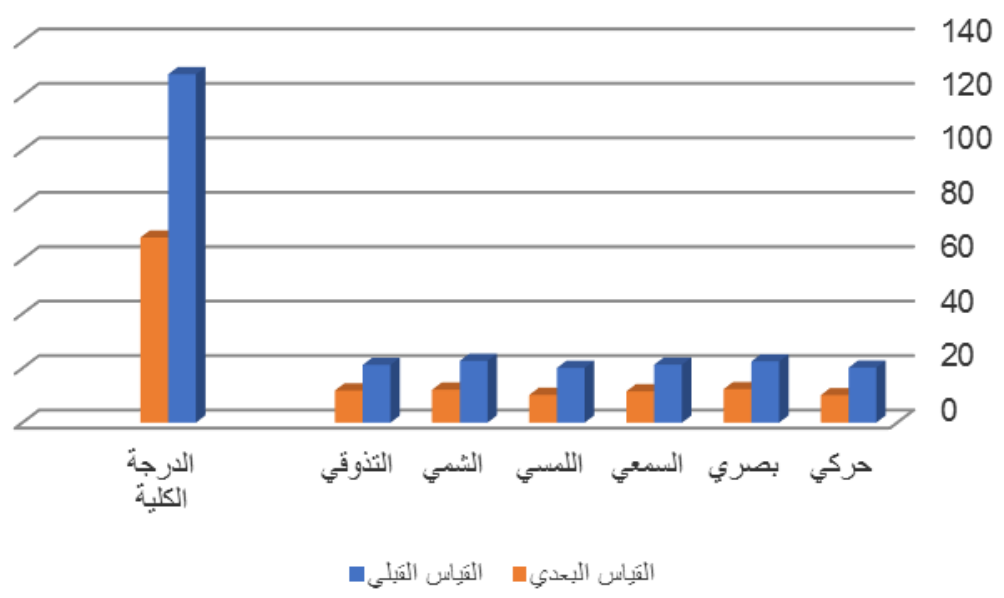

r-باستخدام اختبار ويلكوكسن لحساب دلالة الفروق بين القياس القبلي والبعدي لرتب درجات أفراد المجموعة التجريبية، وكانت النتائج كما يلي : وللتأكد أيضـاً من هذا الفرض استخدمت الباحثة اختبار ويلكوكسن كأسـلوب إحصـائي لا بـارامتري للمقارنــة بـين عينتين

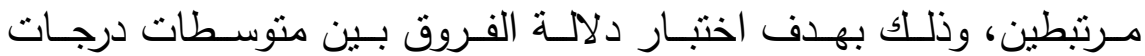

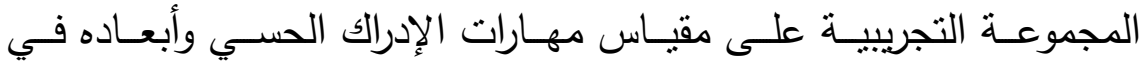

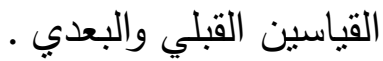




\section{المجلة العلمية لكلية رياض الأطفال - جامعة بورسعيد}

جدول (r I ) نتائج اختبار " ويلكوكسن" لالالة الفروق بين القياسين القبلي والبعدي للمجموعة

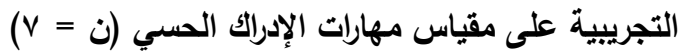

\begin{tabular}{|c|c|c|c|c|c|c|c|c|c|c|}
\hline \multirow{2}{*}{\multicolumn{2}{|c|}{ باستخدام معادلة كوهين }} & \multirow[t]{2}{*}{ الدلالة } & \multirow[t]{2}{*}{ قيمة } & \multicolumn{3}{|c|}{ 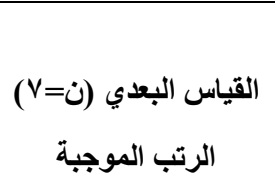 } & \multicolumn{3}{|c|}{$\begin{array}{c}\text { القياس القبلي } \\
\text { الرتب السالبة } \\
\text { (V= }\end{array}$} & \multirow[t]{2}{*}{ الأبعاد } \\
\hline & & & & متوسط & مجموع الرتب & ن & متوسط & مجموع & ن & \\
\hline مرتفعة & $\cdot, 70$ & $\cdot, \cdot \theta$ & $r, .0$ & $r$ & 10 & $V$ & . & . & . & الحركييز \\
\hline مرتفعة & •, & $\cdot, \cdot 0$ & $r, \cdot r$ & $r$ & 10 & V & . & . & . & البصري \\
\hline مرتفعة & •, $7 \leqslant$ & $\cdot, \cdot \theta$ & Y, $\varepsilon$ & $r$ & 10 & V & . & . & . & السمعيز \\
\hline مرتفعة & •, $7 \leq$ & $\cdot, \cdot \theta$ & $r, \cdot r$ & $r$ & 10 & V & . & . & . & اللمسييز \\
\hline مرتفعة & $\cdot, 7 \leq$ & $\cdot, \cdot \theta$ & $r, \cdot r$ & $r$ & 10 & V & . & . & . & الثمييز \\
\hline مرتفعة & •, $7 \leq$ & $\cdot, \cdot \theta$ & $r, \cdot r$ & $r$ & 10 & V & . & . & . & التذوقيز \\
\hline مرتفعة & $\cdot, r 0 Y$ & $\cdot, \cdot \theta$ & $r, \cdot V$ & $r$ & 10 & V & . & . & . & الكلية \\
\hline
\end{tabular}

يتضح من جدول (T) ما يلي:

• وجود فروق ذات دلالـة إحصـائية عند مستوى (0 ، , • ) بين رتب أفراد

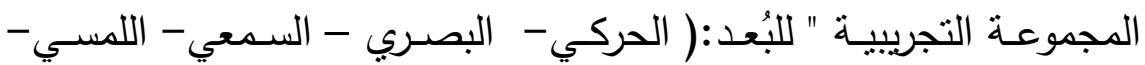

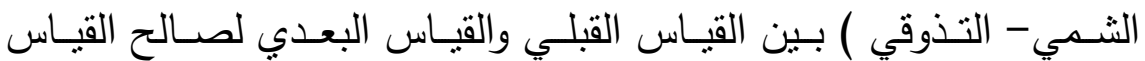
البعدي. 
• وجود فروق ذات دلالة إحصـائية عند مستوى (0 . • ) بين رتب أفراد

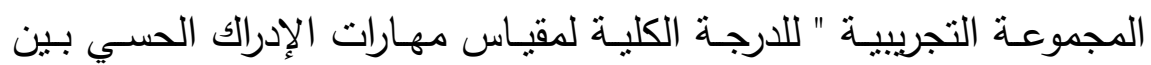
القياس القبلي والبعدي لصالح القياس البعدي.

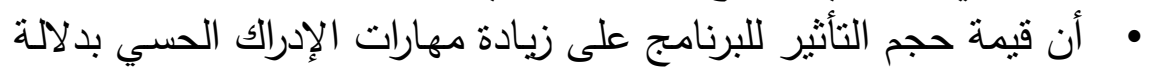
مقياس مهارات الإدراك الحسي لدى أفراد العينة بلغت (r=0.652) وهي قبمة مرتفعة وجيدة.

-حساب نسبة الكسب من خلال البرنامج من خلال معادلة مـاك جويجان وكانت التثائج: جلول ( 1 ) نسبة الكسب لماك جويجان لمقياس لمقياس مهارات الإدراك الحسي

\begin{tabular}{|c|c|c|c|c|}
\hline نسبة الكسب & العظمى & البعدي البياس & القباس & الأبعاد \\
\hline$\Delta \wedge, I \vee$ & $r$. & 11,1 & $r \leqslant, r$ & التمييز الحركي \\
\hline 71,11 & $r$. & IY,r & $r r, 0$ & التمييز البصري \\
\hline or,vq & $r$. & 11,0 & YY,Y & التمبيز السمعي \\
\hline ov, I. & $r$. & $11, r$ & $Y Y, 1$ & التمييز اللمسي \\
\hline$V T, 07$ & $r$. & $\mid Y, 1$ & $Y, V$ & التمييز الشمي \\
\hline $94, \wedge q$ & $r$. & 11,1 & $r \cdot, r$ & التمييز التذوقي \\
\hline$\wedge q, \diamond \wedge$ & $1 \wedge$. & V. & $1 \% \varepsilon$ & الارجة الكلية \\
\hline
\end{tabular}

$$
\text { بتضح من جدول (ع ا ) ما يلي: }
$$

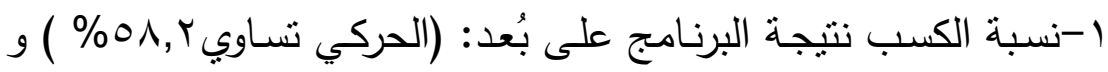

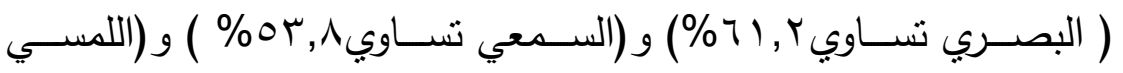

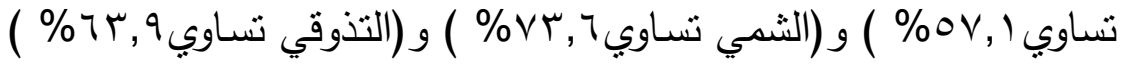




\section{المجلة العلمية لكلية رياض الأطفال - جامعة بورسعيد}

\section{وهي نسب مقبولة طبقاً لمعادلة نسبة الكسب لماك جويجان.}

Y-نسبـة الكسب نتيجـة البرنـامج على مقبـاس مهارات الإدرالك الحسـي

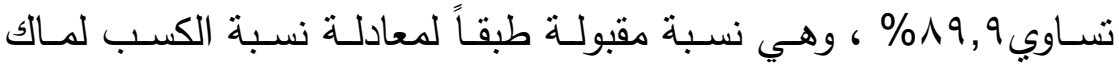

جويجان.

-ثم قامت الباحثة بالآتي: بالإحصاء الوصفي: " المتوسطات والانحرافات

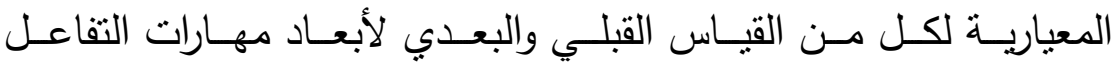
الاجتماعي والدرجة الكلية جدول (10).

\begin{tabular}{|c|c|c|c|c|}
\hline \multicolumn{2}{|c|}{ القياس البعدي ن=7 } & \multicolumn{2}{|c|}{ القياس القبلي ن=7 } & \multirow[t]{2}{*}{ الأبعاد } \\
\hline $\begin{array}{c}\text { الانحراف المعياري } \\
\text { (ع) }\end{array}$ & المتوسط (م) & 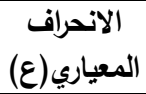 & المتوسط (م) & \\
\hline$r, I V$ & rq, r & r,rr & $r \leq$ & التواصل الاجتماعي \\
\hline $1, \wedge r$ & rq, & $\cdot, \wedge \varepsilon$ & $r r, \Lambda$ & الاستقبال \\
\hline$r, r$ & $r v, r$ & $\cdot, \wedge 9$ & rr, & التقليد \\
\hline$\cdot, V_{1}$ & $\varepsilon r$ & $1,7 \leq$ & $r 0,1$ & التعاون \\
\hline $0, V Y$ & 100,1 & $\varepsilon, \cdot 7$ & $9 V$ & الارجة الكلية \\
\hline
\end{tabular}

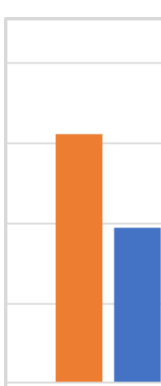

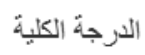

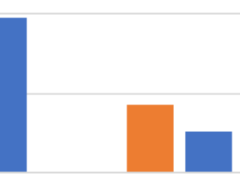

الثنعاون

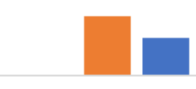

الثتليد

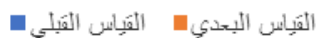

شكل (ץ) الفروق بين المتوسطات لكل من القياس القبلي والبعدي لأبعاد مقياس مهارات التفاعل الاجتماعي والدرجة الكلية الكئ 


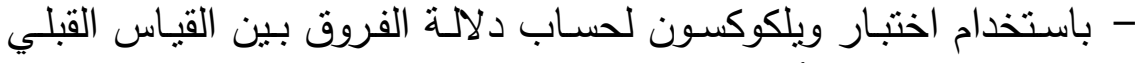

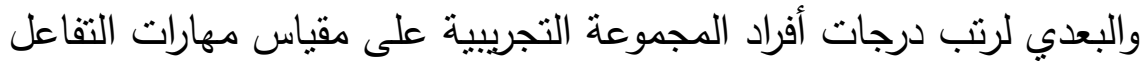

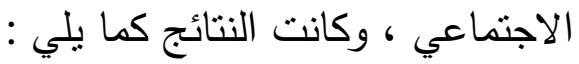

جدول (7 ا ) نتائج اختبار " ويلكوكسون" لدلاية الفروق بين القياسين القبلي والبعدي

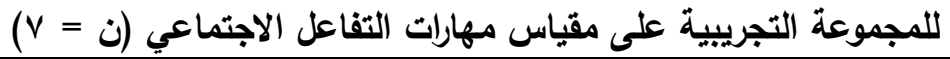

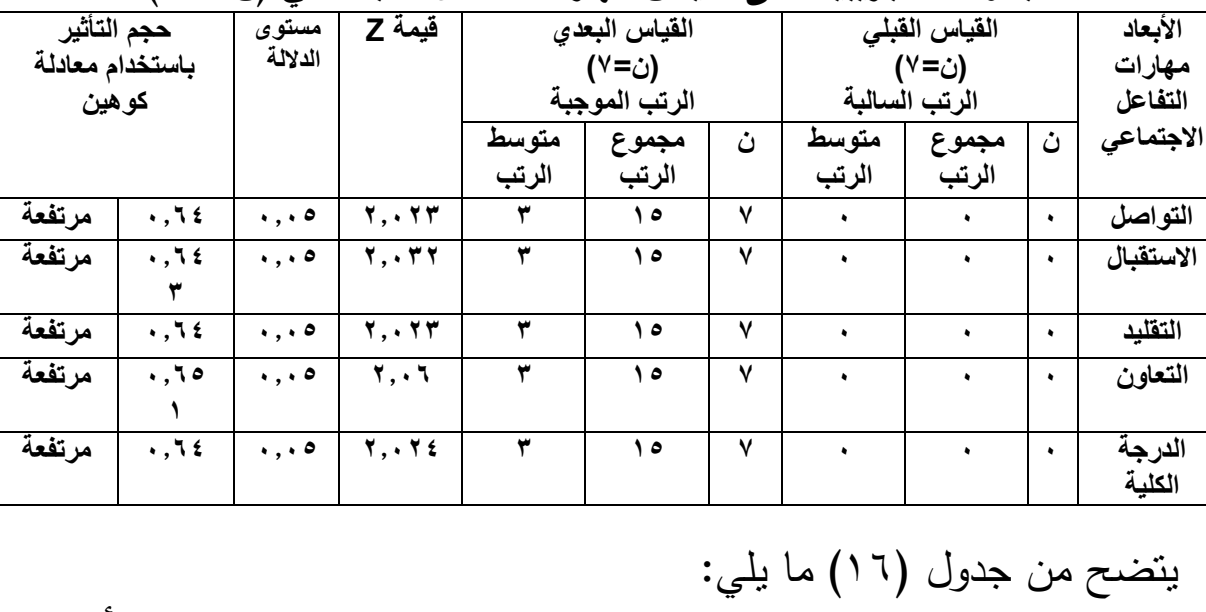

- وجود فروق ذات دلالة إحصـائية عند مستوى (0 . . • ) بين رتب أفراد المجموعة التجريبية "(لمهارة التواصل الاجتماعي ، لمهارة الاستقبال، لمهارة التقليد ، لمهارة التعاون) بين القياس القبلي والقياس البعدي لصـالح القياس البعدي. - وجود فروق ذات دلالـة إحصـائية عند مستوى (0 . , • ) بين رتب أفراد المجموعة التجريبية "للارجة الكلية للمهارات التفاعل الاجتماعي" بين القياس القبلي والبعدي لصالح القياس البعدي.

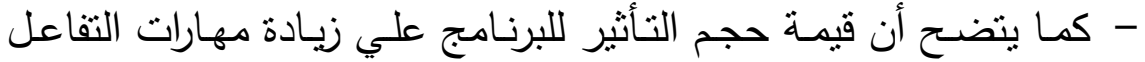
الاجتماعي لدى أفراد العينة بلغت (r=0.64) وهي قيمة مرتفعة وجيدة، في 
حين بلغت حجم التأثنر أعلى درجة في مهارة التعاون ثم الاستقبال ثم التقليد

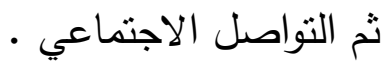

-حساب نسبة الكسب من خلال البرنامج من خلال معادلة مـاك جويجان وكاتت النتائج: جدول (IV) نسبة الكسب لماك جويجان لمقياس مهارات التفاعل الاجتماعي

\begin{tabular}{|c|c|c|c|c|}
\hline نسبة الكسب & العظمى & البعدي & القبياس & الأبعاد \\
\hline $0 \wedge, 1$. & $\leqslant 0$ & ru, & $r \varepsilon$ & التواصل الاجتماعي \\
\hline$V \Gamma, O \Lambda$ & $\leqslant 0$ & rq, & rr,A & الاستقبال \\
\hline $7 r, \wedge 9$ & $\leqslant 0$ & $r V, r$ & rr, & التقليا \\
\hline 19,01 & $\leqslant 0$ & $\varepsilon r$ & ro, & التعاون \\
\hline$\vee \cdot, \wedge \varepsilon$ & $1 \wedge$. & 100,1 & $9 V$ & الارجة الكلية \\
\hline
\end{tabular}

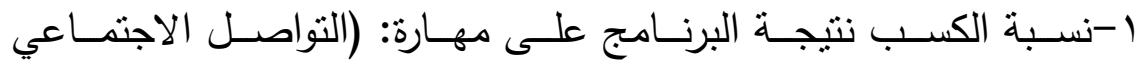

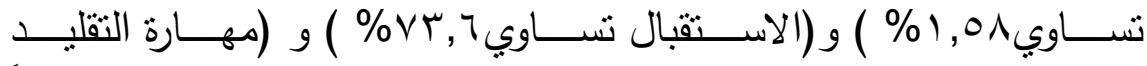

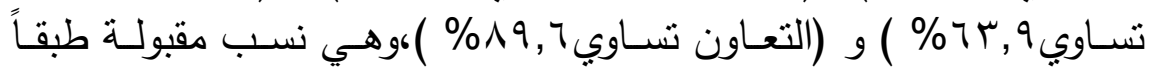
لمعادلة نسبة الكسب لماك جويجان.

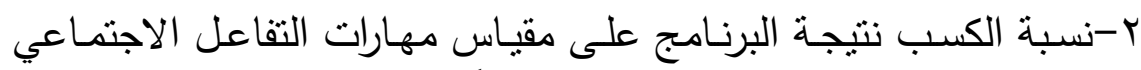

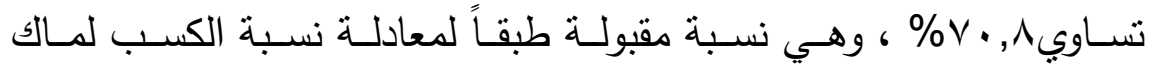

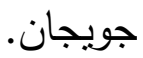

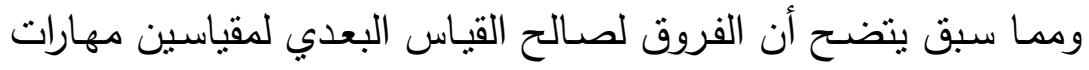
الإدراك الحسي والتفاعل الاجتماعي، وهذه النتائج تحقق الفرض الفي الفي الأول.

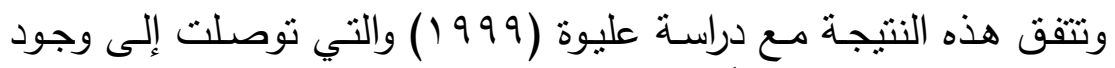

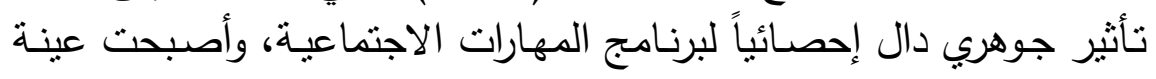


الدراسـة قادرة إلى حد ما على إيجاد شكل من أثنكال التفاعل الاجتمـاعي، كما زادت قدرتهم على التقليد.

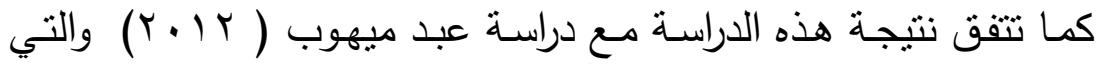
أسفرت عن وجود فروق دالة إحصائياً بين متوسطي درجات القياسين القبلي والبعدي للمجموعة التجريبية على تلك المهارات لصالح التطبيق البعدي.

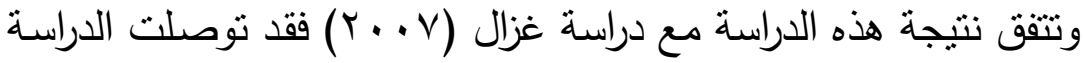

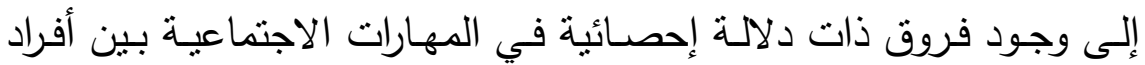
المجموعة التجريبية والمجموعة الضـابطة علي القياس البعدي لصسالح أفراد المجموعة التجريبية، وأيضـاً وجود فروق ذات دلالة إحصائية في المهارات الاجتماعية بين أفراد المجموعة التجريبية والمجموعة الضـابطة على قياس ودئ المتابعة لصالح أفراد المجموعة التجريبية.

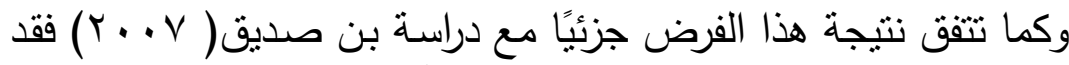
توصلت الدراسـة إلى وجود فروق دالة إحصائياً في مهارات التواصل غيله فير فير اللفظي بين المجموعة التجريبية والمجموعة الضـابطة على القياسين البعدي

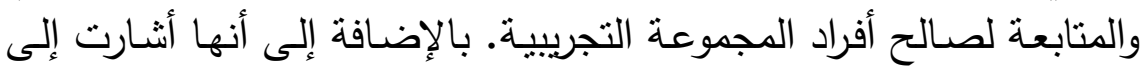
عدم وجود فروق ذات دلالة إحصائية في السلوك الاجتماعي المناسب بين

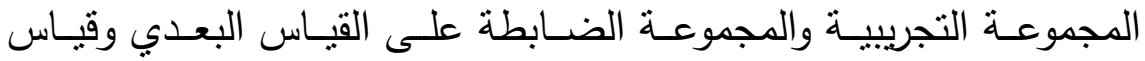
المتابعة، في حين وجدت فروق ذات دلالة إحصائية في السلوك الاجتماعي غير المناسـب بين المجموعـة التجريبية والمجموعـة الضـابطة على القياس وله البعدي وقياس المتابعة لصالح المجموعة التجربيية. وتتفق هذه النتيجة مع ما ورد في الإطار النظري للدراسـة حيث أن هناك عدد كبير من مناهج علاج مهارات التفاعل الاجتماعي المقترحة من قبل 
المتخصصين لتحسين الخلل الاجتماعي في سلوك الأفراد الذين يعانون من

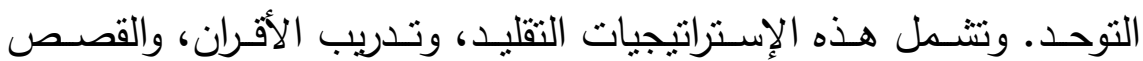
الاجتماعيـة، وتعليم مهارات التفاعل الاجتمـاعي والإدراك الاجتمـاعي في وهي مجموعات. هنالك أيضناً عدد كبير من أساليب العـلاج التي تستخدم لتقليل المشكلات الحسية والحركية، وتشمل هذه العلاجات التعلم الحسي، تدريب التكامـل السـعي وعـلاج التكامـل الحسـي الرجعي التي يكـون لهـا تأثيرات

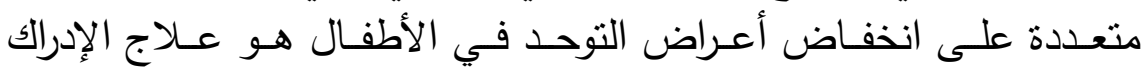

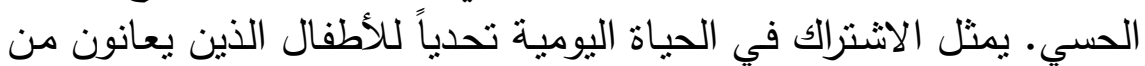
اضطرابات طيف التوحد (ASD) في المشاركة والمهارات في الأنشطة اليومية هي تتأثز بالأداء الحسي، ويلعب التطور الحسي والحركي دورا هاماً في تعليم الأطفال الصغار ، وعادةً ما يستخدمون المهارات الحسية والحركية

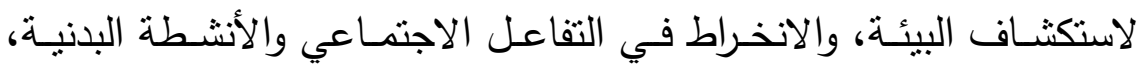

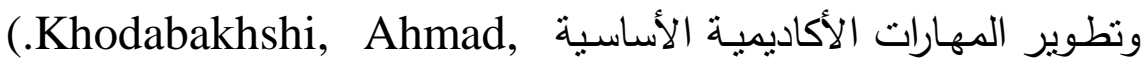
Mokhtar, 2014,39).

وترى الباحثة أنه يمكن التوصل إلى التتوع الكبير في الأسـاليب العلاجية لاضـطراب التوحـد يـدل علي مـدى الاهنمـام مـن جانـب عـد كبيـر مـن المتخصصسين في المجـالات المختلفـة، وأن نجـاح بعض أسـاليب التدريب والتأهيـل، والتفاعـل التربـوي والاجتمـاعي مـع حالـة مـن حـالات الأطفـال التوحديين لا يعني بالضرورة نجاحها في كل الحالات المماثلة؛ وذلك لأن لكل طفل توحدي خصائصسه المحددة التي تميزه عن غيـره مـن الأطفال بسبب الفروق الفرديـة، فلكل طفل ظروفه وقدراته، ونوعيـة ودرجـة إعاقته، وله ما يناسبه من أسس ومناهج وأساليب للتدريب والتأهيل. 


\section{نتائج الفرض الثاني وتفسيره ومناقشته:}

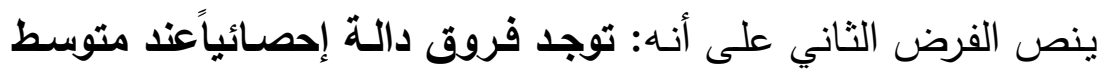

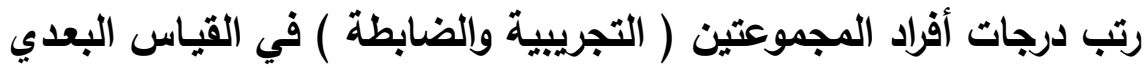

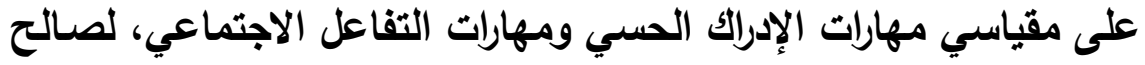
المجموعة التجريبية.

$$
\text { وللتحقق من صحة الفرض قامت الباحثة بالآتي: }
$$

1-الإحصاء الوصفي " المتوسطات والانحرافات المعيارية لكل من القياس

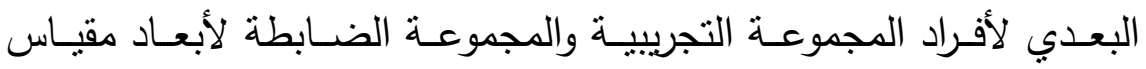
مهارات الإدراك الحسي والدرجة الكلية.

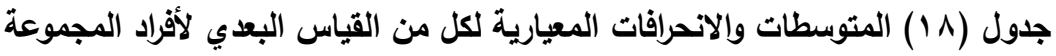
التجريبية والمجموعة الضابطة لأبعاد مقياس مهارات الإدراك الحسي والدارجة الكابل الكلية

\begin{tabular}{|c|c|c|c|c|}
\hline \multicolumn{2}{|c|}{ المجموعة الضابطة ن=V } & \multicolumn{2}{|c|}{ V=المجموعة التجريبية ن V } & \multirow{2}{*}{ أبعاد مهارات } \\
\hline $\begin{array}{c}\text { المعياري } \\
\text { الانحراف) }\end{array}$ & المتوسط (م) & المعياري(ع) الاحراف & $\begin{array}{c}\text { المتوسط (م) } \\
\text { (م) }\end{array}$ & \\
\hline$\cdot, \wedge 9$ & $r \cdot, r$ & $\cdot, \wedge q$ & $1 \cdot, 1$ & التمييز الحركي \\
\hline$\cdot, \mathrm{v} 0$ & YY,O & $\cdot, v_{1}$ & $1 r, r$ & التمييز البصري \\
\hline$\cdot, \mathrm{V} \wedge$ & $r, r$ & $\cdot, \Lambda \Gamma$ & 11,0 & التمييز السمعي \\
\hline$\cdot, \wedge 9$ & $r \cdot, l$ & $\cdot, \wedge 9$ & $1 \cdot, r$ & التمييز اللمسي \\
\hline$\cdot, \mathrm{V} \varepsilon$ & YY,V & $\cdot, \mathrm{V} \wedge$ & $1 Y, 1$ & التمييز الثمي \\
\hline$\cdot, \vee \vee q$ & Y $1, r$ & $\cdot, \Lambda \leqslant$ & 11,1 & التمييز التذوقى \\
\hline $1, v 9$ & TYN & 1 & 71 & الارجة الكلية \\
\hline
\end{tabular}

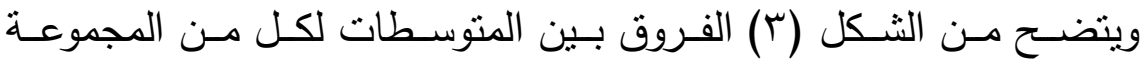

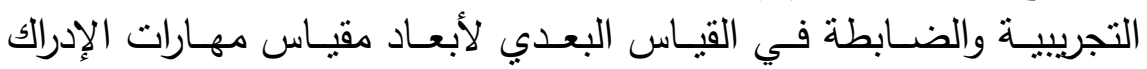
الحسي والدرجة الكلية. 


\section{المجلة العلمية لكلية رياض الأطفال - جامعة بورسعيد}

\section{0}

150

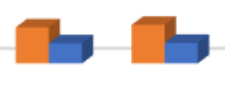

الدرجة

الكلية

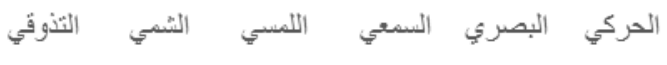

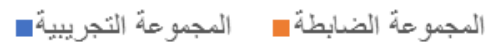

شكل (ץ) الفروق بين المتوسطات لكل من المجموعة التجريبية والضابطة في القياس البعدي لأبعاد مقياس مهارات الإدراك الحسي والدرجة الكوعة الكلية

باستخدام اختبار "مان وتتي u-test "لحساب دلالة الفروق بين القياس

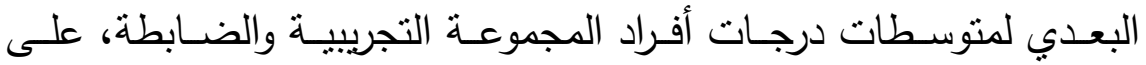
مقياس مهارات الإدراك الحسي وكانت النتائج كما يلي : جدول (9 9 ) متوسطات درجات أفراد المجموعة التجريبية والضابطة في القياس البعدي ونتائج

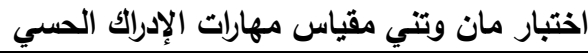

\begin{tabular}{|c|c|c|c|c|c|c|c|c|c|}
\hline \multirow{2}{*}{\multicolumn{2}{|c|}{ حجم التأثير باستخاد }} & \multirow{3}{*}{ مستو } & \multirow[t]{3}{*}{ قيمة z } & \multirow{3}{*}{ قيمة } & \multirow{2}{*}{\multicolumn{2}{|c|}{ 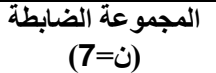 }} & \multirow{2}{*}{\multicolumn{2}{|c|}{ المجموعة التجريبية }} & \multirow[t]{3}{*}{ الأبعاد } \\
\hline & & & & & & & & & \\
\hline & & & & & الرتب & الزرتب & الرتب & الزتب & \\
\hline مرتفع| & $\cdot, \wedge \circ 4$ & $\cdot, \cdot 1$ & $r, V_{1}$ & . & $r$ & 10 & $\Lambda$ & $\varepsilon$. & الحركييز \\
\hline مرتفع| & $\cdot, \wedge \vee \varepsilon$ & $\cdot, \cdot 1$ & Y, Y & • & $r$ & 10 & $\Lambda$ & $\varepsilon$. & البصريز \\
\hline مرتفع| & $\cdot, \wedge \bullet 4$ & $\cdot, \cdot 1$ & Y,VI & • & $r$ & 10 & $\Lambda$ & $\varepsilon$. & التمبيز \\
\hline مرتفع| & $\cdot, \wedge \vee \varepsilon$ & $\cdot, \cdot 1$ & $r, 74$ & • & $r$ & 10 & $\Lambda$ & $\varepsilon$. & اللمبيز \\
\hline
\end{tabular}


المجلة العلمية لكلية رياض الأطفال - جامعة بورسعيد

\begin{tabular}{|c|c|c|c|c|c|c|c|c|c|}
\hline مرتفع & $\cdot, \wedge \vee \varepsilon$ & $\cdot, \cdot 1$ & Y,74 & - & $r$ & 10 & $\Lambda$ & $\varepsilon$. & الثمييز \\
\hline مرتفع & $\cdot, \wedge \circ 4$ & $\cdot, \cdot 1$ & $r, V I$ & . & $r$ & 10 & $\Lambda$ & $\varepsilon$. & التذوقييز \\
\hline مرتفع & $\cdot, \wedge 07$ &., .1 & $r, v i$ & . & $r$ & 10 & $\Lambda$ & $\varepsilon$. & اللارجة \\
\hline
\end{tabular}

يتضح من جدول (19) ما يلي:

ا-وجود فروق ذات دلالة إحصائية عند مستوى ( ( . • ) بين متوسط رتب أفراد المجموعـة التجريبيـة " وأفراد المجوعـة الضـابطة في القيـاس البعـدي

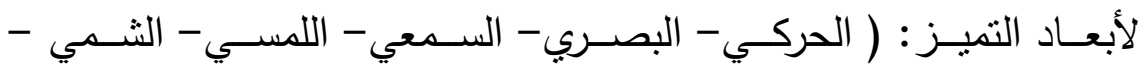
التذوقي)" لصالح المجموعة التجريبية. r-وجود فروق ذات دلالة إحصائية عند مستوى (1 ( , • ) بين متوسط رتب

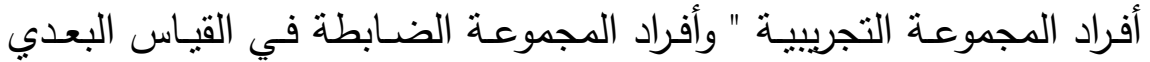
للارجة الكلية لمقياس مهارات الإدراك الحسي " لصالح المجموعة التجريبية.

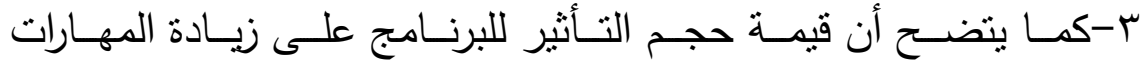
الاجتماعية بدلالة بطاقة الملاحظة لدى أفراد العينة بلغت (r=0.856 )وهي قيمة مرتفعة وجيدة.

ع- كمـا قامــت الباحثة بالإحصــاء الوصـفي "المتوسـطات والانحرافـات المعياربة" لكلٍ من القياس البعدي للمجموعة التجربيية والضابطة في مقياس لإس لإساء مهارات التفاعل الاجتماعي على الأبعاد والدرجة الكلية. 


\section{المجلة العلمية لكلية رياض الأطفال - جامعة بورسعيد}

جدول (·r) المتوسطات والانحرافات المعيارية لكلٍ من القياس البعدي للمجموعة التجريبية

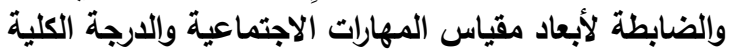

\begin{tabular}{|c|c|c|c|c|}
\hline \multicolumn{2}{|c|}{ المجموعة الضابطة } & \multicolumn{2}{|c|}{ المجموعة التجريبية } & \multirow[t]{2}{*}{ الأبعاد } \\
\hline 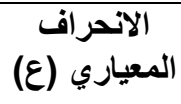 & $\begin{array}{c}\text { المتوسط (م) } \\
\text { (م) }\end{array}$ & 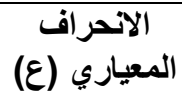 & $\begin{array}{c}\text { المتوسط } \\
\text { (م) }\end{array}$ & \\
\hline $1, .90$ & $1 \wedge, \Lambda$ & $r, I V$ & $r q, r$ & التواصل الاجتماعي \\
\hline 1 & $r \cdot$ & $1, \wedge r$ & $r q, \varepsilon$ & الاستقبال \\
\hline $1, \wedge \vee 1$ & IV & $r, \cdot r$ & $r v, r$ & التقليا \\
\hline$\cdot, \Lambda \mu V$ & $r \varepsilon, \Lambda$ & $\cdot, v_{1}$ & $\varepsilon r$ & التعاون \\
\hline $1,9 \leq 9$ & $\Lambda \cdot, 7$ & $0, V Y$ & 100,1 & الارجة الكلية \\
\hline
\end{tabular}

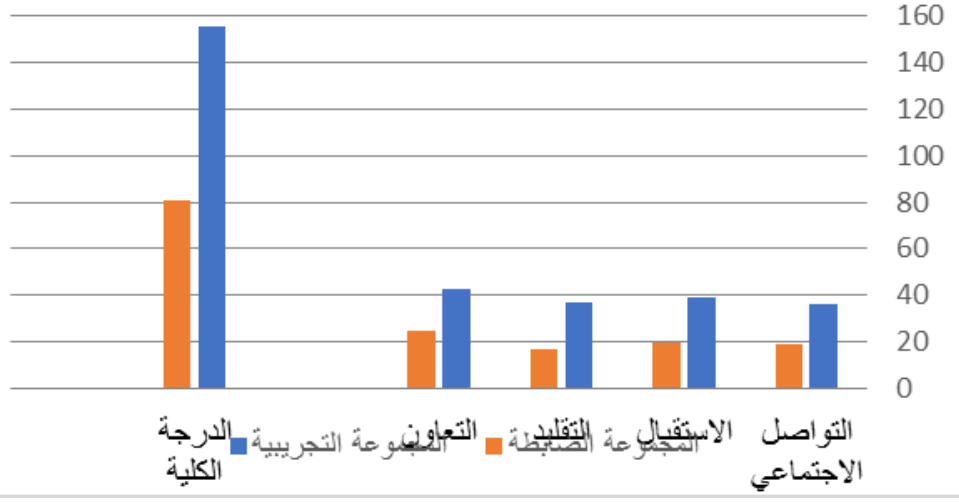

شكل ( ؛ ) يوضح الفروق بين متوسطات القياس البعدي للمجموعة التجريبية والضابطة

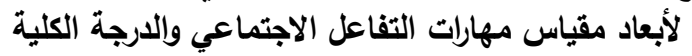


r-باستخدام اختبار "مان وتتي u-test "لحساب دلالة الفروق بين القياس

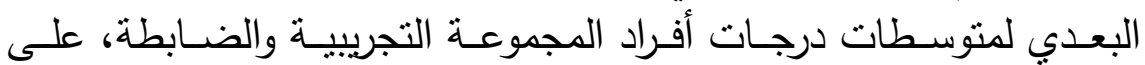
مقياس مهارات التفاعل الاجتماعي وكانت النتائج كما يلي : جدول ( l l متوسطات درجات أفراد المجموعة التجريبية والضابطة في القياس البعدي ونتائج اختبار مان وتني مهارات التفاعل الاجتماعي

\begin{tabular}{|c|c|c|c|c|c|c|c|c|c|}
\hline \multicolumn{2}{|c|}{ باستخدام معادلة كوهين } & \multirow{2}{*}{ مستو } & \multirow[t]{2}{*}{ قيمة Z ق } & \multirow[t]{2}{*}{ قيمة } & \multicolumn{2}{|c|}{ المجموعة } & \multicolumn{2}{|c|}{ 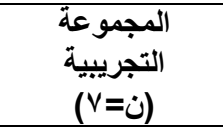 } & \multirow[t]{2}{*}{ الأبعاد } \\
\hline & & & & & متوسط & الرتبوع & متوسط الرتب & الرجبوع & \\
\hline مرتفع & $\cdot, \wedge r \wedge$ & $\cdot, \cdot 1$ & r, Yo & . & $r$ & 10 & $\Lambda$ & $\varepsilon$. & التواصل \\
\hline مرتفع & $\cdot, \wedge r r$ & $\cdot, \cdot 1$ & Y,Tr & . & $r$ & 10 & $\Lambda$ & $\varepsilon$. & الاستقبال \\
\hline مرتفع & $\cdot, \wedge \Upsilon^{q}$ & $\cdot, \cdot 1$ & Y,TY & . & $r$ & 10 & $\Lambda$ & $\varepsilon$ & التقليا \\
\hline مرتفع & $\cdot, \wedge \leqslant 1$ & $\cdot, \cdot 1$ & Y,7 & . & $r$ & 10 & $\Lambda$ & $\varepsilon$ & التعاون \\
\hline مرتفع & $\cdot, \wedge$ & $\cdot, \cdot 1$ & r, 10 & . & $r$ & 10 & $\Lambda$ & $\varepsilon$. & الارجة \\
\hline
\end{tabular}

ا-وجود فروق ذات دلالمة إحصـائية عند مستوى (1 ( , • ) بين رتب أفراد المجموعة التجريبية " وأفراد المجوعة الضـابطة في القياس البعدي لمهارات ( التواصـل الاجتمـاعي_- الاستقبال - التقليد - التعـاون) " لصـالح المجموعـة التجريبية.

ץ- وجود فروق ذات دلالـة إحصـائية عند مستوى (1 ·, • ) بين رتب أفراد

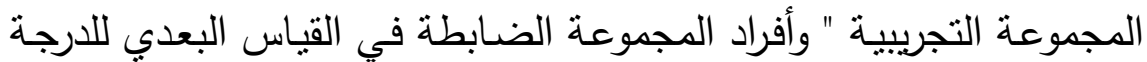
الكلية للمهارات التفاعل الاجتماعي " لصالح المجموعة التجربيية.

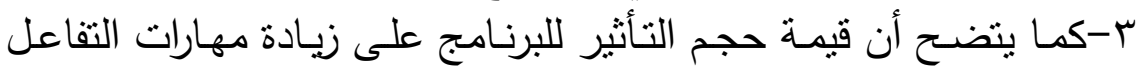
الاجتماعي لدى أفراد العينة بلغت (r=0.838) وهي قيمة مرتفعة وجيدة . 
من خلال النتائج تحققت صحة الفرض الثاني.

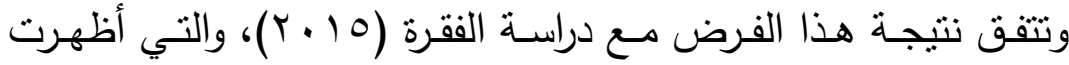

وجود فروق ذات دلالـة إحصـائية بين المجموعـة التجربييـة والضـابطة في

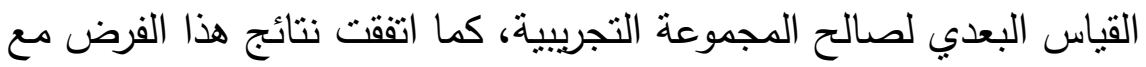

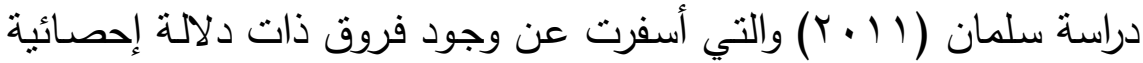
بين درجات المجموعة التجريبية ودرجات المجموعـة الضـابطة في القياس

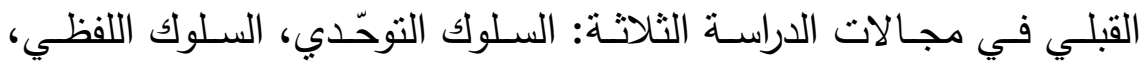
والتفاعل الاجتماعي، وذللك في القياس القبلي والبعدي.

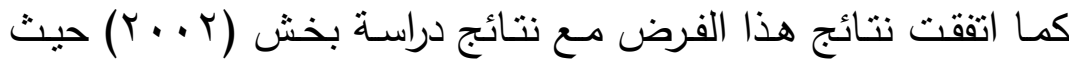
وجـدت فـروق ذات دلالـة إحصـائية بـين متوســات درجـات المجمـوعتين التجريبية والضابطة في القياس البعدي للسلوك العدواني، ووجود فروق ذات دلالـة إحصـائية بـين متوسـي درجـات المجموعـة التجربيــة في القياسـين القبلي والبعدي للسلوك العدواني وأبعاده وتتمية مهارات تفاعلهم الاجتماعي.

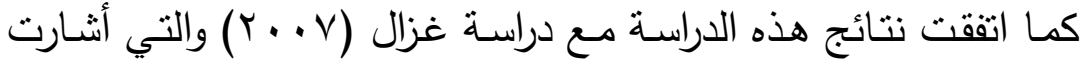

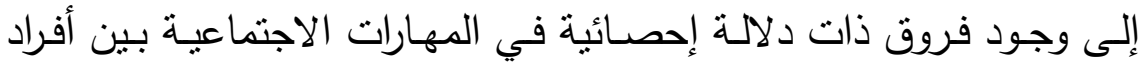
المجموعة التجريبية والمجموعة الضـابطة على القياس البعدي لصسالح أفراد

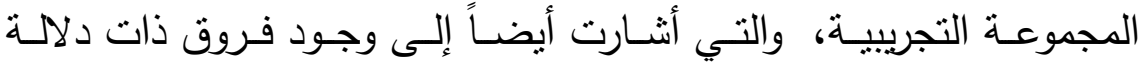
إحصائية في المهارات الاجتماعية بين أفراد المجموعة التجريبية والمجموعة ودية ودية الضابطة علي قياس المتابعة لصالح أفراد المجموعة التجربيية. كما اتفقت نتائج هذا الفرض مع دراسـة عبد الفتاح (9 . . ب) والتي توصلت إلى وجود

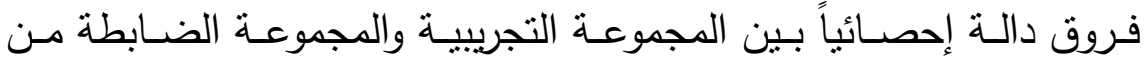
الأطفال الذاتوبين في المهارات الاجتماعية بعد تطبيق البرنامج وذللك لصالح المجموعة التجريبية. 


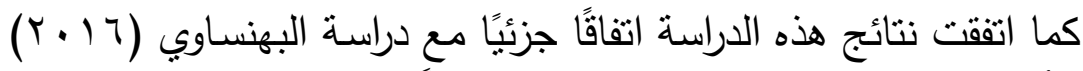

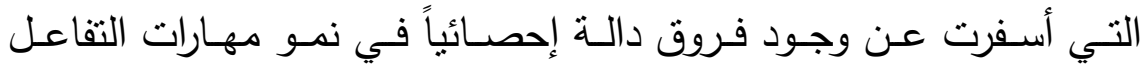
الاجتماعي لأطفال التوحد بين أفراد المجموعتين التجريبية والضـابطة وذلك لصالح المجموعة التجريبية.

بينما اختلفت نتائج هذا الفرض مع نتائج دراسة الغامدي (س ب . ب) والتي توصلت إلى عدم وجود فروق دالة إحصـائياً في منوسطات رتب درجات أفراد المجموعة الضـابطة على مقياس مظاهر العجز في التواصل اللغوي وفي التفاعل الاجتماعي لأطفال التوحّد قبل وبعد تطبيق البرنامج العلاجي .

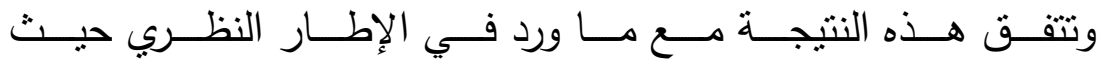
ذكر Khodabakhshi, 2014, P36)إن الاشتراك في الحياة اليومية

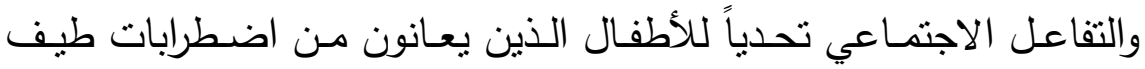
التوحد (ASD) في المشاركة والمهارات بالأنشطة اليومية بمكن أن تتأثز

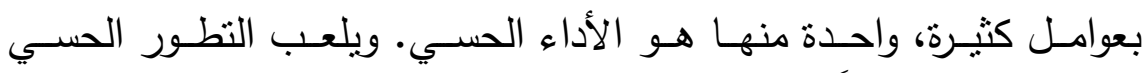

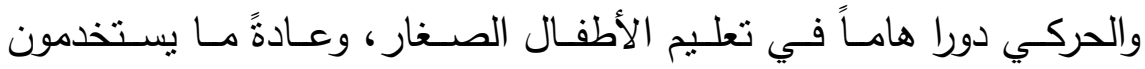

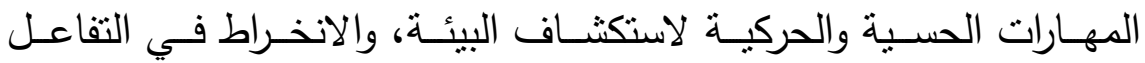
الاجتماعي والأنشطة البدنية، وتطوير المهارات الأكاديمية الأساسية. وترى الباحثة أن التقدم الواضـح الذي يثـهده العصر الحالي في مبدان البرامج التربويـة المقدمـة للأطفال ذوي اضطراب التوحد إلا أن جدلاً كبيـراً

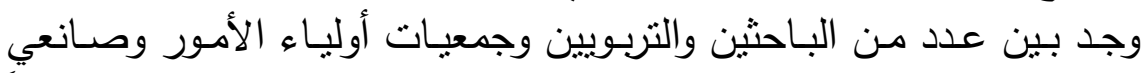
القرار حول فاعليـة بعض تلك البرامج المقترحة، ولعل الجدل ظهر أساسـاً

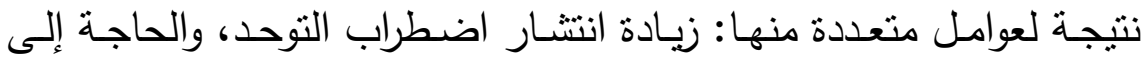
تقديم خدمات التذخل المبكر، والزبادة الكبيرة في الأدب النظري حول مول تعداد البرامج المقدمة، والنقص الواضـح في وجود ضوابط علمية ليتم من خلاللها 
الحكم على مدى فاعلية البرامج التربوية والخدمات المقدمة، أو على الأقل

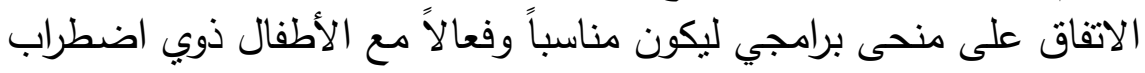
التوحد.

\section{نتائج الفرض الثالث وتفسيره ومناقشته:}

ينص الفرض الثالث على أنه: " لا توجد فروق ذات دلالة إحصائية بين

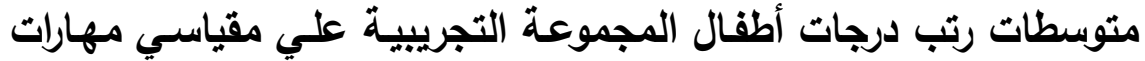

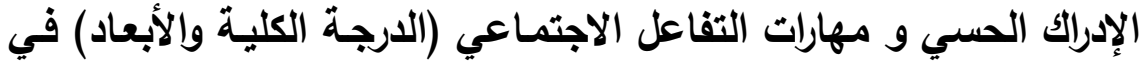
القياسين البعدي والتببعي." مهات وللتحقق من صحة الفرض قامت الباحثة بالآتي: الإحصـاء الوصـفي " المتوسطات والانحرافـات المعياريـة لكل مـن القيـاس التببعي والبعدي لأبعاد مقياس مهارات الإدراك الحسي والدرجة الكلية. كما الحسات

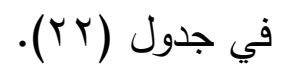

\begin{tabular}{|c|c|c|c|c|}
\hline \multicolumn{2}{|c|}{ القياس التتبعي } & \multicolumn{2}{|c|}{ القياس البعدي } & مهار أبعاد \\
\hline 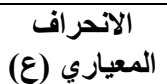 & $\begin{array}{c}\text { المتوسط } \\
\text { (م) }\end{array}$ & 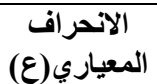 & المتوسط & الإدراك الحسي \\
\hline$\cdot, \wedge \mathrm{V}$ & $1 \cdot, r$ & $\cdot, \wedge q$ & $1 \cdot, 1$ & التمييز الحركي \\
\hline$\cdot, \mathrm{V}$. & $I Y, Y$ & $\cdot, V_{1}$ & Ir,r & التمبيز البصري \\
\hline$\cdot, \wedge \varepsilon$ & 11,7 & $\cdot, \wedge r$ & 11,0 & التمييز السمعي \\
\hline$\cdot, \wedge \vee$ & $1 \cdot, 1$ & $\cdot, \wedge 9$ & $1 \cdot, r$ & التمييز اللمسي \\
\hline$\cdot, V \vee$ & $I Y, Y$ & $\cdot, \vee \wedge$ & $\mid r, 1$ & التمييز الثمي \\
\hline$\cdot, \wedge 0$ & $11, \mathrm{~V}$ & $\cdot, \wedge \varepsilon$ & 11,1 & التمييز التذوقي \\
\hline 1 & 71 & 1 & 71 & الارجة الكلية \\
\hline
\end{tabular}




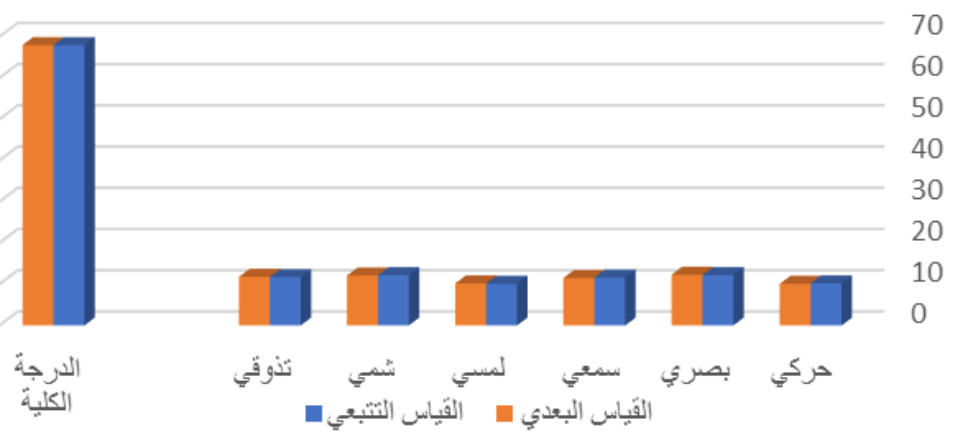

شكل (•) يوضح الفروق بين المتوسطات لكل من القياس التتبعي والبعدي لأبعاد مقياس مهارات الإدراك الحسي والارجة الكلية

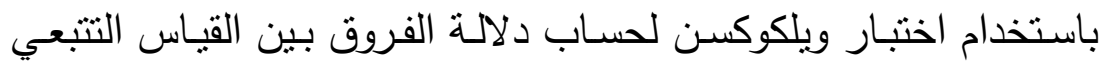
والبعدي لرتب درجات أفراد المجموعة التجريبية على مقياس مهارات الإدراك

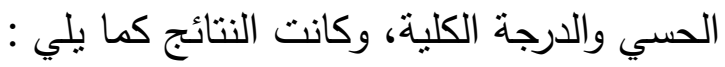

جدول (rr) نتائج اختبار " ويلكوكسن" لدلالة الفروق بين القياسين التتبعي والبعدي

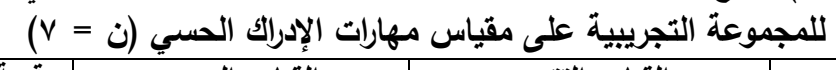

\begin{tabular}{|c|c|c|c|c|c|c|c|c|}
\hline \multirow[t]{2}{*}{ مستوية } & \multirow[t]{2}{*}{ قُ قيمة } & \multicolumn{3}{|c|}{ 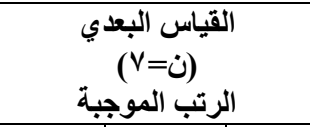 } & \multicolumn{3}{|c|}{$\begin{array}{c}\text { القياس التتبعي } \\
\text { الرتب السالبة }\end{array}$} & \multirow[t]{2}{*}{ مهارات الإدراك } \\
\hline & & متوسط & مجموع الرتب & ن & متوسط & مجموع الرتب & ن & \\
\hline غير دال & $1, Y_{1}$ & 1,0 & $r$ & $r$ & 1,0 & $r$ & $r$ & التمييز الحركي \\
\hline غير دال & $1, \ldots$ & 1,0 & 1,0 & 1 & 1,0 & 1,0 & 1 & التمييز البصري \\
\hline غير دال & $1, r \varepsilon$ & r,o & 0 & $r$ & $r, 0$ & 0 & $r$ & التمييز السمعي \\
\hline غير دال & $1, \ldots$ & 1,0 & $r$ & $r$ & 1,0 & $r$ & $r$ & التمبيز اللمسي \\
\hline غير دال & $1, \pi \varepsilon$ & 1,0 & 1,0 & 1 & 1,0 & 1,0 & 1 & التمييز الشمي \\
\hline غير دال & $1, Y_{1}$ & 1,0 & $r$ & $r$ & 1,0 & $r$ & $r$ & التمييز التذوقي \\
\hline غير دال & $1, r \varepsilon$ & $r$ & Ir & 7 & $r$ & Ir & 7 & الدرجة الكلية \\
\hline
\end{tabular}




$$
\text { يتضح من جدول (Yr) ما يلي: }
$$

• لا توجد فروق ذات دلالة إحصائية بين رتب أفراد المجموعة التجربيية

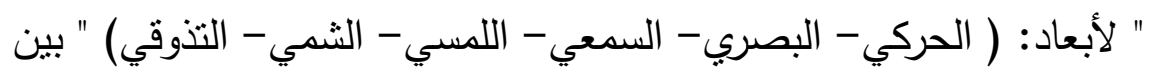
القياس التتبعي والقياس البعدي. • لا توجد فروق ذات دلالة إحصائية بين رتب أفراد المجموعة التجربيية

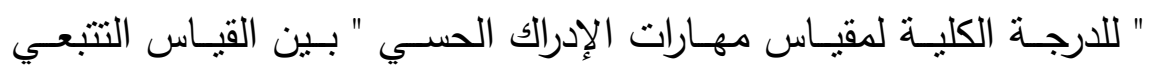
والقياس البعدي.

-ثم قامت الباحثة بالإحصاء الوصفي "المتوسطات والانحرافات المعيارية لكل من القياس التتبعي والبعدي على مقياس مهارات التفاعل الاجتماعي. جدول (؟ r) المتوسطات والانحرافات المعيارية لكل من القياس التتبعي على مقياس مهارات

\begin{tabular}{|c|c|c|c|c|}
\hline \multicolumn{2}{|c|}{ القياس البعدي } & \multicolumn{2}{|c|}{ القياس التتبعي } & \multirow{2}{*}{$\begin{array}{c}\text { التفاعل الاجتماعي } \\
\text { الأبعاد } \\
\text { الأماعي }\end{array}$} \\
\hline 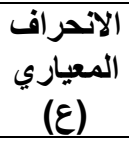 & $\begin{array}{l}\text { المتوسط (م) } \\
\text { (م) }\end{array}$ & المعياري(عاف) & $\begin{array}{c}\text { المتوسط (م) } \\
\text { (م) }\end{array}$ & \\
\hline$r, 1 \uparrow \Lambda$ & $r q, r$ & $r, 1 \pi$ & $r v, \varepsilon$ & التواصل الاجتماعي \\
\hline $1, \Lambda 1 V$ & $r q, \xi$ & $Y, \varepsilon \cdot \Lambda$ & $r 9,7$ & الاستقبال \\
\hline$r, . r r$ & $r v, r$ & r,vrq & $r v$ & 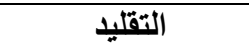 \\
\hline$\cdot, \mathrm{V} \cdot \mathrm{V}$ & 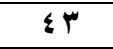 & $\cdot, \wedge q \varepsilon$ & $\varepsilon r, \tau$ & التعاون \\
\hline $0, \vee \backslash \wedge$ & 100,1 & $\varepsilon, \leqslant 0$ & $10 \mathrm{~V}, \mathrm{~T}$ & الدارجة الكلية \\
\hline
\end{tabular}




\section{المجلة العلمية لكلية رياض الأطفال - جامعة بورسعيد}

\section{0}

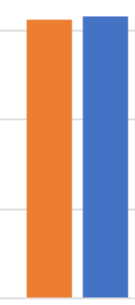

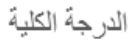

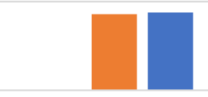

الثنعاون
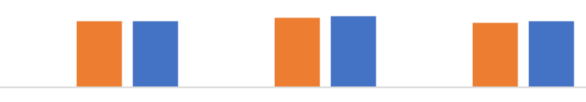

150

100

الثو اصل الاجتماعي الاستقبّل

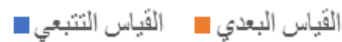

شكل (†) يوضح الفروق بين المتوسطات لكل من القياس التتبعي والبعدي لأبعاد مقياس

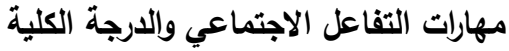

ا-باستخدام اختبار ويلكوكسن لحسـاب دلالة الفروق بين القباس التتبعي

والبعدي لرتب درجات أفراد المجموعة التجريبية، وكانت النتائج كما يلي :

جدول († Y) نتائج اختبار " ويلكوكسن" لالالة الفروق بين القياسين التبعي والبعدي

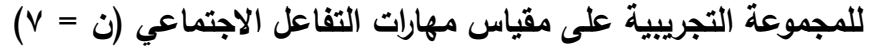

\begin{tabular}{|c|c|c|c|c|c|c|c|c|}
\hline \multirow[t]{2}{*}{ مستوي } & \multirow[t]{2}{*}{ قيمة Z } & \multicolumn{3}{|c|}{ 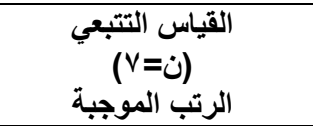 } & \multicolumn{3}{|c|}{ 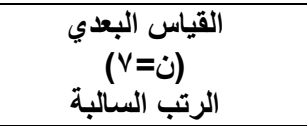 } & \multirow{2}{*}{ الاجتهارل الأبعات } \\
\hline & & متوسط & مجموع الرتب & $\dot{ن}$ & منتوسط الرتب & مجموع الرتب & ن & \\
\hline غير دال & $1, \Gamma \leqslant$ & . & . & . & 1,0 & $r$ & $r$ & الاجتماعي \\
\hline غير دال & $\cdot, \leqslant$ \{ & 1 & 1 & 1 & r & $r$ & 1 & الاستقبال \\
\hline غير دال & $1, \ldots$ & 1 & 1 & 1 & . & . & $\cdot$ & التقليا \\
\hline غير دال & $1, r \varepsilon$ & . & . & . & 1,0 & $r$ & $r$ & التعاون \\
\hline غير دال & $1, r_{1}$ & $r$ & $r$ & 1 & $r$ & $1 r$ & $\xi$ & الدرجة الكلية \\
\hline
\end{tabular}




$$
\text { يتضح من جدول (ro) ما يلي: }
$$

• عدم وجود فروق ذات دلالـة إحصسائية عند مستوى (0 . . ) بين رتب

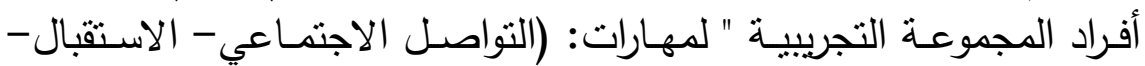
التقليد- التعاون) " بين القياس البعدي والقياس والتتبعي. • عدم وجود فروق ذات دلالة إحصسائية عند مستوى (0. . • ) بين رتب لبن أفراد المجموعة التجريبية " للارجة الكلية للمهارات التفاعل الاجتماعي " بين القياس البعدي والتتبعي. ومن خلال ما سبق يتضح أن هذه النتائج تحقق الفرض الثالث. كمـا اتفقت نتيجـة هذا الفـرض مـع دراسـة بـن صـديق( V . . r) والتي

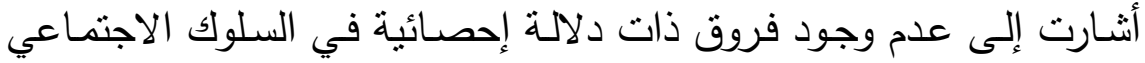
المناسب بين المجموعة التجريبية والمجموعة الضـابطة على القباس البعدي وقياس المتابعة .

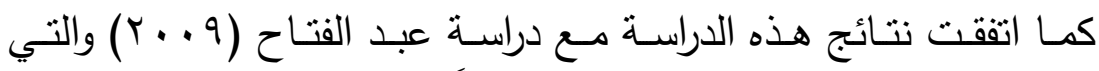

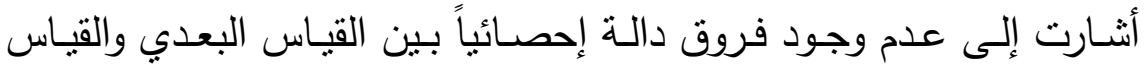
التببعي للمجموعة التجريبية في المهارات الاجتماعية .

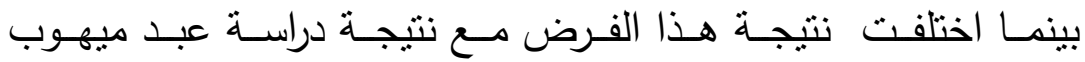

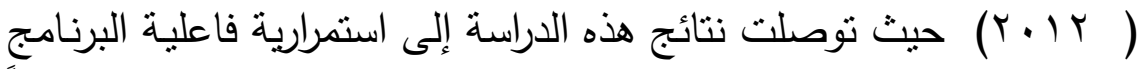
لدى الأطفال التوحديين إلى ما بعد فترة المتابعة، ووجود فروق دالة إحصائياً بين منتسطي درجات المقياسين البعدي والتتبعي للمجموعة التجريبية. - مقد أسفر التحليل الاحصائي للبيانات عن وجود فروق دالة إحصائياً في لئي نمو مهارات الإدراك الحسي والتفاعل الاجتماعي لأطفال التوحد بين أفراد 
المجموعتين التجريبية والضابطة وذلك لصالح المجموعة التجربيية تعزى إلى البرنامج التدريبي القائم على الإثراء الحسي.

وترى الباحثة أن الإدراك الحسي ومهارات التفاعل الاجتماعي واحدة من أكثر الخصائص المتأثزة سلبًا باضطراب التوحد، وبعود ذلك إلى أن الطفل

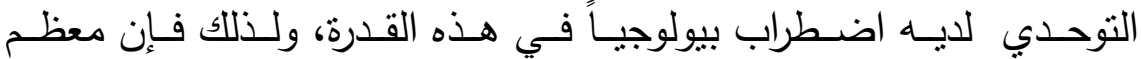

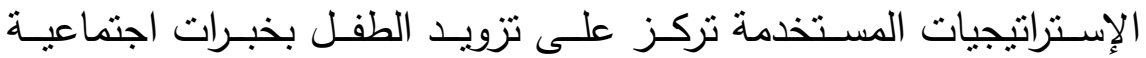

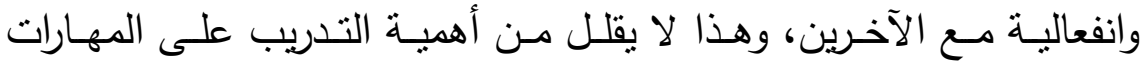
الاجتماعية حيث تمثل جزيًا أساسيًا من البرامج التربوبـة والتدربيبة المقدمـة للطفل.

\section{توصيات الدراسة:}

في ضوء نتائج الدراسة الحالية يمكن تقديم التوصيات التالية: ا.ضـرورة التـدخل المبكر للاضـطراب التوحدي، وتـوفير الآليـات اللززمـة للكثف عن هذا الاضطراب في السنوات الأولى من حياة الطفل، حيث أن تأخر التذخل المبكر وتشخيصـه يؤدي إلى زبادة تعقد اضطراباتهم المختلفة وفي مقدمتهم قصور في الإدراك الحسي ومهارات التفاعل الاجتماعي مما

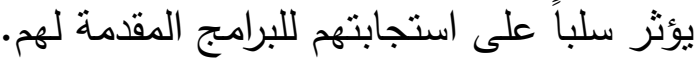

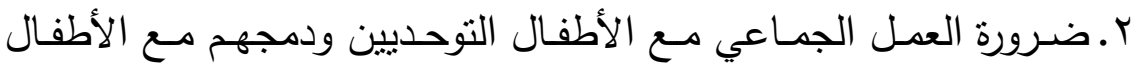
العاديين محددة بأنشطة الإثراء الحسي والتفاعل واللعب الجماعي.

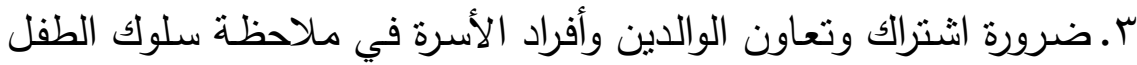
وتطبيق الأنشطة المنزلية باعتبارهم الأشخاص الأكثر اختالاطاً بالطفل.

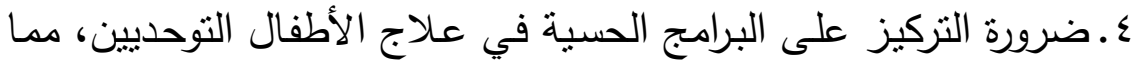
يؤدي إلى تحسين قدرتهم على التفاعل الاجتماعية والتهرئة والتتظيم.

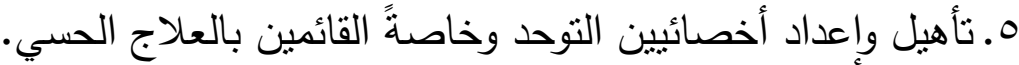


7. ضـرورة تزويد مدراس التربيـة الخاصـة ومراكز تأهيل ذوي الاحتباجـات

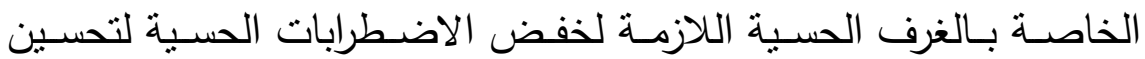

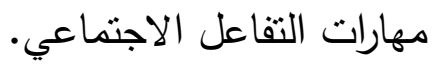

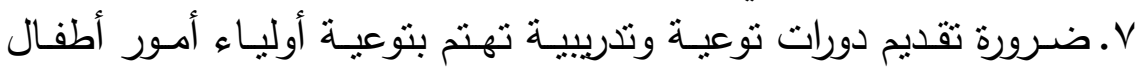
التوحد والمهتمين بهذه الفئة وبطبيعة اضطراباتهم الحسية وأنواعها وأعراضها تورياء وتدريبهر على التعامل معها.

البحوث المقترحة: - اك

في ضوء نتائج الدراسة يمكن اقتراح البحوث التالية:

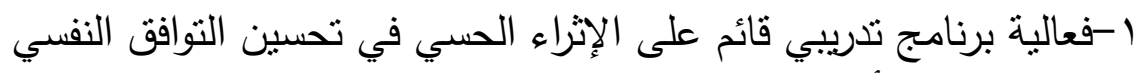
والاجتماعي لدى أطفال التوحد. توني

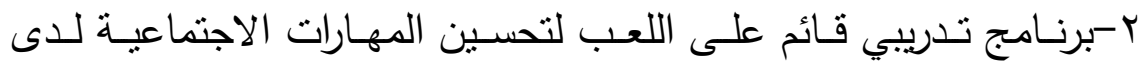

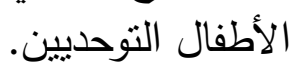

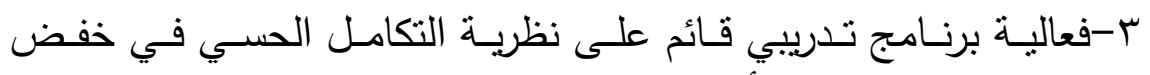

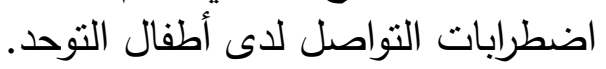

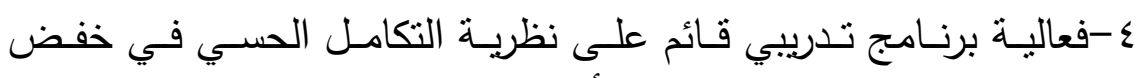
اضطرابات السلوكيات النمطية لاى أطفال التوحد. 


\section{المراجح?}

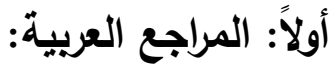

- إبراهيم، علا عبد الباقي (11 + ب). اضطراب التوحد "التوحد، أعراضـه ، أسبابه وطرق علاجها مسع برامج تدربيية وعلاجيبة لتنديبة قدرات الأطفال

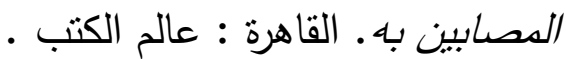

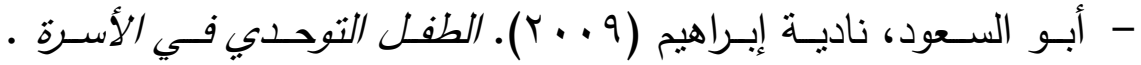

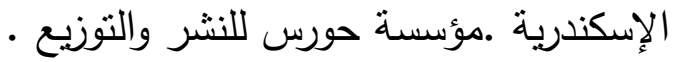

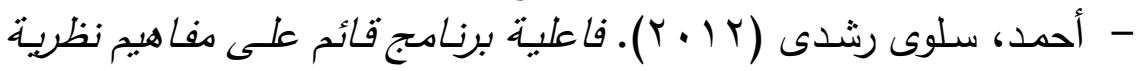

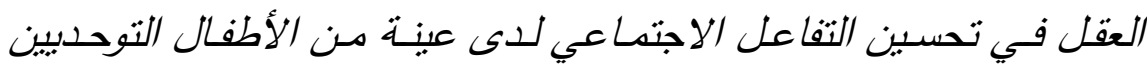

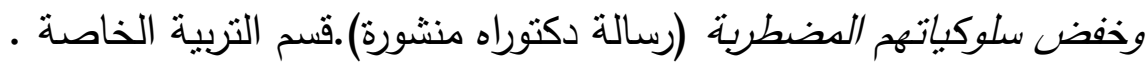

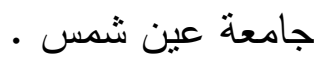
- أحمد، محمد رياض ؛ فئ أبو زيد، خضر مخيمر ؛ إبراهيم، حسام صـابر

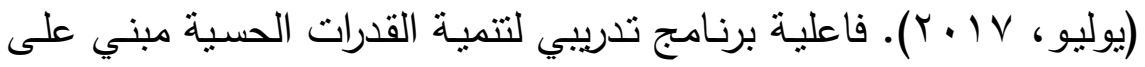
نظرية التكامل الحسي في خفض السلوك الانعزالي لاعى الأطفال التوحديين.

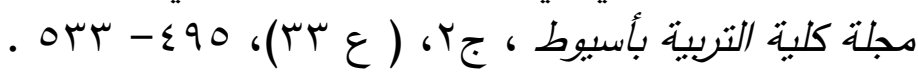

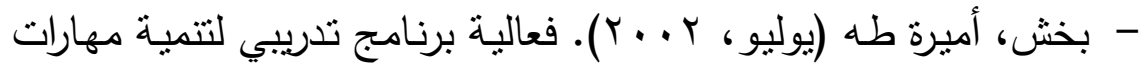

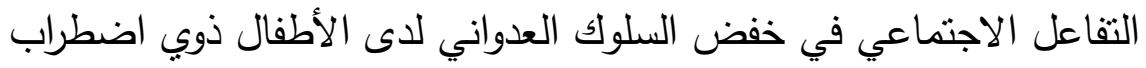

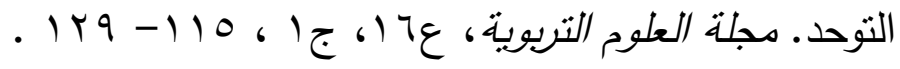

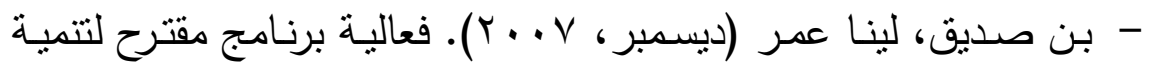

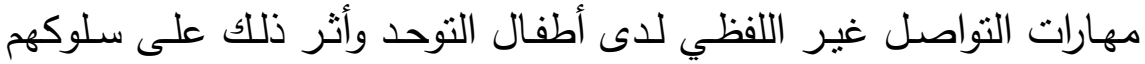

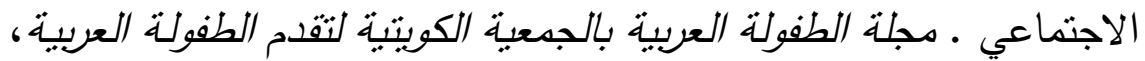

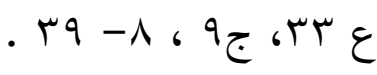


- بهادر ، سعدية محمد علي (997 1997) المرجع في برامج تربية الطفل ما قبل المدرسة . القاهرة : دار الخدمات للنشر . - البهنساوي، أحمد كمال (يوليو ، 7 ( • ب). فاعلية برنامج تلخخل مبكر قائم على التكامل الحسي في تتمية التواصل غير اللفظي لدى عينة من أطفال

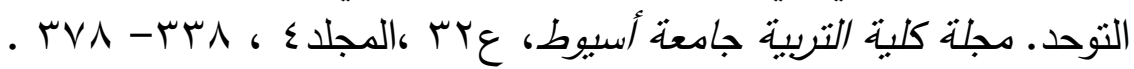

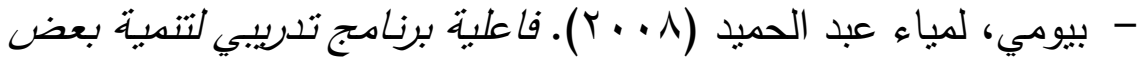
مهارات العنابية بالذات لدى الأطفال التوحدبين ( رسالة دكتوراه منشورة) .

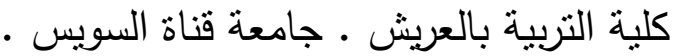

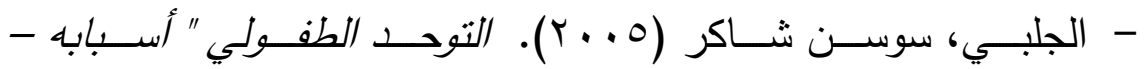

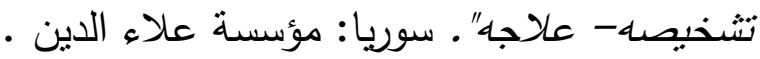

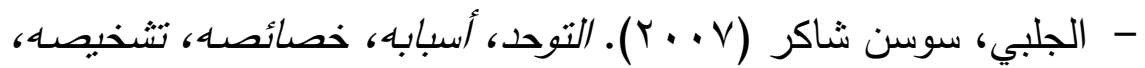
علاجه ـ الأردن: ديبونو للطباعة والنشر .

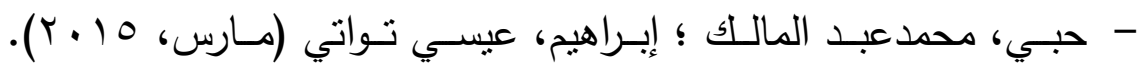
اضـراب الذاتوبـة: بـين الصـعوبات التشخيصـية والآفاق العلاجيـة. مجلـة

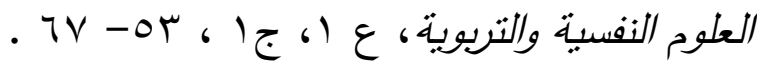

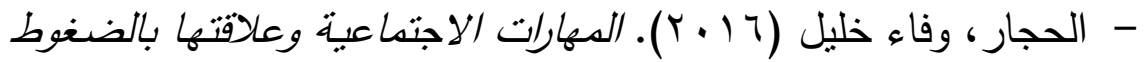
النفسية لدى المرأة القيادية بدحافظات غزة ( رسالة ماجستير منشورة) ـ كلية

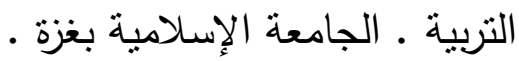

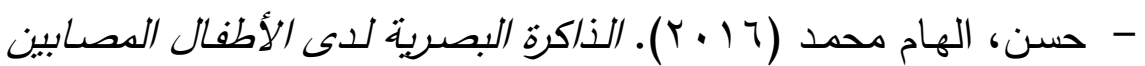

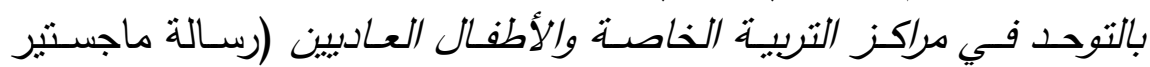

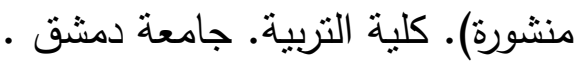

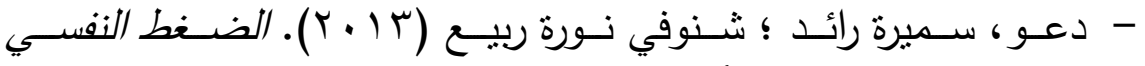
واستراتيجبات المواجهة لدى أم الطفل التوحدي دراسة عبادبية لخدس حالات 
ـ كلبـة العلـوم الاجتماعبـة والإنسـانبة ـ جامعـة أكلـي محنـد - البـويرة .

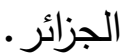

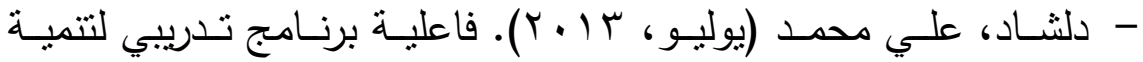

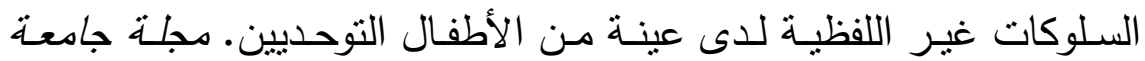

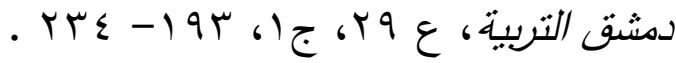

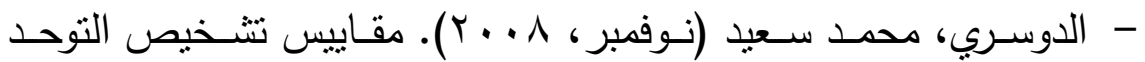

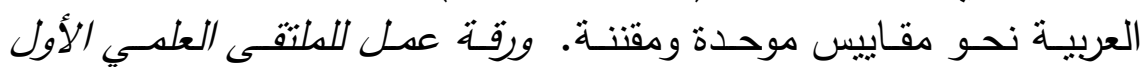
لدراكز التوحد في العالم العربي المنعقد في الغرفة التجاربية الصناعبية بجدة .

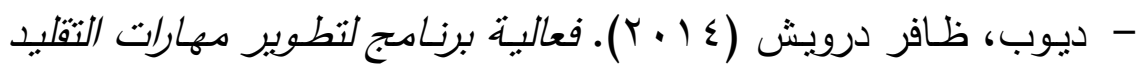

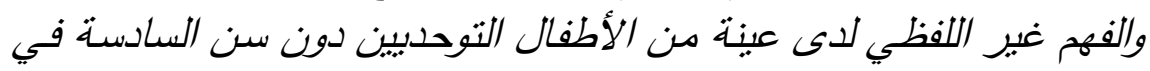

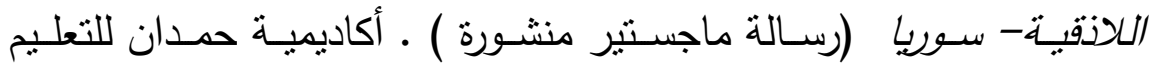

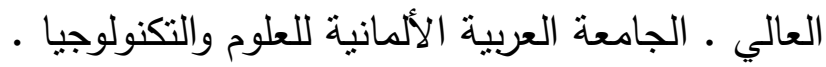

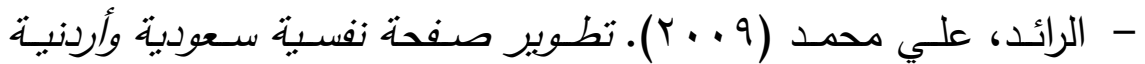

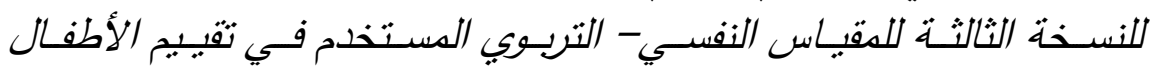

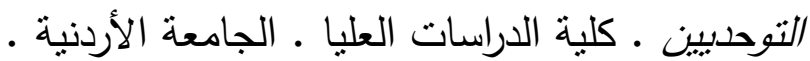

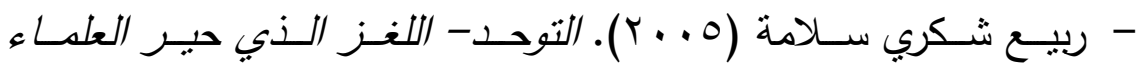

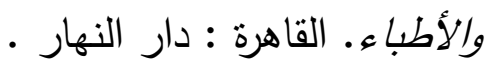

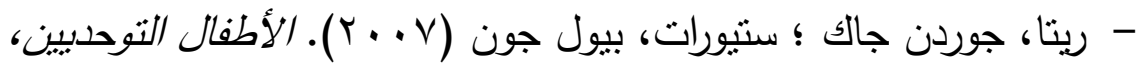
جوانب النمو وطرق النمو وطرق التدربس .(ترجمة رفعت محمود ).القاهرة :

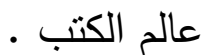
- الزريقـات، إبـراهيم عبـد الله (ع . . ب). التوحـد: الخصـائص والعـلاج.

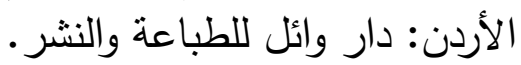


- زبدان، عصام محمد (يناير ، ؟ . . ب). الانهاك النفسي لدى آباء وأمهات

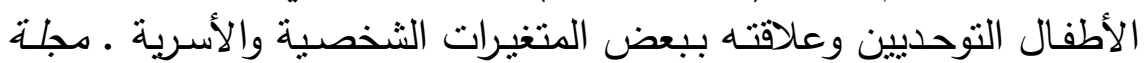

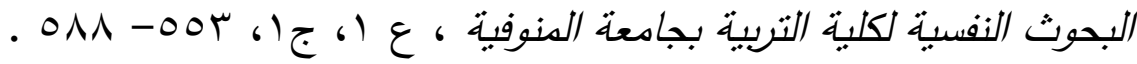

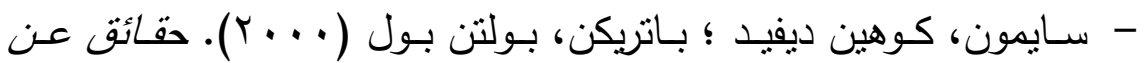

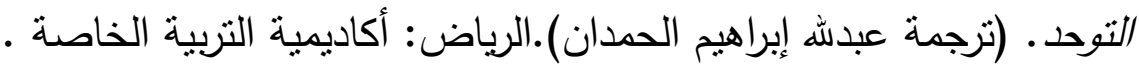

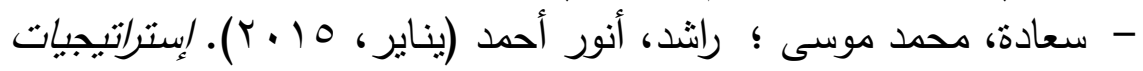

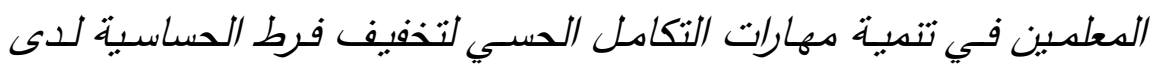
أطفال التوحد: دراسة عبر ثقافة مقارنتة بين مدبنتي عمان والرباض ـ مجلة

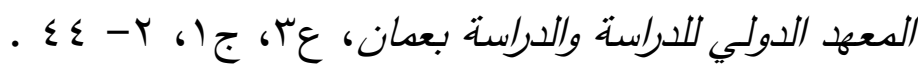

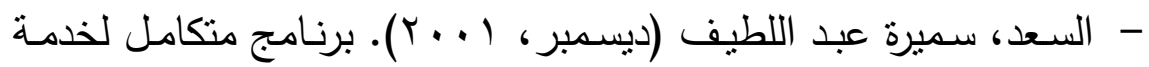
اضطراب التوحد في الوطن العربي. المؤتدر الدولي السابع لاتحاد هبئات الفئات الخاصتة والمعوقين، الثوبخ ، القاهرة .

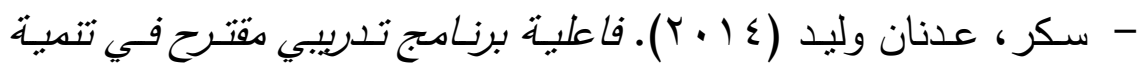
بعض المهارات المعرفية والاستقلالبة الذاتبة لدى الأطفال التوحدبين ( رسالة

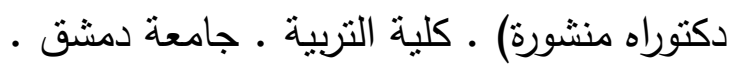

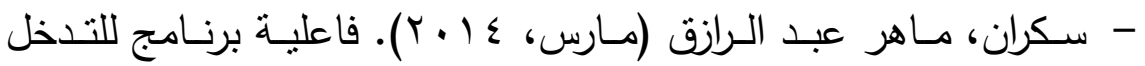

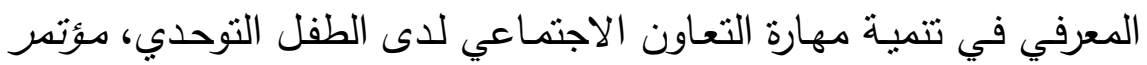

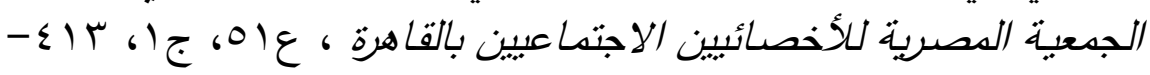
. $\leqslant \leqslant \wedge$

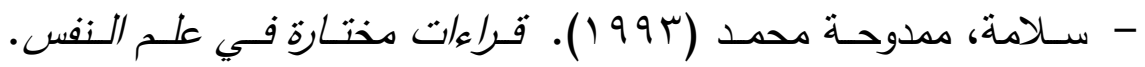

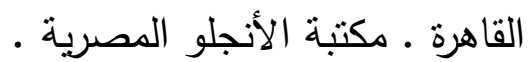

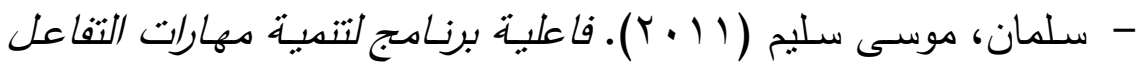

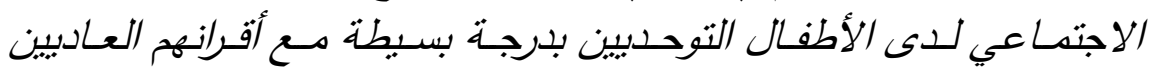
(رسالة ماجستير غير منشورة) كلية التربية . جامعة عين شمس ل 
- سليمان، عبد الرحمن سيد(ب . . r).سبكولوجية زوي الحاجات الخاصسة .

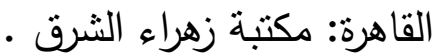

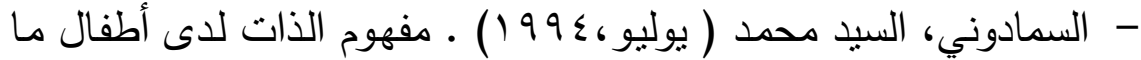
قبـل المدرسـة في علاقته بالمهارات الاجتماعيـة للوالدين ـ مجلـة دراسـات

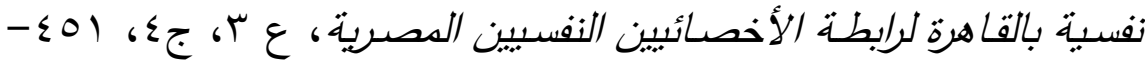
. $\leqslant \wedge 1$

- السبد، كامل أحمد (990 199). مشكلات الطفل السلوكية وأسالبب معاملة الوالدين. الإسكندرية: دار الفكر الجامعي •

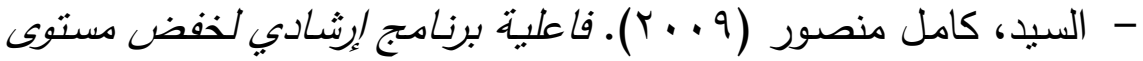
بعض المخاوف المرضبة الثـائعة لدى الأطفال المتخلفبن عقلبًا . (رسالة

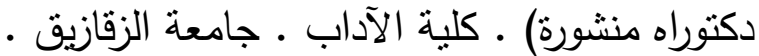

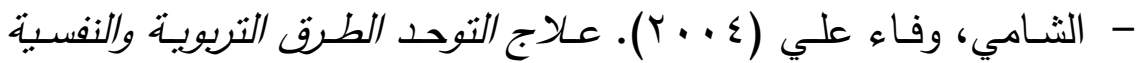
والطبية. . جدة : مركز جدة للتوحد . - الثخص، عبد العزيز السيد ؛ طعيمة، داليا محمود ؛ الطنطاوي، محمود

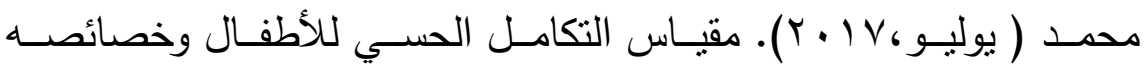

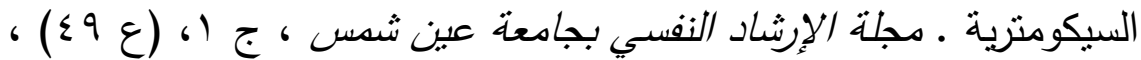
. $0 \leqslant r-\leqslant 9 r$

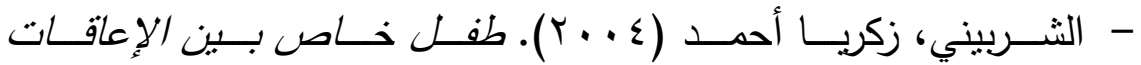
والمنازمات، تعربف وتشخبص • القاهرة : دار الفكر العربي. - شـوقي، طريـف عـادل (ب . . r). المهارات الاجتماعيـة والاتصـالية . القاهرة. دار غريب للطباعة والنشر والتوزبع. طربع

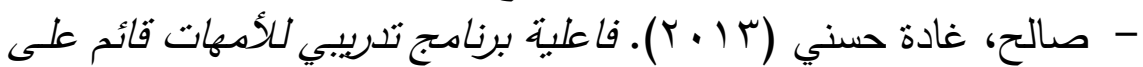
إسـتراتيجية التقلبـ فـي تحسن حالـة أطفـالهن الأوتبزم (رسـالة ماجسـتير

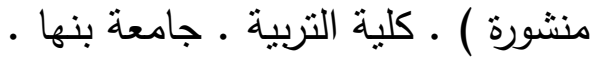


- صسوفي، نجلاء محمد (0 . . r). تصسيم برنامج أنشطة لعب لإكساب

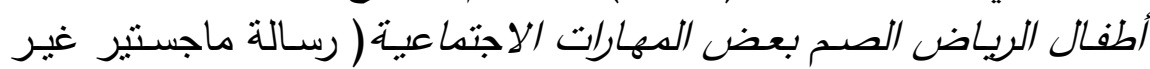

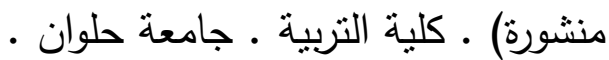

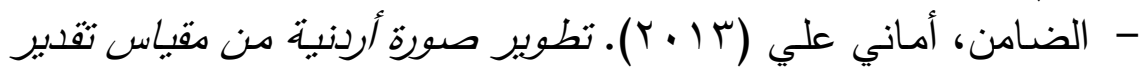
التوحد الطفولهي (رسالة ماجستير منشورة) ـ كلية العلوم التوبوبة والنفسية ، جامعة عمان العربية.

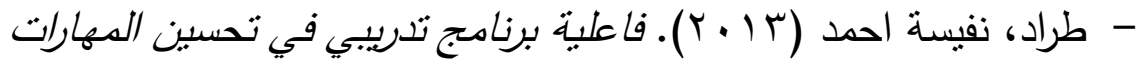
الاجتماعبية لدى عينـة من الأطفال التوحدبين (رسالة ماجستير منثـورة) -

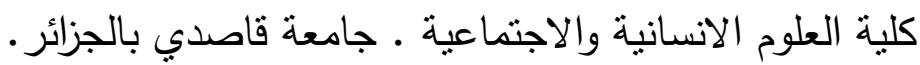

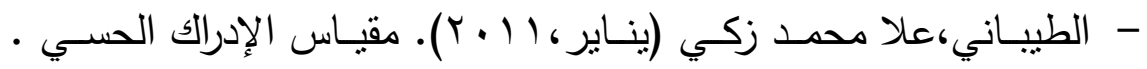

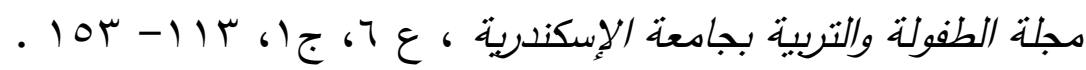

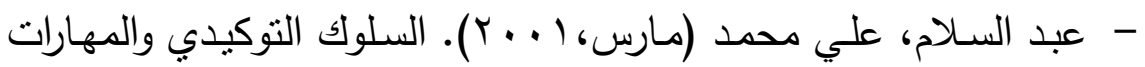
الاجتماعيـة وعلاقتها بالسلوك الانفعالي للغضب بين العاملين والعاماتات.

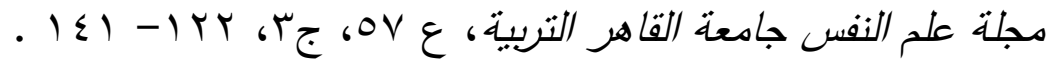

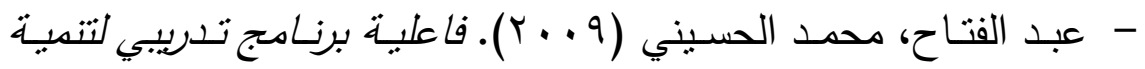

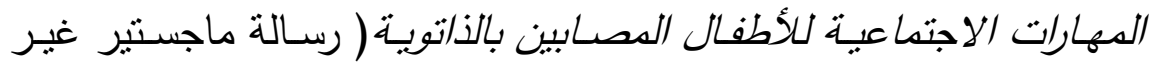

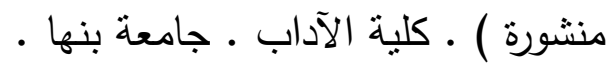

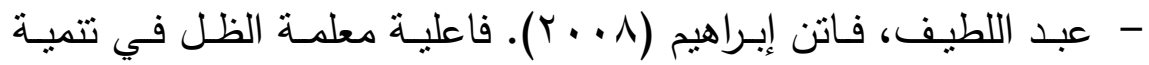
بعض المهارات الاجتماعية للأطفال القابلين بمرحلة رياض الأطفال . مجلة

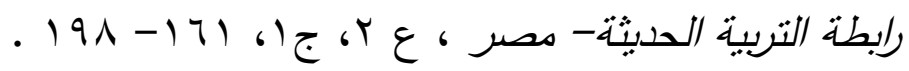

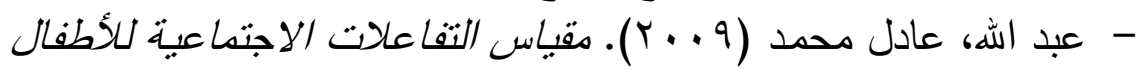
خارج المنزل (الأطفال العادبين وذوي الإحتباجات الخاصنة). القاهرة : دار الرشاد للنشر 
- عبد الله، عـادل محمد ؛ عبد العظبم، إيهاب حامـ (مـارس، م . . ب). فعالبـة العـلاج بالموسـيقى فـي تحسـين مسـتوى النـــو اللغـوي للأطفـال التوحديين. مؤتهر الثامن للجدعبـة الخليجبـة للإعاقـة بجدعبـة أولياء أمسر المعاقبن، المنعقد في الثارقة من الفترة م1 ا- . ب .

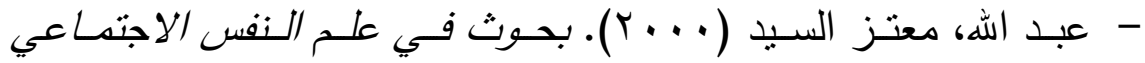
والثخصية . القاهرة : دار غريب للطباعة والنشر والتوزبع.

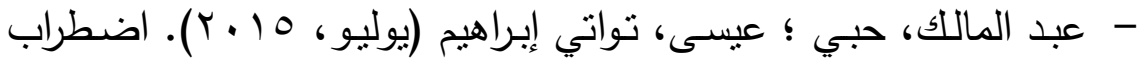

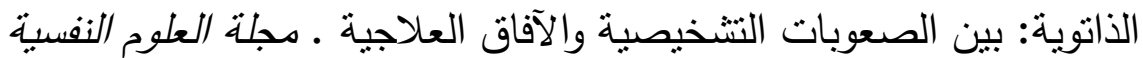

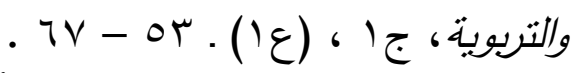

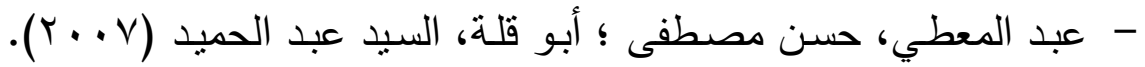

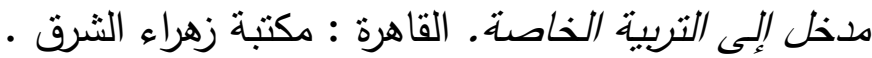

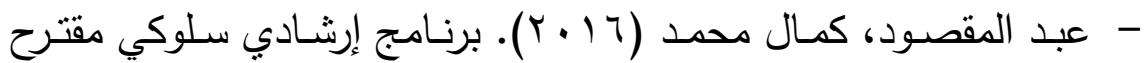
لخفض حدة ترديد الكلام (المصاداة) وأثره في تحسين التواصل لدى عينة

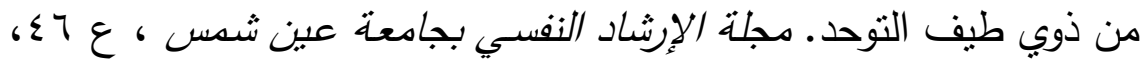
ج)

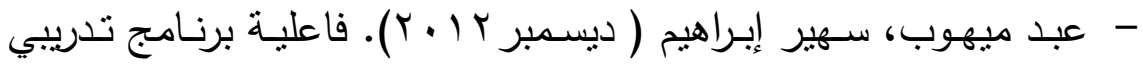

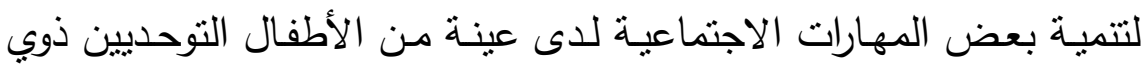

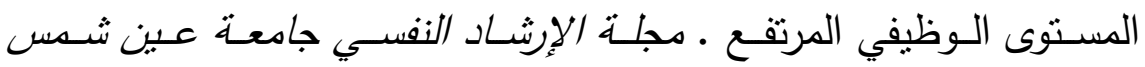

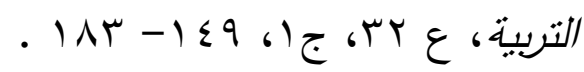
- عبداللاه، فايزة إبراهيم (مارس، 9 . . ب). فعالية برنامج علاجي سلوكي

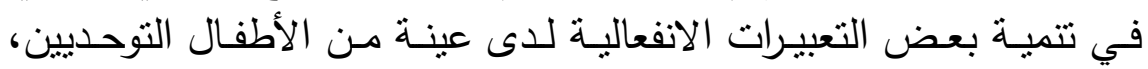

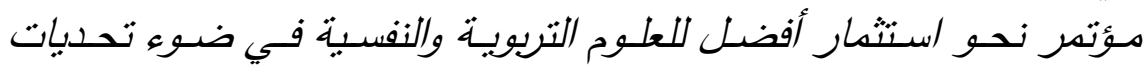

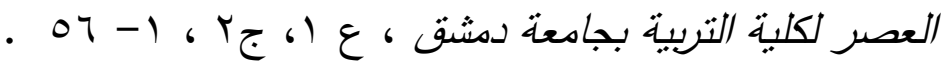




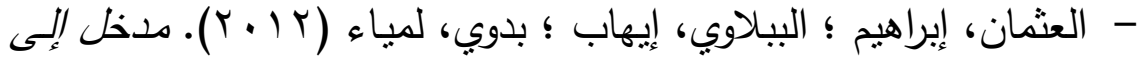

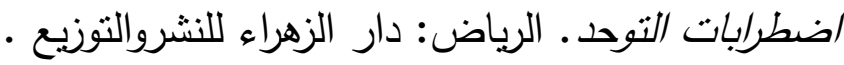

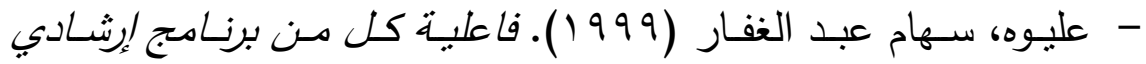

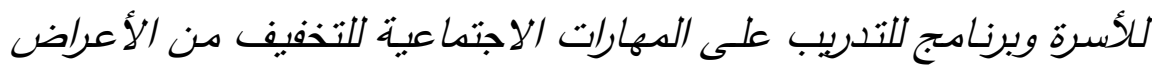
الذاتوبة (الأوتبزم) لدى الأطفال ( رسالة دكتوراه منشورة) . كلية التربية فرع كفر الثيخ · جامعة طنطا ل

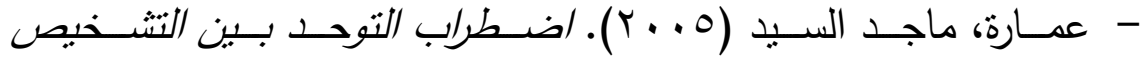

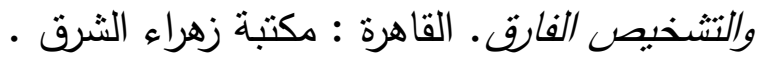

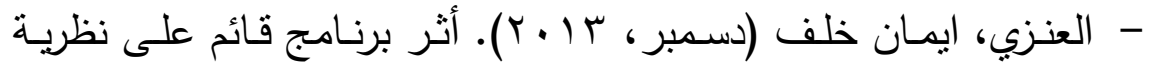

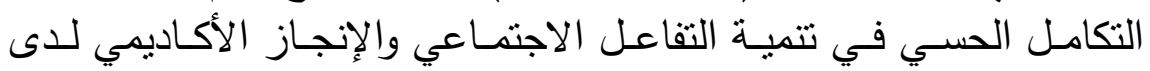

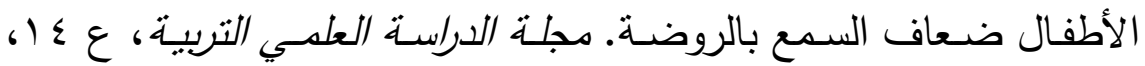

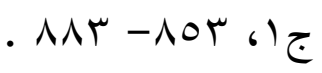

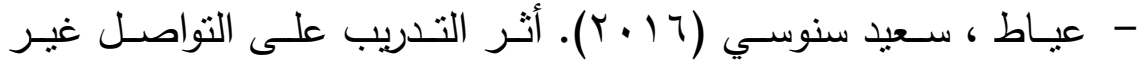
اللفظى في تحسين التفاعل الاجتمـاعي لـدى الأطفـال التوحديين ـ مجلـة

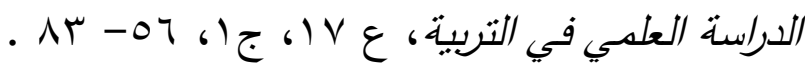

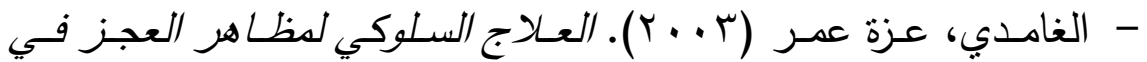
التواصل اللغوي والتفاعل الاجتماعي لدى أطفال التوحد (رسالة دكتوراه غير التها

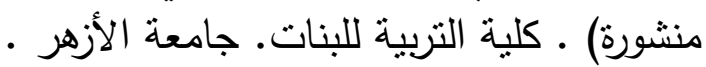

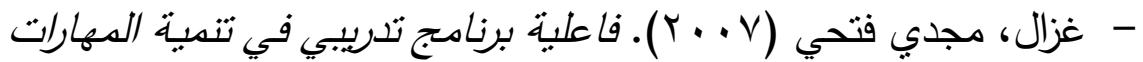

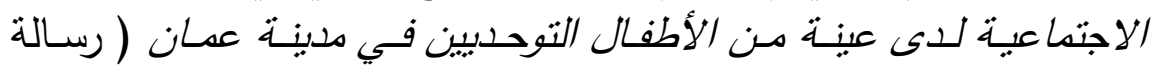

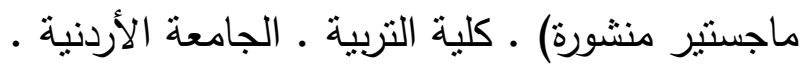

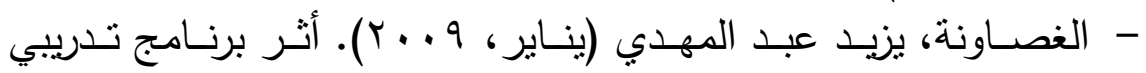
سلوكي في تتمية المهارات الاجتماعية لدي الأطفال التوحديين. مجلة كلية

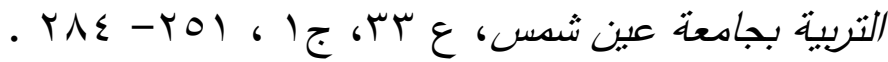




\section{المجلة العلمية لكلية رياض الأطفال - جامعة بورسعيد}

- الغصاونة، يزبد عبد المهدي ؛ الثرمان، وائل عبد الله (يوليو، باء ـ ب). بناء برنامج تدربي قائم على طريقة ماكتون لتنمية التواصل غير اللفظي

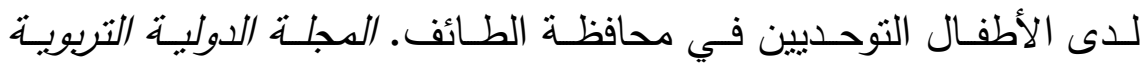

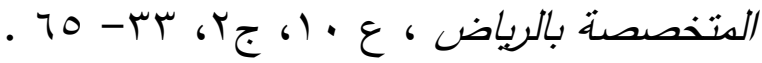

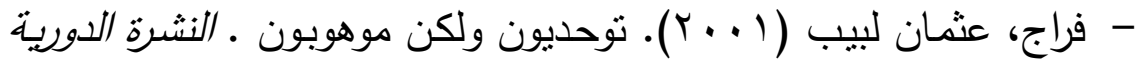

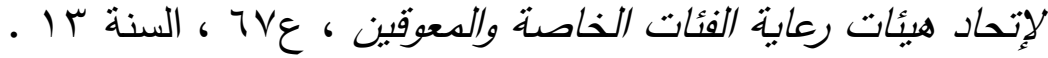

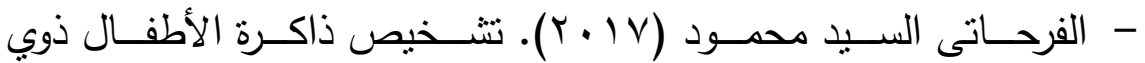
اضـطرابات طبـف التوحد في ضـوء محكات تشـخيص الإصـدار الخـامس الأمريكي. مجلة التربية الخاصتة بعركز المعلومات التربوبية والنفسبية والبيئية

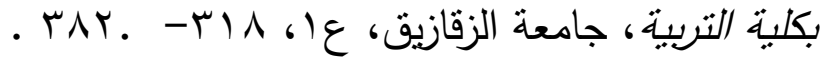

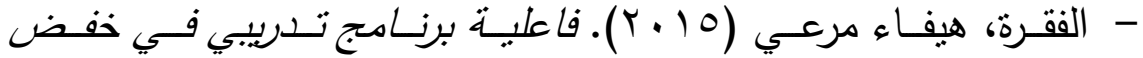
اضطراب النكامل الحسي ذي الاختال الوظبفي لدى أطفال التوحد ( رسالة

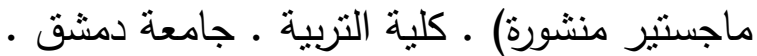

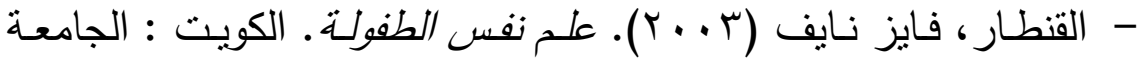

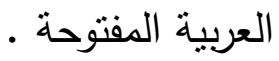

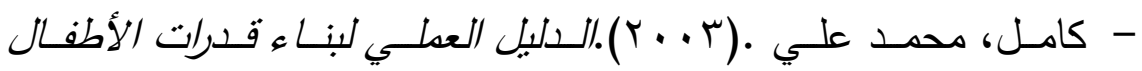

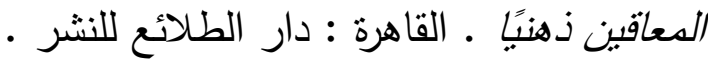
- متولي، فكري لطيف (مارس، 0 ( • ب). فعالية برنامج تدريبي لتحسين التكامـل الحسـي في تدعيم مهـارات الأمسن الجسـدي لـدى أطفـال الأوتيزم.

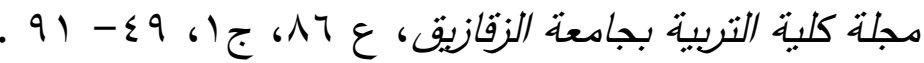

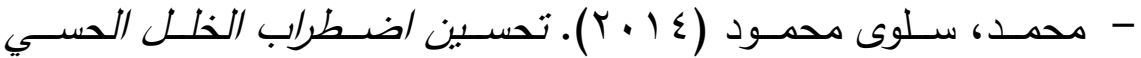
باستخدام غرف الحواس لدى الأطفال الذاتوبين. (رسالة ماجستير منشورة) .

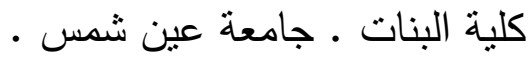




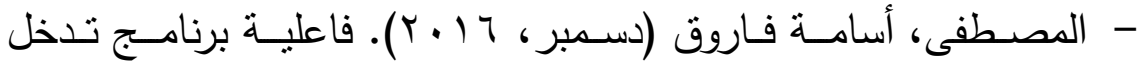

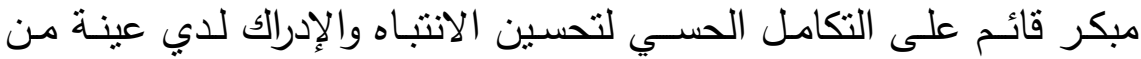

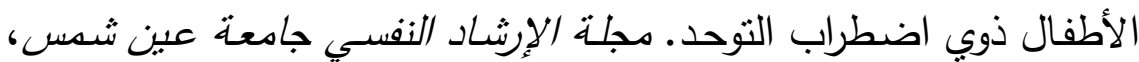

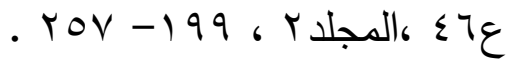

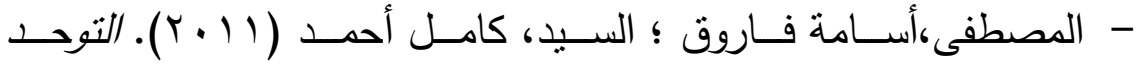
(الأسباب، التشخيص، العلاج). الأردن: دار الميسرة للنشر والتوزيع .

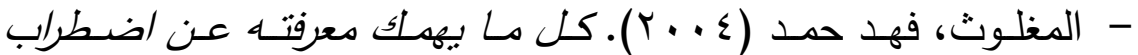
التوحد. الرياض : مطبعة دار التقنية .

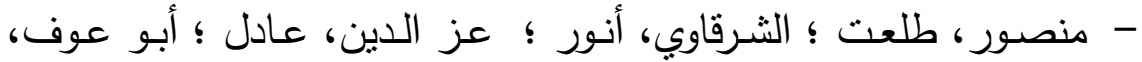
فاروق (919 191) ـ علم النفس العام. القاهرة : مكتبة الأنجلو المصرية . - موسسي، نعمات عبد المجيد (مارس، ؟ | • ب). برنامج تدخل مبكر قائم

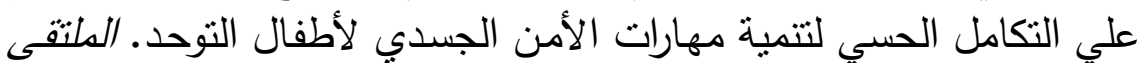

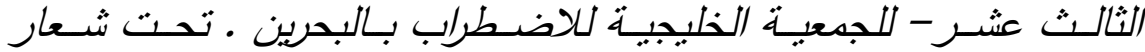

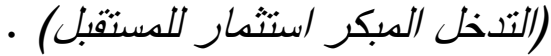

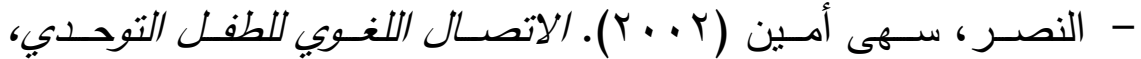

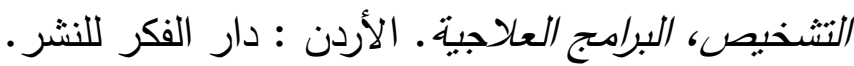

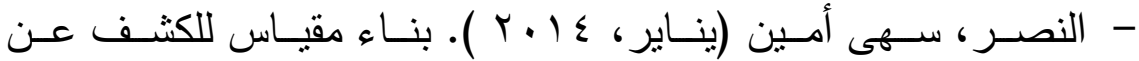
اضطراب المعالجـة الحسية والتحقق مـن فاعليتهـا في عينـة مـن الأطفال

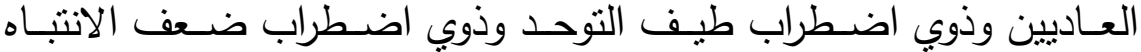
والنشـاط الحركي المفرط ـ مجلـة الطفولـة والتربيـة لكليـة ربـاض الأطفال

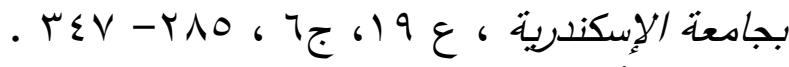

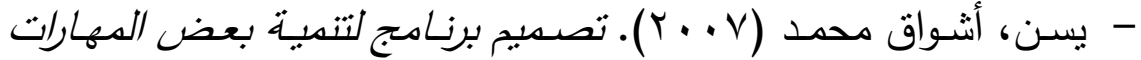
الحسية والحباتية للأطفال الدصابين بالاضطراب التوحدي • (رسالة دكتوراه

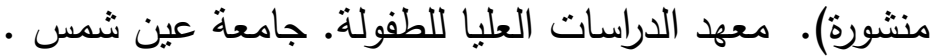




\section{ثانياً: المراجع الأجنبية :}

- Ayres, J Robbins. (2005). Sensory integration and the child: Understanding hidden Sensory challenges. Los Angeles, CA: Western Psychological Services.

- Bailey S1, Pokrzywinski J, Bryant LE (1983). Using water mist to reduce self-injurious and stereotypic behavior, Applies study mental retardation, 41- 229: (3) 4.

- Baranek, G. T .(2002).Efficacy of Sensory and Motor Interventions for Children with Autism, Journal of Autism and Developmental Disorders, 32(5): 379-422.

- Barbara Menting; Pol A.C; van Lier, ؛ Hans M. Koot. (2012). Language skills,Peer rejection, and the development of externalizing behavior from kindergarten to fourth grade,Journal of Child Psychology and Psychiatry, Nol 52,Nol,pp72-79.

- Beth, A. P., Kristie, K., Moya, K., Megan, S. \& Lorrie, H .(2011). Effectiveness of Sensory Integration Interventions in Children with Autism Spectrum Disorders: A Pilot Study, American, Journal of Occupational Therapy, January/February, 65: 76-85. - Black , C., ( 1972 ). A Glossary of Termson Educational Technology, Inc. Rom Tzoskya .I. (Ed) Applet Year Book of Educational and Internatntional Technology. 
- Bogdasbingn, O .(2003). Sensory Perceptual Issues in Autism and Asperger Syndrome Different Sensory Experiences Different Perceptual World, Jessica Kingsley Publishers London and New York.

- Cannon, N.L (2006). The effects of floor time on communication interaction behaviors between typically developing preschoolers and preschoolers with autism. MD, Miami University, Faculty of Miami University, Oxford, $\mathrm{OH}$.

- Cardon,T.A., \&Wilcox,M. J.(2011). Promoting imitation in young children with autism a Comparison of reciprocal imitation training and video modeling, Journal of autism development disorder . 41(5),654-666. - Daniel Hallahan, Kauffman Pand, M.James. (2003). Exceptional learners introduction to special education .bosto, New York.

- Davies, P. L., \& Gavin, W. J .(2007). Validating the diagnosis of sensory processing disorders using EEG technology, American Journal of Occupational Therapy, 61: 176-189.

- Fisch, G; CohenIL, W; \&, Friedman, E .(1983). The Autistic Descriptors Checklist (ADC) a preliminary report. Journal of Autism Dev Disord. 1985 Jun;15(2):233-4.

- Humphry,R..(2002). Young childrens occupationa: Explicating the dynamics of developmental processes. American, Journal of Occupational Therapy,2,171-179. 
- James, A; Green, Marianne, L; Barton, \& Deborah, F. (2010). Using the Childhood Autism Rating Scale to Diagnose Autism Spectrum Disorders, J Autism Dev Disord. Author manuscript; available in PMC 2013 Mar 31.

- Johnston, S., Evans, E; \& Joanne, P. (2004). The use of visual support in teaching young children with Autism Spectrum Disorder to Initiate Interactions. London: Powel company.

- Katherine, S\& Smiley, R. (2015). Raising children with autism 100 thing every parent of an autistic child must know.

- Khodabakhshi, Ahmad, \& Mokhtar. ( 2014). The Effect of Sensor Integration Therapy on Social Interactions and Sensory and Moto Performance in Children with Autism, Iranian Journal of Cognition and Education 2014, Vol.1, No.1, 35-45.

- Megha K,. Pooja . (2015). Sensory Integration Therapy on Social and Self Care Skills in Children with Autism, The International Journal of Indian Psychology, Volume 2, Issue 2.

- Merrel, w.(1993). Assessing social skills and peer relations: Pscychological assessment of children. New York: John Wiley and sons Inc.

- Morrison, G. (1981). Socimetric measurement methodological consideration of its use with mildly leanring handicapped and nonhandicapped children. Jornal of educational psychology, 73.193-200. 
- Roley.ss., Malloux.z., Parham.L.D., Schaaf.R.C., Lane.C.J \& Cetmak.S. (2015). Sensory integration and praxis patterns in children with autism. American Journal of Occupational Therapy, Vol. (22), No. (4), pp. 326-366.

- Samuel,K., James G; Mary C. (2015). Education Exceptional Children.14th Ed. New York.Houghton Mifflin Harcourt publishing Company.Cengage Learning Publisher.

- Sharon, J. (2010).Sensory Integration Interventions for Early shildhood Special Education. Southwest Minnesota State University, Education Department, Minnesota.

- Stefanatos, G., Kinsbourne , M., \& Wasserstein . (2002). Acquired epileptiform aphasia: A dimensional view of Landau - Kleffner syndrome and the relation to regressiveautistic spectrum disorders. Child Neuro psychological ,8,195- 228.

- Vidya ,B.(2004) . Autism Spectrum Disorders in children .N.Y.:Pub. by in forma health care . 

دور تطبيقات الهاتف المحمول في تعزيز قيم المواطنة الرقمية لاى طلاب وطالبات بعض الجامعات المصرية "دراسة ميدانية"

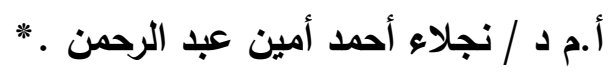

أ. م. د /هيام عبد الرحيم أحمد علي.

ملخص الاراسة : (1) - مل

هدفت الدراسـة الحاليـة إلى تحديد قيم المواطنـة الرقميـة المُراد تعزيزهـا لدى طلاب وطالبات بعض الجامعات المصرية ، تحديد (أكثر تطبيقات

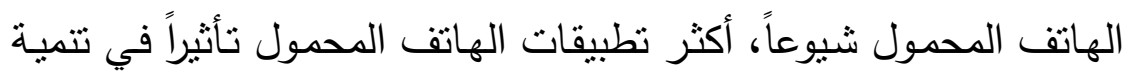
قيم المواطنة الرقمية ) بين طلاب وطالبات بعض الجامعات المصرية ،

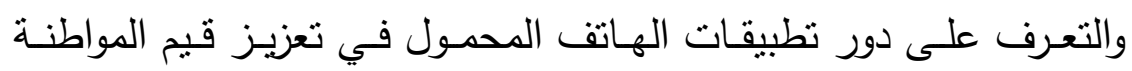

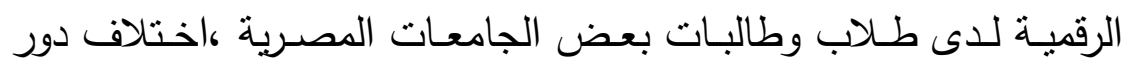

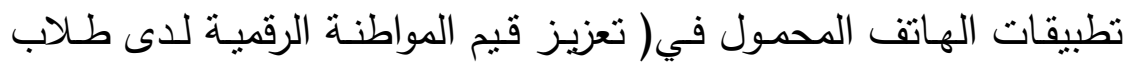
وطالبات بعض الجامعات المصرية باختلاف نوع الكلية (نظربة/ عملية)،

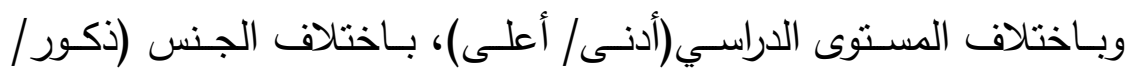

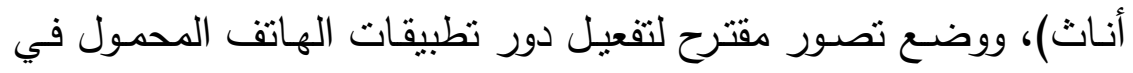

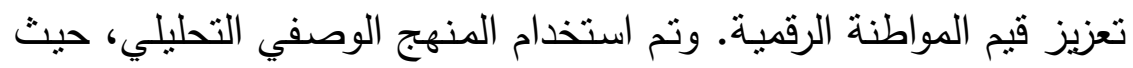

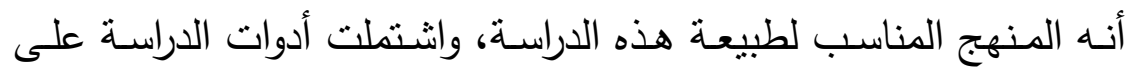

* أستاذ مناهج الطفل المساعد- كلية التربية للطفولة المبكرة - جامعة المنيا. * أستاذ أصول التربية المساعد - كلية التربية - جامعة الإسكندرية. 
قائمــة بقيم المواطنـة الرقميـة، واسـتبيان دور بعـض تطبيقـات الهـاتف

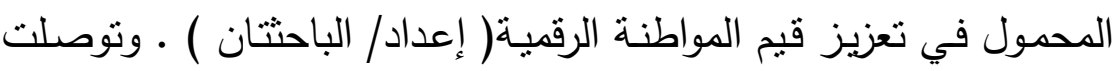
نتائج الدراسة إلى اتفاق طلاب وطالبات بعض الجامعات المصرية -عينة الدراسـة -على الدور الذي تؤديـه تطبيقات الهاتف المحمول مثل (الفيس

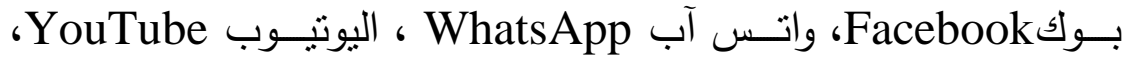
انستجرام Instagram) في تعزيز قيم المواطنة الرقمية بمحاورها التثلاث

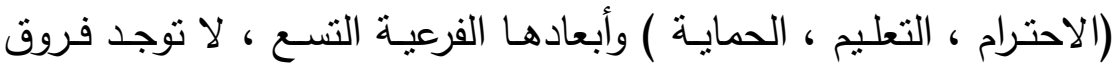

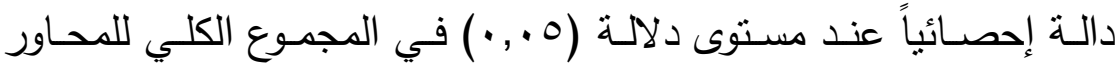
التثلاثة تبعاً لمتغير نوع الكلية (نظرية/ عملية)، وتوجد فروق دالة إلة إحصائياً

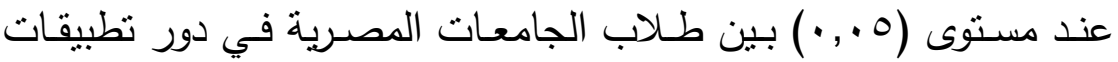

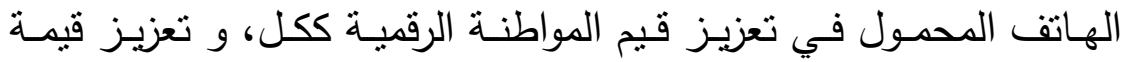

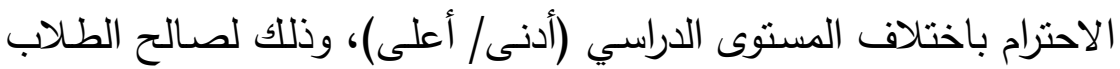

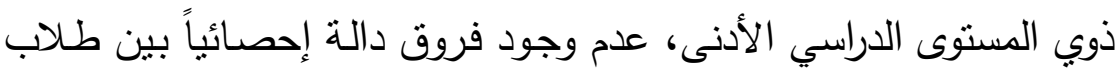

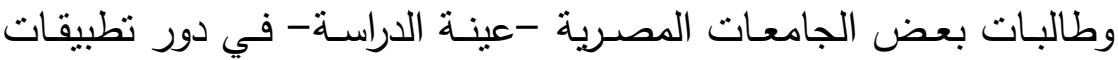

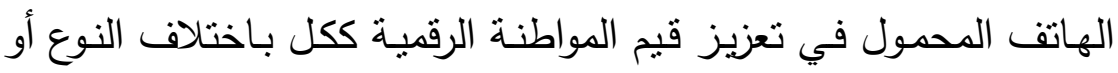

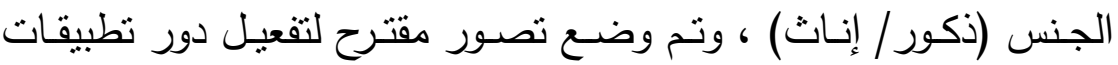

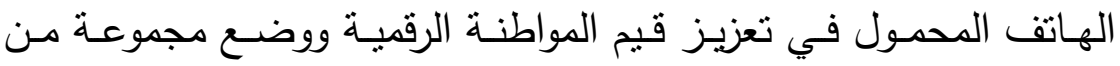
التوصيات والبحوث المقترحة. 
The role of mobile phone applications in promoting the values of digital citizenship among male and female students of some Egyptian universities "field study".

\section{Prepare: Dr / Naglaa Ahmed Amin Abdel-Rahman. *}

Dr / Hayam Abdel Rahim Ahmed Ali. *

\section{Abstract:}

The goal of the current study is to determine the values of digital citizenship to be promoted among male and female students of some Egyptian universities, identify (the most common mobile phone applications, the most influential mobile phone applications in developing digital citizenship values) among male and female students of some Egyptian universities, and identify the role of mobile phone applications in Promoting the values of digital citizenship among male and female students of some Egyptian universities, the difference in the role of mobile phone applications in (enhancing the values of digital citizenship among male and female students of some Egyptian universities, according to the type of college (theoretical / practical), and with the different academic level (lower / higher), and with different gender

* Assistant Professor of Child curricula -Faculty of Early Childhood Education - Minia University.

* Assistant Professor of Pedagogy - Faculty of Education - Alexandria University. 
(males) / Female), and a proposal was developed to activate the role of mobile phone applications in promoting the values of digital citizenship. The descriptive and analytical approach was used, as it was the appropriate approach to the nature of this study, and the study tools included a list of digital citizenship values, and a questionnaire of the role of some mobile phone applications in promoting digital citizenship values prepared by the two studyers -.

The results of the study reached an agreement between male and female students of some Egyptian universities the study sample - on the role that mobile applications such as (Facebook, WhatsApp, YouTube, Instagram) play in promoting the values of digital citizenship in its three axes (respect, education, protection) With its nine subdimensions, there are no statistically significant differences at the level of significance (0.05) in the total sum of the three axes depending on the variable of the type of college (theoretical / practical), and there are statistically significant differences at the level (0.05) between Egyptian university students in the role of mobile phone applications In promoting the values of digital citizenship as a whole, and enhancing the value of respect at different academic levels (lower / higher), for the benefit of students with a lower academic level, the absence of statistically significant differences between male and female students of some Egyptian universities Study sample in the role of mobile phone applications in 


\section{المجلة العلمية لكلية رياض الأطفال - جامعة بورسعيد}

promoting Digital citizenship values And enhancing the value of respect at different academic levels (lower / higher), for the benefit of students with a lower academic level, the absence of statistically significant differences between male and female students of some Egyptian universities - the study sample in the role of mobile phone applications in promoting the values of digital citizenship as a whole with different gender or Gender (male / female), and a proposed conception has been developed to activate the role of mobile phone applications in promoting the values of digital citizenship, and a set of recommendations and proposed study have been developed.

\section{الكلمات المفتاحية Keywords:}

Mobile phone applications

Digital citizenship values

University students

Field study

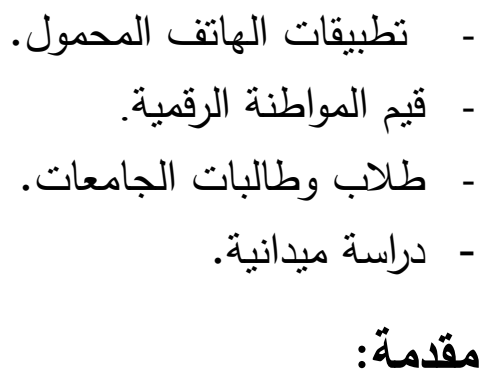

أصبحت التقنيات الحديثة جزءًا مهمًا لا يمكن الاستغناء عنه في حياتتا؛

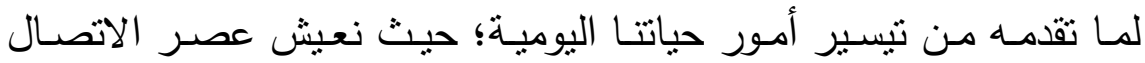

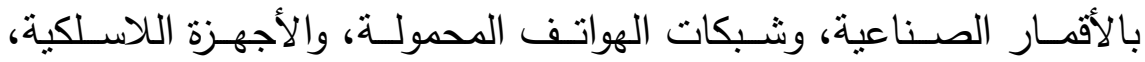

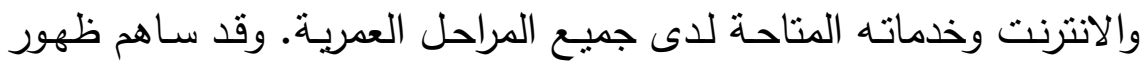

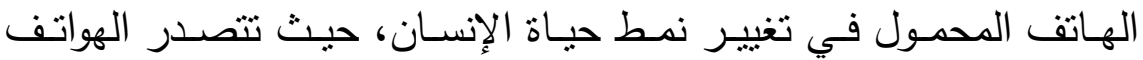


المحمولة قائمة أهم أحدي عثرة تقنية ظهرت خلال العقد الأول من القرن

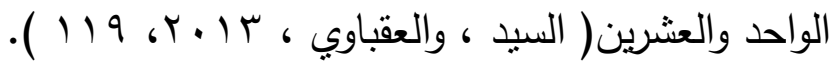

كما تعد تطبيقات الهاتف المحمول منثل (الفيس بوك، اليوتيوب، الواتس آب ، ـ وغيرها) من أسرع وسـائل الاعـلام الرقمية نمواً، وأكثرها شعبيةً بين الأسر ذات الدخل المنخفض (Megan \& Plugged,2013, 3) ؛ بسبب

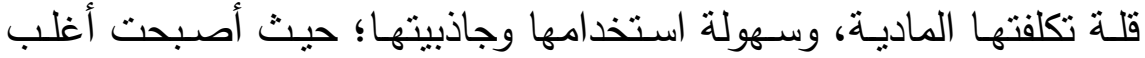
الثرائح العمرية للمجتمع تعيش حياة رقمية بتبادلون فيها رسائلهم الشخصية ومعلوماتهم بأساليب منتوعة منها: الكتابة، الصورة، الصوت، الرمز ، الرسم، الرئه

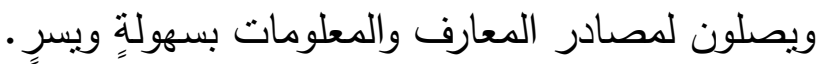

وبعد طـلاب الجامعـات أكثر هذه الثـرائح اسـتخداماً لتطبيقات التقنيـة الحديثة، وأصبحت حياتهم كتابـاً مفتوحاً للجميع، يعرف كل منهم تفاصبل حياة الآخرين، وبياناتهم الثخصية، واهتماماتهم وهواياتهم وأماكن أقامتهم،

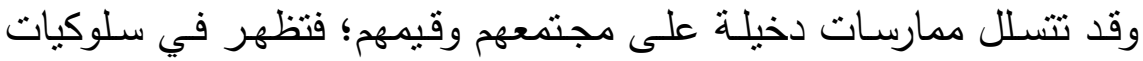
هؤلاء الطلاب وثقافتهم لا يعرف مصدرها، حيث يتعاملون مـ أسماء غير حقيقية وحسابات وهمية؛ مما يشكل خطورة على قيم المواطنة لديهم.

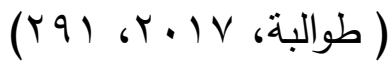

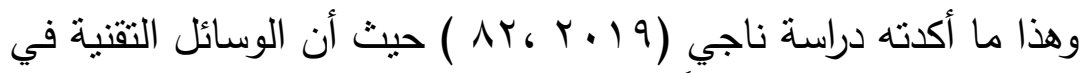
الوقت الراهن استقطبت شرائحاً كبيرةً من الفئات العمرية المختلفة، ولا سيما

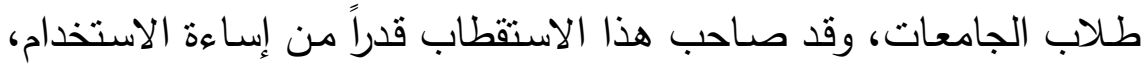
والعديد من الاختراقات المختلفة مثل: تجاوز آداب الحوار ، عمليات انتحال ونصب عبر الانتزنت، انتهاك حقوق الملكية الفكربـة، تحميل المواد بشكلٍ غير قانوني؛ لذا أصبح التفكير في الممارسـات الرقميـة لطـلاب الجامعات وتأثثرها في بنائهم القيمي ضرورةً حتميةً؛ وغدت الحاجة ملحةً لتنقيف هؤلاء 


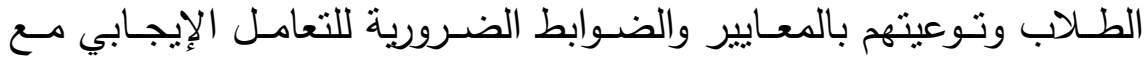

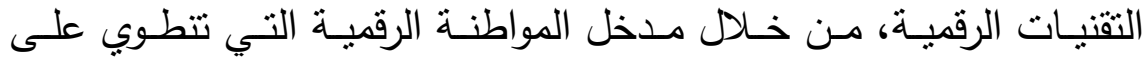
الحقوق والواجبات التي ينبخي أن يلتزم بها الأفراد عند تعاملهم مـع التقنية الرقمية (Ohler, 2011,20) )

وقد ظهر مفهوم المواطنة الرقمية على يد "ربيل" ( Ribble 2006)

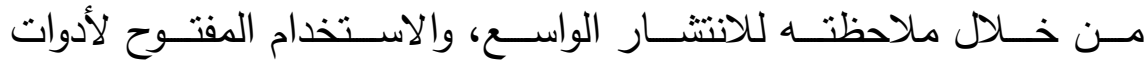
التكنولوجيا، والتواصـل مـع مجهولين رقميين قد يشكلون خطراً على أفراد

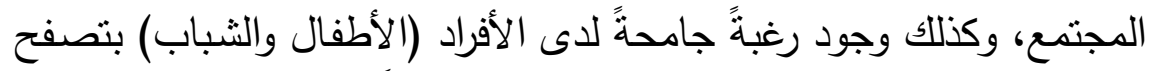

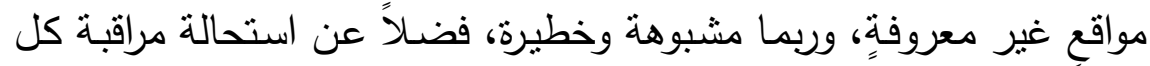

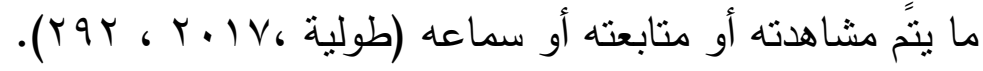

كما دعا ميك " ( Mike" Mike,2012, 149 " بضرورة إلمام طلاب الجامعات بمفهوم المواطنة الرقمية ، والقضايا المرتبطة بها من خلال الإفادة

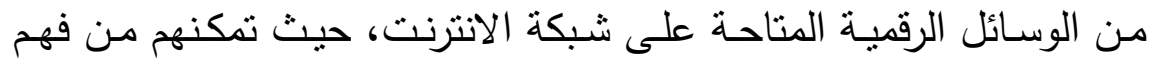

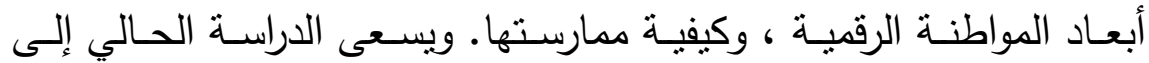

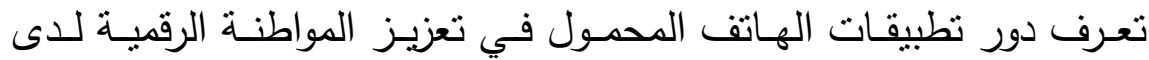
طـلاب بعـض الجامعـات المصـرية، ووضـع تصــور مقتـرح لتفعيـل دور تطبيقات الهاتف المحمول في تعزيز قيم المواطنة الرقمية لديهم.

\section{مشكلة الدراسة:}

اتضحت مشكلة الدراسة الحالية من خلال التالي:

ا-خبـرة البـاحثتين العمليـة والنظريسة وتجربتهمــا الطويلـة في التـدريس الجـامعي، وملاحظتهمـا لانتشـار استخدام الهواتف المحمولة بشكلٍ ملفٍ

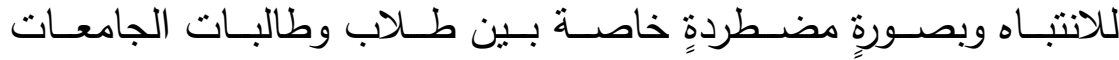


وانشـغالهم بهـا، وتهـافتهم علـى اسـتخدامها لســاعاتٍ طويلـةٍة وبمهـارة، والاستمتاع بتطبيقاتها. ץ-ما أحدثثه تقنية الهاتف المحمول من تغيرات على أسلوب حياة طلاب

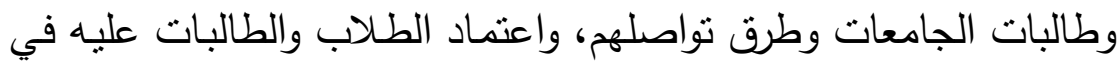

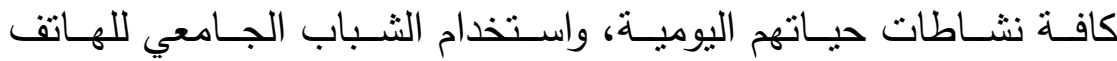

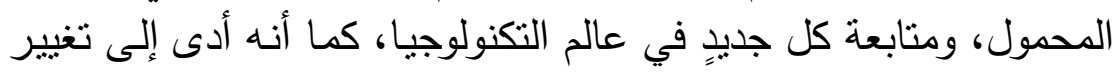

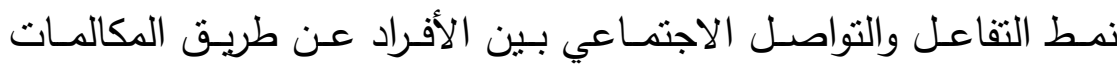
والمحادثات، والتواصل عن طريق التراسل بمختلف أنواعل التهن .

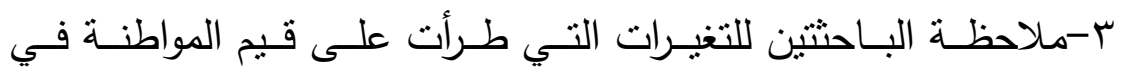

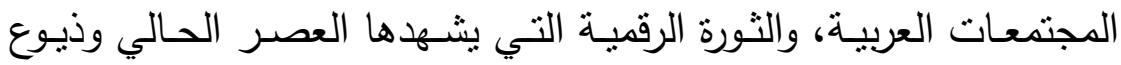

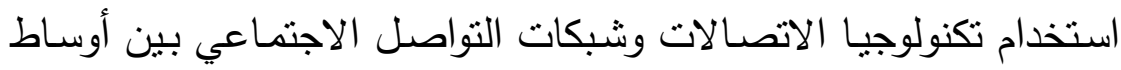

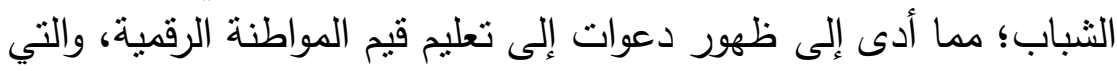

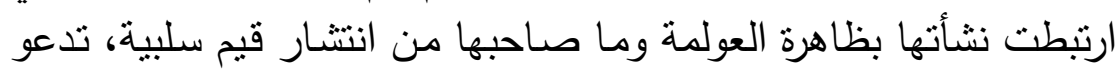
إلى الفردية والسلبية وتضعف من قيم المجتمع ، وهويته الثقافية؛ مما يحتم

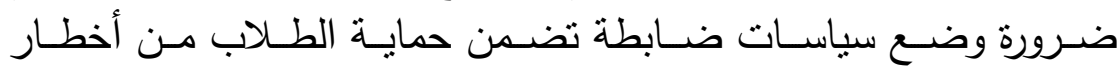

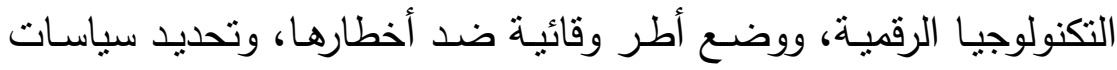

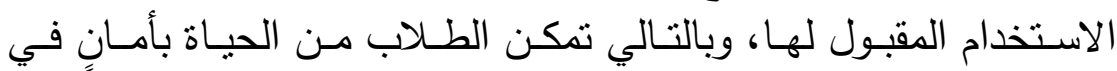
العصر الرقمي. ع -في ضوء نتائج الدراسات والبحوث السابقة التي تتاولت قيم المواطنة

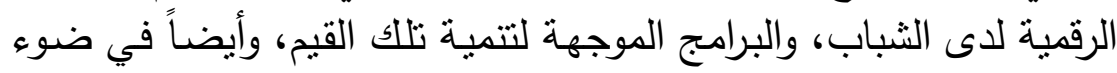

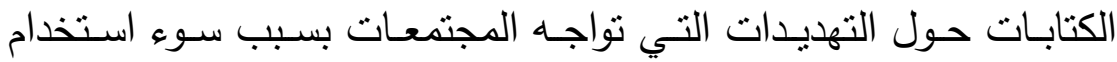

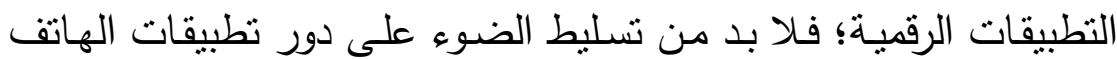

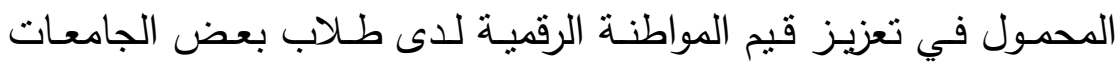
المصرية، في ظل ما يشهده العالم من تطوراتٍ تقنيةٍ وعمليةٍ سريعةٍة. 


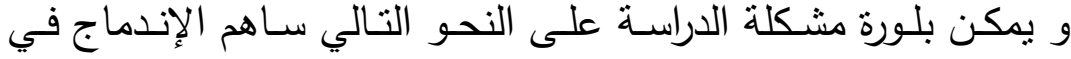
العـالم الرقمي -مـن خـلال عدة تطبيقات مثنل: الفيسبوك ، السناب شـات، الإنستغرام، التوتير، الواتس آب، اليوتيوب وغيرها - نتيجة انتشـار ظاهرة استخدام الهاتق المحمـول ، وبخاصـة بين طـلاب الجامعـات في ظهور

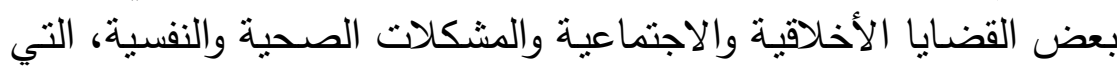

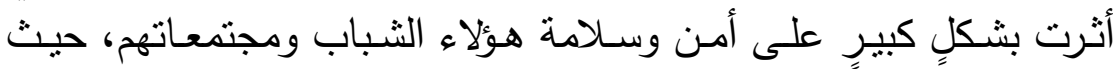

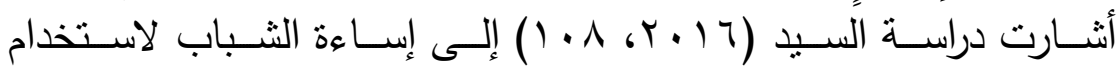
التطبيقـات الرقميـة في نشـر معلومـات مضـللة ، وإرسـال رسـائل نثـهير

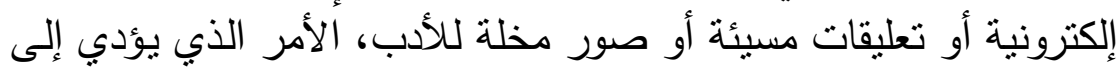

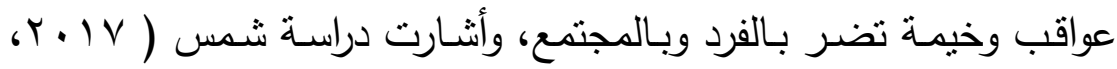
7 Tr) إلى أنه بالرغم من استخدام طلاب الجامعات للتطبيقات التكنولوجيا بشكل احترافي ؛ إلا أنهم يجهلون حجم المخاطر التي قد يتعرضدن لها

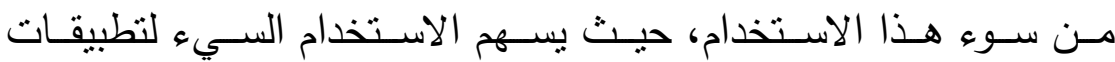

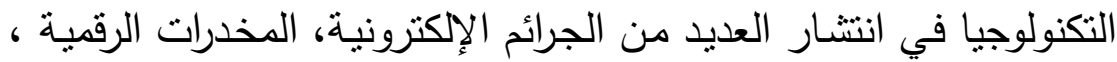

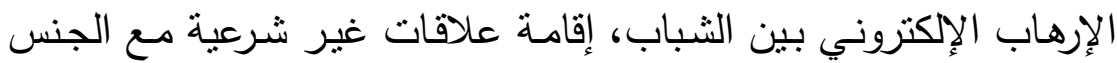
الآخر ، ظهور قيم جديدة تتنافي مع قيم الأسرة والمجنمع، وغيرها.

لذا أصبح من الضروري حمايـة هؤلاء الثباب من سلبيات التطبيقات

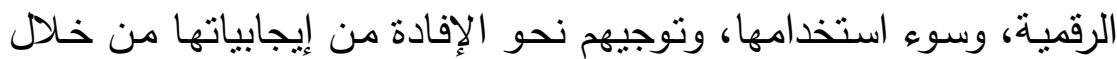
توعيتهم بأساليب الاستخدام الأمتل للتكنولوجيا، ونشر ثقافة وآداب التعامل

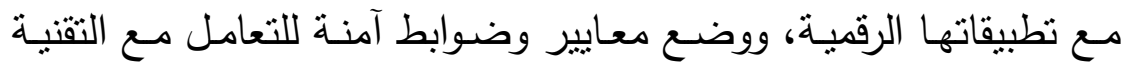

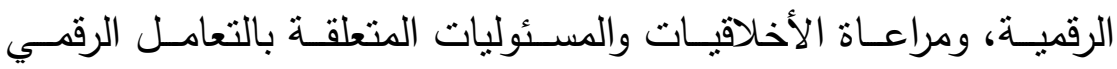
للمعلومات؛ مما دفـع الباحثنان إلى إجراء الدراسـة الحالية، ووضـع تصـور 


\section{المجلة العلمية لكلية رياض الأطفال - جامعة بورسعيد}

مقترح لدور تطبيقات الهاتف المحمول في تعزيز قيم المواطنة الرقمية بين طلاب الجامعات المصرية.

ويمكن صياغة مشكلة الدراسة في السؤال الرئيس التالي :

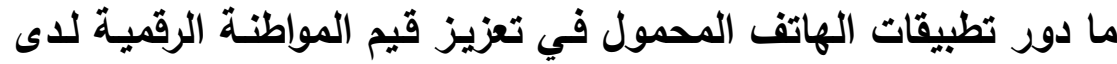

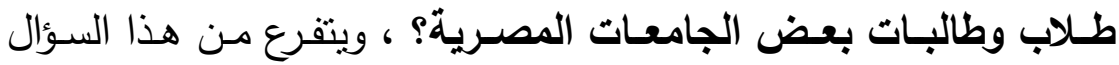

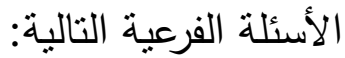

ا-ما قيم المواطنة الرقمية المُراد تعزيزها لدى طلاب وطالبات الجامعات

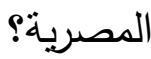

r-مـا أكثر تطبيقـات الهـاتق المحمـول شـيوعاً واسـتخداماً بـين طـلاب وطالبات بعض الجامعات المصرية: ب-ما أكثر تطبيقات الهاتف المحمول تأثيراً في تتمية قيم المواطنة الرقمية

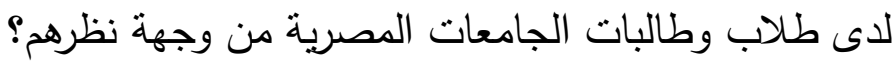

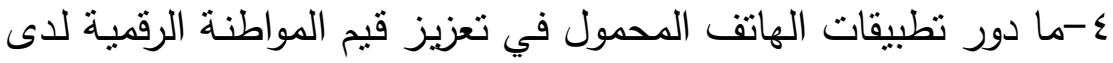
طلاب وطالبات بعض الجامعات المصرية؟

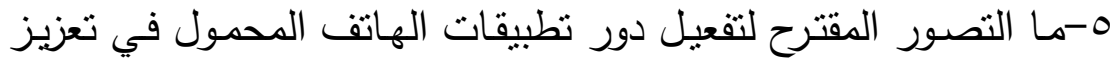
قيم المواطنة الرقمية لدى طلاب وطالبات بعض الجامعات المصرية ؟

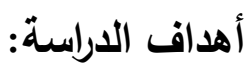
تسعى الدراسة الحالية إلى: ا-تحديد قيم المواطنة الرقميـة المُراد تعزيزهـا لدى طـلاب وطالبات بعض الجامعات المصرية. r-تحديد أكثر تطبيقات الهاتف المحمول شيوعاً بين طلاب وطالبات بعض

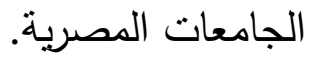


ب-تحديد أكثر تطبيقات الهاتف الهحمـول تـأثيراً في تتميـة قيم المواطنـة الرقمية لدى طلاب وطالبات بعض الجامعات المصرية.

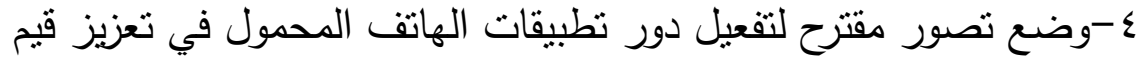
المواطنة الرقمية لدى طلاب وطالبات بعض الجامعات المصرية.

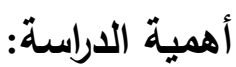

تتمثل أهمية الدراسة في :

• أولاً : الأهمية النظرية:

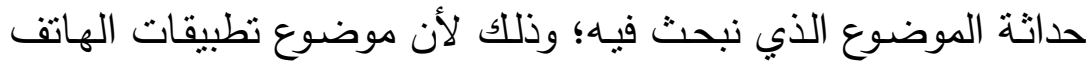

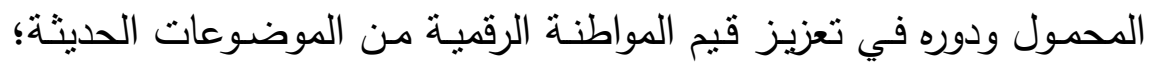

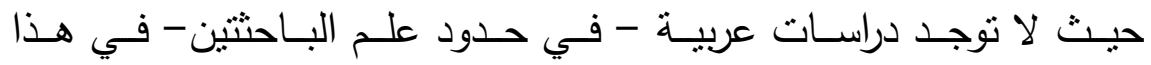

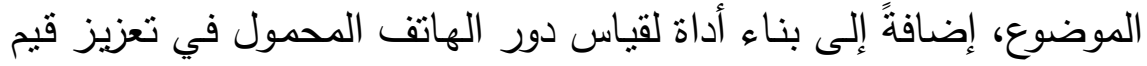

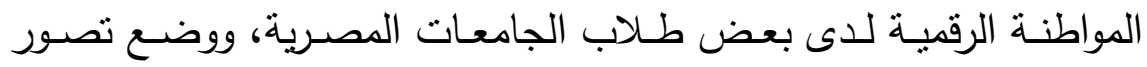

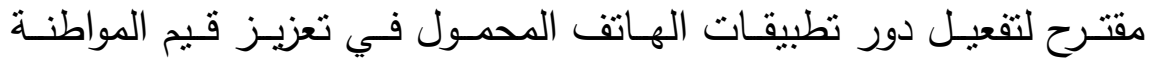

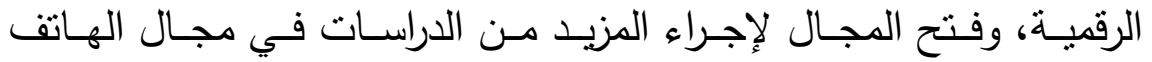
المحمول، وقيم المواطنة الرقمية.

\section{• ثانياً: الأهمية التطبيقية:}

قد تقيد نتائج الدراسة الحالية وتصورها المقترح كلاً من:

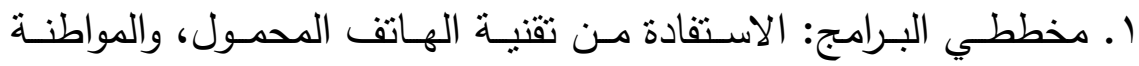

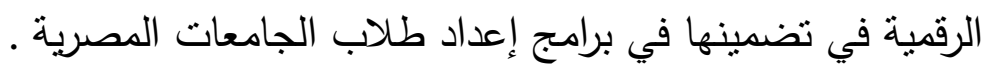

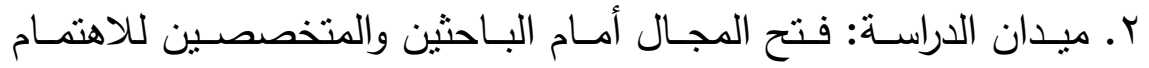

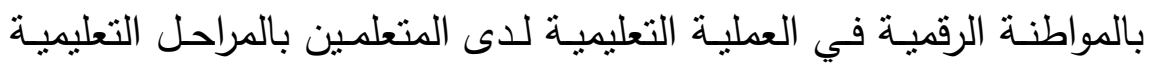


المختلفة، توجيـه أنظـارهم إلى دور بعض تطبيقات الهـاتق المحمـول في تعزيز قيم المواطنة الرقمية.

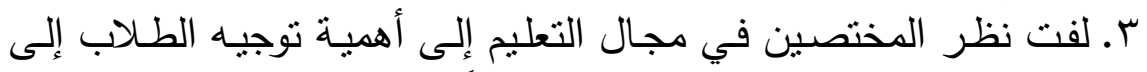

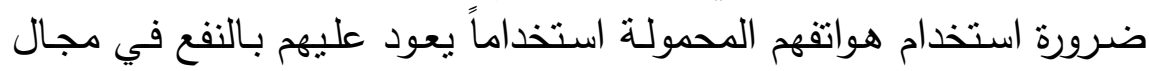

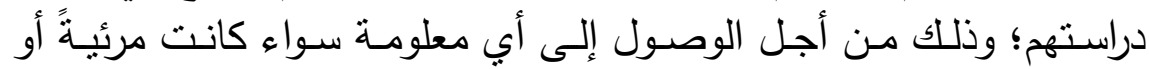

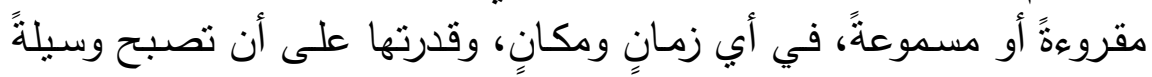

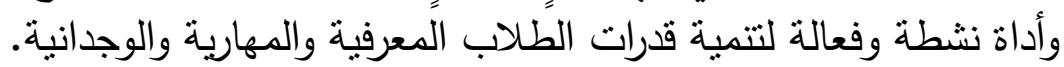

حدود الدراسة:

تتحدد حدود الدراسة الحالية بالحدود التالية:

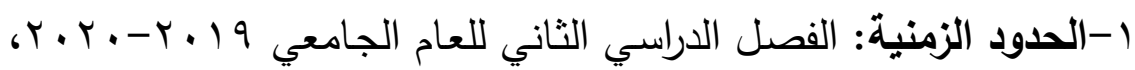

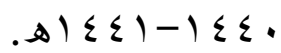

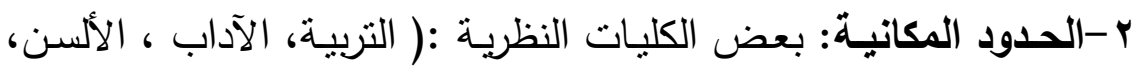

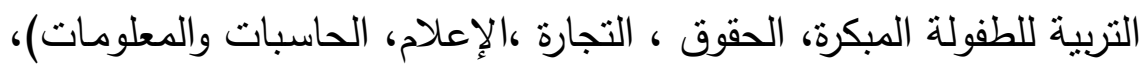

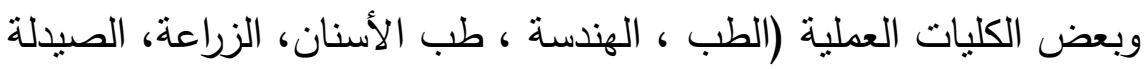

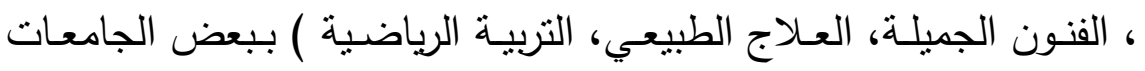

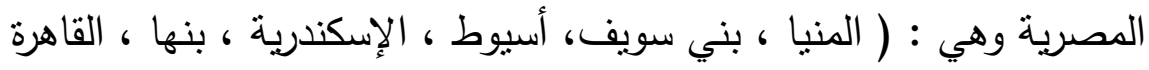

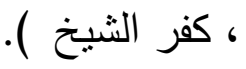
r- الحدود البثـرية: عينـة من طـلاب وطالبـات بعض الكليـات النظريـة

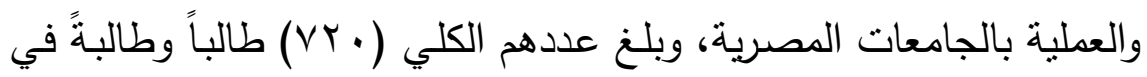

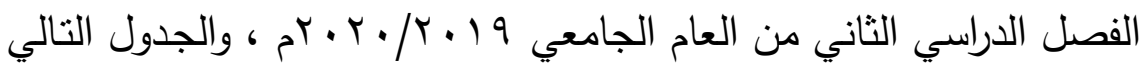
يوضح تفصيل للعينة: 
جدول( 1 ) بيان بأعداد عينة الدراسة وتوزيعها حسب نوع الكليات والجنس

\begin{tabular}{|c|c|c|c|c|}
\hline العدد & 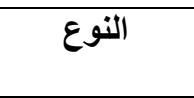 & الفرقة أو & نوع الكلية (نظري/ & \\
\hline$r q$ & ذكور & \multirow{3}{*}{ الأدنى (أولى وثلى) } & \multirow{6}{*}{ كليات نظرية } & \multirow{6}{*}{1} \\
\hline $10 \xi$ & إناث & & & \\
\hline $1 \wedge r$ & الكل & & & \\
\hline 01 & ذكور & \multirow{3}{*}{ ورابعة فأعلى (ثالثة) } & & \\
\hline $1 \leqslant 7$ & إناث & & & \\
\hline $19 V$ & الكل & & & \\
\hline$\Lambda$. & إجمالي الذكور & \multirow{3}{*}{\multicolumn{3}{|c|}{ إجمالي عدد طلاب الكليات النظرية }} \\
\hline$r \ldots$ & إجمالي الإناث & & & \\
\hline rᄉ. & الإجمالي & & & \\
\hline ro & ذكور & \multirow{3}{*}{ والأدنى (أولى } & \multirow{6}{*}{ كليات عملية } & \multirow{6}{*}{ r } \\
\hline 110 & إناث & & & \\
\hline Yr. & الكل & & & \\
\hline or & ذكور & \multirow{3}{*}{ ورابعة فأعلى (ثالثة) } & & \\
\hline TV & إناث & & & \\
\hline IT. & الكل & & & \\
\hline$\wedge \wedge$ & إجمالي الذكور & \multirow{3}{*}{\multicolumn{3}{|c|}{ إجمالي عدد طلاب الكليات العملية }} \\
\hline YOY & إجمالي الإناث & & & \\
\hline TE. & الإجمالي & & & \\
\hline $7 \varepsilon$ & ذكور & \multirow{3}{*}{ والأدنى (أولى } & \multirow{6}{*}{ و الكليات النظرية } & \multirow{6}{*}{ r } \\
\hline quq & إناث & & & \\
\hline$\varepsilon \cdot r$ & الكل & & & \\
\hline $1 \cdot \varepsilon$ & ذكور & \multirow{3}{*}{ ور الأعلى (ثألثلة } & & \\
\hline YIT & إناث & & & \\
\hline TIV & الكل & & & \\
\hline 171 & إجمالي الذكور & \multirow{3}{*}{\multicolumn{3}{|c|}{ إجمالي عدد طلاب الكليات النظرية و العملية }} \\
\hline $00 Y$ & إجمالي الإناث & & & \\
\hline$V Y$. & الإجمالي & & & \\
\hline
\end{tabular}


ع -بعـض تطبيقـات الهـاتف المحمــول وهــي: تطبيــق الفـيس بــوك Facebook

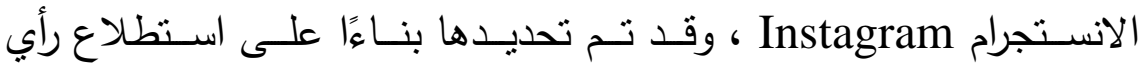

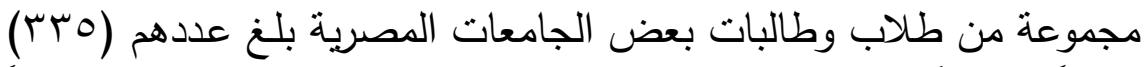

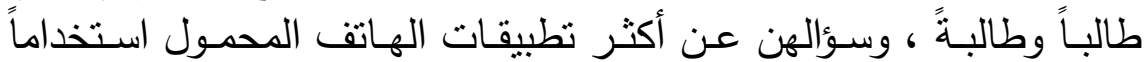
وشيوعاً بينهم. وطال

\section{منهج الدراسة:}

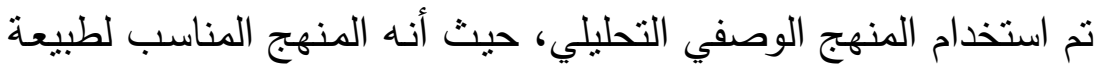

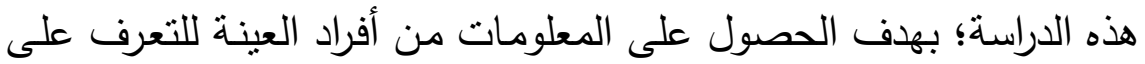
دور تطبيقات الهاتف المحمول في تعزيز قيم المواطنة الرقية لدى طلاب الديات بعض الجامعات المصرية .

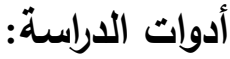

وتتشتمل على أدوات جمع وقياس:

أ- قائمة قيم المواطنة الرقمية. ( إعداد/ الباحثثان)

ب- استنيان دور بعض تطبيقات الهاتف المحمول في تعزيز قيم المواطنة

$$
\text { مصطلحات الارقاسة. ( إعداد/ الباحثنان) }
$$

فيما يلي تعريف للمصطلحات التي تتبناها الباحثتان في الدراسة الحالية : 1-الهاتف المحمول:

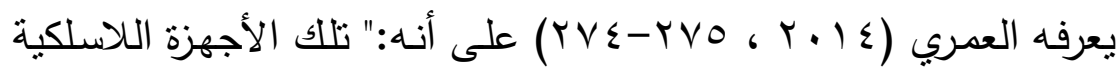

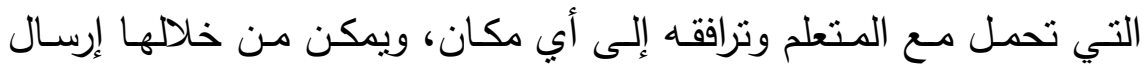


واسـتقبال المكالمـات الهاتقيـة أو الرســائل النصـية الإلكترونيـة أو رسـائل

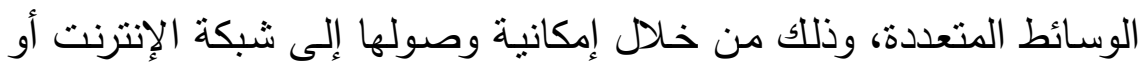

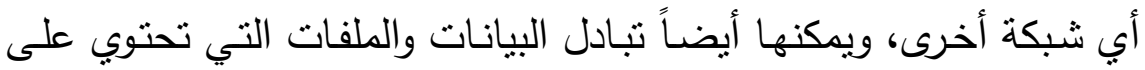
بيانـات إلكترونيـة أو مرفقات على شكل صـور ثابتـة أو صسوت أو مقاطع الفيديو."

يُعرف إجرائياً في الدراسة الحالية بأنها: "وسيلة اتصسال إلكترونية لاسلكية

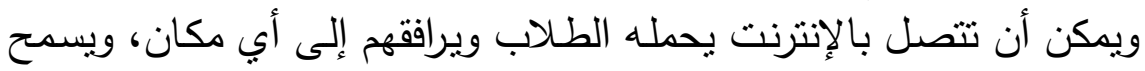

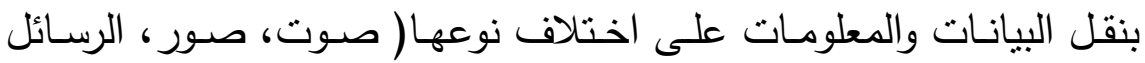
النصية الإككترونية أو رسائل الوسائط المتعددة، فيديوهات ) عبر مسافاتٍ

$$
\text { بعيدةٍ وبشكلٍ سريع. }
$$

\section{r-"طبيقات الهاتف المحمول :}

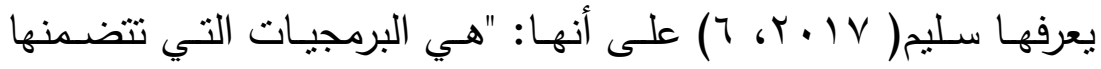

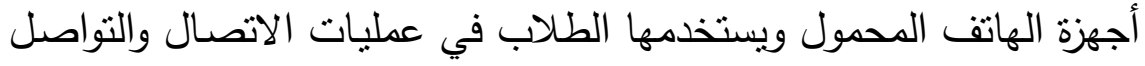

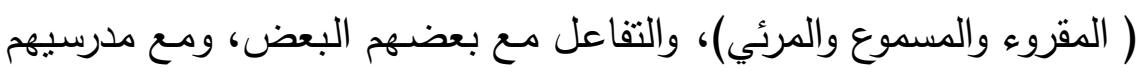
خلال مسيرتهم التعليمية في الفصول المدرسية."

تُعرف إجرائياً في الدراسة الحالية بأنها: "البرمجيات الإلكترونية الموجودة

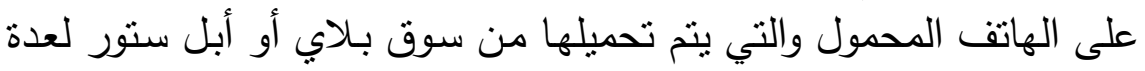

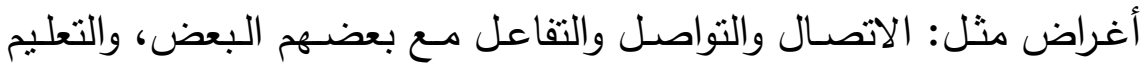

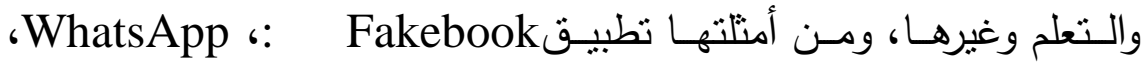
Instagram 


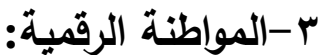

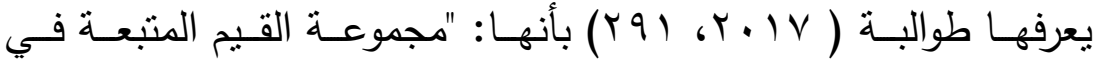
الاستخدام الأمتل والإيجابي للأدوات التكنولوجية التي يحتاجها (المواطنون)

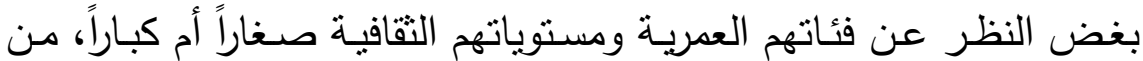
أجل المساهمة في رقي أوطانهم وحمايتها من سوء استخدام أدواتها.

تُعرَّف المواطنة الرقمية في الدراسـة الحاليـة إجرائياً: مجموعة الضوابط والمعايير التي يجب مراعاتها عند استخدامات التكنولوجيا الرقمية، والمتمثلة في مجموعة من الحقوق التي ينبغي أن يتمتع بها طلاب الجامعات أثناء

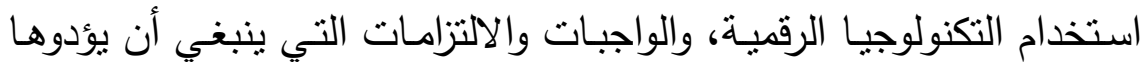

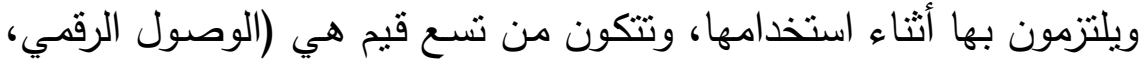

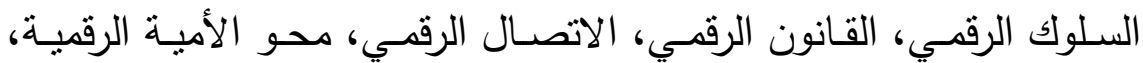

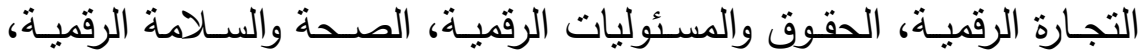
الأمن الرقمي).

\section{ع -طلاب الجامعات المصرية :}

يُقصــــــــلاب الجامعــات المصــرية "الطــلاب الملتحقـين ببرنـامج البكـالوريوس بـبعض الكليـات النظريـة (التربيـة، الآداب، الألسـن، التربيـة

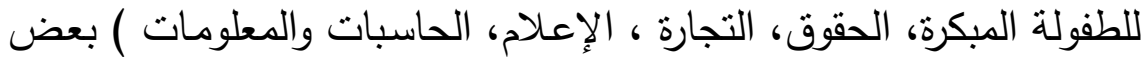

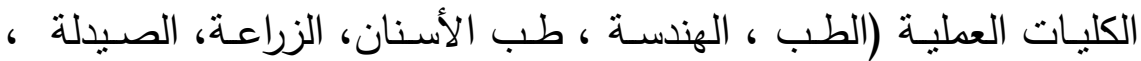

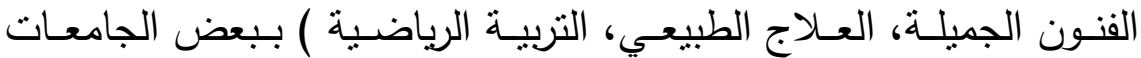

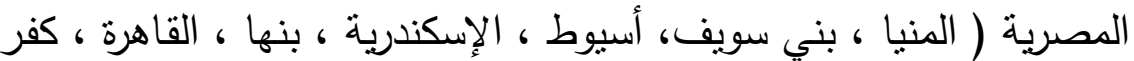
الثيخ ). 

تسير الدراسة وفقاً للخطوات والإجراءات التالية:

أولاً: تحديد قيم المواطنة الرقمية، وذلك من خلال مراجعة وتحليل الدراسات

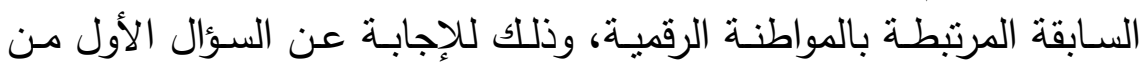

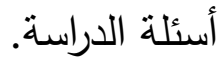

ثانياً: تحديد أكثر تطبيقات الهاتف المحمول شيوعاً بين طلاب وطالبات

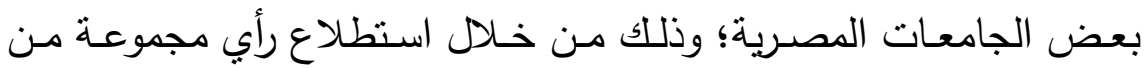

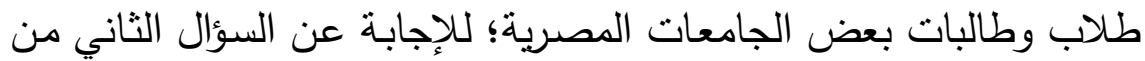

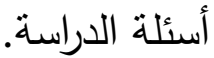

ثالثًا: تحديد أكثر تطبيقات الهاتف المحمول تأثثرًا في تتمية قيم المواطنة

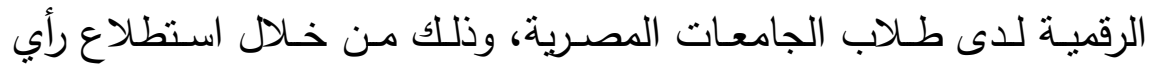

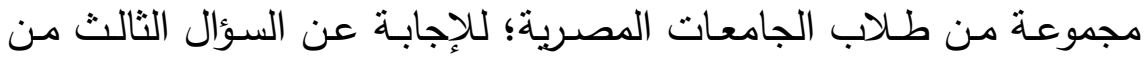

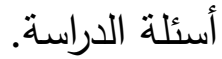

رابعساً: بناء استبيان دور بعض تطبيقات الهاتف الهحمول في تعزبز قيم

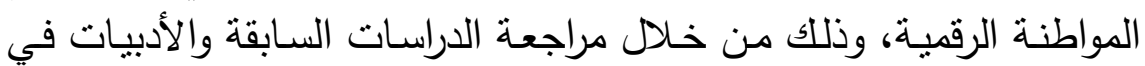

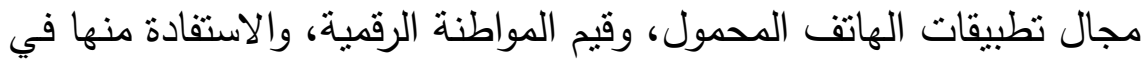
بناء الاستبيان، ثم تحكيمه، وإيجاد الصدق والثيات الثبات الثبات للاستبيان.

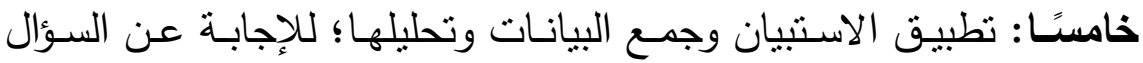

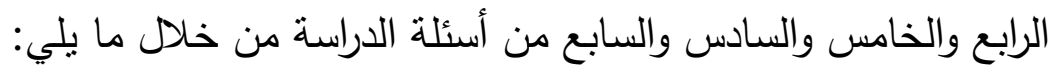

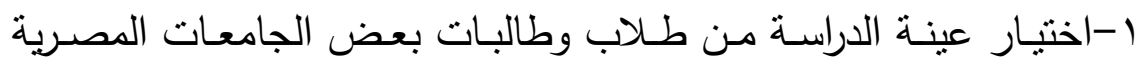
(الكليات النظربة، والعملية). r-إجراء التجربة الاساسية بتطبيق الاستبيان النيان على مجموعة الدراسة. ب-جمع البيانات ومعالجتها إحصائيًا. 


\section{المجلة العلمية لكلية رياض الأطفال - جامعة بورسعيد}

ع-عرض النتائج للإجابة عن أسئلة الدراسة، تفسير النتائج. سادسنًا: وضـع تصور مقترح لتفعيل دور بعض تطبيقات الهاتق المحمول في تعزيز قيم المواطنة الرقمية؛ للإجابة عن السؤال الثامن.

\section{الإطار النظري للارباسة:}

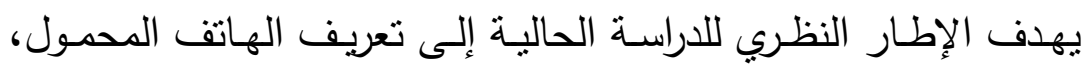

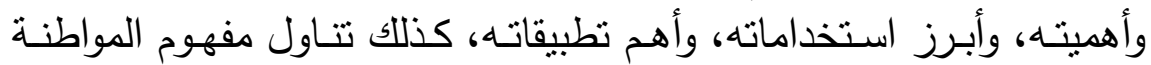
الرقمية، وأهميتها، وأهدافها، وأهم القيم التي تتضمنها، تمهيداً لاستقراء بناء

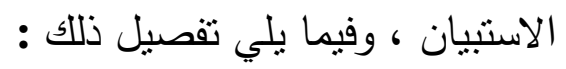
أ- - الهاتف المحمول:

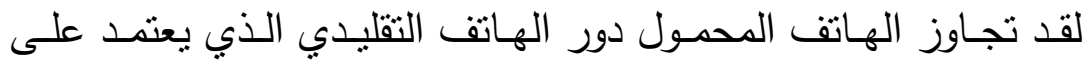

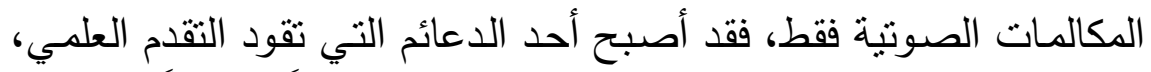

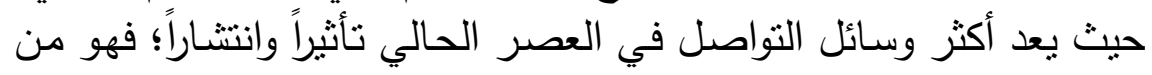
أبرز تقنيات وسائل الاتصـال الحديثة؛ لما يتيحه من تفاعلية وقدرات تقنية

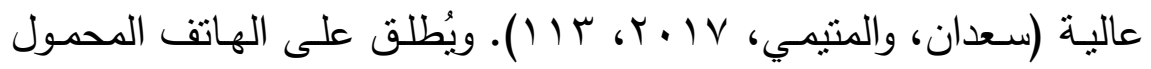
عدة مسميات منها: الهاتف المحمول، الهاتف النقال، والهاتف الخلوي . . استخدامات الهاتف المحمول:

هنالك العديد من الاستخدامات التي يقدمها الهاتق المحمول؛ حيث بُعد وسيلة الاتصـال الأولى داخل مجتمعاتتا، إذ أصبح البديل في التفاعل مـع الأفراد والجماعات؛ نظراً لمميزاته التي تربط الفرد بالآخر من دون حواجز

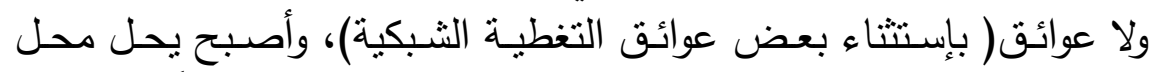
الزبارات والمواجهات المباشرة بين الناس؛ لذا شاع استخدامه كثيراً في مجال ئن 
العلاقـات الاجتماعيـة، وجعل الأفراد شـيدي الالتصـاق بالهاتق المحمول،

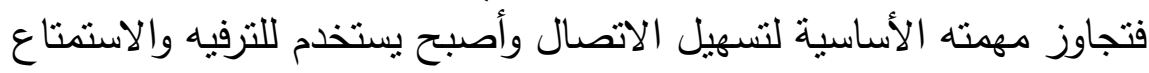

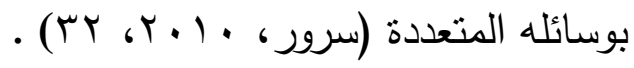

وأصبح الهاتق المحمول أحد الدعائم التي تقود التقدم العلمي، وبعد أكثر وسـائل التواصـل في العصـر الحسالي تـأثيراً وانتشـاراً؛ فهو مـن أبـرز تقنيات وسائل الاتصال الحديثة لما يتيحه من تفاعلية وقدرات تقنية عالية.

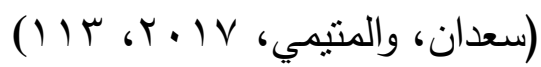

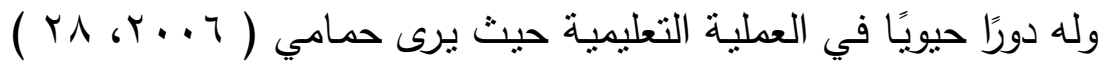
أن الهاتق المحمول يوفر للطلبة الذين لا تتوافر في مناطقهم بنية تحتية ، حيث يتم التعلم من خلالهه في أي مكان وزمان؛ لأنه يعتمد على استخدام تقنيات لاسلكية، ولا يتطلب ضرورة البقاء في أماكن أو أوقات محددة؛ حيث لـان يحقق المشاركة والتعاون المتجاوز للتباعد الجغرافي والجسماني بين الطسلاب وبعضهم البعض، وبينهم وبين معلميهم، ويتيح للمتعلم التواصل السربع مـع شبكة المعلومات الدولية ،وبمتاز بسـهولة تبادل الرسائل بأنواعها (الغويري، وهئ .$(r 09$. $r .19$

كما يستخدم الهاتق المحمول من طرف الجهات المصرفية في التواصل

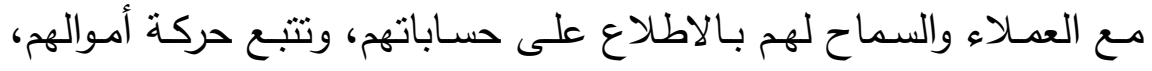
بتصفح حساباتهم، ودفع الفواتير ، وتحوبل مبالغ مالية، وبستخدم في المجال الصحي من خلال نماذج لتقنيات الاتصال المحمول الخاصة بالأطباء ونظم الرعاية الصحية خاصةةً أثتاء تنقلاتهم وزيـاراتهم المبدانية للمرضـى؛ لتتبادل

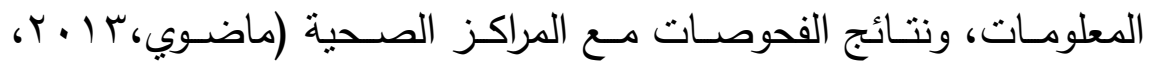
(1) $\leqslant-1)$. 
ويتضـح دوره المهم في عمليـات الترويج والإعـلان مسن خـلال إرسـال

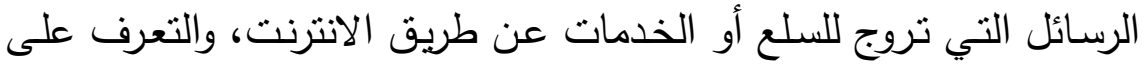

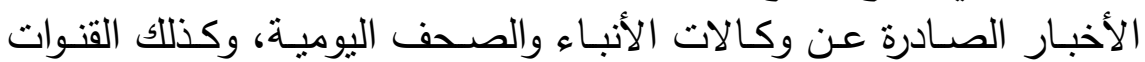
التلفزيونية من خلال الرسائل القصيرة أو رسائل الوسائط المتعددة ـ ولائ ولائل

مما سبق بتضـح أن هناك استخدامات عديدة يمكن أن تقدمها تطبيقات الهاتف المحمـول في شـتى مجـالات الحيـاة الاجتماعبـة والتواصـل والتعليم

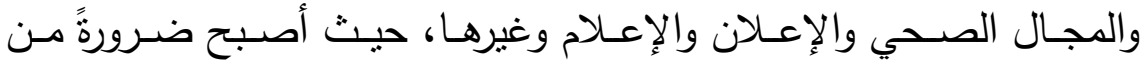
ضرورات الحياة التي لا يمكن الاستغناء عنها في عصرنا الرقمي الحالي،

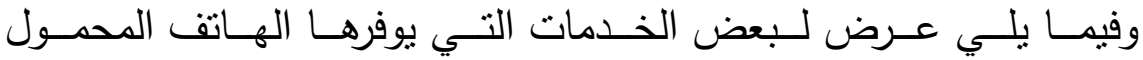
للمستخدمبن:

تتعدد الخدمات التي تقدمها الهواتف المحمولة وتثمثل أهمها فيما يلي: ا-خدمـة الرسـائل القصيرة (SMS) :هي كتابـة رسالة عن طريق لوحة

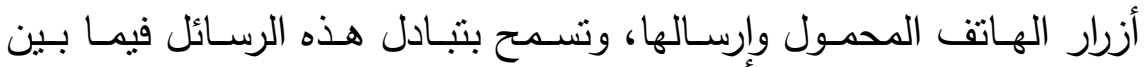
الأفراد.

r -خدمـة MSN المتنقل: يمكن من خلال هذه الخدمة أن تصلك رسـئل MSN Messenger وMSN Hotmail

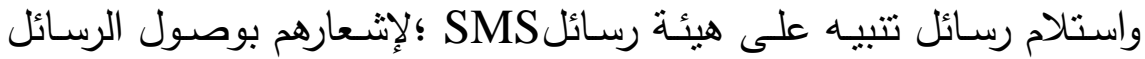

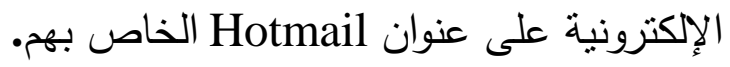
ب-خدمـة الوسـائط المتعددة (MMS): خدمة إرسـال واستقبال الرسـائل المصورة أو الملفات الصوتية أو الفيديو والرسائل النصية بمحتوى أكبر مما هو عليه في الرسائل القصبرة ع -خدمة الويب (WAP) : منل البريد الإلكتروني والأخبار، وغير ذلك. 
ه-خدمة التراسل بالحزم العامـة للراديو (GPRS): التراسل بالحزم العامة

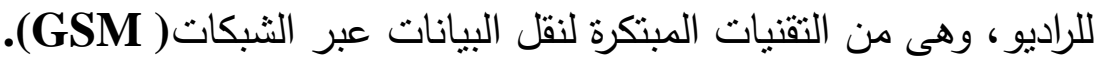
צ-خدمـة البلوتـوث Bluetooth : تقنيـة للتواصـل عبر موجـات راديـو

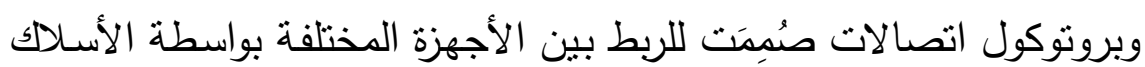
أسلوب وطريقة جديدة تعتمد على الاتصال اللاسلكي.

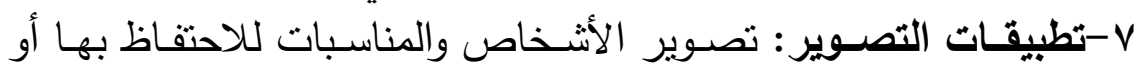

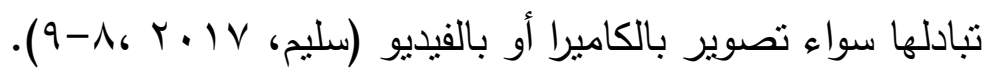

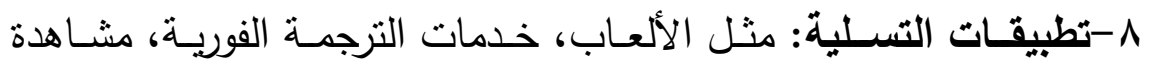

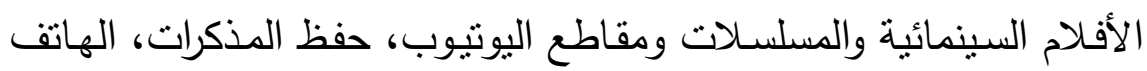

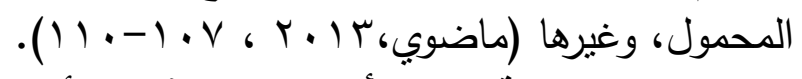
9-خدمات تعليمية: حيث أصبح في الآونة الأخيرة محور اهتمام الهام المربين

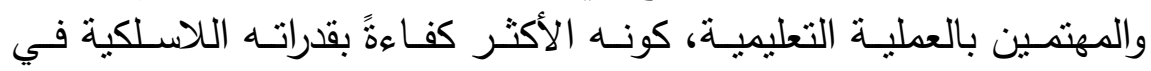

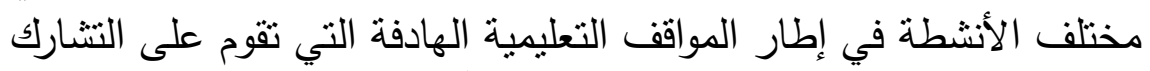

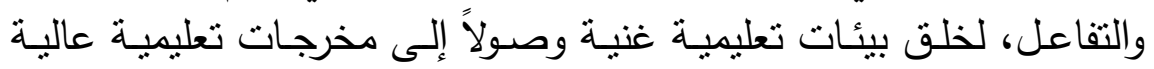

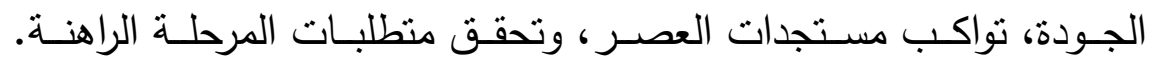
(Gardner et al,2013,20)

مما سبق يتضح لنا أن هنالك العديد من الخدمات التي يمكن أن توفرها

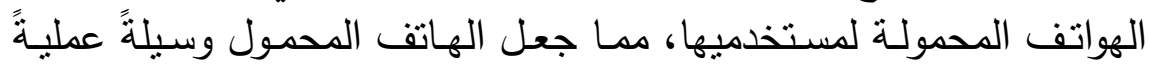

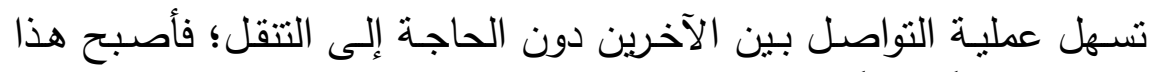

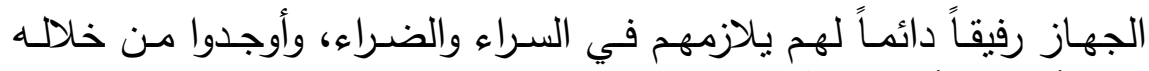

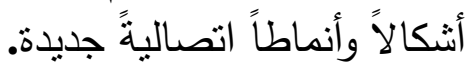


تطبيقات الهاتف المحمول:

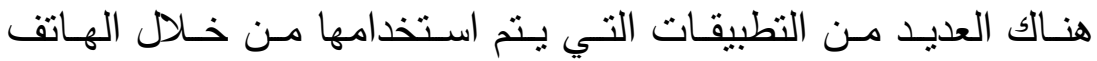

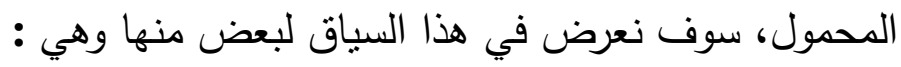
|

يعتبر الفيس بوك من أهم شبكات التواصل الاجتماعي في الوقت الراهن؛ فهو مظهر من مظاهر العولمة لأنه يجعل العالم قرية صغيرة يتواصل فيها

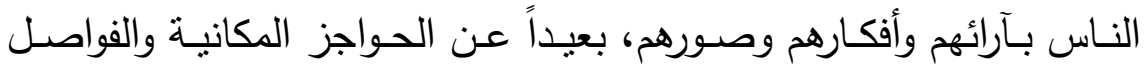

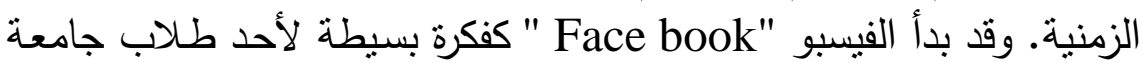
هارفارد " مارك زوكربيرج "Mark Zuck erberg" ؛ لتعزيز التواصل بين الطلاب، والإبقاء على الروابط بينهم بعد التخرج ، بعدها حقق نجاحًا كبيرًا؛

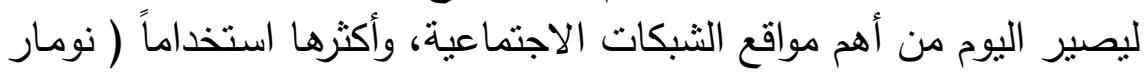

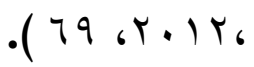

ويتكون الفيسبوك من مجموعة من الثبكات تتألف من أعضاء، وتصنف

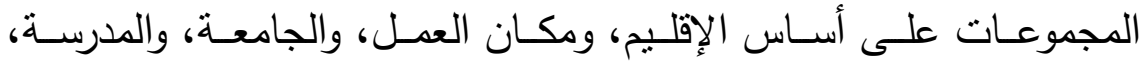

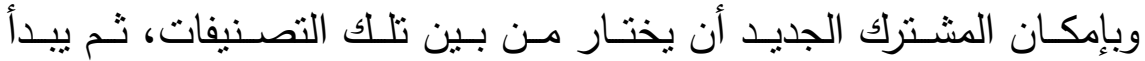

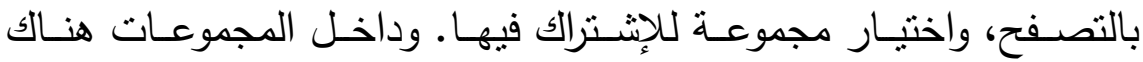

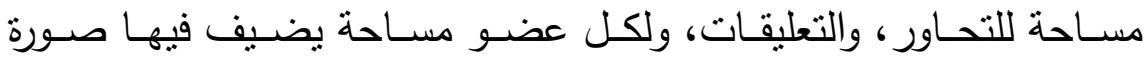

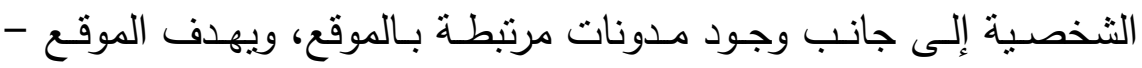

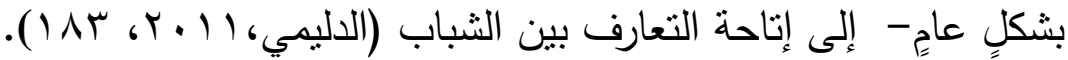
r- تطبيق وإتس آب "What App" أحد تطبيقات الهاتف المحمول المجانيـة المنتشـرة في المجتمعات (Khathami , 2018 (237)، وقد شهد استخدام الوانس آب تداولاً سريعاً 


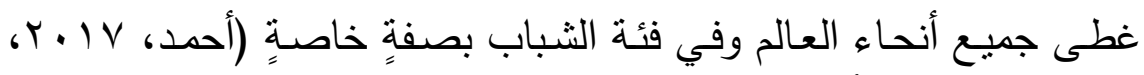

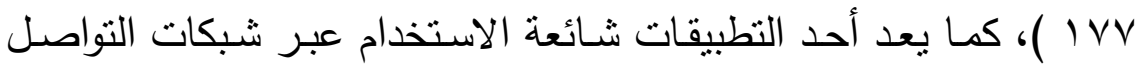

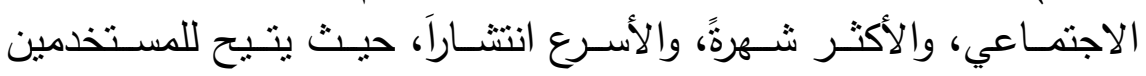

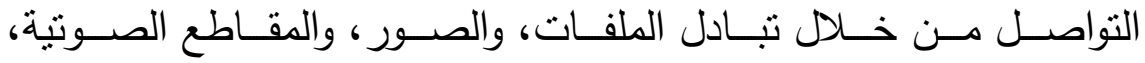

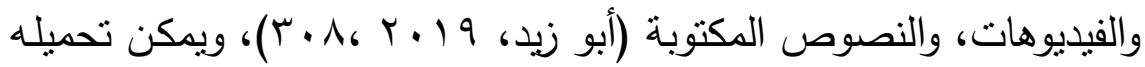

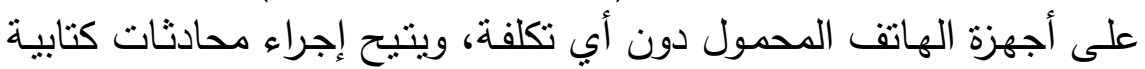

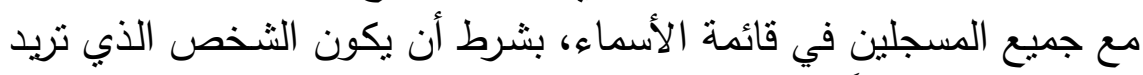

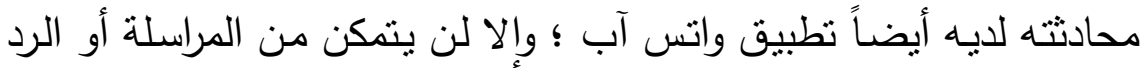

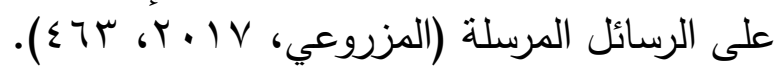

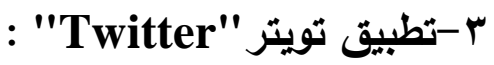

أحد تطبيقات الهاتف المحمول المنتشرة بين المستخدمين، وأخد اسمه

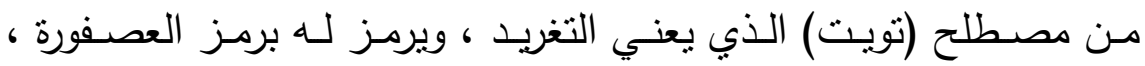

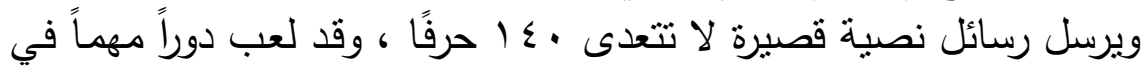

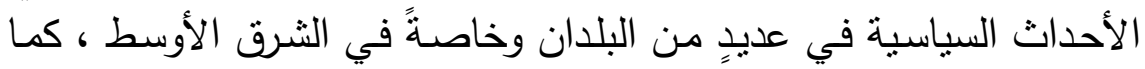

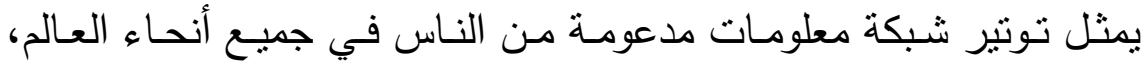

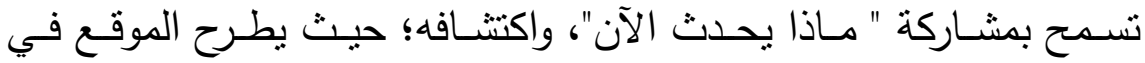

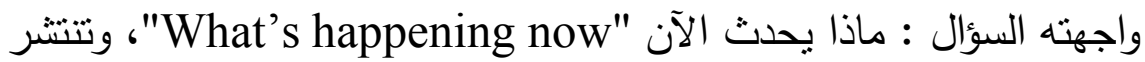
الإجابة إلى الملايين عبر العالم على الفور (Bellin, 2012, 331)،

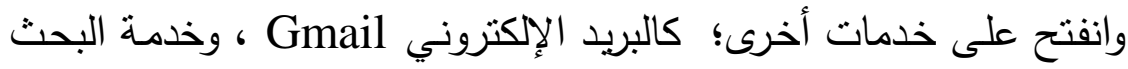

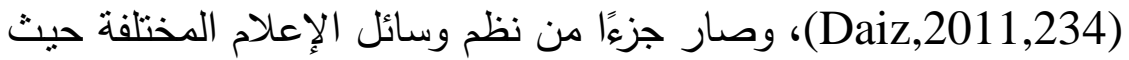

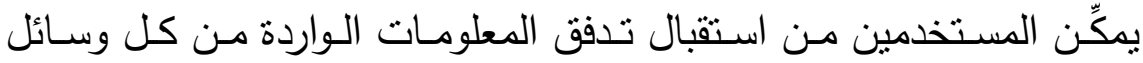
الإعلام) Hermida,2010, 297) 


\section{ع -تطبيق انستجرام " Instagram"}

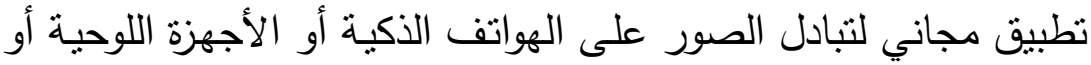

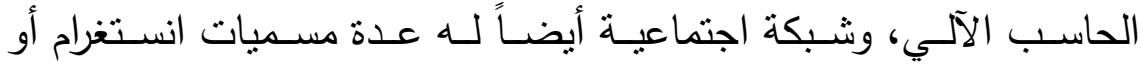

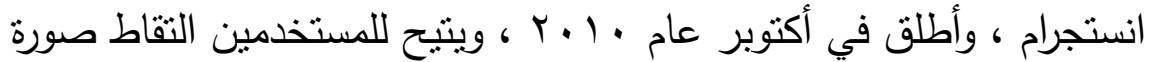

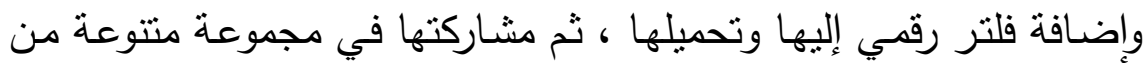

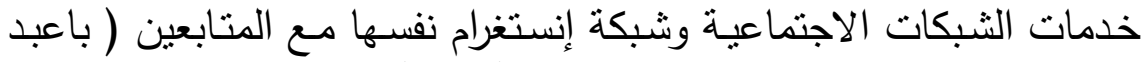

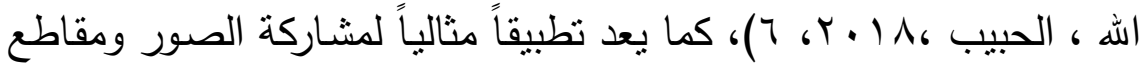

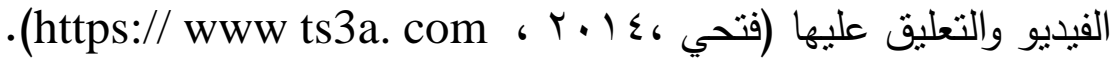

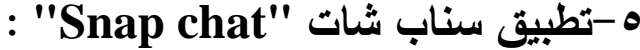

تطبيق مجاني انطلق في عام || (1 ب، يتم استخدامه من خلال الهاتفات المحمولة في إرسال مقاطع فيديو أو صور تحتوي في على تلى تعليقات عن حياة

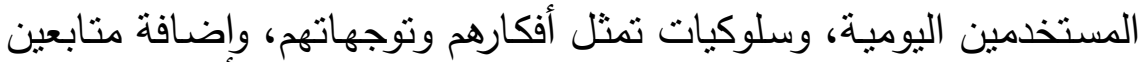

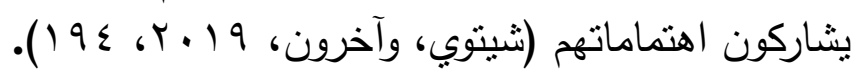

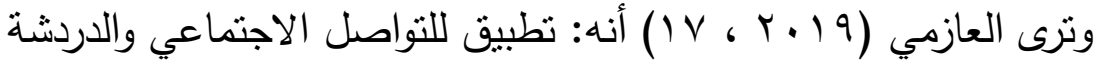

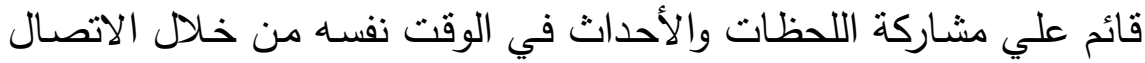

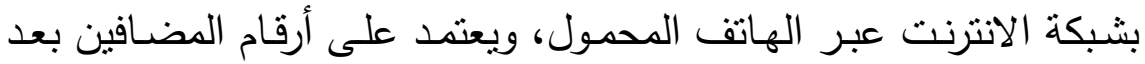
موافقتهم على الإضافة.

مما سبق يتضـح أن هناك العديد من التطبيقات التي يمكن أن تعدل ، التحل

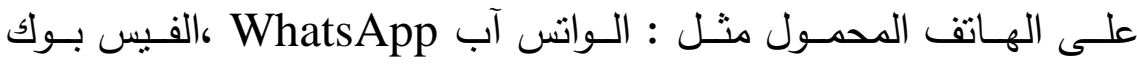

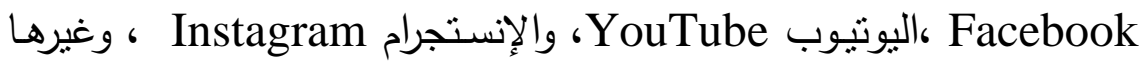
يقبل عليها الجميع بما فيهم طلاب الجامعة . 


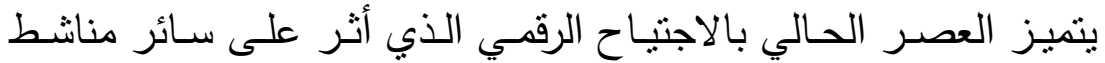

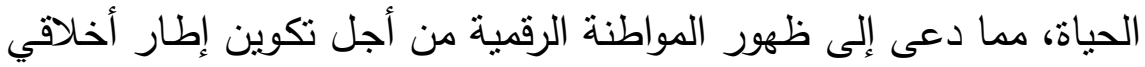

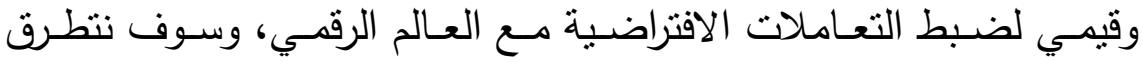
لمفهومها وأهميتها وقيمها ومراحل تتميتها على النحو التالي: مفهوم المواطنة الرقمية : ينظر للمواطنـة الرقميـة على أنها: النموذج الأمثل للمواطنـة في القرن

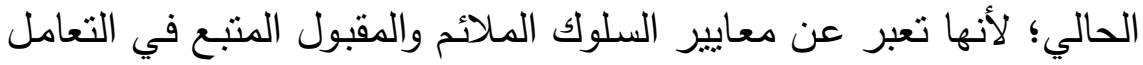

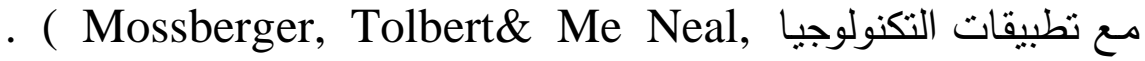
2008, 149).

وعرفها مارك برينسكي "Marc Prensky" " على أنها: الأخلاقيات

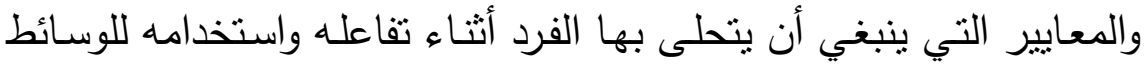

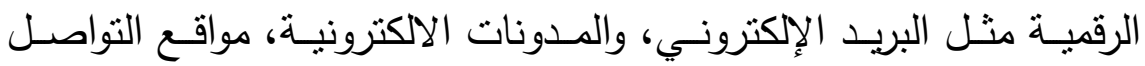
الاجتماعي؛ كالفيس بوك، والتويتز ، والواتس آب Edmonton Catholic) Shools, 2012, 1).

كما أطلق عليها توعية الطلاب بأساليب الاستخدام الأمثل للتكنولوجيا،

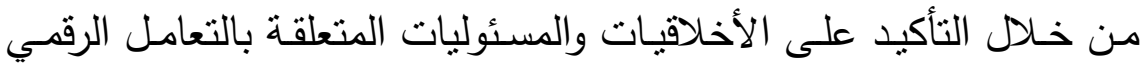
للمعلومات (Ribble, 2013, 2)

وعُرفت بأنها: مجموعـة مـن الممارسـات المبنيـة على أسـاس مسـئول

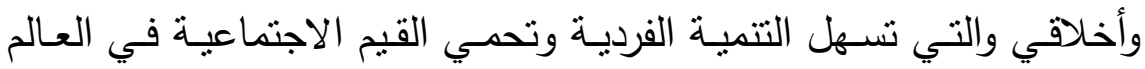
الرقمي) (Gazi, 2016, 139) 
كما عرفها "سيمك وسيمك (Simsek\& Simsek, 2013, 128) بأنها: قدرة الفرد على المشاركة في المجتمع الرقمي؛ بهدف إيجاد الطريق

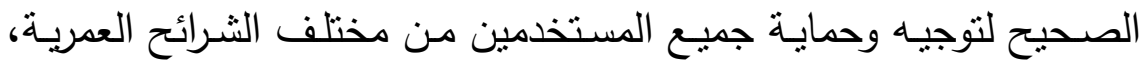

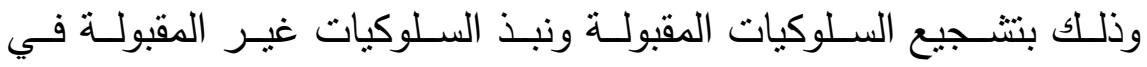
التعاملات الرقمية من أجل مواطن رقمي يحافظ علي وطنه ويجتهذ من أجل

في ضوء التعاريف السـابقة للمواطنـة الرقمية، يمكن تحديد خصائصـها

$$
\text { فيما يلي: في في }
$$

- الوعي بالعالم الرقمي، ومكوناته.

- إجادة مهارات التعامل والتفاعل مع التعالت آليات العالم الرقمي.

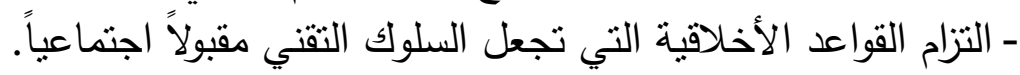

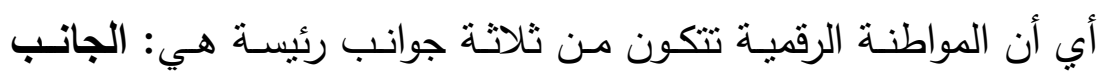

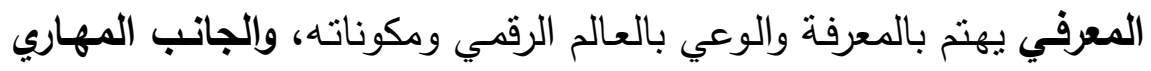

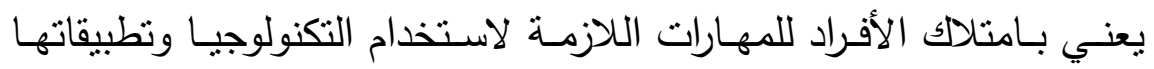

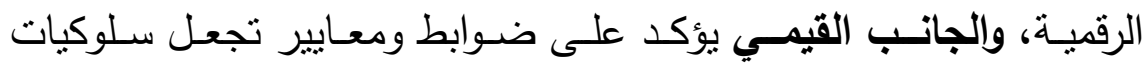

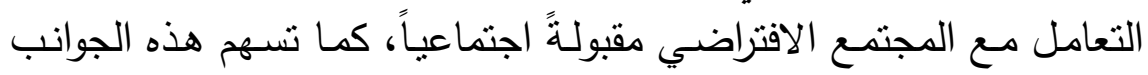

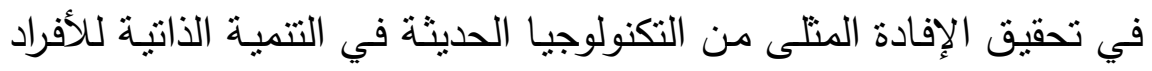
وبناء الاقتصاد الرقمي للمجتمعات، وفي الوقت ذاته تجنه الجنب مخاطرها وآثارها السلبية على الفرد والمجتمع. أهمية المواطنة الرقمية:

أدركت دول العالم المتقدم أهميـة المواطنـة الرقميـة ، ودورهـا في تكوين

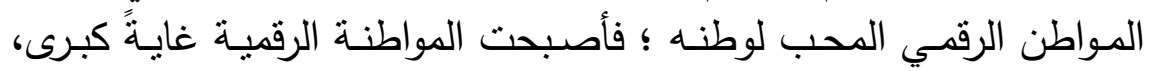


ومطلباً عالمباً؛ حيـث أطلقت كلّ مـن بريطانيا وأستراليا والولايـات المتحدة

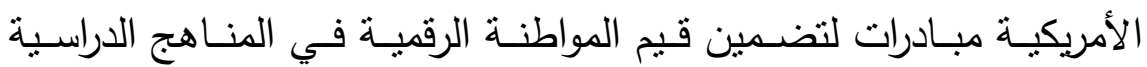

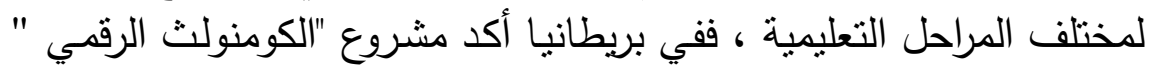
"Digital Commonwealth Project"

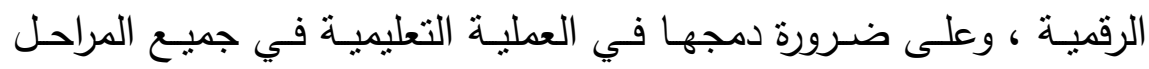
الدراسية ، كذلك أهمية تدريب الثباب وخاصة طلاب الجامعات على الوعي

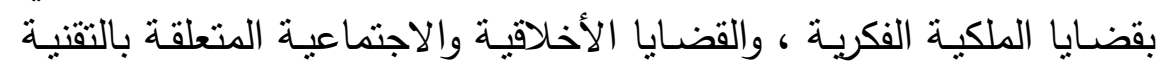

\section{الرقمية( Mcgillivary \& et.al, 2016, 724-729).}

كما وضـعت بعض الولايـات الأمريكيـة معـاييراً للتعلبم تشــل المواطنـة

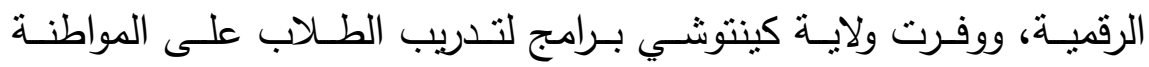
الرقمية، وفي أستراليا تم تدشين برنامج في المدارس يساعد المعلمين في فهم وتدريس المواطنة الرقمية .

\section{وتتبثق أهمبة المواطنة الرقمبة من المبررات التالية :}

أنها نشكل نظام حماية لجميع مستخدمي الوسائط التكنولوجيا وتطبيقاتها المختلفة، حيث تسعى إلى تكوين مواطن رقمي يحب وطنه، وبعمل لخدمته

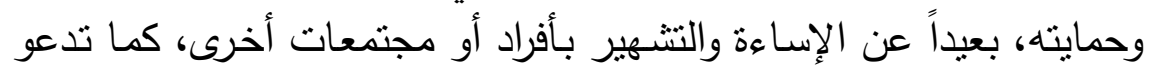

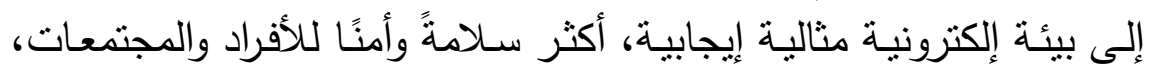

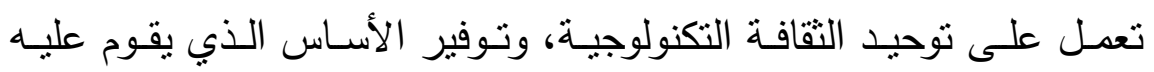

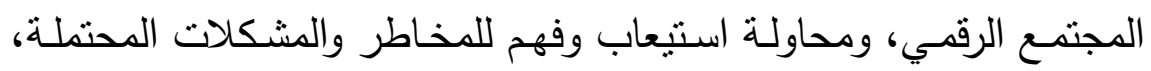

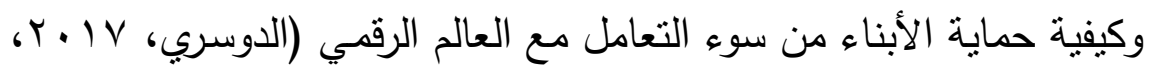

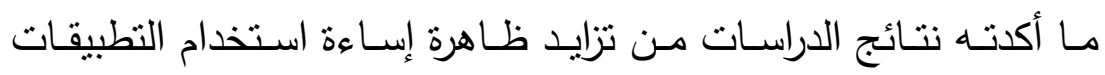

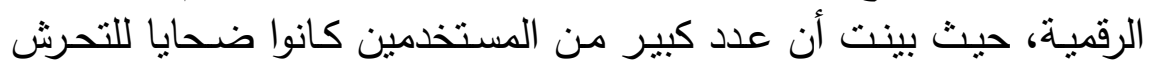


الالكتروني، والنصـب في التجارة الإككترونيـة، واختراق بيانـات الحسـابات

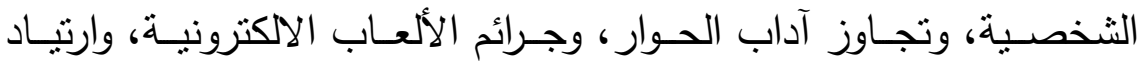
المواقع الإباحية، الأمر الذي جعل نشر قيم المواطنة الرقمية ضرورةً حتميةً،

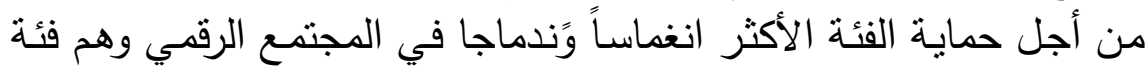

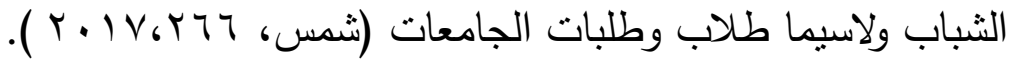

تهـتم المواطنـة الرقميـة بوضـع إطـار عـام؛ لتوعيـة المـواطنين بضـوابط

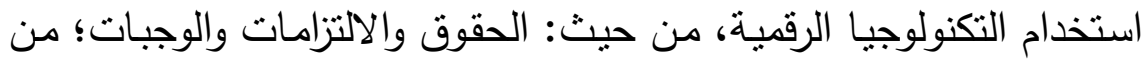

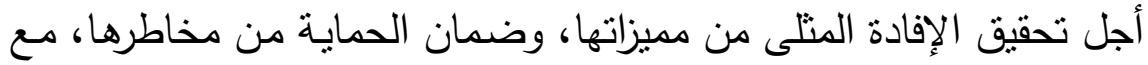
المحافظة على البعد القيمي، والسلوكي في الممارسات الرقمية ( المصري، .$(1796.1 \%$

لم تعد التقنية وتطبيقاتها الرقمبـة من سبل الترفيه والتسلبة ، ولا تقتصر

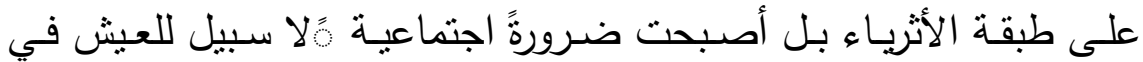

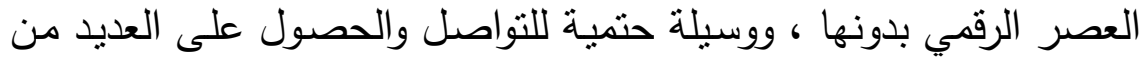

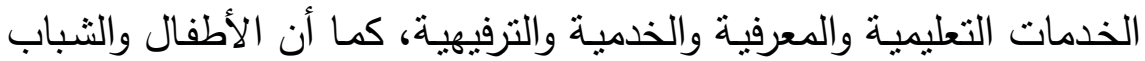
يستخدمون وسـائل الإعلام الرقمي ( الإنترنت والهاتف والآيباد والكمبيوتز )

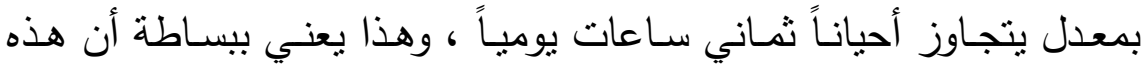
الوسائط تؤثز فيهم أكثر من نصف ساعات الاستيقاظ يومياً ، وأن لها تأثنر لهان

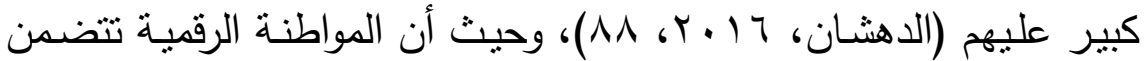

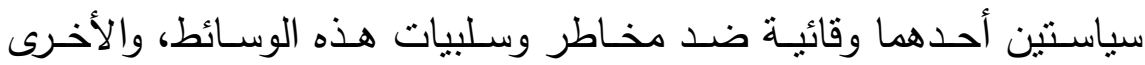
تحفيزية تتطوي على الإفادة المثلى من إيجابيات التقنية الحديثة، لذا صار

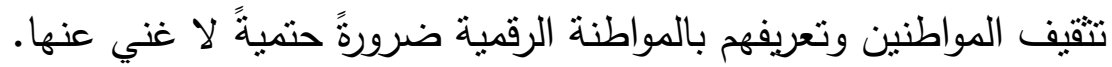

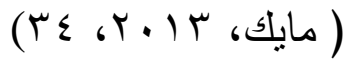


تمثنل التقنيـة الرقمبـة بوابـة للدخول إلى الفضـاء الافتراضـي الذي يتسـم

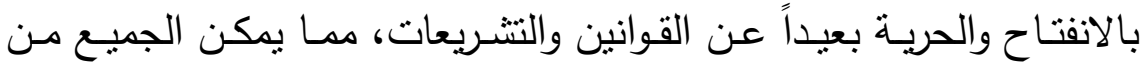

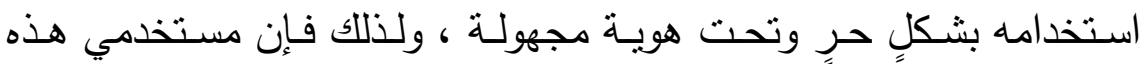

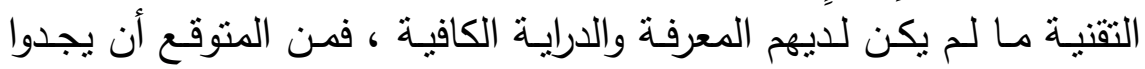

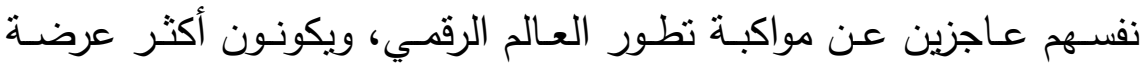

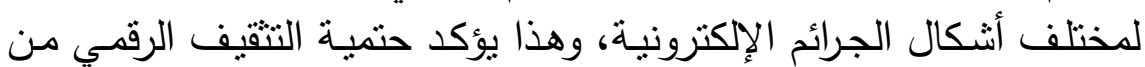

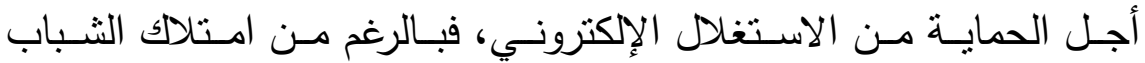

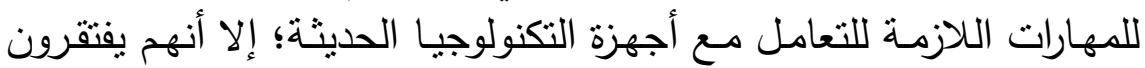
أحيانا القدرة علي توظيف هذه التكنولوجيا في دفع عجلة تتمية مجتمعاتهم

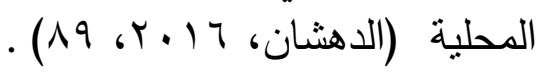

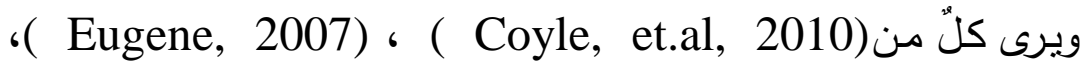
(الحصري، 17 • ( أن المواطنة الرقمية تكمن أهميتها في أنها تمكن الأفراد من:

- - الاستخدام الأخلاقي والمسئول والأمن للتكنولوجيا الرقمية.

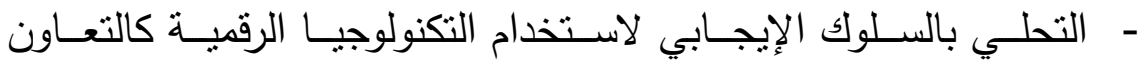
والإنتاجية والإيثار والتعلم . لالإيج. - - فهم طبيعة العالم الرقمي وأساليب التعامل معه.

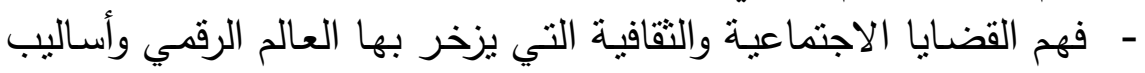
التعامل معها. - - تحمل المسئولية أثناء التعامل مع العالم الرقمي. - تحصين المواطن الرقفي بنسيج أخلافي يحميه من أخطار التكنولوجيا وتطبيقاتها. 
ويتضـح ممـا سبق أهميـة المواطنـة الرقمية، ودورها في تكوين المواطن

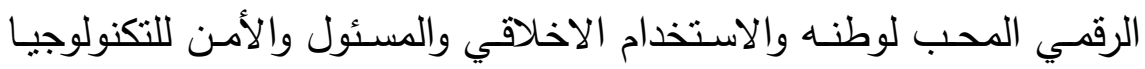

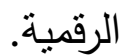

\section{أهداف المواطنة الرقمية:}

تهدف المواطنة الرقمية إلى مجموعة من الأهداف منها: - توجيه جميع شرائح المجتمع إلى كيفية استخدام التكنولوجيا الحديثة، من خلال توضيح الحقوق التي يجب أن يتمتعوا بها عند التئ التعامل مع التكنولوجيا

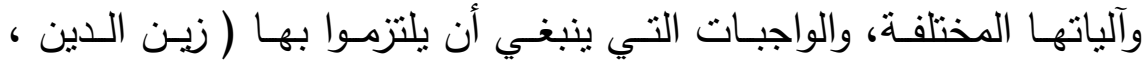

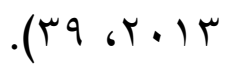

- تطوير مهارات الثباب في مجالين محددين: استخدام السلوك المحترم

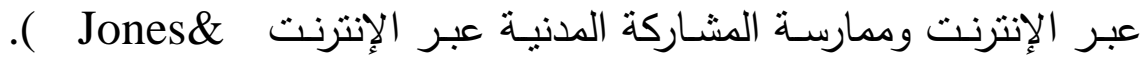
Mitchell, 2015, 2) . - دعم الجوانب والاتجاهات الإيجابية في استخدامات التقنية، كي يسنطيع مسـتخدم التقنيـة مـن إجـادة توظيفهـا بصـورة سـليمة، ويكـون مواطنَّا رقميـاً

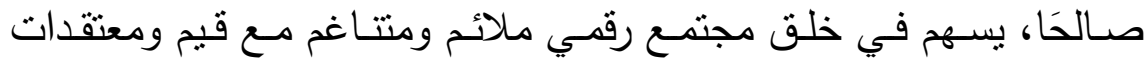

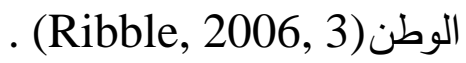

\section{قيم المواطنة الرقمية:}

أشار "ريبل إلى أن المواطنة الرقمية تتكون من تسع قيم تشكل الاستخدام

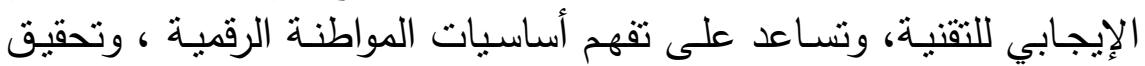

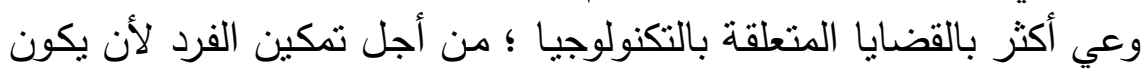

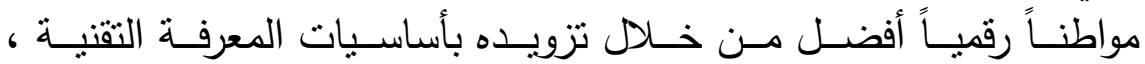
واستخدامها بطريقة آمنة وصحيحة يحمي بها ذاته وخصوصيته وممتلكاتها 


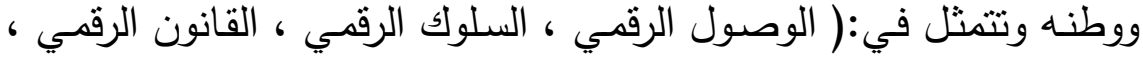

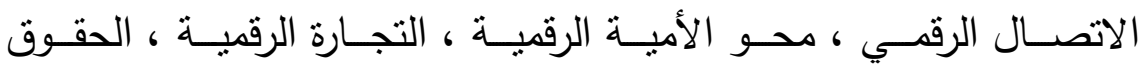

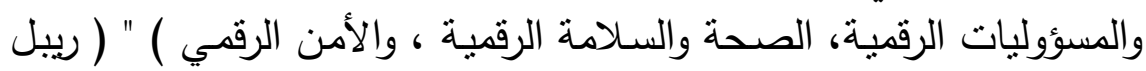
. ( ) V $6.1 r_{6}$ وقد تم تقسيم هذه القيم التسعة إلى ثناثث محاور رئيسة هي : المحور الأول: الاحترام، ويتضمن ثالاث قيم (المسـاواة الرقمية أو الوصسل الرقمي، السلوك الرقمي، القانون الرقمي) . وفيما يلي تقصبل ذلك:

• المسـاوة الرقمية (الوصول الرقمي Digital Access ):وبقصد بها

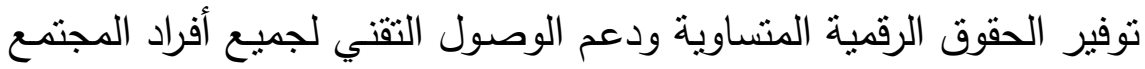

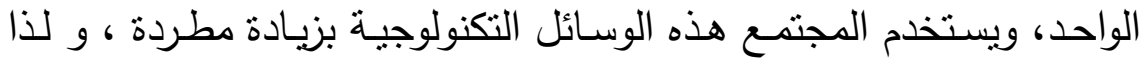
يجب أن يتتبه المسئولون إلى أن الوصول الإلكتروني قد يكون محدوداً عند بعض الأفراد، أو غير متوفر علي الإطلاق ؛ لذا لابـد من توفير وسـائل

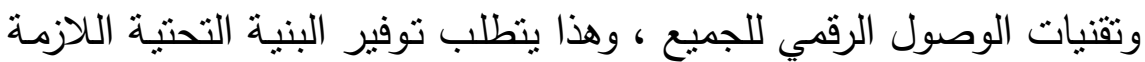
لتقنيات الوصول الرقمي بالتساوي بين جميع المواطنين بـا استثناء ، بحيث

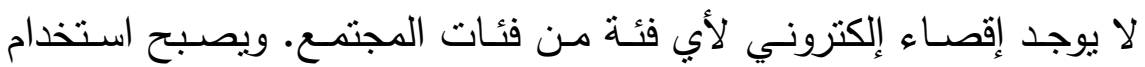

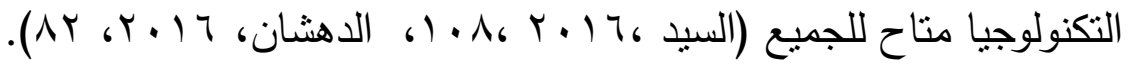
• السـلوك الرقمي ( اللياقة الرقمية Digital Etiquette) : تهنم

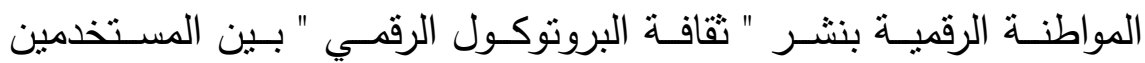

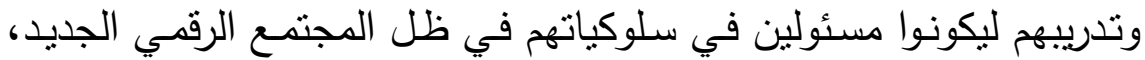
بهدف التصرف بتحضر ، ومراعاة القيم والمباديء ومعايير السلوك القويم

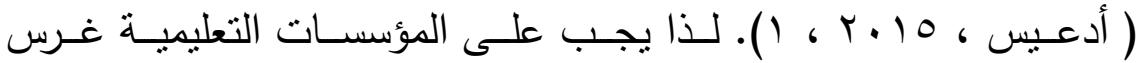
الاستخدامات والتصرفات اللائقة في الطلاب كمواطنين رقمبين، كما أن سن 
اللوائح وصياغة سياسات الاستخدام وحدها لا تكفي فلابد من توعية وتثقيف

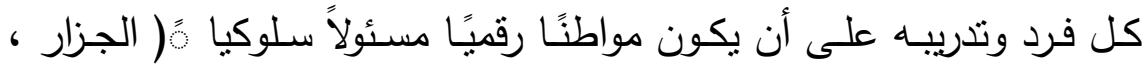

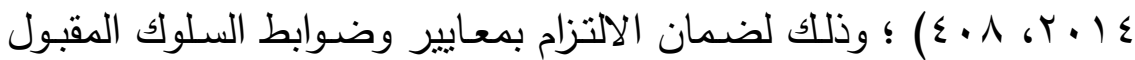
في السياقات الرقمية.

• القانون الرقي : يُقصد بها قوانين ولوائح المجتمع : Digital Law الرقمـي المتعلقـة بمســألة الأخلاقيـات الرقمبـة، ومعاقبـة الاسـتخدام غيـر

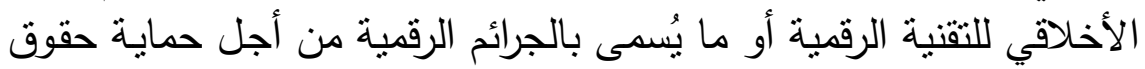

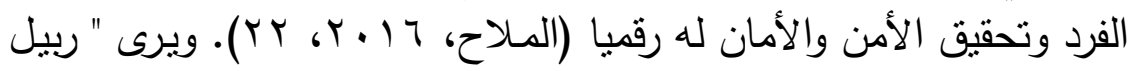
أنه يجب على المؤسسات التربوية ت تثقيف ( Riblle,2011, 32 )

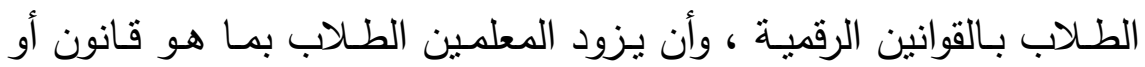
غير قانوني عند تعاملهم مع المجتمع الرقمي.

المحور الثاني: التعليم، ويتضمن ثلاث قيم (الاتصال الرقمي، محو الأمبة الرقمية، التجارة الرقمية). وفيما يلي تفصيل ذلك : ولتهن

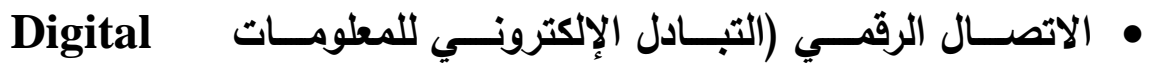
الاتصام (communication الاتصالات ، وتحول العالم إلى قربة صغيرة ، وأصبح التواصل مع الأفراد

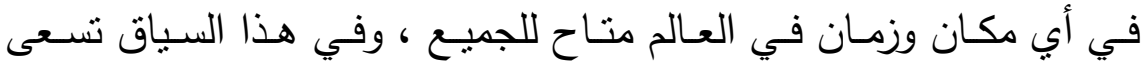
المواطنـة الرقميـة إلى تزوبـد الأفراد بالقدرة على اتخـاذ القرار السـليم أمـام

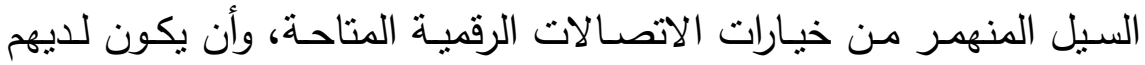

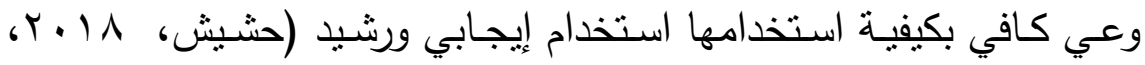




\section{الثقافة الرقمية (محو الأمية الرقمية Digital Literacy ): عملية}

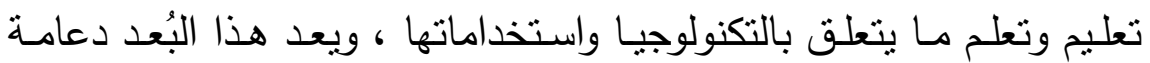

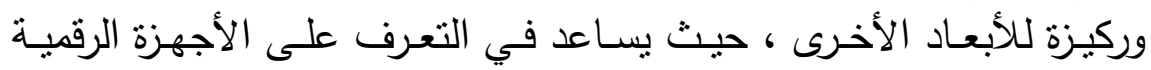

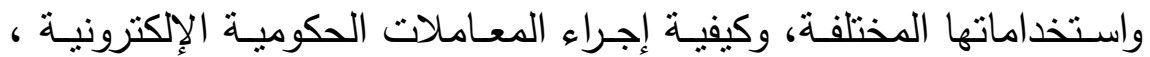

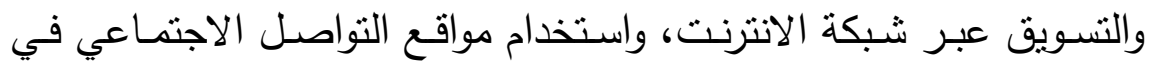

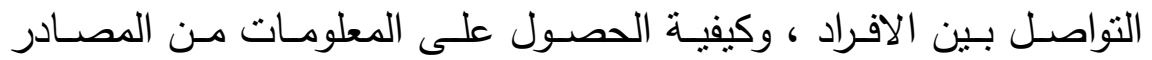

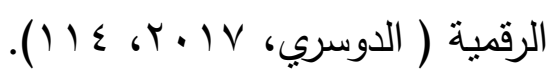

• التجارة الرقميـةDigital Commerce : ويقصد بها عملية البيع والثراء عبر شبكة الإنترنت، والذي أصبح واقعاً ، وفي تزايد مطرد ، وعليه

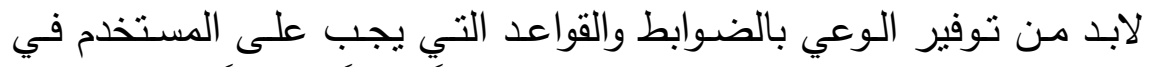

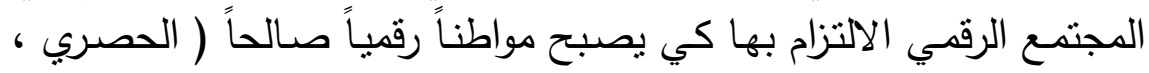

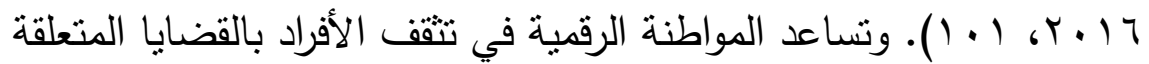

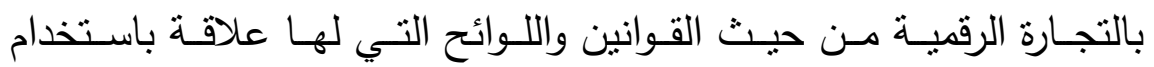

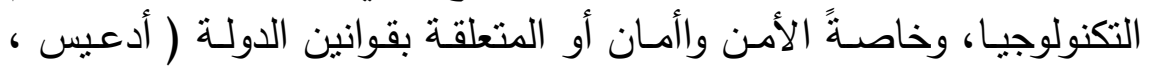
(l) 6.10 المحور الثالث: الحماية، وتثمل ثثلاث قيم (الحقوق والمسئوليات الرقمية،

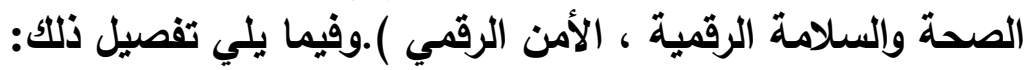

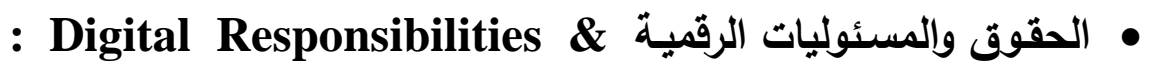
توفير المواطنة الرقمية للمواطن الرقمي مجموعة من الحقوق التيات التي

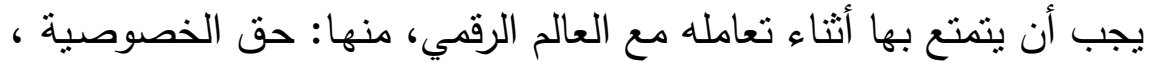

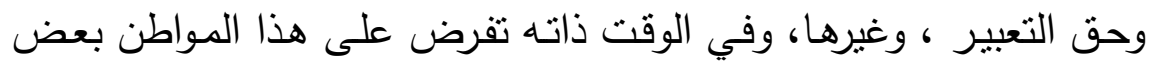

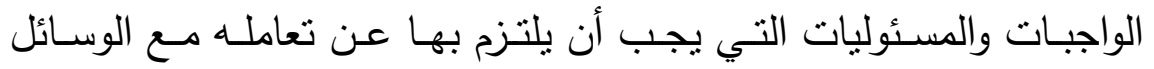

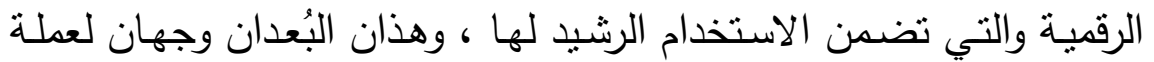


واحدة ، لابد من تفعيلهما معًا كي يصبح كل مواطن رقمياً مواطناً مبتكراً

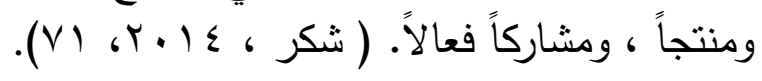

وتتمثل أهم الحقوق والمسئوليات التي ينبغي تدريب الطلاب عليها فيما

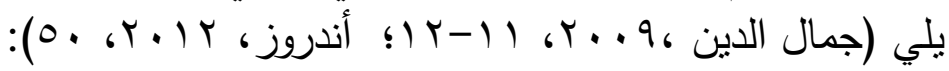
• الحقوق Rights :حق حرية الكلام وحربة التعبير ، حق الاتصال، حق حق الوصول للمعلومات، حق ملكية العمل الفكري، حق التدربب المالأم وإتاحة الأدوات المطلوبة لتحقيق الوصول بشكل كفء، حق خصوصية المعلومات والحفاظ على أمن المعلومات الخاص بالمواطن. • المسئوليات Responsibilities : الإذعان للقواعد والقوانين الثرعية

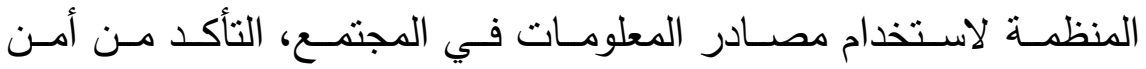
المعلومات، التصرف بشكلٍ أخلاقي، احترام الحقوق الخاصـة للجميع، البُعد عن كل تصرف يؤدي إلى ضياع، احترام تتوع السكان والأفراد. ولقد أشار " نشوي (Choi, 2016, 13 ) "أن القضايا المرتبطة بحقوق المستخدمين الرقمية وما يتبعها من مسئوليات يجب تضمينها في السياقات التعليميـة ، وأكد على أهميـة تـوفير الحمايـة لحقوق ومسـئوليات المـواطن

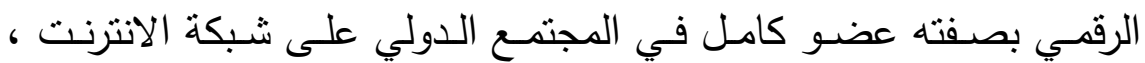
وحماية الآخرين بطريقة تتخطى الحدود الجغرافية والثقافية.

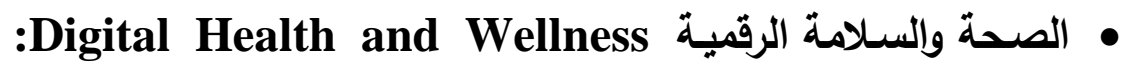
يصاحب استخدام التكنولوجيا وتطبيقاتها المختلفة بإسراف ولفترات طوبلة ، وبشكل غير السليم العديد من المشـاكل البدنيـة والنفسية التي تؤثز بدرجةٍ كبيرة على صحة الفرد ، وقد أدى هذا إلى ظهور ما يُعرف بالهندسة البشرية

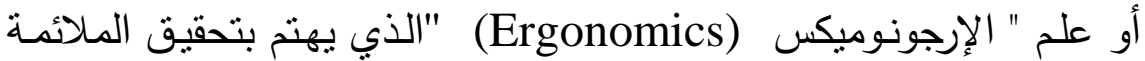
الفيزيائية والنفسية بين الأجهزة بأشكالها المختلفة والبشر الذين بستخدمونها 
ويتعاملون معها ـ ولهذا تعني المواطنة الرقمية بتوعية الأفراد وتثقيفه حول

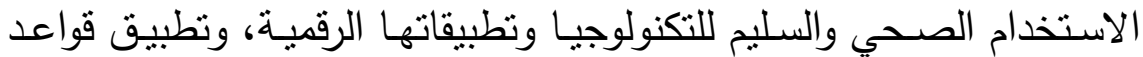

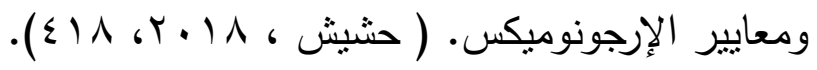

• الأمن الرقمي Digital Security : يختص هذا البُعد بإجراءات توفير الوقاية والحماية التقنية ، حيث ينبغي أن يتوفر لدى مستخدمي التكنولوجيا برامج حماية من الفيروسات ، والاحتفاظ بنسخ احتياطية لبيانتهم ، من أجل الجل

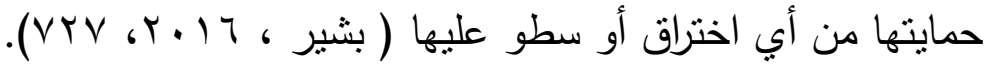
مدا سبق يتضـح لنا أن هنـاك مجموعة من القيم للمواطنـة الرقميـة يجب فئب تتميتها لدى أفراد المجتمع وبخاصة طلاب الجامعات وتتمثل في (الوصول الرقمي، السـلوك الرقمي، القـانون الرقمي، الاتصـال الرقمـي ، محو الأميـة

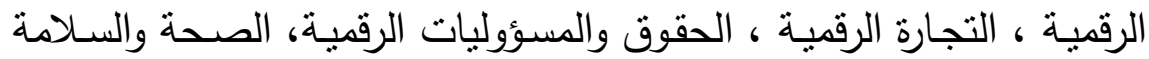
الرقميـة ، والأمـن الرقمي ) حيـث تمثنل الاستخدام الإيجـابي للتقنيـة، وتفهم

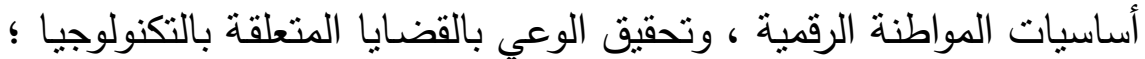
من أجل تمكين المواطنين لكي يكونوا مواطنين رقمين. مراحل تنمية المواطنة الرقمية :

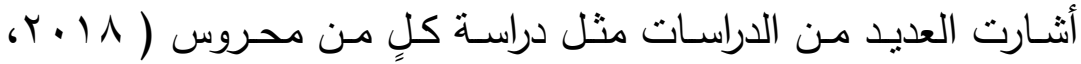

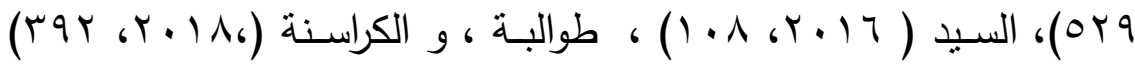
إلى أنه كي يتم إكساب طـلاب الجامعات المؤثرات اللازمة لتعريفهم بقيم المواطنة الرقمية وتعزيزها لديهم لابد من المرور بأربع مراحل أساسية ثتمثل -المرحلـة الأولـى( مرحلـة الـوعي): وفيها بـتم تزوبد الطـلاب بمـا يجعلهم مثقفين تكنولوجيا، والإلمام بالمهارات والمعارف الأساسية، وإدراك الطالب ما ولاب 
هو مناسب وما هو غير مناسب سلوكياً عند التعامل مع التطبيقات الرقمية،

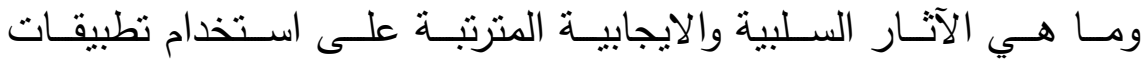

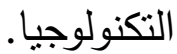

-المرحلة الثانيـة ( مرحلة الممارسـة الموجهة): تهنم بتتمية قدرة الطالب على استخدام التكنولوجيا في جو يشجع على المخاطرة والاكتشاف، لمعرفة المناسـب وغير المناسـب من الاستخدامات التقنيـة تحـت توجيـه مـن الآبـاء والمعلمين في المدارس والجامعات . -المرحلة الثالثة ( مرحلة النمذجة وإعطاء المثل والقدوة): وفيها بتم توعية الطلاب بإجراءات الحماية الذاتية من مخاطر التقنيات الرقمية، حتى يتمكنوا

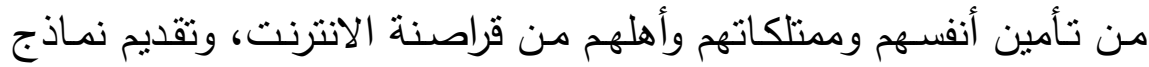
إيجابيـة مثناليـة في البيــت والمدرسـة والجامعـات حـول كيفيـة الاســتخدام الإيجابي والمثالي للوسائط التكنولوجية. -المرحلة الرابعـة ( التغذيـة الراجعـة والتحليـل): وفيها يتم إتاحة الفرصـة داخل المؤسسـات التعليمية للطلاب لمناقتـة مجالات استخدامهم للتطبيقات الرقميـة، وكيف يمكن تحقيق أقصى إفادة من هذه التقنيات، وكيف يمكن

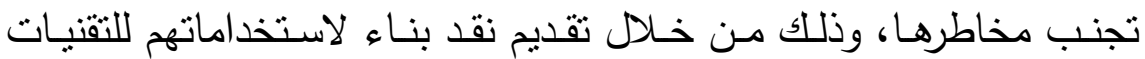
الموجودة في الجامعات والمجتمع.

أي أن تتميـة قيم المواطنـة الرقميـة تـتم من خـلل أربـع مراحل متذاخلـة

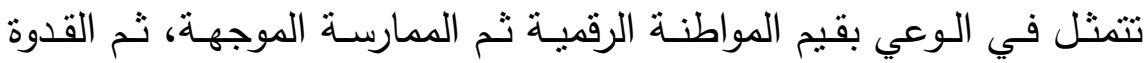
والنمذجة، وأخيراً التغذية الراجعة والتحليل، وأن كل مرحلة من هذه المراحل تؤثر وتتأثز بالمرحلة التي تسبقها، وكذلك التي تليها. وفي ضـوء مـا سـبق من تحليـل للخلفيـة النظربـة للاراسـة الحاليـة، أمكن تعريف الهاتف المحمول، أهميته، أبرز استخداماته، أهم تطبيقاته، ومفهوم 
المواطنة الرقيـة، وأهميتها، وأهدافها، وقيم المواطنـة الرقيـة، مراحل ثتميـة

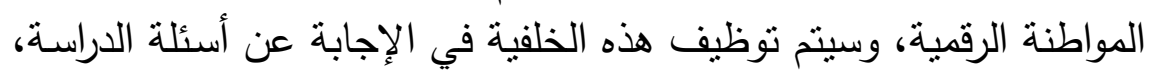

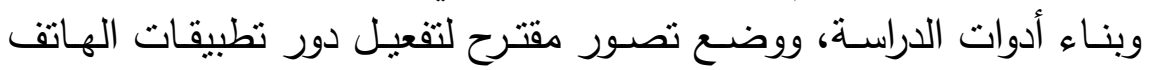
المحمول في تعزيز قيم المواطنة الرقمية لدى طلاب الجامعات المصرية لدرية.

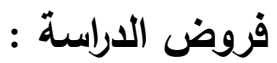

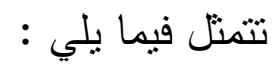

ا-توجد فروق دالة إحصائياً في دور تطبيقات الهاتف المحمول في تعزيز

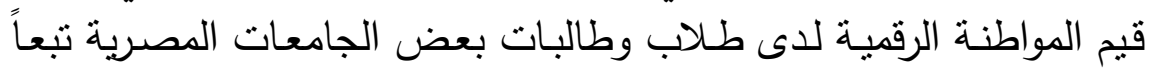
لكتغير نوع الكلية (نظرية/ عملية).

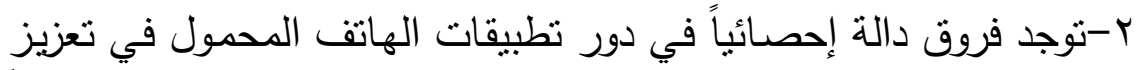

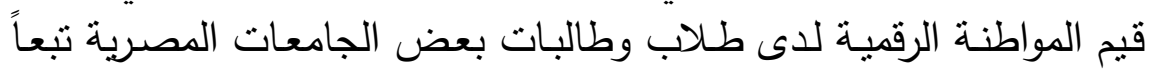

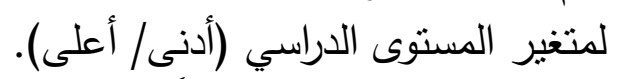
r-توجد فروق دالة إحصائياً في دور تطبيقات الهاتف الهات المحمول في تعزيز

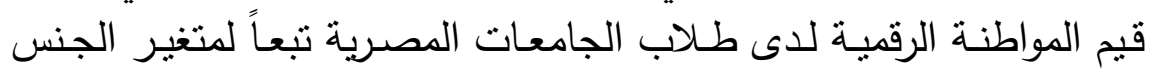

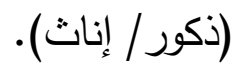

الإجراعات المنهجية للاراسة : سارت الدراسة وفقاً للخطوات التالية: 1-إعداد قائمة بقيم المواطنة الرقمية. (إعداد/ الباحثتين)

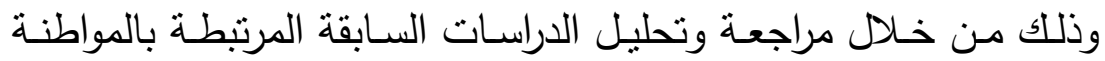

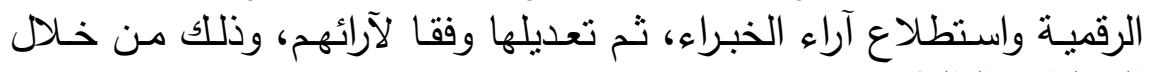

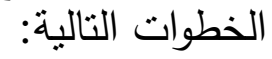


هدفت إلى تحديد مجموعة من القيم التي تتطوي عليها المواطنة الرقمية

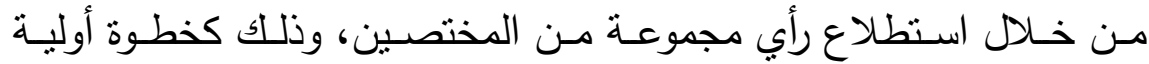
تسـاعد في إعداد استبيان دور تطبيقات الهاتف المحمـول في تعزيز قيم فيم المواطنة لاى طلاب وطالبات بعض الجامعات المصرية. مصادر بناء القائمة:

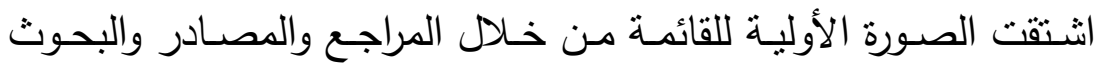

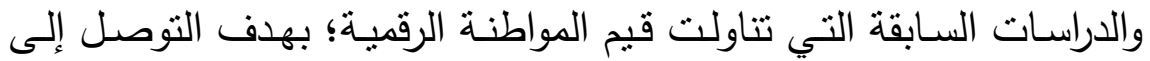

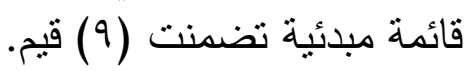
تعديل القائمة:

عُرضـت القائمسة فـي صـورتها الأوليـة على ( عثـرة ) مـن المختصـين

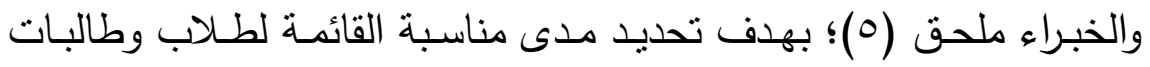

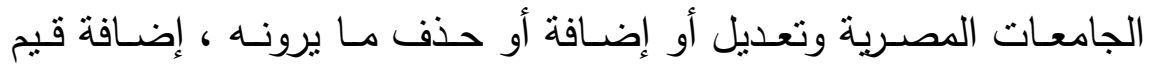

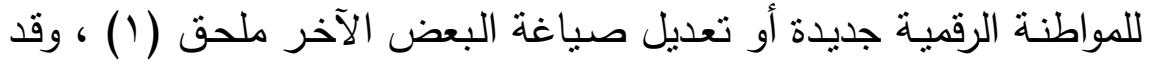

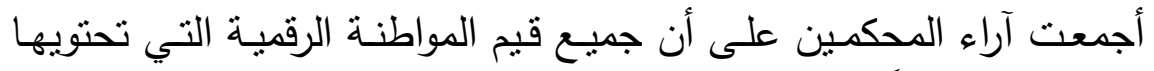

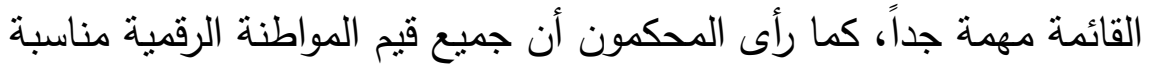

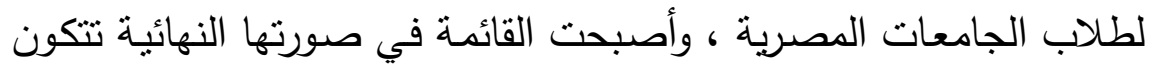

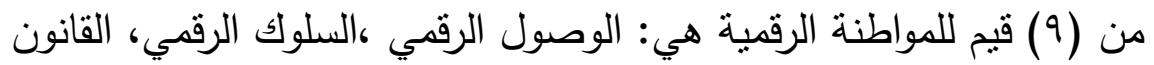

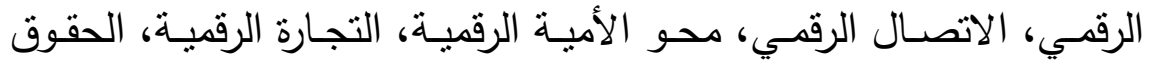
والمسئوليات الرقمية ،الصحة والسلامة الرقمية ،الأمن الرقمي ملحق الرمية (ب) . 


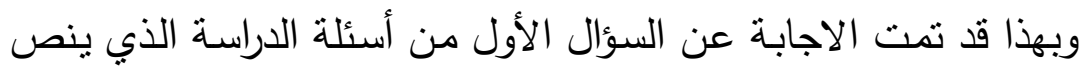

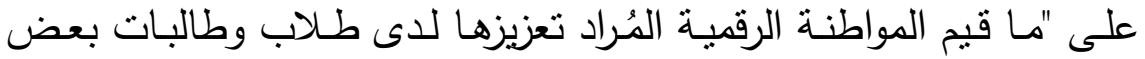

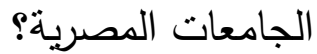

r-تحديد أكثر تطبيقات الهاتف المحمول شيوعاً واستخداماً بين طلاب وطالبات بعض الجامعات المصرية.

تم استطلاع رأي عدد من طلاب وطالبات بعض الجامعات المصرية بلغ

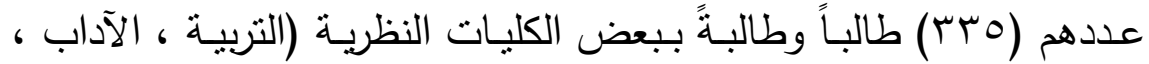

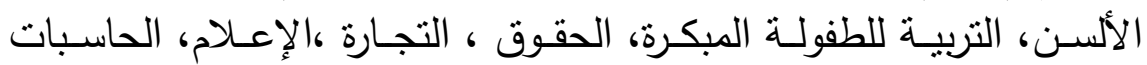

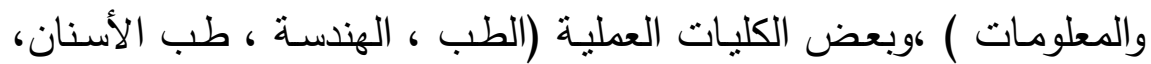

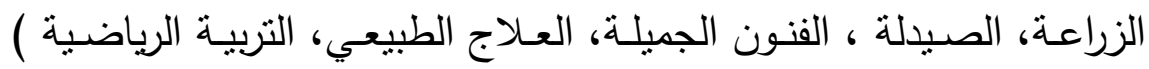

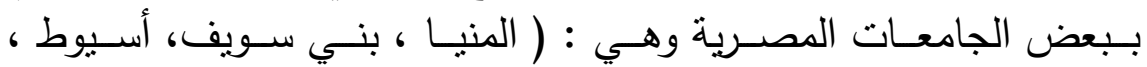
الإسكندرية ، بنها ، القاهرة ، كفر الثيخ) .

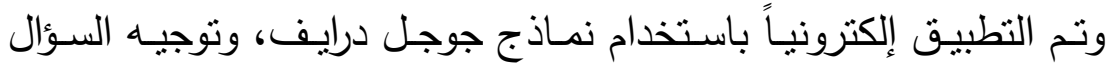

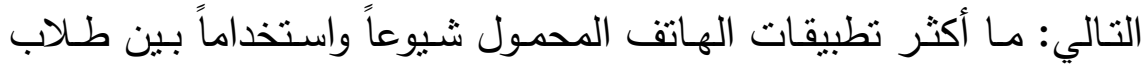
وطالبات بعض الجامعات المصرية، وتم حساب التكرارات والنسب المئوية

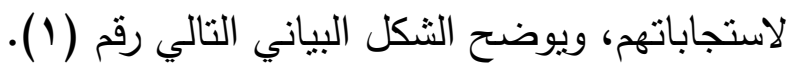




\section{المجلة العلمية لكلية رياض الأطفال - جامعة بورسعيد}

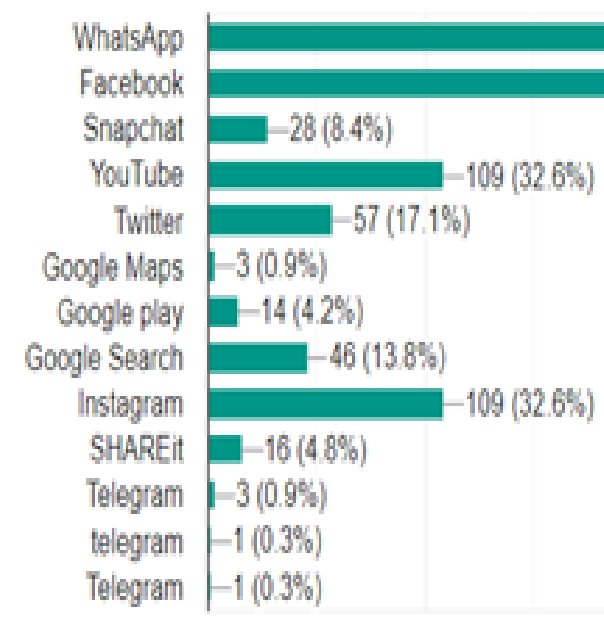

شكل بياني (1) يوضح أكثر تطبيقات للهاتف المحمول شيوعاً واستخداماً بين طلاب وطالبات بعض الجامعات المصرية

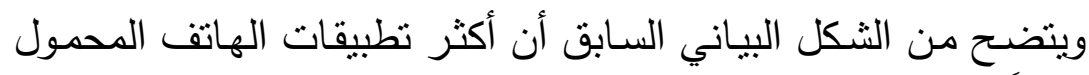

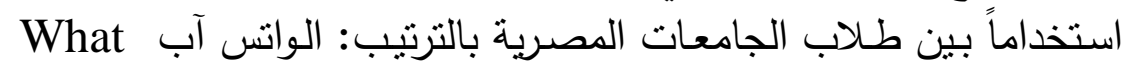

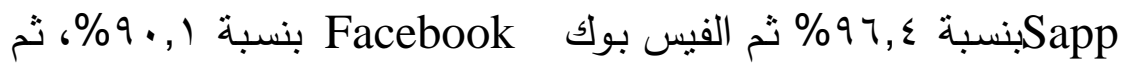

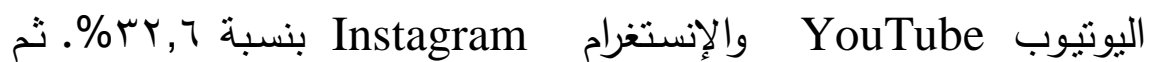
التطبيقات الأخرى، وبـللك قد تمت الإجابـة عن السؤال الثاني من أسئلة

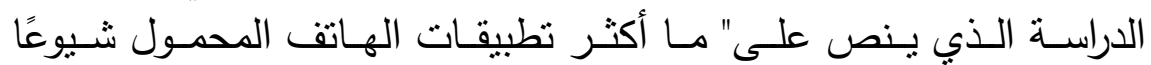
واستخدامًا بين طلاب وطالبات بعض الجامعات المصرية؟

r-تحديد تطبيقات الهاتف المحمول الأكثر تأثيراً في تتمية قيم المواطنة

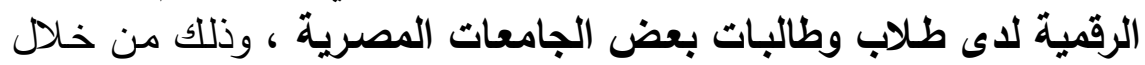

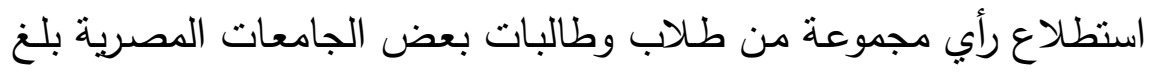




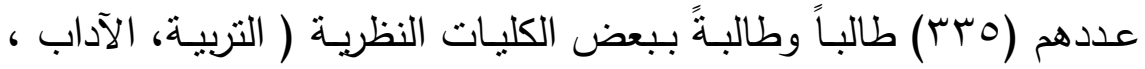

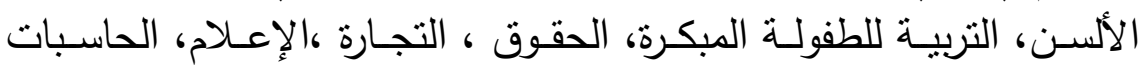

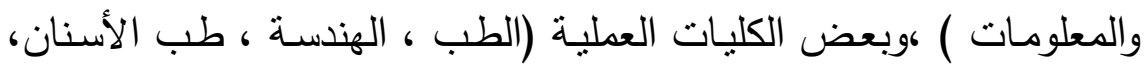

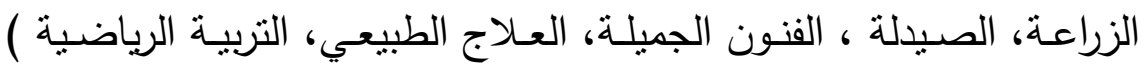

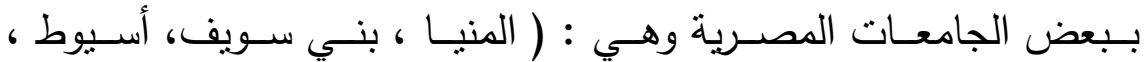
الإسكندربة ، بنها ، القاهرة ، كفر الثبخ ) ، مـن خلاهل سؤالهم إلكترونياً

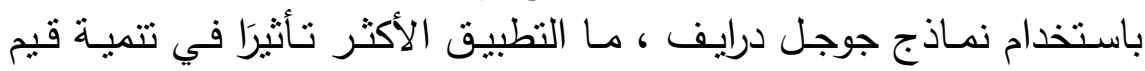
المواطنة الرقمية ؟، وكانت استجابات الطلاب كالتالي كما يوضحه الثكل

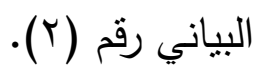

\footnotetext{
WhatsApp

Facebook

Snapchat

YouTube

Twitter

Google Maps

Google play

Google Search

Instagram

SHAREit

telegram

cu vas 1 -1 (0.3\%)

Telegram $-1(0.3 \%)$

Linkedin $1-1(0.3 \%)$

$-48(14.3 \%)$

$-67(20 \%)$

\section{$-45(13.4 \%)$}

$\begin{array}{lll}0 & 50 & 100\end{array}$

\section{$-117(34.9 \%)$}

\section{$-206(61.5 \%)$}

\section{$-100(29.9 \%)$}




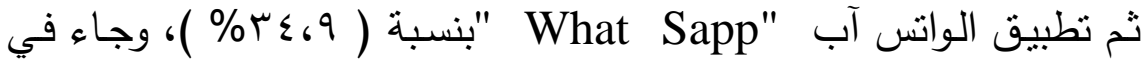

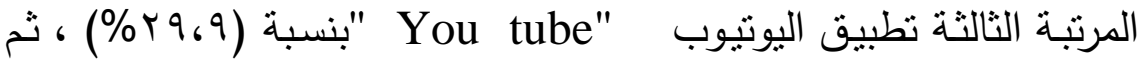

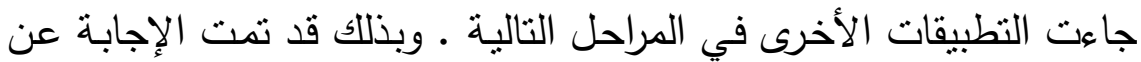

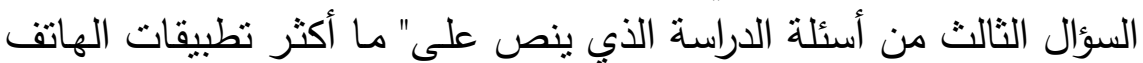

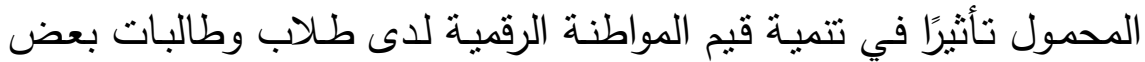

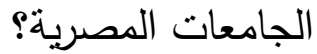

ع -إعداد استبيان دور تطبيقات الهاتف المحمول في تعزيز قيم المواطنة

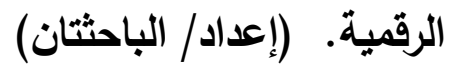

أ- الهُف من الاستبيان:

يهدف هذا الاستبيان إلى قياس دور تطبيقات الهاتف المحمول في تعزيز قيم المواطنة الرقمية لدى طلاب وطالبات بعض الجامعات المصرية. وعند صياغة مفردات الاستبيان قامت الباحثتان بمراعاة ما يلي : - - تجنب العبارات التي تشير إلى حقائق.

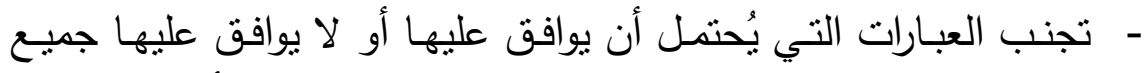
المفحوصين، فمثل هذه العبارات لا تميز بين درجات الموافقة أو الأفضلية.

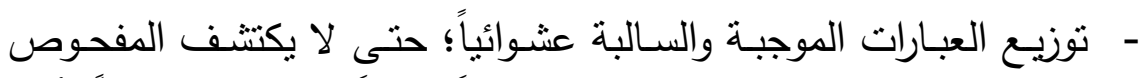

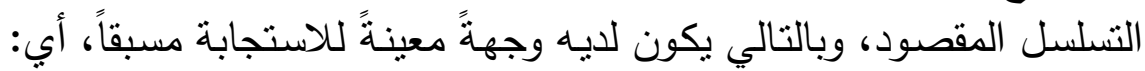
أن يكون لديه تهيؤ عقلي مسبقاً للاستجابة.

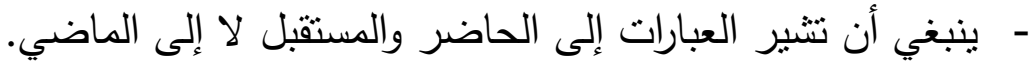
- - استخدام عبارات مباشرة وواضحة وبسيطة. - - استخدام عبارات مختصرة مركزة. 
-تجنب استخدام التعميمات أو العبارات الثمولية مثل : (دائماً، أبداً، كل).

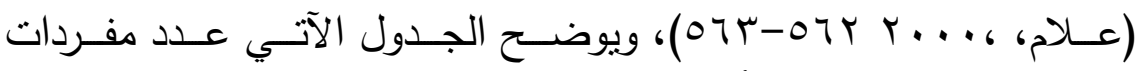

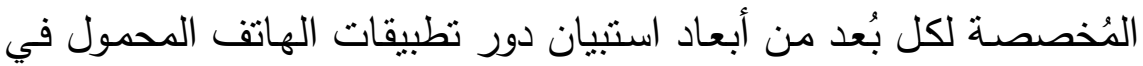
تعزيز قيم المواطنة الرقمية في صورته الأولية.

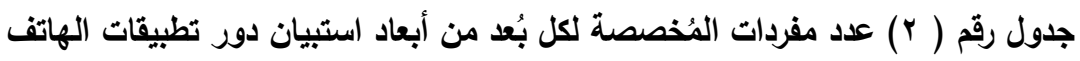
المحمول في تعزيز قيم المواطنة الرقمية في صورته الأولية العية

\begin{tabular}{|c|c|c|}
\hline عدد المفردات & الأبعاد & 5 \\
\hline$r$. & الاحترام. & 1 \\
\hline 19 & التعليح. & $r$ \\
\hline 19 & الحماية. & $r$ \\
\hline$\Delta \wedge$ & \multicolumn{2}{|c|}{ المجموع الكلي } \\
\hline
\end{tabular}

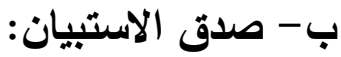

تم حساب صدق الاستبيان عن طريق حساب:

ا -صدق المحكمين وصدق المحتوى للاواشي :

قامت الباحثتان بحساب صدق استبيان دور تطبيقات الهاتف المحمول

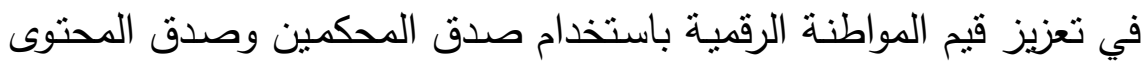

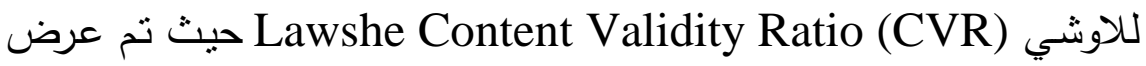
الاستبيان في صورته الأوليـة على عدد (• (1) أسـاتذة من أسـاتذة التربيـة

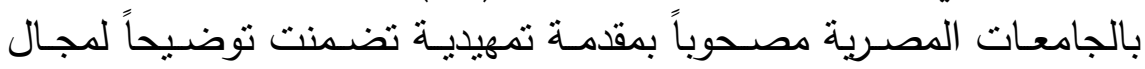

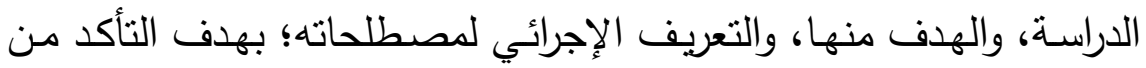

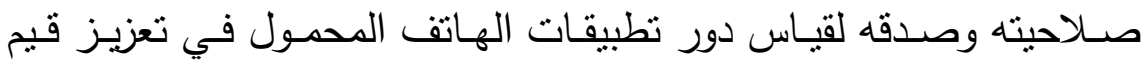
المواطنة الرقمية لدى طلاب الجامعات المصرية ، وابداء ملاحظاتهم حول : 
- مدى وضوح وملائمة صياغة مفردات الاستبيان.

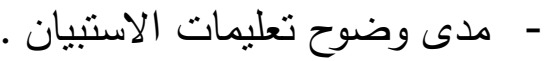
- مدى كفاية مفردات الاستبيان - مدات مدات

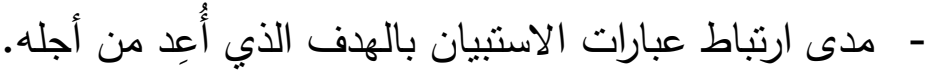
- - مدى صحة كل عبارة علمياً ولغوياً. - مدى مناسبة كل عبارة من عبارات الاستبيان لمستوى طالب الجامعة .

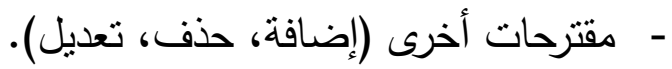
- مدى صلاحية الاستبيان للتطبيق ملحق (r).

وقد قامت الباحثتان بحساب نسب اتفاق المحكمين السادة أعضاء هيئة التدريس بالجامعات على كل مفردةٍ من مفردات الاستبيان من حيث: مدى تمثيل مفردات الاستبيان لقياس دور تطبيقات الهاتف المحمول في تعزيز

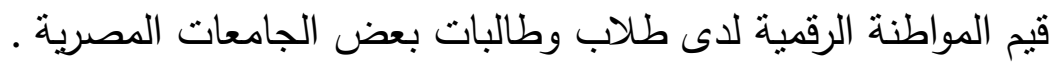

كما قامت الباحثتان بحساب صدق المحتوى باستخدام معادلة "لاوشي "

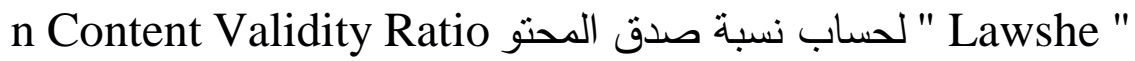
لكل مفردة من مفردات استبيان دور تطبيقات الهاتف المحمول في تعزيز قيم المواطنة الرقمية) (Johnston, \& Wilkinson, 2009,p 5

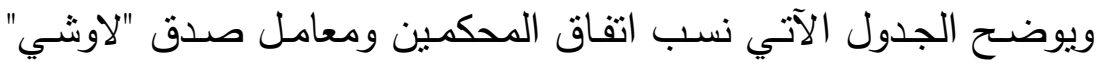
لمفردات استبيان دور تطبيقات الهاتف المحمول في تعزيز قيم المواطنـة

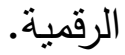


جدول رقم (r) نسب اتفاق المكمين ومعامل صدق لاوشي لمفردات استبيان دور تطبيقات

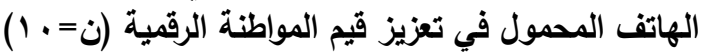

\begin{tabular}{|c|c|c|c|c|c|c|}
\hline الألمُترلق & صدامل & $\begin{array}{l}\text { الاتفاق } \\
\text { \% }\end{array}$ & مراث & مرات & للمحكمين الكلي & p \\
\hline تُقبل & 1 & $1 \ldots$ & صفر & 1. & 1. & 1 \\
\hline تُعدل وتُقبِل & $\cdot, \wedge \cdot$ & $9, \ldots$ & 1 & 9 & 1. & $r$ \\
\hline تُعدل وتُقبِل & $\bullet, \Lambda \cdots$ & $9 \cdot, \ldots$ & 1 & 9 & 1. & $\mu$ \\
\hline تُقبِل & 1 & $1 \ldots$ & صفز & 1. & 1. & $\varepsilon$ \\
\hline تُعدل وتُقبِل & $\bullet, \Lambda \ldots$ & $9 \cdot, \ldots$ & 1 & 9 & 1. & 0 \\
\hline تُقبِل & 1 & $1 \ldots$ & صفر & 1. & 1. & 7 \\
\hline تُعدل وتُقبَل & $\bullet, \Lambda \cdots$ & $9 ., \ldots$ & 1 & 9 & 1. & V \\
\hline تُقبِل & 1 & $1 \cdots$ & صفز & 1. & 1. & $\Lambda$ \\
\hline تُقبْل & 1 & $1 \ldots$ & صفر & 1. & 1. & 9 \\
\hline تُعدل وتُقبِل & $\bullet, \wedge \cdots$ & $9 \cdot, \ldots$ & 1 & 9 & 1. & 1. \\
\hline تُقبِل & 1 & $1 \cdots$ & صفز & 1. & 1. & 11 \\
\hline تُقبِل & 1 & $1 \ldots$ & صفز & 1. & 1. & $1 r$ \\
\hline تُقبِل & 1 & $1 \ldots$ & صفز & 1. & 1. & 14 \\
\hline تُعدل وتُقَبل & $\bullet, \wedge \cdots$ & $9, \ldots$ & 1 & 9 & 1. & $1 \varepsilon$ \\
\hline تُقبِل & 1 & $1 \ldots$ & صفز & 1. & 1. & 10 \\
\hline تُعدل وتُقبَل & , 7. & $\Lambda \cdot, \cdots$ & $r$ & $\Lambda$ & 1. & 17 \\
\hline تُقبّل & 1 & $1 \cdots$ & صفز & 1. & 1. & 18 \\
\hline تُعدل وتُقبل & $\bullet, \wedge \cdot$ & $9 ., \ldots$ & 1 & 9 & 1. & 11 \\
\hline تُعدل وتُقبّل & $\cdot, \wedge \ldots$ & $9 \cdot, \cdots$ & 1 & 9 & 1. & 19 \\
\hline تُقبِل & 1 & $1 \ldots$ & صفز & 1. & 1. & $r$. \\
\hline تُقبِل & 1 & $1 \ldots$ & صفز & 1. & 1. & YI \\
\hline تُعدل وتُقبل & •, & $\Lambda \cdot, \cdots$ & $r$ & $\Lambda$ & 1. & rY \\
\hline تُقبِل & 1 & $1 \cdots$ & صفر & 1. & 1. & $r r$ \\
\hline تُعدل وتُقبل & $\cdot, 7$ & $\Lambda \cdot, \cdots$ & $r$ & $\Lambda$ & 1. & $r \varepsilon$ \\
\hline
\end{tabular}




\section{المجلة العلمية لكلية رياض الأطفال - جامعة بورسعيد}

\begin{tabular}{|c|c|c|c|c|c|c|}
\hline بالمفردُق & لاوشي صدق & $\begin{array}{l}\text { الاتفاقة } \\
\text { \% }\end{array}$ & الاختلاف & مرات & للمحكمين & p \\
\hline تُعدل وتُقبَل & $\cdot, 7$. & $\Lambda \cdot, \ldots$ & $r$ & $\Lambda$ & 1. & ro \\
\hline تُعلدل وتُقُقبل & $\cdot, \wedge \ldots$ & $9 ., \ldots$ & 1 & 9 & 1. & Yq \\
\hline تُقبل & 1 & $1 \ldots$ & صفر & 1. & 1. & TV \\
\hline تُعلدل وتُقْبل & $\cdot, \wedge \ldots$ & $9, \ldots$ & 1 & 9 & 1. & rA \\
\hline تُعدل وتُقبل & $\cdot, 7$. & $\Lambda \cdot, \ldots$ & $r$ & $\Lambda$ & 1. & rq \\
\hline تُعلدل وتُقِقبل & $\cdot, 7$ & $\Lambda \cdot, \cdots$ & r & $\Lambda$ & 1. & $r$. \\
\hline تُعدل وتُقبل & $\cdot, \wedge \ldots$ & $9, \ldots$ & 1 & 9 & 1. & $r_{1}$ \\
\hline تُقبل & 1 & $1 \ldots$ & صفر & 1. & 1. & rY \\
\hline تُقَبل & 1 & $1 \ldots$ & صفر & 1. & 1. & $r r$ \\
\hline تُعدل وتُقبّل & $\cdot, \wedge \ldots$ & $9 \cdot, \ldots$ & 1 & 9 & 1. & $r \varepsilon$ \\
\hline تُعدل وتُقبّل & $\cdot, \wedge \ldots$ & $9 \cdot, \ldots$ & 1 & 9 & 1. & ro \\
\hline تُقبل & 1 & $1 \cdots$ & صفر & 1. & 1. & $r q$ \\
\hline تُعدل وتُقبل & $\cdot, \wedge \ldots$ & $9 \cdot, \ldots$ & 1 & 9 & 1. & $r v$ \\
\hline تُقَبل & 1 & $1 \ldots$ & صفر & 1. & 1. & $\mu \wedge$ \\
\hline تُعْلَ وتُقُبَل & $\cdot, \wedge \ldots$ & $9 \cdot, \ldots$ & 1 & 9 & 1. & rq \\
\hline تُقبل & 1 & $1 \cdots$ & صفر & 1. & 1. & $\varepsilon$. \\
\hline تُقبل & 1 & $1 \ldots$ & صفر & 1. & 1. & $\leqslant 1$ \\
\hline تُعدل وتُقبل & $\cdot, \wedge \ldots$ & $9 \cdot, \ldots$ & 1 & 9 & 1. & $\varepsilon Y$ \\
\hline تُقبل & 1 & $1 \ldots$ & صفر & 1. & 1. & $\varepsilon r$ \\
\hline تُقبل & 1 & $1 \ldots$ & صفر & 1. & 1. & $\leqslant \varepsilon$ \\
\hline تُعدل وتُقبل & $\cdot, \wedge \ldots$ & $9,, \ldots$ & 1 & 9 & 1. & $\leqslant 0$ \\
\hline تُقبل & 1 & $1 \ldots$ & صفر & 1. & 1. & $\leq 7$ \\
\hline تُعدل وتُقبل & $\cdot, 7$. & $\Lambda \cdot, \ldots$ & $r$ & $\Lambda$ & 1. & $\varepsilon V$ \\
\hline تُقبل & 1 & $1 \ldots$ & صفر & 1. & 1. & $\leqslant \wedge$ \\
\hline تُعدل وتُقبل & $\cdot, \wedge \ldots$ & $9 \cdot, \ldots$ & 1 & 9 & 1. & $\leqslant 9$ \\
\hline تُعدل وتُقبل & $\cdot, \wedge \ldots$ & $9 \cdot, \ldots$ & 1 & 9 & 1. & 0. \\
\hline
\end{tabular}


المجلة العلمية لكلية رياض الأطفال - جامعة بورسعيد

\begin{tabular}{|c|c|c|c|c|c|c|}
\hline بالمفردة المُتق & لاوشي & $\begin{array}{l}\text { الاتفبة } \\
\text { \% }\end{array}$ & الاختلاف مرات & مرات & للمحكمين الكلي & م \\
\hline تُقَبَل & 1 & $1 \ldots$ & صفز & 1. & 1. & 01 \\
\hline تُقُبل & 1 & $1 \ldots$ & صفر & 1. & 1. & Or \\
\hline تعدل وتقبل & $\cdot, 7 \ldots$ & $\Lambda,, \cdots$ & $r$ & $\Lambda$ & 1. & Or \\
\hline تُقبِل & 1 & $1 \ldots$ & صفر & 1. & 1. & $0 \leq$ \\
\hline تُعدل وتُقبَل & $\cdot, 7 \ldots$ & $\Lambda \cdot, \cdots$ & $r$ & $\Lambda$ & 1. & 00 \\
\hline تُعدل وتُقبَل & $\cdot, 7 \ldots$ & $\Lambda \cdot, \cdots$ & $r$ & $\Lambda$ & 1. & 07 \\
\hline تُعدل وتُقبْل & $\cdot, \wedge \ldots$ & $9, \ldots$ & 1 & 9 & 1. & $O V$ \\
\hline تُقُبل & 1 & $1 \ldots$ & صفر & 1. & 1. & 01 \\
\hline \multicolumn{2}{|c|}{$\% q r, q r r$} & \multicolumn{5}{|c|}{ متوسط النسبة الكلية للإتفاق على الاستبيان } \\
\hline \multicolumn{2}{|c|}{$\cdot, \Lambda \bullet r$} & \multicolumn{5}{|c|}{ متوسط نسبة صدق لاوشي للاستبيان ككل } \\
\hline
\end{tabular}

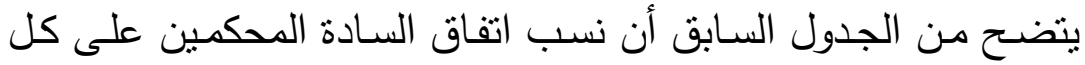
مفردة مـن مفردات اسـتبيان دور تطبيقات الهاتق المحمـول في تعزيز قيم المواطنة الرقمية تنراوح ما بين ( . م- . . 1\%).

كمـا يتضـح مـن الجدول السـابق اتفـاق السـادة المحكمين على مفردات اسـتبيان دور تطبيقات الهـاتف المحمـول في تعزبـز قيم المواطنـة الرقميـة مهية

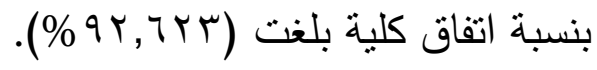

وعن نسبة صدق المحتوى (CVR) للاوشي يتضح من الجدول السابق

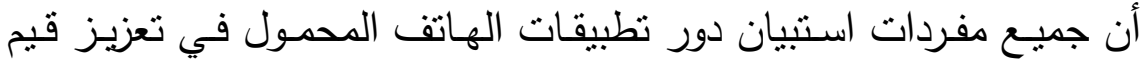
المواطنة الرقميـة تتمتع بقيم صدق محتوى مقبولة، كمـا بلـغ منوسط نسبة

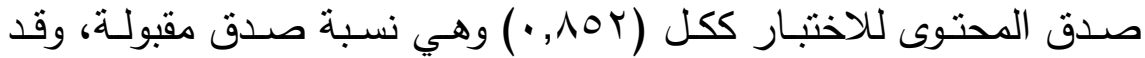

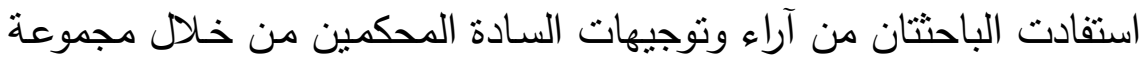
من المالاحظات منث: 
• تعديل صياغة بعض مفردات الاستبيان لتصبح أكثر وضوحاً. • إعادة ترتيب لبعض المفردات بتقديم بعضها على بعض.

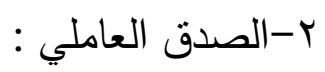

تُعـد المهــة الأساسية للتحليـل العـاملي هـي تحليـل بيانـات المتغيـرات للتوصل إلى مكونات تتضمنها تلك المتخيرات. حيث يقدم التحليل العاملي نموذج عن التكوين النظري، ويتحدد هذا النموذج من العلاقات الخطية بين

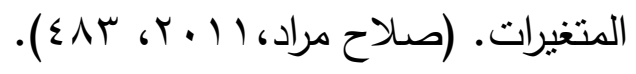

ولحسـاب الصـدق العـاملي لاسـتبيان دور تطبيقات الهاتف المحمول في تعزيز قيم المواطنة الرقمية استخدمت الباحثة التحليل العاملي الاستكثافي لفي Exploratory factor Analysis هـع تدوير المحاور بطريقة الفار ماكس . Varimx Method كما استخدمت الباحثنان اختبار بارتلت

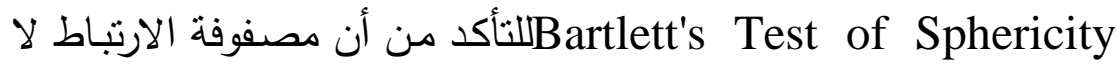
تساوي مصفوفة الوحدة(Field, A, 2009,648) ، وكانت نتيجة اختبار بارتلت Bartlett's Test دالة إحصائياً عند مستوى دلالة (1 ( , •)، وهذا يُنير إلى خلو مصفوفة الارتباط من معاملات ارتباط تامة أي أن مصفوفة الارتباط لا تساوي مصفوفة الوحدة، وأنه يوجد ارتباط بين بعض مض المتغيرات

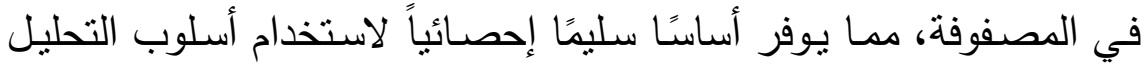
العاملي. وقامت الباحثنان بحساب ما يلي: -مصفوفة الارتباطات لأبعاد استبيان دور تطبيقات الهاتق المحمول في تعزيز قيم المواطنة الرقمية.

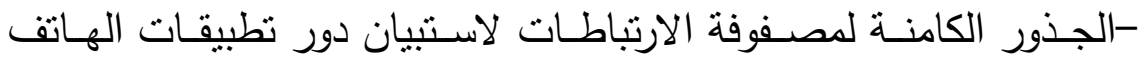
المحمول في تعزيز قيم المواطنة الرقمية. 
- تشـعبات أبعـاد اسـتبيان دور تطبيقات الهـاتف المحمـول في تعزبـز قيم

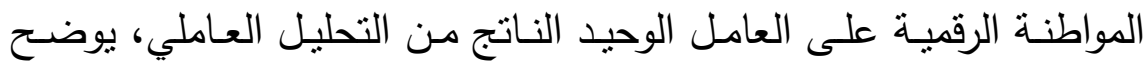

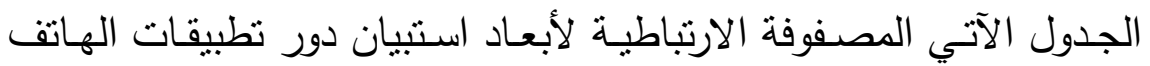
المحمول في تعزيز قيم المواطنة الرقمية.

جدول رقم (ع) المصفوفة الارتباطية لأبعاد استبيان دور تطبيقات الهاتف المحمول في تعزيز

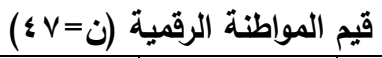

\begin{tabular}{|c|c|c|c|c|}
\hline$\mu$ & $r$ & 1 & البعد & 5 \\
\hline -- & -- & -- & الاحترام. & 1 \\
\hline-- & -- & $* *, 9,9$ & التعليم. & $r$ \\
\hline-- & $* *,, 717$ & $* *$ *, ๆ॰^ & الحماية. & $r$ \\
\hline
\end{tabular}

ويوضـح الجدول الآتي الجذور الكامنـة لمصفوفة الارتباطات لاسـتبيان دور تطبيقات الهاتف المحمول في تعزيز قيم المواطنة الرقمية. جدول رقم (0) الجذور الكامنة لمصفوفة الارتباطات لاستبيان دور تطبيقات الهاتف المحمول

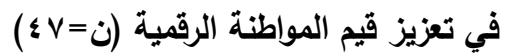

\begin{tabular}{|c|c|c|c|c|c|c|}
\hline \multicolumn{3}{|c|}{ الجذور المستخلصة من عملية } & \multicolumn{3}{|c|}{ الجذور الكامنة الأولية } & \multirow[t]{5}{*}{ العوامل } \\
\hline النسبة & نسبة & القيمة & النسبة & نسبة & القيمة & \\
\hline التجميعية & التباين & & التجميعية & التباين & & \\
\hline$\%$ & المفسر & & $\%$ & المفسر & & \\
\hline & $\%$ & & & $\%$ & & \\
\hline \multirow[t]{3}{*}{$74, \leqslant 9 \varepsilon$} & $74, \varepsilon 9 \varepsilon$ & $1,9 \cdot r$ & $74, \varepsilon 9 \varepsilon$ & $7 r, \varepsilon 9 \varepsilon$ & $1,9 \cdot r$ & 1 \\
\hline & & & $q Y, \cdot \leq q$ & $r \wedge, 000$ & $\cdot, \wedge \wedge \neg$ & $r$ \\
\hline & & & 1 & $v, 901$ & $\cdot, Y \backslash 1$ & $r$ \\
\hline
\end{tabular}

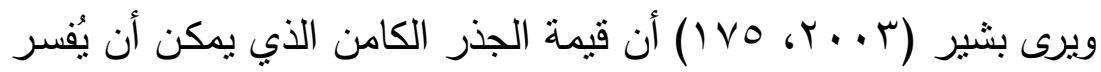
التبـاين الكلي لا تقل قيمته عن واحد صـحيح؛ وعليـه يتضـح مـن الجدول

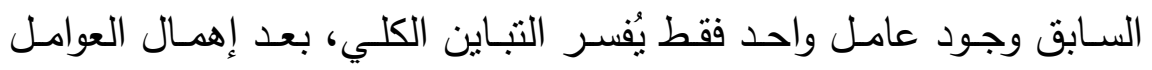


الأخرى لأن جذورها الكامنـة تقل عن قيمة الواحد الصحيح، وبذلك يمكن

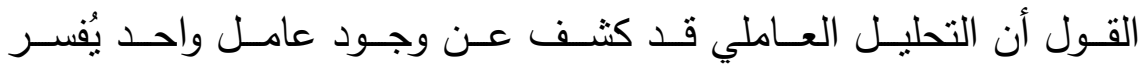

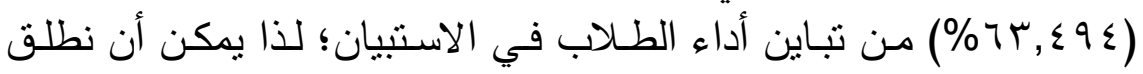
عليه عامل دور تطبيقات الهاتف المحمول في تعزيز قيات الماه المواطنة الرقمية،

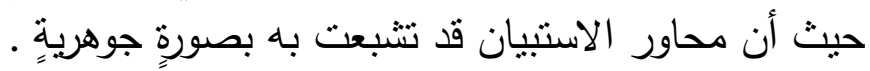

ويوضح الرسم البياني التالي قيم الجذور الكامنة للعوامل الثلاثنة الناتجة

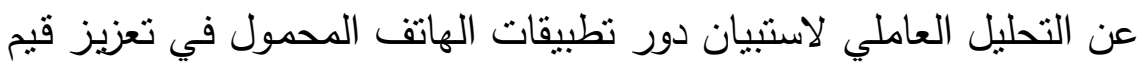
المواطنة الرقمية.

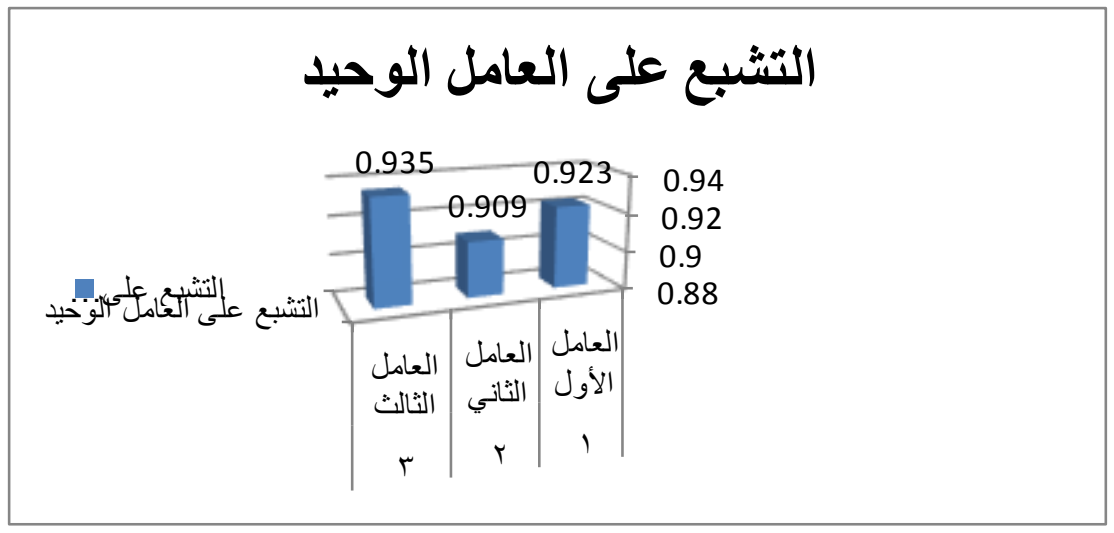

شكل رقم (ץ) رسم بياني لقيم الجذور الكامنة للعوامل الثلاثة الناتجـة

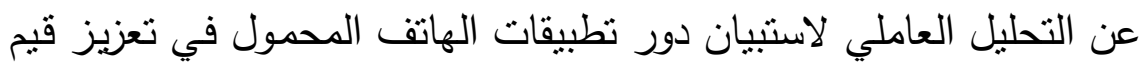
المواطنة الرقمية.

يُبين الجدول الآتي تشبعات أبعاد استبيان دور تطبيقات الهاتف المحمول

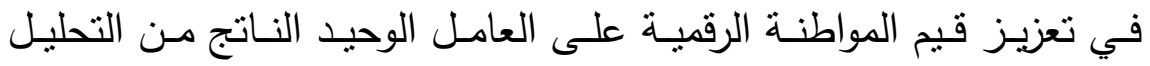
العاملي. 


\section{المجلة العلمية لكلية رياض الأطفال - جامعة بورسعيد}

جدول رقم (†) تثبعات أبعاد استبيان دور تطبيقات الهاتف المحمول في تعزيز قيم المواطنة

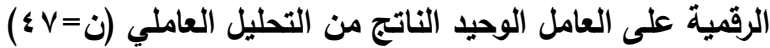

\begin{tabular}{|c|c|c|}
\hline العامل اللوحيد على & الأبعاد & p \\
\hline$\cdot, \neg \wedge V$ & الاحترام. & 1 \\
\hline$\cdot, 7 \vee 1$ & التعليم. & $r$ \\
\hline$\cdot, 717$ & الحماية. & $r$ \\
\hline
\end{tabular}

و التشبع المقبول و الدال إحصائياً بجب ألا تقل قيمته عن ( • ب, •)؛ و عليه يتضح من الجدول السابق أن أبعاد استبيان دور تطبيقات الهاتف المحمـول

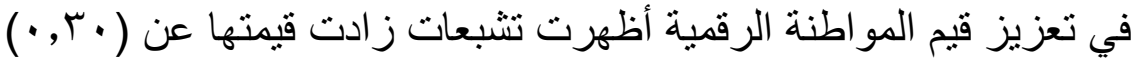
على العامل الوحيد، ولذلك فهي نشبعات دالـة إحصـائياً. (ضـحيان ، عبد إند

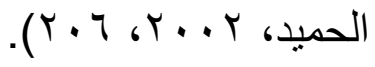

و من خـلال حسـاب صـدق استبيان دور تطبيقات الهاتف المحمول في

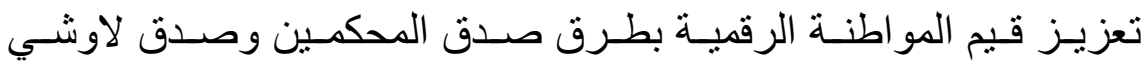
و الصدق العاملي يتضح أن الاستبيان تثمتع بمعامل صدق مقبول؛ مما بثير لثرير إلى إمكانية استخدامها في الدراسة الحالية ، و الوثوق بالنتائج التي سنسفر عنها الدر اسة.

ج- ثباث الاستبيان:

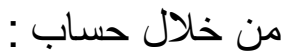

ا ـمعامـل ثبات ألفـا كرونباخ Cronbach's alpha : قامت الباحثتان بحسـاب ثبـات اسـتبيان دور تطبيقات الهـاتف المحمـول في تعزيـز قيم المو اطنة الرقمية باستخدام طريقة ألفا كرونباخ و الجدول التالي يوضح قيم 
معاملات الثبات بطريقة "ألفا كرونباخ" لكل مفردة ومعامل الثبات لاستبيان دور تطبيقات الهاتف المحمول في تعزيز قيم المو اطنة الرقية ككل.

جدول رقم (V) قيم معاملات الثبات بطريقة "ألفا كرونباخ" لكل مفردة ومعامل الثبات

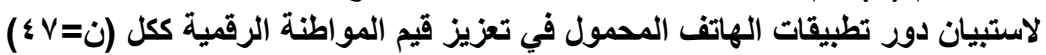

\begin{tabular}{|c|c|c|c|c|c|c|c|}
\hline ثعامل & المفردة & ثعامل & المفردة & ثعامل & المفردة & ثعامل & المفردة \\
\hline $.69 \cdot r$ & $\leqslant 9$ & • ‘А५^ & $r r$ & $.69 \ldots$ & IV & .69 .7 & 1 \\
\hline $.69 \cdot r$ & 0. & $\cdot$ • ^АV. & $r \varepsilon$ & $.69 \cdot 4$ & 11 & $.69 . V$ & r \\
\hline .69 .1 & 01 & $\cdot ، \wedge \vee$. & ro & .69 .7 & 19 & $.69 . V$ & $r$ \\
\hline .69 .8 & Or & . ‘AVI & rq & $.69 \cdot r$ & $r \cdot$ & .69 .8 & $\varepsilon$ \\
\hline $.69 \cdot r$ & Or & .6149 & $r v$ & 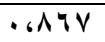 & YI & .69 .7 & 0 \\
\hline .69 .0 & $0 \leqslant$ & . ‘А V & $\mu \wedge$ & $\cdot ، \wedge V \Psi$ & YY & $.69 \cdot r$ & 7 \\
\hline $.69 . \varepsilon$ & 00 & . ‘А V & rq & . ‘АV & $r r$ & $.69 . r$ & $\mathrm{~V}$ \\
\hline $.69 . \varepsilon$ & 07 & $.69 . V$ & $\varepsilon$. & • ، $\wedge \vee \leqslant$ & $r \varepsilon$ & $.69 . \varepsilon$ & $\Lambda$ \\
\hline .69 .8 & OV & .69 .0 & $\sum 1$ & • ‘АV. & ro & $.69 \ldots$ & 9 \\
\hline .69 .0 & $\Delta \wedge$ & .69 .5 & $\varepsilon r$ & • ‘А イ & Yq & .69 .0 & 1. \\
\hline & & $.69 . r$ & $\varepsilon r$ & . เА マ & $r V$ & $.69 \ldots$ & 11 \\
\hline & & .69 .8 & $\varepsilon \varepsilon$ & . ‘А & $r \wedge$ & $.69 \ldots$ & $1 \%$ \\
\hline
\end{tabular}


المجلة العلمية لكلية رياض الأطفال - جامعة بورسعيد

\begin{tabular}{|c|c|c|c|c|c|c|}
\hline & $\cdot 69 \cdot r$ & $\leqslant 0$ & $\cdot$ • ^V. & rq & $.69 \cdot \varepsilon$ & ir \\
\hline & $.69 \cdot r$ & $\leqslant 7$ & $\cdot . \wedge 4 \wedge$ & r. & .69 .1 & $1 \leqslant$ \\
\hline & .69 .1 & $\leqslant V$ & $.6 \wedge \neg \wedge$ & $\mu_{1}$ & $.69 \cdot 4$ & 10 \\
\hline & $.69 \cdot \leq$ & $\varepsilon \wedge$ & $\cdot . \wedge \neg \wedge$ & rr & $.69 \cdot 1$ & 17 \\
\hline., 909 & \multicolumn{6}{|c|}{ معامل ثبات الاستبيان ككل } \\
\hline
\end{tabular}

و إذا كان معامل الثبات بطريقة ألفا لكل سؤالٍ من أسئلة الاستبيان أقل

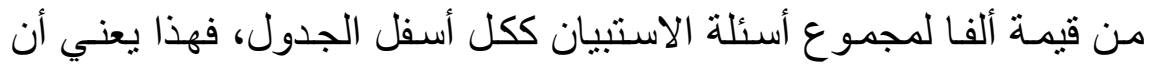
السؤال هام وغيابه عن الاستبيان يؤثر سلباً عليه، و أما إذا كان معامل ثبات الإنيه

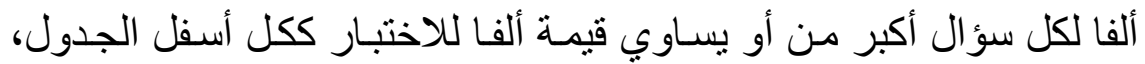
فهذا يعني أن وجود السؤال يقلل أو يُضـعف من ثبات الاستبيان. ( غنيم،

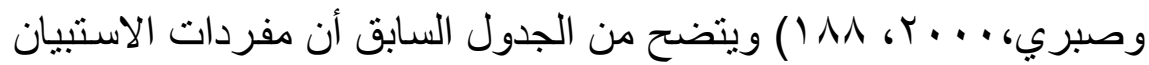
يقل معامل ثباتها عن قيمة معامل ثبات الاستبيان ككل و هي (909, • • ).

\section{Y _معامل ثبات التجزئة التصفية:}

تم حسـاب ثبات استبيان دور تطبيقـات الهـاتف المحمـول في تعزيز قيم

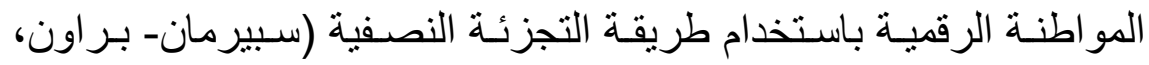

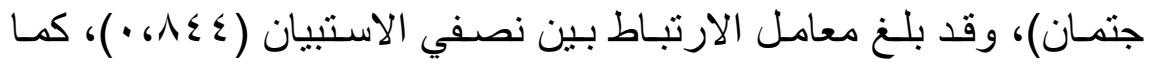

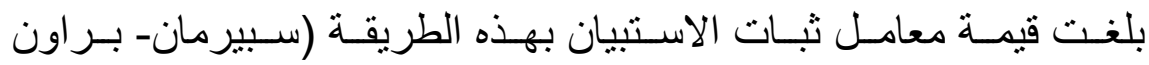

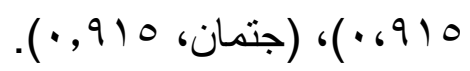




\section{r-معامل ثبات إعادة التطبيق: - مبيق}

تم حساب ثبات الاستبيان باستخدام طريقة إعادة التطبيق، ويُبين الجدول

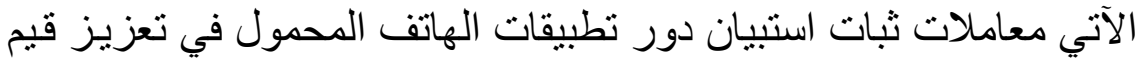
المو اطنة الرقمية لدى طلاب الجامعة بطريقة إعادة التطبيق.

جدول رقم (^) معاملات ثبات استبيان دور تطبيقات الهاتف المحمول في تعزيز قيم المواطنة

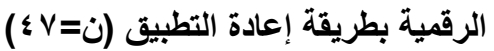

\begin{tabular}{|c|c|c|}
\hline معامل الثارتباط & الأبعاد & b \\
\hline$* *,, \Lambda \backslash r$ & الاحترام. & 1 \\
\hline$* *, \wedge 10$ & التعليم. & $r$ \\
\hline$* *, \wedge, \Lambda$ & الحماية. & $r$ \\
\hline$* *$, , А & \multicolumn{2}{|c|}{ الاستبيان ككل } \\
\hline
\end{tabular}

يتضح من الجدول السابق أن معامل ثبـات إعـادة التطبيق لاستبيان دور

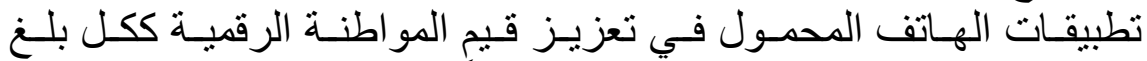

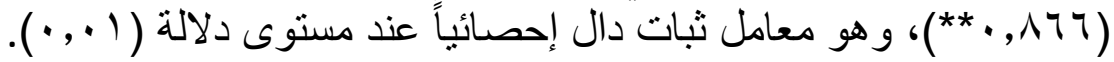

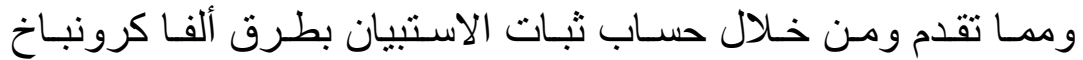

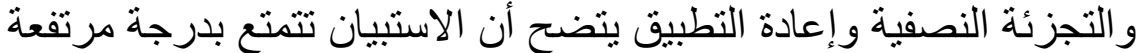

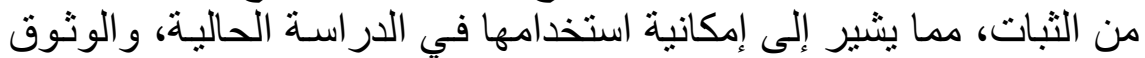
بالنتائج التي ستسفر عنها الدراسة. دـ الاتساق الاخلي الاستبيان :

تم حساب الاتساق الداخلي للاستبيان وذلك من خـلال حسـاب معاملات الارتباط بين درجات المفردات والدرجة الكلية للمحور الذي تنتمي إليه، 
وكذلك حساب معاملات الارتباط بين درجات محساور الاستبيان و الدرجة الكليـة للاسـتبيان. ويوضـح الجدول الآتـي حسـاب معـاملات الارتبـاط بـين درجات المفردات ودرجة المحور، وكذللك بين درجة كل محور والدرجـة الكلية للاستبيان.

جدول رقم (9) قيم معاملات الارتباط بين درجات المفردات والارجة الكلية للمحور الذي الذي تنتمي إليه وبين درجة كل محور والدرجة الكلية لاستبيان دور تطبيقات الهاتف المحمول في في الماتي

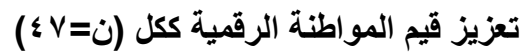

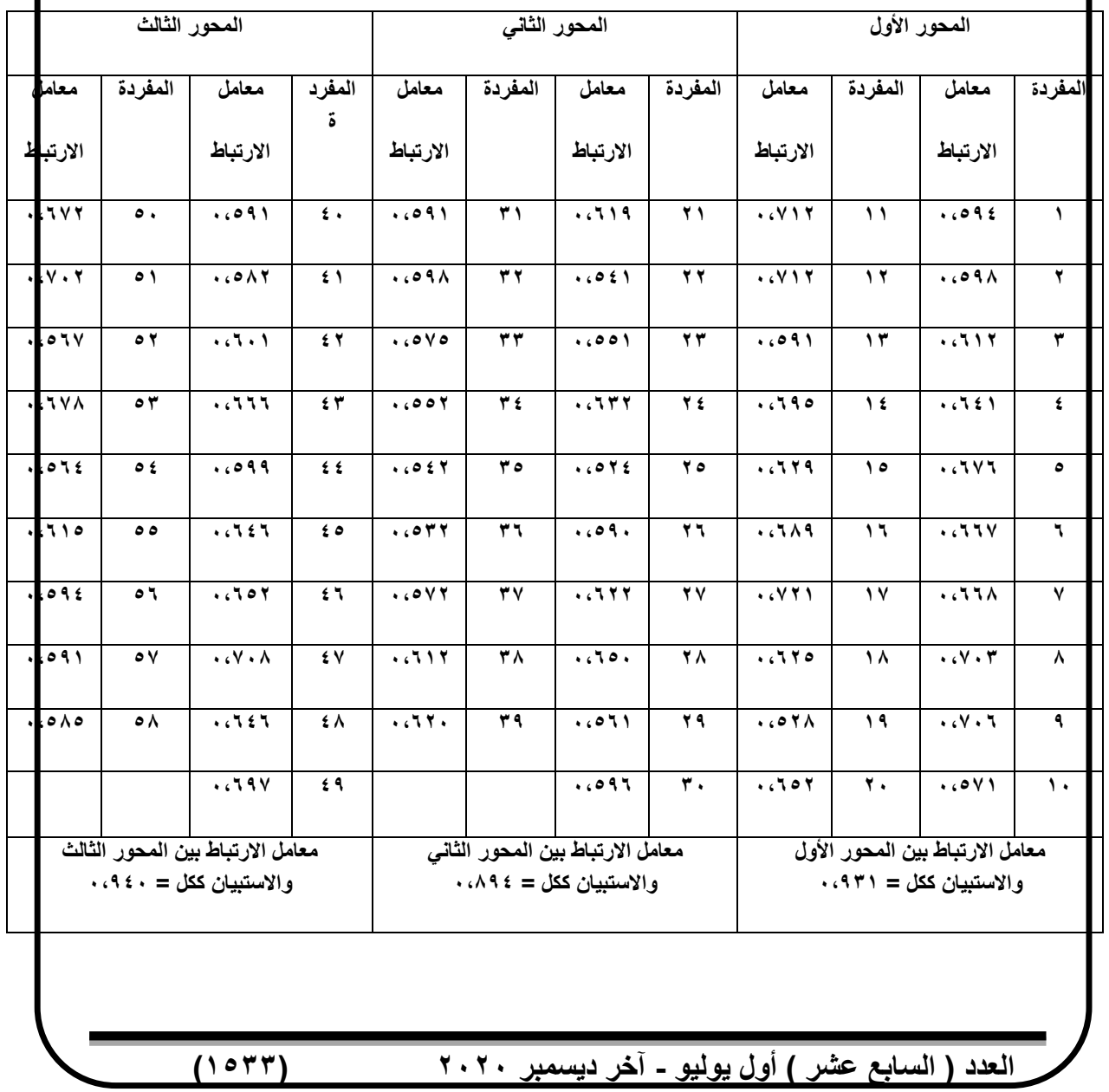


ويتضح من الجدول السابق أن معاملات الارتباط بين درجات مفردات

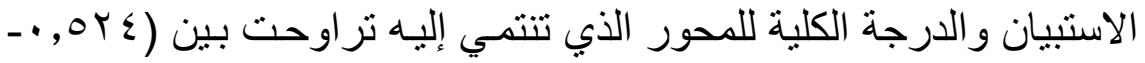

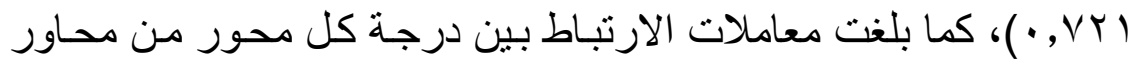

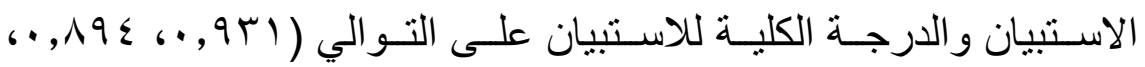

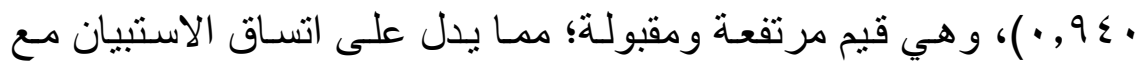
محاوره ومفرداته.

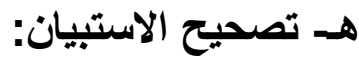

تم تصحيح الاستبيان وفقاً لتدريج ليكرت الخماسي، ويوضح الجدول

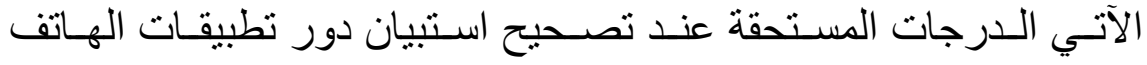
المحمول في تعزيز قيم المو اطنة الرقمية.

جدول رقم ( • ( الدرجات المستحقة عند تصحيح استبيان دور تطبيقات الهاتف المحمول في تعزيز قيم المواطنة الرقمية

\begin{tabular}{|c|c|c|c|c|c|}
\hline \multicolumn{5}{|c|}{ الإجابة } & \multirow[t]{2}{*}{ المتغيرات } \\
\hline غير غوافق بثدة & مو غير & محايد & موافق & موافق & \\
\hline 1 & $r$ & $r$ & $\varepsilon$ & 0 & 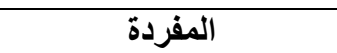 \\
\hline \multicolumn{5}{|c|}{ rq. } & النهائية العظى للاستبيان \\
\hline \multicolumn{5}{|c|}{01} & النهائية الصغرى للاستبيان \\
\hline
\end{tabular}

وبذلك أصبح الاستبيان في صورته النهائية صالحاً للاستخدام ملحق (ع). 


\section{عرض النتائج ومناقشتها وتفسيرها:}

يتناول هذا الجزء الإجابة عن أسئلة الدراسة والتحقق من صحة فروضهـ

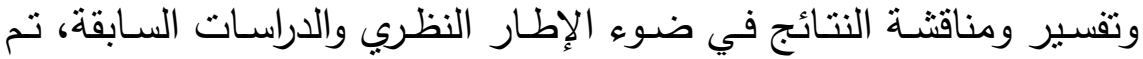
الاعتماد في التحليل الإحصائي للبيانات للإجابة عن أسئلة الدراسـة على الإنى الأساليب الإحصائية الأتية:

ا -المتوسط الحسابي والانحراف المعياري ونسبة الاتئة الاتفاق.

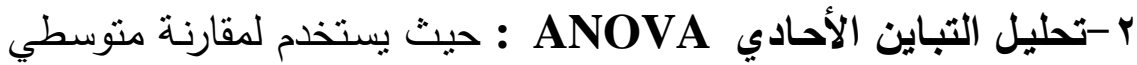

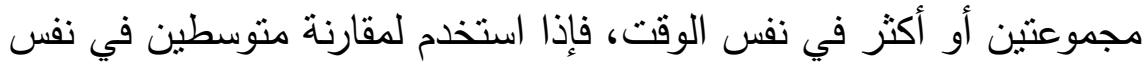

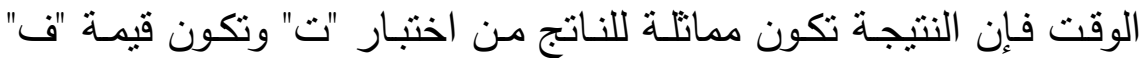
مساوية لقيمة "ت ب"، أما إذا كانت المقارنـة بين عدة متوسطات فإن تحليل

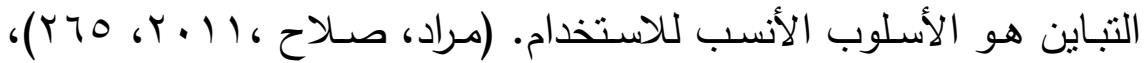

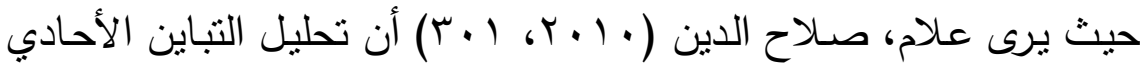
هو الأسلوب الإحصائي المناسب في حالة اختبار الفروق بين متوسطات عينات متعددة عند مستوى دلالة معين. ب-اختبار "ثشيفيه Schefe " : لمعرفة اتجاه الفروق حيث أنه الأسلوب الإحصائي المناسب لإجراء المقارنات المتعددة لأكثر من مجموعتين؛ وذللك الكاه

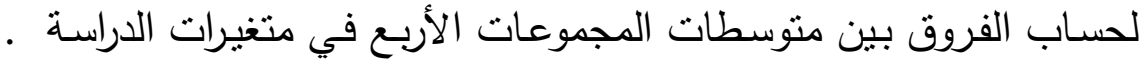

(Surhone, 2010, 33)

وتم استخدام حزمة البرامج الإحصائية للعلوم الاجتماعية (SPSS20) وذلك لإجراء المعالجات الإحصائية. وفيما يلي الإجابة عن أسئلة الدراسـة والتحقق من صحة فروضاه وتفسير ومناقثنة النتائج:

الإجابة عن السؤال الرابع: مـا دور تطبيقات الهاتف المحمول في تعزيز قيم المواطنة الرقمية لاى طلاب وطالبات بعض الجامعات المعات المصرية؟ 
تمد الإجابـة عن هذا السؤال من خلال حساب المتوسطات الحسـابية والترتيب لمحاور الاستبيان وأبعاد هذه المحاور ، والجدول التالي يوضح ذلته جدول (11) المتوسطات الحسابية وإلترتيب لمحاور استبيان دور تطبيقات الهاتف المحمول

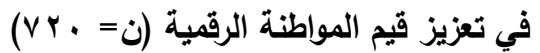

\begin{tabular}{|c|c|c|c|c|c|c|c|c|c|c|c|}
\hline E: & $\nu$ & $\underline{E}$ & $\underline{\xi}$ & $E_{E:}^{E_{:}}$ & $\nu$ & $\underline{E}$ & $\underline{E}$ & 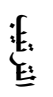 & 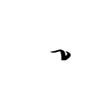 & $\underline{E}$ & \\
\hline r & r.VY & والمسئوليا & & 1 & $r .99$ & الاتصمي & & 1 & $\varepsilon, r q$ & الرقمي & \\
\hline$r$ & ros $\varepsilon$ & والرقلامة & E & $r$ & $r ، \wedge \Lambda$ & $\begin{array}{l}\text { الأمية } \\
\text { الرقمية }\end{array}$ & E. & $r$ & $r \cdot r)$ & الرقمي & $\underset{\underline{E}}{\underline{E}}$ \\
\hline 1 & $r, 9 \leq$ & الرقمي & & $r$ & $r \cdot \wedge \wedge$ & الرقمية & & r & r.00 & الرقمي & \\
\hline & \multicolumn{3}{|c|}{ المحور الثالث ككل ؛ عابr } & & \multicolumn{3}{|c|}{ المحور الثاني ككل بو، بr } & & \multicolumn{3}{|c|}{ المحور الأول ككل بـ، بـ } \\
\hline
\end{tabular}

ا-هـرى طـلاب وطالبـات الجامعـات المصـرية -عينـة الدراسـة -أن دور تطبيقات الهاتف المحمول ( فيس بوك ، يوتيوب ، واتس آب ، انستجرام ، وغيرها ) في تعزيز قيم المواطنة الرقمية يأتي في تعزيز قيمة التعليم أولاً ثم

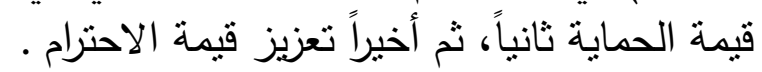

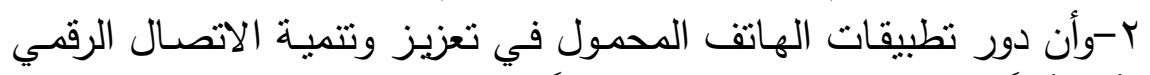

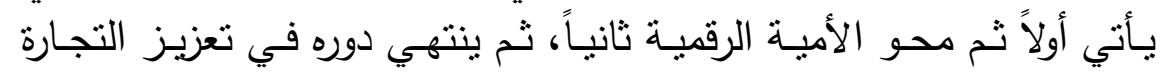

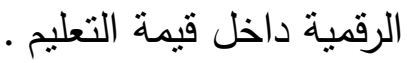


ب- وأن دورها في تعزيز قيمة الحماية يأتي أولاً في تعزيز الأمن الرقمي، ثم الحقوق والمسئوليات الرقمية ثم أخيراً تعزيز الصحة والسلامة الرقية لعية. ع-وأن دورها في تعزيز قيمة الاحترام، في تعزيزها للوصول الرقمي أولاً ثم تُوني تعزيز القانون الرقمي وأخيراً تعزيز السلوك الرقيزي. ه-يتمثل دور تطبيقات الهاتف المحمول في تعزيز قيم المواطنة الرقمية من خلال تعزبزه لتسع قيم هي بالترتيب (من الدور الأعلى إلى الدور الأقل):

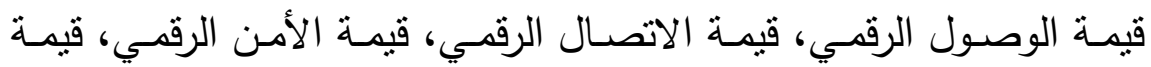

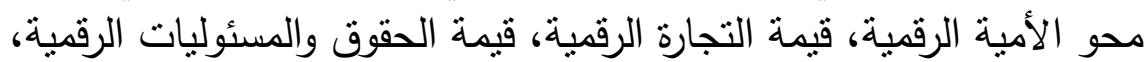

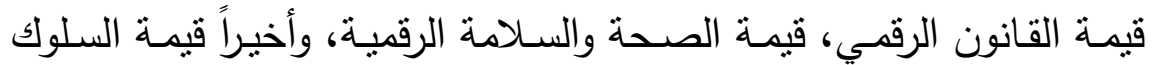
الرقمي، ومن الملاحظ أن السلوك الرقمي هو آخر وأقل قيمة تقوم تطبيقات الهاتف المحمول بتعزيزها وتتميتها من وجهة نظر عينة الدراسة . تثــق نتـائج الدراسـة الحاليـة مــع نتـائج دراسـة السـليحات، والســرحان

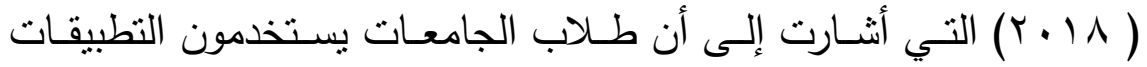

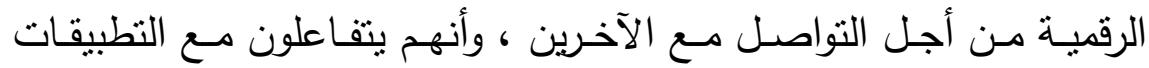
الخاصة بالبيع والثراء عبر الإنترنت مع الوعي ببعض المخاطر كالتعرض التر

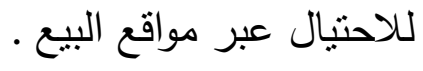

كما تتفق مـع نتائج دراسـة الحربي ( 1 ( • ب) في أن التطبيقات الرقميـة تساهم في تعزيز مفهومي بُعدي القانون الرقمي، والثقافة الرقمية لدى طلاب الجامعات ، وأنها ساهمت في تعرف الطلاب على المواقع الأمنه للتسوق.

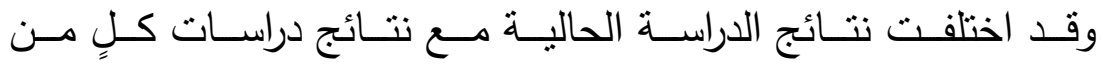

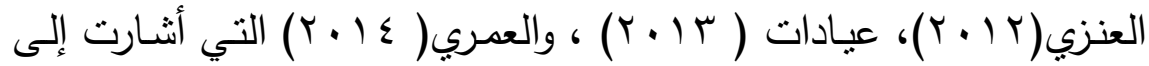

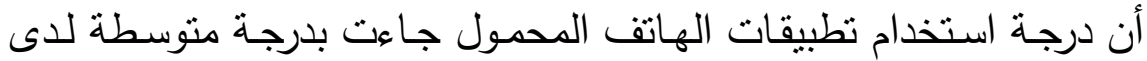
عينات من طلاب الجامعات ، ودراسة يوسف (1 ( ب) التي توصلت إلى 
أن طـلاب الجامعـات يفتقـرون إلـى مهـارات الاسـتخدام السـليم للتطبيقـات

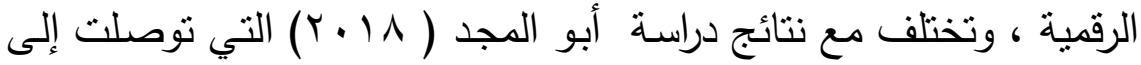

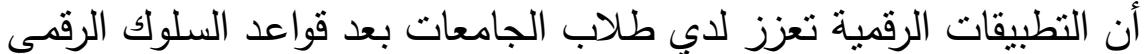

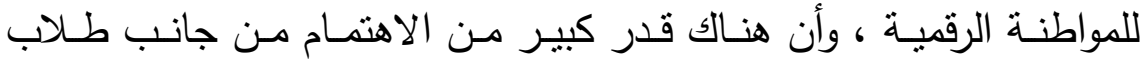
الجامعـات في جعـل التطبيقـات الرقميـة لهـا دور في تعزيـز الحقـوق

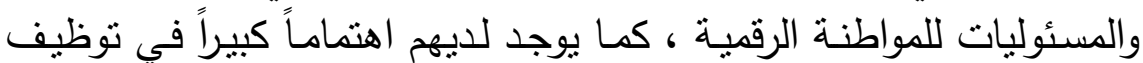

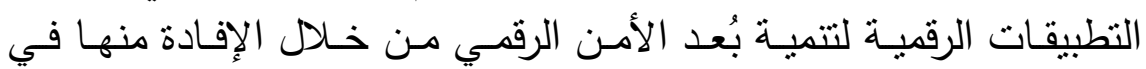
الاحتفاظ بنسخ احنياطية للبيانات الرقمية ، وانها تساعدهم على التحقق من دقة وصسحة المعلومـات، وتوفر لهم محتوبـات رقميـة ذات صـلة بمجـالات تعليمية منتوعة ومختلفة ، وتطور قدراتهم على التعلم الذاتي ، وتسـهم في وتي

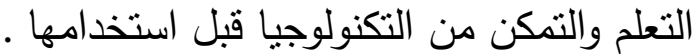

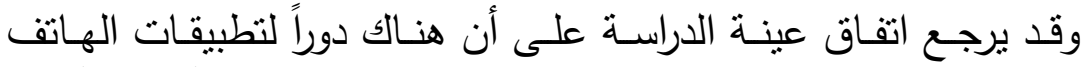

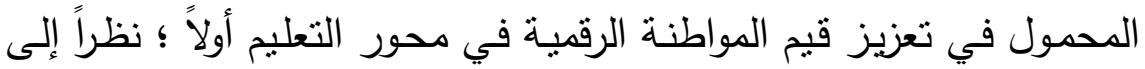
اعتماد الطلاب والطالبات على الهاتف المحمول في عملية التعلم والتواصل فيما بينهم لتبـادل المعلومـات والمعـارف والمحاضـرات والتكليفات إلكترونياً،

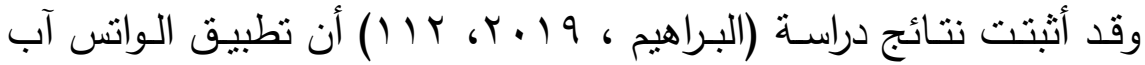
استخدم لأغراض تعليمية بنسبة ( • 7\%) تقريبًا، ووضست توصيات بمكن أن تساعد في استخدام تطبيق الواتس آب بشكلٍ أمثل في عملية التعليم، بالإضافة إلى القيام بعملية البيع والثراء للبضائع إلكترونياً، وجاء تعزيز قيم

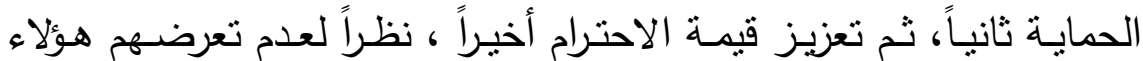

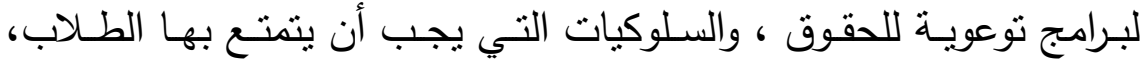
والواجبات التي ينبغي أن يلتزموا بها أثناء تعاملهم مـع العالم الرقمي، وعدم الوعي بحقوقهم وواجباتهم نحو استخدام التقنيات والتعامل معها إلى حدٍ ما. 
ومن خلال الطرح المثقدم يتضـح أن طلاب الجامعات المصرية يتفقوا

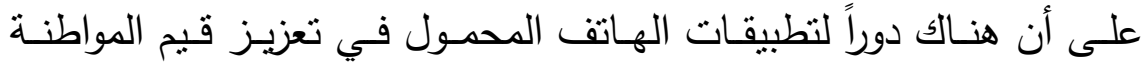
الرقمية من خلال النظر إلى طبيعة الهدف من استخدام التطبيقات الرقمية

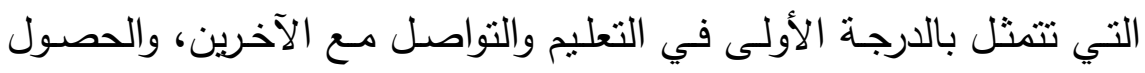
على معلومات و دعم عملية التعلم ، والقيام بعمليات الثراء عبر مواقع آمنة

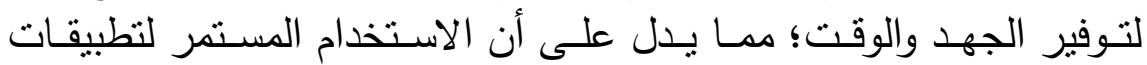

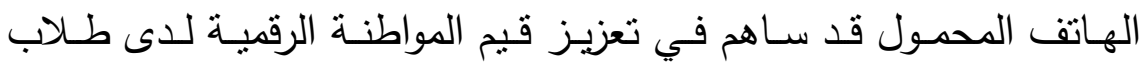

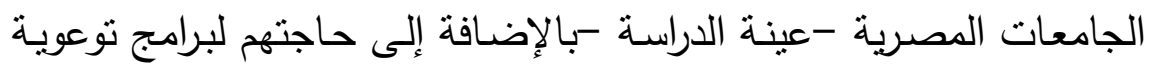

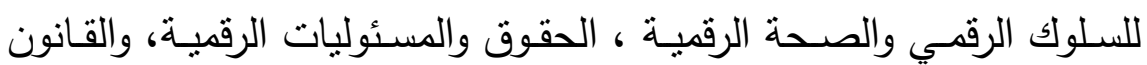

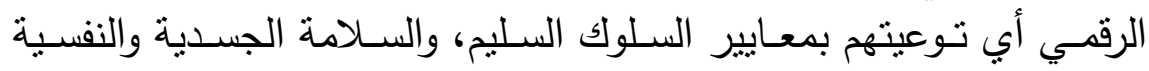

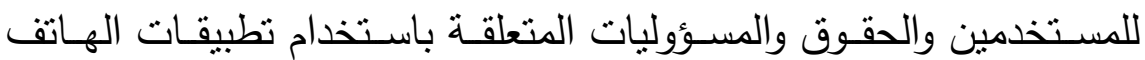
المحمول (فيس بوك ، يوثيوب ، واتس آب ، انستجرام ، وغيرها).

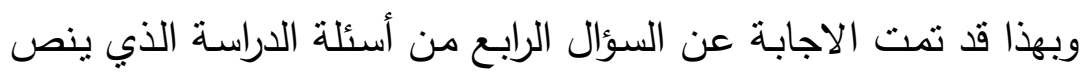
على: ما دور تطبيقات الهاتق المحمول في تعزيز قيم المواطنة الرقمية لدى طلاب وطالبات بعض الجامعات المصرية؛

\section{التحقق من صحة فروض الدراسة :}

ا-التحقق مسن صسة الفـرض الأول الذي ينص على "توجد فروق دالة إحصائياً في دور تطبيقات الهاتق المحمول في تعزيز قيم المواطنة الرقمية

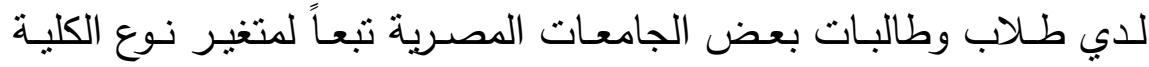

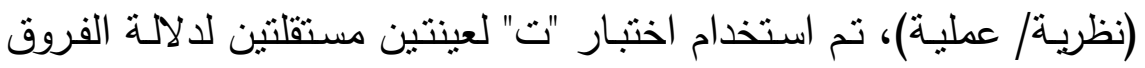
بين متوسطي درجات طلاب الكليات النظرية وطلاب الكليات العملية في دور تطبيقات الهاتف المحمـول في تعزبز قيم المواطنـة الرقميـة، والجدول التالي يوضتح نتائج استخدام اختبار "ت" في ذلك. 
جدول (Y Y): نتائج استخدام اختبار "ت" لالالة الفروق بين متوسطي درجات طلاب الكليات

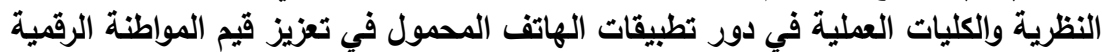

$$
(V Y \cdot=\dot{u})
$$

\begin{tabular}{|c|c|c|c|c|c|c|c|}
\hline مستوى الدلاكة & الحرية & قيمة ت & $\varepsilon$ & P & ن & الكلية & المحور \\
\hline \multirow{2}{*}{ غير } & \multirow[t]{2}{*}{$\mathrm{VIN}$} & \multirow[t]{2}{*}{$\cdot 6 r \leqslant 0$} & $1.6 \wedge 7 \pm$ & 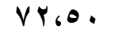 & rᄉ. & نظرية & \multirow{2}{*}{ (الاحتر ام) } \\
\hline & & & $116 \leqslant 1 \pm$ & VY6VI & $r \varepsilon$. & عملية & \\
\hline \multirow{2}{*}{ غير } & \multirow[t]{2}{*}{$\vee \wedge$} & \multirow[t]{2}{*}{$.6 M Y Y$} & $\Lambda_{6} \Delta Y^{\prime} \pm$ & 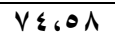 & $r \wedge$. & نظرية & \multirow{2}{*}{ (التعليم) } \\
\hline & & & $\left.q_{6} Y^{\prime}\right) \pm$ & $V \varepsilon \sigma r V$ & TE. & عملية & \\
\hline \multirow{2}{*}{ غير } & \multirow[t]{2}{*}{ 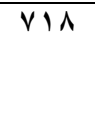 } & \multirow[t]{2}{*}{$\cdots \cdot r$} & $1 \cdot ، \wedge Y \pm$ & $V 1,1 \leq$ & r^. & نظرية & \multirow{2}{*}{$\begin{array}{c}\text { (الحماية) } \\
\text { (الثالث) }\end{array}$} \\
\hline & & & $116 V Y \pm$ & $\mathrm{V} 1.1 \mathrm{~T}$ & $r \varepsilon$. & عملية & \\
\hline \multirow{2}{*}{ غير } & \multirow[t]{2}{*}{$\operatorname{Vi\Lambda }$} & \multirow[t]{2}{*}{.6 .7} & $r V_{6} \wedge r$ & YIAGYY & $r \wedge$. & نظرية & \multirow[t]{2}{*}{ الاستبيان ككل } \\
\hline & & & Y9671 & $Y\left|\Lambda_{6} Y\right|$ & 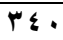 & عملية & \\
\hline
\end{tabular}

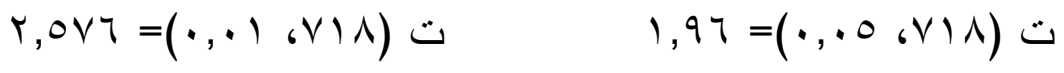$$
\text { يتضح من جدول (Y I)، ما يلي: }
$$

ا-عدم وجود فروق دالة إحصسائياً بين طلاب الجامعات المصسرية لدور

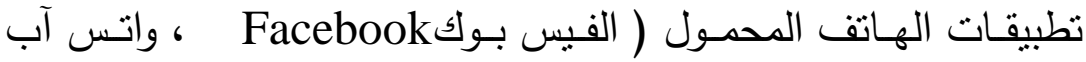

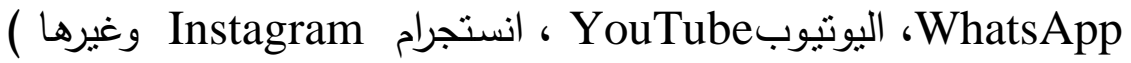
في تعزيز قيم المواطنة الرقمية ككل باختلاف نوع الكلية (نظرية/ عملية). 
r- عدم وجود فروق دالة إحصـائياً بين طـلاب الجامعات المصسرية لدور

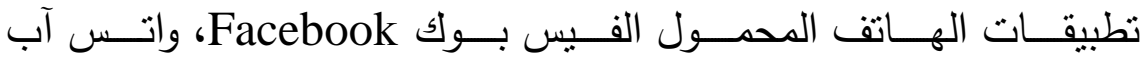
WhatsApp في تعزيـز قيم الاحتـرام والتعلـيم والحمايـة بـاختلاف نـوع الكليـة (نظربـة عملية). والرسم البياني التالي رقم (آ) يوضـح التمثيل البياني للفروق بين طلاب الكلبات النظرية والعملية. ولية

المحور

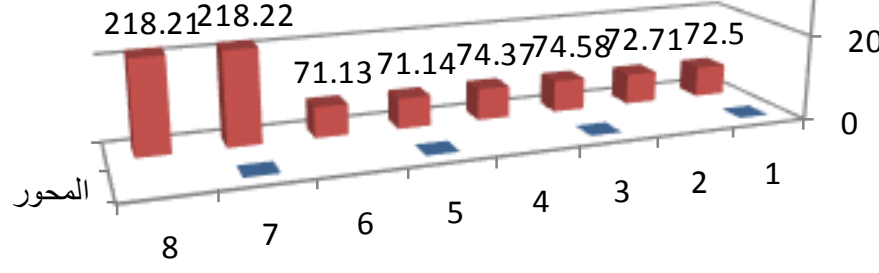

شكل (†) التمثيل البياني للفروق بين طلاب الكليات النظرية والعملية في دور تطبيقات الهاتف المحمول في تعزيز قيم المواطنة الرقمية

وبمكن تفسير هذه النتيجة إلىى أن طـلاب وطالبـات كل مـن الكليـات

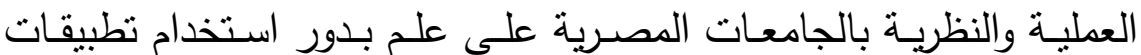

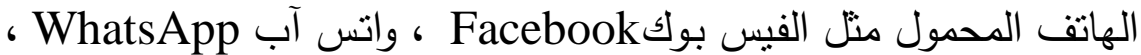
اليوتيوب YouTube ، انستجرام Instagram وغيرها في تعزبز قيم

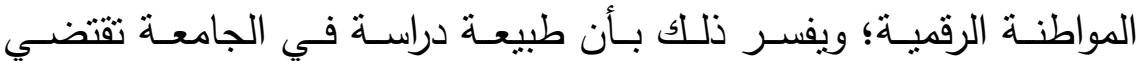

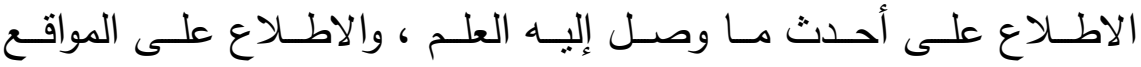
الإلكترونية للجامعات والمكتبات الرقمية، واستخدام هذه التطبيقات والاعتماد عليها في عمليات التعلم والتواصـل الاجتمـاعي ، وكذلك الترفيه وقضـاء أوقات ممتعة ، واهتمامهم بعمليات الثراء الإلكترونية نرجع إلى رغبتهم في 
توفير الوقت والجهد ، كمـا قد يدرس هـؤلاء الطـلاب مقررات لتكنولوجيـا التعليم ، وغيرها في أغلب الكليات العملية والنظرية .

وبهذا قد تم التحقق من صحة الفرض الأول الذي بنص على توجد فروق

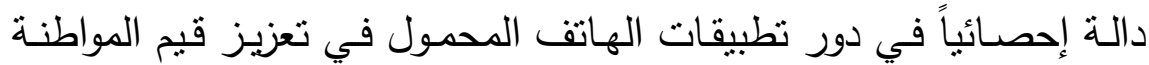

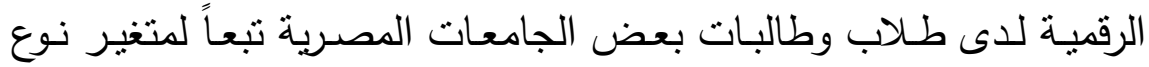

$$
\text { الكلية (نظريةة/ عملية). }
$$

r-التحقق من الفرض الثاني الأي ينص على" توجد فروق دالة إحصائياً

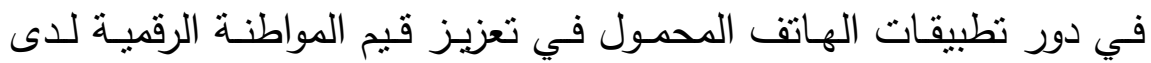
طلاب وطالبات بعض الجامعات المصـرية تبعاً لمتغير المستوى الدراسي

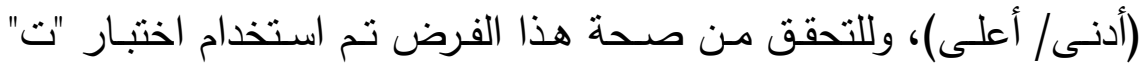
لعينتين مسـتقلتين لدلالـة الفروق بـين متوسـي درجـات طـلاب وطالبـات بعض الجامعات المصرية -عينة الدراسة -لدور تطبيقات الهاتق المحمول في تعزبـز قيم المواطنـة الرقميـة تبعـاً لمتغيـر المسـتوى الدراسـي، والجدول التالي يوضتح نتائج استخدام اختبار "ت" في ذلك.

جدول (r ا ): نتائج استخدام اختبار "ت" لالالة الفروق بين متوسطي درجات طلاب الجامعات

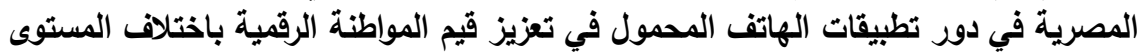

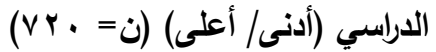

\begin{tabular}{|c|c|c|c|c|c|c|c|}
\hline مستوى الدلالة & الحرية & قيمة ت & $\varepsilon$ & p & ن & الدراستوى & المحور \\
\hline \multirow[t]{2}{*}{$\because \cdot 1$} & \multirow[t]{2}{*}{$\vee \backslash \Lambda$} & \multirow[t]{2}{*}{ r.VVA } & $1 \cdot 6 \vee 7 \pm$ & VT.7Y & $\varepsilon \cdot r$ & أدنى & \multirow[t]{2}{*}{ 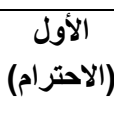 } \\
\hline & & & $11, \leqslant 0 \pm$ & VI,TI & TIV & أعلى & \\
\hline
\end{tabular}




\section{المجلة العلمية لكلية رياض الأطفال - جامعة بورسعيد}

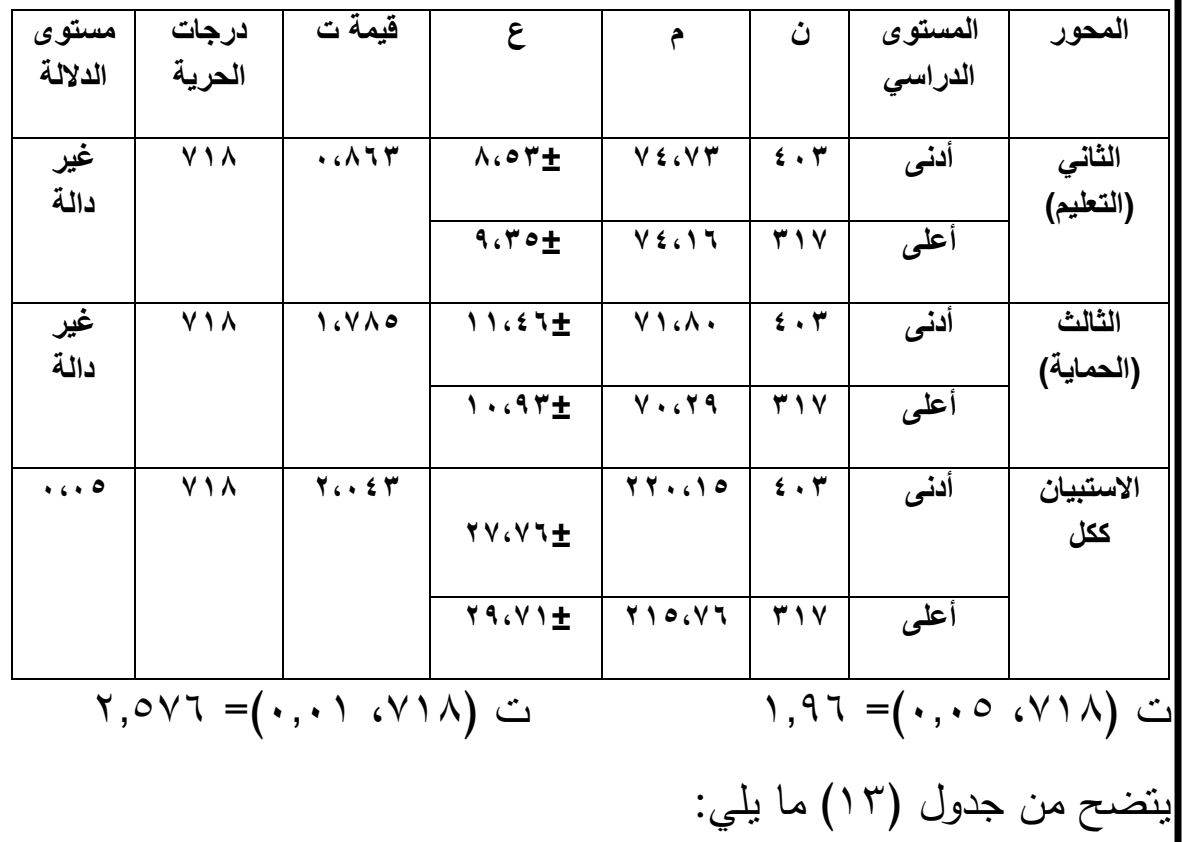

ا -وجـود فروق دالـة إحصـائياً عند مسـتوى (0 . . • ) بين طـلاب وطالبـات الجامعات المصرية -عينة الدراسـة - في دور تطبيقات الهاتق المحمول في

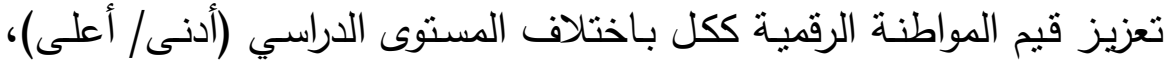
وذلك لصالح الطلاب ذوي المستوى الدراسي الأدنى. ب-وجـود فروق دالـة إحصـائياً عند مسـتوى ( ( , • ) بين طـلاب وطالبـات بعض الجامعات المصرية -عينة الدراسـة - لدور تطبيقات الهاتق المحمول في تعزبز قيمـة الاحترام بـاختلاف المسـتوى الدراسـي (أدنـى/ أعلى)، وذلك لصالح الطلاب ذوي المستوى الدراسي الأدنى. ب- عدم وجود فروق دالة إحصـائياً بين طلاب وطالبات بعض الانب الجامعات

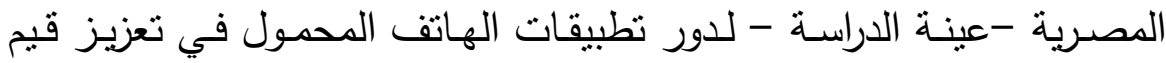
التعليم والحماية باختلاف المستوى الدراسي (أدنى/ أعلى)، والثكل(V) يوضح 


\section{المجلة العلمية لكلية رياض الأطفال - جامعة بورسعيد}

التمثني البياني للفروق بين طلاب المستوى الدراسي الأدنى وطلاب المستوى الدراسي الأعلى.

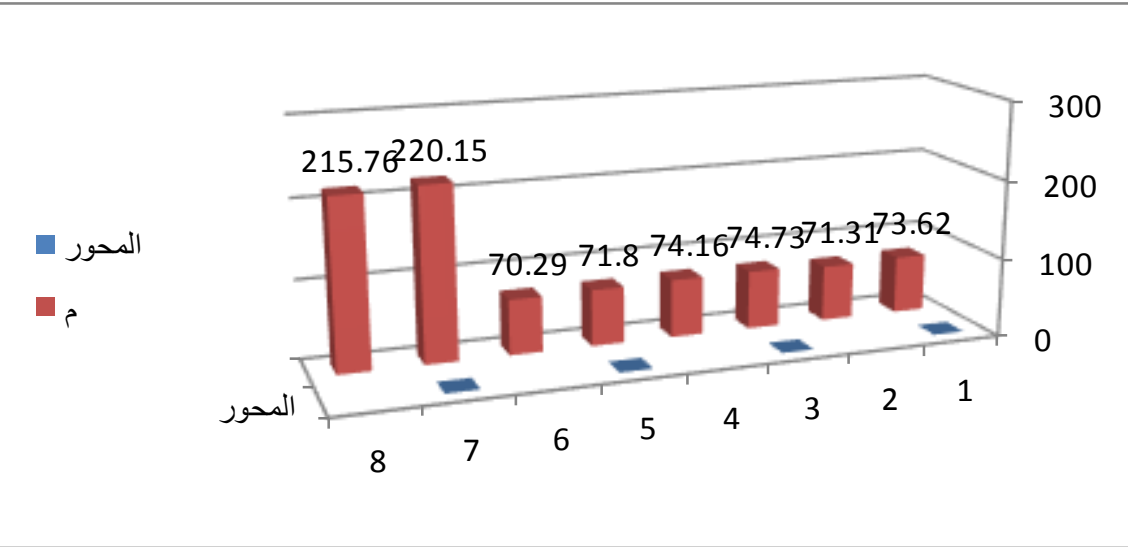

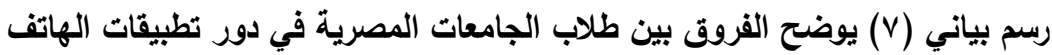

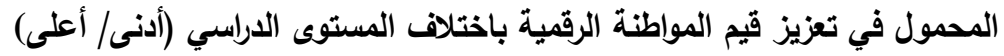
ويمكن تفسير وجود فروق دالة إحصائياً عند مستوى (0 . . . ) بين طلاب

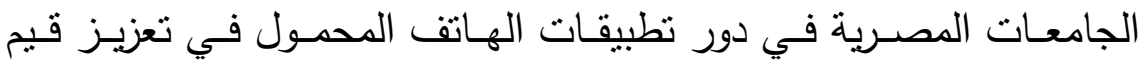

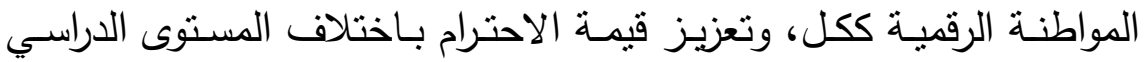
(أدنى/ أعلى)؛ وذلك لصـالح الطـلاب ذوي المستوى الدراسـي الأدنى؛ بـأن

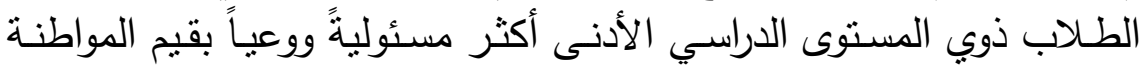
الرقمية، وقد يرجع ذلك لكونهم تعرضوا لدراستها من خـلال المقررات أثناء المرحلة الثانوية منل التربية الوطنية، مراعين في ذلك قيم ومباديء ومعايير السلوك السليم، وقوانين ولوائح المجتمع الرقمي.

كما أظهرت النتائج عدم وجود فروق دالة إحصائياً لدى طلاب الجامعات المصرية في دور تطبيقات الهاتف المحمول في تعزبز قيم التعليم والحماية باختلاف المستوى الدراسي (أدنى/ أعلى)، ويمكن تفسير ذلك بعدم وعي في لتيزي 
طـلاب وطالبـات الجامعات عينـة الدراسـة بقيم المواطنـة الرقمية وتطبيقات

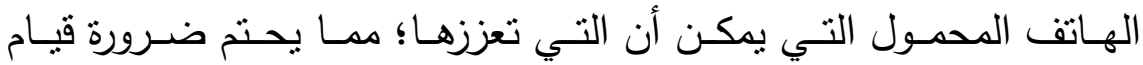
المؤسسات التربوبة المعنية بتدريب وتمكين طلابها من امتلاك قيم المواطنة الرقمية تمهيداً لضمان اتخاذ قرارات سليمة عند مجابهتهم لأخطار المواطنة

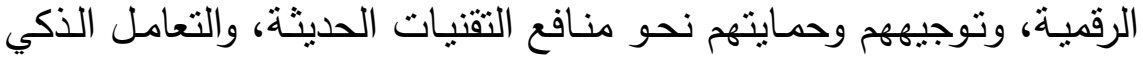
معها والتزام السلوك المسؤول أثثاء التفاعل مع وسائط التكنولوجيا المتتوعة ؛ فالمواطنة الرقمية تهدف إلى تعميق المسؤولية الكاملة عن الأقوال والأفعال المكتوبـة والمنطوقة والمصـورة، ولا تسـعى لمنـع اسـتخدام تطبيقات الهـاتف المحمول؛ لأن ذلك سيحول دون تقدم مجتمعاتتا ورقيها، وذللك لن يتحقق إلا بالتربية المقصودة عن طريق البرامج التوعوبـة والتدريبية لطلاب وطالبات

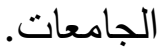

وبهذا قد تم التحقق مـ صـحة الفرض الثاني الذي ينص على" توجد فروق دالـة إحصـائياً فى دور تطبيقات الهـاتف المحمـول في تعزيـز قيم

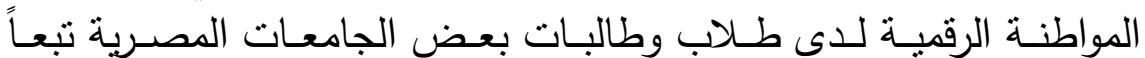
لمتغير المستوى الدراسي (أدنى/ أعلى). ب-التحقق من صحة الفرض الثالث الذي ينص على: " توجد فروق دالة إحصائياً في دور تطبيقات الهاتق المحمول في تعزبز قيم المواطنة الرقمية لدى طلاب وطالبات بعض الجامعات المصرية تبعاً لمتغير الجنس (ذكور ) إناث)". وللتحقق من الفرض تم حساب اختبار "ت" لعينتين مستقلتين لدلالة الفروق بين متوسطي درجات طلاب وطالبات بعض الجامعات المصرية في دور تطبيقات الهاتف المحمـول في تعزيز قيم المواطنـة الرقميـة بـاختلاف النوع (ذكور / إناث)، والجدول التالي يوضح نتائج استخدام اختبار "ت" في التي 


\section{المجلة العلمية لكلية رياض الأطفال - جامعة بورسعيد}

جدول (؛ 1): نتائج استخدام اختبار "ت" لدلالة الفروق بين متوسطي درجات ذكور وإناث

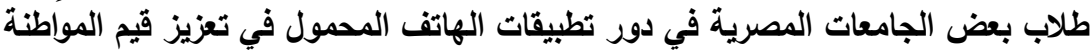

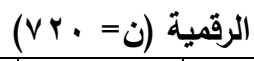

\begin{tabular}{|c|c|c|c|c|c|c|c|}
\hline مستوى الدلالة & الحرية & في قالة & $\varepsilon$ & p & ن & الجنس & المحور \\
\hline \multirow[t]{2}{*}{ غير دالة } & rYT & .699 & $1 \varepsilon_{6} \cdot v \pm$ & VI.9Y & 171 & ذ نكور & \multirow[t]{2}{*}{ 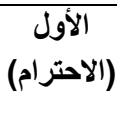 } \\
\hline & & & $1 \cdot 64 \pm$ & VY,AI & OOY & إناث & \\
\hline \multirow[t]{2}{*}{ غير دالة } & PrI & $.6 V 74$ & $1 \cdot ، \leqslant \wedge \pm$ & $v 0,19$ & 171 & ذ كور & \multirow{2}{*}{ (التعليم) } \\
\hline & & & 1.r. & $V \varepsilon, Y q$ & ODY & إناث & \\
\hline \multirow[t]{2}{*}{ غير دالة } & rro & $1, . \leqslant 1$ & $146.9 \pm$ & $8 \cdot .9$. & 171 & ذكور & \multirow{2}{*}{ (الحماية) } \\
\hline & & & $1.67 \leq \pm$ & $V I, r)$ & ODY & إناث & \\
\hline \multirow[t]{2}{*}{ غير دالة } & PrV &.,$T V Y$ & $r 0, r q \pm$ & $r \mid \Lambda_{6} \cdot 1$ & 171 & ذكور & \multirow{2}{*}{ ككل الاستبيان } \\
\hline & & & Yצ.r & rIA,YA & $00 Y$ & إناث & \\
\hline \multicolumn{4}{|c|}{$r, \diamond \vee \neg=(\cdot,+1 ، \vee \backslash \wedge) ت$} & & \multicolumn{3}{|c|}{ ت } \\
\hline
\end{tabular}

ا-عدم وجود فروق دالة إحصـائياً بين طلاب وطالبات بعض الجامعات

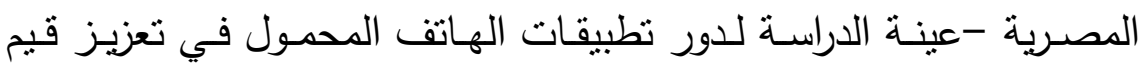
المواطنة الرقمية ككل باختلاف النوع أو الجنس (ذكور / إناث).

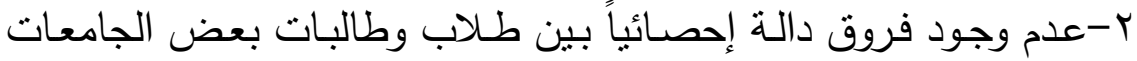
المصـرية عينـة الدراسـة لـدور تطبيقـات الهـاتف المحمـول في تعزيـز قيم 
الاحترام والتعليم والحماية باختلاف النوع أو الجنس (ذكور / إناث) ، والرسم

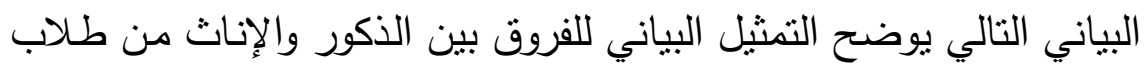
الجامعات المصرية.

المحور

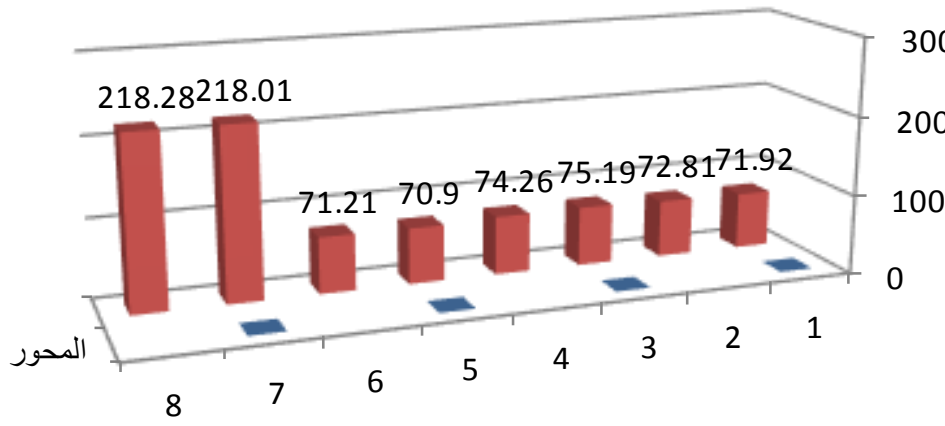

رسم بياني (^) يوضح الفروق بين طلاب الجامعات المصرية في دور تطبيقات الهاتف الفئل المحمول في تغزيز قيم المواطنة الرقمية باختلاف النوع أو الجنس (ذكورا لنوا إناث)

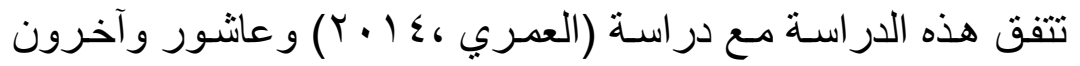

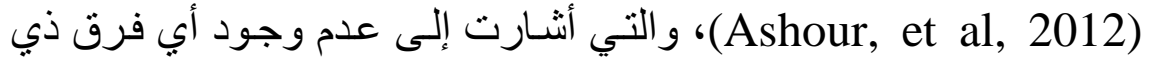

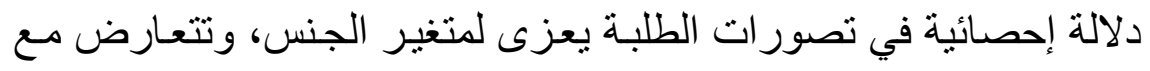

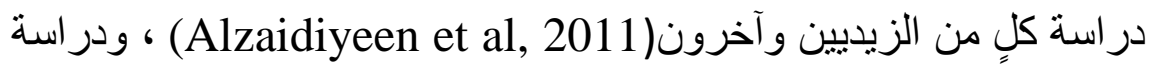

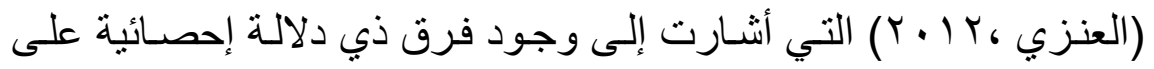
متغير الجنس لصالح الطلاب الذكور.

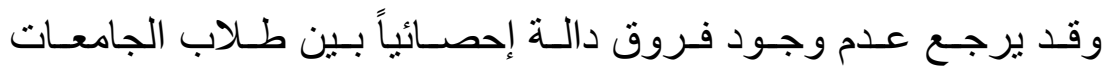

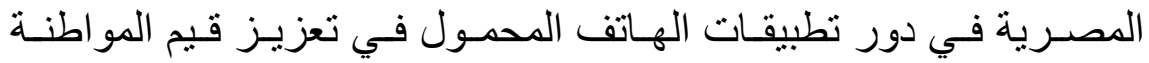


الرقمية ككل باختلاف النوع أو الجنس (ذكور/ إنـاث) إلى تسمية المرحلة

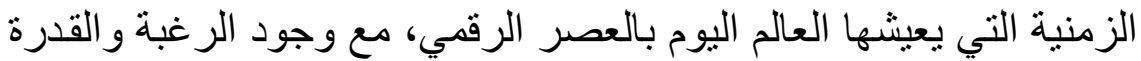
و البنية التحتية لتسهيل استخدام تطبيقات الهاتف المحمول من جميع الطلاب الربه

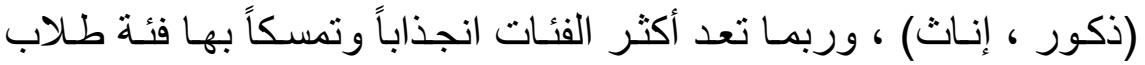

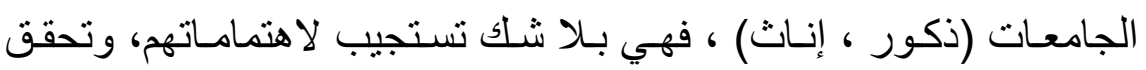
رغباتهم سو اء ذكور أم إناث، وبهذا قد تم التحقق من صحة الفرض اض الثالث

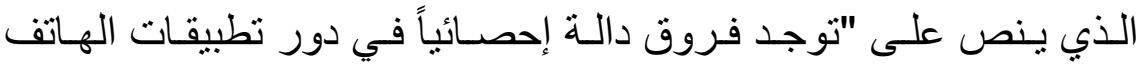

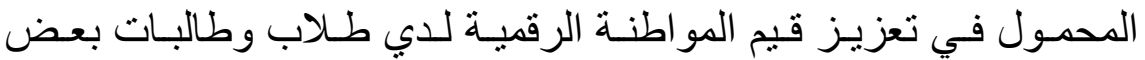
الجامعات المصرية تبعاً لمتغير الجنس(ذكور/ إناث).

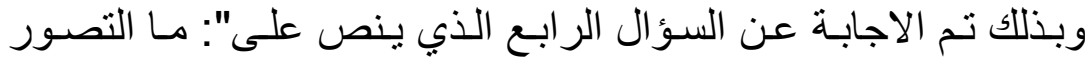

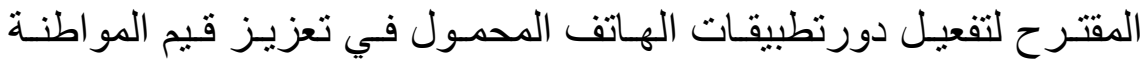

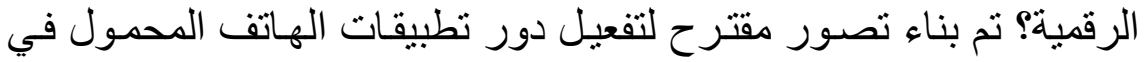
تعزيز قيم المو اطنة الرقمية في ضوء الإطار النظري للار اسة، وما أسفرت

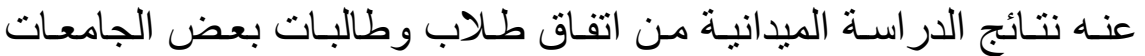

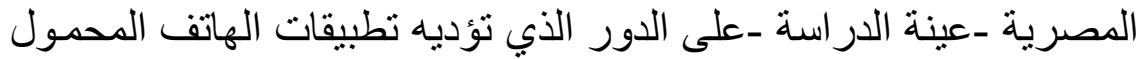

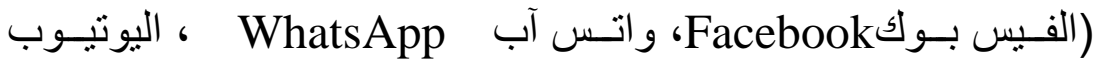
YouTube المواطنة الرقمية بمحاور ها الثلاث (الاحتر ام ، التعليم ، الحماية ) و أبعادهـا لفائ الفرعية التسع ، لا توجد فروق دالة إحصـائياً عند مستوى دلالة (0 ه . . )

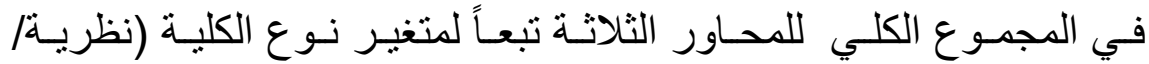

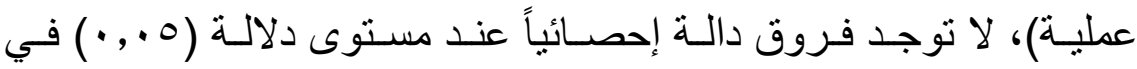

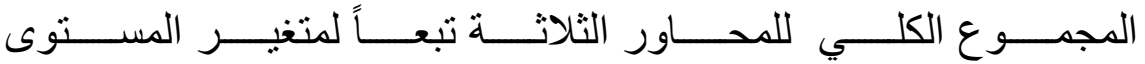
الدر اسي(أدنى/أعلى)، وجود فروق دالة إحصائياً عند مستوى (0 • ، • ) بين 
طلاب الجامعات المصرية في دور تطبيقات الهاتف المحمول في تعزيز قيم المواطنة الرقمية ككل، و تعزيز قيمة الاحتر ام باختلاف المستوى الدراسي

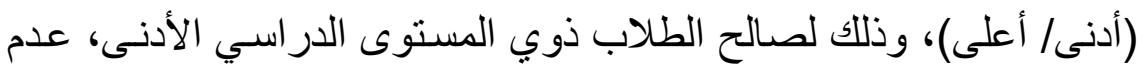

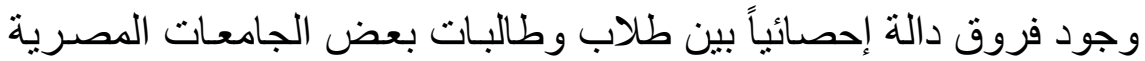
ـعينة الدراسة .في دور تطبيقات الهاتف المحمول في تعزيز قيم المواطنة الرقمية ككل بـاختلاف النوع أو الجنس (ذكور/ إنـاث) ؛ تم وضـع تصـور

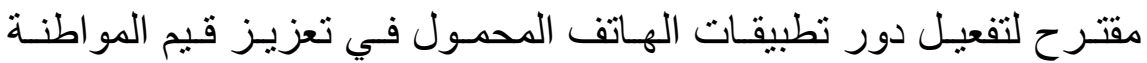
الرقمية . معرة

فلسفة التصور المقترح:

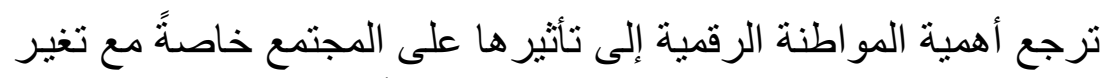

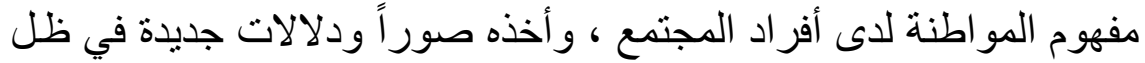

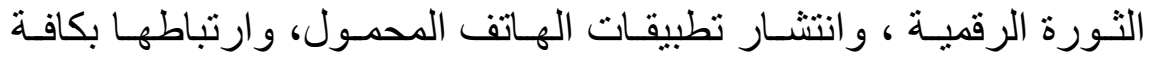

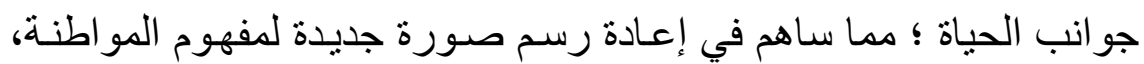
تسـعى إلـى تحويـل المـواطنين - بغـض النظـر عـن مســتوياتهن التقافيـة

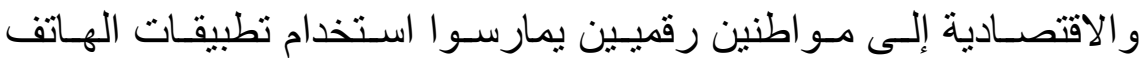

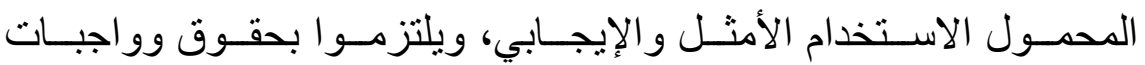
وسلوكيات هذا الاستخدام ؛ من أجل المساهمة في رقي الوطن وحمايته من الآثار السلبية لهذه التطبيقات.

أهداف التصور المقترح :

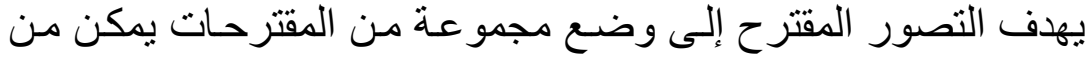

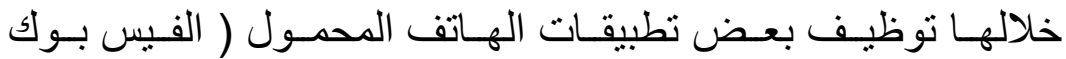

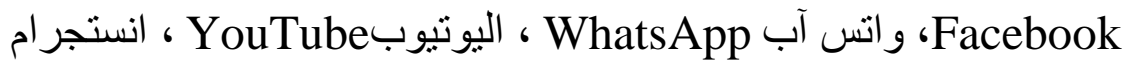




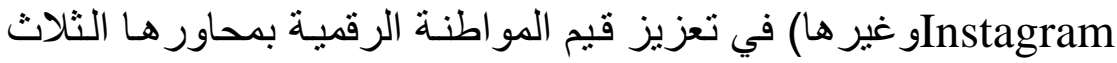

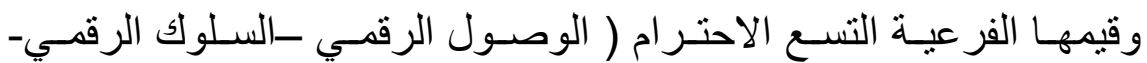

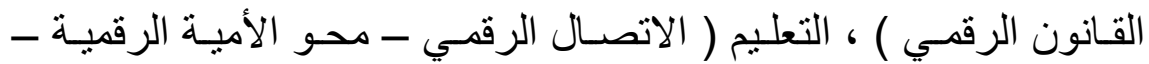

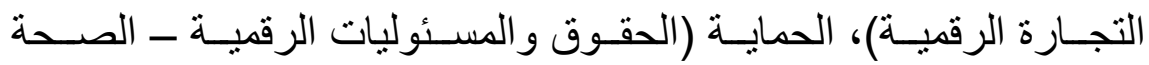
و السلامة الرقمية ــ الأمن الرقمي)، الرقية.

منطلقات التصور المقترح:

- التزايد المستمر في عدد مستخدمي تطبيقات الهاتف المحمول، وبخاصـة

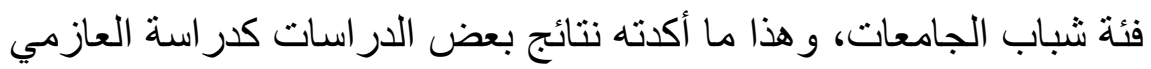

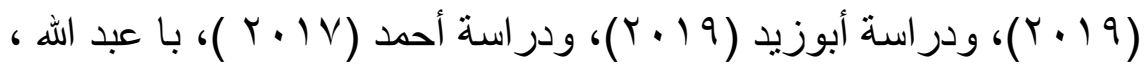

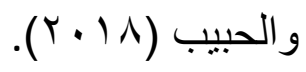

- الحاجة إلى وضـع مجموعـة من الآليات الوقائيـة ضـد أخطسار تطبيقات

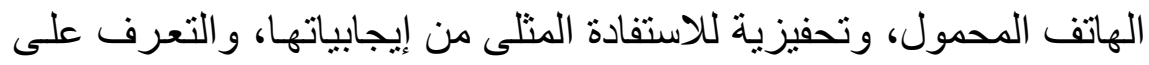

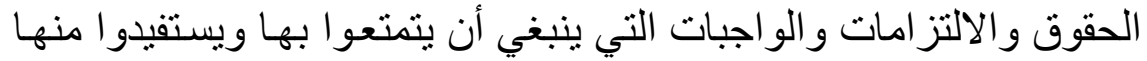
أثناء التعامل مع تطبيقات الهاتف المحمول.

- انتشار تطبيقات الهاتف المحمول التي لم تعد من سبل الترفيه و التسلية

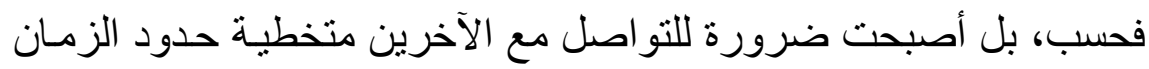

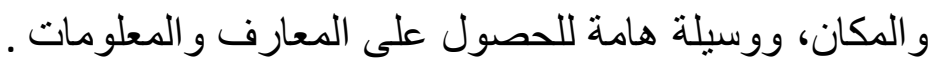

\section{آليات تنفيذ التصور المقترح :}

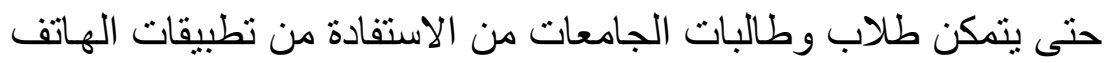

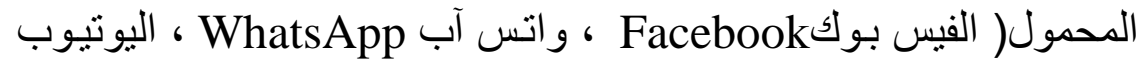


YouTube الرقمية ( التعليم و الاحتر ام و الحماية وقيمها الفر عية التسع )، وتلافي الآثار

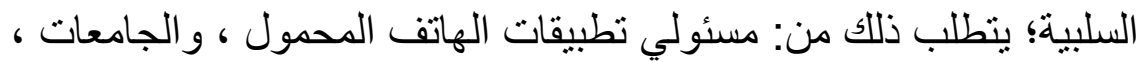

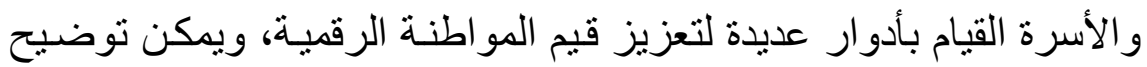

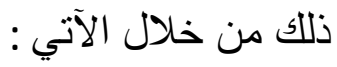

\section{ا-دور مسئولي تطبيقات الهاتف المحمول :}

يجب على مسـؤولي تطبيقـات الهـاتف المحمـول القيـام بـالأدوار الآتيـة لتعزيز قيم المواطنة الرقمية من خلال تطبيقات الهيقات الهاتف المحمول:

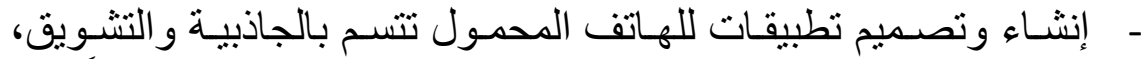

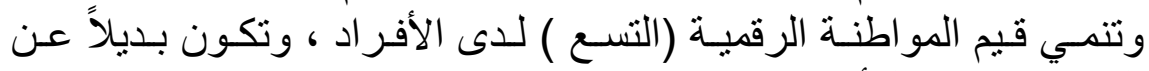
التطبيقات غير المأمونة.

- تحديث تطبيقات الهاتف المحمول الحاليـة بهدف تعزيز قيم المواطنة الرقمية لدى الأفر اد، وبخاصة فئة الثباب (طلاب المدارس و الجامعات ) ) للحد من التأثيرات السلبية والاستفادة من هذه التطبيقات في مناحي الحياة. - إقامة شر اكة بين شركات تصميم تطبيقات الهاتف المحمول و الهيئات

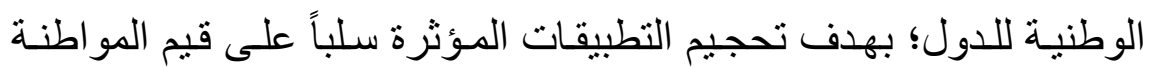

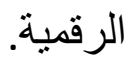

- - تقديم بر امج ثقافية عن طريق مواقع الإنترنت، ترسيخ الهويـة الوطنيـة لاى المواطنين، وتساعد على الحد من تأثير الثقافة الغربية. 
- تطوير آليـات حجب المواقـع الإباحيـة؛ بالتعـاون مـع الهيئـات الوطنيـة

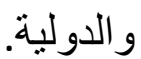

- تحديث بـر امج المحافظـة على الخصوصـية دوريـاً وإرسـال رسـائل التحديث للمستخدمين.

- توعية المو اطنين بالقرصنة و الاحتيال من خلال الإعلانات التي يتم بثها

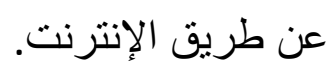

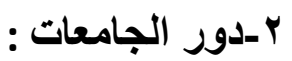

يجب على الجامعات القيام بـالأدوار الآتيـة لتعزيز قيم المواطنة الرقيـة من خلال تطبيقات الهاتف المحمول:

- تطوير معارف الطلاب ومهار اتهم وقيمهم واتجاهـاتهم بمفاهيم ومبادي

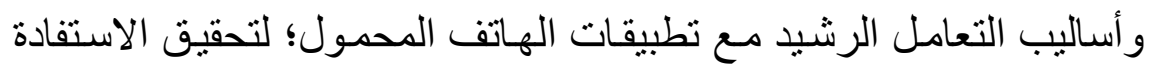
القصوى منها حتى يتكيفن مع مقتضيات المجتمع الرقمية . - توفير محتوى رقمي دقيق ذو صلة بمجالات التعليم المتنوع. ـ تعديل اللوائح؛ لإضـافة مقرر جديد ضمن مقررات التعليم يدرسـه جميع

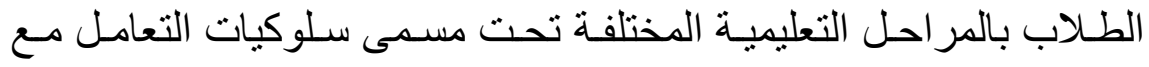
التقنيـات يتضمن قيم المواطنـة الرقميـة بمحاور هـا الثناثلث وقيمها الفرعيـة

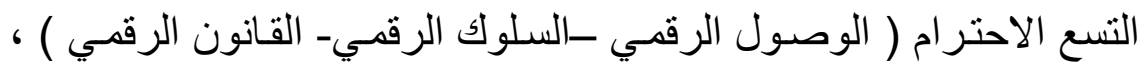

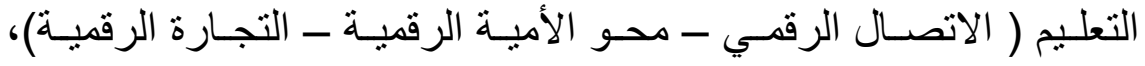
الحماية (الحقوق و المسئوليات الرقمية ــ الصحة والهيلامة الرقمية ــ الأمن 
الرقمي)؛ بهدف إكسـابهم سلوكيات التعامل مـع تطبيقات الهاتف المحمول

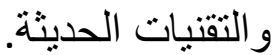

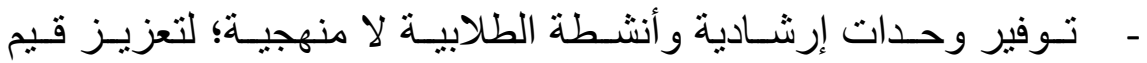

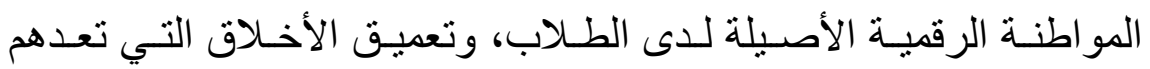

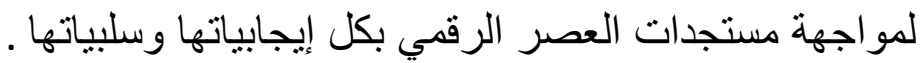

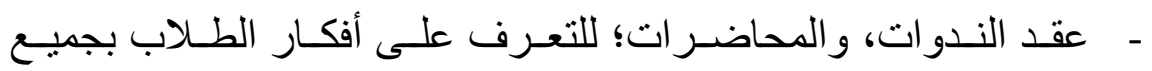

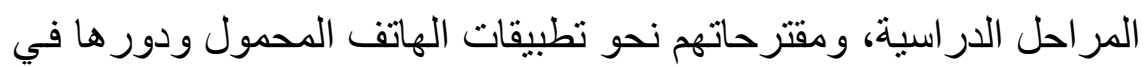
تعزيز قيم المواطنة الرقمية في المجتمع.

- عقد شر اكة بين الجامعات، ومؤسسـات المجتمع لتعزيز قيم المو اطنـة

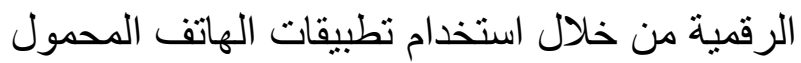

- إعداد مطويات لتوعية طلاب الجامعات بقيم المو اطنة الرقمية بمحاور ها

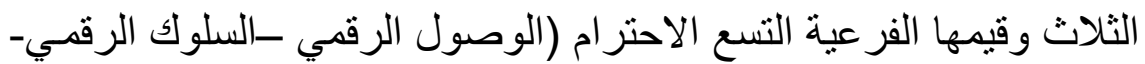

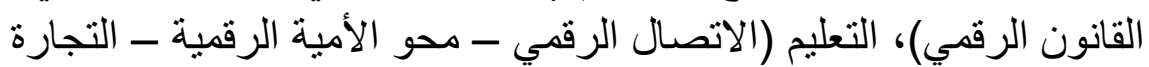

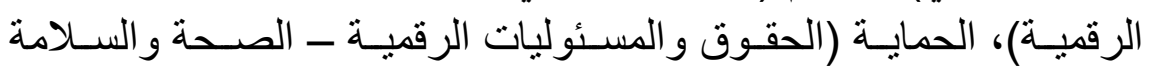

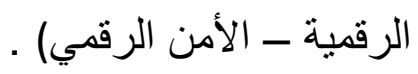

- تدريب الطلاب على بعض المهار ات و المعارف الحياتية التي تسـاعدهم

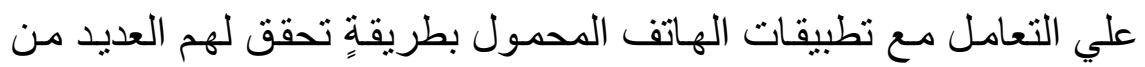
الفوائد في حياتهم العملية، وتعزز لديهم قيم المواطنة الرقمية.

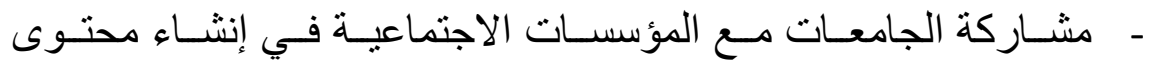

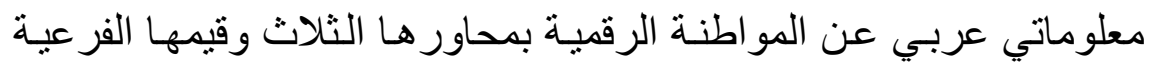




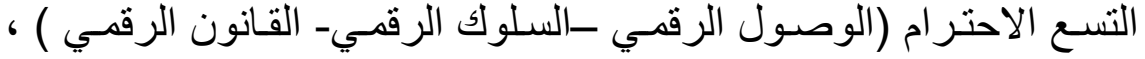

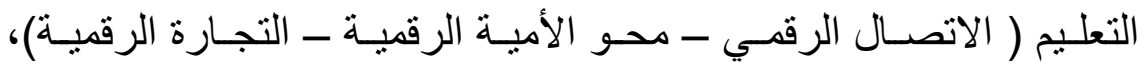

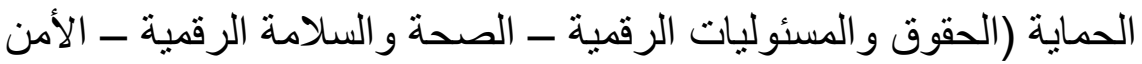

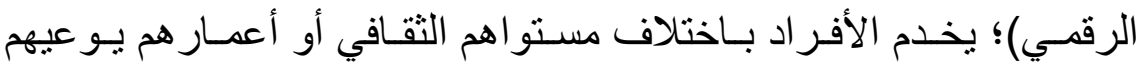
ويثقفهم بقيم المو اطنة الرقمية.

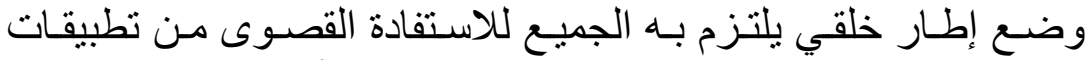

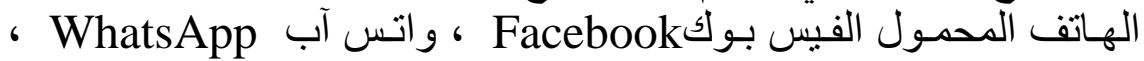

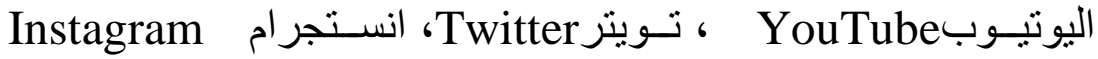
و غيرها)في الحياة الاجتماعية وتعزيز قيم المو اطنة الرقمية ، يتمثل في:

· التسوق من مواقع معروفة وموثوق بها ومشهورة.

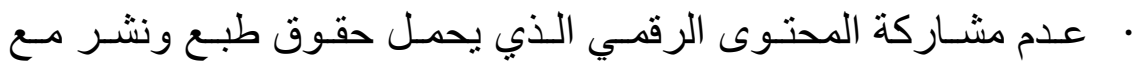

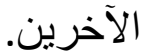
• عدم تبادل المحتوى الرقمي المخل بالآداب.

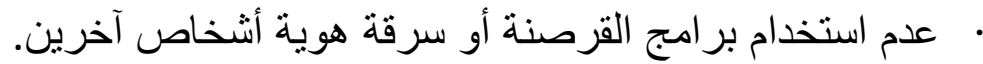
• التأكد من مصداقية وموثوقية المواقع التجارية.

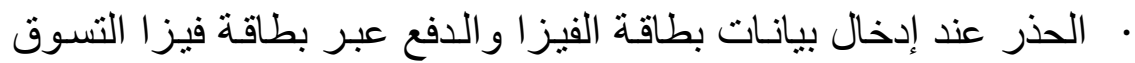
خدم · عشر مقاطع فيديو أو صور تشهر أو تسيء إلى الآخرين أو تخترق خصوصياتهم أو تسبب لهم فئ أذى نفسي أو اجتماعي.

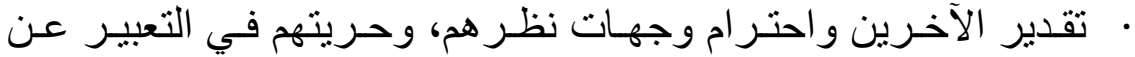
آر ائهم، و أفكار هم. • الاحتفاظ بأسر ار الآخرين، و عدم استخلال المعلومات بطرقٍ غير لائقةٍ. · التأكد من صدق المعلومات قبل نشر ها.

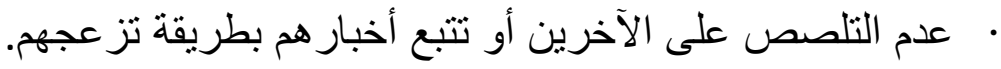


يجب على الأسرة القيام بالأدوار الآتية لتعزيز قيم المواطنـة الرقمية من آلن

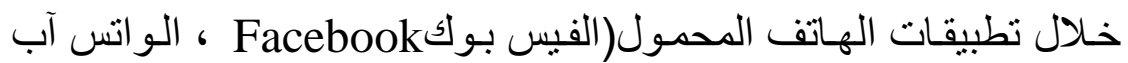
WhatsApp : Instagram

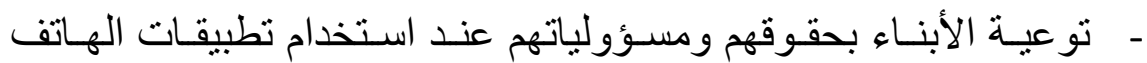

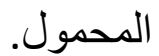
- توعية الأبناء بضرورة استخدام فلتر للرسائل غير المرغوب فيها وعدم فتح مرفقات رسائل مثيرة للاريبة. - مبتخدام برنامج ترشيح أو حجب المئه المو اقع غير الملائمة من الأنترنت.

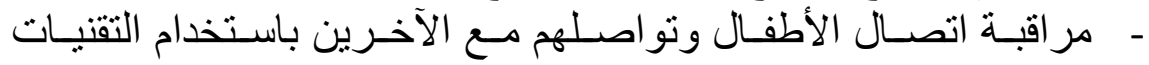

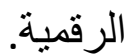
- توعية الأبناء بالآثار الجسدية المترتبة على استخدام تطبيقات الهاتف المحمول لفتر ات طويلة. - التأكد من الإضـاءة المناسبة في مكان استخدام الهواتف المحمولة للتقليل

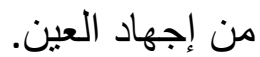
- استثمار وقت فر اغ الأبنـاء بطريقةٍة فعالةٍ وتقنين الفترات التي يقضيها

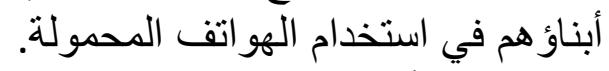

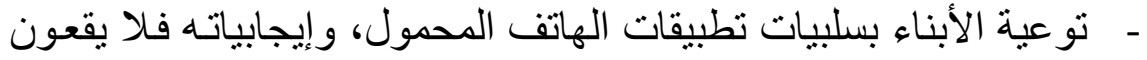

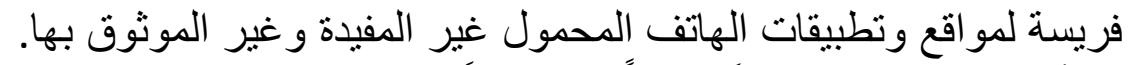

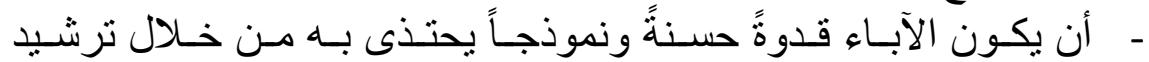

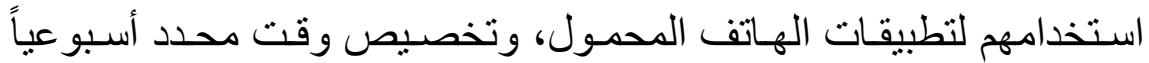
للتجمع الأسري لتبادل الحوار و المناقثنات . 


\section{المجلة العلمية لكلية رياض الأطفال - جامعة بورسعيد}

- تنمية وعي الأبناء بقيمنا، و عاداتنا، وتقاليدنا، و التصدي للعادات، و القيم الاخيلة التي تتنافى مع قيم مجتمعاتنا الإسلامية.

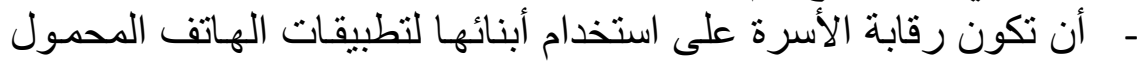
رقابة حذرة تتصف بالحرية، و الايمقر اطية.

وبهذا يكون قد تمت الإجابة عن السؤ ال الثامن مـن أسئلة الدراسـة الذي ينص علي " ما التصور المقترح لتفعيل دور تطبيقات الهاتف المحمول في في تعزيز قيم المواطنة الرقمية؟ ".

\section{توصيات الاراسة:}

ا-فتح المجال أمـام الباحثين والمتخصصين للاهنمام بتعزيز قيم المواطنة الرقمية لدى المتعلمين في المراحل التعليمية الأخرى.

ب-تقديم دورات تدريبـة للطـلاب والطالبـات في المراحل التعليميـة المختلفـة للتدريب على مهارات الاستخدام الآمن والمسؤول لتكنولوجيا المعلومات. ب-توعية مختلف المراحل العمرية بمفهوم المواطنة الرقمية بصورةٍ محببةٍ. ع-تفعيل دور المجتمع في تدعيم ثقافة الاستخدام الرشيد للتقنيات الرقمية.

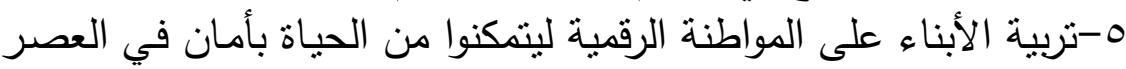
الرقمي.

ج-عقد نـدوات ثتقفيـة نشـارك فيهـا الجامعـات تقوم على تثقـيف وإرشـاد المجتمــع بأكملــه حـول الاسـتخدام المنضـبط لتلك الأجهـزة، وبيـان آثـار الاستخدامات السيئة لها.

V-تضـمين قيم المواطنـة الرقميـة في المنـاهج الدراسية بمختلف المراحل التعليم وفق رؤى واستراتيجيات واضحة. 


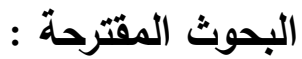

1-قياس دور تطبيقات الهاتف المحمول في تعزيز قيم المواطنة الرقمية لدى طلاب المرحلة الثانوية.

r-فعالية برنامج تدريبي في تتمية قيم المواطنة الرقمية لدى طلاب المرحلة

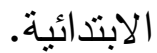
س-فعاليـة برنـامج إلكترونـي في تتميـة قيم المواطنـة الرقميـة لـدى طـلاب

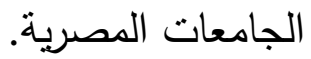

\section{المراجح}

أولاً: المراجع العربية:

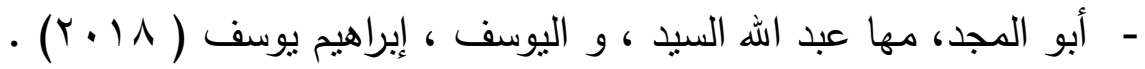
شبكات التواصل الاجتماعي وسبل توظيفها في تعزيز أبعاد المواطنة الرقمية لدى طلبة كلية التربية الجامعات الملك فيصل، الدجلة التربوبية، كلية التربية

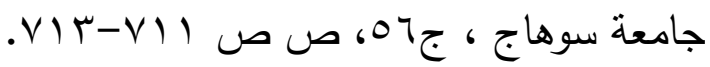

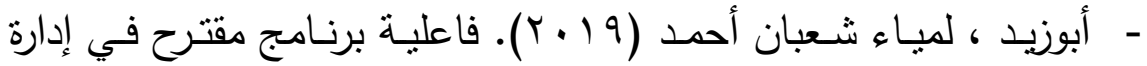

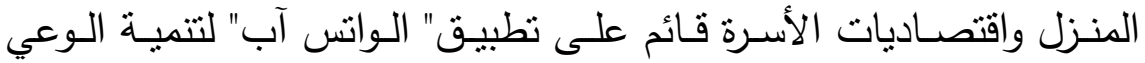

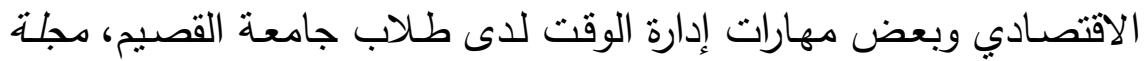

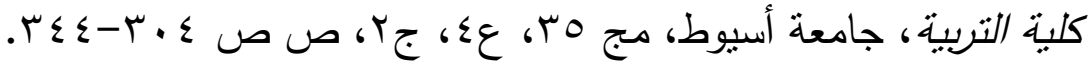

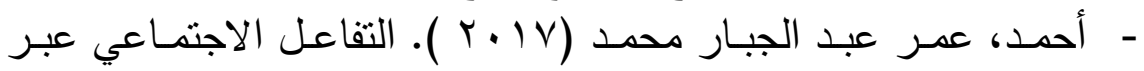

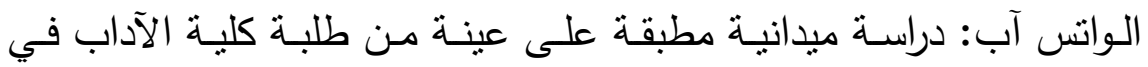

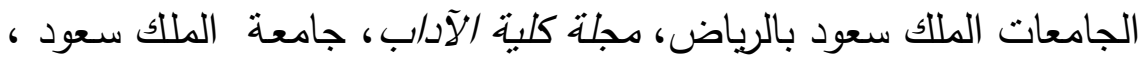

$$
\text { مجqr ، ، }
$$




\section{المجلة العلمية لكلية رياض الأطفال - جامعة بورسعيد}

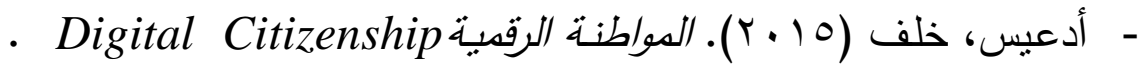
جامعة القدس المفتوحة، ص أ. - آل إبراهيم، أمل عبد الله ( 9 ( ـ ب). فاعلية استخدام طالبات كلية التربية

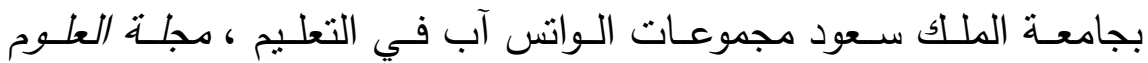

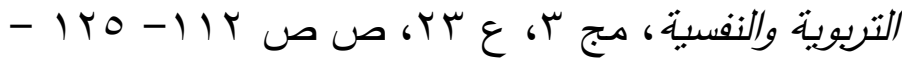

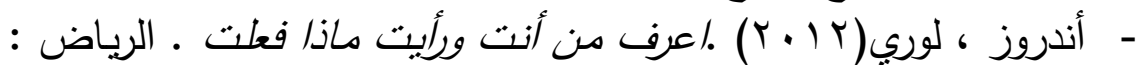

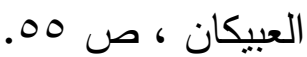

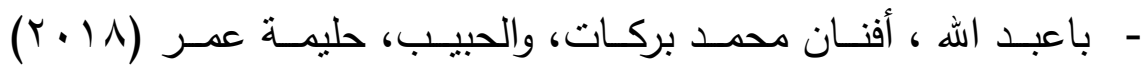

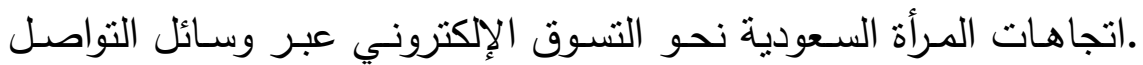

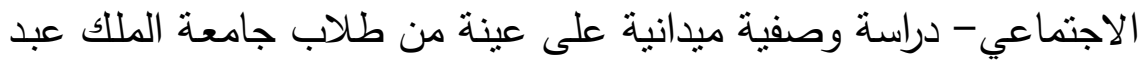

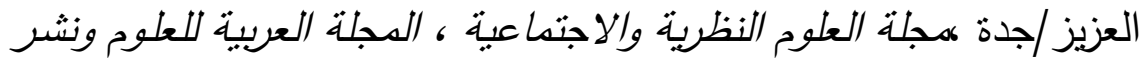

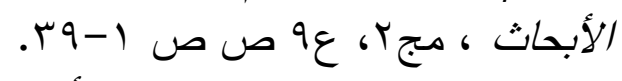

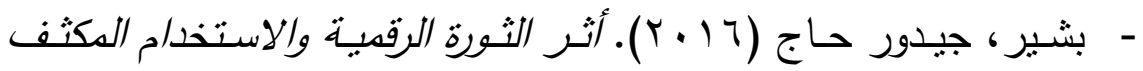

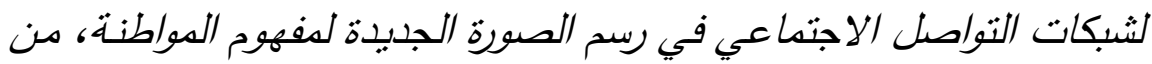

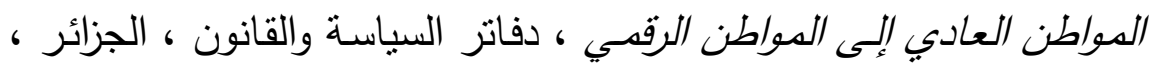

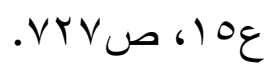

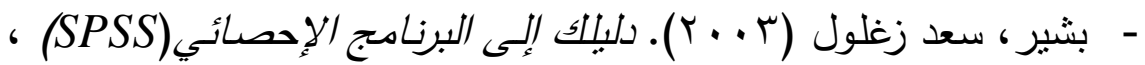

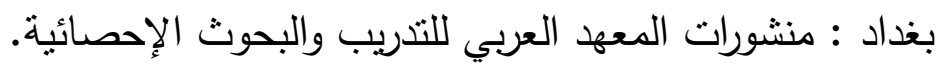

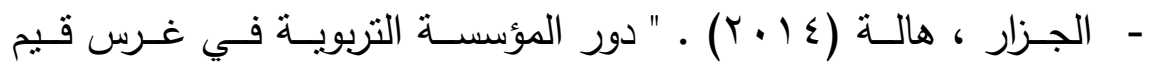

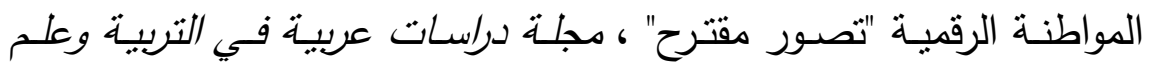

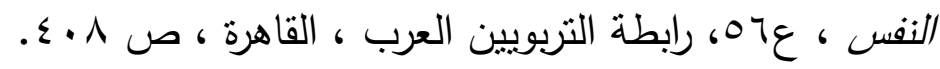

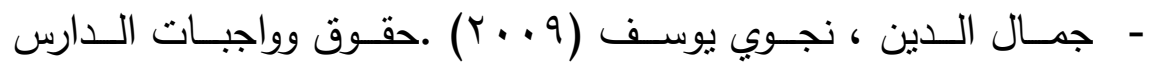

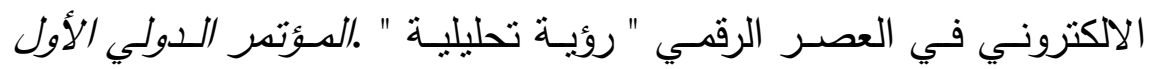


للتعلبم الإلكترونسي والتعليم عن بُعد ، الرياض، الفترة من 7 ا - 1 ( مارس ،

$$
\text { ص | }
$$

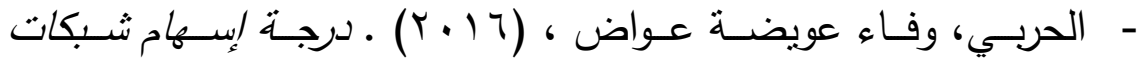

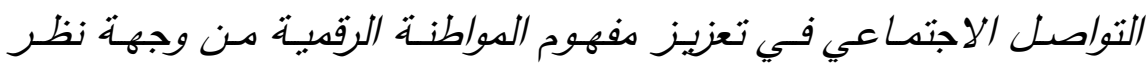

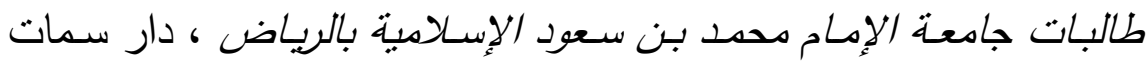

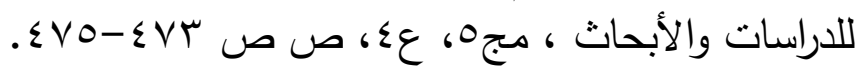

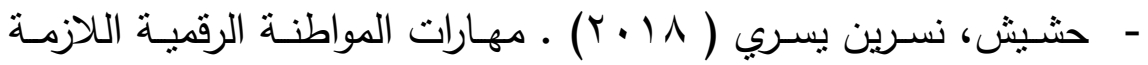
لتلاميذ مرحلة التعليم الأساسي، مجلة دراسـات في التعلبم الجامعي، مركز

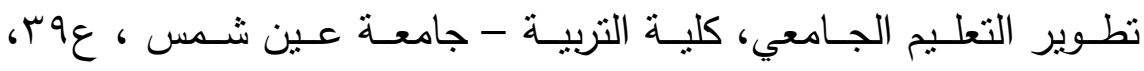

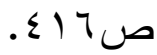

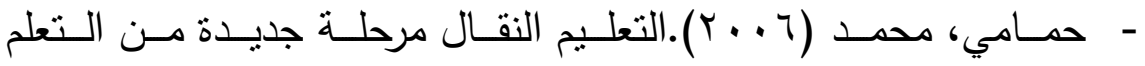

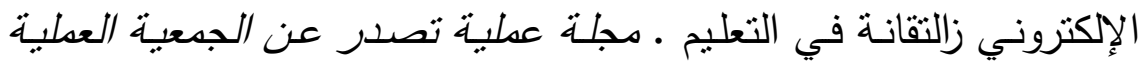

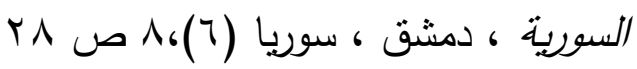

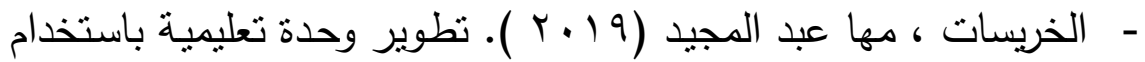

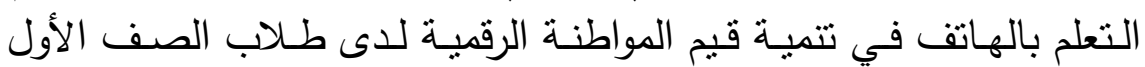

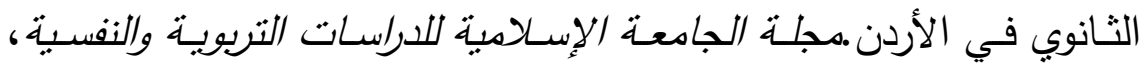

$$
\text { مجVr، }
$$

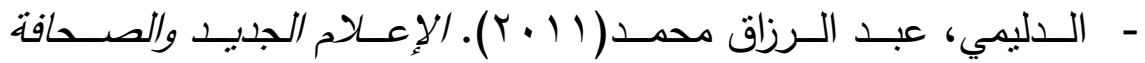

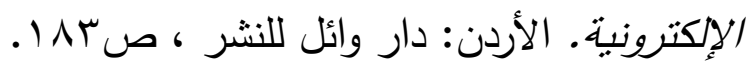

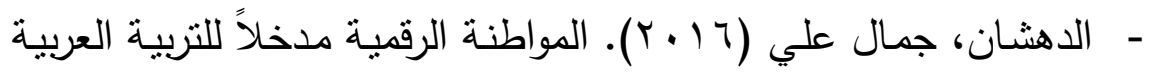

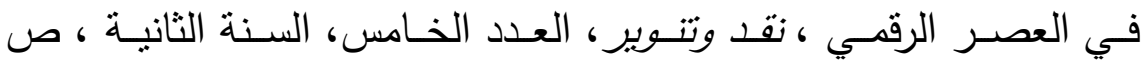
1. 


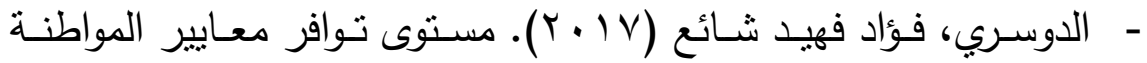

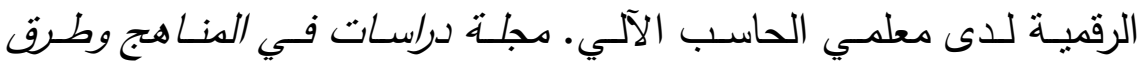

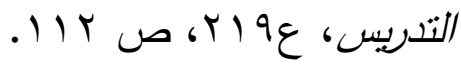

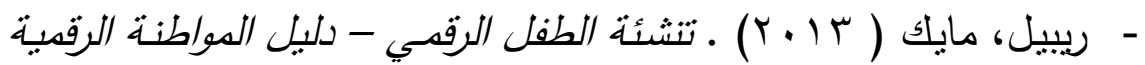

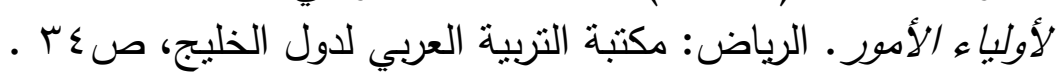

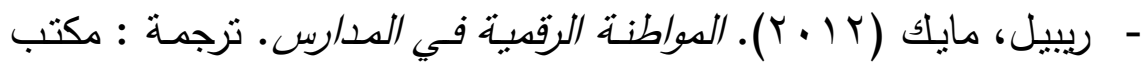

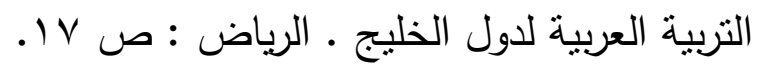

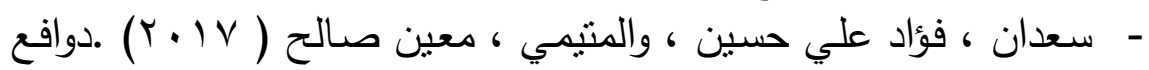

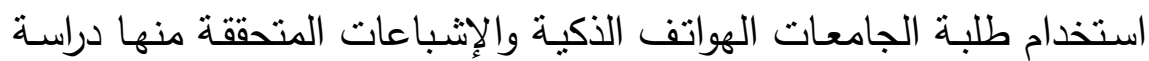

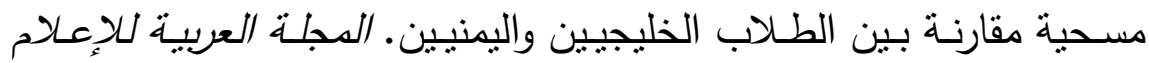

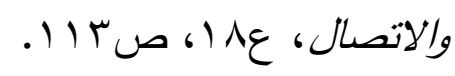
- السـليحات ، روان يوسـف ، وآخـرون ( ^1 • ب). درجـة الـوعي بمفهوم

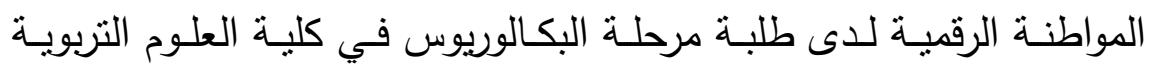

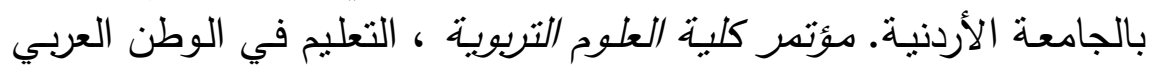

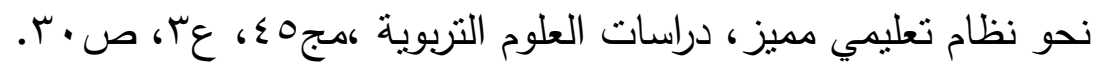
- سليم ، تيسير اندراوس (Y lV).تطبيقات الهاتف المحمول في العملية

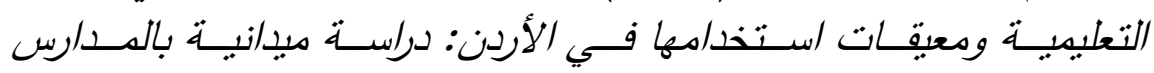

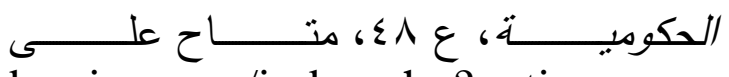

http://www.journal.cybrarians.org/index.php?option=com _content\&view=article\&id=806:tsalim\&catid=313:papers \&Itemid=93 - السـبد ، فاطمـة الزهـراء محمـد أحمـد ، العقبـاوي، بسـنت عبـد المحسن

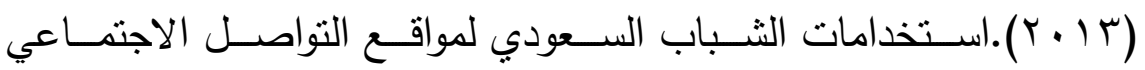

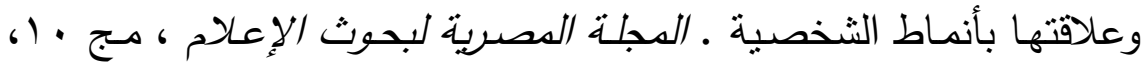
.119 ص ب ع 


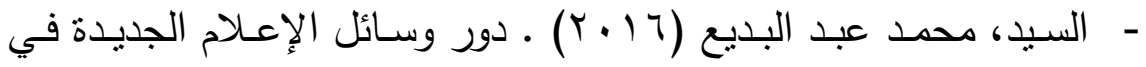
دعم المواطنة الرقمية لدى طلاب الجامعة ـ مجلة بحوث العالاقات العامـة

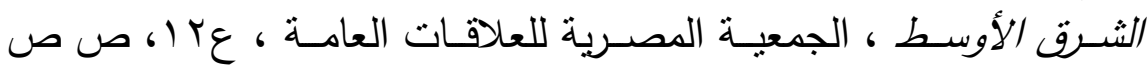

$$
\text { . } 1 \cdot 9-1 \cdot 1
$$

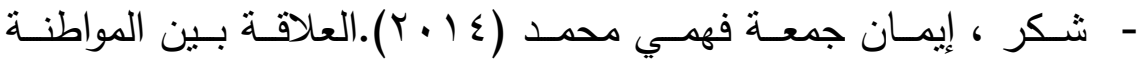

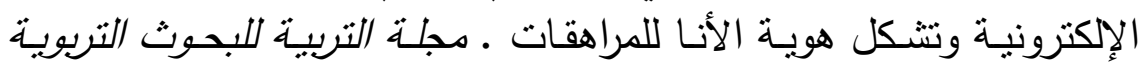

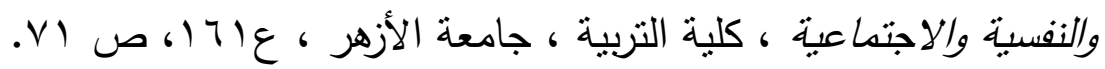

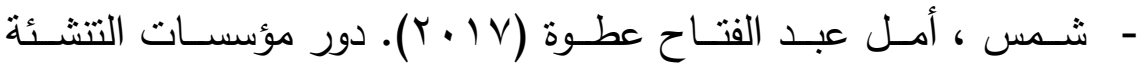
الاجتماعية في نشر قيم المواطنة الرقمية لتحقيق التتمية المستدامة : بحث مبداني في محافظة القاهرة ، حولبات آداب عبن شعس ، كليـة الآداب -

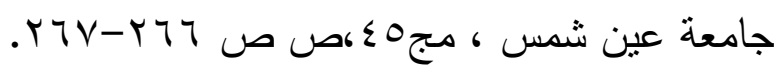

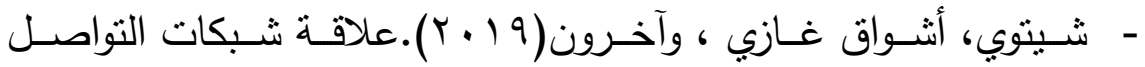
الاجتماعي بـالاغتراب الثقافي استخدام تطبيق السناب شـات وسط الثباب

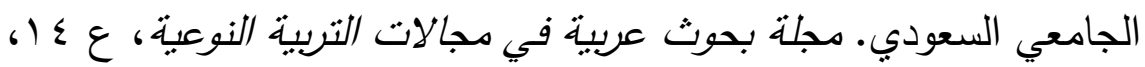
ص ص

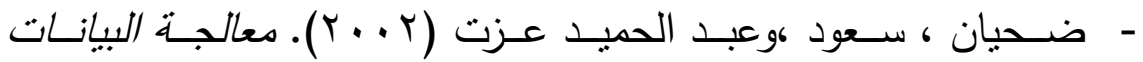

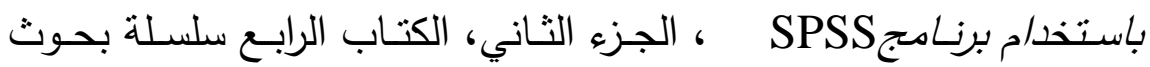
منهجية، الرياض: مكتبة الملك فهد الوطنية.

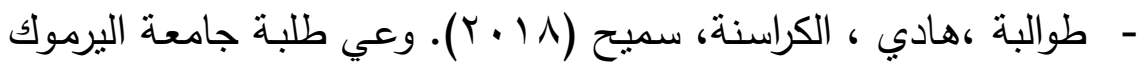

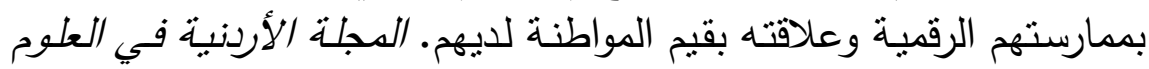

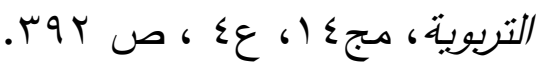

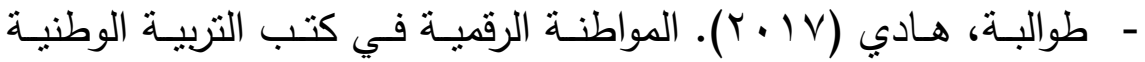

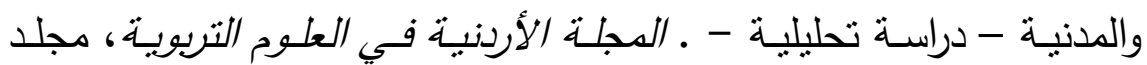
r) 


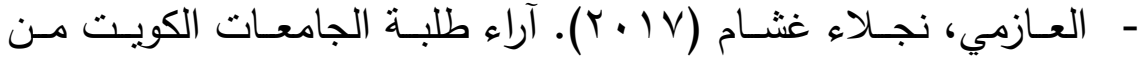
مستخدمي سـاب شـات حول إسـهاماته في الجوانب الاجتماعيـة والتعليميـة

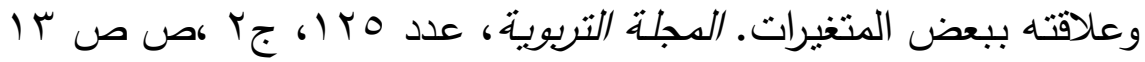

- علام، صـلاح الدين محمود ( . . . r). القباس والثقوبم التنبوي والنفسي أساسباته وتطبيقاته وتوجهاته المعاصرة. القاهرة: دار الفكر العربي •

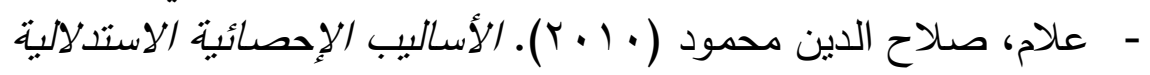

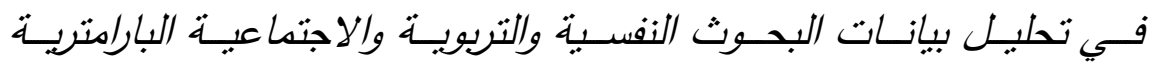

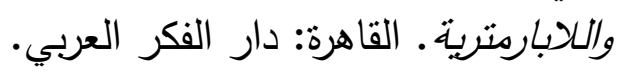

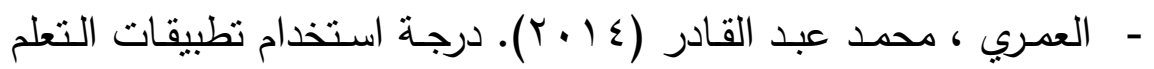
النقال لدى طلبـة الدراسـات العليا في جامعة اليرموك ومعوقات استخدامها،

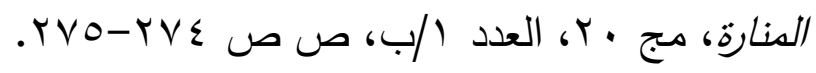

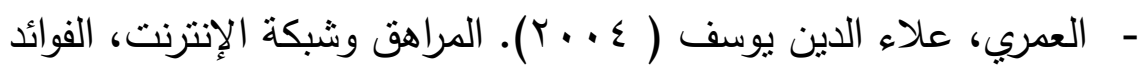

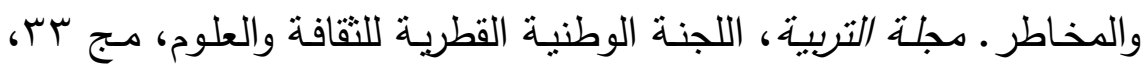

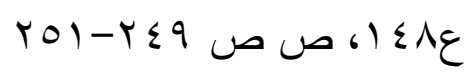

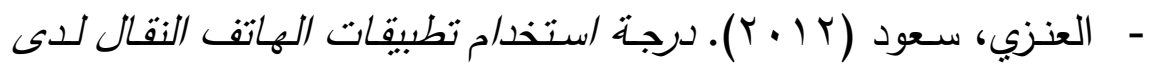
طلبة جامعة طبية في المدلكة العربية السعودية ومعوقات استخد/مه "رسالة

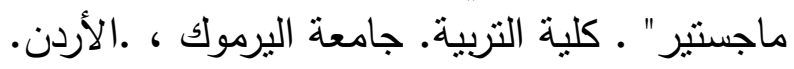

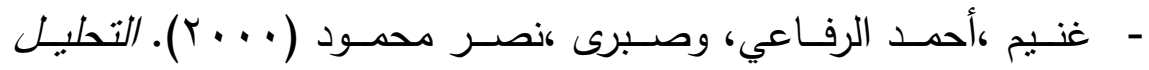
الإحصائي للبيانات باستخد/م برنامج(SPSS) ـ القاهرة : دار قباء للطباعة والنشر - و - الغويرى، خالد محمد فلاح (9 ( • ب). فاعلية الهاتف النقال في تحصيل طلبـة الجامعـة الهاثـمية في الرياضـيات واتجاهـاتهم نحـوه. مجلـة العلـوم 


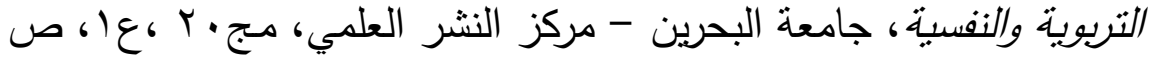
ص ص

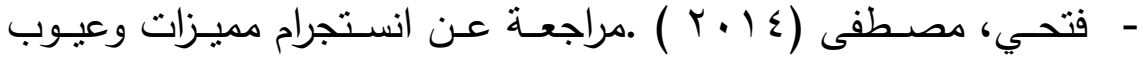

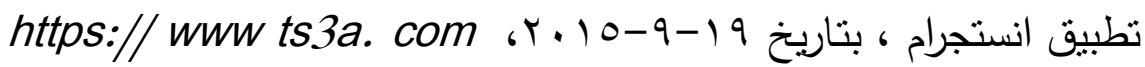

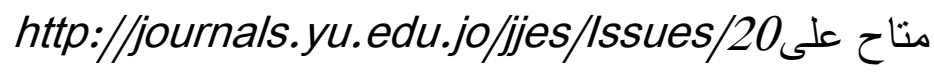

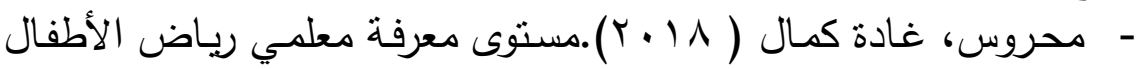

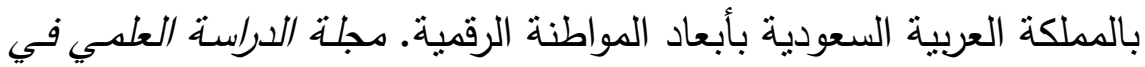

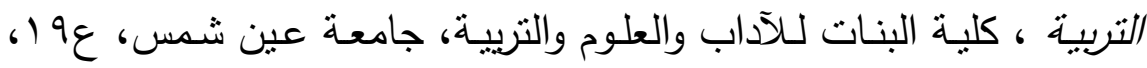

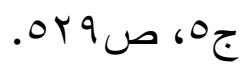

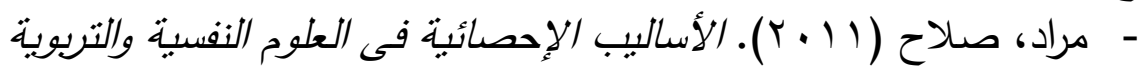
والاجتماعية ـ القاهرة: مكتبة الأنجلو المصرية.

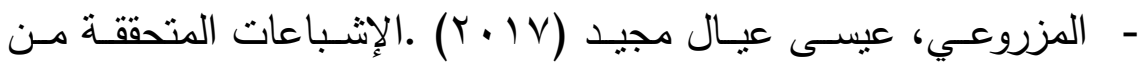
استخدام تطبيقات الاتصال الحديثة عبر الهواتف الذكية: دراسة مسحية على الثى

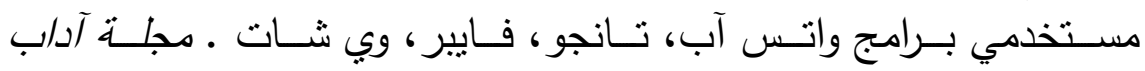

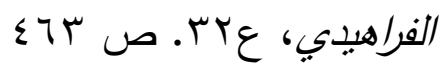

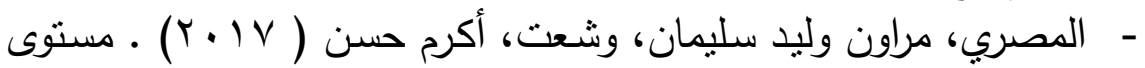

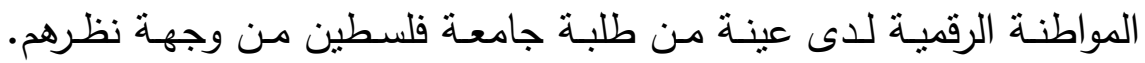

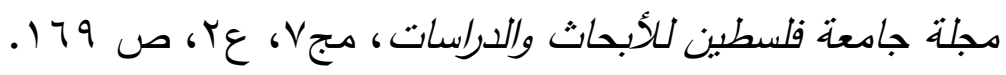

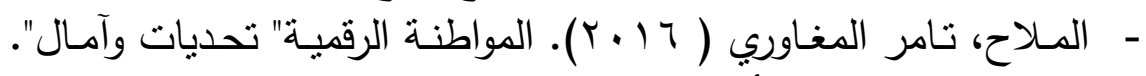

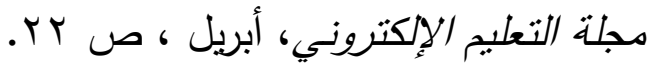

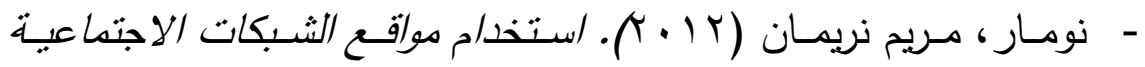

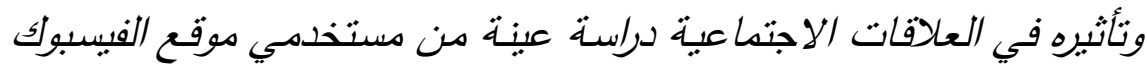

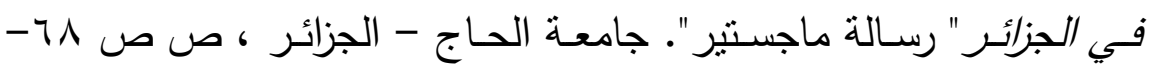




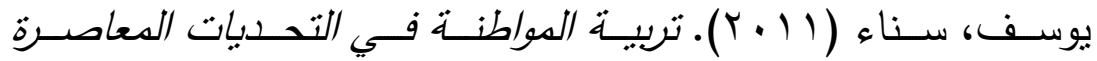
( المواطنة في الفلسفات المختلفة). دار العلم والإيمان للنشر والتوزيع.

\section{ثانياً: المراجع الأجنبية :}

- Ashour, R., ALzghool, H., Iyadat, Y., and Abu-ALruz

J. (2012)" Mobile Phone Applications in the University Classroom: perceptions of undergraduate students in Jordan". E-Learning and Digital Media, 9 (4).p419-425 - Alzaidiyeen, A., Abdullah, A., AlShabatat, A. and Seedee, R. (2011). "The Information Aged: Examination of University Students' Attitudes Towards Personal Digital Assistance (PDAS) Usage in Terms of Gender, Age and School Variables". The Turkish Online Journal of Educational Technology-Tojet, 10(3), P287-295.

- Bellin Jeffrey (2012). Face book, twitter, and the uncertain future of present sense impressions, University of Pennsylvania Law Review,Vol.160,No.2,2012, p 331.

- Choi, Moonsun, (2016), Concept Analysis of Digital Citizenship for Democratic Citizenship Education in the Internet Age, Journal Theory and Study in Social Education, Vol.1, No.1, 1-43.

- Daiz, Ortiz Claire(2011). Twitter for Good: Change the World On Tweet at Time, USA : Jossy-Bass,1edition,30 August, ,p.x.

- Edmonton Catholic Shools, (2012). Digital Citizenship, Administrative Policy, P.1 
- Field, A. (2009). Discovering Statistics Using SPSS, Third Edition, London: SAGE Publications Ltd.

- Gardner, M., Gates, K., \&Stanley, P. (2013).Creating an Effective Mobile App for Higher Ed. University Business, Vol.16, No. 6,P. 20

- Gazi,Z.,A.,(2016). Internatization of Digital Citizenship for the Future of All Levels of Education Education and Science, Eitim ve Bilim, Vol.41, No. 186, P. 139.

- Hermida Alfred(2010).Twittering the News: The Emergence of Ambient Journalism, Journalism Practice, Vol.4,No.3, , p. 297.

- https://papers.ssrn.com/sol3/papers.cfm?abstract_id=17 32598

- Johnston, P; Wilkinson, K (2009). Enhancing Validity of Critical Tasks Selected for College and University Program Portfolios. National Forum of Teacher Education Journal, (19) 3, PP1-6.

- Jones,Lisa.M.,and Mitchell J.Kimberly .(2015). Defining and measuring youth digital Citizenship, New media \& society, No. (18), P. 2.

- Khathami ‘M. D. (2018). The Use of Social Media Networks by Saudi Women and its impact on enhancing their general Knowledge: A case study, Arab Journal of Information Studies ‘Al-Majmaah University- King 
Salman Institute for Studies and Advisory Services،NO.

(8) ،234 - 260.

- Mcgillivary, D. Mcpherson, G., and et.al , (2016). Young People Digital Media Making and Criyical Digital Citizenship, Leisure Studies, Vol., 35, No. 6,PP.724-729. - Megan ,R .Boddum, Plugged (2013). "a focused look at parents use of smartphones among children2-5 year of age,Mills college ,p3

- Ohler, Jason, (2011).Digital Citizenship means Character Education for the Digital age, Eappa, Delta, pi Record,Vol., 47, No.,25-27.

- Ribble, M. \& Bailey, G. (2006). Digital citizenship at all grade levels. International Society for Technology and Education. Information literacy. Avaible at www.iste.

- Ribble, M. (2006). Digital Citizenship in School. International Society for Technology in Education, 2nd ed.,Eugene, Oregon, Washington. http:// citeseerx. ist. psu.edu/viewdoc/download?doi=10.1.1.823.829\&rep=rep $1 \&$ type $=$ pdf

- Riblle , Nike, (2011). Digital Citizenship in School, International Society for Technology in Education, http://www.iste.Org/odcs.

- Simsek , E\& Simsek, A. (2013) .New Literacies for digital Citizenship, Contemporary Educational Technology, Vol.(4), No. (2), P.128. 
- Suki, Norazah M. (2011).“Using M-learning Device for Learning From Students' Perspective", Eric ED522204. 

فاعلية برنامج إرشادي قائم على الأنشطة الحسية في خفض بعض مظاهر الاضطرابات الحسية لاى الأطفال ذوي الإعاقة العقلية البسيطة

* أ.د/ أمل محمد حسونة.

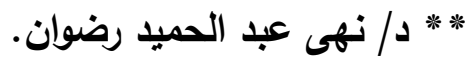

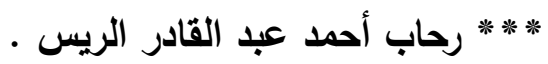

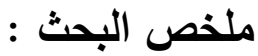

هدف البحث الحـالي إلى إعداد برنـامج إرشـادي فـائم على الأنشـة

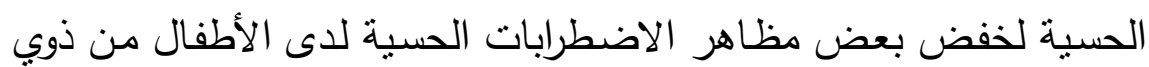
الإعاقـة العقليـة البسـيطة ، تكونـت العينـة مـن خمسـة أطفـالاً ( ب ذكـوراً و Y إناثاً) تتراوح أعمارهم ما بين ( ع : : ) سنوات كعمر عقلي ممن يعانون من مظاهر الاضطرابات الحسية والملتحقين بجمعية التقيف الفكري والتابعة لمديرية التضامن الاجتماعي ، تم استخدام المنهج شبه التجريبي القائم على

* أستاذ علم نفس الطفل (الصحة النفسية) ورئيس قسم العلوم النفسية - عميد كلية التربية للطفولة المبكرة - جامعة بورسعيد. ** مدرس الفئـات الخاصـة بقسم العلوم النفسية بكليـة التربيـة للطفولـة المبكرة -جامعـة بورسعيد.

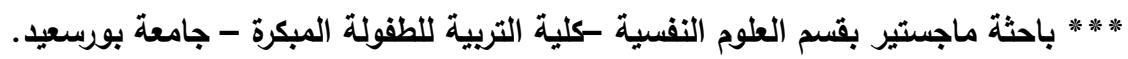


التصميم التجريبي ذي المجموعة الواحدة ، كما استخدمت الباحثة مجموعة من الأدوات كالتالي: مقياس ستانفورد بينيه للذكاء الصسورة الخامسة ( تقنين أ. د//محمود السيد أبو النيـ)، مقياس الاضطرابات الحسية للأطفال من ذوي الإعاقـة العقليـة (إعداد الباحثة)، برنـامج قائم على الأنشـة الحسية (إعداد الباحثة). وتوصلت نتائج البحث الحالي إلى أنه: توجد فروق دالة إحصـائياً بين متوسطي رتب درجـات أطفال الروضـة ذوي الإعاقـة العقليـة البسيطة (العينة التجريبية) على مقياس الاضطرابات الحسية في القياسين القبلي والبعدي للبرنامج لصالح القياس البعدي، لا توجد فروق دالة إحصائياً بـين متوسـط رتب درجـات أطفـال الروضـة ذوي الإعاقـة العقليـة البسـيطة (العينة التجريبيـة) على مقيـاس الاضطرابات الحسية في القياسين البعدي والتتبعي للبرنـامج الإرشـادي القائم على الأنشطة الحسية ، مما بدل على فاعليـة البرامج الإرشـادي القائم على الأنشطة الحسبية في خفض بعض مظــاهر الاضــرابات الحسـية لـدى الأطفـال مـن ذوي الإعاقـة العقليـة البسبطة. 


\section{The effect of acounseling program based on the sensory activities in reducing some aspects of the sensory disorders for children with simple mental disability}

Prof. Dr. Aml Mohamed Hassona. *

Dr. Noha Abdel Hamid Radwan. **

Rehab Ahmed Abdel kader El Rayes. ***

\section{Abstract:}

The aim of the current research is to prepare a counseling program based on sensory activities to reduce some manifestations of sensory disturbances in children with mild mental disabilities. The sample consisted of five children ( 3 males and 2 females) whose ages ranged between (4: 6) years of mental age who suffer from Manifestations of sensory disturbances and those enrolled in the Intellectual Education Association affiliated with the Social Solidarity Directorate. The quasi-experimental approach based on one-group experimental design was used, and the researcher also used a set of tools as follows: Stanford-Binet scale of intelligence, fifth image (codification of Prof. Dr. Mahmoud El-Sayed Abu El-Nil)

* Professor of Child Psychology (Ment: Head of the Psychological Science, Faculty of Early Childhood Education - Portsaid University.

** Lecturer, Department of Psychological Sciences -Faculty of Early Childhood Education- Port Said University.

*** Researcher, Department of Psychological Sciences - Faculty of Early Childhood Education - Portsaid University. 
Sensory Disorders Scale for Children with Mental Disabilities (the researcher's preparation), a program based on sensory activities (the researcher's preparation) The results of the current research concluded that: There are statistically significant differences between the mean scores of kindergarten children with mild mental disabilities (the experimental sample) on the scale of sensory disturbances in the pre and post measurements of the program in favor of the post measurement, there are no statistically significant differences between the average grades of kindergarten children with Simple mental disability (experimental sample) on the scale of sensory disturbances in the post and tracer measurements of the indicative program based on sensory activities, which indicates the effectiveness of counseling programs based on sensory activities in reducing some manifestations of sensory disturbances in children with mild mental disabilities.

الكلمات المفتاحية Keywords:

Counseling program - - برنامج إرشادي. Sensory Activities - الأنشطة الحسية. Sensory Disorders

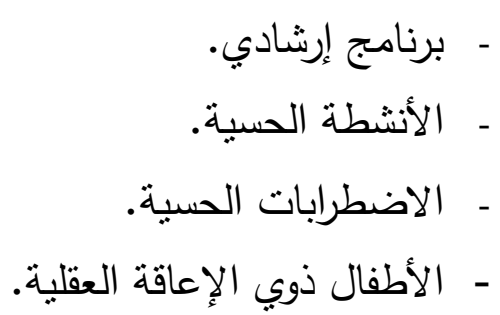

Children with simple mental disability 


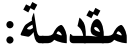

إن قدوم طفل جديد في الأسرة يعنd تغيراً في نمط حياة لهذه الأسرة

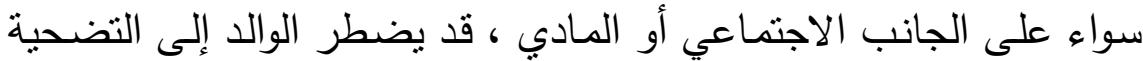

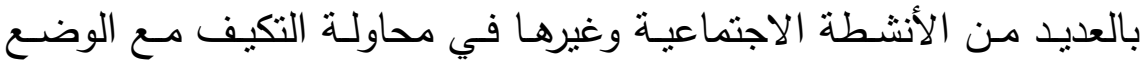
الجديد ، فإذا كان الطفل العادي بقدومه يحدث كل هذه التغيرات فإن الطفل

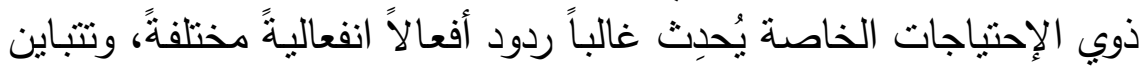

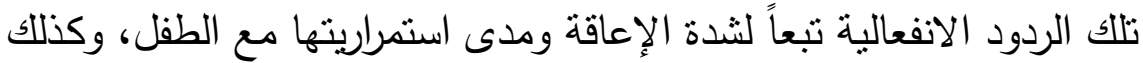
المستوى الثقافي والاجتماعي للوالدين.

وتعتبر الإعاقة العقلية مشكلة ذات أبعاد مختلفة سواء كانت في التباين بين درجة شدتها وما يترتب عليه من آثار نفسية أو جسمية أو أكاديمية أو أو أو أولية

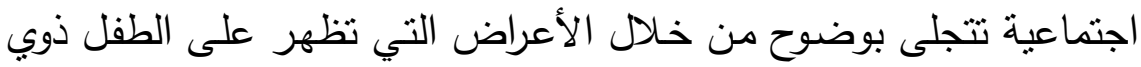
الإعاقة العقلية سواء تأخر مرحل النمو أو قصور في في الانتباه والذاكرة وفي لإني

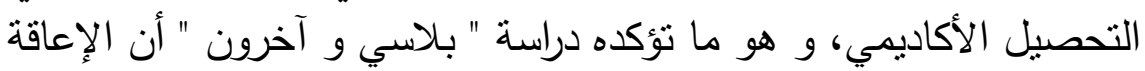

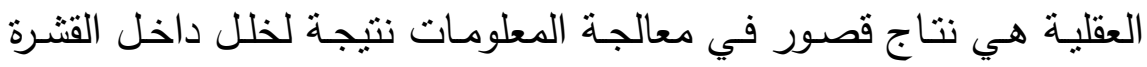

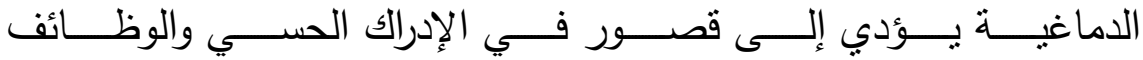
المعرفية(Blasi,et.al,2007,764).

فقدرة الطفل على التواصلـ المعرفي والاجتمـاعي والسـلوكي مـع البيئة المحيطة بـه ترتبط بسـلامة جهازه العصبي، و قدرتهه على القيام بدوره في الفي تفسير و تحليل و تخزين المعلومات و البيانات التي تصل إليها من خـلال

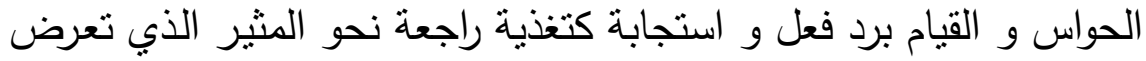
له ، ولكن عندما لا يحدث ادراك للمدخلات الحسية أو تتظيمها و تحليلها بشكل مناسب يحدث اضطراب المعالجة الحسية و ذلك نتيجة لخلل وظيفي في الجهاز العصبي للجسم ( Barbara , 2009 , 10 ) . 
فالطفل الذي يعاني مـن اضطراب المعالجـة الحسية لا يستطيع جهازه العصبي التفاعل و التكيف مـع تلك المشكلات التي تصبح بومبـة فتتأثر حياته الاجتماعية والسلوكية ؛ فاضطراب المعالجة الحسية يحرم الطفل من اكتسـاب الخبرات الحسبة التي يحتاجها مسن أجل التطـور و التعلم فسـواء

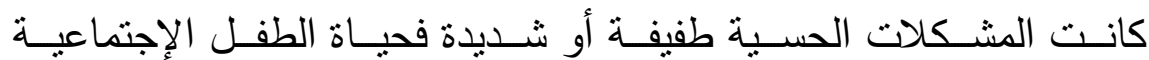

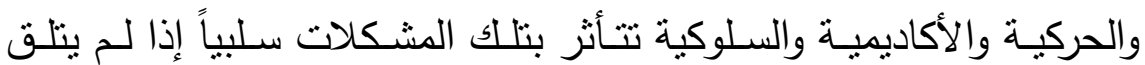
الرعاية المناسبة (13 ـ (Miller , 2006 (

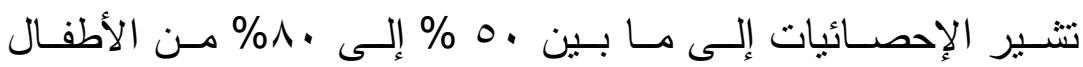

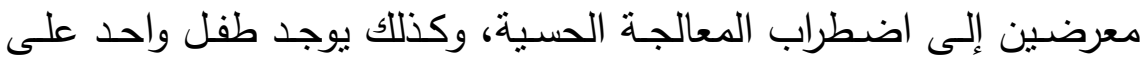
الأقل داخل الفصل الدراسي يعاني من مشكلة في معالجة الجهاز العصبي

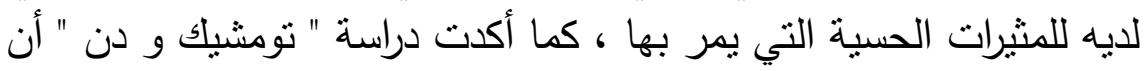

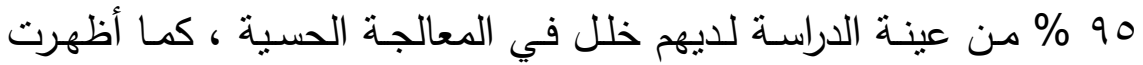
دراسـة أخرى أن ما لا يقل عن 0\% و قد تصل إلى با ب \% من الأطفال

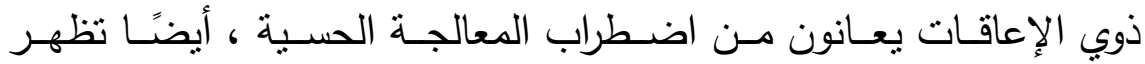

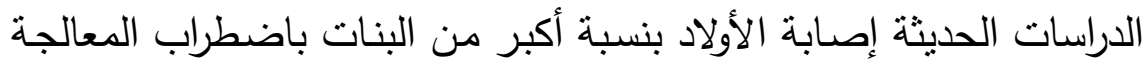
الحسية ( ; Delaney , 2008 , 14 :Tomchek ; Dunn , 2007

- (Sher , 2009 مشكثة البحث وأسئلته:

ترتبط الإعاقة العقلية بالخلل في قدرة الجهاز العصبي المركزي على القيام بوظائفه الطبيعية وهو ما ينتج عنه ونه قدور وتأخر في النمو والتطور الطبيعي للقدرات العقلية والذهنية، مما يؤدي إلى عدم القدرة على أداء المهارات المرتبطة بالقدرات اللغوية والحركية والاجتماعية والمعرفية،

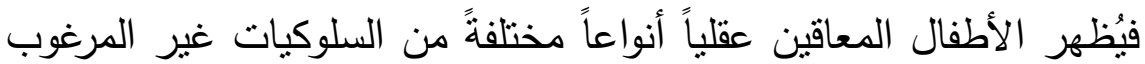


فيها، والناتجة عن قصور في القدرات العقلية سواء في الإدراك أو الانتباه للمثيرات المختلفة وترجمة المخ لتلك المثيرات من خلال استجاباتٍ مقبولةٍ.

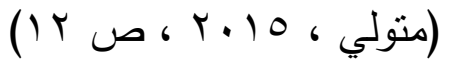

حيث أكدت دراسة شاف و آخرون ( Schaaf et al , 2003 ) على أن الخلل في التفاعل الفسيولوجي و وظائف الجهاز العصبي السمبتاوي يؤثز على سلوك الأطفال ذوي اضطراب المعالجة الحسية ، كما أوضحت دراسة وان و آخرون ( Wuang , at ,al , 2008 أن الوظائف التكاملية الحسية ضعيفة لاى الأطفال ذوي الإعاقة العقلية البسيطة ، ويؤثز هذا الخلل في الوظيفة الحسية على النظم الحسية والعصبية وبالتالي أداء سلوكي ضعيف لدى الأطفال، ولا يتم التعرف على هذا الخلل في المعالجة الحسية إلا من خلال السنوات المبكرة من الدراسة ( رياض الاطفال ) ، كما لإل أشارت دراسة بلاسي و آخرون (Blasi et al , 2007 ) إلى أن الأطفال المعاقين عقلياً تظهر لديهم أعراض الخلل الحسي خاصةً في جانب الإدراك

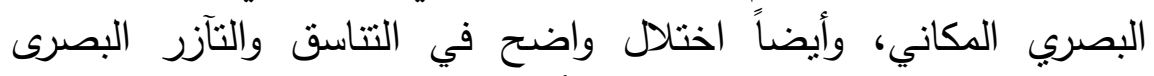
الحركي والتسيق بين العينين، وكما أوضحته دراسة العتيبي ( . ( . ( ) يمكن استخدام الأنشطة الحسية الحركية كمدخل لتعديل السلوك العدواني لتتمية السلوك التعاوني ، كما أثنارت دراسة هاريسون و آخرون

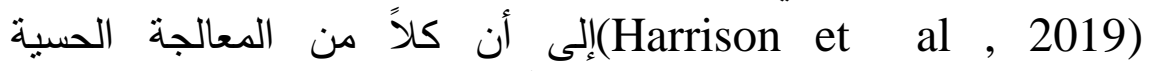
والوظائف العقلية للطفل منتابكين معاً بطريقةٍ معينةٍ ، وبمكن دراسة اضطراب المعالجة الحسية بشكلٍ منفصلٍ من خلال السجل الصحي أو المجالات البحثية.

وبمراجعة للأدبيات والأطر العلمية وفي ضوء علم الباحثة وما استطاعت الوصول له من دراسات وأبحاث وما وجدته من ندرة في الأبحاث التي تربط وفي 
بين الإعاقة العقلية والاضطرابات الحسية ؛ استشعرت الباحثة ضرورة الربط بين الخلل في قدرة الجهاز العصبي المركزي في معالجة المعلومات والمثيرات الحسية، والتي يؤدي إلى مظاهر الاضطرابات الحسية والعجز في قدرة الجهاز العصبي المركزي على ترجمة و تحليل و تفسير تلك فودي المعلومات، والتي تؤدي إلى اضطراب في الوظائف الإدراكية ثم وضع برنامج إرشادي تأهيلي يساعد على استعادة قدرة الجهاز العصبي المركزي على القيام بوظائفه، وذلك عن طريق مجموعة من الأنشطة الحسية التي تعمل على تتمية قدرة الجهاز العصبي على ترجمة المثيرات والمحفزات الحسية بطربقةٍ سليمةٍ. مما سبق يمكن بلورة مشكلة البحث في السؤال

$$
\text { الرئيسي التالي وهو : }
$$

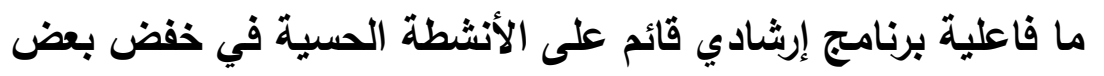

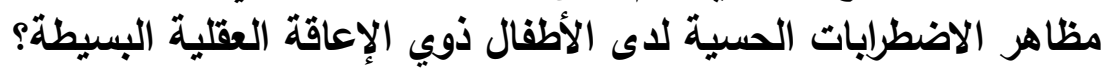

وينبثق من هذا السؤال الأسئلة الفرعية التالية :

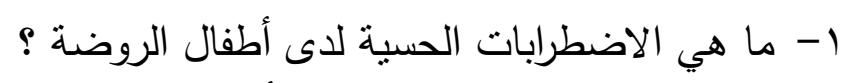

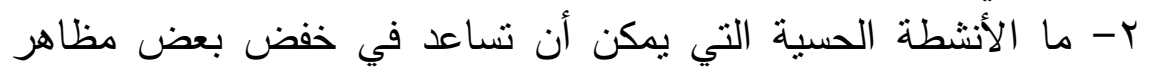

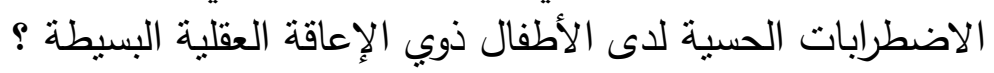
r- هل توجد فروق ذات دلالة إحصائية بين متوسطي رثب درجات الإعاته الأطفال ذوي الإعاقة العقلية البسيطة في القياس القبلي والبعدي على دلى دئي

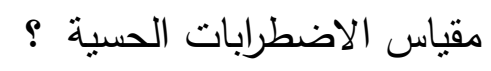

צ- هل توجد فروق ذات دلالة إحصائية بين متوسطي رتب درجات

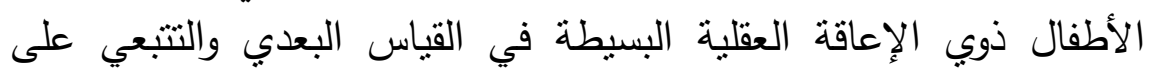
مقياس الاضطرابات الحسية ؟ 


\section{أهد|ف البحث:}

يتضح الهدف من البحث من خلد الهذف الرئيسي لهذا البحث وهو :

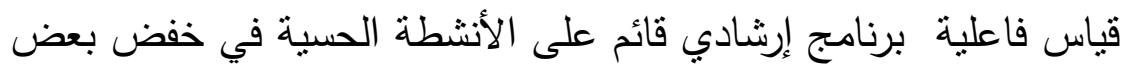
مظاهر الاضطرابات الحسية لدى الأطفال ذوي الإعاقة العقلية البسيطة. وينبثق من هذا الهدف الأهداف الفرعية التالية : 1 - الكثف عن العلاقة بين كلٍ من الخلل في الوظائف الإدراكية

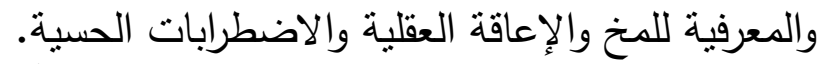

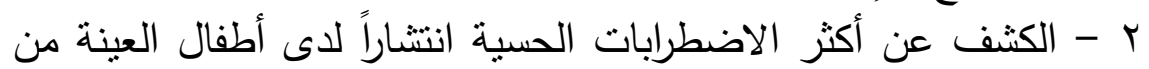

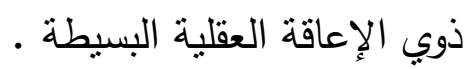

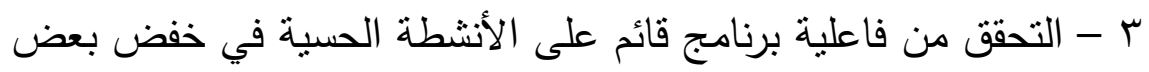
مظاهر الاضطرابات الحسية لدى الأطفال ذوي الإعاقة العقلية البسيطة.

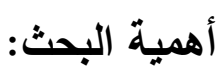

تتمثل أهمية البحث الحالي في الآتي:

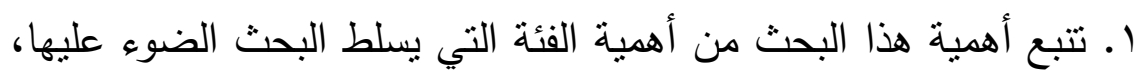
وهي فئة الأطفال من ذوي الإعاقة البسيطة التي تظهر البهر عليهم مظاهر

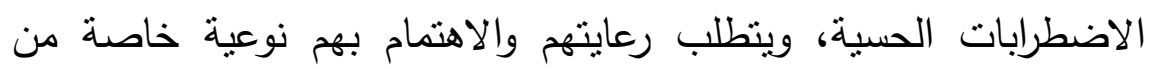
الخدمات و البرامج الإرشادية التي يسنطيع الطفل من خلالها تلتمية مهاراته

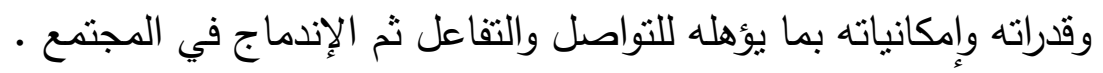

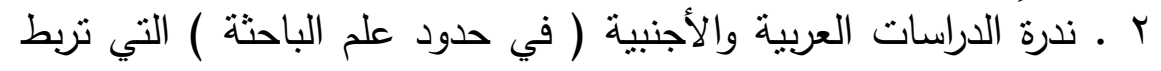

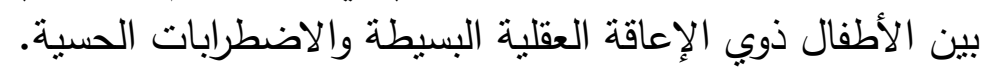

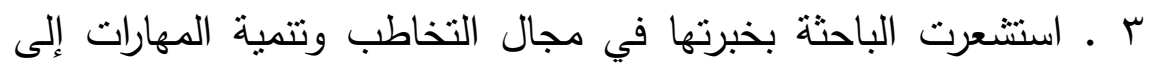
احتياج الطفل ذوي الإعاقة العقلية البسيطة إلى أنشطة وبرامج مختلفة تخرج 
به من نطاق القوالب القديمة للأنشطة التي تعود عليها، والتي أثثتت عدم جدواها على المستوى البعيد وذلك في ظل التطور الهائل في وسائل

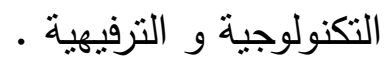

ع. ـ قد يسهم هذا البحث في توجيه النظر إلى فنية جديدة يمكن الاستفادة

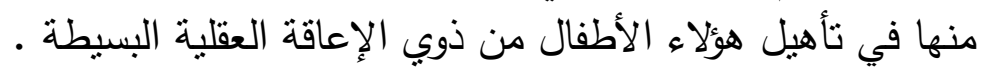
ه . قد يقدم هذا البحث بعض الحلول للأخصائيين العاملين في مجال تأهيل هذه الفئة، وذللك بتوفير نماذج لبعض الأنشطة العملية التي يمكن

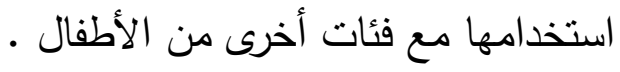

\section{حدود البحث:}

- الحدود البشرية : وتحددت في عينة البحث ( ن = 0 ) من الأطفال ذوي

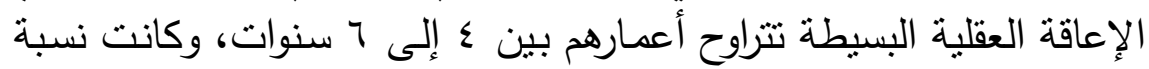

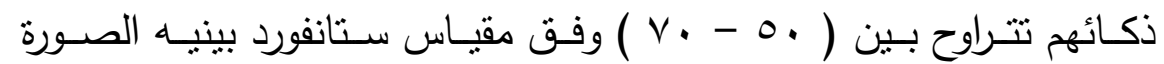
الخامسة تقنين ( محمود أبو النيل). - - الحدود المكانيـة : تم تطبيـق جلسـات البرنـامج الإرشـادي في جمعيـة التنقيف الفكري بمحافظة بورسعيد. - الحدود الزمانية : تم تطبيق البرنامج الإرشادي خلال شهرين.

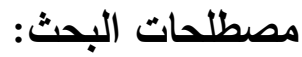
ا - الأطفال ذوي الإعاقة العقلية: هم هؤلاء الأطفال الذين يعانون من قصور في مستوى الأداء الوظيفي

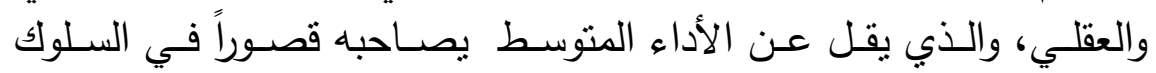
التكيفي، وبظهر خلال مراحل نمو الطفل منذ الولادة وحتى 1 ا سنة. 


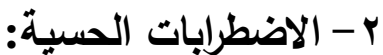

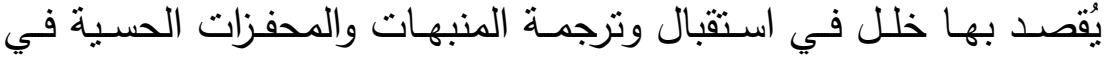

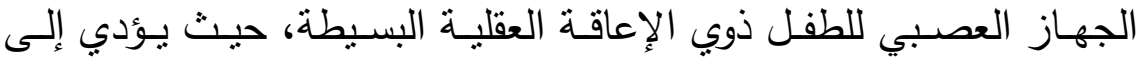

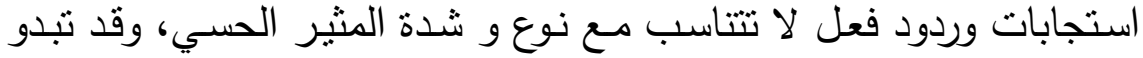
مختلفة سلوكياً للآخرين ليصل الحد إلى تفسير تصرفاتهم بسوء تصدي السلوك.

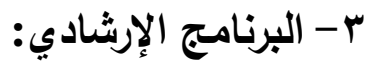

مجموعة من الأنشطة المخططة والمحددة والمنظمة ضمن أسس علمية

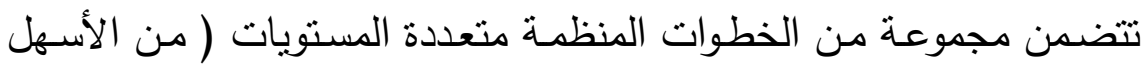

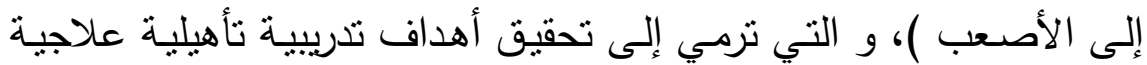

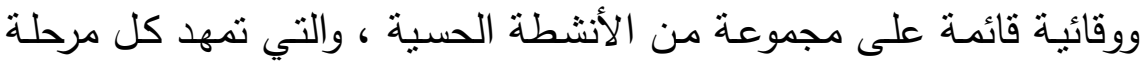

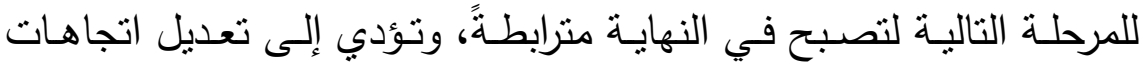

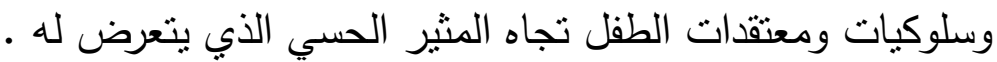
الإطار النظري والدراسات السابقة : المبحث الأول: الأطفال من ذوي الإعاقة العقلية البسيطة : تعريف الإعاقة العقلية :

تعرف منظمة الصحة العالمية ( WHO ) الإعاقة على أنها: التفاعل

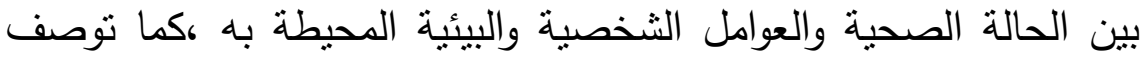
الإعاقة العقلية بأنها: خلل أو قصور في النمو والتطور الطبية النيعي للقدرات

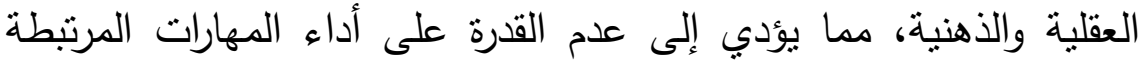

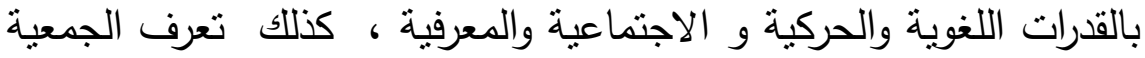

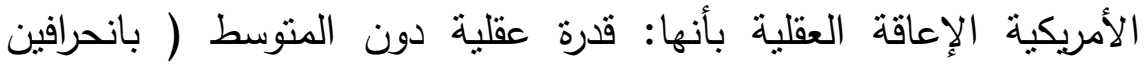


معياريين في اختبار الذكاء ) يصاحبها قصور أو عجز في مجالين أو أكثر

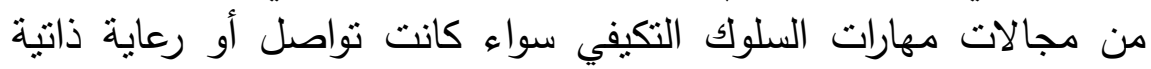

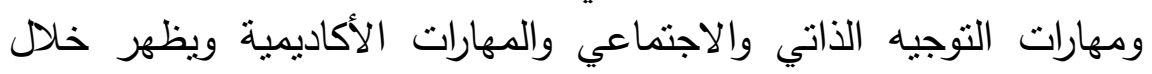

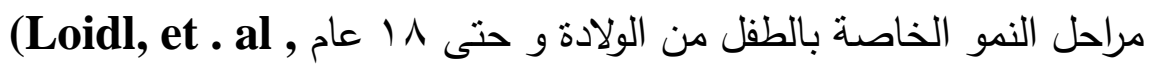

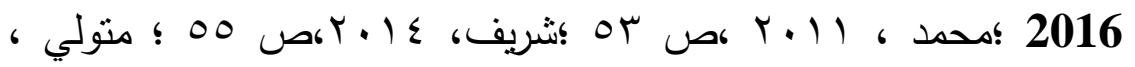
(1) (1) 10 نسبة انتثار الإعاقة العقلية :

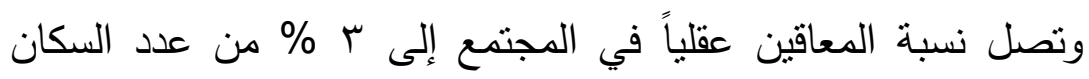
لترتفع إلى V \% مي المناطق الفقيرة وذات كثافة سكانية عالية، كما تزداد

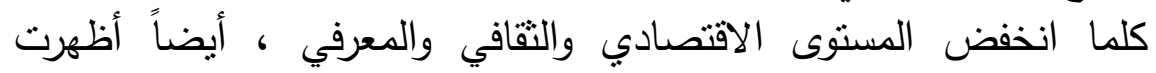

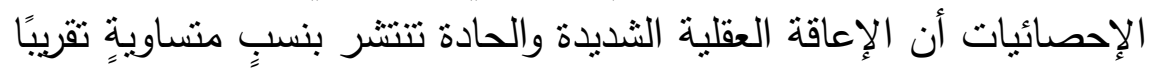

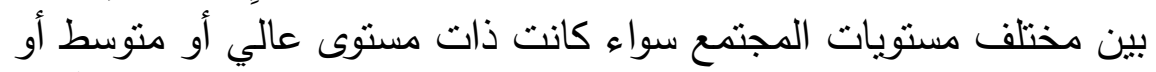

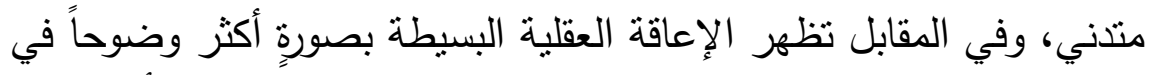
المستويات الفقيرة والمنتنية في المجتمع عن المنابل المستوى المنتوسط أو الو العالي

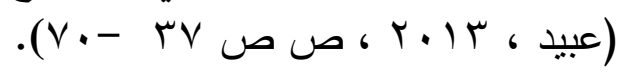

وترتفع نسبة الإعاقة العقلية في دول العالم الثالث والدول النامية بالمقارنة

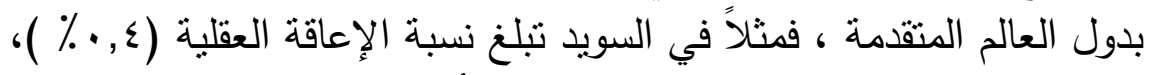

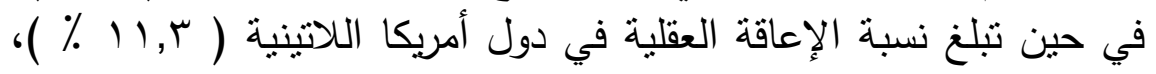

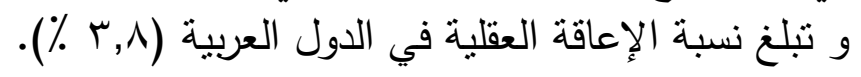

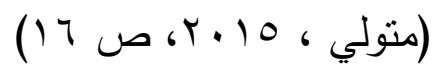

خصائص الأطفال ذوي الإعاقة العقلية :

تظهر على الأطفال ذوي الإعاقة العقلية مجموعة من الألهائه الأنماط والخصائص الانفعالية والعقلية والتربوية و الاجتماعية والسلوكية والنفسية 


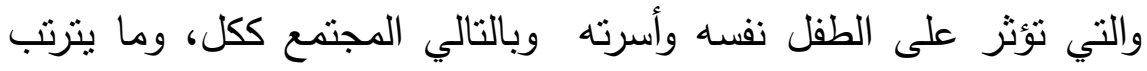

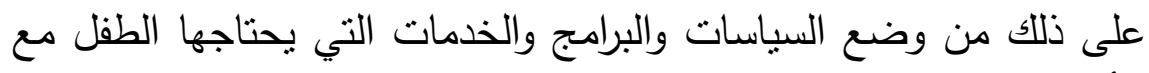
الأخذ في الاعتبار اختلاف وتباين الخصائص لنفس الفئة الواحدة.

\section{1- الخصائص الجسمية وإلحركية:}

تشير الدراسات أن الأطفال من ذوي الإعاقة العقلية نظهر لديهح بشكل

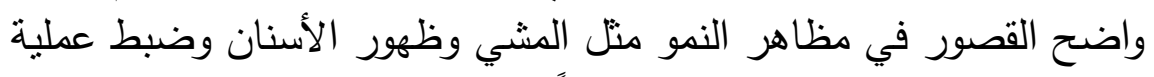

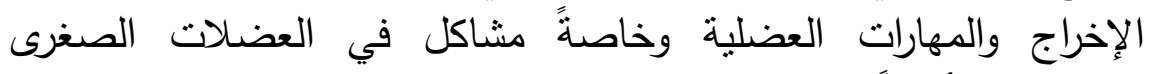

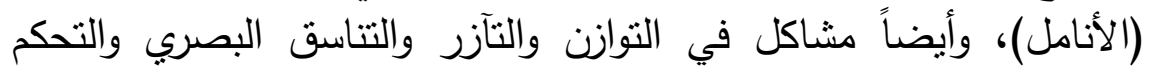

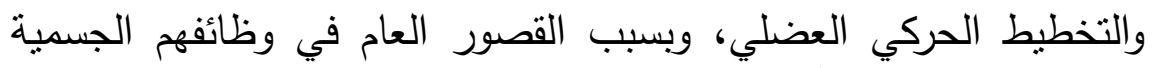

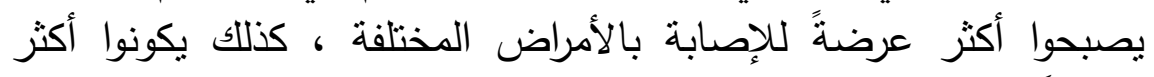

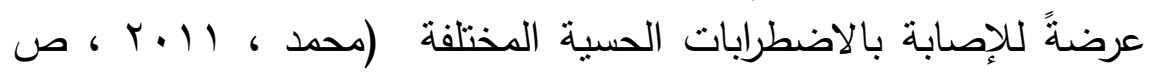

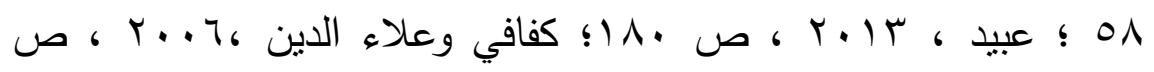
$\cdot(r) r$

\section{r - الخصائص اللغوية :}

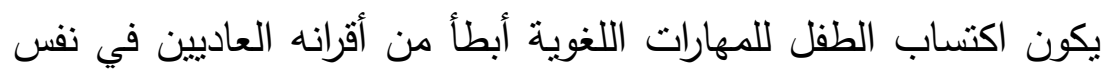

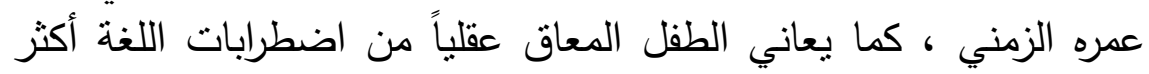

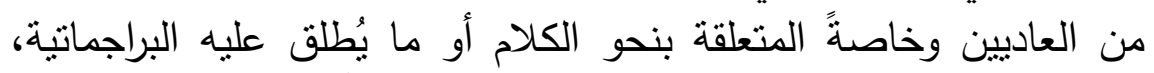

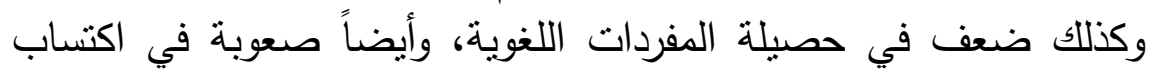

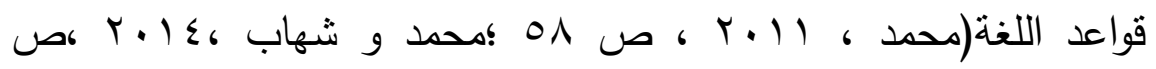

r- الخصائص المعرفية العقلية : توجد علاقة بين فئة الإعاقة العقلية ومستوى التحفية : التحصيل الأكاديمي، وتظهر تلك العلاقة بوضوحٍ عند مقارنة الطفل من ذي ذي الإعاقة العقلية 
والطفل العادي في نفس عمره الزمني ، وبعاني الأطفال المعاقين عقلياً من قصور في مجموعة من الخصائص المعرفية يمكن إجمالها في التالي: ا - بطء في معدل النمو العقلي

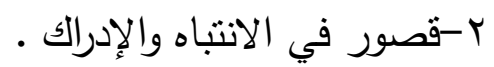
r-صعوبة في التذكر وحفظ المعلومات والخبرات المختلفة. ع -قصور في العمليات العقلية العليا. ه-عدم القدرة على القيام بعملية انتقال أثز التعلم أو التذريب. ج-عدم القدرة على النمو اللغوي السليم.

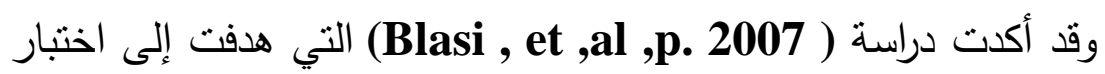

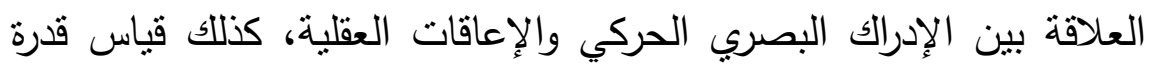

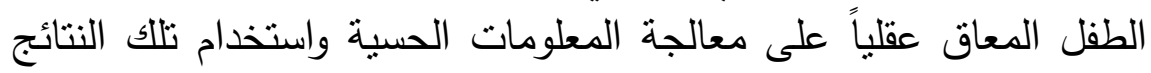

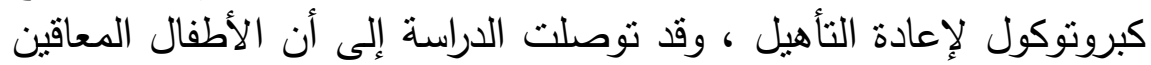

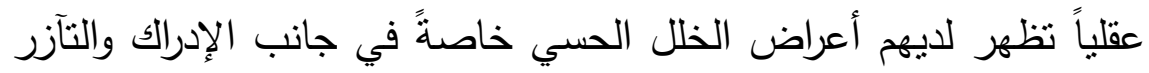

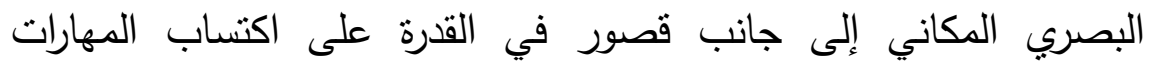

$$
\text { المعرفية وتذكرها فيما بعد. }
$$

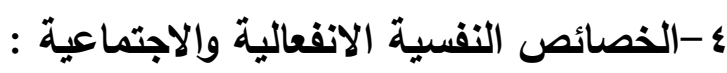

يعاني الأطفال المعاقون عقلياً من بعض المشكلات الانفعالية النفسية

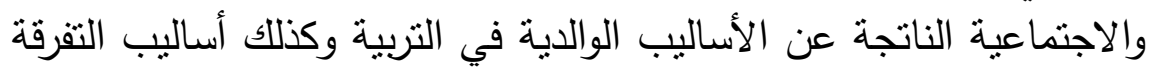

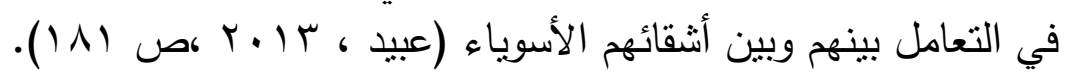
مما يؤدي إلى ظهور بعض السمات على الأطفال نجملها في التالي : 1- انخفاض تقدير الذات والثعور الدائم بالإحباط وعدم التقة بالنفس.

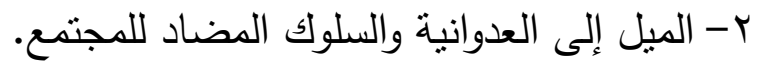


ب-انخفاض الدافعية حيث لا بمنلك الطفل المعاق عقلياً الدافعية تجاه

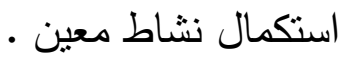

ع -اضطراب مفهوم الذات : وذللك بسبب كثرة الخبرات السلبية والفاشلة التي مروا بها سواء في المنزل أو البيت أو المدرسة، كذللك اعتمادهم الدائم على الغير يولد لديهم شعور بالإحباط والدونية . ه-عدم القدرة على تكوين صداقات وعلاقات اجتماعية إيجابية مع لإبان الآخرين.

7-عجز عن القيام بالمهارات اللازمة لأداء الأنشطة اليومية. V-عدم القدرة على فهم و إدراك القواعد و المعايير الاجتماعية العامة .

$$
\begin{aligned}
& \text { 1-سهولة الانقياد والإستهواء. }
\end{aligned}
$$

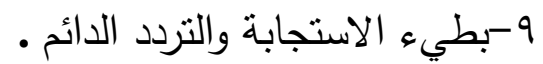

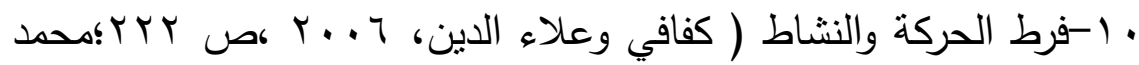

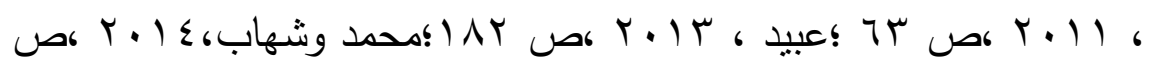

\section{أسباب الإعاقة العقلية}

تعتبر الإعاقة العقلية من الموضوعات أو الظواهر التي يتجلى فيها تذاخل دور كلٍ من العوامل الوراثية الجينية والبيئية والاجتماعية في ظهور

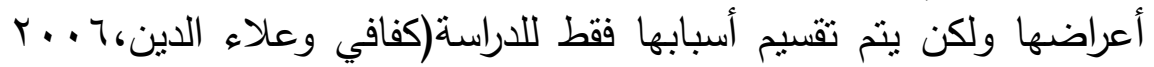

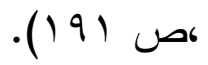

- أسباب ما قبل الولادة : وهي الأسباب التي تؤدي إلى الإعاقة العقلية قبل الميلاد وسواء كانت متعلقة بالأم أو خلل جيني منل : خلل في الكروموسومات" فوجيل إكس ، داون " أو عمر الأم الحامل وسوء التغذية والاضطرابات النفسية للأم، كذللك تعرض الأم للإثعاع أو الإدمان 
والأمراض المعدية للأم " الحصبة الألمانية ، الزهري ، التهابات السحايا و مضاعفات عامل ( RH ) .

r-أسباب أثناء الولادة : وهي الأسباب التي نؤدي إلى الإعاقة العقلية أثثاء

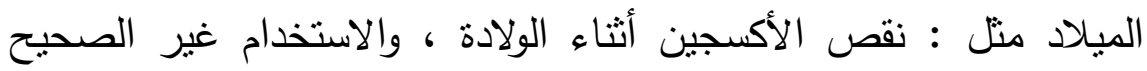

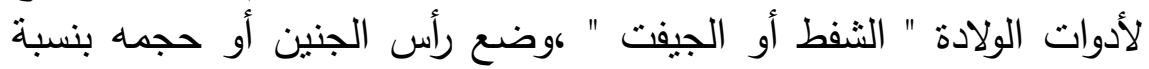

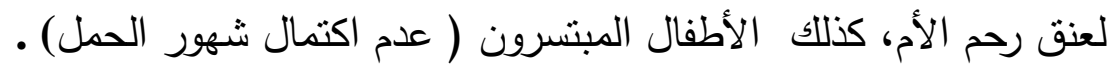
r-أسباب ما بعد الولادة : وهي الأسباب التي تؤدي إلى الإعاقة العقلية

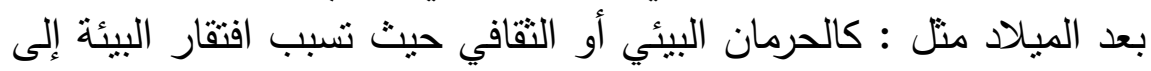
عوامل الإثراء المعرفي والتفاعل والتكيف الاجتماعي، إلى جانى جانب ظهور مظاهر الإعاقة العقلية لدى الطفل واضطرابات عملية التمثيل الغذائي

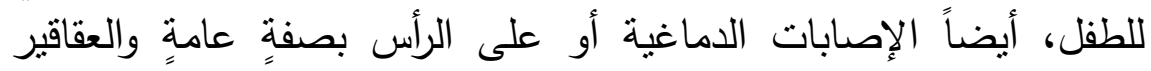

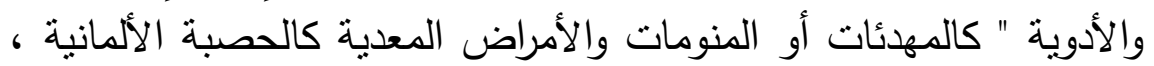

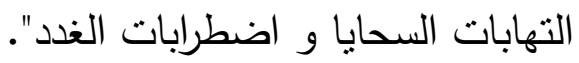

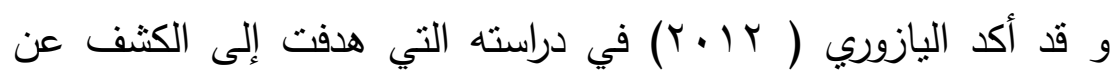

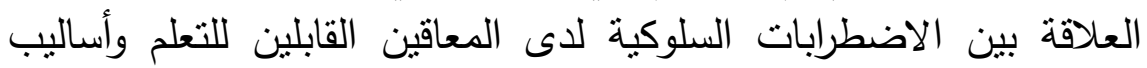

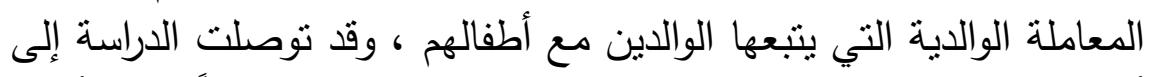

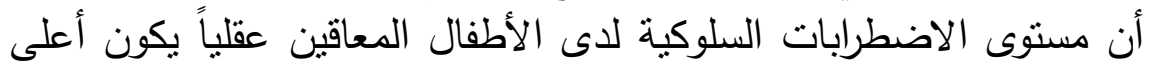

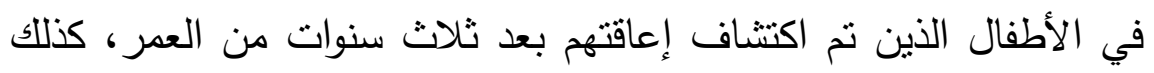

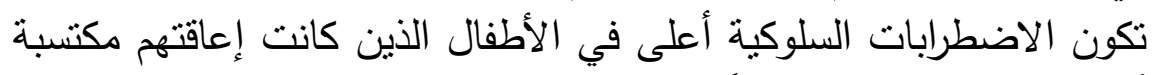

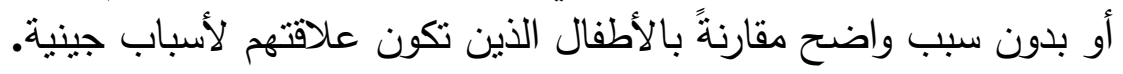

\section{تشخيص الإعاقة العقلية:}

يهدف تقييم وتشخيص الأطفال المعاقين عقلياً إلى: ا ـ التأكد من وجود الإعاقة العقلية لدى الطفل. 
r r r تحديد الفئة التي تقع نسبة ذكاء الطفل بها.

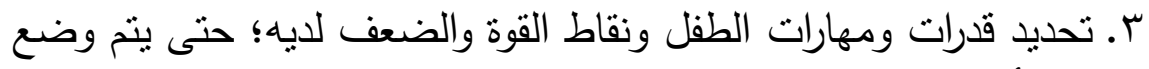

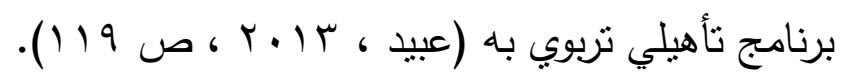
محكات تثخيص الإعاقة العقلية:

يذكر ( Saad , 2019 , p.52) في دراسته معايير تشخيص الإعاقة العقلية في DSM5 الدليل النتخيصي الإحصائي للاضطرابات العقلية الخامس للجمعية الأمريكية للطب النفسي كالتالي :

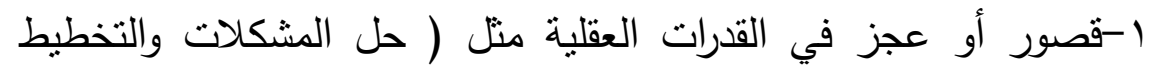

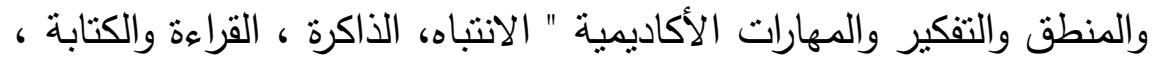

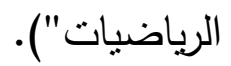

r-قصور أو عجز في الأداء التكيفي مما يؤدي إلى خلل في المهارات

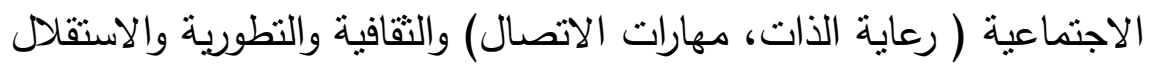
الذاتي، وواحدة أو أكثر من أنشطة الحية التياة الاجتماعية.

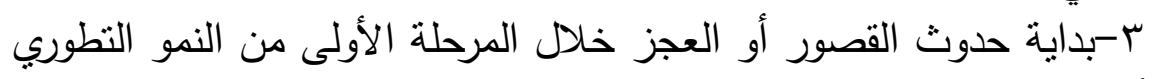
أبي قبل سن 1 1 سنة. تأهيل الأطفال المعاقين عقلياً :

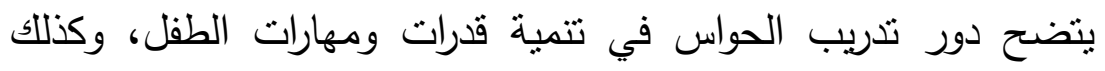

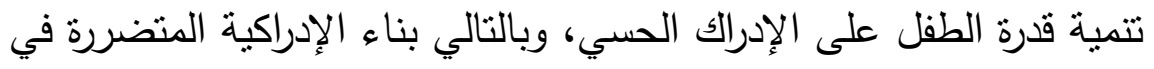

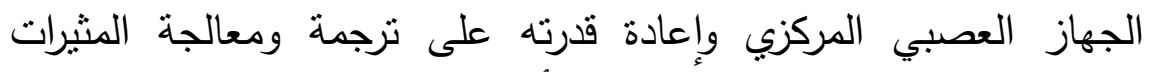

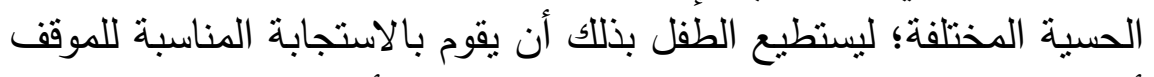

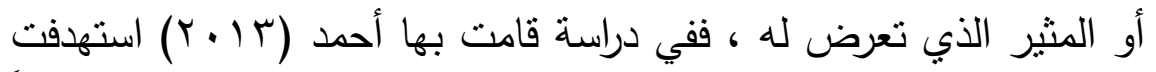
الكثف عن مدى فاعلية برنامج تأهيلي لتمكين الأطفال المعاقين عقلياً 
والتوحديين من مهارات الحياة اليومية والتحقق من مدى فاعلية وكفاءة البرنامج في تحقيق الهدف منهه، وقد توصلت الدراسة إلى أن البرنامج

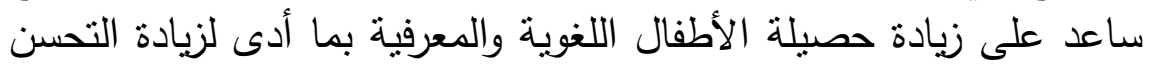
في تفاعلهم وتعاملهم مع الآخرين، كما ساعد البرنامج في تتمية حواسهم ومهاراتهم الإدراكية.

أهداف برامج التأهيل التريوي الخاصة بالطقل المعاق عقلياً:

يتمثل الهدف الأساسي في مساعدة الطفل على الاستقلالية ورعاية

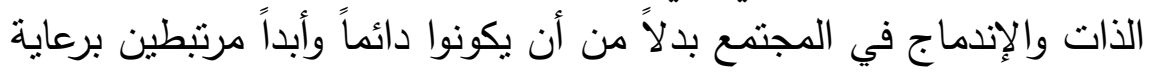

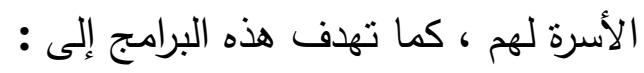
ا - تتمبة الكفاءة الاجتماعية.

r- تنمية الإستقلال العاطفي والنفسي في البيئة المحيطة بهم. ب-استغلال أوقات الفراغ بطريقةٍ مفيدةٍ وجذابةٍ. ع -تتمية مهارات رعاية الذات والحركية واللغوبة .

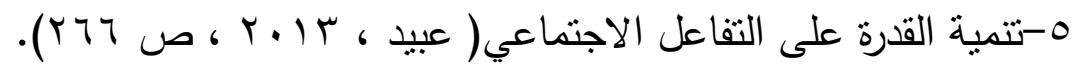
أهداف البرنامج التريوي الحسي للطقل المعاق عقلياً : • التعرف على الخامات المختلفة في البيئة. • التمبيز بين مالمس الخامات المختلفة.

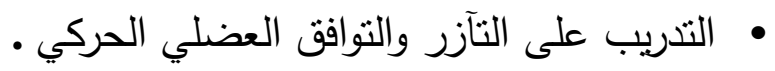
• تدريب العضالات الصغرى. • تعرف الطفل على نفسه وعلى البيئة المحيطة.

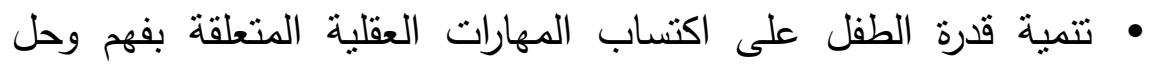
المشكلات والتعميم وانتقال أثز التعلم ـ التهيله 


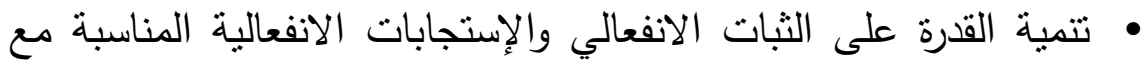

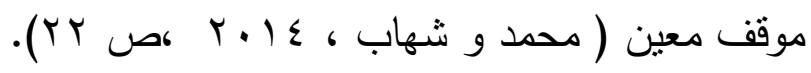
خطوات إعداد البرنامج التربوي للطقل المعاق عقلياً:

مع بداية وضع برنامج تربوي للطفل المعاق عقلياً يجب مراعاس الفروق

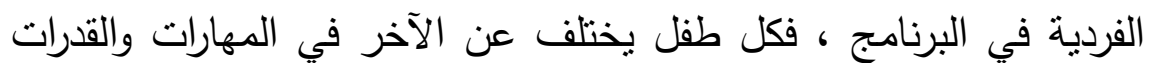
والإمكانيات ، ويتم وضع البرنامج التربوي عن طريق عددٍ من الخطوات كالتالي:

• التشخيص المبكر من قِبِل فريق من المتخصصين يتضمن (الطبيب الأخصائي النفسي والاجتماعي- أخصائي التربية الخاصة- أخصائي

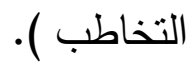

• مشاركة الوالدين في وضع خطة البرنامج الفردي للطفل. • وضع الأهداف التربوية التي تتناسب مع قدرات ومهارات وإكانيات الطفل.

• وضع الأهداف التربوية بتسلسلٍ هرمي من الأسهل إلى الأصعب ومن البسيط إلى المركب.

• تدريب الطفل على التعميم وانتقال أثز التعلم من موقف متعلم إلى آخر جديد. • توفير فرص النجاح للطفل.

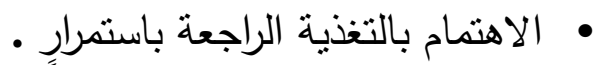

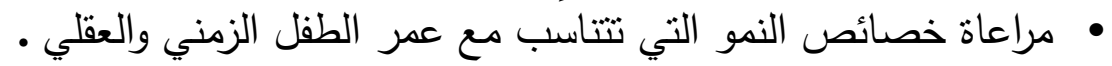

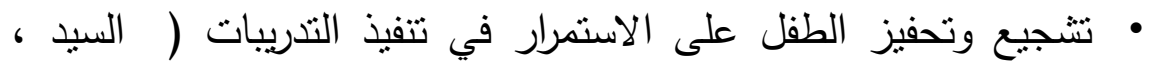

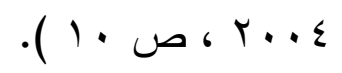


المبحث الثاني : الاضطرابات الحسية :

\section{تعريف اضطراب المعالجة الحسي :}

عرفت " جين أبريس " : - الاضطراب في التكامل الحسي على أنه خلل

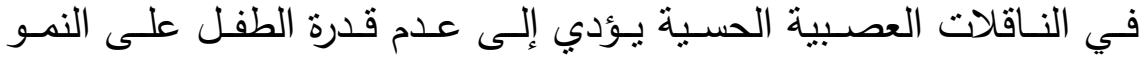

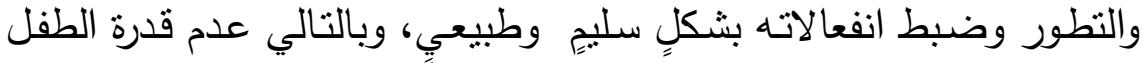

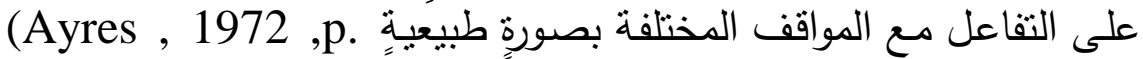
257 ).

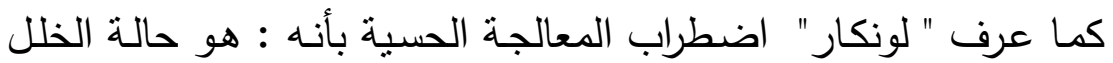

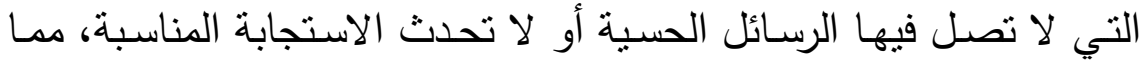

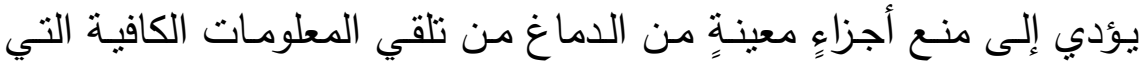
يحتاجها الجهاز العصبي للرد على المثيرات الحسية الموجودة في البيئة. (Lonkar, 2014 )

عرفت " نصر " اضطراب التكامل الحسي هو : خلل وظيفي يؤدي إلى الى الحي

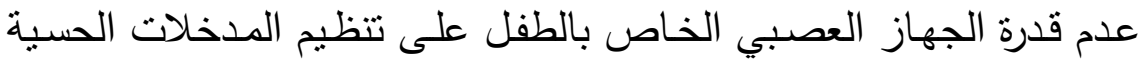

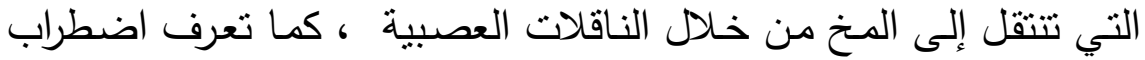

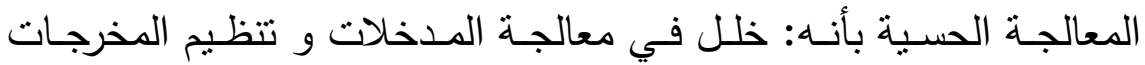

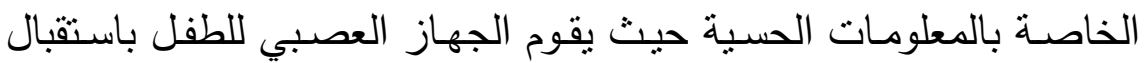

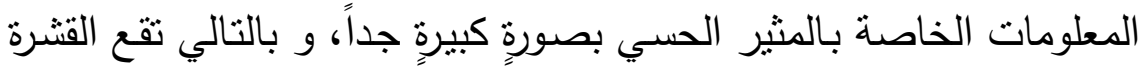

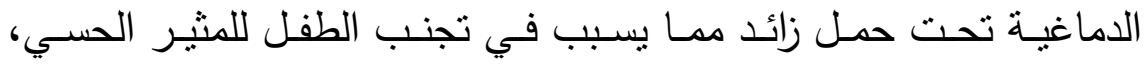

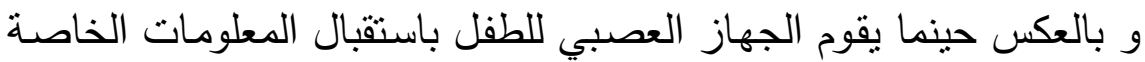
بالمثير الحسي بصورة قليلةٍ جداً تفسر القترة الدماغية ذللك بصورةٍ خاطئةٍة فتعطي الجسم استجابةً غير سليمة بتوجيه للبحث عن عن مزيد من المن المثيرات

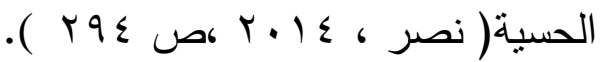


ممـا سبق يمكن وضـع تعريف إجرائسي لاضطراب المعالجـة الحسية: (Sensory Processing Disorder )

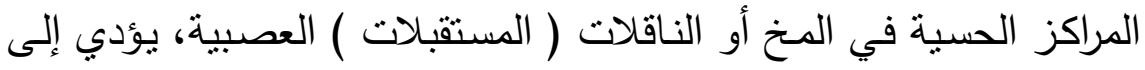

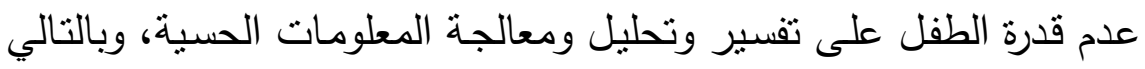
عدم قدرته على اكتساب الخبرات والمفاهيم الحياتية وكذللك التعلم . نسبة انتشار الاضطرابات الحسية :

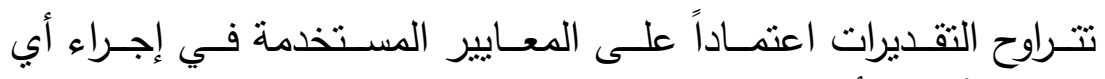

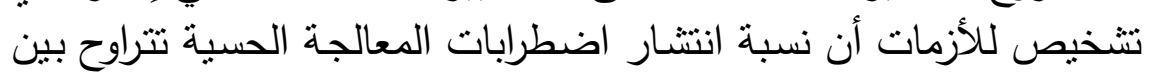

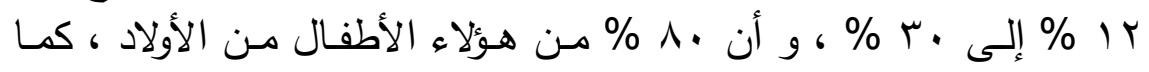

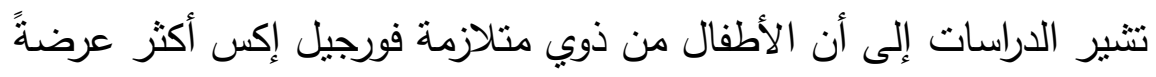

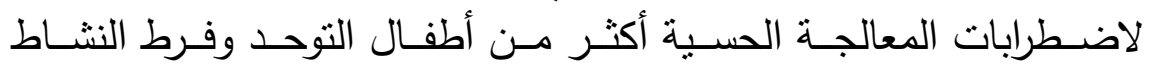

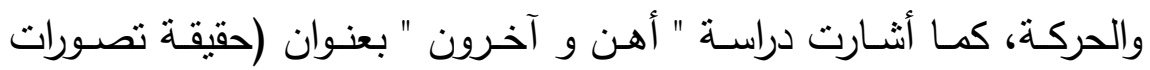

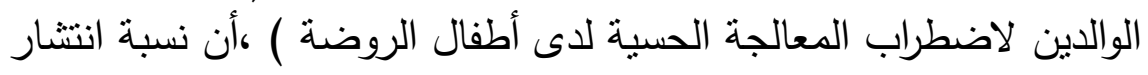

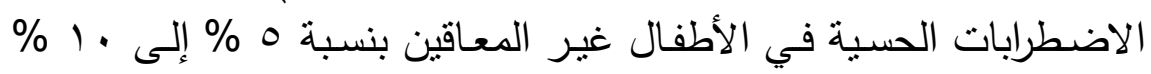

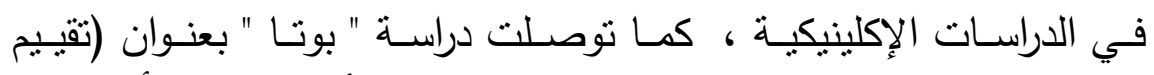

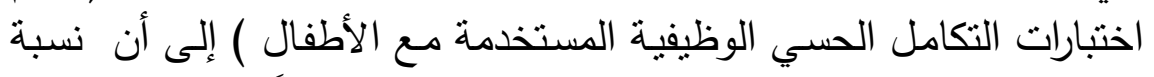

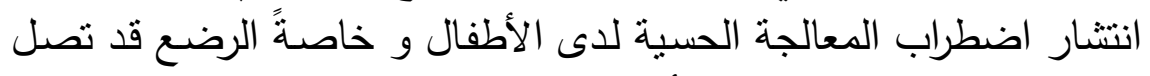

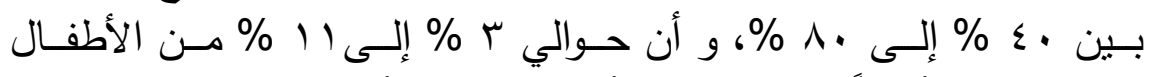

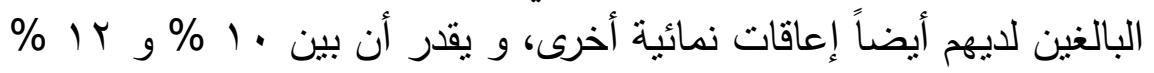

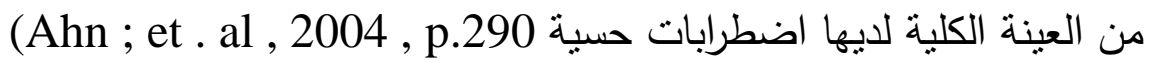
; Kranowitz , 1998 ,p. 25 ; Baranek ; et . al , 2002 ,p. 359 ; Botha, 2015 ,p. 14 ). 


\section{أنواع الاضطرابات الحسية :}

\section{Sensory Modulation Disorder ( SMD )}

1- اضطراب التعديل ( التشكيل) الحسي:

يشير اضطراب (SMD) إلى العملية التي تتنقل بها الرسائل(المعلومات ) من النظام الحسي حول شدة المحفزات أو المثيرات الحسية، ونسبة تكرارئية ومدتها وتعقيدها وحداثتها في الطبيعي يكون الرد على هذه الرسائل بشكلٍ

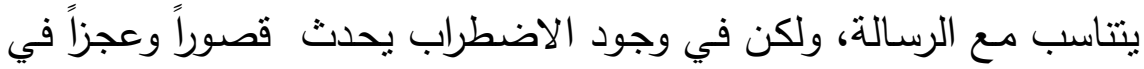
تتاسب شدة الاستجابة مع شدة الرسالة (Sher , 2009 ,p. 12). وتوضـح " ميلر و فولر " أن اضطراب التعديل الحسي هو مشكلة في

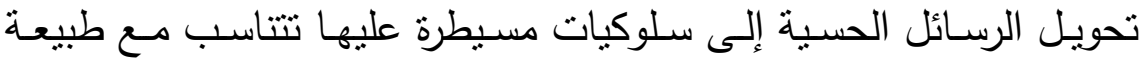
وكثافة المعلومات الحسية، فيحدث التعديل الحسي عندما يكون لدى الطفل

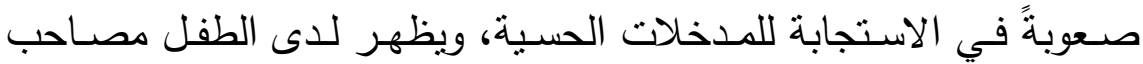

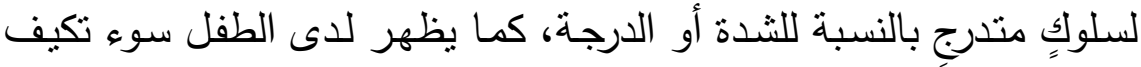

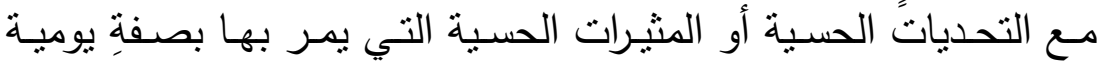
(Miller ; Fuller , 2006 ,p. 12 ; Miller et al , 2007 ,p. 136) مما سبق يمكن تقبيم اضطراب التعديل الحسي إلى: أ - اضطراب الإفراط في الاستجابة الحسية: Sensory Over-Responsivity Disorder (SOR)

يستجيب الأطفال الذين يعانون من هذا النوع من الإحساس بشكلٍ أسرع

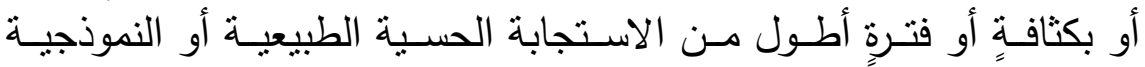

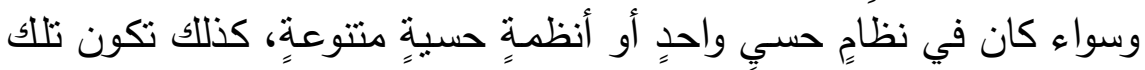

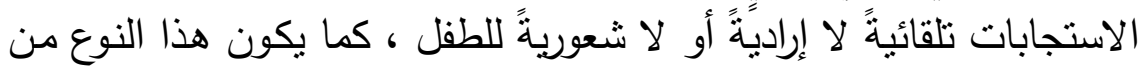
الأطفال مُلاحِظين و مُنتبِهين جيدين للمحفزات الحسية الموجودة في بيئته ، 
يمكن تحفيز الطفل في هذا النـوع بسـهولة حيـث تكون اسـتجابته الحسبية

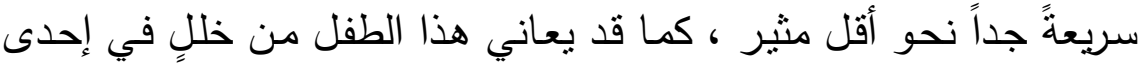

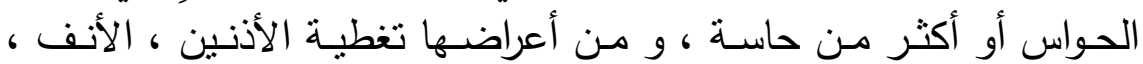
العينين - صعوبة اللعب الجماعي - صعوبة رؤبة نوعين من الطعام في طبـق واحد - عدم تحمـل الملابس الصسوفية أو البطانيـات الفـايير - عدم فئه

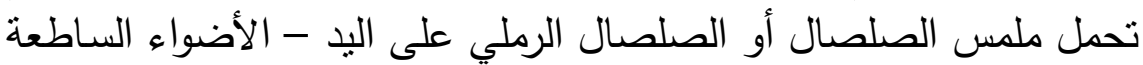
أو ضوء الثمس - سريع الانفعال و مزاجي - الضيق من التغير المفاجيء

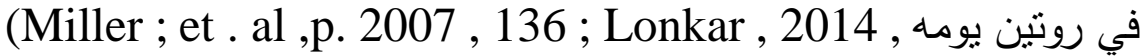
p.5 : 9 ) Horowitz ; Röst , 2004) .

ب -اضطراب الحد الأدنى (ضعف) من الاستجابة: Sensory Under-Responsivity Disorder ( SUR ) لا بستجيب الأطفال الذين يعانون من ضعف الاستجابة الحسية إلى

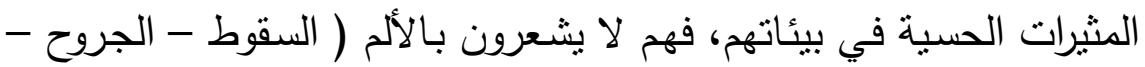

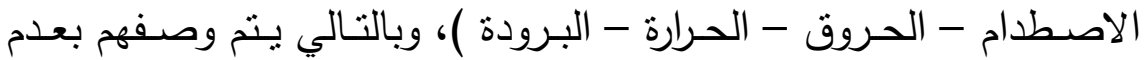

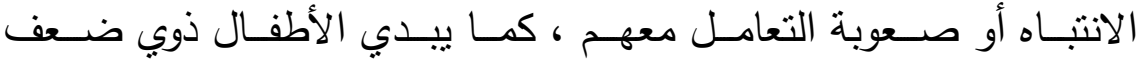
الاستجابة الحسية استجابةً حسيةً أقل مما يتطلبه الموقف و يحتاجون وقتاً

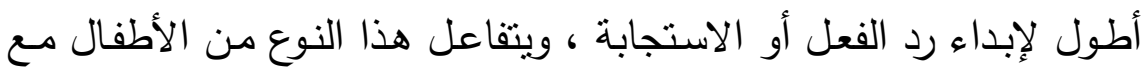

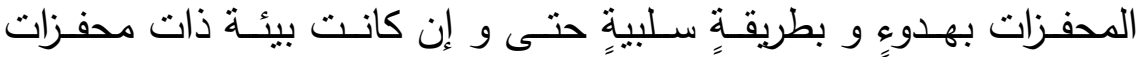
صاخبة، ويبدو هؤلاء الأطفال غير مهتمين ومنسـبين وتكون استجابتهم للمثيرات الحسية في البيئة أقل بكثيرٍ عن الطفل الطبيعي سواء في المدة أو

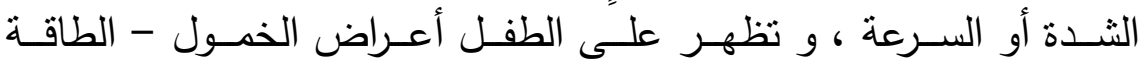
المنخفضـة - عدم التفاعل مـع الأضـواء السـاطعة أو الضوضـاء العالية -

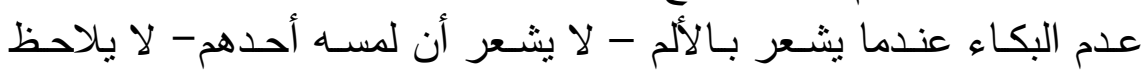




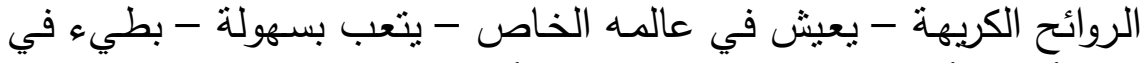
ردود أفعاله أو التعرف على الاتجاهـات أو استكمال المهام الموكلة إليهه ،

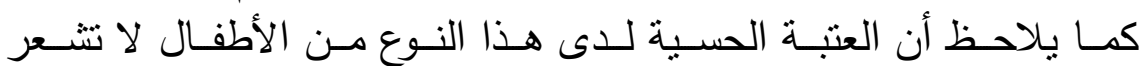

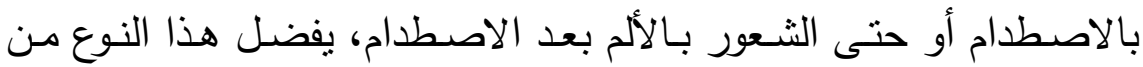

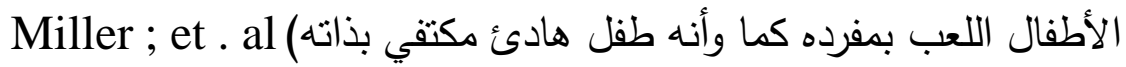
, 2007 ,p. 136 Delaney , 2008 ,p. 25 Lonkar,2014,p.5:9 ; Horowitz ; Röst , 2004 ) .

\section{Sensory Seeking; Craving (SS)}

يظهر عندما يحتاج الجهاز العصي للطفل إلى كميات غير عاديـة أو الو الجياء

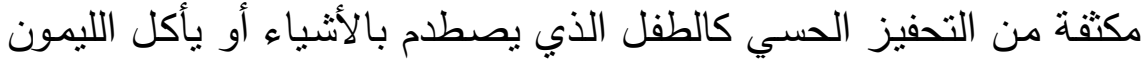

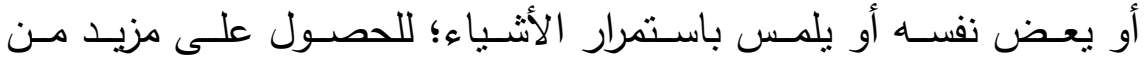

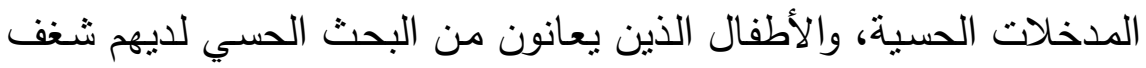

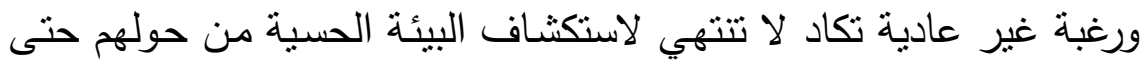

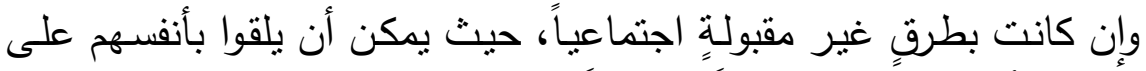

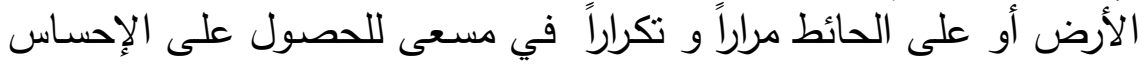

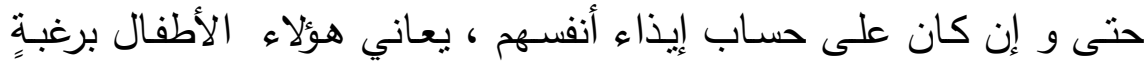

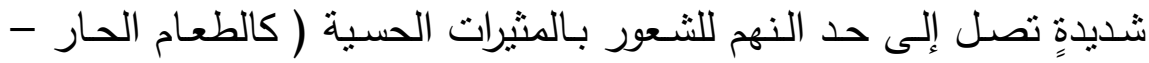

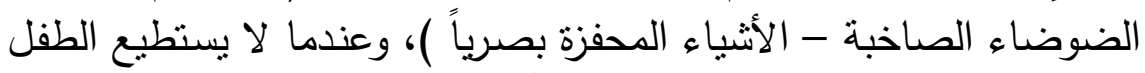

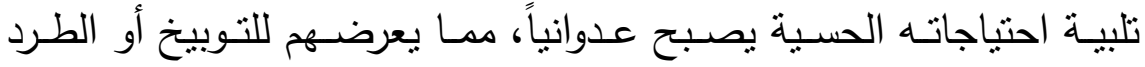
(Delaney , 2008 ,p. 17 - 28; وخاصةً في مرحلة رياض الأطفال Miller, et . al , 2007,p. 137) . 


\section{Sensory Discrimination Disorder ( SDD )}

أحد وظائف الجهاز العصبي الحسي هي إعطاء تحديث للمعلومات حول

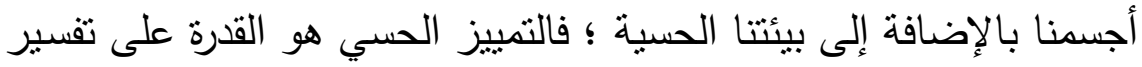

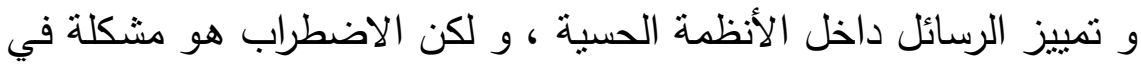

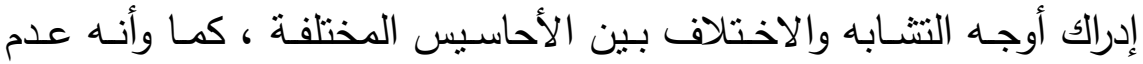

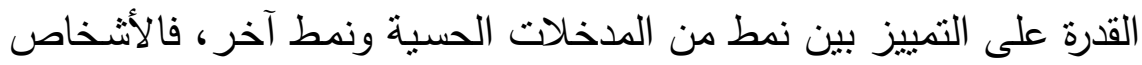

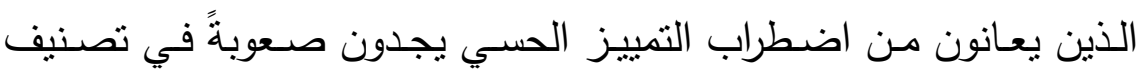
و تمييز أنماط متتوعة أو مختلفة عن البيئة المحيطة.

(Delaney,2008,p.17; Miller;Fuller,2006,p. 37).

كما أن اضطراب التمييز الحسي هو عدم القدرة على تمييز بين الرسائل

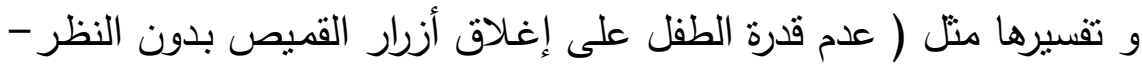

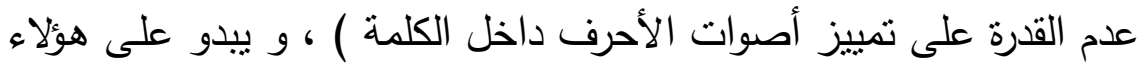

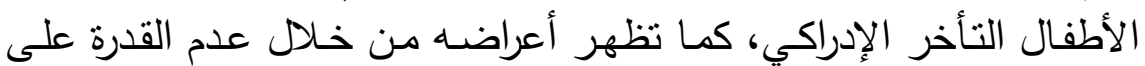

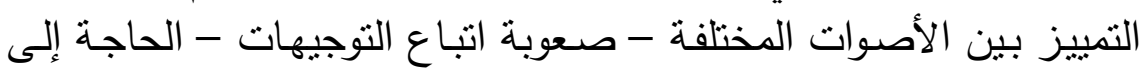

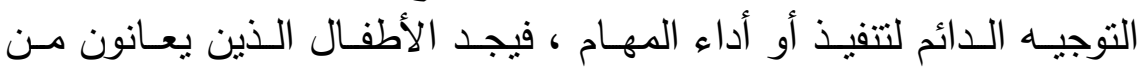

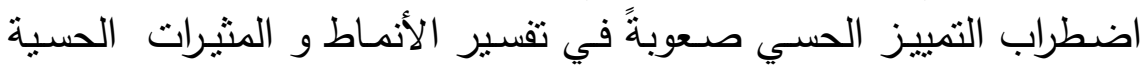

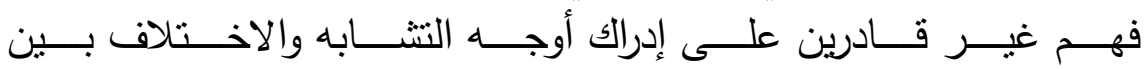
المثيرات (Miller;et.al , 2007,p.137;Lonkar,2014,p.10) ب- الاضطرابات المرتبطة بالحركة الحسية: Sensory-Based Motor Disorders (SBMD)

يصف الخلل الوظيفي في الرسائل الحسية المرتبطة بالنظام الدهليزي

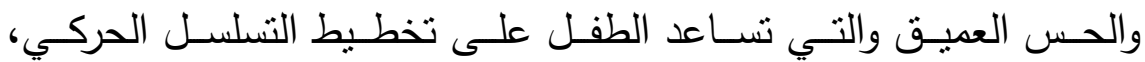


وبالتالي تسمح لجسم الطفل بالتحرك والثـور بوضعه في الفراغ ، حيث يحدث هذا الاضطراب عند إساءة فهم النظام الدهليزي للمدخلات الحسية أو

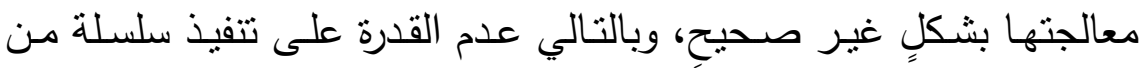
الإجراءات أو الحركات للقيامٍ بمهارةٍ مـا منثل ركوب الدراجـة ( العجلة ) أو أو تسلق السلم. (Sher,2009,p.13; Lonkar, 2014)

و هذا ما أكدته دراسة " أيمانويل " التي كان عنوانها (تأثير الإستجابات الحسية و الحركية على المهارات الوظيفية في الأنشطة اليومية للأطفال ما قبل سن المدرسة الذين يعانون من اضطراب طيف التوحد ) ، و توصلت الدراسة إلى أن الأطفال سواء التوحد أو الاضطرابات الحركية أو تأخر النمو

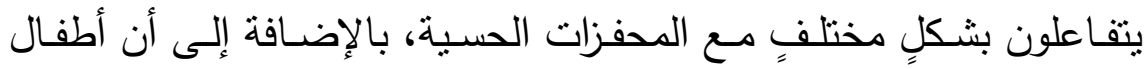

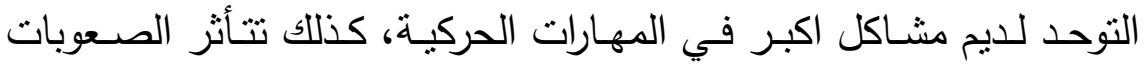
الحسية والحركية على المهارات الوظيفية (Emmanuelle , 2007). وتتقسم الاضطرابات المرتبطة بالحركة الحسية إلى:

\section{أ - الاضطرابات الوضعية Postural Disorder}

يتمثل في صسعوبة الحفـاظ على أوضـاع الجسـم المناسبة لأي مهمـة حركية واضـحة، وصسوبة استقرار توازن الجسم أثتاء الحركة حيث يعاني

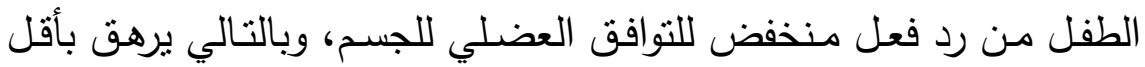
تدريب يقوم بـه ، كمـا يظهر عند الأطفال في صسورة انخفاض في في إيقاع العضلات ، وتحكم غير كافٍ بالجسم أثتاء الحركة ، ضنعف التوازن أثتاء تمديد أجزاء الجسم ، عدم تماثل خط المنتصف خلل في التوازن الحركي في

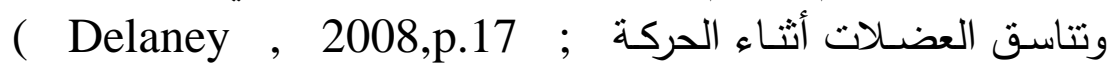
Lonkar,2014 ,p. 10 ; Miller ; et al , 2007 ,p. 137 ). 
وهذا ما أكدت عليه دراسة " بلاسي و آخرون " في دراسة بعنوان العلاقة

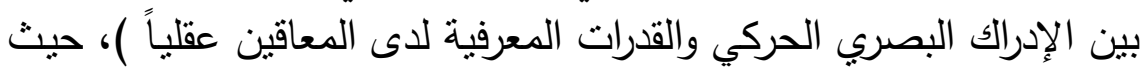

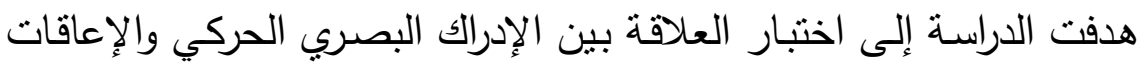

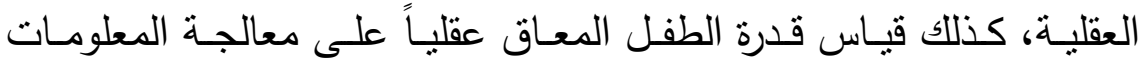

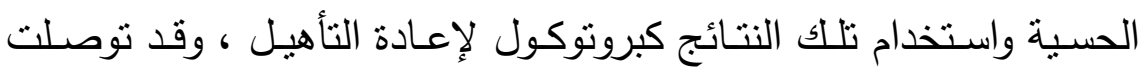

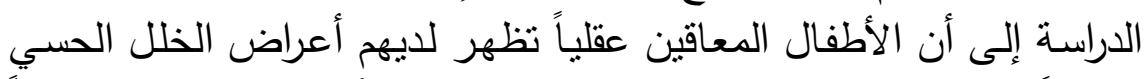

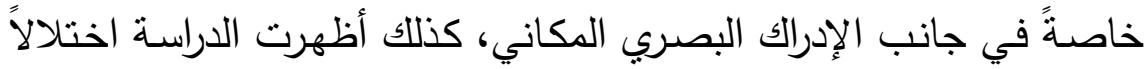
واضحاً في التتاسق والتآزر البصرى الحركي والتتسيق بين العينين; Blasi) et al, 2007 ) .

\section{ب - Dyspraxia عسر القراءة}

هم الأطفال الذين لديهم صعوبة في نرجمة المعلومات الحسية إلى مادية

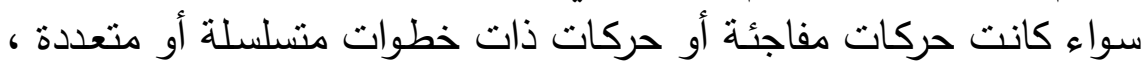

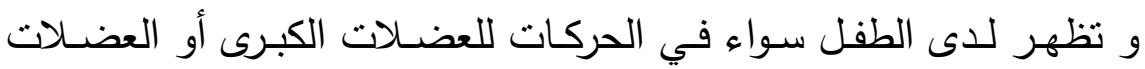

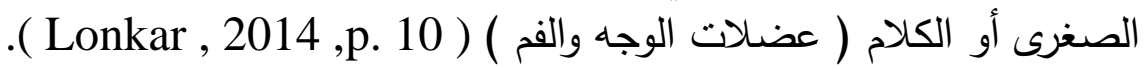

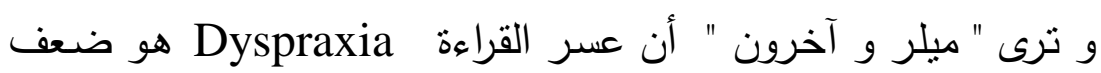

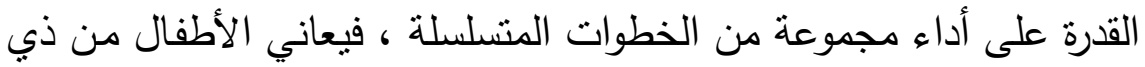

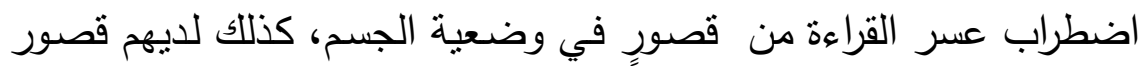

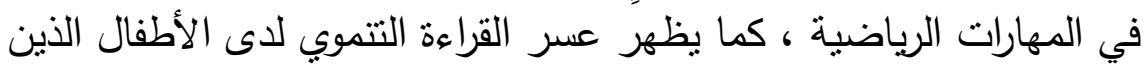

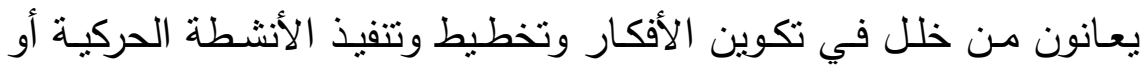

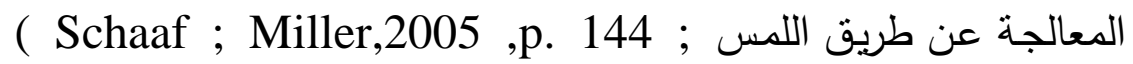
Miller ,et . al , 2007 ,p. 138 ). 


\section{أسباب الاضطرايات الحسية :}

يرى كل" " كرأنويتز ، زافيسكي ، هورويتز و فويس " أن الأسباب التي

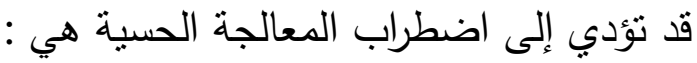

1-أسباب جينية ( الاستعداد الوراثي ) : غالباً ما يكون أحد أقارب الطفل في الوابل

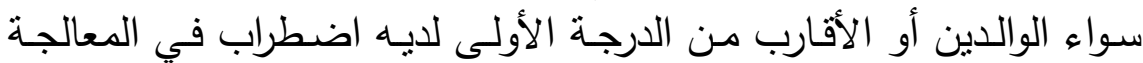
الحسية حتى وإن لم يكن واضحاً. r-ما قبل الولادة : سواء أمراض أو أثنعة أو تلوث قد تكون الأم تعرضت

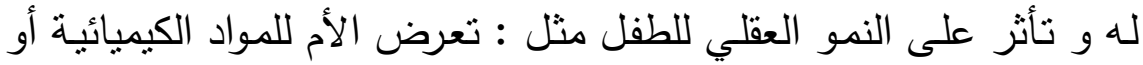

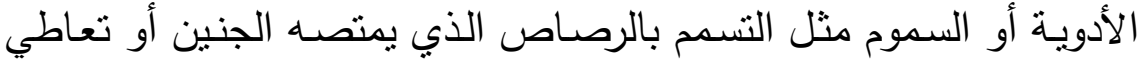

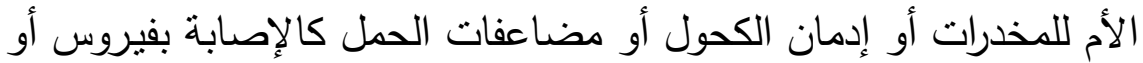
مرض مزمن أو إجهاد كبير.

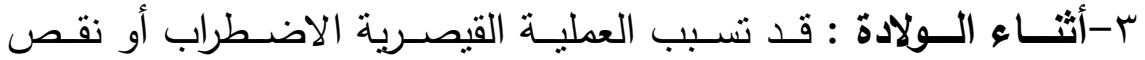

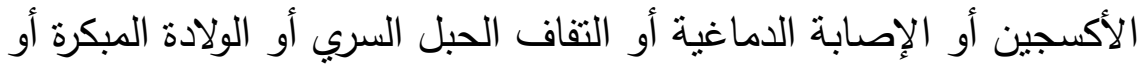

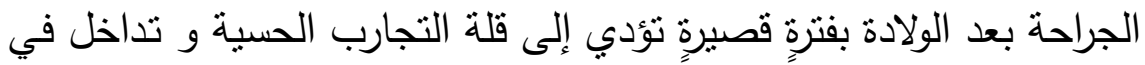
التطور الجهاز العصبي للطفل. ع-مـا بعد الـولادة : التعرض إلى الملوثات البيئيـة بشكلٍ مفرطٍ قد تكون

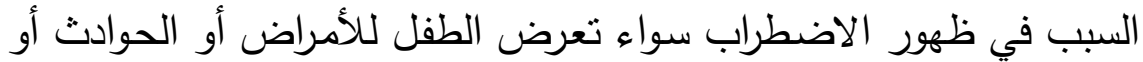

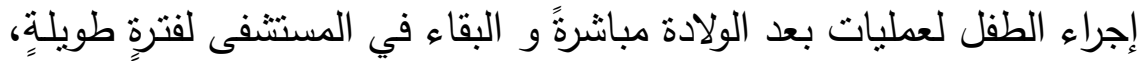

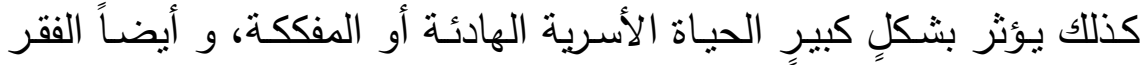

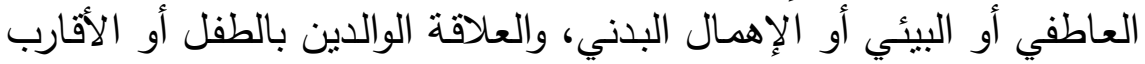

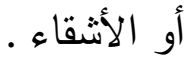

• - الولادة المبكرة ( الأطفال المبتشرين) ـ ( Kranowitz , 1998 ,p.23;Horowitz ; Röst,2004 ,p.11; Zavesky: 2011 ,p.61 ) 


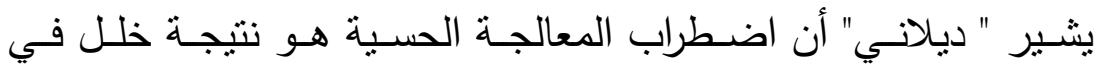
التتظيم العصبي يؤثر في معالجة الجهاز العصبي بعدة طرقٍ مختلفة : ا - عدم قدرة المخ على تلقى الرسائل من الناقلات العصبية.

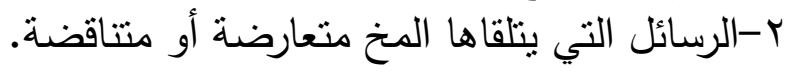

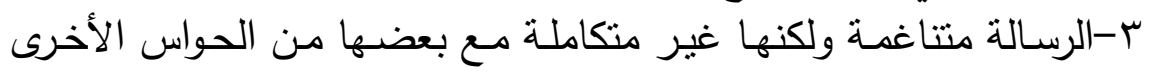
كما ينبغي) (Delaney , 2008,p.12).

وتؤكد دراسة " شاف " على دور الجهاز العصبي المستقل ( السمبتاوي ) أحد المسببات لاضـطراب المعالجة الحسبة، حيث كان عنوانها (الأطفال

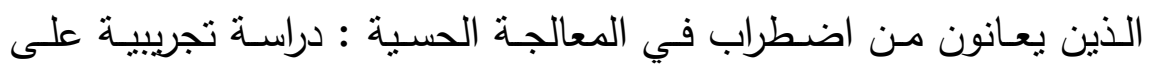

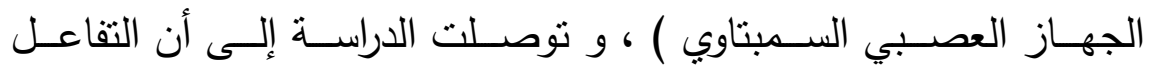
الفسيولوجي للطفل قد يؤثز على أسـوب المعالجـة الحسبة و بالتالي دوره المحدد في إظهار السلوك (Schaaf ; et al , 2003).

أعراض اضطراب المعالجة الحسية:

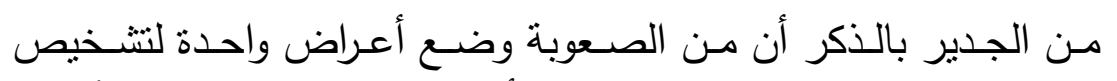
اضطراب المعالجة الحسبة؛ وذلك بسبب أنه لا تظهر على جميع الأطفال نفس الأعراض ولكن يظهر على كل طفل عدد من المشكلات والأعراض المختلفة لاضطراب المعالجة الحسية ، و بمكن تصنيف أعراض اضطي وطراب

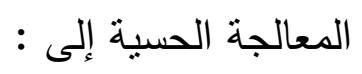




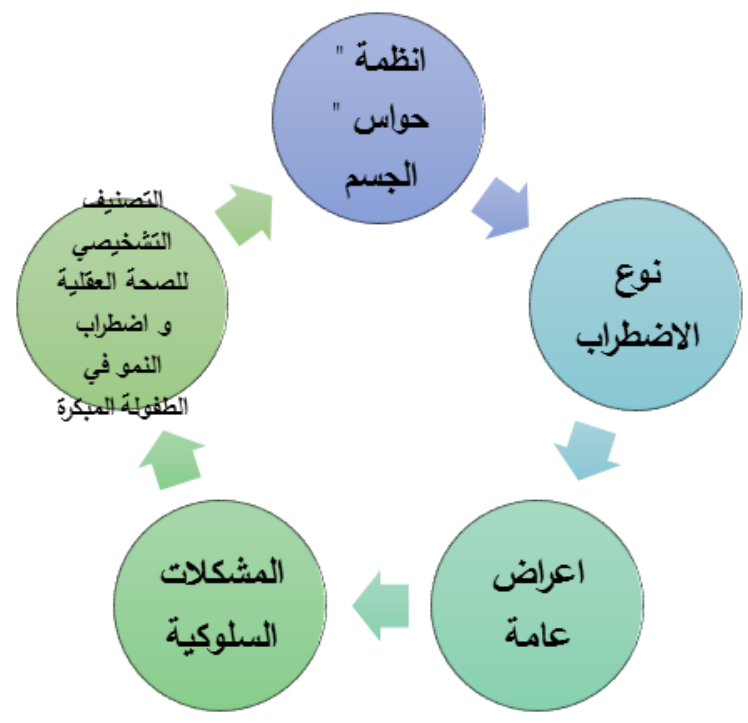

شكل (1) يوضح أعراض اضطراب المعالجة الحسية

أهداف التأهيل الحسي لاضطراب المعالجة الحسية :

الهدف الأساسـي مـن التأهيـل بالتكامـل الحسـي هـو تحسين قدرة دمـاغ

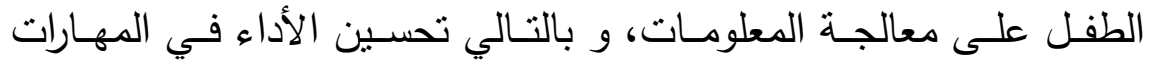

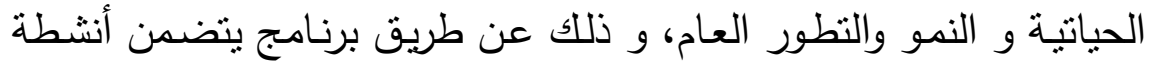
شيقة و مثيرة و محببة للطفل ( Horowitz ; Röst , 2004,p. 89 ). إن التدخل بمنهج التكامل الحسي يهدف إلى تحسين القدرة على معالجـة

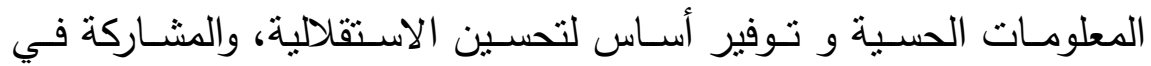

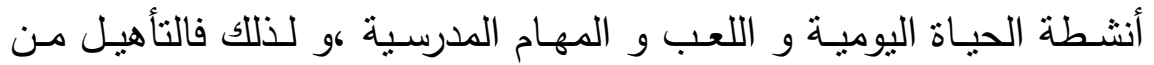

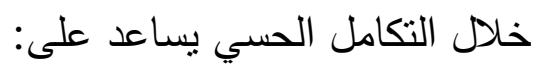
ا -مساعدة الأهل على فهم احتياجات وسلوك الطفل من المنظور الحسي. 
r-نكييف البيئة وفقاً لإحتياجات الطفل . ب-اكتساب الخبرات الحسية والحركية اللازمة لحئة لحياته اليومية. ع -مساعدة الطفل على أن يصبح أكثر تفاعلاً و تواصلاً مع حياته اليومية. ه-تعزيز قدرات الدماغ على التصور والتذكر والإدراك والتخطبط الحركي ) . (Schaaf ; Miller, 2005,p. 144 )

ولذلك ينم وضع برنامج لتأهيل الطفل يتضمن تحسين في بيئة التعلم، كما يتطلب تغيير في بيئة المنزل؛ وذلك لتأهيل الطفل وتدريبه وتتميـة قدرات

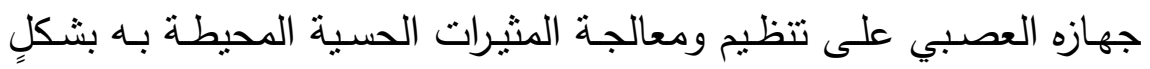

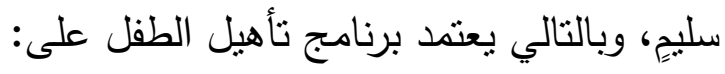

ا المرونـة العصبية : يتطور الدماغ بصفةٍ مستمرةٍ عن طريـق التدريب

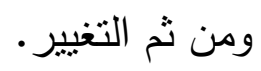

ץ-التسلسل الارتقائي : بصبح كل سلوك متعلم تمهيداً لسلوك أكثر تعقيداً على سلم التطور والنمو. r- تدرج الجهاز العصبي المركزي : تعتمد سلامة و صحة وظائف المراكز

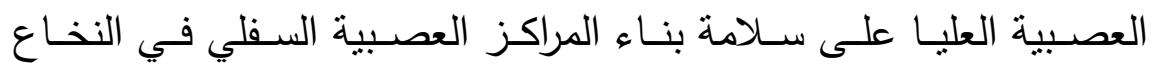
• الشوكي ع -السلوك التكيفي : تعديل و تغيير السلوك التكيفي يحفز و يطور التكامل

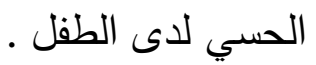
0-الدافع الداخلي : يؤي اكتسـاب مهارات متعلمة إلى تكوين دافعيـة لتعلم

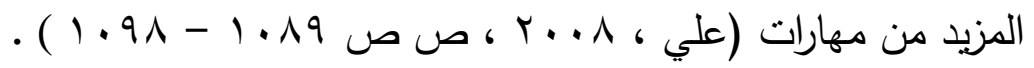
وهذا يتفق مـع دراسـة " شـاف و ميلر " وكان عنوانها (استخدام منهج

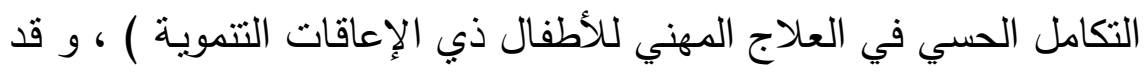

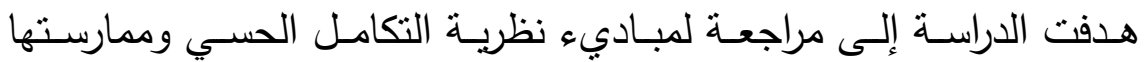


العلاجيـة مـع الأطفـال ذي الإعاقـات التتمويـة ، ثم تحديد الأنـواع الفرعيـة

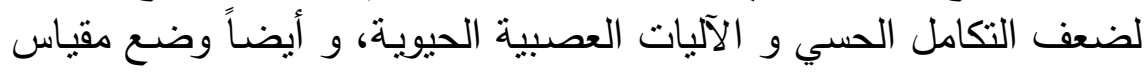

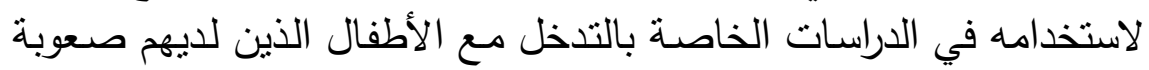

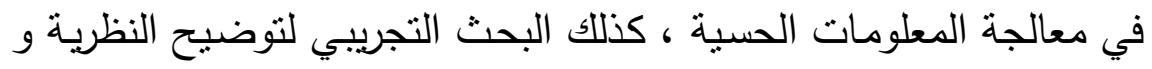

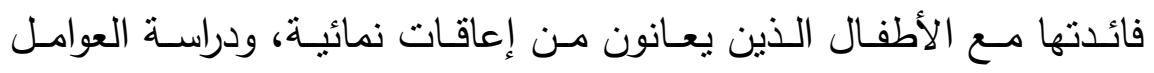

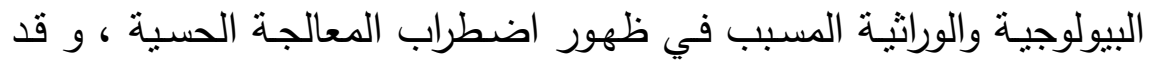

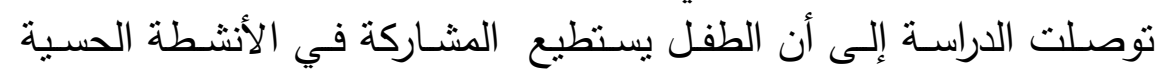

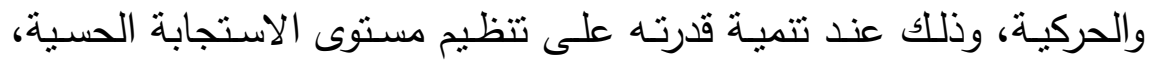
وأيضـاً تحسين قدرة الطفل على المشاركة بشكلٍ مستقلٍ في أنشطة الحياة اليومية (Schaaf ;Miller , 2005 ).

الإجراءات المنهجية للبحث : • منهج البحث :

تتطلب طبيعة البحث الحالي وتحقيقاً لأهدافه ، قامت الباحثة باستخدام

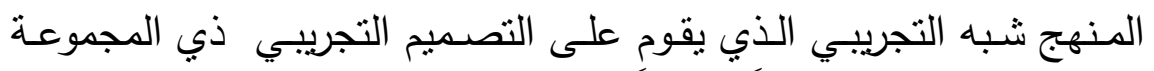

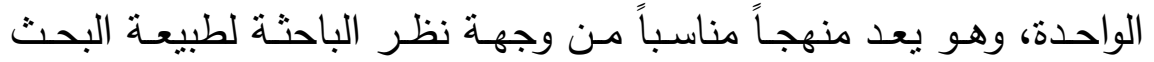

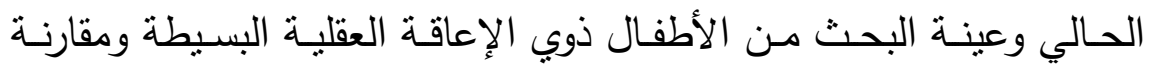

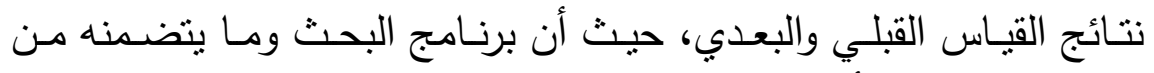

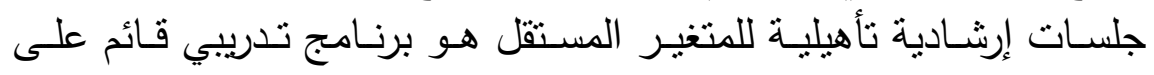

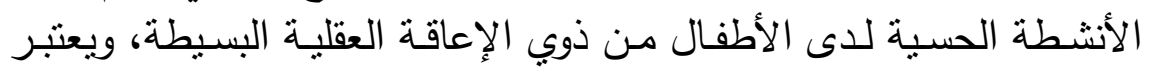

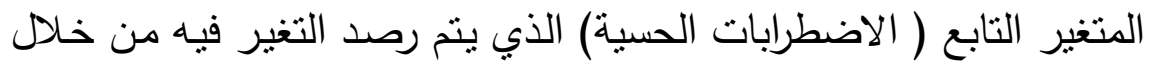

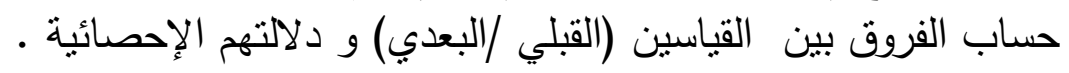




\section{: ع عنة البحث:}

تكونت العينة منه أطفالاً ( ب ذكوراً، ب إناثاً) من ذوي الإعاقة العقلية البسيطة و الملتحقين بجمعيـة التنقيف الفكري ، وقد راعت الباحثة توافر الثروط الآتية في اختيار عينة البحث الحالي : 1 - أن يكون الأطفال من ذوي الإعاقة العقليـة البسيطة ، وقد تـم تحديد ذللك من خلال اختبار ستانفورد بينيه للذكاء.

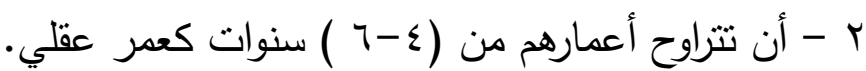

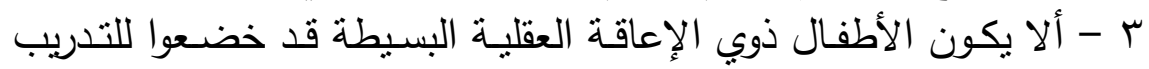
على المهارات قبد البحث من قبل. • الأدوات المستخدمة في البحث : ا مقياس ستانفورد بينيه لحساب نسبة الذكاء الصورة الخامسة. ( تقنين محمود أبو النيل )

r • مقياس الاضطرابات الحسية للأطفال من ذوي الإعاقة العقلية البسيطة.

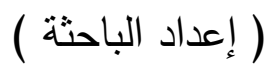

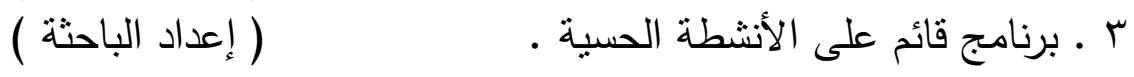
ا ـ مقياس ستانفورد بينيه لحساب نسبة الذكاء الصورة الخامسة ( تقتين محمود أبو النيل )

الخصائص السيكومترية للمقياس : - صدق وثبات المقياس:

قام فربق التقنين بحساب صدق المقياس بطربقتين: الأولى هي صدق التمبيز العمري حيث تم قياس قدرة الاختبارات الفرعية المختلفة على التمبيز

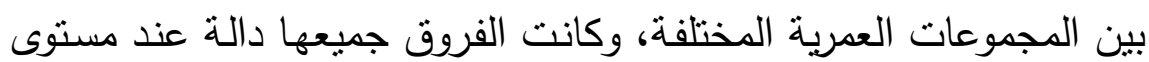


I • , ، ، و الثانيـة هي حسـاب معامل ارتبـاط نسـب ذكاء المقيـاس بالدرجة

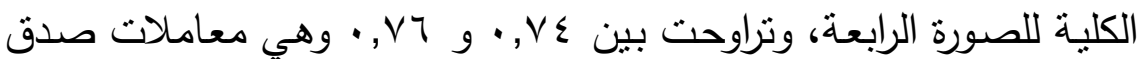
مقبولة بوجهٍ عامٍ ونشير إلى ارتفاع مستوى صدق المقياس.

كمـا تـم حسـاب الثبـات للاختبـارات الفرعيـة المختلفـة بطربقتهي إعـادة

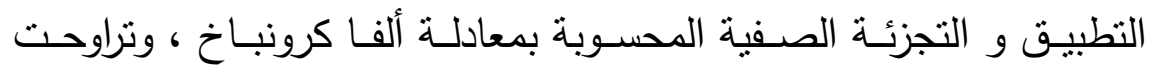

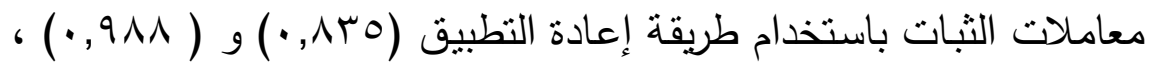

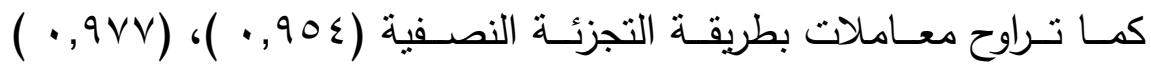

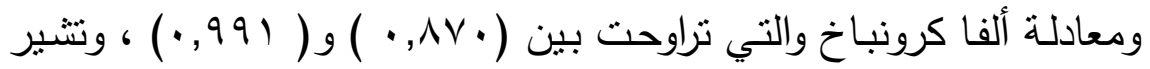
النتائج إلى أن المقياس بتسم بثبات مرتفع سواء عن طريق إعادة الاختبار

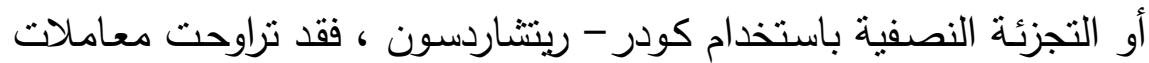
الثبات على كلٍ من اختبارات المقياس ونسب الذكاء و العوامل من به بـ إلى .94

r ـ مقيـاس الاضــرابات الحسـية للأطةـال مـن ذوي الإعاقـة العقليـة ( إعداد الباحثة ) دوي الاعاهة ) البسيطة.

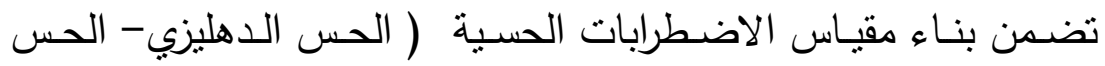
العميق - حاسة اللمس - حاسة الثم- حاسة التذوق - حاسـة البصر - حاسـة السمع ) لدى الأطفال من ذوي الإعاقة العلية البسيطة عدة خطوات يمكن إجمالها فيما بليل:

1- استقراء التراث النظري والإطلاع على بعض المقاييس السابقة.

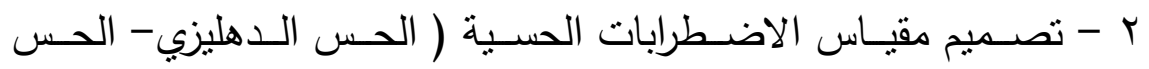

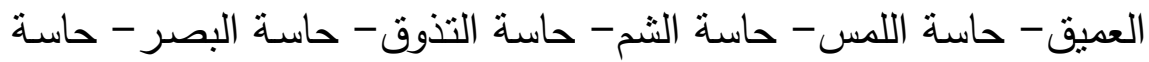
السمع) لدى الأطفال من ذوي الإعاقة العقلية البسيطة في صورته الأولية. 
ب - عرض المقبـاس على مجموعـة مـن الخبـراء والمتخصصسين في علم النفس والتربية الخاصة لتحكيمه. ع - إعداد المقياس في صورته النهائية. 0 - الخصائص السيكومتربية للمقياس.

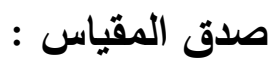
أ - الصدق الظاهري :

وبُطلق على هذا الصدق "صـدق المحكمين أو الأسـاتذة المتخصصين"

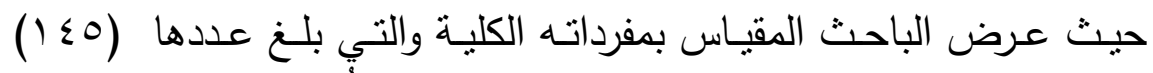
مفردةً؛ للكثـف عن مظـاهر الاضطرابات الحسية الُّشـار إلبها في بدايـة عرض المقياس وهي : ( الحس الدهليزي - الحس العميق - حاسة اللمس - هردئ حاسة الثم- حاسة التذوق - حاسة البصر - حاسـة السمع) على عدد ( (1)

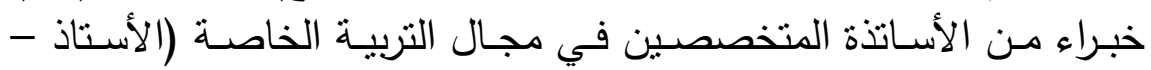

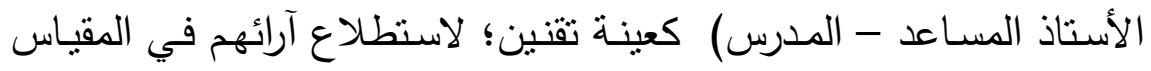
من خلال معايير محددة وضعتها الباحثة تمثلها النقاط التالية: - شـمول المقباس لأبعاد الاضطرابات الحسية الأكثر شيوعاً عند أطفال الروضة ذوي الإعاقة العقلية البسيطة.

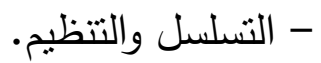

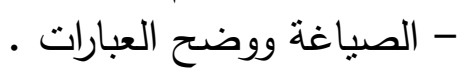

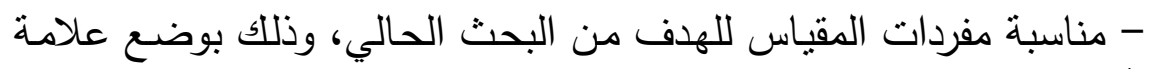

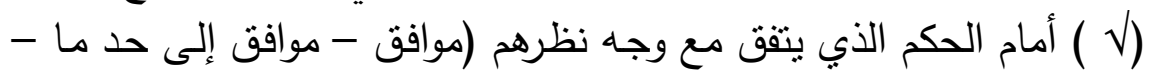
غير موافق - تحتاج إلى تعديل). وجاءت ملاحظات وآراء الأساتذة المحكمين لتشير إلى : - تعديل الصياغة اللغوية لبعض واعض المفردات. 
- إضافة بعض المفردات التي تتناسب مع الهدف من البحث. - تبديل بعض المفردات فيما بين أبعاد المقياس.

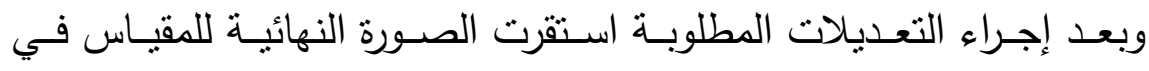

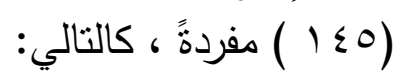
جدول ( ) يوضتح أبعاد المقياس

\begin{tabular}{|c|c|}
\hline المفردة & البُعد \\
\hline r r مفردة & حاسة البصر \\
\hline וץ مفردة & حاسة اللمس \\
\hline וץ مفردة & الحس الدهليزي \\
\hline rr مفردة & الحس العميق \\
\hline 9 1 مفردة & حاسة السمع \\
\hline 9 1 مفردة & حاسة التذوق \\
\hline • r مفردة & حاسة الثم \\
\hline $1 \leqslant 0$ & المجموع \\
\hline
\end{tabular}




\begin{tabular}{|c|c|c|c|c|c|}
\hline نسبة الاتفاق & تعتاج إلى تعديل & غير موافق & موافق إلى حد ما & موافق & التحكيم \\
\hline$\% \quad 1 \ldots$ & - & - & - & 1. & شقول \\
\hline$\% \quad 1 \ldots$ & - & - & - & 1. & والتنظيم \\
\hline$\% \wedge \bullet, \vee 1$ & - & - & 1 & 9 & الصوضياغة \\
\hline$\% 1 \ldots$ & - & - & - & 1. & مناسبة \\
\hline
\end{tabular}

وبتضـح مـن الجدول السـابق و الخـاص بالأهميـة النسـية لآراء الأسـاتذة الخبـراء في بنـود التحكيم الأساسـية للمقيـاس، وبُلاحـظ أن بنـود التحكيم جميعها حصلت على نسبة ، \% فيما فوق بالنسبة لاستجابة (موافق). وبالتالي لم يتم استبعاد أي سؤال من أسئلة المقياس، وتمت مراعاة عنصر

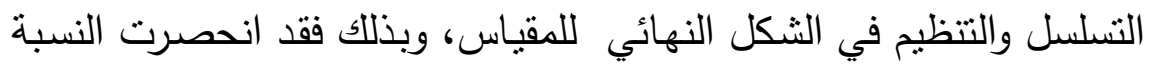
المئويـة لاتفاق المحكمين على مفردات المقياس بين ( \% ) ، وهي نسبة عالية تدل على صدق المقياس. ب - صدق الاتساق الاخلي:

قامت الباحثة من خلال الدراسـة الإستطلاعية بـإجراء المعاملات العلمية

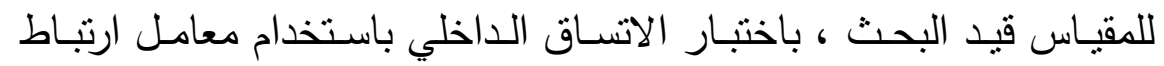
بيرسون؛ وذلك لإيجاد معاملات الارتباط بين درجة كل مفردة من مفردات 
المقياس والدرجة الكلية للبُعد المنتميـة إليهه ، وإيجاد معاملات الارنباط بين مجموع كل بُعد و مجموع مفردات المقبـاس ككل، كمـا بيضـح مـن جدول

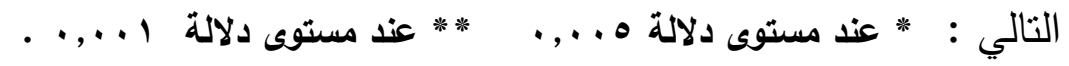
جذول ( ) يوضت أبعاد المقياس

\begin{tabular}{|c|c|c|c|}
\hline مستوى الالالة & $\begin{array}{c}\text { معامل الارتباط } \\
\text { (ر) }\end{array}$ & ن للعبارات & أبعاد المقياس \\
\hline$\cdot, \ldots$ & $* *,, \leq 97$ & rt & حاسة البصر \\
\hline$\cdot, \cdots r$ & $* *, 0 \leqslant r$ & r) & حاسة اللمس \\
\hline$\cdot, \cdot r \leq$ & $*, r \wedge \wedge$ & (1) & الحس الدهليزى \\
\hline$\cdot, \cdots$ & $* *$, , $\$ 97$ & r & الحس العميق \\
\hline$\cdot, \cdots$ & **, , 777 & 19 & حاسة السمع \\
\hline$\cdot, \cdots$ & $*, \Gamma \wedge \wedge$ & 19 & حاسة التذوق \\
\hline$\cdot, \cdots$ & $* *, \leq 99$ & $r$. & حاسة الشم \\
\hline \multicolumn{2}{|l|}{$1, \cdots$} & 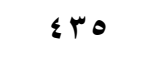 & الارجة الكلية للمقياس \\
\hline
\end{tabular}

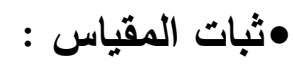

Cronbachs Alpha"a اسـتخدمت الباحثة (معادلـة ألفـا كرونبـاخ) لحساب معامل الارتباط (ر) بين الدرجة الكلية لكل بُعد من أبعاد المقياس

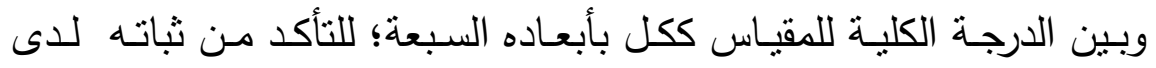
العينة الكلية (ن= • ب) ، حيث يمثل معامل ألفا متوسط المعاملات الناتجة

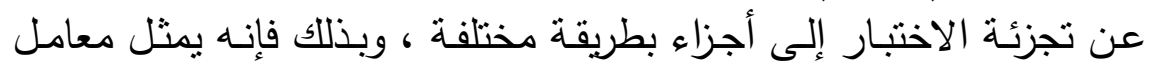


الارتباط بين جزئين من أجزاء الاختبار • والجداول التالية توضـح نتائج هذا التحليل : جدول( ) يوضح معامل ثبات ألفا كرونباخ لأبعاد مقياس الاضطرابات الحسية السبع

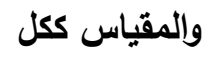

معامل ألفا كرونباخ

( ر)

$\cdot, \wedge 77$

$\cdot$, AYO

$\cdot, 9 \vee r$

$\cdot, V \cdot r$

$\cdot, 94 \cdot$

$\cdot, \vee \wedge$.

$\cdot, \wedge \cdot 1$

$\cdot, \wedge \wedge$.

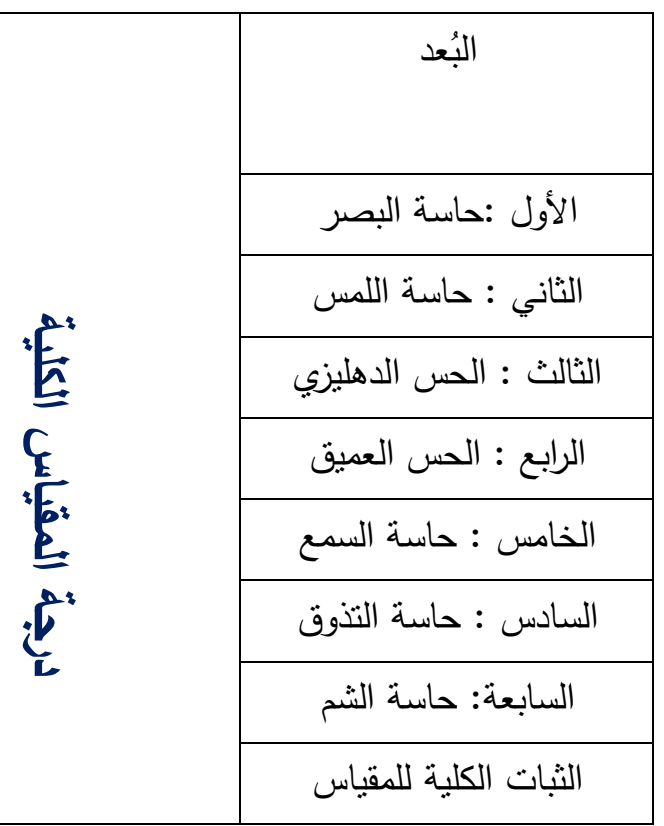

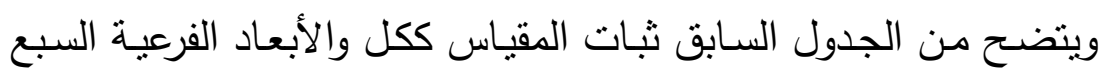
المتمثلة ( الحس الدهليزي - الحس العميق - حاسـة اللمس - حاسـة الثـم-

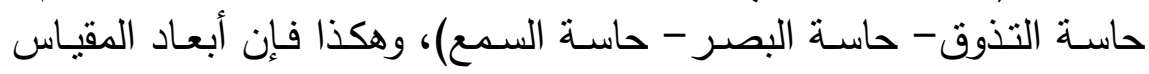

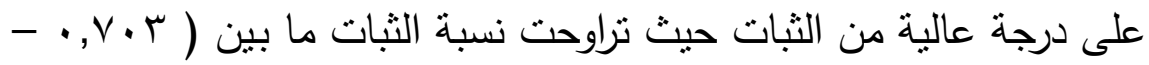

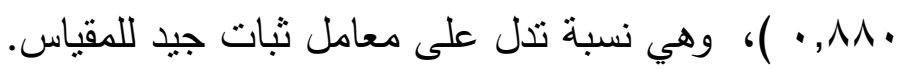


( إعداد الباحثة)

r- برنامج قائم على الأنشطة الحسية.

قامت الباحثة بتصميم برنامج إرشادي تأهيلي قائم على الأنشطة يتكون

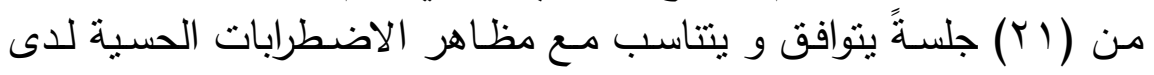
الأطفال ذوي الإعاقة العقلية البسيطة.

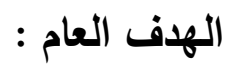

التحقق من أثر برنامج إرشادي قائم على الأنشطة الحسية لدى الأطفال ذوي الإعاقة العقلية البسيطة.

\section{• الأهداف الفرعية:}

تتوعت الأهداف الفرعية بين السلوكية والوجدانية والمهارية ومنها:

- كسر الحاجز النفسي بين الباحثة و المشاركين ( الأمهات والأطفال )

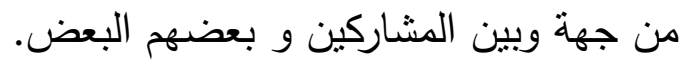

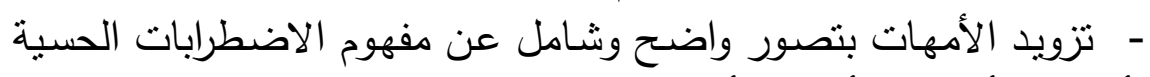
وأنواعه وأشكاله وأسبابه وأعراضه.

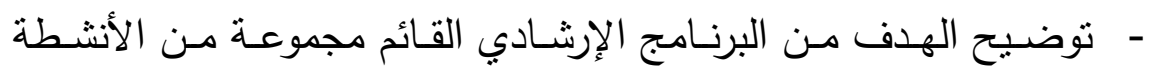

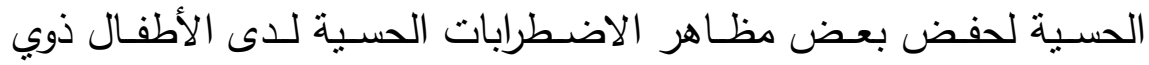
الإعاقة العقلية البسيطة. - - تحديد الخطوات التي سوف يتثم اتباعها لتحقيق الهـف مـن البرنـامج الإرشادي.

- التعرف على الملامس ( خشن ، ناعم ، قاسي ، لين ).

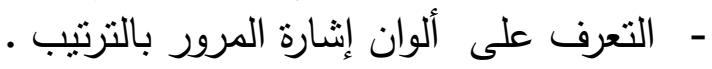

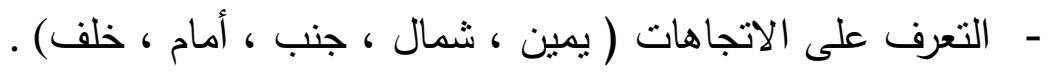
- - إتقان تتفيذ النشاط بتشلسل محدد. 
- التوازن أثناء الوقوف على قدم واحدة لمد ب ثانية .

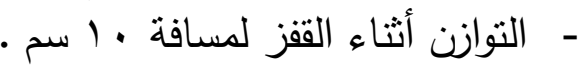

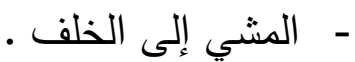
- - المشي إلى الأمام. - - إتقان مهارة الوعي الجسمي " وضع الجسم في الفراغ " . • فلسفة البرنامج :

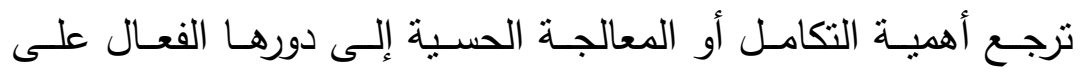

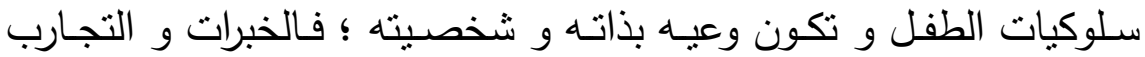
الحسية تؤثز على تطور شخصية الطفل و المراهق، و بالتالي الأطفال

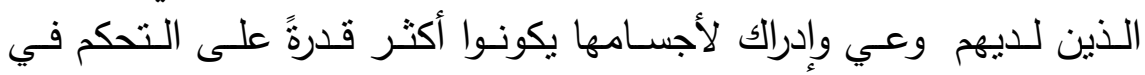
مشاعرهم و إدراك و تفسير الأحاسيس المختلفة، وعن طريق عمليات التعلم والتطوير واكتساب الخبرات الإيجابية المختلفة( 12 , Zavesky , 2011 ).

تعتمد فرضية نظرية التكامل الحسي على العلاقة بين السلوك و الجهاز العصبي و كيفية تأثير أي خلل في الجهاز العصبي على سلوك الطفل وتفاعله الاجتماعي والأكاديمي ، حيث يتطور الوعي لدى الطفل من خلايل

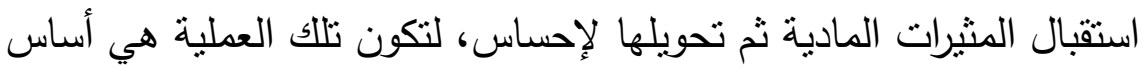
للعمليـات العقليـة العليـا مثل الإدراك والتفكير والانتبـاه ، وبالتالي يستطيع الطفل التعلم) (Ahn ; et . al , 2004 , 288 : 494 (

\section{• أهمية البرنامـج التدريبي:} تتضح أهمية البرنامج التدريبي فيما بلي: أ - الأهمية المعرفية : 
تتضـح أهميـة البرنـامج من خـلال الأسـاس التأهيلي الذي يقدم للطفل

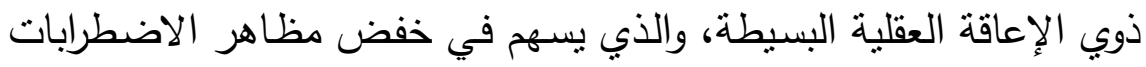

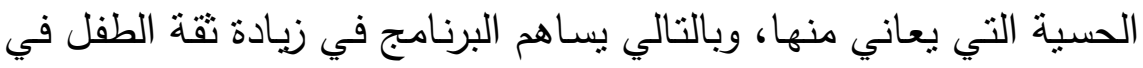

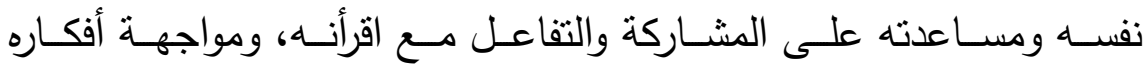

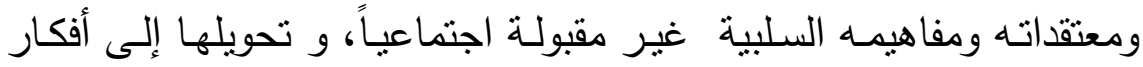
ومعتقدات ومفاهيم إيجابية ومقبولة اجتماعياً ذَ وذللك في مواقف حئه حياتية. ب - الأهمية الوجدانية :

1-تثمية الثقة بالنفس والإفصاح عن مشاعر الطفل و التعبير عنها.

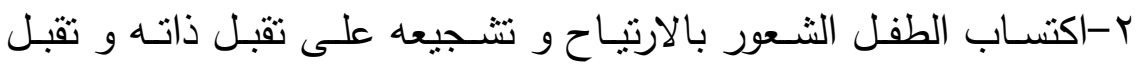
الآخربن. ب-إحداث تغيير مرغوب إيجابي عن طريبق التأثير في عمليات الإدراك

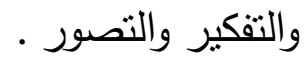
ع -إحداث تغيير في السلوك والمهارات و تطوير مستوى الأداء الطفل.

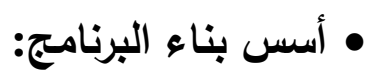
- يراعى البرنـامج خصـائص ومطالب النمو المختلفة للطفل ذوي الإعاقة العقلية البسيطة. - ضرورة استخدام أساليب التعزيز الإيجابية للسلوك المرغوب من الطفل.

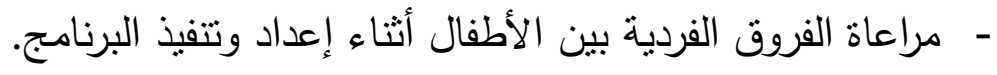

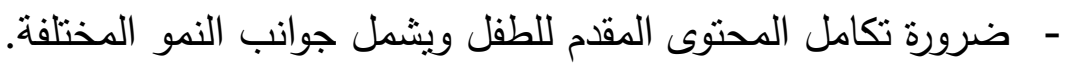

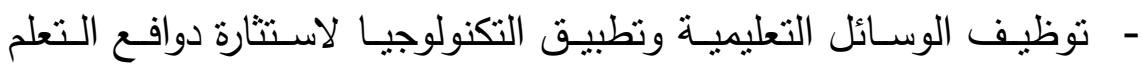
للطفل ذوي الإعاقة العقلية البسيطة.

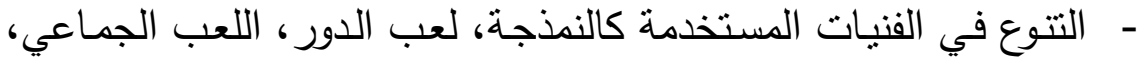

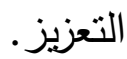


- السـلامة والأمـان في الأنشـطة المقدمـة للأطفـال ذوي الإعاقـة العقليـة البسيطة . - إتاحة الفرصة لجميع الأطفال للمشاركة والعمل. فروض البحث ونتائجه:

ا-توجد فروق دالـة إحصـائياً بين منوسطي رتب درجات أطفال الروضـة

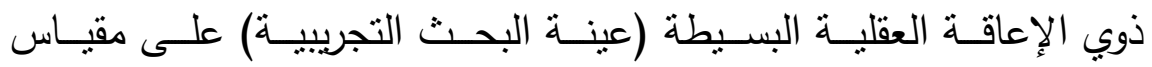

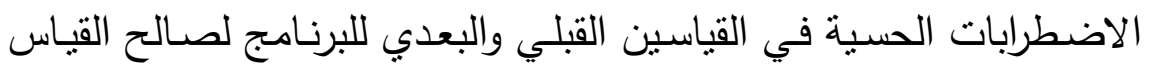
ك-لا توجد فروق دالة إحصـائياً بين متوسط رتب درجات أطفال الروضـة

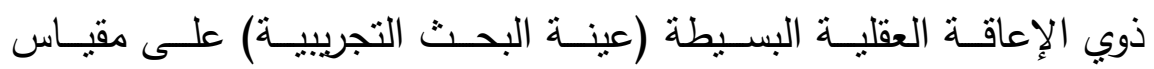

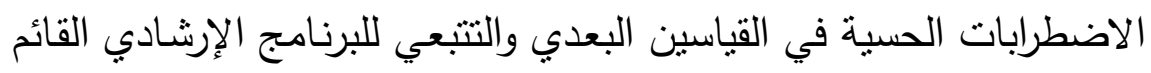
على الأنشطة الحسية .

\section{• الفرض الأول ونتائجه :}

ينص الفرض الأول للبحث على أنه:

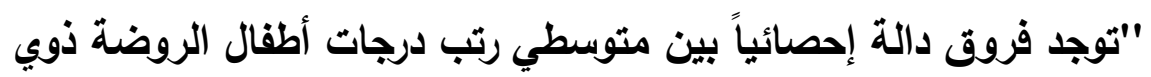

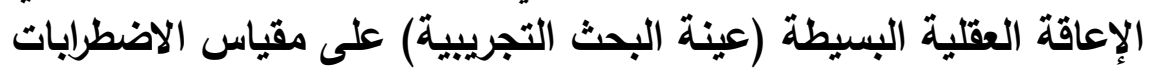

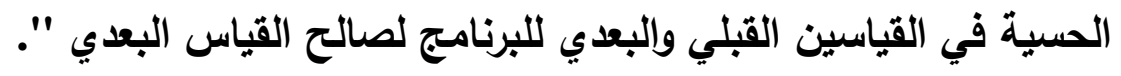
حيث توصلت نتائج الفرض الأول إلى وجود فروق ذات دلالة إحصائية

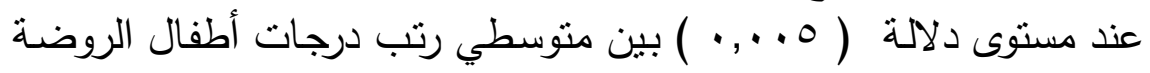

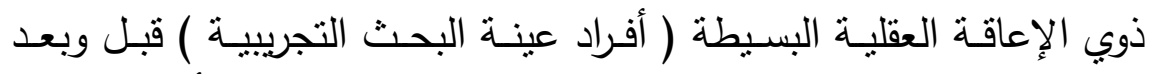

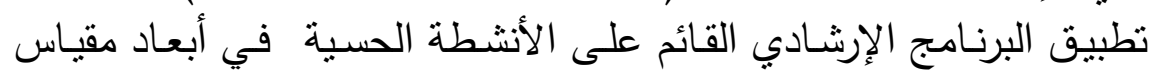
الاضطرابات الحسية ككل لصالح التطبيق البعدي، وبلغت قيمة الإنة ل 


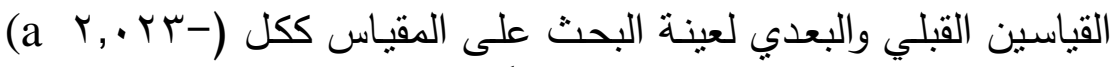

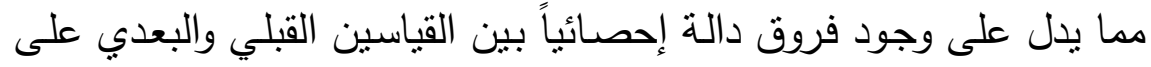

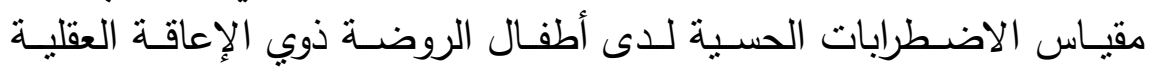
البسيطة ( أفراد عينة البحث التجريبية).

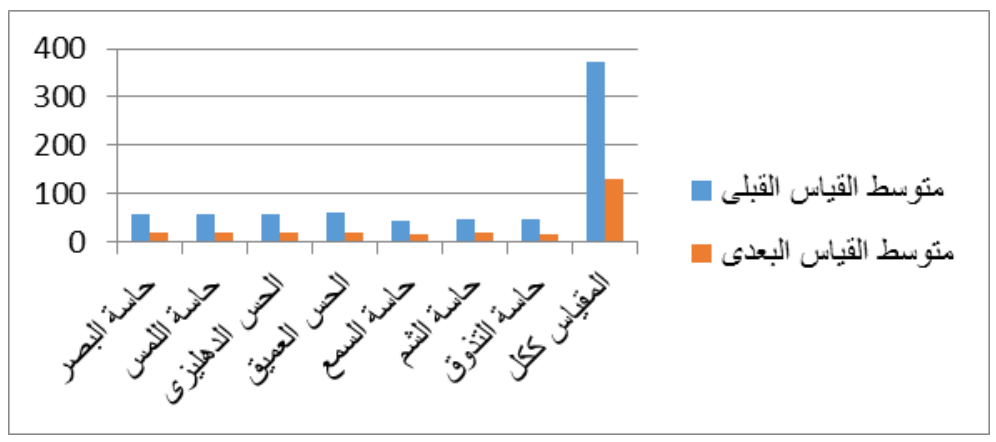

شكل ( ) يوضح متوسط القياسين القبلي والبعدي على المقياس ككل

مدا سبق يتضـح التأثير الإيجابي للبرنامج القائم على الأنشطة الحسية في خفض بعض مظاهر الاضطرابات الحسية لدى الأطفال ذوي الإعاقة

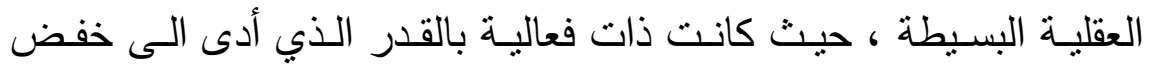

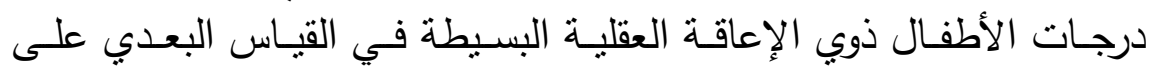
مقياس الاضطرابات الحسية والمتمثل في ( حاسة البصر - حاسـة اللمسالحس الـدهليزي- الحس العمبـق - حاسـة الثـم- حاسـة التـوق - حاسـة

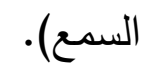

وترى الباحثة أن نتائج البحث أوضـحت فعالية استخدام برنـامج إرشادي

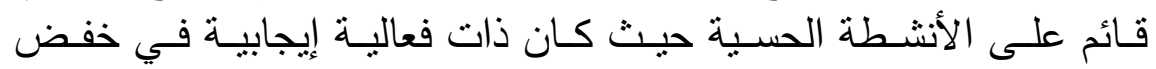

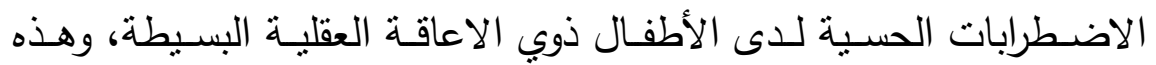

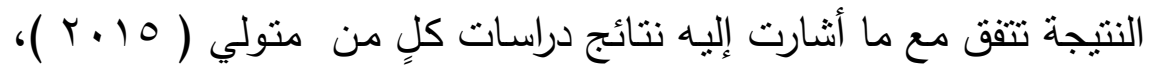




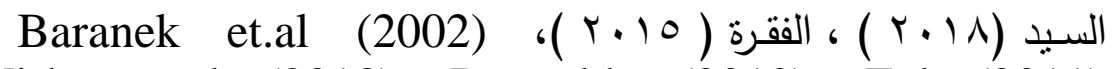
Mirko;et al (2013), Reynolds (2010), Zyl (2011)

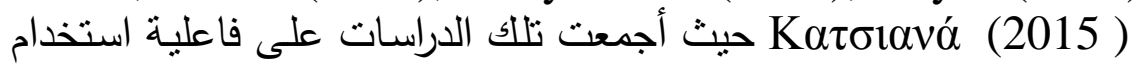

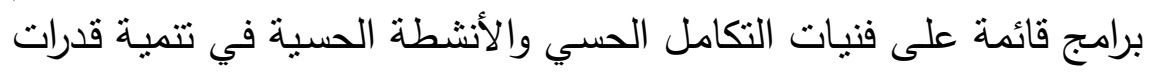

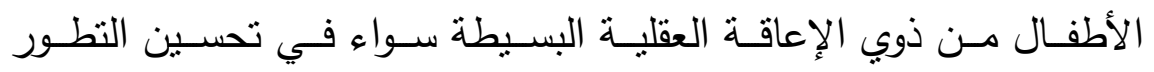

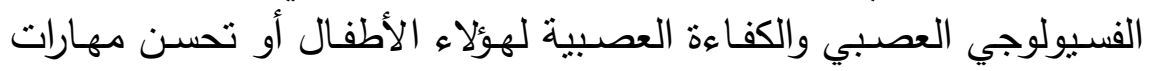

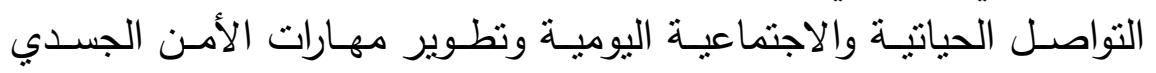

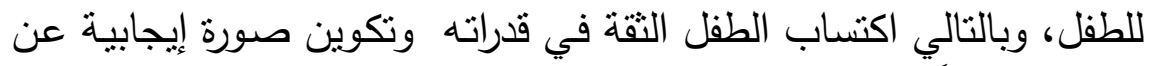

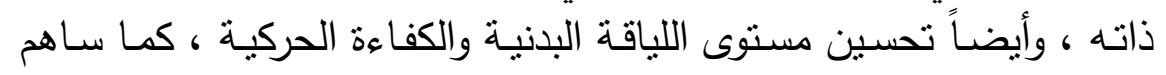

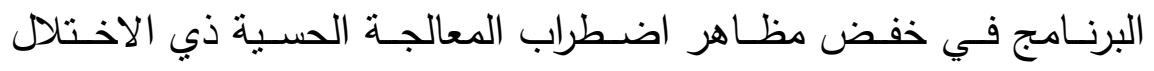
الوظيفي، وبالتالي ثبوت الفرض الأول للبحث الحالي .

• الفرض الثاني ونتائجه : ينص الفرض الثاني للبحث على أنه:

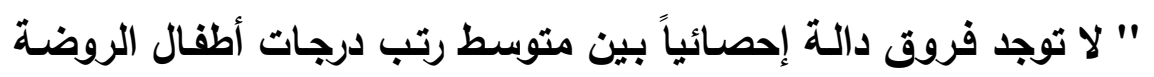

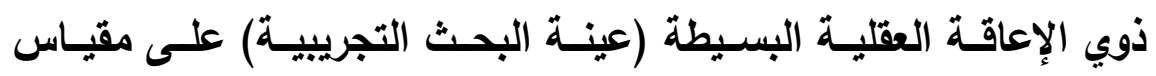

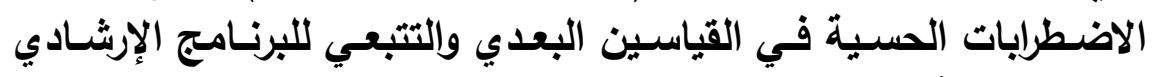
القائم على الأنشطة الحسية".

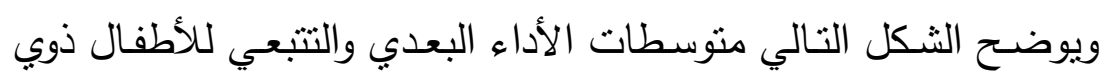

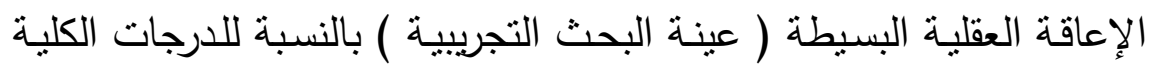
على مقياس الاضطرابات الحسية . 


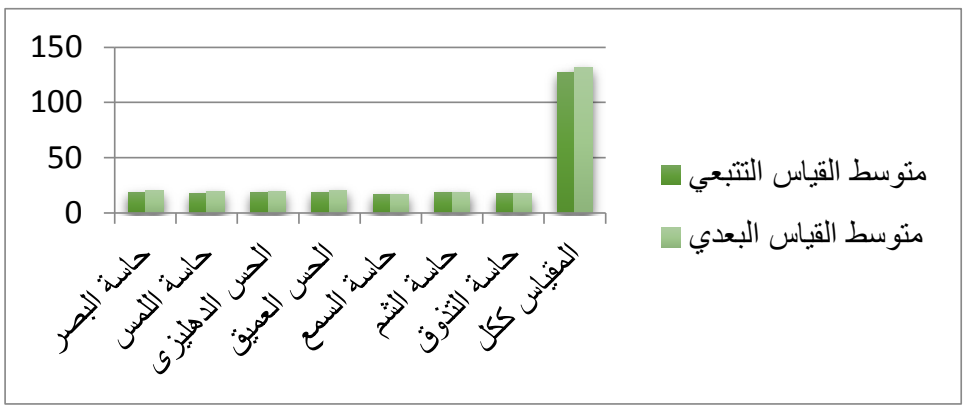

حيث أوضحت نتائج الفرض الثاني للبحث على عدم وجود فروق ذات دلالـة احصـائية بين متوسـى رتب درجات الأطفال ذوي الإعاقـة العقليـة البسيطة في القياسيين البعدي والتتبعي لمقياس الاضطرابات الحسية بأبعاده (حاسـة البصـر - حاسـة اللمس - الحس الـدهليزي- الحس العميـق - حاسـة

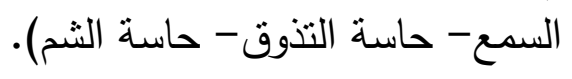

حيـث أكدت نتائج البحث الحسالي على أثر برنـامج قـائم على الأنثـة

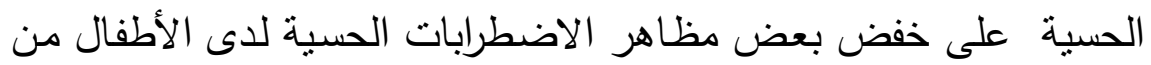
ذوي الإعاقة العقلية البسيطة عينة البحث التجريبية مـع استمرار هذا الأثر الإيجابي للبرنامج خلاله فترة المتابعة.

وترجـع الباحثة نتيجـة هـذا التحسـن بشـكل كبيـر إلىى جلسـات البرنـامج الإرشادي القائم على الأنشطة الحسية التي تنتاسب مـع خصائص وقدرات هـؤلاء الأطفال ، والتي أدت إلىى بقاء أثره بعد مـرور فترة زمنيـة قدرها شهرين، وأيضاً ما حصل عليه الأطفال من تعزيز إيجابي بجلسـات البرنامج

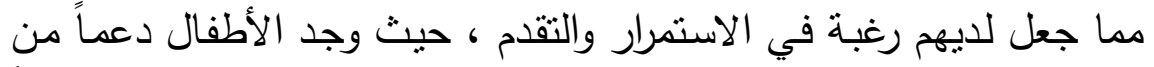
الباحثة وأسرتهم في المنزل ، كما ساعد البرنامج في توعية الوالدين وتحديداً

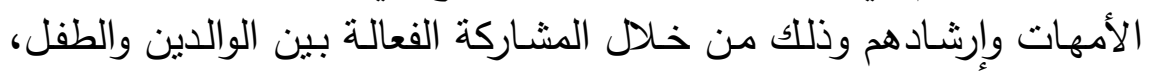


ومالاحظة الوالدين لتقدم طفلهما ومناقثته فيمـا تدرب عليه في الجلسـات،

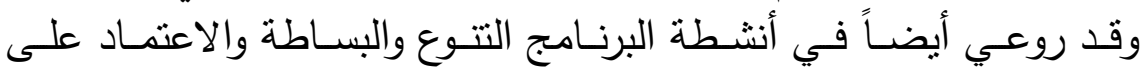
المحسوسات والسرعة في الزمن طبقاً لخصائص مرحلة الأطفال حيث يقل

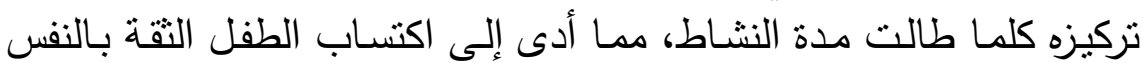

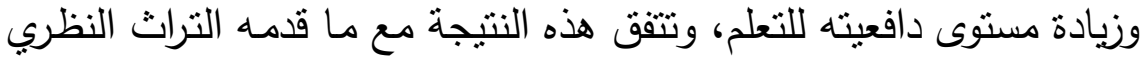
والدراسات السابقة حول البرامج التي تعمل على خفض مظاهر الاضطرابات

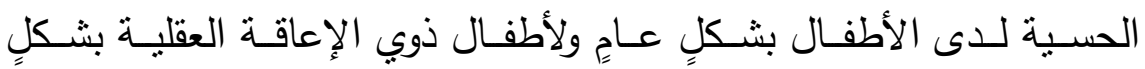
خاصٍ.مع ضـرورة التأكيد على إثراء البيئة المحيطة بالطفل ذوي الإعاقة

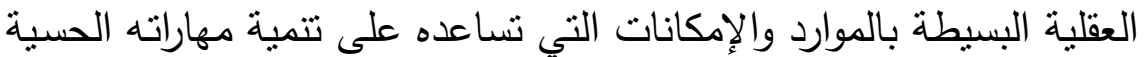
المثتوعة.

توصياث البحث:

في ضـوء مـا توصـل إلبـه البحث مـن نتائج ثتقدم الباحثة بالتوصسيات التالية للاستفادة منها: ا - دراســة مظــاهر الاضــرابات الحسـية لـدى فئسات أخـرى مـن ذوي الاحتياجات الخاصة. ץ-ضـرورة الكثـف المبكر عن مظـاهر الاضطرابات الحسية لدى الطفل وخاصةً في سنواته الأولى •

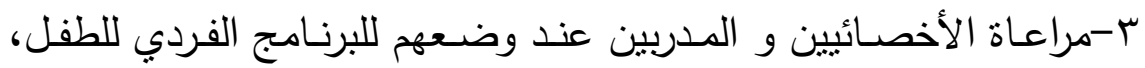
ووضع أهداف تتضمن أنشطة حسية مرتبطة بأدراك الطفل لجسمه و التوازن

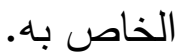

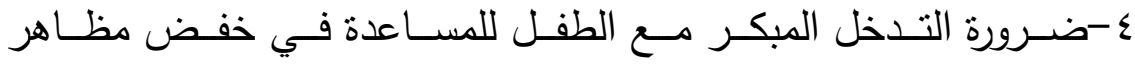
الاضطرابات الحسية لدى الأطفال من ذوي الإعاقة العقلية البسيطة. 
ه-ضرورة تدريب معلمات رباض الأطفال قبل وأثتاء الخدمة على الكثف

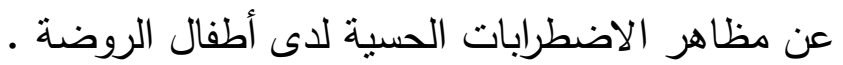

\section{المراجن}

\section{أولاً : المراجع العربية:}

- أحمد ، محمد رياض؛ وأبو زيد ، خضر مخيمر • (Y. IV) . فاعلية برنامج تدربي لتتمية القدرات الحسية مبني على نظرية التكامل الحسي في خفض السـلوك الانعزالـي لـى الأطفال التوحديين ـ المجلـة العلمبـة لكلبـة

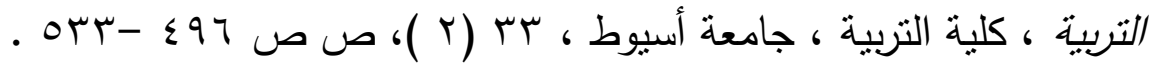

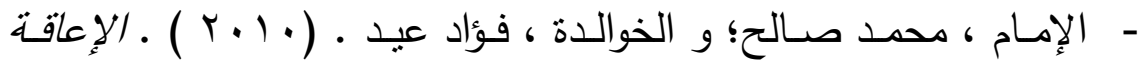
العقلبـة و مهارات الحباة في ضسوء نظربـة العقل " سلسـة نظربـة العقل في التربية الخاصنة ـ مج" ا " ـ الأردن : دار التقافة للنشر والتوزبع •

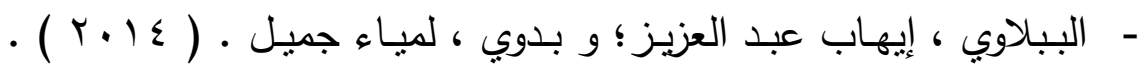
الإششاد النفسي في التربية الخاصة لذوي الإعاقات و الموهوبين ـالرباض : دار الزهراء للنشر و التوزيع • - بركات ، سري رشدي • ( ؟ ا ب ) ـ الإشاد النفسي لذوي الاحتباجات الخاصة • ط r ـ الرياض : دار الزهراء للنشر و التوزبع • - البهنساوي ، كمال؛ والحديبي ، مصطفى عبد المحسن • ( 17 . ( ) . فاعليـة برنـامج تدخل قائم علي التكامـل الحسـي في تتميـة التواصـل غير 
اللفظي للدى عينة من أطفال التوحد ـ المجلة العلمبية لكلبة التربية ، كلية

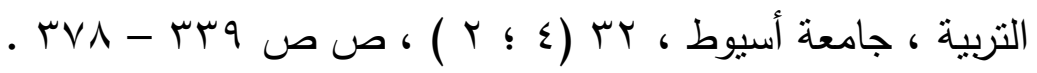

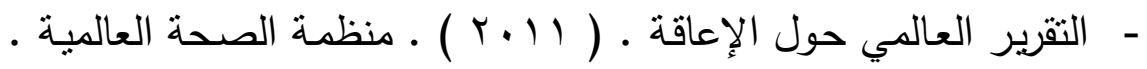
https:;www.who.int;disabilities;world_report;2011;report;

- الجهاز المركزي للتعبئة العامـة و الإحصـاء . ( 9 ( • ) ) . السكان : بحوث و دراسات . مجلة نصف سنوية ـ العدد 9^ . - الحديدي ، هناء تيسير حمد الله . ( ( . ب ) . مشكلات أسر الأطفال المعاقين عقلبًا من · : 11 سـنة - دراسـة علهى عبنـة مسن الأمهات فـي محافظة العاصدة . ( رسـالة ماجستير منشـورة ) . كليـة الدراسـات العليا .

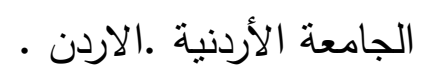
- الخطبـب ، جمـال؛ والحدبدي ، منـى · ( ع . • ) ) برنـامج تدربي للأطفال المعاقين. عمان : دار الفكر للطباعة والنشر والتوزيع • - خليفـة ، وليـد السـبد، أحمـد و عيسـى ، مـراد علـي • ( 10 . ب ) . الاتجاهـات الحدبثـة فـي مجـال التربيـة الخاصــة ( التخلـف العقلـي ) • الإسكندرية : دار الوفاء لدينا الطباعة و النشر . - الخميسي ، السبد سعد؛ وسليمان ، نبيل علي؛ والمطيري ، مريم راهي

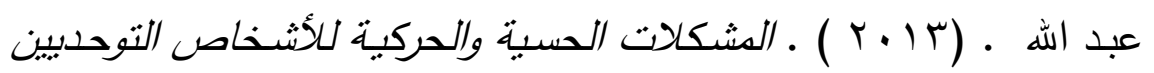
في دولة الكوبت : دراستة مسحبية . مجلة البحث العلدي في الآداب . كلية 
البنات للآداب و العلوم والتربية ، جامعة عين شمس ، ؛ ( ع ا ) ، ص ص $101-11 \mathrm{r}$

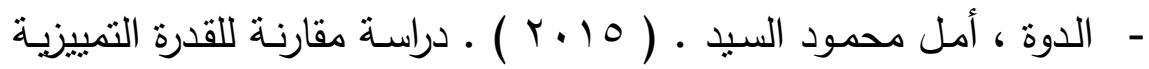
لاستبيان البروفيل الحسي ذي الأبعاد التسعة بين بعض فئات الأطفال ذوي الاضـطرابات النمائيـة ـ مجلـة كلبـة التربيـة ، كليـة التربيـة ، جامعـة عين شمس العدد . 1 ( qr ) . . ص ص - ربحاوي ، ليلي عبد الكربم • (Y. IV ) . المعالجـة الحسية المدخل الرئيسي لتنمية مهارات الطفل التوحدي • ورقة مقدمة إلى المؤتمر العلدي المهنـي العربـي: (تعلبم و دمـج ذوي الاحتباجـات الخاصــة ) الواقفع و المدارسة المهنبة ، المنيا ، مصر ، ص ص . ب : اب . - السبد ، السيد عبد النبي . ( ؟ . . ) : البرامج التربوبـة لطفل مـا قبل المدرسـة المتخلف عقلبـاً والقابـل للتعلم . مجلـة خطـوة ، المجلس العربـي للطفولة و التتمية ، جب ، ص ص •1 - 11 . - السبد ، عبير عثمان عبد النبي؛ و عبد الخالق ، شادية؛ و عبد الستار

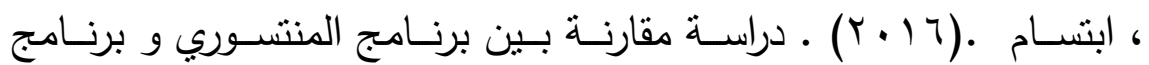
البورتاج في تتمية المهارات الاجتماعية لدى الأطفال المعاقين عقلياً . مجلة

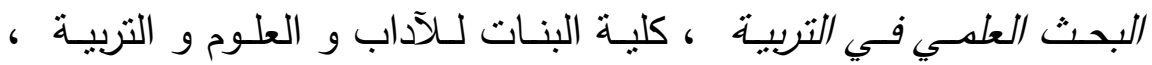

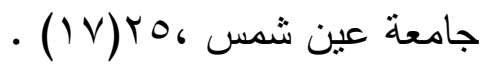


- الشربيني ، زكريا ـ ( ع . . F ) ـ طفل خاص بين الإعاقة و المتلازهات " تعريف تثخيص " ، القاهرة :دار الفكر العربي •

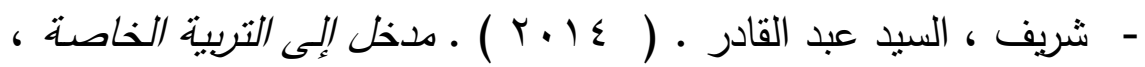
القاهرة : دار الجوهرة للنشر و التوزيع •

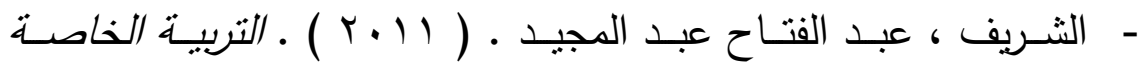
و برامجها العلاجية ـ القاهرة : مكتبة الأنجلو المصرية .

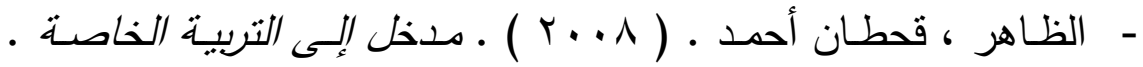

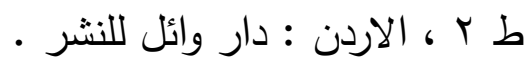

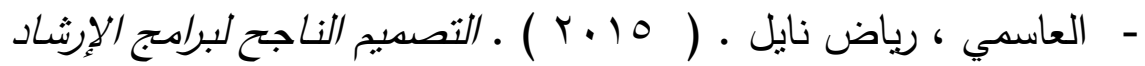

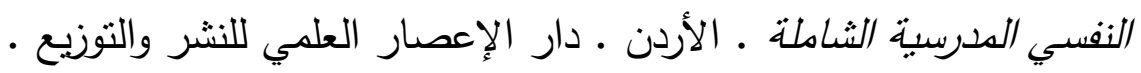
- عبد السميع ، عبد الموجود ـ (Y. V ) . مقباس ستانفورد - بينبيه لللكاء الصسورة الخامستة ـ القاهرة : المؤسسة العربية لإعداد وتقنين ونشر الاختبارات النفسية . - عبد العاطي ، حسن الباتع محمد؛ و شهاب إسراء رأفت محمد على •

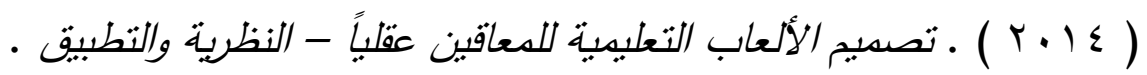
الإسكندربة ـ دار الجامعة الجديدة . - العتيبي ، علي سـليم • ( · · م ) ـ النشـاط الحسي الحركي كمدخل لتعديل لسـوك المضطرب لـدى الأطفال الدعاقين عقليًا القابلبن للتعلبيم بالمدلكتة العربية السعودية ( رسـالة ماجستنير منشورة ) معهد الدراسـات 
- ماهرة

a

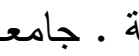

وث التربوب

والبح

.https;search.mandumah.com;Record;605097

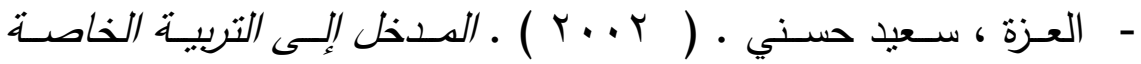
للأطفال ذوي الحاجات الخاصة (المفهوم - التشخيص - أساليب التنربس). ، الأردن : دار التقافـة للنشـر و التوزيـع و الـدار العلميـة الدوليـة للنشـر و

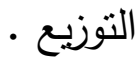

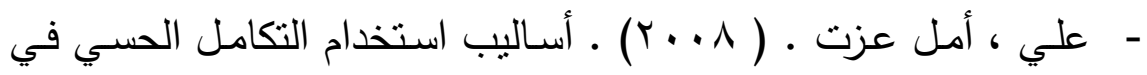
تتمية اللغة لدى الصم المكفوفين بحث مقدم إلى المؤتمر الدولي السادس. - تأهيـل ذوي الاحتياجـات الخاصــة. ( يوليـو، 1 ، . ب). رصــ الواقـع و استثــراق المسـتقبل ، معهـد الدراسـات التربويـة ، جامعـة القـاهرة ، ص

$$
\text { ص }
$$

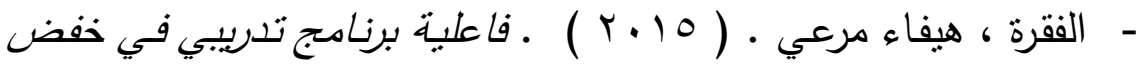
اضطراب التكامل الحسي ذي الاختلال الوظبفي لدى أطفال التوحد " دراستة تجربيبة في مراكز التربية الخاصسة " ( رسـالة ماجستير منشـورة ) ، كلبـة التربية ، جامعة دمثق ، سوربا .

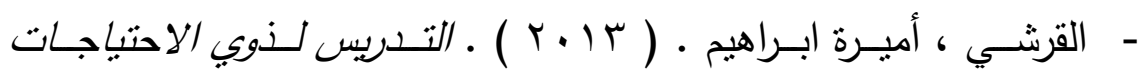
الخاصة بين التصديم و التنفبز . القاهرة :عالم الكتب .

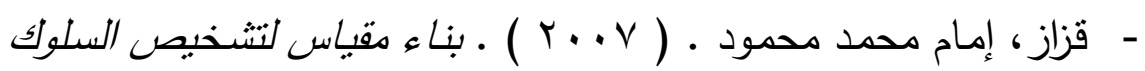
التوحدي والتحقف من فاعليته في عينـة أردنية من حالات التوحد و الإعافة 
العقليـة والعـادبين (رسـالة دكتـوراه منشـورة ) كليـة الدراسـات العليـا ،

$$
\text { الجامعة الأردنية ، الأردن. }
$$

- القطاونة ، وعد ابراهيم • ( 17 . r ) . مشكات أسر الأطفال المعاقبن عقلبًا في محافظة الكرك وأساليب التعامل المستخدمة معها وعاقتها ببعض المتغبرات ( رسـالة ماجستير منشـورة ) . عمـادة الدراسـات العليا . جامعـة

$$
\text { مؤنة الأردن }
$$

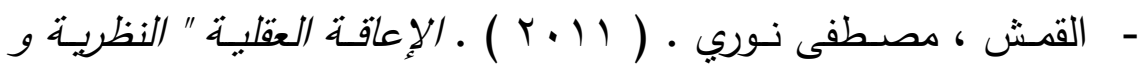
المدارسة " ـ الأردن : دار المسيرة للنشر والتوزيع والطباعة . - كفـافي ، عـلاء الـدين؛ وعـلاء الدين ، جهـاد .( ج . . r ) . موسـوعة النفس التأهيلي - المجلد الثالث : الإصـابات "سلسلة المراجع في التربية و علم النفس( گr : r ) " . القاهرة :دار الفكر العربي • - اللالا ، زياد كامل؛ والزبيري ، شريفة عبد الل؛ و اللالا ، صائب كامل؛ و الجلامدة ، فوزيـة عبد الله؛ وحسونة ، مـأمون محمد جميـ؛ والثـرمان وائل محمد و العلي ، وائل أمين ؛ و القبالي ، يحيى أحمد . (r ا . r ) . أساسـبات التربيـة الخاصــة . طب ، الأردن : دار المسيرة للنشـر والتوزيـع والطباعة .

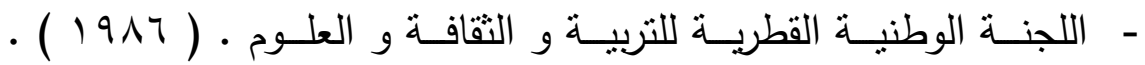
سيكولوجية الطفل وتربيته " الإدراك الحسي عند الأطفال" . مجلة التربية ،

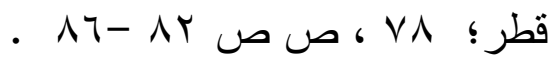




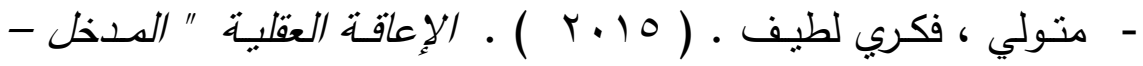
النظربات المفسرة - طرق الرعابة " ـ الرياض : مكتبة الرشد - ناشرون . - محمد ، عـادل عبد الله • ( ع . . ) ـ الإعاقات العقلبة " سلسلة ذوي الاحتياجات الخاصة - 1 " ـ القاهرة : دار الرشاد . - محمد ، عادل عبد الله . (1) ( I ) . مدخل إلى التربية الخاصسة " علم نفس ذوي الإعاقة و الموهبة. الرياض : دار الزهراء للنشر والتوزيع •

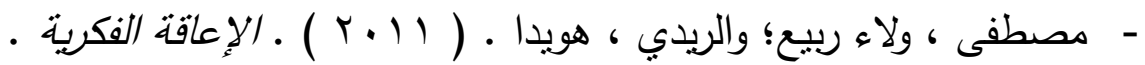
الرياض :دار الزهراء - (إ)

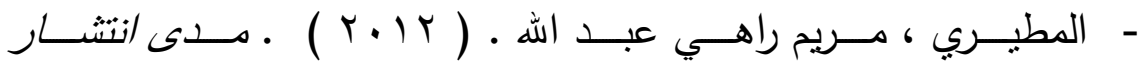
الاضطرابات الحسية والحركية و علاقتها ببعض المتغبرات الدبيوغرافية ل لدى الأشخاص التوحدبين في دولثة الكوبت ( رسالة ماجستير منشورة ) كلية الدراسات العليا ، جامعة الخليج العربي،البحرين •

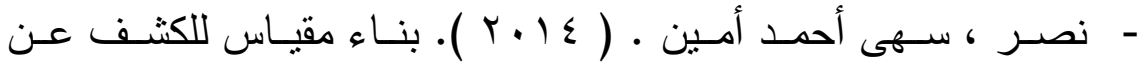
اضطرابات المعالجة الحسية والتحقق من فاعليتها في عينة من الأطفال العـاديين وذوي اضـطراب طيـف التوحـد و ذوي اضـطراب ضـعف الانتبـاه والنشاط الحركي المفرط ـ مجلة الطفولة و التربية ، كلية رباض الأطفال ، جامعة الإسكندرية ، 7 ( 9 ( ) ) ، ص ص

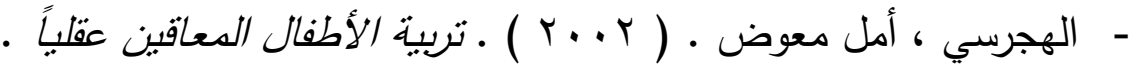
القاهرة : دار الفكر العربي • 
- البازوري ، محمد علي • ( r ( r ) ) الاضطرابات السلوكية للمعاقبن القابلين للتعلم و علافتها بأسـابب المعاملتة الوالديبة في قطاع غزة ( رسالة ماجستير منثورة ) ـ كلية التربية ـ الجامعة الإسلامية ـ غزة .

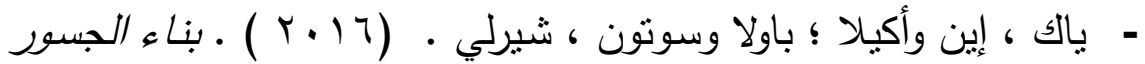

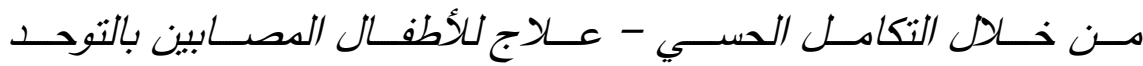
والاضطرابات النمائبة الثـاملة الأخىى (ترجهة : منبر زكربيا ، مراجعة : هشام الضلعان ) ، الرباض : مكتبـة الملك فهد الوطنبة ، ( تاربخ النشر

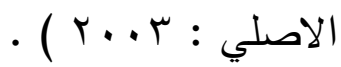
ثانيًَا: المراجع الأجنبية:

- Ahn , Roianne R. ; Miller , Lucy Jane ; Milberger Sharon \& N. McIntosh , Daniel . (2004) . Prevalence of parents' perceptions of sensory processing disorders among kindergarten children. American Journal of Occupational Therapy, 58 : 287-293 https:;doi.org;10.5014;ajot.58.3.287

- Auer, Christopher R. ; Blumberg, Susan L. . ( 2006 ) . Parenting A Child With Sensory Processing Disorder, A family Guide To Understanding \& Supporting Your Sensory - Sensitive Child . Calif : New Harbinger Publications.

https;archive.org;details;parentingchildwi00auer;page;n4 
- Ausderau , Karla ; Sideris , John ; Furlong , Melissa ; Lauren M. Little ; John Bulluck \& Grace T. Baranek . (2014) . National Survey of Sensory Features in Children with ASD " Factor Structure of the Sensory Experience Questionnaire (3.0). Journal of Autism and Developmental Disorders , 44 : 915-925 https:;idoi.org;10.1007;s10803-013-1945-1

- Ayres , A. Jean. ( 1972 ). Sensory integration and learning disorders, Los Angeles: Calif; Western Psychological Services.

https;archive.org;details;sensoryintegrati00ayre - Baranek , Grace . ( 1999 ) . Autism During Infancy: A Retrospective Video Analysis of Sensory-Motor and Social Behaviors at 9-12 Months of Age . Journal of Autism and Developmental Disorders , $29: 213$ - 224 https;doi.org;10.1023;A:1023080005650

- Baranek , Grace T. ; Chin , Yuki H ; Hess , Laura M. Greiss ; Yankee , Jann G. ; Hatton , Deborah D. \& . Hooper , Stephen R . ( 2002) . Sensory Processing Ccorrelates of Occupational Performance in Children with Fragile X syndrome: Preliminary findings . American Journal of Occupational Therapy , 56 ( 5 ) : $538-546$

- Blasi , Francesco D. Di ; Elia , Flaviana ; BuonoGer , Serafino ; Ramakers , J. A.\& Nuovo , Santo F. Di .(2007). Relationships between Visual-Motor and Cognitive Abilities in Intellectual Disabilities. Perceptual 


\section{and Motor Skills , 104 ( 3) : 763-772.}

https:;;doi.org;10.2466;pms.104.3.763-772

- Botha, Marica . ( 2015 ) . Evaluation Of The Tests Of Sensory Integration Function Used With Infants. Unpublished Master of Science in Occupational Therapy, Johannesburg University, USA .

- Brownlee, Fiona \& Munro , Lindsay . ( 2010 ) . Fuzzy Buzzy Groups for Children with Developmental and Sensory Processing Difficulties, A Step-by-Step Resource . London and Philadelphia: Jessica Kingsley Publishers.

- B . S , Christene Maas . ( 2010 ). Sensory Processing and Social Participation in Children with Autism Spectrum Disorders. Published Master Dissertation, Texas Woman's University . U S .

- Carvill , S.. ( 2001 ). Sensory impairments, intellectual disability and psychiatry. Journal of Intellectual Disability Research, 45 ( 6 ) : 467 - 483 . https:;;doi.org;10.1046;j.1365-2788.2001.00366.x

- Delaney, Tara . ( 2008 ). The Sensory Processing Disorder - Answer Book - Practical Answers to the Top 250 Questions Parents Ask . Naperville, Illinois : Source Book ,INC,

- Eeles, Abbey L .; Spitter, Alicia J . ; Anderson, Peter J .; Brown , Nisha ;Lee, Katherine J .\& Doyle , Lex w.( 2012 ). Assessments of Sensory Processing in Infants: A systematic Review . Development Medicine \& Child Neurology,55: 314:326. 
- Emmanuelle, Jasmin . (2007) . Impact of Sensory Responses And Motor Skills On Functional Skills In Activities Of Daily Living Of Pre-School Children With Autism Spectrum Disorders. (Unpublished Master study) . McGiII University, Montrea: 1 Canada

- Emmons , Polly Godwin \& Anderson , Liz Mckendry . ( 2005 ). Understanding Sensory Dvsfunction . London and Philadelphia : Jessica Kingsley publishers

- Galvin . Jane, Froude . Elspeth H., Imms . Christine . (2009) . Sensory Processing Abilities of Children who have Sustained Traumatic Brain Injuries. American Journal of Occupational Therapy, 63, 701:709.

- Garland , Teresa . (2014 ) . Self-Regulation Intervention And Strategies, Keeping The body, mind \& Emotions on Task in Children With Autism ADHD or Sensory Disorders . PESI publishing \& Media .

- Harrison, Laura A. ; Kats , Anastasiya ; Williams , Marian E. \& Zadeh , Lisa Aziz . ( 2019 ). The Importance of Sensory Processing in Mental Health: A Proposed Addition to the Research Domain Criteria $(R D o C)$ and Suggestions for RDoC 2.0 . Frontiers in Psychology,https;doi.org;10.3389;fpsyg.2019.00103

- Horowitz . Lynn \& Röst , Cecile . ( 2004 ) . Helping Hyperactive Kids -A Sensory Integration Approach " Techniques and Tips for Parents and Professionals" . USA : Hunter House Publishers .

- Kolacz , Jacek ; Raspa ,Melissa ; Heilman , Keri J. \& Porges , Stephen W. . ( 2018 ). Evaluating Sensory 
Processing in Fragile $\mathrm{X}$ Syndrome: Psychometric Analysis of the Brain Body Center Sensory Scales (BBCSS) , Journal of Autism and Developmental Disorders 48:2187-2202, https:;;link.springer.com;article;10.1007;s10803-0183491-3

- Kranowitz , Carol Stock ( 1998 ). The Out Of Syns Child, Recognizing And Coping With Sensory Integration Dysfunction, New York: Perigee Book. https;archive.org;details;outofsyncchildre00kran;page;28 - Kuhaneck , Miller Heather ; Henry , Diana. A ; Glennon ,Tara .J \& Mu ,Keli . (2007) . Development of the Sensory Processing Measure-School: Initial studies of reliability and validity. American Journal of Occupational Therapy . 61 ( 2 ) : 170-175. https;doi.org;10.5014;ajot.61.2.170

- Laia , Cynthia Y.Y. ; Chung , Jenny C.C. ; Chan , Chetwyn C.H. \& Li-Tsang, Cecilia W.P . (2011) . Sensory Processing Measure-HK Chinese version: Psychometric properties and pattern of response across environments. Research in Developmental Disabilities. ( 32 ) $6: 2636$ - 2643 . https;www.sciencedirect.com - Larkey, Sue . ( 2007 ) . Practical Sensory Programmes For Students With Autism Spectrum Disorder And Other Special Need. London and Philadelphia: Jessica Kingsley .

- Loidl , Verena ; Oberhauser , Cornelia ; Ballert , Carolina ; Coenen ,Michaela ; Cieza , Alarcos \& 
Sabariego, Carla . (2016) : Which Environmental Factors Have the Highest Impact on the Performance of People Experiencing Difficulties in Capacity? . International Journal of Environmental Research and Public Health, 13 (4 ), https;doi.org;10.3390;ijerph13040416 - Lonkar, Heather . ( 2014 ) . An Overview of Sensory Processing Disorder: Use of Sensory Integration Theory. Western Michigan University , U.S , http;scholarworks.wmich.edu

- Mauro , Terri . ( 2006 ). The Everything Parent's Guide To Sensory Integration Disorder, Get The Right Diagnosis, Understand Treatments, And Advocate For Your Child . Adams Media; Avon \& Mass Publisher :USA

https;archive.org;details; everythingparent0000maur;page; n5

- Metz, Alexia E .; Boling, Daniella ; DeVore, Ashley ; Holladay, Holly ; Liao, Jo Fu \& Vlutch, Karen Vander. (2019). Dunn's Model of Sensory Processing: An Investigation of the Axes of the Four-Quadrant Model in Healthy Adults. Brain Sciences, 9(2), 35. https;doi.org;10.3390; brainsci9020035

- Miller , Lucy Jane \& Fuller, Doris A. . ( 2006 ). Sensational Kids, Hope and Help For Children With Sensory Processing Disorder ( SPD) . New York : Penguin Group . http;www.help-curriculum.com;?p=1707 - Miller ,Lucy Jane ; Anzalone , Marie E. ; Lane, Shelly J.; Cermak , Sharon A.; Osten , Elizabeth T. (2007 ). 
Concept Evolution in Sensory Integration: A Proposed Nosology for Diagnosis. The American Journal of Occupational Therapy,

61(2).

https;doi.org;10.5014;ajot.61.2.135

- Noriuchi , Madoka ; Kikuchi , Yoshiaki ; Yoshiura , Takashi ; Kira , Ryutaro ; Shigeto , Hiroshi ; Hara , Toshiro ; Tobimatsug, Shozo ; Kamio , Yoko . ( 2010 ). Altered white matter fractional anisotropy and social impairment in children with autism spectrum disorder . Brain Research . $1362 \quad$ (29) ,141-149 https;doi.org;10.1016;j.brainres.2010.09.051

- Owen. Julia P, Marco . Elysa J , Desai . Shivani, Fourie . Emily, Harris . Julia, Hill . Susanna S , Arnett . Anne, Mukherjee . Pratik . ( 2013 ). Abnormal white matter microstructure in children with sensory processing disorders. NeuroImage: Clinical. 2 ( 844-853) https;www.sciencedirect.com;science; article;pii;S221315 8213000776

- Pollock , Nancy . (2006) . Sensory Integration. Can Child Center for Childhood. Disability Research .

- Reynolds, Christopher \& Reynolds , Kathleen Sheena . ( 2010 ). The Effectiveness of Sensory Integration Therapy on Neuro-Physiological Development . The British Institute for Learning Development, Dubai : UAE , https;eric.ed.gov;?id=ED510594

- Reebye , Pratibha \& Stalker, Aileen . ( 2008 ). Understanding Regulation Disorders of Sensory Processing in Children. Philadelphia : Jessica Kingsley. 
- Robles , Ruth Pe'rez- ; Jane , Ma Claustre ; Doval, Eduardo ; da Silva , Pedro Caldeira ; Papoila , Ana Luisa \& Virella , Daniel . ( 2013 ). The Role of Sensory Modulation Deficits and Behavioral Symptoms in a Diagnosis for Early Childhood . Child Psychiatry \& Human Development, 44(3):400-411https; link.springer.com;article;10.1007;s10578-012-0334-x. - Roley , Susanne Smith ; Mailloux, Zoe ; Parham L. Diane ; Schaaf, Roseann C. ; Lane, Christianne Joy \& Cermak, Sharon . (2014) . Sensory integration and praxis patterns in children with autism. American Journal of Occupational Therapy.

https;ajot.aota.org; article. aspx? articleid $=2087152$

- Saad, Mourad Ali Eissa \& ElAdl, Adel M. ( 2019 ) . Defining And Determining Intellectual Disability Intellectual Developmental Disorder ) - Insights From DSM-5 . International Journal of Psycho-Educational Sciences , 8 ( 5 ) $)$ : 51 - 54 . https;eric.ed.gov;?id=ED594326

-Schaaf, Roseann \& Miller ,Lucy Jane . ( 2005 ). Occupational therapy using a Sensory Integrative Approach for Children with Developmental Disabilities . Mental retardation and developmental disabilities research reviews , 56(5) 538 - 546 https;doi.org;10.1002;mrdd.20067

-Sher, Barbara . ( 2009 ). Early Intervention Games, Fun, Joyful Ways to Develop Social and Motor Skills in 
Children with Autism Spectrum or Sensory Processing Disorders, San Francisco : Jossey-Bass A Wiley Imprint. -S ,Reynolds (2008). Sensory Integration \& School Success, Making Sense Of sensory Integration . US : Alamy magazine .

- Schaaf , Roseann C . ; Miller, Lucy Jane ; Seawell, Duncan \& O. Keefe , Shannon . (2003) . Children with disturbances in sensory processing: A pilot study examining the role of the parasympathetic nervous system. American Journal of Occupational Therapy. 57 : 442-449

https;ajot.aota.org; article.aspx ?articleid=1869400

- Taylor , Nicole . ( 2016 ) . Associations between Sensory Issues Mealtime Behaviours, and Food and Nutrient Intakes in Children with Autism Spectrum Disorder . ( Unpublished Master study ), Massey University, Albany. New Zealand

- Tekinarslan, Ilknur Cifci ; Pinar, Elif Sazak \& Sucuoglu , Bulbin . (2012 ) . Teachers' and Mothers' Assessment of Social Skills of Students with Mental Retardation. Educational Sciences: Theory and Practice, 12 ( 4 ) : 2783-2788 . https:;;eric.ed.gov;?id=EJ1002875

- Tomchek, Scott .D \& Dunn, Winnie . (2007 ) . Sensory processing in children with and without autism: A comparative study using the Short Sensory Profile. American Journal of Occupational Therapy, 61, 190-200 https;ajot.aota.org;article.aspx?articleid=1866937 
-Uljarević , Mirko . ( 2013 ). Repetitive Behaviours, Anxiety and Sensory Problems in Children with Autism and Correlates of Anxiety in their Parents. (Published Doctor Dissertation, Cardiff University), Wales, U.K . - Watling, Renee L. ; Deitz , Jean \& White ,Owen . ( 2001 ) . Comparison of Sensory Profile Scores of Young Children With and Without Autism Spectrum Disorders. American Journal of Occupational Therapy, 55: $\quad 416-423$.

;ajot.aota.org; article.aspx?articleid $=1869016$

- Wuang, Y.P ; Wang, C.-C. ; Huang, M.-H. \& Su , C.-Y.. ( 2008 ) . Profiles and cognitive predictors of motor functions among early school-age children with mild intellectual disabilities. Journal of Intellectual Disability Research, 52 (12) : 1048-1060 https:;;doi.org;10.1111;j.1365-2788.2008.01096.x.

-Zavesky , Karin Susanne . ( 2011 ). Störungen der sensorischen Integration Teille is tungss chwächen Auswirkungen auf die Persön lichkeit sentwicklung und integrativ-therapeutische Intervention. (Published Master Dissertation), Wien University, Wien. https;nanopdf.com;download;universitt-wien-4_pdf -Zyl ,Elsie Wilhelmina van . ( 2011 ) . Exploring Who Gestalt Play Therapists Establish Sensory Contact With Children Who Have Sensory Integration disorder. (Published Master Dissertation), South African Universit 


\section{فاعلية برنامج قائم على طريقة المشروع في تنمية عملية} الإستنتاج للمعاقين ذهنياً المدمجين برياض الأطفال * أ. أد/ / إبراهيم محمد شعير.

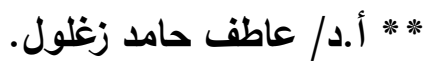

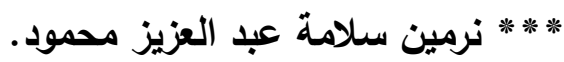

\section{ملخص البحث :}

يهدف البحث إلى الكثف عن فاعلية برنامج قائم على طريقة المشروع

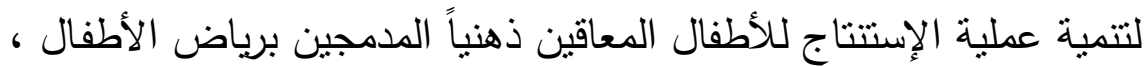

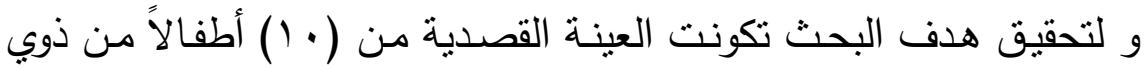
الإعاقة الذهنية المدمجين بروضـات محافظة بورسعيد من خـال ( اختبار ستانفورد بينيه ) ، وتطبيق الأدوات التالية وهي ( الاختبار المصور لعملية الإسـتنتاج للأطفـال المعـاقين ذهنيـاً المـدمجين بريـاض الأطفال ( إعداد/ الباحثة ) ، برنامج أنشطة لتتمية عملية الإستتناج للأطفال المعاقين ذهنياً المدمجين برياض الأطفال طريقة المشروع ( إعداد/ الباحثة )، وعولجت البيانـات باستخدام اختبار ويلكوكسون اللابـارامنري ومقارنـة متوسطي رتب

* أستاذ المناهج وطرق التدريس-كلية التربية- جامعة المنصورة.

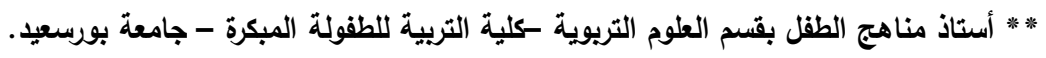
*** * باحثة دكتوراه بقسم العلوم التربوية -كلية التربية للطفولة المبكرة - جامعة بورسعيد. 
درجـات الأطفال بـين التطبيقين القبلي والبعدي على الاختبـار المصـور للإسـتنتاج ، وأظهرت النتائج فاعليـة البرنـامج القائم على طريقة المشـروع لتتمية عملية الإستتناج للأطفال المعاقين ذهنياً المدمجين برياض الأطفال ، وأوصى البحث بتضمين طريقة المشروع في جميع الأنشطة المقدمة للطفل ذوي الإعاقـة الذهنيـة البسبطة المدمجين بريـاض الأطفال؛ لأنها تزيد مـن

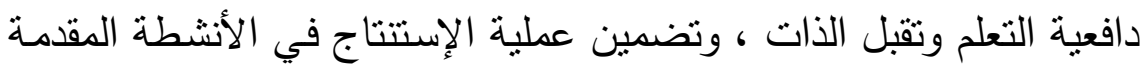
للطفل ذوي الإعاقة الذهنية المدمجين برياض الأطفال .

The effectiveness of a program based on the project method in developing the reasoning process for the mentally handicapped Integrated into kindergarten

Prof.Dr/ Ibrahim Mohammed Shoair. *

Prof.Dr / Atef Hamed Zaghloul. **

Nermin Salama Abdel Aziz Mahmoud. ***

\section{Abstract:}

The research aims to reveal the effectiveness of a program based on the project method for developing the deduction process for mentally handicapped children who are integrated into kindergartens, and to achieve the goal

* Professor of Curricula and Teaching Methods - Faculty of Education Mansoura University.

** Professor of Child Curriculum, Department of Educational Sciences, Faculty of Education Early Childhood - Port Said University. *** Researcher, Department of Educational Sciences - Faculty of Early Childhood Education - Port Said University. 
of the research, the intended sample consisted of (10) children with intellectual disabilities who were integrated into the Kindergartens of Port Said Governorate through (the Stanford-Binet test), and the application of tools The following (illustrated test of the reasoning process for mentally handicapped children integrated into kindergarten (the researcher's preparation), a program of activities for developing the inference process for mentally handicapped children who are integrated into kindergartens. And the post on the visual test of the conclusion, and the results showed the effectiveness of the program based on the project method for developing the deduction process for mentally handicapped children who are integrated into kindergarten, and the research recommended including the project method in all activities provided to the child with mild intellectual disability integrated in kindergarten because it increases learning motivation and self-acceptance And the inclusion of the deduction process in the activities provided for the child with disabilities Intellectual disability integrated into kindergarten.

الكلمات المفتاحية Keywords:

Inferring Process

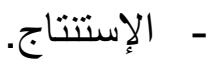
- المعاقين ذهنياً القابلين للتعلم. - - - الدمج التربوي برياض الأطفال. Educational inclusion in kindergarten

Project method

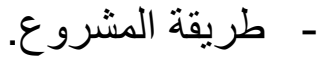


تعد الإعاقة الذهنيـة من الإعاقات النمائيـة التي تؤئز على الطفل في

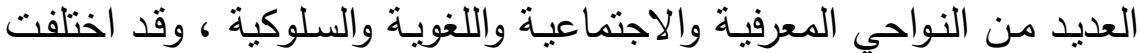

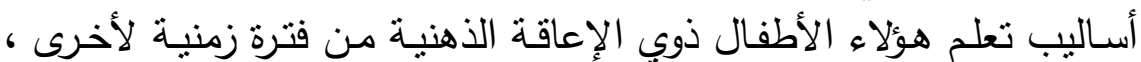

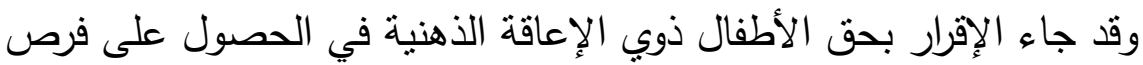

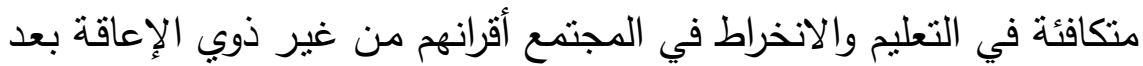

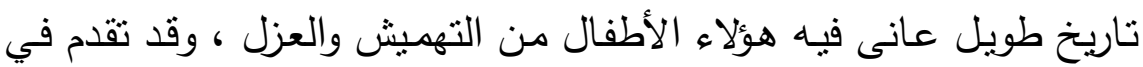

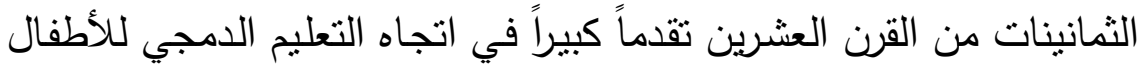

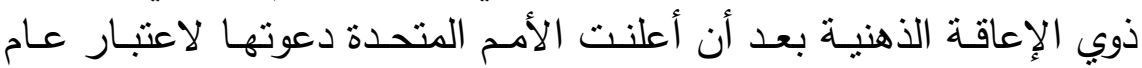

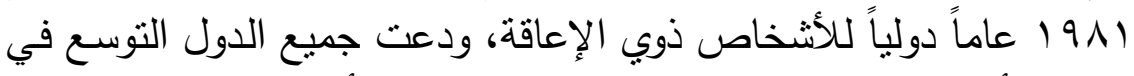
برامج التأهيل من جهة وتحديثها وتطويرها من جهة أخرى.

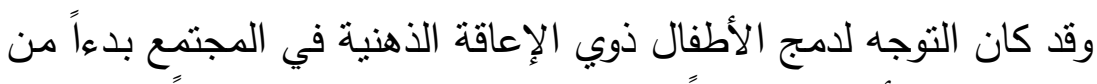

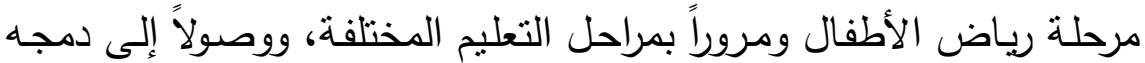

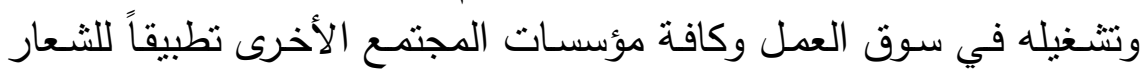

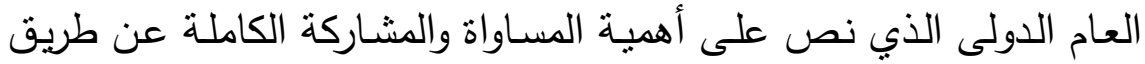

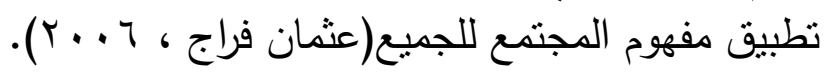

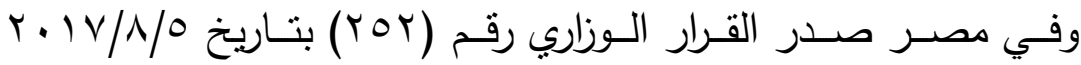

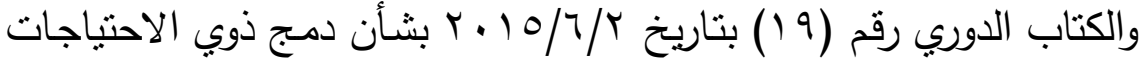

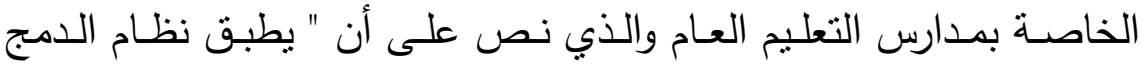

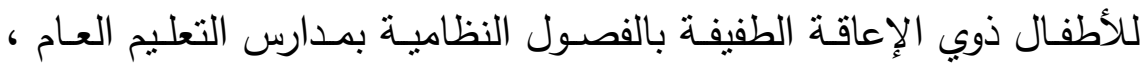

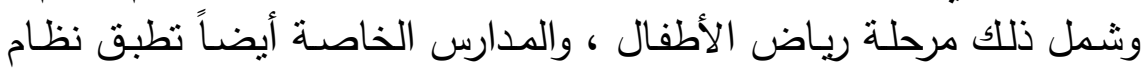

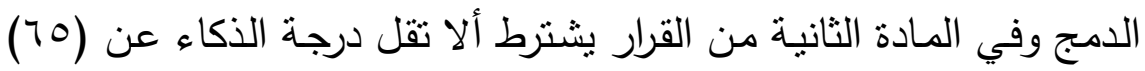
بمقياس ستانفورد بينيه ولا تزيد عن (عـد) على نفس المقياس مـع مراعاة 
الصحة النفسية للطفل وبما يتوافق مع نتائج المقياس التكيفي المناسب للدمج

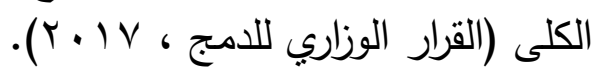

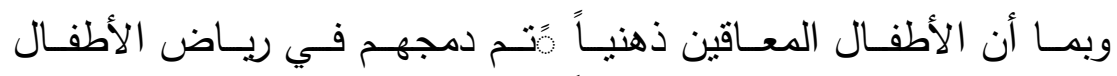

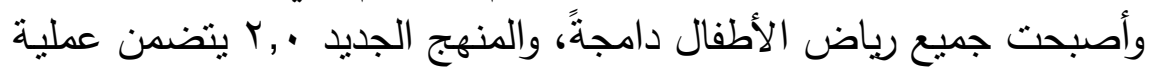

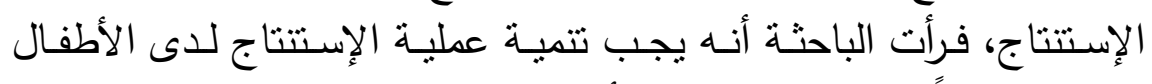

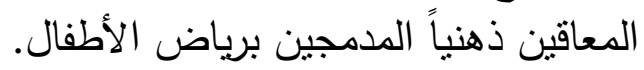

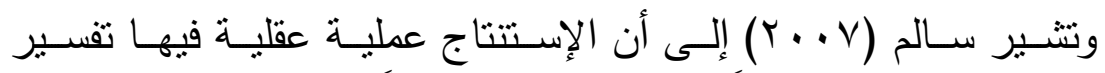

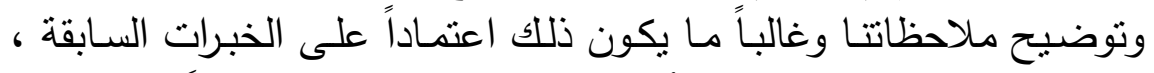
كما نشير بعض الأدبيات إلى أن تعليم الأطفال المعاقين ذهنياً يثبه تعليم

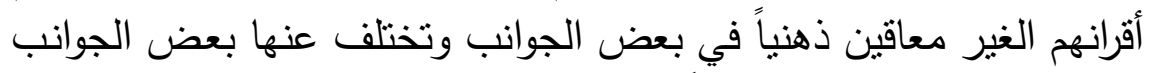
الأخرى ، فالطفل المعاق ذهنياً له نفس حاجات الطفل غير المعاق ، ويتعلم وبكتسب الخبرات والمعلومات تدربجيا وبختلف أيضاً الطفل المعاق ذهنياً في

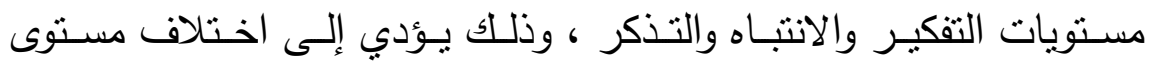
العمليات المعرفية التي يتعلمها ، فيتعلم العمليات البسيطة التي تحتاج إلى في

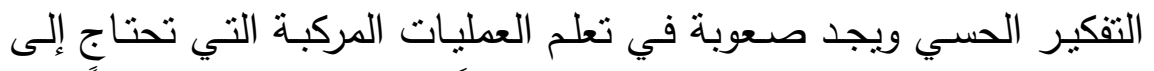
تفكيرٍ مجردٍ ، لذلك توجد طرق تعليم خاصـةً للأطفال المعاقين ذهنياً وفق

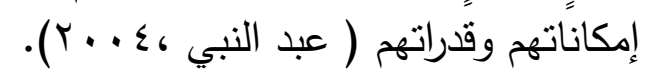

تعد طربقة المشروع واحدة من الطرق التربوبة المعاصرة في مجال تربية

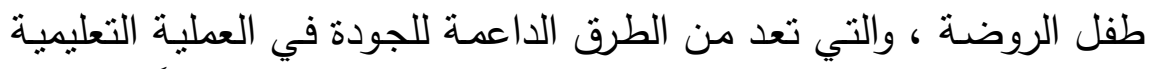

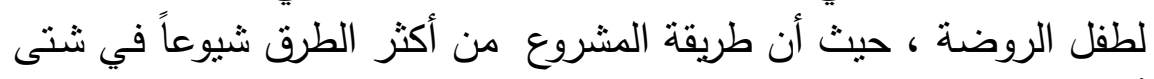

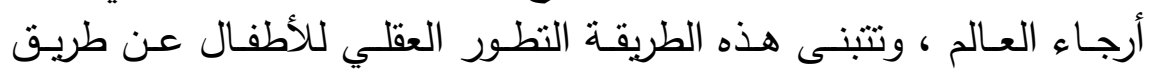

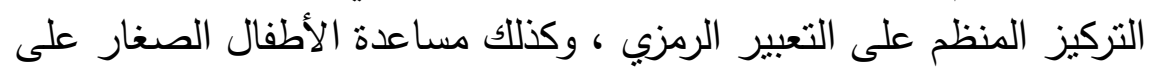

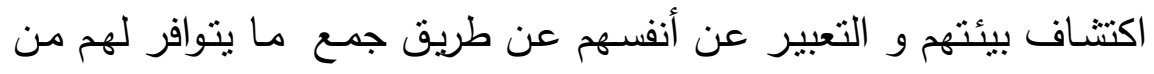


طرق التعبير والاتصال واللغات المعرفية ، أياً ما كانت هذه الطرق: كلمات

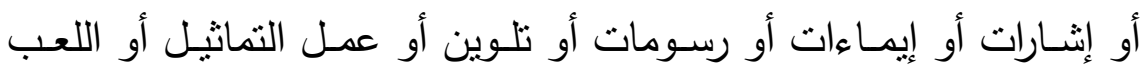

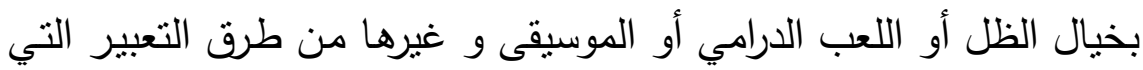

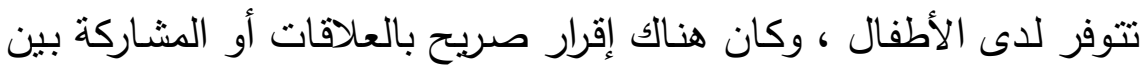

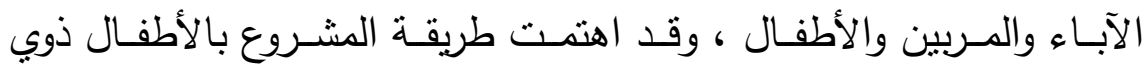

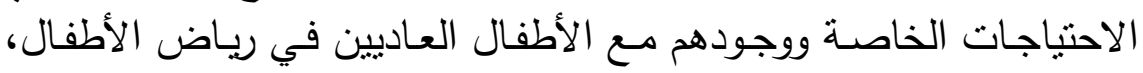
ولذلك فقد قامت الباحثة باختيار طريقة المشروع في البحث التالي لإمكانية تطبيقها مع الأطفال المدمجين.

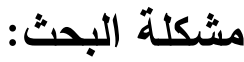

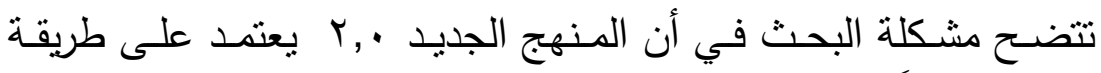

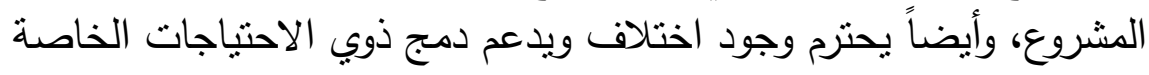

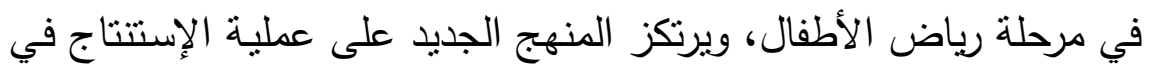

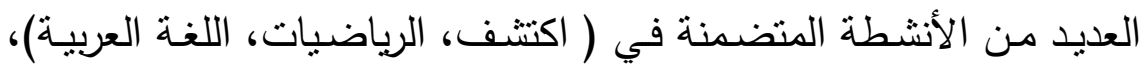

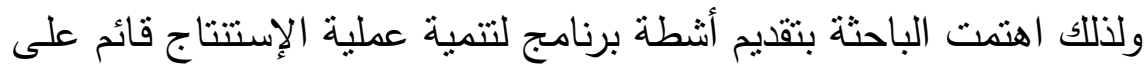
طريقة المشروع وهذا البرنامج مناسب لقدراتهم وإمكاناتهم. وتوجد بعض المؤشرات العلمية التي تؤكد على أهميـة الاهتمـام بتتمية

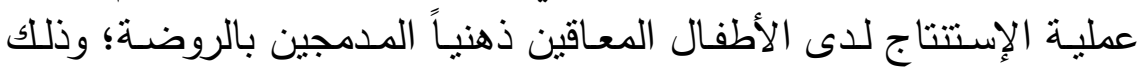

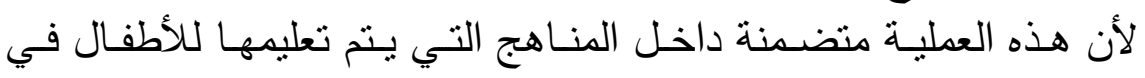

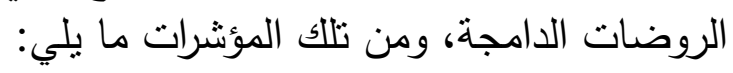

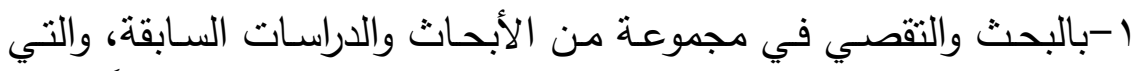

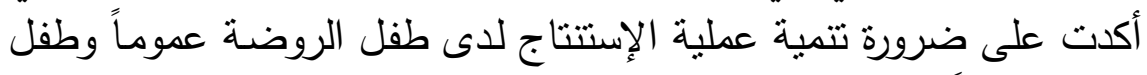

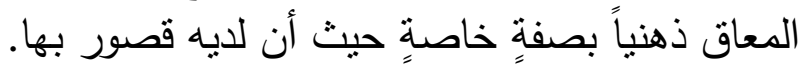




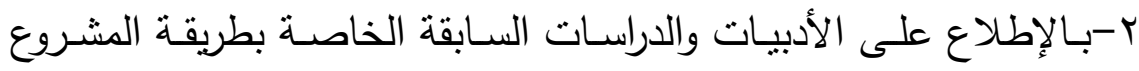

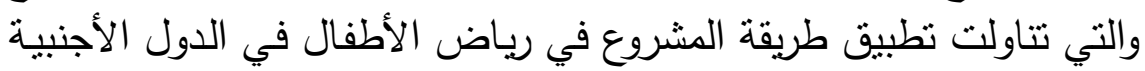

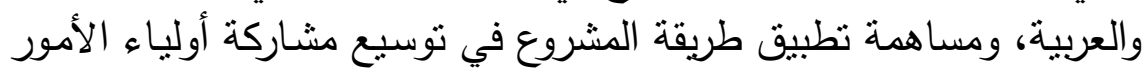
في العملية التعليمية لأبنائهم. ب-بالإطلاع على الأدبيات والدراسات السابقة والتي تتاولت التهات الدمج وأهميته

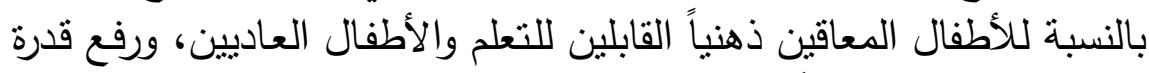

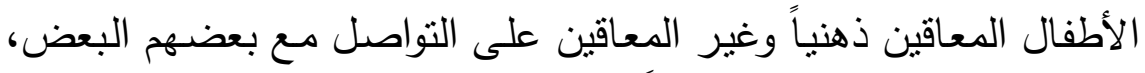

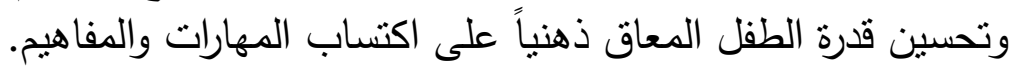

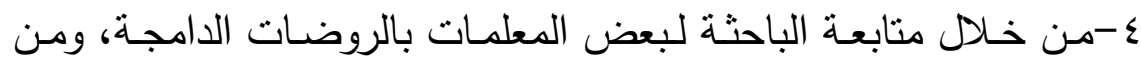

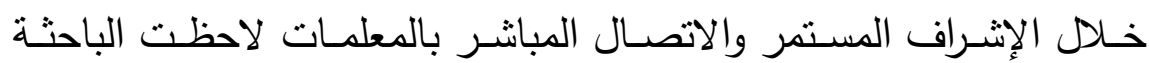

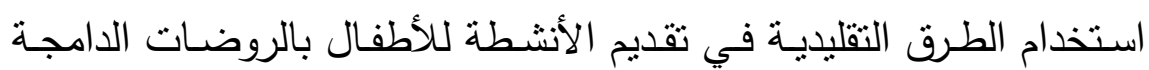

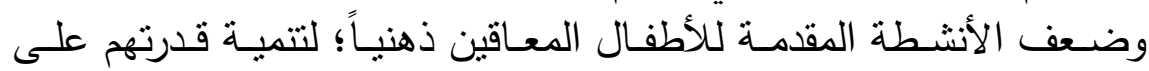
التحصبل الأكاديمي و قلة المعلومات لدى المعلمات عن الطرق المنات المناسبة لتقديم الأنشطة للأطفال المدمجين.

وقد لاحظت الباحثة ندرة الدراسـات التي اهتمت بتتمية عملية الإستتناج

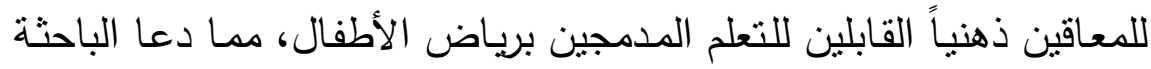
إلى النطرق لموضوع البحث. وتتحدد مشكلة البحث في الإجابة على السؤال الرئيس التالي: ما فاعلية برنامج قائم طريقة في تنمية عملية الإستتتاج للأطفال المعاقين ذهنياً المدمجين في رياض الأطفال ؟ ويتفرع من السؤال الرئيس عدداً من الأسئلة الفرعية وهي:

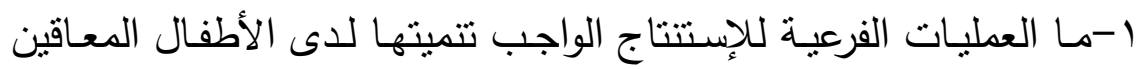
ذهنياً المدمجين في رياض الأطفال 
r-مـا أنشـة البرنـامج المقترح القـائم على طربقة المشـروع لتنميـة عمليـة

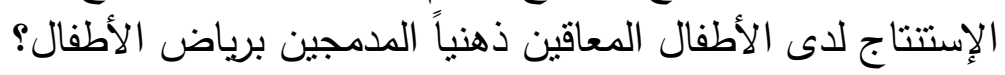

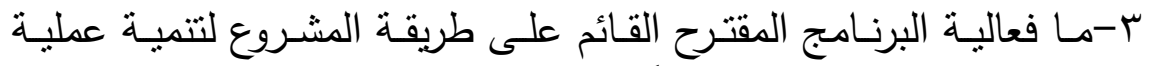
الإستتاج للأطفال المعاقين ذهنياً المدمجين برباض الأطفال؟ أهداف البحث: يهذف البحث الحالى إلى ما بلي: "الكثف عن فعالية طريقة المشروع في تتميـة عملية الإستتناج للأطفال

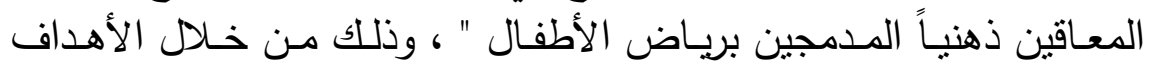
الفرعية التالية:

ا-إعداد قائمسة بالعمليـات الفرعيـة للإِــتتناج التي يجب تتميتهـا للأطفال المعاقين ذهنياً المدمجين في الروضدة. باعيات. ب-إعداد اختبـار مصـور لقياس عمليـة الإستتناج للأطفال المعـاقين ذهنياً المدمجين في الروضة. ب-تصـميم مجموعـة مـن الأنشـة لتنميـة عمليـة الإسـتنتاج لـدى الأطفـال المعاقين ذهنياً المدمجين بالروضة باستخدام طريقة المشروع.

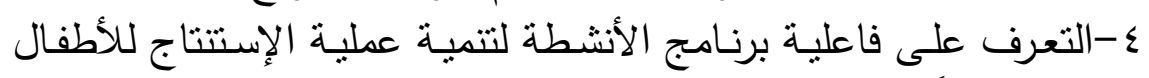
المعاقين ذهنياً المدمجين بالروضئ. أهمية البحث: أولاً: الأهمية النظرية:

ا-تقيد مخططي المناهج بمرحلة رياض الأطفال في إعداد أنشطة تعليمبة للأطفال ذوي الإعاقة الذهنية المدمجين في رياض الأطفال. 
ץ-تحديد عمليات الإستتناج الفرعية التي يمكن تتميتها للطفل المعاق ذهنياً المدمج في رياض الأطفال. ب-قد يسـهم هذا البحث في تبصير معلمات رياض الأطفال بأهمية تتمية

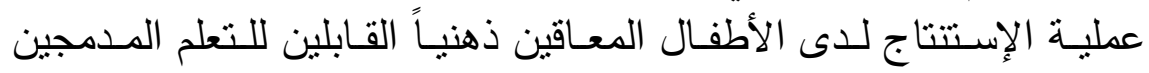
بالروضة. ع-قد يسهم البحث بالقاء الضـوء على طريقة المشروع وامكانية تطبيقه في رباض الأطفال الدامجة. ه-قلة عدد الدراسات التي أجريت في مجال الأطفال المعاقين ذهنياً لتتميـة

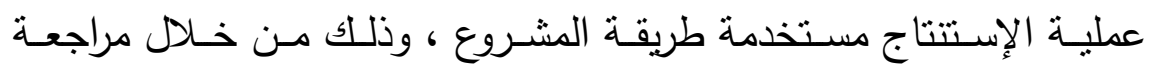

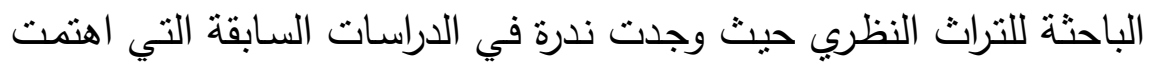
بموضوع البحث ، وذلك في حدود علم الباحثة.

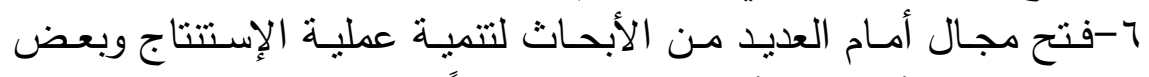
عمليات العلم الأساسية للأطفال المعاقين ذهنياً المدمجين. ثانياً: الأهمبة التطبيقية :

ا-تقديم برنامج أنشطة لتتميـة عمليـة الإستتناج في ضوء استخدام طريقة المشروع لأطفال المعاقين ذهنياً المدمجين برياض الأطفال. ب-قد تقيد نتائج البحث بعض مخططي ومؤلفي المناهج للأطفال المعاقين

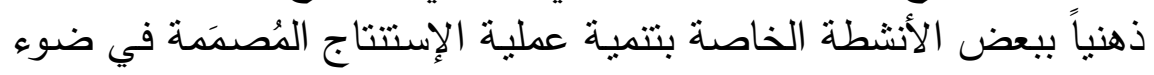
طريقة المشروع. ب-قد تقيد نتائج البحث بعض أخصـائي ومعلمي المعـاقين ذهنيـاً بكيفيـة

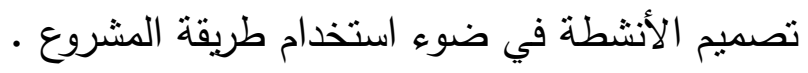


التزم البحث الحالي بالحدود التالية:

-الحدود البثرية: تم التوصل إلى عينة البحث من خلال تحديد الأطفال

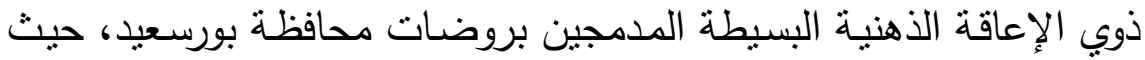

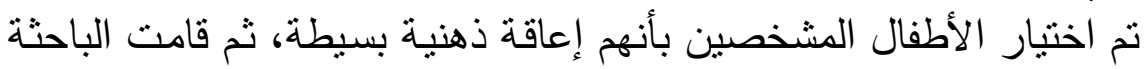

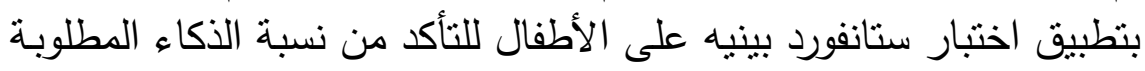

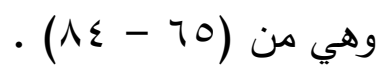

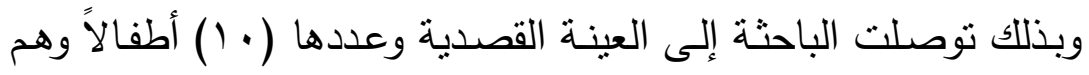

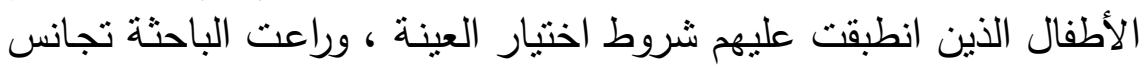

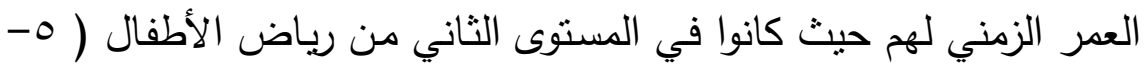

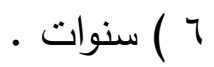

-الحدود المكانيـة: تم تطبيق البحث على الأطفال المعاقين ذهنياً القابلين

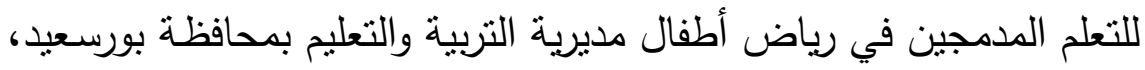

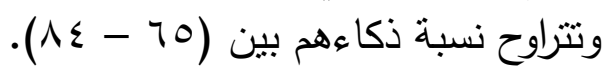

-الحدود الزمنية: بدأت التجربة من منتصف شهر سبتمبر واستمرت لمدة

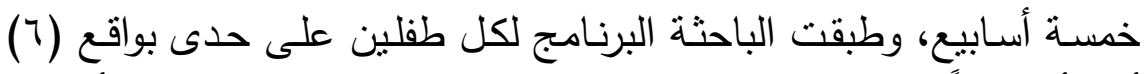

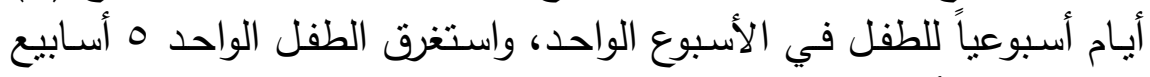

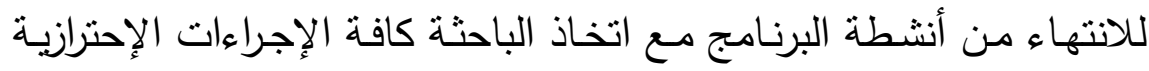
للحفاظ على سلامة الأطفال. فروض البحث : 1-توجد فروق ذات دلالـة إحصـائية عند مستوى (0. . •) بين متوسطي

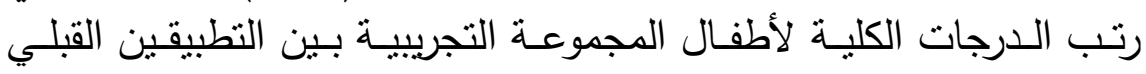


والبعـدي على اختبـار عمليـة الإسـتتناج المصـور للأطفـال ذوي الإعاقـة الذهنية المدمجين برياض الأطفال لصالح التطبيق البعدي.

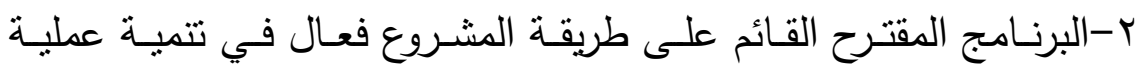

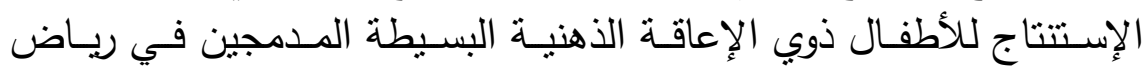
- الأطفال الإنسل

$$
\text { أ- عصلية الإستنتات البحث: }
$$

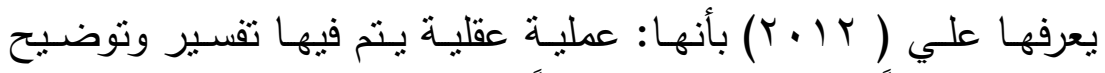
ملاحظاتتا وغالباً مـا يكون ذلك اعتمـاداً على خبرتتا السـابقة ، فالمالاحظـة خبرة يستدل عليها من الحواس، ثم يأتي الإستتناج ليفسر هذه الملاحظة فإذا قربنـا قطعـة معدنيـة مسن بعض الـبابيس انجذبـت القطعـة المعدنيـة، فإنتـا

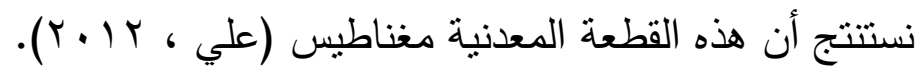

$$
\text { ب- المعاقين ذهنياً: }
$$

وبعرفها كله من كوافحة ، عبد العزبز (ب . . ب) المعاقين ذهنباً القابلين

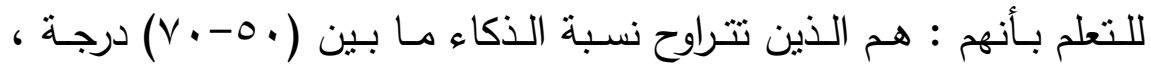

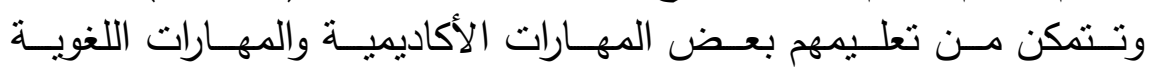
والاجتماعبـة والإستفادة من المنـاهج التعليميـة العاديـة، ولكن عمليـة تقدمهم تكون بطيئةً مقارنةً مع الأطفال العادينة ولين. ج- الامجج برياض الأطفال:

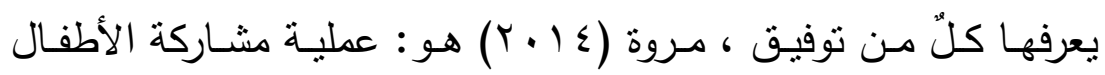

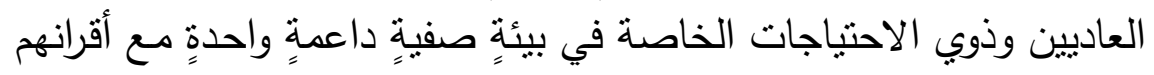


العاديين ، وتلبيـة احتياجـات الجميع التربوبـة والاجتماعية بمـا يتتاسـب مـع قدراتهم و إمكاناتهم.

وتعرف الباحثة الدمهج إجرائياً بأنـه: قضـاء الأطفال ذوي الإعاقة الذهنية

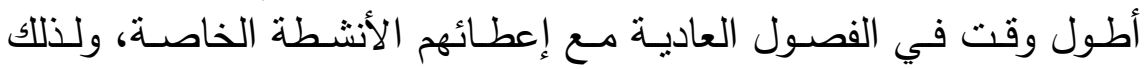
يستوجب وجود غرف مصسادر من أجل تقديم أنشطة مخصصسة للأطفال المعاقين ذهنياً تثري قدراتهم وإمكاناتهم.

\section{د- طريقة المشروع:}

وعرفه إتزيريوجيو المشروع على أنه: بحث متعمق يقوم به الأطفال حول

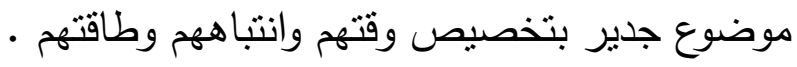

(Hadzigeorgiou , Yannis,2013,p373)

الإطار النظري والدراسات السابقة : المحور الأول: طريقة المشروع :

عـرف كـلارك المشـروع على أنسه : " استكثــافات أو أبحـاث متعمقة يشارك خلالها الطفل في تصميم وفحص الأنشطة التي نشكل مكوناً نهائياً • " (Clark, Marie,2006,p2) تكثف معلومات لأحداثٍ معينة وعرف أبرسكاتو المشروع على أنه :" عملية متعمقة طويلة الأجل لسمات

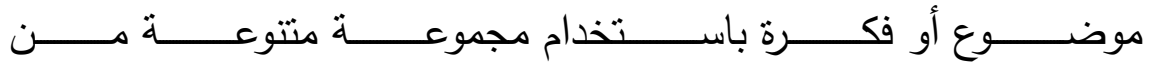

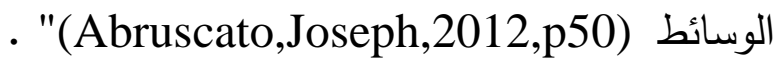
أهمبة المشروع:

تتضـح أهميـة المثـروع في تتميـة عمليـات العلـم الأساسـية بمرحلـة الطفولة المبكرة ، حيث تتاسب طربقة المشروع تتمية عمليات العلم الأساسية 
وتتــع طريقة المشـروع الأطفال على صـياغة الأسئلة واكتشـاف الحلـول

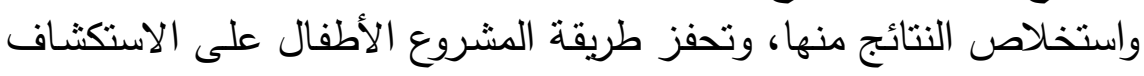
والتعلم بطريقتهم الخاصة و تتمية مهاراتهم.

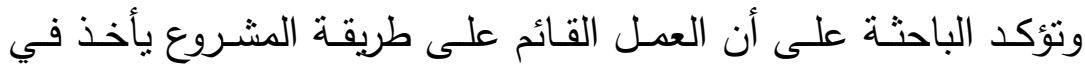

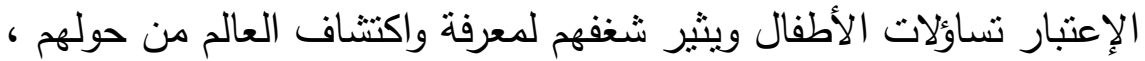

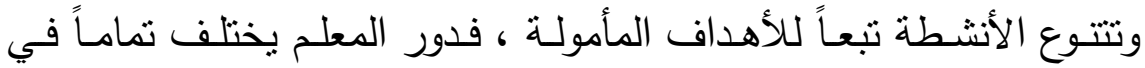

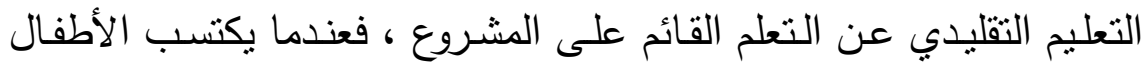

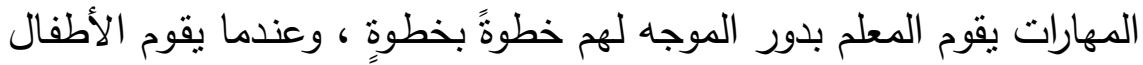

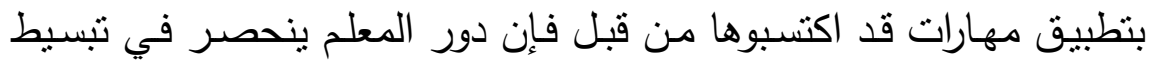
العمل فيشعر الطفل باختلافٍ كبيرٍ و استقلاليةٍ تامةٍٍ.

وتقدم طريقة المشروع الدوافع للطفل للتعلم الذاتي ، فعندما تتفذ المعلمات

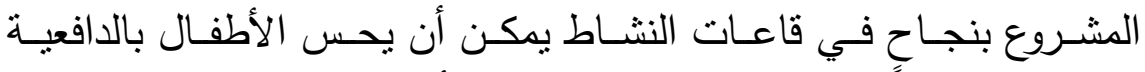
والنشاط للمساهمة النشطة في تعلمهح و إنتاج أعمال تعليمية عالية الجودة . (Opper,Sylvia,2010,p60)

حيث يعتمد المشروع على النظرية البنائية ، فالمشروعات تتيح للأطفال الفرص العديدة لبناء واكتسـاب المعرفة، والمعلومات، والمفاهيم من خـلال

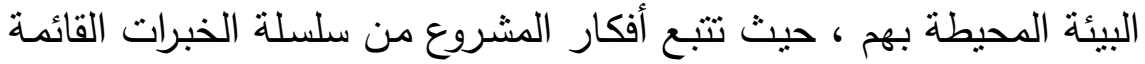

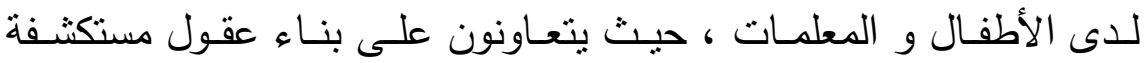
• للطفل (Tellis,Winston,2007,p30)

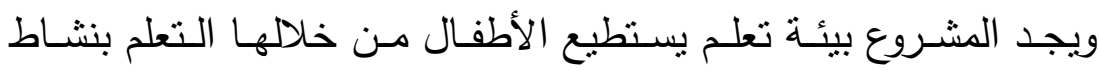

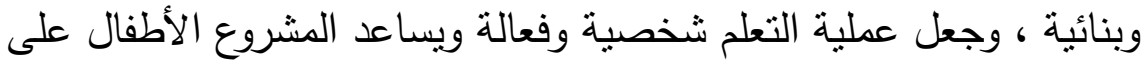
التميز في قدرتهم الطبيعية على بناء معرفتهم . 


\section{خصائص طريقة المشروع:}

حدد ليكينيـان وإدواردز الخصـائص الرئيسية لطريقـة المشـروع والتـي

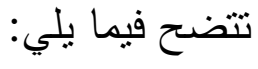
1-إناحة الفرصة للأطفال لممارسة مهاراتهم. r-التركيز على إمكانيات وقدرات الأطفال. ب-التركيز على الدوافع الأساسية للطفل. ع-تشجيع الأطفال على تحديد ما يرغبون العمل بـأه كخبراء يمكنهم تحديد إحتياجاتهم.(Leekenan,Debbie,Edwards,Carolyn,2009,p67)

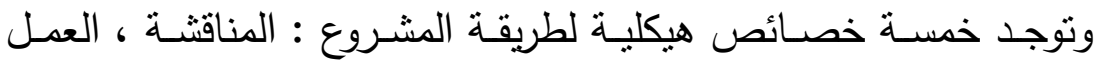

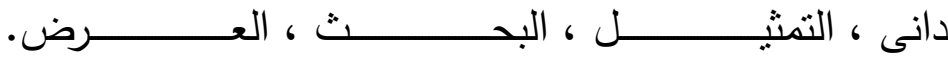

(Kartz,Lilian,Chard,Sylvia,2000,pp5-8) ولخص كريستسن،فيث، واطسن الخصائص العامة لطريقة المشروع فيما يلي:

-التمحور حول المشكلات مع التركيز على المهارات المعرفية. -بناء بيئة تعلم تركز على الطفل من خلال استعمال المجموعات الصنغيرة والتعلم النشط. -التركيز على إنماء المهارات والدوافع وحب التعلم. (Christensen,Lois,Faith,Cheri,Watson,2008,pp10-17) مراحل العمل في طريقة المشروع:

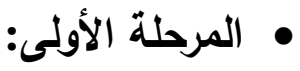

في بداية المشروع يكون دور المعلمة الرئيسي اكتشاف ما لداف كل فئ فرد

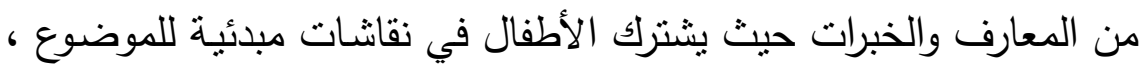
ويقدمون أفكارهم وخبراتهم المرتبطة بالموضوع المبت ، ويرسمون ويلونون ويكتبون فئن 
ويمثلون هذه الخبرات المتعلقة بالدراسة ، ومن ثم يكتسب الأطفال أساسيات الموضوع ويفهمونه فهماً مبدئياً من خلال عرض تجاربهم الخاصة ومشاركة

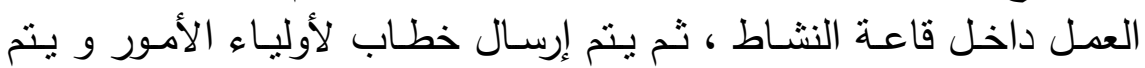

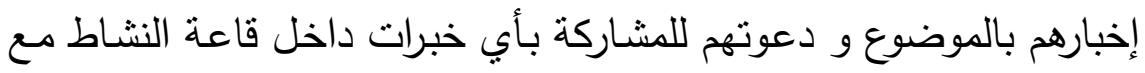
الأطفال، ومن خلال المرحلة الأولى للمشروع يتم تجميع الأسئلة التي يرغب دوفي الأطفال في معرفة إجاباتها، وتكون هذه الأسئلة نهاية المرحلة الأولى ومن لهن ثم ننتقل إلى المرحلة الثانية.

\section{• المرحلة الثانية:}

تشمل تخطيط العمل المبدانى ودعوة الخبراء للتكلم مـع الأطفال داخل القاعـات ، ويتركز اهتمـام المعلمـة على إمـداد الأطفـال بخبـرات جديـدة

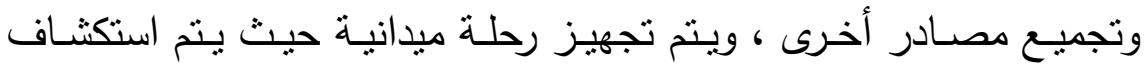

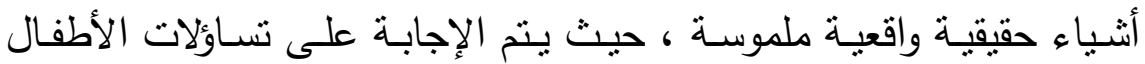
وطرح المزبد من الأسئلة والرغبة في الإجابة عليها وتوضيحها ، وفي هذه

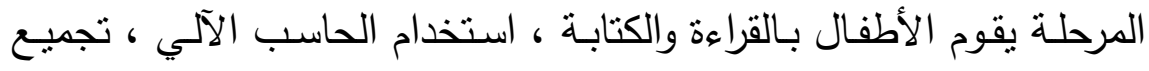
المعلومات ، وتمثنيل بيانات ما تم اكتشافه وردود الأفعال ، ويتث استعراض ذلك كله على الحوائط والأرفف داخل القاعة حتى يراه كل الأطفال ، ومن ون ثم ينتقل إلى المرحلة الثالثة. • المرحلة الثالثة:

وتتنهي المرحلة الثالثة بتقديم ومشاركة المشروع مع الآخرين ، نفس قاعة

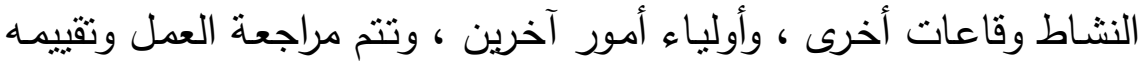

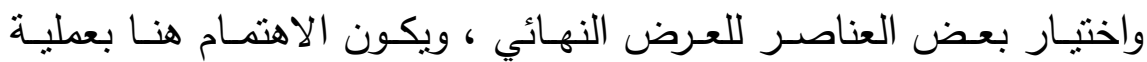
الاتصال والتواصل التعليمي ، وهناك فرص متوفرة لكل فرد إظهار انطباعه 
الثخصسى لمـا اكتسبه مـن معلومـات جديدة ، بطريقة خيالبـة فنبـة ونشـاط

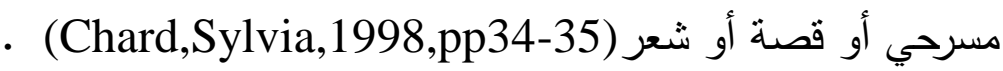
وترى الباحثة أن خطوات تتفيذ المشروع تثضح في المنهج الجديد حيث اعتمد على طريقة المشـروع في اكتشف والرياضـيات واللغـة حيـث يـزداد

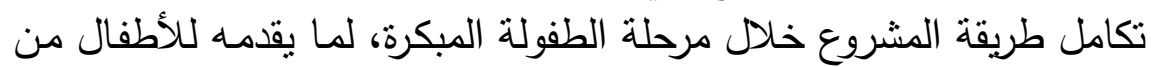
إمكانية الاختيار من بين منهجيات عديدة لاستخدامها. ومن خـلال إطـلاع الباحثة على العديد من الدراسـات والأبحاث التي تم

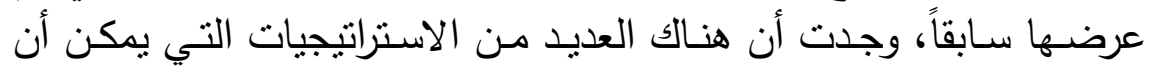
تستخدم في تتمية المفاهيم المختلفة لدى طفل الروضــة والتي منها طريقة

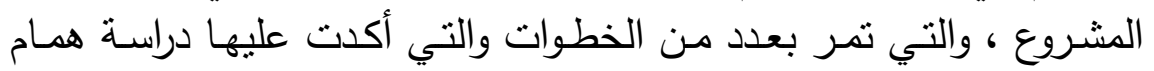

$$
\text { : و (r) (r) }
$$

ا-اختبار المشروع ، والذي يقوم على المناقثـة الجماعية ، وطرح الأسئلة

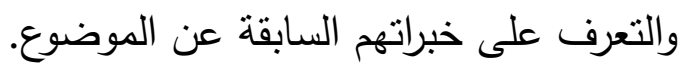

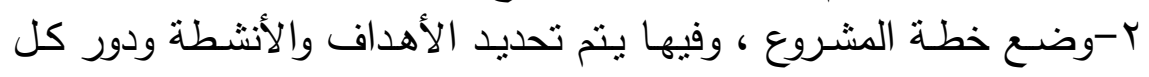
طفل فيها.

ب-تنفيذ المشروع من خلال المناقثـات والعمل الميداني والوصف والتمثيل والبحث والعرض. ع - تقويم المشروع. مميزات طريقة المشروع:

حددت الدراسة التي أجراها Fillippini,Toni(2013 المميزات الآتية لتطبيق طربقة المشروع في تعليم أطفال الروضة المفاهيم المختلفة: 
• العصف الذهني لحلول المشكلات المختلفة والكثف عن المواهب المتوفرة

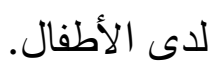

• التفكير في المشروعات التي تثير انتباه الأطفال.

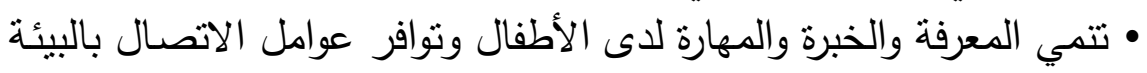

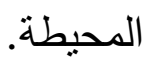

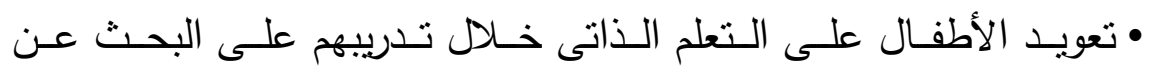

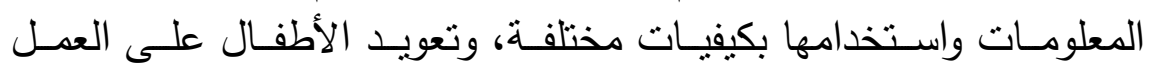

$$
\text { الجماعي. }
$$

\section{المحور الثاني: الإستنتاج :}

ويقصد بها: مقدرة الفرد العقلية على محاولة الوصول إلى نتائجٍ معينةٍ

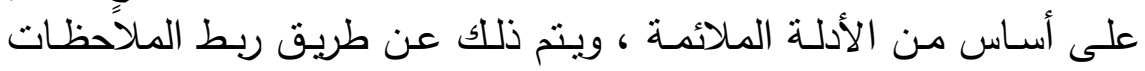

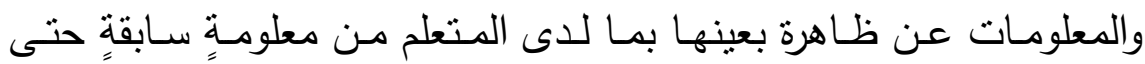

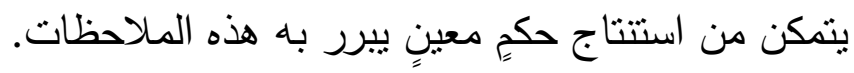
كما تعرف بأنها: مهارة عقلية ترمي إلى قيام المتعلم للوصول إلى نقل نتائج

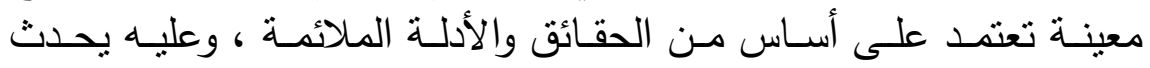

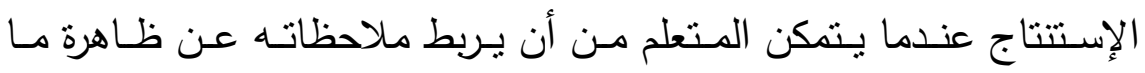

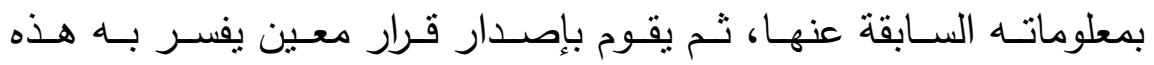

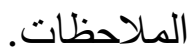

ومن التعريفات السابقة تتبنى الباحثة التعريف التالي لعملية الإستنتاج

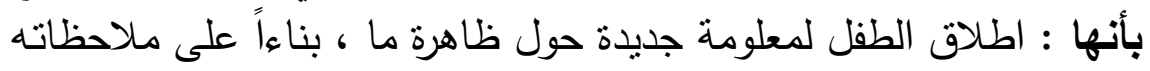

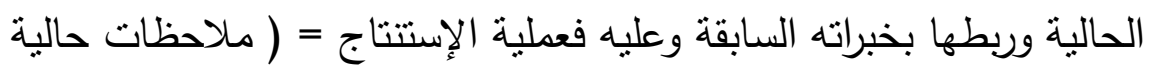
+ خبرات سابقة) . 
و يستلزم هنا التقرقة بين الملاحظة والإستتناج بشكل أكثر إيضاحاً خبرة

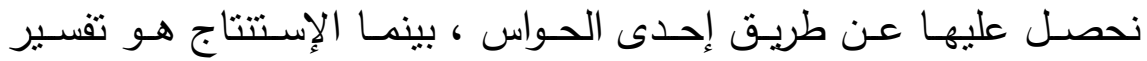

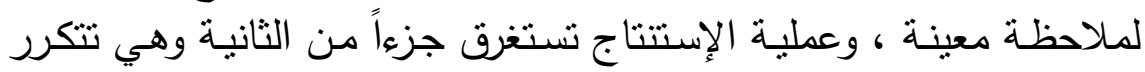

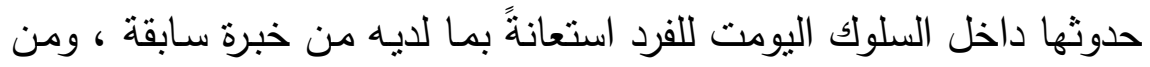

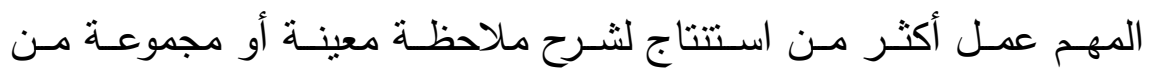

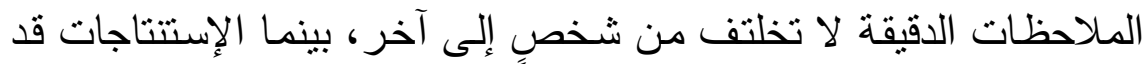

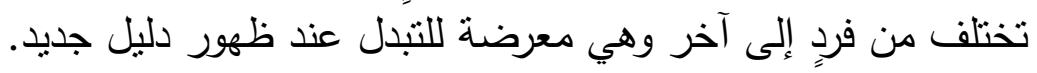

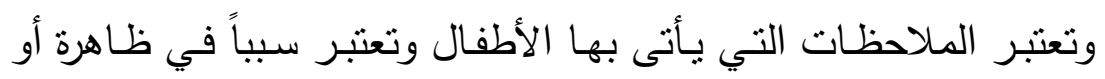
خاصية والعلاقات بين الأسباب وأثرها، وفهم الارتباط بين المتغيرات خاصنية يعرف بها مستوى التفكير العالي.

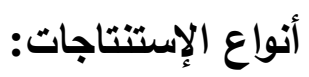

أ- الإستتتاج التعميمي : وهو عبارة عن إيجاز لعدٍٍ كبيرٍ من الملاحظات

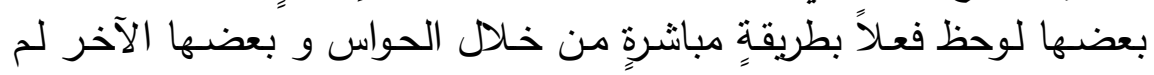

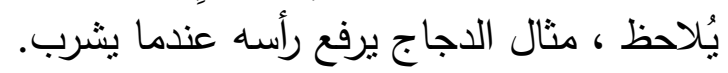

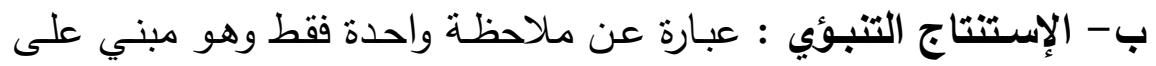

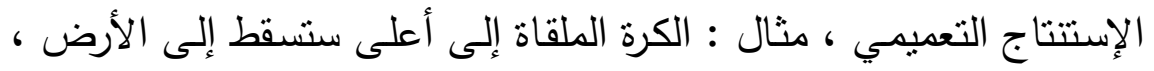

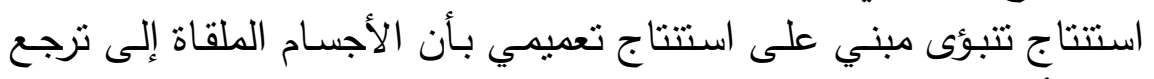

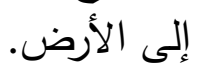
ج- الإســتنتاج التفسـيري : عبـارة عـن الإســتنتاج الـذي يحساول شـرح

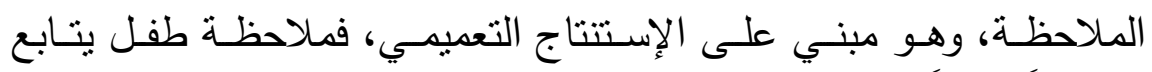

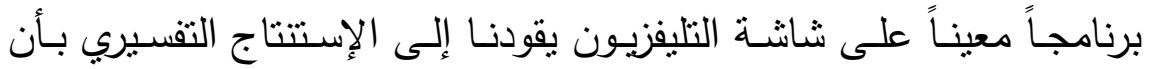

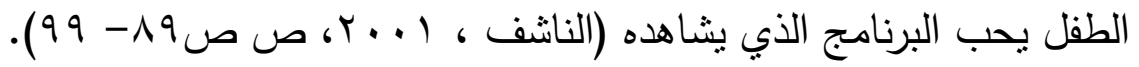




\section{أهداف عملية الإستنتاج:}

ترمي عملية الإسنتاج إلى أن يكون المتعلم قادراً على: 1-استخلاص استتناج واحد أو أكثر من مجموعة من الملاحظات. r-تحديد الملاحظات التي تدعم الإستتناج.

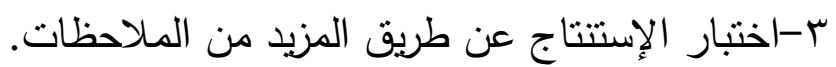

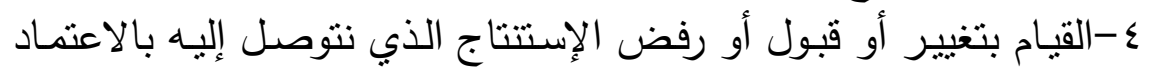

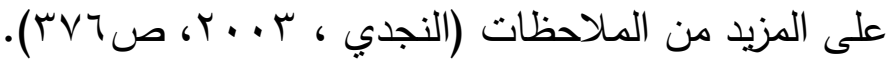
وترى الباحثة أن عملية الإستنتاج تنضمن عمليات فرعية منها: - إيجاد حل لمشكلة. - التمييز بين أثنكال الثيء التئ الواحد التي بينها اختلافات. - عمل أثنكال ورسوم نمطية. - معرفة الأجزاء المفقودة.

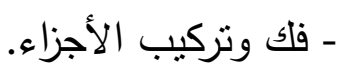
المحور الثالث : المعاقين ذهنياً القابلين للتعلم : الإعاقة العقلية من المنظور التربوي:

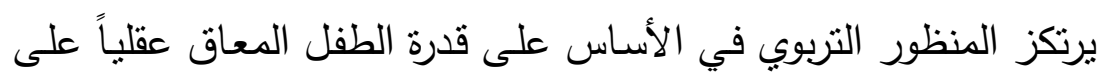

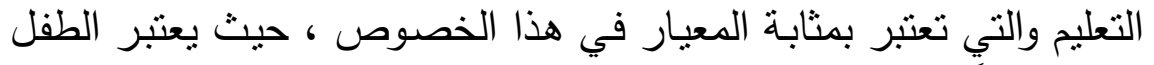

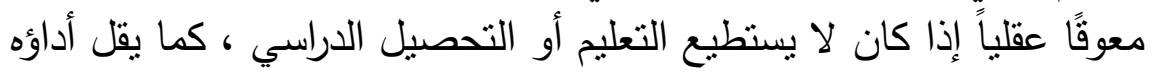

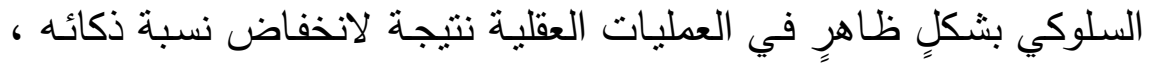

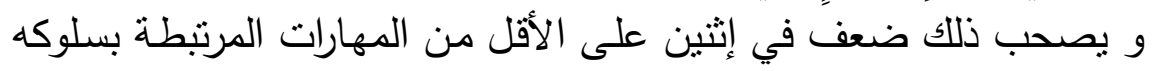

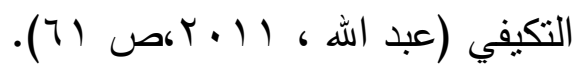


وتشمل الإعاقة العقلية من هذا المنظور ثلاث فئات يمكن تقديمها على

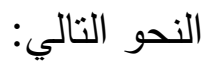

-القـابلون للتعطم Educable : : وتكون عند الطفل بعض القدرات الأكاديمية التي تعينه على التحصيل حتى مستوى الصف الخامس فقط بحد أقصى ، و يكون المتوسط هو الصف الثالث أو الرابع. -القابلون للتدريب Trainable : تكون عند الطفل قدرات أكاديمية أقل تؤهله حتى مستوى الصف الأول بحد أقصى بينما يقل المتوسط عن ذلك ، وبمكن تدربب الطفل على القيام ببعض المهن البسيطة.

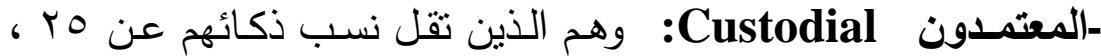

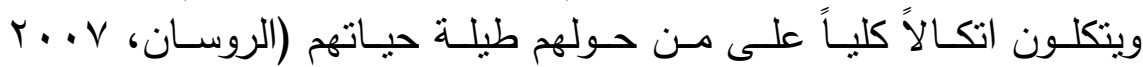
(90)

ومن ثم يتبين أن كل منظور يؤكد على وجود انخفاض واضح في القدرة

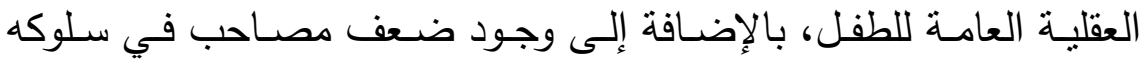
التكيفي يحصل خلال مرحلة النمو والتي تمتد حتى سن 1 ا سنة ، أي أن

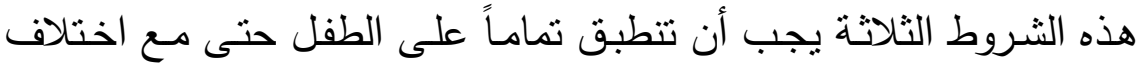
المعيار المستعمل الذي نحكم من خلاله على الطفل بوجود الإعاقة العقلية من عدمـه ، و بذللك فإن الإكتفاء بمقياس الذكاء فقط في التشخيص كمـا

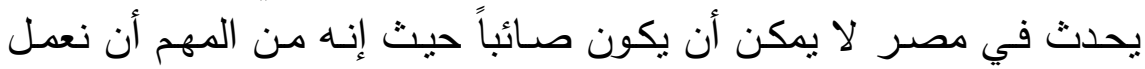

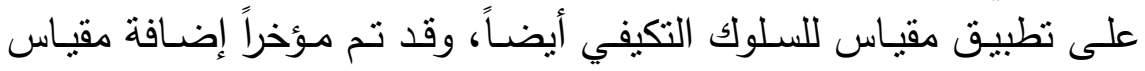
السلوك التكيفي في إجراءات الدمج.

واستخلصـت الباحثة مـن خـلال التعريفـات السـابقة للمعـاقين ذهنيـاً القابلين للتعم التي يهتم بهم هذا البحث بأنهم : هم الأطفال الذين تكون نسبة ذكائهم تقع بين ( 1 - - 10) درجة، وبطلق عليهم فئة الإعاقة الذهنية 
البسيطة ، والمعـاقين في هذه الفئة يمكن تعليمهم و تدريبهم على بعض هض

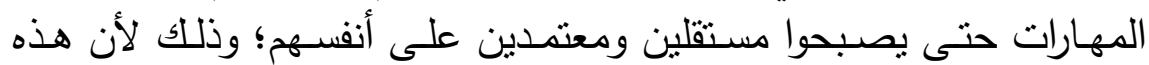

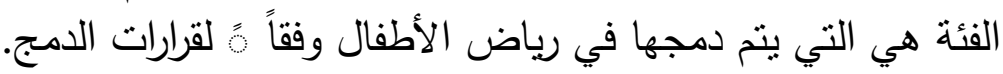
التصنيفات المختلفة للإعاقة الذهنية:

ظهرت مسـاع متعددة لتصـنيف المعـاقين ذهنيـاً في فئات، ومسن تلك في

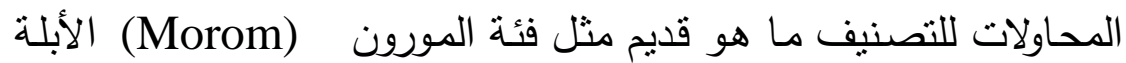
(Enbecile) طويلةٍ من الزمن لتضمنها تسميات مهينة. وظهرت بعـد ذلـك التصـنيفات الجديـدة للمعـاقين ذهنيـاً وهـي مختلفـة، و تختلف تبعاً لتباين التخصصات العلمية. أولاًا : التصنيف على حسب درجة الإعاقة ، وتتقسم إلى: - شديد الإعاقة : هو أكثر درجات النقص العقلي، وعمره العقلي أقل من

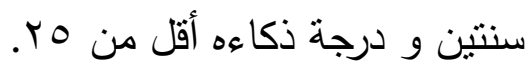
- متوسط الإعاقة : أقل شدة من شديد الإعاقة، وعمره العقلي من سنتين

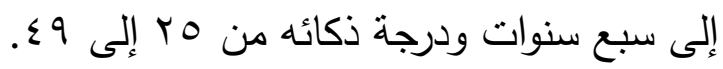
- بسيط الإعاقة : أقل درجات النقص العقلي شدة، وعمره العقلي ما بين

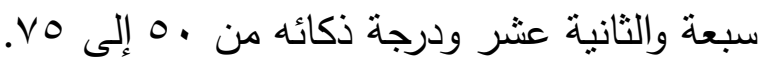
ثانياً : التصنيف على أساس مصدر العلة ، وتتقسم إلى: - الضعف العقلي الأولي : و يكون راجعاً إلى عوامل وراثية و يحدث في

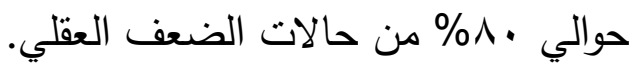

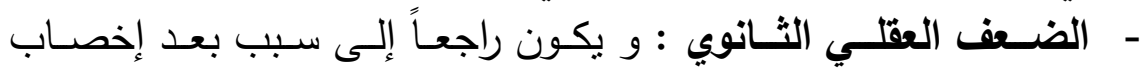
البويضة سواء أثناء الحمل أو نتيجة إصابة الأم. 


\section{ثالثاً : التصنيف على أساس درجة الإستقرار ، وينقسم إلى:}

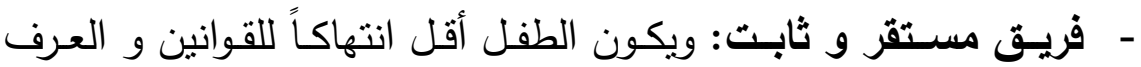
وهادئاً.

- فريق غير مستقر وغير ثابت: وهو ما تصدر عنه تصرفات مخالفة للقوانين.

رابعاً : التصنيف على أساس العوامل التريوية ، وينقسم إلى: - فئسة القـابلين للتعلم : وتقابل طبقة بسيطي الإعاقة، وتلحق هذه الفئة بمعاهد التربية الفكرية. - فئة غير القابلين للتعلم : و تقابل طبقتين متوسطي الإعاقة وشديدي

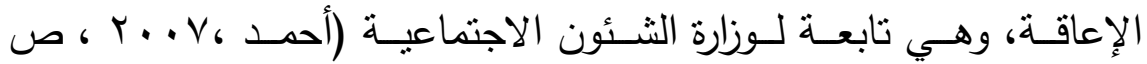

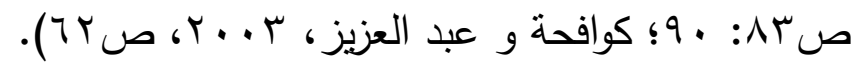

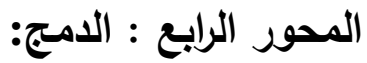
الاتجاهات الحديثة في رعاية الأطفال المعاقين:

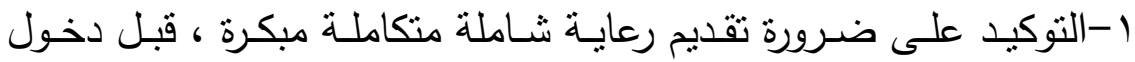

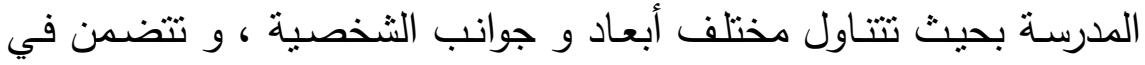
الوقت الـراهن الرعايـة الصـية والنفسية والاجتماعيـة والتزبويـة والتأهيليـة فئة

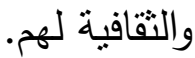

r-الاتجاه للاهتمام بإعطاء الرعاية المناسبة لفئة الإعاقات الطفيفة.

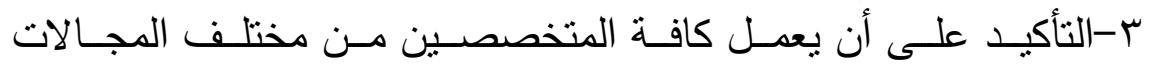
و التخصصات الذين يتعاملون مع حالات الإعاقة بروح الفريق.

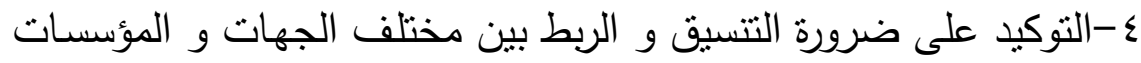

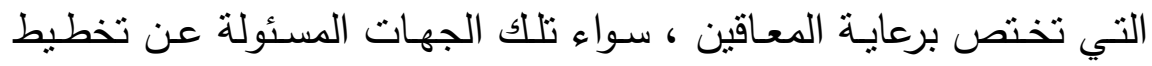


برامج الرعايـة أو تلك التي تتولى مسئولية تتفيذ هذه البرامج و متابعتها و تقويمها.

ه-التأكيد على أهميـة إثـراك الوالدين في عمليـة الرعايـة كعامل أساسي

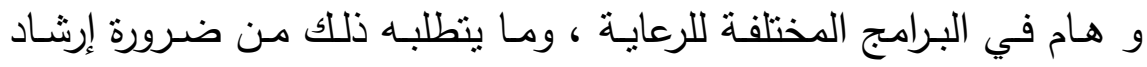
و استمرار جهود الوالدين.

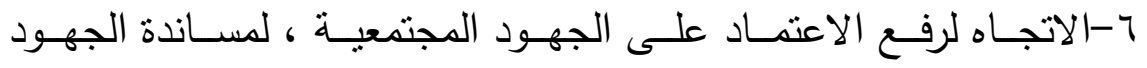

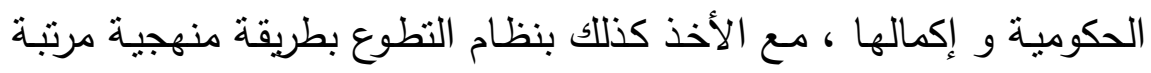

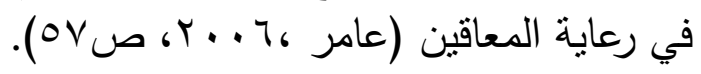

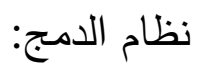
وينقسم نظام الدمج إلى نوعين:

$$
\text { 1-الدمج الجزئي. }
$$

وسوف أتناول فيما يلي الدمج الكلي الذي تتاوله البحث:

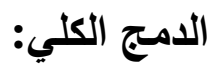

هناك نوعان من الدمج الكلي وهي كالتالي:

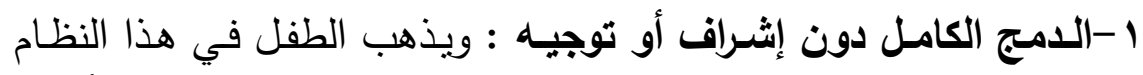

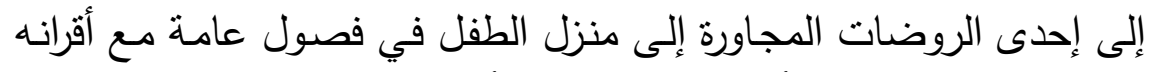

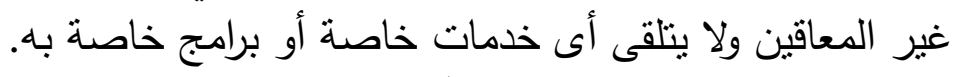

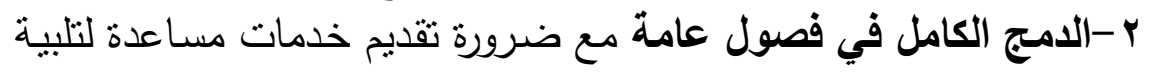

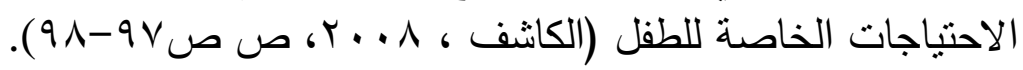




$$
\text { وتصنف جاد (11 · ( الدمج إلى : }
$$

ا-الدمج الكلي التريـوي : ويقصد بـه دمهج الطفل المعاق ذهنياً مـع أقرانه

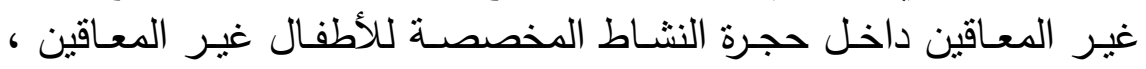
ويدرس نفس المناهج الدراسية التي يدرسـها نظيره الطفل العادى مـع تقديم خدمات التزبية الخاصة.

وقد أصدرت وزارة التربيـة والتعليم المصـرية القرار الوزاري رقم (Yor)

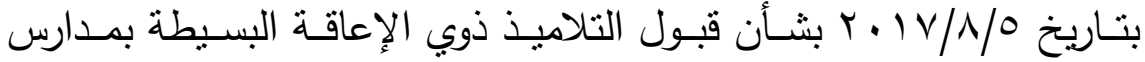

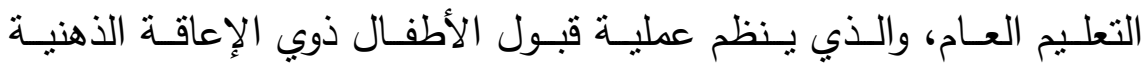
البسيطة، والذي تم تحديد درجة الإعاقة الذهنية التي تقبل بالمدارس العادية في المـادة رقم (Y، د)، وينص على " يشترط للقبول ألا تقل درجة الذكاء

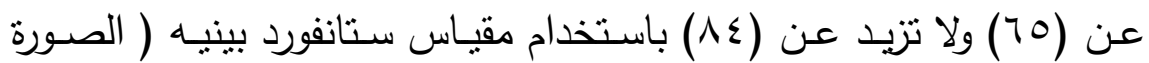
الرابعـة أو الخامسـة)، مـع مراعـاة الصـحة النفسية ، وبمـا يتوافق منـع نتائج مقياس السلوك التكيفي المناسب للدمج الكئي.

ويوضتح القرار أن الإعاقة الذهنية تتضمن جميع المنالزمات التي تتدرج

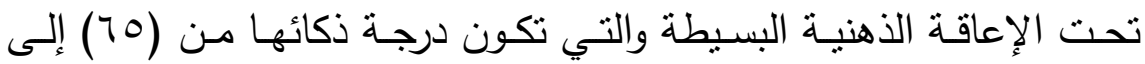
(^乏) على مقيـاس سـانفورد بينيـه ( الصـورة الرابعـة أو الخامسـة)، وأيضــاً بطيئوا التعلم هم التلاميذ الذين يكون التحصيل الدراسي لديهم منخفضنًا في

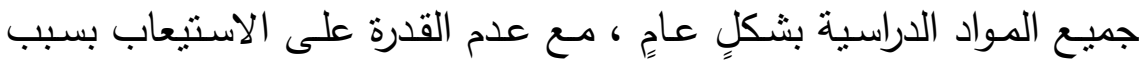

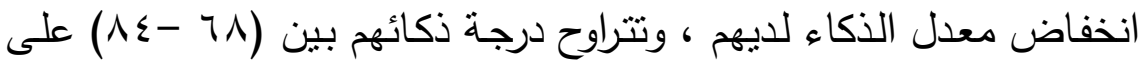
مقياس ستانفورد بينيه ( الصورة الرابعة أو الخامسة). 
الإجراءات المنهجية للبحث:

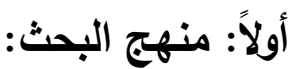

يستخدم البحث الحالي كلا مَّن:

أ- المنهج الوصفي التحليلي : الذي يقوم بوصف ما هو كائن وتفسيره ،

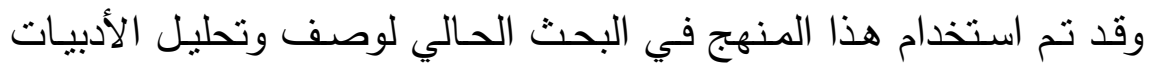

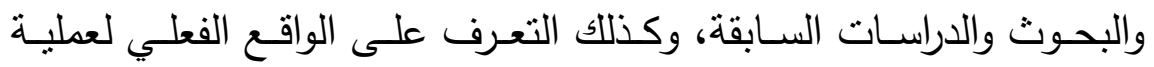

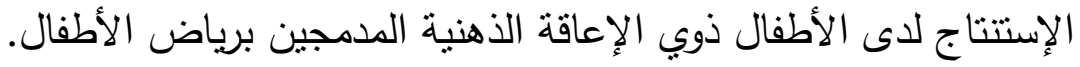

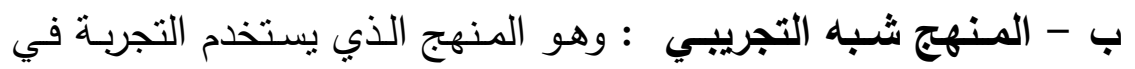

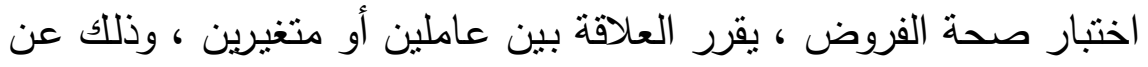

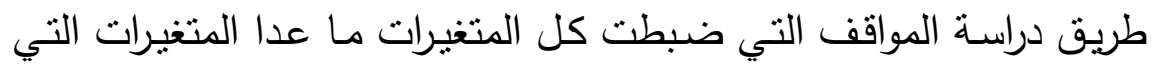

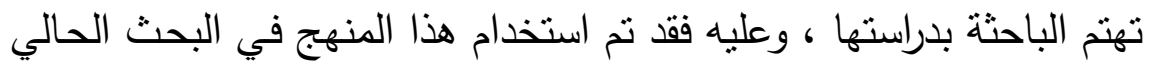
للكثف عن تأثير بين المتغيرين الإثنين: -متغير مستقل: طريقة المشروع. - متغير تابع : عملية الإستتناج.

وتم ذلك باستخدام التصـيم التجريبـي ذي المجموعـة الواحدة واختبـار (ويلكوكسون ) كأسلوب إحصائي؛ لحساب الفروق بين منوسطي التطبيقين القبلي والبعدي لعينة البحث.

\section{مجتمع وعينة البحث:}

- مجتمع البحث: الأطفال المعاقين ذهنياً المدمجين برياض أطفال محافظة بورسعيد.

- عينة البحث: تم اختار عينة عمدية من الأطفال المعاقين ذهنياً

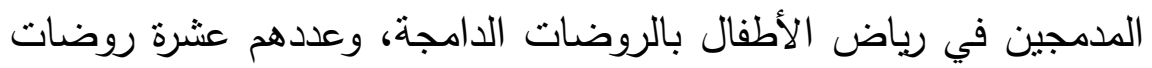


على مستوى المحافظة، وتكونت المجموعة من عشرة أطفالاً معاقين ذهنياً المدمجين عبارة عن مجموعة واحدة تجربيية. - تم عمل تجربة استطلاعية شملت (7) أطفالاً معاقين ذهنياً مدمجين؛ بغرض التقنين العلمي لاختبار عملية التصنيف المصور ، وللتحقق من التكافؤ في التطبيق القبلي تم استخدام مقياس ستانفورد بينيه للتأكد من نسبة ذكاء الأطفال المدمجين قيد البحث ضمن فئة الدمج بين ( تحديد معامل السهولة والصعوبة للاختبار ، تم استخدام ويلككسون كأحد اختبارات الإحصاء اللابارامترى وفق عينة البحث والبالغ عددها ( . ( )

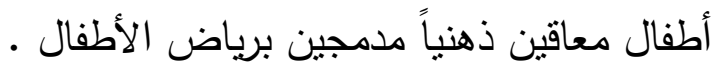
أدوات البحث:

أ- إعداد قائمسة بـبض عمليـات الإسـتنتاج الفرعيـة التي تتـدرج تحـت

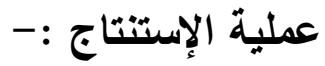

للإجابة على السؤال الأول للبحث و نصه : " ما هي عملية الإستتناج

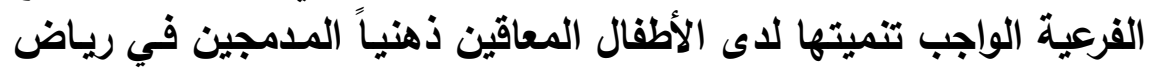
الأطفـال ؟ "، وتم في ضـوئها إعداد أداة القباس ، والبرنـامج المقترح القائم على طريقة المشروع لتتمية عملية الإستتناج.

تطلب ذلك إعداد قائمسة بـعض عمليـات الإسـتنتاج الفرعيـة التي يمكن تتميتهـا لدى الأطفال المعـاقين ذهنياً المدمجين بريـاض الأطفال المقيدين بالمستوى الثاني رياض أطفال رباض أطفال ( رقم 1 ) الصورة النهائية لقائمة عمليات الإستتناج الفرعية.

- الإطـلاع على الدراسـات و البحـوث العربيـة والأجنبيـة السـابقة المتعلقـة بتتمبـة عملية الإستتناج لطفل الروضـة والطفل ذوي الإعاقة الذهنية بصفة 


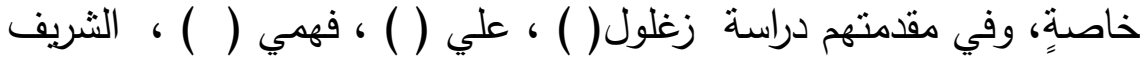

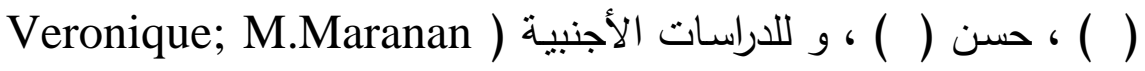
•(2017) (Erin Miles2010

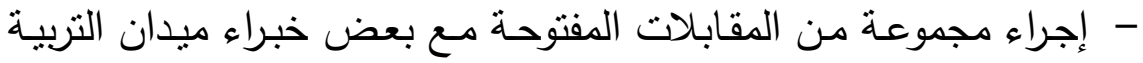

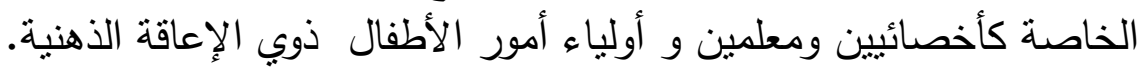

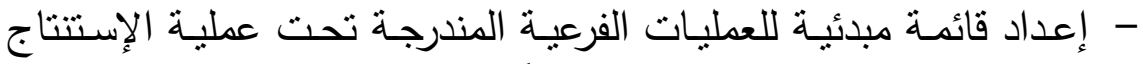
التي يجب تتميتها للأطفال المعاقين ذهنياً المدمجين برياض التهات الأطفال .

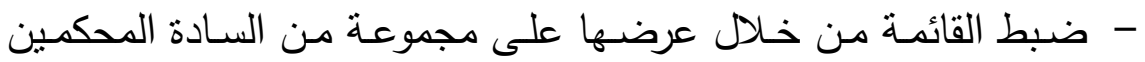

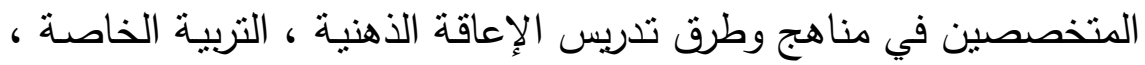

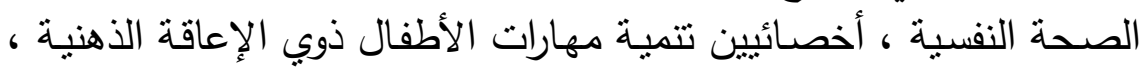

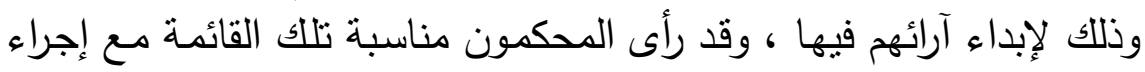

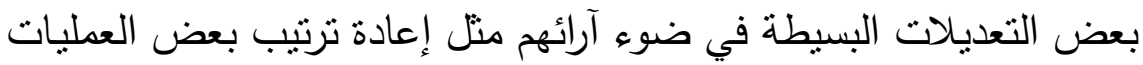
الفرعية ذات العلاقة ببعضها.

- إعداد الصورة النهائية لقائمة عمليات الإستنتاج الفرعية الواجب تتميتها

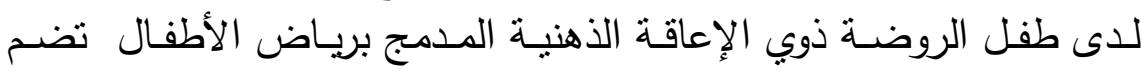

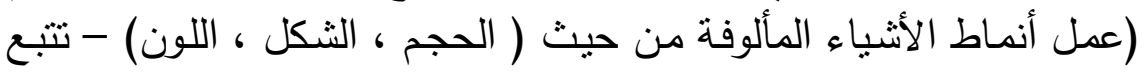

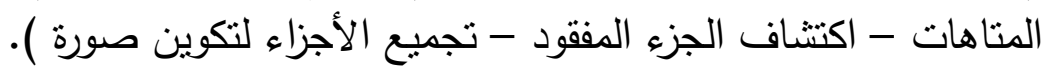

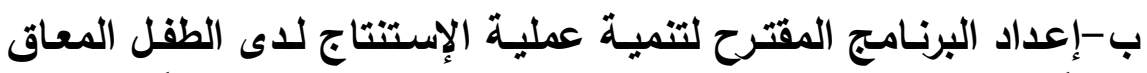

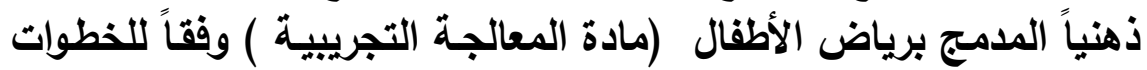
التالية :- دنيا

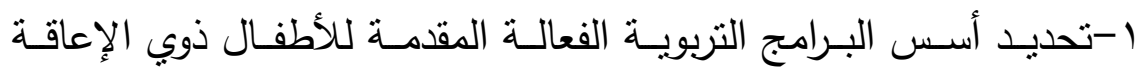
الذهنية التي التزمت بها الباحثة في البحث الحالي وشملت ما يلي :- 
• الأسس القلسفية : حيث يستند البرنامج إلى النظرية البنائية الإجتماعية التي نـادى بها بياجيهـ ، فيجوتسكي ، ديوي وغيرهم ، التي انبثقت أفكار لوريس مالاجوزي منها(Malaguzzi , Loris , 1994 - 2011 ,p 55).

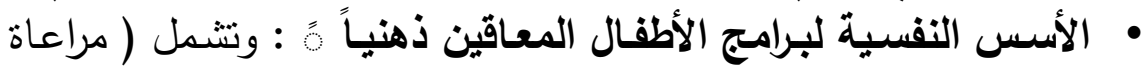

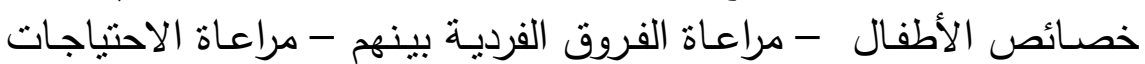
الخاصة بكل طفل ) (الاصن ) • الأسس الاجتماعية لبرامج الأطفال ذوي الإعاقة الذهنية ونتمل ( البيئة التعليمية - الأدوات والوسائل المستخدمة في النشاط ).

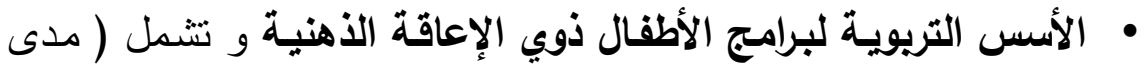

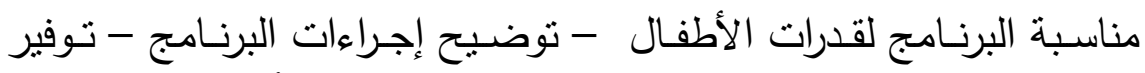

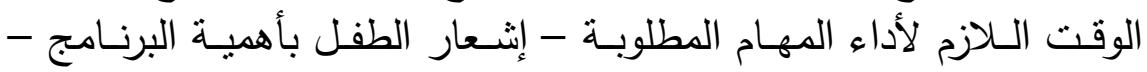

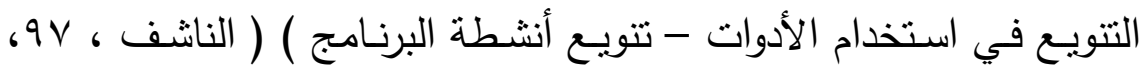

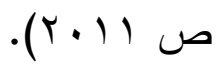
• الاتجاهات الحديثة : في بناء برامج الأطفال ذوي الإعاقة الذهنية.

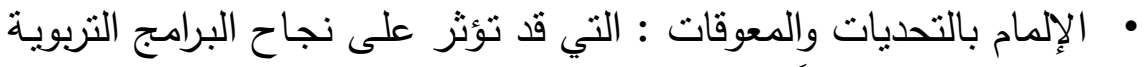
كلأطفال المعاقين ذهنياً ـ. r -تحديد الأهداف العامة للبرنامج في ضوء الهدف الرئيسي للبحث و هو " تتمبة عملية الإستتناج باستخدام برنامج قائم على طريقة المشروع ". ب-تصميم البرنامج وبتضمن البرنامج العناصر التالية :

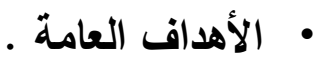

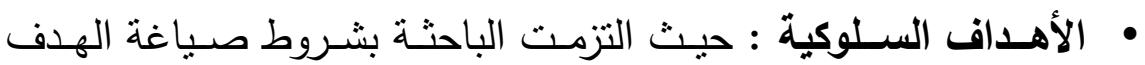
السلوكى بما يتلاءم مع مراعاة الفروق الفردية للأطفال المعاقين ذهنياً ـ. 
• تحديـ محتوى البرنـامه : من خلال قائمـة عمليات الإسـتنتاج الفرعيـة

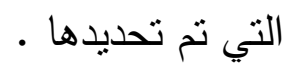
• الإســراتيجيات والطـرق التدريسية المسـتخدمة في البرنـامج : حيـث التزمت الباحثة بطريقة المشروع وتم تتظيم محتوى التعلم بما يتلاعم مع تلك مئك الطريقة، واستخدمت الباحثة مجموعة من الفنيات والطرق التدريسية ضمن فئن

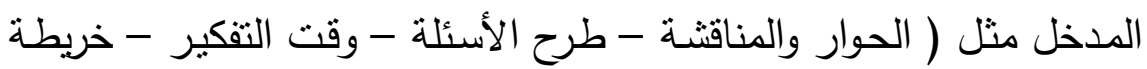

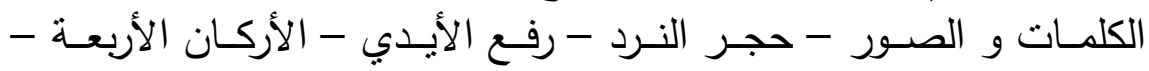
معرض التجول - الزميل المجاور - الرحلات الميدانية - KWL ).

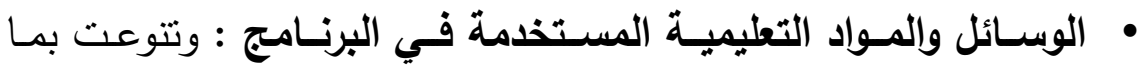
يتلاعم مع طريقة المشروع ونوع العملية والمهارة المستهدفة بالنشاط .

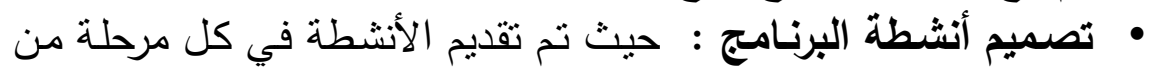

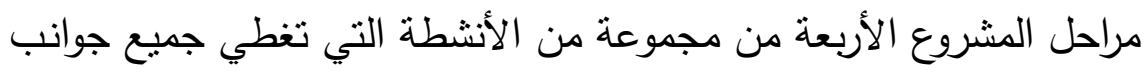

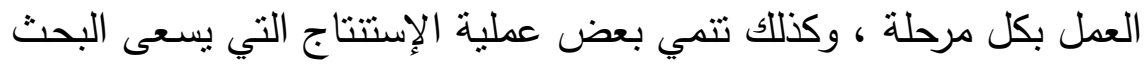
• إلى تتميتها • أسـاليب التقويم المستخدمة في البرنـامج : تتوعت مـا بين التقوبمات

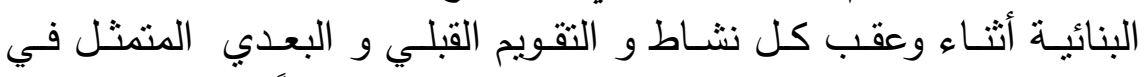

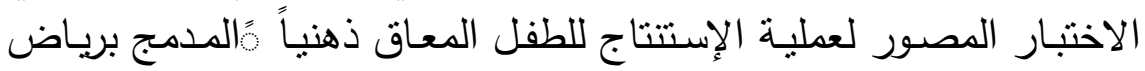
- الأطفال • كيفية السير في البرنامج : تم إعداد دليل للبرنامج •

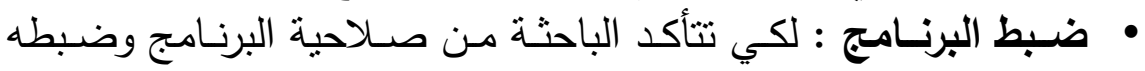
اعتمدث على :

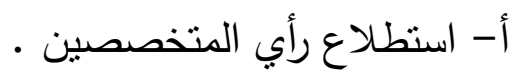
ب-إجراء التجربـة الاسـتطلاعية : قامـت الباحثة بتطبيـق بعض الأنثـة

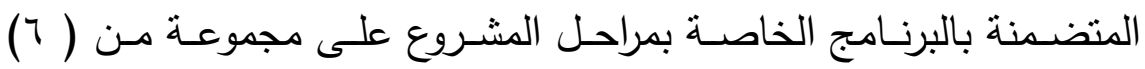


أطفالاً من أطفال المستوى الثاني من ذوي الإعاقة الذهنية المدمجين برياض

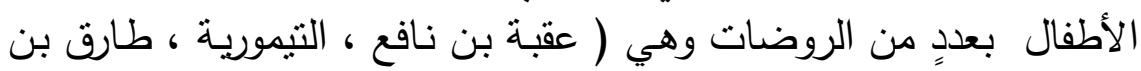

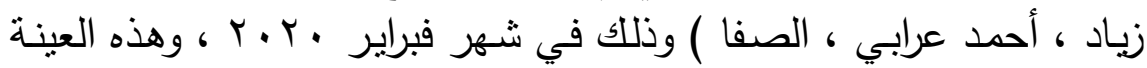

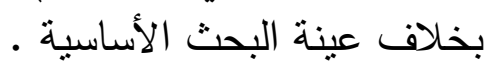

ج - إعداد اختبـار مصـور لقيـاس عمليـة الإسـتنتاج للطفل المعـاق ذهنيـاً

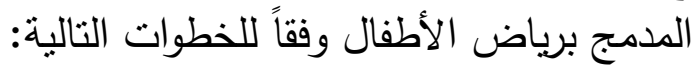

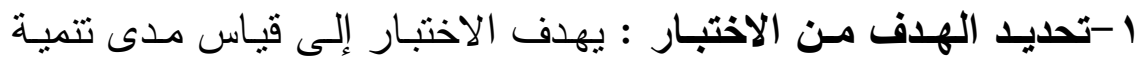

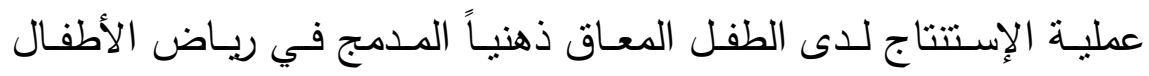

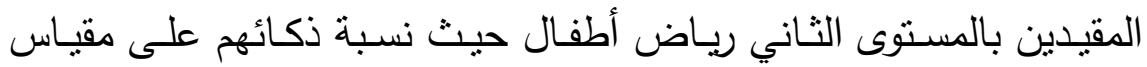

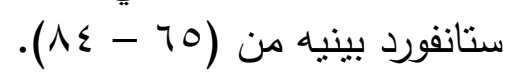

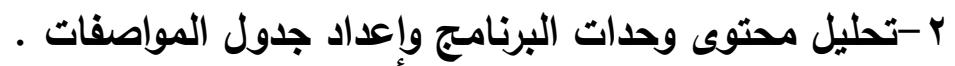

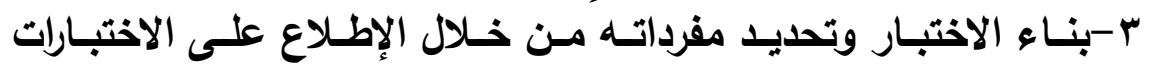
والاراسات التالية : • مقياس عمليات العلم الأساسية لطفل الروضة ( قداح ، ( . . ب) . • • اختبار عمليات العلم الأساسية. Test of Basic and Integrated Process Skills (Miles , 2010) • اختبار عمليات العلم الأساسية .

Science Basic Process Skills Test (M.Mranan , 2017)

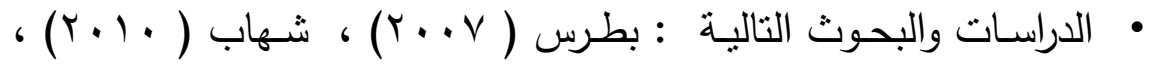

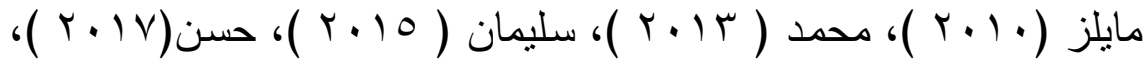

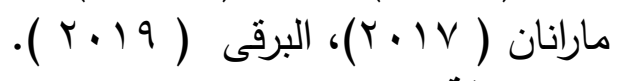

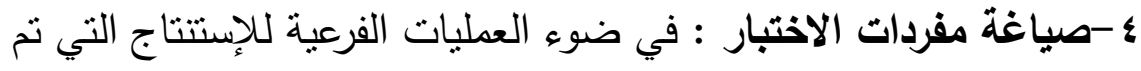

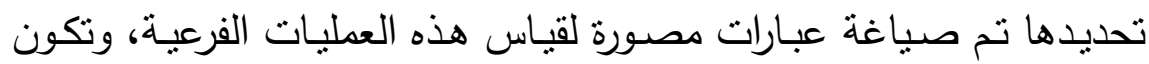

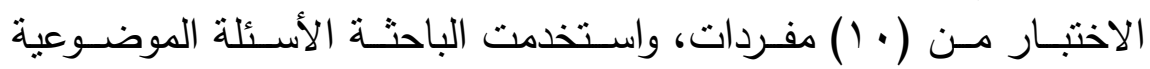


المصورة للأسباب الآتية : ( تتناسب مـع المدخل التدريسي للبحث ،تتوافر

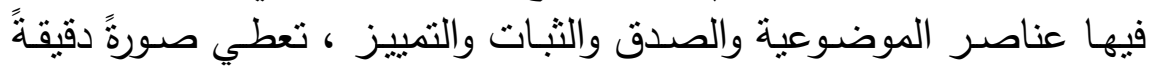

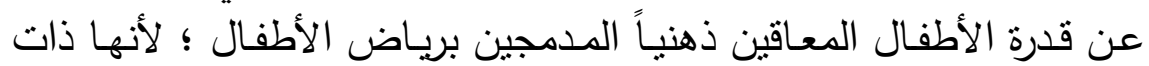

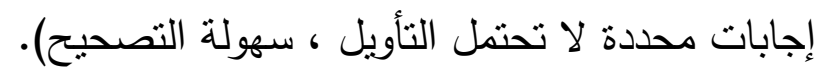
ه-تقدير درجات الاختبار .

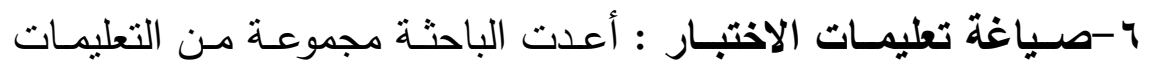

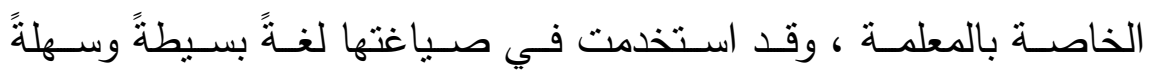
وواضحةً، وهذه التعليمات توضح للمعلمة كيفية عرض الاختبار على الطفل وكيفية تسجيل درجات الطفل وحسابها.

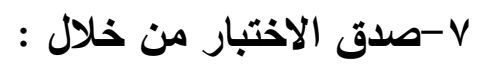

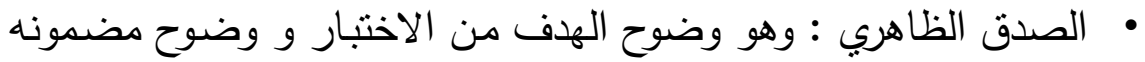

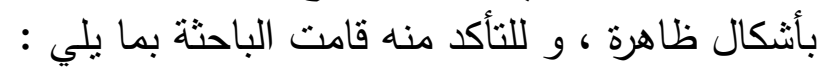

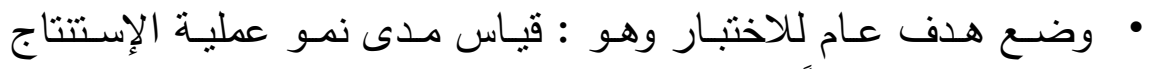

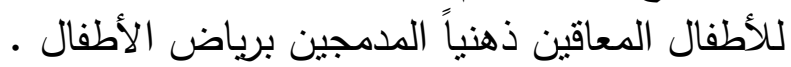

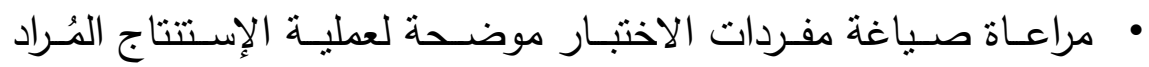

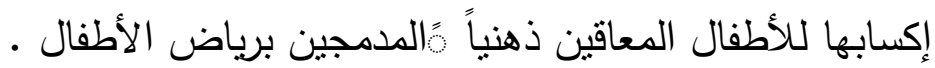

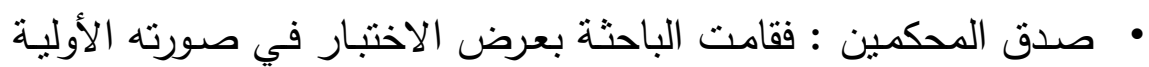

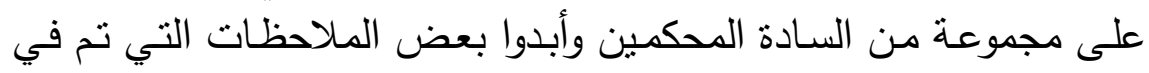

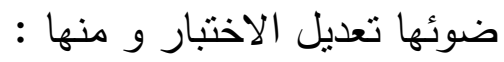

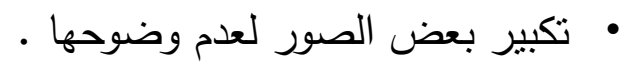

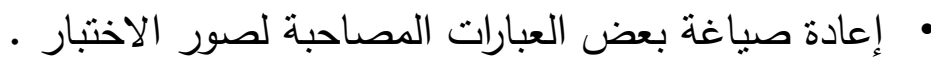

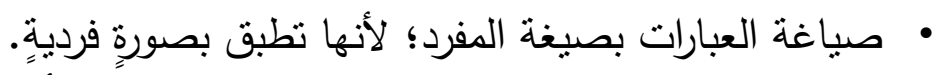

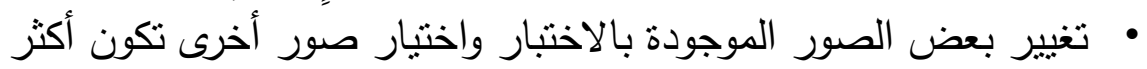
وضوحاً ة. 


\section{1-التجرية الاستطلاعية للاختبار بغرض تحديا :}

• حساب معامل ثبات الاختبار : استخدمت الباحثة معادلة كيودر ريتشارد

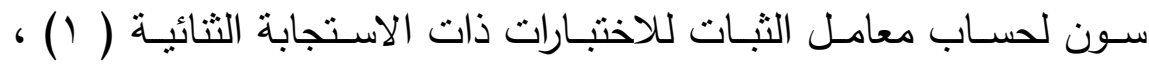
(صفر) لكل مفردة من المفردات ، و كان معامل ثبات كيودر ريتشارد سون

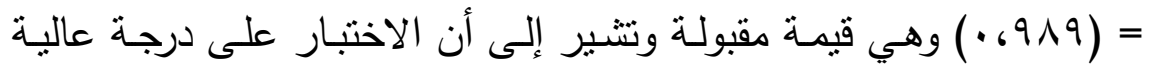
من الثبات.

• ســاب زمسن تطبـق الاختبـار : ونظـراً لأن الاختبـار مقدم للأطفـال

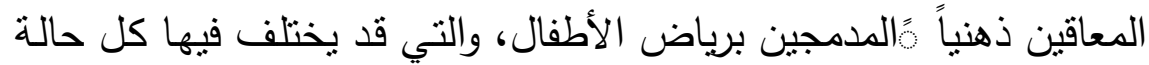

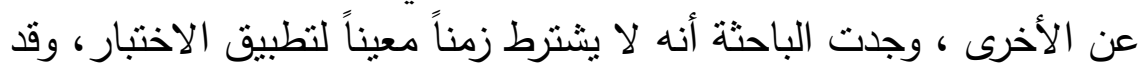
يختلف الزمن المستخرق من طفلٍ لآخر على حسب حالة الطفل وفق تقيبم المعلمهة وملاحظتها لـه، و لكن في الحالات التي طبقت الباحثة الاختبار

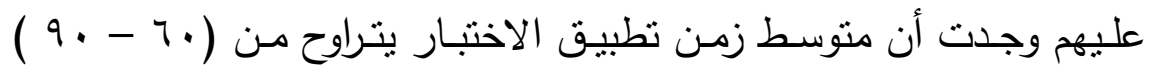
دقبقة

• سـاب صدق الاختبار : قامت الباحثة باستخراج قيمة معامل الارتباط لبيرسون؛ لحساب صدق الاتساق الداخلي لاختبار عملية الإستتناج المصور

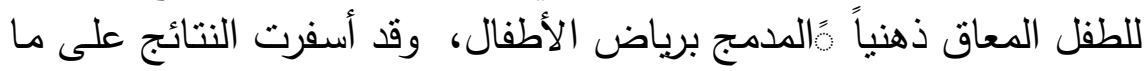
: يلي

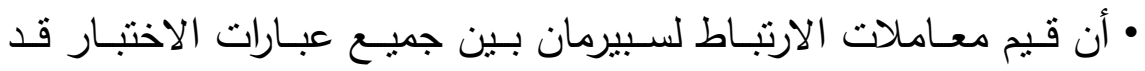

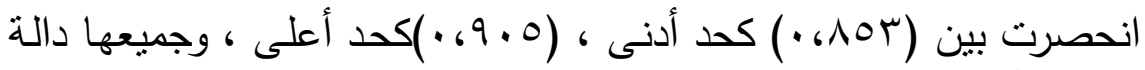

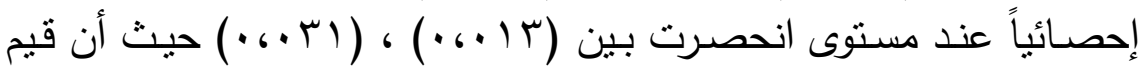
معاملات الارتباط المحسوبة أكبر من قيمتها الجدوليـة و هي أقل من أو أو تساوى (0 • ، •) ، مما يدل على صدق الإتساق الداخلى للاختبار .

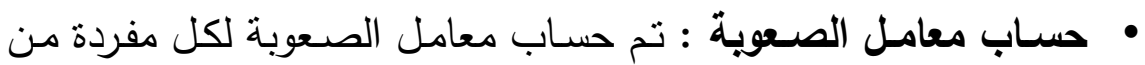
مفردات الاختبار باستخدام المعادلة التالية : 
معامل الصعوبة = عدد الإجابات الصحيحة ؛ عدد محاولات الإجابة ، وقد

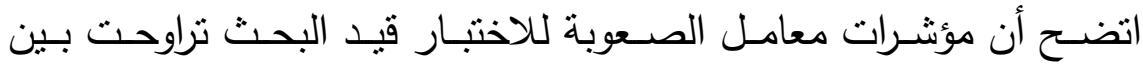

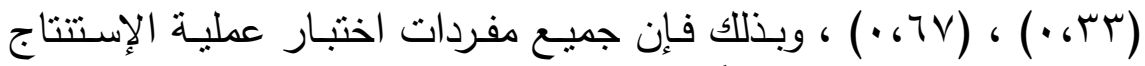
المصور للطفل المعاق ذهنياً ـالمدمج برياض الأطفال مقبولة . 9-الصورة النهائية للاختبار : في ضوء النتائج التي قد تم الحصول عليها بعد تطبيـق التجربـة الاسـتطلاعية للاختبـار ، وبعد تقنينه بحسـاب صـدقه وثباته و إجراء التعديلات في ضوء آراء السادة الخبراء المحكمين ، توصلت الباحثة إلى الصورة النهاءئية للاءختبار .

$$
\text { - التصميم التجريبي : التجيبي :- }
$$

هدف البحث الحالي إلى تتمية عملية الإستتناج لدى الطفل المعاق ذهنياً المدمج برباض الأطفال باستخدام طربقة المشروع ، ولذك استخدمت الباحثة الإنة

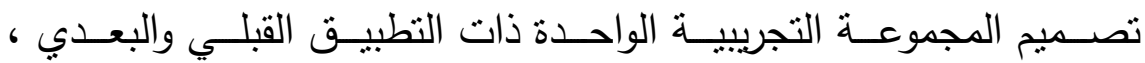

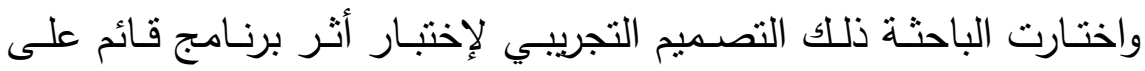

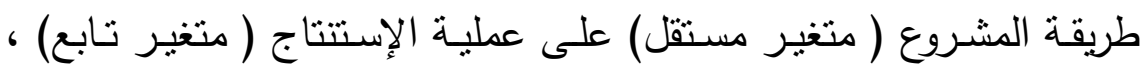

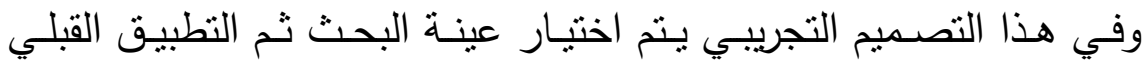
لأدوات البحث و بعد ذلك يتم التطبيق البعدي للأدوات ، وبذللك يتم حساب الته الفروق و دلالتها بين التطبيقين القبلي والبعدي للمجموعة التجربيية ، وتقييم مدى فاعلية البرنامج المُعَد باستخدام طريقة المشروع لتتمية عملية الإستتناج للطفل المعاق ذهنياً المدمج برياض اضئ الأطفال . - تحديد أفراد البحث وضبط تجانسها :

تم التوصـل إلى عينـة البحث مـن خلال تحديد الأطفال ذوي الإعاقة الذهنبـة البسيطة المدمجين بروضـات محافظـة بورسعيد ، حيث تم اختيـار 
الأطفال المشخصين بأنهم إعاقة ذهنية بسيطة ، ثم قامت الباحتة بنطبيق

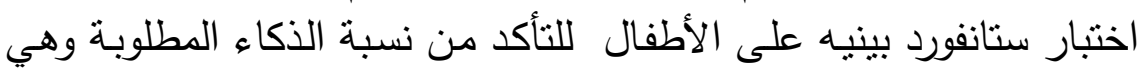

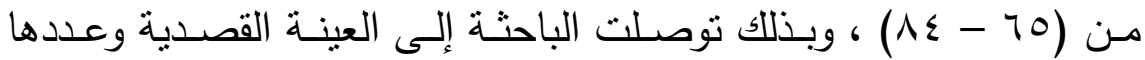

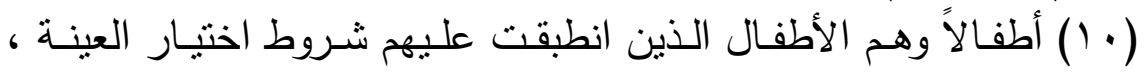

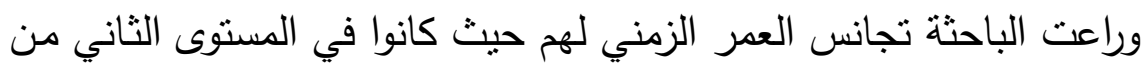

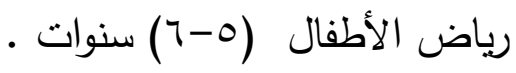
- إجراءات تنفيذ البحث :

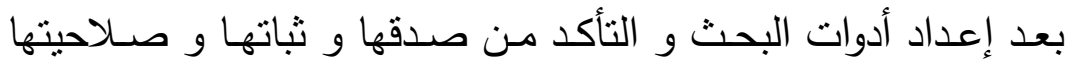

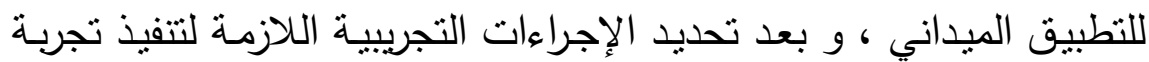

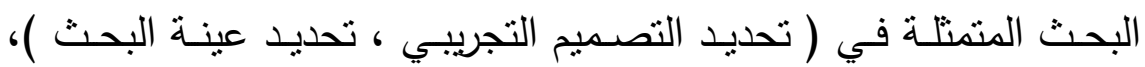

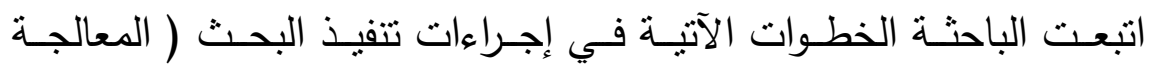
• التجريبية)

أولاً : إجراءات قبل تطبيق البرنامج و تثضمن :

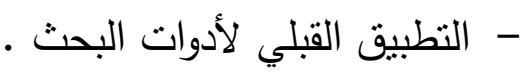

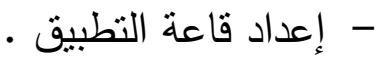
ثانياً : إجراءات تطبيق البرنامج :

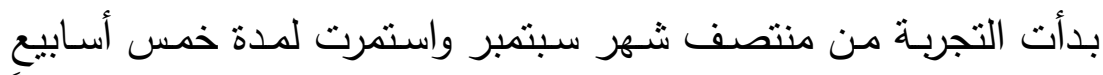
و طبقت الباحثة البرنامج لكل طفلين على حدى بواقع ( 7 ) ) أيام أسبوعياً

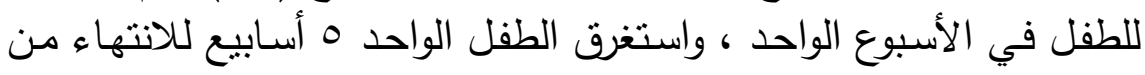

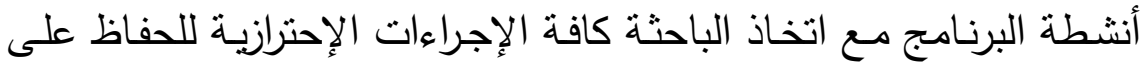

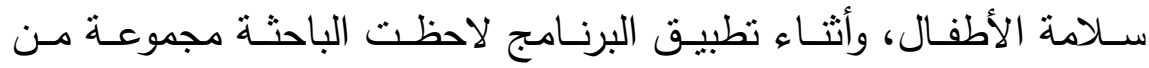

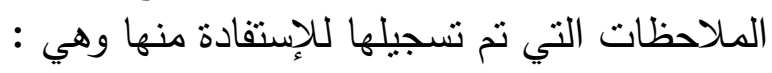
- 
- - إقبال الأطفال على ممارسة الأنشطة المصورة .

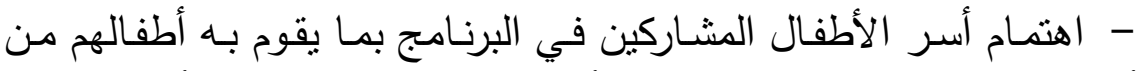

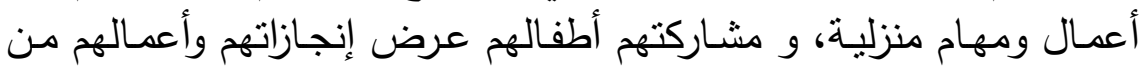

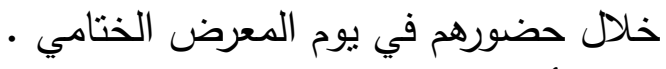

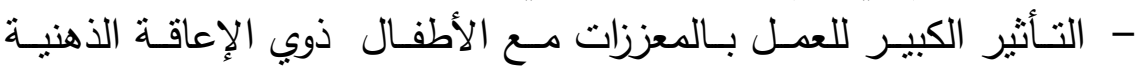
البسيطة؛ و ذلك للإستجابة لتنفيذ التعليمات و الأوامر .

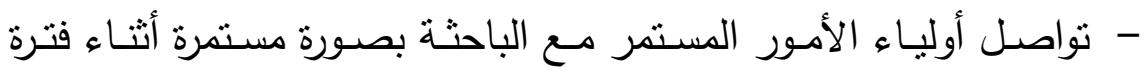

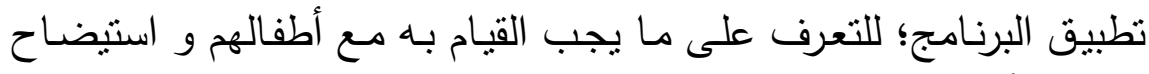

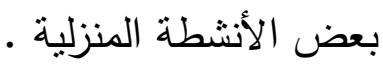

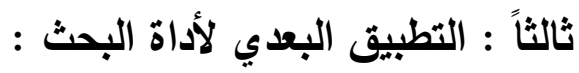

بعـد الإنتهـاء مـن تطبيـق مراحل المشـروع القائم عليـه البرنـامج ( مـادة

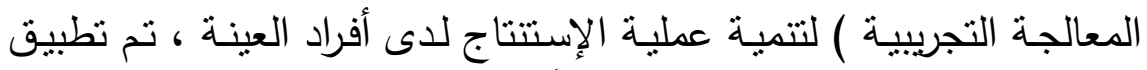

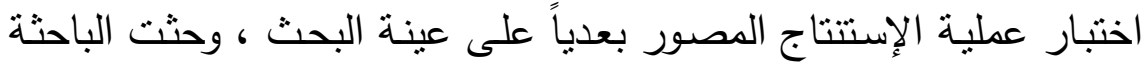

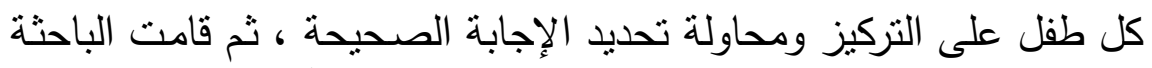

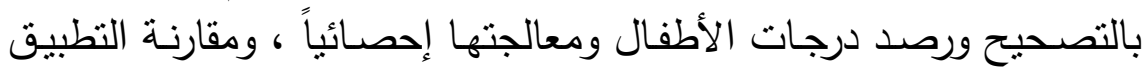

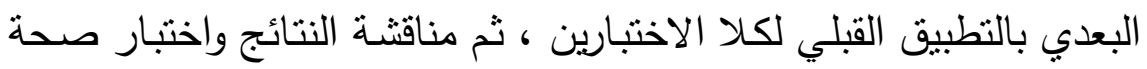
الفروض و تفسيرها.

الأساليب الإحصائية المستخدمة :

استخدمت الباحثة اختبار ويلكوكسن والذي يعد أحد اختبارات الأسـاليب

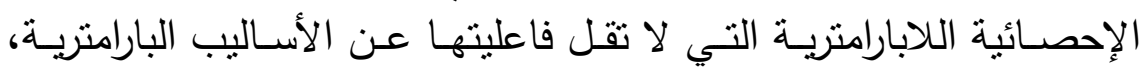

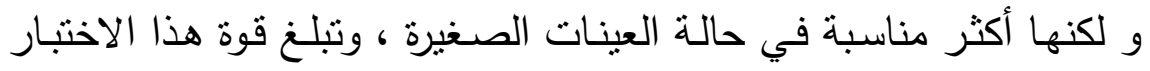

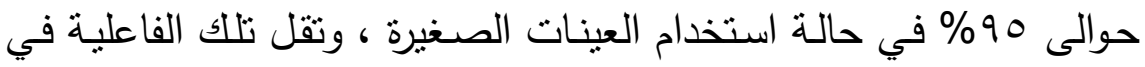
حالة العينات الكبيرة . 
نتائج البحث :

اختبار صحة القرض الأول:

ينص الفرض الأول على أنه:

" توجد فروق ذات دلالـة إحصائية عند مستوى (ع •، + ) بين متوسطي رتب الدرجات الكليـة لأطفال المجموعـة التجريبيـة بين التطبيقين القبلي مئي والبعدي على اختبـار عمليـة الإسـتنتاج المصسور للأطفال ذوي الإعاقة

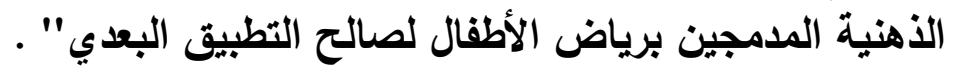

وللتحقق من صحة هذا الفرض استخدمت الباحثة اختبار رتب الإشـارة لويلكوكسون لدلالـة صـحة الفروق القياسين القبلي والبعدي لاختبـار عمليـة الإستتناج ، و يوضـح الجدول التالي ما توصلت جدول (1) نتائج اختبار ويلكوكسـن للفـروق بـين التطبيـق القبلـي بـين متوســات رتبـ درجـات

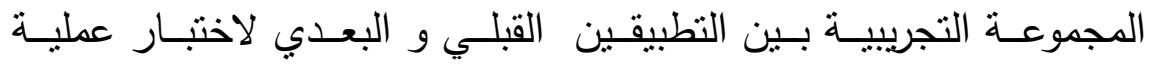

$$
\text { الإستنتاج إلبه النتائج : الميه }
$$

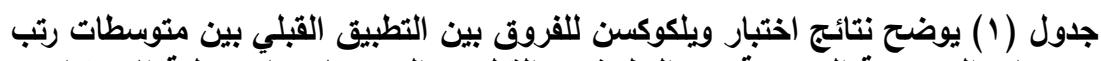

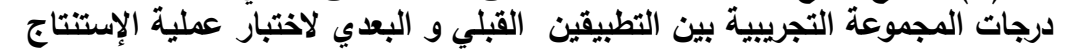

\begin{tabular}{|c|c|c|c|c|c|c|c|c|c|}
\hline \multirow{2}{*}{ مستوى } & \multirow{2}{*}{ قيمة Z } & \multicolumn{2}{|c|}{ مجموع الرتب } & \multicolumn{2}{|c|}{ متوسط الرتب } & \multicolumn{2}{|c|}{ عدد الرتب } & \multirow{2}{*}{ وحدة } & \\
\hline & & + & - & + & - & + & - & & \\
\hline$\cdot, \ldots$ & r,Arч & $00, \ldots$ & صفر & 0,0 . & صفر & 1. & صفر & الدرجة & الإسنتتاج \\
\hline
\end{tabular}

ويتضــح مـن الجـدول السـابق وجـود فـرق دال إحصـائياً عنــ مسـتوى (0 • ، • ) بين متوسـطي رتب درجـات المجموعـة التجريبيـة بـين التطبيقين 
القبلي و البعدي لاختبار عملية الإستتناج المصور للأطفال المعاقين ذهنياً

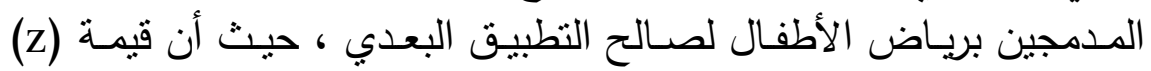

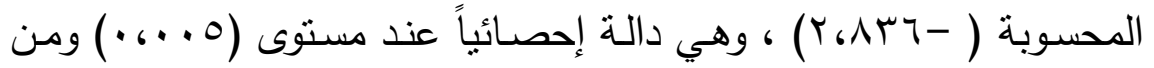
ثم يتضح صحة الفرض الأول

\section{تفسير و مناقثة النتائج المتعلقة بالقرض الأول:}

أظهرت نتيجة صحة الفرض الأول وجود فرق ذي دلالة إحصائية عند مستوى (0 . ، • ) بين منتوسطي رتب درجات أطفال المجموعـة التجريبية

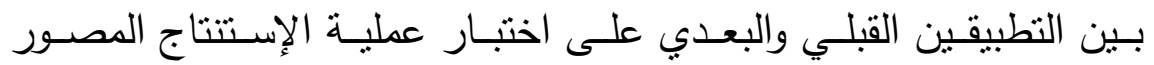
للأطفال ذوي الإعاقة الذهنيـة المدمجين بربـاض الأطفال لصـالح التطبيـق البعدي.

وقد ترجح الزيادة في درجات أفراد المجموعة التجربييـة للتطبيق البعدي لاختبار عمليـة الإسـتناج المصـور للأطفال ذوي الإعاقة الذهنيـة البسيطة المدمجين برياض الأطفال إلى : ا-تضمين عملية الإستتاج خلال مراحل العمل بالمشروع. r-استخدام فنيات تدريسية منتوعة تتمي عملية الإستنتاج في البحث. ب-تحديد دور كلٍ من المعلمة والطفل خلال إجراءات المشروع لتتمية عملية الإستنتاج.

צ-تحديد عدد كافي من الممارسات لكل هدفٍ فرعي على حدى.

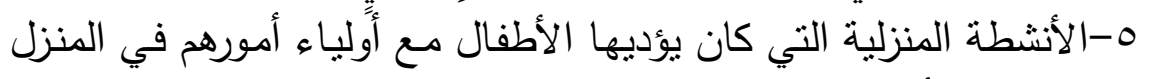

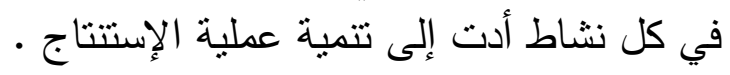




\section{اختبار صحة الفرض الثاني: \\ ينص الفرض الثاني على أنه:}

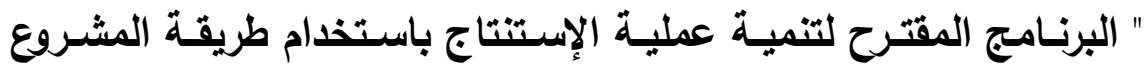

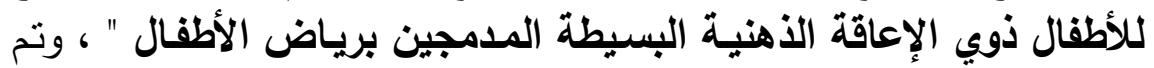

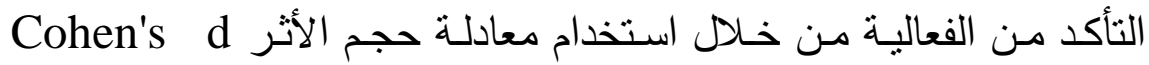
للعينات المرتبطة

\section{قيمة Wilcoxon

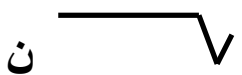

حيث Z هي قيمة Z الناتجة من اختبار ويلكوكسون ، ن هو عدد

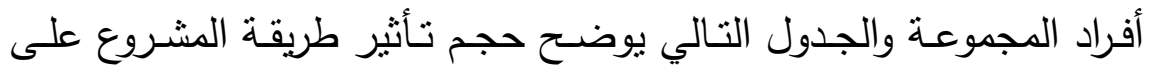

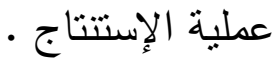
جدول (ץ) يوضح حجم التأثثر لاستخدام طريقة المشروع لتمية عملية الإستتاج للأطفال المعاقين ذهنياً المدمجين برياض الأطفال

\begin{tabular}{|c|c|c|c|c|}
\hline التأثخير & $\begin{array}{c}\text { Cohen's } \\
\text { d }\end{array}$ & قيمة Z & القياس & \\
\hline كبير & $\cdot, \wedge 9 \vee$ & r,Аץ & الدرجة & التصنيف \\
\hline
\end{tabular}

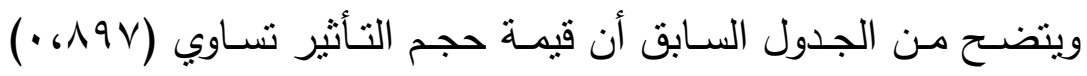

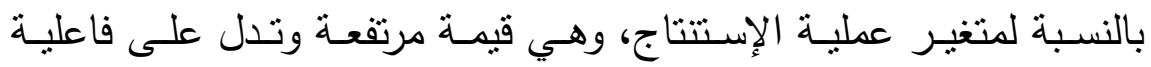

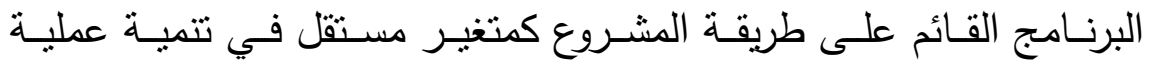

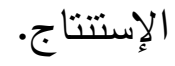




\section{تفسير ومناقشة النتائج المتعلقة بالفرض الثاني:}

أظهرت نتائج اختبار صحة الفرض الثاني ما يأني :

فاعلية البرنامج القائم على طريقة المشروع لتتمية عملية الإستتناج للأطفال

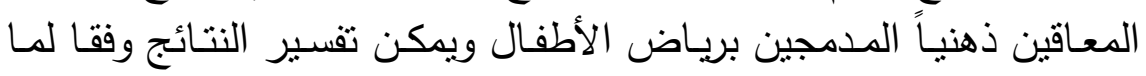
يلي:

ا-وجـود علاقـة ارتباطيـة بـين طريقـة المشـروع وتتميـة عمليـة الإسـتنتاج لكأطفال المعاقين ذهنياً المدمجين برياض الطين الأطفال.

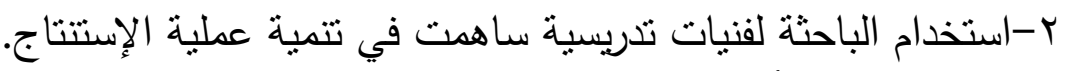

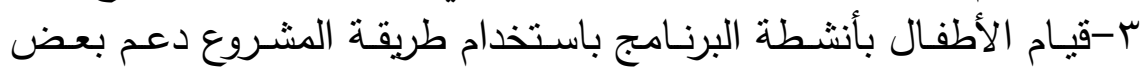

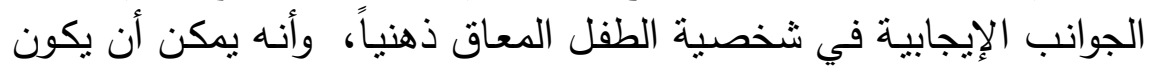
شخصاً منتجاً في مجتمعه. ع-استخدام الباحثة لأسـاليب التعزيز ، مما أثر إيجابيًا في دافعية الأطفال للتعلم.

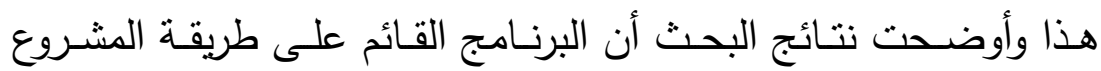
كمتغير مستقل له تأثير كبير وفعال في تتمية عملية الإستتناج المستهدفة في البحث الحالي ( كمتغير تابع) • توصيات البحث :

في ضوء نتائج البحث الحالي توصي الباحثة بما يلي :

ا-تضمين تعليم بعض عمليات العلم الأساسية في الأنشطة المقدمة للطفل ذوي الإعاقة الذهنية البسيطة المدمج برياض الأطفال. 
r-تضــمين اسـتراتيجية المشـروع في جمبـع الأنشـة المقدمـة للطفـل ذوي الإعاقة الذهنية البسبطة المدمجين برياض الأطفال؛ لأنها تزبد من دافعيـة الإنية

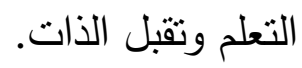
ب-توفير دورات تدربيية لمعلمات رياض الأطفال لتدريبهن على تتمية عملية الإستتناج للطفل ذوي الإعاقة الذهنية البسيطة المدمج برياض الأطفال.

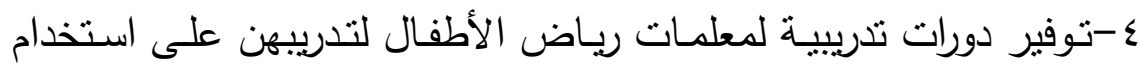

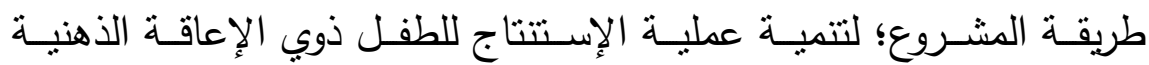
البسيطة المدمجين برياض الأطفال. ه-الاهنمـام بتتميـة مختلـف المفـاهيم والمهـارات لـدى الطفـل ذوي الإعاقـة الذهنية البسيطة من خلال استخدام طربقة المشروع.

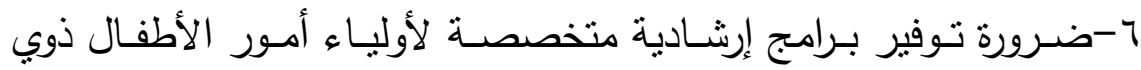
الاعاقة الذهنية البسيطة يتعلمون من خلالها تتمية عملية الإستتناج لأبنائهم. V-ضـرورة عمـل نـدوات لتوعيـة أوليـاء الأمسور بصفةٍة عامـةٍ وأوليـاء أمسور

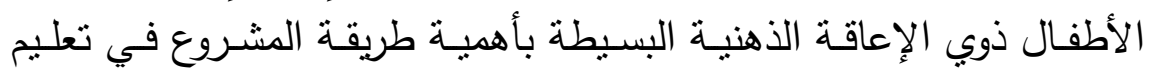

$$
\text { أبنائهم. البحوث المقترحة: }
$$

1 -

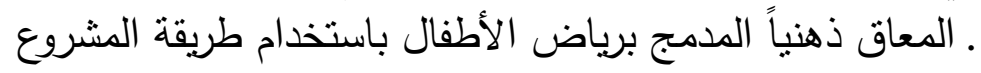

تميـة عمليـة الإستنتاج للطفل ذوي الإعاقة الذهنية البسيطة باستخدام -

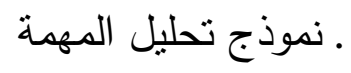

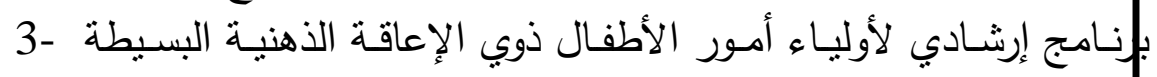

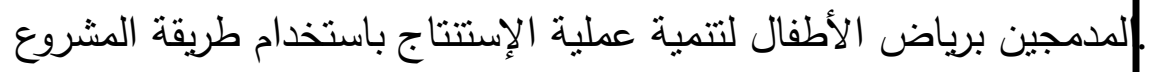


ـ-برنـامج كمبيوتري قائم على المعالجة البصرية لنتميـة عملية الإسنتناج

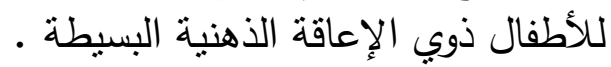

\section{المراجع}

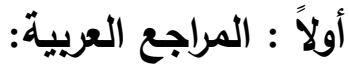

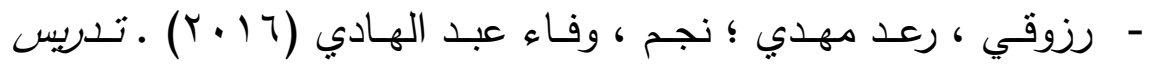

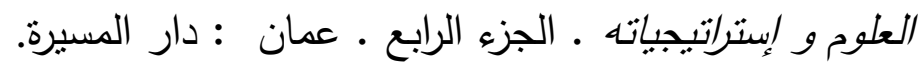

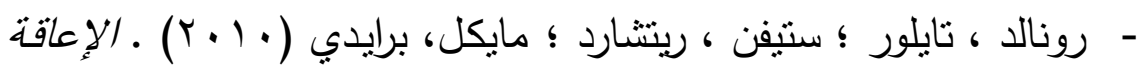

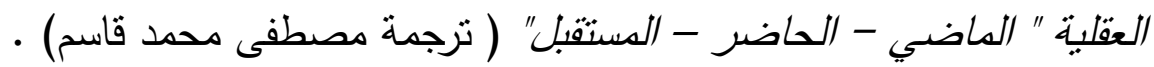
عمان : دار الفكر ناشرون و موزعون.

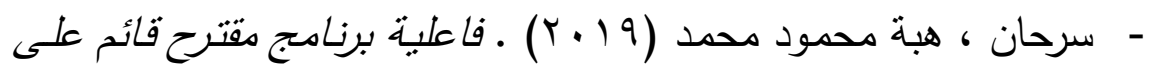

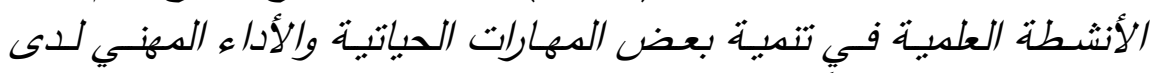

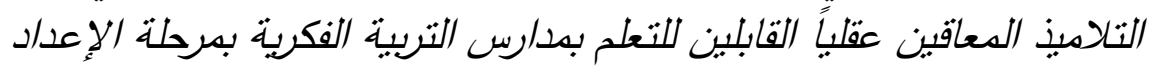
الهينى (دكتوراه ). جامعة القاهرة ـ كلية الدراسات العليا.

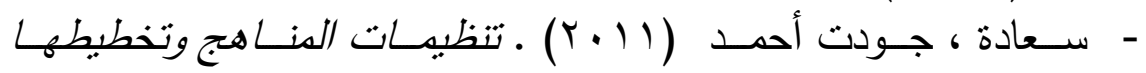

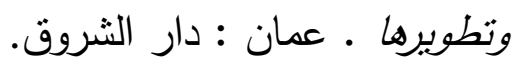

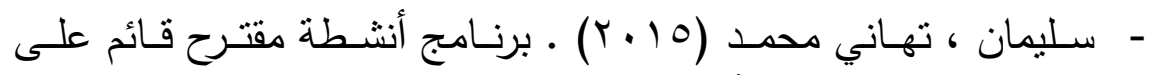

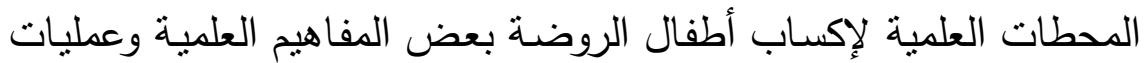

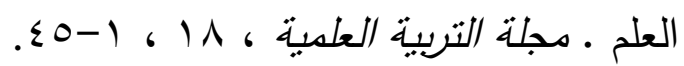

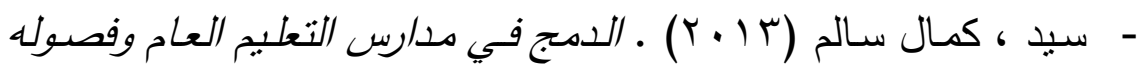

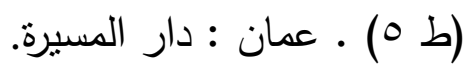

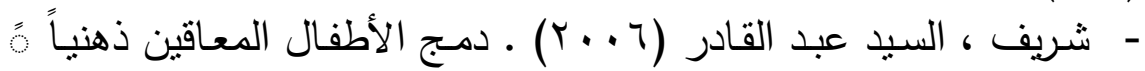

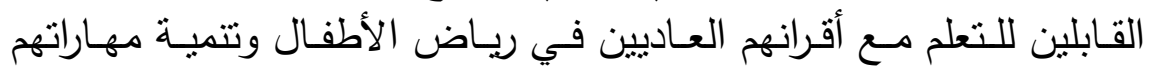
الاجتماعية ـ المؤتمر السنوي لكلية رباض الأطفال ـ جامعة القاهرة. 


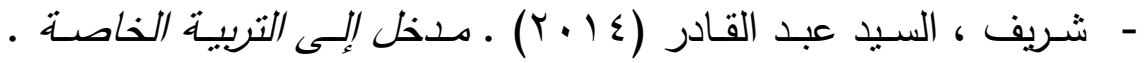
القاهرة : دار الجوهرة.

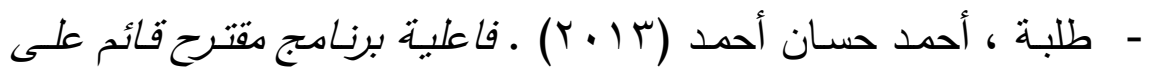

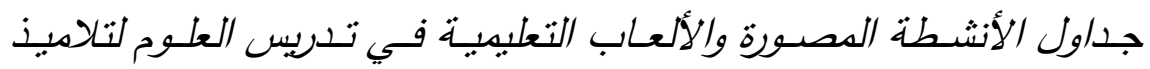

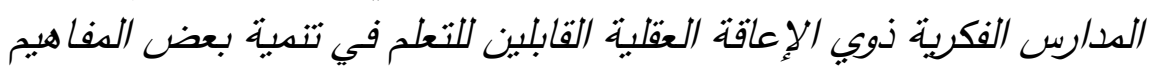
العلمية و المهارات الحياتية ( دكتوراه) • جامعة الفيوم .كلية التربية.

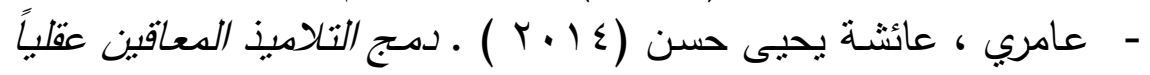

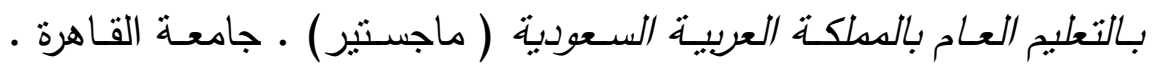
معهد الدراسات والبحوث التربوية.

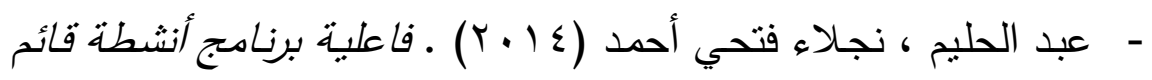

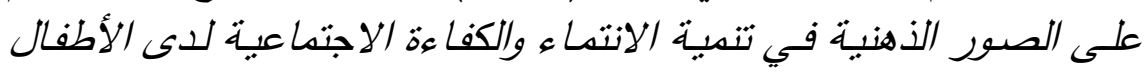

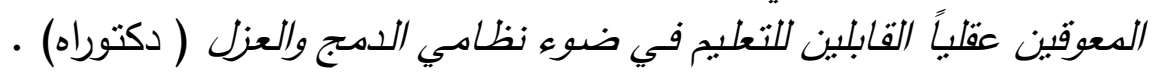
جامعة القاهرة ـ معهز دراسات الطفولة.

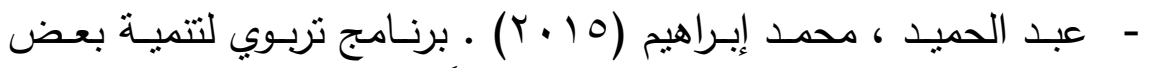

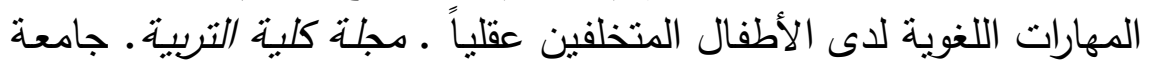
بورسعيد.

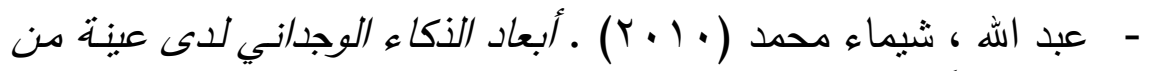

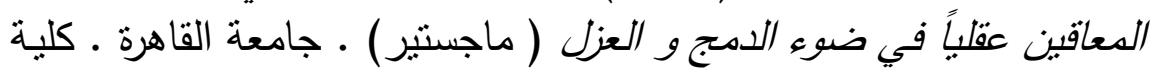
رياض الأطفال.

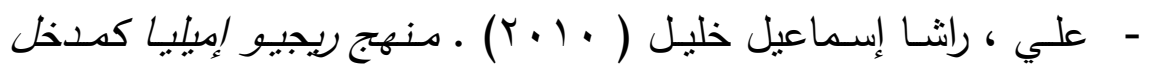
لإكساب طفل الرياض بعض الكفاهيم الهياعل الهرتبط بحقائق الحياة ( دكتوراه ). كلية رياض الأطفال ـ جامعة الإسكندرية. 


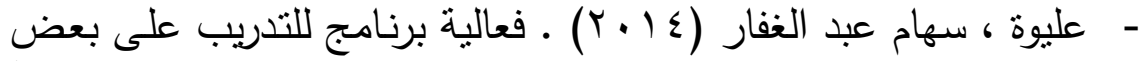

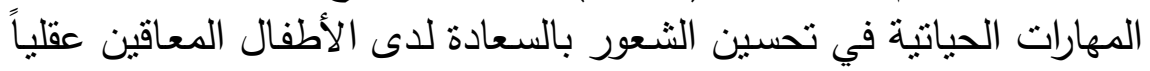

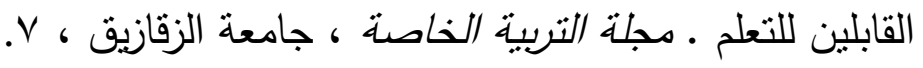

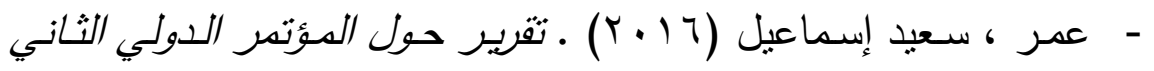

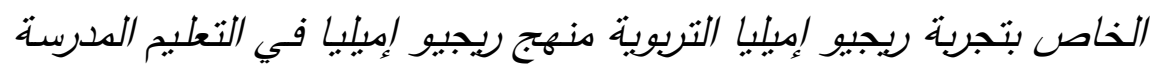

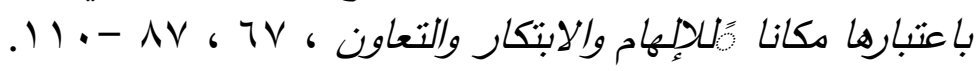

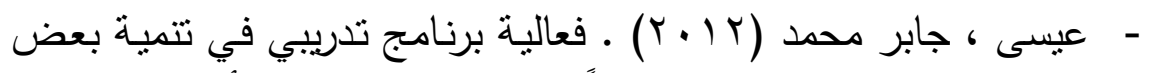

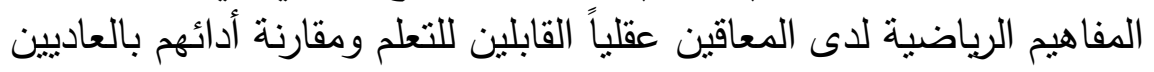

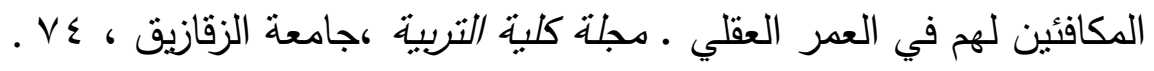

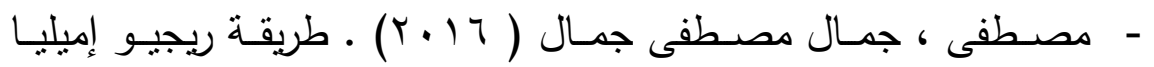

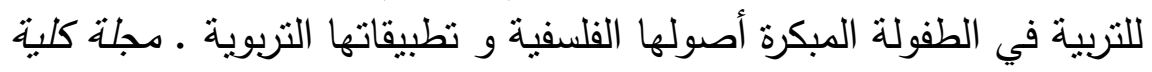

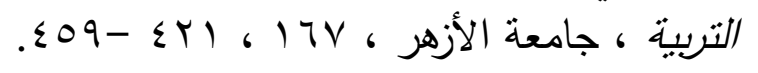

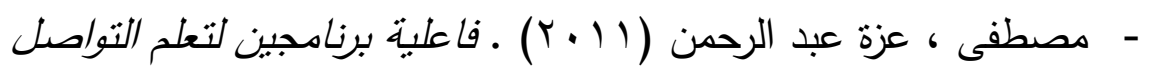

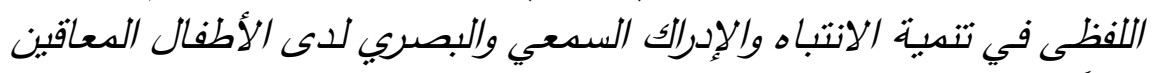

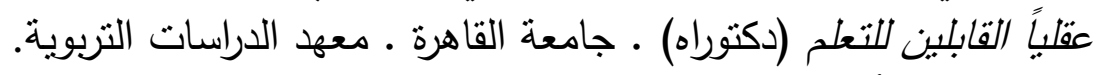

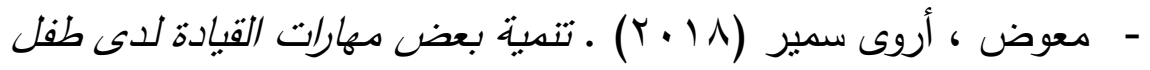

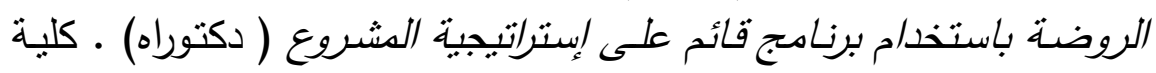
رياض الأطفال ـ جامعة بورسعيد. براسن.

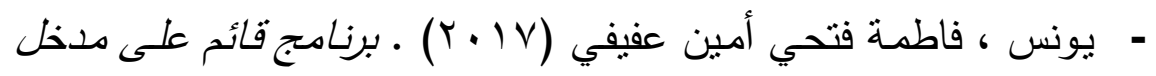
ريجبو إمبليا لتحقيق معابيير مجال العلوم لدى طفل الروضة لجامعة القاهرة . 


\section{ثانياً : المراجع الأجنبية:}

- Bower , Jaclyn Morris . (2014) . Montessori Method and Reggio Emilia approach and science in kindergarten compared and contrasted. Research Starters Education 2 From ( www.young childrens learning . Ecsd . Net) .

- Brown, Karr . (2011). The Reggio Emilia Approch . (p.p. 1-1) . Great Neck Publishing .

- Burns , Marcia V.lewis Alishal . (2016). How the project approach challenges young children . Gifted Child Today, V 39 n 3 p 140-144.

- Buyuktaskapu , S. , Celikoz , N. \& Akman , B. (2012) .The Effects of constructivist sciece teaching program on scientific proseccing skills of 6 years old children . Eduction and Science. 37 (165) . P. P. 275-292 .

- Chung - Hee, C. (2010). The Effects of Science Activities using nofication literature on preschool children's scientific process skills. Attitudes and comcepts, Korean Journal of child studies, 31 . P.P. 167191 .

- De Kock, Jill . (2015) . Science in early children a program inspired by Reggio Emilia Approach. ACE papers . 30 . P.P. 117-133 From http://www.research gate .net/ publication /229901424 . 
- Dijana, Hristovska, Snezana Javanova - Mitkovska, practical. (2010) . Strateguies to improve learning and Achievements of pupils with special educational needs in Elementry school. Social and Behavioral Sciences. Vol . 2. I .2.Issue2 .p.p.2911 - 2916.

- Fyfe, Brenda, Hovey, Sally Miller, Strange Jennifer . (2011). Thinking with parents about learning. INJ .Hendrick (Ed), Next steps towards teaching the Reggio way accepting the challenge (2nd ed ) .p.p.96-105). Upper saddle river, NJ Education, Inc availabke at http://www.world cat . Org/title/next-steps- towardteaching.

- Galini , Rekalidou\& Efthymia , Penderi . (Oct ,2010). Acollaborative Action Research Project in the kindergarten perspectives and challenges for teacher development through evaluation process . New Horizons Education. Vol . 58 Issue 2, P . P. 18-33

- Gandinin , Lio . (2012) . Foundations of the Reggio Emilia Approach in J.Hendric (Ed) Next steps toward teaching the Reggio way accepting the challenge to change (2nd ed). P.p.13-26 . Upper Saddle River . N.J .person/ Merill/ prentice. Hall . Available at : http://www.pearson highered .com /program/Hendrick- 
Next-Steps- Toward-Teaching- the Reggio - way accepting.

- Glassman , Michael, Whaley, Kimberlee. (2013). Dynamic Aims. The use of long term projects in early childhood classroom in light of Reggio Emilia's Educational philosophy. Child development. 2From : http://ecrp.illinois.edu/v2nl/index.html .

- Hall, Claire .(2013) . Implementing a Reggio Emilia Inspired Science. The Impact on Early Childhood Teachers professional role. Published. M A thesis. Edith Cowan University . Perth Austra lia . From http://ro.ecu.edu.au/theses//1082/

- Hendrick , Joanne. (2012) . Reggio Emilia and American schools telling them apart and putting them togeather-can we DO IT? INJ. Hendrick ED.NEXT steps towards teaching the Reggio Way. 2nd . Ed . P.p.p. 38-49. Upper Saddle RIVER .Pearso Merrill Prentice Hall from http://www.paper back swap.com/next-step-towardjoanne-hendrick/book/013049657/

- Idiege, Kimson Joseph, Ja, Cecilia, Ugwu .(2017) . Development of Science Students and pupils. An oppinion International Journal of Chemistry Education, Vol . (2) . P.P 13-21. 
- Kuru , N . , \& Ahman , B . (2017) . Examining The Science Process Skills of preschoolers with regards to teachers and children variables . Education and Science, 42 . P .P . 269-279 .

- M. Maranan, Vernique . (2017) . Basic Process Skills and attitude toward science to an enhanced student cojnitive performance. Laguna State Polytechnin University . Sanpablo city campus . Master .

- Syarifah Ihda, Tasuah, Neveng . (2018). The Science Process Skills of class B children reviewed from the decision-making learning model at TK ABA rendeng, Purworeijo City . Early Childhood Eduction Papers from http://journal.Unnes.ac.idl/index.Ptp/belia. 

برنامج قائم على إستراتيجية التعلم المستثد إلى الاماغ لتنمية المهارات اللغوية الاتصالية وعلاقته بتحسين مستوى الوعي المورفولوجي للغة لاى أطفال ما قبل المدرسة ذوي صعويات التعلم

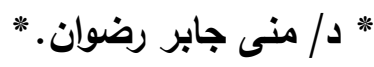

ملخص البحث :

استهدف البحث الحالي التحقق من فاعلية برنامج قائم على إستراتيجية التعلم المستتد إلى الدماغ لتتمية المهارات اللغوية الاتصالية، كما استهدف البحث قياس العلاقة بين تتمية المهارات اللغوية الاتصالية وتحسن مستوى

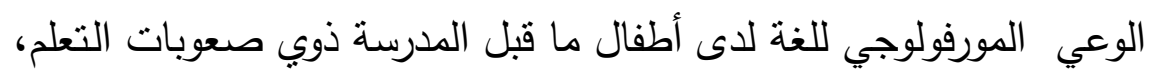
وقد اتبع البحث المنهج شبه التجريبي ذي المجموعة الواحدة ،حيث طبق لوبق

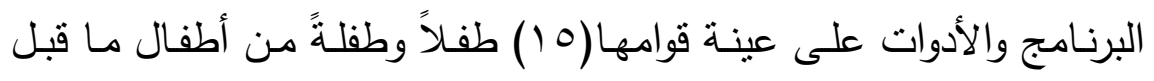
المدرسة ذوي صعوبات التعلم، وتم اختيار العينة بطريقةٍ عمديةٍة من روضهة معهد فتيات الزهور التجريبي بمحافظة بورسعيد، واستخدمت الباحثة مقياس

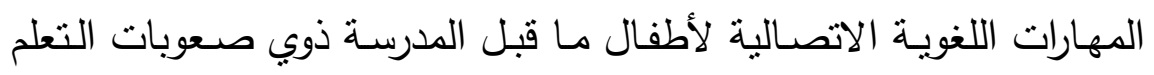

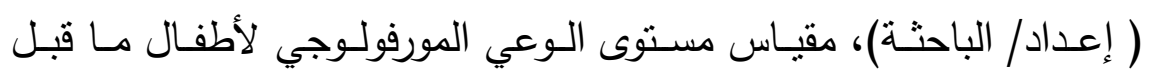
المدرسة ذوي صعوبات التعلم ( إعداد/ الباحثة)، البرنامج التدريبي المقترح *** مدرس علم نفس الطفل بقسم العلوم النفسية -كلية التربية للطفولية المبكرة - جامعة بورسعيد. 
القائم على إستراتيجية التعلم المستتد إلى الدماغ ( إعداد/ الباحثة). توجد علاقة ارتباطية بين درجات أطفال المجموعة التجريبية على كلٍ من (مقياس المهـارات اللغويـة الاتصـالية المصـور) ومقيـاس الوعي المورفولـوجي، وقد أثنتت نتائج البحث فاعلية البرنامج القائم على إستراتيجية التعلم المستتد إلى الدماغ لتنميـة المهارات اللغويـة الاتصـالية، كما تحققت النتائج مـن وجـود علاقـة ارتباطيـة إيجابيـة بـين تتميـة المهارات اللغويـة الاتصـالية وتحسـن مستوى الوعي المورفولوجي للغة لدى أطفال ما قبل المدرسـة ذوي صعوبات

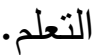

\section{A program based on a brain-based learning strategy to develop communicative language skills and its relationship to improving the level of morphological awareness of language in preschool children with learning difficulties}

Dr. Mona Gaber Radwan. *

\section{Abstract:}

The current research aimed to verify the effectiveness of a program based on a brain-based learning strategy for developing communicative language skills. The research also aimed to measure the relationship between developing communicative language skills and improving

* Lecturer, Department of Psychological Sciences - Faculty of Early

Childhood Education - Portsaid University. 
the level of morphological awareness of language in preschool children with learning difficulties. The research followed the quasi-experimental approach. One group, where the program and tools were applied to a sample of (15) pre-school children with learning difficulties, and the sample was deliberately chosen from the kindergarten of the experimental flower girls institute in Port Said governorate, and the researcher used the communicative language skills scale for preschool children with difficulties Learning (preparation / researcher), morphological awareness level measure for preschool children with learning difficulties (preparation / researcher), proposed training program based on brainbased learning strategy (preparation / researcher). There is a correlative relationship between the scores of the children of the experimental group on both the (illustrated communicative language skills scale) and the morphological awareness scale. The results of the research demonstrated the effectiveness of the program based on the brain-based learning strategy for developing communicative language skills. The results also verified the existence of a positive correlation between development. Communicative language skills and improvement of the level of morphological awareness of language among preschool children with learning difficulties. 


\section{الكلمات المفتاحية Keywords:}

- - إستراتيجية التعلم المستتد إلى الدماغ.

Brain-based learning strategy

- المهارات اللغوية الاتصالية. Communicative language skills - الوعي المورفولوجي للغة.

Morphological awareness of language

$$
\text { - أطفال ما قبل المدرسة ذوي صعوبات التعلم. }
$$

Preschool children with learning difficulties

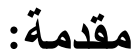

لاقت صـعوبات التعلم اهتمامـاً كبيـراً مـن البـاحثين نظـراً لتزايـد أعداد

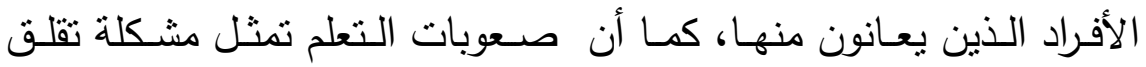

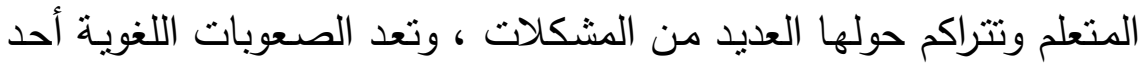

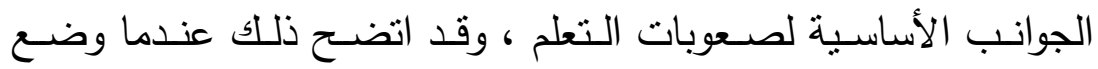
مفهوم صسوبات التعلم، حيث أنثار إلى أن الطبيعة الحقيقية

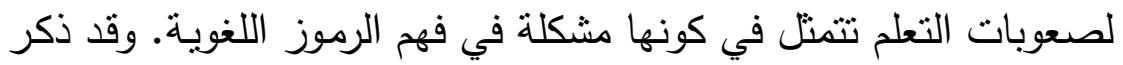

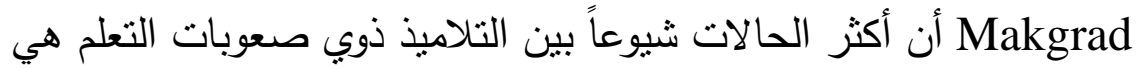

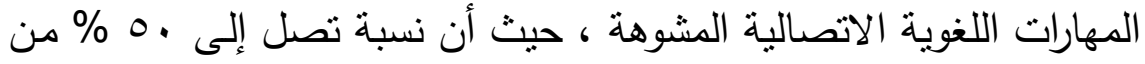

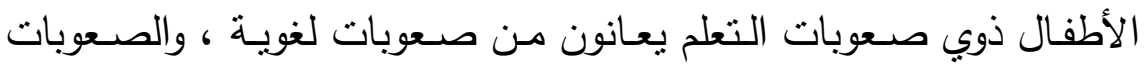
اللغوية لها آثارها السلبية الثابتة على التحصيل الدراسي الأكاديمي.

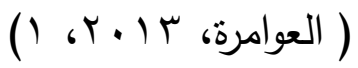

وقد اتجهت الدراسـات والبحوث المعاصرة إلى التركيز على المشكلات والعمليات التي تقف خلف صعوبات التعلم ، وقد أخذت البحوث والدراسات التهات التحات 


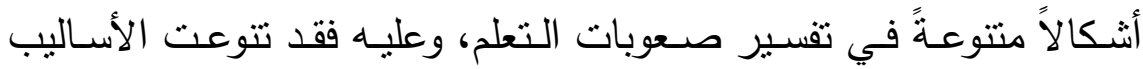

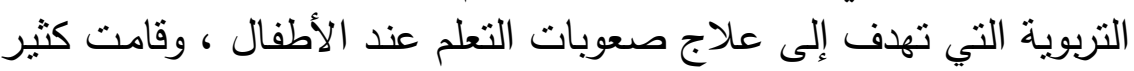

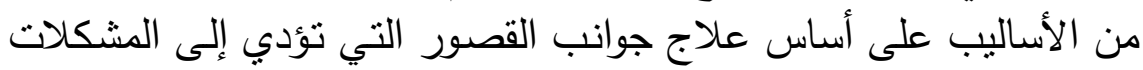

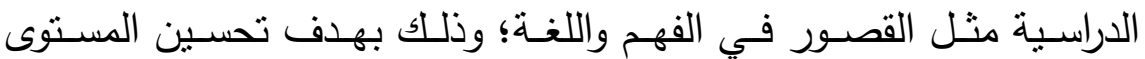

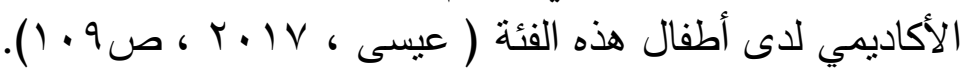

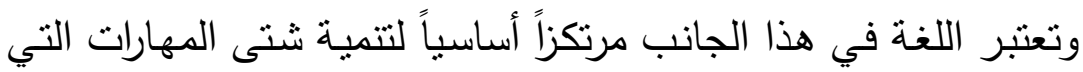

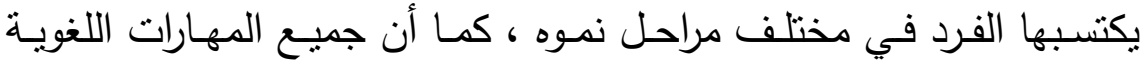

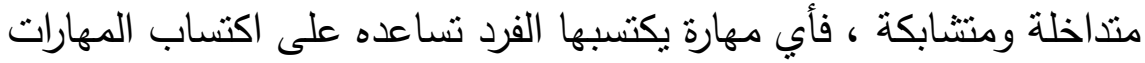

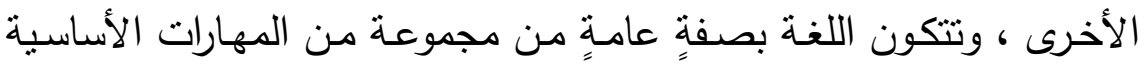

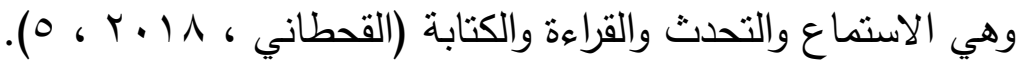
فاللغة نظام رمزي صوتي تتفق عليه جماعة معينة من الناس للتفاهم

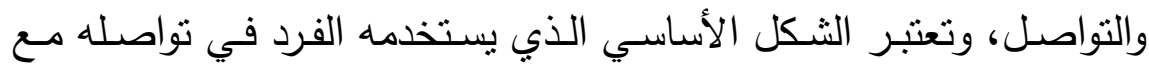

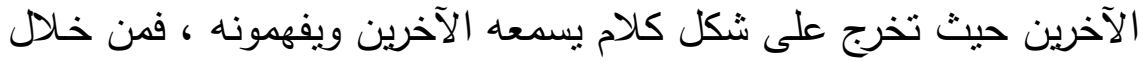

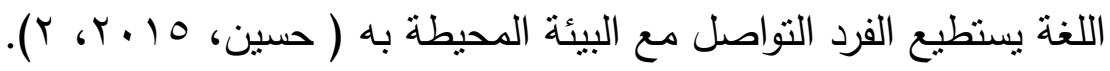

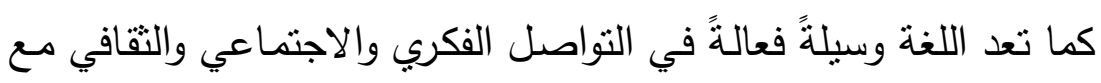

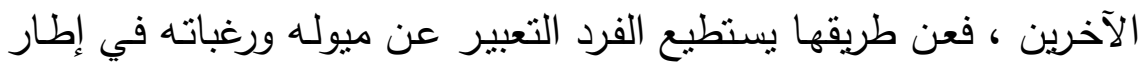

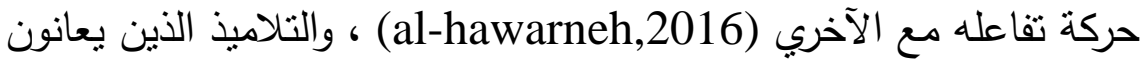
من صعوبات في اللغة تظهر لديهم صعوبة في المستوى المورفولوجي للغة،

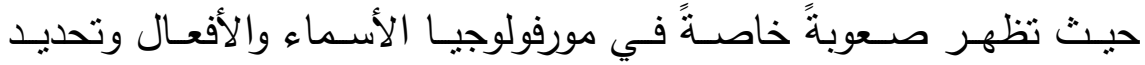

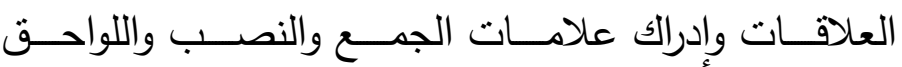

(lukacs;leonared,\&kas,2010, 145-161) وهذا ما أكدته دراسة ( (Ann j., \&Julia, c,2015من أن التلاميذ

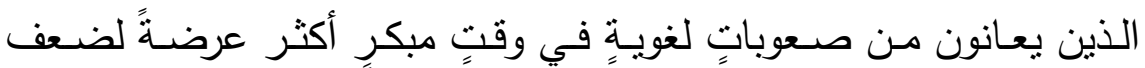


مهـارات القـراءة عـن غيـرهم ، كمـا أن هنـاك علاقـة بـين مسـتوى الـوعي

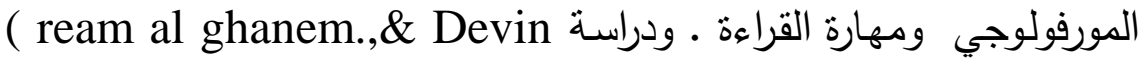
kearns,2015) التي أظهرت نتائجها وجود علاقة قوبة بين مستوى الوعي

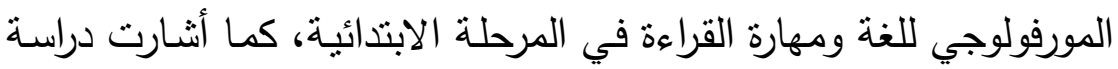
(pasquarella,et al,2011) دوراً هامًا في زبادة الحصيلة اللغوبة والفهم القرائي ونمو القدرة على القراءة والكتابة.

وبذللك يمكن القول أنـه لكي نستطيع تتميـة المهارات اللغوبـة الاتصـالية

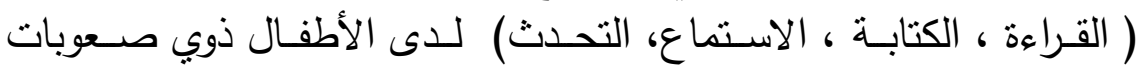

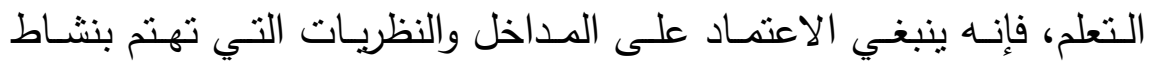

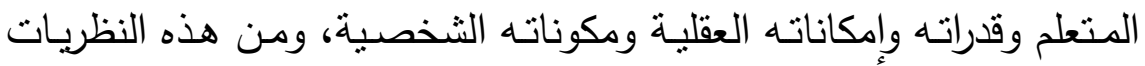
نظرية التعلم المستتد إلى الدماغ، والتي تعد أحد الأسـاليب الحديثة والمهـة في رفع مستويات التحصيل الأكاديمي لدى المتعلمين وبؤدي إلى الاستقرار النفسي والاجتماعي ، ما يترتب عليه تحقيق الأهداف التربوية بسهولة.

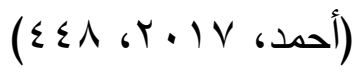

وترى هذه النظرية أن التعلم المستند إلى الدماغ بحدث طالما أن الدماغ

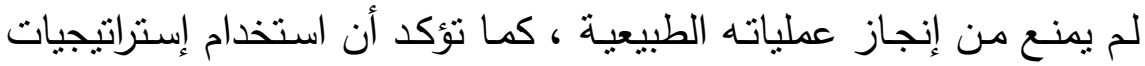

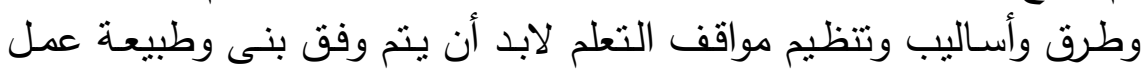

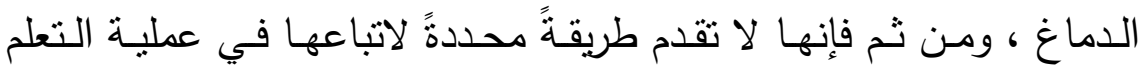

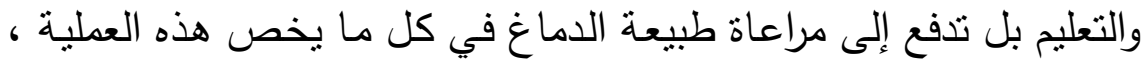

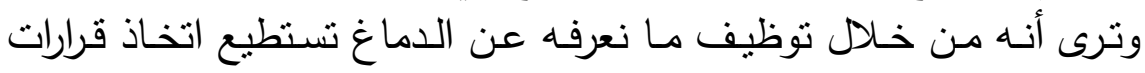
أفضل في مواقف التعلم وتحقيق نواتج التعلم بأقل درجة من الاخفاق.

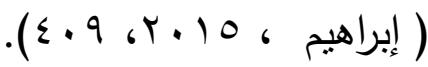


كما أكدت نظرية التعلم المستتد إلى الدماغ على أن كل فرد قادر على لقد

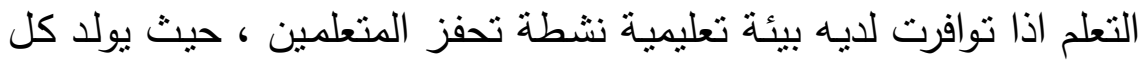

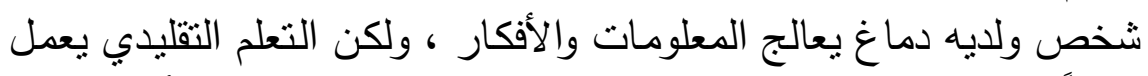

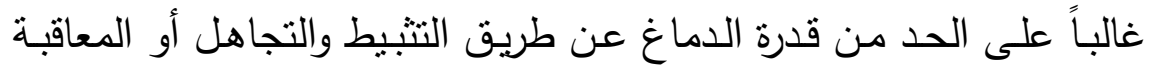
والتخويف. (funderstanding,2011 ).

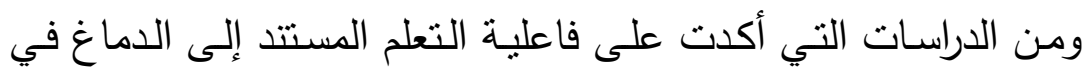

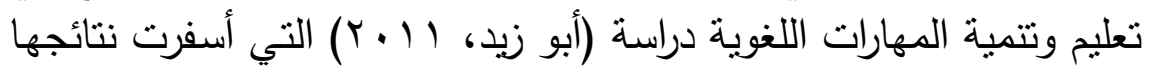

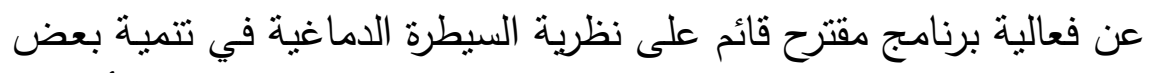

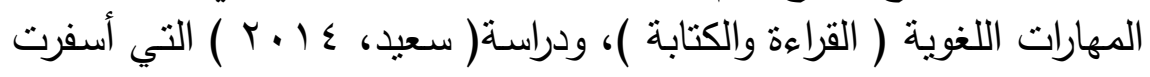

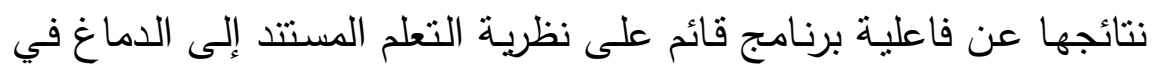

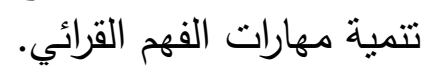

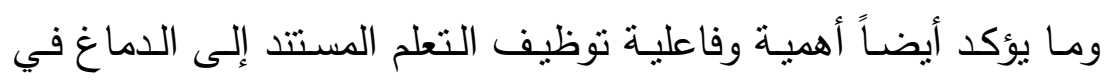

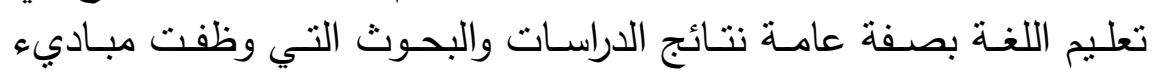

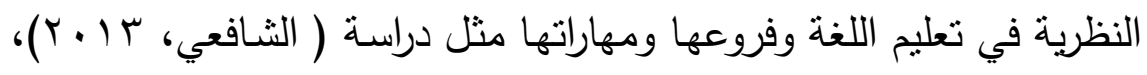
ودراسة(EVA,2010)

وترى الباحثة أن استخدام برامج قائمـة على التعلم المستتد إلى الدماغ

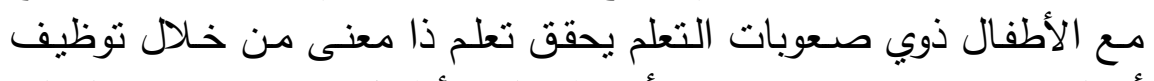

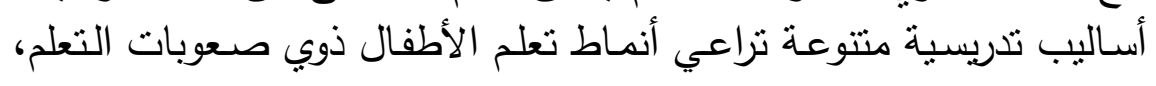

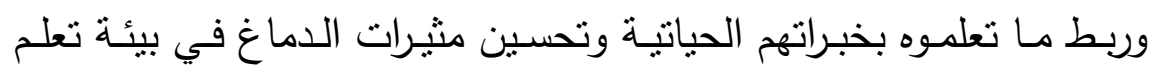

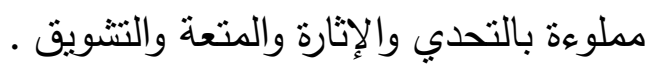

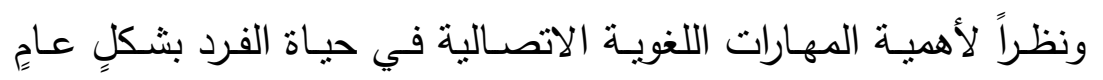
وتحسين المستوى المورفولوجي للغة في جميع النواحي الأكاديمية للأطُفال

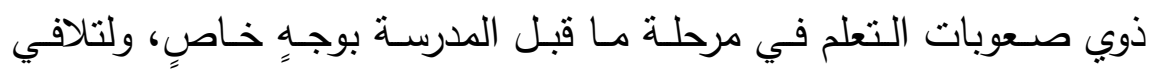


الآثار المترتبـة على تدني التحصبل الأكاديمي للمجالات المتعلقة بالقراءة

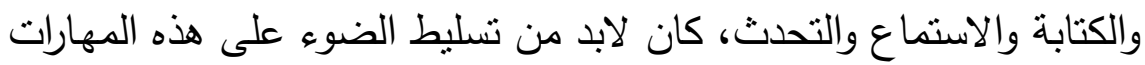
( الاستماع ، التحدث ، القراءة ، الكتابة).

وبهذا يمكن القول أن البحث الحالي يسعى إلى القيام بخطوةٍ أبعد لمـا

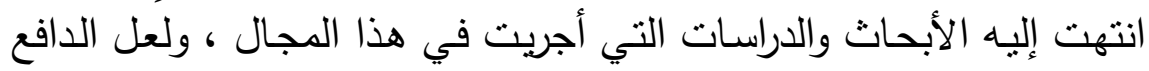
الذي جعل الباحثة تتتاول هذا الموضوع هو ندرة البحوث والدراسات العات العربية

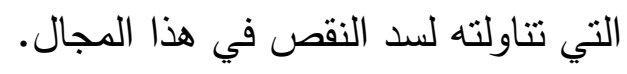

\section{مشكثة البحث وأسئلته :}

إن الاهتمام باكتساب اللغة عند الأطفال بصفةٍ عامةٍ وذوي صعوبات

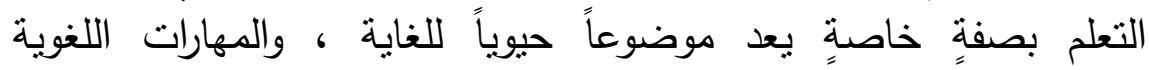

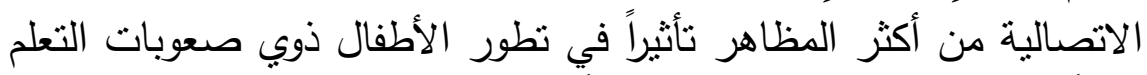

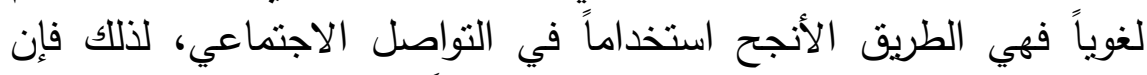
ضعف تلأك المهارات عند الأطفال يسبب تأخراً في تطور المهارات اللغوية الطاتية

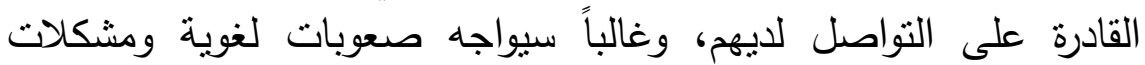
تربوية وأكاديمية .

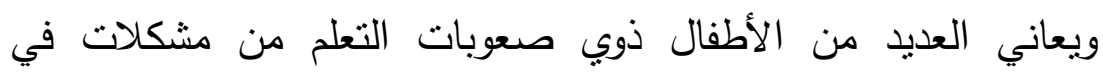

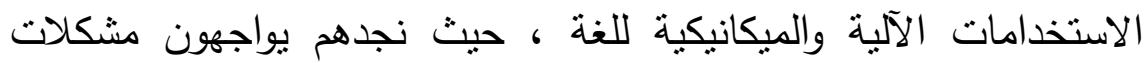

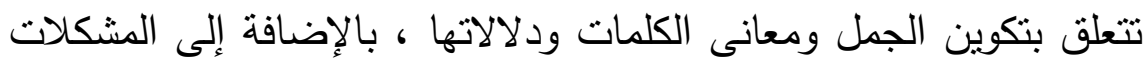

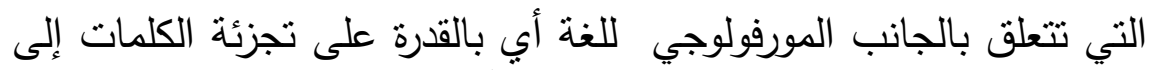

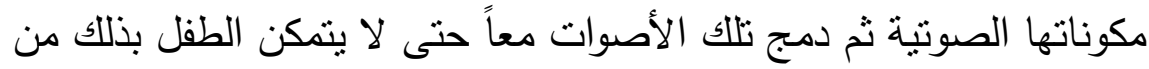

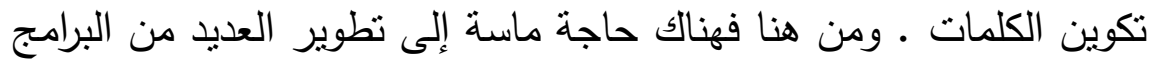

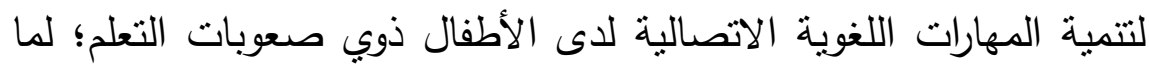


لصعوبات التعلم آثار وأبعاد تتجاوز المجالات الأكاديمية فيما بعد في المراحل التعليمية اللاحقة.

ولذا لابد من تسليط الضوء على هذه الفئة وإعطائها اهتمام؛ لأن لها مشكلات عديدة بحاجةٍ ماسة إلى التغلب عليها وعلاجها ، وذلك بابتكار أساليب وإستراتيجيات غير تقليدية تساعدهم على تتمية مهاراتهم اللغوبة فية الاتصالية، وذلك من خلال برامج تدربيية مختلفة تهدف إلى مساعدتهم ، وهذا ما دفع الباحثة إلى تتاول هذا الموضوع •

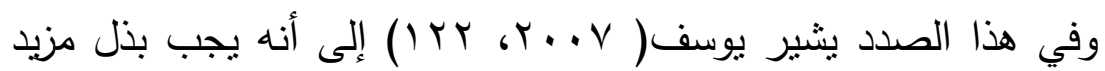
من الجهد في تبنى برامج قائمة على أساس التكامل بين نصفي المخ

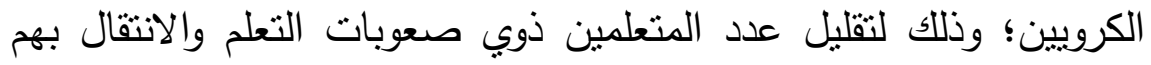
من دافعية سالبة معطلة إلى دافعية موجبة نشطة ترفع مستوى التحصيل الدراسي.

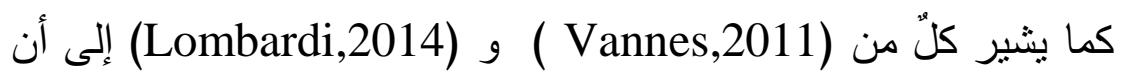
عملية التدريس والتعلم المستتد إلى الدماغ ينيح مشاركة الأطفال في عملية

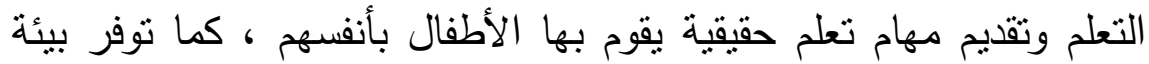

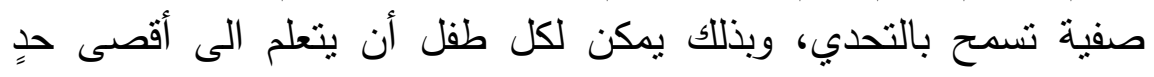
ممكن.

ونظراً لخطورة قصور المهارات اللغوية الاتصالية لاى الأطفال ذوبي البهري صعوبات التعلم كان من الضروري البحث عن إستراتيجيات غير تقات القليدية

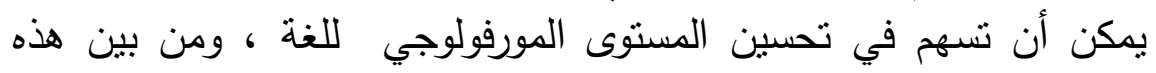

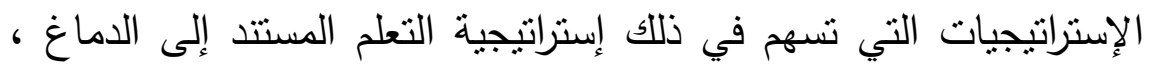

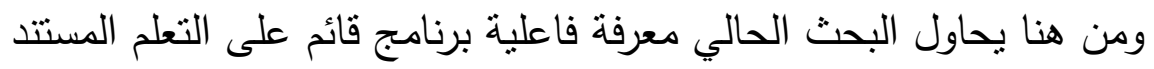


إلى الدماغ في تتمية المهارات اللغوية التواصلية وعلاقته بتحسين المستوى المورفولوجي للغة لدى أطفال ما قبل المدرسة ذوي صعوبات التعلم. لتهريه

ومن هنا تبلورت مشكلة البحث الحالي وسعت إلى البحث عن إستراتيجية تعليمية مناسبة لبيئة أطفال ما قبل المدرسة ذوي صعوبات التعلم، وهي مرحلة لها أهمية خاصة ألا وهي التعلم المستتد إلى الدماغ التي تحقق دعانه تفاعلاً بجعل الأطفال أكثز مشاركة في العملية التعليمية، وتزبد القدرة على وهي اكتساب المهارات اللغوبة الاتصالية وتحسين المستوى المورفولوجي للغة لديهم، وبناءًا على ما تقدم يمكن تحديد مثكلة البحث الحالي في الاجابة على السؤال الرئيس التالي:

ما فاعلية البرنامـج المقترح باستخدام إستراتيجية التعلم المستثد إلى الاماغ في تنمية المهارات اللغوية التواصلية لدى أطفال ما قبل المدرسة بله ذوي صعويات التعلم وعلاقته بتحسين المستوى المورفولوجي للغة لايهم؟ وبتفرع من السؤال الرئيس الأسئلة الفرعية التالية: -ما المهارات اللغوبة الاتصالية اللازمة لطفل ما قبل المدرسة ذوي صعوبات التعلم من (0-7) سنوات؟ مالت - ما مستوى الوعي المورفولوجي المناسب لطفل ما قبل المدرسة ذوي صعوبات التعلم من (0-7) سنوات؟ ماتوبو - ما الفروق بين درجات أطفال المجموعة التجريبية (عينة البحث ) في القياس القبلي والبعدي على مقياسي المهارات اللغوية الاتصالية والمستوى

$$
\text { المورفولوجي للغة ؟ }
$$

- ما الفروق بين درجات أطفال المجموعة التجريبية (عينة البحث ) في القياس البعدي والتتبعي على مقياسي المهارات اللغوبة الاتصالية والمستوى المورفولوجي للغة ؟ الغعدي 


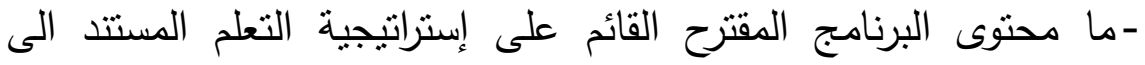
الدماغ في تتمية المهارات اللغوبة الاتصالية لدى أطفال ما قبل المدرسة ذوي صعوبات التعلم؟ - ما أثر البرنامج القائم على إستراتيجية التعلم المستتد الى الدماغ في تتمية المهارات اللغوية الاتصالية لدى أطفال ما قبل المدرسة ذوي صعوبات التهات التعلم?

- هل توجد علاقة بين المهارات اللغوية الاتصالية والمستوى المورفولوجي للغة

\section{أهداف البحث: - n}

يهدف البحث الحالي إلى تحقيق ما يلي:

ا ـ التعرف على فاعلية البرنامج المقترح القائم على إستراتيجية التعلم المستتد إلى الدماغ في تتمية المهارات اللغوية الاتصالية لدى أطفال ما قبل المدرسة ذوي صعوبات التعلم. r . التعرف على أثز تتمية المهارات اللغوية الاتصالية على تحسين المستوى المورفولوجي للغة لدى عينة البحث. r. تسليط الضوء على أهمية استخدام إستراتيجية التعلم المستتد إلى الدماغ

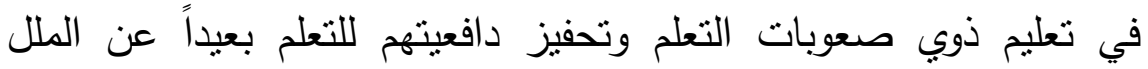
والثرود في المواقف التعليمية. ع ـ إعداد برنامج تدربي قائم على إستراتيجية التعلم المستتد إلى الدماغ في تتمية المهارات اللغوية الاتصالية لدى أطفال ما قبل المدرسة ذوي صعوبات التعلم. 
هـ معرفة أثز البرنامج التدريبي المقترح باستخدام إستراتيجية التعلم المستند

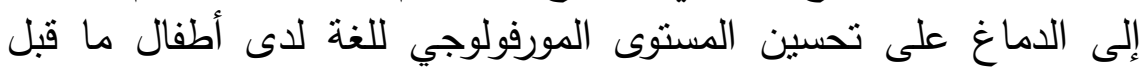
المدرسة ذوي صعوبات التعلم.

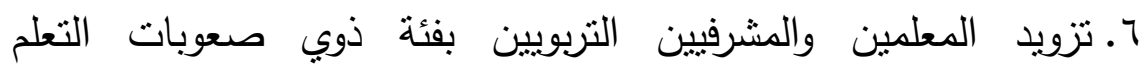
بإستراتيجيات تعليمية مستقاة من نظرية التعلم المستتد إلى الدماغ في تعلئين فئين

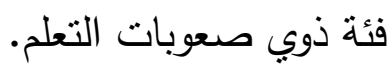

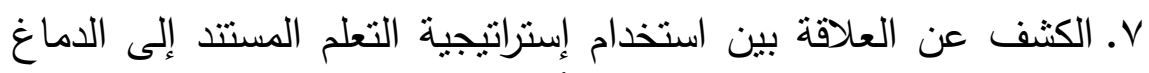

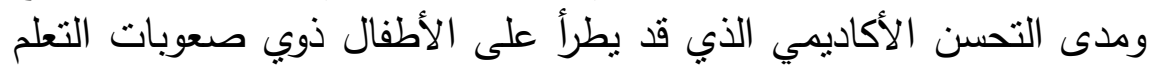
في المهارات اللغوية الاتصالية والمسنوى المورفولوجي للغة الإئ. أهمية البحث:

تتحدد أهمية البحث الحالي في النقاط التالية:

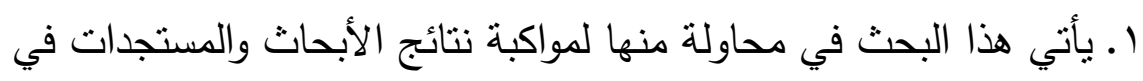

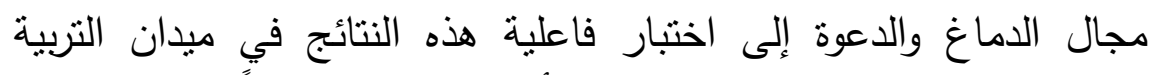

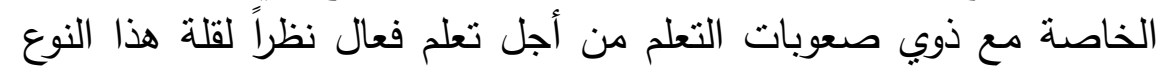
من الدراسات في هذا الجانب. r. كما تبرز أهمية هذا البحث أيضاً في أنها تلبي دعوة الاتجاهات

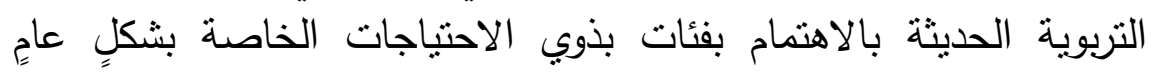

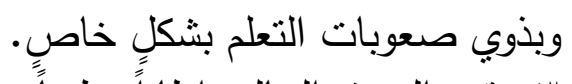
r. يقدم البحث الحالي إطاراً نظرياً حول مفهوم المهارات اللغوية الاتصالية

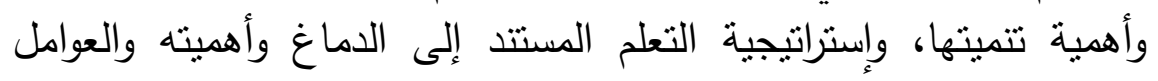

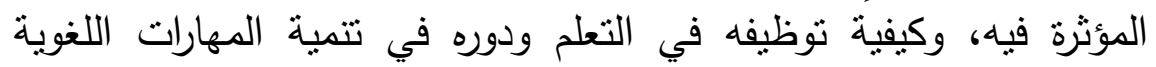
الاتصالية وتحسين المستوى المورفولوجي للغنة. 
ـ ـ توجه أنظار مؤلفي ومطوري المناهج الخاصة بتعليم فئة صعوبات التعلم إلى العناية بالمهارات اللغوبة الاتصالية، بحيث تساعد على تلى تنميتها لدى الدى الأطفال ذوي صعوبات التعلم وتسهم في تفعيل المداخل والنظريات الحديثة في التذربس والتي تعتمد على إمكانات المتعلم وخاصةً إستراتيجية التعلم المستند إلى الدماغ. ه. قد يكون هذا البحث نواة لدراسات جديدة في مجال إستراتيجية التعلم المستتد إلى الدماغ في المجالات الأكاديمية الأخرى في ضوءه فئه مداخل ونظريات أخرى غير إستراتيجية التعلم المستند إلى الدماغ.

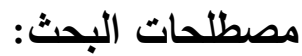

\section{: Program البرنامجج}

هو برنامج يقدم للأفراد بهدف تتمية مهاراتهم على أسس ومباديء تتحدد في تدرج التدخل والاستجواب التدريجي الذي يقوم على التدرج في تعليم الطلاب المعرفة والسلوكيات الصحيحة والخاطئة في إطار صيخ استفهامية.

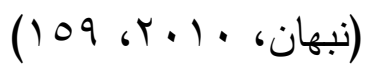

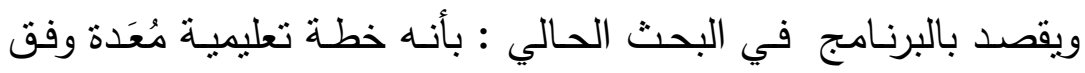
أسس تعنمد على إستراتيجية التعلم المستتد إلى الدماغ بهدف تتمية المهارات اللغوية الاتصسالية وتحسين المستوى المورفولوجي للغنة لدى أطفال مـا قبل المدرسة ذوي صعوبات التعلم.

\section{Brain Based Learning Strategy}

- إستراتيجية التعلم المستثد إلى الدماغ :

مجموعة من الخبرات التعليمية المنظمة والمنتربطة التي تقدَم في صورة مواقف تعليميـة، حيـث يقـوم المــخ بمعالجتهـا وربطهـا بـالخبرات الحياتيـة 
الواقعبـة، مدـا يحقـق التعلم ذا المعنىى والفهم العمبـق للمحتوى الـذي يقدَم

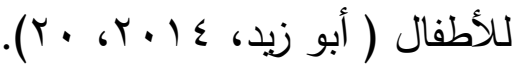

وتعرف الباحثة إسـتراتيجية التعلم المستتد إلى الدماغ إجرائيـاً بأنـه :

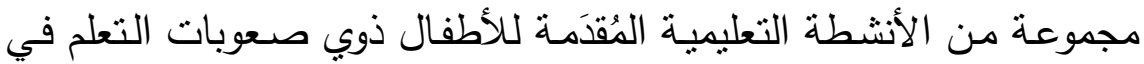

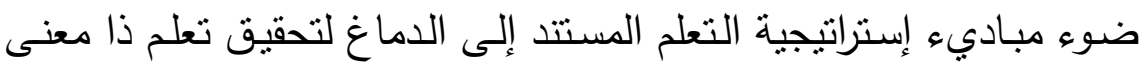
من أجل تتمية المهارات اللغوبـة الاتصـالية وتحسين المستوى المورفولوجي الميكي للغة لديهم.

\section{-المهارات اللغوية الاتصالية: Communication language skills} هي أداء يتم في سرعة ودقة ويختلف نوع الأداء وكيفيته باختلاف المجال

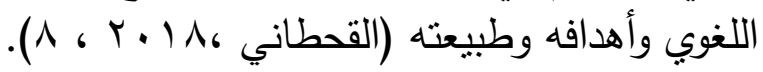

وتعرف الباحثة المهارات اللغويـة الاتصالية إجرائياً بأنها: مجموعة من النا

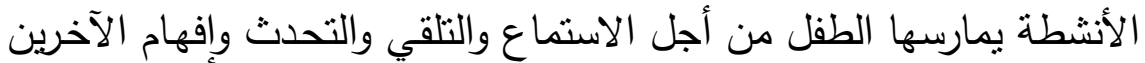

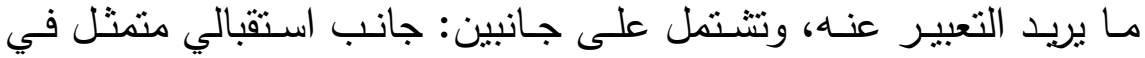
( مهارة الاسـتماع والقراءة)، وجانب تعبيـري متمثل في في ( مهارة التحدث

\section{Awarenes Morohology مستوى الوعي المورفولوجي للغة}

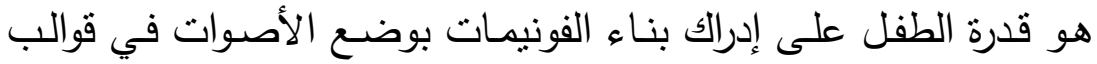

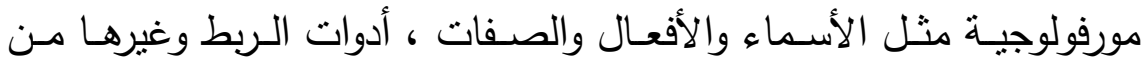

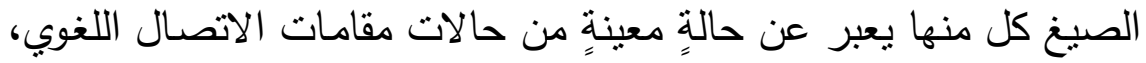

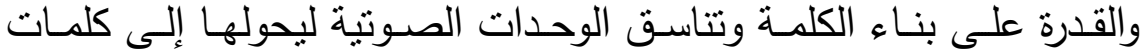
( مورفيمات)، بحيث تعطي معنى وصياغة الكلمات في جمل مفهومة.

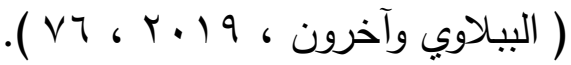


وتعرف الباحثة مستوى الـوعي المورفولـوجي للغـة إجرائيـاً بأنسه: قدرة

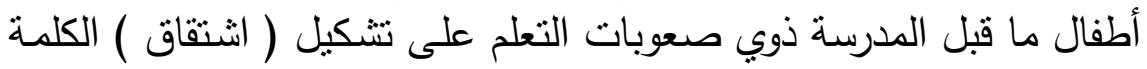

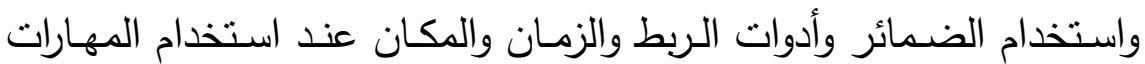
اللغوية الاستماع والتحدث والقراءة والكتابة.

\section{Children at risk of learning difficulties}

\section{-الأطفال ذوي صعويات التعلم :}

يعرف بيتمان Baeman الأطفال ذوي صعوبات التعلم بأنهم : الذين

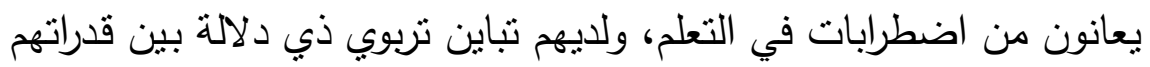

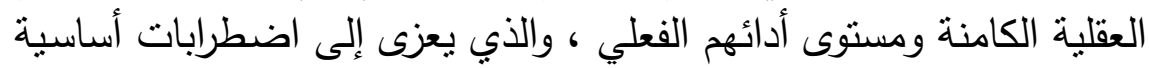

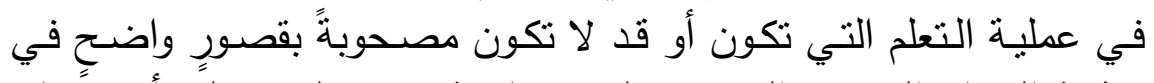

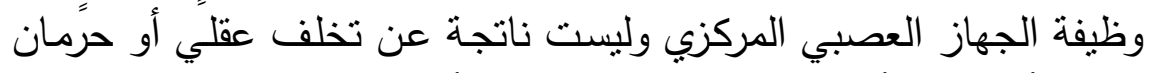
تربوي أو ثقافي أو اضطراب انفعالي شديد أو فقدان للحواس ( البطانيـة، (r) 6 (r. 10

وتعرف الباحثة أطفـال مـا قبـل المدرسـة ذوي صـويات التعلم إجرائيـاً

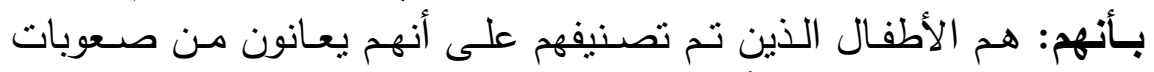

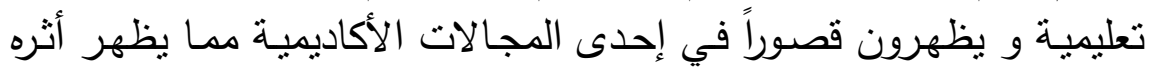
في انخفاض أدائهم الأكاديمي المدرسي في في احني الأساليب الاحصائية:

لتحقيق أهداف البحث سيتم استخدام برنـامج الحزم الاحصـائية للعلوم

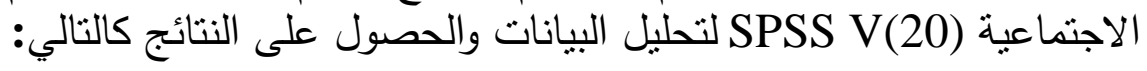
1-اختبار (ويلككسون Wiloxon Test ) للمجموعات المرتبطة: للتحقق

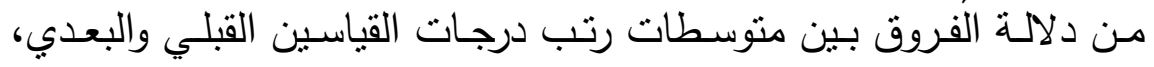

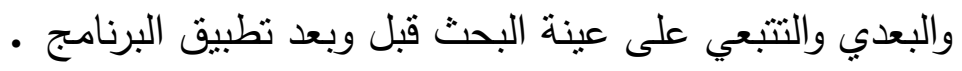


r-معامل ( ألفا كرونبا Cronach, Alpha): لحساب درجة ثبات مقياس

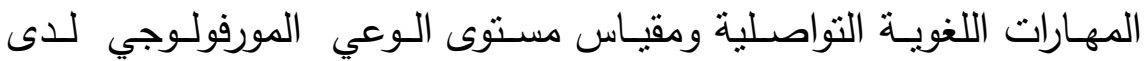

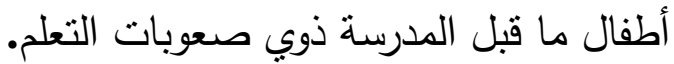
r-معامل ارتباط بيرسون Person Correlation : لحساب صدق مقياس ديس المهارات اللغوية الاتصالية ومقياس مستوى الوعي المورفولوجي لدى أطفال ما قبل المدرسة ذوي صعوبات التعلم. צ-معامل ارتباط بيرسون Person Correlation: لحساب معامل الارتباط بين كل مفردة والدرجة الكلية للبُعد التي تتنمي إليها؛ وذلك لتقدير الاتساق الداخلي لأداتي البحث ( الصدث البنائي).

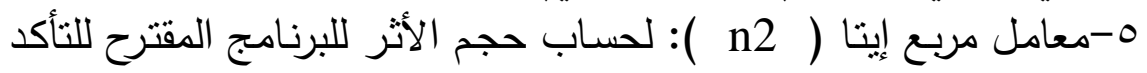

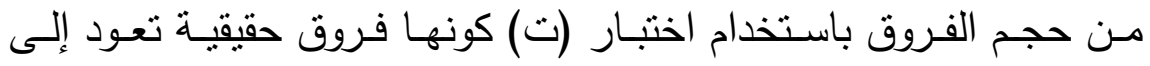

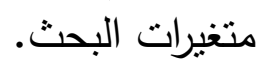

الإطار النظري والدراسات السابقة : المحور الأول: إستراتيجية التعلم المستثد إلى الاماغ :

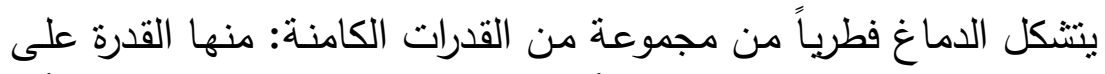

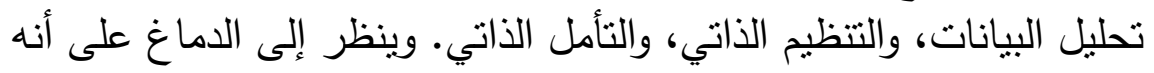

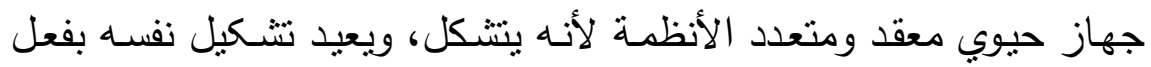

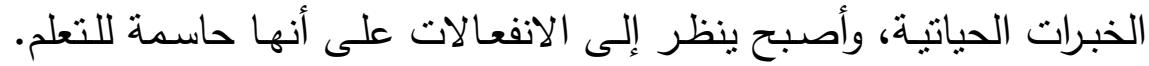

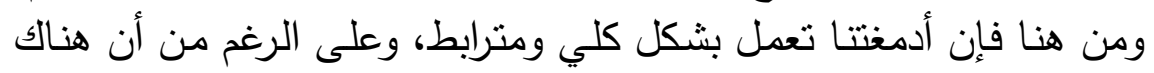

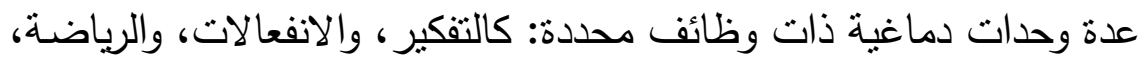

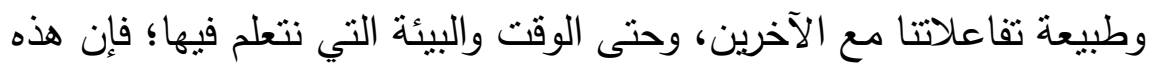

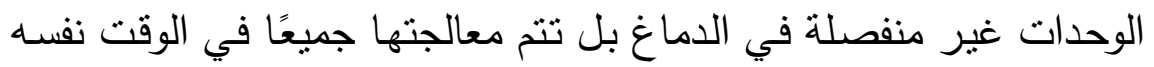
مما يؤثر في كيفية تعلمنا، وفيما نتعلمه ( werbos,2009,200). 
واستتاداً إلى نتائج أبحاث الدماغ وعلوم الأعصاب برزت نظريـة التعلم

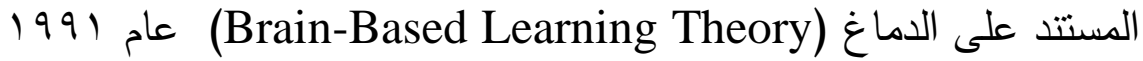
لصاحبها "كين" و "كين التي تستتد إلى بناء الدماغ واغل وظيفة أجزائه، وتؤكد

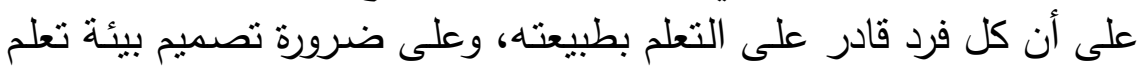

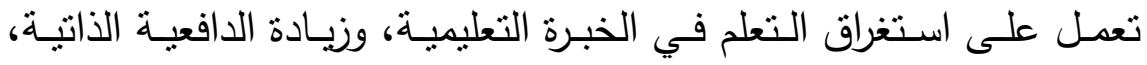

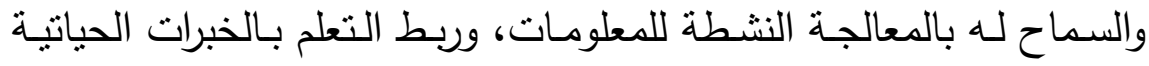

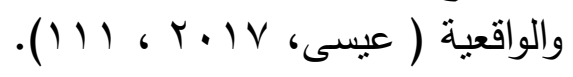

مفهوم إستراتيجية التعلم المستند إلى الاماغ:

إستراتيجية التعلم المستتد إلى الدماغ: هي تلك الإستراتيجية التي تهنت

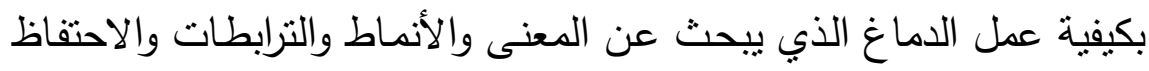

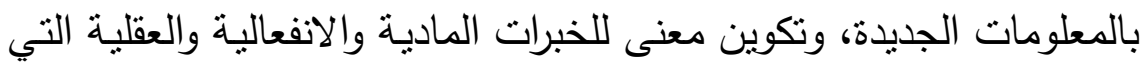

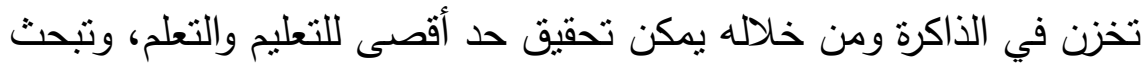

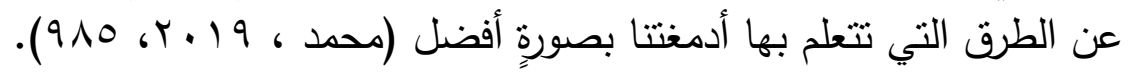
وتعرف السلطي (ع · . ب) إستراتيجية التعلم المستتد إلى الدماغ بأنها:

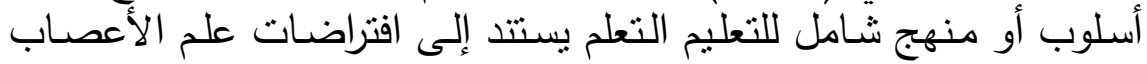

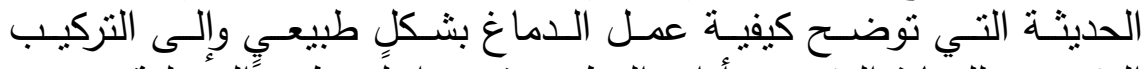

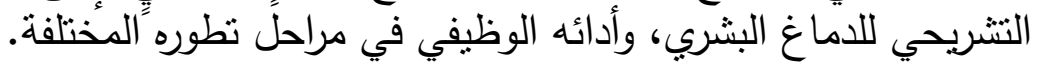

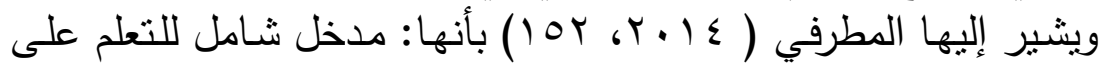

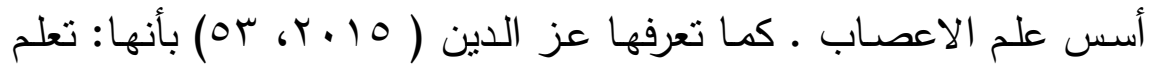
الدماغ مع حضور الذهن وفق إنجاز عملياته الطبيعية.

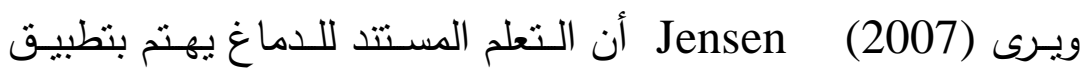

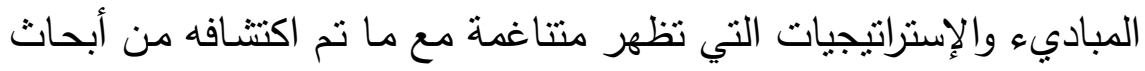

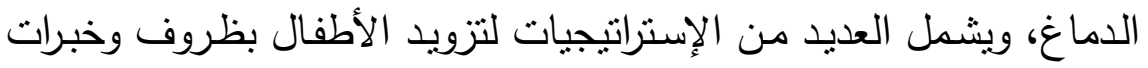


لإحداث حالة الوعي والإدراك في نصفي الدماغ، بما يسمح بالتعلم والتنريس الأفضل.

وكذلك تعرف على أنها: تلاكل النظريـة التي تهنت بالخصـائص المميزة

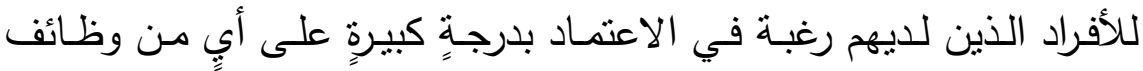

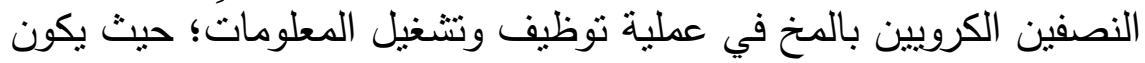

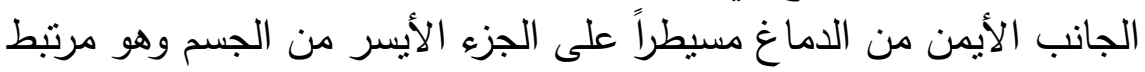

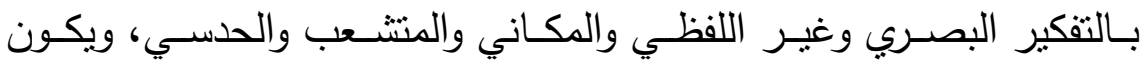

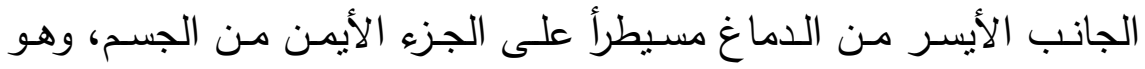
مسئول عن التفكير المنقارب والتصنيفي والمنطقي واللفظي(محمد ، 9 1 ـ ؟، .$(910$

وتعتبر هذه النظرية أن التعلم هو الوظيفة العظمى للدماغ، فيظل الدماغ إن إنهاغ

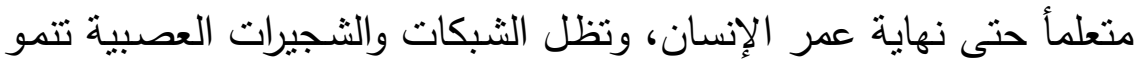

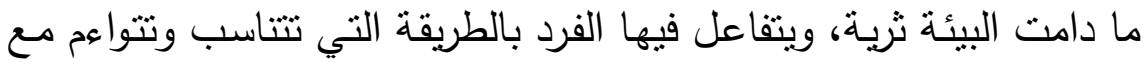

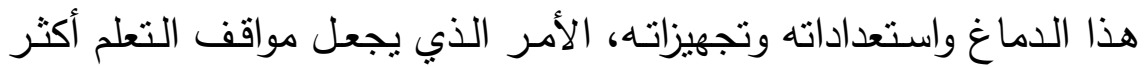
سهولةً ومرونةً وعمقاً.

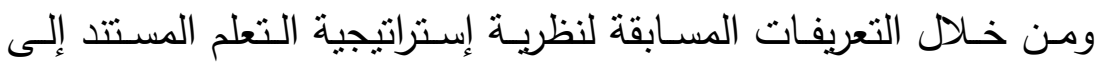

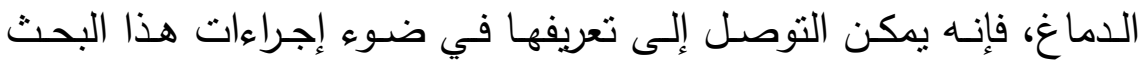
بأنها: نظرية تعليمية تقوم على الاعتماد على جانهي الاني الدماغ الأيمن والأيسر

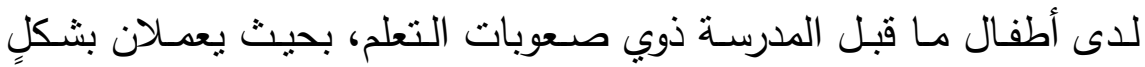

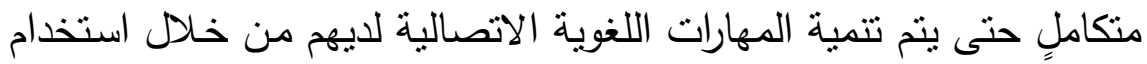
وأنشطة تعليمية لتنشيط جانبي الدماغ الأيمن والأيسر لدى هؤلاء الألهُ لأطفال. 


\section{فوائد إستراتيجية التعلم المستتد إلى الدماغ:}

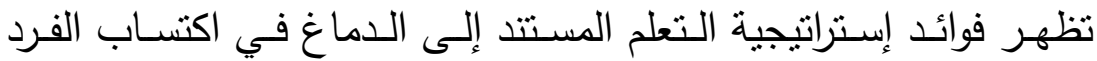

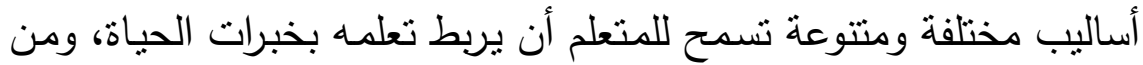

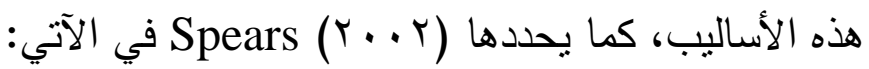

- التعلم المتقن - أساليب التعلم - أنواع الذكاءات المتعددة - التعلم التعاوني - المحاكاة العملية Practical Simulation. - التعلم التجريبي - التربية الحركية - التعلم المبني على المشكلات أهمية إستراتيجية التعلم المستتد إلى الدماغ:

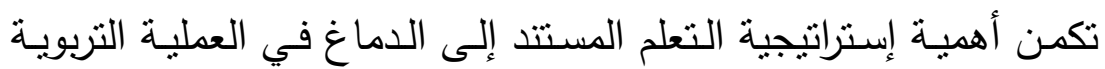

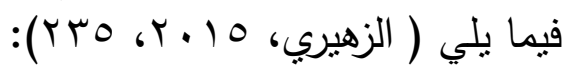

- يمكن المتعلم من حل المشكلات بطرائقٍ مختلفةٍ.

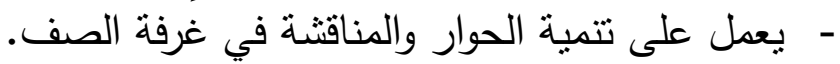
- - يدفع المتعلم إلى المشاركة في صنع القرارات. - - يساهم في تكوين خبرات للمتعلمين.

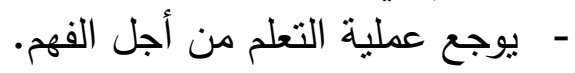
- يمكن المتعلم من التعامل مع أكثر من عمل الفه في الوقت ذاته نظراً لقدرة الدماغ الديناميكية. 


\section{مباديء نظرية إستراتيجية التعلم المستند إلى الاماغ:}

يذكر Laine\&Caine أن نظرية إستراتيجية التعلم المستتد إلى الدماغ

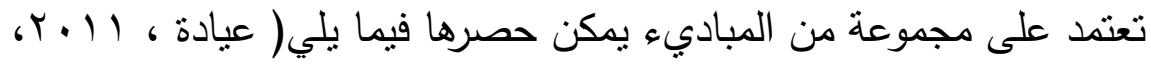
: 100

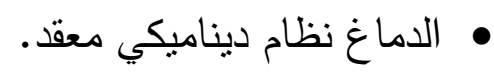
• • الدماغ (العقل) ذو طبيعة اجتماعية.

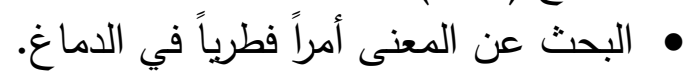

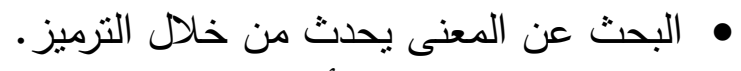

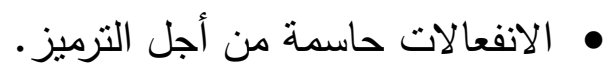

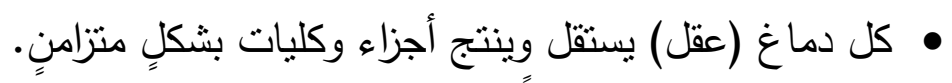

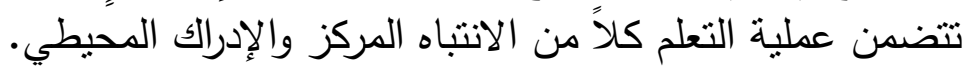

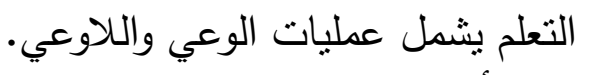
•وجد أكثر من طريقة لتنظيم الذاكرة.

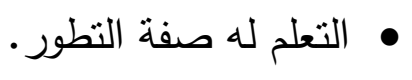
• • ينمو التعلم المعقد بالتحدي ويُعاق بالتهديد.

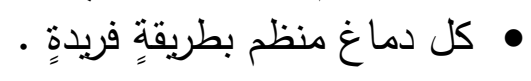

التطبيقات التريوية لمباديء إستراتيجية التعلم المستند إلى الاماغ : من خلا الاطلاع على البحوث والكتابات التي تتاولت إستراتيجية التعلم

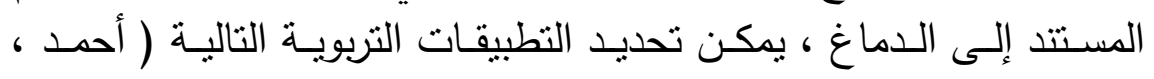
$:(\Sigma 0)$ ، r. IV - التتويـع في اسـتخدام طـرق التـدريس، والوسـائل التعليميـة، والأنشـطة التعليمية . تصنية - تقديم معلومات عن الدماغ وتركيبة وكيفية عمله . 
- إناحة الفرصة للأطفال للتعاون معًا في حل المشكلات واتخاذ القرارات .

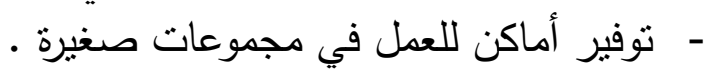
- تقديم أنشطة ومشكلات مرتبطة بحياة الطفل واهتماماته. - توفير بيئة تعلم غنية بالمثيرات تحفز الأطفال على التفكير والتساؤل . - مراعاة المعلمة المشاعر الأطفال واتجاهاتهم وطرائق تفكيرهم.

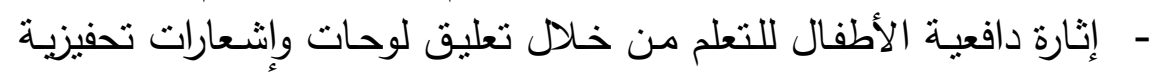

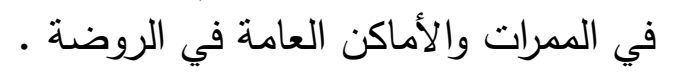
- الاهتمام بتصميم أنشطة متكاملة تتيح للاماغ التعامل مـع الموقف بشكلٍ - كلٍٍ تشجيع الطفل على التأمل والتفكير في كل مـا يتعلمه وأن يكون على - العمل على ربط كل ما يتعلمه الطفل بخبراته السابقة من أجل نرابط

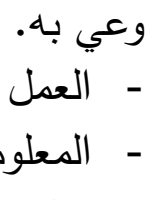
- توفير بيئة تعلم هادئة ومربحة ومشجعة ومحفزة للتحدي. - غياب التهديد وتوفير الأمن النفسي للطفل. - نشجيع كل طفل على التعبير عن نفسه بالطربقة التي يفضلها .

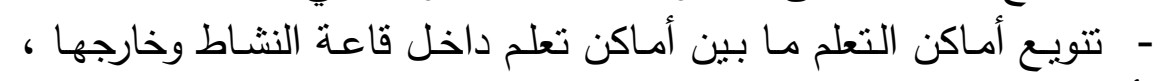

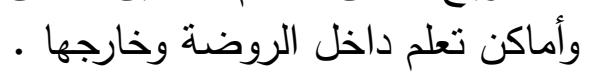

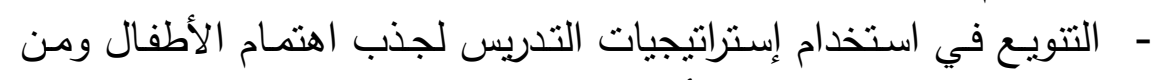

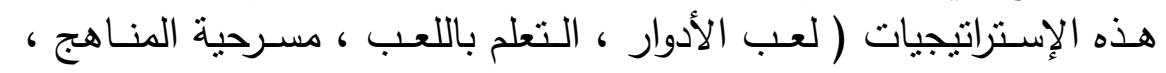
الرحلات الميدانيـة ، العمل في مجموعات ، النمذجة ، المحاكاة ، الخرائط الذهنية المشاربع ، توظبف الذكاءات المتعددة ) . 


\section{أسس إستراتيجية التعلم المستند إلى الدماغ:}

تتحدد أسس إستراتيجية التعلم المستتد إلى الدماغ فيمـا يلي (محمد ،

$$
\text { :(9人7 6 Y. } 19
$$

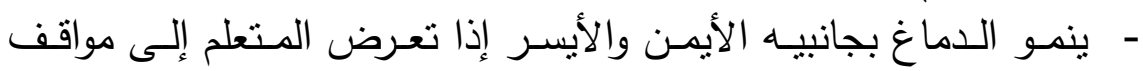
وخبرات تعليمية مرتبطة بالبيئة المحيطة بها.

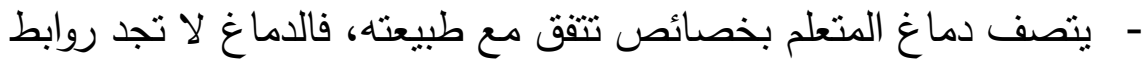

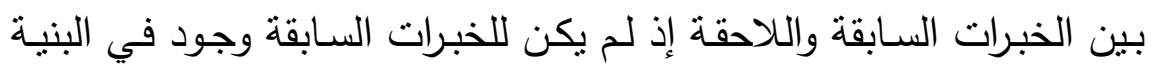

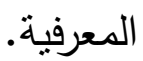

- ينمو الدماغ ويتطور من خلال التفاعل والتعاون مـع الآخرين، فيتفاعل

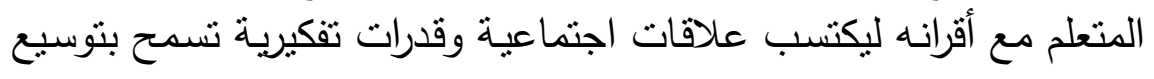
سعة الدماغ.

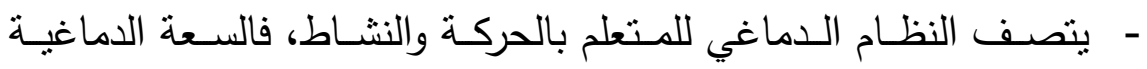
تفرض أنماطأ من التفاعل الديناميكي الذي يمكن استيعابه من خلادل نشاط المتعلم. - يسـتطيع الـدماغ البشـري أن ينمـذج الخبـرات ويسـميها لإدراك معناهـا وسهولة فهمها. - يختلف الـماغ البشـري في تكوينها وخبراته وقدراته وسعته مـن مـتعلم لآخر ، فكل متعلم له صفات دماغية خاصة بـ لهاه.

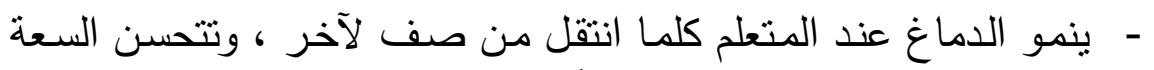
الدماغية كلما كان المتعلم أكثر نضجاً. - يفقد دماغ المتعلم المعنى إذا كانت الخبرات التعليمية التي يتعرض لها. لها لها أعلى أو أقل من مستواه.

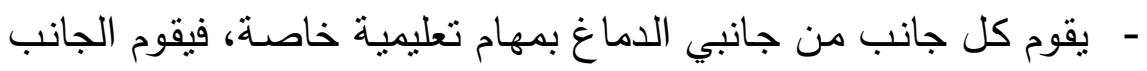

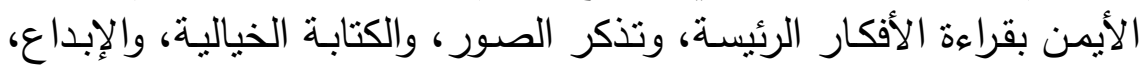


ويقوم الجانب الأيسر بقراءة التفاصيل واسترجاع الكلمات، والكتابة الوظيفية، وتذكر الأسماء، وتجميع الأشياء.

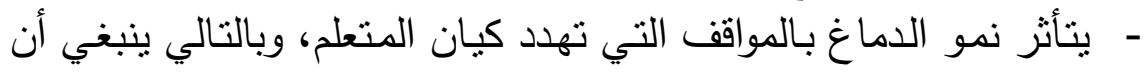
يتعرض المتعلم لهذه المواقف حتى ينمو الدماغ. بأل مراحل إستراتيجية التعلم المستتد إلى الاماغ:

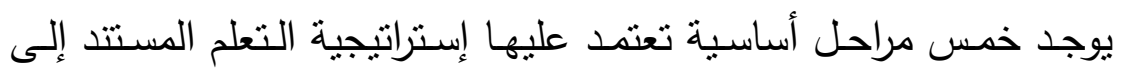

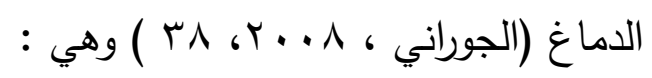

• مرحلة الإعداد : وفيها يتم إعطاء الطفل فكرة عامة عن الموضوع المراد

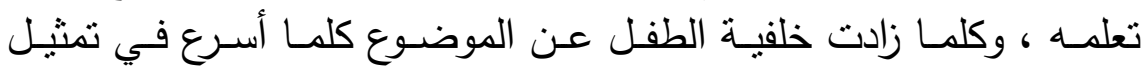

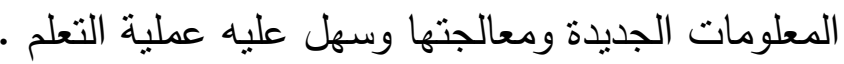

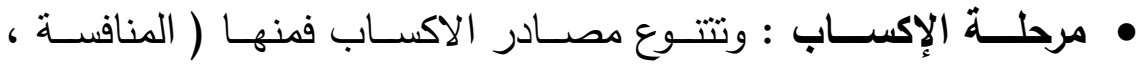

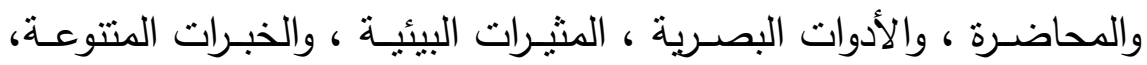

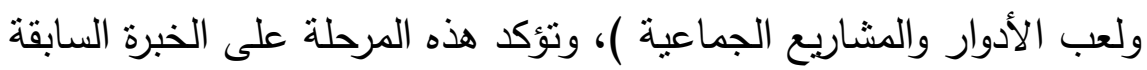
أو القبلية.

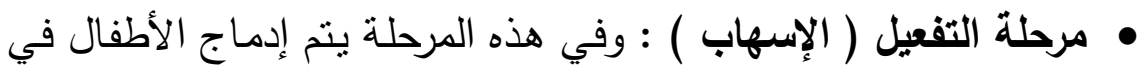

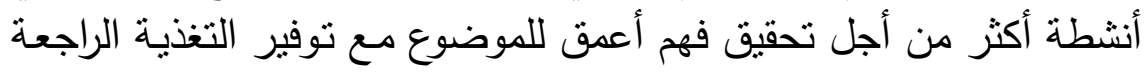

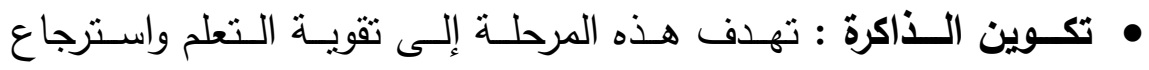

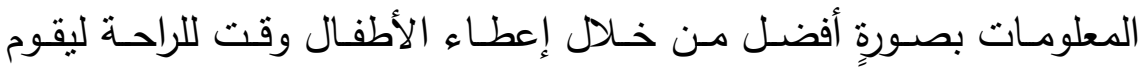

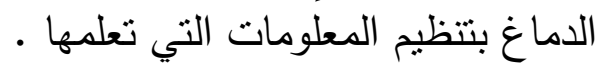
• التكامل الوظيفي : حيث يتم في هذه المرحلة تطبيق التعلم على مواقف تلف جديدة. 


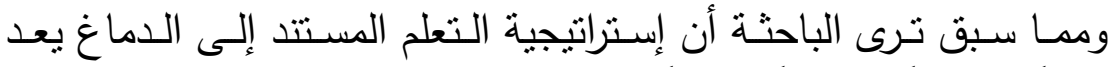

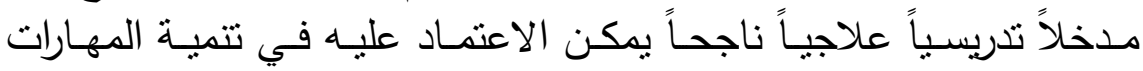
الأكاديمية والنمائية، حيث أن معظم الدراسات التي اعتمدت على التى إستراتيجية

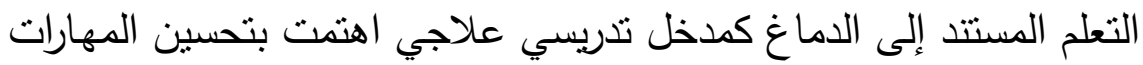

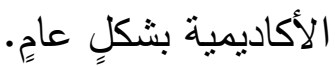

\section{المحور الثاني : المهارات اللغوية الاتصالية:}

اللغة العربية لغة عالميـة تكفل الله بحفظها بما لا يتيح مجالاً لتهميشها، وبما يثير الدافعية المستمرة تجاه مسؤولية نشرها لسموها وارتباطها بقدسية لإنة

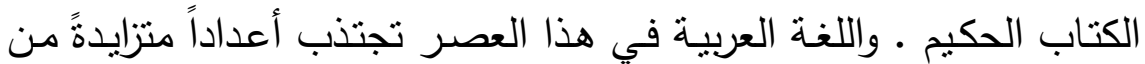
طالبي تعلمها و الراغبين في إتقانها للاستفادة منها في التجارة والاستفادة التهادية

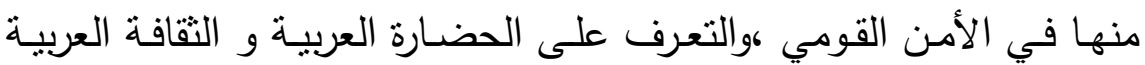

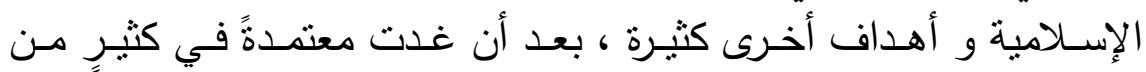

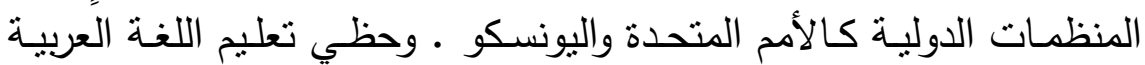
للناطقين بغيرها بعنايةٍ خاصةٍ من المهتمين بتعليمها ، وقد تعددت الجهات

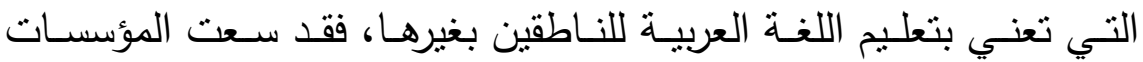

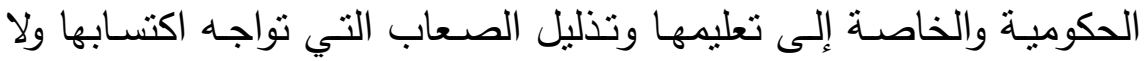
سيما للناطقين بغيرها.واللغة العربية بمهاراتها : الاستماع والتحدث والقراءة

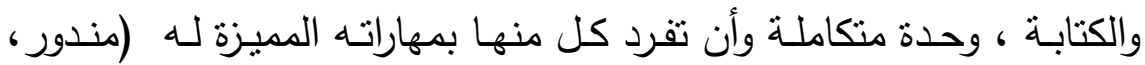
$\cdot(r \cdot r, r \cdot$

وينظر للغة على أنها وسيلة للتفكير، والتعبير ، والتعليم، ولحفظ التراث

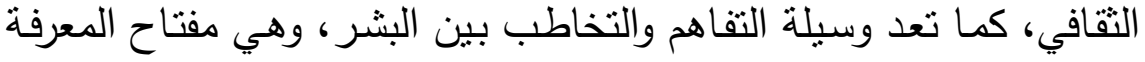
والوسيلة الرئيسـة للتواصـل الفكري والتقافي، ويعتمد عليها الإنسـان بشكلٍ

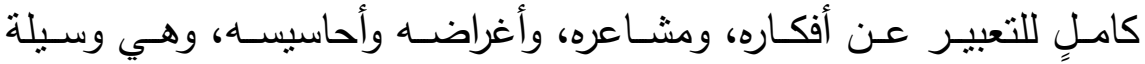


الحركة الفكرية والترابط الوجداني بين أبناء الأمة الواحدة، والهدف الأساسي

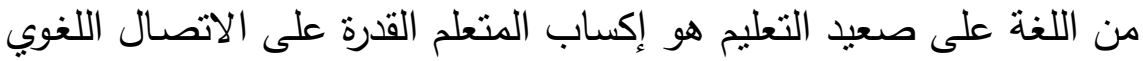

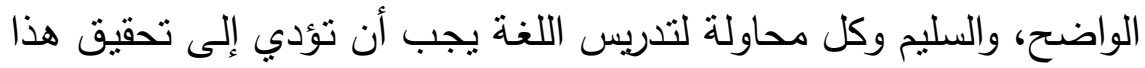

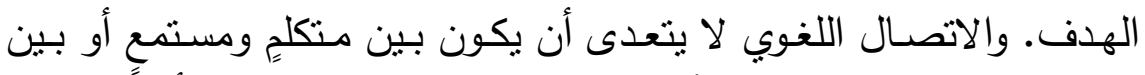

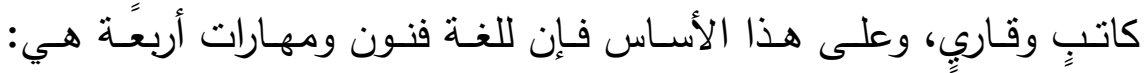

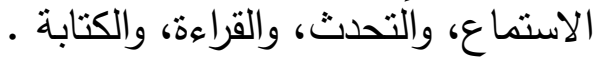

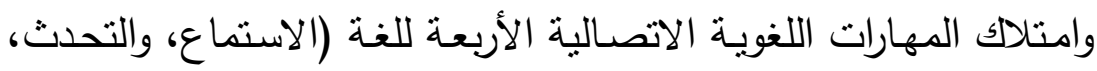

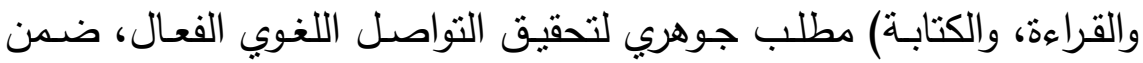

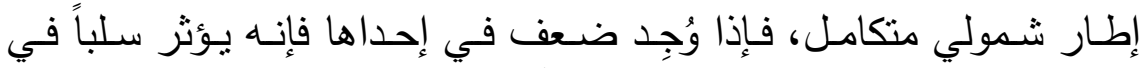

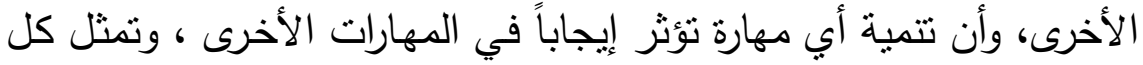

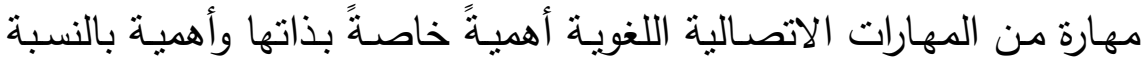

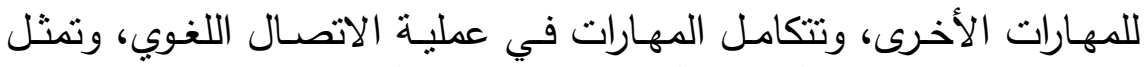

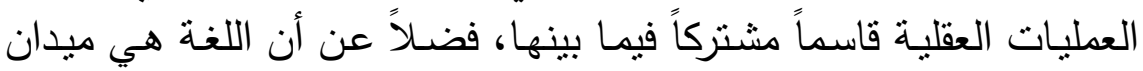

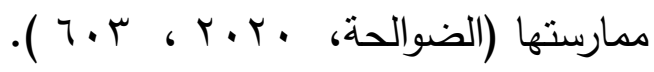

أولاً: مهارة الاستماع لاى أطفال ما قبل المدرسة ذوي صعويات التعلم: الاستماع هو حاسـة من حواس الإنسان التي وهبها الله لـه ليستقبل بها

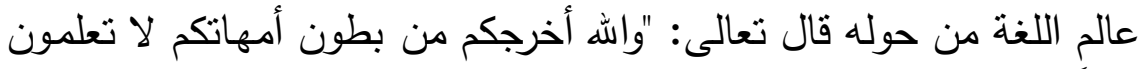

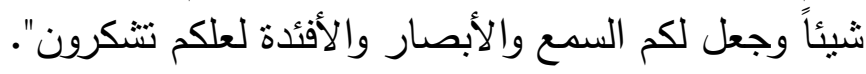
فهو يعني التعرف على الأصوات ، والفهم والتحليل والتفسير والتطبيق

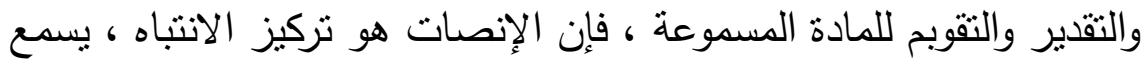

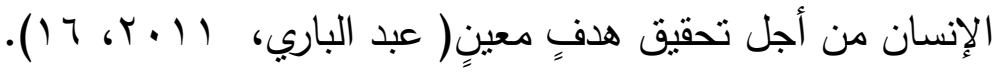


وبعـرف الاسـتماع بأنـهـ : اسـتقبال الصـوت ووصـوله إلـى الأذن بقصدٍ وانتباهٍ، وهو الوسيلة الأكثر استخداماً بين وسائل الاتصال البشري المختلفة. ( ع ألهادي وأبو حثيش وبسندي ، IV )

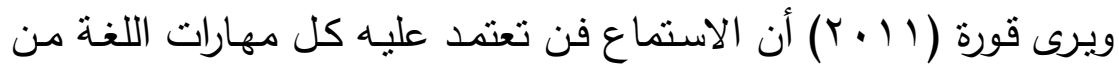
تحدثٍ وقراءةٍ وكتابةٍ ، لذا لابد من الاهتمام بالمهارات والخبرات التي تؤدي إلى تحسين القدرة على الاستماع بوصفه وسيلة أساسية في التفاعل مـع الآخرين ، حيث يقضي المتعلمون معظم أوقاتهم في الاستماع إلى معلميهم

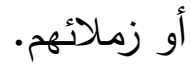

وتتلخص أهمية الاستماع لطفل ما قبل المدرسة في النقاط التالية (عبد

$$
\text { الرحمن، }
$$

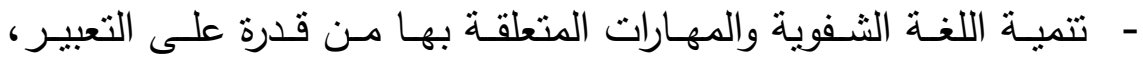
وصياغة الجمل الصحيحة والنطق الصحيح و ترتيب الأفكار وتتظيمها. - ت تنمبـة قدرة الطفل على تمييز الأصــوات، والحروف، والكلمـات تمييـزاً صحيحاً.

- إثراء حصيلة الطفل اللغوبة بالعديد من الألفاظ ، والأساليب، والعبارات الجديدة ، أو تصحيح ما هو خطأ. - مساعدة الطفل على تتظيم أفكاره بصورة مرتبة ومتسلسلة.

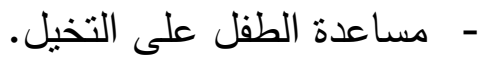
- ت تتمية التفكير النقدي لدى الطفل من خلاعل ما بسمعه من آراء ، وأفكار متفقة، أو مختلفة حول موضوع معين. - ت تميـة الذاكرة السمعية لدى الطفل، وتدريبه على على الاحتفاظ بالمعلومـات

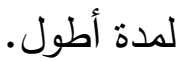


- زبـادة مـدى الانتبـاه لـدى الطفـل مـن خـلال التـدرج فـي اسـتماعه

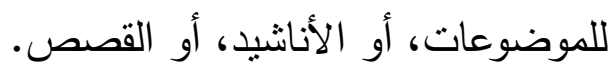

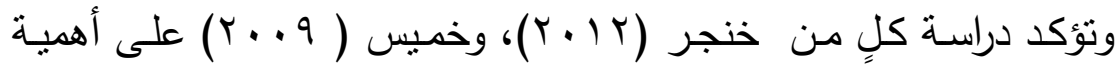

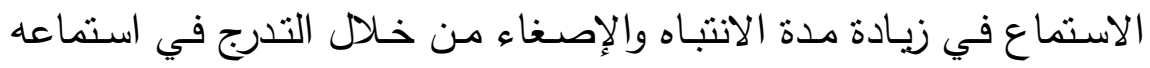
للأناشيد والقصص والبرامج الاذاعية. أركان عملية الاستماع: يوجد للاستماع أربعة أركان أشار إليها ( سيف الدين ، IV . Y وهي: - - - فهم المعنى الإجمالي. - تقفير الكلام والتفاعل معه.

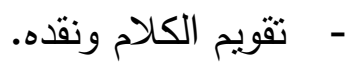
- ربط المضمون المقبول بالخبرات الثخصية. معوقات عملية الاستماع:

أشار طعيمة ومناع ( 7 ( ا ب) إلى وجود معوقات لعملية الاستماع تتمثل في:

- - الشرود الذهني لدى المستمع. - الضجر والملل من المادة المسموعة. - - ضعف طاقة المستمع عند الاستماع. - التربص بالمتحدث وحب النقد. 


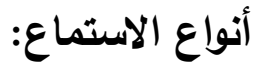

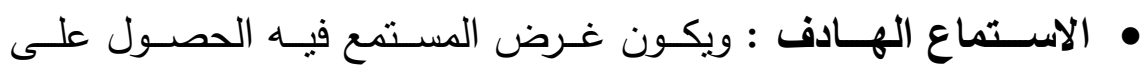

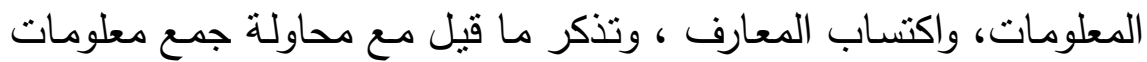

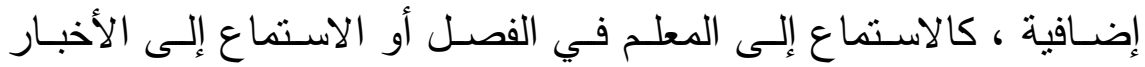
المهمة.

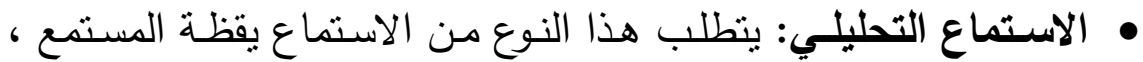

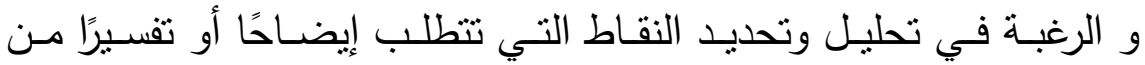
المتحدث، والتعرف على لغـة الحديث ، ومعـاني الكلمات وتحديد الأفكار

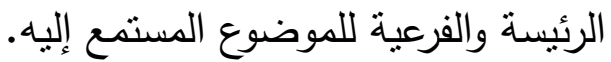

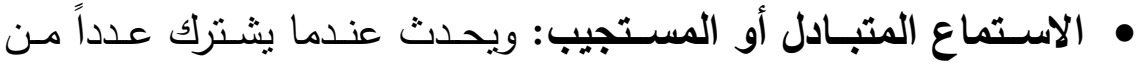

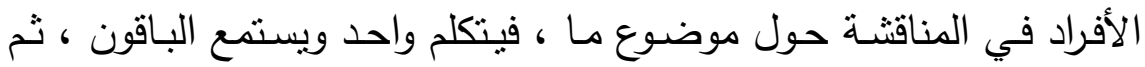

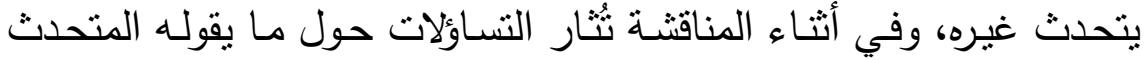
والذي بدوره يقوم بالرد عليها وتوضيحها.

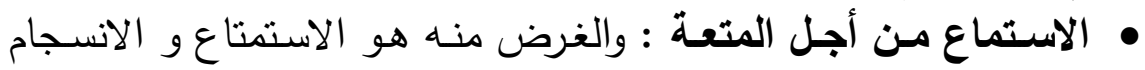

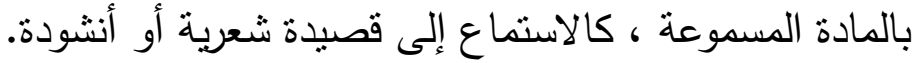

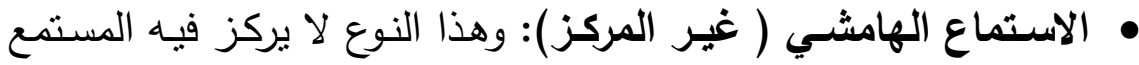

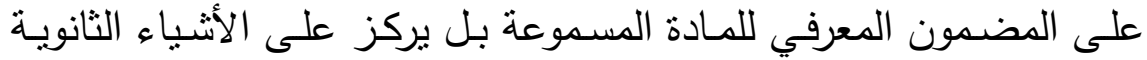

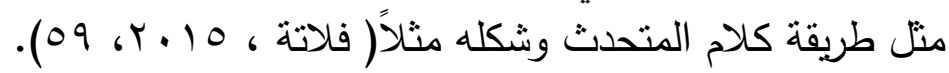

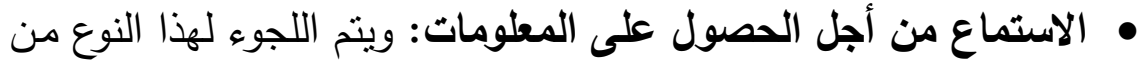

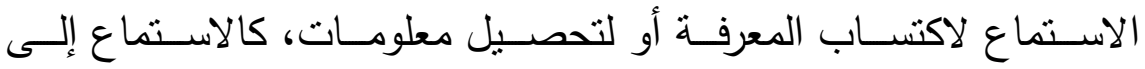

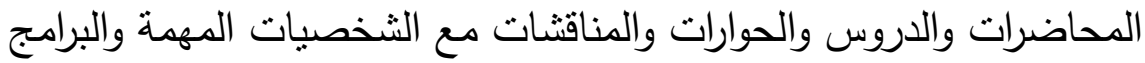

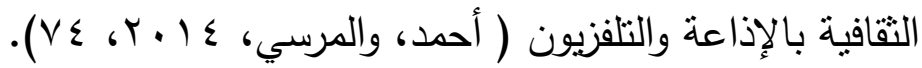


مهارات الاستماع التي تناسب طقل ما قبل المدرسة ذوي صعويات التعلم: - التمييز السمعي: قدرة الطفل على تحليل الكلمات إلى عناصره الصوتية،

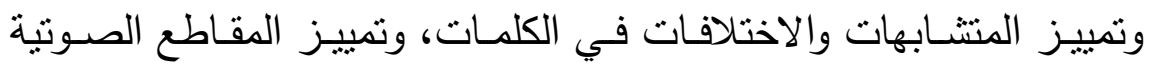
المنقاربة.

- تمبيز صوت محدد في الكلمة. - تمييز أصوات الحروف المتشابهة.

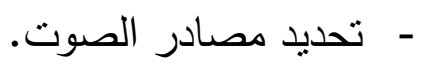

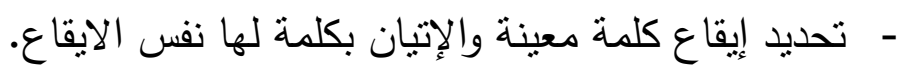

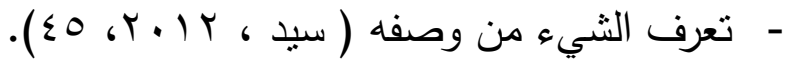

خطوات لتدريب طفل مـا قبل المدرسـة ذوي صعويات التعلم على تنميـة

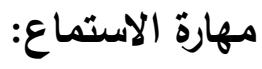
1-إجلاس الطفل في أماكن ملائمة خالية من الضوضاء الأنماء .

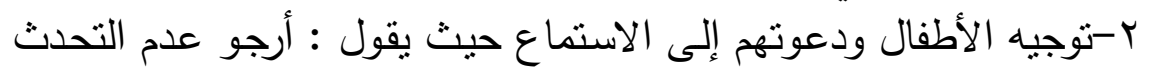
مع زميلك. r-التدريج في التدريب على مواقف الاستماع، كأن يسألهم عن أسمائهم،

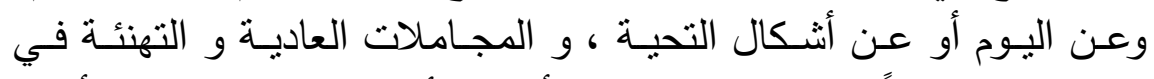

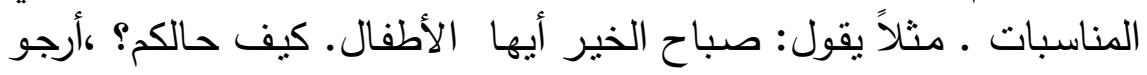

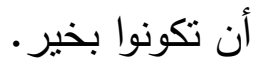
ع-تهيئة الأطفال لسماع قصة سهلة ، ومفهومة،وشائقة وقياس مدى فهمهم لها.

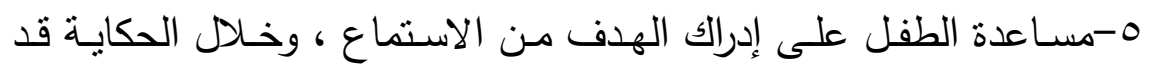
يوجه بعض الأسئلة، مثناً يسأل بعض إلد الأسماء التي ذكر فيها. 
7-كبط المادة المسموعة بخبرات الأطفال وتوضبح معاني الكلمات الجديدة وإلقاء الأسئلة المثيرة.

V-تحديد بعض البرامج الاذاعية أو التلفازبة المناسبة للمنهج لتكون مجالاً لنشاطات لغوية ـ وتنشر الإذاعات و القنوات العربية برامج عديدة قد يشير المدرس على المتعلمين إليها، وإن كان لديه إلمسام بالوقت فيمكن أن يذكر لهم ذلك.

م-أقراص سمعية وبصرية: إذا توفر لدى المعلمة أقراصاً خاصةً بتعلم اللغة

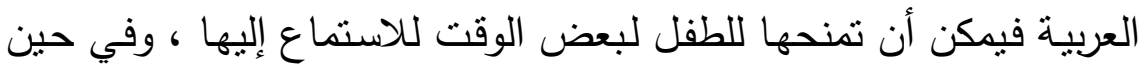

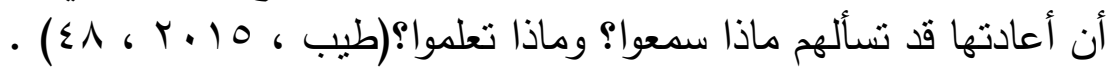

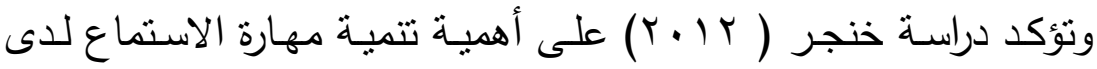
طفل ما قبل المدرسـة وأثزها على مستوى التحصيل الدراسي، وزيادة قدرتهم اللغوية والمعرفية في المراحل التعليمية اللاحقة ـ

ومن هذا المنطلق تتضح أهمية الاستماع كفن ومهارة من مهارات اللغة

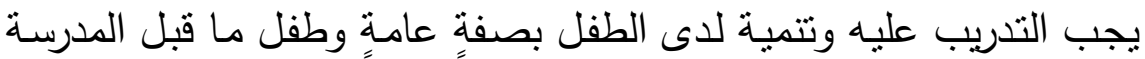
حتى يصبح مستمعاً جيداً.

ثانياً: مهارة التحدث لاى أطفال ما قبل المدرسة ذوي صعويات التعلم: يعد التحدث وسيلةً للتعبير عن معانٍ وأفكارٍ و عواطفٍ و أحاسيسٍ تختلج

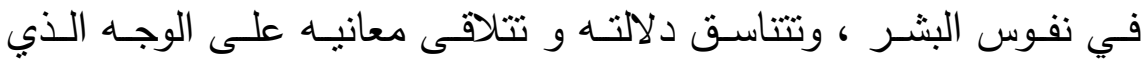
يقتضيه العقل. فقد عرف الإنسـان الكلام والتحدث قبـل أن يعرف الكتابـة، والأسوباء من الناس يتحدثون لغاتهم الأم دون أدنى صعوبة، في حين أن أن

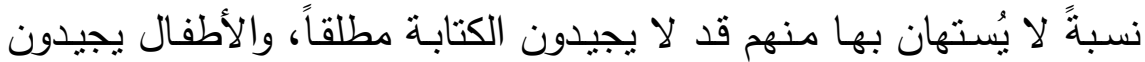

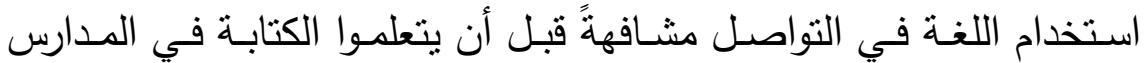


النظامبـة، فالكالام هو المظهر الرئيس للغـة، واللغـات تثمايز بمدى قدرتها على الانتشار بين قاعدة من المتكلمين قابلةً للاتساع المطرد، واللغة العربية ولهية يتواصل بها ملايين الناس في العالم، وهي مرشحة لبلوغ مكانة مرموقة بين

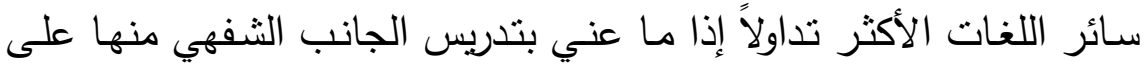
النحو الأمثنل. ولعل التركيب الحواري هو الأثـهر بين القوالب الكلامية؛ إذ إذبائ إنه يمد الطفل بألوانٍ من الجمل والتعبيرات والألفاظ والأصسوات التي يحتاج إليها في سياقات مختلفة، وأن المتعلم يضـم بعض التركيبات النحوبـة في حواره؛ ممـا يعني أن هذا التدريب بمكن الطفل من ممارسـة اللغـة بمعظم عناصرها ومكوناتها التي تجري على لسانه، لكي ينشأ عن طربقها جسوراً للتواصل مع الأفراد والجماعات (Al-Bashir,and Al-Waili،2011). فالتحدث عملية مركبة و معقدة تؤثز عليها عوامل كثيرة منها : الحالة النفسية و الموقف الاجتمـاعي ، فالتحدث يمـر بعمليـة عقليـة كالاسـتقبال وتتظيم وبناء ، وعرض فهو العملية التي تترجم بها الصـورة الذهنية التي بهي تكونت في عقل المتعلم ، ولإنتاج اللغـة الثفوية تتطلب مستلزمات معينة وهي مزبج من العوامل الداخلية والخارجية التي تجعل الفرد متمكناً من إنتاج

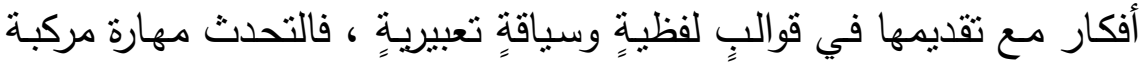

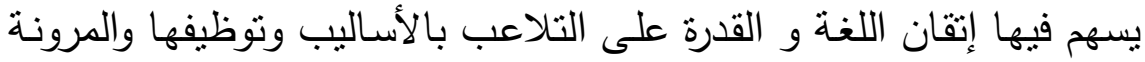

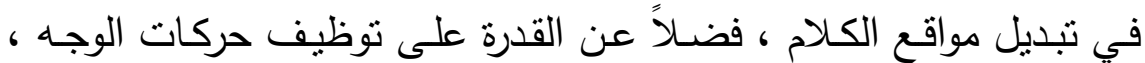

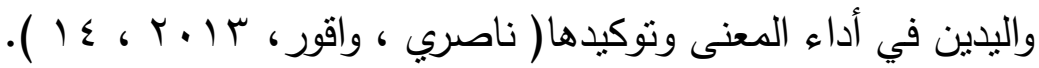

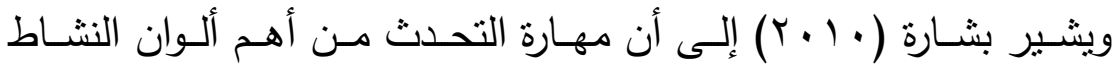
اللغوي، كونها وسبط التواصل اللغوي بين البشر قبل القراءة والكتابـة وهي

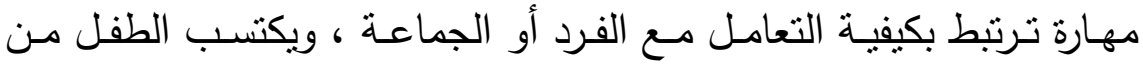
خلالها آداب المخاطبة ولباقة التصرف واحترام الآخرين والتعاون معهم. 
كما بعرف التحدث بأنه: القدرة على التعبير عن اللغة المستهدفة بطلاقةٍ وبشكلٍ مناسبٍ باستخدام هيئاتٍ مركبةٍ من النمط النحوي والمفردات والجمل بهل والمعاني (sijali.keshab kumar,2017,62).

وتفيد دراسـة حسن ، وعبد الوهاب ( ع ( ب أن الاستماع يسبق عملية التحدث وهو ضروري لإتمامها ولا تواصل اجتماعي بدونهما ، وتعتمد عملية

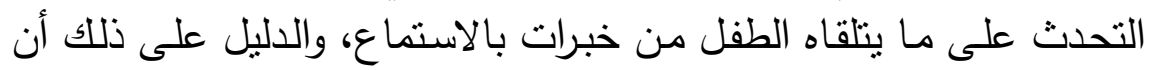
المُصاب بالصمم الكلي منذ الولادة لا يستطيع الكلام على الرغم من سـلامة

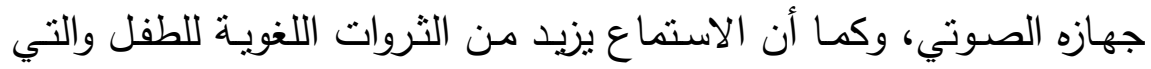

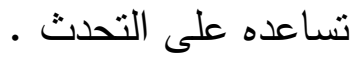

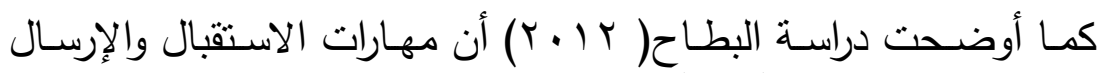

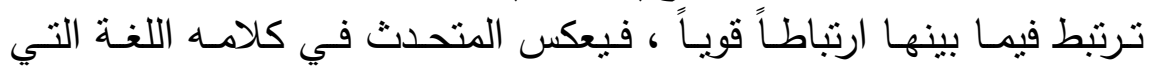

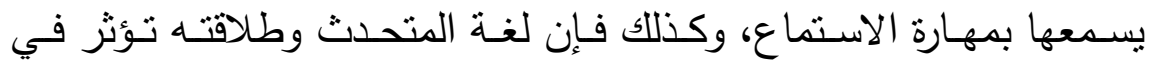

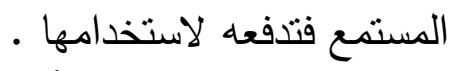
ومن هنا ترى الباحثة أن مهارة التحدث مكملة لعملية الاستماع ، حيثة

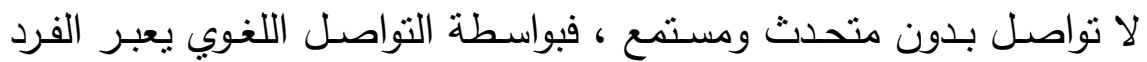

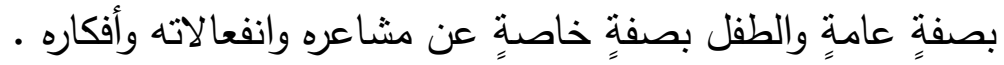

مكونات مهارة التحدث:

تتكون مهارة التحدث من الخطوات الآتية :

1 - الاستثارة : فلابد من وجود مثير يدفع المتحدث للحديث ، سواء كان

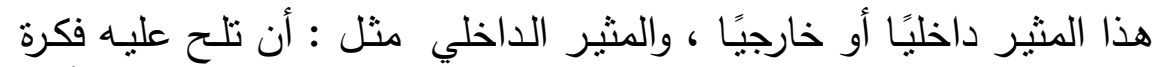

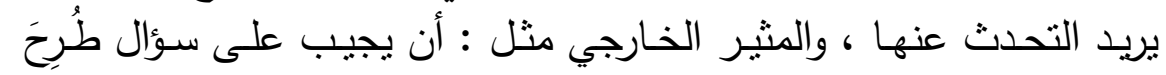
عليه ، فمن دون هذا المثير قد بصبح الحديث ركيكًا أو بلا هدف . 
ب-التفكير : وفي هذه الخطوة يبدأ المتحدث في التفكير فيما سيتحدث بـه ، فيحدد موضوعه ثم يختار الأفكار المناسبة وبرتبها ، ويجمع المعلومات التي

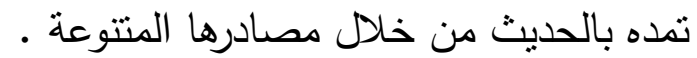
ب-الصـياغة : وفي هـذه الخطـوة يختـار المتحـدث المفردات والأسـاليب

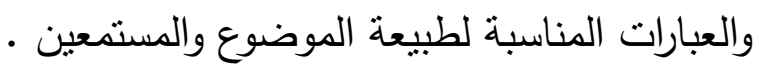

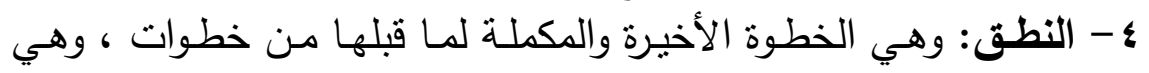
المظهر الخارجي لمهارة عملية التحدث حيث يجب أن يكون النطق سليمًا

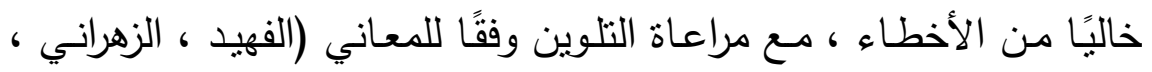

$$
\text { . }(\varepsilon r . r .) \varepsilon
$$

مهارات عملية التحدث التلازمـة لأطفال مـا قبـل المدرسـة ذوي صعويات التعلم:

تتضـن مهارات التحدث اللزمـة لأطفال مـا قبل المدرسـة ذوي صـوبات

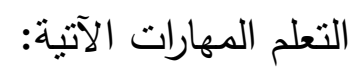

( ) القدرة على تحديد الأفكار التي يريد أن يتحدث عنها.

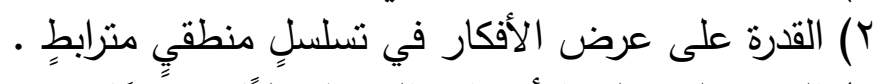

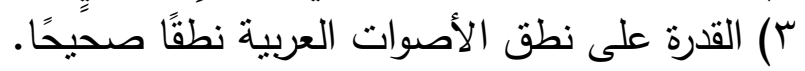

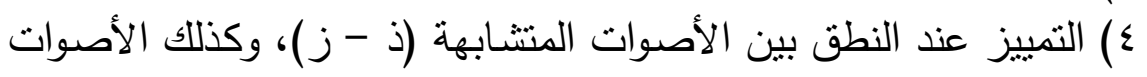
المتجاورة (ب-ت ك-ث) تمبيزًا واضحًا. 0) التمبيز عند النطق بين ظواهر اهر المد والثدة. 7) التمبيز عند النطق بين الحركات الطويلة والقصبرة.

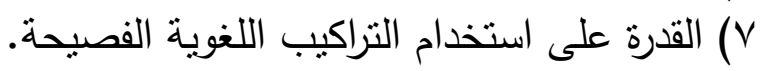

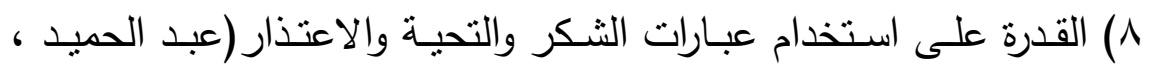

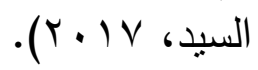


أهميـة تنميـة مهارة التحدث لـى أطفال مـا قبل المدرسـة ذوي صعويات التعلم:

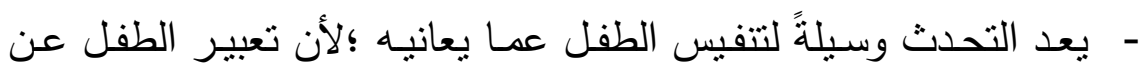
نفسه يخفف من حدة المواقف التي تعترضده.

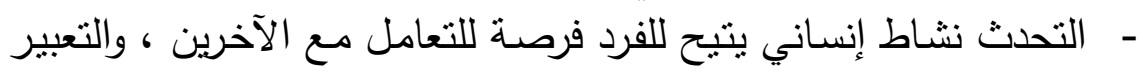
عن مطالبه الضرورية. - التحدث وسيلة ضرورية لتتفيذ العملية التعليمية في مختلف المراحل ،

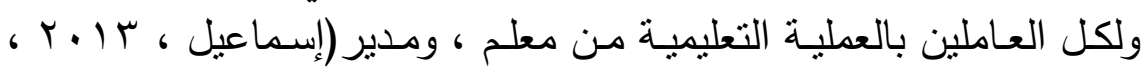
.$(19 \mathrm{~V}$

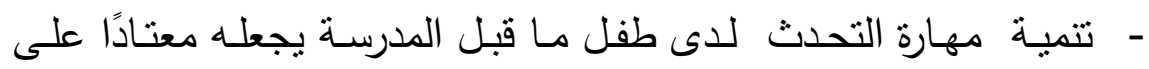
الطلاقة في التعبير عن أفكاره ، والقدرة على مواجهة الآخرين.

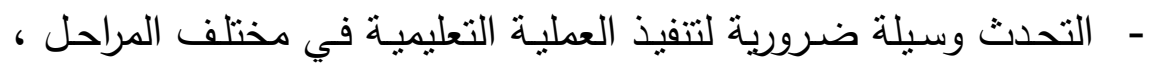
ولكل العاملين بالعملية التعليمية من معلمِ و مديرِ .

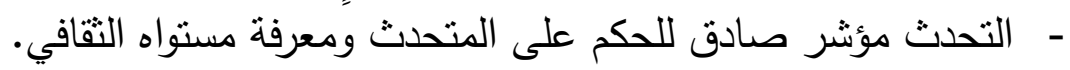

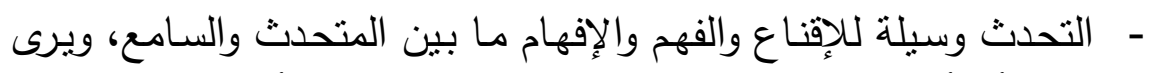

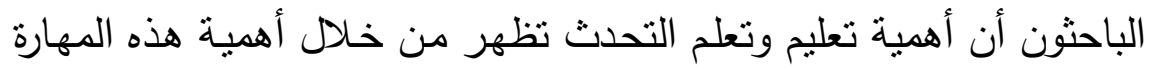

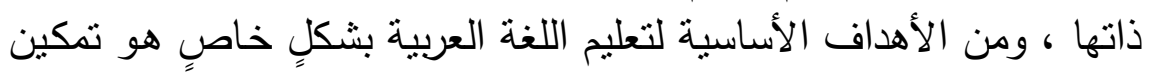

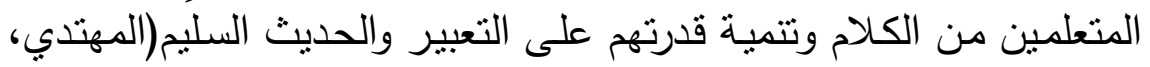

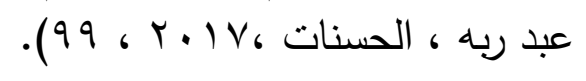

خطوات لتدريب طفل مـا قبل المدرسـة ذوي صسويات التعلم على تنميـة

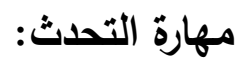

- إعطاء الطفل فرصة للحديث عن الرحلات الأسرية والمتنزهات ، وغيرها من الأنشطة الاجنماعية. 
- تشجيع الطفل على إعادة سرد القصص المصورة المعروضـة عليه مـع تقليد حركات وأصوات الحيوانات والطيور الواردة فيها.

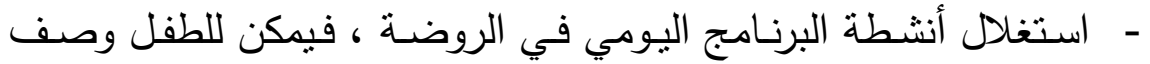

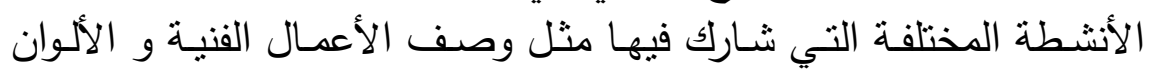
وأدوات الرسم ، ووصف الألعاب التي اشترك فيها.

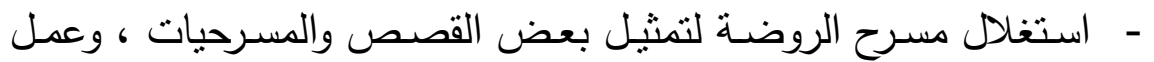
العروض لأعمال مختلفة مما يساعد على التحدث بطلاقةٍة.

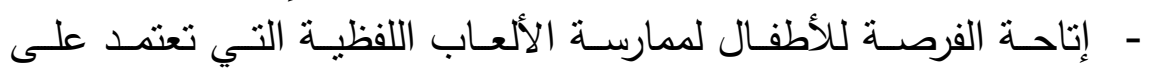
المفردات. وعلى المعلمة في مرحلة ما قبل المدرسة أن: - تراعي الفروق الفردية بين الأطفال.

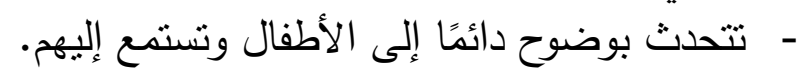

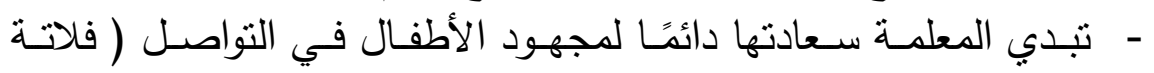
. (VY 6 . 106

وفي هذا الصدد تعددت الدراسات والبحوث التي تتاولت تتمبة مهارتي الاسـتماع والتحدث بصفةٍ خاصسةٍ في مرحلـة مـا قبـل المدرسـة مثل دراسـة

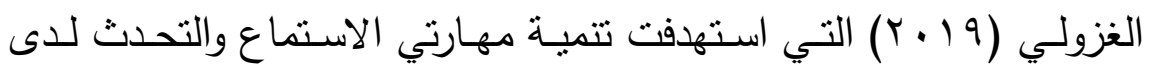
أطفال الروضـة ذوي صـعوبات التعلم النمائيـة باسـتخدام برنـامج قائم على على الفنون الأدائية الروفية

ودراسـة الثمري والقيسي ( 11 ـ ب) التي استهدفت معرفة مهارة التحدث لدى أطفال الروضنة، وكذلك التعرف على دلالة الفروق في مهارة التحدث لدى أطفال الرباض تبعًا لمتغير الجنس (ذكور ، وإناث)، وأوصت نتائجها بتشجيع الأطفال على التعبير بحرية في ما بودون التحدث بـه، وعلى معلمة واتهات 
الروضة إعطاء الأهمية لكلام الأطفال والإصغاء الجيد لهم، بالإضـافة إلى

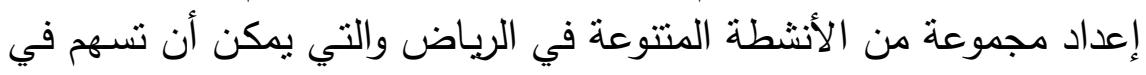
تتمبة مهارة التحدث لدى الأطفال.

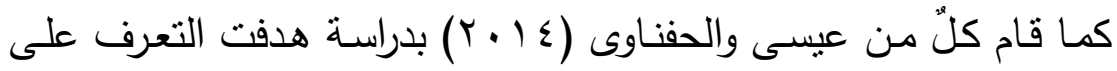
أثر استخدام تلميحات الفيديو الرقمية في ضوء المعايير وحاجات الأطفال ضـعاف السـع بمرحلة ربـاض الأطفال لتنميـة مهارتي الاستماع والتحدث لديهم.

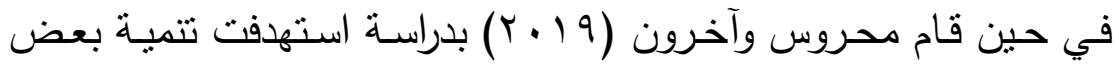

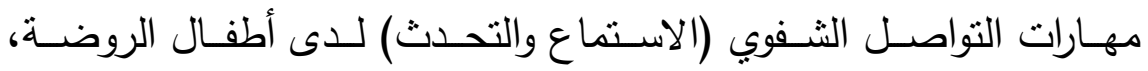
باستخدام إستراتيجية (فكر -زاوج -شارك) من خلال تحقيق بعض مؤشرات

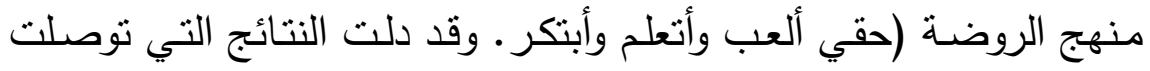

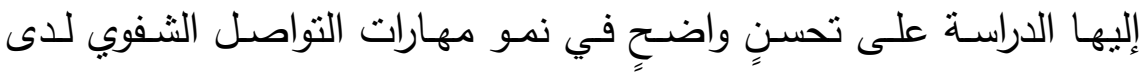
مجموعة الدراسة التجريبية.

المؤثراث الدالة على القصور اللغوي لمهارتي الاستماع والتحدث لطفل ما قبل المدرسة ذوي صعويات التعلم: - يتحدث بجملٍ غير مفهومةٍ. - - صعوبة في اختيار الكلمات المناسبة. - تكرار الكثير من الكلمات. - استخدام جمل متقطعة وأحياناً تكون دون معنى.

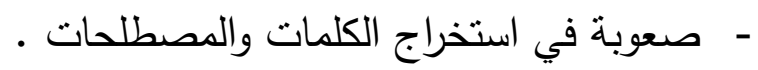
- - صعوبة في تسمية الأشياء. - قصور في تذكر بعض الأسماء أو الأحداث. 
- عندما يطلب مـنهم التحدث عـن تجربـة معينة قد تطـول قصـتهم دون

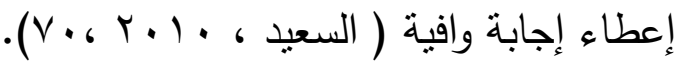
- عدم التمكن من تفسير المثيرات السمعبة. - - صعوبة إدراك التتابع والتسلسل السمعي. - عدم تذكر ما يُقال أمامه وما يُوجه إليه. - عدم القدرة على تذكر التعليمات الخاصة بلعبةٍة ما. - عدم تذكر بعض الأحداث القربية التي وقعت أمامه.

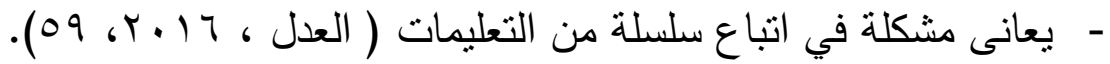

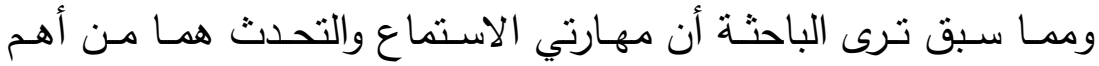
المهارات إن لم يكونا أهمها على الاطلاق التي تُبنى عليها مهارات التعلم في حياة الطفل ، فهما مهارتان أساسيتان في تطور الوظائف اللغوية لدى الإن الطفل و التواصل اللغوي بين الطفل وبيئته المحيطة بـه ، كما أنهما بسبقان مرحلة تعليم القراءة والكتابة ، فأي خلل في إتقان مهارتي الاستماع والتحدث

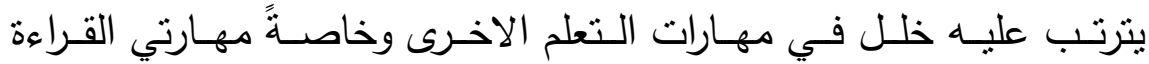
والكتابة .

ثالثاً: مهارة القراءة لدى أطفال ما قبل المدرسة ذوي صعويات التعلم: تعد القراءة المصسدر الأسـاسـي لتعلم اللغـة العربيـة خـارج الصـف، وهي مهارة تحتاج إلى تدريبات خاصـة ومتتوعة، وينبغي أن تقدم القراءة للمتعلم

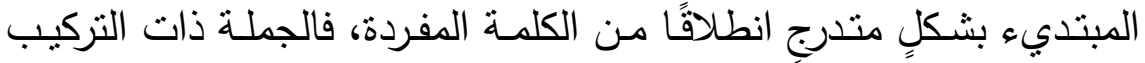
المبسط، ثم الجملة المركبة مـن مفردات أكثر ، ثم يقرأ المتعلم الفقرة التي

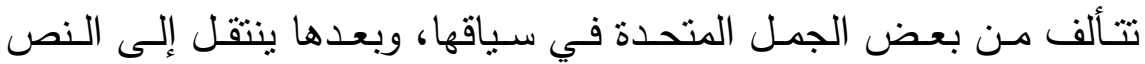
الطوبـل المكون من فقرات متعددة تتتظم تحت عنوان واحد، وتتتاول كل في واحـدة فكـرة جزئيـة، ومـن البـديهي أن يواجـه المـتعلم فـي بـاديء الأمـر 
صـعوبات فيمـا بتعلـق بـالقراءة الجهربـة؛ كـالتمبيز بـين الحركـات الطوبلـة والقصـيرة، والحـروف التـي تُردد أحيانـاً صـوائت وأخـرى صسوامت. وللقراءة

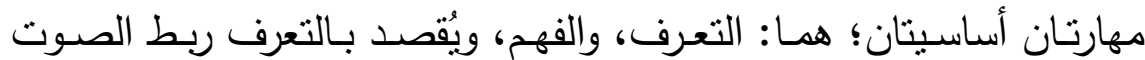

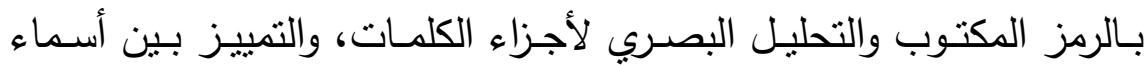
الحروف وأصواتها. أما الفهم فهو محاولة إقامة علاقة بين الألفاظ والمعاني لأني للتوصـل إلى إدراك الوحدات الفكربـة للنص، والتظظيم الذي اتبعـه الكاتب، واستتناج الأفكار العامة (Kandari،2010).

وتعد مهارة القراءة من أهم مجالات النشاط اللغوي التي يمارسها الطفل ، وهي من أدوات التواصل بنتاج العقل البشرى ، فلا يمكن أن بؤدي الطفل ما هاء

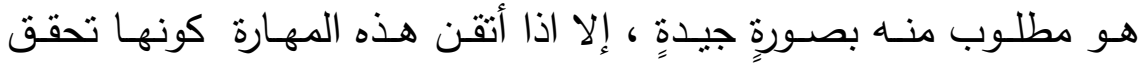

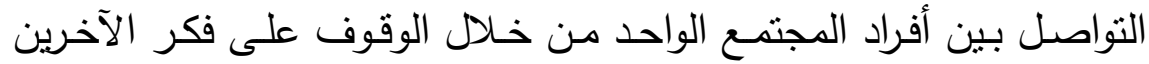

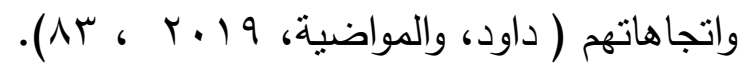

رابعاً: مهارة الكتابة لاى أطفال ما قبل المدرسة ذوي صعويات التعلم: يـأتي دور مهارة الكتابـة متأخراً في تدريس مهارات اللغـة؛ لأنها تمثنل المحصلة النهائية لمـا اسـتوعبه الطفل واختزنـه من العناصـر اللغوبـة، فهو

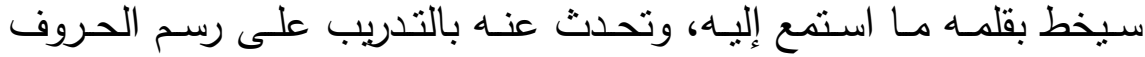

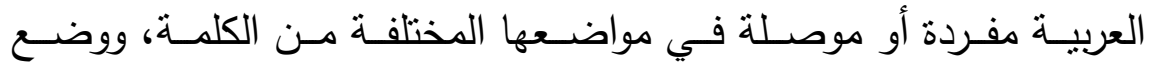
الحركات، ومعرفة كيفية التهجئة، ووظائف علامـات الترقيم، وبقيـة القواعد مواهـ المتعلقة بالجانب الثكلي لعملية الكتابة، الذي قد يتسبب إسقاطه أحياناً في ووفي حدوث لبس في المعنى، أمسا الجانب العقلي للكتابـة، فهو يختص بالمعرفة الجيدة بالألفاظ ومعانيها، وقواعد النحو والتراكيب.

(Ashour,and Al-Hawamdeh،2010) 
والكتابة مهارة متعلمة بمكن أن يتقنها الطفل بوصفها نشاطاً ذهنياً يقوم

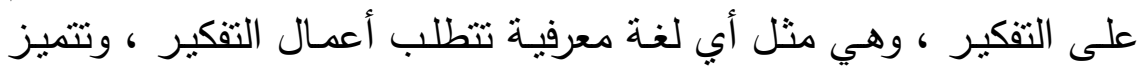

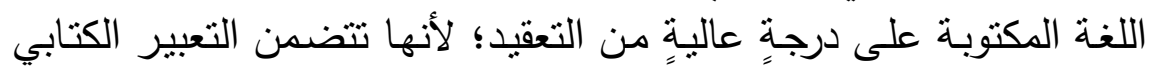

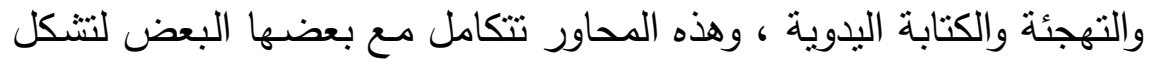

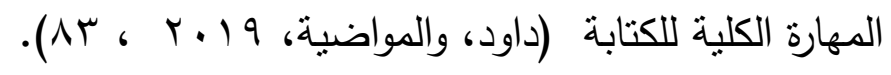

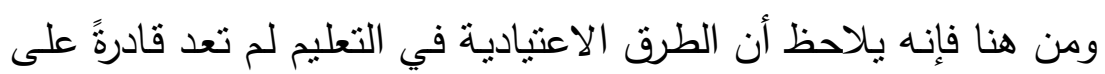

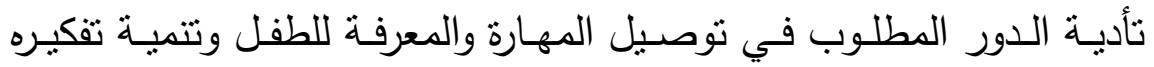

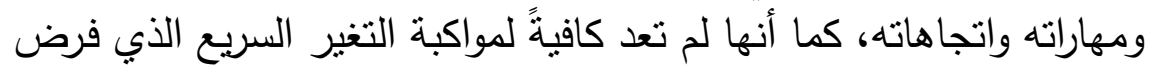

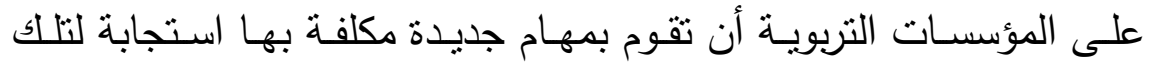

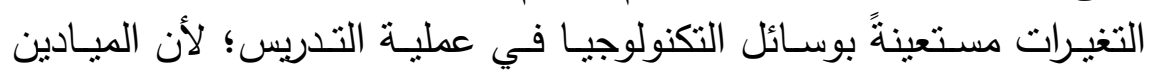

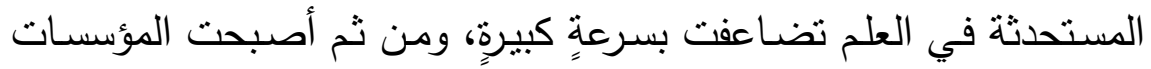

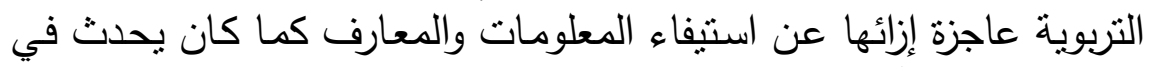

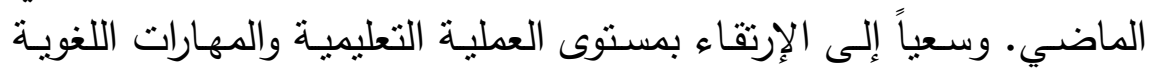

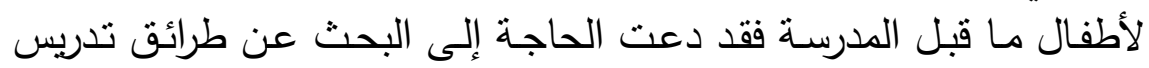

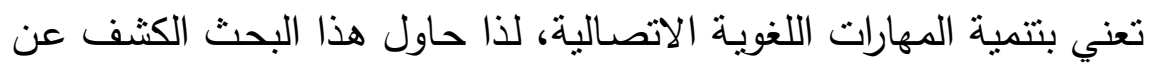

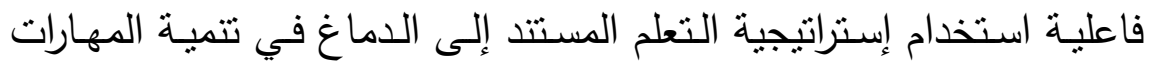

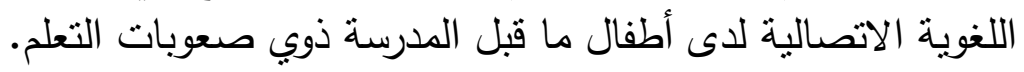
المحور الثالث: الوعي المورفولوجي للدى أطفال مـا قبل المدرسـة ذوي

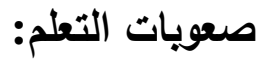

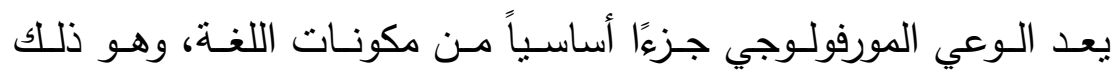

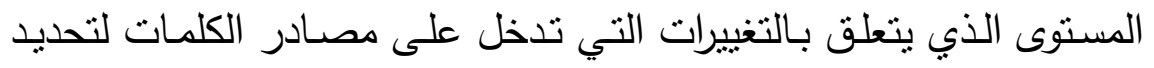

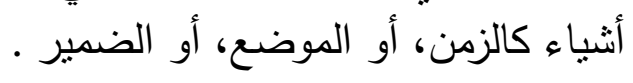


والمورفولوجيا أو علم الصرف مصطلح لساني حديث مأخوذ من الككلمة

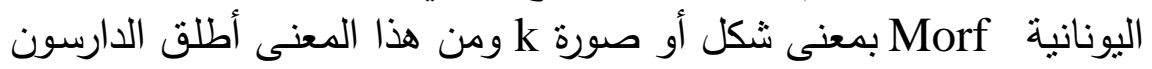
المحدثون الغربيون المورفولوجيا على الدراسة الصرفية.

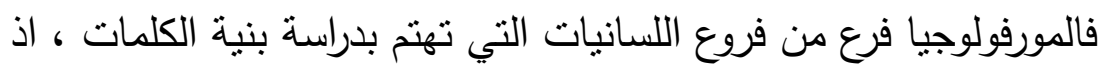

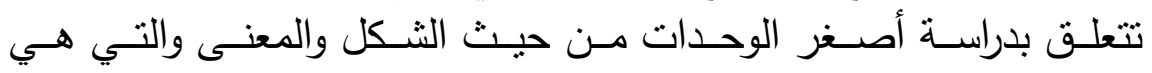

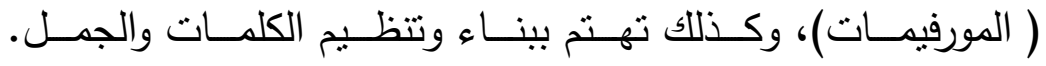
(Huaart,2016,6)

وفي علم اللسانيات تعرف المورفولوجيا على أنها: دراسـة البنية الداخلية للكلمات ، وترتكز على المورفيوم(Morpheme ).

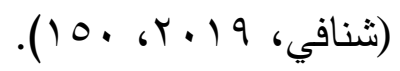

ويعرف المورفيم بأنه: أصغر وحدة ذات معنى ومتميزة في الصرف، وأن

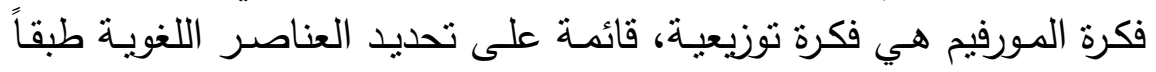

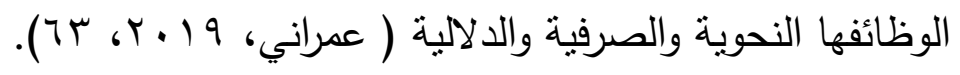

أنواع المورفيم (Morpheme) : للمورفيم أنواع عديدة أهمها:

ا-قد يكون عنصراً صوتياً، وهذا العنصر الصوتي قد يكون صوتاً واحداً

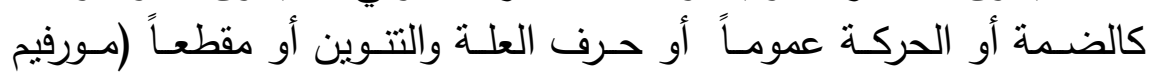

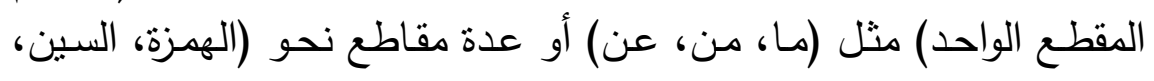

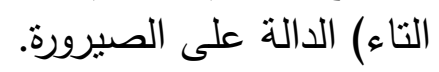
ץ-أن يكون المورفيم من طبيعة العناصر الصئه الصوتية المعبرة عن المعنى أو التصور أو الماهية أو من ترتيبها. 
ب-القسـم الثالث من (المورفيم) ذاته وهو الموضـع الذي يحتله من الجملة كل عنصر من العناصر الدالة على المعنى. ويرى أكثر المحثثين النحويني أن المورفيمات تتكون من نوعين: ا-المورفيم الحر (Free Morpheme) أو المستقل: وهو الذي يمكن

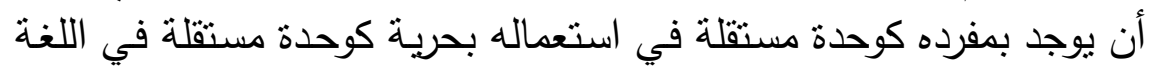

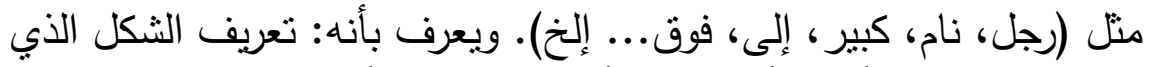

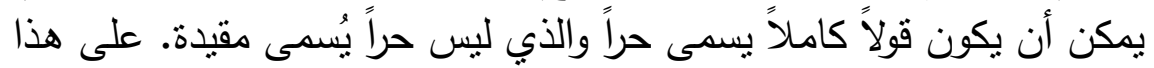

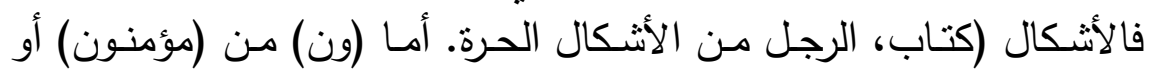
(ات) من (مؤمنات)، فهي تتطوي ضمن الأشكال المقيدة. أطلق عليها اسم الكلمـة الحرة وهي التي تحمل المعنى الأساسي. وسميت بهذا الاسم لأسم لأنها يمكن أن تُتعمل منفردة. ونجد بعض اللغوبين المحدثين يفضلون استعمال

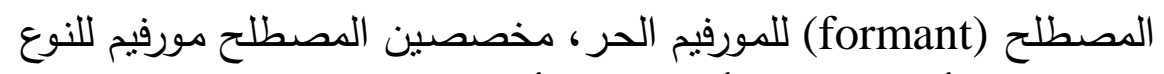
المتصل فقط أو الذي بمكن أن يوصف بأنه يدل على فكرة إضافية ( . ( . ,Cristial).

r-المسورفيم المقيـ (Bound Morpheme): فهو الذي لا يمكن استخدامه منفرداً، بل يجب أن يتصل بمورفيم حر أو مقيد آخر ، وأمنلة هذا

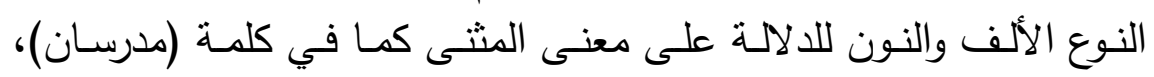

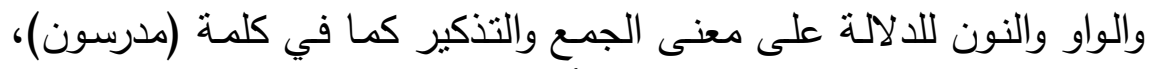
والتاء المربوطة للادلة على معنى التانيبث كما في كلمة (صغيرة)، والألف

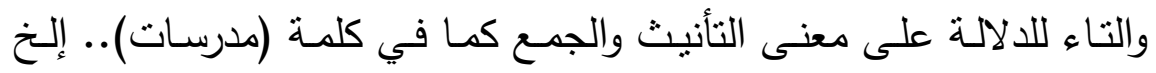
وغيرها كثير في اللغة العربية. (Al ghazal, 2005) . 


\section{وتقسم المورفيمات المقيدة إلى نوعين رئيسين هما:}

• المورفيم الاثتقاقي: هو الذي يدخل في الاشتقاق، ومن ذلك ما يطرأ

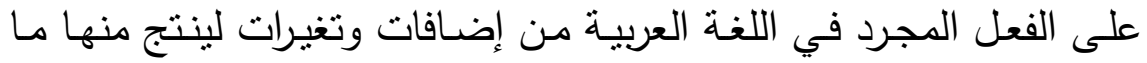

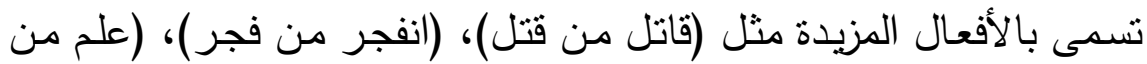

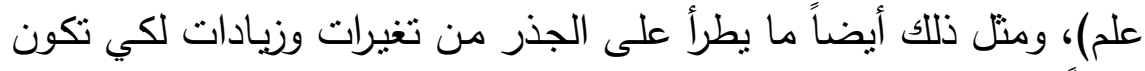

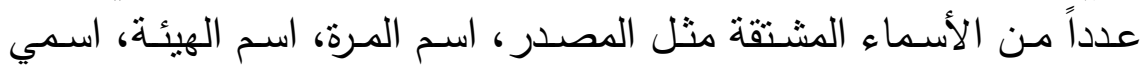

$$
\text { الزمان والمكان، صيخ المبالغة.. إلخخ). }
$$

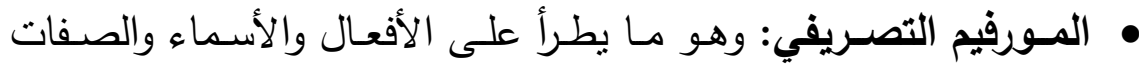

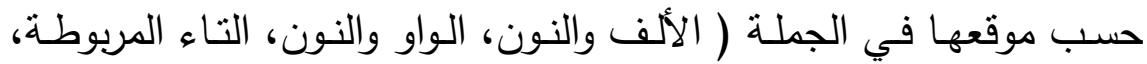
الألف والتاء) وتدخل كلها في باب التصريف ، أبي أنها متصلة اتصالاً وثيقاً

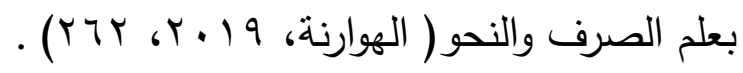

وظائف المورفيمات في اللغة: تتحصر وظائف المورفيمات في اللغة بثلاث مهماتٍ رئيسةٍ هي:

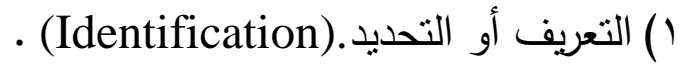
(r) (r) التصنيف (r) (r)

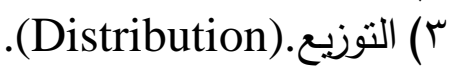
وهذا يعنـي أن إضـافة مورفيم إلى مورفيمٍ آخرٍ أو نزعـه منـه أو مقابلـة

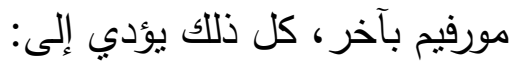

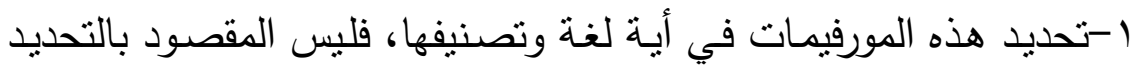

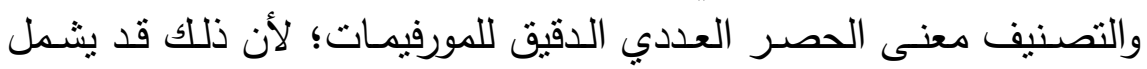

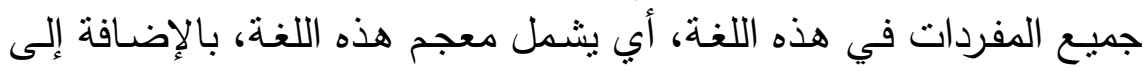


الأدوات الأخرى مثثل حروف الجر ، وأدوات النصب والجزم، كما في اللغـة العربية.

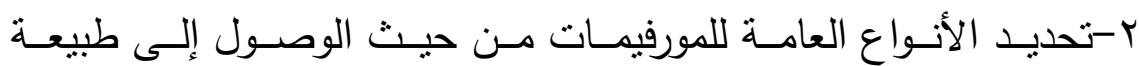

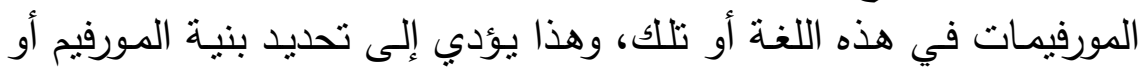

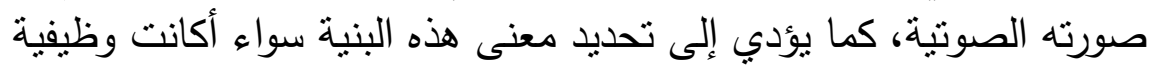
أم دلالية.

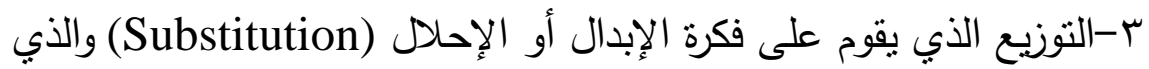

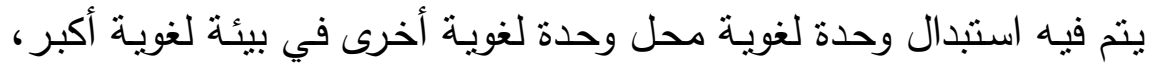

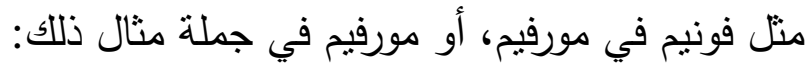

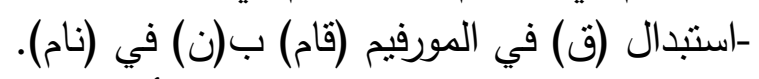

-إحلال (رجل) محل (فرس) مثل جملة(رأيت فرسا) (Al ghazal,2005).

\section{نمو وتطور الوعي المورفولوجي:}

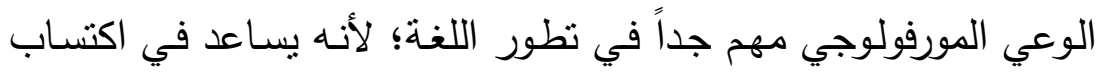

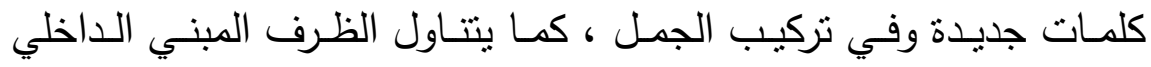

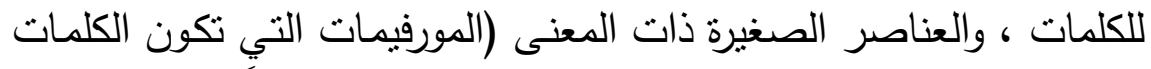

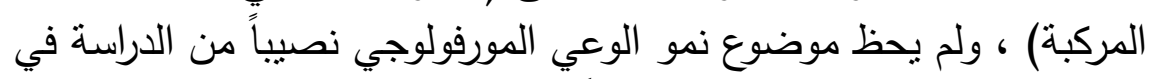

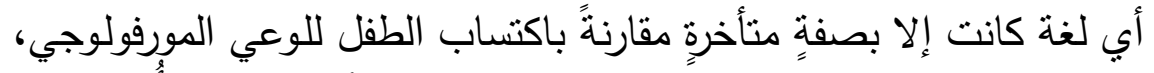

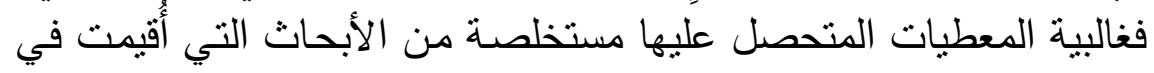
اللغات الرومانية وفي اللغة الإنجليزية، وفي المقابل وعلى التيلى حد علم الباحثة

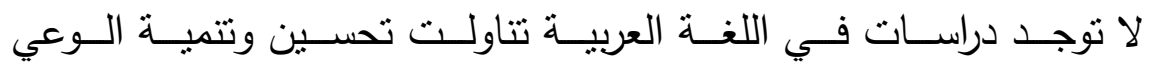

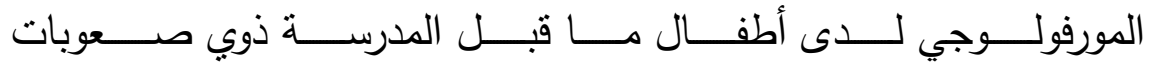

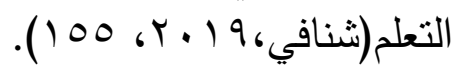


وفي هذا الصدد فقد أجريت دراسات متعددة تتاولت الوعي المورفولوجي

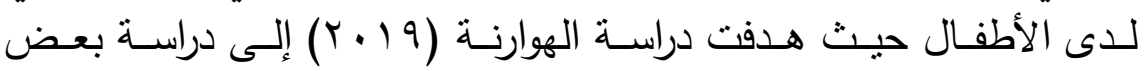

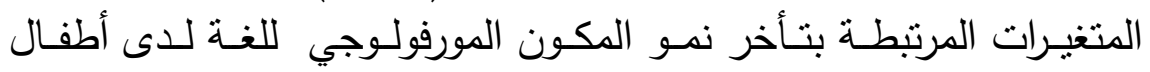
الروضة.

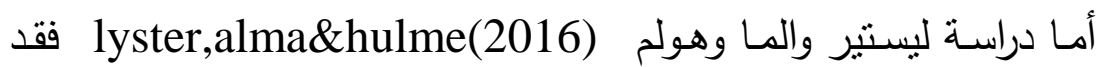

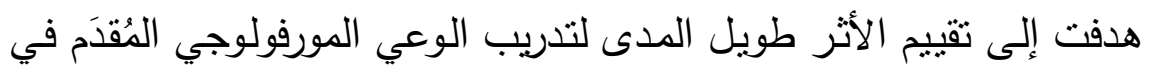

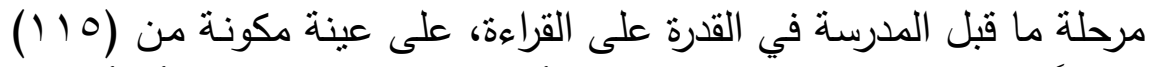

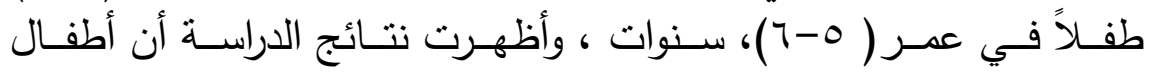

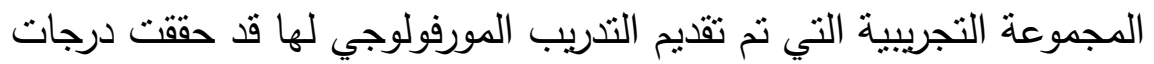

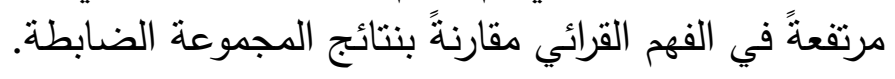

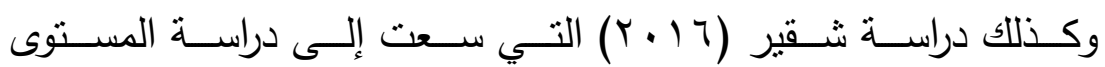
المورفولوجي للغة لاى الأطفال ذوي صعوبات التعلم الأكاديمية والعاديين.

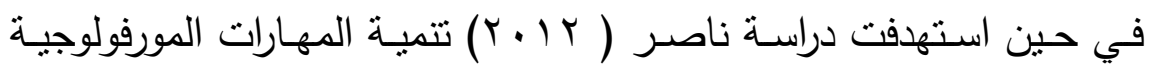

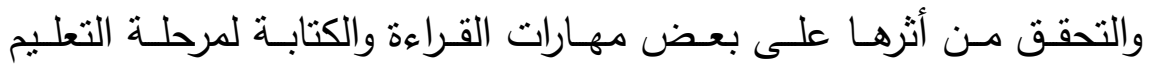
الأساسي.

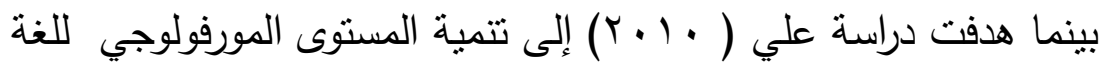

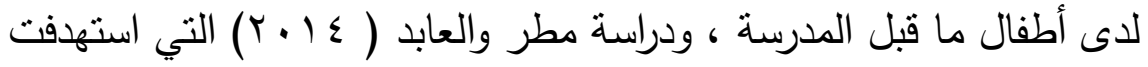

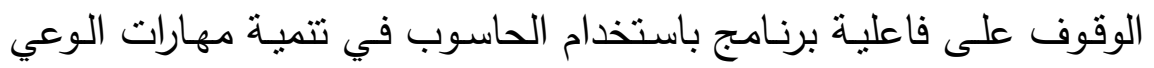

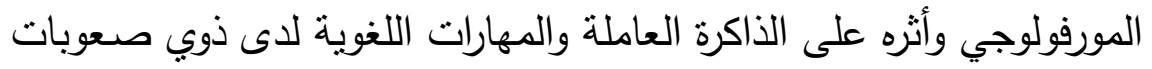
تعلم القراءة.

واستهدفت دراسة ( Pittas,Evdokia.,\&NunesTerezinha,2014)

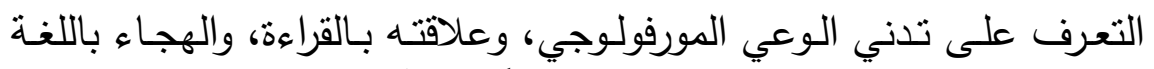

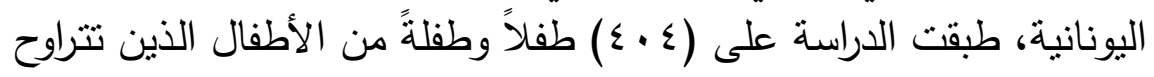


أعمارهم مـا بين (7-9) سنوات، وأظهرت النتائج أن الوعي المورفولوجي

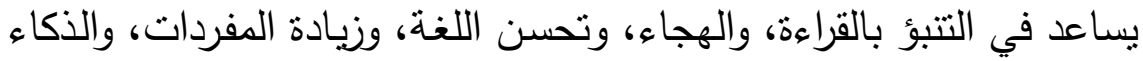

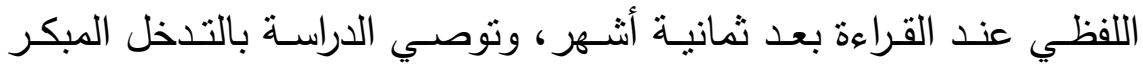
لإثبات هذه العلاقة، فضلاً عن زيادة المهارات الإملائية.

كما توصلت دراسـة ( Erin,2014 ) ) إلى أن الأطفال العاديين أقل

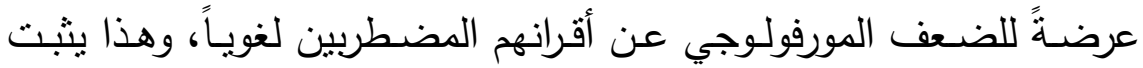

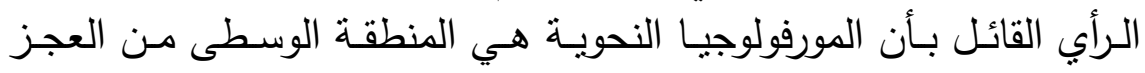

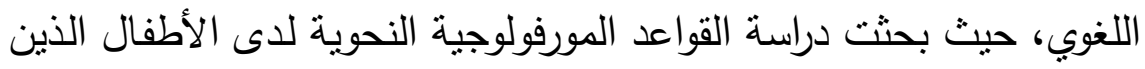

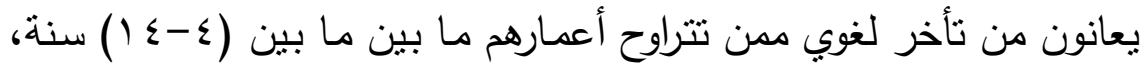

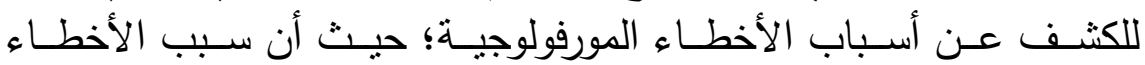

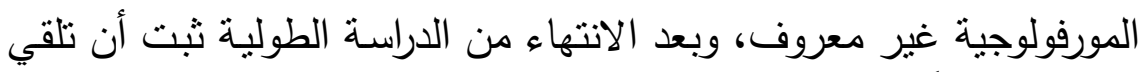

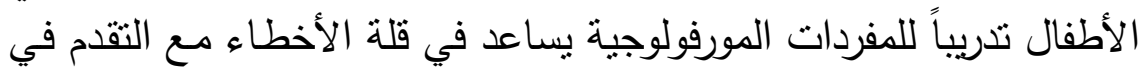

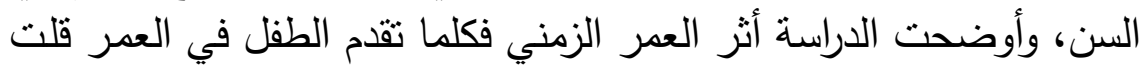
أخطاءه المورفولوجية.

وهدفت دراسـة كلاوتير ( Cloutier, 2002 (الحى وصف المهارات

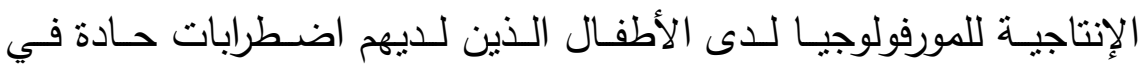

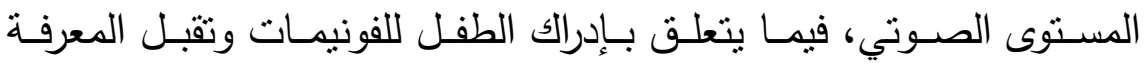

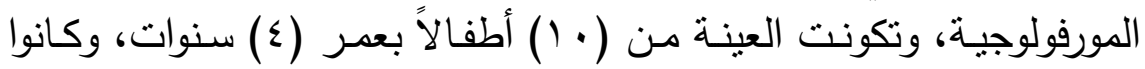

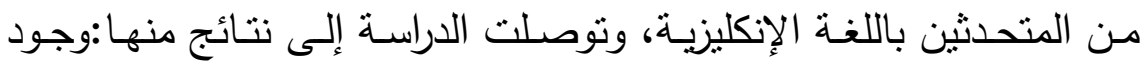

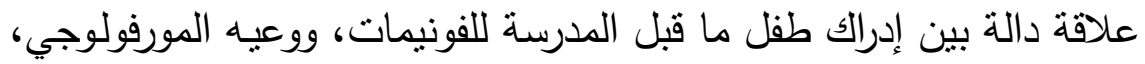

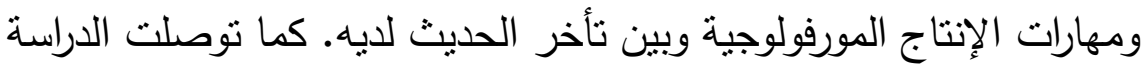

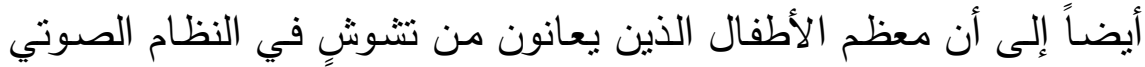


لديهم يعانون كذلك من عجزٍ في المجال المورفولوجي ومن أخطاءٍ في

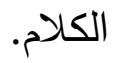

أسسباب اضطرابات وظـائف المـورفيم لـدى أطفـال مـا قبـل المدرسـة ذوي

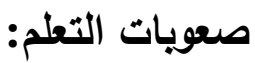

ترجـع أسباب اضطراب وظـائف المـورفيم لـدى الأطفـال ذوي صـوبات

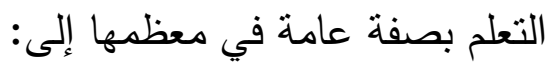

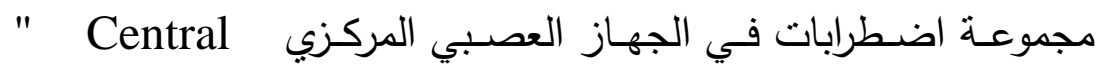
Neurological System"Disorders

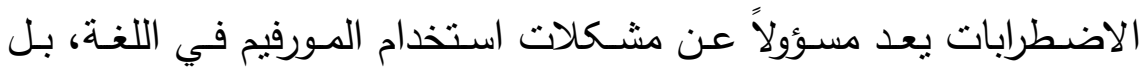

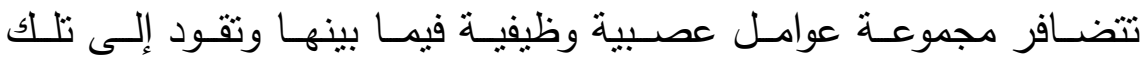

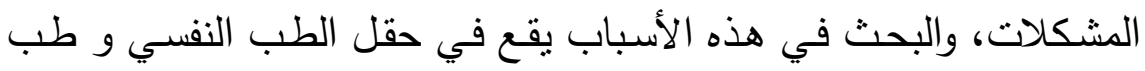

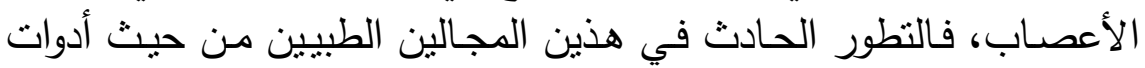

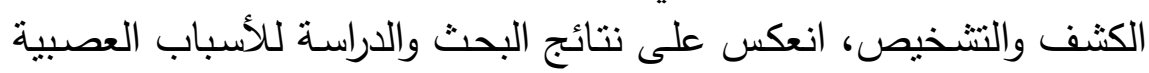
التي تقف خلف تطور صعوبات التعلم، ولا سيما النمائية منها.

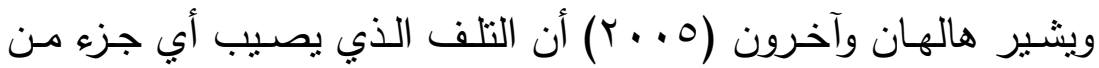

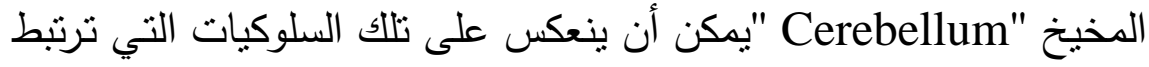

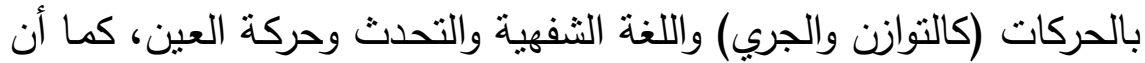

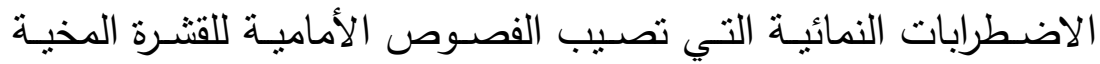
"Frontal Lobes of the Cerebral Contex"

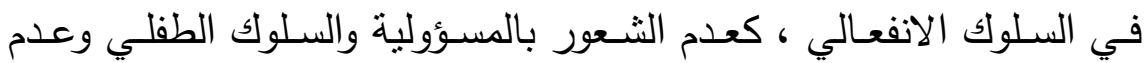

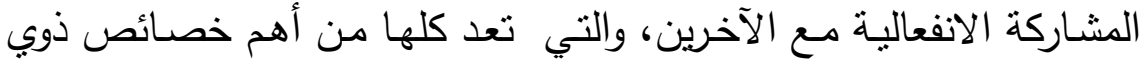

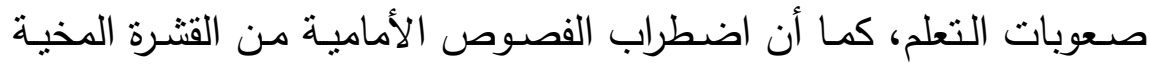

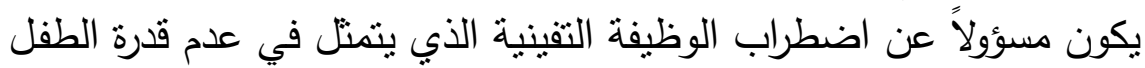


على تحديد حاجاته من المهارات والإستراتيجيات اللزمة لأداء مهمة معينة،

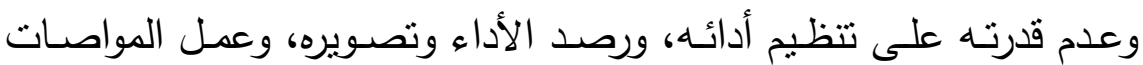

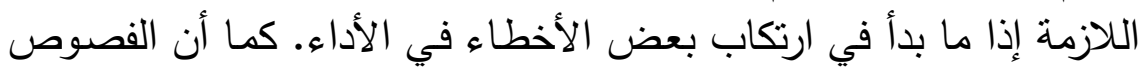

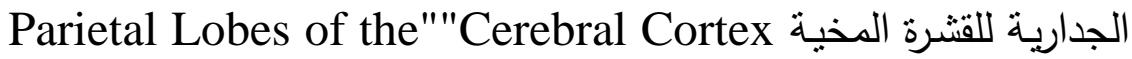
تكون مسـؤولةً عن حدوث التكامـل بـين الإحساسـات الجسـية والإدراكات

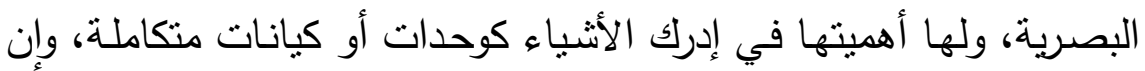
حدوث أي اضطراب نمائي في الفصوص الجدارية، يمكن أن يكون سببًا في إني اضطراب عمليات الإدراك المكاني البصري، أو بكون سبباً في اضطراب

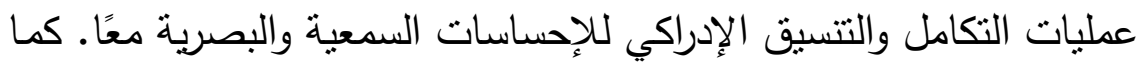

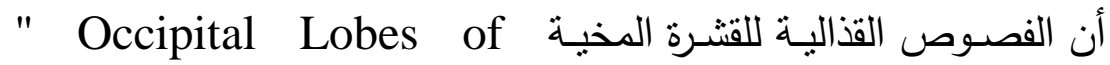
the"Cerebral Cortex

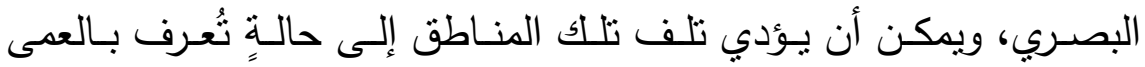
البصري" "Visual Agnosia" ، والتي تعني عدم قدرة الطفل أو عجزه عن البن

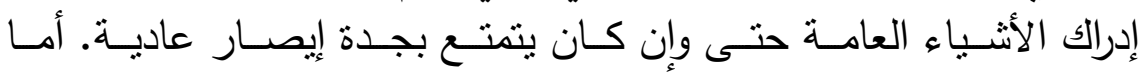

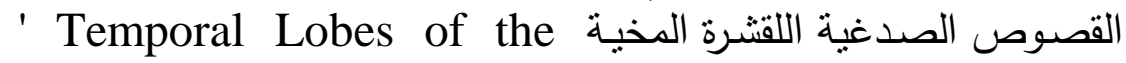
Cقتوم بمجموعـة مـن الوظـائف المهنـة التي ترتبط بالتعلم، حيث نكون مسؤولةً عن الانتهاء والذاكرة واللغة إصداراً واستقبالاً، ونظراً لأهمية تلك العمليات بالنسبة للتعلم، كان هناك اعتقاد كبير بناءًا على الألى تلك الأدلة بأن الفصوص الصدغية هي المسؤولة عن صعوبات التعلم.

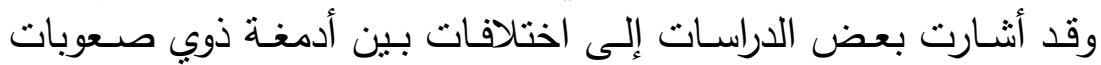

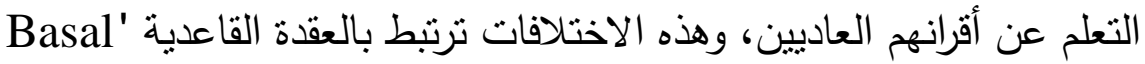
Ganglion الدراسات أن العقدة القاعدية ذات العلاقة بالأنشطة المتلوكية الروتينية تكون

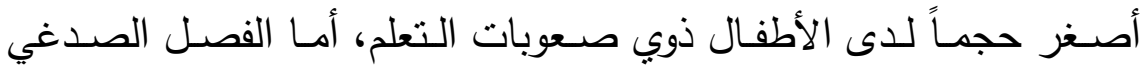




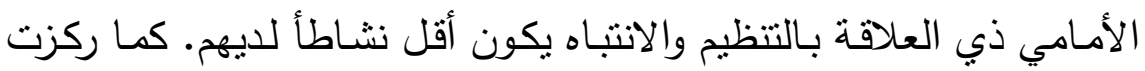

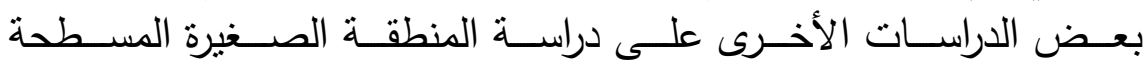

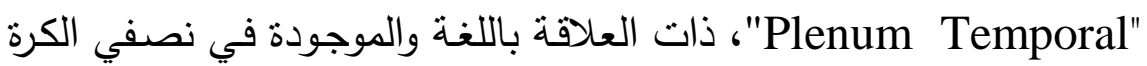

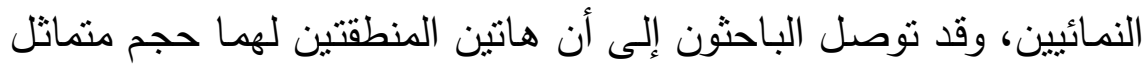

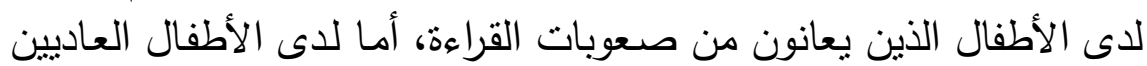

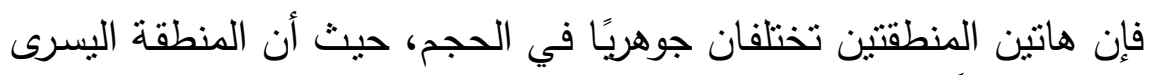

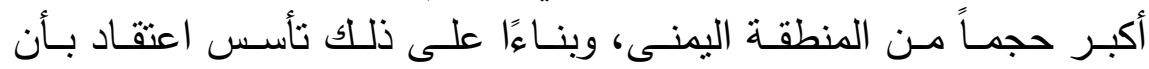
صعوبات القراءة والرياضيات واللغة قد تكون مرتبطةً بهذه الاختلافات.

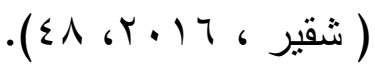

\section{فروض البحث:}

ا ـ توجد علاقة ارتباطية بين درجات أطفال المجموعة التجربيية على كلٍ

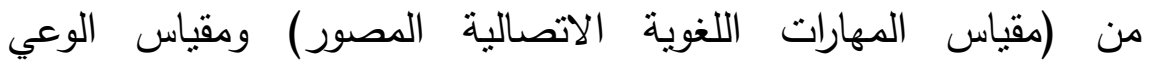
r. توجد فروق ذات دلالة إحصائية بين متوسطي رتب درجات أطفال

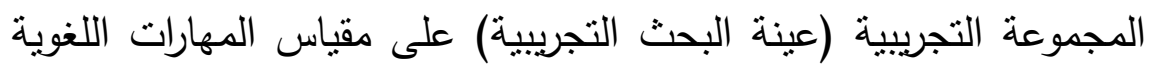

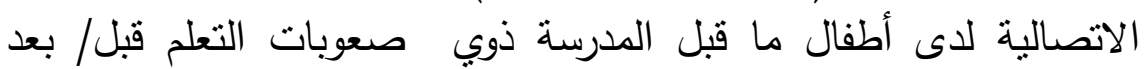

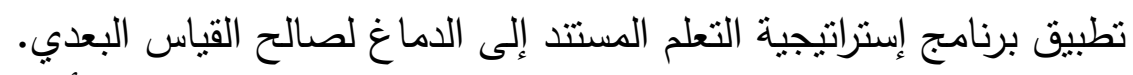

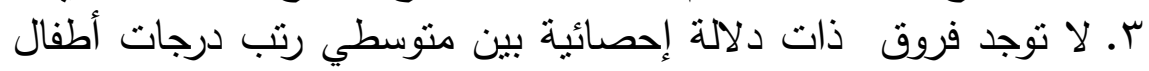

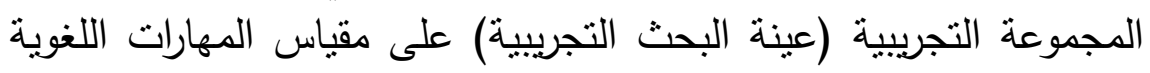

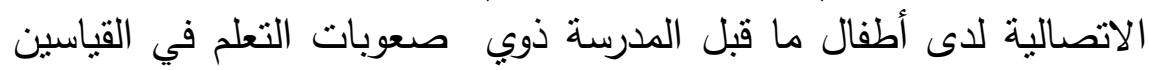
البعدي والتتبعي. ع. توجد فروق ذات ذاتي دلالة إحصائية بين متوسطي رتب درجات أطفال

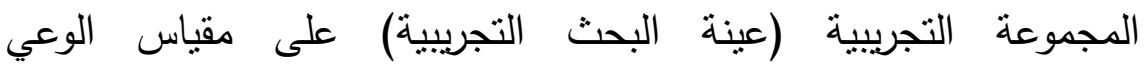


المورفولوجي لدى أطفال ما قبل المدرسة ذوي صعوبات التعلم قبل/ بعد تطبيق برنامج إستراتيجية التعلم المستند إلى الدماغ لصالح القياس البعدي. ه. لا توجد فروق ذات دلالة إحصائية بين متوسطي رتب درجات أطفال

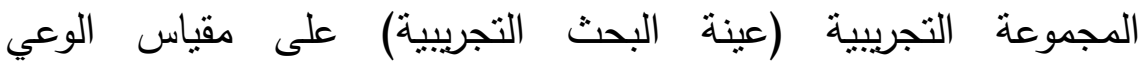
المورفولوجي ل لاى أطفال ما قبل المدرسة ذوي صعوبات التعلم في القياسين البعدي والتتبعي.

\section{الإجراءات المنهجية للبحث:}

\section{أولاً: عينة البحث:}

تكونت عينـة البحث الحـالي من (0 1) طفلاً وطفلةً مـن أطفال مـا قبـل

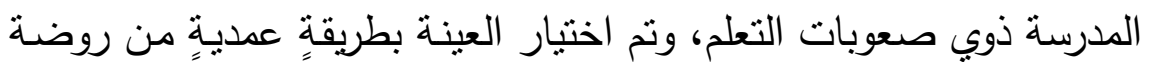
معهد فتيات الزهور التجريبي بمحافظة بورسعيد.

وتم اختيار العينة وفقاً للأطفال الذين ينطبق علبهم الثروط التالية:

ا - أن يتراوح العمر الزمني لكل أطفال العينة مابين ه إلى 7 سنوات.

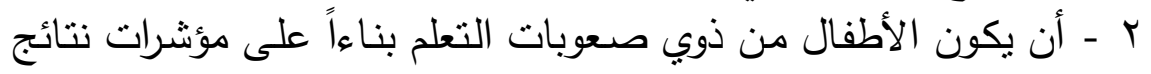
بطارية اختبارات لبعض المهارات فبل الأكاديمية كمؤشر لصعوبات التعلم. ( إعداد: أ. د د/ عادله عبدالهة).

ب - ألا تقل نسبة الذكاء الأطفال عن 9 درجة على مقياس ستانفورد بينيه

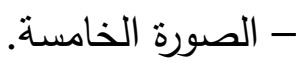
ع - أن يكون أطفال العينة ممن يلتزمون الحضور إلى الروضة . ولإيجـاد التجـانس بين أطفال العينـة قامـت الباحثة بايجـاد التكافؤ بين

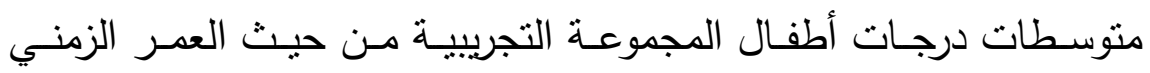
ودرجة الذكاء باستخدام اختبار كا r كما يتضح في الجدول التالي: 
جدول رقم (1) - (1) - (1)

دلالة الفروق بين متوسطات رتب درجات أطفال المجموعة التجريبية من حيث العمر الزمني ونسبة الأكاء

\begin{tabular}{|c|c|c|}
\hline مستوى الدلالة & كاץ & المتغيرات \\
\hline غير دالة & $1, \cdots$ & العمر الزمني \\
\hline غير دالة & $1, r \ldots$ & درجة الذكاء \\
\hline
\end{tabular}

وبتضح من الجدول أعلاه عدم وجود فروق دالة إحصائياً بين متوسطات

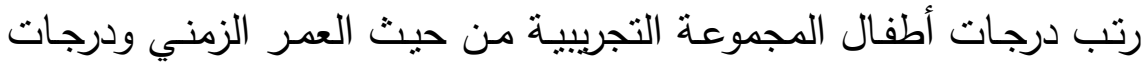
الذكاء مما بشير إلى تكافؤ العينة. ثانيًا: منهج البحث:

بما أن هدف المنهج هو قياس مدى فاعلية برنامج قائم على إستراتيجية

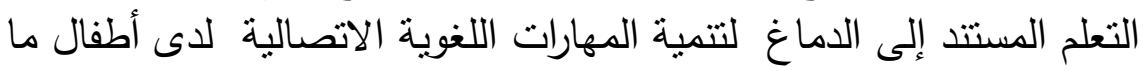
قبل المدرسـة ذوي صسوبات التعلم، فقد كان الاعتمـاد على المنهج شبه

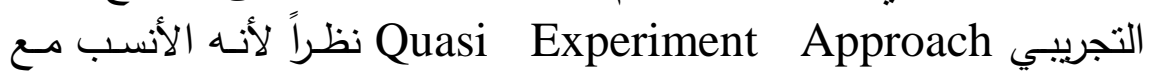

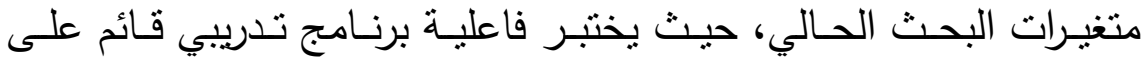
إسـتراتيجية التعلم المستتد إلى الدماغ ( كمتغير مسـتقل) وتتمبـة المهارات اللغوبة الاتصالية وعلاقته بتحسين مستوى الوعي المورفولوجي ( كمتغير

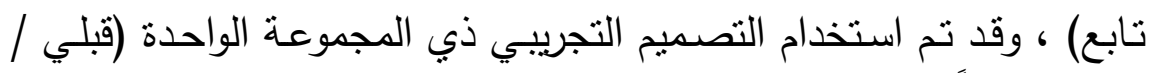
بعدي)، نظراً لصغر حجم العينة المتاحة من ذوي صعوبات التعلم. ثالثًا: أدواث البحث: للإجابـة على أسئلة البحـث وتحقيـق مـا يرمهي إلبـه مـن أهدافٍ، قامـت الباحثة بإعداد الأدوات التالية: 
ا ـ مقبـاس المهــارات اللغويـة الاتصــالية لأطفـال مــا قبـلـ المدرسـة ذوي صعوبات التعلم ( إعداد/ الباحثة).

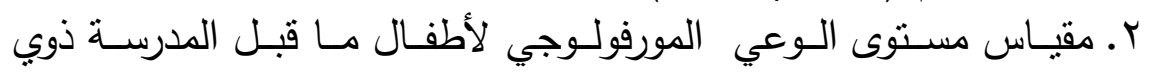
صعوبات التعلم ( إعداد/ الباحثة).

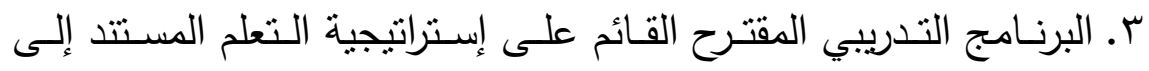
الادماغ ( إعداد/ الباحثة).

أولاً : مقبـاس المهارات اللغوبـة الاتصـالية لأطةـال مـا قبـل المدربـة ذوي صعوباث التعلم المصور:

مبررات إعداد مقياس المهارات اللغوية الاتصالية المصور لقياس مستوى

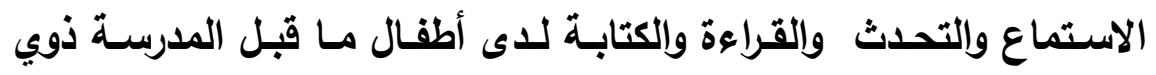

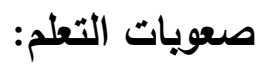

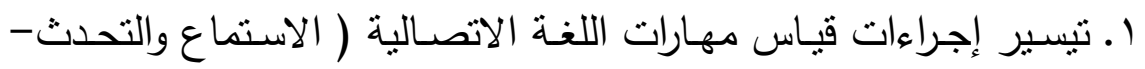
القراءة والكتابة ) لدى أطفال ما قبل المدرسـة ذوي صسوبات التعلم ؛ حيث

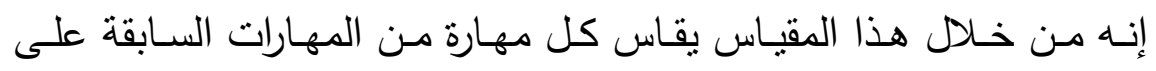

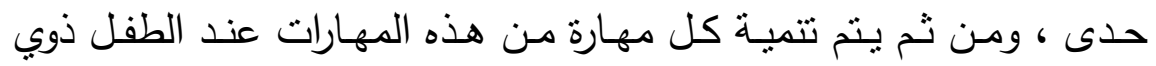
صعوبات التعلم.

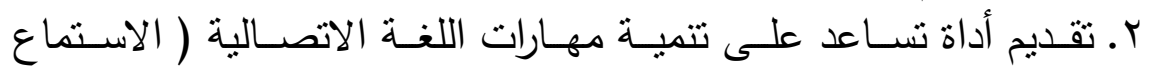

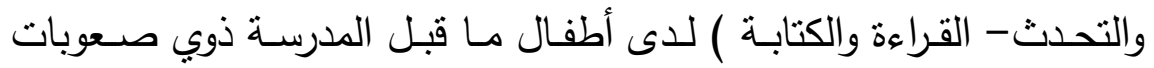
التعلم؛ للحد من التعرض لخطر صعوبات تعلم قراءة اللغة العربية، حيث إنه مقياس مصور يناسب المستوى العمري والعقلي لأطفال ما قبل المدرسة ذوي

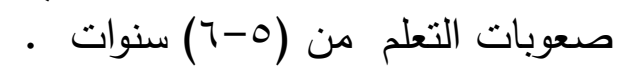


خطوات بناء مقياس المهارات اللغويـة الاتصـالية المصور لأطفال مـا قبل المدرسة ذوي صعويات التعلم:

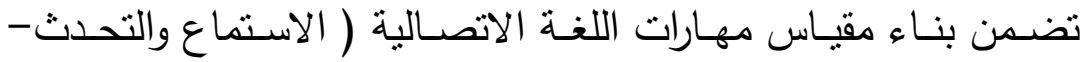

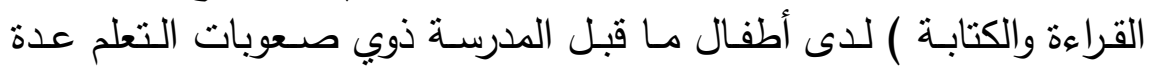
خطوات يمكن إجمالها فيما يأتي:

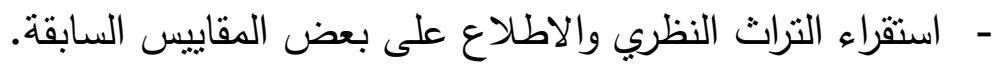

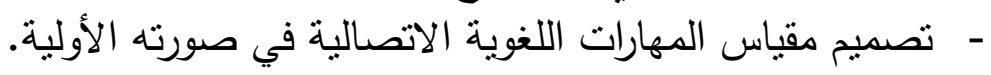

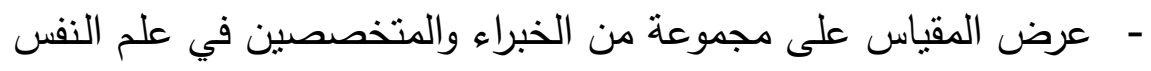
ورياض الأطفال لتحكيمه. - إعداد المقياس في صورته النهائية. الخصائص السيكومترية للمقياس: وفيما يلي عرض تفصيلي لهذه الخطوات: استقراء التراث النظري والاطلاع على بعض المقاييس السابقة:

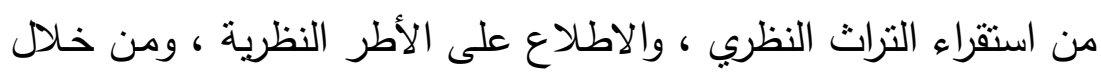

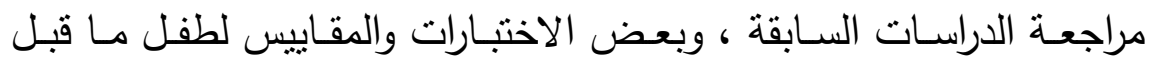

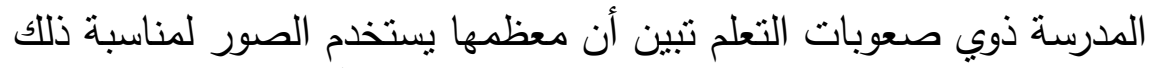

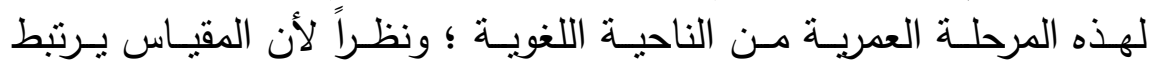

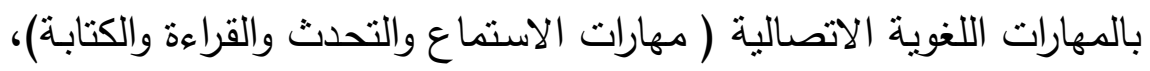

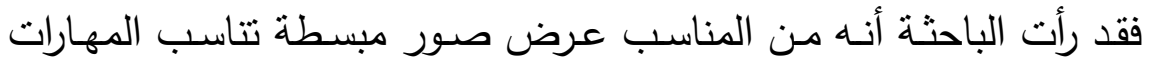

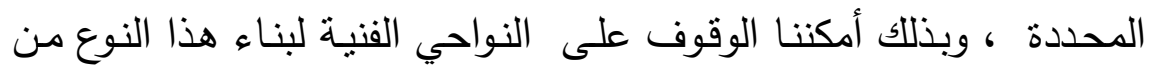

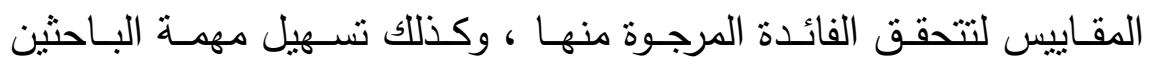
الآخرين ليستفيدوا منها في أبحاثهم القادمة. 
تصميم مقياس المهارات اللغوية الاتصالية المصور في صورته الأولية: تم بناء مقياس المهارات اللغوية الاتصالية لأطفال ما قبل المدرسة ذوي صعوبات التعلم وفقاً لعدد من الخطوات كالآتي:

\section{تحديد الهذف من المقياس :}

تم تصـيم هذا المقياس كوسيلة للكثـف عن بعض القدرات والمهارات

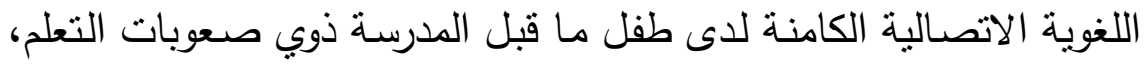

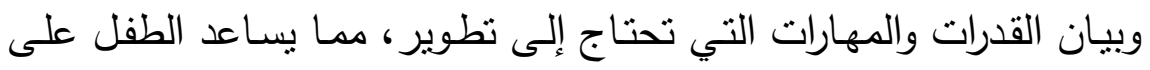

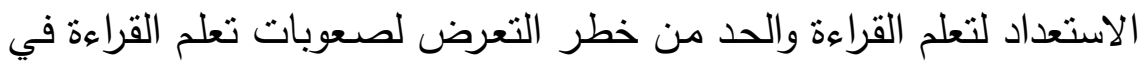
المرحلة اللاحقة. تحديد أبعاد المقياس:

يتكون هذا المقياس من مجموعة من الأسئلة الخاصـة بمهارات الاستماع

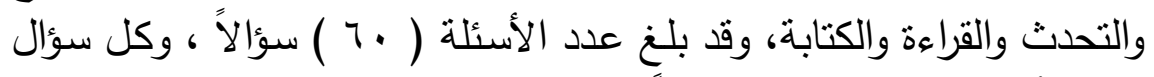

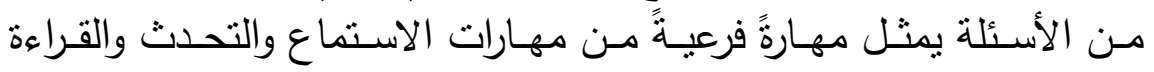
والكتابة، وقد نم تقسيم هذا المقياس إلى بُعدين:

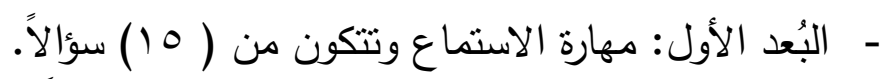

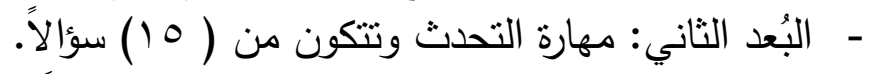
- البُعد الثالث: مهارة القراءة وتتكون من ( 10 (1) سؤالاً. - البُعد الرابع: مهارة الكتابة وتتكون من ( 10

وذلك بعد الاستفادة من استقراء التراث النظري ، والأبحاث والدراسـات السابقة ، وبعض من المقاييس السابقة. 


\section{ج. صياغة مفردات المقياس :}

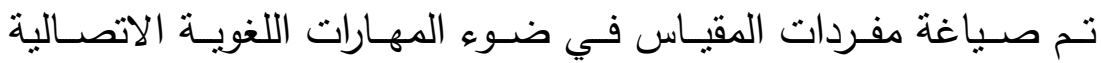

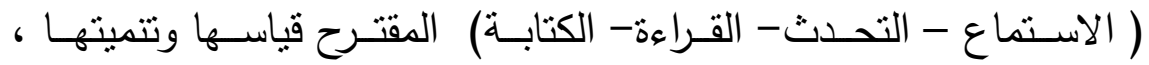

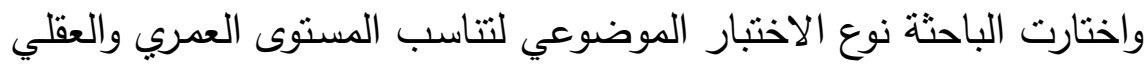

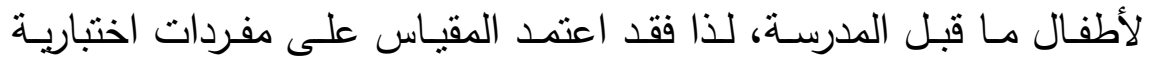

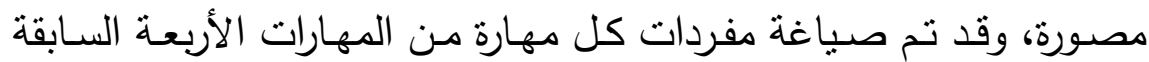
على حدى، وقد روعي الآتي :

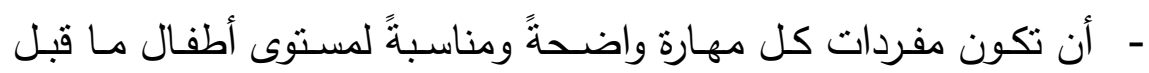

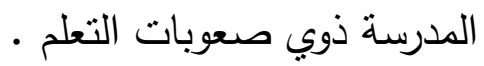

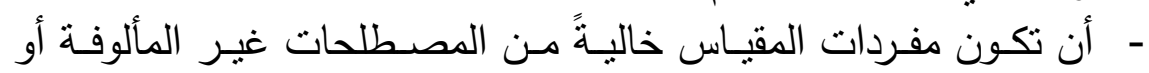

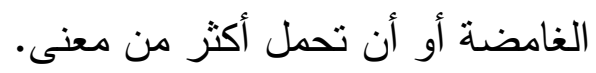
- أن يحدد المطلوب من كل سؤالٍ بوضوح. د. صياغة تعليمات المقياس:

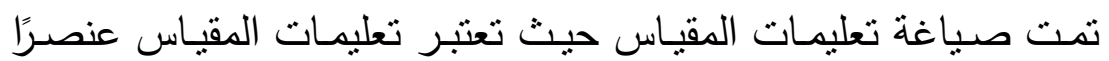

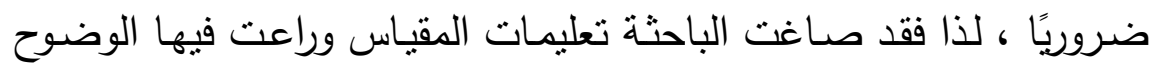

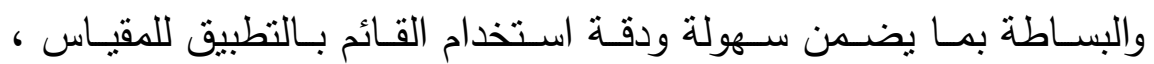

وتضمنت تعليمات المقياس العناصر الآتية: - - خلق جو نفسي قبل تطبيق المقياس وفي أثنائه.

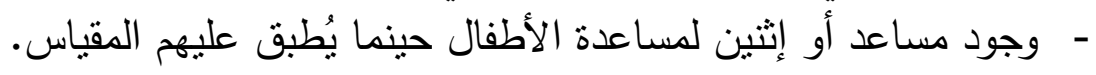

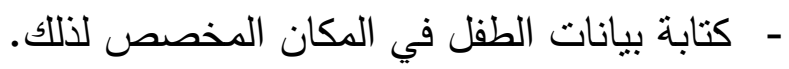

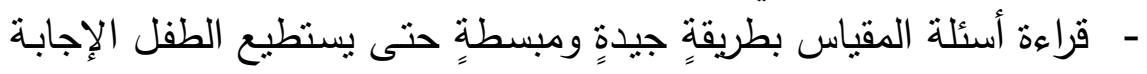

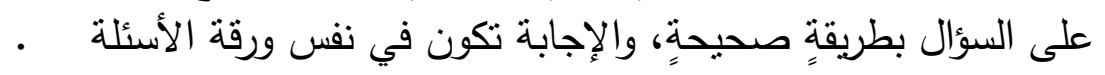


- إذا رغب الطفل في تغيير إجابته ؛ فيجب التأكد منه أنه قد محي إجابته السابقة تمامًا.

عرض المقياس على مجموعة من الخبراء والمتخصصين في علم النفس ورياض الأطفال والتربية الخاصة مُعة هن

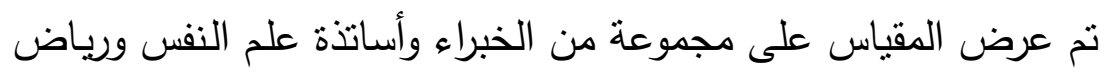

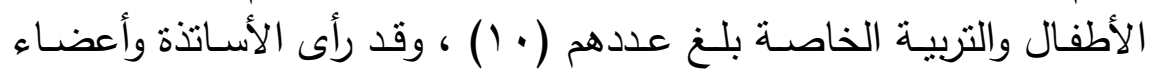

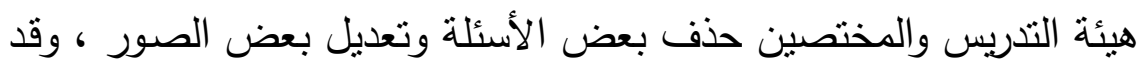

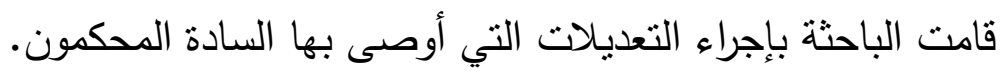
هـ إعداد المقياس في صورته النهائية:

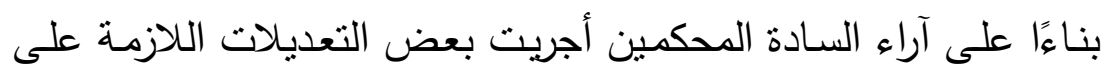
بعض الفقرات وحذف بعضها، ثم وضع المقياس في صورته النهائية . الخصائص السيكومترية للمقياس: أولاً: ثبات المقياس Reliability : قامت الباحثة بحساب ثبات المقياس بطريقتين كالتالي: معامل ألفا ( كرونباخ):

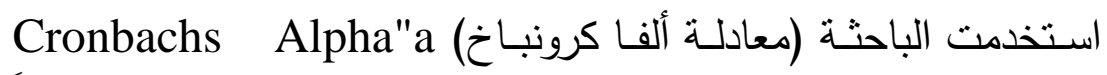

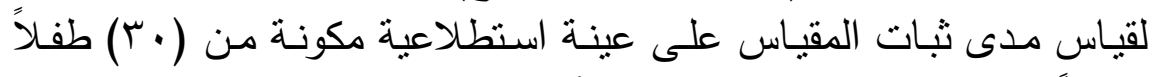

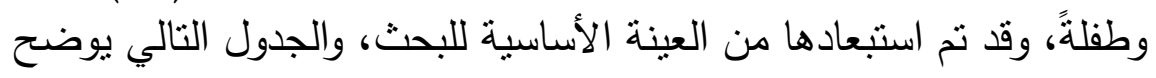

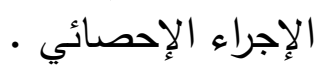




\section{جدول (r)}

معاملات ثبات مفردات مقياس المهارات اللغوية الاتصالية لطقل ما قبل المدرسة ذوي

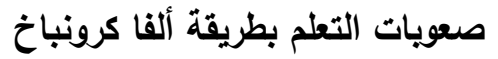

$$
(r \cdot=)
$$

\begin{tabular}{|c|c|c|}
\hline معامل ثبات ألفا كرونباخ & عدد الأسئلة & البُعد \\
\hline$*, \wedge \mid \wedge$ & 10 & الأول: مهارة الاستماع \\
\hline$*, \wedge Y q$ & 10 & الثاني: مهارة التحدث \\
\hline$* ., q r$. & 10 & الثالث: مهارة القراعة \\
\hline$*,, \vee 9 \wedge$ & 10 & الرابع:مهارة الكتابة \\
\hline$*, 9 \vee 1$ & 7. & الثبات الكلي للمقياس \\
\hline
\end{tabular}

وبتضح من الجدول أعلاه أن معامل الثبات العام لأبعاد المقياس مرتفع حيث بلـغ (9V1, • * * لإجمالي فقرات المقياس السـتون ، فيما تراوح ثبات

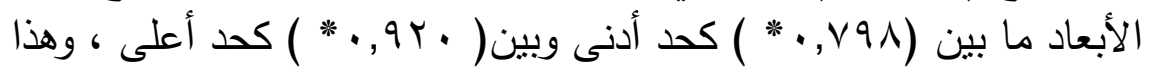
يدل على أن المقياس يتمتع بدرجة عالية من الثبات يمكن الاعتماد عليه في التطبيق الميداني للبحث بحسب مقياس نانلي والذي اعتمد • V, • كحد أدنى لأنى للثباث.

$$
\text { : (Y) طريقة إعادة الاختبار }
$$

تـم إعـادة تطبيـق مقيـاس المهـارات اللغوبــة الاتصــالية ( الاســماعالتحدث- القراءة - الكتابة ) على عينة التقنين بفاصل زمني قدره أسبوعين، وتم حسـاب معامل الارتباط بين درجات الأطفال في التطبيقين ، وجاءت جميعها دالة عند مستوى ( ( . • ) والجدول التالي يوضح ذلك: 


\section{جدول (r)}

معاملات ثبات مفردات مقياس المهارات اللغوية الاتصالية لطقل ما قبل المدرسة ذوي صعويات التعلم بطريقة إعادة الاختبار

\begin{tabular}{|c|c|c|}
\hline الإحصائية & الارثباط & 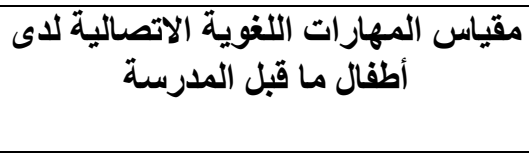 \\
\hline$\cdot, \cdot 1$ & $\cdot, \Delta \wedge r$ & الأول: مهارة الاستماع \\
\hline$\cdot, \cdot 1$ & $\cdot, 71 \wedge$ & الثاني: مهارة التحدث \\
\hline$\cdot, \cdot 1$ & $\cdot, V q r$ & الثالث: مهارة القراعة \\
\hline$\cdot, \cdot 1$ &., 099 & الرابع:مهارة الكتابة \\
\hline$\cdot, \cdot 1$ & $\cdot, \wedge 9 r$ & الارجة الكلية للمقياس \\
\hline
\end{tabular}

ثانياً: صدق المقياس Validity

لتحديد مدى صدق محتوى المقياس استخدمت الباحثة في بحثها طريقتين

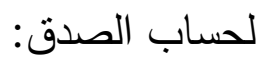

(1) صدق المقارنات الطرفية:

تم حسـاب الصدق الكلي لمقياس المهارات اللغوبـة الاتصـالية لدى عينة التقنين (ن= • ب) عن طريت حساب الصدق التمبيزي أو صدق المقارنات

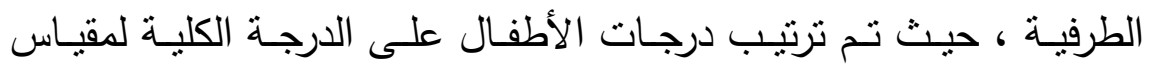

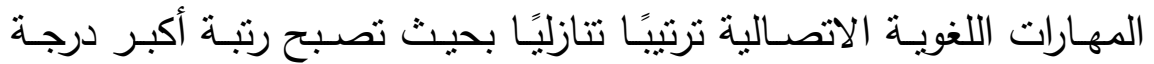

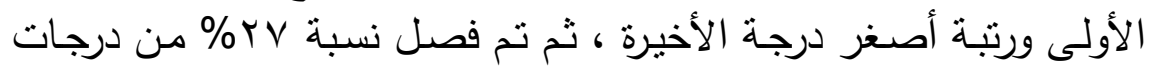

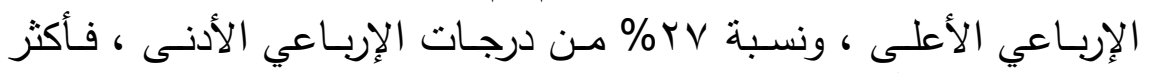

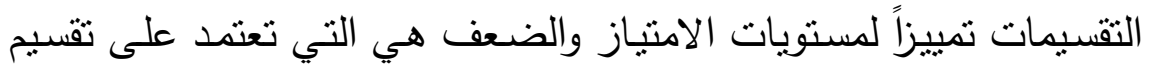


درجات الميزان إلى طرفين الأعلى والأدنى بحيث يتألف الإرباعي الأعلى

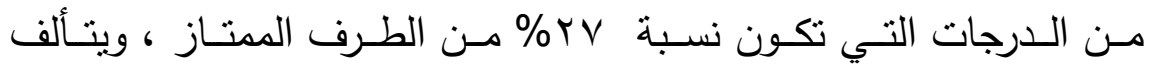

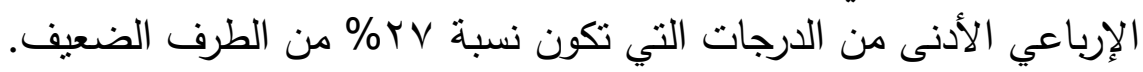

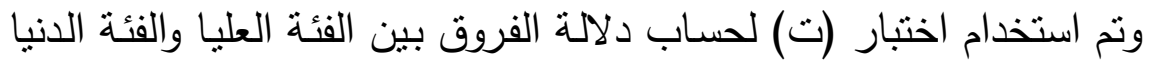

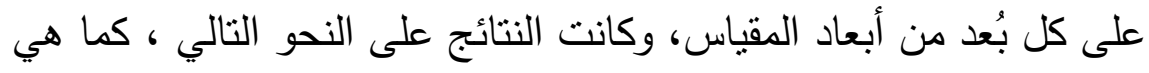

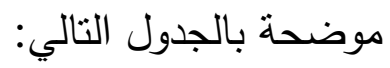

\section{جدول ( ؛ )}

نتائج اختبار "ت" لدراسة الفروق بين متوسطات المجموعة الطرفية لمقياس المهارات اللغوية الاتصالية لاى عينة التقتين

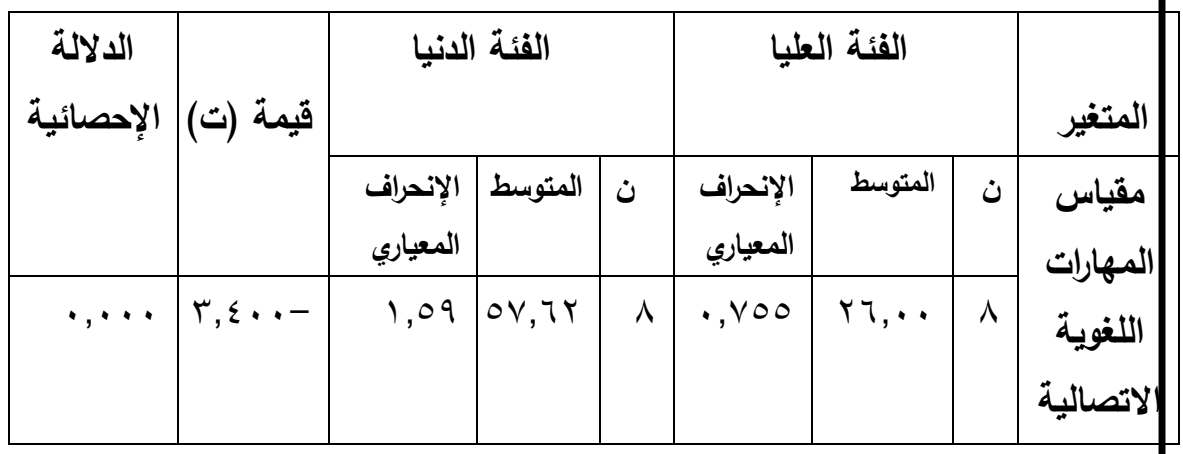

ويتضـح مـن الجـدول السـابق وجـود فـرق دال إحصــائباً بمسـتوى دلالـــة

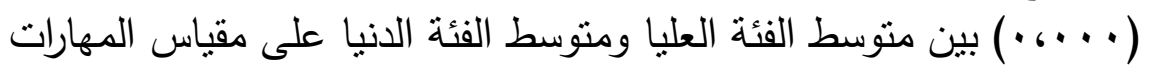

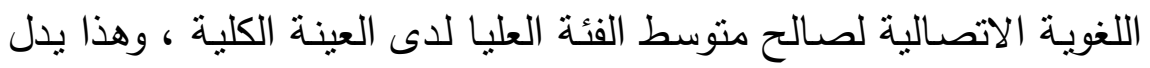

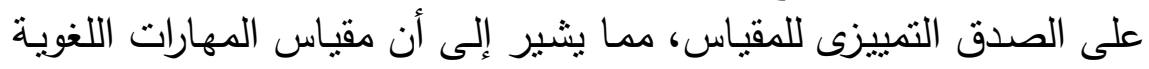

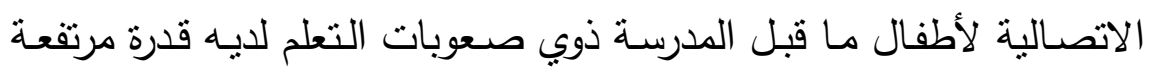
على التمييز بين مرتفعي ومنخفضي المهارات اللغوية الاتصالية. 


\section{(r) طريقة الاتساق الداخلي:}

قامت الباحثنة بحساب الارتباطات الداخلية للأبعاد الأربعة للمقياس، كما تم حساب ارتباطات الأبعاد الأربعة بالدرجة الكلية للمقياس، والجدول التالي

جدول (0)

يوضنح ذلك:

درجة الارتباط الاخلي بين أبعاد المقياس ببعضها البعض وبالارجة الكلية لمقياس

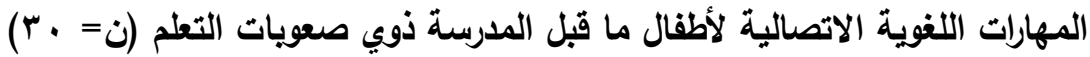

\begin{tabular}{|c|c|c|c|c|c|}
\hline الالدلية & الكتابة & القراءة & التحدث مهارة & الاستماع مهارة & أبعاد \\
\hline- & - & - & - & - & 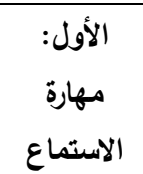 \\
\hline- & - & - & - & $* *,, \leq Y$. & التاني: التحدث \\
\hline- & - & - & $* * ., 799$ & $* *,, \varepsilon \wedge$. & الثهارة \\
\hline- & - & $* *,, \vee 47$ & $* *,, \uparrow, \Lambda$ & $*_{.}, r q r$ & الكرابع:مهارة \\
\hline$* *,, \wedge \odot r$ & $* *,, \wedge 0 \leqslant$ & $* *, 9 \ldots$ & $* *, \wedge \bullet r$ & $* *,, 797$ & الكلية \\
\hline
\end{tabular}

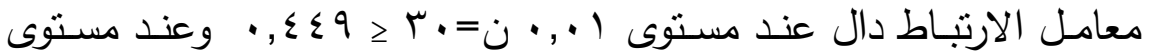
$\cdot, r \leqslant q \geq . \cdot \cdot, 0$ 
يتضح من الجدول السابق أن جمبع معاملات الارتباط دالة عند مستوى دلالة ( ( +، · )، مما بدل على تمتع المقياس بثبات الاتساق الداخلي.

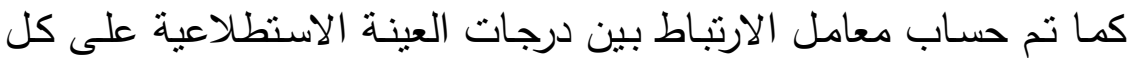
مفردة والدرجة الكلية للعامل الذي تتنمي إلبه كالتالي:

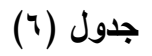

معاملات الارتباط بين درجة كل مفردة والدرجة الكلية للبعد الذي تتنمي إليه

\begin{tabular}{|c|c|c|c|c|c|c|c|}
\hline \multicolumn{2}{|c|}{ مهارة الكتابة } & \multicolumn{2}{|c|}{ مهارة القراءة } & \multicolumn{2}{|c|}{ مهارة التحدث } & \multicolumn{2}{|c|}{ مهارة الاستماع } \\
\hline الارتباط معامل & المفردة & الارتباط معامل & المفردة & الارتباط & المفردة & الارتباط & المفردة \\
\hline$* *, Y, 7$ & (1) & $* *, 001$ & (1) & $* *$, T T V V & (1) & $* *, 011$ & (1) \\
\hline$* *, \quad T \leq r$ & $(Y)$ & $* *, \neg) \varepsilon$ & $(r)$ & $* *, 7) 7$ & $(r)$ & סזד, •** & $(r)$ \\
\hline$* *, \tau, T r \mu$ & $(r)$ & ש * • • ש & $(r)$ & ש * • • ש & $(r)$ & $* *,, \vee \vee \varepsilon$ & $(r)$ \\
\hline **, • T TV & $(\varepsilon)$ & $* *$, , $10 \mathrm{~V}$ & $(\varepsilon)$ & **, r r & $(\varepsilon)$ & ***, • & $(\varepsilon)$ \\
\hline$* * 0.574$ & (0) & $* *, 9$, & (0) & $* *,, \vee \vee \varepsilon$ & (0) & $* *,, \vee \wedge \varepsilon$ & $(0)$ \\
\hline$* *, 00 \leqslant$ & (7) & $* *, 990$ & (7) & 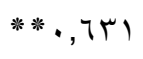 & (7) & $* *, \neg \ldots$ & (7) \\
\hline **, r T & $(v)$ & $* *,, T \leq 1$ & $(v)$ & $* *$, , T9Y & $(v)$ & $* *,, 719$ & $(v)$ \\
\hline$* *,, T \leq V$ & $(\wedge)$ & $* *, 01 \leq$ & $(\wedge)$ & $* *$, , vor & $(\wedge)$ & $* *,, \vee \vee 1$ & $(\wedge)$ \\
\hline$* *, 701$ & (9) & $* *, 9 Y_{1}$ & (9) & $* *, 09$. & (9) & $* *, 0,7$ & (9) \\
\hline$* *, 9 \vee \leq$ & $(1 \cdot)$ & $* *$, oro & $(1 \cdot)$ & $* *, 701$ & $(1 \cdot)$ & $* *, \wedge, \uparrow$ & $(1 \cdot)$ \\
\hline$* *, 071$ & $(11)$ & $* *, \pi$, & $(11)$ & $* *$, , vor & $(11)$ & $* *,, \vee \vee \wedge$ & $(11)$ \\
\hline$* *,, 0 \vee \leq$ & $(I Y)$ & $* *, 0 \leqslant r$ & $(I Y)$ & $* *, \Lambda \cdot r$ & $(I Y)$ & $* * .099$ & $(I Y)$ \\
\hline$* *,, 7 \wedge \wedge$ & $(1 T)$ & $* *$, , vor & $(1 T)$ & $* * ., 07 r$ & $(I T)$ & $* *, 719$ & $(I T)$ \\
\hline$* *, 7,9$ & $(1 \leq)$ & $* *, 07 r$ & $(1 \leq)$ & $* *,, T \leq r$ & $(1 \leq)$ & $* *, \wedge \wedge 1$ & $(1 \leq)$ \\
\hline$* *,, 741$ & $(10)$ & $* * ., 01 \mathrm{~V}$ & $(10)$ & ס*, • & $(10)$ & $* *, \vee \vee \wedge 0$ & $(10)$ \\
\hline
\end{tabular}




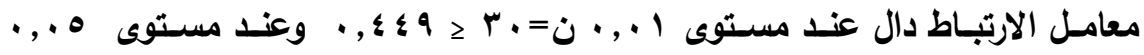
.,, $4 \leqslant q$..

وبتضـح من جدول (7) أن قيم معامالات الارتباط بين درجة كل مفردة

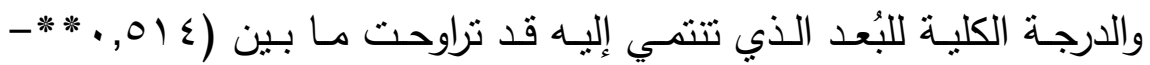
990 , • ***)، وهذه المعامالات كانت دالة عند مستوى ( •., •.

وبذلك تأكدت الباحثة من تمتع مقباس المهارات اللغوبـة الاتصـالبية بدرجة مرتفعة من الثبات على عينة التقنين للبحث الحالي.

ثانياً: مقياس مستوى الوعي المورفولوجي لأطفال مـا قبل المدرسـة ذوي صعوبات التعلم المصور:

مبررات إعداد مقياس الـوعي المورفولـوجي المصسور لقيـاس مستوى

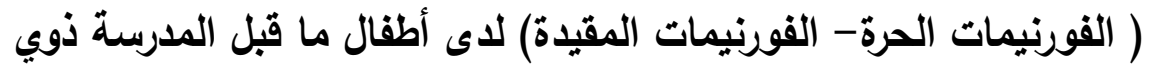
صعوباث التعلم:

o تيسير إجراءات قياس مستوى الوعي المورفولوجي ( الفورنيمات الحرة-

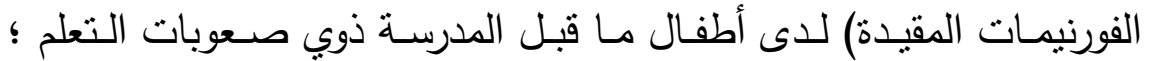
حيث أنسه من خـلال هذا المقياس يُقاس كل مجـالٍ من المجالين السـابقين

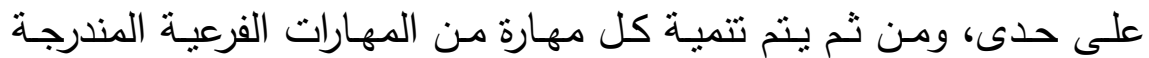
تحتها عند الطفل ذوي صعوبات التعلم.

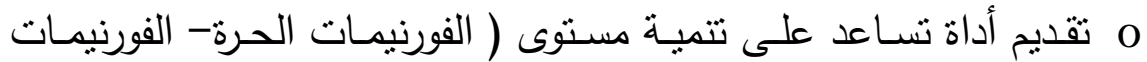
المقيدة) لدى أطفال ما قبل المدرسة ذوي صعوبات التعلم للحد من التعرض فه

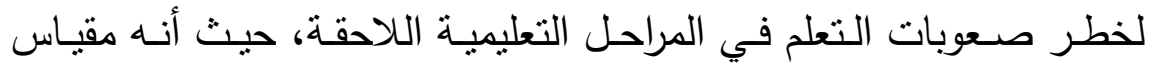
مصـور يناســب المسـتوى العدري والعقلِي لأطفـال مـا قبـل المدرسـة ذوي

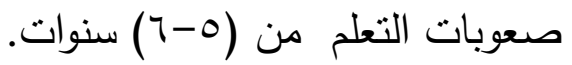




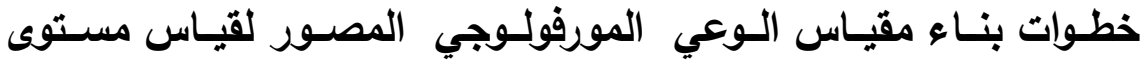

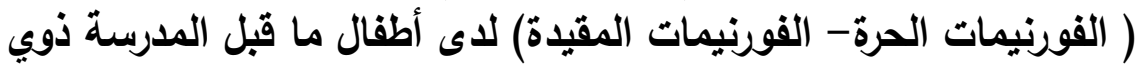

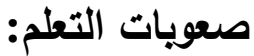

تضمن بناء مقياس مسنتوى الوعي المورفولوجي ( الفورنيمات الحرة-

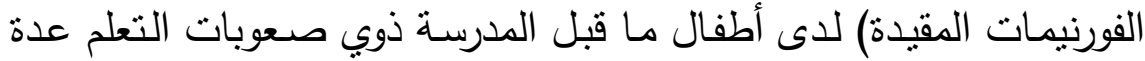
خطوات يمكن إجمالها فيما يأتي:

• استقراء التراث النظري والاطلاع على بعض المقاييس السابقة.

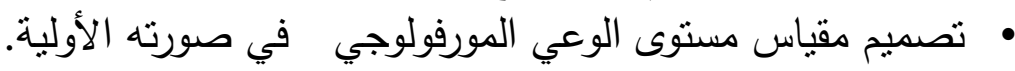

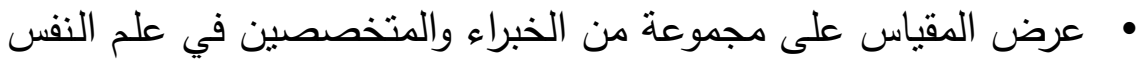
ورياض الأطفال والتربية الخاصة لتحكيمه. • • إعداد المقياس في صورته النهائية. • الخصائص السيكومنرية للمقياس. وفيما يلي عرض تقصيلي لهذه الخطوات:

- استقراء التراث النظري والاطلاع على بعض المقاييس السابقة :

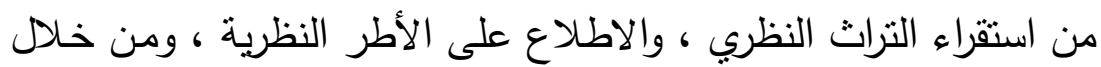

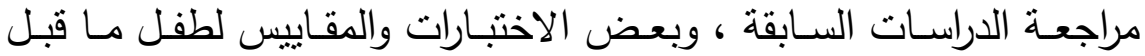

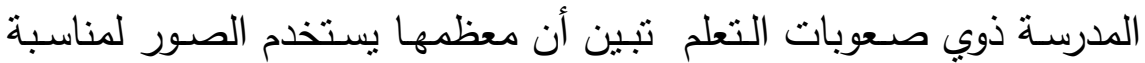

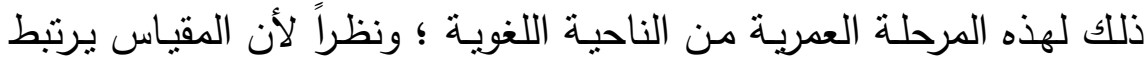

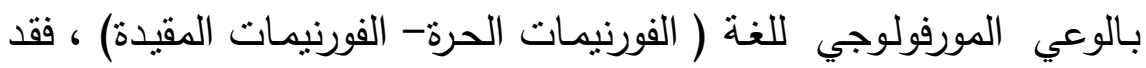

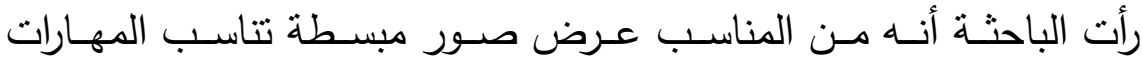

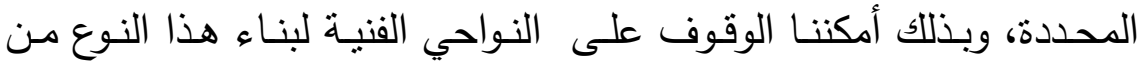


المقاييس لتتحقـق الفائدة المرجـوة منهـا ، و كذلك تسـهيل مهمـة البـاحثين الآخرين ليستقبدوا منها في أبحاثهم القادمة.

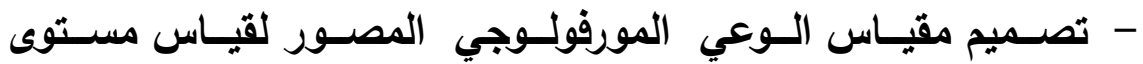
( الفورنيمات الحرة- الفورنيمات المقيدة) لاى أطفال ما قبل المدرسة ذوي صعويات التعلم في صورته الأولية:

تم بنـاء مقياس الوعي المورفولوجي للغـة لأطفال مـا قبـل المدرسـة ذوي

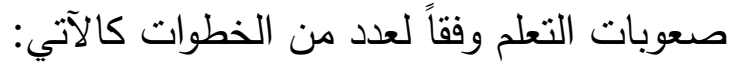
أ.تحديا الهوف من المقياس:

تم تصميم هذا المقياس كوسيلة لتحديد مستوى الوعي المورفولجي للغـة لاى طفل ما قبل المدرسة ذوي صعوبات التعلم من سن (

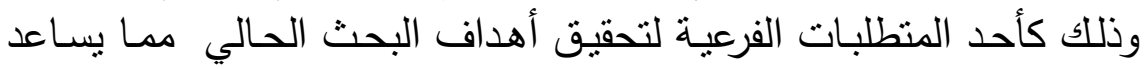

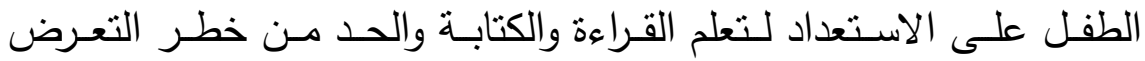
لصعوبات تعلم في المرحل التعليمية اللاحقة. ب.تحديد أبعاد المقياس: يتكون المقياس من (Yr ) مفردةً موزعةً بالتساوي على مجالين كما يلي:

المجال الأول ( المورفيمات الحرة) : ويتكون من أربعة أبعاد فرعية هي:

• أسماء الإشارة : ويضم المفردة ( (-r-r-؟)) والتي تقيس قدرة الطفل اللغوبة الخاصة بمعرفته بأسماء الإشارة.

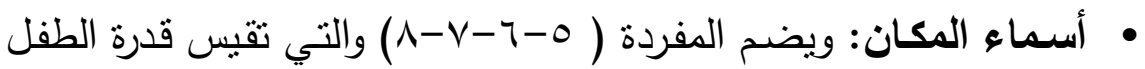
اللغوبة الخاصة بمعرفته بأسماء المكان. 
• أحرف الجر: ويضم المفردة (9- (1-1 - (1) والتي تقيس قدرة الطفل

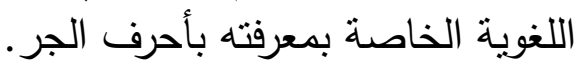

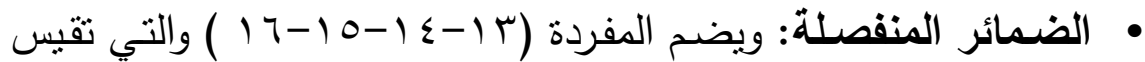
قدرة الطفل اللغوية الخاصة بمعرفته بالضمائر المنفصلة. المجال الثاني ( المورفيمات المقيدة) : ويتكون من أربعة أبعاد فرعية هي:

• التـذكير والتأنيــث : وبضـم المفـردة ( (1-r-r-ع) والتي تقيس قدرة الطفل اللغوبة الخاصة بمعرفته باستخدام التذكير والتأنيث.

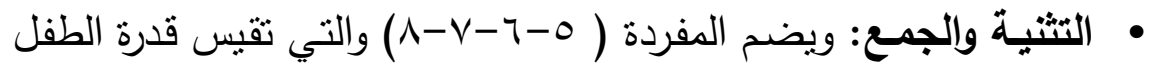

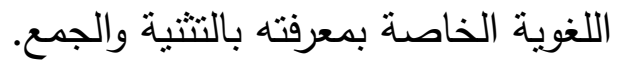

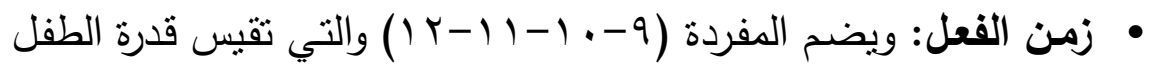
اللغوبة الخاصة بمعرفته بزمن الفعل.

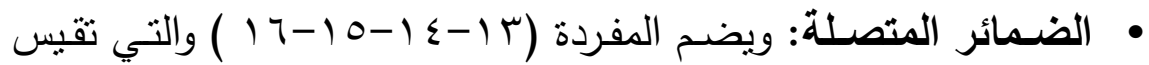
قدرة الطفل اللغوية الخاصة بمعرفته بالضمائر المتصلة. والدرجـة الكليـة للمقيـاس هـي ( بr) حيـث تأخذ ( () للإجابـة الصـحيحة و ( صفر) للإجابة الخاطئة وفق مفتاح التصحيح الذي أعدته الباحثة. ج. صياغة مفردات المقياس:

تم صياغة مفردات المقياس في ضـوء ( الفورنيمات الحرة- الفورنيمات المقيدة) المقترح قياسها وتتميتها ، واختارت الباحثة نوع الاختبار الموضوعي في

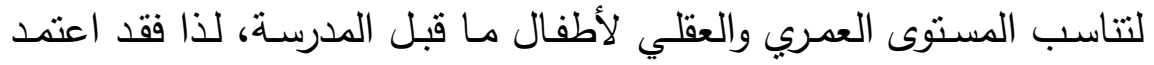
المقياس على مفردات اختباربة مصورة وقد تم صياغة مفردات كل بُعد من الأبعاد السابقة على حدى، وقد روعي الآتي: 
• أن تكون مفردات كل مهارة واضحة ومناسبة لمستوى أطفـال مـا قبـل المدرسة ذوي صعوبات التعلم.

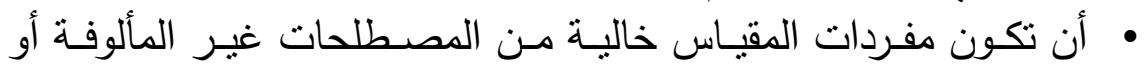

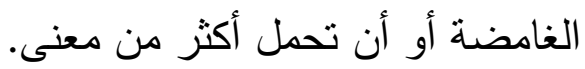
• أن يحدد المطلوب من كل سؤالٍ بوضوح. د. صياغة تعليمات المقياس:

تمت صياغة تعليمات المقياس حيث تعتبر تعليمات المقياس عنصرًا

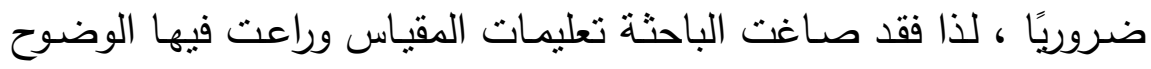

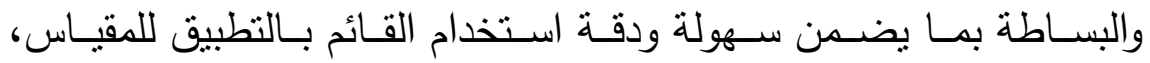
وتضمنت تعليمات المقياس العناصر الآتية : - - خلق جو نفسي قبل تطبيق المقياس وفي أثنائه.

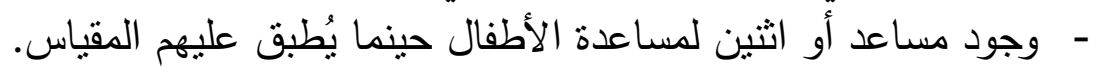

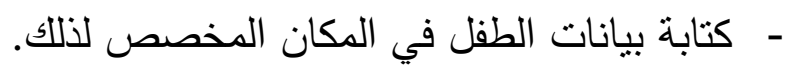

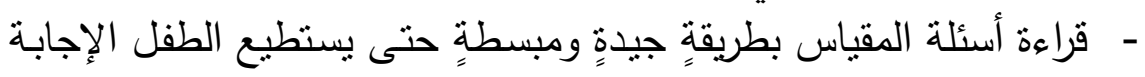

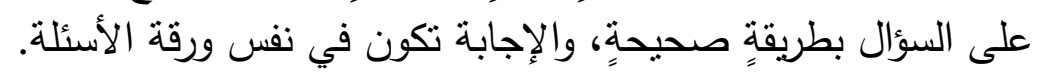

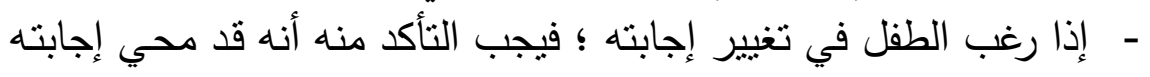
السابقة تمامًا.

هـ عرض المقيـاس على مجموعـة مـن الخبراء والمتخصصين في علـم

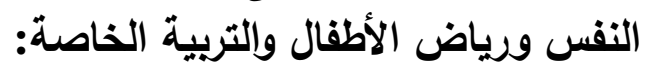

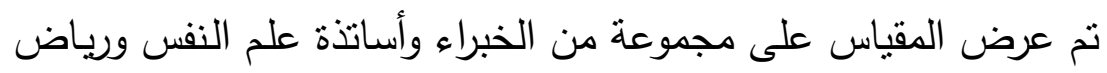

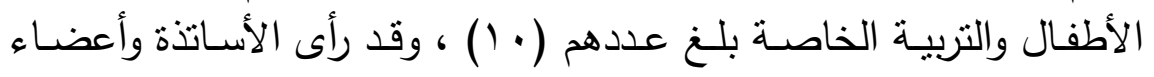


هيئة التذريس والمختصين حذف بعض الأسئلة وتعديل بعض الصور ، وقد قامت الباحثة بإجراء التعديلات التي أوصى بها السادة المحكمون . و.إعداد المقياس في صورته التهائية :

بنـاءًا على آراء السـادة المحكمين أجريت بعض التعديلات اللزمهـة على بعض الفقرات وحذف بعضها، ثم وضع المقياس في صورته النهائية. الخصائص السيكومترية للمقياس: أولا": ثبات المقياس Reliability قامت الباحثة بحساب ثبات المقياس بطربقتين كالتالي: معامل ألفا ( كرونباخ): استخدمت الباحثة (معادلة ألفا كرونباخ) Cronbachs Alpha"a لقياس (ه) مداس مدى ثبات المقياس على عينة استطلاعية مكونة من ( ب ب) طفلاً وطفلةً،

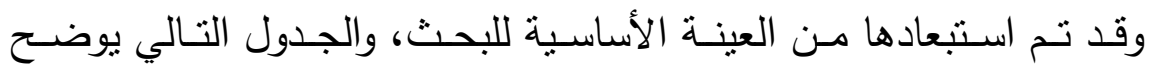
الإجراء الإحصائي.

\section{جدول (V)}

معاملات ثبات مفردات مقياس مستوى الوعي المورفولوجي لطقل ما قبل المدرسة ذوي

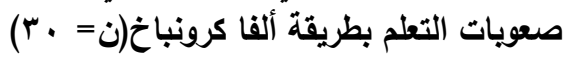

\begin{tabular}{|c|c|c|c|}
\hline كرونباخ ثبات ألفا & الأسئلة & البعد & المجال \\
\hline$*, \wedge \mid \wedge$ & $\varepsilon$ & أسماء الاشارة & \multirow{3}{*}{ المورفيمات } \\
\hline$*,, \wedge Y q$ & $\varepsilon$ & اسماء المكان & \\
\hline$*, q Y$. & $\varepsilon$ & أحرف الجر & \\
\hline
\end{tabular}




\begin{tabular}{|c|c|c|c|}
\hline$*_{., \vee \vee q \wedge}$ & $\varepsilon$ & الضمائر المنفصلة & \\
\hline$*,, \wedge \wedge 1$ & 17 & المورفيمات الحرة & \\
\hline$*, \Lambda Y \varepsilon$ & $\xi$ & التذكير والتأنيث & \multirow{5}{*}{ المورفيمات } \\
\hline$*, \wedge \mid \mu$ & $\varepsilon$ & التنثية والجمع & \\
\hline$*, \wedge \vee$ & $\xi$ & زمن الفعل & \\
\hline$*, 911$ & $\varepsilon$ & الضمائر المتصلة & \\
\hline$* \cdot, 9 \ldots$ & 17 & المورفيمات المقيدة & \\
\hline$* ., 9 \vee 1$ & Mr & للمقياس & الثبات \\
\hline
\end{tabular}

ويتضح من الجدول أعلاه أن معامل الثبات العام لأبعاد المقياس مرتفع حيث بلغ (9V), • (*) لاجمالى فقرات المقياس الاثثان وثثلاثون ، فيما تراوح

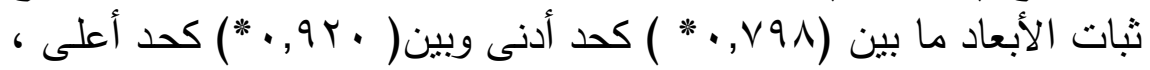
وهذا يدل على أن المقياس يتمتع بدرجـة عاليـة من الثبات يمكن الاعتمـاد عليه في التطبيق الميداني للبحث بحسب مقياس نانلي والذي اعتمد • V, • كحد أدنى للثبات. طريقة إعادة الاختبار :

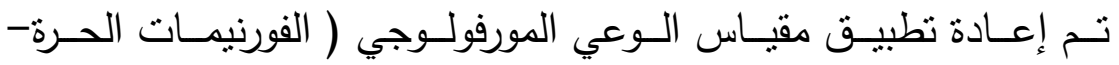
الفورنيمات المقيدة ) على عينة التقنين بفاصلِ زمني قدره أسبوعين ، وتم 
حساب معامل الارتباط بين درجات الأطفال في التطبيقين ، وجاءت جميعها دالة عند مستوى (1 ·, · ) والجدول التالي يوضح ذللك.

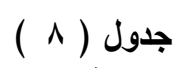

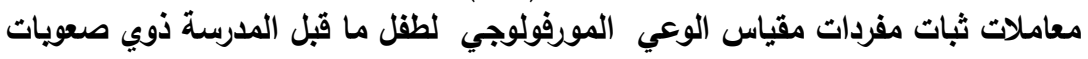
التعلم بطريقة إعادة الاختبار

\begin{tabular}{|c|c|c|c|}
\hline الدلالة الإحصائية & معامل الارتباط & الفرعية & لالمى أطفاس المولو الوعي \\
\hline$\cdot, \cdot 1$ & $\cdot, O \wedge r$ & أسماء الإشارة & \multirow[t]{4}{*}{ المورفيمات الحرة } \\
\hline$\cdot, \cdot 1$ & $\cdot, 711$ & أسماء المكان & \\
\hline$\cdot, \cdot 1$ & $\cdot, V q r$ & أحرف الجر & \\
\hline$\cdot, \cdot 1$ &., 099 & الضمائر & \\
\hline$\cdot, \cdot 1$ & $*$., qYo & والتأنكيث & \multirow[t]{4}{*}{ المورفيمات المقيدة } \\
\hline$\cdot, \cdot 1$ & *, , VYr & التثنية والجمع & \\
\hline$\cdot, \cdot 1$ & $* ., 799$ & زمن الفعل & \\
\hline$\cdot, \cdot 1$ & $*,, \vee 04$ & الضمائر & \\
\hline$\cdot, \cdot 1$ & $*, \wedge q r$ & \multicolumn{2}{|c|}{ الدرجة الكلية للمقياس } \\
\hline
\end{tabular}




\section{: Validity ثانياً :صدق المقياس}

لتحديد مدى صدق محتوى المقياس استخدمت الباحثة في بحثها طريقتين

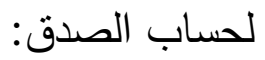

(1) صدق المقارنات الطرفية:

تم حساب الصدق الكلي لمقياس الوعي المورفولوجي لاى عينة التقنين

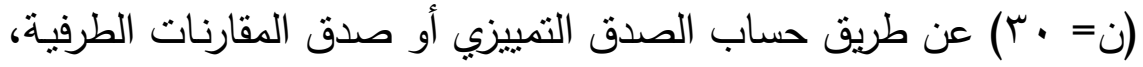

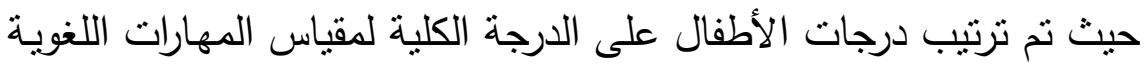

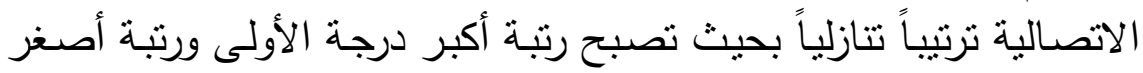

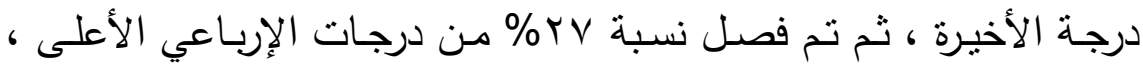

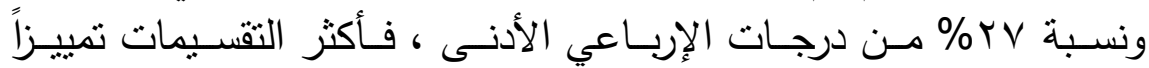

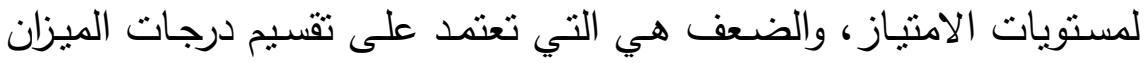

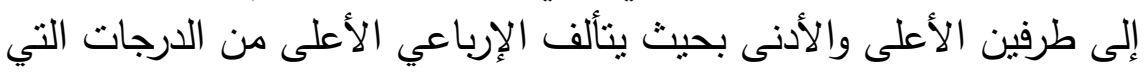

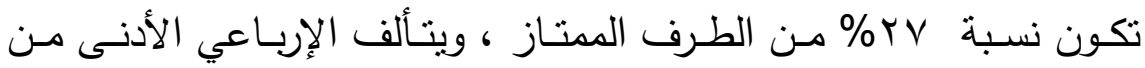

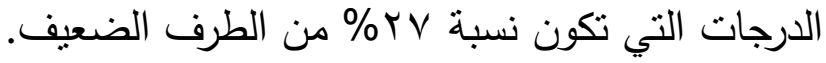

وتم استخدام اختبار (ت) لحسباب دلالة الفروق بين الفئة العليا والفئة

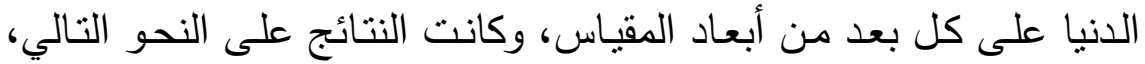
كما هي موضحة بالجدول التالي. 


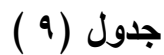

نتائج اختبار "ت" لاراسة الفروق بين متوسطات المجموعة الطرفية لمقياس الوعي المورفولوجي لاى العينة الاستطلاعية مئوسنة المبوعة الطرف

\begin{tabular}{|c|c|c|c|c|c|c|c|c|}
\hline \multirow{2}{*}{ الاحصائية } & \multirow[b]{2}{*}{ قيمة (ت) } & \multicolumn{3}{|c|}{ الإرباعي الأدنى } & \multicolumn{3}{|c|}{ الإرباعي الأعلى } & المتغير \\
\hline & & الإنحراف & المتوسط & ن & الانحراف & المتوسط & ن & مقياس \\
\hline$\bullet, \cdots$ & $r, r \leq \tau$ & $\cdot, \cdots$ & $r V, T r$ & $\Lambda$ & $\varepsilon T r_{.}$ & $17, \ldots$ & $\wedge$ & للمورفولوجي \\
\hline
\end{tabular}

ويتضــح مـن الجـدول السـابق وجـود فـرق دال إحصــائياً بمسـتوى دلالــة

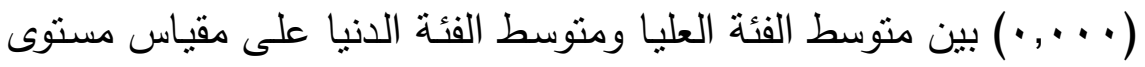
الوعي المورفولوجي لصالح منوسط الفئة العليا لدى العينة الكلية ، وهذا

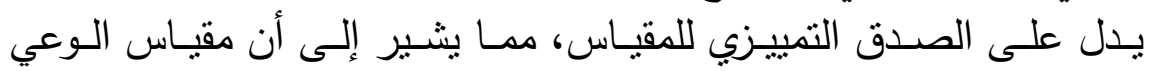
المورفولوجي لأطفال ما قبل المدرسة ذوي صعوبات التعلم لديه قدرة مرتفعة على التمبيز بين مرتفعي ومنخفضي القدرات المورفولوجية للغة.

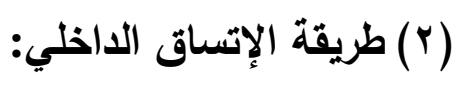

قامت الباحثة بحساب الارتباطات الداخلية للأبعاد الثمانبة للمقياس كما تم حساب ارتباطات الأبعاد الأربعة بالدرجة الكلية للمقياس والجدول التالي يوضنح ذللك. 


\section{جدول (·) (1)}

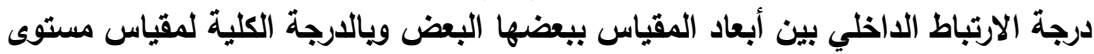

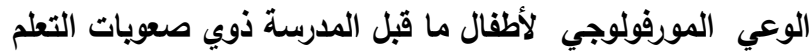

$$
(r \cdot)
$$

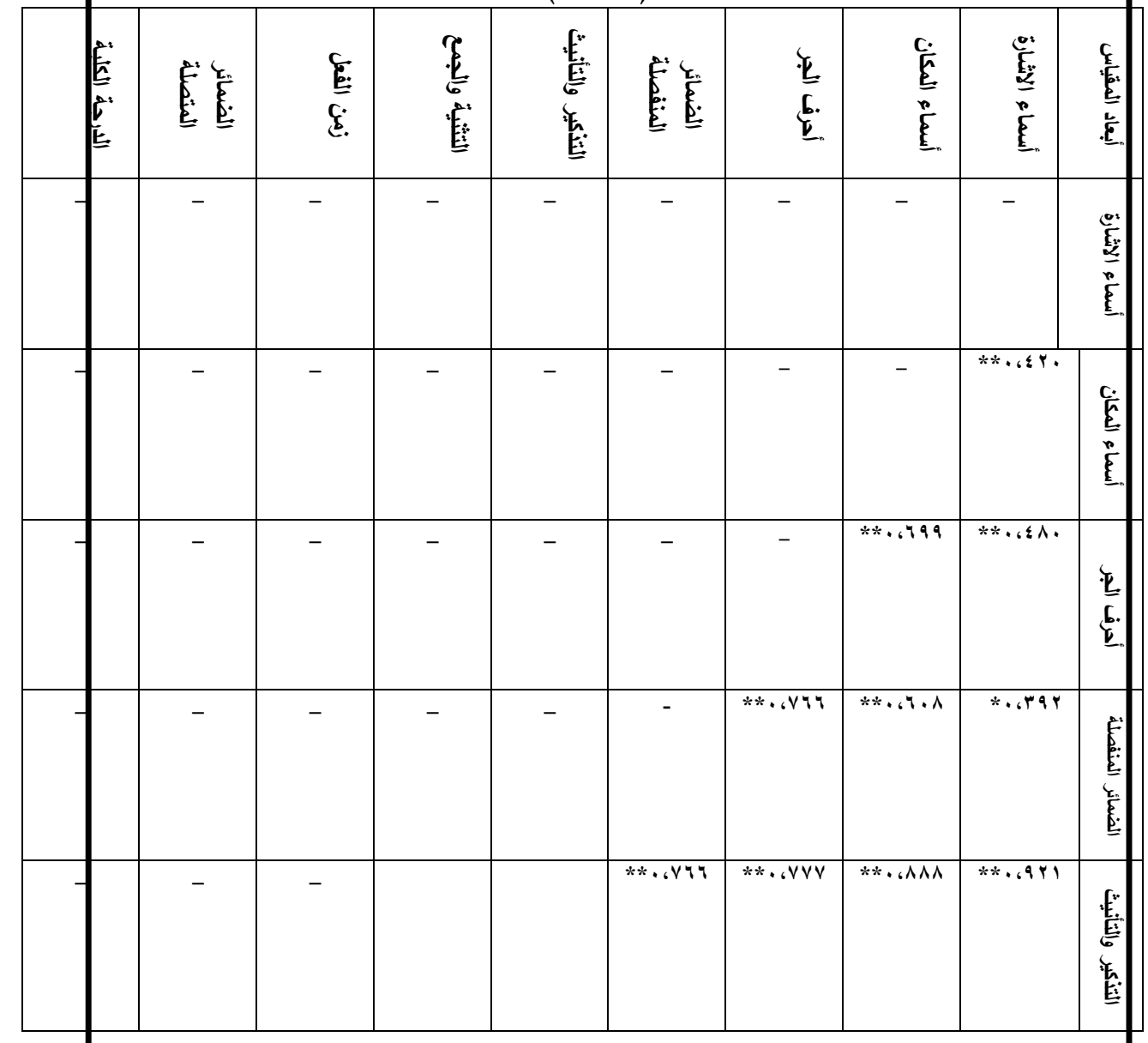




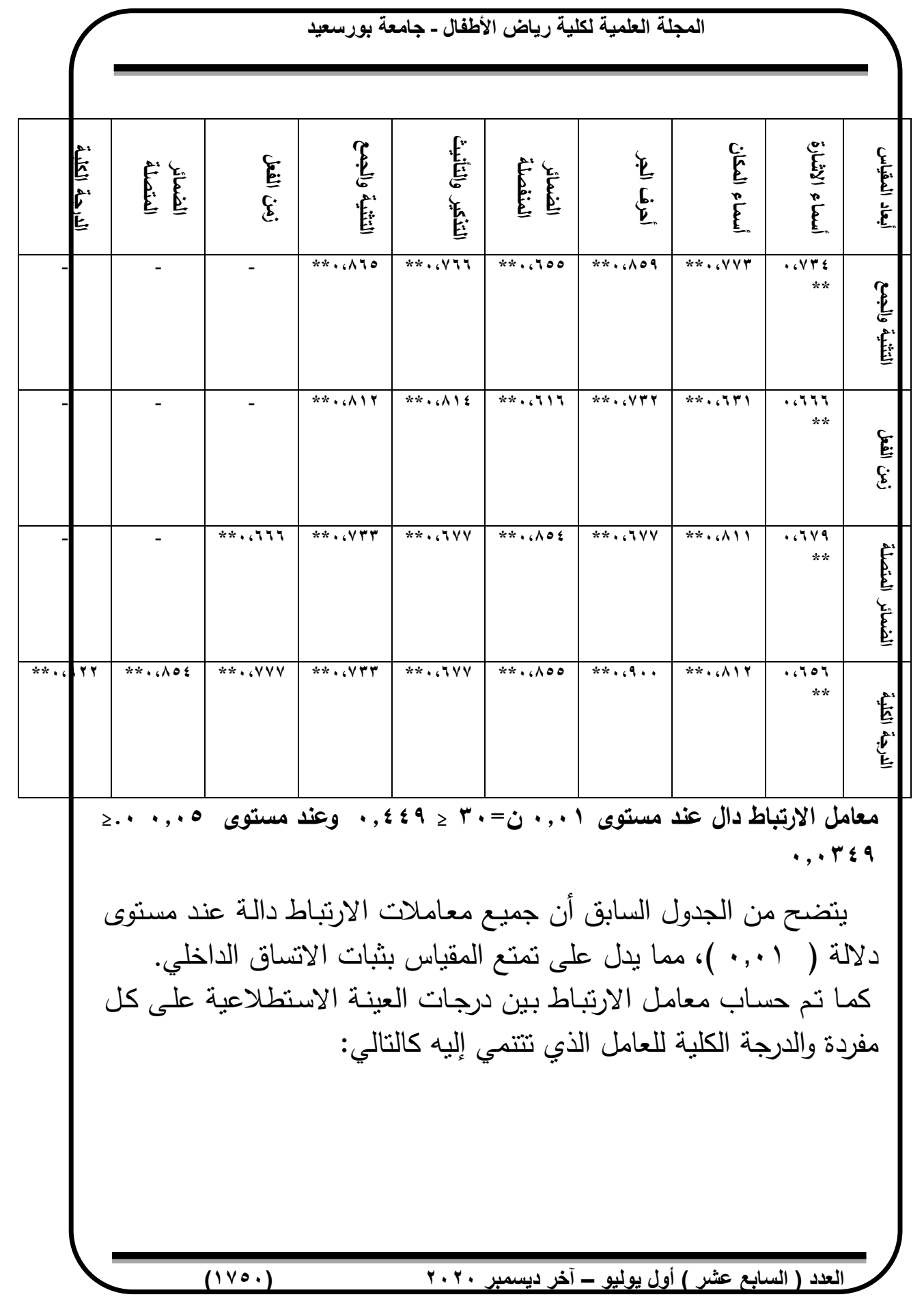




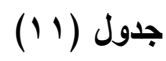

معاملات الارتباط بين درجة كل مفردة والدرجة الكلية للبعد الذي تنتمي إليه

\begin{tabular}{|c|c|c|c|c|c|c|c|}
\hline \multicolumn{2}{|c|}{ الضمائر المنفصلة } & \multicolumn{2}{|c|}{ أحرف الجر } & \multicolumn{2}{|c|}{ أسماء المكان } & \multicolumn{2}{|c|}{ أسماء الاشارة } \\
\hline معامــــــل & المفردة & معامـــــل & المفردة & 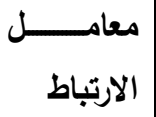 & المفردة & 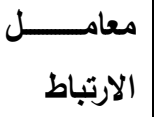 & المفردة \\
\hline$* *, 7,7$ & ( & $*, 001$ & (9) & $* *, 77 \mathrm{~V}$ & $(0)$ & $* *, 011$ & (1) \\
\hline$r \leqslant Y$ & 161 & $\leqslant$ & 8 & 7 & (1) & ט & $(r)$ \\
\hline TVT & $(10)$ & & 1 & 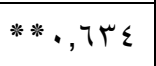 & 1 & $*, \vee \vee \vee \varepsilon$ & $(r)$ \\
\hline **, ๆ YV & $(17)$ & $*, 70 \mathrm{~V}$ & & r & 1 & $\cdot, T Y \leq$ & $(\varepsilon)$ \\
\hline \multicolumn{2}{|c|}{ الضمائر المتصلة } & \multicolumn{2}{|c|}{ زمن الفعل } & \multicolumn{2}{|c|}{ التثية والجمع } & \multicolumn{2}{|c|}{ التنكير والتأنيث } \\
\hline الارتباط معامل & المفردة & معامـــــل & ردة & 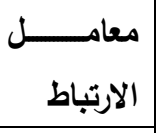 & & معامـــــل & المفر \\
\hline$* *,, 7,7$ & $(1+)$ & $* *, 001$ & (9) & $* *, 7 T V$ & $(0)$ & $* *, 0 \wedge 1$ & (1) \\
\hline$* *, r \leq r$ & $(1 \leq)$ & $, 7) \leq$ & $(1 \cdot)$ & $* *, 717$ & (7) & **, מ ט & $(r)$ \\
\hline$* *, T V T$ & $(10)$ & $\cdot, 7 \pi \leq$ & (1') & $* *, 7 \pi \leq$ & $(\mathrm{V})$ & $* *,, \vee \vee \leq$ & $(r)$ \\
\hline$* *, 77 \mathrm{~V}$ & $(17)$ & $* *, 70 \mathrm{~V}$ & $(I Y)$ & $* *, 704$ & $(\wedge)$ & $* *, 7 r \varepsilon$ & $(\varepsilon)$ \\
\hline
\end{tabular}

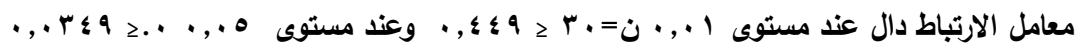

ويتضح من جدول (1) أن قيم معاملات الارتباط بين درجة كل مفردة

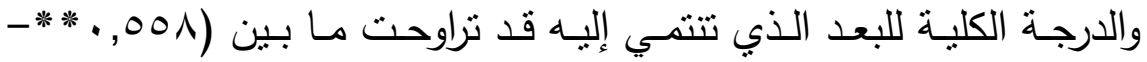

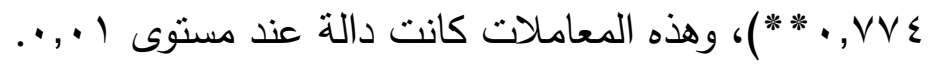

وبذلك تأكدت الباحثة من تمتع مقياس الوعي المورفولوجي للغـة بدرجة مرتفعة من الثبات على عينة التقنين للبحث الحالي. 
ثالثـاً: برنـامج إسـتراتيجية التعلم المسـتند إلى الـدماغ لتنميـة المهـارات اللغوية الاتصالية لاى أطفال ما قبل المدرسة ذوي صعويات التعلم: (إعداد/ الباحثة)

قامت الباحثة ببناء برنامج قائم على نظرية إستراتيجية التعلم المستتد إلى

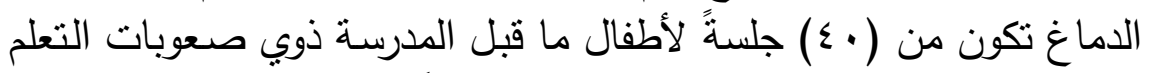
من ( 0-7 ) سنوات ، وقد تم بناء البرنامج وفقاً لمجموعة من الأسس وعدد من الخطوات كالتالي : من أسس بناء البرنامج:

اعتمدت الباحثة على مجموعة من الأسس لبناء البرنامج وهي كالتالي: • أسس مرتبطة بخصـائص واحتياجـات وميول أطفـال مـا قبل المدرسـة

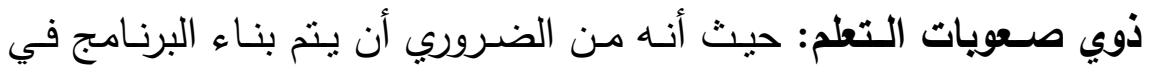
ضوء الخصـائص العقلية والجسمية والحركية والاجتماعية والانفعالية، وفي مئي ضوء الميول والاحتياجات العقلية لأطفال مـا قبل المدرسـة ذوي صـعوبات واجيه التعلم.

• أسس مرتبطة بنظريات تعليم وتعلم أطفال ما قبل المدرسة: حيـث روعـي في بنـاء البرنـامج نظربـات تعليم وتعلم أطفال مـا قبـل المدرسة وما تتاولته فيما يتعلق بنظرية إستراتيجية التعلم المستتد إلى الدماغ وتتمية المهارات اللغوبة الاتصالية (الاستماع والتحدث والقراءة والكتابة).

• أسس تتمية المهارات اللغوية الاتصالية: روعـي في بنـاء البرنـامج طبيعـة مهـارات الاسـتماع والتحـدث والقـراءة والكتابة وأساليب تتمية كل منهما ومعايير الأنشطة التي تهدف إلى تتميتها، وقد تم بناء البرنامج في ضوء مجموعة أنشطة متنوعة. 


\section{خطوات بناء البرنامج:}

تم بناء البرنامج بالخطوات التالية: ا -تحديد الأهداف العامة والفرعية للبرنامج:

يمثل تحديد الأهداف العامة purposes والأهداف طويلة المدى ضرورة

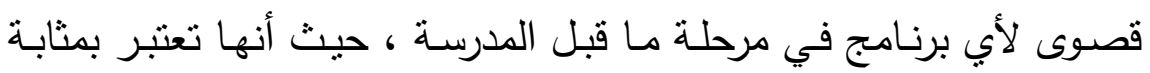

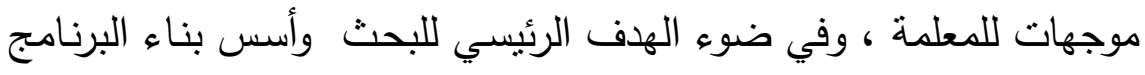

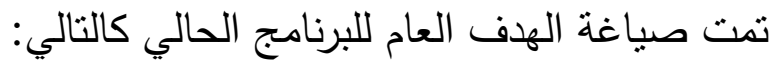

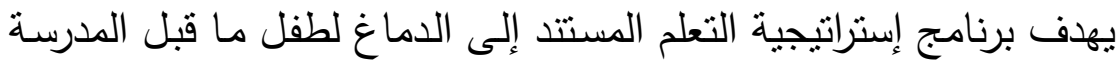

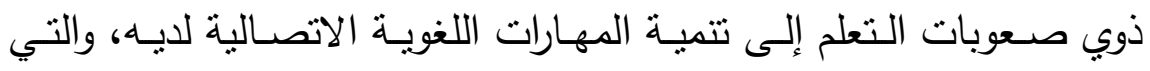

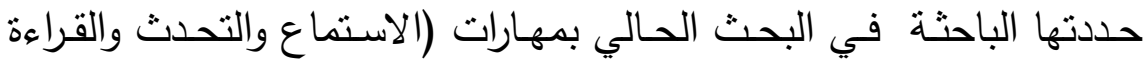
والكتابة)، وكذلك التعرف على فلى علاقته بتحسين مستوى الوعي المورفولوجي للغة.

ولتحقيق ذلك الهدف هناك عدة أهداف عامـة فرعيـة متمثلة في تتميـة المهارات اللغوية الاتصالية (الاستماع والتحدث والثة القراءة والكتابة) وهي :

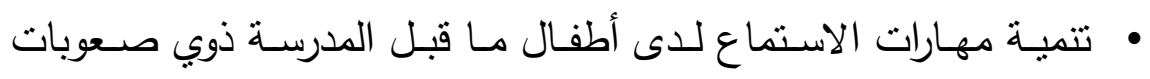
التعلم. • تمية مهارات التحدث لدى أطفال ما قبل المدرسة ذوي صعوبات التعلم.

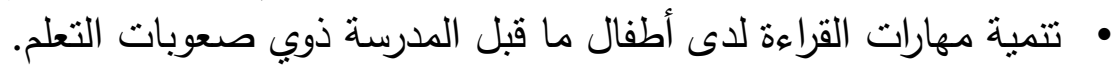

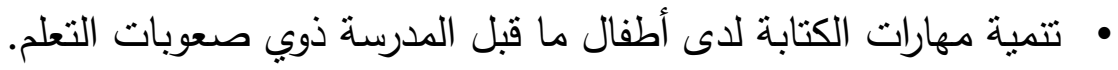

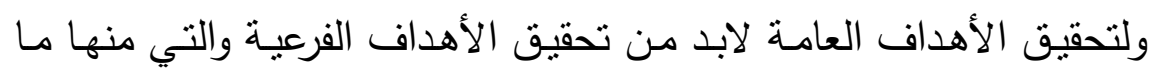
يأتي: - ت تتمية قدرة الطفل على التمييز السمعي. 
- ت تتمية قدرة الطفل على الترتيب والتسلسل السمعي.

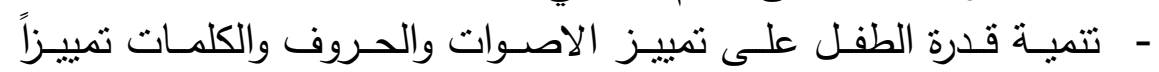
- ت تقمية قدرة الطفل على قلى الفهم السمعي. - ت تتميـة قدرة الطفـل على التعبيـر وصـياغة الجمـل الصـحيحة والنطـق - ت تتمبـة قدرة الطفل على نطـق وإخـراج الحـروف العربيـة مـن مخارجها الصحيحة. - ت تمية قدرة الطفل على كتابة الكلمات بطربقة صحيحة.

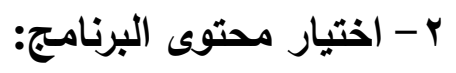
تم اختيار محتوى البرنامج في ضوء المعايير التالية: - أن يكون ملائماً للأهداف الإجرائية.

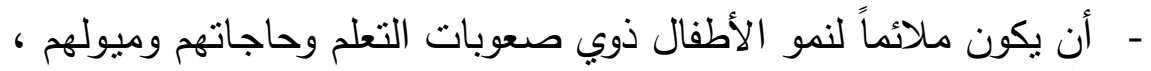

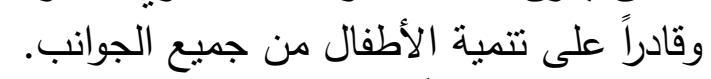

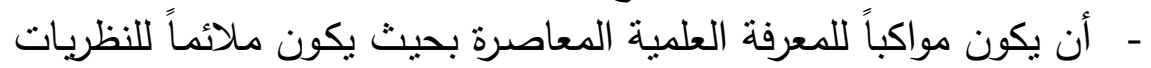
العلمبة الحديثة والتقدم التكنولوجي السربع. ب-بناء أنشطة البرنامج:

في ضوء الأهداف التي يسعى البرنامج لتحقيقها تم تحديد ( . ب) نشاطاً

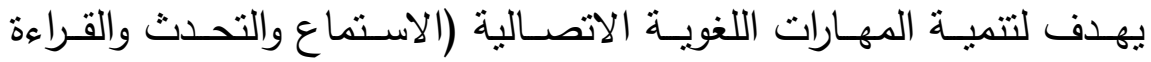

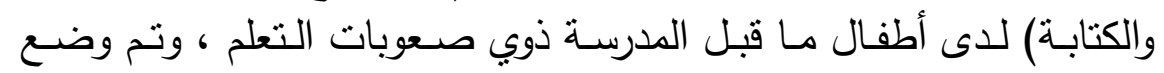

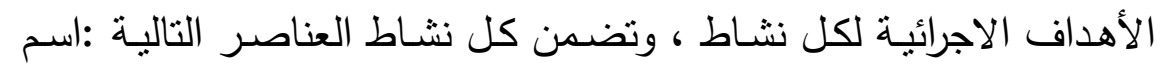


النشـاط-زمن النشـاط- الأهداف الإجرائية - المواد المستخدمة - المهارة

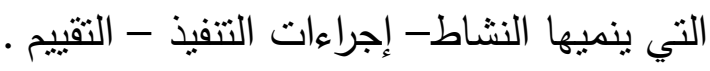
ع - إعداد البرنامج في صورته الأولية :

تم تصميم هذا البرنامج بعد اطلاع الباحثة على التراث النظري الخاص

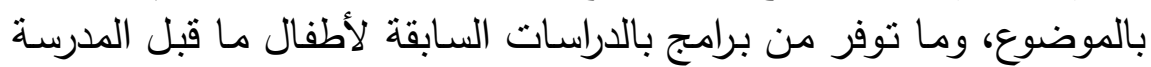
ذوي صعوبات التعلم.

\section{•-إعداد المواد والموارد المستخدمة:}

ونتشمل كافة المواد والمـوارد المستخدمة في تتفيذ الأنشطة بهدف تعمبق استفادة الأطفال من محتوى البرنـامج المستهدف تطبيقه ، وقد تم الإعداد

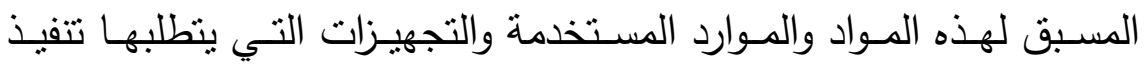
البرنامج، واعداد تلك المواد والموارد المستخدمة قبل التففيذ لضمان الاقتصاد

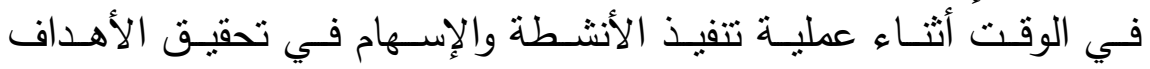
المرجوة ، لذا فقد تم تحديد المواد والمـوارد المسـتخدمة والتي تمثلت في

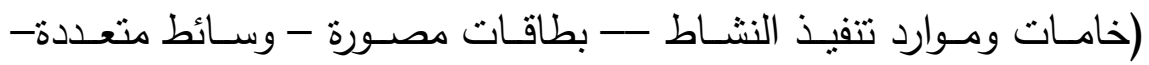

$$
\text { قصص مصورة - آلات موسيقية ). }
$$

$$
\text { ૧-إعداد أدوات التقويم: }
$$

يعتبر التقوبم من الخطوات الأساسية التي يجب أن تؤخذ بعين الاعتبار عند تصميم أي برنامج؛ لأنه يوضح نتائج التعلم الذي حققه الطفل و الفرق لأح

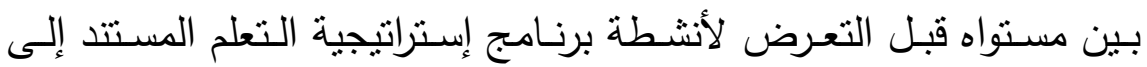
الدماغ وبعده و تظهر أغراض تقويم البرنامج الحالي فيما بلي : 


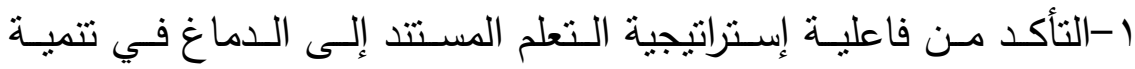
المهارات اللغوية الاتصـالية ( الاستماع- التحدث- القراءة - الكتابة ) لدى الئ أطفال ما قبل المدرسة ذوي صعوبات التعلم.

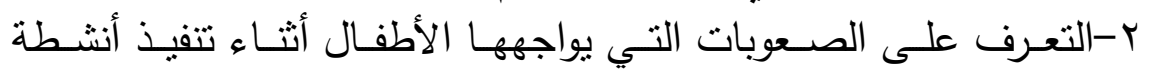

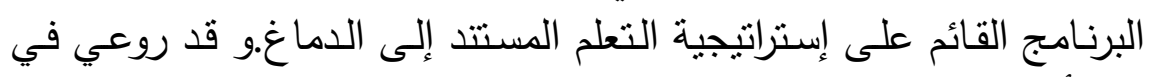
بناء أدوات تقويم البرنامج التتوع والاستمرارية.

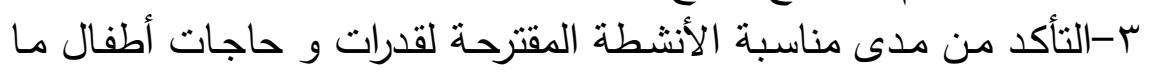
قبل المدرسة ذوي صعوبات التعلم.

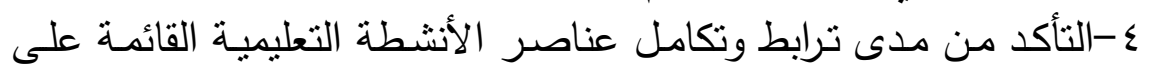
إستراتيجية التعلم المستتد إلى الدماغ بالبرنامج. ويستخدم في البرنامج ثلاث أساليب للتقويم هي:

ا-التقـويم القبلـي: وهـو يـتم قبـل تطبيـق البرنـامج وذلك بتطبيـق مقيـاس

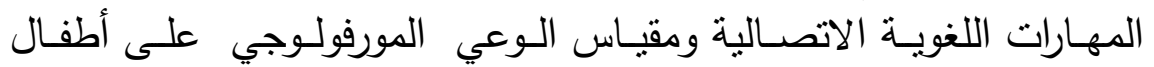
المجموعة التجريبية، وتسجيل درجات الأطفال على المقياسين بهدف تحديد

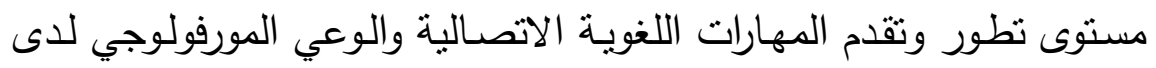
الأطفال . مأنوى نطور

r -التقويم البنائي: و يتم فيه تقويم الطفل بشكل مستمر منذ بداية البرنامج

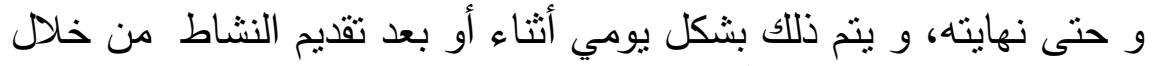
بطاقات تقدم للأطفال يومياً كتطبيق على النشاط، و يمكن تسميتها (بالتقويم

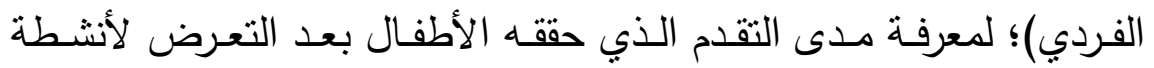

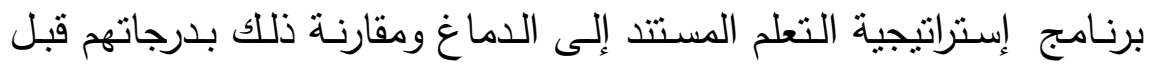
التعرض للبرنامج. 
r-التقويم البعدي: و يستخدم هذا النوع من التقويم بعد انتهاء من تطبيق

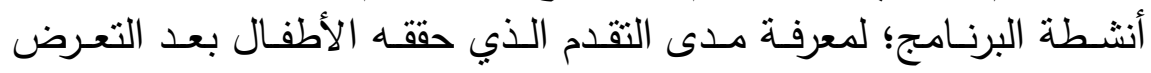
لأنشطة البرنامج ومقارنة ذلك بدرجاتهم قبل التعرض للبرنامج، ويتم بإعادة تطبيـق مقبـاس المهـارات اللغوبـة الاتصـالبة ومقيـاس الـوعي المورفولـوجي لأطفال ما قبل المدرسة ذوي صعوبات التعلم. V-إعداد البرنامج في صورته النهائية:

حيثت أنه في ضـوء الخطوات السـابقة أصبح البرنـامج معداً في صـورته النهائية النه

\section{نتائج البحث: :}

• القرض الأول ونتائجه : ينص الفرض الأول على أنه:

"توجد علاقة ارتباطية بين درجات أطقال المجموعة التجريبية على كلٍ

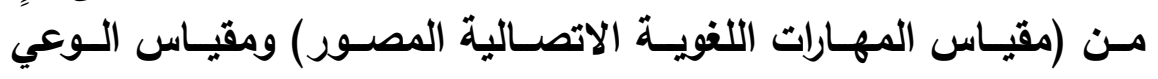
المورفولوجي.

وللتحقق من صحة هذا الفرض قامت الباحثة بحساب دلالة الارتباط بين درجـات أطفال المجموعـة التجريبيـة على مجموع درجات مقيـاس المهارات

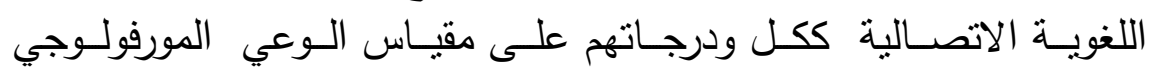
باستخدام معامل ارتباط بيرسون person correlation وكانت النتائج

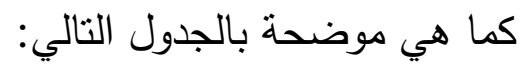




\section{جدول (Y )}

دلالة الارتباط بين كلٍ من ( مقياس المهارات اللغوية الاتصالية ومقياس الوعي

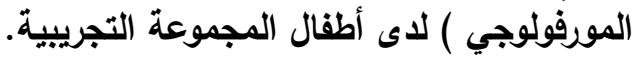

\begin{tabular}{|c|c|c|c|}
\hline الالالة الإحصائية & قيمة معامل ارتباط بيرسون & 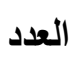 & المجموعة \\
\hline دالة عند مستوى I +. . & .691 & 10 & التجريبية \\
\hline
\end{tabular}

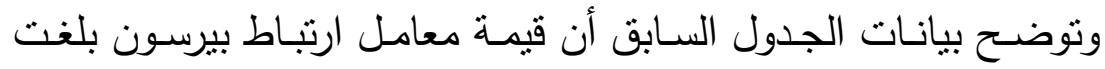
91، • وهي دالة إحصائية عند مستوى I +, • وعلى ذلك فقد تحققت صحة الفرض الأول للبحث الحالي.

• الفرض الثاني ونتائجه: ينص الفرض الثاني على أنه:

"توجـ فروق ذات دلالـة إحصـائية بـين متوسـطي رتب درجـات أطفال المجموعة التجريبية (عينة البحث) على مقياس المهارات اللغوية الاتصسالية

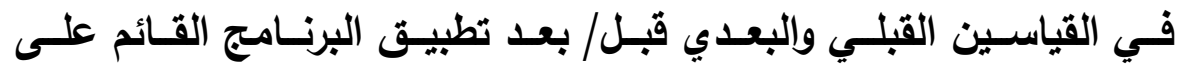

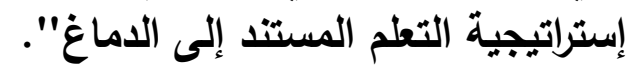

وللتحقـق مـن صـحة هـذا الفـرض قامــت الباحثـة باسـتخدام اختبـار ويلكوكسون للمجموعات المرتبطة ، لإيجاد دلالة الفروق بين منوسطي رتب

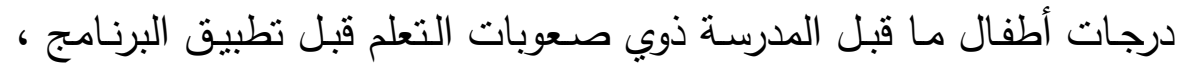
ومتوسطي رتب درجات نفس المجموعة بعد تطبيق البرنامج كما هو موضـح بالجدول التالي. 


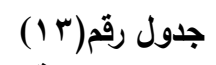

قيمة (Z) ودلالتها الإحصائية بالنسبة للارجات الكلية على مقياس المهارات اللغوية الاتصالية

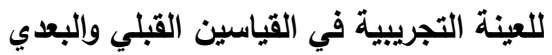

\begin{tabular}{|c|c|c|c|c|c|c|}
\hline \multirow[b]{2}{*}{ الاحصائية دلائها } & \multirow[b]{2}{*}{ قيمة z } & \multicolumn{2}{|c|}{ القياس القبلي / البعدي } & \multirow{2}{*}{ العدد } & \multirow{2}{*}{ رتب متغير مقياس المهارات } & \multirow[t]{2}{*}{ الأبعاد } \\
\hline & & مجموع & متوبط & & & \\
\hline \multirow[t]{4}{*}{ 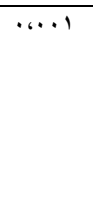 } & \multirow{4}{*}{$r, \varepsilon r}$. & 0,00 & 0,00 & 0,0 & الرتب السالبة & \multirow{4}{*}{ الاستماع } \\
\hline & & 120 & 8 & 15 & الرتب الموجبة & \\
\hline & & & & 0 & الرتب المحايدة & \\
\hline & & & & 15 & المجموع الكلي & \\
\hline \multirow[t]{4}{*}{$\cdots+1$} & \multirow{4}{*}{$\begin{array}{c}- \\
\mu_{6} \leq \leq 9\end{array}$} & 0,00 & 0,00 & 0,0 & الرتب السالبة & \multirow{4}{*}{ مهارات } \\
\hline & & 120 & 8 & 15 & الرتب الموجبة & \\
\hline & & & & $\mathbf{0}$ & الرتب المحايدة & \\
\hline & & & & 15 & المجموع الكلي & \\
\hline \multirow[t]{4}{*}{$\ldots 1$} & \multirow{4}{*}{$\begin{array}{c}- \\
r, \leqslant Y 1\end{array}$} & 0,00 & 0,00 & 0,0 & الرتب السالبة & \multirow{4}{*}{ مهارات } \\
\hline & & 120 & 8 & 15 & الرتب الموجبة & \\
\hline & & & & $\mathbf{0}$ & الرتب المحايدة & \\
\hline & & & & 15 & المجموع الكلي & \\
\hline \multirow[t]{4}{*}{$\cdots+1$} & \multirow{4}{*}{ 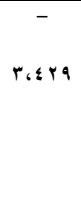 } & 0,00 & 0,00 & 0,0 & الرتب السالبة & \multirow{4}{*}{ مهارات } \\
\hline & & 120 & 8 & 15 & الرتب الموجبة & \\
\hline & & & & $\mathbf{0}$ & الرتب المحايدة & \\
\hline & & & & 15 & المجموع الكلي & \\
\hline \multirow[t]{4}{*}{$\cdots 1$} & \multirow{4}{*}{$\begin{array}{c}- \\
\text { r, , }\end{array}$} & 0,00 & 0,00 & 0,0 & الرتب السالبة & \multirow[t]{4}{*}{ الدرجة الكلية } \\
\hline & & 105 & 7.50 & 15 & الرتب الموجبة & \\
\hline & & & & 0 & الرتب المحايدة & \\
\hline & & & & 15 & المجموع الكلي & \\
\hline
\end{tabular}




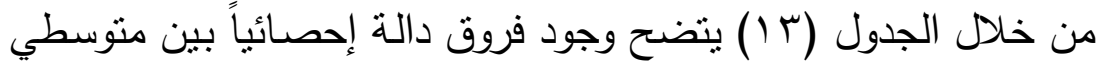
رتب درجات المجموعة التجريبية في القياسين القبلي والبعدي لدئ فئس أطفال

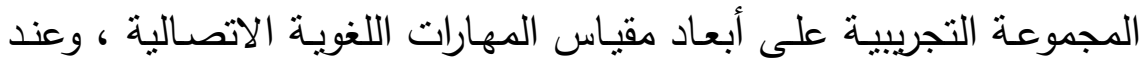

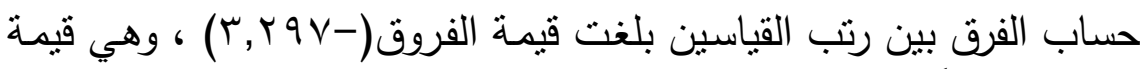

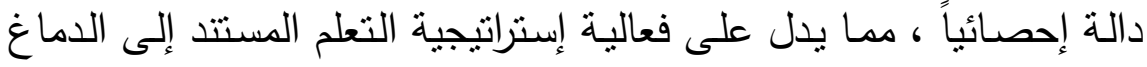

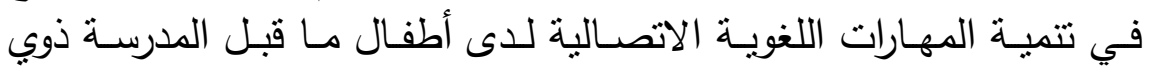

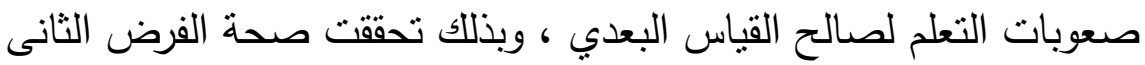
للبحث .

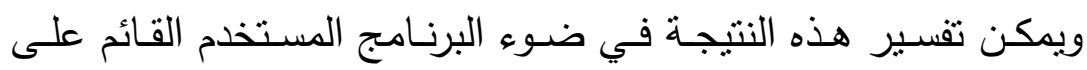

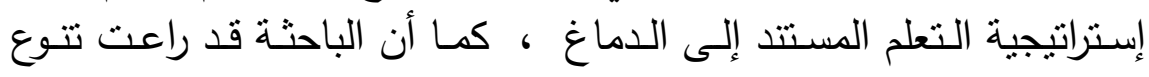

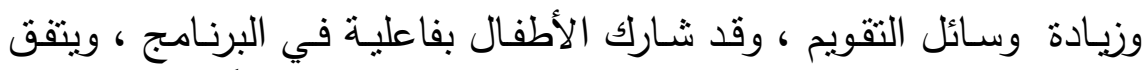

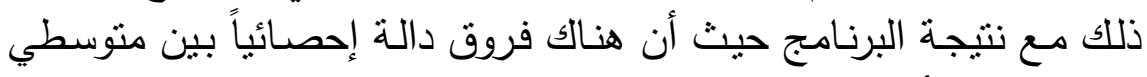

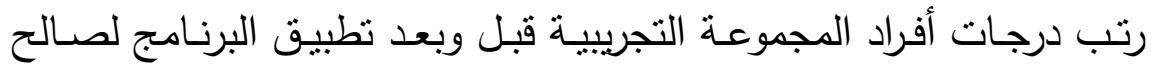
التطبيق البعدي.

ومما سبق نجد أن البرنامج له تأثنر إيجابي وفعال في مساعدة أطفال ما

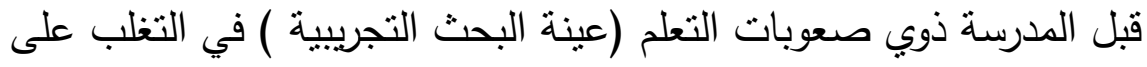

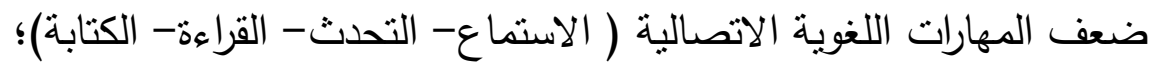
وذلك للحد من خطر صعوبات التعلم في المراحل التعليمية اللاحقة.

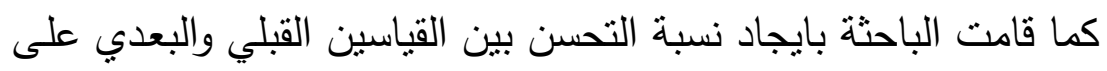

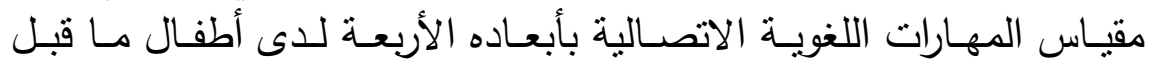

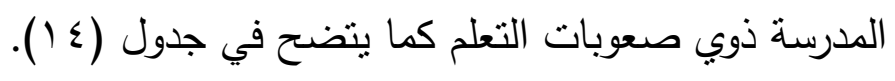




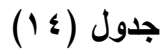

نسبة التحسن بين القياسين القبلي والبعدي على مقياس المهارات اللغوية الاتصالية ككل

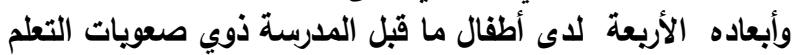

\begin{tabular}{|c|c|c|c|}
\hline التحبة & متوسط القياس & متوسط القياس & أبعاد مقياس المهارات \\
\hline$\% 39.10$ & 11.933 & 6.0667 & البعد الأول: الاستماع \\
\hline$\% 34.66$ & 11.866 & 6.666 & البعد الثانى: التحدث \\
\hline$\% 37.77$ & 11.666 & 6.000 & البعد الثالث: القراءة \\
\hline$\% 40.88$ & 11.266 & 5.1333 & البعد الرابع: الكتابة \\
\hline$\% 36.96$ & 46.642 & 24.466 & المقياس ككل \\
\hline
\end{tabular}

ومن نتائج الجدول السـابق رقم (ع ا) نجد أن البرنـامج له تأثير إيجابي وفعال في تتمية المهارات اللغوية الاتصالية ( الاستماع- التحدث - القراءة-

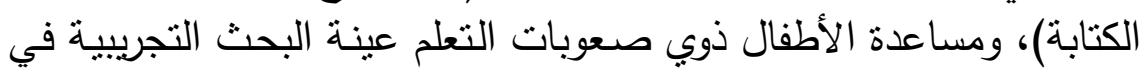
التغلب على المشكلات اللغوية للتغلب على خطر صعوبات التعلم حيث

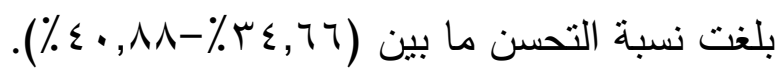

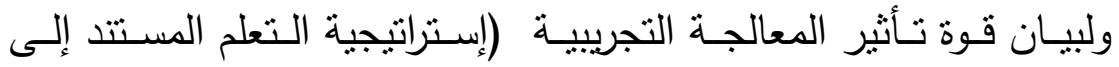
الدماغ) في تتميـة المهارات اللغوبـة الاتصـالية لدى أطفال ماقبل المدرسـة فئة ذوي صـوبات التعلم ، تم حسـاب المتوسط الحسـابي والانحراف المعياري

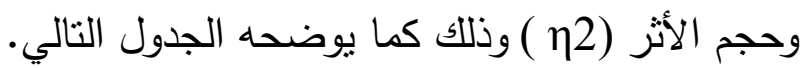




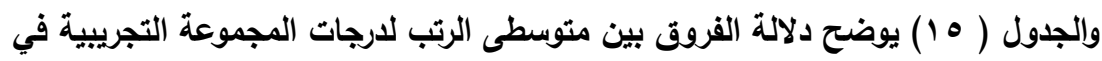

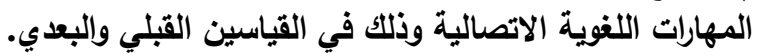

\begin{tabular}{|c|c|c|c|c|c|c|}
\hline \multirow[t]{2}{*}{ المستوى } & \multirow[t]{2}{*}{$(\eta 2)$} & \multicolumn{2}{|c|}{ القياس البعدي } & \multicolumn{2}{|c|}{$\begin{array}{c}\text { القياس القبلي } \\
10=0\end{array}$} & \multirow[t]{2}{*}{ الأبعاد } \\
\hline & & الإنحراف & المتوسط & الإنحراف & المتوسط & \\
\hline مرتفع & rד, . & 1.437 & 11.933 & 1.099 & 6.0667 & الاستماع مهارات \\
\hline مرتفع & $\cdot, \Lambda \backslash \vee$ & 1.060 & 11.866 & 0.899 & 6.666 & مهارات \\
\hline مرتفع &., 977 & 1.447 & 11.666 & 0.985 & 6.000 & مهارات \\
\hline مرتفع & س人, & 0.9611 & 11.266 & 1.060 & 5.1333 & مهارات \\
\hline مرتفع &., $99 \varepsilon$ & 4.199 & 46.642 & 2.133 & 24.466 & الارجة \\
\hline
\end{tabular}

ويتضـح مـن الجدول (0 1) ارتفـاع المتوسط الحسـابي لأفراد المجموعـة

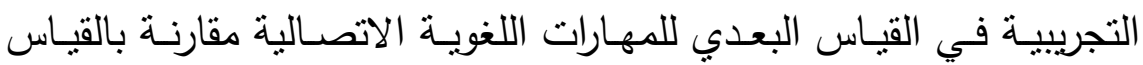
القبلي

• القرض الثالث ونتائجه: ينص الفرض الثالث على أنه: "لا توجد فروق ذات دلالـة إحصسائية بـين متوبسطي رتب درجـات أطقال

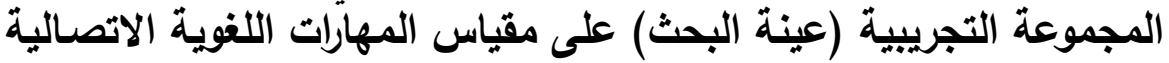
في القياسين البعدي والتتبعي". 
وللتحقق دن صحة هذا الفرض قامت الباحثة باستخدام اختبار ويلكوكسون للمجموعات المرتبطة لإيجاد دلالة الفروق بين متوسطي رتب درجات أطفال

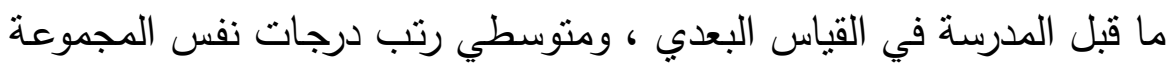
بعد مرور شـهر على تطبيق البرنامج التدربي القائم على إستراتيجية التعلم

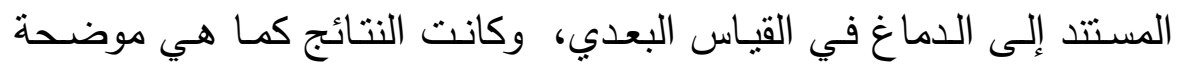
بالجدول التالي.

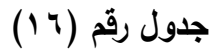

قيمة (Z) ودلالتها الإحصائية بالنسبة للارجات الكلية على مقياس المهارات اللغوية الاتصالية

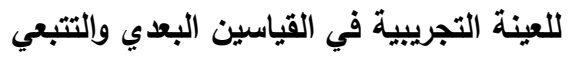

\begin{tabular}{|c|c|c|c|c|c|c|}
\hline \multicolumn{7}{|c|}{$(10)=\dot{u}$} \\
\hline مستوى الدلالة & قيمة & مجموع الرتب & متوبط & ن & القباس التبدي & المتغيرات \\
\hline \multirow{4}{*}{ غير 0.083} & \multirow[t]{4}{*}{-1.732} & .6 & $\cdot, \cdots$ & . & الرنب & \multirow{4}{*}{ الالاتصهاس اللغوية } \\
\hline & & 6.00 & 2.00 & 3 & الرتب & \\
\hline & & & & IT & الرحايدة & \\
\hline & & & & 10 & المجموع & \\
\hline
\end{tabular}

ويتضـح مسن جدول ( ا (1) عدم وجـود فـروق دالـة بـين منوسـي رتب درجات المجموعـة التجريبيـة في القباس البعدي ، ومتوسطي رتب درجب درجات نفس المجموعة في القياس التببعي حيث كانت قيمة ( - غير دالة إحصائياً ، وهذا يعني أن الدرجات التي حصل عليها الأطفال في 
القياسين البعدي والتتبعي كانت متقاربة، مما بدل على استمرار أثر البرنامج

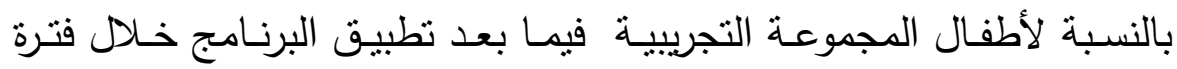
المتابعة، وبذللك فقد تحققت صحة الفرض الثالث للبحث. باث.

وتزجع الباحثة هذه النتيجة إلى استمرار أثر البرنامج التدربيى القائم على إنى

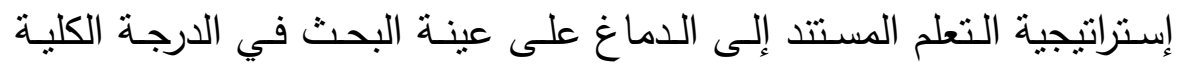
لمقياس المهارات اللغوية الاتصالية في القياسين البعدي والتتبعي.

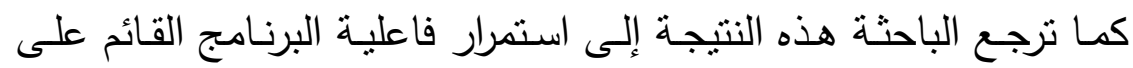

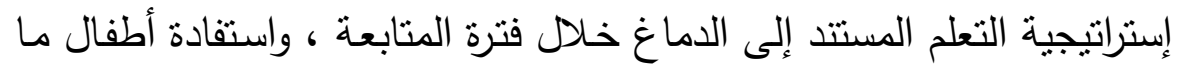
قبل المدرسة ذوي صعوبات التعلم من الأنشطة المقدمة في البرنـامج ، والذي

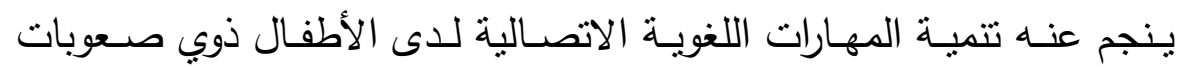

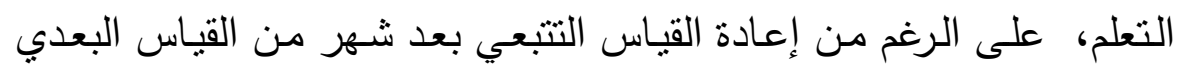
مدا بدل على بقاء أثر البرنامج. والجـدول ( IV يوضـح المتوســ الحسـابي والإنحـراف المعيـاري لـدرجات المجموعة التجربيية في المهارات اللغوبة الاتصالية وذلك في القياسين البعدي

\section{جدول (iv)}

والتبتعي.

المتوسط الحسابي والإنحراف المعياري في القياسين البعدي والتتبعي لاى أفراد المجموعة التجريبية

\begin{tabular}{|c|c|c|c|c|}
\hline \multicolumn{2}{|c|}{ القياس البعدي } & \multicolumn{2}{|c|}{ ن القياس القبلي } & مقياس المهارات \\
\hline الإنحراف & المتوسط & الإنحراف & المتوسط & الاتصالية \\
\hline 4.0567 & 46.8000 & 4.0496 & 46.600 & اللارجة الكلية \\
\hline
\end{tabular}


وبتضـح مـن الجـول (IV) تقـارب المتوسـط الحسـابى لـدى أفراد المجموعـة التجريبية في القياسين البعدي والتتبعي في المهارات اللغوية الاتصالية ككل.

• القرض الرابع ونتائجه: ينص الفرض الرابع على أنه: " توجـ فروق ذات دلالـة احصـائية بـين متوبسطى رتب درجـات أطفـال

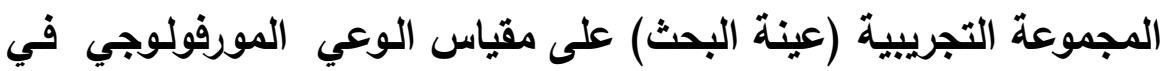
القياسين القبلي والبعدي قبل/ بعد تطبيق البرنـامج القائم على إستراتيجية

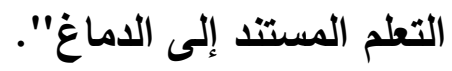

وللتحقـق مـن صــحة هـذا الفـرض قامــت الباحثـة باســتخدام اختبـار ويلكوكسون للمجموعات المرتبطة ،لإيجاد دلالة الفروق بين متوسطي رتب

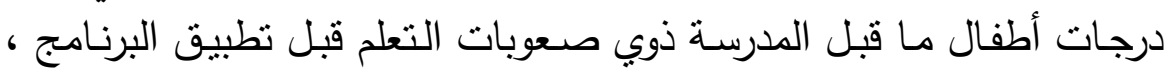
ومتوسطى رتب درجات نفس المجموعة بعد تطبيق البرنامج كما هو موضـح بالجدول التالي.

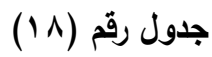

قيمة (Z) ودلالتها الإحصائية بالنسبة للارجات الكلية على مقياس الوعي المورفولوجي للعينة

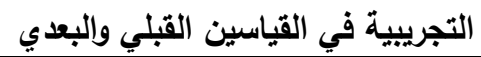

\begin{tabular}{|c|c|c|c|c|c|c|c|}
\hline \multirow[b]{2}{*}{ الاحصائية } & \multirow[b]{2}{*}{ قيمة z } & \multicolumn{2}{|c|}{ القياس القبلي / البعدي } & \multirow{2}{*}{ العدد } & \multirow{2}{*}{ رتب متغير مقياس } & \multirow[t]{2}{*}{ الأبعاد } & \multirow[t]{2}{*}{ المجال } \\
\hline & & مجموع الرتب & متوسط & & & & \\
\hline \multirow[t]{4}{*}{$\ldots \ldots$} & \multirow{4}{*}{ TITS } & 0,00 & 0,00 & 0,0 & الرتب السالبة & \multirow{4}{*}{ أسماء } & \multirow{4}{*}{ 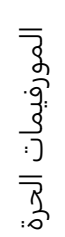 } \\
\hline & & 120 & 8 & 15 & الرتب الموجبة & & \\
\hline & & & & 0 & الرتب المحايدة & & \\
\hline & & & & 15 & المجموع الكلي & & \\
\hline
\end{tabular}


المجلة العلمية لكلية رياض الأطفال - جامعة بورسعيد

\begin{tabular}{|c|c|c|c|c|c|c|c|}
\hline \multirow[t]{4}{*}{$\ldots$} & - & 0,00 & 0,00 & 0,0 & الرتب السالبة & \multirow{4}{*}{ أسماء } & \\
\hline & \multirow[t]{3}{*}{ rotor } & 120 & 8 & 15 & الرتب الموجبة & & \\
\hline & & & & 0 & الرتب المحايدة & & \\
\hline & & & & 15 & المجموع الكلي & & \\
\hline \multirow[t]{4}{*}{$\cdots \cdots$} & - & 0,00 & 0,00 & 0,0 & الرتب السالبة & \multirow[t]{4}{*}{ أحرف الجر } & \\
\hline & \multirow[t]{3}{*}{ r.or. } & 120 & 8 & 15 & الرتب الموجبة & & \\
\hline & & & & 0 & الرتب المحايدة & & \\
\hline & & & & 15 & المجموع الكلي & & \\
\hline \multirow[t]{4}{*}{$\cdots \cdots$} & - & 0,00 & 0,00 & 0,0 & الرتب السالبة & \multirow{4}{*}{ منفصلة } & \\
\hline & \multirow[t]{3}{*}{ LITE } & 120 & 8 & 15 & الرتب الموجبة & & \\
\hline & & & & 0 & الرتب المحايدة & & \\
\hline & & & & 15 & المجموع الكلي & & \\
\hline \multirow[t]{4}{*}{$\ldots \ldots$} & - & 0,00 & 0,00 & 0,0 & الرتب السالبة & \multirow{4}{*}{ الارجة الكلية } & \\
\hline & \multirow[t]{3}{*}{$r, 0 \leqslant r$} & 120 & 8 & 15 & الرتب الموجبة & & \\
\hline & & & & 0 & الرتب المحايدة & & \\
\hline & & & & 15 & المجموع الكلي & & \\
\hline \multirow[t]{4}{*}{$\ldots .1$} & - & 0,00 & 0,00 & 0,0 & الرتب السالبة & \multirow{4}{*}{ والتنانيث } & \multirow{7}{*}{ 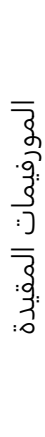 } \\
\hline & \multirow[t]{3}{*}{$r, \leqslant q 0$} & 120 & 8 & 15 & الرتب الموجبة & & \\
\hline & & & & 0 & الرتب المحايدة & & \\
\hline & & & & 15 & المجموع الكلي & & \\
\hline \multirow[t]{3}{*}{$\ldots \ldots 1$} & - & 0,00 & 0,00 & 0,0 & الرتب السالبة & \multirow{3}{*}{ والجمع } & \\
\hline & \multirow[t]{2}{*}{ r، ¿VV } & 120 & 8 & 15 & الرتب الموجبة & & \\
\hline & & & & 0 & الرتب المحايدة & & \\
\hline
\end{tabular}




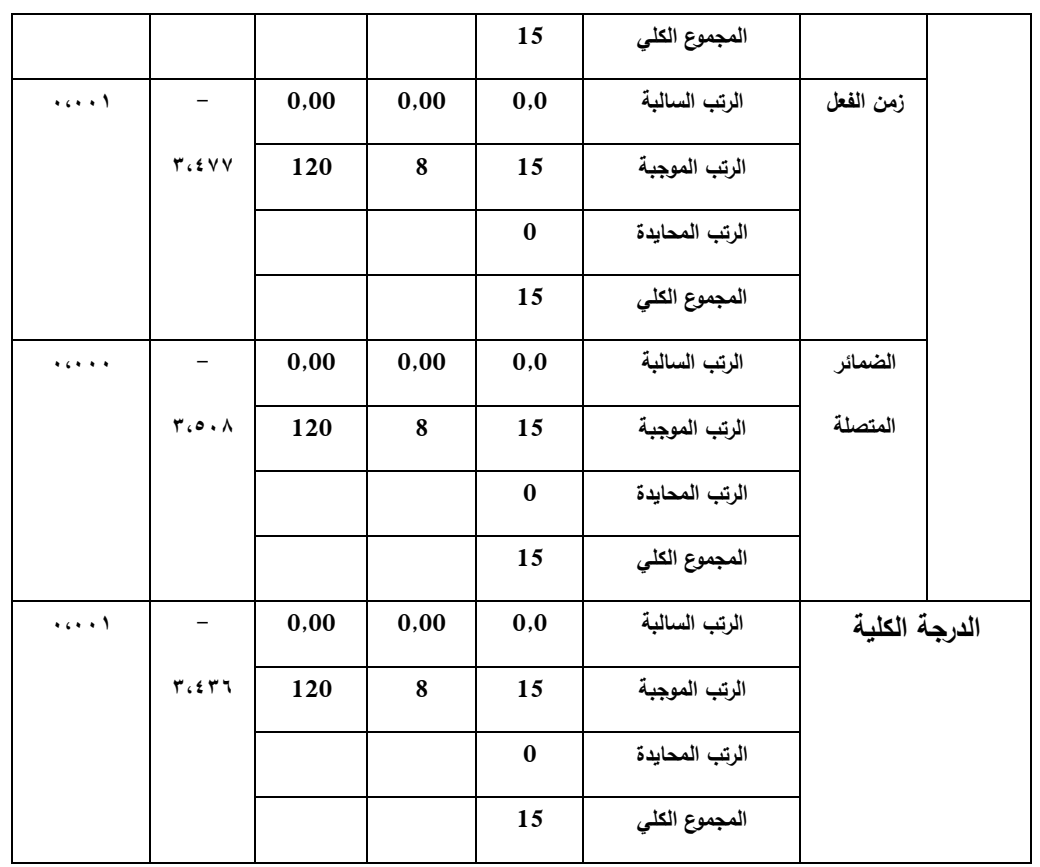

من خلال الجدول (1 1 ) يتضـح وجود فروق دالة إحصسائياً بين متوسطي رتب درجات المجموعـة التجريبيـة في القياسـين القبلي والبعدي لـدى أطفال المجموعة التجريبية على مجالات وأبعاد مقياس الوعي المورفولوجي ، وعند

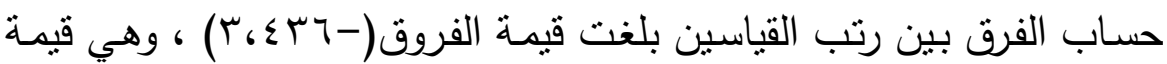
دالة إحصائياً ، مما يدل على فاعلية إستراتيجية التعلم المستتد إلى الدماغ في في فئي

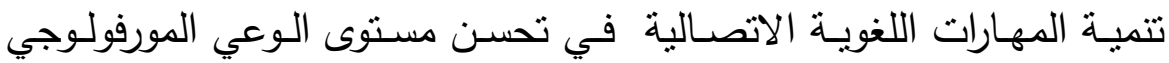

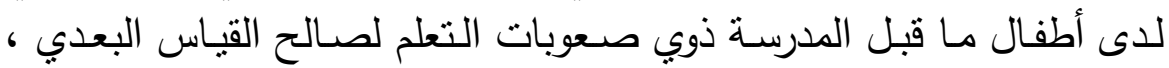
وبذلك تحققت صحة الفرض الرابع للبحث . ويمكن تفسـير هـذه النتيجـة في ضـوء البرنـامج المسـتخدم القـائم على التى إستراتيجية التعلم المستتد إلى الدماغ ، كما أن الباحثة قد راعت ثتوع وزبادة 
وسـائل التقويم ، وقد شـارك الأطفال بفاعليـة في البرنـامج ، ويتفق ذلك مـع نتيجة البرنامج حيث أن هناك فروق دالة إحصائياً بين متوسطي رتب درجات أفراد المجموعة التجريبية قبل وبعد تطبيق البرنامج لصالح التطبيق البعدي. ومما سبق نجد أن البرنامج لله تأثير إيجابي وفعال في مساعدة أطفال ما

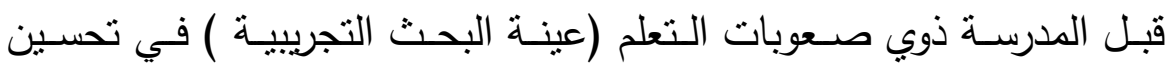
مستوى الوعي المورفولوجي لديهم.

كما قامت الباحثة بايجاد نسبة التحسن بين القياسين القبلي والبعدي على

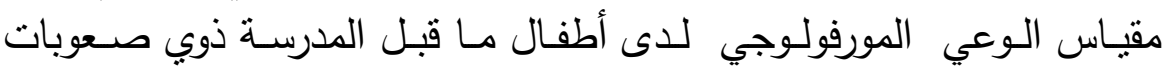

$$
\text { التعلم كما يتضح في جدول (9 1). }
$$

نسبة التحسن بين القياسين القبلي والبعدي على مقياس الوعي المورفولوجي كل وأبعاده

\begin{tabular}{|c|c|c|c|c|}
\hline نسبة & متوسط القياس & متوسط القياس & أبعاد مقياس الوعي & المجال \\
\hline$\% 51.65$ & 3.466 & 1.400 & أسماء الاشارة & \multirow{4}{*}{$\begin{array}{l}\overline{3} \\
\overline{3} \\
\overline{3} \\
\overline{3} \\
\overline{7}\end{array}$} \\
\hline$\% 48.32$ & 3.533 & 1.600 & أسماء المكان & \\
\hline$\% 60.00$ & 3.4000 & 1.000 & أحرف الجر & \\
\hline$\% 46.67$ & 3.2000 & 1.1333 & الضمائر المنفصلة & \\
\hline$\% 52.08$ & 13.466 & 5.133 & الدرجة الكلية للدجال & \multirow{5}{*}{ 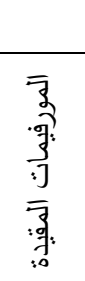 } \\
\hline$\% 41.65$ & 3.666 & 2.000 & التنكير والتأنيث & \\
\hline$\% 48.32$ & 3.666 & 1.733 & التثثية والجمع & \\
\hline$\% 76.67$ & 3.600 & 0.533 & زمن الفعل & \\
\hline$\% 68.35$ & 3.200 & 0.466 & الضمائر المتصلة & \\
\hline$\% 59.16$ & 14.200 & 4.733 & الدرجة الكلية للمجال & \\
\hline$\% 55.62$ & 27.666 & 9.866 & المقياس ككل & \\
\hline
\end{tabular}

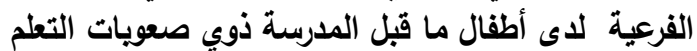


ومن نتائج الجدول السـابق رقم (9 (1) نجد أن البرنـامج لـه تـأثير إيجـابي وفعـال فـي تحسـين مسـتوى الـوعي المورفـووجى ( المورفيمـات الحـرة-

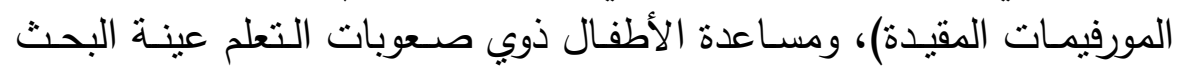
التجريبية في التغلب على مشكلات اللغة للتخلب على خطر صسوبات التعلم

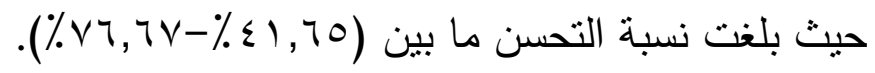

ولبيان قوة تأثير المعالجة التجربيية (إستراتيجية التعلم المستند إلى الدماغ)

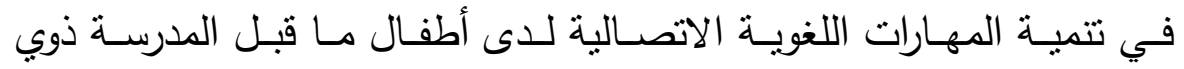
صسعوبات التعلم ، تم حسـاب المتوسط الحسـي والانحراف المعياري وحجم الإنه الأثز (12 ) وذلك كما بوضحه الجدول التالي:

والجدول ( r) يوضـح دلالـة الفروق بين المتوسط والإنحراف المعيـاري لدرجات المجموعـة التجريبيـة في مسـتوى الـوعي المورفولـوجي وذلك في لئي

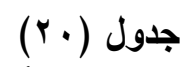$$
\text { القياسين القبلي والبعدي. }
$$

المتوسط الحسابي والإنحراف المعياري وحجم الأثر في القياسين القبلي والبعدي لاى (الى أفراد المجموعة التجريبية

\begin{tabular}{|c|c|c|c|c|c|c|}
\hline \multirow[t]{2}{*}{ المستوى } & \multirow[t]{2}{*}{$(\eta 2)$} & \multicolumn{2}{|c|}{ القياس البعدي } & \multicolumn{2}{|c|}{ القياس القبلي } & \multirow[t]{2}{*}{ الأبعاد } \\
\hline & & الإنحراف المعياري & المتوسط & الإلمعراف & المتوسط & \\
\hline مرتفع &., 911 & 0.5164 & 3.466 & 0.5070 & 1.400 & أسماء \\
\hline مرتفع & $\cdot, 910$ & 0.5164 & 3.533 & 0.5070 & 1.600 & أسماء \\
\hline
\end{tabular}


المجلة العلمية لكلية رياض الأطفال - جامعة بورسعيد

\begin{tabular}{|c|c|c|c|c|c|c|}
\hline \multirow[t]{2}{*}{ المستوى } & \multirow[t]{2}{*}{$(\eta 2)$} & \multicolumn{2}{|c|}{ 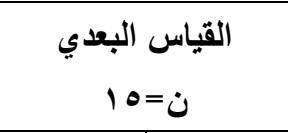 } & \multicolumn{2}{|c|}{ 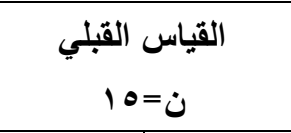 } & \multirow[t]{2}{*}{ الأبعاد } \\
\hline & & الإنحراف & المتوسط & الإنحراف & المتوسط & \\
\hline مرتفع &., 97. & 0.5070 & 3.4000 & 0.000 & 1.000 & أحرف \\
\hline مرتفع & •, qAr & 0.4140 & 3.2000 & 0.3518 & 1.1333 & الضمائر \\
\hline مرتفع & $\cdot, \wedge \vee \neg$ & 0.4879 & 3.666 & 0.000 & 2.000 & والتأنيث \\
\hline مرتفع & $\cdot, 9 \ldots$ & 0.4879 & 3.666 & 0.4577 & 1.733 & والجمع \\
\hline مرتفع & $\cdot, \wedge \vee \cdot$ & 0.5164 & 3.600 & 0.5333 & 0.533 & زمن الفعل \\
\hline مرتفع & $\cdot, 971$ & 0.4140 & 3.200 & 0.5164 & 0.466 & الضمائر \\
\hline مرتفع & $\cdot, 99 \leq$ & 1.9518 & 27.666 & 1.245 & 9.866 & الارجة \\
\hline
\end{tabular}

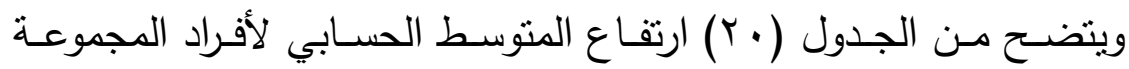
التجريبيـة في القيـاس البعـي لمسـتوى الـوعي المورفولـوجي مقارنـة بالقيـاس 


\section{• القرض الخامس ونتائجه:}

ينص الفرض الخامس للبحث على أنه:

" لا توجد فروق ذات دلالـة إحصـائية بـين متوبسطي رتب درجـات أطفال المجموعة التجريبية (عينة البحث) على مقياس الوعي المورفولوجي في في فئوفي القياسين البعدي والتتبعي'".

وللتحقق من صحة هذا الفرض قامت الباحثة باستخدام اختبار ويلكوكسون للمجموعات المرتبطة لإيجاد دلالة الفروق بين متوسطي رتب درجات أطفال ما قبل المدرسة في القياس البعدي ، ومتوسطي رتب درجات نفس المجموعة بعد مرور شـهر على تطبيق البرنامج التدربي القائم على إستراتيجية التعلم

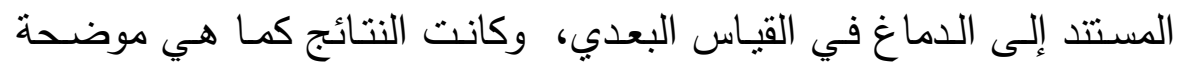

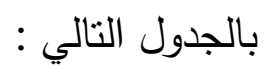

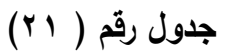

قيمة (Z) ودلالتها الإحصائية بالنسبة للارجات الكلية على مقياس الوعي المورفولوجي للعينة

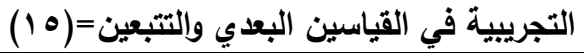

\begin{tabular}{|c|c|c|c|c|c|c|}
\hline مستوى الدلالة & قيمة Z & الرتب & متوسط & ن & التيعدي/ التبعي & المتغيرات \\
\hline \multirow{6}{*}{$\begin{array}{l}0.180 \\
\text { غير دالة }\end{array}$} & \multirow[t]{6}{*}{-1.342} & .6. & $\cdot, \cdots$ & . & الرتب & \multirow{6}{*}{ 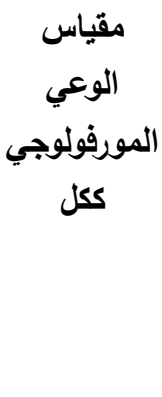 } \\
\hline & & & & & السالبة & \\
\hline & & 3.00 & 1.50 & 2 & الرتب & \\
\hline & & & & & الموجبة & \\
\hline & & & & 13 & الرحايدة & \\
\hline & & & & 10 & المجموع & \\
\hline
\end{tabular}


ويتضـح مسن جدول ( (Y) عدم وجـود فـروق دالـة بـين منوسـي رتب

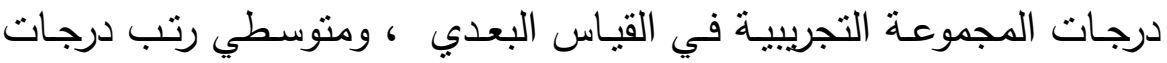
نفس المجموعة في القباس التبعي حيث كانت قيمة (1.342 ل دالـة إحصـائياً ، وهـذا يعنـي أن الـدرجات التي حصـل علي عليهـا الأطفـال في القياسين البعدي والتتبعي كانت منقاربة، مدا بدل على استمرار أثر البرنامج

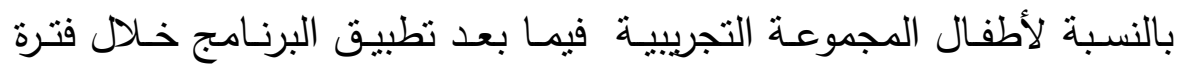
المتابعة، وبذلك فقد تحققت صحة الفرض الخامس للبحث.

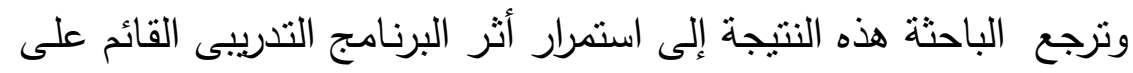

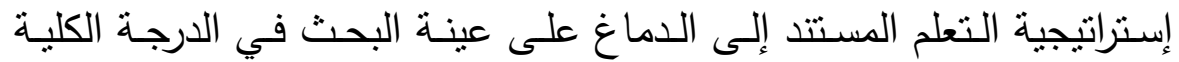
لمقياس الوعي المورفولوجي في القياسين البعدي والتتبعي.

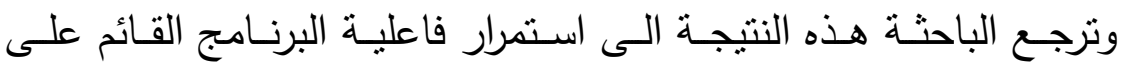

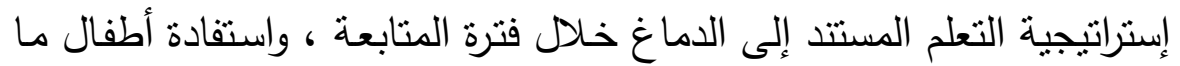
قبل المدرسة ذوي صعوبات التعلم من الأنشطة المقدمة في البرنـامج ، والذي

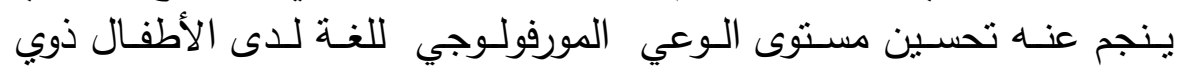
صعوبات التعلم ، على الرغم من إعادة القياس التتبعي بعد شهر من القياس البعدي مما بدل علي بقاء اثز البرنامج.

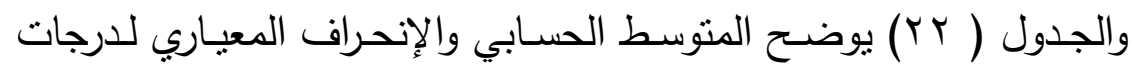
المجموعـة التجريبيـة في الـوعي المورفولـوجي وذلك في القياسـين البعـي لإيـي والتتبعي. 


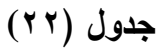

المتوسط الحسابي والإنحراف المعياري في القياسين البعدي والتتبعي لدى أفراد المجموعة التجريبية في التينية

\begin{tabular}{|c|c|c|c|c|}
\hline \multicolumn{2}{|c|}{ القياس البعدي } & \multicolumn{2}{|c|}{ القياس القبلي } & \multirow[t]{2}{*}{ مقياس الوعي } \\
\hline الإنحراف & المتوسط & الإنحراف & المتوسط & \\
\hline 1.922 & 27.866 & 1.951 & 27.666 & اللارجة الكلية \\
\hline
\end{tabular}

وبتضـح من الجدول (Yr) تقارب المتوسط الحسابي لدى أفراد المجموعة التجريبية في القياسين البعدي والتتبعي في مستوى الوعي المورفولوجي . مناقشة نتائج البحث:

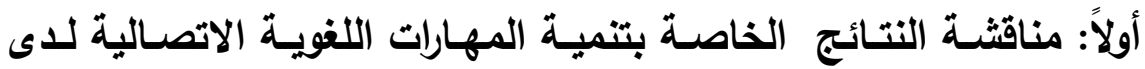
أطفال ما قبل المدرسة ذنافة ذئه صعويات التعلم:

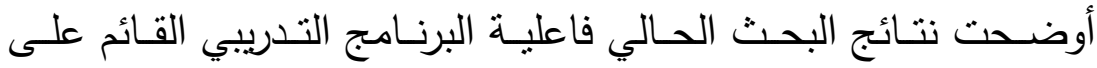
إستراتيجية التعلم المستتد إلى الدماغ في تتمية المهارات اللغوية الاتصـالية (مهارات الاستماع والتحدث والقراءة والكتابة ) لدى أطفال ما قبل المدرسـة

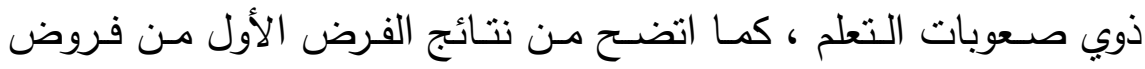
البحث ، وهذا يعكس التحسن الملموس في (مهارات الاستماع والتحدثث

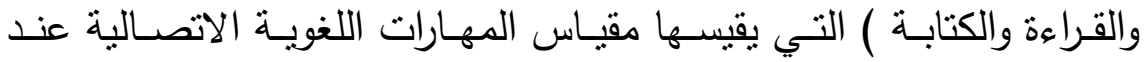

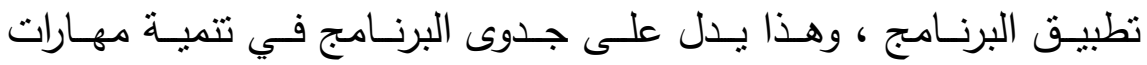
(الاستماع والتحدث والقراءة والكتابة ) . 
ولعل اعتماد البرنامج على إستراتيجية التعلم المستتد إلى الدماغ، قد زاد

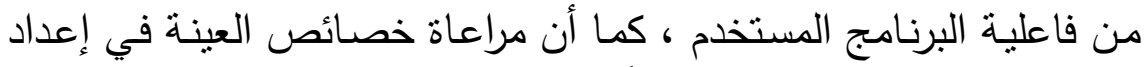

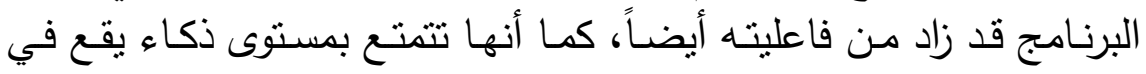
المدى المتوسط ، وبالتالي عندما هيئت لهم بيئة تعليمية مناسبة تمكنهم من الاستفادة من قدراتهم أسفرت عن تعلمهم، كما بدا في تحسن مستوى مهارات

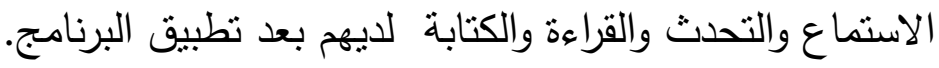

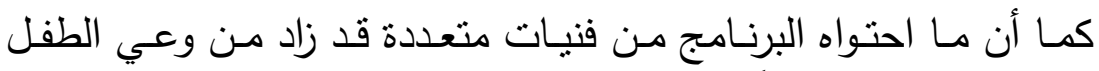
بالمهارات اللغوية ، فضلاً عن أن البرنامج المقترح بأنشطته المتتوعة القائم على إستراتيجية التعلم المستتد إلى الدماغ كان يخاطب أكثر من حاسة لدى الطفل ذوي صعوبات التعلم ، مما زاد من فعالية البرنامج. وتتفق هذه النتيجة مـع مـا قدمـه التراث النظري والدراسـات السـابقة حول

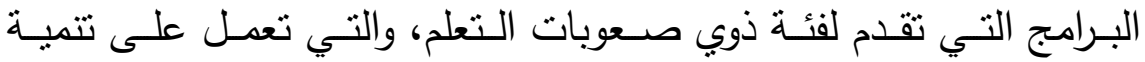

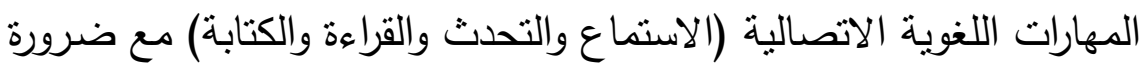
التأكيد على إثراء البيئة المحيطة بالطفل بالموارد والإمكانات التي تشـاعده على إثارة دافعيته للتعلم وتتميه مهاراته اللغوية الاتصالية. ولقد أكدت الدراسات السابقة والأطر النظربية على استفادة أطفال الروضة

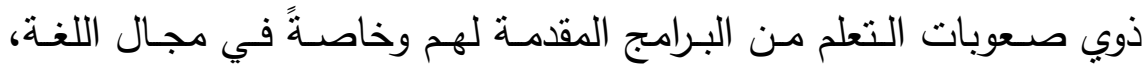

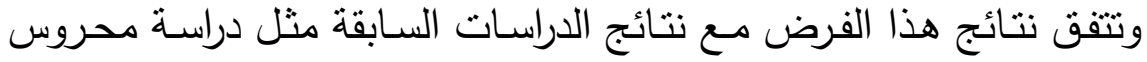

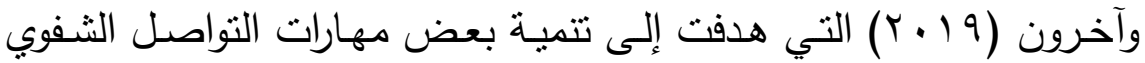
(الاستماع والتحدث) لاعى أطفال الروضـة، باستخدام إستراتيجية فكر -زاوج -ثارك وودراسة الغزولي (19 ( 19) والتي استهدفت تتمية مهارتي الاستماع والتحدث لدى أطفال الروضة ذوي صعوبات التعلم النمائية باستخدام برنامج

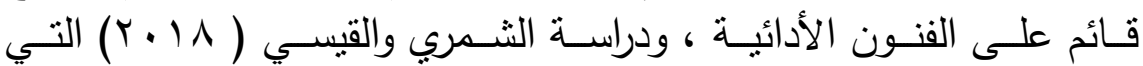


استهدفت معرفة مهارة التحدث لدى أطفال الروضـة، وكذلك التعرف على

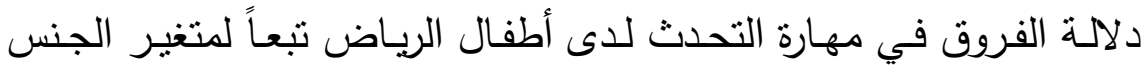
(ذكور ، إناث). وبذلك اتفقت نتيجة البحث الحالي مع نتائج تلك الدراسات

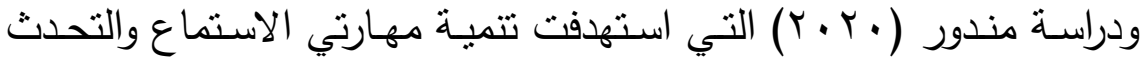

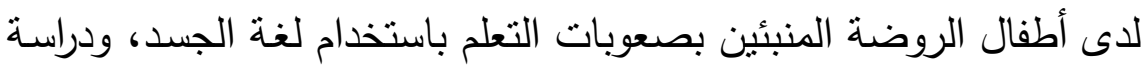

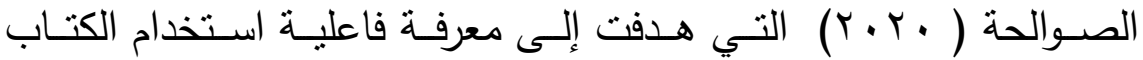
الإلكتروني في تتمية المهارات اللغوية لدى أطفال الروضة.

وتفسر الباحثة فاعلية برنامج البحث الحالي لتضمنه إسـتراتيجية التعلم المستتد إلى الدماغ والتي من شـأنها إثارة وتثشيط قدرات الطفل اللغوبـة

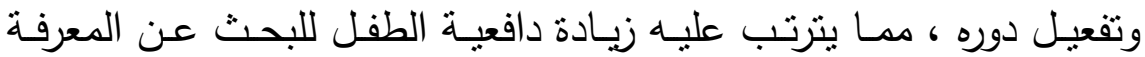
مسـتخدما" في ذلك مهاراته اللغوبـة الاتصـالية بصـورة نشـة وذات كفـاءة مرتفعة.

وتتضح فاعلية البرنامج المقترح القائم على إستراتيجية التعلم المستند إلى الدماغ في الحد من صعوبات التعلم في هذا البحث من خلال التحسن الذي

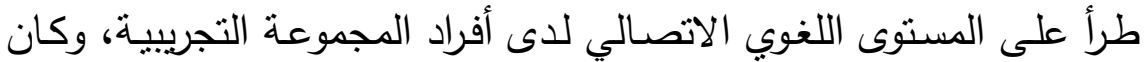
ذلك من خلال مقياس المهارات اللغوية الاتصـالية ( الاستماع- التحدث -

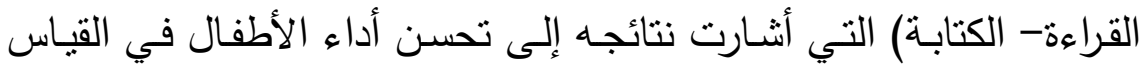

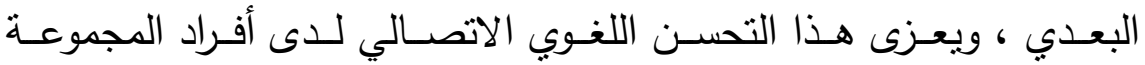
التجريبية إلى كونهم قد تأثروا بالبرنامج القائم على إستراتيجية التعلم المستتد الاتئ إلى الدماغ الذي كان يهدف إلى تتمية المهارات اللغوية الاتصالية. ونظراً لما قدمه البرنامج من إثارة لدافعية للطفل وزيادة رغبته في البحث عن المعرفة ، وبالتالي تتمية المهارات اللغوبة الاتصالية لديه التي أدت إلى ملى إلى

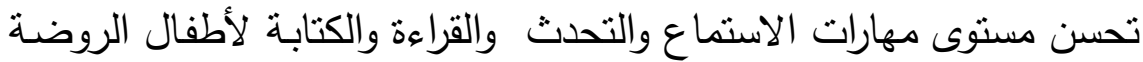




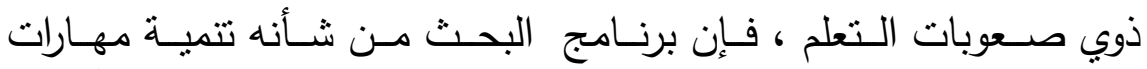

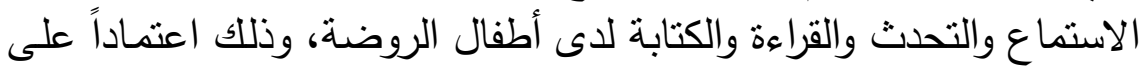

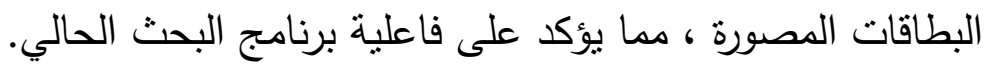

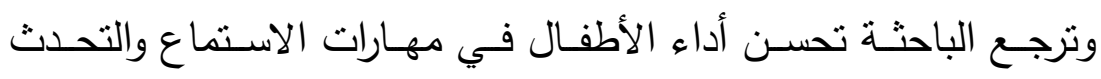

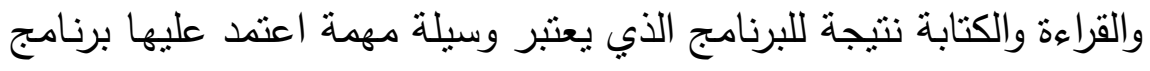

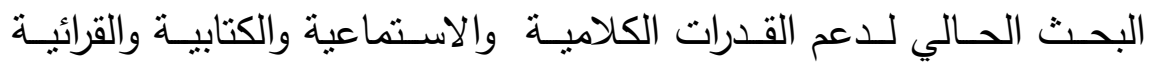
موضوع البحث.

وتفسـر الباحثـة التحسـن في أداء الأطفـال بعـد البرنـامج نظـراً لمراعـاة

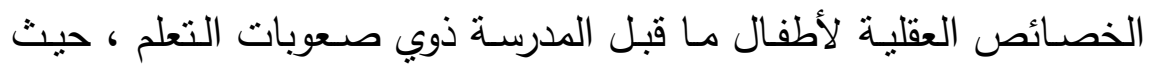

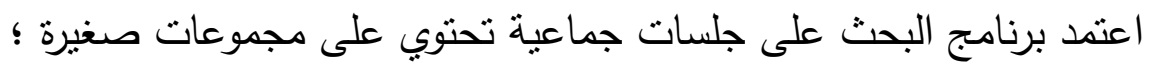

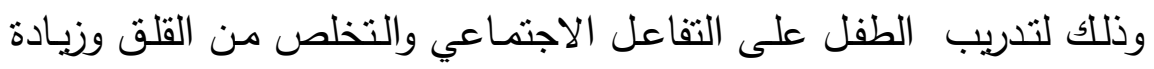

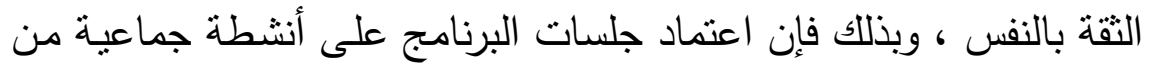

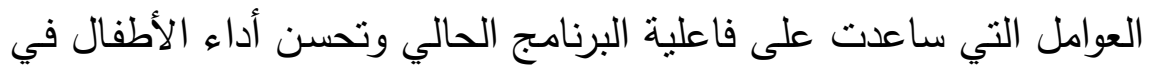

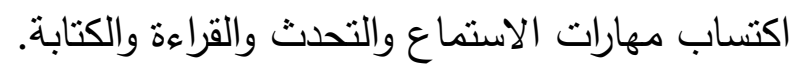

كما ترى الباحثة إرجاء فاعلية البرنامج إلى مراعاته للتدرج الزمني لكل

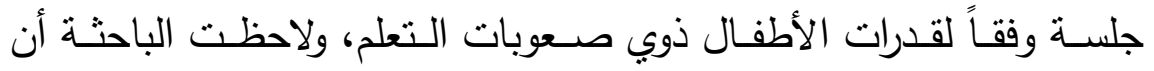

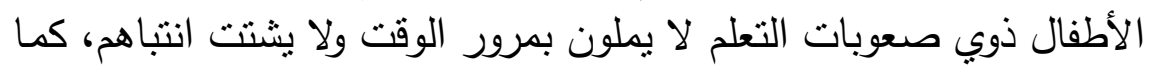

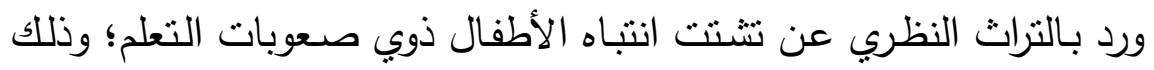

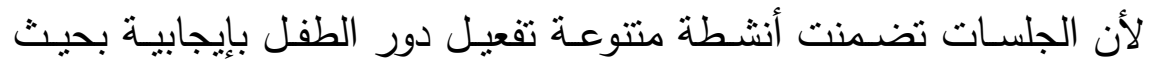
يصبح مشـاركاً في عملية التعلم ييتعد عن التلقين أو أن يكون دوره متلقياً سلبيا." 


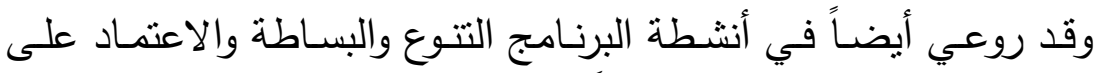
المحسوسات والسرعة في الزمن طبقاً لخصائص مرحلة طفل الروضة حيث

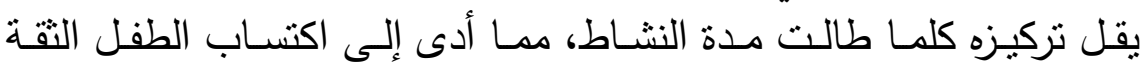
بالنفس وزيادة مستوى دافعيته للتعلم.

وقد أثـارت نتـائج الفـروض إلى نجـاح البرنـامج المسـتخدم في البحـث الحالي في تتميـة المهارات اللغويـة الاتصـالية الأربعة ( مهارات الاستماع

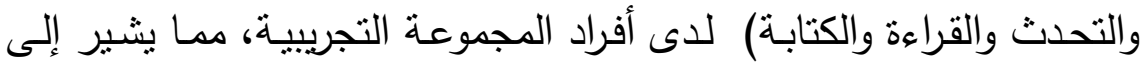
وجود آثار ايجابية للبرنامج في توفير الخبرات والممارسات اللغوية الاتصالية التي أدت إلى تحسن مستوى الوعي المورفولوجي للغة، مما يمكن أن يؤدي إلى الكثير من الآثار الايجابية على أطفال ما قبل المدرسة. لذا كان منطقياً أن يظهر الأطفال من أفراد المجموعة التجريبية تحسناً ملحوظاً بعد تعرضهم الإنه لبرنامج البحث القائم على إستراتيجية التعلم المستتد إلى الدماغ. ثانياً: مناقشة النتائج الخاصة بمستوى الوعي المورفولوجي لدى أطفال ما قبل المدرسة ذيا: منافي صعويات التعلم:

بعد الانتهاء من تطبيق البرنامج التدريبي القائم على إستراتيجية التعلم

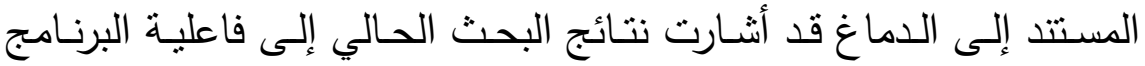
التدريبي في تحسين مستوى الوعي المورفولوجي لدى أطفال ما قبل المدرسة

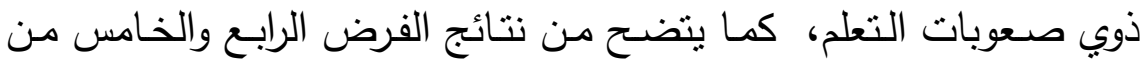

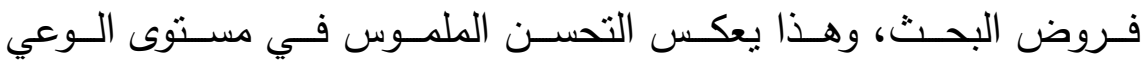
المورفولوجي لدى أطفال المجموعة التجريبية بحيث ظهر هذا التحسن من

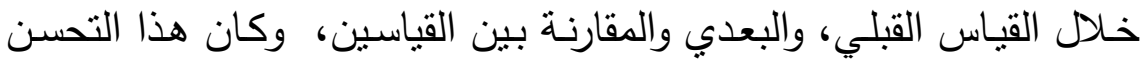
لصالح القياس البعدي، كما ظهر في شبه ثبات، و جاء في نتيجة الفرض وني 
الخامس وذلك في النسبة بين القياسين البعدي والتتبعي، وهذا يثير إلى أن

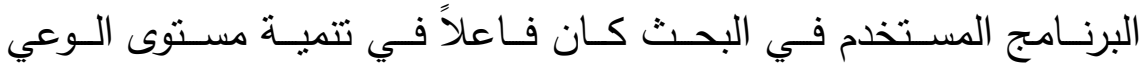

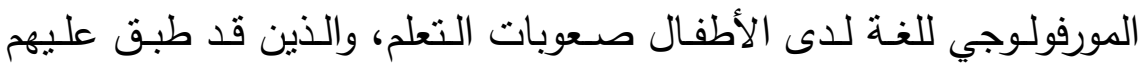

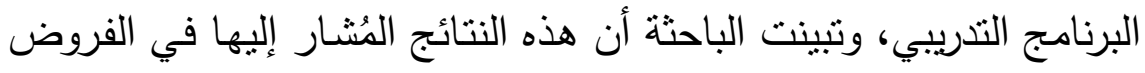

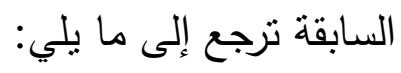

الطريقة التي تم من خلالها تقديم أنشطة المحتوى التدريبي، حيث تم

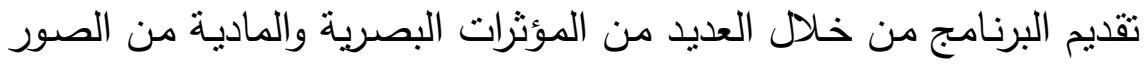

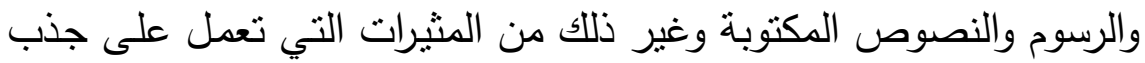

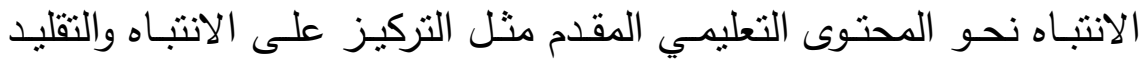

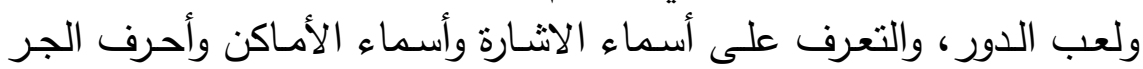

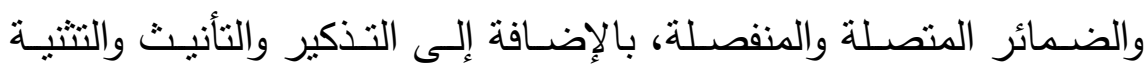
والجمع وزمن الفحل.

التذرج في تقديم المحتوى التعليمي من خلال تقديم محتوى بسيط يناسب

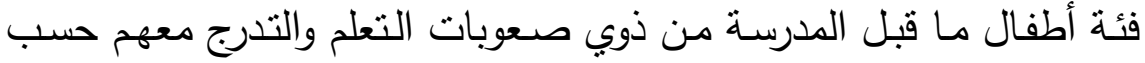
قدراتهم على الاستقبال والاستيعاب والتقدم خلال التهل البرنامج. بالإضافة الى استخدام الحواس والتي تتيح فرصا أكبر للتعلم.

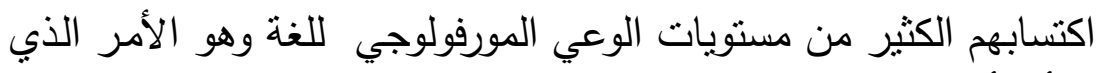

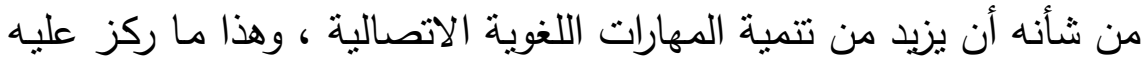

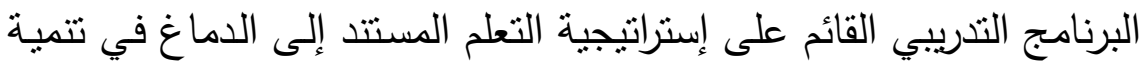

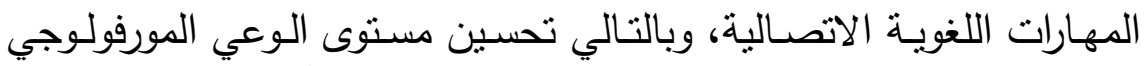

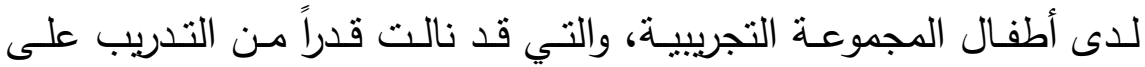
اكتساب الوعي المورفولوجي في القدرة على التعرف على أسماء الإشـارة

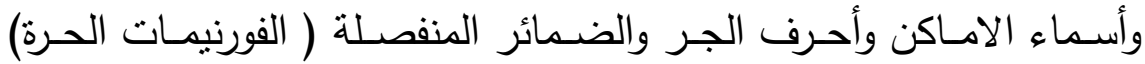




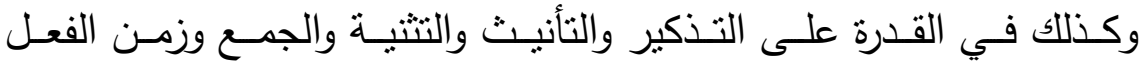
والضمائر المتصلة ( المورفيمات المقيدة).

كما أن البرنامج التدرببي راعى توفير العوامل التي تجعل من التدريب

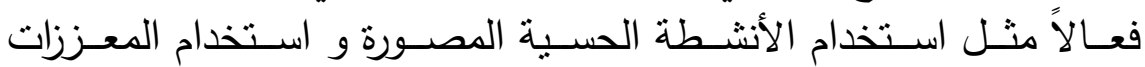
والمكافآت.

كذلك يرجع التحسن الملحوظ في مستوى الوعي المورفولوجي للغـة الى الى الفي

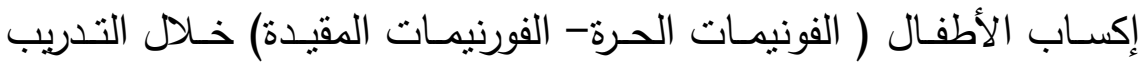

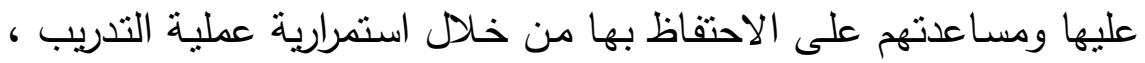

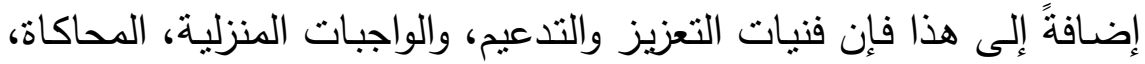

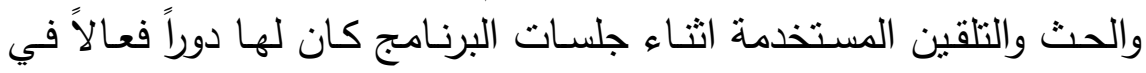

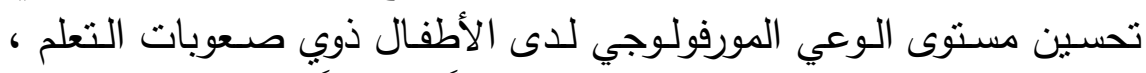

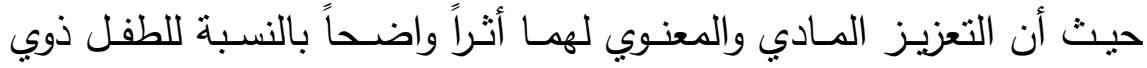

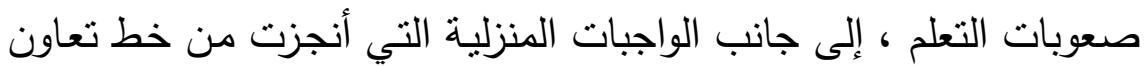

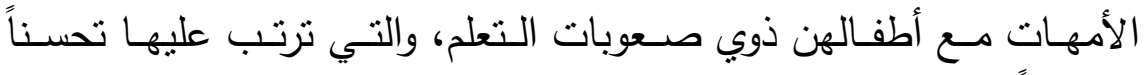

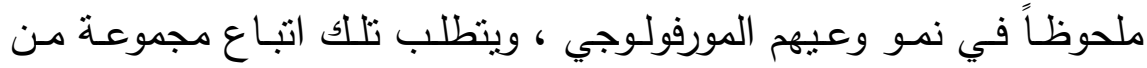
القواعد أو الخطوات وتعتمد على التفاعل بين الأطفال لتحقيق الأهداف.

ومن حيث ثبات المستوى بين القياسين البعدي والتبعي، كما جاء في ألتي نتيجة الفرض الخامس وهذا بعني أن البرنامج أسهم في تحسين أداء أطفاء

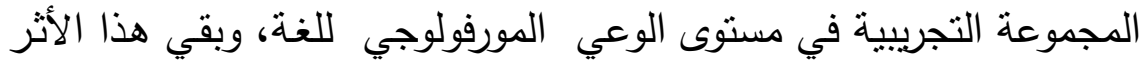

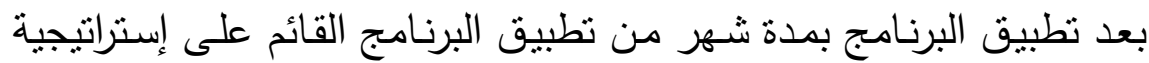

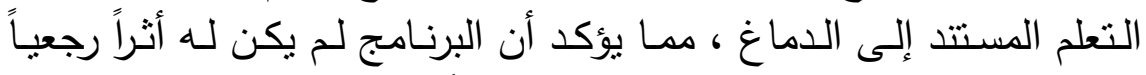

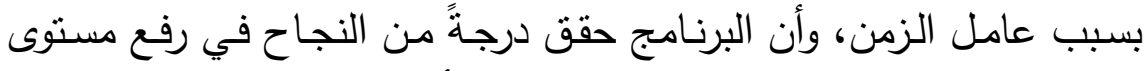

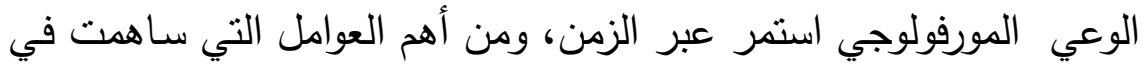


بقاء أثر التعلم والتي ترجعها الباحثنة إلى متابعة الأسـرة بالمنزل لأطفالهح

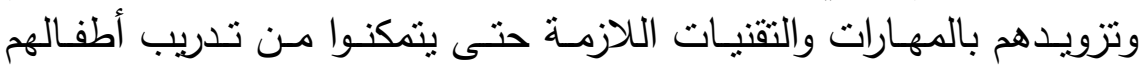

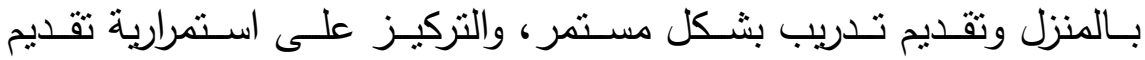

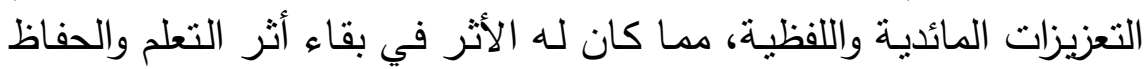

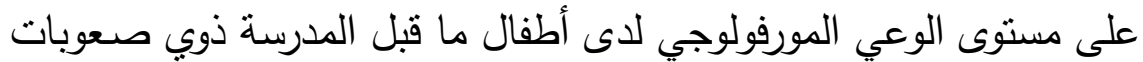
التعلم.

ومما سبق نجد أن البرنامج التدريبي القائم على إستراتيجية التعلم المستتد

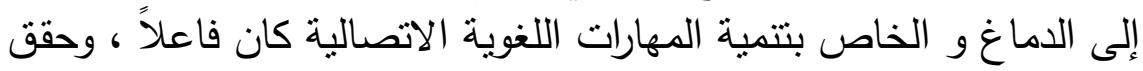

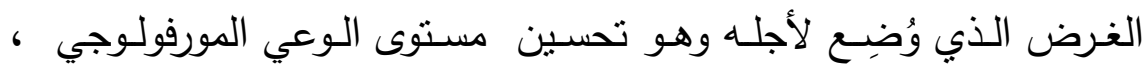

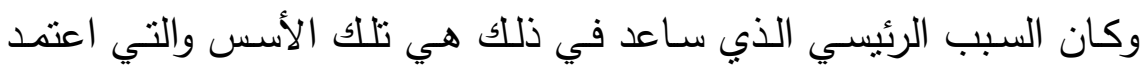

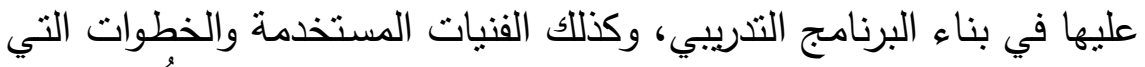

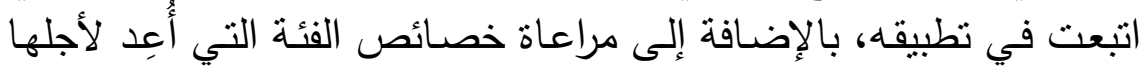

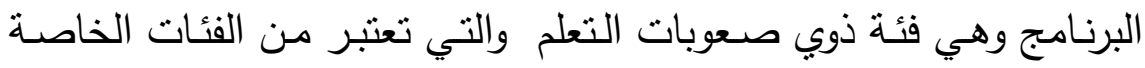
التي تحتاج إلى طرق وأساليب مختلفة للتعامل معها.

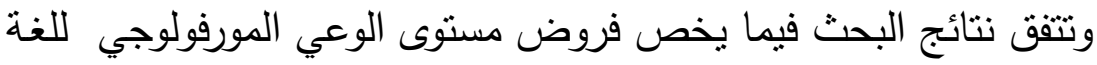

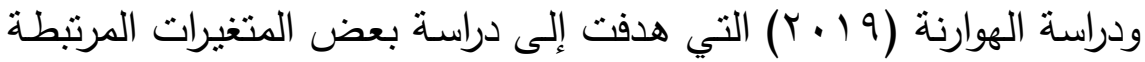

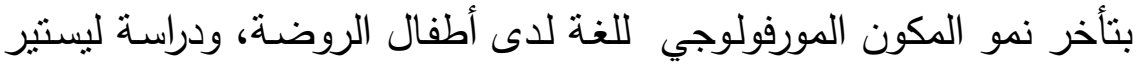

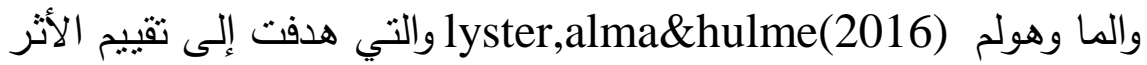

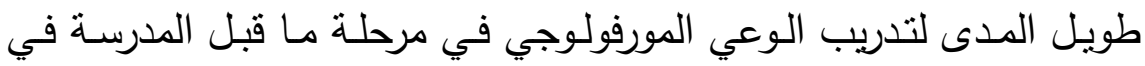

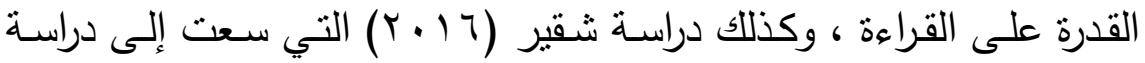

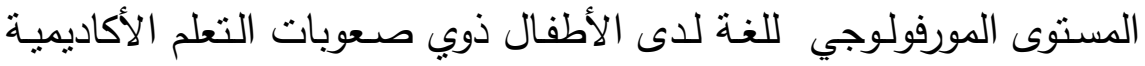

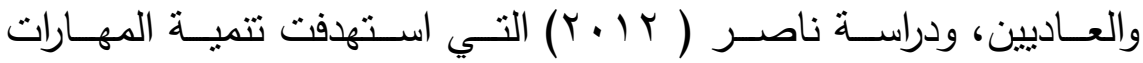


المورفولوجية والتحقق من أثرها على بعض مهارات القراءة والكتابة لمرحلة

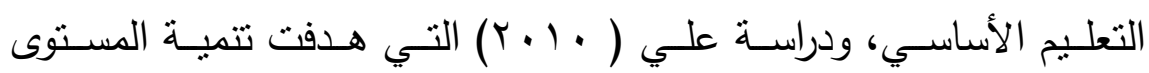

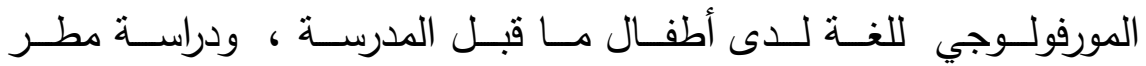

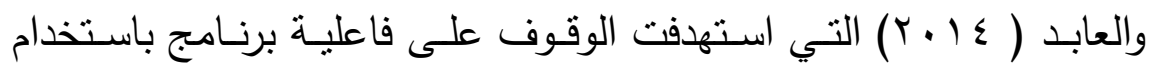
الحاسوب في تتمية مهارات الوعي المورفولوجي وأثثره على الذاكرة العاملة والمهارات اللغوية لدى ذوي صعوبات تعلم القراءة.

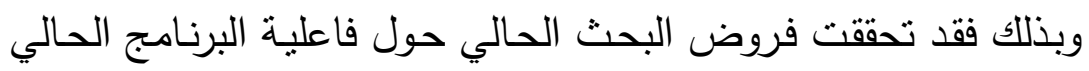

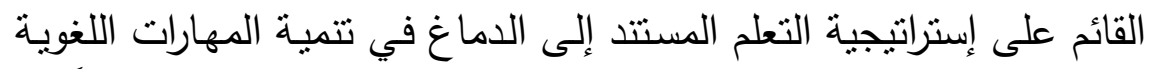

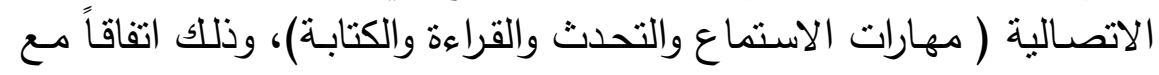

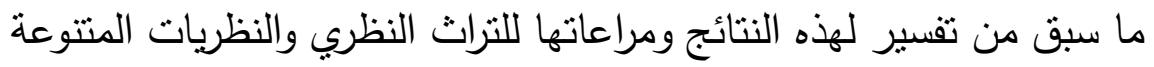
للتعلم.

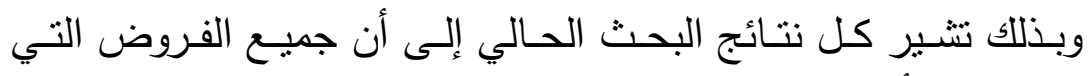

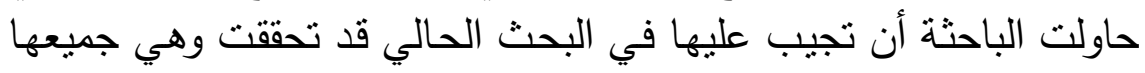
تهدف إلى التحقق من تأثثر البرنامج التدريبى القائم الته على إستراتيجية التعلم

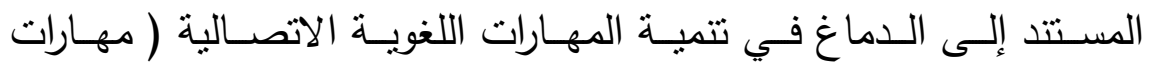

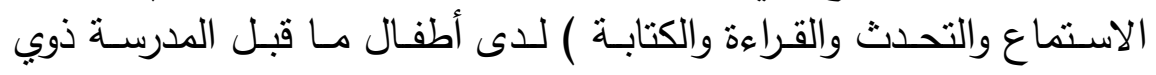

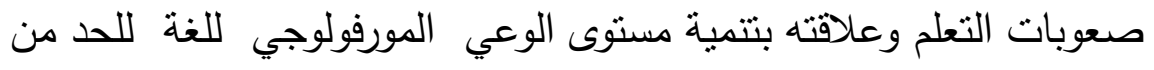

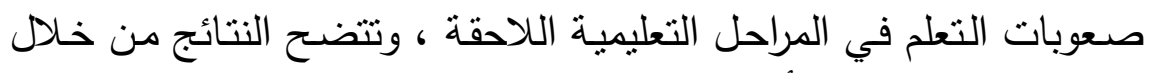

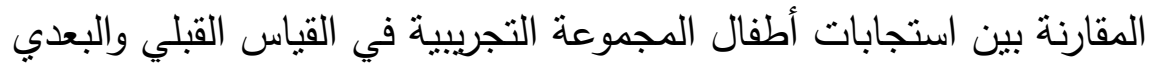
والتتبعي.

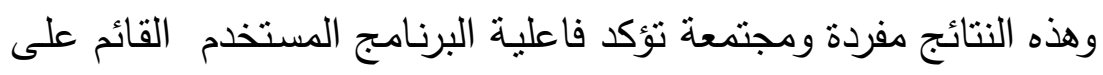

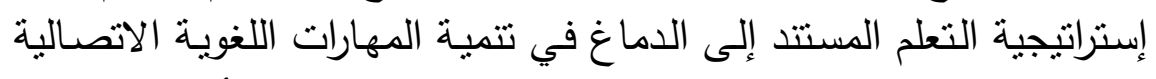

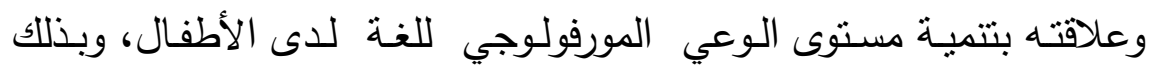


تتفـق هـه النتائج مـع الخلفيـة العلميـة للاراسـة سـواء مـن حيـث النظربـات والتفسيرات النظرية في ميدان صعوبات القراءة أو من حيث نتائج الدراسات السابقة التي توفرت للباحثة.

وبنـاءاًعلى مـا سبق ومن خـلال قبول فروض البحث الخمس قد نجح

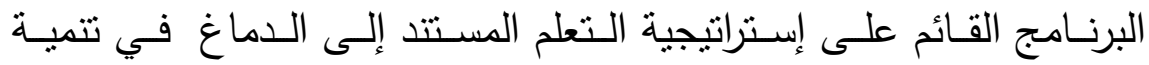

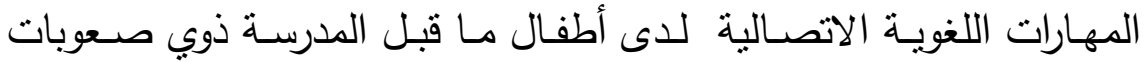

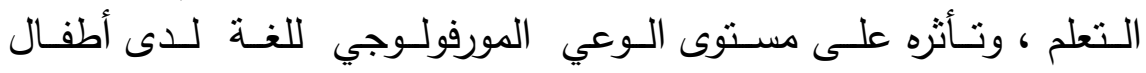

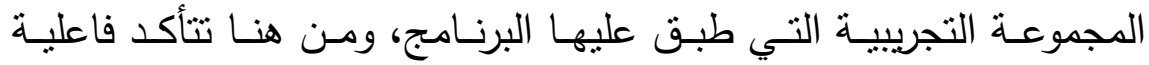

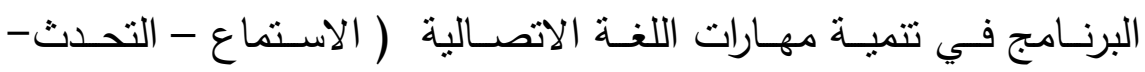
القراءة- الكتابة ) لدى أطفال ما قبل المدرسة ذوي صعوبات التعلم. توصيات البحث:

في ضـوء مـا توصـل إلبـهـ البحـث الحـالي مـن نتـائج تثقـدم الباحثـة بالتوصيات التالية للاستفادة منها:

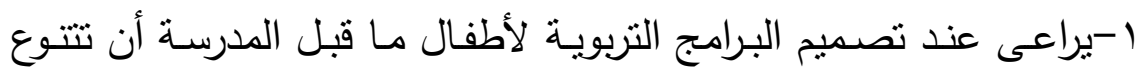
الأنشطة الفعالة للبرنامج لهذه الفئة من الأطفال ذوي مشكاتلات في المهارات اللغوبة الاتصالية، والأنشطة المصممة خصيصاً ذات المكافآت والتي تعمل داتل

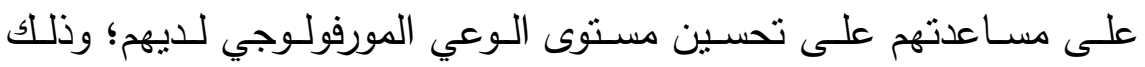
لمراعاة خصائص طفل ما قبل المدرسة. r-البُعد عن طرق التدريس التقليديـة التي تعتمد على التلقين دون اعتبار

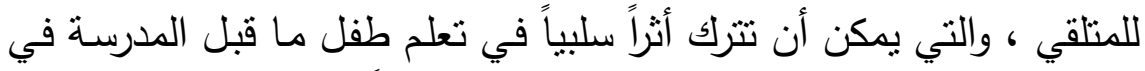
حين تتمكن طرق التعلم الحديثة والتي تعطي قدراً أكبر للمتعلم بالمشـاركة في الأنشطة والتي تعنمد على إستراتيجية التعلم المستتد إلى الدماغن، والتي تتناسب مع هذه الفئة من الأطفال. 
ب-ضرورة تدريب معلمات رياض الأطفال قبل وأثتاء الخدمة على استخدام نظريـة إسـتراتيجية التتعلم المسـتند إلىى الـدماغ في الممارســات التعليميـة وتصميم الأنشطة التعليمية المناسبة لها.

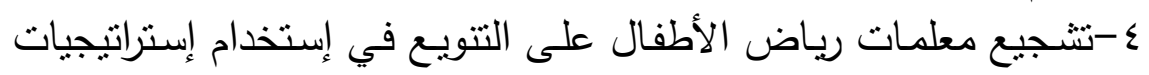

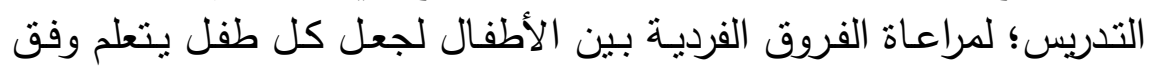
أسلوب التعلم المفضل لدي؛ه وتمكينهم من انتقاء الأنشطة التي تتناسب مع

$$
\text { قدراتهم وموا هبهم. }
$$

ه-توعية الأهل بوسائل الاهتمام بالنمو العقلي والمعرفي للطفل؛ لما لله من

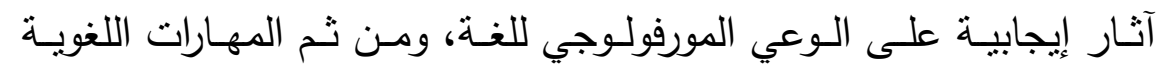

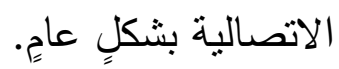

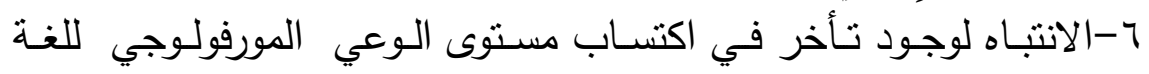
بشـكل واضـح، والاسـتعانة باختصاصـي اللغـة والكـلام حتى يـتم معالجـة المشكلة.

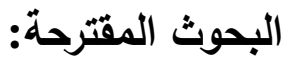

من خلال نتائج البحث الحالي اقترحت الباحثة البحوث الآثية:

ا ا-فاعليـة برنـامج قائم على إسـتراتيجية الحواس المتعددة لتنميـة المهارات المورفولوجية للغة لدى عينة من الأطفال ذوي صعوبات التعلم.

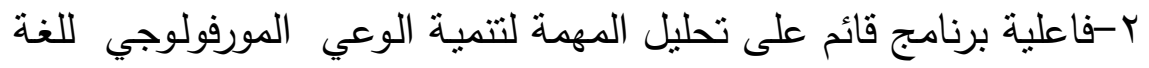
لدى عينة من أطفال ما قبل المدرسة ذوي صعوبات التعلم. ب- المهارات اللغوية الاتصالية وعلاقتها بالوعي المورفولوجي لدي لدى الأطفال في مراحل عمرية متتالية ، دراسة مقارنة بين الذكور والإناث. 
ع -فاعليـة برنـامج تدريبي قائم على إسـتراتيجية العمليـات النمائيـة السمعية

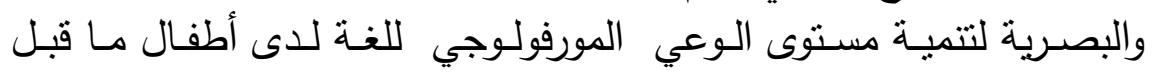
المدرسة.

0-فعاليـة برنـامج قـائم على بعض العمليـات النمائيـة ( الانتبـاه- الإدراك

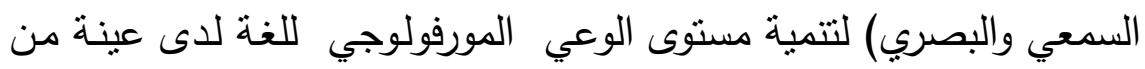
أطفال ما قبل المدرسة ذوي صعوبات التعلم.

\section{المراجن}

\section{أولاً : المراجع العريبة:}

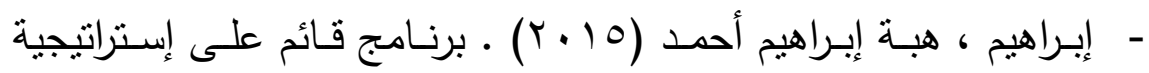
التعلم المستتد إلى الدماغ لتتمية مهارات النحو لدى طلاب المرحلة الثانوية • مجلة البحث العلدي في التربية ، ع (7 ( ) ـ كليـة التربية. جامعة عين

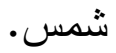

- أبو زبد، إيناس (ع ( • r). فاعلية برنامج مقترح لتدربس العلوم في ضوء نظربية التعلم القائم على المسخ لتلامبذ المرحلة الإعدادية لتنمبة التحصسبل ومهارات التفكبر الإبداعي • ( رسالة دكتوراه). كلية التربية. جامعة الفيوم. - أبو زيد، شريف مختار محمد (11 (Y). فاعلية برنـامج مقترح قائم على نظربـة السـبطرة الدماغيـة في تنمبـة بعض المهارات اللغوبـة لـدى تلامبذ المرحلة الابتدائية (رسالة ماجستير) . كلية التربية. جامعة بني سويف. 


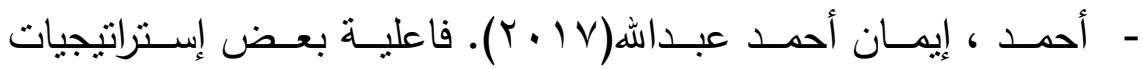
إستراتيجية التعلم المستتد إلى الدماغ في تتمبـة بعض عادات العقل والكفاءة الذاتية الأكاديمية لدى طالبات الدبلوم العام في التربية ـ مجلة كلية التربية،

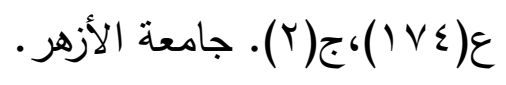

- أحمد ، سمير عبد الوهاب؛ المرسي ، محمد حسن ( ؛ ا . r). توجهات تربوبة في تعلبم اللغة العربية ـ دمياط : مكتبة نانسي.

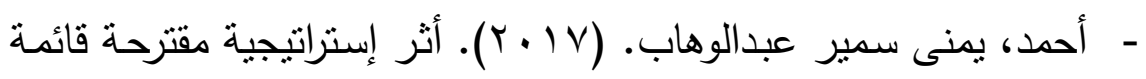
على نظربـة إستراتيجية التعلم المستتد إلى الدماغ في تتميـة عادات العقل لدى الأطفـال المتفوقين في مرحلـة ريـاض الأطفـال. مجلـة كليـة ربـاض الأطفال: جامعة بورسعيد - كلبة رياض الأطفال، ع) ا .

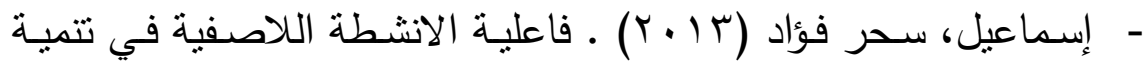
مهارات التحدث لدي طلاب الصف الثاني الإعدادي في ضوء نظريـة التعلم ذي المعنـى رابطـة التربـوبين العـرب . دراسـات عربيـة فـي التربيـة وعلـم

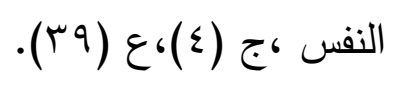

- الببلاوي، إيهاب عبد العزبز؛؛ محمد، عطبـة عطيـة؛ الأسـود، صفاء حسـن إبـراهيم (ينـاير ،9 1 ب). الـوعي المورفولـوجي وعلاقتـه بمهـارات 
القراءة لدى الأطفال المتأخرين لغويـاً ـ مجلـة التربية الخاصـة ، مـج(^)، .$(r T) \varepsilon$

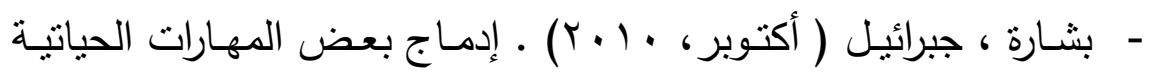
المعاصرة في مناهج التعليم ( الحوار وإكساب التلاميذ مهاراته الحياتيـة) . دراسة مقدمة لمؤتدر نحو استثمار أفضل للعلوم التربوية والنفسية في ضوء تحديات العصـر المنعقد فـي كليـة التربيـة بجامعـة دمشـق في الفترة مـن

$$
\cdot\left(r V-r_{O}\right)
$$

- البطاح ، عبداله أحمد ( r r r). أثر إستراتيجية لعب الدور في تحسين بعض مهارات الاستماع والتحدث لدى طسلاب الصف التاسـع · (رسالة دكتوراة غير منشورة) ـ كلية التربية. جامعة تبوك. - البطانية، أسـامة محمود (10 • ب). صعوبات التعلم النظرية والمعارسة.

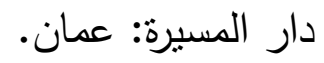

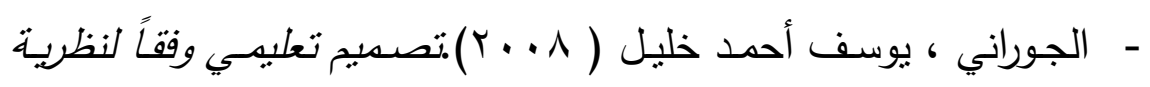
إستراتيجية التعلم المستتد إلى الدما غ وأثره على تحصبل طالبات الصف الثالث المتوسط في مادة الأحياء وتتمبية تفكبرهم العلدي .( رسالة دكتوراه غير منشورة). كلية التربية. جامعة بغداد. 
- حسين، إيمان خيرو (0 ( ب). فاعلبة برنامج تلدبيجي سدعي لفظي في اكتسـاب اللغـة لدى الأطفال زارعسي الحلـزون في مرحلـة الطفولـة المبكـة. ( رسالة ماجستثر) .كلية التربية. جامعة دمشق. - خميس، هناء أبو دية ( و . . r) • برنامج محوسب لتنمبية بعض مهارات تـدربس الاسـتماع فـي اللغــة العربية لـدى الطالبات المعلمـات فـي الكلبـة الجامعية للعلوم التطبيقية بغزة • (رسالة ماجستير غير منشورة). كلية التربية

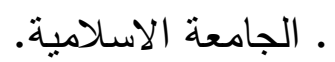

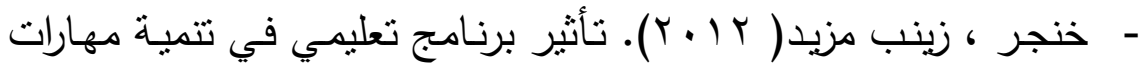
الاستماع النشط لدى أطفال الرباض، مجلة الأستاذ ،ع( ب • r). العراق.

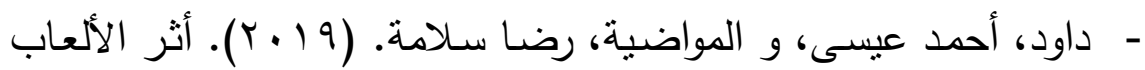
اللغوية في تحسين مهارات التواصل اللغوي للي مرحلة رياض الأطفال في الأردن. مجلـة البلقاء للبحوث والدراسـات : جامعـة عمـان الأهليـة - عمـادة 6 الدراسات العليا والبحث العلمي، مجب ك، ع - الزهيري ، حيدر عبد الكريم ( V . r). الدماغ والتفكبر : أسس نظربية واستر/تيجيات تدربسية ـ الأردن : مركز ديبونو لتعليم التفكير •

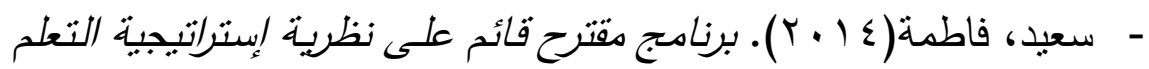
المستند إلسى الـداغ لتنمبية مهارات الفهم القرائسي الإبداعي وعادات العقل 
المنتج لدى طسلب الصف الأول الثانوي •(رسالة ماجستير). كلية التربية. جامعة أسيوط.

- السعيد، هلا( 1 • r). صعوبات التعلم بين النظربية والتطبيق والعلاج • القاهرة : مكتبة الأنجلو المصرية. - السلطي، ناديا سميع أمين ( r . . r). أثر برنامج تعليمي تعلمي مبني على نظربـة إستراتبيجية التعلم المستند إلـى الدماغ في تطسبر القدرة على التعلم الفعـال • ( رسـالة دكتوراه منشورة). كليـة الدراسـات التربويـة. جامعـة عمان العربية للاراسات العليا. - سيف الدين ، هند ( V . r). الاتصال الإنسانسي بين اللغة وحوار الجسد • مكتبة الأنجلو المصرية : القاهرة.

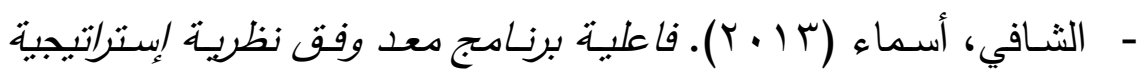
التعلم المستند إلى الدماغ في تنمبية مهارات اللغة العربية لدى تلامبذ الصف الرابع الابتدائي .( رسالة دكتوراه). كلية التربية . جامعة أسوان. - شقير ، مدلين شفيق( 1 ( ب). دراسـة المستوى الموفولوجي للغـة لدى الأطفال ذوي صعوبات التعلم الأكادبية والعادبين. ( رسالة ماجستير). كلية التربية. جامعة دمشق. 


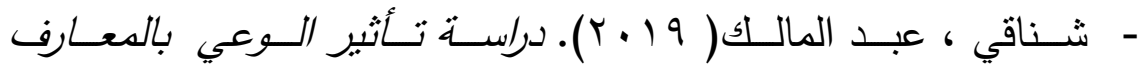
الفونولوجية والمسورا شتقاقية فـي اكتساب القراءة في اللغـة العربية ( دراسـة مقارنة بين أطفال لديهم صعوبات تعلم في القراءة وأطفال عادبين). أطروحة مقدمة ضمن متطلبات نيل شهادة دكتوراة علوم في فرع الارطوفونيا. جامعي سطبف (r) • الجزائر • - الصوالحة، علي سليمان. ( • · . ). فاعلية استخدام الكتاب الإككتروني في تنمبة المهارات اللغوبة لدى طلبة رباض الأطفال . دراسـات - العلوم التربوية: الجامعة الأردنية - عمادة البحث العلمي، مجل乏، ع广. - طعيمة ، رشدي ؛ ومناع ، محمد ( 1 ( ـ ب). تلدربس العربية في التعلبم العام نظربات وتجارب ـ دار الفكر العربي : القاهرة. - طيب، عبيد الرحمن (10 r ). ضسورة تنمبة مهارة الاستماع لمتعلمي اللغــة العربيـة : خطـوات وتقنبـات ـ الجامعـة الســلفية - دار التــأليف و

$$
\text { الترجمة . صوت الأمة ، مج (\&V) ، ع ( ) ). }
$$

- بد الباري ، ماهر ( (1 • (1). مهارات الاستماع النشط ـ دار المسيرة للنشر والتوزيع : عمان. - ان - عبد الحميد، محمد إبراهيم ، فكري ، إيمان جمال محمد ، جودة ، آيـة محمد عبد الباقي السيد (Y V · r) • برنامج مقترح في تتمية بعض مهارات 
التحـدث لـدى أطفـال الروضــة ذوي صـوبات التعلم الأكـاديمي . جامعـة بورسعيد - كلية رياض الأطفال . مجلة كلية رباض الأطفال، ع ( ( ). - عبـد الهـادي ، نبيـل؛ وأبـو حشـيش، عبـد العزبـز ؛ وبسـندي، خالـــ

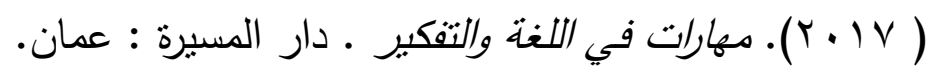
- عبدالرحمن، آيـات عبدالرحمن مصـفى؛ و المـاحي، عـوض حسـان.

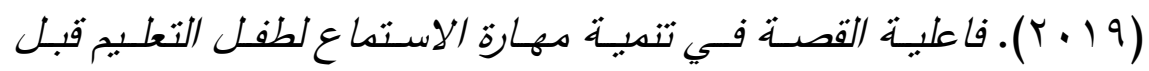
المدرسـي من وجهة نظـر المعلمـات : ولايـة الخرطوم - محليـة الخرطوم وحدة الخرطوم شرق (رسالة ماجستير غير منشورة). جامعة إفريقيا العالمية، الخرطوم.

- العـدل، عـادل محمـد ( 17 • (Y). تشـخبص وتقبيم صـعوبات التعلم . مصر : دار عالم الكتب.

- عز الدين ، سحر ( 10 ( ب).التعلم المستند للدماغ في تدربس العلوم • الأردن : مركز ديبونو لتعليم التفكير •

- علي ، نشـوة سمير ( • ( • ). فعالبة برنامج اثثرائسي في تنمبة المستوى المورفولوجي لدى أطفال ما قبل المدرسة . ( رسالة ماجستير غير منثورة). كلية التربية بالعريش. جامعة قناة السوبس. 


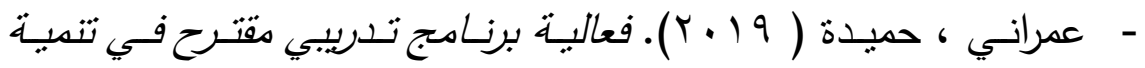
الـوعي المورفو اثـتقاقي لدى التنالمبذ المعشـبن قرائباً . ( رسـالة ماجستير غير منشورة). كلية العلوم الاجتماعية والانسانية. جامعة العربي بن مهيدي.

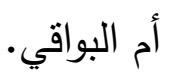

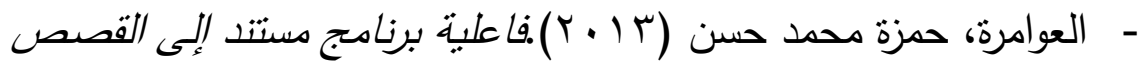
القرآنسي فحي تنمبة المهارات اللغوبية والاجتماعبة لدى عينـة من الطلبة ذوي صـعوبات التعلم. (رسـالة دكتوراه).كليـة الدراسـات العليـا. جامعـة العلـوم الإسلامية العالمية. الأردن.

- عيـادة ، عبد الـرازق محمد ( (1) أثر اسـتخدام نظريـة إسـتراتيجية التعلم المستتد إلى الدماغ في تحصيل طالبات الصف الخامس العلمي مجلة ديالس، ع (سه).

- عيسى، سامي عبد الحمبد محمد؛ و الحفناوي، أحمد محمد محمد السيد. ( ( ا . Y). أثز استخدام تلميحات الفيديو الرقمية في ضوء المعايير وحاجات الأطفال ضـعاف السـمع بمرحلـة ريـاض الأطفـال لتتميـة مهارتي الإسـتماع والتحدث لديهم. دراسـات تربوبة واجتماعبية : جامعة حلوان - كلية التربية،

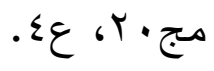




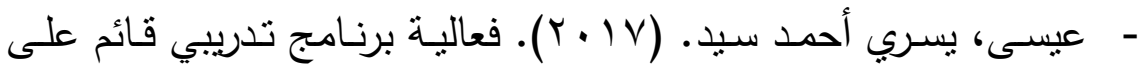
إستراتيجية التعلم المستتد إلى الدماغ لتتميـة الوعي الفونولوجي وأثره على الذاكرة السـعية لدى التلاميذ ذوي العسر القرائي. المجلـة التربوبة الدوليـة المتخصصة: دار سمات للدراسات والأبحاث، مج7، ع ا . - الغزولي ، آيـة محمد أحمد ( 9 ( ب) .فعالبة الفنون الأدائبة في تندبية مهارتى الاسـتماع والتحدث لـدى أطفـال الروضـة ذوي صـعوبات الـتعلم النمائبة • (رسالة ماجستير غير منثورة). كلية التربية النوعية.جامعة بنها. - فلاتـة، أحمـد بكـر آدم ( 10 . ب). مههـات تنمبـة مهـارات الاسـتماع والتحدث والقـراءة في أداء معلم اللغـة الإنجليزبـة . (رسـالة ماجستير غير منشورة) • جامعة أم القرى. المملكة العربية السعودية.

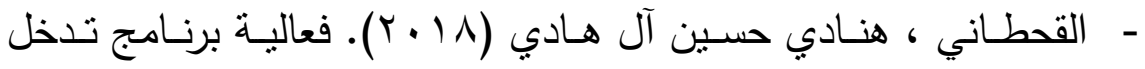
مبكر قائم على مهارات الانتباه المشترك في بعض المهارات اللغويـة لدى الأطفال ذوي الإعاقات المتعددة. مجلة كلبة التربية. جامعة الأزهر .

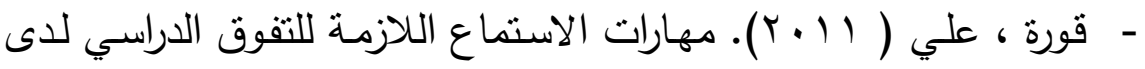
طلبة جامعة طيبة : دراسـة تحليلية، مجلة كلبة التربية و جامعة المنصسور، $\cdot(\mathrm{V} 0)^{\mathrm{r}}$ 
- القيسي، خولة عبد الوهاب عبد اللطيف؛ و الثمري، مروة صالح علوان كاظم. (1 ( • ب). مهارة التحدث لدى أطفال الرباض. مجلة البحوث التربوبة والنفسية: جامعة بغداد - مركز البحوث التربوية والنفسية، ع7ه. - محروس، محروس محمود؛ رضوان، شادية محمد الجامع عبد الحميد؛ أبـو زيـد، لمبـاء شـعبان أحمـد؛ وعبـدالقادر، محمـود هـلال عبـد الباسـط. (9 1 • (Y). فاعلية استخدام إستراتيجية "فكر ، زاوج، شـارك" في تدريس تتفيذ منهج ريـاض الأطفال المطور على تتميـة مهارات التواصل الثـفوي لدى أطفال الروضة. المجلة التربوبة: جامعة سوهاج - كلية التربية، جسا . - محمـد، إيمـان شـعبان السـيد؛ يوسـف، مـاجي وليم؛ المنسـي، محمـود عبدالحليم؛ و منتصـر ، شـادية عبدالعزيز مهتدي. (9 1 ـ ( ). تتميـة بعض العمليات المعرفية للتلاميذ ذوي صعوبات التعلم في ضوء نظرية إستراتيجية التعلم المستتد إلى الدماغ. مجلـة البحث العلمسي في التربية : جامعة عين شمس - كلية البنات للآداب والعلوم والتربية، ع. ب ج جا 1 . - مطر ، عبد الفتاح رجب علي؛ العايد، واصف محمد سـلامة. (19 ـ ب). فعالية برنامج باستخدام الحاسوب في تتمبة الوعي المورفولوجي وأثره على الذاكرة العاملـة والمهارات اللغوبـة لـدى ذوي صـعوبات تعلم القراءة. بحث 
منشور في مجلة العلوم الإنسانية والتتربوبة. العدد. (Y). المجلد.( (). جامعة الطائف. الطائف: المملكة العربية السعودية.

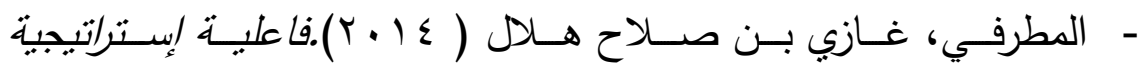
إستراتبيجية التعلم المستند إلسى الدماغ وندط السـبطرة الدماغبية في تنمبـة التفكبر الناقـ والاتجـاه نحـو مـادة العلـوم لـدى طلاب مسـاق (1). علـوم بجامعة أم القرى بالسعودية ، مجلة التربية بنها.ع (9 9) مج(1).

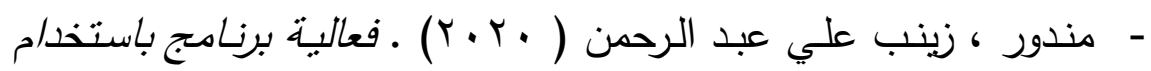
لغتة الجسد لتنمبية مهارتي الاستماع والتحدث لدى أطفال ما قبل المدستة المنبئبن بصعوبات تعلم قراءة اللغة العربية . ( رسالة دكتوراه غير منشورة). كلية التربية للطفولة المبكرة. جامعة بورسعيد. - المهتدي، ريهام محمد ؛ أبو عمر ، ريمـا أسعد ؛ الحسنات ،حسن عبد

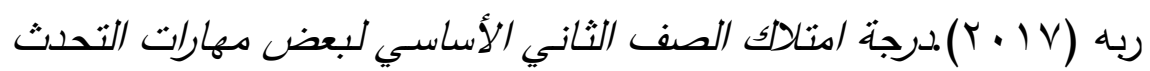
في ضوء المحتوى التعلبيسي. جامعة الحسين بن طلل للبحوث . مـ(ب) ، $\cdot(1) \varepsilon$

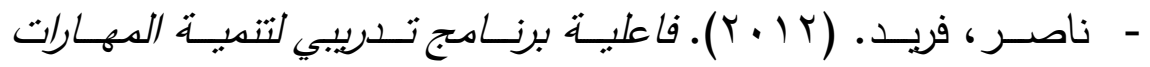
المورفولوجية والتحقق من أثره على بعض مهارات القراءة والكتابة لدى ذوي 
صعوبات التعلم بعرحلة الصف الثاني. رسالة ماجستير غير منشورة. معهد

$$
\text { البحوث والدراسات العربية. القاهرة: مصر • }
$$

- ناصري ، صافية ؛واقور، نبيلة (ب ا · ب)دور مهارة التحدث في تطوبر الكفاءة التواصلية لدى طلبة قسم اللغة العربية وآد/بها (رسالة ماجستير) . جامعة بجاية .كلية الآداب واللغات .

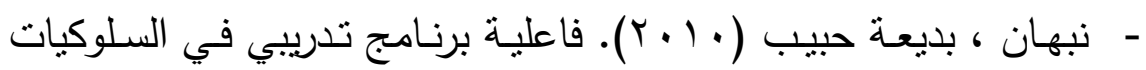
الأمنيـة لتنميـة الثقـة بـالنفس وتقدير الذات لـدى الأطفـال المعـاقين عقليً القابلين للتعلم • المجلة المصرية للدراسات النفسبة ، المجلد هب، العدد ^ج.

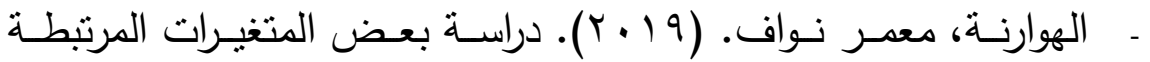
بتأخر نمـو المكون المورفولوجي للغـة لـى أطفال الروضــة: دراسـة حالـة. المجلة الأردنية في العلوم التربوبة: جامعة البرموك - عمادة البحث العلمي،

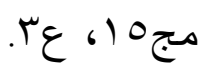

\section{ثانيًا: المراجع الأجنبية:}

- Al ghazal, S. (2005). In the Arabian movement system. Tunisia: The Tunisian University Annuals.

- Al-Hawarneh, M. (2010). Children language and communication disorder. The phenomenon and the cure. 
Damascus, Ministry of Culture: The Syria Public Organization for Books.

- Anna J., \& Julia, C. (2015) .Early predictors of phonological and morphological awareness and the link with reading: Evidence from children with different patterns of early deficit. Applied Psycholinguistics. 36(3), 509-531.

- Ashour. Rateb and Al-Hawamdeh, Mohammed (2010). Methods of teaching Arabic language: between theory and practice. (3), Jordan,Amman: Dar Al-Masirah for Publishing, Distribution and Printing

- Cloutier, G. (2002). Phonemic perception, receptive morphology and productive morphology skills of speech delayed preschoolers, The University of Calgary.

- comprehension. US National Library of Medicine National Institutes of Health. 29. 1269. 1288

- Cristial, D. (2010) . linguistics definition, 1s ed, Alexandria: the Egyptian Book Organization Publications.

- Eva .pp(2010). Brain - based learning theory the incorporation of of Movement to increase the learning of grammar by high school students, PHD, Liberty :at available , 2013/3/15: IN VISITED 
cgi.viewcontent/cgi/edu.liberty.digitalcommons://http PM 15:5: AT.

- Funderstanding. (2011) . Brain-based Learning, available on line at : http:// www. Funderstanding .com/theory/brain-basedlearning/brain-based-learning/ . (Accessed 8 Octopar, 2014) .

- Jensen, E. (2007). Introduction to brain - compatible learning (2nd ed). California: Crowin Press.

- Journal of Education, 144 (7), 21-30.

- Kandari, Abdullah (2010). Teaching reading according to American nternational standards for teaching languages in Kuwait

- Laxman, K., \& Chin, Y. K. (2010). Brain-Based Education: Its Pedagogical Implications and Research Relevance. Journal On Educational Psychology, 4(2), 15.

- Lombardi ,j( 2011).positive effects of brain-based education on teacher performance assessment outcomes., education as change,dec,v.15,i.2,pp225-238.

- Lukacs,A; Leonard,L., \& Kas,B.(2010). Use of noun morphology by children with language impairment: the case of Hungarian. international journal of language \& Communication Disorders .45(2),145-161. 
- Lyster, S.; Alma, L.; A. \& Hulme, C. (2016).Preschool morphological training produces long- term improvements in reading comprehension. US National Library of Medicine National Institutes of Health. 29. 1269. 1288

- Pasquarella, A.; Chen, X.; Lam, K.; Luo, Y. \& Ramirez, G. (2011). Cross-language transfer of morphological awareness in Chinese- English bilinguals. Journal of Research in Reading. 34(1), 23-42..

- Pittas, Evdokia., \& Nunes, Terezinha (2014). The relation between morphological awareness and reading and spelling in Greek: A longitudinal study. Reading and Writing.27(8), 1507-1527.

- Ream, G., and Devin,K.(2015).Orthographic phonological, and morphological skills and children's word reading in Arabic: A literature review.

- Spears, W. (2002). Brain-Based Learning. Hilghlights.

- Vanes ,f(2011).mathematics education and neurosciences ;towards interdisciplinary insights into the development of young children's mathematical abilities., educational philosophy and theory,v,43,n.1,p75-81. 
أثثر برنامج في الرياضة الدماغية في تحسين كفاءة الإنجاز

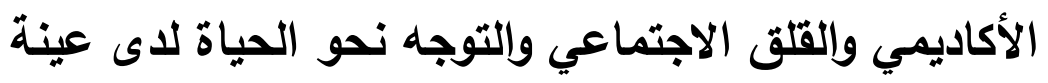

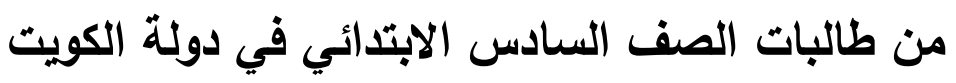

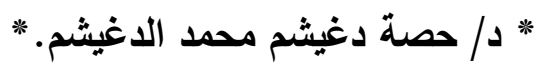

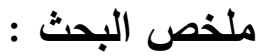

هدف البحث الحسالي إلى التحقق مـن فاعليـة وتأثثر برنـامج الرياضــة

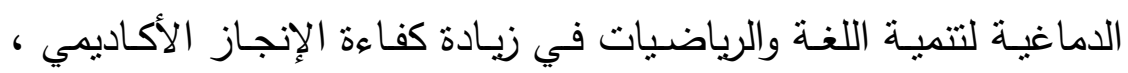

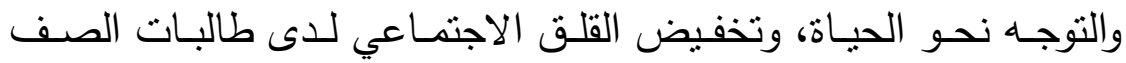

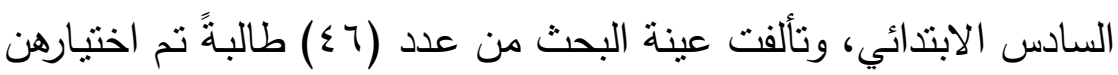

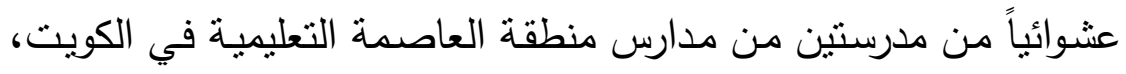

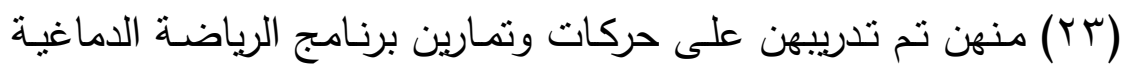
في إحدى المدارس كمجموعة تجريبية، و (Yr) طالبةً منهن لم يتم تدريبهن

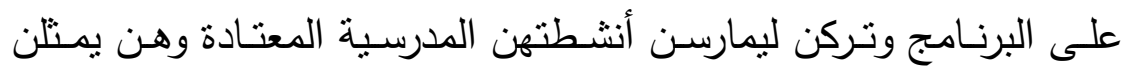

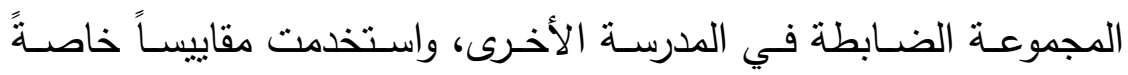

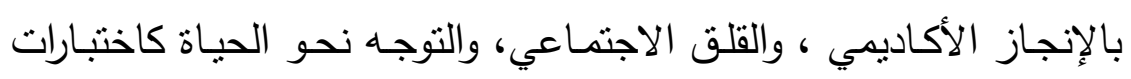

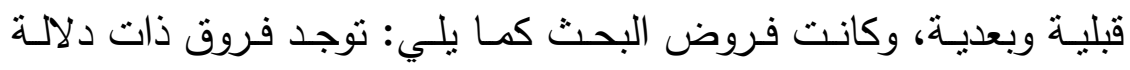

* أستاذ مشارك بقسم علم النفس - كلية التربية الأساسية (بنات) - الهيئة العامة للتعليم

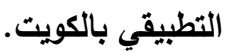


إحصائية بين المجموعة التجريبية والمجموعة الضابطة في القياس البعدي

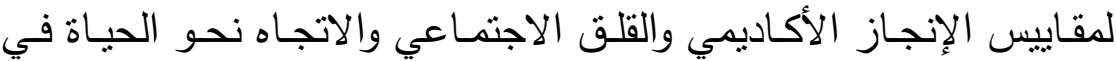
الاتجـاه الأفضل للعينـة التجريبيـة، توجد فروق ذات دلالــة إحصـائية بين الإني القياس القبلي والقياس البعدي للمجموعة التجريبية على مقاييس الإنجاز

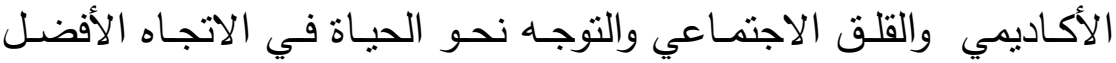
لصـالح القياس البعدي، توجد فروق ذات دلالـة إحصـائية بـين درجـات

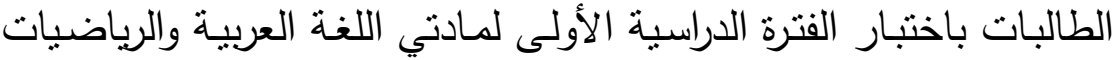
(قبل تطبيق البرنامج) وبين درجاتهن في الفترة الدراسية الثانية (بعد تطبيق

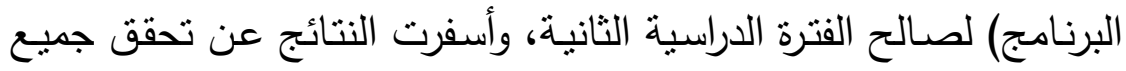
فروض البحث لصالح المجموعة التجريبية.

The effect of a program on cerebral sports in improving the efficiency of academic achievement, social anxiety and orientation towards life among a sample of sixth grade female students in the State of Kuwait.

Prepare: Dr / Hessa Dugishem Mohammad El-Dughaishem. *

\section{Abstract:}

The aim of the current research was to investigate the effectiveness and effect of the Brain Gym program on the development of language and mathematics in increasing

* Associate Professor of Psychology Department, Faculty of Basic Education (Girls) - Public Authority for Applied Education. 
the efficiency of academic achievement, life orientation and reducing the social anxiety of sixth graders. The sample consisted of (46) randomly selected students (23) of them were trained in the movements and exercises of the brain exercise program in one of the schools as a pilot group, and (23) of them from the other school were not trained in the program and were left to practice their usual school activities which named the control group. The researcher used, social anxiety, and orientation towards life, and academic achievement measurements as pre-test and post-tests. The research hypotheses was; there were statistically significant differences between the experimental group and the control group in the postmeasurement of measures of academic achievement and social anxiety, and the trend towards life in the best direction of the experimental sample. There are statistically significant differences between the premeasurement and the post-measurement of the experimental group on the measures of academic achievement, social anxiety and orientation toward life in the best direction for the benefit of post-test measurements. There were statistically significant differences between the grades of female students in the first period of research in Arabic and Mathematics (before applying the program) and their grades in the second period (after application of the program) for the second term. The results yielded all the hypotheses for the experimental group. 


\section{الكلمات المفتاحية Keywords:}

Cerebral sports

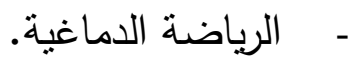

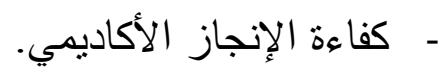

The efficiency of academic achievement

Social anxiety

$$
\text { - - - القلق الاجتماعي. }
$$

- - طالبات الصف السادس الابتدائي.

Sixth grade female students

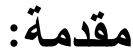

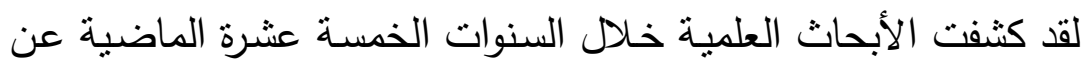
الكثير من أسرار الدماغ البشري، وأدت هذه المعلومات إلى إلى تغييراتٍ مذهلةٍ

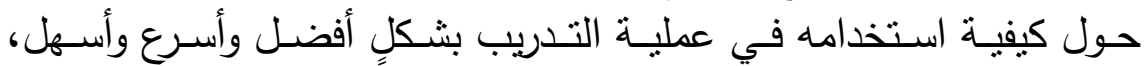
وتعالت الصـيحات التربويـة لإعـادة النظـر في محتـوى العمليـة التدريبيـة

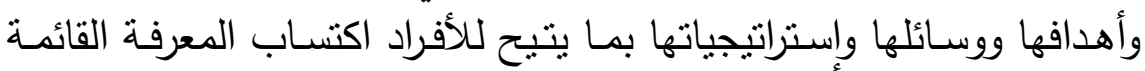

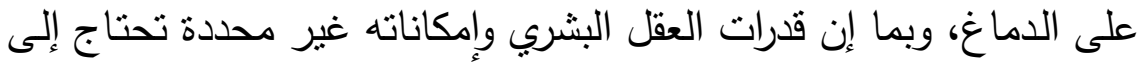

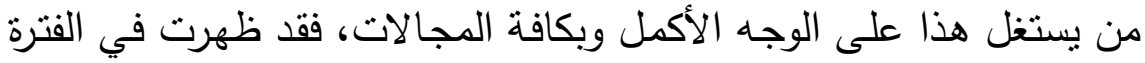

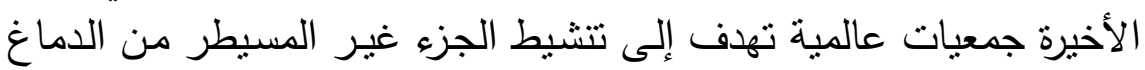

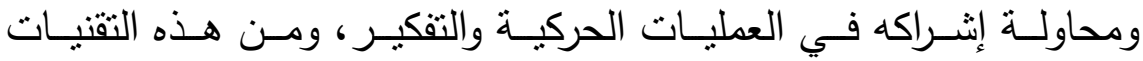

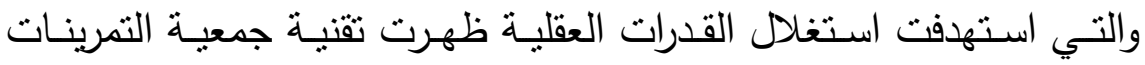

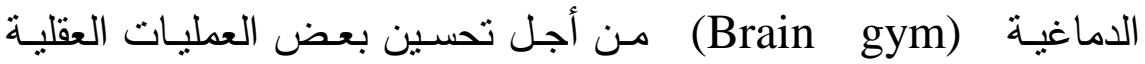
والتحصيل الأكاديمي والأداء الحركي، فالطالب الذي يستطيع أنس أن يستخدم

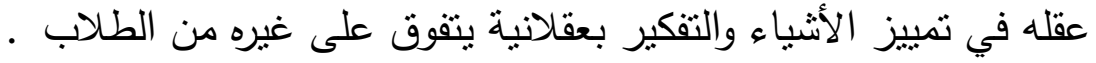


وبـرى "بـاهي"، و "جـاد" "أن التدربب العقلي يمكن الجهاز العصبي مـن تسجيل الأنماط الحركية والحسية ويساعده على التركيز وإعادة تتظيم صور الأداء، كما يؤكد بعض العلماء على أن التذريب له تأثير واضـح في التغلب التبل

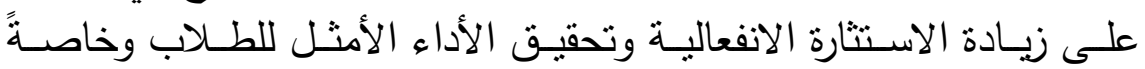

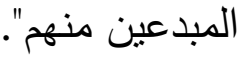

وبشـير كلّ مسن " حسـين"، و " العنبكي" إلـى "أن مركز الدقـة وسـرعة الاســتجابة في المــخ هـي المنطقة السادسـة التي تتطلـق منهـا الإثـارات

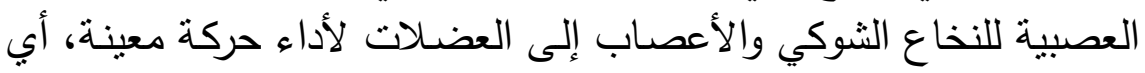

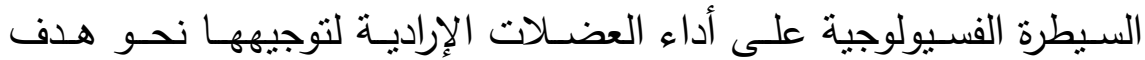

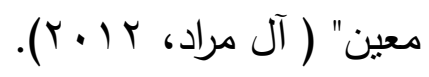

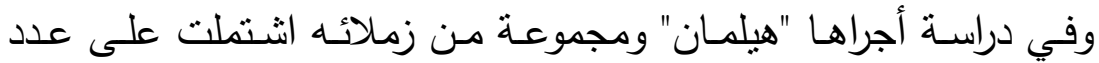

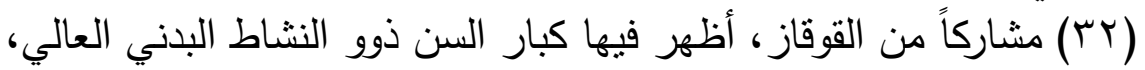
والمعتدل زيادة في التحكم الإدراكي مقارنةً بأولئك البالغين غير النشطين في

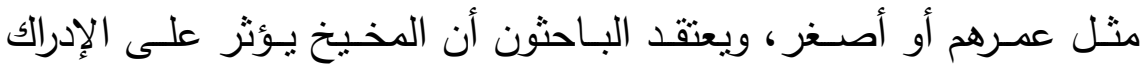

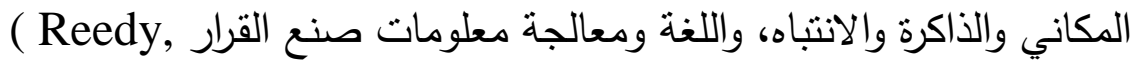

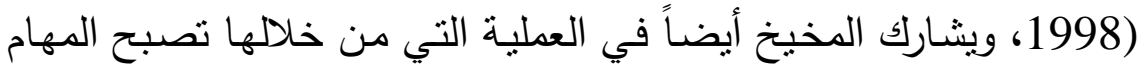
الجديـدة عند الممارسـة تلقائبـة، حيـث أن ممارسـة الحركـات بشـكلٍ متتـابع تؤدي مع مرور الوقت إلى تحسين الأداء الحركي بشكلٍ أدق وأسرع. ويرتبطاً

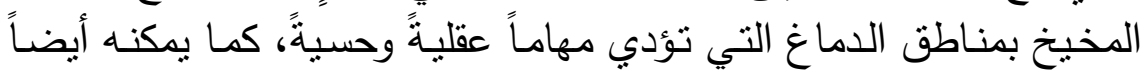
التحكم في المهارات العقلية والحسية (Leiner \& Leiner, 1997) . وقد تمكن العديد من الباحثين في دراسـاتهم من الحصـول على نتائجٍ

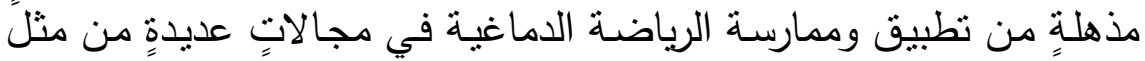
التعليم وفرط الحركة، وبطيئي التعلم، وصسعوبات التعلم وعلاقتها بالبرمجة 


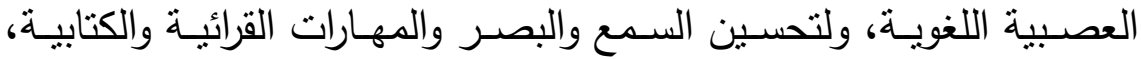
ولزيادة كفاءة المهارات الدراسية والاجتماعية، والتحصبل الدراسي، ومنها ما والهي هو تجريبي أو شبه تجريبي، أو وصفي، أو ارتباطي وهي ما يلي؛ ولأيك ( Spalding, J. (1999), Koelman, A. (1997), Sifft, J. M., \& Khalsa, G.C.K (1991), Khalsa, G.C.K., Morris, D., \& Sifft J. M., (1988), Khalsa, G.C.K. \& Sifft, J. M., (1987), Diamond, S. J. (2001) ).

وعلى هذا الأسـاس فإن الاهتمام بالبرامج الحركية في هذه المرحلة تعد من المقومات المهمة والأساسية؛؛ لما تقدمه من قاعدةٍ عربضـة لبناء وتطوير العناصر والقدرات والاستعدادات لدى الطالب.

وقد رأت الباحثة أن الدراسـات تلك قد اهتمـت بجوانـب تتمبـة المهارات الحسية المختلفة كالسمع والبصر والمهارات الكتابية والقرائية وركزت بشكلٍ خاصٍ على تتمية التحصيل الدراسي وبعض المهارات الاجتماعية، وأغفلت الكثير من الجوانب النفسية التي لها أهمية كبيرة في توافق الفرد شخصياً واجتماعياً مع البيئة التي يعيش فيها، وأنها قد تتأثز وتتحسن بتطبيق برنامج

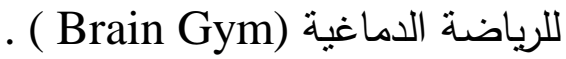

وقد تمكن الأمريكي " دينسـون" المختص في التربيـة الحسية الحركيـة وزوجته "جيل دينسون(Dennison Paul Dennison, Gail) " ، من دن تأسيس تقنية"Brain Gym" أو الرياضة الدماغية والتي اعتمدت منذ ذلك الحين إلى الآن في علاج الاضطرابات السلوكية والانفعالية التي تؤدي إلى في صعوبات في التعلم في أمربكا. ويقول " دينسون"؛ Dennison ، أنه إذا كانت التربية البدنية توقظ الدماغ، فإن حركات الرياضـة الدماغية؛ Brain

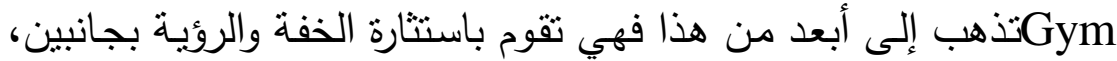
والتآزر والتتاسق بين اليدين - والعينين التي تؤهل لنجاح الطالب، كما تتمي لتهي 
العمليـات العقليـة كالتركيز والانتبـاه والتفكير والتذكر والإبداع ...إلـخ. (Dennison, P., \& Dennison, G., 2010)

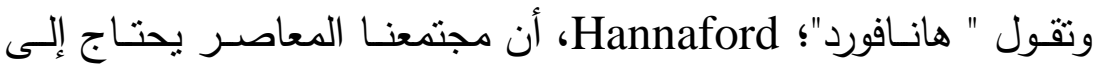
وسائل بسيطة، سهلة وأنيقة للقيام ببعض العمليات، وهو ذاته بالنسبة لعملية التعليم التي تتطلب منسا الإدراك الحسي، والإدمـاج، والاستيعاب والفعل. فتقنية الرياضة الدماغية Brain Gym تسهل هذه المتطلبات بتتشيط النظام النفس فيزيولوجي، وتهيؤه للتعلم بفضل حركات بسيطة وسهلة التطبيق، وهذه

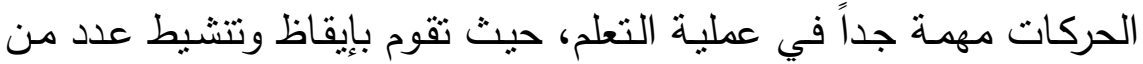

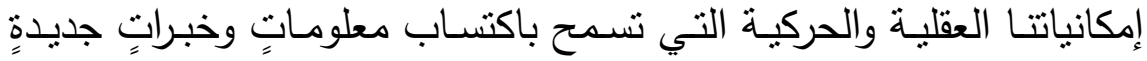
لنظامنا النووي (Hannaford, C., 1998).

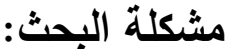

ومن العرض السابق، تتضح مشكلة البحث في الإجابة على الأسئلة التالية: ا -هل يؤدي التدريب على برنامج الرياضـة الدماغية إلى تحسين الإنجاز

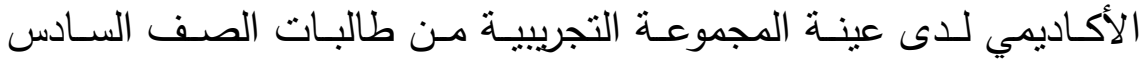
الابتدائي ؟ الأبي

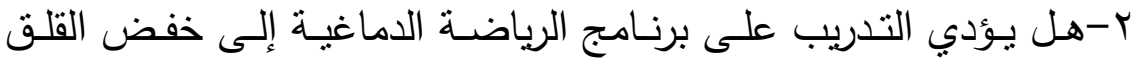

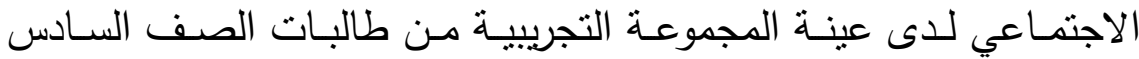
الابتدائي ؟ الاجئ

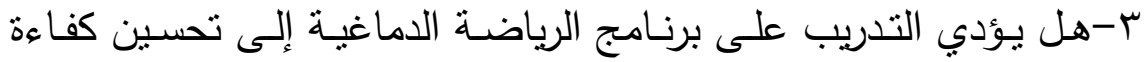

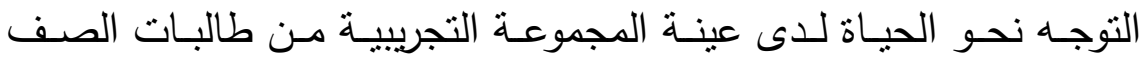

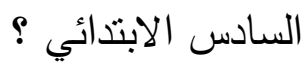


ـ-هـل يـؤدي التـدريب على برنـامج الرياضــة الدماغيـة إلـى زيـادة كفـاءة

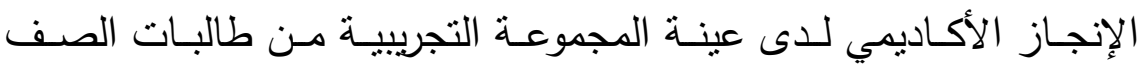

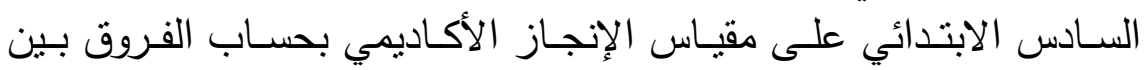

$$
\text { الاختبارين القبلي والبعدي؟ }
$$

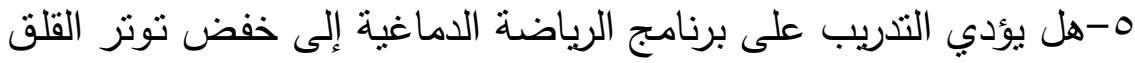

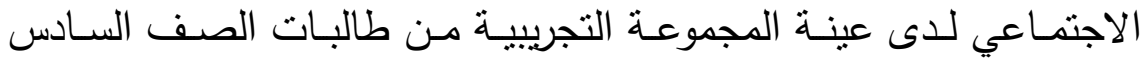
الابتدائي على مقياس القلق الاجتمـاعي بحسـاب الفروق بين الاختبـارين

$$
\text { القبلي والبعدي ؟ الأبي }
$$

צ-هل يؤدي التدريب على برنامج الرياضة الدماغية إلى زيادة كفاءة التوجه

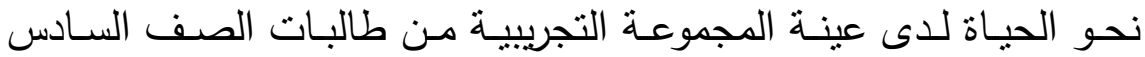
الابتدائي على مقياس التوجـه نحو الحياة بحسـاب الفروق بين الاختبارين

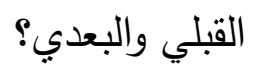

V- الهل يؤدي التدريب على برنامج الرياضـة الدماغية إلى ارتفاع التحصيل

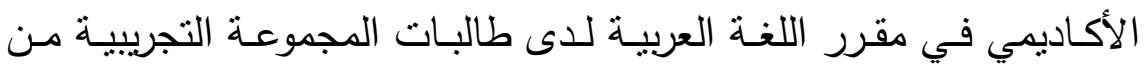

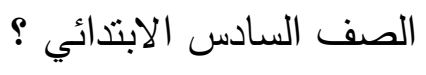

1- هل يؤدي التدريب على برنامج الرياضـة الدماغية إلى ارتفاع التحصيل

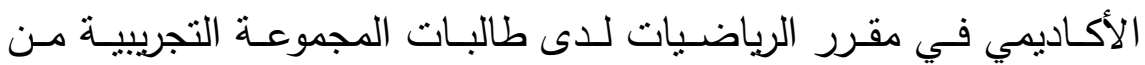

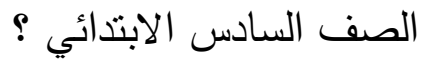

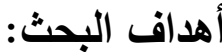

\section{يهدف البحث الحالي إلى ما يلي:}

1-التحقق من كفاءة برنامج في الرياضة الدماغية على تتمية مهاراتٍ عامةٍ

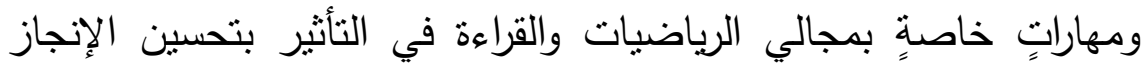


الأكاديمي لطالبات الصف السادس الابتدائي، وتوجهـن نحو الحياة، وخفض القلق الاجتماعي لديهن. r-التأكيد على أهمية برامج الرياضة الدئي لادهاغية في مجالاتٍ متعددةٍ لم يكن يتوقع تأثيرها عليها.

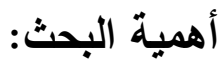

• أولاً : الأهمية النظرية:

ا - يستمد البحث أهميته من أهمية العلاقة الترابطية بين الدماغ وأعضاء الهياء

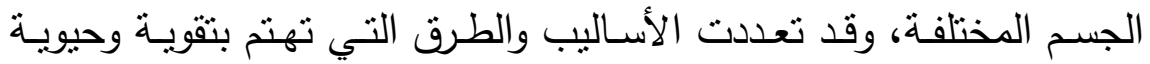

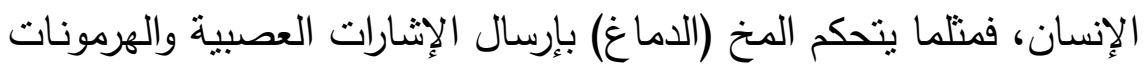

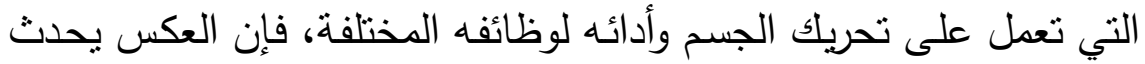

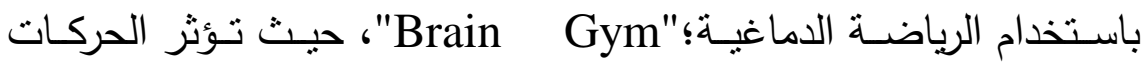
الجسمية بأسـاليبٍ معينةٍ على أداء الدماغ، وتزيدِ من فعاليته في مجالات نشاطه المختلفة.

ب-توجيه اهتمام المسؤولين والمرتمين بأهمية الرياضة الدماغية؛ Brain"

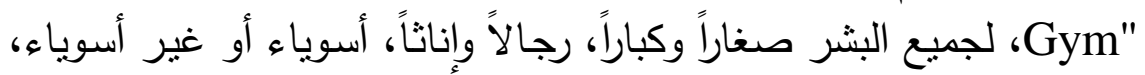

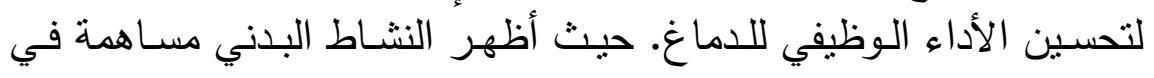

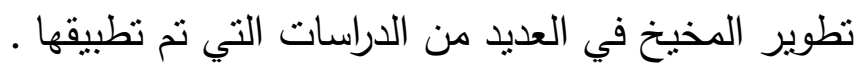
• • ثانياً: الأهمية التطبيقية: وتتمثل الأهمية التطبيقية للبحث فيما يلي:

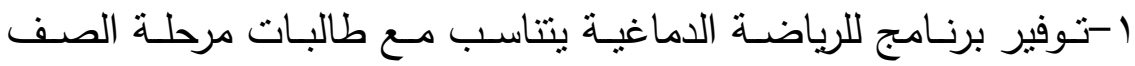

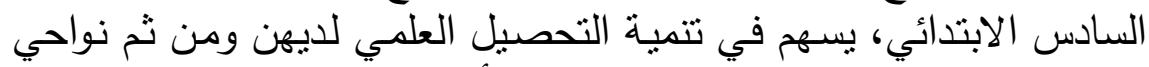
خفض القلق الاجتماعي، وارتفاع الإنجاز الأكاديمي، والاتجاه نحو الحياة. 
ب-تصميم وإعداد برامج منوعة وهادفة في الرياضـة الدماغية نتتاسب مـع منطلبات التتمية وتحسين الأداء في المجالات المختلفة، ولفئاتٍ متعددةٍ من فن

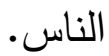

\section{حدود البحث:}

-الحدود البشرية: طالبات الصف السادس الابتدائي ممن تتراوح أعمارهن

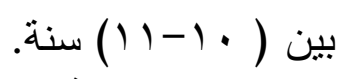

-الحدود المكانية: مدرسة الفيحاء المشتركة للبنات في منطقة الفيحاء، ومدرسة "سعدى بنت عوف" الابتدائية للبنات في منطقة النزهة التابعتين لمنطقة العاصمة التعليمية. -الحدود الزمانية: مدة ^ أسابيع، وتم إضافة أسبوعين آخرين بتكرار التمارين والتدريبات. مصطلحات البحث: ومما سبق تتضح مفاهيم ومصطلحات البحث كما يلي:

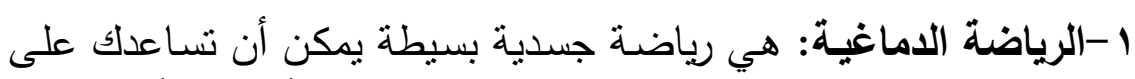
تعلم أي شيء بشكلٍ أسرع وأكثر سهولة ولكن أكثر تركيزاً وتتظيماً .

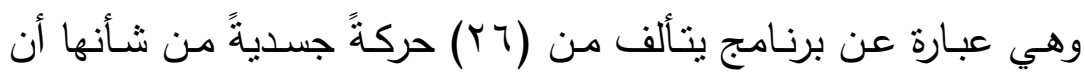

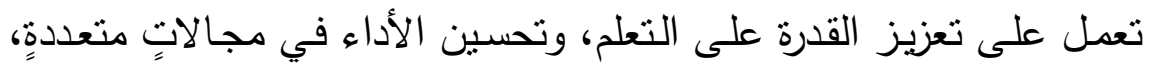

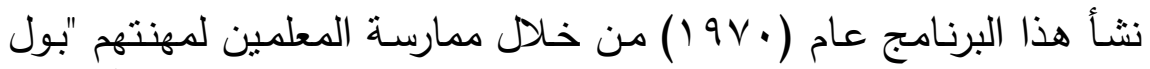

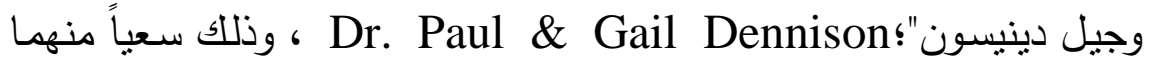

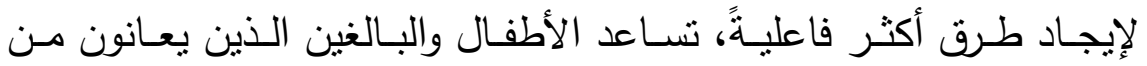

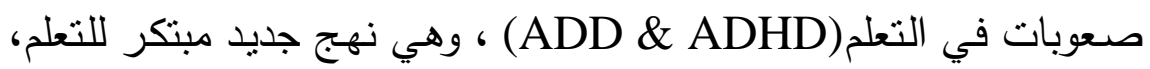
تم استخلاصها من البحوث الواسعة للمتخصصين في التتمية، والتي نركز 
على الدور الذي تلعبه حركات الجسد في تعزبز قدرات التعلم، وقد حصلت فم فمات الرياضة الدماغية على قبول وامتتان في جميع أنحاء العالم، وتُشتخدم الآن في كثيـرٍ مـن دول العـالم، وتُدرس في آلافٍ مـن المـدارس وفي مجـالاتٍ متتوعةٍ منّ؛ الفنون الأدائية والمسرحيات، وألعاب القوى، وحتى في المجال الصناعي إذ يحقق سهولة الوصول إلى مستوباتٍ جديدةٍ من التميز • وتنتابه

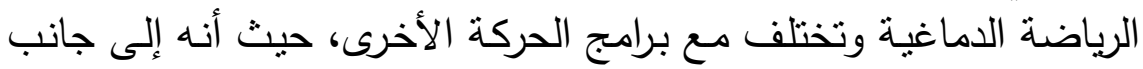

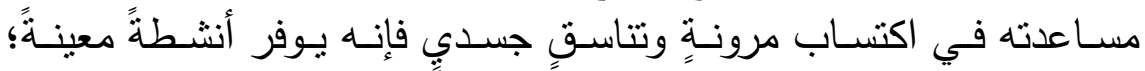

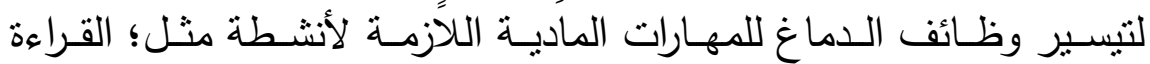
والكتابة والإمحلاء ( Spaulding, et al., 2010) (

وتعرف الباحثة الرياضـة الاماغيـة إجرائيـاً بأنهـا: مجموعة الأنشطة والأداءات والحركـات الجسـدية، التي تعمـل على تنشـيط وتحسـين الأداء المطلوب في المتغيرات التابعة في البحث الحالي (الإنجاز الأكاديمي، القلق الاجتماعي، والتوجه نحو الحياة)، وكذلك التحصيل الأكاديمي. r-الإنجاز الأكاديمي أ. ويُقصــ بـه رغبـة الطالب في إنجـاز مهامـهـ الدراسـية على الرغم مـن العوائق التي يواجهها (سالم، 9 . . ب). ب. وهو استعداد الفرد للسعي في سبيل تحقيق التفوق والاقتراب من النجاح

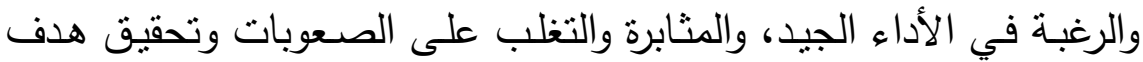
معين في مواقف تتضمن مستويات من التميز ( جواد، 1 ( • ب).

وتعرفـه الباحثـة إجرائيـاً بأنــهـ: مجمـوع الـدرجات التي تحصـل عليهـا المستجيبة نتيجة إجابتها على فقرات المقياس الإنجاز الأكاديمي في البحث الحالي. 


\section{ب-القلق الاجتماعي :}

أثـارت " جمـال "، 99 V بـأن القلت الاجتمــاعي هـو: وصـف لحالـة مرضية تتكون من شعور بالقلق والتوتز في المناسبات الاجتماعية أو عند هـون التعرض للتركيز من قبل مجموعة من الناس كالاضطرار لإلقاء كلمة أمام

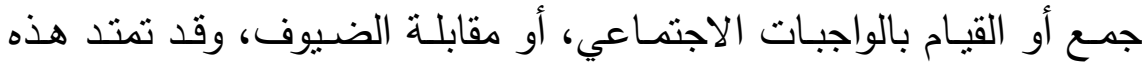

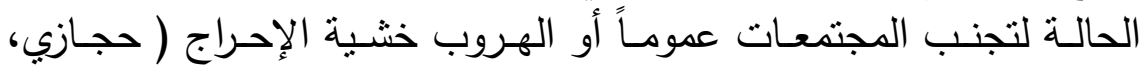

$$
\cdot(r \cdot 1)
$$

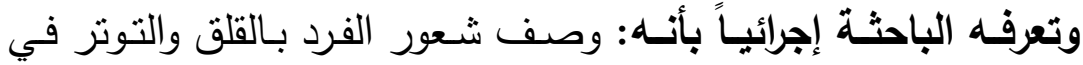
المواقف والمناسبات الاجتماعية المختلفة، وبعبر عنها بالدرجة الكلية التي بـاني سيحصل عليها المستجيب على مقياس القلق الاجتماعي.

$$
\text { ع -التوجه نحو الحياة: }
$$

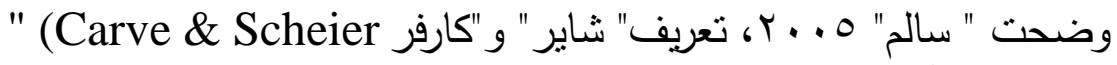

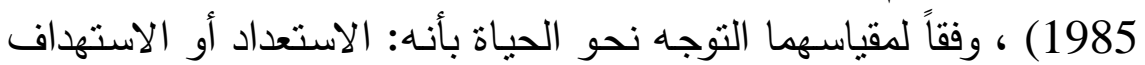

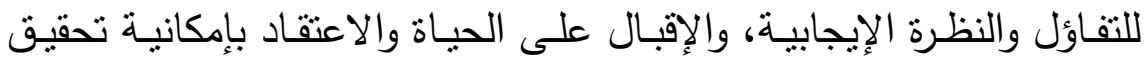

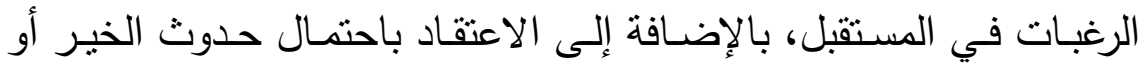
الجانب الجيد من الأثياء بدلاً من حدوث الثر أو الجانب السيء.

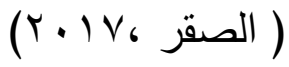

وعرفـه "جابر" و "كفـافي" بو99 أنـه: اتجـاه إزاء الحيـاة أو إزاء أحداث

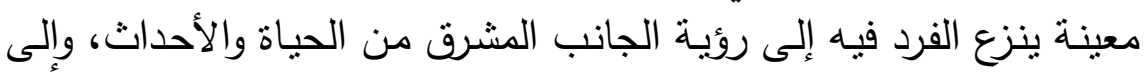

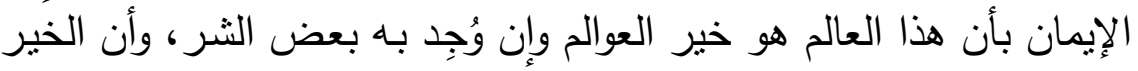

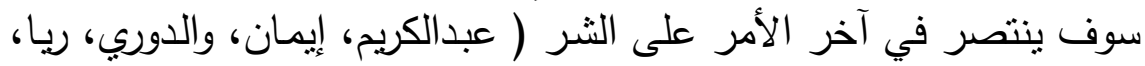

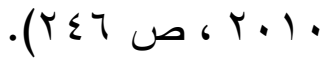




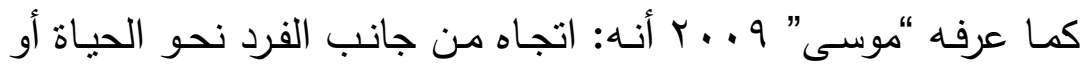

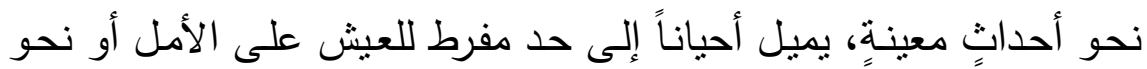

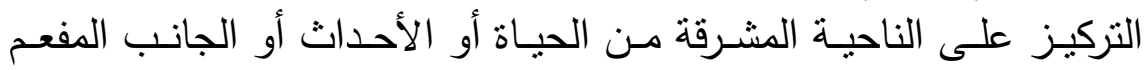
بالأمل والخير .

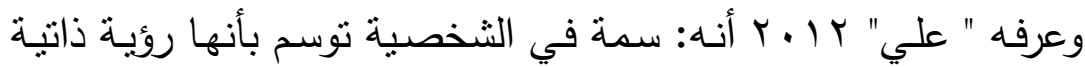
إيجابية واستعداد كامن لدى الفرد - غير محدودة بشروط معينة - يمكنه

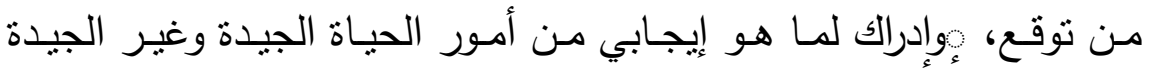

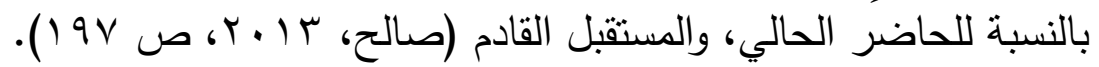
وتعرفه الباحثة إجرائياً بأنه : التوقع العام للفرد لحدوث أثنياء أو أحداث

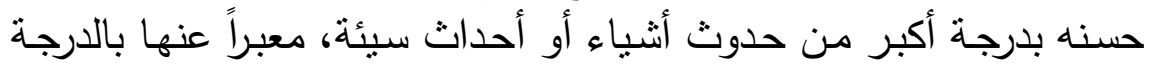
الكلية التي سيحصل عليها المستجيب على مقياس التوجه نحو الحياة. ه-طالبات الصف السادس الابتدائي: يُقصد بهم الطالبات المقيدات بالصف السادس الابتدائي للعام الجامعي

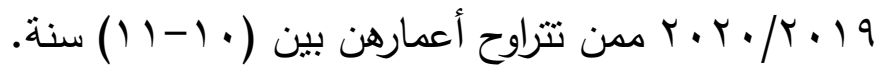
: الإطار النظري : لمحة تاريخية عن تقنية الرياضة الاماغية Brain Gym

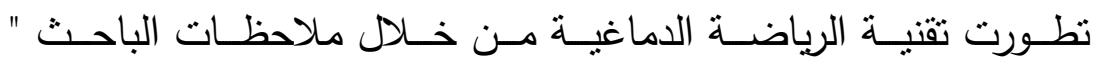

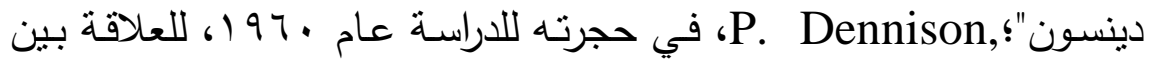

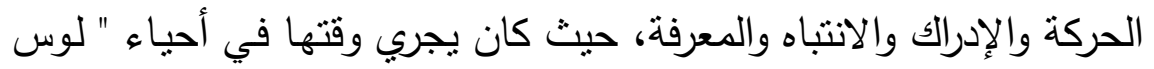

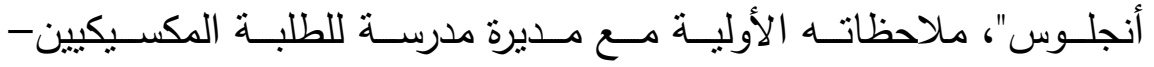

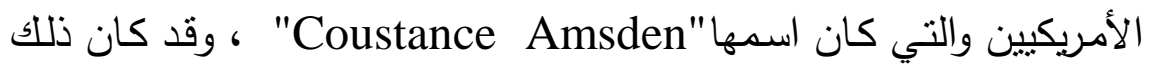


المشروع يهدف إلى تسهيل عملية التعلم والقراءة بتطوير الكفاءات الحسية

وقد نشرت وبينت بعض الأبحاث المتعلقة بثقنية " الرياضـة الدماغية"؛

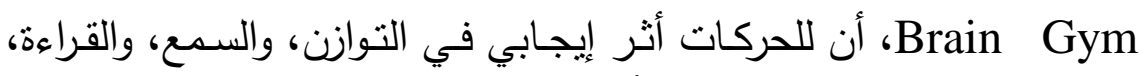

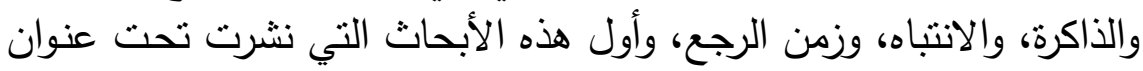

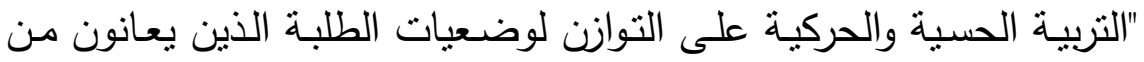

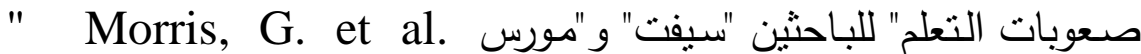
(1988)، حيث تتاولت هذه الأبحاث إحصائيات دالة حول المتعلمين الذين يجدون صعوبات وحسنّوا إمكانياتهم في الوقوف بتوازنٍ على رجلٍ واحدةٍ بعد "(Dennison, P., تطبيق بانتظام بعض نشاطات تقنية" الرياضة الدماغية \& Dennison, G., 2010, 24).

استتد برنامج الرياضة الدماغية؛ Brain Gym على أسسٍ نظريةٍ هي ما ها

أ. إعادة التغير العصبي.

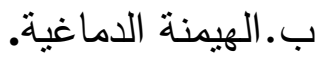
ج. التدريب على الإدراك الحركي.

ورغم وجود تداخل بين هذه النظريات إلا أنه تم تصنيفها حسب أكثر مميزاتها بروزاً؛ لتوفير درجة من البنية المرجعية وهي مده ما يلي: أ. نظرية إعادة التغير العصبي:

يعتبر التغير العصبي هو الافتراض الأساسي للرياضـة الدماغية؛ Gym

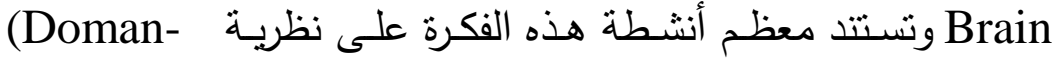

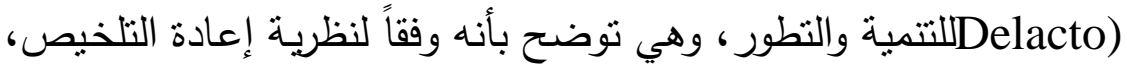


فإن التكوين الجيني يلخص التطور ، بمعنى أن تطور الفرد يعكس تطور النوع (Crain,2000). وبالتالي فإنه لتحقيق التتمية العصبية الفعالة يجب على الفرد اكتسـاب مهارات حركية محددة بشكلٍ كافٍ خلال مراحل النمو

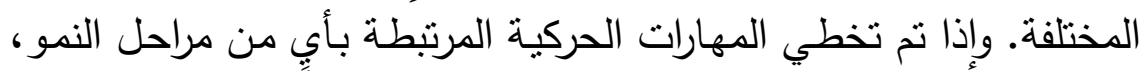
فسيؤدي ذلك إلى إعاقة التطور العصبي وتصبح قدرات التعلم محدودةً. ووفقاً ل "دومان"؛(Doman (1968) ، فإن الطفل الذي يسبر فبل فيل أن يحبو

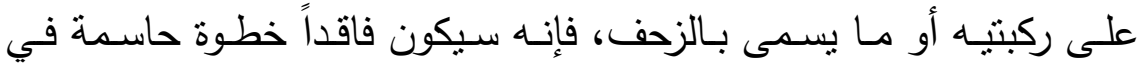
التطور الحركي، مما سيؤدي إلى صعوبات مستقبلية في العمليات العصبية

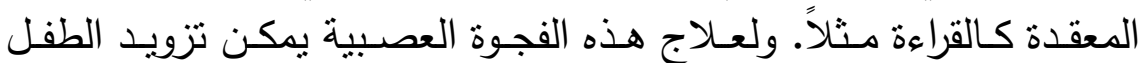
بتمـارين تحـاكي حركات النمـو النمائية البدائيـة لضـمان إتقان الحركات في

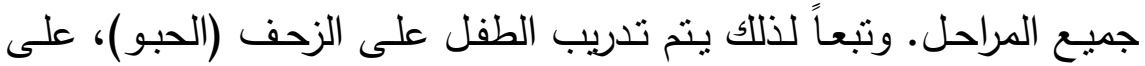
اعتبار الفكرة أن هذا من شأنه سيغير الخلايبا العصبية مما سيجعل الطفل

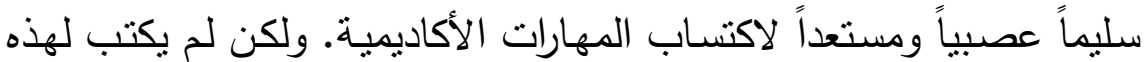
النظرية النجاح فقد فثلت في تلبية صعوبات البحث العلمي، ولم تقبل من العديد من الجهات المتخصصة في طب الأطفال وإعادة التأهيل . ب. نظرية الهيمنة الدماغية:

لاحظ "دينسن" وزوجته؛(1994) Dennison \& Dennison ( أن

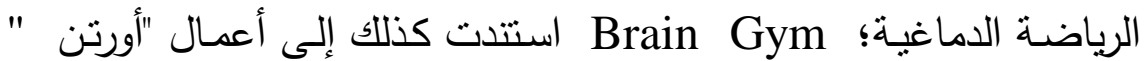

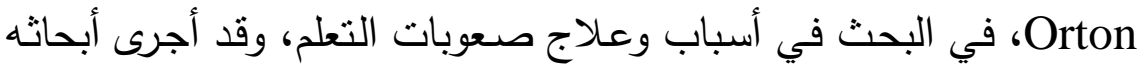
في أوائل القرن العشرين، وأوضح في نظريته أن الهيمنة الدماغية المختلطة بمعني هيمنة نصف الكرة الأيسر للاماغ على النصف الأيمن أو العكس،

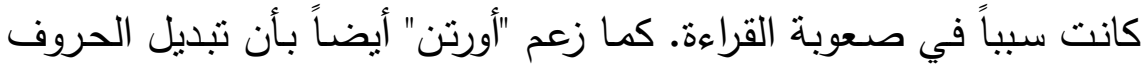
وعكسها بشير إلى وجود مشـاكل في الهيمنـة الدماغيـة وتشير إلى مشـاكل رونل 
التعلم. وهذا النهج، كمـا وصـفه "شـيفيلد"، (199 1) هو في الواقع فلسـة

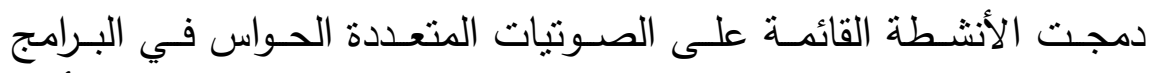
التعليمية، ولكنها ليست استراتيجية محددة، ومع ذلك لم يثبت البحث تأثنر

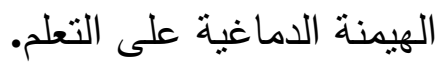

ج. نظرية الإدراك الحسي- التدريبات على الحركات: وهو أسلوب تعليمي يعزو مشـاكل التعلم على التكامل غير الفعال لأي الإني

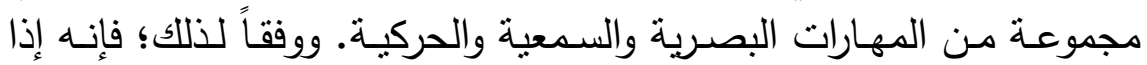

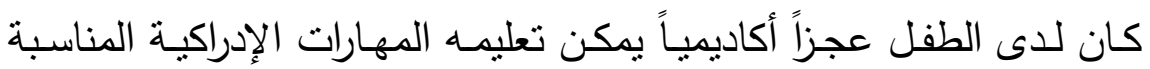

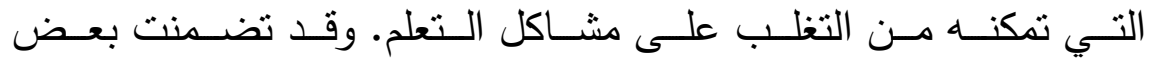
الإسـتراتيجيات المسـتخدمة لتحسـين المهـارات الحركيـة الإدراكيـة المزعومـة فهـة وتحسين التعلم باستخدام أنشطة مثل الزحف والكرات المرتدة، ورمي أكياس القماش المملوءة بالحبوب، والمشي على عارضة التوازن الخشبية، وقد تمكن

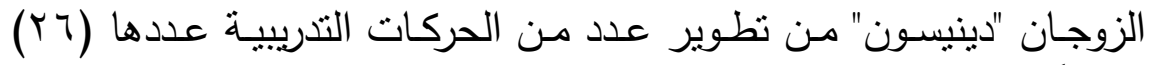
تدربياً لأجـل رفع كفـاءة وتحسـين العديــ مـن تلك الأغـراض المختلفــة. (Hyatt,K.J.2007)

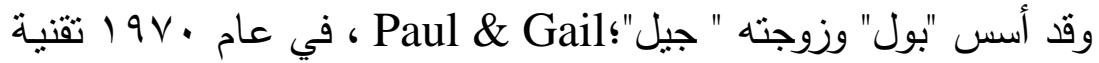

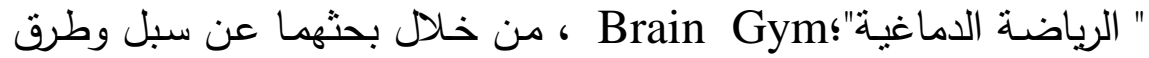

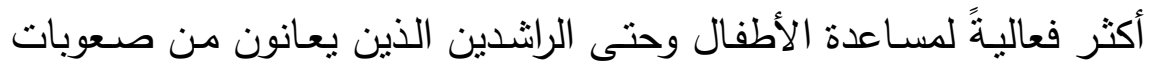

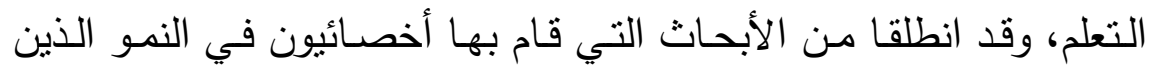
حاولوا استعمال الحركة لتحسين إمكانيات التعلم، وقد نجحا في تأسبس هذه الته التقنية التي تُطبق الآن في الكثير من بلدان العالم وكان ثمار جهدهما في الأعمال التي نشرت تحت عنوان" التربية الحسية الحركية البيداغوجيبة"؛ •(Hannaford, 1998) Kinésiologie Pédagogique 


\section{علم الحركة أو علم دراسة الحركة(Wikipedia, 2009 ) :}

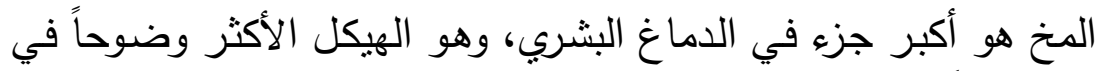

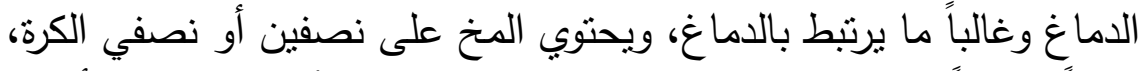

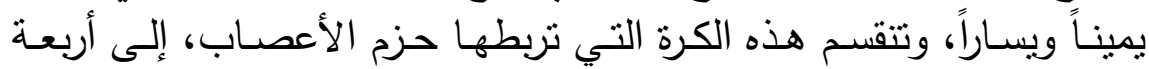

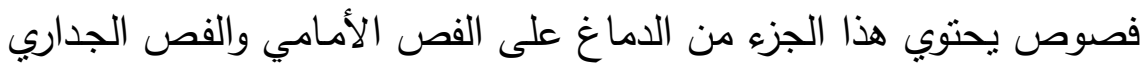

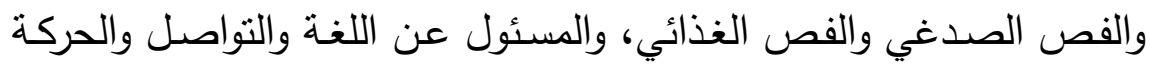
وحس الثم والذاكرة (Reedy,1998).

يقع وراء المـخ مـا يعرف بـالمخيخ أو الدماغ الصـغير الذبي يلعب دوراً

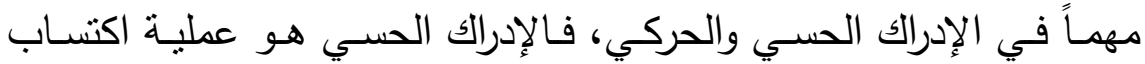

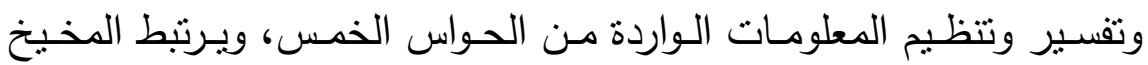

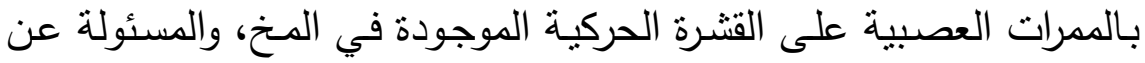
إرسال إثارات إلى العضات في جميع أنحاء الجسم مما يؤدي إلى حدوث الحركة(Reedy, 1998)

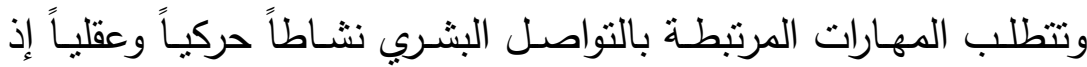

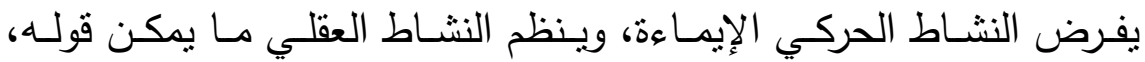

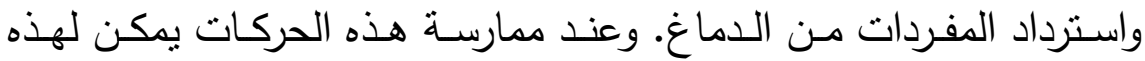

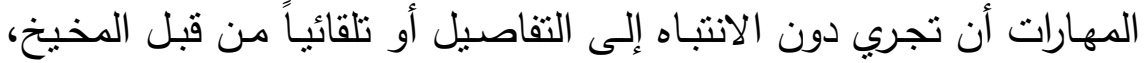

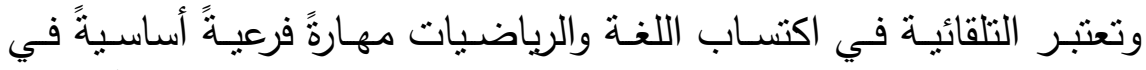

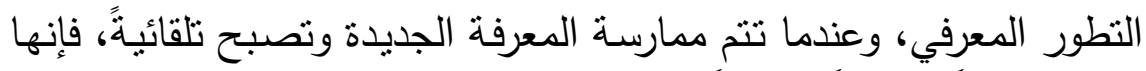

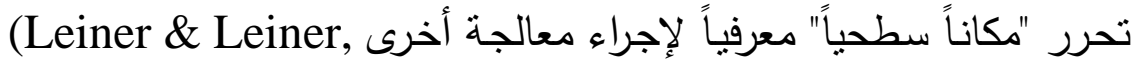
1997).

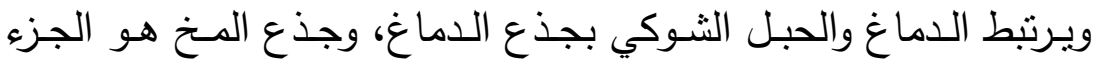
الأدنى من الدماغ الذي يرسل ويستلم المعلومات من خلال الحبل الثوكي. 


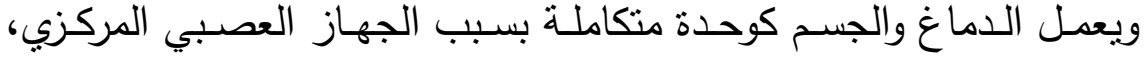
والذي يبـدأ مسن الدماغ ويمتد عبر الجسـم كله وتتلقى أجزاء مختلفـة مـن الدماغ والجسم المعلومات من خلال الخلايـا العصبية والألياف العصبية أو الو

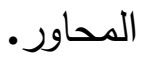

ويوضـح "قريدريكس"؛ Fredericks أن الخلايبا العصبية قابلة للاستثارة حيث ثقوم بمعالجة وإرسال المعلومات، وهي تحتوي على ثثلاثة أجزاء؛ جسم

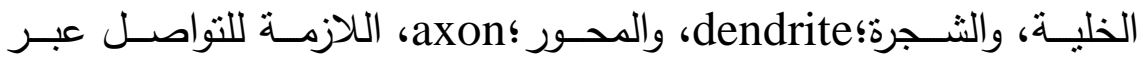
المثـابك الكيميائيـة والكهربائيـة بين الخلايـا العصبية، من خـلايل عمليـة "Myelinization"

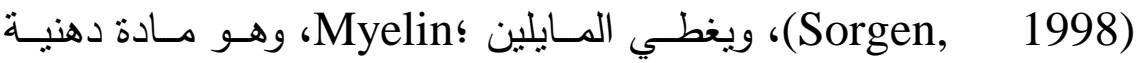

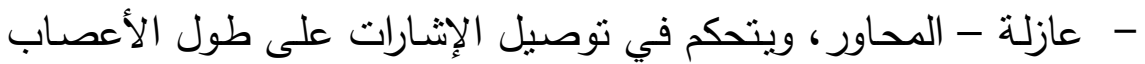
ويزيد من معدل إرسال المعلومات على طول المحاور ، وتسمح عملية ولية

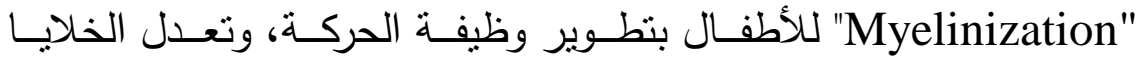
العصبية خصائصسها بتأثير المحفزات الخارجيـة، وهذه المرونة هي أسـاس التعلم والتكيف، ونسـاعد الحركة كحدث حسي - حركي على حدوث فهم للعالم المادي الذي يستمد منه كل التعلم.(Cherenick, 2009). ويستخدم المـخ · r \% من الأكسجين في الجسم من أجل البقاء، وينقل الأكسجين عبر الدماغ بواسطة الثعيرات الدموية، وتخلص البحوث إلى أن أن النشـاط البدني يزيد عدد الثـعيرات الدمويـة في الدماغ، والتي تشـاعد في (Pangrazi, et al امتصـاص المواد الغذائية والتخلص من النفايـات

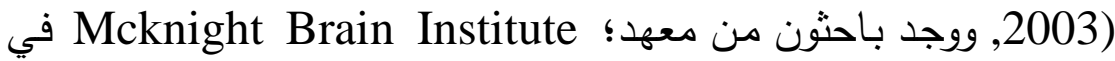
جامعة فلوريدا أن التمرين مدى الحياة يقلل من شيخوخة الخلايا في الدماغ، وأظهر البحث أن الفئران النشطة باعتدال لديهم خلايا دماغية أكثر قوةً من من 
القئران الهادئهة، ممـا قـاد البـاحثُون إلـى أن التمرينـات الرياضـية المعتدلـة

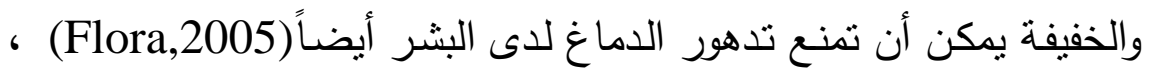
وتسهم في تحسين الحالة النفسية.

وفي البحث الحالي نزعم بأن الرباضـة الدماغية؛ Brain Gym ستعمل

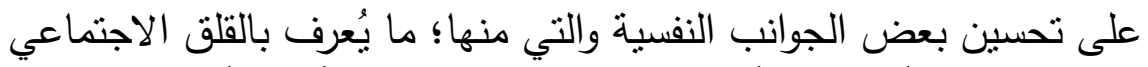

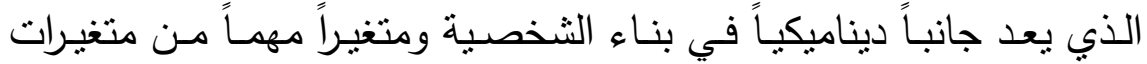
السلوك البشري وبطرأ تأثيره السلبي على العديد من النواحي النفسية، حيث ترجع مصسادر القلق الاجتمـاعي بالدرجـة الأولى إلى العلاقات الاجتماعيـة

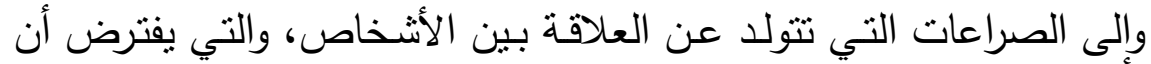
يتفاعل فيه الفرد مع الآخربن وبكون معرضاً نتيجة لذلك إلى نوع من أنواع التقبيم.

كمـا يعـد القلق محسوراً أساسياً مسن محساور الدراسـات النفسية على وجـه

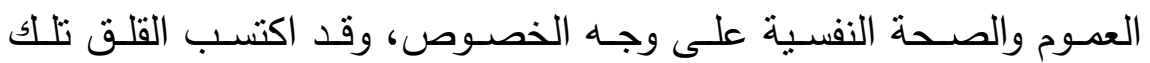

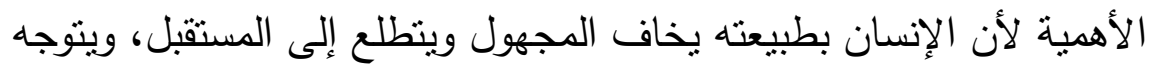

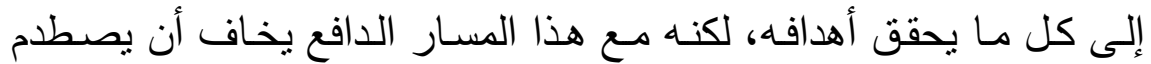
بعقبة أو يعاني من عطلة، قد تقف حجر عثرة في تحقيق تلاك الأهداف.

ويمثل القلق الاجتماعي كذلك النواة في عصاب القلق الذي يعتبر القاعدة الأساسية والمشكلة المحورية لكافة الأعصبة كما يرى "فروبد"؛ .Freud وأن الأن المحور الدينامي للعصـاب النفسي ليس في الأمراض النفسية فقط بـل في الاضي أفعال الناس السوبة وغير السوبة حسبما برى "هورني"؛ Horney ( حجازي، 
وهو لـيس حالـة تجلب لصـاحبها الفزع بـل قد يكون دافعـاً لـه للنجـاح

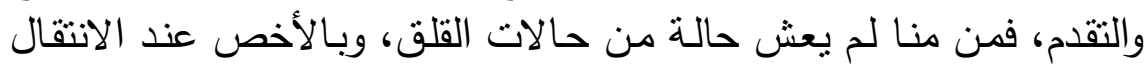

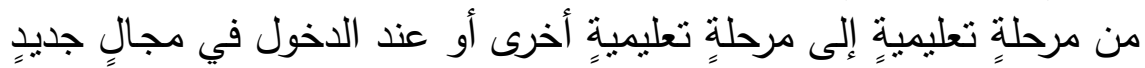

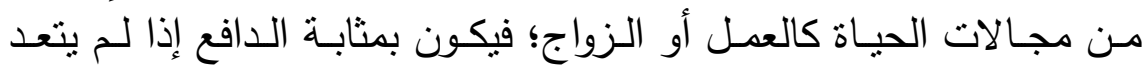

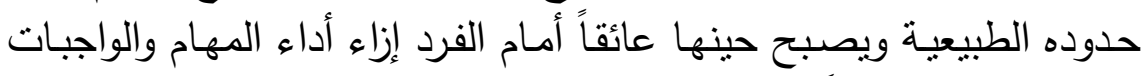
بذللك يصبح اضطراباً يتعين التنخل والعلاج.

ويمكننا أن نسمي عصرنا هذا بعصر القلق، القلق الذي لا يعيق الفرد

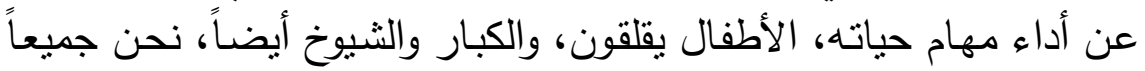

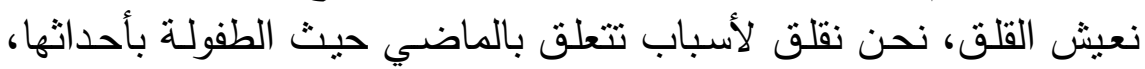

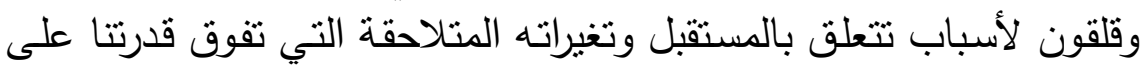

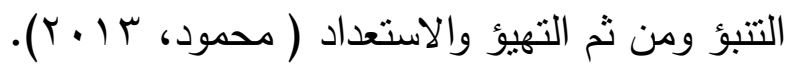

وقد أنثار "غريب" أن للقلق وجهان مختلفان فهو يساعد على تحسين

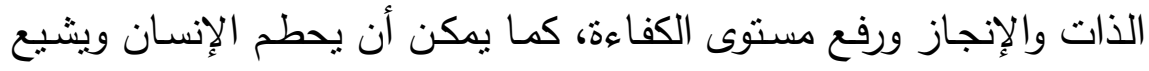

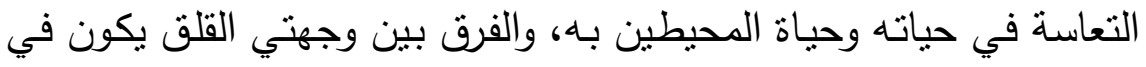

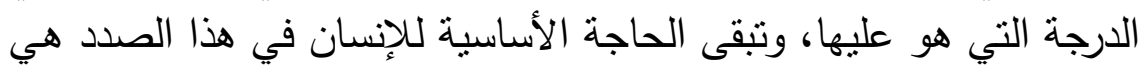

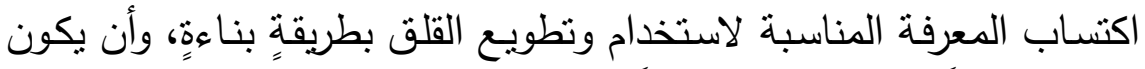

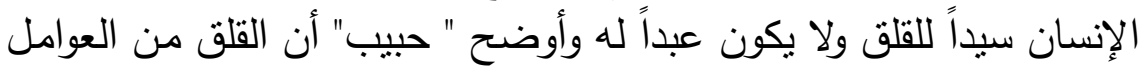

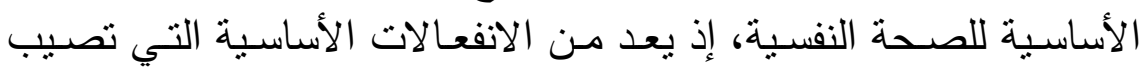

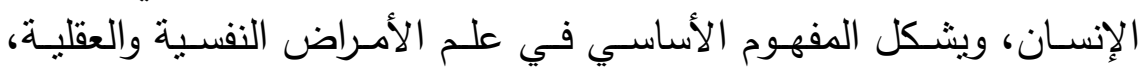
والعرض الجوهري في الاضطرابات النفسية، وفي أمراض عضدية الاضية كثيرة،

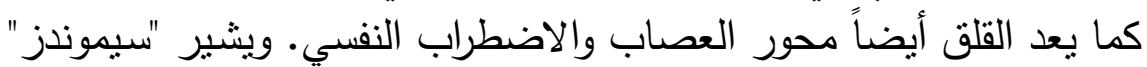

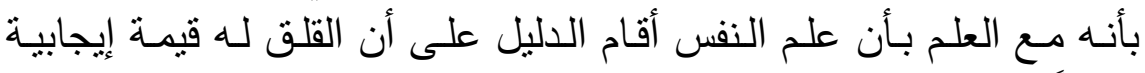

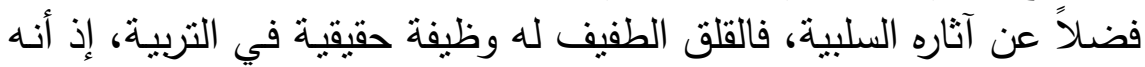


يعمل كمنشطاً وبمعنى آخر أن القلق الطفيف يعمل على دفع السلوك نحو

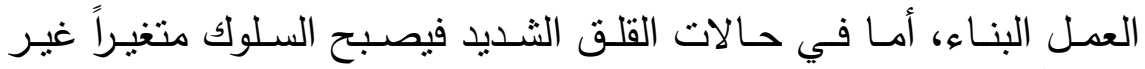
منتظماً، وقد تتضاعف هذه النتائج عندما يزداد انشغال الشخص باحتمالات الفثل والإذلال والأمور الأخرى المماثلة، التي تهدد كيانه ويمكن أن ينتشر

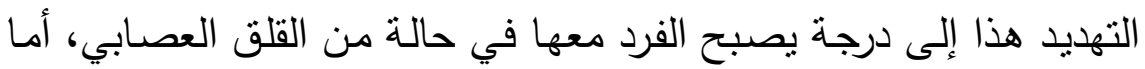

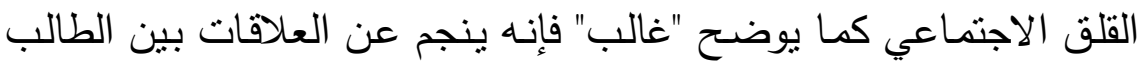

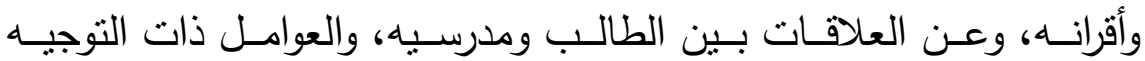
التحصيلي، والخبرات المدرسية، ويرى بعض علماء النفس أن هذا النوع من ون

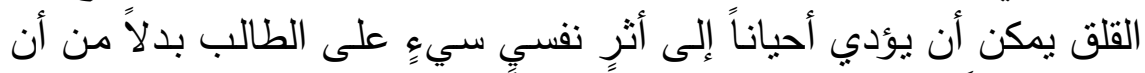

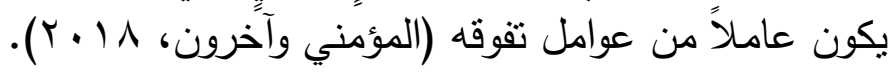

وبيبين "رووف"؛ Roof أنـه أصبح علمـاء النفس والتربية على معرفـة متزايدة بدور القلق الناتج عن التحصسيل المدرسي خاصسةً في المجتمعات

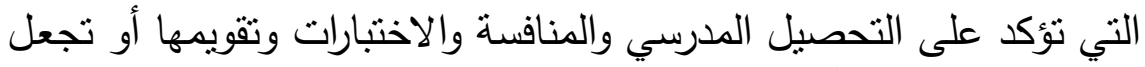
التهديد بالفشـل عالقاً في أذهان الطلاب. ويقول "اليوسفي" إن البحث عن ؤن القوى الدافعة التي تظهر سلوك المتعلم وتوجيهه أمر بالغ الأهمية بالنسبة لعملية التعلم والتعليم، فالدافعية شرط أساسي يتوقف عليه تحقيق الأهداف التعليمية في مجالات التعلم المتعدد، سواء في تحصيل المعلومات والمعارف أو جانـب تكـوين الاتجاهـات والقيم وجانب تكوين المهارات المختلفـة التي

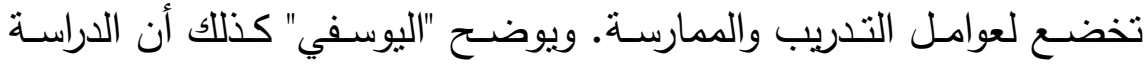
العلميـة لطبيعـة القلق وتأثيراته المختلفـة على الجوانب النفسية والتحصيلية والعلاقات الاجتماعية تعد ذات أهمية تتسجم مع ما تهدف إلبه المؤسسات التربوبة في إحداث نمو مرغوب في الجانب الاجتماعي لدى الطلبة بشكلٍ 
يتتاسـق مـع الجوانـب العقليـة والجسـية والنفسية وذلك لبنـاء إنسـان بسـهم مساهمةً فعالةً في خدمة المجتمع (المؤمني وآخرون، 1 ( ـ ب).

وكذللك الإنجـاز الأكـاديمي الذي يعـد مـن العوامـل الأساسـية التي تـم

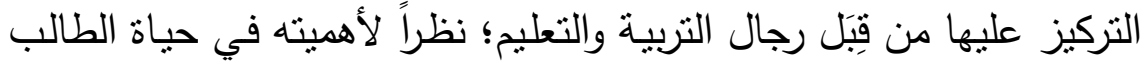

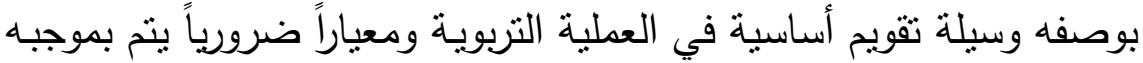

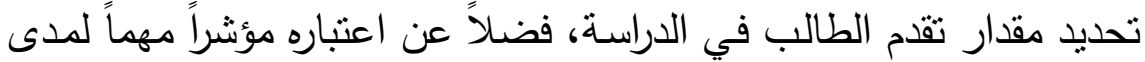
تقدم المؤسسات التربوبة نحو أهدافها التربوبة (العزي، وخثاب، ـ ( • ب). إذ يتسـم العصـر الحسالي عصر العلم والتكنولوجيا بـالتغيرات والتحولات واسـة النطاق في شـتى مجـالات الحيـاة نحو التطور والتقدم والاسـتغلال الأمنت للموارد البشرية كعامل له تأثيره، والذي يفوق تتمية الثروات الطبيعية،

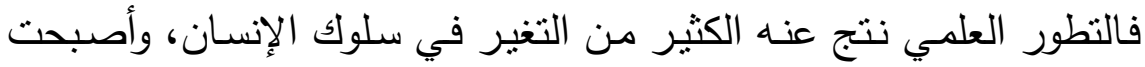

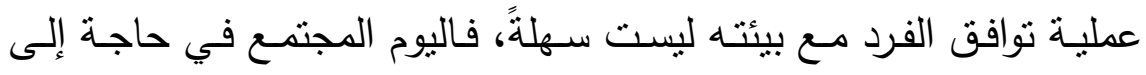
طاقات بشرية متسلحة بالعلم والقيم الإيجابية والسلوك الحضاري. فغرض التربيـة الأساسـي الذي نسـى للوصسول إلبـه وتحقيقه هـو خلتق وتطوير القدرات الطبيعية والعقلية عند الطالب، حسب ما يتلاعم مع قدراته وما يربد لنفسه، وشروط المجتمع والمحيط الذي يعيش فيه.

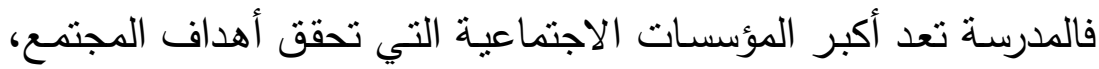
وذلك من خلال سعيها إلى تتمية قدرات الفرد وتزويده بالمعارف والمهارات وتعديل سلوكه وضبطه، كل ذلك لمحاولة بناء أفراد لديهم القدرة على تحقيق

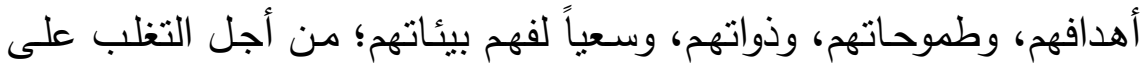

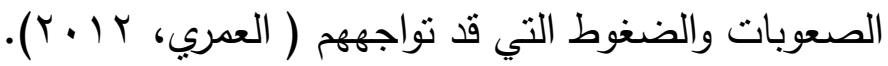


ويؤكد " عبد الخالق" أن الإنجاز الأكاديمي يمثل أحد الأمور المهمة في الإنها

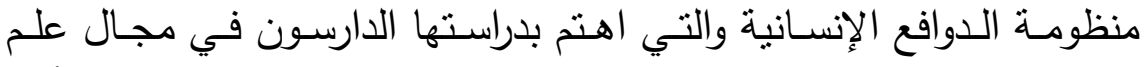

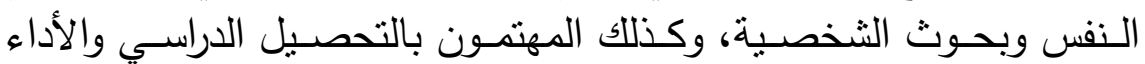

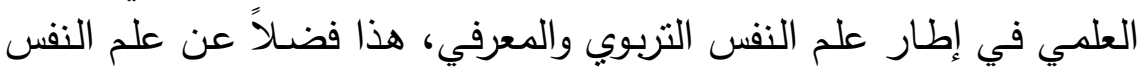

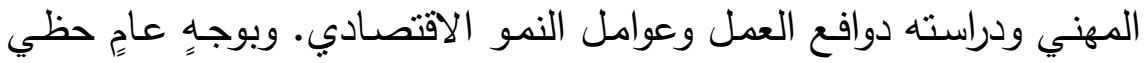

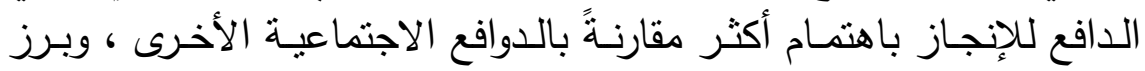

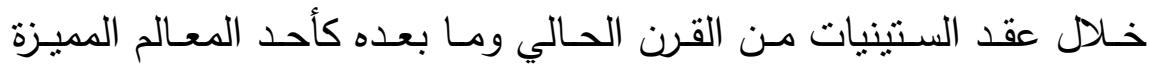

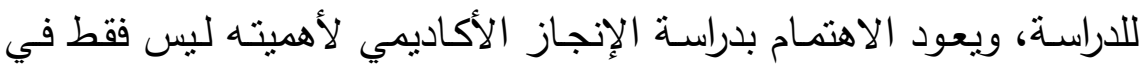

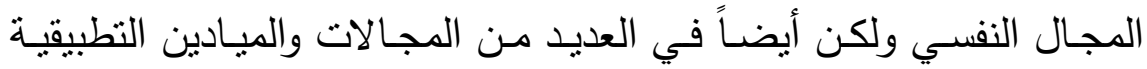

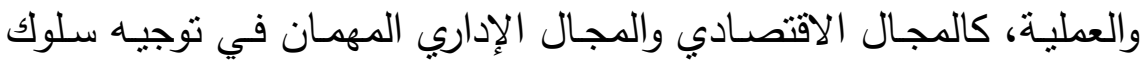

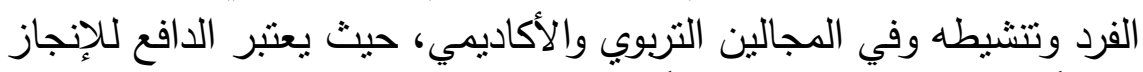

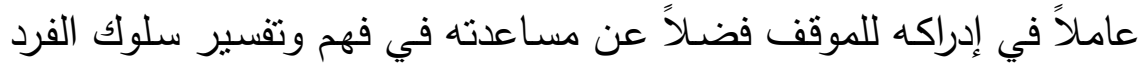

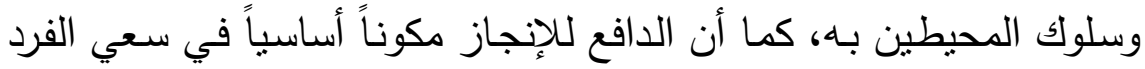
تجاه تحقيق ذاته وتوكيدها حيث يشعر الفرد بتحقيق ذاتـه من خـلال مـا

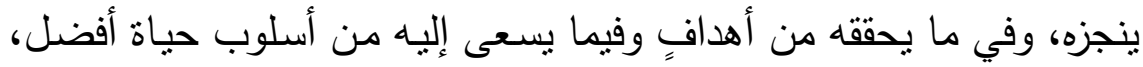

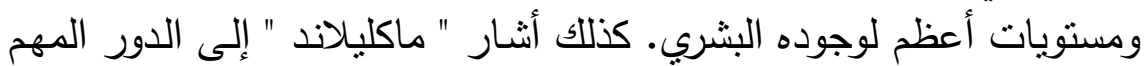

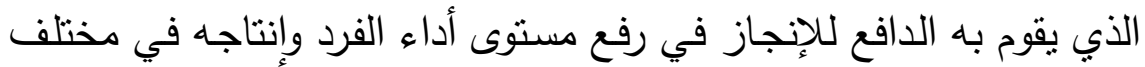

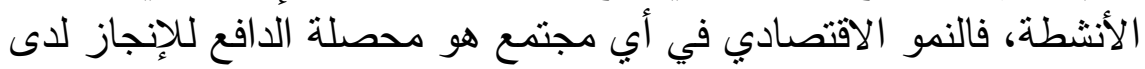

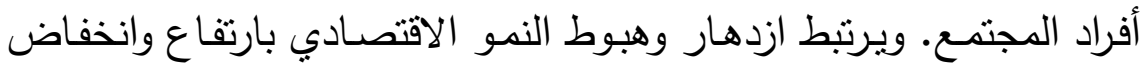

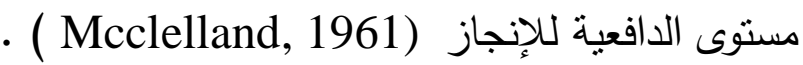

حيث يحول ضعف التوجه الإنجازي دون بذل الجهد وتكريس الطاقة في

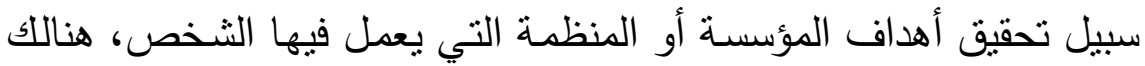
أيضاً ارتباط بين الأداء الإبداعي والدافعية المرتفعة للإنجاز وارتباط الإثتين 
معاً في ظروف المناخ النفسي والاجتمـاعي الذي يوفره المجتمع بوجهِه عامٍ

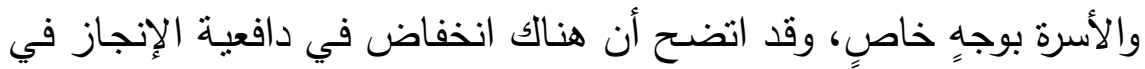
بعض المجتمعـات حتى التـي نطلـق عليهـا مجتمعـات متقدمسة، إذ نشـر

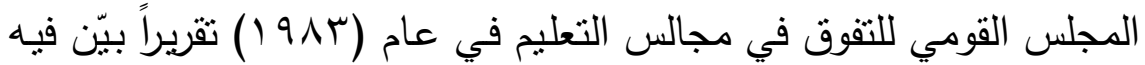
أن المجتمع الأمريكي يواجه ظواهر تستحق التوقف أمامها، فهناك انخفاض

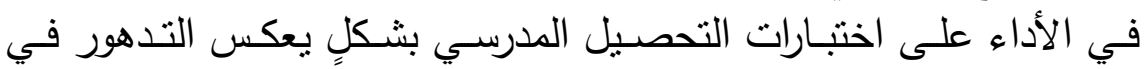
الأداء المدرسي وفي مجال العمل بعد ذلك، فقد انخفض متوسط الدرجات

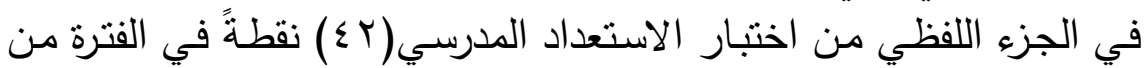

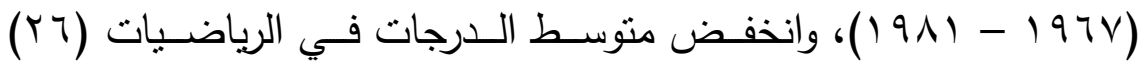
نقطةً، كما أثـار التقرير إلى أن طالب الجامعة أصبح أقل استطاعةً على مثلى القراءة وفهم المادة المركبة إذا ما قورن بطالب الجامعة قبل هذه الفترة بعثرة سنوات، فالطلبـة عاجزون عن التعبير عن أنفسهم وعن صياغة الأفكار التجريدية والربط بينها (جواد، 1 ( • ب).

وقد تعددت نظريات الإنجاز الأكاديمي ودوافعه ومنها ما يلي:

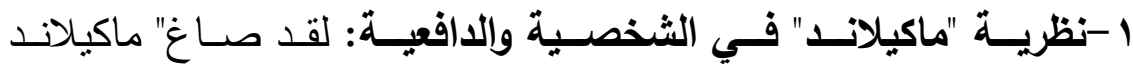
وواتكنسون" (Watkinson \& Mcclelland,1953) نظربية عن دافع مئح الإنجاز الدراسي على أسس نظرية إمبريقية جديدة، وبعد هذا الدافع بالنسبة

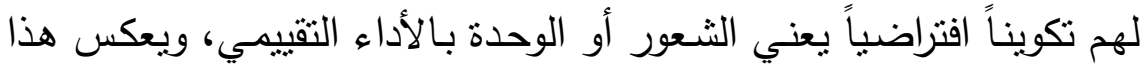
الثـعور متغيرين رئيسين هما: الأمل في النجاح، الخوف من الفشل وذلك الك

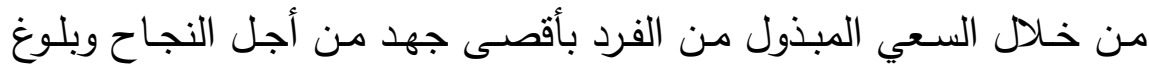

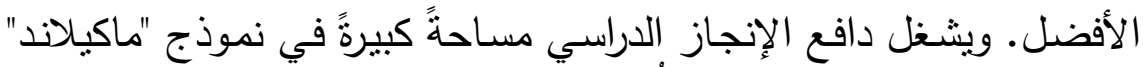

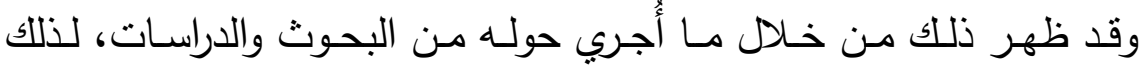
ظهرت توقعات مخالفة بخصوص الأشخاص الذين لا يتبنون وجهة الإنجاز 
الدراسي في حالةٍ معينةٍة عن سواهم، ويتأثر دافع الإنجاز الدراسي بعوامل

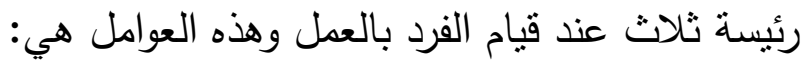

1-الادفع للوصول إلى النجاح:

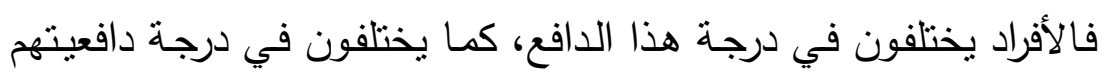

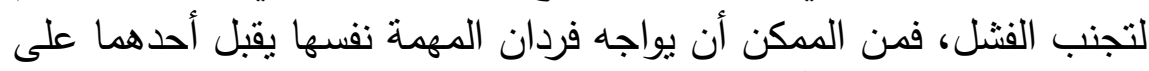

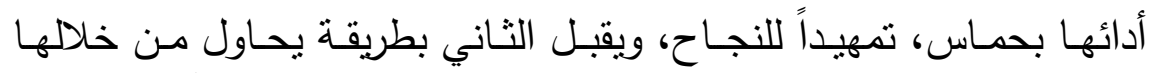

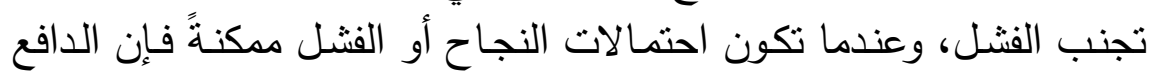
للقيام بهذا النوع من المهمات يعتمد على الخبرات السابقة.

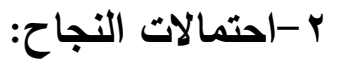

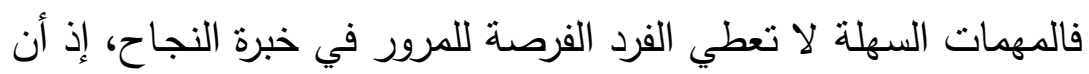

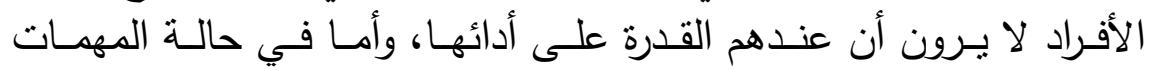

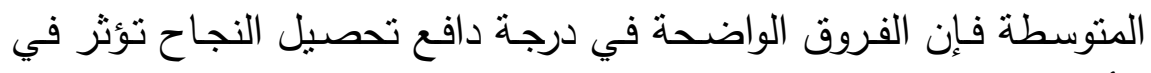

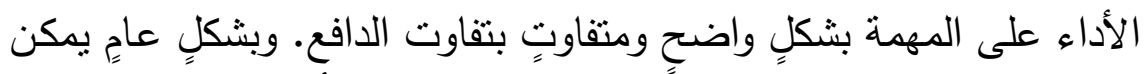

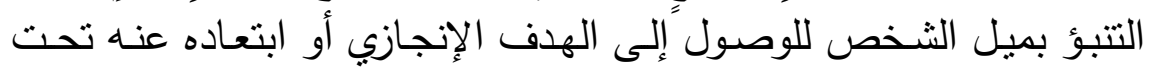

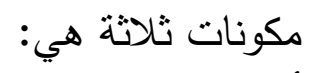

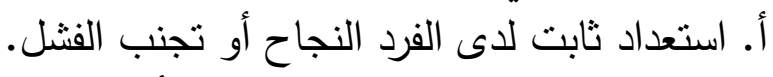

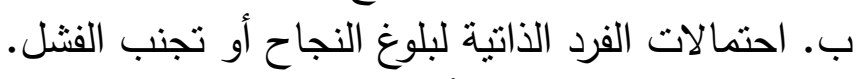

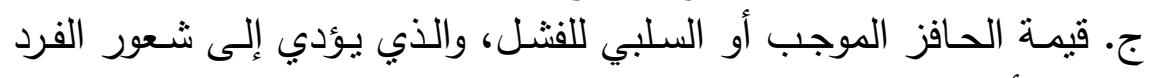
بالنجاح أو الفتل ويعتمد ذلك على خبرة الفرد. 


\section{r- القيمة الباعثية للنجاح:}

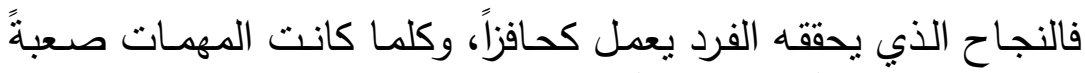

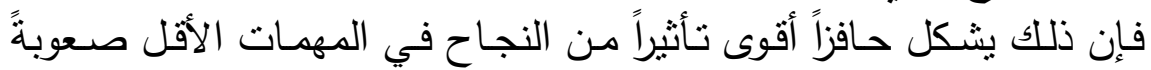

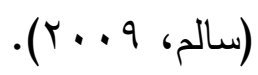

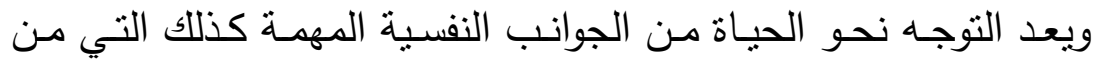

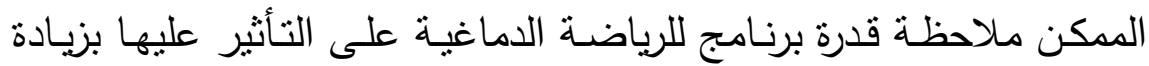
كفاءتها.

ويبين كلّ من "هويدي" و" فرج " إن دراسـة التوجه نحو الحياة هو خطوة

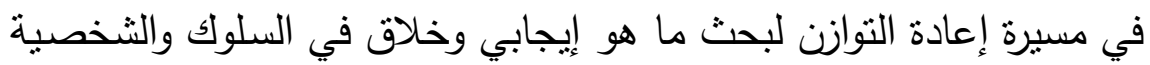

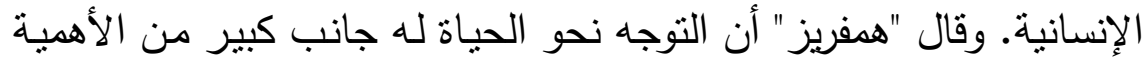

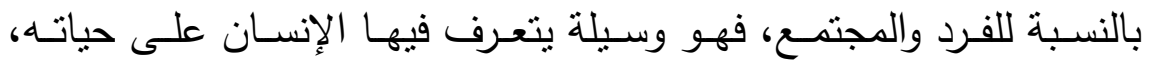

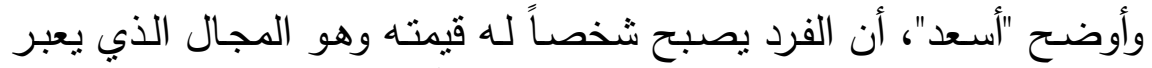

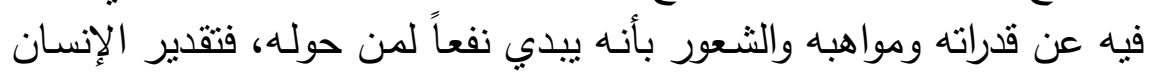

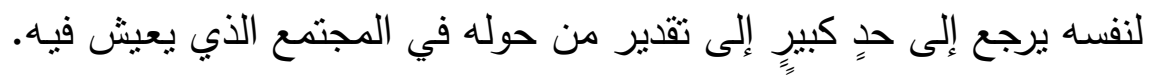

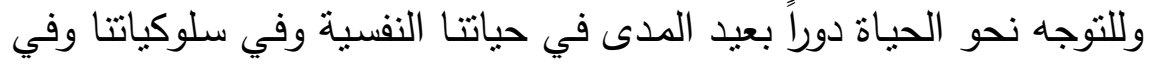

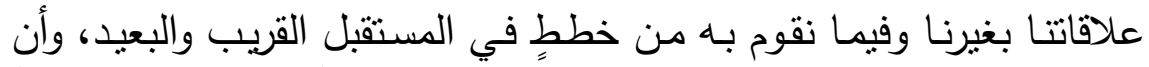

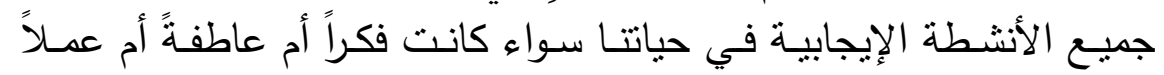

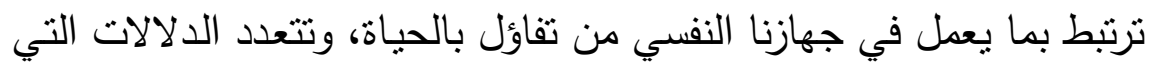

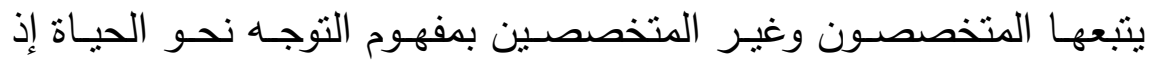

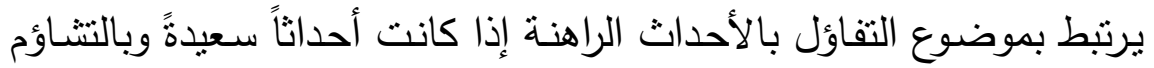

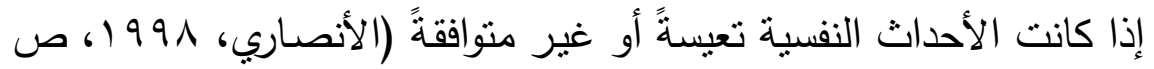


وقد أصبح معنى الحياة؛ Meaning of life في الآونـة الأخيرة من المفاهيم التي استمرت من القرن الماضـي مستحوذة على اهتمـام العلمـاء والباحثين في مجال علم النفس والصحة النفسية، وفي فئات ونوعيات عديدة

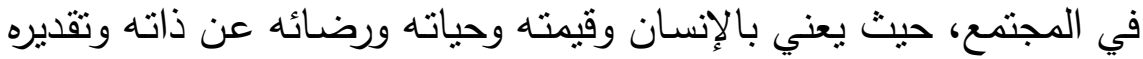

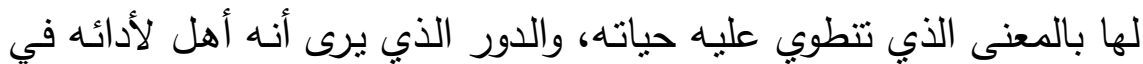

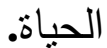

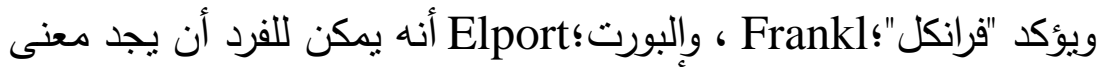

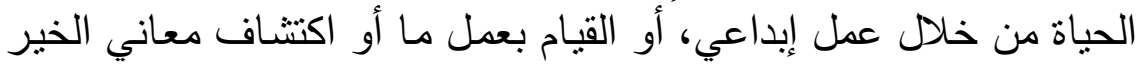

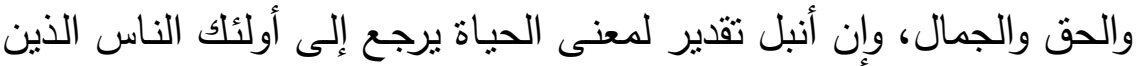

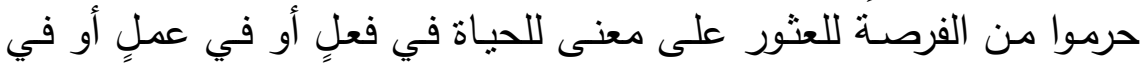
حبٍ، والذين يرتفعون فوق المحنة ويتجاوزونها نحو الاتجاه الذي يختارونه فئه

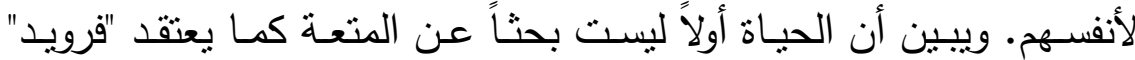

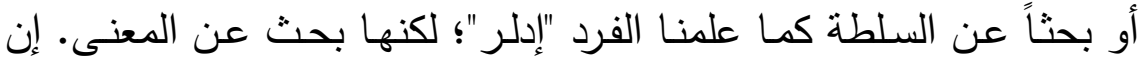

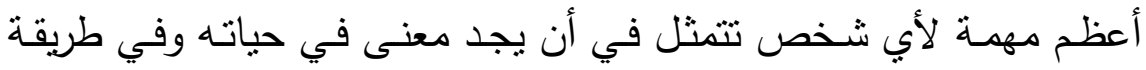

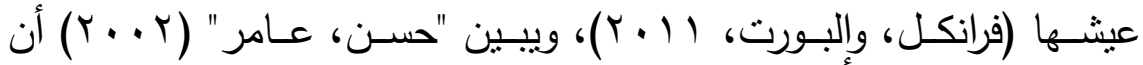

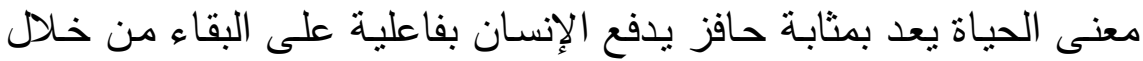

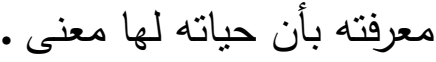

ويقول "فرانكل"؛ Frankl مؤكداً على ذلك أنه لا يوجد شيئًاً في العالم

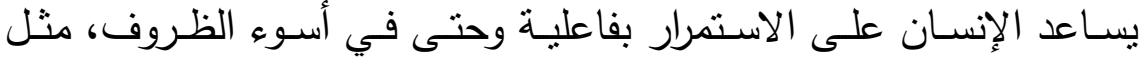

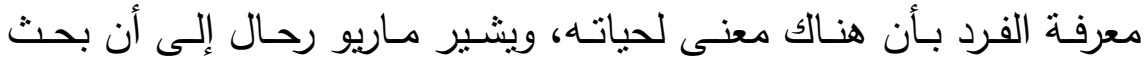

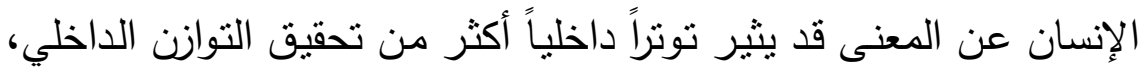

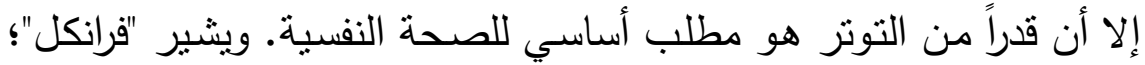
Frankl أنه من الممكن مساعدة الفرد على إيجاد معنى لحياته من خلال 
العـلاج بـالمعنى الذي يجعلـه واعيـاً لوجـوده، وبهـتم بالحقـائق مثنل تحقيـق

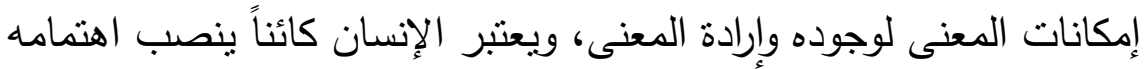
الرئيسي على تحقيق المعنى وتحقيق القيم (الصقر ، V V . r).

الاراسات السابقة:

أولاً: دراسات سابقة تناولث التوجه نحو الحياة:

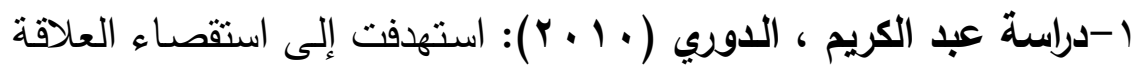
بين التفاؤل والتوجه نحو الحياة لدى عينة من طالبات كلية التربية للبنات/

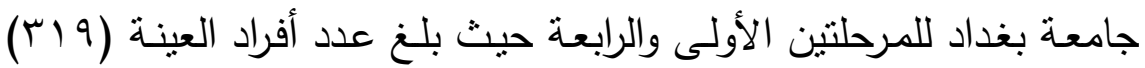

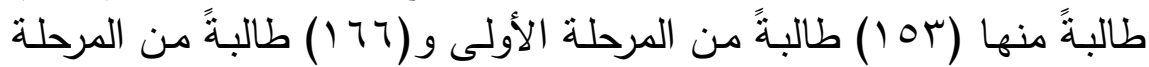

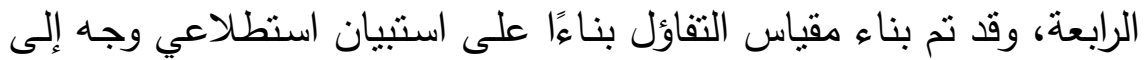

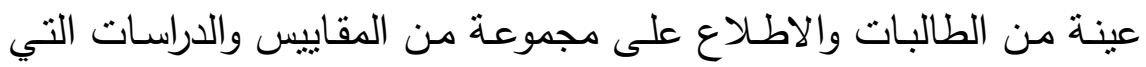

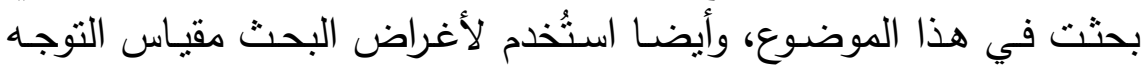

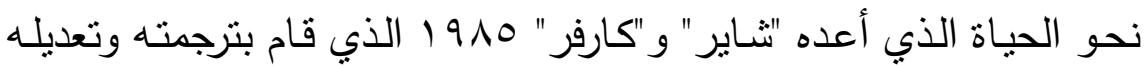
"ألأنصاري" ه9 99 (، وأظهرت اعده النتائج وجود علاقة ارتباطية دالة بين التفاؤل

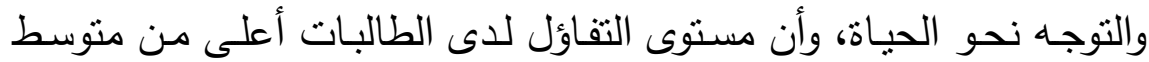
المجتمع، وكذلك مستوى التوجه نحو الحياة لدى الطالبات أعلى من متوسط

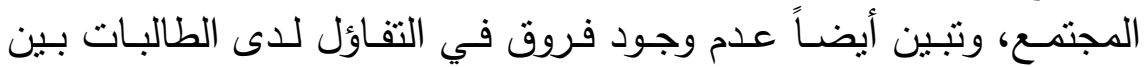
المرحلة الأولى والرابعة ووجود فروق دالتة في التوجه نحو الحياة ولصسالح طالبات المرحلة الرابعة.

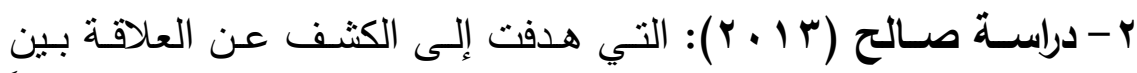

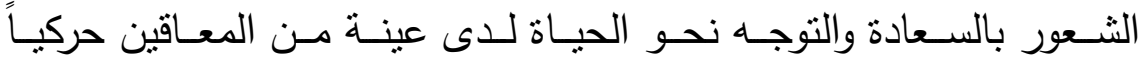
المتضررين من العدوان على غزة، كما هدفت إلى معرفة إذا ما كان هناك 
فروق ذات دلالـة إحصـائية بين متوسـات درجـات الطـلاب على مقيـاس

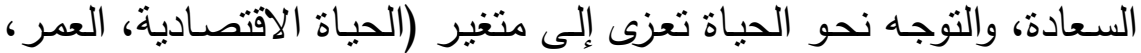

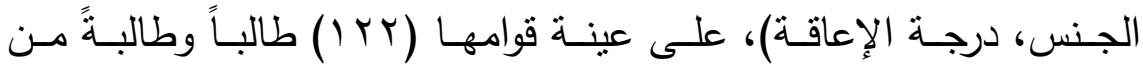
المعاقين حركياً الملتحقين ببرنامج التعليم المستمر بالجامعة الإسـلامية، وقد استخدمت الباحثة مقياس السعادة ومقياس التوجه نحو الحياة من إعدادها،

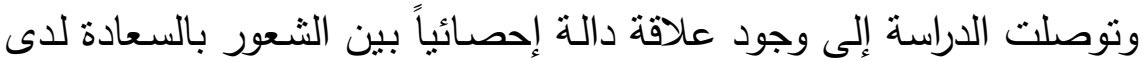
المعاقين حركياً المتضررين من العدوان الإسرائيلي على غزة، والتوجه نحو الحياة، وأظهرت النتائج عدم وجود فروق ذات دلالة إحصائية بين الطلاب البعة

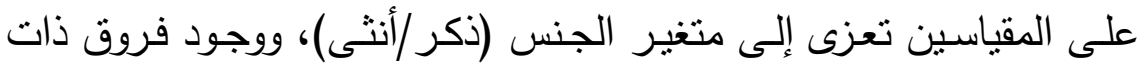
دلالة إحصائية بين متوسطات درجات الطلاب على المقياسين تعزى إلى إلى متغيـر (درجـة الإعاقـة)، بـين الفئة المتوسـة والكبيـرة جداً، وبـين الكبيـرة والكبيرة جداً، وبين الإصـابة البسيطة والكبيرة جداً وجميعها لصسالح الكبيرة ولهين

\section{ثانياً: دراسات سابقة تناولت القلق الاجتماعي :}

ا - دراسـة محمود (ب ( • Y): التي استهدفت التعرف على مستوى القلق

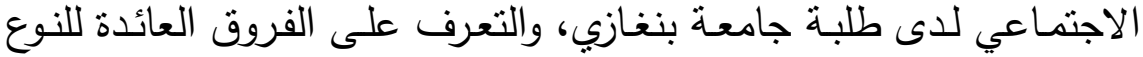

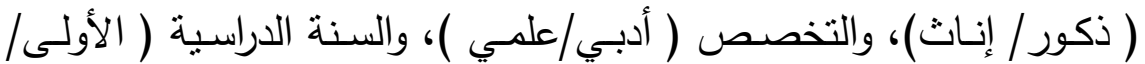

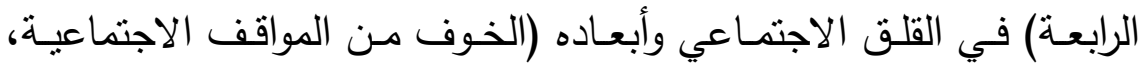

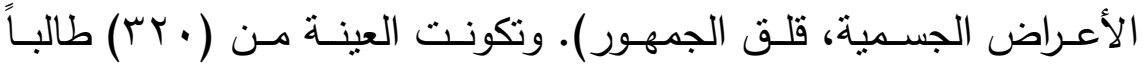
وطالبةً من طلاب جامعة بنغازي، قسمت بالتساوي. وتم إعداد مقياس القلق

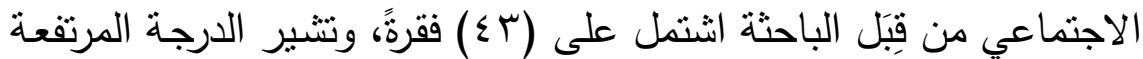
إلـى ارتفـاع القلـق الاجتمـاعي، وقـد تم التحقـق مـن الخصـائص القياسـية (السيكومترية) للمقياس. وأظهرت النتائج أن متوسط العينة أقل من المتوسط 
النظري في الدرجة الكليـة للمقياس وأبعاده، وهذا يشير إلى انخفاض القلق

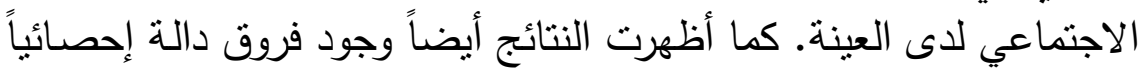

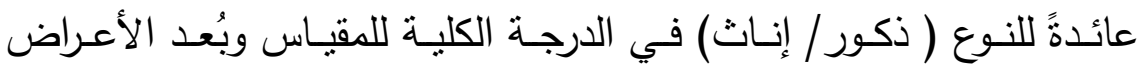
الجسمية حيث كان متوسط الإنـاث أعلى من متوسط الذكور أي الإنـاث

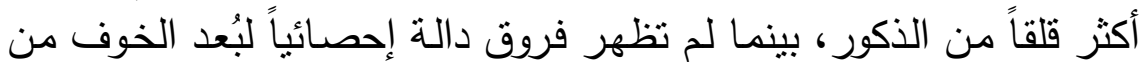

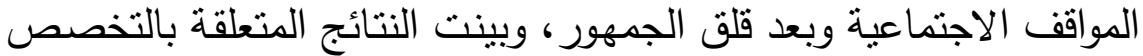
( أدبـ/علمي) عدم وجود فروق عائده للتخصص في القلق الاجتمـاعي وأبعاده، كما بينت النتائج وجود فروق عائدة للسنة الدراسية ( أولى/ رابعة) في الدرجة الكلية وفي بُعد الخوف والبُعد الجسمي حيث كانوا طلبة السنة الأولى أكثر قلقاً من طلبة السنة الرابعة.

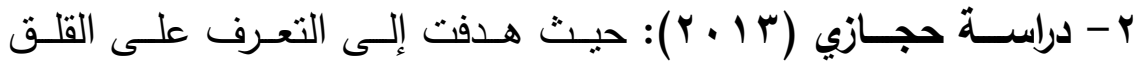

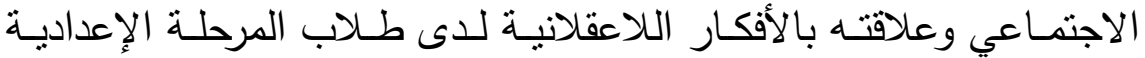
بالمدارس الحكومية في محافظات غزة، ومعرفة مدى انتشار كلٍ من القلق الاجتمـاعي والأفكار اللاعقلاتبـة، والتعرف على الفروق بين الطلاب تبعاً

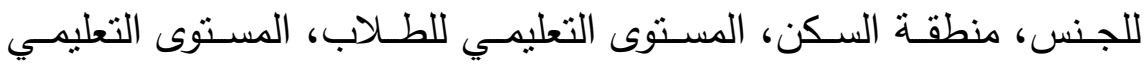
للأب، المستوى التعليمي للأم، حجم الأسرة، والترتيب الولادي، وأجريت هذه

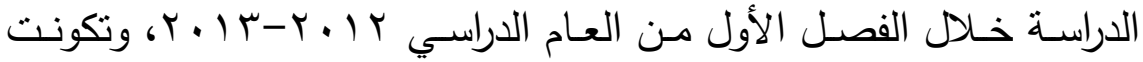

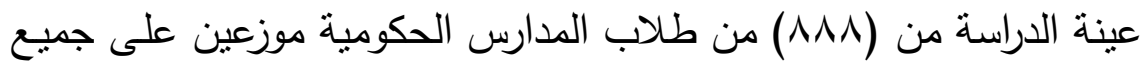

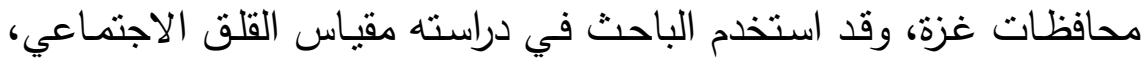

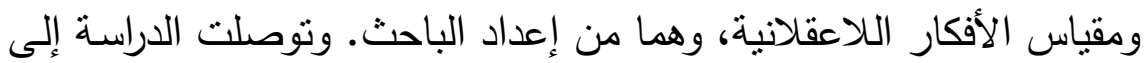

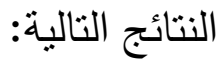
ا-توجد علاقة ارتباطية موجبة بين القلق الاجتماعي والأفكار اللاعقلانية، أي أنه كلما زادت الأفكار اللاعقلانية زاد القلق الاجتماعي والعكس صحيح. 


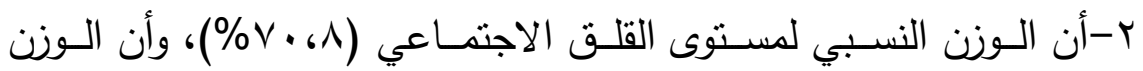

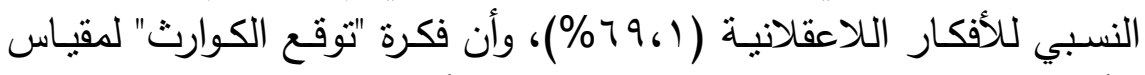

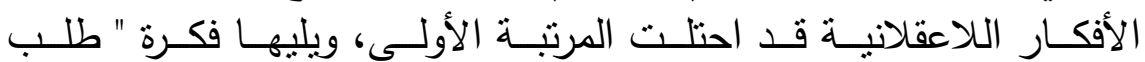

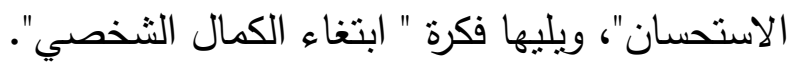

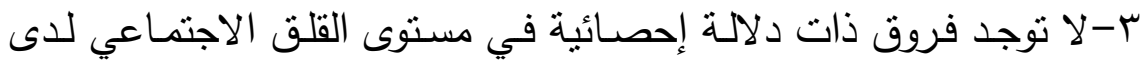

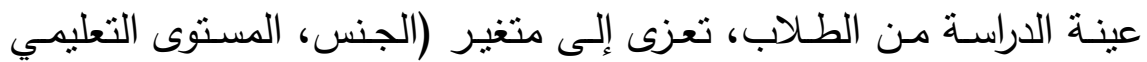

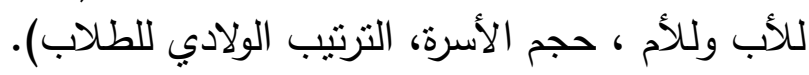

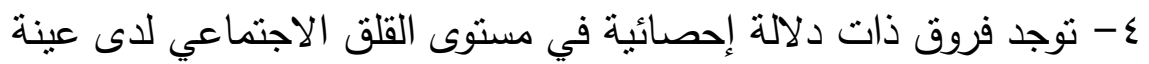

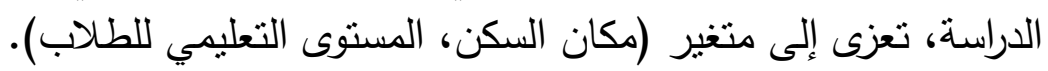

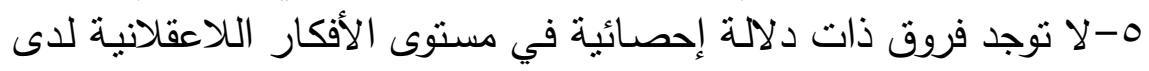

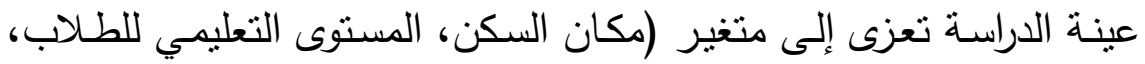

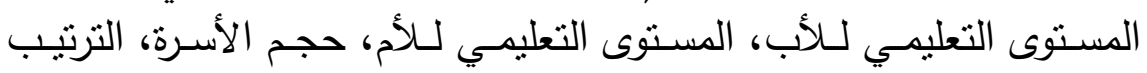
الولادي للطلاب). 7- توجد فروق ذات دلالة إحصائية في مستوى الأفكار اللاعقلانية لدى الدى

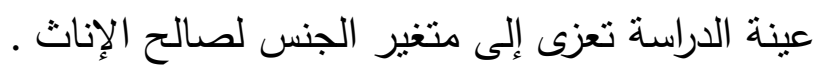
ثالثاً: دراسات سابقة تناولت علاقة القلق الاجتماعي بالإنجاز الأكاديمي:

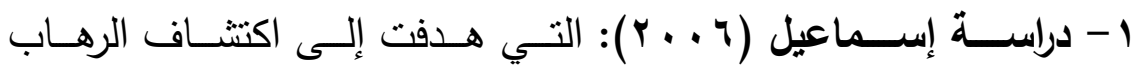

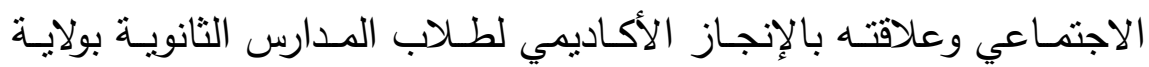

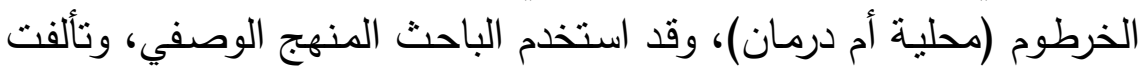

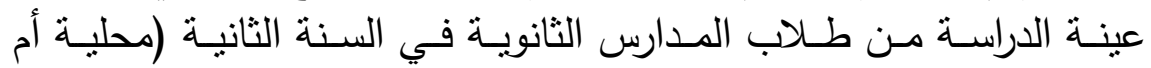

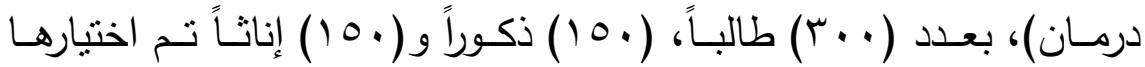
عشوائياً، وكانت أدوات الدراسة عبارة عن (مقياس الرهاب الاجتماعي الذي اهي 
أعده؛ "حسن المالح" ومقياس الإنجاز الأكاديمي الذي أعده؛ "محيي الدين المتوكل"). ونوصلت الدراسة إلى النتائج التالية: 1- وجود الرهاب الاجتماعي المتصاعد بين طلاب المرحلة الثانوية (الدرجة الثانية). r - الإنجاز الأكاديمي المرتفع بين طالب المرحلة الثانوية.

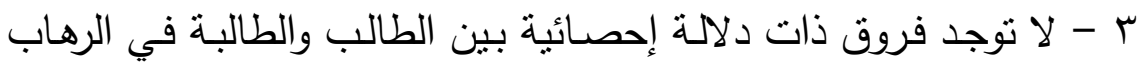

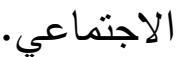
ع - لا توجد علاقة إيجابية بين الرهاب الاجتماعي والإنجاز الأكاديمي.

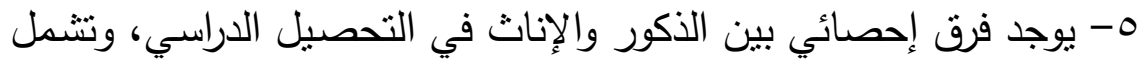

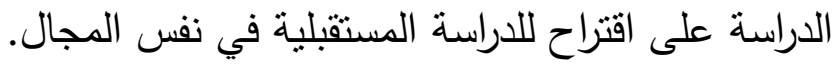

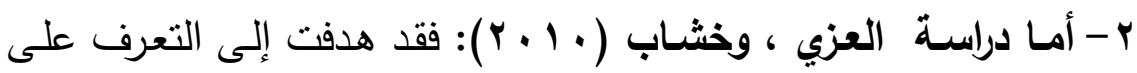

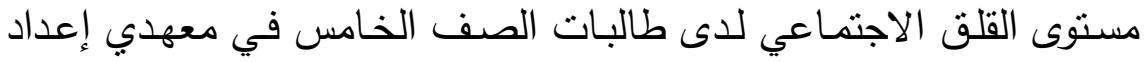

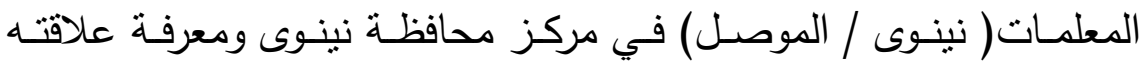

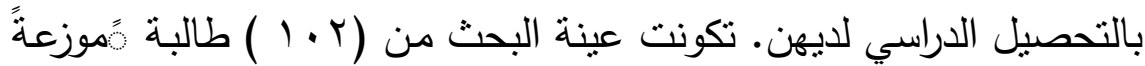

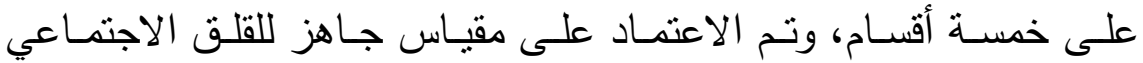

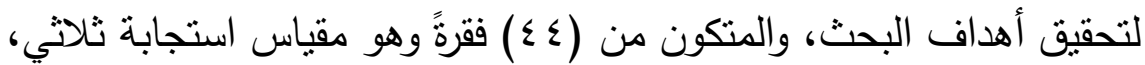
وقد تحققت الباحثتان من مؤشرات الصدق والثبات للمقياس قبل تطبيقه، وتم

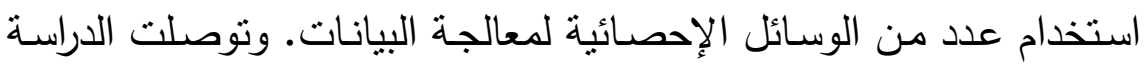

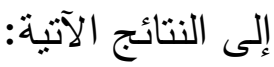
إل إن مستوى القلق الاجتماعي لإى الطالبات منخفض مقارنةً مع الوسط

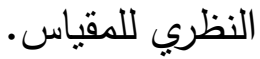

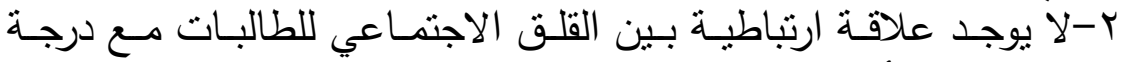

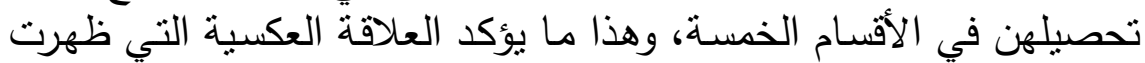
فيها معاملات الارتباط. 


\section{وخرج البحث بعدد من التوصيات والمقترحات كان أهمها:}

ا - تشجيع الطالبات على الإسهام في أنشطة وفعاليات المعهد بما يحقق

الاندماج فيما بينهن.

r - تتميـة الإحسـاس بأهميـة ومكانــة الطالبـة في المعهد كونهـا معلمـة المستقبل ولدورها الكبير في خدمة أبناء الوطن.

أما المقترحات فكانت؛ إجراء دراسة تهدف إلى التعرف على العلاقة بين

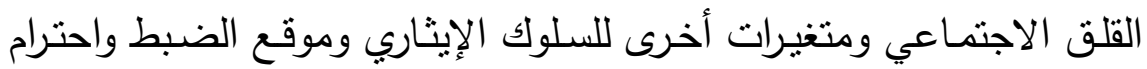

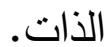

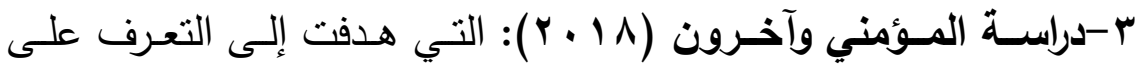

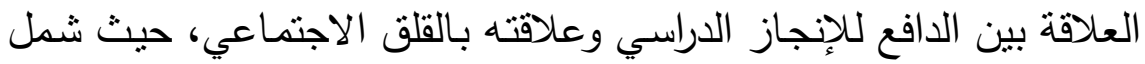

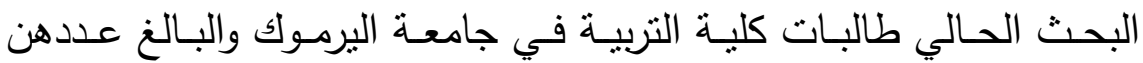

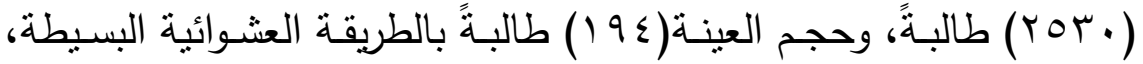

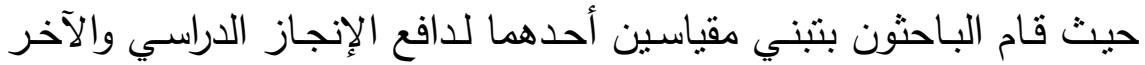

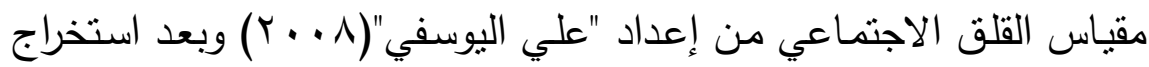

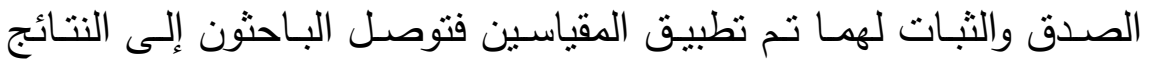
الآتية:

إ-إن مستوى الانجاز الدراسي لدى طالبات كلية التربية في جامعة اليرموك كان مرتفعاً. r- إن مسـتوى القــق الاجتمـاعي لـدى طالبـات كليـة التربيـة في جامعـة اليروكوك كان متوسطاً.

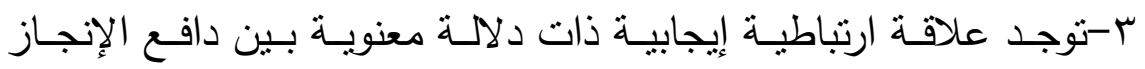
الدراسي والقلق الاجتماعي لدى طالبات كلية التربية في جامعة اليرموك. 
رابعاً: دراسات سابقة تناولت الرياضة الدماغية Brain Gym ا-دراسـة مورس وآخرون ( Morris, et al., 1988 ) : هدفت إلى

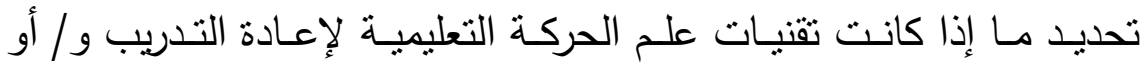

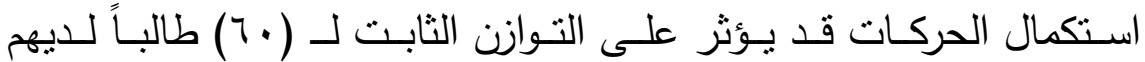

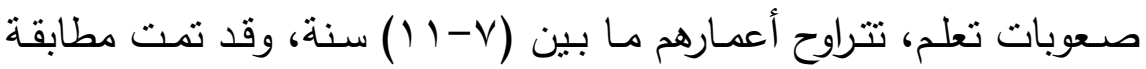

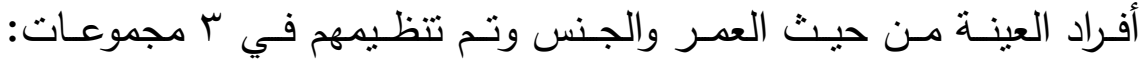

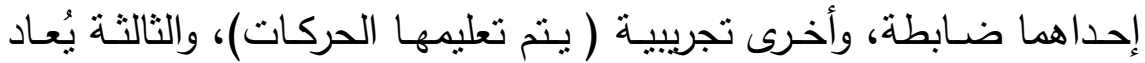

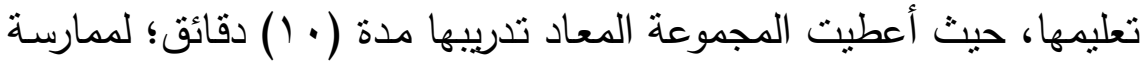
جلسـة فرديـة في حركات الذراع والسـاق المشتركة بالتتسيق مـع العين قبـل

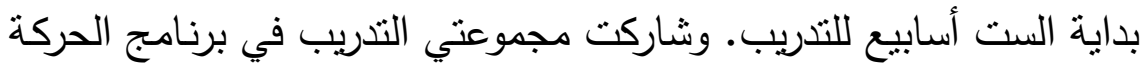

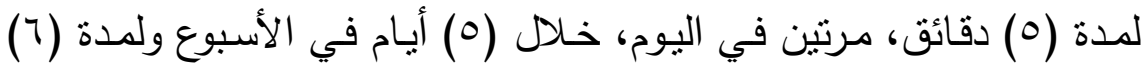

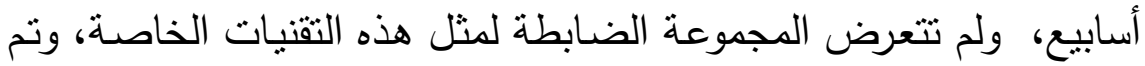

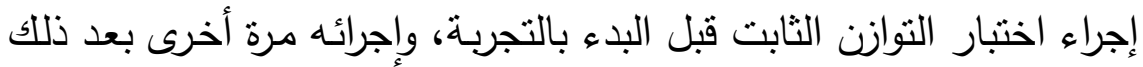
في كل مجموعة باستخدام اختبار Stand Stork Stand ، ويشير تحليل

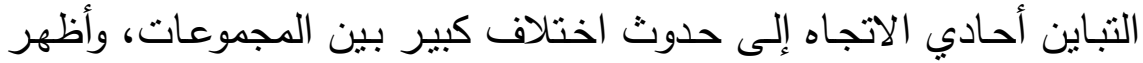

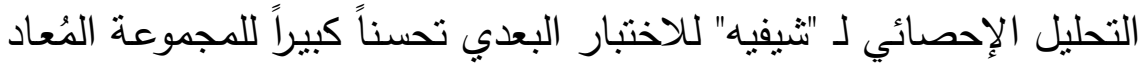

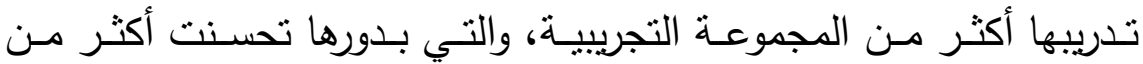
المجموعة الضابطة.

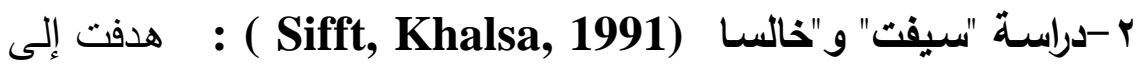

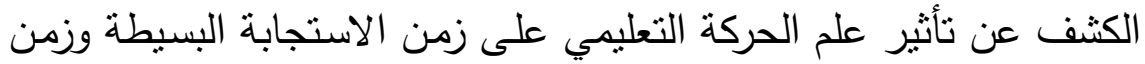

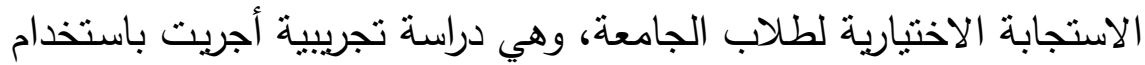

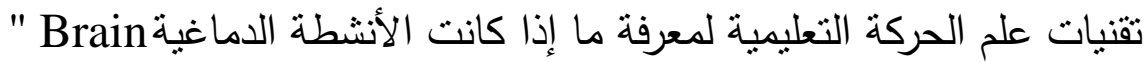

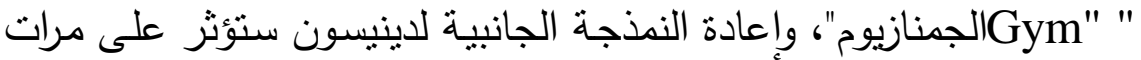




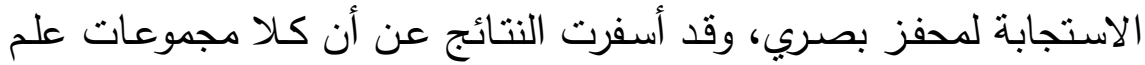

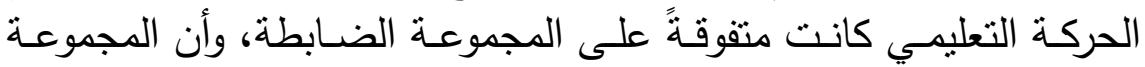

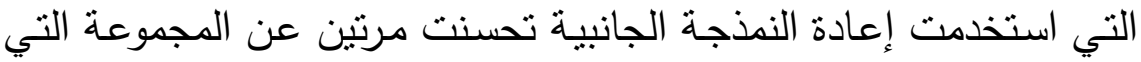

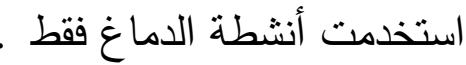

ب- دراسـة دونزيك (Donczik, 1994) : هدفت إلى التحقق من تأثير

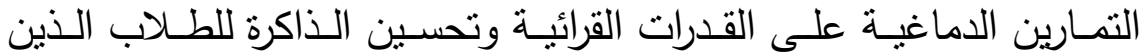
يعانون من القراءة واللغـة، وبينت الدراسـة كفاءة تقنية إعادة التدريب على التى التمارين الجانبية لدينيسون (DLR) في تقليل الأخطاء القرائية وتحسين الذاكرة والفهم لأولئك الطلاب الذين يعانون من صعوبات في اللغة. وقد كان

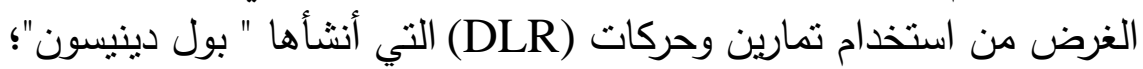
Paul, E., Dennison

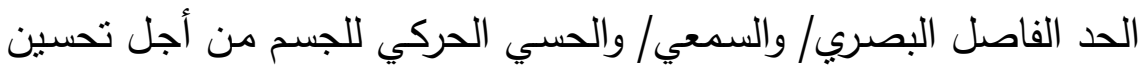

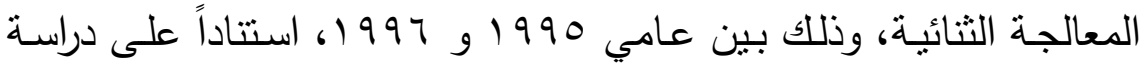

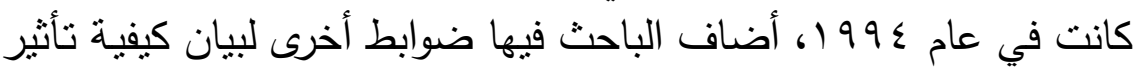
التواصل الجانبي لدينيسون؛ (DLR) على معدل القراءة، وكذلك عمليات

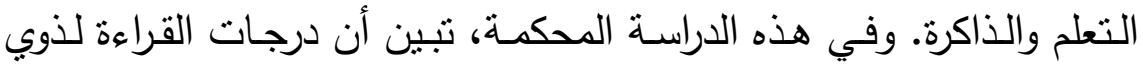

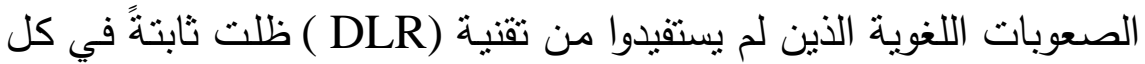

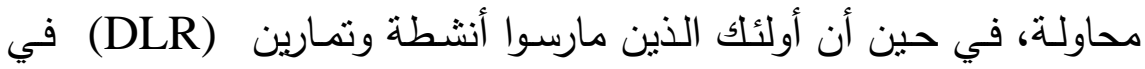

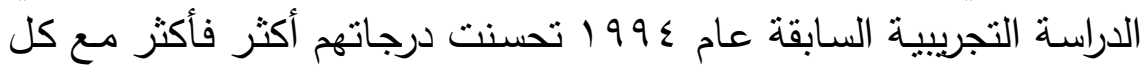

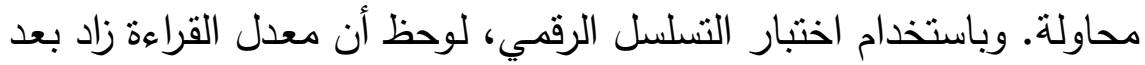

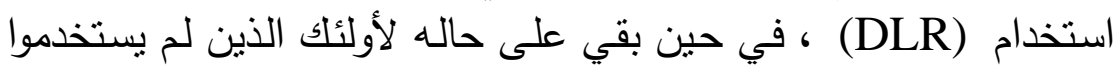
وأخيراً، وجد أيضا أن الاحتفاظ بالذاكرة على المدى الطويل تحسناً (DLR).

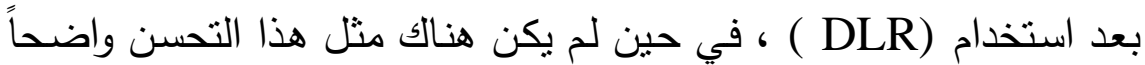

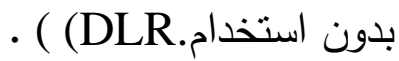




\section{ع -وفي نفس السياق دراسة بيجل وآخرون (Beigel, et al., 2002):}

إذ في خلال (^) أسابيع تمكنت دراسة باستخدام تقنية الرياضة الدماغية ( مـ التأثثر على القدرات القرائيـة وقدرات الفهم لـدى (Brain Gym)

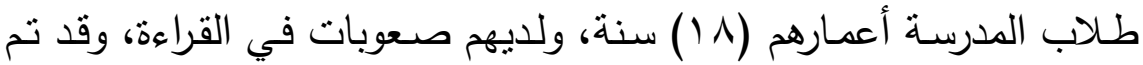

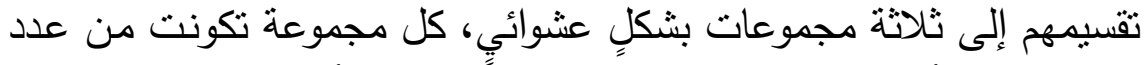

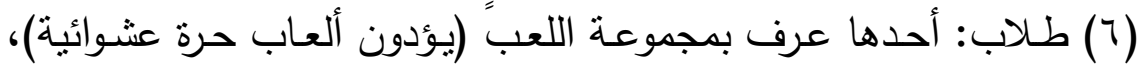

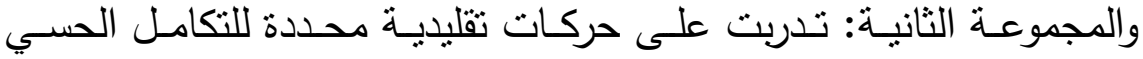
الحركي، والمجموعة الثالثة:استخدمت تمارين وأنشطة تقنية (Brain Gym)

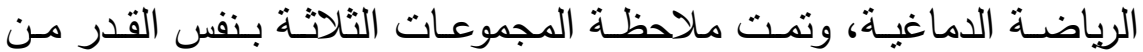

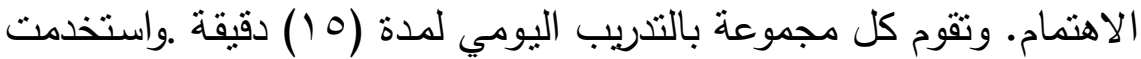

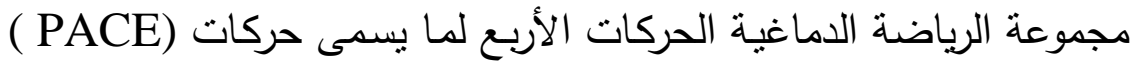

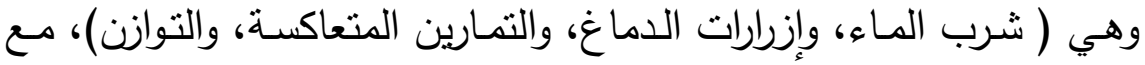

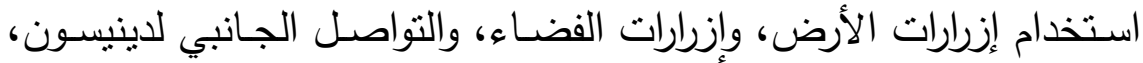

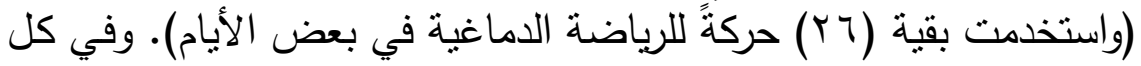

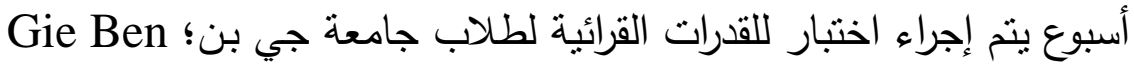

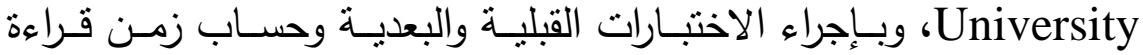

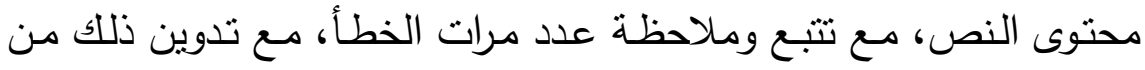

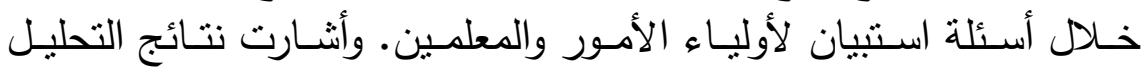

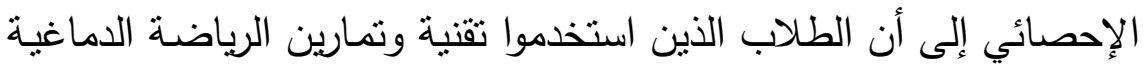

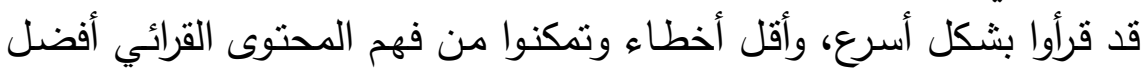
من طلاب المجموعتين الآخرين.

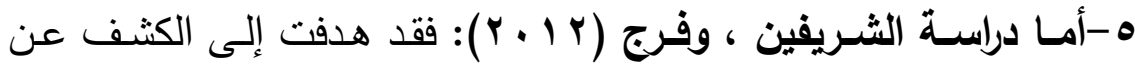

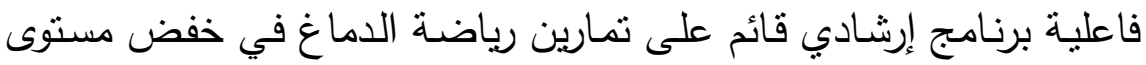


اضطراب نقص الانتباه المصحوب بالنشـاط الحركي الزائد. وتنكونت عينة الدراسة من ( • r) طالباً وطالبةً من كلية المرحلة الأساسية من مديرية تلابية

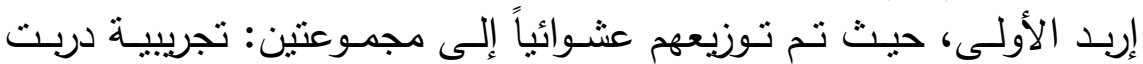

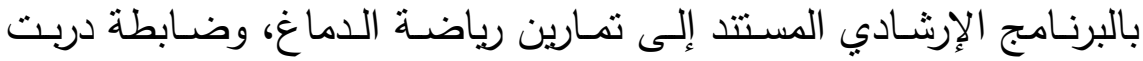
بالأساليب الإرشادية الاعتيادية. أظهرت نتائج الدراسة أن مستوى اضطراب

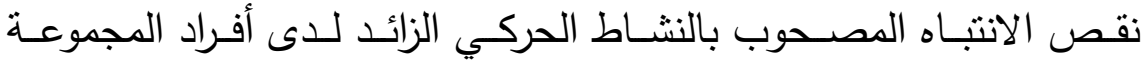
التجريبية كان أقل بشكل دال إحصائياً مما لدى أفراد المجموعة الضـابطة، كما كثفت النتائج عن وجود فروق ذات دلالة إحصائية تعزى للجنس في مجالي نقص الانتباه والاندفاعية على المقياس ككل لصالح الذكور ولم تكن همالك فروق ذات دلالة إحصائية تعزى لبقية المتغيرات .

צ-و دراسة آل مراد (Y Y • r): التي هدفت إلى البحث عن تصميم برنامج

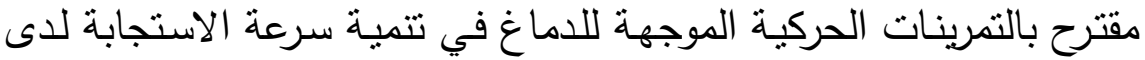

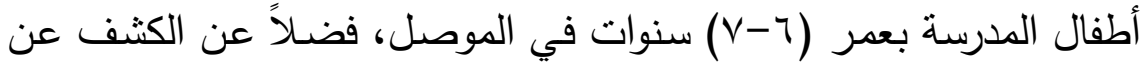

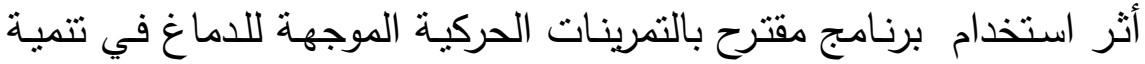

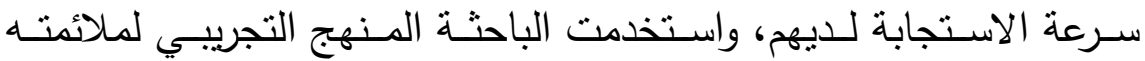

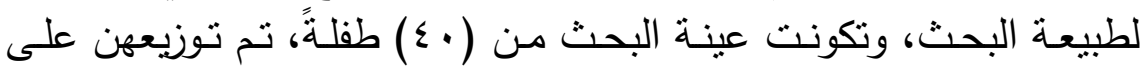

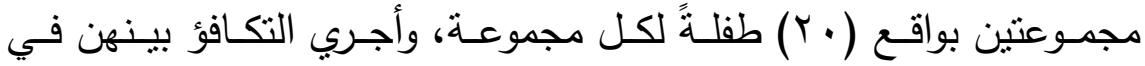
متغيرات ترتيب الطفل بين إخوته في الميلاد، والعمر ، والتحصبل الدراسي

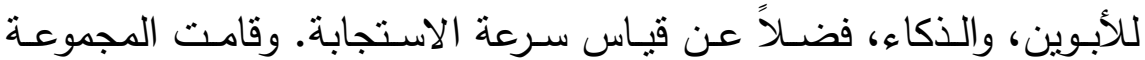

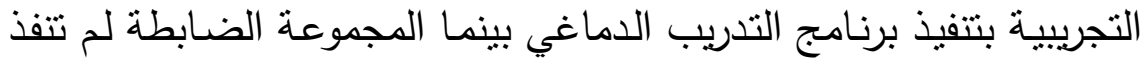
أي برنامج. واستغرق تتفيذ البرنامج (عشرة أسابيع) بواقع وحدتين تدربييتين

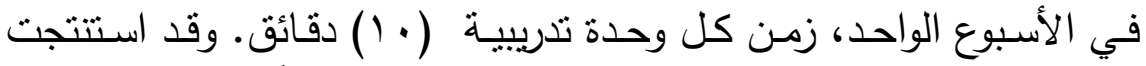

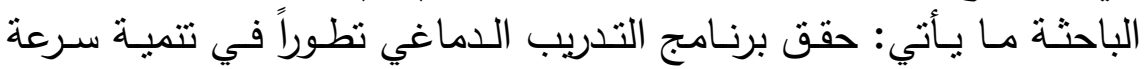


الاسـتجابة عنـــ المقارنـة بـين القياسـين القبلي والبعـي لأطفـال المجموعـة التجريبية. وتفوق برنامج التدربب الدماغي في تتمية سرعة الاستجابة لدى بلئ

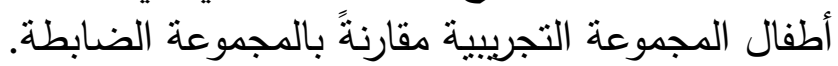

: Andrea, W., et al., 2014) دراسـة أندريا واطسون وآخرون التي هدفت إلى التحقق من تأثير الرياضـة الدماغية؛Brain Gym ، على إنى

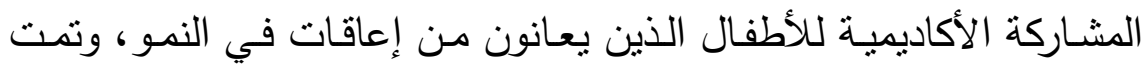

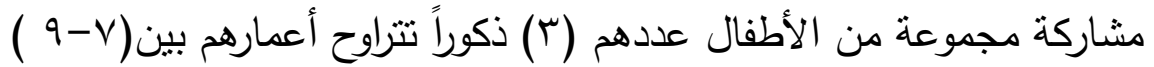

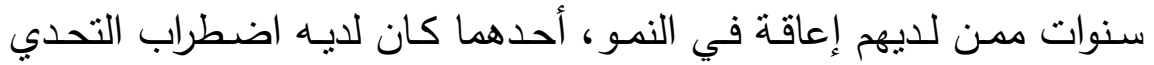
المعارض، والآخر لديه اضطراب نقص الانتباه وفرط النشاط، والثالث بعاني من اضطراب المعالجة السمعية، كما يظهر على أحدهم أعراضناً تتفق مـع

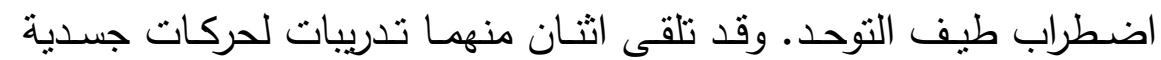
لتتميـة مهارات القراءة، بينمـا تلقى الثالث تدريبات جسدية تسـهم في تتمبـة مهارات الرباضيات. وقد تم التدريب في ( ^- • (1) دقائق الأولى من بدء

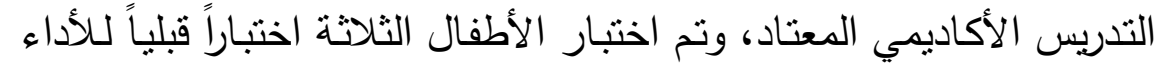

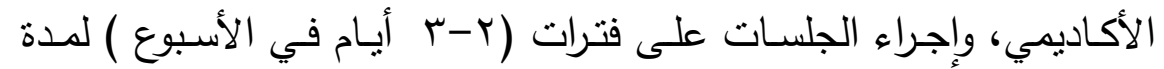

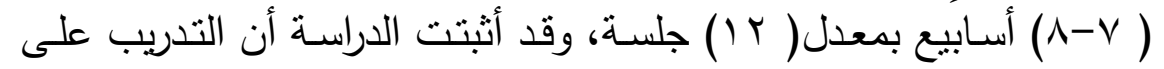
تمـارين الرياضـة الدماغية؛Brain Gym ، من خلافل النشـاط البدني في تدربياتها أدت إلىى تحسين السـولك الأدائي الأكـاديمي في الفصـل لأولئك الطلبة

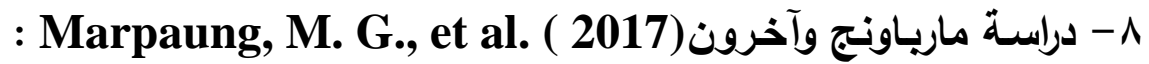

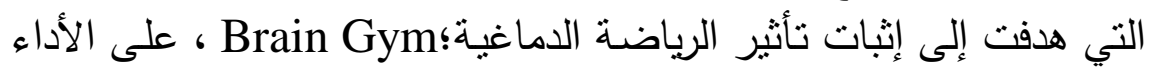

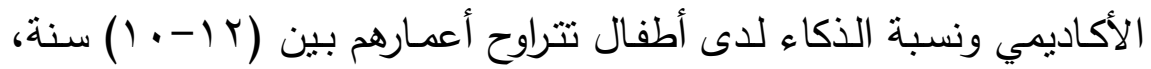

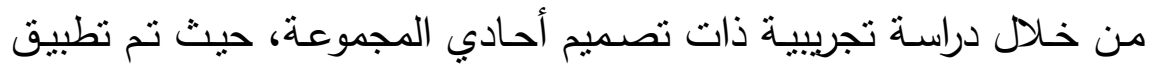




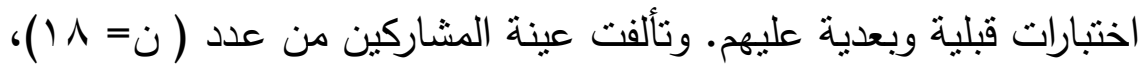

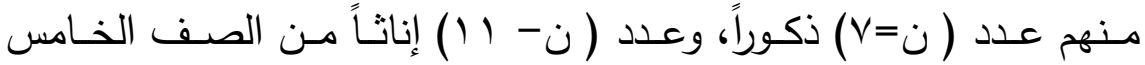

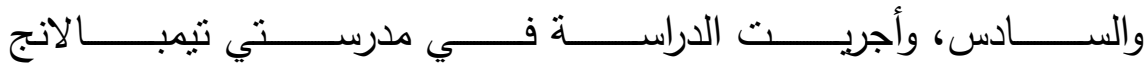

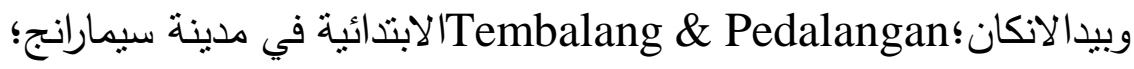
Semarang الرياضــة الدماغيـة؛ Brain Gym ، بعد أداء الاختبـار القبلـي لـلأداء

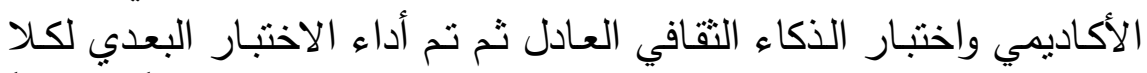

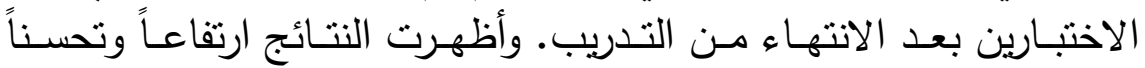

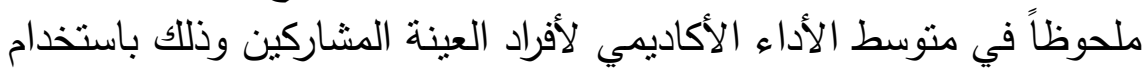

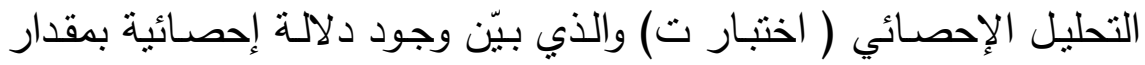

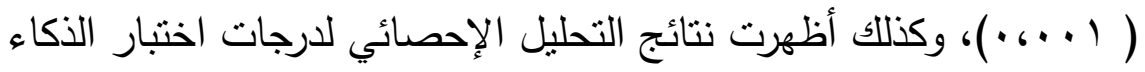

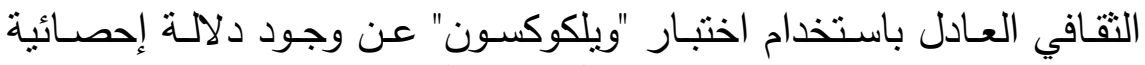

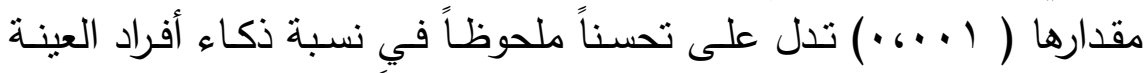

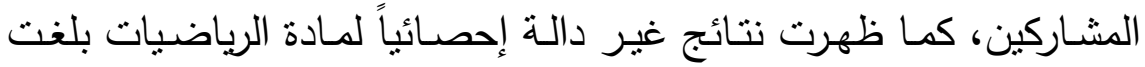

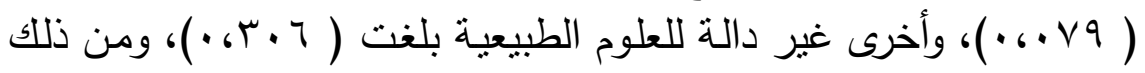

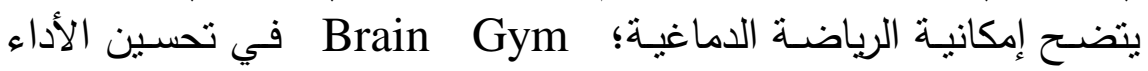

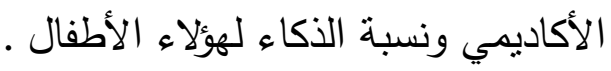

9- دراسـة Bungawali ؛ بنجاوالي (1 ا • r): والتي هدفت إلى تحديد

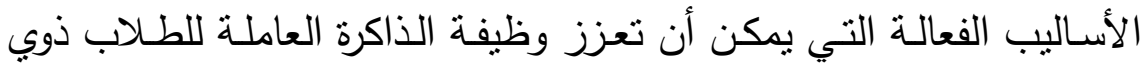

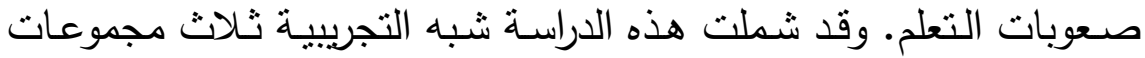

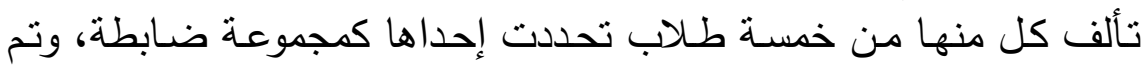
تطبيـق تـدريبات الرياضــة الدماغيـة للمجموعـة الثانيـة والتـدريبات العقليـة (ألعـاب ذهنيـة) للمجموعـة الثالثـة. وقد قـام فريـق التـدخل بتقديم تدريبات 
الرياضة الدماغية بإجراء تمرين(التمدد الزائد Brain Gym Superspace)

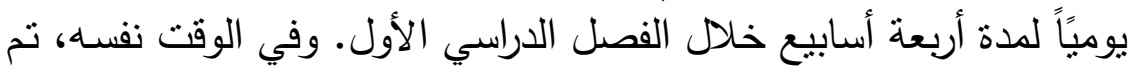

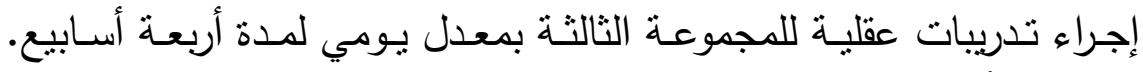

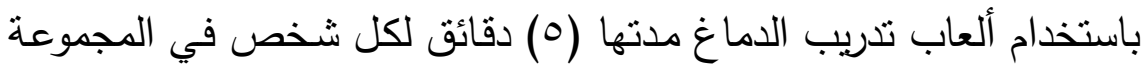
أثناء وقت الفراغ في المدرسة. وقد جمعت البيانات الخاصة بالثة بالذاكرة العاملة

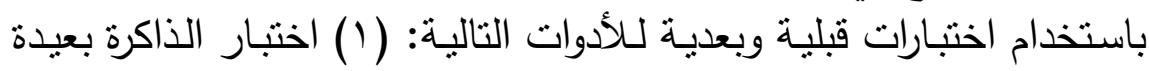

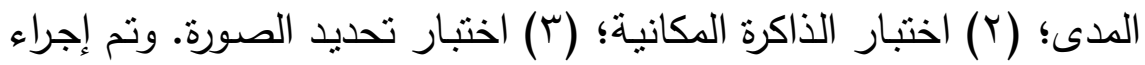

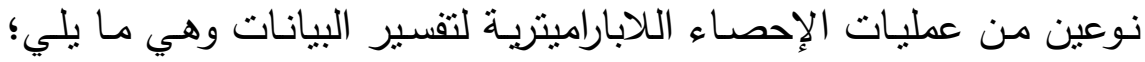

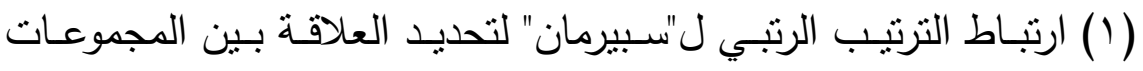

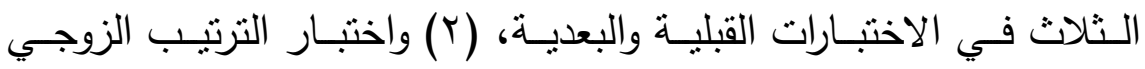

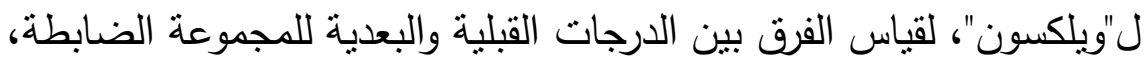

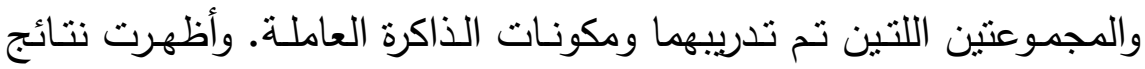

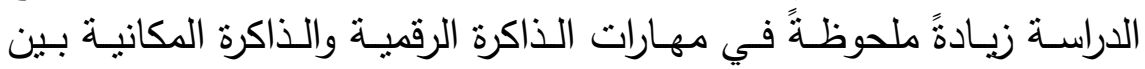
المشـاركين في المجموعات التي تم تدريبها. كمـا استتتجت التهات الدراسـة أيضًا تحسناً كبيراً في وظيفة الذاكرة العاملة لكلا المجموعنين اللتين تم تدريبهما.

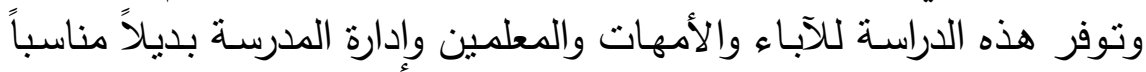

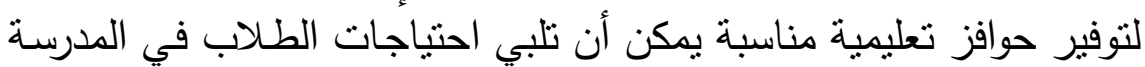

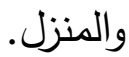

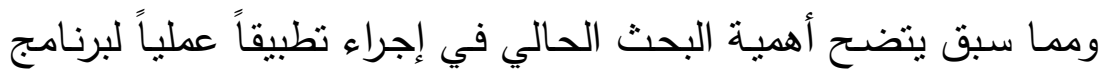

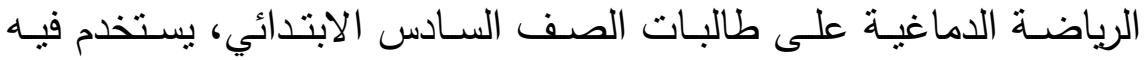

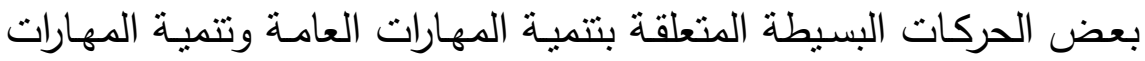

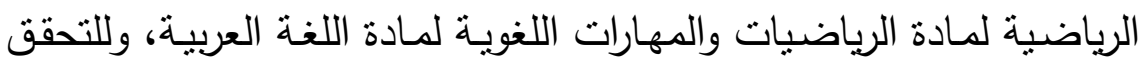
من إمكانية تأثنيره على الإنجاز الأكاديمي والقلق الاجتماعي والتوجها نحو 
الحيـاة لـيهن، حيث أن الباحثة قد مارست تلك الرياضــة من خـلال دورة

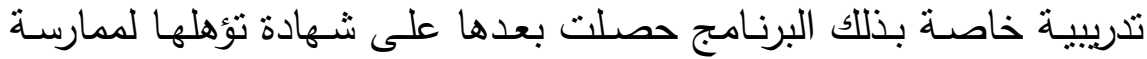

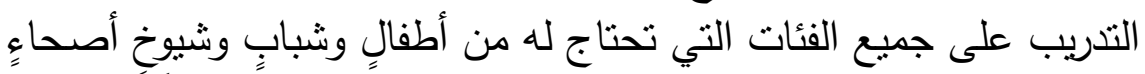

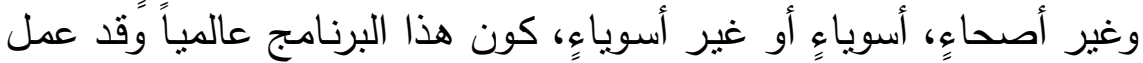

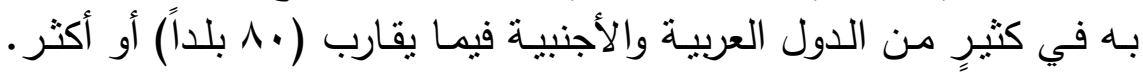
(Spaulding, et al., 2010)

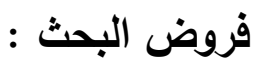

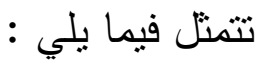

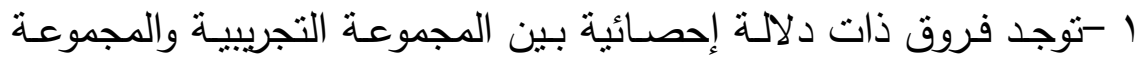
الضابطة في القياس البعدي لمقياس الإنجاز الأكاديمي في الاتجاه الإنة الأفضل للعينة التجريبية. ب-توجد فروق ذات دلالـة إحصـائية بين المجموعـة التجريبيـة والمجموعـة الضابطة في القياس البعدي لمقياس القلق الاجتماعي في الاتجاه الإنسائل الأفضل للعينة التجريبية. ب-توجد فروق ذات دلالــة إحصـائية بين المجموعـة التجريبيـة والمجموعـة الضابطة في القياس البعدي لمقياس الاتجاه نحو الحياة في الاتجاه الأفضل الحتل للعينة التجريبية. ـ-توجد فـروق ذات دلالــة إحصـائية بـين القيـاس القبلي والقيـاس البعدي للمجموعـة التجريبيـة على مقياس الإنجاز الأكاديمي في الاتجـاه الأفضل الفيل لصالح القياس البعدي.

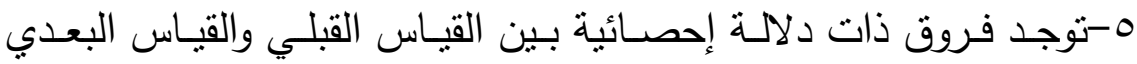

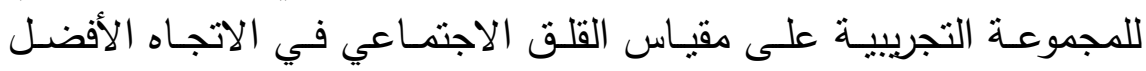
لصالح القياس البعدي. 
ج-توجد فـروق ذات دلالـة إحصـائية بـين القيـاس القبلـي والقيـاس البعـدي للمجموعـة التجريبيـة على مقبـاس التوجهـ نحو الحيـاة في الاتجـاه الأفضـل لصالح القياس البعدي. V-توجد فروق ذات دلالـة إحصـائية بين درجـات الطالبـات باختبـار الفترة الدراسية الأولى لمادة اللغة العربية (قبل تطبيق البرنامج) وبين درجاتهن في

الفترة الدراسية الثانية ( بعد تطبيق البرنامج) لصالح الفترة الدراسية الثانية. 1-توجد فروق ذات دلالـة إحصـائية بـين درجات الطالبـات باختبـار الفترة

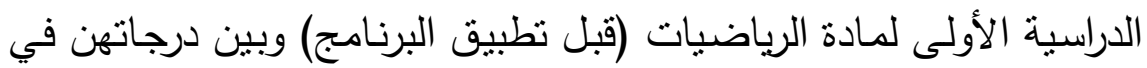
الفترة الدراسية الثانية ( بعد تطبيق البرنامج) لصالح الفترة الدراسية الثانية. الإجراءات المنهجية للبحث : أولاً : منهج البحث:

اتبع البحث الحالي المنهج شبه التجربي القائم على فحص أثر إدخال

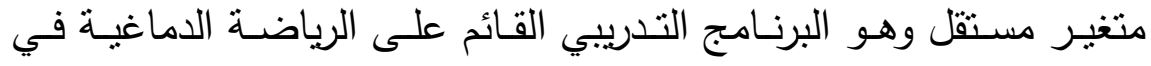
المتغيـر التابع وهو المستوى التحصيلي بمـادتي الرياضيات واللغـة العربيـة وتأثيره على المتغيرات التابعة التالية؛ القلق الاجتماعي والإنجاز الأكاديمي والتوجه نحو الحياة لدى طالبات الصف السادس بالمرحلة الابتدائية.

مع ضبط المتغيرات التي يحتمل تأثيرها على البحث التجريبي، والذي يعتمد على تطبيق الاختبار القبلي على مجموعتين إحداهما تجريبية وأخرى ضابطة، ثم يتم تطبيق برنامج الرباضـة الدماغية على المجموعة التجريبية، لهية بينما لا يتم تطبيق البرنامج على المجموعة الضـابطة، وإنما تترك لتمارس

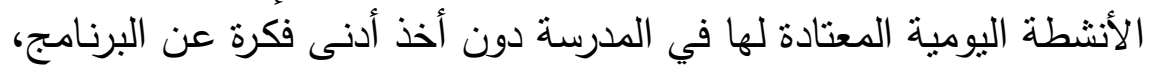
ثم يتم تطبيق الاختبار البعدي على المجموعتين كما في الجدول التالي: 
جدول (1)

\begin{tabular}{|c|c|c|c|}
\hline الاختبار البعدي & البرنامج & الاختبار القبلي & المجموعات \\
\hline$\sqrt{ }$ & $\sqrt{ }$ & $\sqrt{ }$ & المجموعة التجريبية \\
\hline$\sqrt{ }$ & $x$ & $\sqrt{ }$ & المجموعة الضابطة \\
\hline
\end{tabular}

ثانياً :مجتمع البحث:

يمثل طالبات الصف السادس بالمرحلة الابتدائية بالتعليم العام بدولة الكويت ثالثاً : عينة البحث:

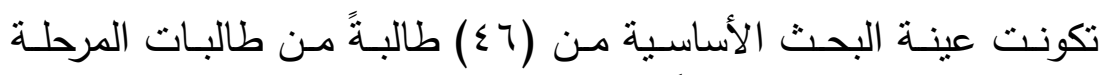

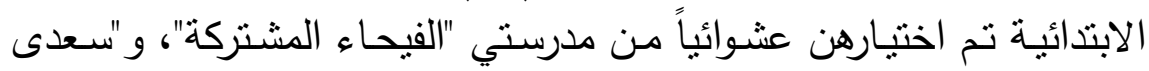

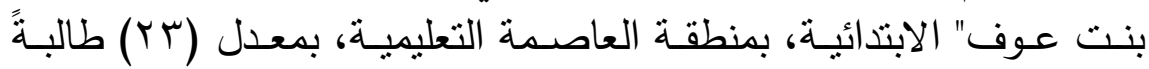

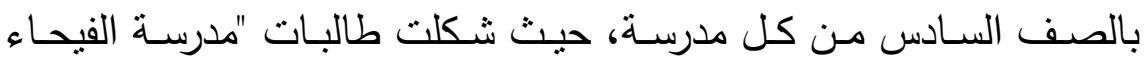

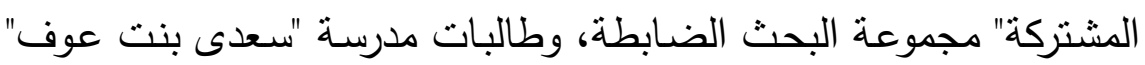
مجموعة البحث التجريبية.

وقد تم التحقق من تكافؤ المجموعتين في كلٍ من المستوى التحصيلي

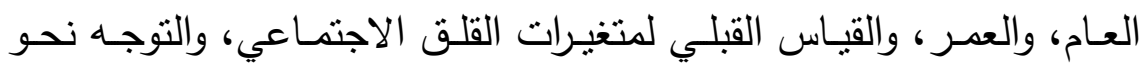

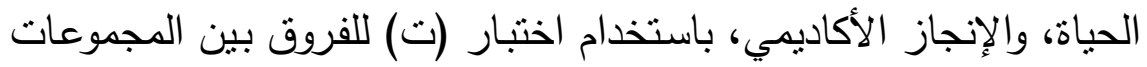
المستقلة، كما يعرضه الجدول (Y). 


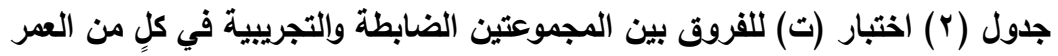

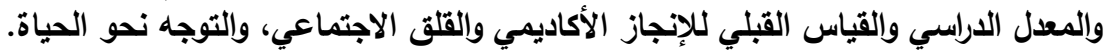

\begin{tabular}{|c|c|c|c|c|c|c|}
\hline الالالة & قيمة ت & الانحراف المعياري & المتوسط & العدد & المجموعة & المقياس \\
\hline \multirow[t]{2}{*}{.726} & -.353 & 1.738 & 10.74 & 23 & الضابطة & \multirow{2}{*}{ العمر } \\
\hline & & .344 & 10.87 & 23 & التجريبية & \\
\hline \multirow[t]{2}{*}{.165} & 1.413 & 21.301 & 85.50 & 23 & الضابطة & \multirow{2}{*}{ الدعدل } \\
\hline & & 6.424 & 92.09 & 23 & التجريبية & \\
\hline \multirow[t]{2}{*}{.379} & .889 & 13.848 & 72.30 & 23 & الضابطة & \multirow{2}{*}{ الألإنجاز الإيمي القياس } \\
\hline & & 3.612 & 74.96 & 23 & التجريبية & \\
\hline \multirow[t]{2}{*}{.823} & .225 & 9.836 & 34.26 & 23 & الضابطة & \multirow{2}{*}{ الاجتماعي القياس القبل } \\
\hline & & 8.498 & 34.87 & 23 & التجريبية & \\
\hline \multirow[t]{2}{*}{.498} & .684 & 15.006 & 36.57 & 23 & الضابطة & \multirow{2}{*}{ التوجيه } \\
\hline & & 5.130 & 34.30 & 23 & التجريبية & \\
\hline
\end{tabular}


من الجدول (Y) يتبين عدم وجود فروق ذات دلالة إحصائية عند مستوى الحئ

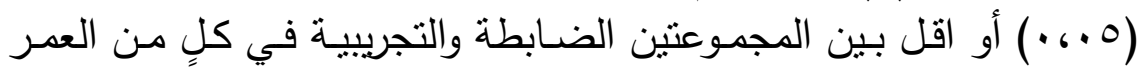

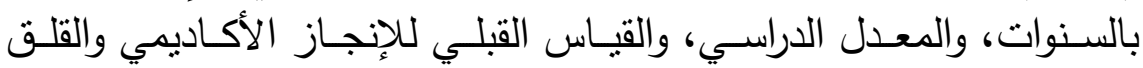

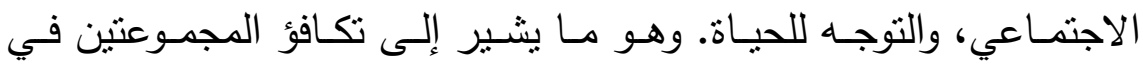
المتغيرات التابعة والدخيلة قبل الإجراء التجريبي للباحثة. أدوات البحث :

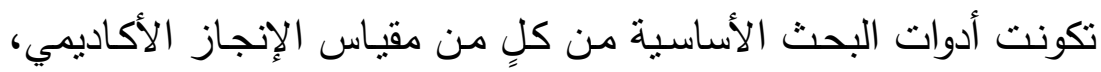

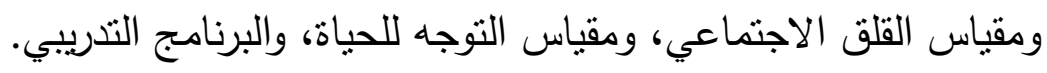

\section{أولاً: مقياس الإنجاز الأكاديمي :}

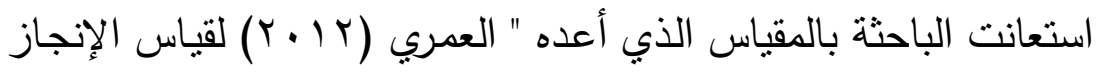

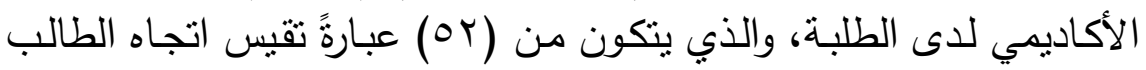

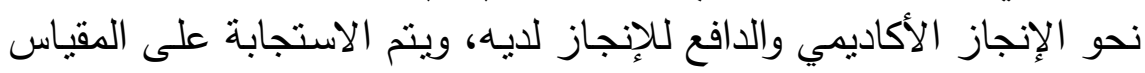

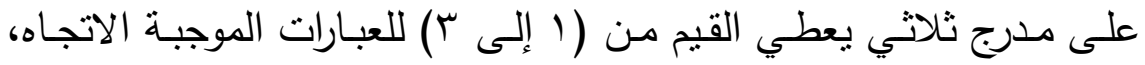

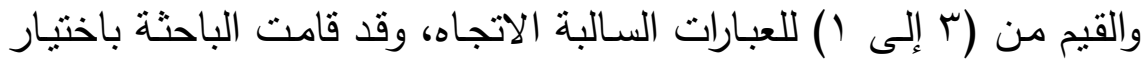

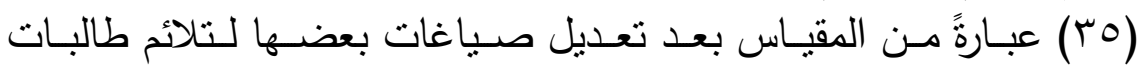

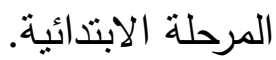

وقد قـام مُعِد المقبـاس بـالتحقق مـن صـدق المقيـاس بحسـاب الصـدق

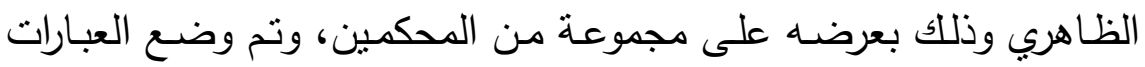

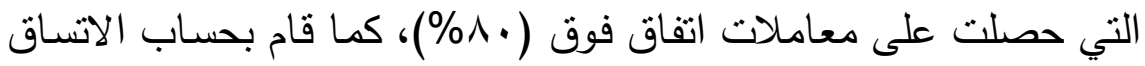

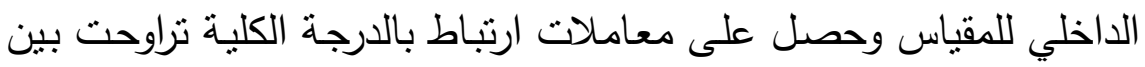

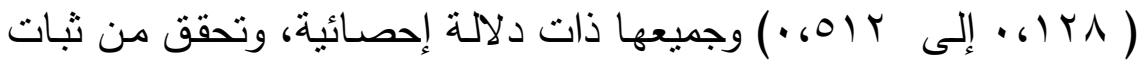




\section{المجلة العلمية لكلية رياض الأطفال - جامعة بورسعيد}

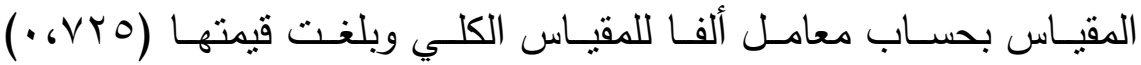
والتجزئة النصفية التي بلغت بمعادلة "سبيرمان براون" (VIV، • ).

وقد قامد الباحثة بـالتحقق مسن صدق مفردات المقبـاس بحسـاب علاقة

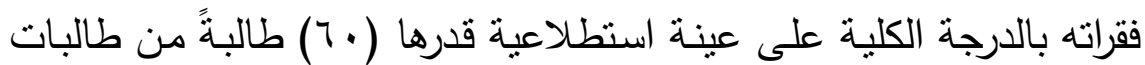
الصف السادس بالمرحلة المتوسطة باستخدام معامل ارتباط بيرسون، الذي

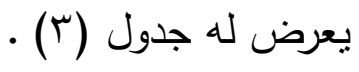

جدول (r) معامل الارتباط بين الفقرات واللارجة الكلية لمقياس الإنجاز الأكاديمي

\begin{tabular}{|c|c|c|c|c|c|c|c|}
\hline الارتباط معامل & الفقرة & معامل الارتباط & الفقرة & الارتباط معامل & الفقرة & معامل الارتباط & الفقرة \\
\hline $.241^{* " *}$ & 31 & $.267^{* *}$ & 21 & $.388^{* \prime \prime}$ & 11 & $.218^{* *}$ & 1 \\
\hline $.360^{\text {"** }}$ & 32 & $.387^{* * *}$ & 22 & $.441^{* * *}$ & 12 & $.318^{* * *}$ & 2 \\
\hline $.291^{* *}$ & 33 & $.312^{* * *}$ & 23 & $.428^{* * "}$ & 13 & $.286^{* * *}$ & 3 \\
\hline $.325^{* * *}$ & 34 & $.341^{* * *}$ & 24 & $.366^{\prime \prime \prime}$ & 14 & $.328^{* * *}$ & 4 \\
\hline \multirow[t]{6}{*}{$.229^{* * *}$} & 35 & $.287^{* *}$ & 25 & $.189^{* " *}$ & 15 & $.342^{* " *}$ & 5 \\
\hline & & $.431^{* " *}$ & 26 & $.306^{* *}$ & 16 & $.302^{* * "}$ & 6 \\
\hline & & $.361^{* " *}$ & 27 & $.440^{* \prime \prime}$ & 17 & $.426^{* *}$ & 7 \\
\hline & & $.430^{* *}$ & 28 & $.372^{* * *}$ & 18 & $.375^{* *}$ & 8 \\
\hline & & $.213^{* \prime \prime}$ & 29 & $.321^{* \prime \prime}$ & 19 & $.349^{* *}$ & 9 \\
\hline & & $.214^{* \prime \prime}$ & 30 & $.330^{* \prime \prime \prime}$ & 20 & $.500^{* *}$ & 10 \\
\hline
\end{tabular}

**** عال عند مستوى I •,. 
تشــير قيم معـاملات الارتبـاط بالجـدول (Y) إلـى وجـود ارتبـاط دال

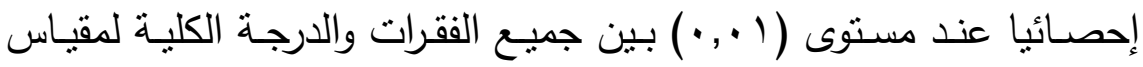

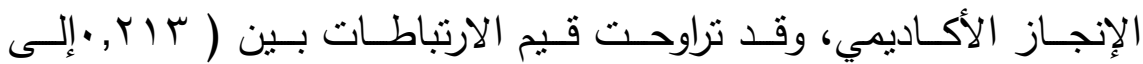

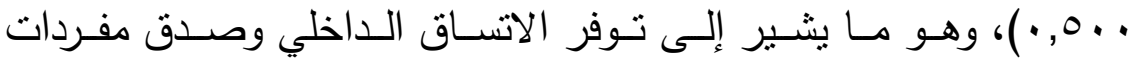

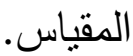

وقامت الباحثة بحسـاب ثبـات المقيـاس باستخدام معامل ألفـا كرونبـاخ

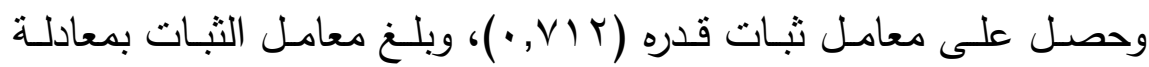

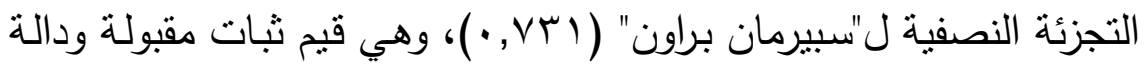
على ثبات المقياس المستخدم. ثانياً: مقياس القثق الاجتماعي:

استخدمت الباحثة المقياس الذي أعده "رضوان" (999 1) لقياس القلق

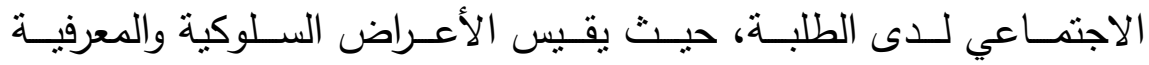

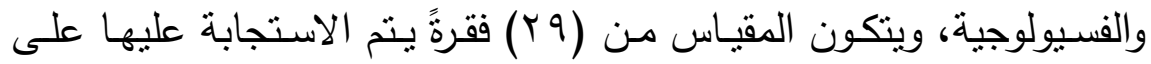

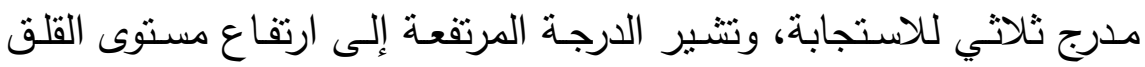
الاجتماعي لدى الطلبة.

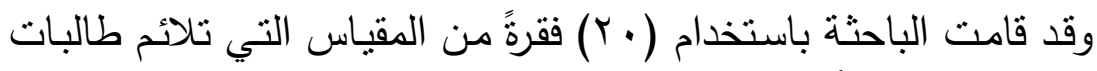

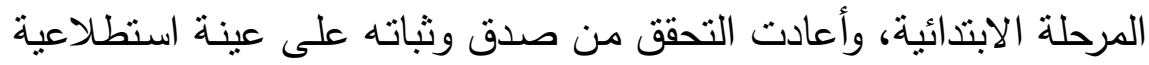
قدرها ( • ج) طالبةً من طالبات الصفاد الصف السادس.

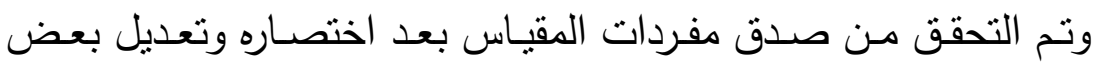

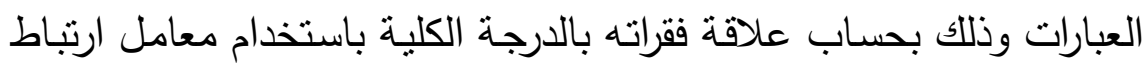
بيرسون، الذي يعرض له جدول (ع) التالي. 
المجلة العلمية لكلية رياض الأطفال - جامعة بورسعيد

جدول (ء) معامل الارتباط بين الفقرات والدرجة الكلية لمقياس القلق الاجتماعي

\begin{tabular}{|c|c|c|c|}
\hline معامل الارتباط & الفقرة & معامل الارتباط & الفقرة \\
\hline $.506 * *$ & 11 & $.648 * *$ & 1 \\
\hline $.652 * *$ & 12 & $.572 * *$ & 2 \\
\hline $.423 * *$ & 13 & $.528 * *$ & 3 \\
\hline $.706 * *$ & 14 & $.552 * *$ & 4 \\
\hline $.481 * *$ & 15 & $.584 * *$ & 5 \\
\hline $.641 * *$ & 16 & $.548 * *$ & 6 \\
\hline $.587 * *$ & 17 & $.675 * *$ & 7 \\
\hline $.470 * *$ & 18 & $.607 * *$ & 8 \\
\hline $.521 * *$ & 19 & $.567 * *$ & 9 \\
\hline $.652 * *$ & 20 & $.660 * *$ & 10 \\
\hline
\end{tabular}

تثير قيم معاملات الارتباط بالجدول (ع) إلى وجود ارتباط دال إحصـائياً

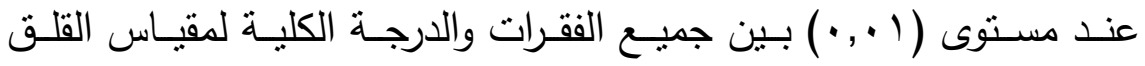
الاجتماعي، وقد نراوحت قيم الارتباطات بين (Trع, · إلى 7 • V, •)، وهو ما يشير إلى توفر الاتساق الداخلي وصدق مفردات المقياس.

وقامت الباحثة بحسـاب ثبات المقياس باسـتخدام معامل ألفا “كرونبـاخ"

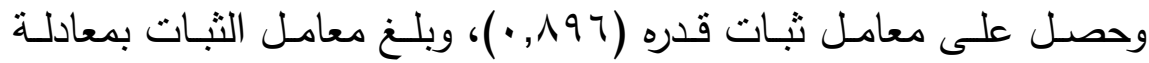

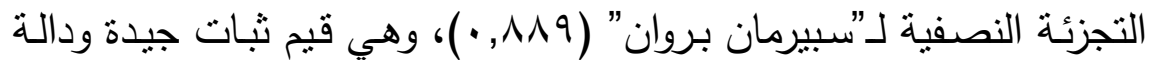
على ثبات المقياس المستخدم. 


\section{ثالثاً: مقياس الاتجاه نحو الحياة:}

استخذمت الباحثـة مقيـاس "كارفر" و "نــاير" للتوجـهـ نحـو الحيـاة وقام

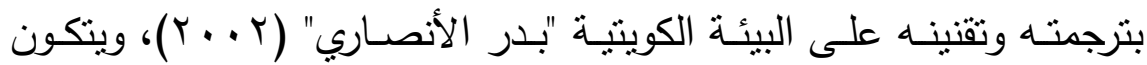

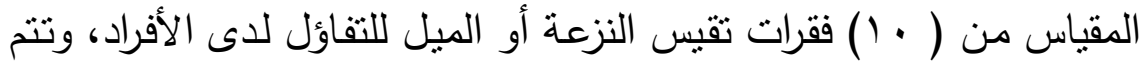

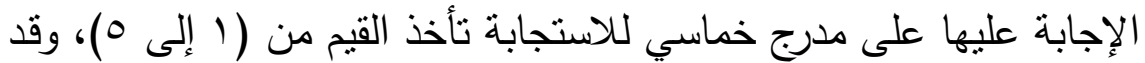

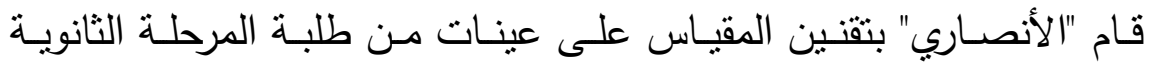

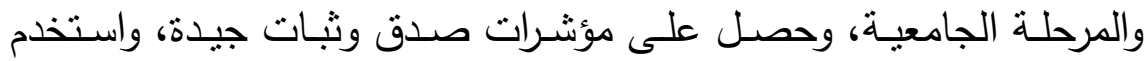
المقياس في العديد من البحوث والدراسات الخاصة بالبيئة الكويتية.

وقد قامت الباحثة بالتحقق من صدق مفردات المقياس بحساب علاقة

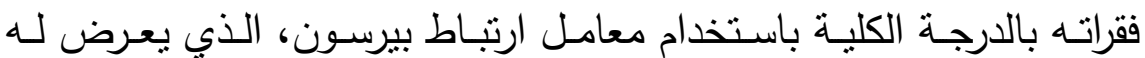

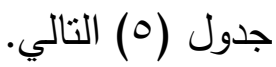

جدول (0) معامل الارتباط بين الفقرات والدرجة الكلية لمقياس الاتجاه نحو الحياة

\begin{tabular}{|c|c|c|c|}
\hline معامل الارتباط & الفقرة & معامل الارتباط & الفقرة \\
\hline $.271 * *$ & 6 & $.528 * *$ & 1 \\
\hline $.230^{* * *}$ & 7 & $.573 * *$ & 2 \\
\hline $.214 * *$ & 8 & $.671 * *$ & 3 \\
\hline $.663 * *$ & 9 & $.684 * *$ & 4 \\
\hline $.205^{* * *}$ & 10 & $.638 * * *$ & 5 \\
\hline
\end{tabular}

** دال عند مستوى 1 .,.,

تشير قيم معاملات الارتباط بالجدول (0) إلى وجود ارتباط دال إحصائباً

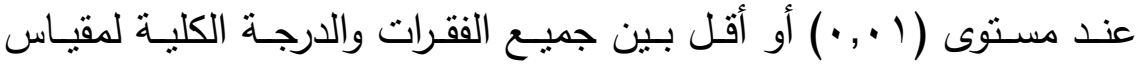




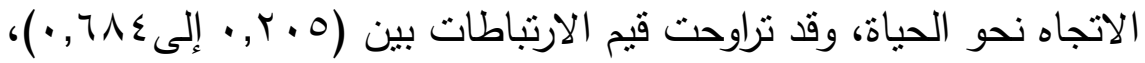
وهو ما يشير إلى توفر الاتساق الداخلي وصدق مفردات الدقات الدقياس.

وقامت الباحثنة بحسـاب ثبات المقياس باسـتخدام معامل ألفـا "كرونباخ"

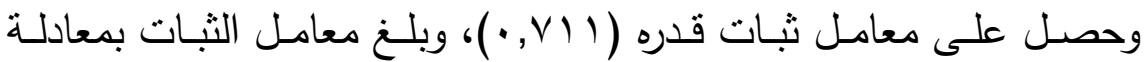

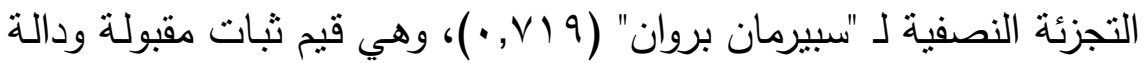
على ثبات المقياس المستخدم. رابعاً: البرنامج التدريبي القائم على الرياضة الدماغية: وهو برنامج مخطط منظم في ضوء أسسٍ علميةٍ وتربويةٍ يتضمن مجموعة

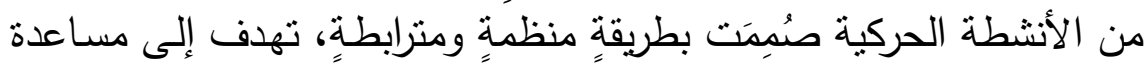

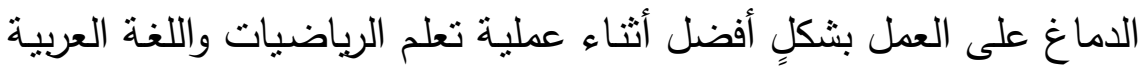

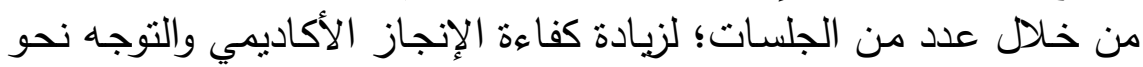
الحياة وتخفيض القلق الاجتماعي لدى طالبات الصف السادي لردادة الابتدائي. مصادر إعداد البرنامج التدريبي: اعتمدت الباحثة في إعداد هذا البرنامج على عدة مصادر ، ألا وهي: ا-الإطار النظري للبحث الحالي حيث اعتمدت في بناء البرنامج على ما تضمنه الإطار النظري لهذا البحث.

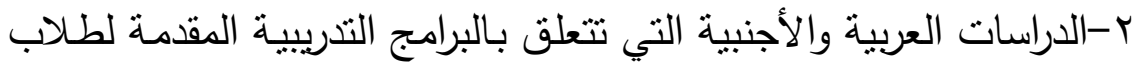
المرحلة الابتدائية. ץ-الملاحظات المباشرة لطالبات الصف السادس الابتدائي أثناء دراسة اللغة العربية والرياضيات . العنات 


\section{التخطيط العام للبرنامج:}

تشـتمل عمليـة التخطيط العـام للبرنـامج على تحديــ الأهـداف العامـة

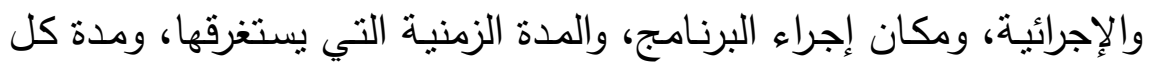

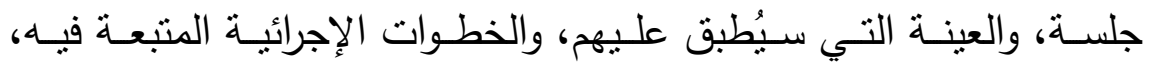
والوسائل المعينة ومحتوى الجلسات ثم تقييم البرنامج ككل.

الهرف العام من البرنامـج:

يهدف البرنامج التدريبي المقترح القائم على الرياضة الدماغية إلى تتمية

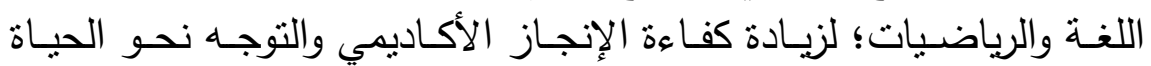
وتخفيض القلق الاجتماعي لدى طالبات الصف السادة الصاد الابتدائي .

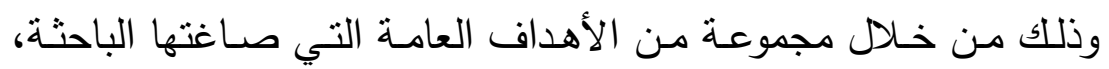
والتي يتوقع أن تكون كل طالبة من طالبات المجموعة قادرةً على تحقيقها لإنها بعد الانتهاء من البرنامج التدريبى وهي:

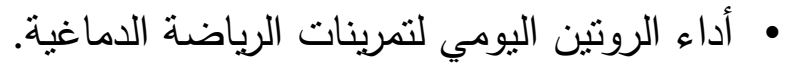
• • تمية القدرة الحسابية لاى الطالبات. • • تحسين الفهم القرائي لدى الطالبات.

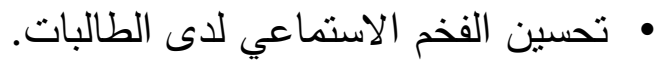

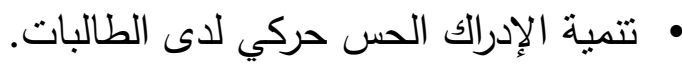

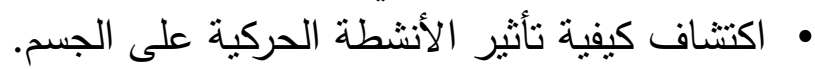

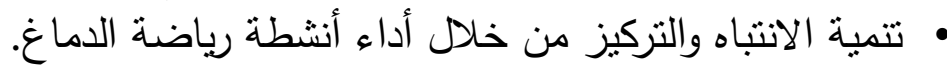

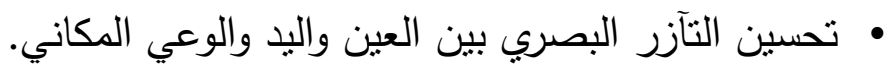

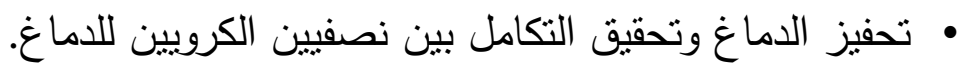




\section{المجلة العلمية لكلية رياض الأطفال - جامعة بورسعيد}

• زيادة الإنتباه البصري للأطفال تحسين المهارات البصرية من اليسار إلى اليمين.

• العمل على زيادة مدى الانتباه.

زيادة القدرة على التركيز والتفكير المجرد.

• تتمبة مهارات الاتزان الحركي وتحفيز نظام توازن الجسم. زبادة القدرة على التواصل والتركيز واكمال المهام.

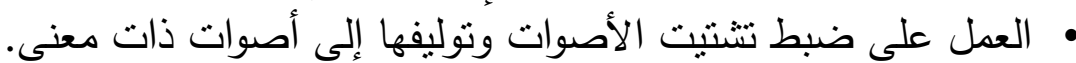
• تحسين القدرة الإبداعية عن طريق زيادة الدورة الدموية في المخ. زيادة تدفق الدم إلى الفص الجبهي من أجل تفكيرٍ أفضل. لإنه

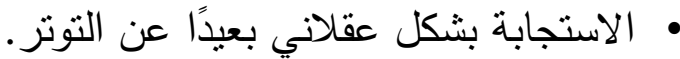

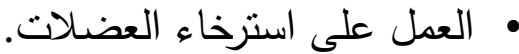
• العمل على إزالة التوتر من الرقبة وزيادة مستوى الإسترخاء. • ت تشنيط الدماغ من خلال زيادة تدفق السائل النخاعي إلى المخ. • زيادة القدرة على التعبير والتخيل والاستجابة والفهم.

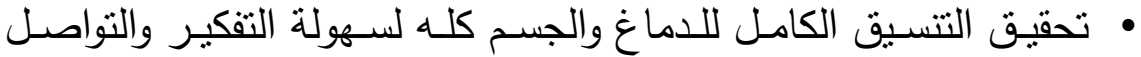

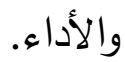

• تعزيز القدرة اللغوية والقدرة على التعبير عن الأفكار. • الثعور بالتوازن والتسسيق بين الجزء العلوي والسفلي للجسم. • تحسين الرؤية والسمع من خلال زيادة تدفق الدم إلى الدماغ. فلسفة البرنامج:

اشتقت فلسفة البرنامج التدريبي من نظربـة التعلم المستتد على الدماغ والتي تستند على الفرضيات البحثية الحديثة لعلم الأعصـاب، وتوضـح كيفية

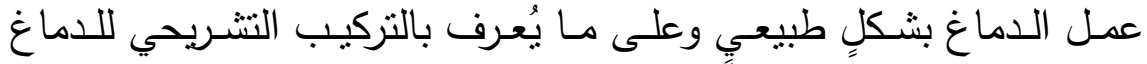


البشـرى وأدائه الوظيفي في مراحل النمو المختلفة، ويوفر هذا النوع مـن

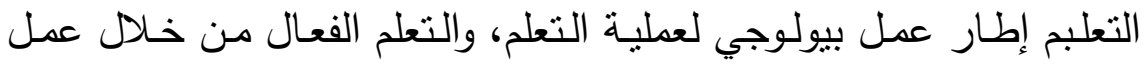

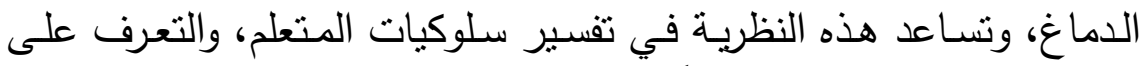

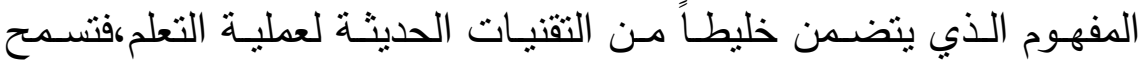

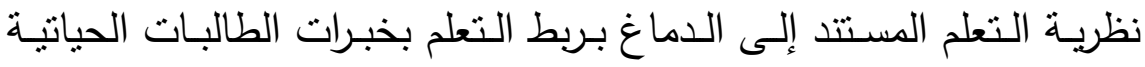
الواقعية.

وتقوم الفلسفة كذللك على المعرفة التي يتعلمها البشر من خلال الحركة

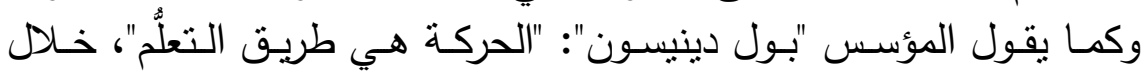

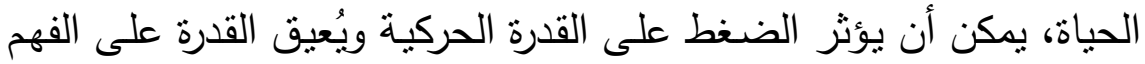

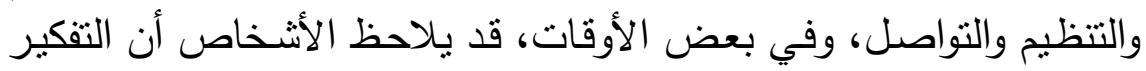
أو الثعور أو الإحساس قأ يؤثر على الأداء. أهمية البرنامج التدريبي القائم على الرياضة الدماغية: تتضح أهمية البرنامج التدريبي فيما يلي: 1-الاهنمام بمرحلة هامة من مراحل الطفولة وهي مرحلة الطفولة المتأخرة .

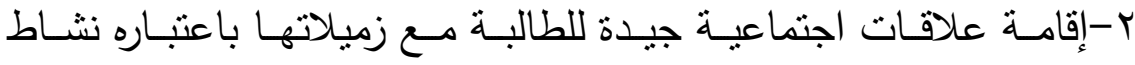

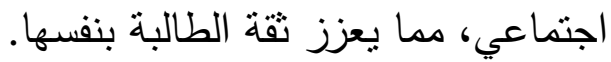

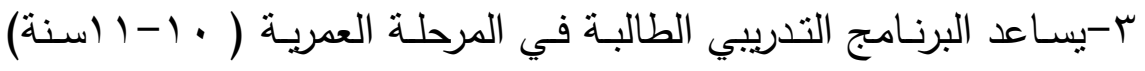

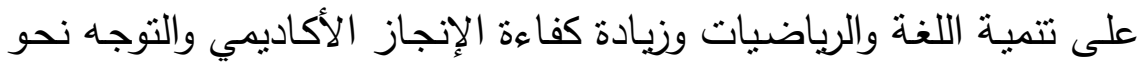
الحياة وتخفيض القلق الاجتماعي لدى الطالبات. 


\section{محتوى البرنامج التدريبي:}

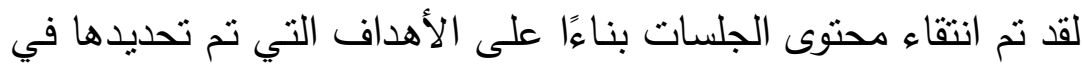

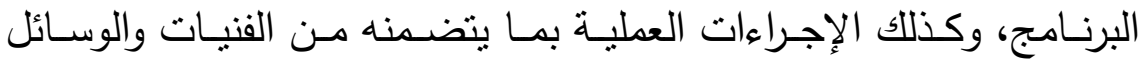
المستخدمة في كل جلسة من الجلسات.

وقد روعي عند تصميم البرنامج التدريبي القائم على الرياضـة الدماغية

الثروط التالية:

• مراعاة مطالب واحتباجات وخصائص الطالبات في هذة المرحلة.

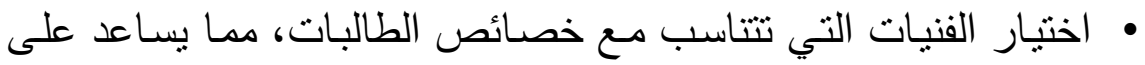

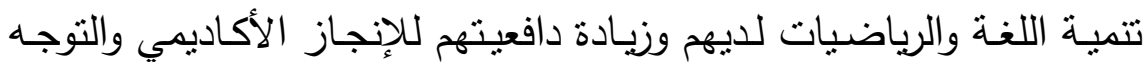

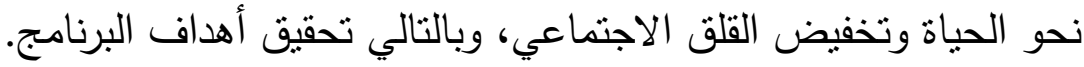

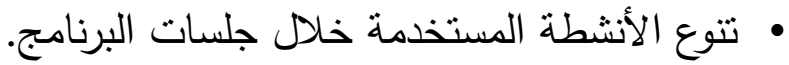

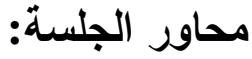

*الهدف العام من الجلسة.

*الأهداف الإجرائية.

**الفنيات المستخدمة خلال الجلسة. *متوى الجلسة ومهامها.

القنيات المستخدمة في البرنامج:

$$
\begin{aligned}
& \text { • النمذجة . } \\
& \text { • التعزيز الإيجابي. }
\end{aligned}
$$

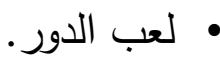

$$
\begin{aligned}
& \text { • • اللعب الجماعي. } \\
& \text { • التقليد والمحاكاة. }
\end{aligned}
$$




\section{الحدود الإجرائية للبرنامج :}

يتم تطبيق البرنامج على النحو التالي :

o مكان تنفيذ البرنـامج: تم تتفيذ البرنامج في مدرسـة سعدى بنت عوف

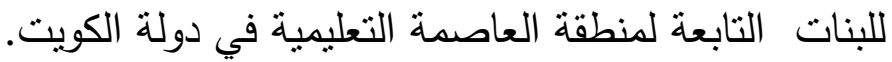
o

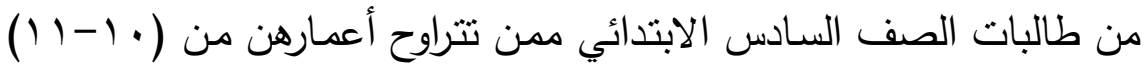
سنة.

o

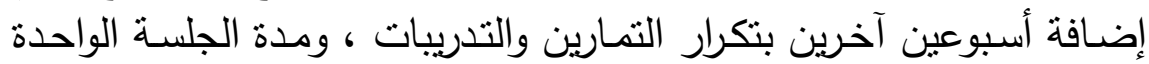

$$
\text { (r.) }
$$

الوسائل المعينة والخامات المستخدمة:

وتتشمل كافة المواد والموارد المستخدمة في تتفيذ أنشطة رياضـة الدماغ؛

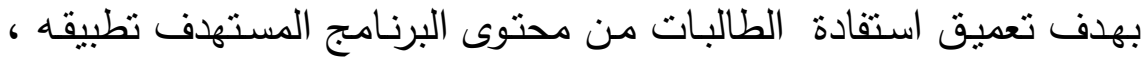

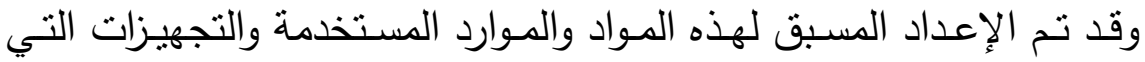

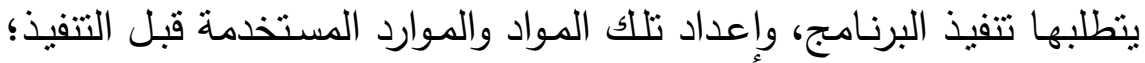

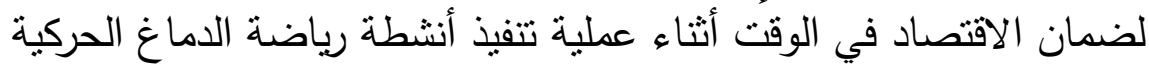
والإسهام في تحقيق الأهداف المرجوة.

الإستراتيجيات المستخدمة ببرنامج الرياضة الاماغية: • إستراتيجية التقويم لبرنامج أنشطة رياضة الدماغ: 1-التقويم القبلي: ويتم قبل تطبيق البرنامج وذلك بتطبيق :

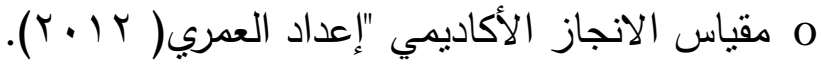


o مقياس القلق الاجتماعي "إعداد رضوان( 999 (1).

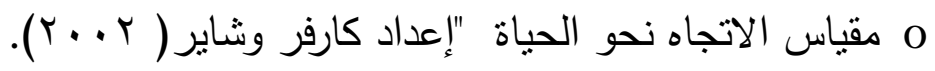
ץ-التقويم المرحلي: وذلك من خلال التمارين والتدريبات التي تتدرب عليها الطالبات بعد برنامج الرياضة الدماغية، وتعد إجاباتهم الصحيحة على على أسئلة

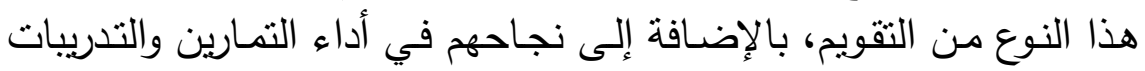
مؤشرًا على نجاح البرنامج.

r-التقويم البعدي: ويتم بعد تطبيق البرنامج وذلك بتطبيق :

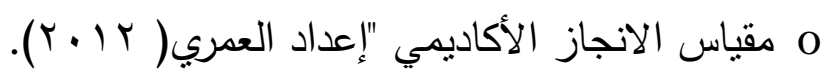

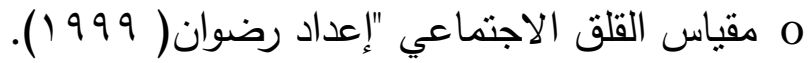

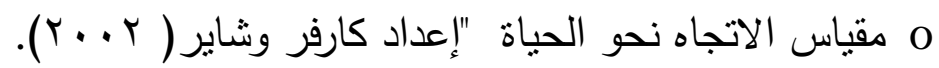
ع - التقويم التتبعي: يتم بعد تطبيق البرنامج بفترة زمنية؛ للتأكد من استمرار أثز البرنامج على المجموعة التجريبية.

• استراتيجية الأنشطة والممارسات التريوية المستخدمة: تم تصميم التمارين والتدريبات المتضمنة في البرنامج المستخدم وفقاً للشروط

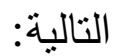
ا ارتبـاط تمـارين وتـدريبات الرياضــة الدماغيـة بأهـداف البحـث وتوقعهـا

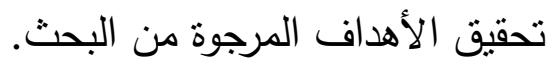

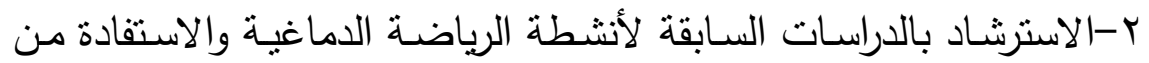
إستراتيجيات الدراسات السابقة.

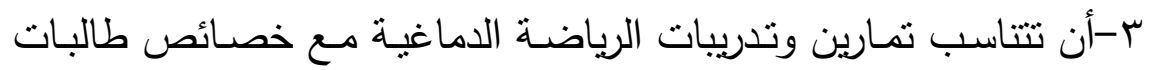

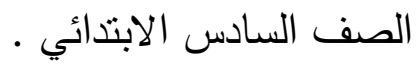




\section{ث إستراتيجية الموقف التربوي:}

-أولاً: دور الباحثة: يتلخص دور الباحثة في القاعة الدراسية مـع الطالبات في تجهيز القاعة من الأدوات والوسائل المستخدمة في البرنامج. -ثانياً: دور الطالبـة: لا يقتصر دور الطالبة على المشـاهدة ولكن نشترك الطالبة في كل مراحل البرنامج. نموذج من برنامج الرياضة الدماغية: برنامج الرياضة الدماغية المقترح من (إعداد/ الباحثة)

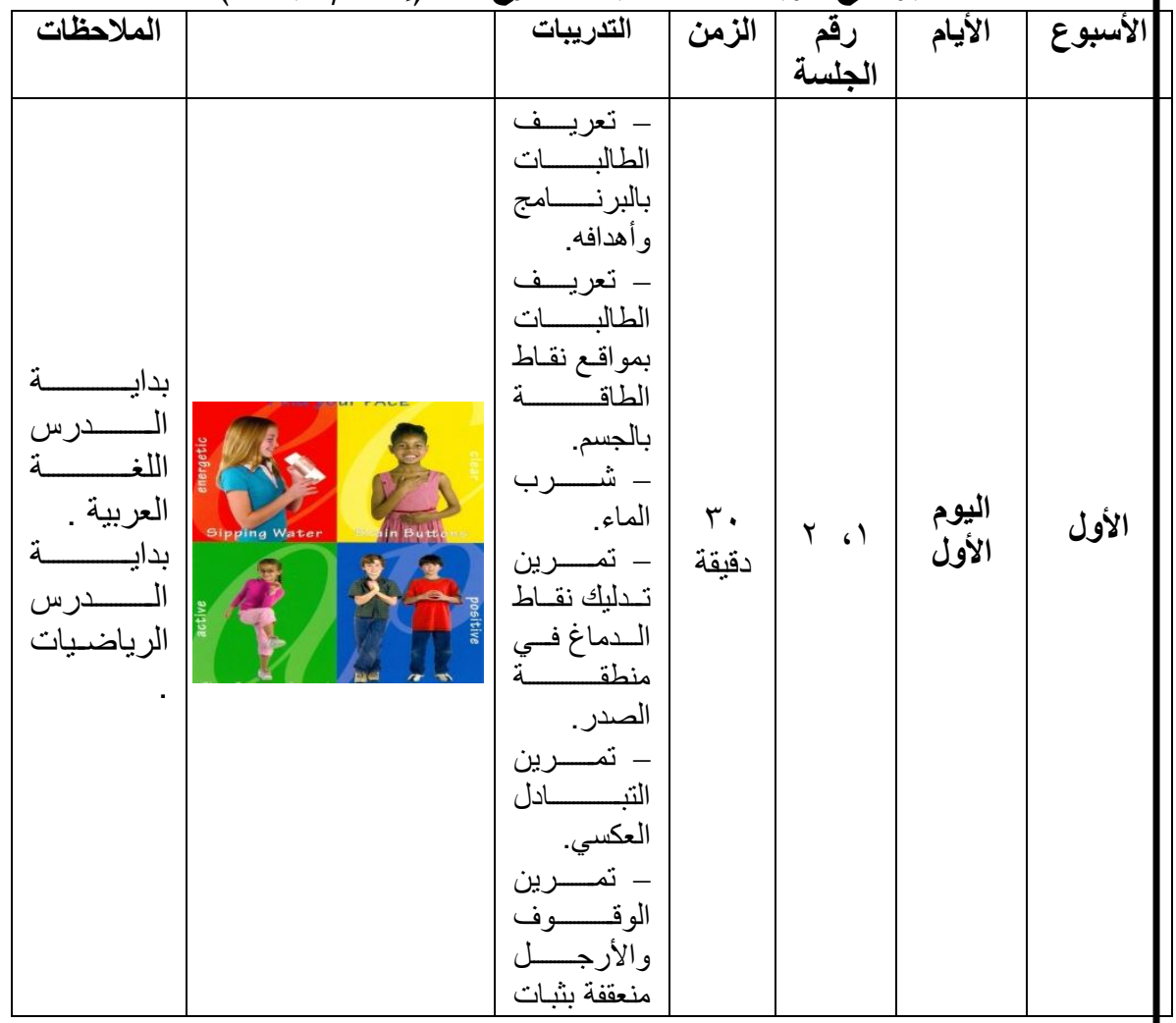




\section{المجلة العلمية لكلية رياض الأطفال - جامعة بورسعيد}

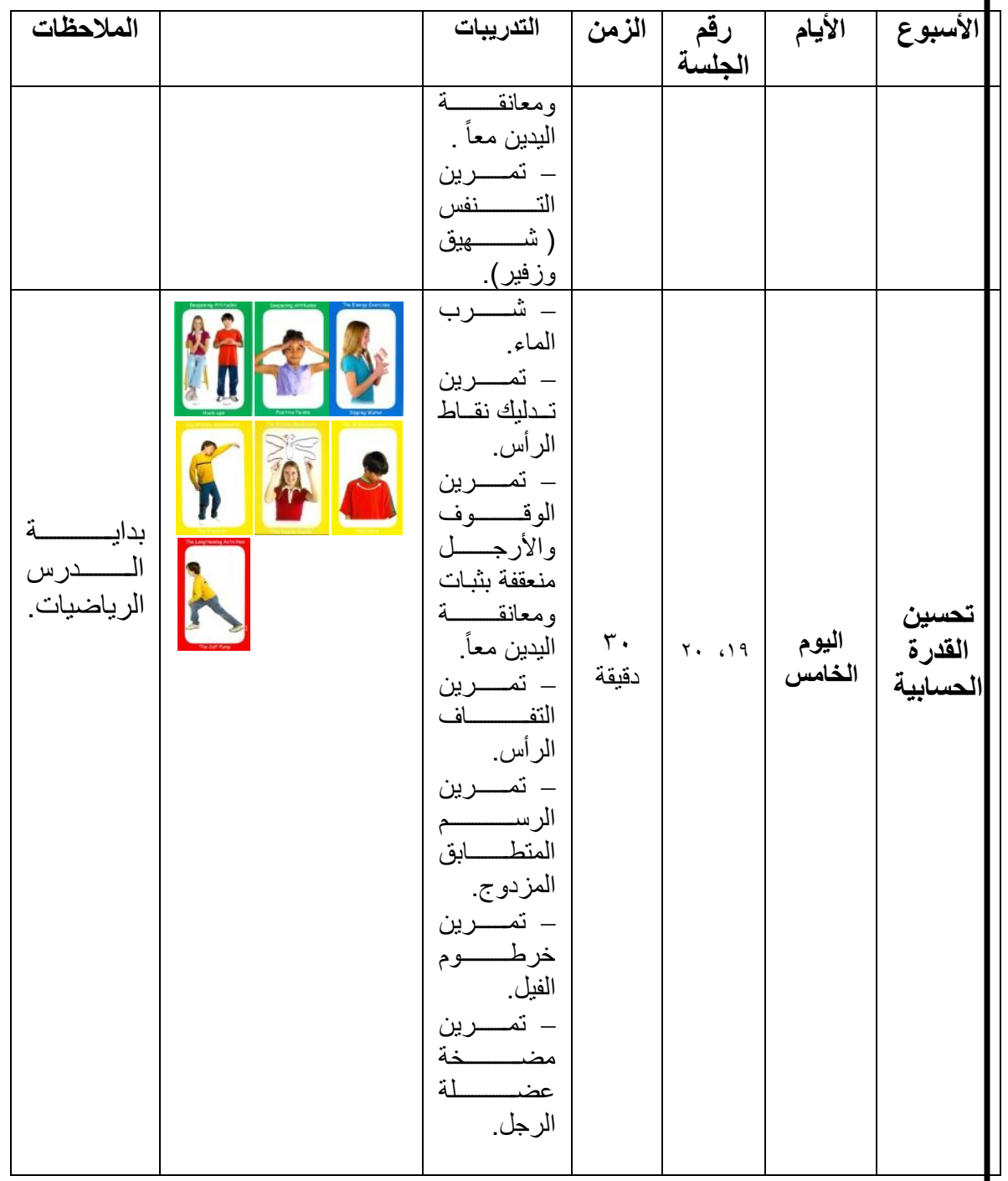


المجلة العلمية لكلية رياض الأطفال - جامعة بورسعيد

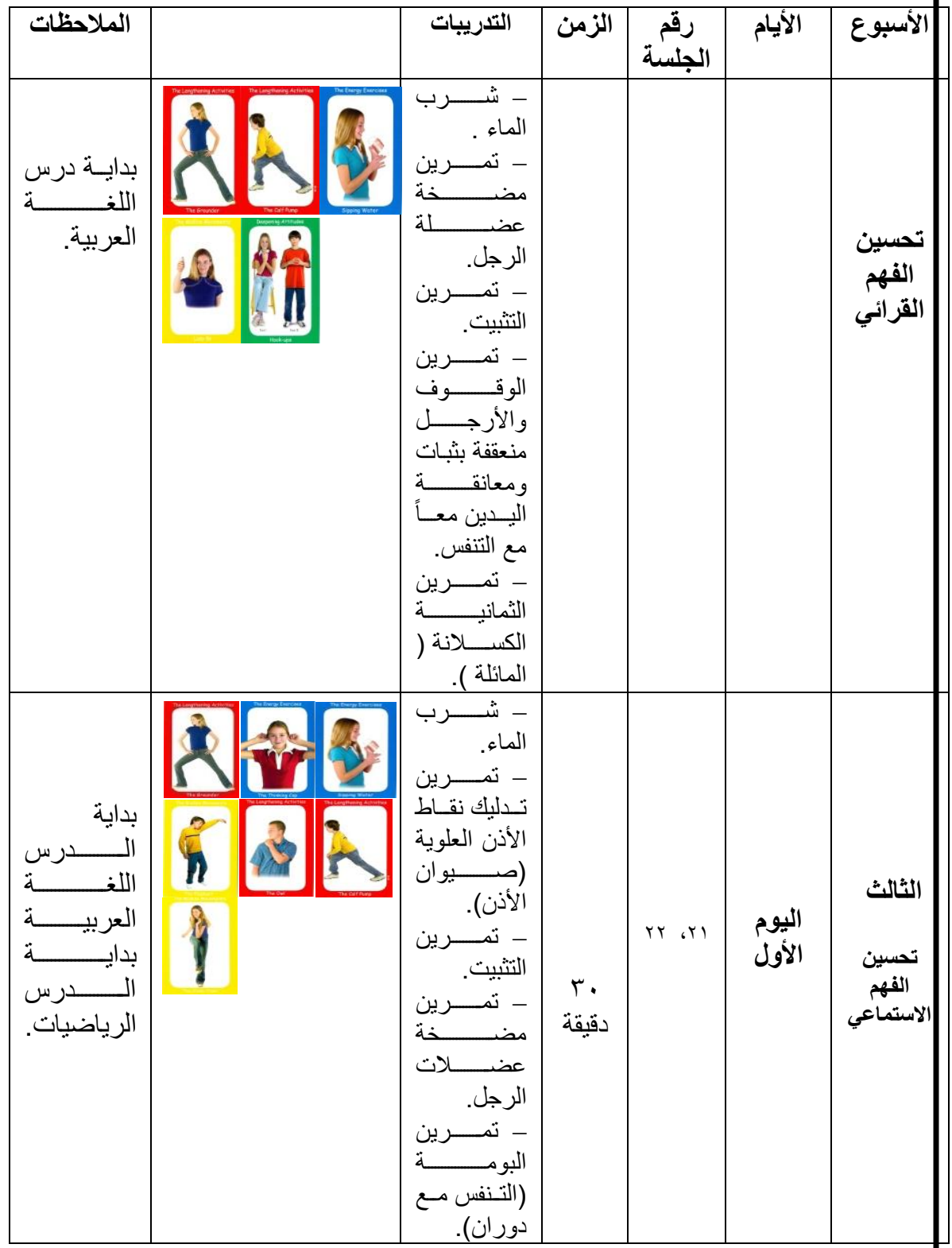


المجلة العلمية لكلية رياض الأطفال - جامعة بورسعيد

\begin{tabular}{|c|c|c|c|c|c|}
\hline الملاحظات & التدريبات & الزمن & الجلسمة & الأيام & الأسبوع \\
\hline & 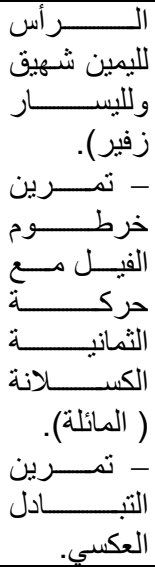 & & & & \\
\hline
\end{tabular}

الأساليب الإحصائية المستخدمة:

للتحقـق مـن فـروض البحـث تـم اســتخدام اختبــار (ت) للفـروق بــين

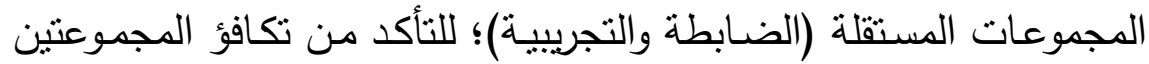

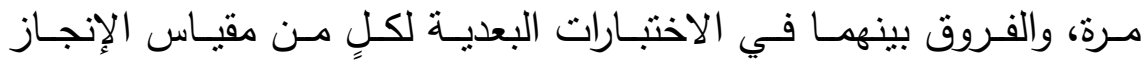

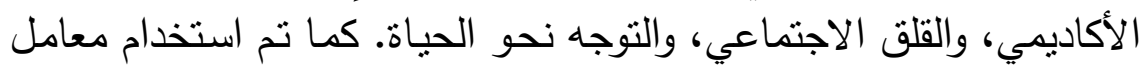

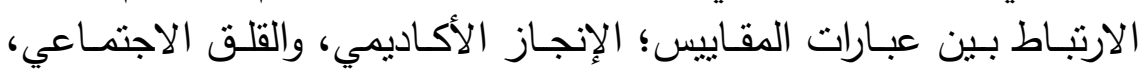
والتوجه نحو الحياة والدرجات الكلية لكل منـ؛ وذللك للتحقق من صدق تلآلك الته

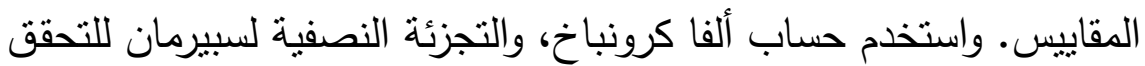
من ثبات المقاييس المستخدمة.

بالإضـافة إلى اسـتخدام اختبـار (ت) للفروق بـين المجموعـات المسـنقلة (ضابطة وتجريبية) في الاختبار البعدي في جميع المقاييس، واختبار (ت) للمجموعة المترابطة لاستخراج الفروق في المجموعة التجريبية في الاختبار

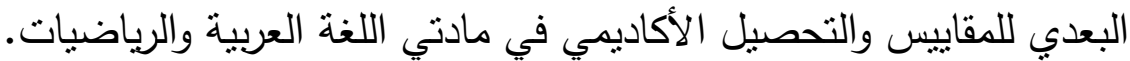


الفرض الأول: توجد فروق ذات دلالـة إحصـائية بين المجموعـة التجربيية

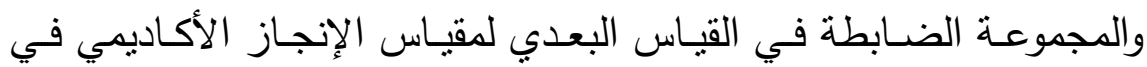
الاتجاه الأفضل للعينة التجربيية.

للتحقق من صحة الفرض استخدمت الباحثة اختبار (ت) للفروق بين المجموعات المستقلة، ويعرض الجدول (؟) لنتائج الاختبار النهائي. جدول (؟) اختبار (ت) للفروق بين المجموعتين الضابطة والتجريبية في القياس البعدي

\begin{tabular}{|c|c|c|c|c|c|c|}
\hline \multicolumn{7}{|c|}{ للإنجاز الأكاديمي } \\
\hline الدلالة الدالة & قيمة ت & الانحراف & الحسابي & 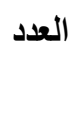 & المجموعة & المقياس \\
\hline \multirow[t]{2}{*}{0,001} & 5.173 & 4.773 & 72.65 & 23 & الضابطة & \multirow{2}{*}{ الألكاديمي } \\
\hline & & 6.943 & 81.74 & 23 & التجريبية & \\
\hline
\end{tabular}

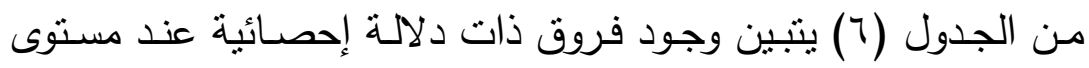

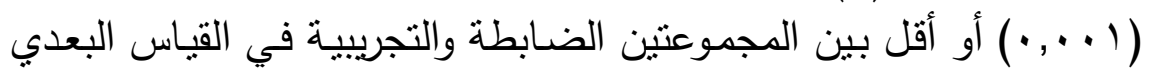

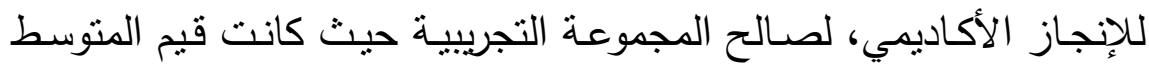

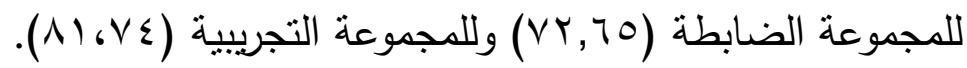

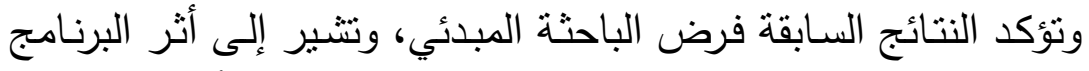

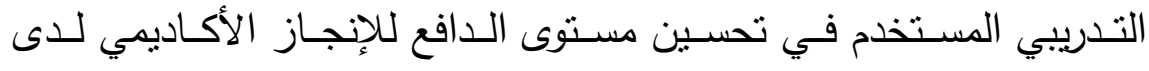

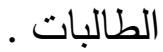


الفرض الثاني: توجد فروق ذات دلالة إحصائية بين المجموعة التجريبية

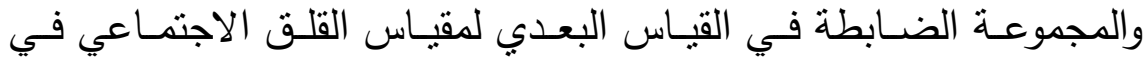
الاتجاه الأفضل للعينة التجريبية.

للتحقق مـن صـحة الفرض استخدمت الباحثة اختبـار (ت) للفروق بين المجموعات المستقلة، ويعرض الجدول (V) لنتائج الاختبار النهائي.

جدول (V) اختبار (ت) للفروق بين المجموعتين الضابطة والتجريبية في القياس البعدي

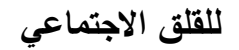

\begin{tabular}{|c|c|c|c|c|c|c|}
\hline الدلالة & قتيمة & المعياري & العسابي & العدد & المجموعة & المقياس \\
\hline .001 & $\begin{array}{c}3.51 \\
6\end{array}$ & 7.494 & 36.43 & 23 & الضابطة & الاجتماعي \\
\hline & & 6.653 & 29.09 & 23 & التجرييية & \\
\hline
\end{tabular}

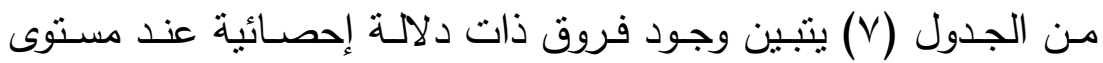

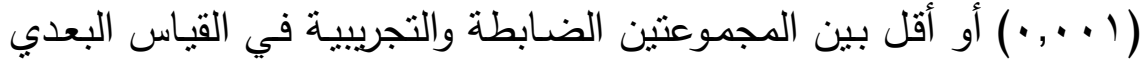

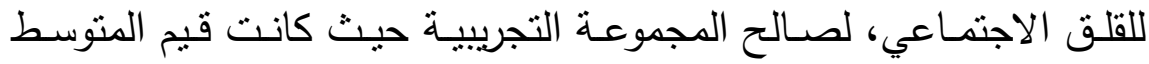

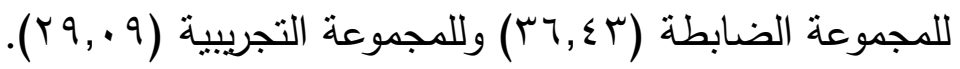

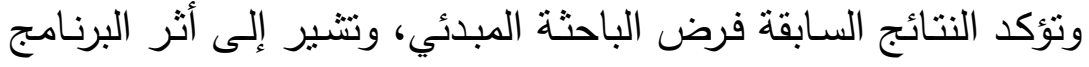
التدريبي المستخدم في خفض مستوى القلق الاجتماعي لدى الطالبات . الفرض الثالث: توجد فروق ذات دلالة إحصائية بين المجموعة التجريبية

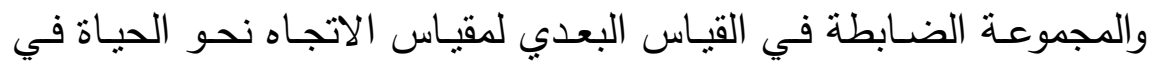
الاتجاه الأفضل للعينة التجريبية. 
للتحقق مـن صـحة الفرض اسـتخدمت الباحثة اختبـار (ت) للفروق بين المجموعات المستقلة، ويعرض الجدول (^) لنتائج الاختبار النهائي. جدول (^) اختبار (ت) للفروق بين المجموعتين الضابطة والتجريبية في القياس البعدي للتوجه نحو الحياة

\begin{tabular}{|c|c|c|c|c|c|c|}
\hline الالالة & قيمة ت & الانحراف & المتوسط & العدد & المجموعة & المقياس \\
\hline \multirow[t]{2}{*}{0,001} & 3.874 & 4.139 & 33.30 & 23 & الضابطة & التوجه للحياة \\
\hline & & 4.746 & 38.39 & 23 & التجربيية & البعدي \\
\hline
\end{tabular}

من الجدول (^) يتبين وجود فروق ذات دلالـة إحصـائية عند مسـتوى ( ( . . . • ) أو أقل بين المجموعتين الضـابطة والتجربيية في القياس البعدي

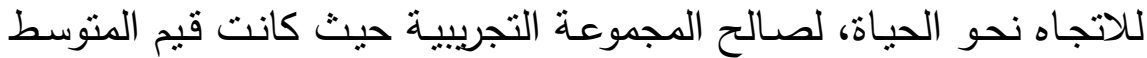

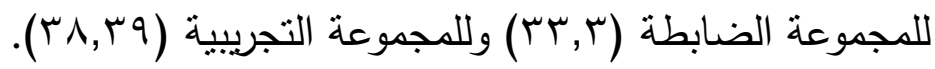
وتؤكد النتائج السابقة فرض الباحثة المبدئي، وتثبر إلى أثر البرنامج التدربيي المستخدم في تحسين مستوى الاتجاه نحو الحياة لدى الطالبات. الفرض الرابع: توجد فروق ذات دلالة إحصائية بين القياس القبلي والقياس

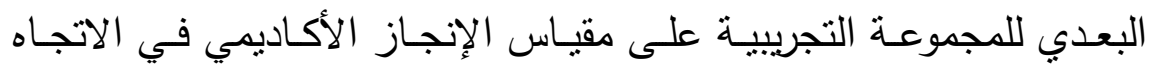
الأفضل لصالح القياس البعدي.

للتحقق من صسحة الفرض استخدمت الباحثة اختبار (ت) للمجموعات المترابطة، وبعرض الجدول (9) لنتائج الاختبار النهائي. 
جدول (9) اختبار(ت) للفروق بين القياسين القبلي والبعدي بالمجموعة التجريبية لمقياس الإنجاز الأكاديمي

\begin{tabular}{|c|c|c|c|c|c|}
\hline الدلالة & قيمة ت & الانحراف & المتوسط الحسابي & القياس & المقياس \\
\hline 0.001 & 4.258 & $\begin{array}{l}3.612 \\
6.943\end{array}$ & $\begin{array}{l}74.96 \\
81.74\end{array}$ & القياس القبلي البعدي & الأكاديمي \\
\hline
\end{tabular}

مـن الجدول (9) يتبين وجـود فروق ذات دلالـة إحصـائية عند مسـتوى

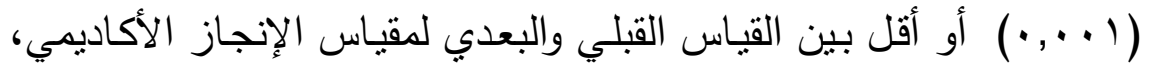

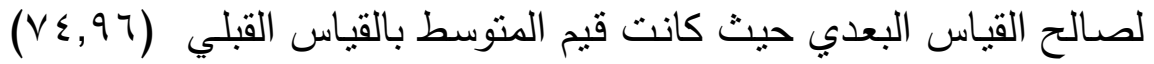

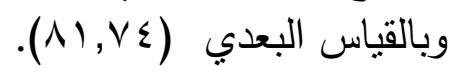

وتؤكد النتائج السابقة فرض الباحثة المبدئي، وتثير إلى فعالبة البرنامج التدريبي المستخدم في تحسين مستوى الإنجاز الأكاديمي لدى الطالبات. الفـرض الخـامس: توجد فروق ذات دلالـة إحصـائية بـين القيـاس القبلي

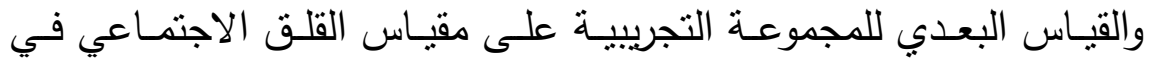
الاتجاه الأفضل لصالح القياس البعدي.

للتحقق من صسحة الفرض استخدمت الباحثة اختبار (ت) للمجموعات المترابطة، وبعرض الجدول ( • () لنتائج الاختبار النهائي. جدول ( • 1) اختبار (ت) للفروق بين القياسين القبلي والبعدي بالمجموعة التجريبية لمقياس القلق الإئق

\begin{tabular}{|c|c|c|c|c|c|}
\hline \multicolumn{6}{|c|}{ الاجتماعي } \\
\hline الدلالة & قيمة ت & الانحراف & الحستوسط & القياس & المقياس \\
\hline 0,02 & 2.519 & $\begin{array}{l}8.498 \\
6.653\end{array}$ & $\begin{array}{l}34.87 \\
29.09\end{array}$ & القياس البعدي القبلي & الاجتماعي القلق \\
\hline
\end{tabular}




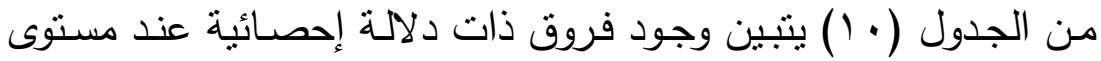

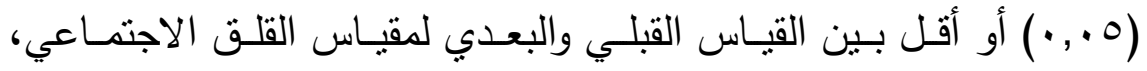

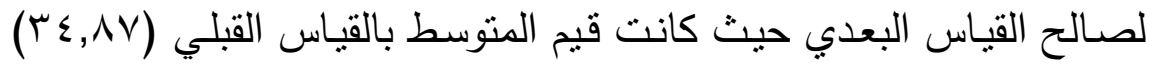

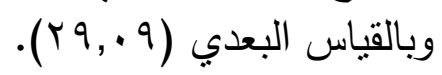

وتؤكد النتائج السابقة فرض الباحثة المبدئي، ونتير إلى فعالية البرنامج

التدريبي المستخدم في خفض مستوى القلق الاجتماعي لدى الطالبات.

الفـرض السـادس: توجد فروق ذات دلالــة إحصـائية بـين القياس القبلي

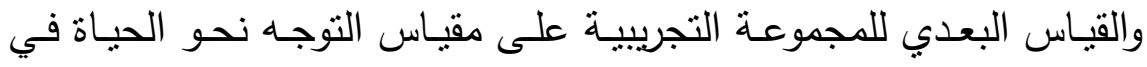
الاتجاه الأفضل لصالح القياس البعدي.

للتحقق من صحة الفرض استخدمت الباحثة اختبار (ت) للمجموعات التبات المترابطة، ويعرض الجدول (1) (1) لنتائج الاختبار النهائي.

جدول (11) اختبار (ت) للفروق بين القياسين القبلي والبعدي بالمجموعة التجريبية لمقياس

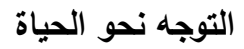

\begin{tabular}{|c|c|c|c|c|c|}
\hline الدلالة & قيمة ت & الانحـراف & الحستوسط & القياس & المقياس \\
\hline 0,02 & 3.072 & $\begin{array}{l}5.130 \\
4.746\end{array}$ & $\begin{array}{l}34.30 \\
38.39\end{array}$ & القباس القبلي & التوجه للحياة \\
\hline
\end{tabular}

من الجدول (11) يتبين وجود فروق ذات دلالة إحصـائية عند مستوى

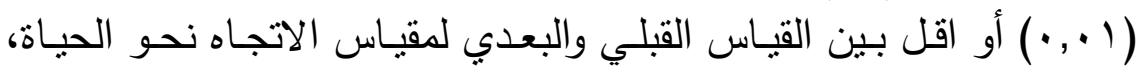




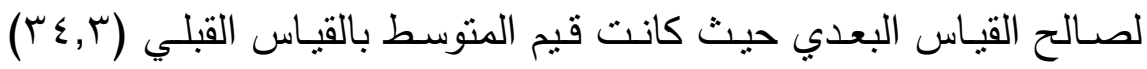
وبالقياس البعدي (q, (ب).

وتؤكد النتائج السـابقة فرض الباحثة المبـئي، الذي يشير إلـى فعاليـة

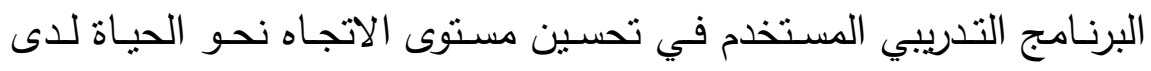
الطالبات.

الفـرض السـابع: توجد فروق ذات دلامـة إحصـائية بـين درجـات الطالبـات باختبار الفترة الدراسية الأولى لمادة الرباضبات (قبل تطبيق البرنامج) وبين

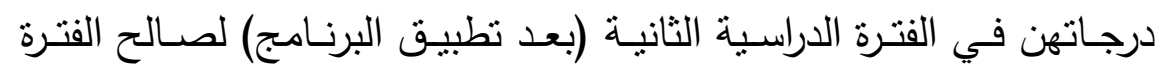
الدراسية الثانية.

للتحقق مـن صـحة الفرض اسـتخدمت الباحثة اختبـار (ت) للمجموعات المترابطة، وبعرض الجدول (Y I) لنتائج الاختبار النهائي.

جدول (r ا ) اختبار (ت) للفروق بين درجات الفترتين الأولى والثانية لمادة الرياضيات للمجموعة التجريبية

\begin{tabular}{|c|c|c|c|c|c|}
\hline الدلالة & قيمة ت & الانحراف & المتوبط الحسابي & القياس & المادة \\
\hline 0,001 & 6.371 & $\begin{array}{c}14.22 \\
14.751\end{array}$ & $\begin{array}{l}72.22 \\
76.77\end{array}$ & الفترة الأولى & الرياضيات \\
\hline
\end{tabular}

من الجدول (Y Y) يتبين وجود فروق ذات دلالة إحصـائية عند مستوى (1 ( . . • ) أو أقل بين درجات الطالبات بمادة الرباضيات في الفترة الدراسية الأولى قبل تطبيق البرنامج ودرجاتهن في الفترة الدراسية الثانبة بعد البرنامج

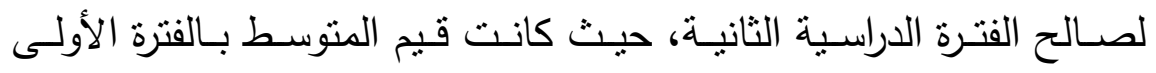

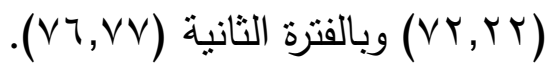


وتؤكد النتائج السابقة فرض الباحثة المبدئي، ونتير إلى فعالية البرنامج التدريبي المستخدم في تحسين مستوى الطالبات بمادة الرباضيات.

الفـرض الثـامن: توجد فروق ذات دلالـة إحصـائية بـين درجـات الطالبـات باختبار الفترة الدراسية الأولى لمادة اللغة العربية (قبل تطبيق البرنامج) وبين درجـاتهن في الفترة الدراسية الثانيـة ( بعد تطبيـق البرنـامج) لصـالح الفترة الدراسبة الثانبة.

وللتحقق من صسحة الفرض استخدمت الباحثة اختبار (ت) للمجموعات المترابطة، وبعرض الجدول (M I) لنتائج الاختبار النهائي.

جدول (r I ) اختبار (ت) للفروق بين درجات الفترتين الأولى والثانية لمادة اللغة العربية للمجموعة التجريبية

\begin{tabular}{|c|c|c|c|c|c|}
\hline الالالة & قيمة ت & الانحراف & المتوبط & القياس & المادة \\
\hline 0,001 & 7.604 & $\begin{array}{l}12.512 \\
11.757\end{array}$ & $\begin{array}{l}68.76 \\
72.88\end{array}$ & الفترة الأولى & اللغة العربية \\
\hline
\end{tabular}

من الجدول (T) يتبين وجود فروق ذات دلالـة إحصـائية عند مستوى

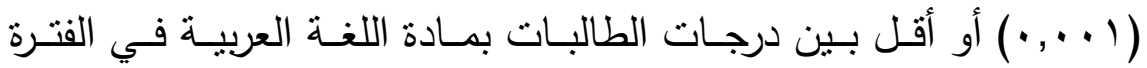
الدراسية الأولى فبل تطبيق البرنامج ودرجاتهن في الفترة الدراسية الثانية بعد

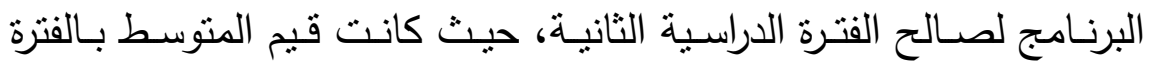

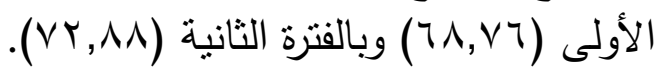
وتؤكد النتائج السـابقة فرض الباحثة المبدئي، ونتير إلى فعالية البرنامج التدريبي المستخدم في تحسين مستوى الطالبات بمادة اللغة العربية. 
يتبين من النتائج الإحصـائية السـابقة تحقق فروض البحث جميعها كما

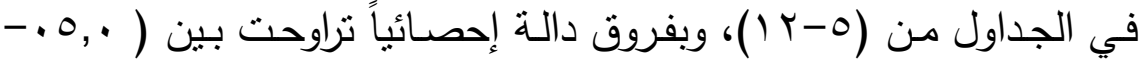
( + . • ) وهي تتم عن أهمية برنامج الرباضة الدماغية وقدرته على تحسين العديـد مـن المتغيـرات النفسية التـي كـان البحـث بصــدهدا وهـي الإنجـاز

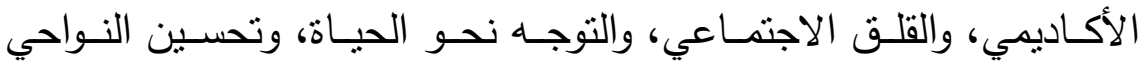

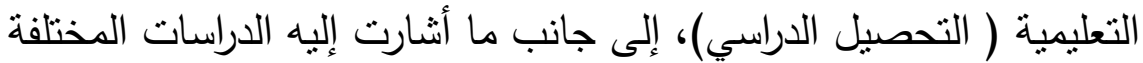
العربية منها والأجنبية، كتقوبة قدرات الحواس وزبادة كفاءة المهارات، والكفاء إهاء

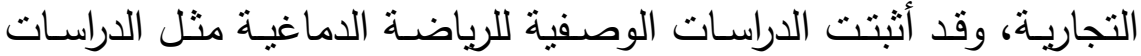

(Teplitz, 2001; Primost, J., 1992; Winkelmann, التالية؛ 2001a; Winkelmann,2001b; McGovern, N., 1991; Winkelmann, 2001c; Winkelmann, 2001d; Dennison, G., E., 2001 Teplitz, 2002 ).

(Eyestone, 1990; والدراسـات الارتباطيـة منثل مـا يلـي؛ (Sifft \& والدراسات والتجريبية مثل ما يلي؛؛Masgutova, 2001 ) ؛Khalsa, 1991; Beigel, Steinbauer, \& Zinke, 2002;

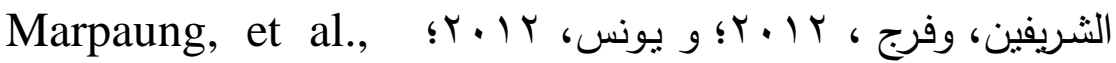

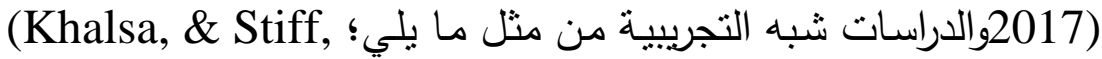
1988; Khalsa, Morris, \& Stiff, 1988; Donczik, 1994) (Stiff, 1990; Khalsa, Sifft, 1990; \ما قبل التجريبية من مثل؛ Hamaford, 1990; Kuznetsova, \& Kudryavtseva, 2002; Wofsont, 2002).

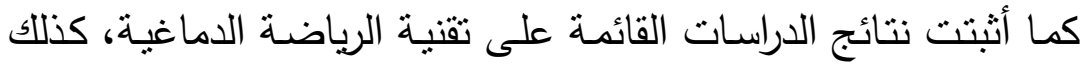

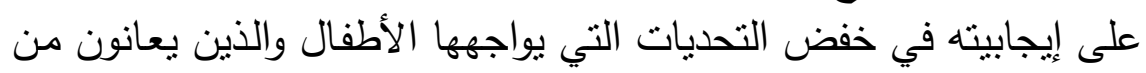
صعوبات التعلم، والتوحد، وفرط النشاط ونقص الانتباه، والإعاقات السمعية 
والبصرية (2014) Anderea, w., et al والذهنية والجسدية، ومتلازمة

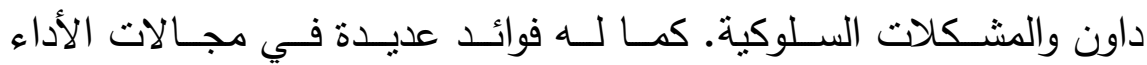

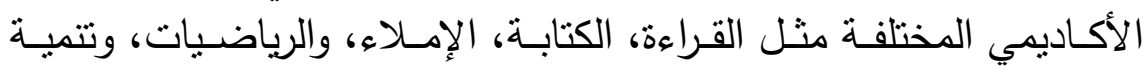

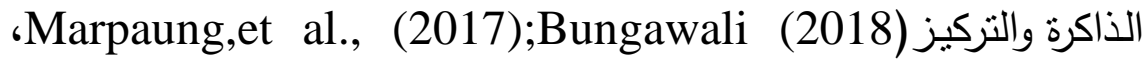

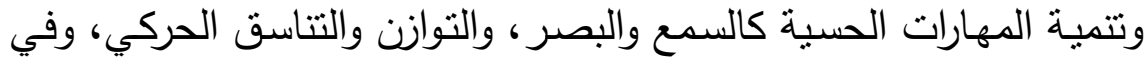

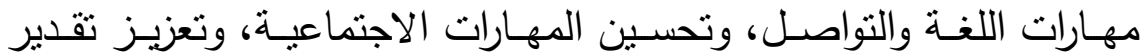

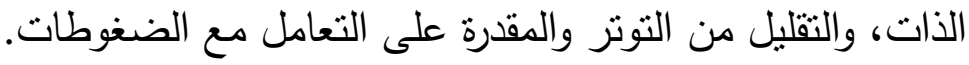
وتقوم تقتية الرياضة الاماغية على ثلاثة محاور أساسية هي ما يلي: محور التواصل الجانبي (Laterality): وهو يصف العلاقة $-1$

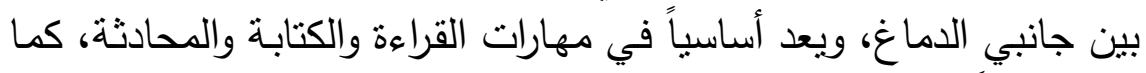

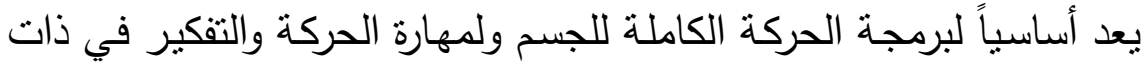

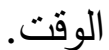
r-محور التركيز (Focus): يصف العلاقة ما بين المناطق الأمامية

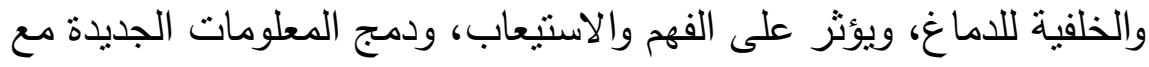

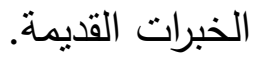
r-محور التـوازن(Centering) : : يهتم بالعلاقـة بين الأجزاء العلويـة

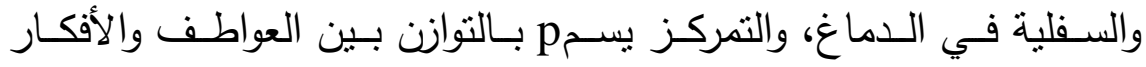

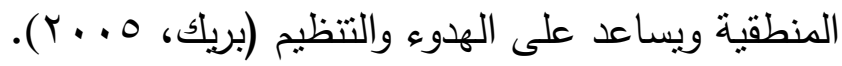

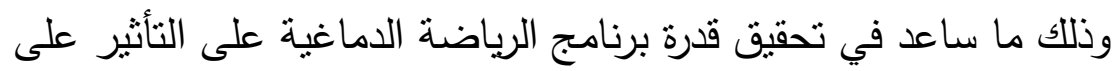

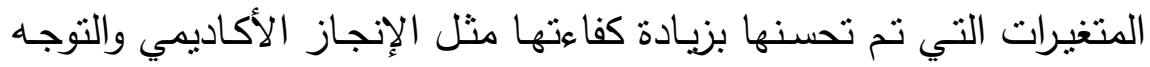

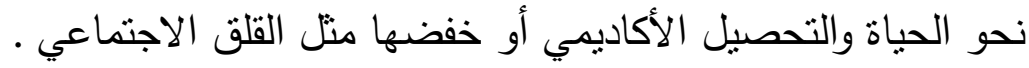




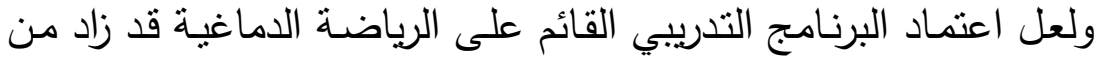

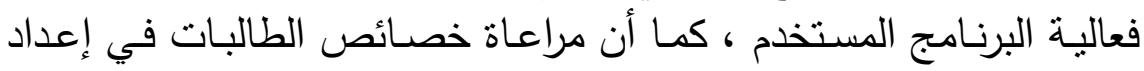

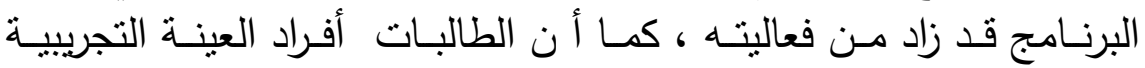
يتمتعون بمستوى ذكاء يقع في المدى المتوسط، فبالتالي عندما هيئت لهم

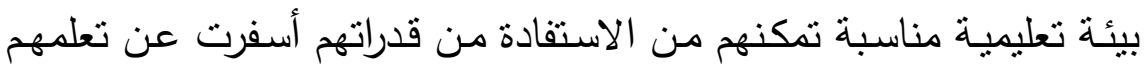

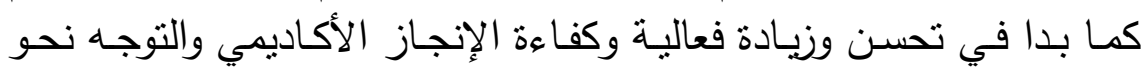
الحياة والتحصيل الأكاديمي لديهم بعد تطبيق البرنامج التدربيي المقترح. وتفسر الباحثة فاعليـة برنـامج البحث الحسالي لتضـمنه إسـتراتيجية التعلم

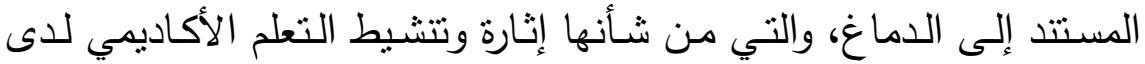
الطالبـات وتفعيـل دورهن ، مدـا يترتب عليـه زبـادة دافعيـة الطالبـات للتعلم بصورة نشطة وذات كفاءة مرتفعة.

ويمكـن أن تعـزى فاعليـة البرنـامج التـدريبي المسـتخدم إلـى اســتخدام إستراتيجية التعلم المستند الى الدماغ وروح المرح التي غلبت عليها وجعلها في سياق ألعاب تتافية بين الطالبات، مما زاد من انتباههن وحسن وعبهن وادراكهن.

كما يأتي مبدأ السعي نحو النجاح والكفاح في سبيل التفوق في أداء

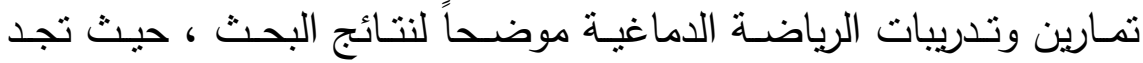

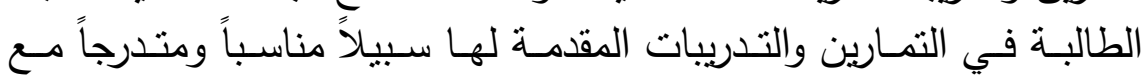
قدراتها، وذللك من أجل التفوق واثبات الذات وهو الأمر الذي يدعم فعالية

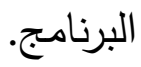

وبعود أيضاً سبب فاعلية البرنامج التدريبي القائم على الرياضة الدماغية

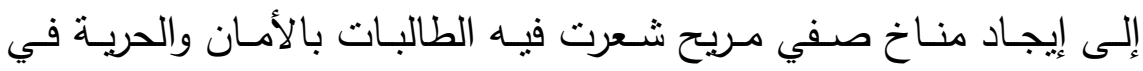


التعبير عن حركاتهن دون خوف ، مدا سمح لهن بالتفاعل الإيجابي مـع بعضهن البعض ، وبناء جسور الثقة ، وتكوين علاقات إيجابية ، والتعاون والمنافسة وإتباع التعليمات ، كل ذلك انعكس على أداء طالبات المجموعة التجريبية وأدى وإلى خفض مظاهر القلق الاجتماعي لديهم.

وقد أشـارت نتائج الفروض إلى نجاح البرنامج المستخدم في البحث في تتميـة اللغـة والرباضـيات لـدى طالبـات الصـف السـادس الابتـدائي ( أفـراد البـان المجموعة التجريبية )، مما يشير إلى وجود آثار إيجابية للبرنامج في توفير الخبرات والممارسات الدماغية الحركية التي أدت إلى تحسن مستوى الإنجاز

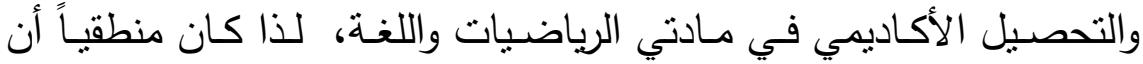

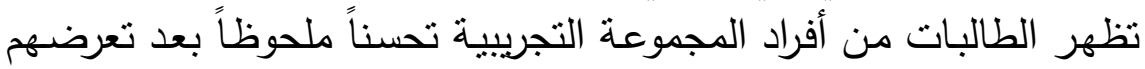
لبرنامج البحث القائم على الرياضة الدماغية.

وبذلك فقد تحققت فروض البحث الحالي حول فاعلية البرنامج الحالي في في تتمية اللغة والرياضيات، وذلك اتفاقاً مع ما سبق من تفسير لهذه النتائج ومراعاتها للتراث النظري والنظربات المتتوعة للتعلم.

وبـذلك تشـير كل نتائج البحـث الحـالي على أن جميـع الفـروض التهي حاولت الباحثة أن تجيب عليها في البحث الحالي قد تحققت، وهي جميعها تهدف إلى التحقق من تأثير البرنامج التدربي القائم على الرياضـة الدماغية في تتميـة اللغـة والرياضيات لدى طالبات الصف السـادس الابتدائي وزيـادة فعالية و كفاءة الإنجاز الأكاديمي والتوجه نحو الحياة والتحصيل الأكاديمي،

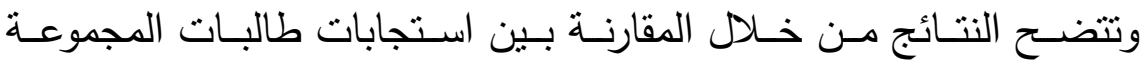
التجريبية في القياس القبلي والبعدي. 


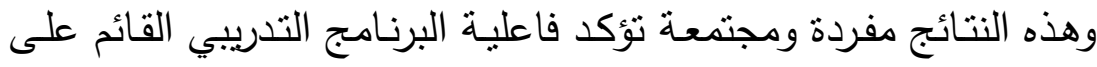

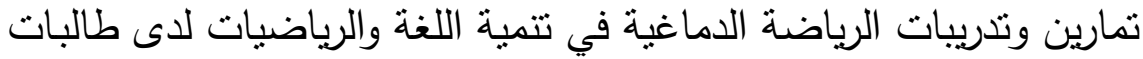

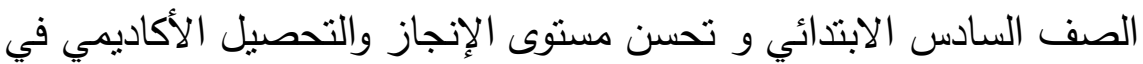

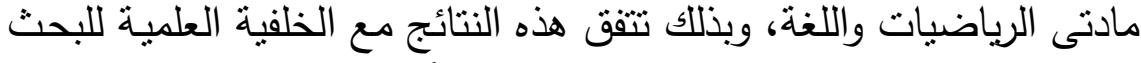

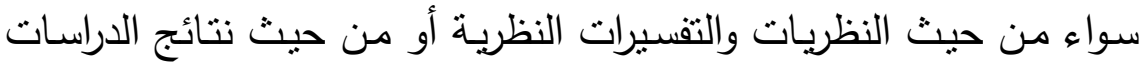
السابقة التي توفرت للباحثة.

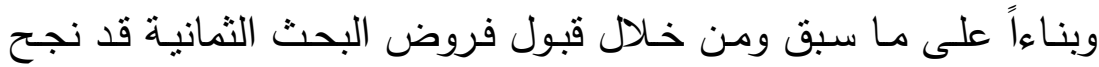

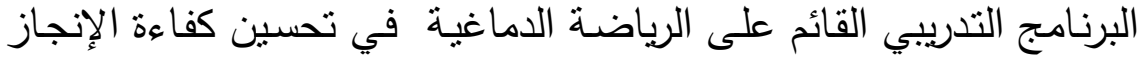
الأكاديمي والقلق الاجتماعي والتوجه نحو الحياة، وتأثيره على مستوى اللغنة

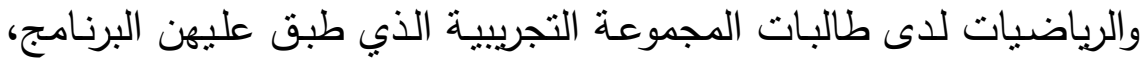

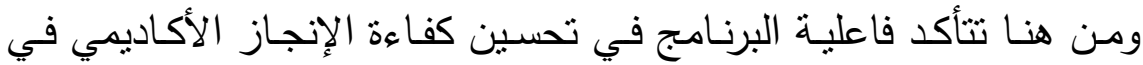

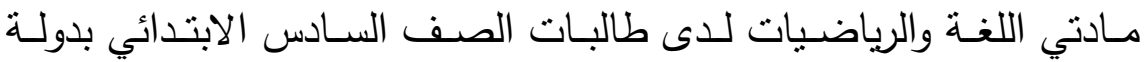

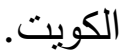

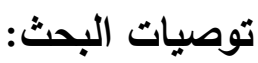

من خلال نتائج البحث تضع الباحثة التوصيات التالية:

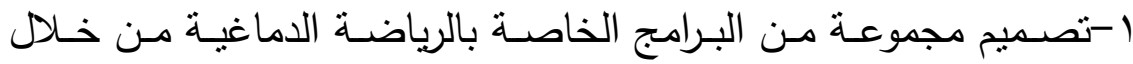

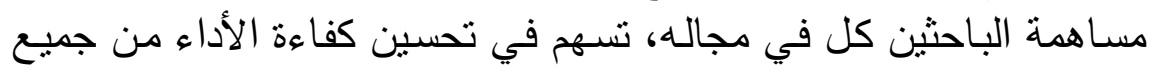
الجوانب من منل؛ ضعف الإنجاز، صعوبات التعلم، وبطء التعلم، الإعاقات

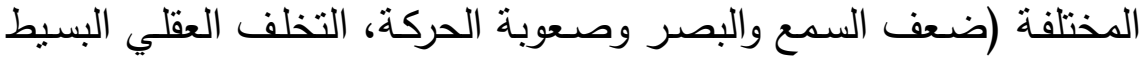

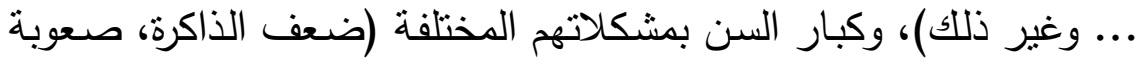
الحركة، ضعف السمع والبصر ... وغير ذللك). 
ب-توجيـه اهتمـام البـاحثين إلـى أهميـة بـرامج الرياضــة الدماغيـة في تتميـة الجوانب النفسية المرغوبة وخفض الجوانب النفسية غير المرغوبة.

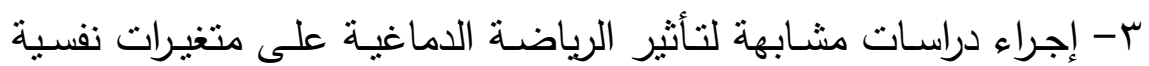
وغير نفسية أخرى، كذلك إجراء دراسات أخرى على البنين.

\section{المراجـ2}

\section{أولاً: العراجع العربية:}

- إبراهيم، مجدي عزيز (Y . . (Y). تتظبيات حدبثة للمناهج التربوبية - دعوة

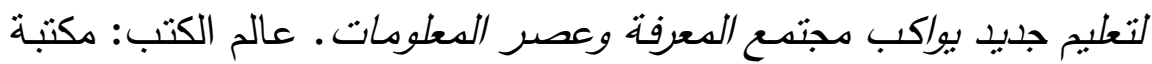
الأنجلو المصرية- جمهورية مصر العربية.

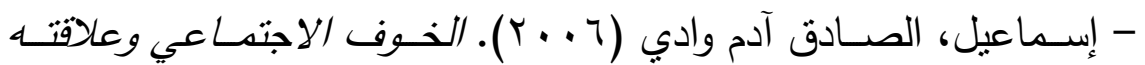
بدافع الإنجاز الأكادبيهي: دراستة مبد/نبية على طلاب المرحلة الثانوبية بولاية الخرطوم - محلبة أم درمان. رسالة ماجستير غير منشورة. السودان: جامعة الانة

النيلين.

- آل مـراد، نبـراس بـونس محمـد (Y ( • Y). أثـر اسـتخدام برنـامج مقترح بالتمرينات الحركية الموجهة للدماغ في تتمية سرعة الاستجابة لدى أطفال

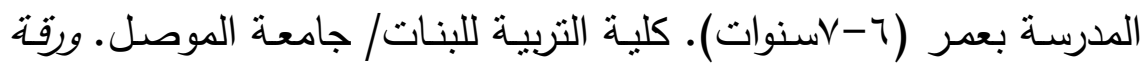
عدل في المؤتدر الدوري الثامن لكليات وأقفام التربية الرباضية في العراق.

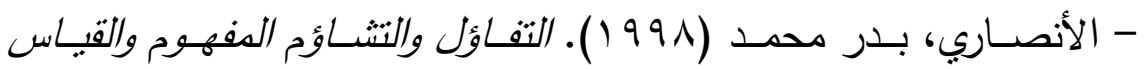

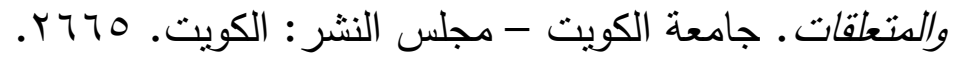

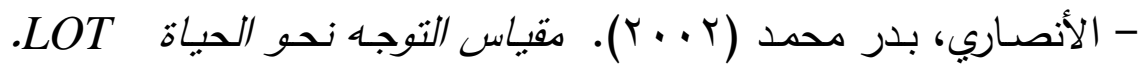
في مقابيس الثخصبة: تقنبن على المجتهع الكوبتحي (ص ص • و ب-r اسب)، الكوبت: دار الكتاب الحديث. 


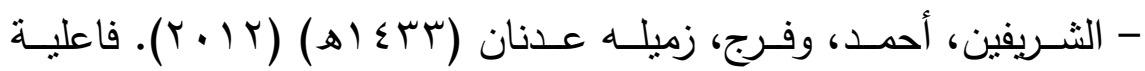
برنامج إرشادي مستتد إلى رياضة الدماغ في خفض اضطراب نقص الانتباه المصحوب بالنشاط الزائد. مجلة العلوم الإنسانية والاجتماعبية، العدد الثالث

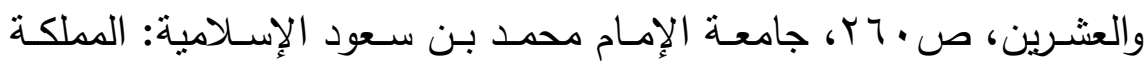
العربية السعودية.

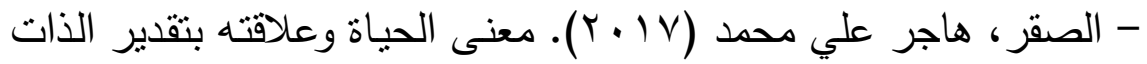

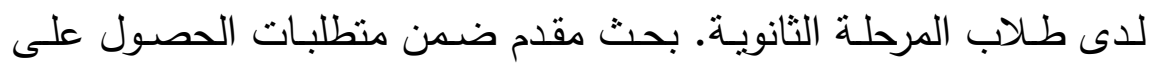
درجة دكتوراه الفلسفة في التربية/ علم نفس تعليمي/ جامعة عين شمس -

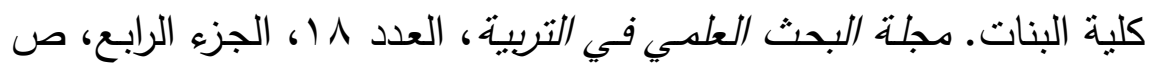

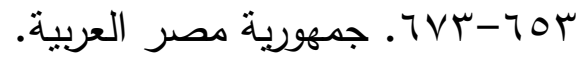

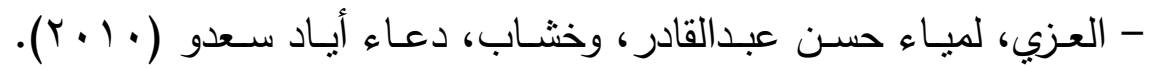
القلق الاجتماعي وعلاقته بالتحصيل الدراسي لدى طالبات الصف الخامس وداء في معهدي إعداد المعلمات (نينوى - الموصل) في مركز محافظة نينوى.

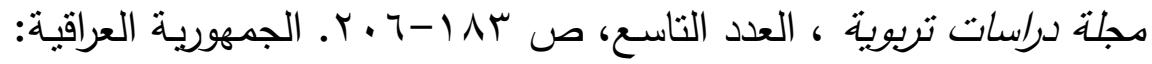
نينوى

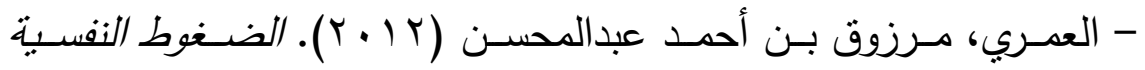

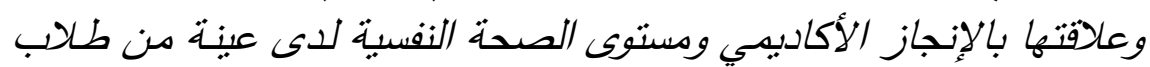

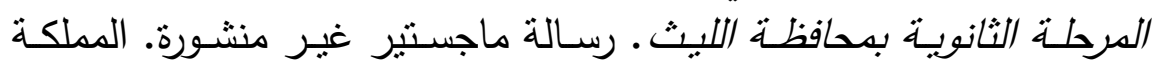
العربية السعودية: جامعة أم القرى.

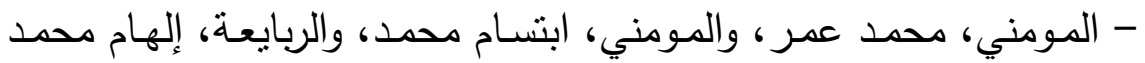

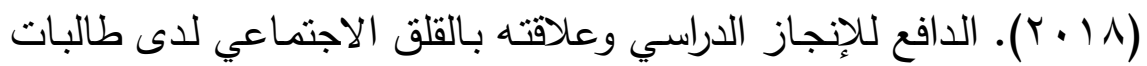

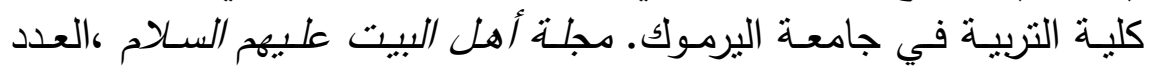

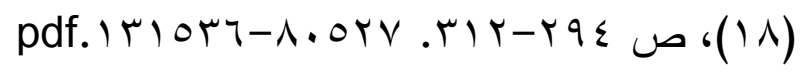


- بريك، ياسمين (ديسمبر ، 0 . . ب). الرياضـة الدماغية، مجلة بريد المعلم،

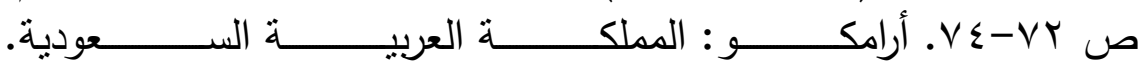
https://Www.linkedin.com/li/track - جواد، تبارك عادل (1 ( • ب). دافع الإنجاز الأكادبيسي لدى طلبة المرحلة

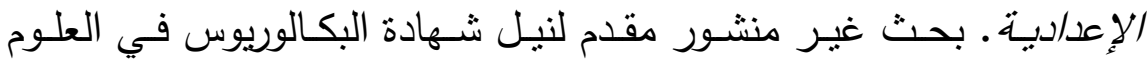

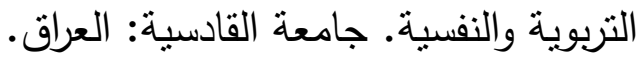

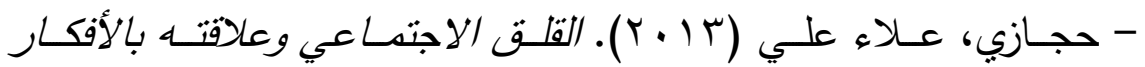
اللاعقلانبة لدى طلبة المرحلة الإعدادبية بالمدارس الحكومبية في محافظات

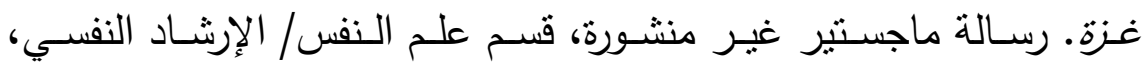
الجامعة الإسلامبة- غزة: فلسطين.

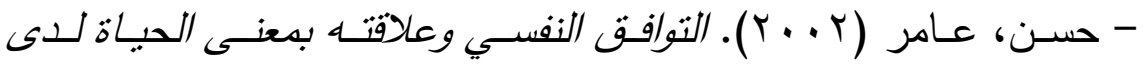
المراهفين من الجنسين. رسالة ماجستير غير منشورة، كلبة التربية، جامعة اهنة عين شمس: القاهرة. - حسين، قاسم حسن؛ والعنكبي، منصسور جميل (9^^ (1). اللباقة البننية وطرق تحقبقها . بغداد: مطبعة التعليم العالي.

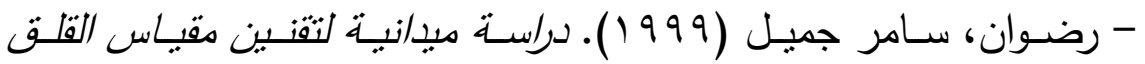
الاجتماعي على عينات سوربية. جامعة دمشق/ كلية التربية، في أبو السعد. - أحمد عبداللطيف (1 (1 ب). دلبيل المقابيس والاختبارات النفسبية والتربوبة. الجزء الأول: مقابيس الصسة النفسبة ومقابيس المشكات والاضطرابات، طץ، مركز ديبونو لتعليم التفكير، عمان: التوره الأردن. - سالم، رفقة خليف (9 . . (Y). علاقة فاعلية الذات والفرع الأكاديمي بدافع

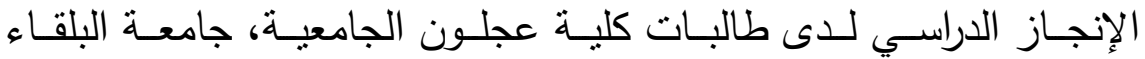

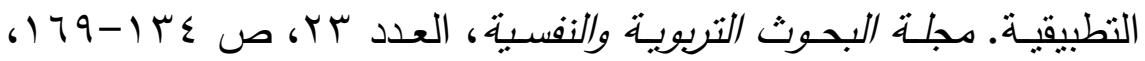
جامعة بغداد: العراق. 


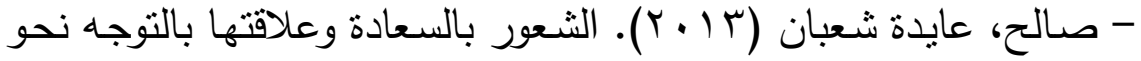

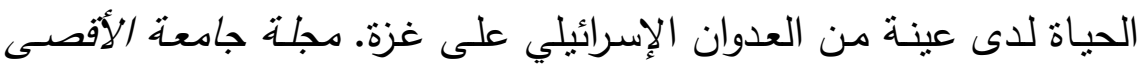

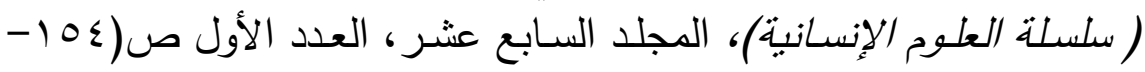

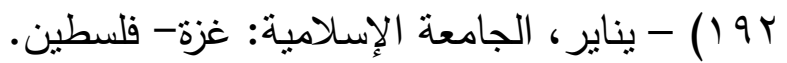

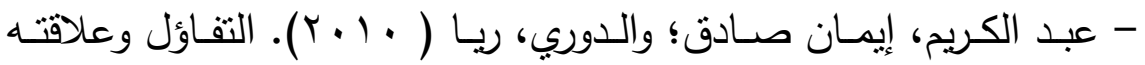
بالتوجه نحو الحياة لدى طالبات كلبة التربية للبنات. مجلة البحوث التربوبية

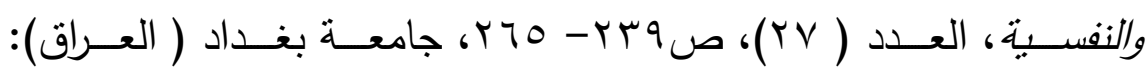

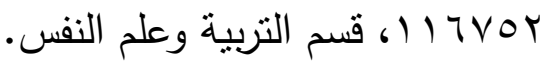

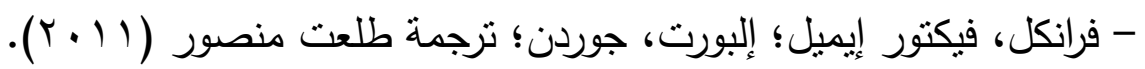

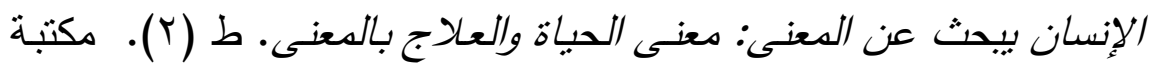

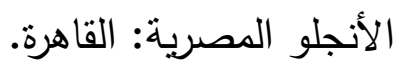

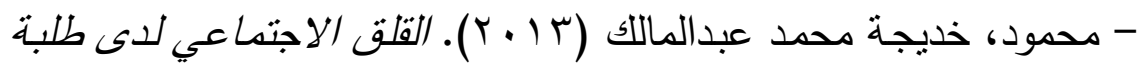
جامعة بنغازي وقةًا لبعض المتغيرات . رسالة ماجستير غير منشورة. كلية الآداب- قسم التربية وعلم النفس. جامعة بنغازي: ليبيا.

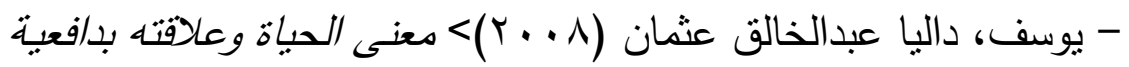

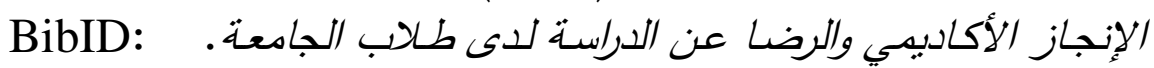
10215440. القاهرة: جمهوربية مصر العربية. ثانياً: المراجع الأجنبية :

- Andrea, W., Ginger, L. K. (2014). The effect of Brain Gym® on academic engagement for children with developmental disabilities. International Journal of Special Education. Vol. 29, No.2,. Stephen, F. Austin State University. 
- Bungawali, A., \& Tahar, M.M. (2018). The effectiveness of Brain training intervention on working memory performance of student with learning disability. Journal of ICSAR, volume 2, No.2. Print: 25488619;ISSN (online): $\quad 2548-8600$.

University

Kebangsaam Malaysia.

- Beigel, D., Steinbauer, W., \& Zinke, K. (2002). Available in German only. Published by VAK Verlags GmbH Kirchzarten bei Freiburg.

- Brain Gym® is a program of physical activities that enhance learning ability. Australia's \#1 Natural Health Site (2018). Available at:

- http://www.naturaltherapypages.com.au/cognitive/Bra in_Gym\#ixzz4L1366fIC

- Chernick, A. M. (2009). The Effects of Movement Based Intervention Programs on Learning in Grades $K$ 12. Submitted in partial fulfillment of the requirements for the degree of Master of Arts in education at northern Michigan University. U.S.A.

Dennison, P. E.; Dennison, G. E., (2010). Brain Gym, Teacher's Edition. Edu- Kinesthetics Inc. California, USA.

- Diamond, S. J. ( 2001). Educational Kinesiology, movement, and sensory integration: A review of recent, relevant, neuroscientific literature. Brain Gym ${ }^{\circledR}$ Journal, Volume XV, Nos. 1 and 2, Ventura, CA, U.S.A. - Donczik, J. (1994). The following summary is from an edited English language translation by Christine $\mathrm{M}$. 
Grimm and Sigrid Wong, republished in the Brain Gym® Journal, Volume XV, Nos. 1 and 2, 2001, from "Konnen edukinestetische Ubungen (Brain-Gym®) Legasthenikern helfen?" in Die Sprach-heilarbeit 39 (1994), S. 297-305, a German publication.

- Eyestone, R. (1990). Correlates of Edu-K repatterning pre-checks with "at-risk" populations. Published in Brain Gym® Magazine, Volume 11, No.2, as "Heterolateral or Homolateral Processing".

- Equilibrium Kinesiology \& Brain Gym® Supplies . Established 1984. PH: 039578 1229:10am to 2pm EST, Mon-Fri (info@braingym.com.au) PO Box 155. Ormond VIC 3204, Australia. ABN 93816861143.

- Available at: http://www.braingym.com.au/AboutBrain-Gym-pg6639.html

- -Flora, C., (2005). Fit "N" Brainy. Psychology Today, $98,121$.

- -GASKELL, K. H., (2018). Physical Development in Late Childhood, available at:

- https://www.livestrong.com/article/88282-latechildhood-physical-development/

- Hannaford. C., (1998). Smart moves: Why learning is not all in your head, Second Edition: jetzt kaufen. ISBN: 0884298694383. Alington, Va.: Great publishers, c1995. - Hannaford, C., L. (1990). The brain option for hyperactivity, ADD, E.H., Sp. Ed. L.D. and FAS. Published in the Australian Journal of Remedial Education, Volume 26, No. 1. 
- Hyatt, K. J. (2007). Brain Gym® Building stronger brains or wishful thinking?. Remedial and Special Education Journal. Vol. 28, no.2, p:117-124.

- Khalsa, G. K., \& Sifft, J. M. (1988). Effects of Educational Kinesiology upon the static balance of learning disabled boys and girls. Available from Educational Resources Information Center, or on microfiche (ERIC Document Reproduction Series No. ED 289835).

- Khalsa, G.C.K., Morris, D.,\& Sifft, J. M.,(1988). The effects of Educational Kinesiology on the static balance of learning-disabled students. Published in Perceptual and Motor Skills, 67, 51-54. California State Polytechnic University, Pomona. U.S.A.

- Kkhsou, M. (2017). Late childhood. Available online at:

http://m.kkhsou.in/EBIDYA/EDUCATION/MODIFY_1 ate_childhood.html

- Koelman, A. (1997).Movement or medication? The alleviation of ADD. Brain Gym® Journal, Volume XI, No. 3.

- Kuznetsova, O.M.D. \& Kudryavtseva, G.M.D. (2002). Whole-brain integration in a case of reverse reading and writing. Brain Gym ${ }^{\circledR}$ Journal, volume XVI, No. 1, from articles originally published in Russian and presented at the symposia of two medical congresses. 
- Leiner, C., H. \& Leiner, A., L. (1997). The treasure at the Bottom of the Brain Retrieved from:

www.http://grants.hhp.coe.uh.edu/clayne/6397/Unit6_fil es/Cerebellumreading.htm.

- Marpaung, M. G.; Sareharto, T. P.; Purwanti, A.; Hermawati, D.,(2017). Brain Gym to increase academic performance of children aged 10-12 years ohd ( experimental study in Tembalang elementary school and Pedalangan elementary school Semarang. IOP Conf. Series: Earth and Environmental Science 55, 012017. Indonesia.

- Masgutova, S., K. (1999). The influence of Brain Gym ${ }^{\circledR}$ movements on the work of muscles and on dynamics and posture reflexes. See also "Edu-K and Vigotsky's Mind-Body Psychology," Brain Gym ${ }^{\circledR}$ Journal, Volume X, No 3, 1996; "Educational Kinesiology in Russia: The Possibilities in Education and in Psychological Practice," Volume IX, No 3, 1996; and "Brain Gym® in Russia: Applications in Psychological Practice."

- McClelland, D. C.; Atkinson; J.W.; Clark, R. A., \& Lowell, E. L. (1953). The achievement motive. New York: Appleton-Century-Crofts.

- McClelland, D. C. (1961). The achieving society. London: Collier-Macmillan Ltd.

- - McGovern, N. (1991). The effects of Brain Gym® in a district-wide Canadian field study. The Educational Kinesiology Foundation, Ventura, CA, U.S.A. 
- Moore, L.L.; Grabsch, D. K.: Rotter, C. (2010). Using Achievement motivation theory to explain student participation in a residential leadership learning Community. Journal of Leadership Education. Volume 9, Issue2.

- Pangrazi, R., Darst, P., Pangrazi-Orlowicz, C., \& Landers, D., (2003). Physical activities in the school curriculum that are designed to enhance thinking and learning. Retrieved from:

http://ezpolson.nmu.edu:5558/itx/infomark/do?contentS et $=$ IAC -

Document $\&$ type $=$ retrieve $\&$ tabID $=$ T002 $\&$ prodld $=$ SPJ.$S$ P05\&docld $=$ A99492858\&source $=$ gale $\&$ srcprod $=$ SP05 $\&$ userGroupName=Iom_olsonlib\&version $=1.0$.

- Primost, J. (1992). The effects of educational kinesiology on academic and social skills of high school students in Israel. Brain Gym® Magazine, Volume VI, No.1.

- Reedy, M. E. (1998). Physical education study committee. The Maryland Association for Health Physical Education, Recreation, and Dance, 5-6. Retrieved from: http://www.mcps.k12.md.us/curriculum/physed/Study\% 20Group\%20Report\%20-\%20State\%20.pdf

- Spalding, J. (1999). The ADHD controversy: Drugs, labels, and stifled potential. Brain Gym® Journal, Volume XI, No. 3. 
- Spaulding, L. S. ; Mostert, M. P. \& Beam, A. P. (2010). Is Brain Gym ${ }^{\circledR}$ an Effective Educational Intervention?. A Special Education Journal. Volume 18, 2010 - Issue 1: Empirically Unsupported Interventions in Special Education.

- Sifft, J. M., \& Khalsa, G.C.K (1991). The effect of Educational Kinesiology upon simple response times and choice response times. Perceptual and Motor Skills, 73,1011-1015, as "The effect of Educational Kinesiology upon simple response times and choice response times." Previously presented at the American Alliance for Health, Physical Education, Recreation and Dance Southwest District Convention, March,1989, Salt Lake City, Utah. Reported on in the Brain Gym ${ }^{\circledR}$ Magazine, Volume II, No. 3, 1988.

- -Sorgen, M. (1998). Brain research: Implications for teaching and learning. Paper presented at the Mary land Association for supervision and Curriculum Development state Conference, Ocean City, MD. - - Teplitz, J. V. (2001). Switched-on selling research report. Brain Gym® Journal. A part of " a revolution in training: Bottom line results of the switched-on selling seminar, Volume XV Nos. $1 \& 2$.

- Teplitz, J. V. (2002). The results of the use of Brain Gym ${ }^{\circledR}$ movements in a network-markiting seminar. Available at: www.teplitz.com/switched=main.htm.

- Wikipedia (2009). Kinesiology. Retrieved from: http://en.wikipedia.org/wiki/kinesiology. 
- Winkelmann, P., (2001)a. Using Brain Gym with hearing impaired children in Flores, East Indonesia. Published in Brain Gym® Journal, Volume , XV, Nos. 1 and 2, 2001.

- Winkelmann, P., (2001)b. Results of a Brain Gym course at an educational program for underprivileged children in Bangladesh. The document is related to two research documents. See: "The impact of Brain Gym" processes on sales of insurance" by Robert Donovan, 1993, and "Switched-On Selling Research Report" by Dr.Jerry V. Teplitz, 1992, updated in 2001.

- Winkelmann, P.,(2001)c. Brain Gym in a program for teachers and health staff, in North Sulawesi, Indonesia. Published in Brain Gym® Journal, Volume , XV, NOs.1 and 2, 2001.

- Winkelmann, P., (2001)d. A year of Learning Gymnastics (Brain Gym) at Dorkes Kindergarten, North Sulewesi. Published in Brain Gym® Journal, Volume , XV, NOs.1 and 2, 2001.

- - Wolfsont, C. A. (2002). Increasing behavioral skills and level of understanding in adults: A brief method integrating Dennison's Brain Gym ${ }^{\circledR}$ balance with piaget's reflective processes, Journal of Adult Development, 9(3), 185-201, (ISSN: 1068-0667), issued quarterly by Kluwer Academic Plenum Publishers, P.O. Box 322,3300 AH Dordrecht, The Netherlands. 



\section{هجب}

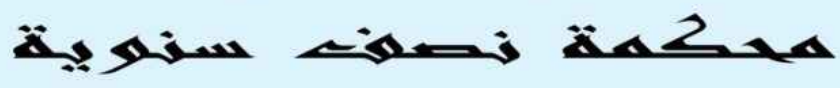

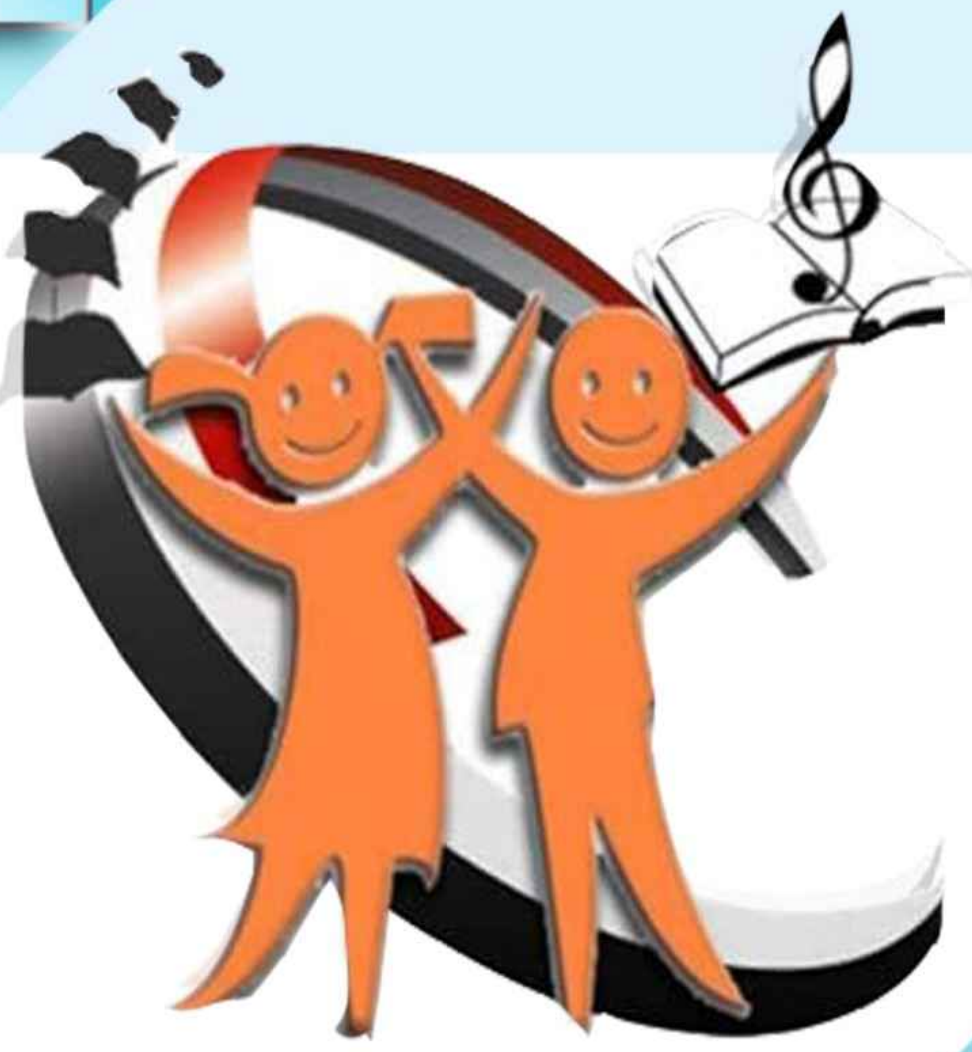

ISSN.Print :2356- 6485

ISSN.OnLine : 2682-3276 